\title{
Technology, Safety and Costs of Decommissioning a Reference Boiling Water Reactor Power Station
}

\author{
Appendices
}

Manuscript Completed: October 1979

Date Published: June 1980

Prepared by

H. D. Oak, G. M. Holter, W. E. Kennedy, Jr., G. J. Konzek

Pacific Northwest Laboratory

Richland, WA 99352

\section{Prepared for}

Division of Engineering Standards

Office of Standards Development

U.S. Nuclear Regulatory Commission

Washington, D.C. 20555

NRC FIN No. B2117

\section{DISCLAIMER}

This report was prepared as an account of work sponsored by an agency of the United States Government. Neither the United States Government nor any agency thereof, nor any of their employees, makes any warranty, express or implied, or assumes any legal liability or responsibility for the accuracy, completeness, or usefulness of any information, apparatus, product, or process disclosed, or represents that its use would not infringe privately owned rights. Reference herein to any specific commercial product, process, or service by trade name, trademark, manufacturer, or otherwise does not necessarily constitute or imply its endorsement, recommendation, or favoring by the United States Government or any agency thereof. The views and opinions of authors expressed herein do not necessarily state or reflect those of the United States Government or any agency thereof. 


\section{DISCLAIMER}

This report was prepared as an account of work sponsored by an agency of the United States Government. Neither the United States Government nor any agency Thereof, nor any of their employees, makes any warranty, express or implied, or assumes any legal liability or responsibility for the accuracy, completeness, or usefulness of any information, apparatus, product, or process disclosed, or represents that its use would not infringe privately owned rights. Reference herein to any specific commercial product, process, or service by trade name, trademark, manufacturer, or otherwise does not necessarily constitute or imply its endorsement, recommendation, or favoring by the United States Government or any agency thereof. The views and opinions of authors expressed herein do not necessarily state or reflect those of the United States Government or any agency thereof. 


\section{DISCLAIMER}

Portions of this document may be illegible in electronic image products. Images are produced from the best available original document. 



\section{STUDY CONTRIBUTORS}

STUDY LEADER

H. D. Oak

APPENDIX A - EVALUATIONS OF DECOMMISSIONING FINANCING ALTERNATIVES

R. I. Simith

APPENDIX B - REFERENCE SITE DESCRIPTION

H. D. Oak

APPENDIX C - REFERENCE BWR FACILITY DESCRIPTION

H. D. Oak

APPENDIX D - RADIATION DOSE RATE AND CONCRETE SURFACE CONTAMINATION DATA

M. G. Arndt (a)

4. D. Oak

k. Fox

G. J. Konzek

APPENDIX E = RADIONUCLIDE INVENTORIES

R. I. Smith

W. E. Kennedy, Jr.

H. D. Oak

M. G. Zimmerman

B. A. Napier

\section{APPENDIX F - PUBLIC RADIATION DOSE MODELS AND CALCULATED MAXIMUM ANNUAL DOSES}

W. E. Kennedy, Jr

APPENDIX G - DECOMMISSIONING METHODS

G. M. Holter

H. D. Oak

G. J. Konzek

\section{APPENDIX H - GENERIC DECOMMISSIONING INFORMATION}

G. M. Holter

G. J. Konzek

H. D. Oak
APPENDIX I - IMMEDIATE DISMANTLEMENT DETAILS

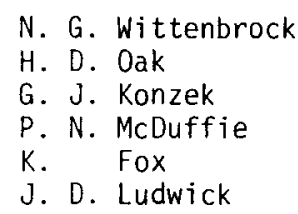

APPENDIX J - PASSIVE SAFE STORAGE, CONTINUING CARE, AND DEFERRED DISMANTLEMENT DETAILS

G. J. Konzek

J. D. Ludwick

P. N. McDuffie

APPENDIX K - ENTOMBMENT DETAILS

G. M. Holter

P. N. McDuffie

J. G. Bradley(b)

E. M. Greene(b) $\frac{\text { APPENDIX L - DEMOLITION AND SITE RESTORATION }}{\text { DETAILS }}$

J. M. McFarland (C)

N. G. Wittenbrock

APPENDIX M - COST ESTIMATING BASES

G. M. Holter

H. D. Oak

G. J. Konzek

APPENDIX N - PUBLIC RADIOLOGICAL SAFETY

W. E. Kennedy, Jr.

S. L. Sutter

$\frac{\text { APPENDIX } 0-\text { DETAILS OF ALTERNATE STUDY }}{\text { BASES }}$

L. M. Polentz $(\mathrm{a})$

R. I. Smith

H. D. Oak

EDITOR

D. R. Payson

PROJECT MANAGER

R. I. Smith

(a) Private consultant.

(b)Associated with Westinghouse Hanford Company, Richland, WA.

(c) Associated with McFarland Wrecking Corporation, Seattle, WA 



\section{REPORT CONTENTS OUTLINE}

VOLUME 1

CHAPTER 1 - INTRODUCTION

CHAPTER 2 - SUMMARY

CHAPTER 3 - STUDY APPROACH AND BASES

CHAPTER 4 - DECOMMISSIONING: ALTERNATIVES, CONSIDERATIONS, AND EXPERIENCE

CHAPTER 5 - REGULATORY CONSIDERATIONS FOR DECOMMISSIONING

CHAPTER 6 - FINANCING OF DECOMMISSIONING

CHAPTER 7 - CHARACTERISTICS OF THE REFERENCE BWR POWER STATION

CHAPTER 8 - SUGGESTED METHODOLOGY FOR DETERMINING ACCEPTABLE RESIDUAL RADIOACTIVE CONTAMINATION LEVELS FOR THE DECOMMISSIONED BWR

CHAPTER 9 - DECOMMISSIONING ACTIVITIES AND MANPOWER REQUIREMENTS

CHAPTER 10 - DECOMMISSIONING COSTS

CHAPTER 11 - DECOMMISSIONING SAFETY

CHAPTER 12 - COMPARISONS WITH OTHER STUDIES

CHAPTER 13 - CONSIDERATIONS FOR DECOMMISSIONING FACILITATION

CHAPTER 14 - IMPACTS OF ALTERNATE STUDY BASES

CHAPTER 15 - GLOSSARY

VOLUME 2

APPENDIX A - EVALUATIONS OF DECOMMISSIONING FINANCING ALTERNATIVES

APPENDIX B - REFERENCE SITE DESCRIPTION

APPENDIX C - REFERENCE BWR FACILITY DESCRIPTION

APPENDIX D - RADIATION DOSE RATE AND CONCRETE SURFACE CONTAMINATION DATA

APPENDIX E - RADIONUCLIDE INVENTORIES

APPENDIX F - PUBLIC RADIATION DOSE MODELS AND CALCULATED MAXIMUM ANNUAL DOSES

APPENDIX G - DECOMMISSIONING METHODS

APPENDIX H - GENERIC DECOMMISSIONING INFORMATION

APPENDIX I - IMMEDIATE DISMANTLEMENT DETAILS

APPENDIX J - PASSIVE SAFE STORAGE, CONTINUING CARE, AND DEFERRED DISMANTLEMENT DETAILS

APPENDIX K - ENTOMBMENT DETAILS

APPENDIX L - DEMOLITION AND SITE RESTORATION DETAILS

APPENDIX M - COST ESTIMATING BASES

APPENDIX N - PUBLIC RADIQLOGICAL SAFETY ASSESSMENT DETAILS

APPENDIX 0 - DETAILS OF ALTERNATE STUDY BASES 


$$
8
$$


NUREG/CR-0672

Vol. 2

\section{Technology, Safety and Costs of Decommissioning a Reference Boiling Water Reactor Power Station}

Appendices

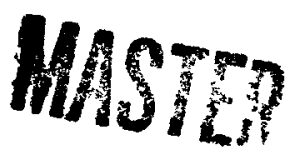

Prepared by H. D. Oak, G. M. Holter, W. E. Kennedy, Jr., G. J. Konzek

Pacific Northwest Laboratory

Operated by

Battelle Memorial Institute

Prepared for

U. S. Nuclear Regulatory

Commission 


\section{NOTICE}

This report was prepared as an account of work sponsored by an agency of the United States Government Neither the United States Government nor any agency thereof, or any of their employees, makes any warranty, expressed or implied, or assumes any legal liability or responsibility for any third party's use, or the results of such use, of any information. apparatus product or process disclosed in this report, or represents that its use by such third party would not infringe privately owned rights

Available from

GPO Sales Program

Division of Technical Information and Document Control

U. S. Nuclear Regulatory Cormission Washington, D. C. 20555

Printed copy price:

and

National Technical Information Service Springfield, Virginia 22161 


\section{CONTENTS}

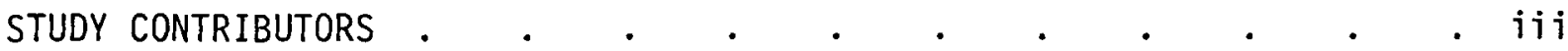

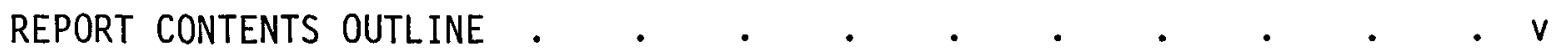

FIGURES

TABLES

APPENDIX A - EVALUATIONS OF DECOMMISSIONING FINANCING ALTERNATIVES •

A. 1 INFORMATION ABOUT REVENUE REQUIREMENTS . . . . • . A-1

A.2 CALCULATION OF REVENUE REQUIREMENTS . . . . . . A-1

A.2.1 Revenue Requirement for the Prepayment

Alternative . . . . . . . . A-2

A.2.2 Revenue Requirement for the Internal Unfunded
Reserve Alternative . . . . . . . A-3

A.2.3 Revenue Requirement for the Sinking Fund
Alternative. . . . . . . . A-5

A.2.4 Revenue Requirement for the Payment When Needed
Alternative . . . . . . . . . . A-6

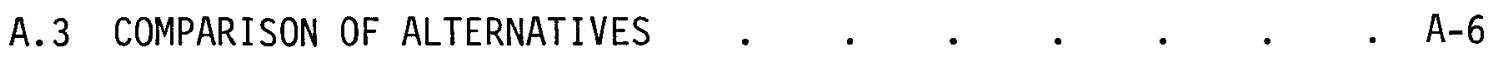

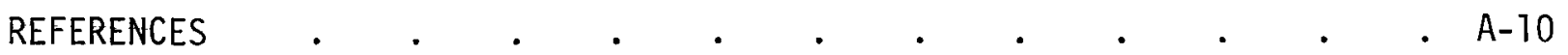

APPENDIX B - REFERENCE SITE DESCRIPTION . . . . . . . . . . B-1

B. 1 SITE LOCATION AND SIZE . . . . . . . . . . B-1

B.2 DEMOGRAPHY . . . . . . . . . . . . B-2

B.3 LAND USE . . . . . . . . . . . . . . . . B

B.4 METEOROLOGY . . . . . . . . . . . . . B-3

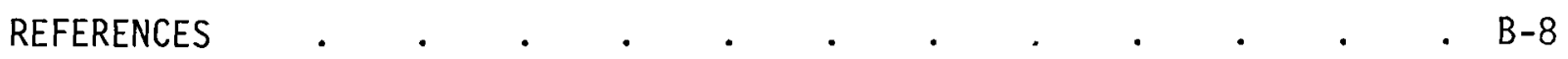

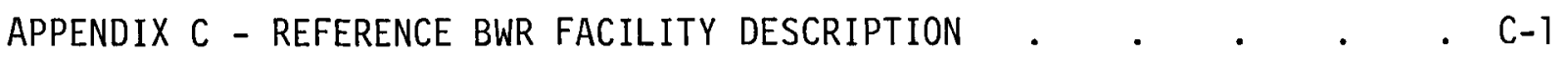

C. 1 GENERAL PLANT DESCRIPTION $\quad . \quad . \quad . \quad . \quad . \quad . \quad . \quad$ C-1

C.1.1 Design Criteria . . . . . . . . C-3 
C.1.2 Operating Characteristics . . . . . . C-3

C.1.3 Nuclear Steam Supply System . . . . . . C-3

C.1.4 Power Conversion . . . . . . . . C-5

C.1.5 Electrical Power . . . . . . . . C-6

C.1.6 Fuel Handling System . . . . . . . C-6

C.1.7 Radioactive Waste Treatment Systems . . . . C-6

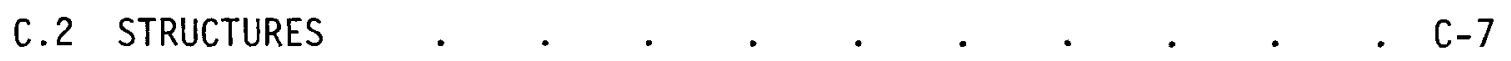

C.2.1 Reactor Building . . . . . . . . . C-8

C.2.1.1 Primary Containment Vessel . . . . C-19

C.2.1.2 Primary Containment Vessel Internals . . C-25

C.2.2 Turbine Generator Building . . . . . . C-27

C.2.3 Radwaste and Control Building . . . . . C

C.2.4 Diesel Generator Building . . . . . . C-45

C.2.5 Service Building . . . . . . . . C C-46

C.2.6 Cooling Tower Complex . . . . . . . C C-47

C.2.7 Spray Pond Complex . . . . . . . . C -47

C.2.8 Makeup Water Pumphouse . . . . . . . C-48

C.2.9 Auxiliary Buildings . . . . . . . . C-48

C.3 CONTAMINATED EQUiPMENT . . . . . . . . . . . . C C49

C.3.1 Reactor Building Equipment . . . . . . C C 49

C.3.1.1 Reactor Vessel . . . . . . . C-49

C.3.1.2 Reactor Vessel Internals . . . . . C-52

C.3.1.3 Reactor Coolant Recirculation Pumps . . . C-58

C.3.1.4 Spent Fuel Storage Pool . . . . . C-62

C.3.2 Turbine Generator Building Equipment . . . . C-62 
C.3.2.1 Main Turbine . . . . . . . . C-65

C.3.2.2 Main Condenser . . . . . . . C-70

C.3.3 Radwaste and Control Building Equipment . . . C C-72

C.3.4 Contaminated Piping and Valves . . . . . C-72

C.4 HEATING, VENTILATING AND AIR CONDITIONING SYSTEMS . . . C-85

C.4.1 HVAC - Reactor Building and Primary Containment . . C-85

C.4.1.1 Reactor Building . . . . . . . C-85

C.4.1.2 Primary Containment . . . . . . . C-93

C.4.2 HVAC - Turbine Generator Building . . . . C-98

C.4.3 HVAC - Radwaste and Control Building . . . . C-104

C.5 RADWASTE SYSTEMS . . . . . . . . . . C C 111

C.5.1 Liquid Radwaste System . . . . . . . C-111

C.5.1.1 Equipment Drain (Radioactive) Subsystem . . C-111

C.5.1.2 Floor Drain (Radioactive) Subsystem . . . C-118

C.5.1.3 Miscellaneous Waste (Radioactive) Subsystem . C-118

C.5.2 Solid Radwaste System . . . . . . . C -119

C.5.3 Gaseous Radwaste System . . . . . . C-120

C.5.3.1 Condenser off Gas Treatment System . . . C-120

C.5.3.2 Reactor Building Standby Gas Treatment
System . . . . C . C 122

C.6 ACRONYMS, ABBREVIATIONS, AND EQUIPMENT KEY NUMBERS . . C-123

REFERENCES . . . . . . . . . . . . . C C 127

$\begin{array}{r}\text { APPENDIX D - RADIATION DOSE RATE AND CONCRETE SURFACE CONTAMINATION } \\ \text { DATA } . \\ \hline\end{array} \cdot$.

D.1 ESTIMATED RADIATION DOSE RATES AT SHUTDOWN . . . . D D-1

0.1.1 Assumptions and Definitions. . . . . . D-1 
D.1.2 Presentation of Dose Rate Data . . . . . D-2

D.1.3 Application of Radiation Dose Rate Data . . . D-18

D.2 ESTIMATED CONCRETE SURFACE CONTAMINATION AT SHUTDOWN • . D-19

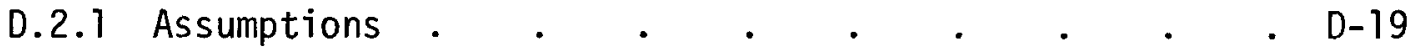

D.2.2 Concrete Surface Contamination Data . . . . D-20

D.2.3 Application of Concrete Surface Contamination Data . D-20

REFERENCES .

'APPENDIX E - RADIONUCLIDE INVENTORIES . . . . . . . . . E-1

E.1 NEUTRON-ACTIVATED COMPONENTS . . . . . . . . . E-1

E.1.1 Radionuclide Inventories in Neutron-Activated
Structural Materials . . . . E-1

E.1.1.1 Reference Radionuclide Inventories 1, 2,
and 3. . . . E-2

E.1.1.2 Calculational Methods . . . . . E-2

E.1.2 Estimated Total Radioactivity in Neutron-Activated
Components . . . E-12

E.1.3 Radiation Dose Rates from Neutron-Activated
Components . . . . . E-16

E.1.3.1 Radioactive Decay Characteristics of
Selected Radionuclides . . . E-16

E.1.3.2 Radiation Dose Rates . . . . . . . E-21

E.2 SURFACE CONTAMINATION . . . . . . . . . . . E-23

E.2.1 Radionuclide Inventories in Internally Contaminated

Piping and Equipment . . . . . . E-24

E.2.1.1 Reference Radionuclide Inventory 4 . . . E-24

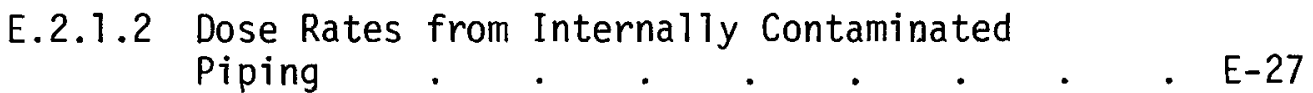

E.2.1.3 Estimated Total Radioactivity in Internally
Contaminated Piping. . . . E-30 
E.2.1.4 Dose Rates from Internally Contaminated

Equipment . . . . . . . . E-32

E.2.1.5 Estimated Total Radioactivity in Interna11y

Contaminated Equipment . . . . . E-32

E.2.2 Radionuclide Inventories on Externally Contaminated

Structural Surfaces . . . . . . . E-35

E.2.2.1 Reference Radionuclide Inventory 5 . . . E-37

E.2.2.2 Dose Rates from Externaliy Contaminated

Structural Surfaces. . . . . E-37

E.2.2.3 Estimated Total Radioactivity on Externally

Contaminated Structurai Surfaces . . . E-40

E.2.3 Radionuclide Inventory on the Reference Site . . E-42

E.2.3.1 Radionuclide Release Data and Inventory
Calculational Methods . E-42

E.2.3.2 Reference Radionuclide Inventory 6 . . . E-44

REFERENCES . . . . . . . . . . . . E-46

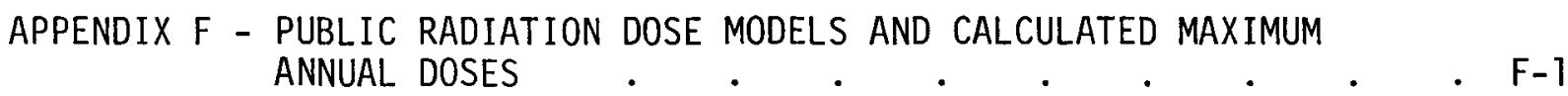

F.1 RADIATION DOSE TERMINOLOGY AND DEFINITIONS . . . . . F-1

F.2 GENERAL MODELS FOR ESTIMATING RADIATION DOSE . . . . . F-3

F.2.1 External Exposure . . . . . . . . . F-7

F.2.2 Ingestion . . . . . . . . . F-7

F.2.2.1 Deposition on Food Products or Ground
Surfaces . . . F-8

F.2.2.2 Concentration in Vegetation . . . . F-9

F.2.2.3 Concentration in Animal Products . . . F-10

F.2.3 Inhalation . . . . . . . . . . F-11

F.3 MODEL FOR ESTIMATING ANNUAL DOSE . . . . . . . . F-11

F.3.1 Model of a Reference BWR Room . . . . . F-15 
F.3.2 Airborne Radioactivity Concentrations for Annual Dose Calculations. . . . . . . F-16

F.4 CALCULATED MAXIMUM ANNUAL DOSES AT THE DECOMMISSIONED

REFERENCE BWR . . . . . . . . . . . F-19

F.4.1 Assumptions for Calculating Maximum Annual Dose . . F-19

F.4.2 Radionuclide Inventories for Calculating Maximum Annual Dose. . . . . . . . . F-19

F.4.3 Maximum Annual Dose Listings . . . . . F-20 REFERENCES

APPENDIX G - DECOMMISSIONING METHODS . . . . . . . .

G.1 DECONTAMINATION

G.1.1 Surface Film Dissolution . . . . . . . . G-1

G.1.1.1 Chemical Decontamination . . . . . . G-1

G.1.1.2 Electropolishing . . . . . . G-3

G.1.2 Physical Cleaning . . . . . . . . G-5

G.1.3 Removal of Structural Material . . . . . G-6

G.1.3.1 Bulk Concrete Removal . . . . . G-8

G.1.3.2 Concrete Surface Removal . . . . . G-9

G.2 EQUIPMENT DISASSEMBLY . • . . . . . . . G-14

G.2.1 Underwater Manipulator . . . . . . . G-15

G.2.2 Cutting Equipment . . . . . . . . G-15

G.2.2.1 Plasma-Arc Torch . . . . . . G-16

G.2.2.2 Arc Saw . . . . . . . . G-19

G.2.3 Linear-Shaped Explosive Charges . . . . . G-20

G.3 RADIOACTIVE WASTE PACKAGING AND SHIPPING • • . . G-22

G.3.1 Packaging of Radioactive Wastes . . . . . G-22

G.3.2 Shipment of Radioactive Wastes . . . . . G-24 
G.4 CONTAMINATION CONTROL $\quad$. . . . . . . . . . . . G-27

G.4.1 Local Mitigation of Contamination Sources . . . G-27

G.4.2 Collection of Contamination . . . . . . G-28

G.4.2.1 Vacuum Collection . . . . . . G-28

G.4.2.2 Portable Ventilation Systems . . . . G-29

G.4.3 Isolation of Contaminated Areas . . . . . G-32

G.4.3.1 Isolation During Active Decommissioning . . G-32

G.4.3.2 Isolation During Continuing Care . . . G-32

G.5 QUALITY ASSURANCE . . . . . . . . . . . G-34

G.5.1 Method Review . . . . . . . . G-34

G.5.2 Procurement Document Control . . . . . G-34

G.5.3 Work Instructions, Procedures, and Drawings . . G-35

G.5.4 Document Control . . . . . . . . G-35

G.5.5 Identification and Control of Procured Items . . G-35

G.5.6 Special Processes . . . . . . . . G-35

G.5.7 Inspection and Test . . . . . . . G-35

G.5.8 Calibration . . . . . . . . . G-36

G.5.9 Shipping and Receiving . . . . . . G-36

G.5.10 Operating Status . . . . . . . . G-36

G.5.11 Nonconformance and Corrective Action . . . . G-36

G.5.12 Specialty Quality Records . . . . . . G-36

G.5.13 Quality Auditing . . . . . . . . G-37

G.6 ENVIRONMENTAL SURVEILLANCE . . . . . . . . G G-37

G.6.1 Environmental Surveillance During Active
Decommissioning. . . . . G-37

G.6.2 Environmental Surveillance During Continuing Care . G-40 
H.1 DECOMMISSIONING STAFF . . . . . . . . . . $\mathrm{H}-1$

H.2 PLANNING AND PREPARATION . . . . . . . . . . H-5

H.2.1 Regulatory Requirements . . . . . .

H.2.2 Data Gathering and Analysis . . . . . . H-7

H.2.3 Development of Detailed Work Plans and Procedures - $\mathrm{H}-7$

H.2.4 Design, Procurement, and Testing of Special
Equipment . . . . . . H-8

H.2.5 Staff Selection and Training . • • • . H-8

H.2.6 Selection of Specialty Contractors • • • . H-8

H.2.7 Removal of Accumulated Spent Fuel and Unneeded Spent
Fuel Storage Racks . . . H-9

H.2.8 Install HEPA Filters . . . . . . . H-9

H.3 SPECIALTY CONTRACTORS . . . . . . . . . . .

H.4 ESSENTIAL SYSTEMS AND SERVICES . . . . . . . . H-10

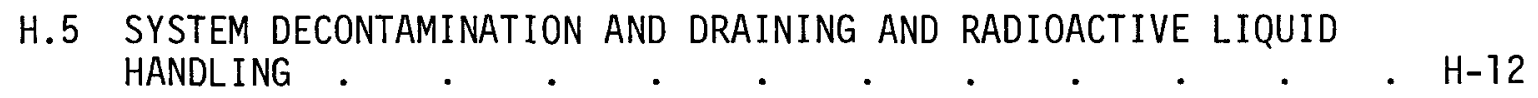

H.5.1 Details of System Decontamination and Draining and
Radioactive Liquid Handling. . . H-12

H.5.1.1 Key Bases and Assumptions . . . . . H-12

H.5.1.2 System Decontamination . . . . . H-14

H.5.1.3 System Draining . . . . . . . $\mathrm{H}-21$

H.5.1.4 Radioactive Liquid Handling . . . . $\mathrm{H}-21$

H.5.2 Time and Manpower Requirements for System Decontamination and Draining and Radioactive Liquid Handling . . . . . . . . . $\mathrm{H}-24$

H.5.2.1 Time Requirements . . . . . . H-24 
H.5.2.2 Manpower Requirements . . . . . H-25

H.5.3 Costs for System Decontamination and Draining and Radioactive Liquid Handling . . . . . . H-26

H.5.3.1 Costs for Materials . . . . . . H-26

H.5.3.2 Costs for Special Equipment . . . . . H-27

H.5.3.3 Costs for Energy . . . . . . . H-28

H.5.3.4 Costs for Disposal of Wet Solid Wastes . . H-28

H.5.4 External Occupational Radiation Dose for System

Decontamination and Draining and Radioactive Liquid

Handling . . . . . . . . . H-30

H.6 EQUIPMENT DEACTIVATION AND CONTAMINATED AREA ISOLATION • . H-30

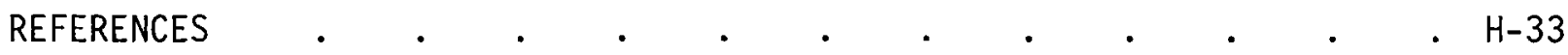

APPENDIX I - IMMEDIATE DISMANTLEMENT DETAILS . . . . . . . I- I

I.1 DISASSEMBLY METHODS . . . . . . . . . . . . I-1

I.1.1 Reactor Building/Primary Containment . . . . I-2

I.1.2 Turbine Generator Building . . . . . . I-7

I.1.3 Radwaste and Control Building . . . . . I-9

I.1.4 Special Tools and Equipment . . . . . . I-9

I.1.5 Summary of Disassembly Methods . . . . . . I-9

I.2 SCHEDULES AND MANPOWER REQUIREMENTS . . . . . . . I-9

I.2.1 Reactor Building/Primary Containment . . . . I-13

I.2.2 Turbine Generator Building . . . . . . I-14

I.2.3 Radwaste and Control Building . . . . . I-14

I.2.4 Overall Schedule and Manpower Requirements . . . I-21

I.3 COSTS FOR IMMEDIATE DISMANTLEMENT . . . . . . . . I-30

I.3.1 Costs for Disposal of Radioactive Materials . . I-32

I.3.1.1 Neutron-Activated Materials . . . . I-33 
I.3.1.2 Contaminated Materials . . . . . I-37

I.3.1.3 Radioactive Wastes . . . . . . I-41

I.3.2 Costs for Staff Labor . . . . . . . I-43

I.3.3 Costs for Energy . . . . . . . . . . . I-43

I.3.4 Costs for Special Tools and Equipment. . . . I-43

I.3.5 Costs for Miscellaneous Supplies . . . . . I-48

I.3.6 Costs for Specialty Contractors . . . . . I-49

I.3.7 Costs for Nuclear Insurance . . . . . . I-49

I.3.8 Costs for Licensing Fees . . . . . . I-50

I.3.9 Other Possible Costs . . . . . . . . I-5I

I.3.9.1 Spent Fue1 Shipment . • . • . . I-51

I.3.9.2 Facility Demolition and Site Restoration . . I-52

I.3.9.3 Deep Geologic Disposal of Highly Activated
Materials. . . . . . . I-52

I.3.9.4 Fuel Channel Disposal . . . . . . I-54

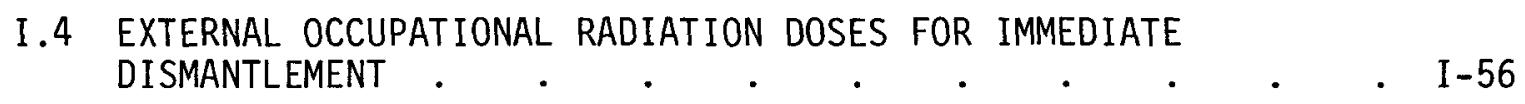

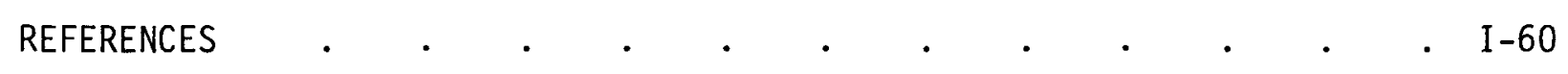

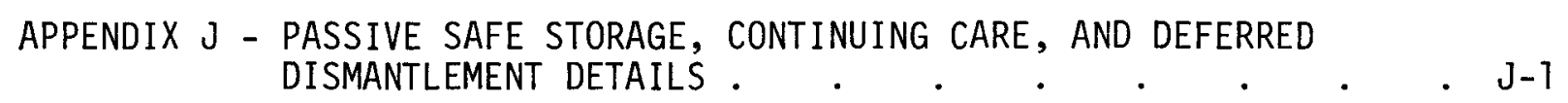

J.1 SELECTION OF PASSIVE SAFE STORAGE • • • • • • • .

J.2 PASSIVE SAFE STORAGE SUPPORTING INFORMATION • . • • J-3

J.2.1 Decontamination, Deactivation, and Sealing Methods . J-3

J.2.2 Spray Painting . • • • • • • • • • J-4

J.2.3 Transfer of Contaminated Equipment and Materials • J-4

J.2.4 Decontamination and Isolation Procedure . . . J-5

J.2.5 Speciar Tools and Equipment . . . . . . J-5 
J.2.6 Essential Systems and Services . . . . . J-6

J.3 PREPARATIONS FOR PASSIVE SAFE STORAGE . . . . .

J.3.1 Preparation of the Reactor Building for Passive

Safe Storage . $. \quad . \quad . \quad . \quad . \quad . \quad . \quad . J$

J.3.2 Preparation of the Turbine Generator Building for

Passive Safe Storage . . . . . . . . J-9

J.3.3 Radwaste and Control Building . . . . . . . J-9

J.3.4 Site and Support Facilities. . . . . . J-10

J.4 PASSIVE SAFE STORAGE SCHEDULES AND MANPOWER ESTIMATES . • $\mathrm{J}-10$

J.4.1 Reactor Building/Primary Containment . . . . . J-11

J.4.2 Turbine Generator Building . . . . . . J-13

J.4.3 Radwaste and Control Building . . . . . J-13

J.4.4 Site and Support Facilities . . . . . . J-13

J.4.5 Summary of Schedule and Manpower Estimates for
Preparations for Passive Safe Storage . . . . J-14

J.4.6 Manpower Estimates for the Continuing Care Period . J-16

J.5 COSTS FOR PASSIVE SAFE STORAGE . . . . . . . J-17

J.5.1 Costs for Preparations for Passive Safe Storage . . J-17

J.5.1.1 Costs for Disposal of Radioactive Materials . J-19

J.5.1.2 Costs for Staff Labor . . . . . J-20

J.5.1.3 Costs for Energy . . . . . . . . J-23

J.5.1.4 Costs for Special Tools and Equipment . . J-24

J.5.1.5 Costs for Miscellaneous Supplies . • • J-25

J.5.1.6 Costs for Specialty Contractors . . . J J-26

J.5.1.7 Costs for Nuclear Insurance . . . . . J-27

J.5.1.8 Costs for Licensing Fees . . • • • • J-27

J.5.1.9 Other Possible Costs . . . . . . . J-27 
J.5.2 Costs for Continuing Care During Passive Safe

Storage . . . . . . . . J J-29

J.6 ESTIMATED OCCUPATIONAL RADIATION DOSES FOR PASSIVE SAFE

STORAGE . . . . . . . . . . . . J-33

J.6.1 Estimated External Occupational Radiation Dose

During Preparations for Passive Safe Storage . . J-34

J.6.2 Estimated Occupational Radiation Dose During the

Continuing Care Period. . . . . . . J-35

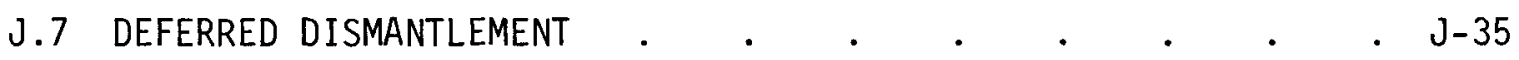

J.7.1 Costs for Deferred Dismantlement . . . . . J-40

J.7.2 Occupational Radiation Dose from Deferred
Dismantlement . . . . J J .42

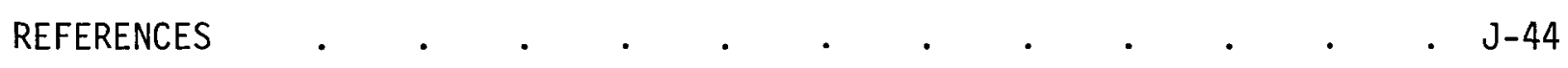

APPENDIX K - ENTOMBMENT DETAILS . . . . . . . . . . . $k-1$

K.1 POSTULATED ENTOMBMENT SCENARIOS . . . . . . . . .

K.1.1 Entombment Scenarios . . . . . . . . K-4

K.1.1.1 Scenario I. . . . . . . . . . . K-5

K.1.1.2 Scenario 2 . . . . . . . . . . . $\mathrm{K}-5$

K.1.2 Adaptation of the Primary Containment Vessel and
Biological Shield to Entombment. . . K-5

K.1.3 Storage Volume Within the Entombment Structure . . K-6

K.1.4 Special Tools and Equipment . . . . . . K-10

K.1.5 Summary of Disassembly Methods . . . . . . K-11

K.2 ENTOMBMENT SCHEDULES AND MANPOWER ESTIMATES . . . . . $\mathrm{k}-11$

K.2.1 Scenario-1 Entombment . . . . . . . K-12

K.2.2 Scenario-2 Entombment . . . . . . . K-17

K.3 COSTS FOR ENTOMBMENT . . . . . . . . . . . K-17

K.3.1 Costs for Disposal of Radioactive Materials . . K-19 
K.3.1.1 Neutron-Activated Materials . . . . K-20

K.3.1.2 Contaminated Materials . . . . . . K-23

K.3.1.3 Radioactive Wastes . . . . . . K-27

K.3.2 Costs for Staff Labor . . . . . . . K-27

K.3.3 Costs for Energy . . . . . . . . . K-29

K.3.4 Costs for Special Tools and Equipment . . . . K-29

K.3.5 Costs for Miscellaneous Supplies. . . . . . K-29

K.3.6 Costs for Specialty Contractors . . . . . K-30

K.3.7 Costs for Nuclear Insurance . . . . . . K-31

K.3.8 Costs for Licensing Fees . . . . . . . K-31

K.3.9 Costs for Continuing Care and Possible Deferred
Dismantlement . . K-32

K.3.10 Other Possible Costs . . . . . . . . K-33

K.3.10.1 Spent Fuel Shipment . . . . . . K-33

K.3.10.2 Facility Demolition and Site Restoration . K-34

K.3.10.3 Deep Geologic Disposal of Highly Activated
Materials. K-34

K.3.10.4 Fuel Channel Disposal . . . . . . K-35

K.4 EXTERNAL OCCUPATIONAL RADIATION DOSE FOR ENTOMBMENT * . K-35 REFERENCES . APPENDIX L - DEMOLITION AND SITE RESTORATION DETAILS . . . . . L L

L.1 ASSUMPTIONS FOR DEVELOPMENT OF COST ESTIMATES . . . . L-1

L.2 FACTORS CONSIDERED IN ESTIMATION OF DEMOLITION COSTS . . L-2

L.2.1 Demolition Methods . . . . . . . . . . L-2

L.2.2 Problem Areas in Estimation of Demolition Costs . L-3

L.2.3 Salvage Considerations . . . . . . $\mathrm{L}-3$ 
L.2.4 Transport of Demolition Debris . . . . . $L-4$

L.2.5 Labor Rates. . . . . . . . . L L-4

L.2.6 Equipment Requirements for Demolition . . . L-5

L.3 DEMOLITION AND SITE RESTORATION COSTS . . . . . . L L-6

L.3.1 Reactor Building and Primary Containment Vessel . L-7

L.3.2 Turbine Generator Building . . . . . . L-8

L.3.3 Radwaste and Control Building . . . . . L-8

L.3.4 Diesel Generator Building . . . . . . L-9

L.3.5 Service Building. . . . . . . . L-9

L.3.6 Cooling Towers . . . . . . . . L-10

L.3.7 Circulating Water Pumphouse . . . . . L-10

L.3.8 Spray Pond Complex . . . . . . . $\mathrm{L}-11$

L.3.9 Makeup Water Pumphouse . . . . . . L-11

L.3.10 Office Building . . . . . . . . . L L-11

L.3.11 Warehouse . . . . . . . . . L-11

L.3.12 Guard House . . . . . . . . . L L-11

L.3.13 Gas Bottle Storage Building . . . . . L-11

L.3.14 Site Restoration. . . . . . . . L-11

L.4 AREAS FOR POTENTIAL COST REDUCTION . . . . . . . L-12

L.4.1 Crushing of Concrete . . . . . . . L-12

L.4.2 Degradation of Concrete by Heating . . . . L-12

REFERENCES . . . . . . . . . . . . . . . L-14

APPENDIX M - COST ESTIMATING BASES . . . . . . . . . . $M-1$

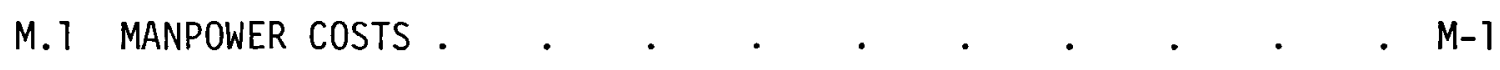

M.2 RADIOACTIVE WASTE PACKAGING COSTS . . . . . . . M- 
M.2̇.1 Shipping Containers Costs . . . . . . M-1

M.2.2 Additional Shielding Costs . . . . . . M-3

M.2.3 Solidifying Agent Costs . . . . . . M-3

M.3 CASK CHARGES . . . . . . . . . . M-3

M.4 TRANSPORATION COSTS . . . . . . . . . . . . . . M-4

M.4.1 Shipment by Exclusive-Use Trucks . . . . . M-4

M.4.2 Shipment by Rail . . . . . . . . . M-8

M.5 WASTE DISPOSAL COSTS . . . . . . . . . . . M-8

M.5.1 Costs for Shallow-Land Burial . . . . . M-8

M.5.2 Costs for Deep Geologic Disposal of Highly
Activated Reactor Components . . . . . M-8

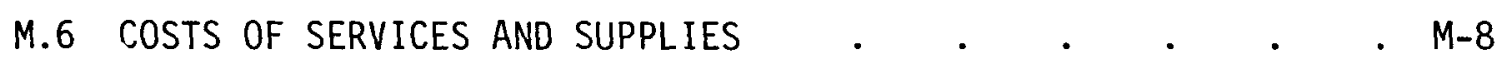

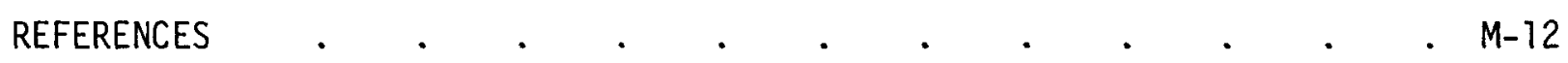

APPENDIX N - PUBLIC RADIOLOGICAL SAFETY ASSESSMENT DETAILS • • . $\quad \mathrm{N}-1$

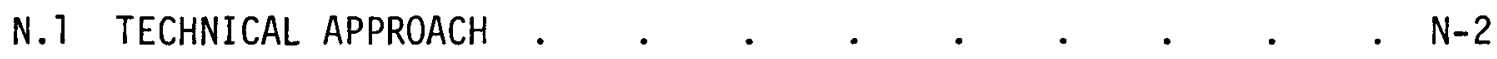

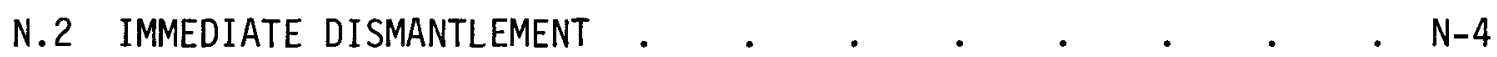

N.2.1 Routine Immediate Dismantlement Tasks . . . . . N-4

N.2.1.1 Methods for Calculating Atmospheric Releases of Radioactivity . . . . . . N-6

N.2.1.2 Atmospheric Releases from Immediate
Dismantlement Tasks. . . . . . . N-20

N.2.1.3 Public Radiation Doses from Routine
Immediate Dismantlement Tasks . . . . N-20

N.2.2 Postulated Accidents During Immediate Dismantlement . N-33

N.2.2.1 Postulated Operational Accidents . . . N-44

N.2.2.2 Natural Phenomena . . . . . . . N-53

N.2.2.3 Aircraft Crashes . . . . . . N-54 
N.2.2.4 Man-Caused Events . . . . . . $\mathrm{N}-55$

N.2.2.5 Radiation Doses from Postulated Immediate Dismantlement Accidents . . . . . $\mathrm{N}-55$

N.3 PASSIVE SAFE STORAGE $. \quad . \quad$. . . . . . . N-55

N.3.1 Routine Tasks During Preparations for Passive Safe Storage . . . . . . . . . . N-57

N.3.1.1 Methods and Data for Calculating Atmospheric Releases of Radioactivity. . . . . N-57

N.3.1.2 Atmospheric Releases from Preparations for Passive Safe Storage . . . . . . N-59

N.3.1.3 Public Radiation Doses from Routine Tasks During Preparations for Passive Safe Storage . N-59

N.3.2 Postulated Accidents During Preparations for Passive Safe Storage. . . . . . . . . . $\mathrm{N}-59$

N.3.3 Continuing Care . . . . . . . . . $\mathrm{N}-65$

N.3.4 Deferred Dismantlement . . . . . . . $\mathrm{N}-65$

N.4 ENTOMBMENT

N.4.1 Routine Entombment Tasks . . . . . . . N-66

N.4.1.1 Methods for Calculating Atmospheric Releases
of Radioactivity . . . . . N-67

N.4.1.2 Atmospheric Releases from Entombment . . N-68

N.4.1.3 Public Radiation Doses from Routine

Entombment . . . . . . . . $\mathrm{N}-69$

N.4.2 Postulated Accidents During Entombment . . . N-69

N.5 RADIATION DOSES FROM ROUTINE TRANSPORTATION TASKS . . . $\mathrm{N}-74$

N.5.1 Technical Approach . . . . . . . . $\mathrm{N}-74$

N.5.1.1 Rail Shipments of Spent Fuel . . . . $\mathrm{N}-75$

N.5.1.2 Truck Shipments of Radioactive Waste . . N-76

N.5.2 Transportation Accidents . . . . . . . $\mathrm{N}-76$ 
N.5.2.1 Calculations of the Airborne Radioactive Concentration from a Transportation Accident . N-78

N.5.2.2 Accidents During Rail Transportation of Spent Fuel . . . . . . . . $\mathrm{N}-80$

N.5.2.3 Accidents During Truck Transportation of Radioactive Wastes . . . . . . N-82

REFERENCES

APPENDIX 0 - DETAILS OF ALTERNATE STUDY BASES . . . . . . . $0-1$

0.1 SENSITIVITY OF DECOMMISSIONING COSTS AND RADIATION DOSES

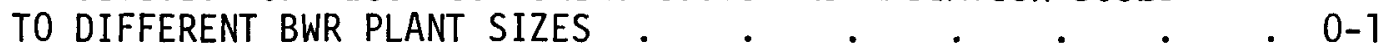

0.1.1 Development of the Scaling Factor Relationship . . 0-2

0.1.1.1 BWR Power Plants Used . . . . . . 0-2

0.1.1.2 BWR Plant Components Used . . . . . . 0-3

0.1.1.3 Scaling Factor Methodology Used . . . 0-3

0.1.1.4 Development of the Scaling Factor
Relationship . . . . . . 0-5

0.1.1.4.1 Component-Specific Scaling Factors and Reference-Plant Dismantlement

Costs for the Reactor Vessel. . . 0-5

0.1.1.4.2 Component-Specific Scaling Factors and Reference-Plant Dismantlement

Costs for the Reactor Vessel Internals . 0-7

0.1.1.4.3 Component-Specific Scaling Factors

and Reference-Plant Dismantlement

Costs for the Reactor Building . . 0-9

0.1.1.4.4 Plant-Specific Scaling Factors for
the Selected BWR Power Plants . . 0-24

0.1.1.4.5 Scaling Factor Relationship . . . 0-24

0.1.2 Application of the Scaling Factor Relationship . . 0-26

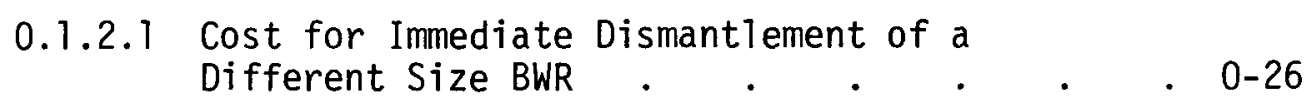

0.1.2.2 Cost for Passive Safe Storage of a . . . . 0-26
Different Size BWR . . . . 
0.1.2.3 Cost for Entombment of a Different Size BWR . 0-29

0.1.2.4 Radiation Doses for Decommissioning a Different Size BWR . $. \quad . \quad . \quad . \quad 0-31$

0.1.3 Cost for Demolition of a Different Size BWR . . 0-31

0.1.3.1 Reactor Building and Primary Containment

Demolition Cost. . . . . . . 0-33

0.1.3.2 Turbine Generator Building Demolition Cost . 0-35

0.1.3.3 Cooling Tower Demolition Cost . . . . 0-36

0.1.3.4 Cost for Demolition of a Different Size BWR . 0-37

0.2 SENSITIVITY OF OCCUPATIONAL RADIATION DOSES AND

DECOMMISSIONING COSTS TO INCREASED RADIATION DOSE RATES • $0-38$

0.2.1 Occupational Radiation Doses . . . . . 0-38

0.2 .2 Decommissioning Costs . . . . . . . $0-42$

0.2.2.1 Staff Labor Costs . . . . . . . 0-42

0.2.2.2 Chemical Decontamination Costs . . . . 0-44

0.2.2.3 Disposal Costs . . . . . . . . . $0-45$

0.2.2.4 Conclusions . . . . . . . . . $0-46$

0.3 SENSITIVITY OF IMMEDIATE
CONTRACTUAL ARRANGEMENTS
.

0.3.1 Postulated Organization for Decommissioning by
Contract . . . 0 . . . . . . .

0.3.2 Impact on Immediate Dismantlement Costs . . . 0-47

0.3.2.1 Contractual Considerations . . . . 0-49

0.3.2.2 Contractor Overhead Rates. . . . . 0-51

0.3.2.3 Mobilization and Demobilization . . . 0-51

0.3.2.4 Impact on Immediate Dismantlement Costs . . 0-53

0.4 SENSITIVITY OF IMMEDIATE DISMANTLEMENT COSTS TO WASTE
DISPOSAL CHARGES..
.

0.4.1 Impact of Increases in Shallow-Land Burial Charges . 0-54

0.4.2 Impact of Higher Deep Geologic Disposal Costs . . 0-55 


\subsection{SENSITIVITY OF IMMEDIATE DISMANTLEMENT COSTS TO DIFFERENT}

BWR CONTAINMENT DESIGNS $. \quad . \quad . \quad . \quad . \quad \cdot \quad \cdot \quad \cdot 0-57$

0.5.1 BWR Primary Containment Design Description . . . 0-57

0.5.1.1 Mark I Containment Design . . . . . 0-58

0.5.1.2 Mark II Containment Design . . . . 0-60

0.5.1.3 Mark III Containment Design . . . . 0-61

0.5.2 BWR Containment Dismantlement Cost Comparisons . . 0-62

0.5.2.1 Water Treatment and Disposal . . . . 0-63

0.5.2.2 Decontamination of Wetwel1 Steel Surfaces . 0-63

0.5.2.3 Removal and Disposal of Contaminated Concrete Surfaces . . . . . . . 0-63

0.5.2.4 Removal and Disposal of Contaminated Concrete . 0-64

0.5.2.5 Overall Effect of Containment Design on

Dismantlement Cost . . . . . . 0-65

REFERENCES . 
8

8 


\section{FIGURES}

B.4-1 Average $\left(\bar{x} / Q^{\prime}\right)$ Values Versus Distance in a Sector from the

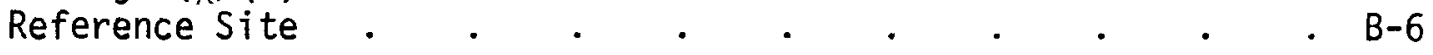

C.1-1 Site Layout of the Reference BWR Plant Facilities . • • C-2

C. 1-2 Functional Diagram of a Boiling Water Reactor . . . . . C-4

C.2-1 Reactor Building Section . . . . . . . . . . . C-9

C.2-2 Reactor Building Floor Plans - Sheet 1 . . . . . C-11

C.2-3 Reactor Building Floor Plans - Sheet 2 . . . . . . C-13

C.2-4 Reactor Building Elevation Sections . . . . . . . . c-15

C.2-5 Reactor Building Foundation . . . . . . . . . . C-18

C.2-6 Major Primary Containment Vessel Penetrations . . . . . C-23

C.2-7 Turbine Generator Building Floor Plan, Elevation $134.4 \mathrm{~m}$. . C-29

C.2-8 Turbine Generator Building Floor Plan, Elevation $143.6 \mathrm{~m}$. . . C-31

C.2-9 Turbine Generator Building Floor Plan, Elevation $152.7 \mathrm{~m}$. . C-33

C.2-10 Turbine Generator Building, Elevation Sections . . . . C-35

C.2-11 Radwaste and Control Building Floor Plans - Sheet 1 . . . C-39

C.2-12 Radwaste and Control Building Floor Plans - Sheet 2 . . . C-41

C.2-13 Radwaste and Control Building, Elevation Sections . . . . C-43

C.3-1 Reactor Vessel and Internals . . . . . . . . . C-51

C.3-2 Reactor Coolant Recirculation Jet Pump Assembly _ . . C-56

C.3-3 Reactor Water Recirculation System . . . . . . . . . C-59

C.3-4 Reactor Water Recirculation Pump . . . . . . . . C-61

C.3-5 Spent Fuel Storage Facilities . . . . . . . . . . . C-63

C.3-6 Main Steam Turbine and Generator . . . . . . . . C-67

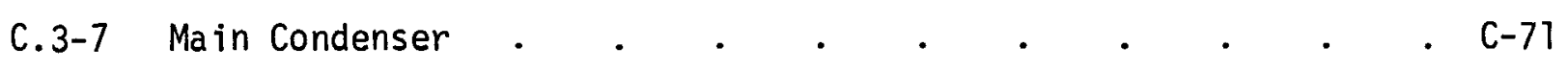

C.4-1 Reactor Building HVAC System . . . . . . . . . . . . C-87 
C.4-2 Primary Containment Cooling System . . . . . . . . C $\quad$ C 95

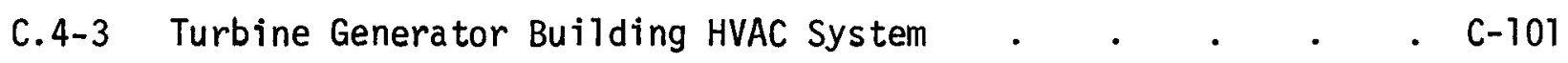

C.4-4 Radwaste Area HVAC System . . . . . . . . . C-107

C.5-1 Liquid and Solid Radwaste System Process Diagram . . . . C-113

C.5-2 Liquid Radwaste System Block Flow Diagram . . . . . . C -115

C. 5-3 Solid Radwaste System Process Diagram . . . . . . . C-119

C. 5-4 Reactor Building Standby Gas Treatment System . . . . . C-123

D. 1-1 Radiation Dose Rates in the Reactor Building - Sheet 1 . . D-3

D. 1-2 Radiation Dose Rates in the Reactor Building - Sheet 2 . . D-5

D.1-3 Radiation Dose Rates in the Turbine Generator Building -
Elevation $134.4 \mathrm{~m}$..$\quad \cdot \quad \cdot \quad \cdot \quad \cdot \quad$.

D. 1-4 Radiation Dose Rates in the Turbine Generator Building -
Elevation $143.6 \mathrm{~m}$

D.1-5 Radiation Dose Rates in the Turbine Generator Building -
Elevation $152.7 \mathrm{~m} . . \quad . \quad$. $0-11$

D.1-6 Radiation Dose Rates in the Radwaste and Control Building -
Sheet 1 . . . . . . . D . . . . . . .

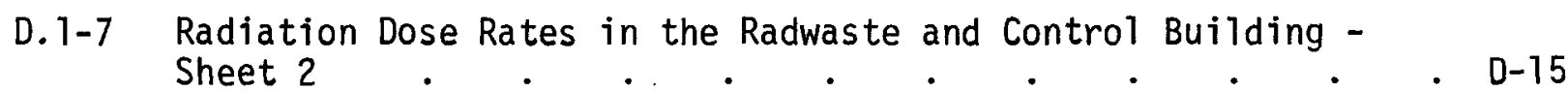

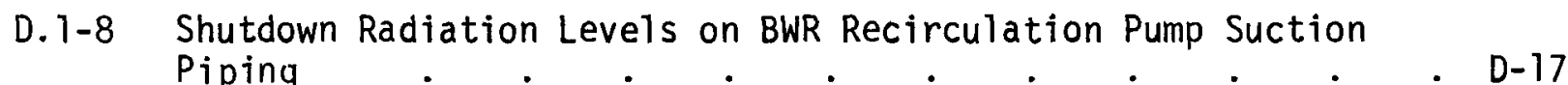

D. Concrete Surface Contamination in the Reactor Building -
Sheet 1
.

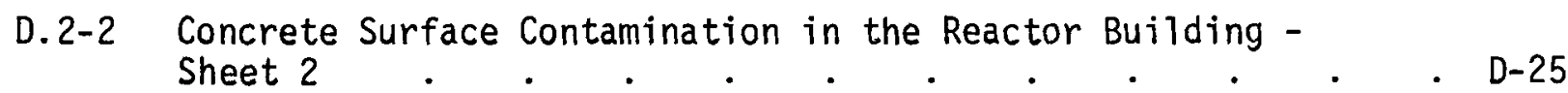

D.2-3 Concrete Surface Contamination in the Turbine Generator
Building - Elevation $134.4 \mathrm{~m}$. . $_{\text {. }}$. . . D-27

D.2-4 Concrete Surface Contamination in the Turbine Generator
Building - Elevation $134.4 \mathrm{~m}$. . $_{\text {. }}$. D-29

D.2-5 Concrete Surface Contamination in the Turbine Generator
Building - Elevation $152.7 \mathrm{~m} . . \quad . \quad$. . . . . . . . 
D.2-6 Concrete Surface Contamination in the Radwaste and Control

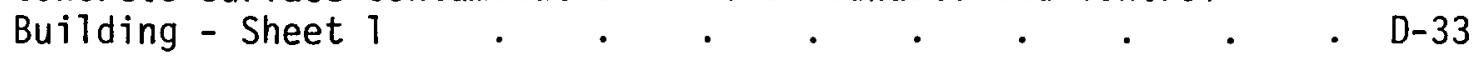

D.2-7 Concrete Surface Contamination in the Radwaste and Control
Building - Sheet 2 . . . D-35

E.1-1 BWR Model for Radial Neutron Flux Distribution Calculation . E-8

E.1-2 BWR Model for Axial Neutron Flux Distribution Calculation . . E-9

E.1-3 Radial Thermal Neutron Flux Distribution at Core Axial

Midplane . . . . . . . . . . . . E-10

E.1-4 Axial Thermal Neutron Flux Distribution . . . . . E-11

E.1-5 Calculated Buildup of Selected Activation Products in the Core Shroud as a Function of Time at Full Power. . . . . E-14

E.1-6 Time Dependence of Radioactivity and Dose Rate in the NeutronActivated Core Shroud . . . . . . . . . E-23

E.2-1 Radioactive Decay of Deposited Internal Surface Contamination . E-27

E.2-2 Calculated Contact Dose Rates for BWR Piping as a Function of Deposited Internal Surface Radioactivity . . . . . E-28

E.2-3 Calculated Contact Dose Rates for Air-Filled and Water-Filled. Schedule 20, 914-mm-OD BWR Pipe as a Function of Deposited Internal Surface Radioactivity . . . . . . . E-29

E.2-4 Calculated Contact Dose Rates from Schedule 120 and Schedule 160, 610-mm-OD BWR Pipe as a Function of Deposited Internal Surface Radioactivity. . . . . . . . . E-30

E.2-5 Relative Dose Rate as a Function of Distance in Air from Pipe Outer Surface . . . . . . . . . . . E-31

E.2-6 Cross Section of the Cylindrical Model of a Nonregenerative
Heat Exchanger . . . . . . . E . . . E3

E.2-7 Calculated Contact Dose Rate from a Nonregenerative Heat Exchanger as a Function of Deposited Internal Surface Radioactivity . . . . . . . . . . E-34

E.2-8 Calculated Dose Rates in Air $1 \mathrm{~m}$ Above Structural Surfaces as
a Function of Deposited External Surface Radioactivity . E-40

F.3-1 Dose Rate as a Function of Room Volume for a ${ }^{60}$ Co Deposition
of $1 \mathrm{Ci} / \mathrm{m}^{2}$. $. .5-16$

F.3-2 Time Dependent Surface Resuspension Factor for the Site . . F-18

G.T-1 Schematic Diagram of an Electropolishing Cell . . . . G-4 
G.1-2 Schematic of Concrete Spaller . . . . . . . G-13

G.2-1 P1asma-Arc Torch Schematic Diagram . . . . . . G-16

G.2-2 Arc Saw Schematic Diagram . . . . . . . . G-19

G.2-3 Cross Section of Typically Positioned Linear-Shaped Charge . G-21

G.3-1 Typical Plywood Shipping Container . . . . . . G-23

G.3-2 Radiation Dose Limits for Closed Exclusive-Use Vehicles . . G-25

G.3-3 Typical Shielded Shipping Containers . . . . . . . G-26

G.4-1 Vacuum Collection System Schematic . . . . . . G-29

G.4-2 Portable Filtered Ventilation Enclosure . . . . . G-30

G.4-3 Portable Filtered Fume Exhauster . . . . . . . G-31

H.1-1 Decommissioning Staff Organization . . . . . . H-2 H.5-1 Refèrence BWR Reactor Piping Systems Selected for Chemical
Decontamination . . . . . H-16

1.1-1 Cutting Pattern for Removal of the Reactor Vessel Internals
and the Reactor Vessel. . . . . . . . . .

I.2-1 Task Schedule and Sequence and Decommissioning Worker Requirements for Immediate Dismantlement of the Reactor Building/Primary Containment . . . . . . . I-15

I.2-2 Task Schedule and Sequence and Decommissioning Worker Requirements for Immediate Dismantlement of the Turbine Generator Building . . . . . . . . . I-17

I.2-3 Task Schedule and Sequence and Decommissioning Worker Requirements for Immediate Dismantlement of the Radwaste and Control Building . . . . . . . . . . . I-19

I.2-4 Overall Task Schedule and Sequence for Immediate Dismantlement
of the Reference BWR . . . I-23

J.4-1 Task Schedule and Sequence of the Preparations for Passive
Safe Storage. . . . . . . J . . . . . . .

J.4-2 Staff Organization for the Continuing Care Period . . . J-16

J.5-1 Postulated Security and Administrative Notification and
Reporting Process. . . . . . . J J 34 
K.1-1 Postulated Entombment Structure for the Reference BWR . . K-3

K.2-1 Overall Schedule and Sequence and Decommissioning Worker Requirements for Scenario-1 Entombment Tasks . . . . K-13

N.5- 1 Pasquill Type $F$ Centerline $X / Q$ Values for Building-Wake Modification Factors Versus Downwind Distance . . . . . N-81

0.3-1 Postulated Organization for Decommissioning by Contract . . 0-48

0.5-1 BWR Mark I Containment . . . . . . . . . . . . 0-59

0.5-2 BWR Mark II Containment . . . . . . . . . . . . 0-60

0.5-3 BWR Mark III Containment . . . . . . . . . . . 0-62 



\section{$\underline{\text { TABLES }}$}

A.2-1 Annual and Total Revenue Requirements for the Prepayment Alternative as Functions of Rates of Return and Interest Rates

A.2-2 Annual and Total Revenue Requirements for the Sinking Fund Alternative as Functions of Rates of Return and Tax

Treatment

A.3-1 Revenue Requirements for the Financing Alternatives . . . A-7

A.3-2 Revenue Requirements for the Passive Safe Storage/Deferred

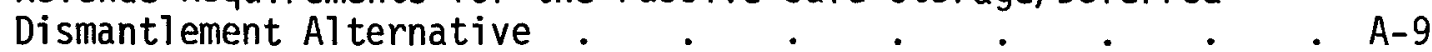

B.2-1 Population Distribution Around the Reference Site for the Year 2000

B.4-1 Monthly Meteorological Statistics at the Reference Site . . B-3

C.2-1 Estimated Structural Material Quantities in the Reference

BWR Facilities . $. \quad . \quad . \quad . \quad . \quad . \quad . \quad . \quad$ C-7

C.2-2 Primary Containment Vessel Penetration Information . . . C-21

C.3-1 Contaminated Equipment: Reactor Building . . . . . C C-50

C.3-2 Reactor Vessel Design Parameters . . . . . . . . C-53

C.3-3 Reactor Water Recirculation System Design Parameters . . C-60

C.3-4 Contaminated Equipment: Turbine Generator Building . . . C-66

C.3-5 Physical Parameters of the Main Turbine Components . . . C-69

C.3-6 Contaminated Equipment: Radwaste and Control Building . . C-73

C.3-7 Contaminated Piping and Valves: Reactor Building . . . . C-75

C.3-8 Contaminated Piping and Valves: Primary Containment . . C-77

C.3-9 Contaminated Piping and Valves: Turbine Building . . . C C-79

C.3-10 Contaminated Piping and Valves: Radwaste and Control . . C-81

C.4-1 Reactor Building HVAC System Component Design Data . . . C-89

C.4-2 Primary Containment Cooling System Component Design Data . . C-97 
C.4-3 Turbine Generator Building HVAC System Component Design Data . C-100

C.4-4 Radwaste Area HVAC System Component Design Data . . . . C-109

C.5-1 Liquid Radwaste Equipment Design Data . . . . . . C-117

C.5-2 Liquid Radwaste Equipment Performance Factors . . . . C-118

C.5-3 Wet Solid Radwaste Equipment Design Data . . . . . C-121

C.6-1 Acronyms and Abbreviations in Appendix C . . . . . C-124

C.6-2 Equipment Key Numbers in Appendix C . . . . . . C-125

E.1-1 Reference Radionuclide Inventory 1, Neutron-Activated Stainless Steel . . . . . . . . . . . E-3

E.1-2 Reference Radionuclide Inventory 2, Neutron-Activated Carbon Steel • . . . . . . . . . . . E-4

E.1-3 Reference Radionuclide Inventory 3, Neutron-Activated Concrete . E-5

E.1-4 Material Densities for Calculating Neutron Flux Distributions . E-7

E.1-5 Material Compositions Used in Radionuclide Inventory Calculations. . . . . . . . . . . E-13

E.1-6 Estimated Total Radioactivity in Neutron-Activated Structural Components . . . . . . . . . . . E-15

E.1-7 Calculated Radiation Dose Rates from Selected Neutron-Activated Reference BWR Components . . . . . . . . E-22

E.2-1 Reference Radionuclide Inventory 4, BWR Internal Surface Contamination

E.2-2 Activated Corrosion Product Data . . . . . . . E-26

E.2-3 Typical Reference BWR Piping Characteristics . . . . E-28

E.2-4 Piping Contact Dose Rate/Internal Radioactivity Deposition E-32

E.2-5 Estimated Contaminated Piping Internal Radioactivity Deposition . . . . . . . . . . . E-33

E.2-6 Summary of Equipment Internal Radioactivity Deposition Levels . E-35

E.2-7 Estimated Contaminated BWR Equipment Internal Radioactivity Deposition 
E.2-8 Reactor Water Radionuclide Concentrations in an Operating BWR

E.2-9 Reference Radionuclide Inventory 5, BWR Structural Surface External Contamination . . . . . . . . . . E-39

E.2-10 Estimated Structural Surface External Contamination in the Reference BWR . . . . . . . . . . E-41

E.2-11 Annual Airborne Radionuclide Release Rates from the Reference BWR

E.2-12 Reference Radionuclide Inventory 6, Reference BWR Site Surface Contamination

F.1-1 Solubility Classes for the Elements Present in the Radionuclide Inventory at Final Shutdown of the Reference BWR . . . F-4

F.2-1 Parameters Used for Calculation of Radiation Doses from Consumption of Foods . . . . . . . . . . F-6

F.4-1 Estimated Maximum Annual Dose to the Maximum-Exposed Individual Working in the Decommissioned BWR Facility at Various Times After Shutdown

F.4-2 Estimated Maximum Annual Dose to the Maximum-Exposed Individual Residing on the Decommissioned BWR Site at Various Times After Shutdown

G.1-1 Selected Chemical Decontamination Methods for BWR Systems . . G-2

G. 1-2 Concrete Removal Methods . . . . . . . . . . G-7

G.1-3 Explosives for Bulk Concrete Removal . . . . . . . G-10

G.1-4 Comparison of Concrete Surface Removal Techniques . . . . G-11

G.2-1 Typical Conditions for Plasma-Arc Cutting of Stainless Steel in Air . $. \quad . \quad . \quad . \quad . \quad . \quad . \quad . \quad . \quad . \quad$ G-18

G.6-1 Recommended Basic Environmental Monitoring Program for the Active Decommissioning Period . . . . . . . . G-39

H.4-1 Systems and Services Required During Decommissioning . • . H-11

H.5-1 Reference BWR Liquid and Solid Radwaste Equipment Selected for Chemical Decontamination . . . . . . . H-17

H.5-2 Estimated Volumes of Chemical Decontamination Solutions . . H-19 
H.5-3 Estimated Volumes of Contaminated Water from Water-Jet

Cleaning . . . . . . . . . . . H-20

H.5-4 Estimated Volumes of Contaminated Water from System Draining Activities . . . . . . . . . . . . H-22

H.5-5 Time Requirements for System Decontamination and Draining and Radioactive Liquid Handling . . . . . . . $\mathrm{H}-25$

H.5-6 Manpower Requirements for System Decontamination and Draining and Radioactive Liquid Handling . . . . . . . H-26

H.5-7 Costs for Materials for System Decontamination and Draining and Radioactive Liquid Handling . . . . . . . . H-27

H.5-8 Costs for Special Equipment for System Decontamination and Draining . . . . . . . . . . . . H-27

H.5-9 Costs for Energy for System Decontamination and Draining and Radioactive Liquid Handling . . . . . . . H-28

H.5-10 Costs for Disposal of Wet Solid Wastes . . . . . . . H-29

H.5-11 Estimated External 0ccupational Radiation Doses for System Decontamination and Draining and Radioactive Liquid Handling . H-31

I.1-1 Special Tools and Equipment for Immediate Dismantlement . . I-10

I.1-2 Immediate Dismantlement Removal Data and Methods . . . I-11

I.2-1 Dedicated Manpower Requirements for Immediate Dismantlement

I.2-2 Overal1 Decommissioning Worker Requirements for Immediate I-27

I.2-3 Staff Labor Requirements for Immediate Dismantlement • • . I-29

I.3-1 Summary of Estimated Costs for Immediate Dismantlement • . I-31

$\begin{array}{llll}\text { I.3-2 } & \text { Summary of Information Regarding Disposal of Radioactive } \\ \text { Materials from Immediate Dismantlement } & . & . & .\end{array} \quad$ I-33

I.3-3 Costs for Disposal of Neutron-Activated Materials . . . . I-35

I.3-4 Costs for Disposal of Contaminated Materials . . . . . I-39

I.3-5 Costs for Disposal of Dry Solid Wastes . . . . . . . I-42

I.3-6 Costs for Staff Labor During Immediate Dismantlement • . I-44 
I.3-7 Dedicated Manpower Costs for Immediate Dismantlement . . I-45

I.3-8 Costs for Energy During Immediate Dismantlement . . . I-46

I.3-9 Costs for Special Tools and Equipment for Immediate

Dismantlement $\cdot \quad \cdot \quad \cdot \quad \cdot \quad \cdot \quad \cdot \quad \cdot \quad \cdot \quad \cdot$ I-47

I.3-10 Costs for Miscellaneous Supplies During Immediate
Dismantlement . . . . . . . . I-48

I.3-11 Costs for Specialty Contractors During Immediate

I.3-12 Costs for Nuclear Liability Insurance During Immediate I-50

I.3-13 Costs for Licensing Fees During Immediate Dismantlement . . I-50

I.4-1 Estimated Occupational Radiation Doses for Immediate

Dismantlement . . . . . . . . . . I-57

J.2-1 Special Tools and Equipment for Preparations for Passive
Safe Storage . . . J . . . . . . . . .

Systems and Services Required During the Continuing Care
Period. . J . . . . . .

3.4-1 Staff Labor Requirements for Preparations for Passive Safe Storage . . . . . . . . . . . . J-15

J.4-2 Estimated Annual Manpower Requirements for the Continuing J J

J.5-1 Summary of the Estimated Costs for Preparations for Passive Safe Storage $. \quad . \quad . \quad . \quad . \quad . \quad . \quad . \quad . \quad J-18$

J.5-2 Summary of Shipments, Volumes, and Costs for Disposal of Radioactive Materials During Preparations for Passive Safe Storage . . . . . . . . . . J-19

J.5-3 Costs for Disposal of Dry Solid Wastes . . . . . J-2l

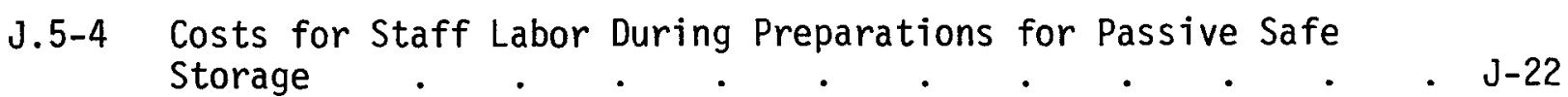

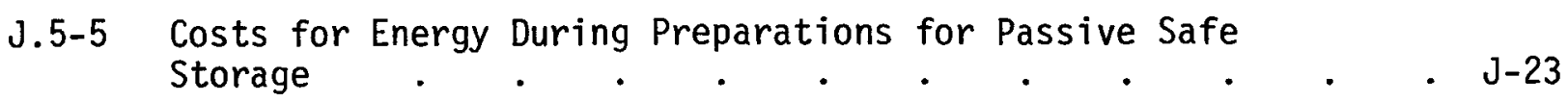

J.5-6 Costs for Special Tools and Equipment for Preparations for Passive Safe Storage . . . . . . . . . . J-24 
J.5-7 Costs for Miscellaneous Supplies During Preparations for

Passive Safe Storage . . . . . . . . . J-25

J.5-8 Costs for Specialty Contractors During Preparations for

Passive Safe Storage . . . . . . . . . J-26

J.5-9 Costs for Nuclear Liability Insurance During Preparations for

Passive Safe Storage . • . . . • • . . J-27

J.5-10 Costs for Licensing Fees During Preparations for Passive Safe

Storage $. \quad \cdot \quad \cdot \quad \cdot \quad \cdot \quad \cdot \quad \cdot \quad \cdot \quad \cdot \quad \cdot \quad \cdot \mathrm{J}-28$

J.5-11 Estimated Annual Costs for Surveillance, Maintenance, and

Security During Continuing Care . . . . . . . J-30

J.5-12 Estimated Annual Costs for an Ongoing Environmental

Monitoring Program During Continuing Care . . . . . J-31

J.5-13 Estimated Security Costs During Continuing Care . . . J-32

J.6-1 Estimated Occupational Doses for Preparations for Passive

Safe Storage . . . . . . . . . . J-37

J.6-2 Estimated Cumulative Occupational External Radiation Dose

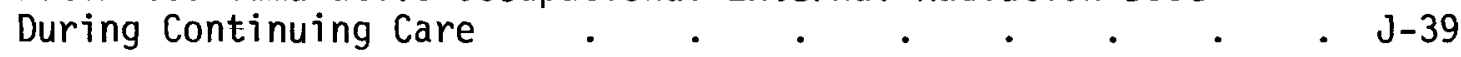

J.7-I Burial Volumes of Radioactive Materials from Decommissioning . J-4l

J.7-2 Estimated Dismantlement Costs . . . . . . . J-42

J.7-3 Total Costs for Various Decommissioning Alternatives . . J-42

J.7-4 Estimated Occupational Radiation Dose from Various

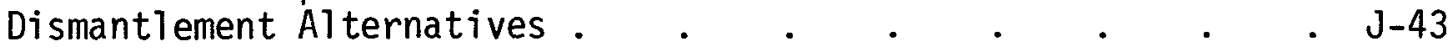

K.1-1 Estimated Storage Volume Within the Primary Containment
Vesse1. . . . . . . K-7

Kstimated Volumes of Contaminated Material Outside the Primary
Containment Vessel . . . . . . . . .

K.1-3 Entombment Disassembly Data and Methods . . . . . K-11

K.2-1 Manpower Requirements for Scenario-1 Entombment Tasks . . K-15

K.2-2 Staff Labor Requirements for Scenario-1 Entombment . . . K-16

K.3-1 Summary of Estimated Costs for Entombment . . . . . K-18

K.3-2 Summary Information Regarding Offsite Disposal of
Radioactive Materials from Entombment
. . . . . . K-20 
K.3-3 Costs for Disposal of Neutron-Activated Materials

(Scenario-1 Entombment) . . . . . . . . K-21

K.3-4 Costs for Disposal of Contaminated Materials Assumed to be Shipped Offsite (Scenario-1 Entombment) . . . . . K-25

K.3-5 Costs for Staff Labor During Entombment (Scenario 1) . . . K-28

K.3-6 Costs for Energy During Entombment . . . . . . K-30

K.3-7 Costs for Specialty Contractors During Entombment . . . K-31

K.3-8 Costs for Licensing Fees During Entombment . . . . . K-32

K.4-1 Estimated Occupational Radiation Doses for Scenario-1 K-37

L.2-1 Labor Rates for Demolition . . . . . . . . L-4

L.2-2 Equipment Requirements for Demolition of the Reference BWR - L-5

L.3-1 Summary of Estimated Costs for Demolition and Site Restoration of the Reference BWR . . . . . . . . . L-6

L.3-2 Estimated Demolition Costs for the Reactor Building and the
Primary Containment Vessel . . . L-7

L.3-3 Estimated Demolition Costs for the Turbine Generator Building . . . . . . . . . . . L-8

L.3-4 Estimated Demolition Costs for the Radwaste and Control
Building . . . L-9

L.3-5 Estimated Demolition Costs for the Diesel Generator Building . L-9

L.3-6 Estimated Demolition Costs for the Service Building . . . L-10

L.3-7 Estimated Demolition Costs for the Cooling Towers . . . L-10

L.3-8 Estimated Demolition Costs for the Circulating Water Pumphouse . L-10

L.3-9 Estimated Site Restoration Costs . . . . . . . L-12

M.1-1 Decommissioning Staff Salary Data . . . . . . M-2

M.2-1 Shipping Containers for Packaging Radioactive Materials . . M-3

M.3-1 Shielded Casks for Shipment of Radioactive Materials . . . M-4

M.4-1 Transportation Rates for Legal-Size and -Weight Truck
Shipments . . . . . . M-5 
M.4-2 Additional Charges when Gross Vehicle Weight Exceeds $20.41 \mathrm{Mg}$. M-6

M.4-3 Requirements for Oversize Truck Shipments . . . . . M-7

M.4-4 Shipping Cost per Truck Shipment . . . . . . . M-7

M.5-1 Shallow-Land Burial Costs . . . . . . . . M-9

N.2-1 Summary of Radioactive Contamination at the Reference BWR . N-5

N.2-2 Immediate Dismantlement Safety Analysis Summary . . . N-7

N.2-3 Cutting Parameters for Piping and Equipment Removal . . . N-14

N.2-4 Immediate Dismantlement Public Safety Analysis Data Summary for the Reactor Building and Primary Containment . . . N-21

N.2-5 Immediate Dismantlement Public Safety Analysis Data Summary for the Turbine Generator Building . . . . . . N-25

N.2-6 Public Safety Analysis Data for Immediate Dismantlement of the Radwaste and Control Building . . . . . . . N-27

N.2-7 Calculated Atmospheric Releases for Immediate Dismantlement of the Reactor Building and Primary Containment . . . . N-29

N.2-8 Calculated Atmospheric Releases for Immediate Dismantlement of the Turbine Generator Building . . . . . . . N-31

N.2-9 Calculated Atmospheric Releases for Immediate Dismantlement of the Radwaste and Control Building . . . . . $\mathrm{N}-32$

N.2-10 Radiation Doses to the Maximum-Exposed Individual from Atmospheric Releases During Routine Immediate Dismantlement Tasks in the Reactor Building and Primary Containment . . N-35

N.2-11 Radiation Doses to the Maximum-Exposed Individual from Atmospheric Releases During Routine Immediate Dismantlement Tasks in the Turbine Generator Building . . . . . N-37

N.2-12 Radiation Doses to the Maximum-Exposed Individual from Atmospheric Releases During Routine Immediate Dismantlement Tasks in the Radwaste and Control Building . . . . N-38

N.2-13 Radiation Doses to the Population from Atmospheric Releases During Routine Immediate Dismantlement Tasks in the Reactor Building and Primary Containment . . . . . . N-39

N.2-14 Radiation Doses to the Population from Atmospheric Releases During Routine Immediate Dismantlement Tasks in the Turbine Generator Building 
N.2-15 Radiation Doses to the Population from Atmospheric Releases During Routine Immediate Dismantlement Tasks in the Radwaste and Control Building . . . . . . . . $\mathrm{N}-42$

N.2-16 Postulated Accidental Atmospheric Releases During Immediate Dismantlement of the Reference BWR

N.2-17 LPG Explosion Information . . . . . . . . . N -44

N.2-18 Example Explosive Data for Aceytylene/Air Mixtures . . . N-47

N.2-19 Radiation Doses to the Maximum-Exposed Individual from Accidental Atmospheric Releases During Immediate Dismantlement . $\quad . \quad . \quad . \quad . \quad . \quad . \quad$. $\quad .56$

N.3-1 Safety Analysis Requirements for Preparations for Passive Safe Storage . . . . . . . . . . N-58

N.3-2 Public Safety Analysis Data for Preparations for Passive Safe Storage . . . . . . . . . . N-60

N.3-3 Calculated Atmospheric Releases During Preparations for Passive Safe Storage . . . . . . . . . . N-61

N.3-4 Radiation Doses to the Maximum-Exposed Individual from Atmospheric Releases During Routine Preparations for Passive Safe Storage

N.3-5 Radiation Doses to the Population from Atmospheric Releases During Preparations for Passive Safe Storage . . . . N-63

N.3-6 Comparison of Postulated Accidents for Immediate Dismantlement and Passive Safe Storage . . . . . . . . . N-64

N.4-1 Comparison Between Entombment and Immediate Dismantlement

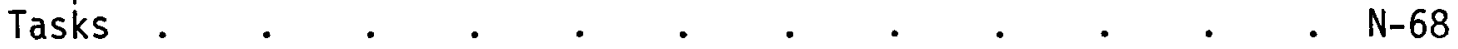

N.4-2 Public Safety Analysis Data for Entombment of the Reactor Building and Primary Containment . . . . . . N-70

N.4-3 Calculated Atmospheric Releases for Entombment of the Reactor Building and Primary Containment

N.4-4 Radiation Doses to the Maximum-Exposed Individual from Atmospheric Releases During Routine Entombment Tasks . . N-72

N.4-5 Radiation Doses to the Population from Atmospheric Releases During Routine Entombment Tasks . . . . . . . N-73

N.5-1 Calculated Radiation Doses from Rail Transport of Spent Fuel . N-76 
N.5-2 Calculated Radiation Doses from Routine Radioactive Waste Transportation . . . . . . . . . . N-77

N.5-3 Transportation Accident Severity Categories . . . . N-78

N.5-4 Minor Accidents for Type A Packages During Truck Transportation . . . . . . . . . . N-83

N.5-5 Severe Accidents for Type A Packages During Truck Transportation N-83

N.5-6 Radiation Doses to the Maximum-Exposed Individual from

Accidental Atmospheric Releases During Transportation

Accidents . . . . . . . . . . . . N-85

0.1-1 Component-Specific Scaling Factors for BWR Reactor Vessels • 0-6

0.1-2 Identifiable Costs for Immediate Dismantlement of the WNP-2

Reactor Vessel . . . . . . . . . 0-7

0.1-3 Component-Specific Scaling Factors for BWR Reactor Vessel

Internals . . . . . . . . . . . 0-8

0.1-4 Identifiable Costs for Immediate Dismantlement of the WNP-2

Reactor Vessel Internals . . . . . . . . 0-9

0.1-5 Identifiable Costs for Immediate Dismantlement of the WNP-2

Reactor Building . . . . . . . . . . 0-10

0.1-6 Component-Specific Scaling Factors for BWR Reactor Buildings . 0-11

0.1-7 Scaling Factor for BWR Sacrificial Shields . . . . 0-12

0.1-8 Identifiable Costs for Dismantlement of the WNP-2

Sacrificial Shield . $. \quad . \quad . \quad . \quad . \quad . \quad 0-13$

0.1-9 Identifiable Costs for Immediate Dismantlement of the WNP-2

Pressure Suppression Chamber . . . . . . . 0-14

0.1-10 Scaling Factors for BWR Pressure Suppression Chambers . . 0-14

0.1-11 Scaling Factors for BWR Reactor Building Piping Systems . . 0-15

0.1-12 Identifiable Costs for Dismantlement of the WNP-2 Reactor
Building Piping Systems . . . . . . 0-16

0.1-13 Identifiable Costs for Dismantlement of the WNP-2 Reactor
Building HVAC and Electrical Systems . . . . 0-17

\begin{tabular}{l} 
0.1-14 Scaling Factors for BWR Reactor Building HVAC and Electrical \\
Systems.. \\
\hline
\end{tabular}

0.1-15 Identifiable Costs for Immediate Dismantlement of the WNP-2

Reactor Refueling Pools . . . . . . . . 0-19 
0.1-16 Scaling Factors for the Reactor Refueling Pools . . . 0-20

0.1-17 Scaling Factors for BWR Reactor Building Contaminated Concrete Surfaces . . . . . . . . . . 0-21

0.1-18 Identifiable Costs for Immediate Dismantlement of the WNP-2
Reactor Building Contaminated Concrete Surfaces . . 0-22

0.1-19 Scaling Factors for BWR Reactor Building Miscellaneous Equipment . . . . . . . . . . . 0-22

0.1-20 Identifiable Costs for Immediate Dismantlement of the WNP-2 Reactor Building Miscellaneous Equipment . . . . . 0-23

0.1-21 Summary of Identifiable Costs for Immediate Dismantlement of the WNP-2 Selected Components . . . . . . . 0-24

0.1-22 Plant-Specific Scaling Factors for the Selected BWR Power Plants. . . . . . . . . . . 0-25

0.1-23 Estimated Costs for Immediate Dismantlement of Different Size BWR Power Plants....... . . . . . . 0-27

0.1-24 Estimated Costs for Passive Safe Storage of Different Size BWR Power Plants. . . . . . . . . . . 0-28

0.1-25 Estimated Costs for Entombment of Different Size BWR Power Plants. . . . . . . . . . 0-30

0.1-26 Estimated Radiation Doses for Decommissioning Different Size

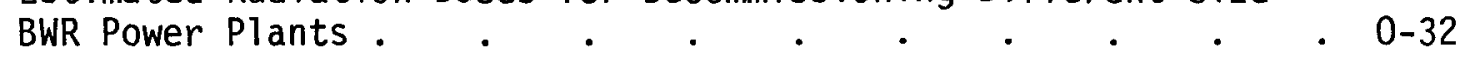

0.1-27 Comparison Data for BWR Mark I and Mark II Containment
Designs

0.1-28 Scaling Factors for BWR Turbine Generator Buildings . . . 0-35

0.1-29 Estimated Demolition Costs for Different Size BWR Power
Plants. . . . . 0-37

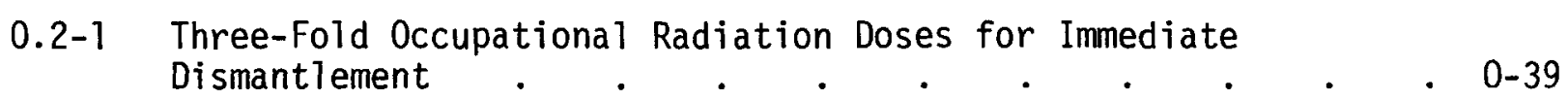

Three-Fold Occupational Radiation Doses for Preparations for
Passive Safe Storage. 0-40

0.2-3 Three-Fold Occupational Radiation Doses for Entombment . . 0-41

0.3-1 Staff Labor Requirements and Costs for Immediate

Dismantlement by Contract . . . . . . . 0-52 
0.3-2 Comparison of Costs Estimated for Dismantlement Using the Utility-Only Approach or the Utility-Contractors Approach . . 0-53

0.4-1 Summary of Estimated Costs for Disposal of Radioactive Materials During Immediate Dismantlement . . . . . 0-55

0.4-2 Estimated Costs for Deep Geologic Disposal of the Highly Activated Materials

0.5-1 Pertinent Characteristics of the Three Different BWR Containment Designs . . . . . . . . . 0-58 


\section{APPENDIX A \\ EVALUATIONS OF DECOMMISSIONING FINANCING ALTERNATIVES}

This appendix contains evaluations that estimate the revenue requirements for the alternatives for ensuring the availability of financing for decomissioning, as presented and discussed qualitatively in Chapter 6 of Volume 1. The evaluations in this appendix are in terms of constant dollars, assuming certain interest rates. They are sensitive to local, state, and federal taxes. However, only the impact of federal income taxes at the $46 \%$ rate is examined.

\section{A.1 INFORMATION ABOUT REVENUE REQUIREMENTS}

An examination of the present nuclear power plant ownership arrangements shows that about $81 \%$ of the nuclear power reactors operating or planned in the U.S. are investor-owned, while the remaining 19\% are publicly owned (including government corporations). (1) Thus, the analyses presented in this appendix are based on scenarios appropriate for investor-owned utilities.

The development of the revenue requirements of a regulated investor-owned utility is a rather complex task. The utility is entitled to recover the costs of operation and capital investment in the nuclear power plant and, in addition, to obtain a reasonable return on its capital investment. Capital recovery is normally accomplished via a predetermined depreciation schedule.

The components of the revenue requirements related to a nuclear power plant include such non-taxable items as debt servicing, capital recovery (depreciation), operating expense, and applicable taxes. Revenues in excess of these items are normally controlled by the state's rate commission to allow a reasonable return on the depreciated capital investment in the plant.

\section{A.2 CALCULATION OF REVENUE REQUIREMENTS}

In this section, calculations are made of the annual and total revenue required by an investor-owned utility to fund decommissioning via the financing approaches discussed in Chapter 6 of Volume 1: prepayment, internal unfunded 
reserve, sinking fund, and payment from revenue when needed. The calculations are only for the purpose of illustration, and no attempt is made to do an exhaustive study of all of the possible variations in scenarios. The effects of inflation are not included in the calculations in this section, but are discussed and presented in Section A.3.

\section{A.2.1 Revenue Requirement for the Prepayment Alternative}

In the prepayment alternative, it is assumed that the utility pays the estimated decommissioning cost in year-of-startup dollars into a trust fund operated by an agency of the state or federal government. The prepayment funds are obtained in the same manner as construction funds (i.e., from the sale of bonds or similar funding instruments) and the prepaid decommissioning costs are treated as a capital investment.

For this evaluation, it is assumed that the capital investment is recovered via straight-line depreciation and the annual revenues to cover depreciation are not subject to income taxes. Therefore, the annual revenue, $R$, needed to cover the decommissioning costs is given by:

$$
R=\left\{\begin{array}{c}
\text { Debt Service on the } \\
\text { Prepaid Decommissioning } \\
\text { Costs }
\end{array}\right\}+\left\{\begin{array}{c}
\text { Depreciation on the } \\
\text { Prepaid Decommissioning } \\
\text { Costs }
\end{array}\right\}
$$

$$
\text { or }
$$

$$
R=\left(\begin{array}{c}
\text { Prepaid } \\
\text { Decommissioning }
\end{array}\right) \times\left(j+\frac{1}{\text { Depreciation Lifetime }}\right)
$$

where $\mathrm{j}$ is the interest rate paid on the borrowed capital.

Not included in Equation $A .1$ is the return on the money in the trust fund. The excess of the trust fund over the decommissioning costs could be returned to the customers after decommissioning is completed and represent a windfall rate reduction at that time; or it could be returned on an annual basis through a reduction in the annual revenue requirement, which depends on the rate of return on 
the fund. Because of the customer equality offered, the latter return alternative is chosen for evaluation. Assuming the estimated decommissioning cost remains constant, the annual refund, AR, is given by:

$$
A R=\left(\begin{array}{c}
\text { Prepaid } \\
\text { Decommissioning } \\
\text { Cost }
\end{array}\right) \times(i)
$$

where $i$ is the rate of return on the trust fund.

Thus, the reduced annual revenue requirement, $R R$, is given by a combination of Equations A.lb and A.2:

$$
R R=\left(\begin{array}{c}
\text { Prepaid } \\
\text { Decommissioning }
\end{array}\right) \times\left(j+\frac{1}{\text { Depreciation Lifetime }}-i\right)
$$

where $j$ is the interest rate paid on the borrowed capital and $i$ is the rate of return achieved by the trust fund.

The evaluation results are obviously sensitive to the interest rates paid on the borrowed capital and to the rate of return obtained by the trust fund. If the estimated decommissioning cost is $\$ 44$ million and the depreciation lifetime is 30 years, the annual and total revenue requirements during this period are calculated using Equation A.3 and are tabulated in Table A.2-1 for a range of rates of return and interest rates.

\section{A.2.2 Revenue Requirement for the Internal Unfunded Reserve Alternative}

The internal unfunded reserve alternative is probably the simplest method for ensuring decommissioning funds since it fits readily into the normal accounting practices of the utilities. The estimated decommissioning cost is amortized over the life of the plant, on a straight-line depreciation schedule. Since these funds are collected in advance of the expenditure, they are not classified as an expense until the actual decommissioning takes place. Thus, these funds must come from the after-tax revenues. As a result, during the 
TABLE A.2-1. Annual and Tota1 Revenue Requirements for the Prepayment Alternative as Functions of Rates of Return and Interest Rates

\begin{tabular}{|c|c|c|c|c|c|}
\hline \multirow{2}{*}{$\begin{array}{c}\text { Fund } \\
\text { Rate of Return } \\
\text { (\% per year) }\end{array}$} & \multicolumn{5}{|c|}{ Interest Rate on Borrowed Capital (\% per year) } \\
\hline & $\frac{2}{\text { Annua }}$ & $\frac{4}{/ \overline{T o t a l} \operatorname{Rev}}$ & $\frac{6}{\text { nue Requirer }}$ & $\frac{8}{\text { ments }(\$ \mathrm{mi})}$ & $\frac{10}{10}$ \\
\hline 1 & $1.90 / 57.2$ & $2.79 / 83.6$ & $3.67 / 110.0$ & $4.55 / 136.4$ & $5.43 / 162.8$ \\
\hline 2 & $1.47 / 44.0$ & $2.35 / 70.4$ & $3.23 / 96.8$ & $4.11 / 123.2$ & $4.99 / 149.6$ \\
\hline 3 & -- & $1.90 / 57.2$ & $2.79 / 83.6$ & $3.67 / 110.0$ & $4.55 / 136.4$ \\
\hline 4 & -- & $1.47 / 44.0$ & $2.35 / 70.4$ & $3.23 / 96.8$ & $4.11 / 123.2$ \\
\hline 5 & -- & -- & $1.90 / 57.2$ & $2.79 / 83.6$ & $3.67 / 110.0$ \\
\hline
\end{tabular}

(a) Estimated decommissioning cost $=\$ 44$ million; depreciation lifetime $=$ 30 years.

plant's lifetime, the utility pays taxes on the revenue through higher rates charged to the customers, and, at shutdown when the funds are spent, the utility receives a tax credit that is passed on to the customers. Thus, the annual revenue requirement for this alternative is basically that which provides an after-tax amount equal to the estimated decommissioning cost divided by the depreciation lifetime of the plant.

The annual taxed revenue requirement, ATRR, is given by:

$$
\text { ATRR }=\frac{\text { Estimated Decommissioning Cost }}{(1-\text { Tax Rate }) \text { (Depreciation Lifetime) }}
$$

For a decommissioning cost of $\$ 44$ million, an income tax rate of $46 \%$, and a depreciation lifetime of 30 years, the annual taxed revenue requirement for decommissioning costs is calculated using Equation A.4 to be $\$ 2.72$ million per year for 30 years, for a total of $\$ 81.5$ million. If the revenue is not taxed, the annual revenue requirement is calculated to be $\$ 1.47$ million per year for 30 years, for a total of $\$ 44.0$ million.

It may be possible for the tax credit to be distributed over the same time period as the depreciation lifetime. If so, the annual revenue requirement would be reduced to that of the untaxed case. 


\section{A.2.3 Revenue Requirement for the Sinking Fund Alternative}

Under the sinking fund alternative, the utility makes annual payments to an external escrow account. For this evaluation, the escrow account is assumed to be under the control of a state or federal agency, thereby exempting the income generated by the escrow account from income taxes. However, it is not presently clear whether the annual payments into the account would be from taxed revenue or from untaxed revenue, so both situations are evaluated. Since, in addition to the annual payments, the sinking fund also depends on the income from interest on its capital to reach the desired final amount at the end of the accumulation period, a range of interest rates (rates of return) for the funds in escrow is considered.

The untaxed annual revenue requirement, ARR, for payment into the escrow account is given by:

$$
\operatorname{ARR}=S\left\{\frac{i}{(1+i)^{n}-1}\right\}
$$

where $S$ is the estimated decommissioning cost in constant dollars, $i$ is the annual rate of return on the escrow account, and $n$ is the number of years that payments are made.

If the revenue is taxed, the annual taxed revenue requirement, ATRR, is given by:

$$
\operatorname{ATRR}=\frac{S}{(1-\text { Tax Rate })}\left\{\frac{i}{(1+i)^{n}-1}\right\}
$$

For the evaluation, a decommissioning cost of $\$ 44$ million and a depreciation period of 30 years are assumed with a tax rate of $46 \%$ as applicable. The evaluation of the sinking fund alternative uses Equations A.5 and A.6. The results, shown in Table A.2-2, are very sensitive to the rate of return and to the tax treatment. 


\section{TABLE A.2-2. Annual and Total Revenue Requirements for the Sinking Fund Alternative as Functions of Rates of Return and Tax Treatment(a)}

\begin{tabular}{|c|c|c|}
\hline $\begin{array}{l}\text { Fund } \\
\text { Rate of Return } \\
\text { (\% per year) }\end{array}$ & \multicolumn{2}{|c|}{$\begin{array}{l}\text { Annual/Total Payment ( } \$ \text { millions) } \\
\text { Untaxed Revenue Taxed Revenue }\end{array}$} \\
\hline 1 & $1.265 / 37.95$ & $2.34 / 70.28$ \\
\hline 2 & $1.086 / 32.54$ & $2.01 / 60.19$ \\
\hline 3 & $0.925 / 27.75$ & $1.71 / 51.33$ \\
\hline 4 & $0.785 / 23.54$ & $1.46 / 43.69$ \\
\hline 5 & $0.662 / 19.87$ & $1.22 / 36.67$ \\
\hline
\end{tabular}

(a) Estimated decommissioning cost $=\$ 44 \mathrm{mil}-$ lion, depreciation lifetime $=30$ years, income tax rate $=46 \%$.

\section{A.2.4 Revenue Requirement for the Payment when Needed Alternative}

Under this alternative, there are no annual revenue requirements prior to decommissioning. The decommissioning costs are paid from utility revenues as the work is performed. For comparison purposes, the total cost of dismantlement is assumed to be paid in 1 year. Thus, the revenue requirement is $\$ 44$ million in the first year of dismantlement.

\section{A. 3 COMPARISON OF ALTERNATIVES}

The calculations presented in Section A.2 do not include the effects of inflation on the cost of decommissioning and on the annual revenue required to pay those costs. The effective rate of return on capital in an inflating economy is the difference between the obtainable interest rate and the inflation rate. In recent times, the interest rate on safe, conservative investments has generally exceeded the inflation rate by about $2 \% / y r$, and the interest rate on borrowed capital generally has exceeded the inflation rate by about $4 \% / y r$. On these bases and an estimated decommissioning cost of \$44 million, the resultant annual revenue requirements and the resultant total revenue requirements over 30 years for the financing alternatives are summarized in Table A.3-1. 


\begin{tabular}{|c|c|c|c|}
\hline \multirow{2}{*}{$\begin{array}{c}\text { TABLE A.3-1 } \\
\text { Financing } \\
\text { Al ternative } \\
\end{array}$} & \multicolumn{3}{|c|}{$\begin{array}{l}\text { Revenue Requirements for the Financing } \\
\text { Alternatives }(a)\end{array}$} \\
\hline & $\begin{array}{l}\text { Tax } \\
\text { Treatment }\end{array}$ & $\begin{array}{l}\text { Annual Payments } \\
\text { (\$ millions) }\end{array}$ & $\begin{array}{l}\text { Total Payments } \\
\text { (\$ millions) }\end{array}$ \\
\hline Prepayment & untaxed & 2.35 & 70.4 \\
\hline $\begin{array}{l}\text { Internal } \\
\text { Unfunded } \\
\text { Reserve }\end{array}$ & $\begin{array}{l}\text { untaxed } \\
\text { taxed (b) }\end{array}$ & $\begin{array}{l}1.47 \\
2.72\end{array}$ & $\begin{array}{l}44.0 \\
81.5\end{array}$ \\
\hline $\begin{array}{l}\text { Sinking } \\
\text { Fund }\end{array}$ & $\begin{array}{l}\text { untaxed } \\
\text { taxed }(b)\end{array}$ & $\begin{array}{l}1.09 \\
2.01\end{array}$ & $\begin{array}{l}32.5 \\
60.2\end{array}$ \\
\hline $\begin{array}{l}\text { Paid When } \\
\text { Needed }\end{array}$ & untaxed & -- & 44.0 \\
\hline
\end{tabular}

(a) Estimated decommissioning cost $=\$ 44$ million, depreciation lifetime $=30$ years, effective interest rate on fund $=2 \% / y r$, effective interest rate on borrowed capital $=4 \% / y r$.

(b)Most likely situation regarding taxes.

Considering the results from the three most likely cases given in Table A.3-1, the sinking fund alternative is the least costly. However, if some kind of bonding or insurance is required to ensure funding during the early portion of plant life, the cost of the bond or insurance could easily make the total cost of the sinking fund exceed the cost of the prepayment alternative. The internal unfunded reserve alternative appears to be the most expensive alternative, especially if some form of bonding or insurance during early plant life is required.

Another interesting case is when the facility is placed in safe storage for a number of years and is eventually dismantled. This case is more complex because the funds needed are collected during the operating lifetime of the plant and are disbursed during preparations for safe storage, continuing care, and deferred dismantlement. The unspent funds continue to accumulate interest during the continuing care period.

Let $F$ represent the amount of money that must be in a fund at final reactor shutdown that, with interest accumulated during the safe storage period, is sufficient to pay al1 decommissioning costs. PSS is the cost of preparing the 
plant for safe storage, $C C$ is the annual cost of surveillance and maintenance, and $D D$ is the cost of deferred dismantlement.

At time zero (reactor shutdown), $F$ dollars are in the fund. Immediately, PSS dollars are paid out for preparations for safe storage. The balance remaining is F - PSS. At the end of the first year of safe storage, the fund will be increased by $(1+i)$, where $i$ is the annual interest rate earned by the fund and is decreased by $C C(1+j)$, and where $j$ is the annual inflation rate. The balance in the fund is $(F-P S S)(1+i)-C C(1+j)$. At the end of the second year the fund balance is

$$
[(F-P S S)(1+i)-C C(1+j)](1+i)-C C(1+j) \text {. }
$$

Expanding to the end of the nth year, when deferred dismantlement is to take place, the balance in the fund must equal the deferred dismantlement cost, $\mathrm{DD}(1+j)^{\mathrm{n}}$ :

$$
(F-P S S)(1+i)^{n}-C C \sum_{a=1}^{n}(1+i)^{n-a}(1+j)^{a}=D D(1+j)^{n}
$$

Equation (A.7) can be solved for $F$, the amount needed in the fund when reactor operation ceases:

$$
F=\frac{D D(1+j)^{n}+C C \sum_{a=1}^{n}(1+i)^{n-a}(1+j)^{a}}{(1+i)^{n}}+P S S
$$

The values of F, presented in Table A.3-2, are calculated assuming the values of DD, CC, and PSS estimated in this study; safe storage periods of $10,30,50$, and 100 years; and either the interest rate is equal to the inflation rate or the interest rate is $2 \%$ greater than the inflation rate. From these values of $F$, the annual revenue required to create the fund is calculated for the prepayment, internal reserve, and sinking fund alternatives. 
TABLE A.3-2. Revenue Requirements for the Passive Safe Storage/Deferred Dismantlement Alternative(a)

\begin{tabular}{|c|c|c|c|c|c|c|c|c|c|}
\hline \multirow{3}{*}{$\begin{array}{c}\text { Safe Storage } \\
\text { Period }\end{array}$} & \multirow{2}{*}{\multicolumn{2}{|c|}{$\begin{array}{l}\text { Funds Required } \\
\text { at Shutdown }\end{array}$}} & \multicolumn{7}{|c|}{ Annual Revenue Requirement } \\
\hline & & & \multirow{2}{*}{\multicolumn{2}{|c|}{ Prepayment $(\mathrm{b})$}} & \multicolumn{3}{|c|}{ Interna] Reserve (c) } & \multicolumn{2}{|c|}{ Sinking Fund(d) } \\
\hline & $i=j$ & $=j+2$ & & $i=j+2$ & $i=j$ & & +2 & $i=j$ & $i=j+2$ \\
\hline $10^{(e)}$ & 57.55 & 51.43 & 3.07 & 2.74 & 3.55 & 3. & & 2.63 & 2.35 \\
\hline $30^{(e)}$ & 59.05 & 43.26 & 3.15 & 2.31 & 3.65 & 2. & & 2.70 & 1.97 \\
\hline $50^{(f)}$ & 51.45 & 34.08 & 2.74 & 1.82 & 3.18 & 2. & & 2.35 & 1.56 \\
\hline $100^{(f)}$ & 55.20 & 28.73 & 2.94 & 1.53 & 3.41 & 1. & & 2.53 & 1.31 \\
\hline
\end{tabular}

(a) PSS $=\$ 21.3$ million, $C C=\$ 0.075$ million.

(b) Effective interest rate paid for capital is $4 \%$, effective interest rate earned by fund is $2 \%$.

(c) Tax rate is $46 \%$, depreciation lifetime is 30 years.

(d) Tax rate is $46 \%$, fund collection period is 30 years, effective interest rate earned is $2 \%$.

(e) $D D=\$ 35.5$ million.

(f) $D D=\$ 26.4$ million.

Comparing the results presented in Table A.3-1 with those in Table A.3-2 for the case of the earned interest rate exceeding the inflation rate by $2 \%$ $(i=j+2)$, it is seen that the annual revenue requirement for the safe storage/deferred dismantlement alternative becomes less than for immediate dismantlement after a safe storage period of at least 30 years, and continues to decrease as the length of the storage period increases. This result is obviously very sensitive to the difference between the interest rate earned by the fund and the inflation rate. 


\section{REFERENCES}

1. R. S. Wood and K. Kominars, Owners of Nuclear Power Plants, NUREG-0327 October 1977.*

\# Available for purchase from the National Technical Information Service, Springfield, Virginia 22161. 


\section{APPENDIX B}

\section{REFERENCE SITE DESCRIPTION}

A reference site is used to assess the public safety and potential environmental effects of conceptually decommissioning various nuclear fuel-cycle facilities. (1-3) A summary of the site description found in References 1 through 3 is presented in this appendix. Only information directly relating to the radiation exposure pathway analysis, required in determining acceptable residual contamination levels and in calculating radiation doses for the public radiological safety analysis, is included here. The meteorological parameters and population distribution for the year 2000 are based on information presented in Reference 4. Other necessary site information is based on data reported in the site description of an operating nuclear power station. Estimates of the residual radioactivity mixtures and levels for the reference site are presented in Appendix E. All information in this appendix is felt to be representative of most existing and potential BWR power stations in the midwestern or middle southeastern United States.

Individual features of an actual site (for a specific facility) may vary from those of this reference site. However, it is believed that this approach (i.e., use of a reference site) results in a more meaningful overall analysis of the potential impacts associated with decommissioning most BWR facilities. A site-specific assessment is required for a similar analysis of a specific BWR power station.

\section{B. 1 SITE LOCATION AND SIZE}

The reference site is located in a rural area with characteristics similar to those found in the midwestern or middle southeastern United States. The site occupies about $4.7 \mathrm{~km}^{2}$ in a rectangular shape of about $2 \mathrm{~km}$ by $2.35 \mathrm{~km}$. A moderate-size river flows through one corner of the site. 


\section{B.2 DEMOGRAPHY}

The site is located in a rural area with a relatively low population density, with highest population densities occurring at distances of 20 to $60 \mathrm{~km}$. Population distribution data for the year 2000 is given in Table B.2-1. The total population residing within an $80-\mathrm{km}$ radius of the BWR site is about 3.52 million.

\section{TABLE B.2-1. Population Distribution Around the Reference Site for the Year 2000(4)}

\begin{tabular}{|c|c|c|c|}
\hline $\begin{array}{c}\text { Distance From } \\
\text { Site Boundary } \\
(\mathrm{km})\end{array}$ & $\begin{array}{c}\text { Population } \\
\text { Density } \\
\left.\text { (Persons } / \mathrm{km}^{2}\right) \\
\end{array}$ & $\begin{array}{l}\text { Total Population } \\
\text { In Annulus }(\mathrm{a}, \mathrm{b}) \\
\end{array}$ & $\begin{array}{l}\text { Cumulative } \\
\text { Population } \\
\end{array}$ \\
\hline 0 to 2 & $--(c)$ & 10 & 10 \\
\hline 2 to 3 & 136 & 2130 & 2140 \\
\hline 3 to 5 & 104 & 5230 & 7370 \\
\hline 5 to 6 & 230 & 7940 & 15300 \\
\hline 6 to 8 & 133 & 11700 & 27000 \\
\hline 8 to 20 & 85 & 89300 & 116000 \\
\hline 20 to 30 & 239 & 375000 & 491000 \\
\hline 30 to 50 & 175 & 878000 & 1370000 \\
\hline 50 to 60 & 298 & 1030000 & 2400000 \\
\hline 60 to 80 & 127 & 1120000 & 3520000 \\
\hline
\end{tabular}

(a) It is assumed that the population in each annulus is uniformly divided in each of 16 uniform 22.5 degree sectors.

(b) Totals are rounded to three significant figures.

(c) Indicates a population density less than $1.0 / \mathrm{km}^{2}$.

\section{B.3 LAND USE}

Use of any part of the total site area for anything other than reactor operations is assumed to be prohibited during the 40-year BWR operational lifetime. The major plant facilities are located inside a $0.12-\mathrm{km}^{2}$, fenced portion of the site. The minimum distance from the point of airborne release to the outer site boundary is $1 \mathrm{~km}$. The outer site boundary is fenced and marked. 
About $80 \%$ of the land within $16 \mathrm{~km}$ of the site is used for farming. The main crops are soybeans $(60 \%)$, corn, oats, and other grains $(30 \%)$ and hay $(10 \%)$. It is expected that this area will remain largely agricultural, and that the population will not change significantly because of the BWR operations.

A wildlife refuge and a state forest and campground are located about $14 \mathrm{~km}$ from the site. A state park is located about $10 \mathrm{~km}$ from the site in the opposite direction.

There are large truck gardens in the area. The nearest dwelling (the residence location of the maximum-exposed individual for the public safety analysis of decommissioning) is a farm located about $1.3 \mathrm{~km}$ from the site. A milk cow is kept at this farm and is maintained on fresh pasture 7 months of the year. A family garden with a growing season of 5 months is kept for fresh vegetables. River water is used to irrigate the crops on this farm.

\section{B.4 METEOROLOGY}

The reference site has a typical continental climate. It is characterized by wide variations in temperature, modest winter precipitation, normally ample spring and summer rainfall, and a general tendency to extremes in all climatic features. January is the coldest month and July is the warmest. Table B.4-1 shows monthly meteorological statistics.

TABLE B.4-1. Monthly Meteorological Statistics at the Reference Site

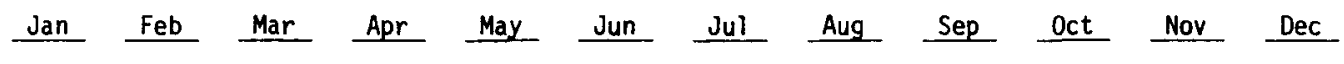

Air Temperature $\left({ }^{\circ} \mathrm{C}\right)$

\begin{tabular}{|c|c|c|c|c|c|c|c|c|c|c|c|c|}
\hline Maximum & -6.1 & -4.4 & 3.3 & 12.8 & 20 & 25 & 28.3 & 26.7 & 22.2 & 15 & 4.4 & -3.3 \\
\hline Minimum & -16.1 & -14.4 & -6.7 & 1.7 & 7.8 & 13.3 & 16.1 & 15 & 10 & 3.9 & -4.4 & -12.2 \\
\hline Mean & -11.1 & -9.4 & -1.7 & 7.2 & 13.9 & 18.9 & 22.2 & 21.1 & 16.1 & 9.4 & 0.0 & -7.8 \\
\hline Extreme Maximum & 15 & 16.1 & 27.8 & 32.8 & 40.6 & 39.4 & 41.7 & 40 & 40.6 & 32.2 & 23.9 & 17.2 \\
\hline Extreme Minimum & -38.9 & -36.7 & -34.4 & -15.6 & -6.7 & 0.6 & 5.6 & 3.3 & -5.6 & -13.3 & -27.8 & -33.9 \\
\hline
\end{tabular}


On the average, 12 days per year have maximum temperatures of $32^{\circ} \mathrm{C}$ and above. Annually, an average of 168 days have minimum temperatures of $0^{\circ} \mathrm{C}$ and below, with 40 of them at $-18^{\circ} \mathrm{C}$ or below. The January average relative humidities at 7:00 a.m., 1:00 p.m., and 7:00 p.m. are 76, 68, and 70\%, respectively. The corresponding humidities for Juty are 86,55 , and $55 \%$.

The average annual rainfall in the area is $610 \mathrm{~mm}$. The months of May through September have the greatest amounts of rainfall, with an average during this period of 432 to $457 \mathrm{~mm}$ (70\% of the annual total). The maximum 24-hr total rainfall for the period 1894 through 1965 was $127 \mathrm{~mm}$ and occurred in May. Thunderstorms, with an average annual frequency of 36 , are the chief source of rain from May through September. Snowfall in the area averages $1070 \mathrm{~mm}$ annualiy, with occurrences recorded in all months except June, July, and August. The extremes in annual snowfall of record are $152 \mathrm{~mm}$ minimum and $2235 \mathrm{~mm}$ maximum.

Annually, the winds are predominantly bimodal. This bimodal distribution is characteristic of the seasonal wind distributions as wel1. The average wind speed for spring is $11 \mathrm{~km} / \mathrm{hr}$ and for the other seasons is about $16 \mathrm{~km} / \mathrm{hr}$. The maximum reported wind speed of $148 \mathrm{~km} / \mathrm{hr}$ was associated with a tornado. Tornadoes and other severe storms occur occasionally. Eight tornadoes were reported from 1916 through 1967 in the county where the site is located. The probability of a tornado striking a given point in this area is about $5 \times 10^{-4}$ per year. For design purposes a wind velocity of $480 \mathrm{~km} / \mathrm{hr}$ is assumed to be associated with tornadoes.

Natural fog that restricts visibility to $0.4 \mathrm{~km}$ or less occurs about $30 \mathrm{hr} / \mathrm{yr}$. Icing caused by freezing rain can occur between October and April, with an average of one to two storms per year. The mean duration of icing on utility lines is $36 \mathrm{hr}$.

Diffusion climatology comparisons with other locations indicate that the site is typical of the region, with relatively favorable atmospheric dilution conditions prevailing. Thermal inversions occur about $32 \%$ of the year, and the frequency of thermal stabilities is $19 \%$ slightly stable, $27 \%$ stable, $20 \%$ neutral, and $34 \%$ unstable. 
Data from a number of river sites used for nuclear power reactors are used to calculate the "typical" annual atmospheric dispersion pattern in an average 22.5-degree sector around the site. Dispersion factors at selected distances for the average sector are determined from joint-frequency distributions for each site. This is done by calculating the dispersion factor, $\bar{X} / Q^{\prime}$, for each sector at selected downwind distances and then calculating the average dispersion factor at each distance. In other words, the dispersion factors in those sectors corresponding to overiand trajectories are added without regard to direction and divided by the number of sectors involved. Thus, an average dispersion factor is obtained for each selected downwind distance for a 1116 sectors, based on data given in Reference 4.

Standard groups of meteorological data are interpolated from the specific site data. The groupings provide four stability classes based on vertical temperature gradient and five wind speed classes based on the Beaufort wind scale. ${ }^{(6)}$. The stability classes are based on Reference 7 information, with Pasquill classes A, B, and C classified as B (unstable); Pasquill class D (neutral); Pasquill Class E (slightly stable); and Pasquill classes $F$ and $G$ are classified as $F$ (moderately stable).

Some of the wind-speed data is available for only one height. In this event, the measured values are extrapolated to the 10-m level for ground level release calculations and to the 150-m level for reference-BWR stack release calculations. Where measurements at two heights are available, the highest is extrapolated to $150 \mathrm{~m}$ and the lowest to $10 \mathrm{~m}$, using a standard power law extrapolation procedure. (6)

The ratio of the maximum sector dispersion factor to the average sector dispersion factor is 2.5. This value is used for all release heights in this study. Investigation of the change in this ratio with increasing distance from the site shows that the ratio remains essentially constant. The dispersion factors for the average sector as a function of height of release and downwind distance are shown in Figure B.4-1. 


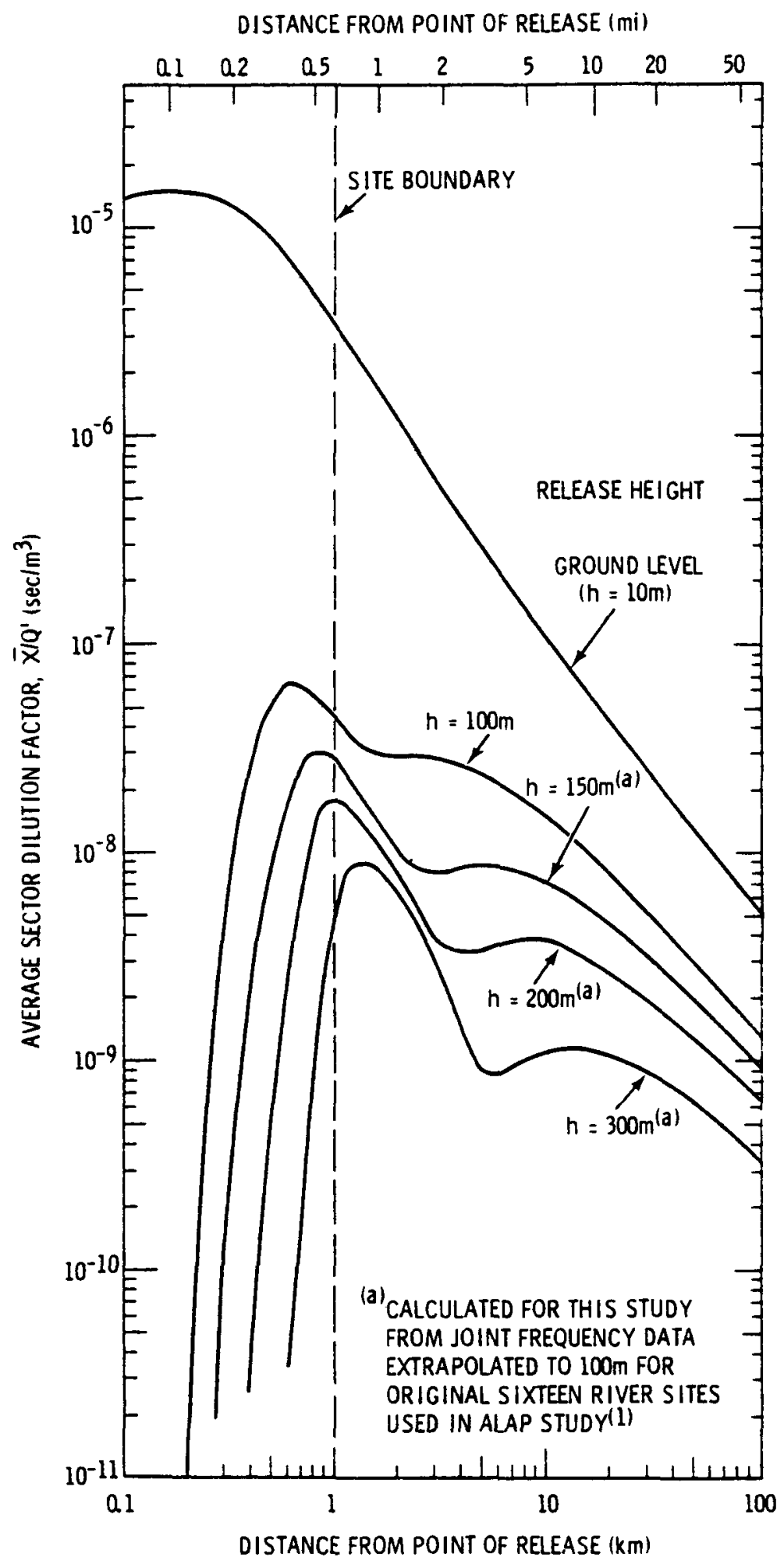

FIGURE B.4-1. Average $\left(\bar{x} / Q^{\prime}\right)$ Values Versus Distance in a Sector from the Reference Site 
To assess the effect of increased stack height, atmospheric dispersion factors for stack heights of 150,200 , and $300 \mathrm{~m}$ are estimated from the original joint frequency distributions of the information from Reference 4 . These values are graphically presented in Figure B.4-1.

No credit for plume rise from either momentum or buoyancy is taken in this study. Where large volumes of heated air are being ejected, the plume rise constant for momentum is estimated to be about $50 \mathrm{~m}^{2} / \mathrm{sec}$. Assuming an annual average wind speed of 2 to $3 \mathrm{~m} / \mathrm{sec}$, the increase in effective stack height because of momentum would be about 15 to $25 \mathrm{~m}$. Plume rise from buoyancy (heat effect) would add at least another 25 to $100 \mathrm{~m}$ of effective stack height, depending on the temperature of the exhaust gases. Thus, the $\bar{x} / Q^{\prime}$ values illustrated in Figure B.4-1 are larger than they would be if credit had been taken for momentum and buoyancy. 


\section{REFERENCES}

1. K. J. Schneider and C. E. Jenkins, Technology, Safety and Costs of Decommissioning a Reference Nuclear Fuel Reprocessing Plant, NUREG-0278, Prepared by Pacific Northwest Laboratory for the U.S. Nuclear Regulatory Commission, October 1977.*

2. R. I. Smith, G. J. Konzek and W. E. Kennedy, Jr., Technolugy, Safety and Costs of Decommissioning a Reference Pressurized Water Reactor Power Station, NUREG/CR-0130, Prepared by Pacific Northwest Laboratory for the U.S. Nuclear Regulatory Commission, June 1978. **

3. C. E. Jenkins, E. S. Murphy and K. J. Schneider, Technology, Safety and Costs of Decommissioning a Reference Small Mixed Oxide Fuel Fabrication Plant, NUREG/CR-0129, Prepared by Pacific Northwest Laboratory for the U.S. Nuclear Regulatory Commission, February 1979. **

4. U.S. AEC, Final Environmental Statement Concerning Proposed Rule-making Action: Numerical Guides for Design Objectives and Limiting Conditions for Operation to Meet the Criteria "As Low As Practible" for Radioactive Material in Light-Water-Cooled Nuclear Power Reactor Effluents, WASH-1258, Directorate of Regulatory Standards, Volume 1 of 3 , Figure 6B-7, p. $6 \mathrm{~B}-43$ and Figure 6C-8, p. 6C-12, Table 6B-6 p. 6B-36, July 1973.

5. U.S. AEC, Final Environmental Statement Related to Operation of Monticello Nuclear Generating Plant, Docket No. 50-263, pp. II-15 through II-26, November 1972

6. Meteorology and Atomic Energy 1968, TID 24190, Edited by D. H. Slade, p. 73, JuTy 1968.

7. U.S. NRC, Regulatory Guide 1.23, "Onsite Meteorological Programs (Safety Guide 23), "February 1972.

\footnotetext{
Available for purchase from the National Technical Information Service, Springfield, Virginia 22161.

** Available for purchase from the NRC/GPO Sales Program, U.S. Nuclear Regulatory Commission, Washington, D.C. 20555, and the National Technical Information Service, Springfield, Virginia 22161.
} 


\section{REFERENCE BWR FACILITY DESCRIPTION}

This appendix describes the reference boiling water reactor (BWR) in sufficient detail to provide an appreciation of the problems associated with decontamination and decommissioning efforts. A 3320-MWt (1155-MWe) BWR is characterized. Descriptions of the structures and the equipment housed therein are included. The information contained here is based on the Washington Public Power Supply System (WPPSS) Final Safety Analys is Report for the WPPSS Nuclear Project No. 2 (WNP-2), (1) from the WNP-2 Environmental Report, (2) and from drawings and other data supplied by WPPSS personnel. The single-unit WNP-2 employs a BWR nuclear steam supply system, supplied by the General Electric Company and designated BWR/5.

\section{C.1 GENERAL PLANT DESCRIPTION}

The reference site occupies approximately $4.7 \mathrm{~km}^{2}$ in a rectangular shape of $2 \mathrm{~km}$ by $2.35 \mathrm{~km}$. The plant itself requires an area of $0.12 \mathrm{~km}^{2}$ within the larger plant site. A well-labeled perimeter fence exists around the total site to exclude the public. Another fence surrounds the smaller plant area and includes a security entrance to the plant. A moderately sized river runs through one corner of the site. The reference BWR site layout is shown in Figure C.1-1. The principal structures located on the reference plant site are:

- Reactor Building - houses the nuclear steam supply system, the primary containment vessel, new and spent fuel storage, refueling equipment, and emergency core cooling systems

- Turbine Generator Building - houses the power conversion equipment

- Condensate Storage Tanks (2 each)

- Radwaste and Control Building - houses the liquid and solid radwaste systems, components of the condenser off gas system, and the plant's main control room 


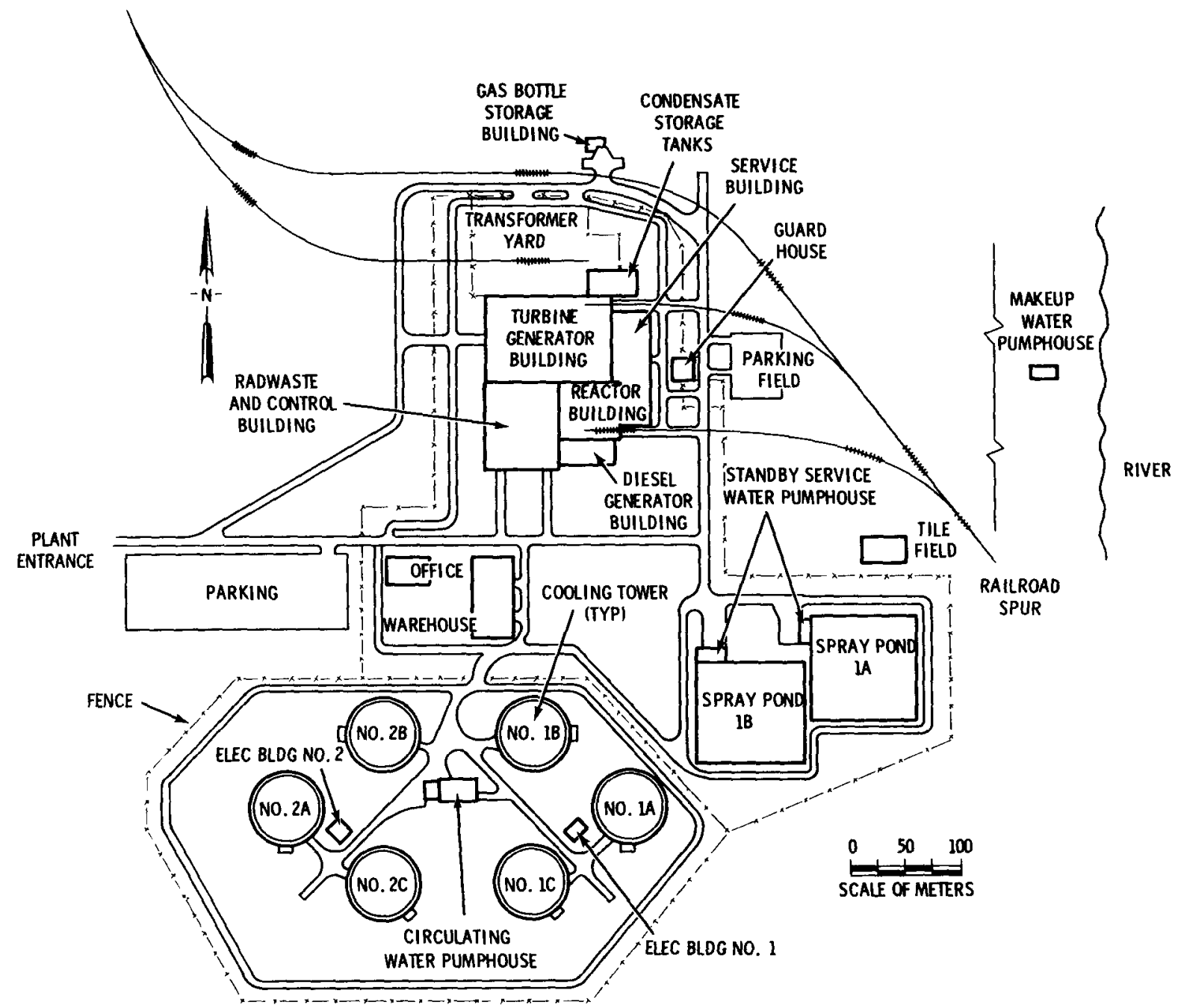

FIGURE C.1-1. Site Layout of the Reference BWR Plant Facilities

- Diesel Generator Building - houses the standby diesel generators and $0 i 1$ storage tanks

- Service Building - houses the makeup water treatment system, a machine shop, and an office area

- Cooling Towers (6 each)

- Circulating Water Pumphouse - houses the circulating water pumps, plant service water pumps, and fire pumps

- Spray Ponds - cooling ponds provided as the ultimate heat sink 
- Standby Service Water Pumphouses - house the redundant standby service water pumps

- Makeup Water Pumphouse - houses the plant makeup water pumps.

\section{C.1.1 Design Criteria}

The bases for development and selection of the design criteria used in this plant are: provide protection of public safety, provide for reliable and economic plant performance, and provide an attractive appearance.

The essential systems and components of the plant are designed to enable the facility to withstand, without loss of the capability to protect the public, the additional forces that might be imposed by natural phenomena. The designs are based upon the most severe of the natural phenomena recorded for the vicinity of the site, with margin to account for uncertainties in the historical data.

\section{C.1.2 Operating Characteristics}

The design and 1 icense power level for the reactor core is approximately 3320 MWt with a corresponding generator electrical output of approximately 1155 WWe. The principle of operation is shown in Figure C.1-2.

\section{C.1.3 Nuclear Steam Supply System}

The nuclear steam supply system includes a direct-cycle, forced-circulation BWR that produces steam for direct use in the steam turbine.

The nuclear steam supply system includes those systems most closely associated with the reactor vessel that are designed to contain or be in communication with water going to and steam coming from the reactor core. The nuclear steam supply system includes the following:

- reactor vessel

- reactor vessel internals

- reactor core

- main steam lines from the reactor vessel out to and including the isolation valves outside the primary containment structure 
- neutron monitoring system

- reactor water recirculation system

- control rod drive system

- residual heat removal system

- reactor core isolation cooling system

- emergency core cooling systems

- reactor water cleanup system

- reactor vessel pressure relief system.

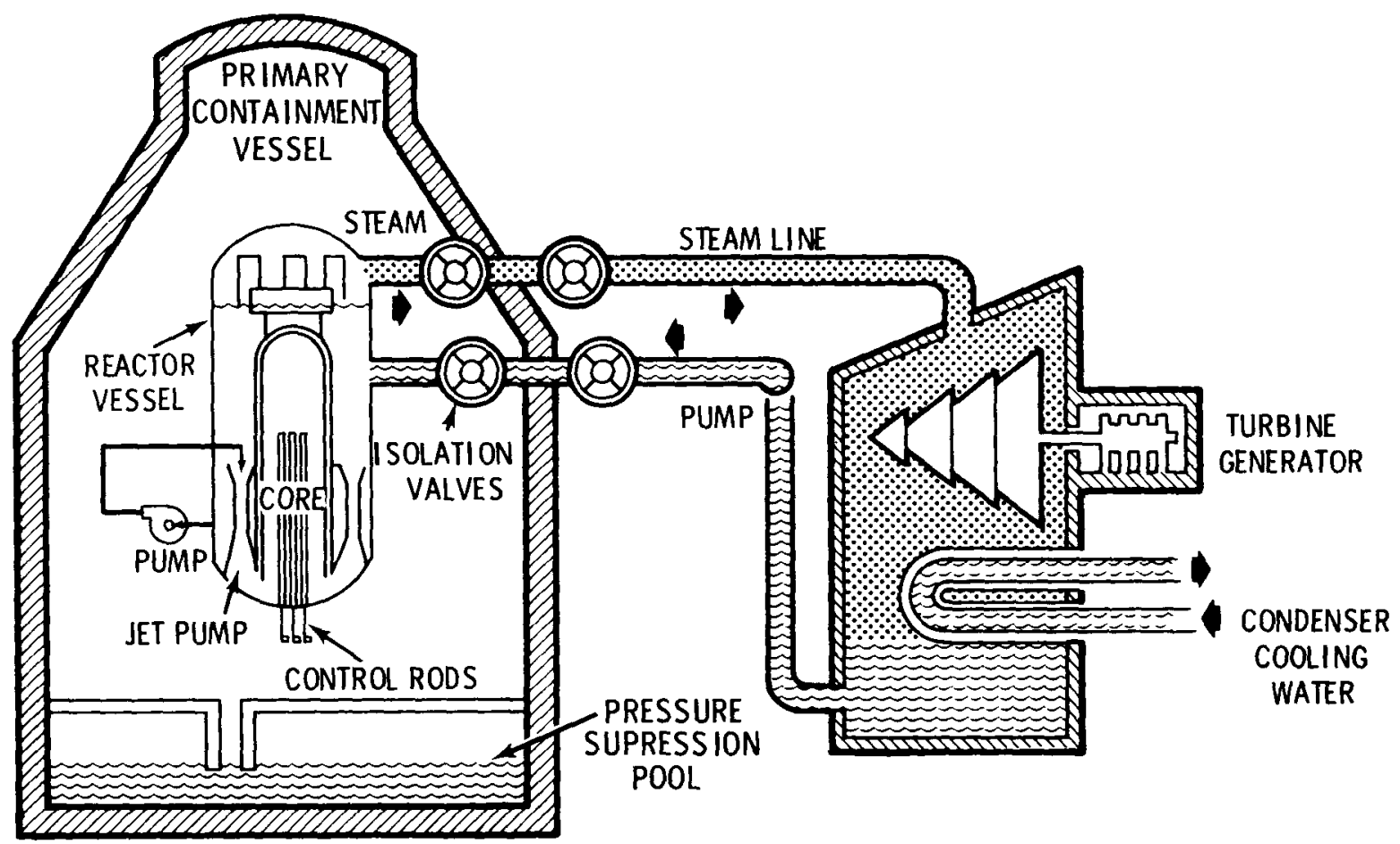

A NUCLEAR POWER REACTOR PRODUCES STEAM TO DRIVE A TURBINE WHICH TURNS AN ELECTRIC GENERATOR. THE BWR SHOWN HERE IS A TYPE OF REACTOR FUELED BY SLIGHTLY ENRICHED URANIUM IN THE FORM OF URANIUM OXIDE PELLETS HELD IN ZIRCONIUM ALLOY TUBES IN THE CORE. WATER IS PUMPED THROUGH THE CORE, BOILS, AND PRODUCES STEAM THAT IS PIPED TO THE TURBINE.

FIGURE C.1-2. Functional Diagram of a Boiling Water Reactor (BWR) 
The fuel for the reactor core consists of slightly enriched uranium dioxide pellets sealed in Zircaloy-2 tubes. The fuel rods are assembled into 764 individual fuel assemblies. The 185 moveable, bottom-entry control rods are cruciform in shape and are dispersed throughout the lattice of fuet assemblies.

The reactor vessel contains the core and supporting structures, the steam separators and dryers, the jet pumps, the control rod guide tubes, and other components. The low-alloy steel reactor vessel is cylindrical with hemispherical heads. Except for the top hemispherical head, the reactor vessel is clad internally with stainless steel.

Four steam lines exit the upper portion of the reactor vessel. Between the reactor vessel and the turbine, each steam line is provided with two isolation valves in series, one on each side of the primary containment structure wall.

The reactor water recirculation system has two loops external to the reactor vessel but inside the primary containment structure. Each external loop contains a pump and a flow control valve. The portion of each loop that is inside the reactor vessel consists of the jet pumps that are located in the annular region between the core shroud and the vessel's inner wall.

Auxiliary systems purify reactor recirculation water, cool system components, remove residual heat when the reactor is shut down, sample reactor coolant water, provide for emergency water injection, and provide for reactor vessel pressure relief.

\section{C.1.4 Power Conversion}

The turbine is a tandem-compound, four-element, 1800-rpm unit, having one high-pressure and three identical low-pressure elements. Combination moisture separator-reheaters are employed to dry and superheat the steam between the high- and low-pressure turbines. The auxiliaries include a deaerating surface condenser, steam jet air ejectors, turbine-driven feedwater pumps, motordriven condensate and condensate booster pumps, a full-flow condensate demineralizer system, and six stages of feedwater heaters. The steam and turbine systems are designed to receive the heat energy produced in the reactor during 
normal operation, as well as during a $25 \%$ load reduction on the turbinegenerator. The generator is directly coupled to the turbine and has a hydrogencooled rotor and a water-cooled stator. It is a three-phased, 60- $\mathrm{Hz}, 25,000-$ volt, 1800-rpm unit rated at 1230 MVA at a 0.975 power factor.

\section{C.1.5 Electrical Power}

Normal auxiliary power is provided by two normal auxiliary transformers fed from the main generator $25-\mathrm{kV}$ isolated phase bus. The startup transformer is connected to the 230-kV offsite power. These auxiliary systems each have the capacity to carry the full plant auxiliary load. A backup transformer is provided to supply all plant emergency system loads. This transformer is supplied from an offsite 115-kV line to the plant.

Two diesel generators, at $4.16 \mathrm{kV}$ each, are provided as standby sources of emergency power in the event of a loss of normal AC power. A third diesel generator supplies emergency power to the high-pressure core spray system. Each generator has sufficient capacity to operate the equipment necessary to prevent undue risk to the public in an emergency situation. In addition, storage batteries are provided as onsite sources of power in the event of a loss of normal DC power.

\section{1.6 Fuel Handling System}

The reactor is refueled with equipment designed to handle the spent fuel under water from the time it leaves the reactor vessel until it is placed in a cask for shipment from the site. Underwater transfer of spent fuel provides an optically transparent radiation shield, as well as a reliable source of coolant for removal of decay heat from the spent fuel. This system also provides capability for receiving, handling, and storing new fuel.

\section{C.1.7 Radioactive Waste Treatment Systems}

The radioactive waste treatment systems provide a11 equipment necessary to collect, process, monitor, and discharge radioactive liquid, gaseous, and solid wastes produced diring reactor operation.

Liquid wastes potentially containing radioactive material are collected, filtered, and concentrated or demineralized as required. The treated water from 
the demineralizers or the concentrator distillate may be recycled for use in the plant or may be discharged to the nearby river. The concentrator bottoms, spent demineralizer resins, and spent filters are solidified, packaged, and shipped to a licensed disposal site. Gaseous wastes are collected and discharged to the environment after filtration.

\section{C.2 STRUCTURES}

This section describes the structures of the reference BWR. Refer to Figure C.1-1 for the arrangement of the struciures on the plant site. Table C.2-l lists the structural materials used in the various plant structures.

In this section and subsequent sections, equipment key numbers (EKN) are supplied each time a piece of equipment is mentioned to facilitate cross correlation between the text, the figures, and the equipment lists in this appendix. The equipment key numbers in this appendix are identical to numbers assigned by the facility owner (see Reference 1, Figure 1.2-2). A complete listing of all the equipment key numbers and the corresponding equipment identified in this. appendix is presented in Section C.6.

TABLE C.2-1. Estimated Structural Material Quantities in the Reference Boiling Water Reactor Facilities

\begin{tabular}{|c|c|c|c|}
\hline Structure & $\begin{array}{c}\text { Concrete, } \\
\mathrm{m}^{3}\end{array}$ & $\begin{array}{c}\text { Rebar, } \\
\mathrm{Mg}\end{array}$ & $\begin{array}{l}\text { Structural } \\
\text { Steel, } \mathrm{Mg}\end{array}$ \\
\hline $\begin{array}{l}\text { Reactor Building } \\
\text { Primary Containment } \\
\text { Turbine Generator Building }\end{array}$ & $\begin{array}{rr}42 & 804 \\
1 & 225 \\
46 & 672\end{array}$ & $\begin{array}{l}8608 \\
187 \\
4 \quad 717\end{array}$ & $\begin{array}{l}902 \\
693 \\
742\end{array}$ \\
\hline $\begin{array}{l}\text { Radwaste and Control Building } \\
\text { Diesel Generator Building } \\
\text { Service Building }\end{array}$ & $\begin{array}{rr}26 & 697 \\
2 & 964 \\
2 & 359\end{array}$ & $\begin{array}{r}2746 \\
408 \\
151\end{array}$ & $\begin{array}{r}372 \\
0 \\
395\end{array}$ \\
\hline $\begin{array}{l}\text { Circulating Water Pump House } \\
\text { Spray Pond Complex } \\
\text { Makeup Water Pump House } \\
\text { Yard and other buildings }\end{array}$ & $\begin{array}{rr}2 & 963 \\
8 & 321 \\
1 & 278 \\
12 & 825 \\
\end{array}$ & $\begin{array}{l}321 \\
789 \\
163 \\
247 \\
\end{array}$ & $\begin{array}{r}112 \\
0 \\
0 \\
91 \\
\end{array}$ \\
\hline Total & 147880 & 18351 & 3307 \\
\hline
\end{tabular}


The Reactor Building, the Turbine Generator Building, the Radwaste and Control Building, the Diesel Generator Building, and the Service Building are in close proximity to each other, being supported on separate foundation mats and physically separated from each other, above and below grade. Abutting walls between these buildings are separated by several millimeters.

The Reactor Building, the Turbine Generator Building, and the Radwaste and Control Building are the only bujldings on the plant site that contain radioactive materials.

\section{C.2.1 Reactor Building}

The Reactor Building (Figures C.2-1 through C.2-4) is a Seismic Category $I^{(a)}$ structure consisting of two containment barriers: the stee 1 primary containment vessel and the building itself, which provides secondary containment. The primary containment vessel (General Electric Co. Mark II containment design) contains a drywe11, a suppression chamber, a structural floor separating the drywell from the suppression chamber, a sacrificial shield wall, and a reactor pedestal. The building secondary containment encloses the biological shield wall, the spent fuel storage pool, the dryer and separator storage pool, and the reactor well pool.

The Reactor Building completely surrounds the primary containment vessel. The building provides secondary containment when the primary containment vessel is closed and in service, and serves as a primary containment during periods when the primary containment vessel is open. The reactor building also houses refueling and reactor servicing equipment, new and spent fuel storage facilities, and other reactor safety and auxiliary systems.

(a) The design bases for individual structures and portions of structures are dependent on the systems that the structures support and house. Design bases for Seismic Category I structures are defined as being within the following broad classifications: 1) support, 2) biological shield, 3) missile shield, 4) administrative access control, 5) atmosphere control, 6) liquid control, 7) seismic protection, and 8) wind protection. One or more of these may apply to each portion of the structure. The number and quantitive degree of design bases is dependent on the specific needs of components (locally) and systems (general1y). 


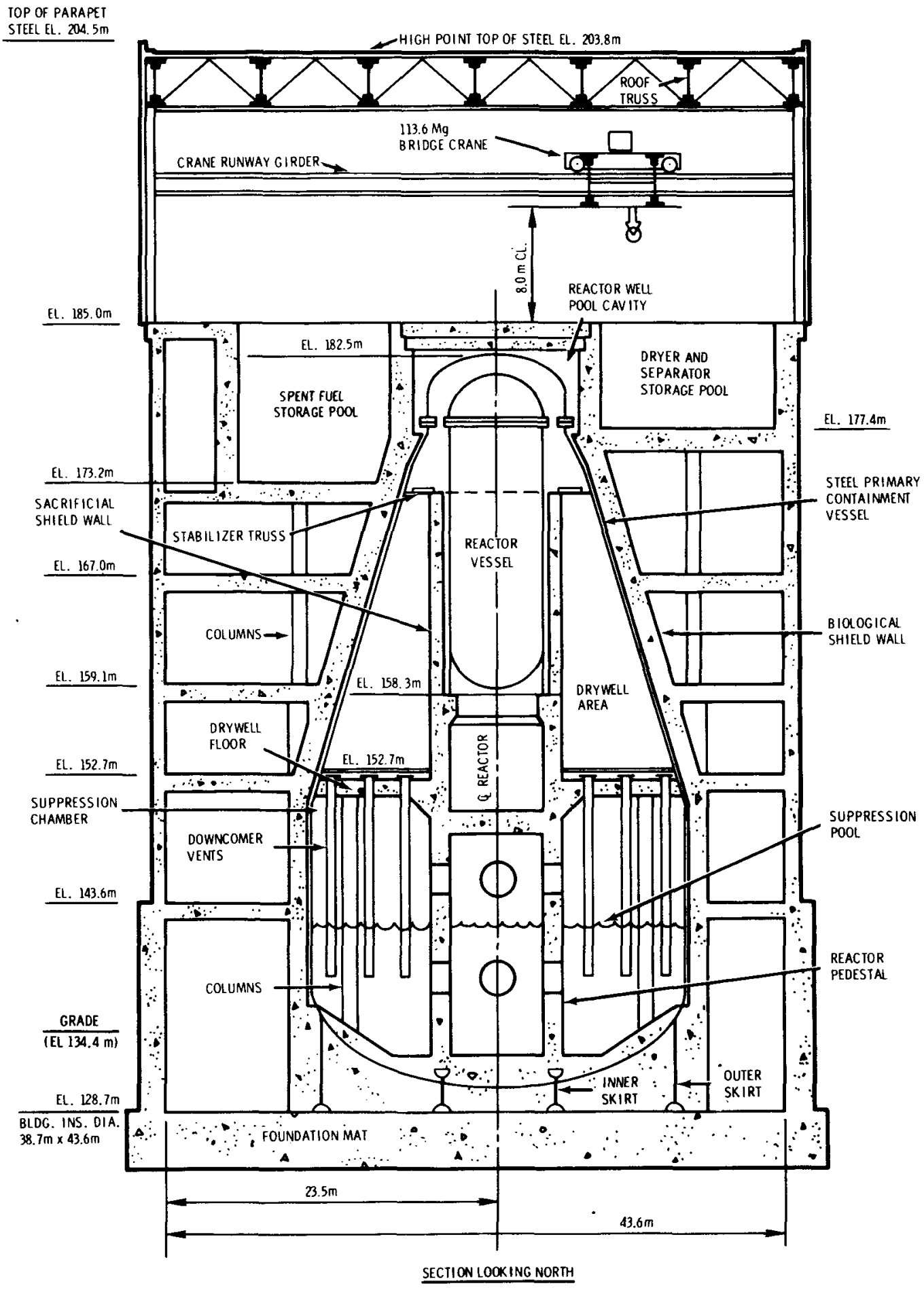

FIGURE C.2-1. Reactor Building Section 


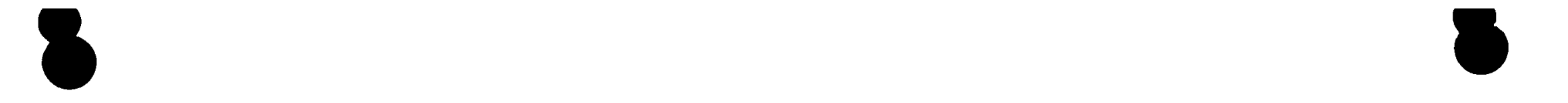



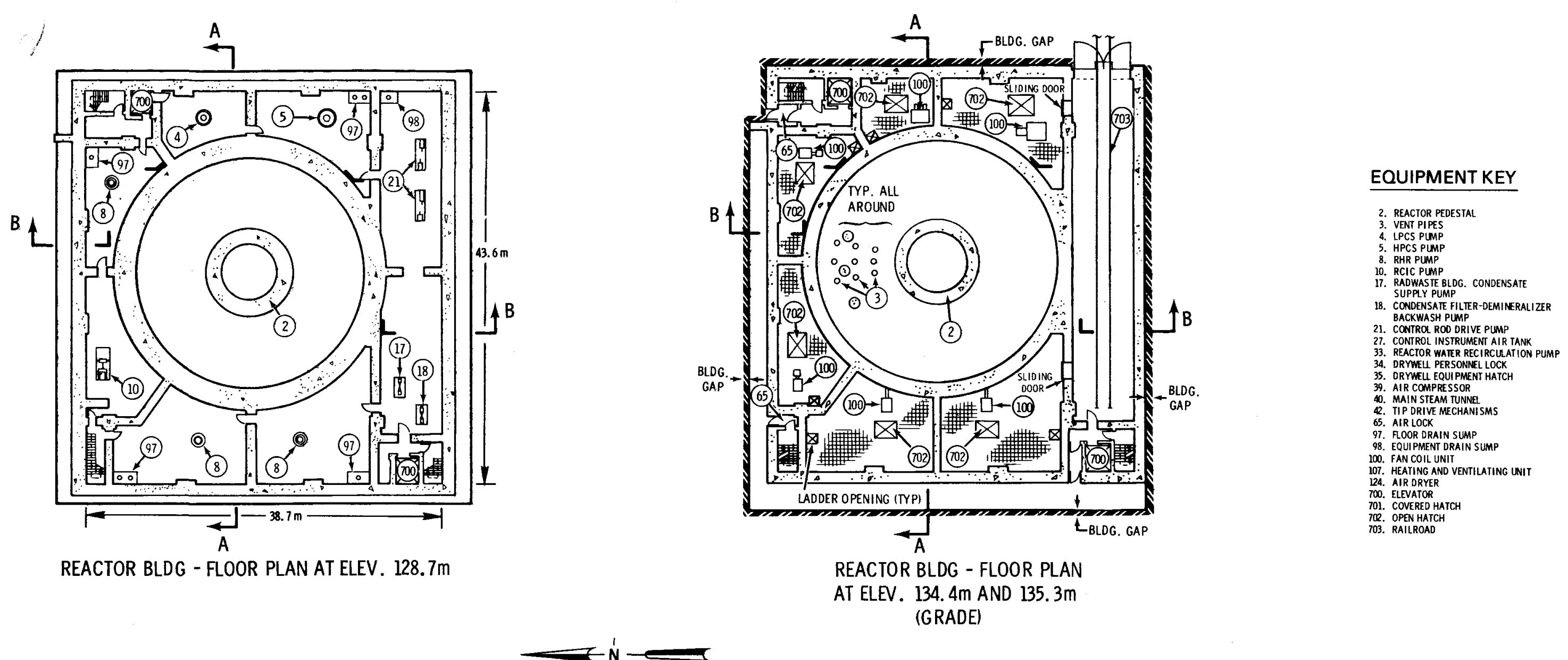

REACTOR BLDG - FLOOR PLAN AT ELEV. $128.7 \mathrm{~m}$

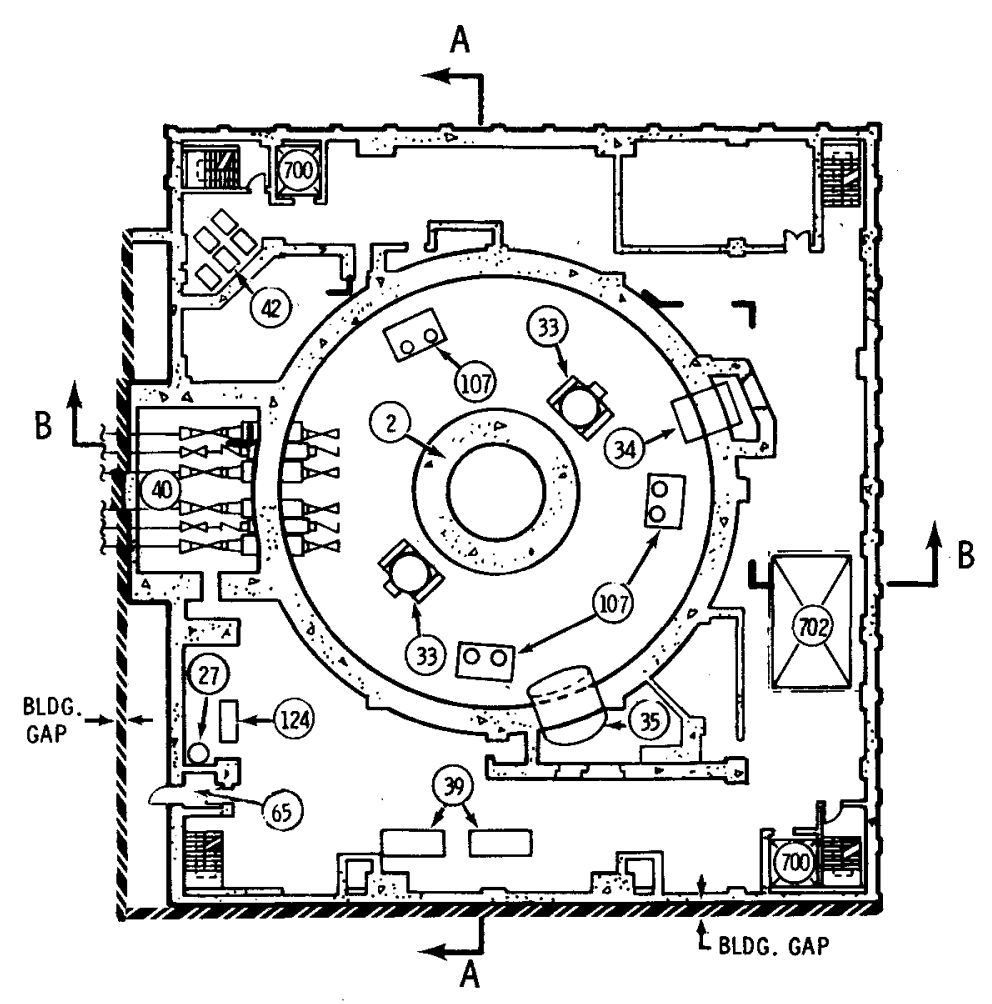

REACTOR BLDG - FLOOR PLAN AT ELEV. 152.7m

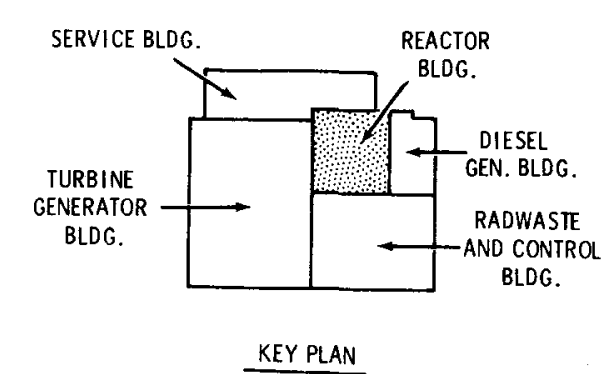

FIGURE C.2-2. Reactor Building Floor Plans - Sheet 1 


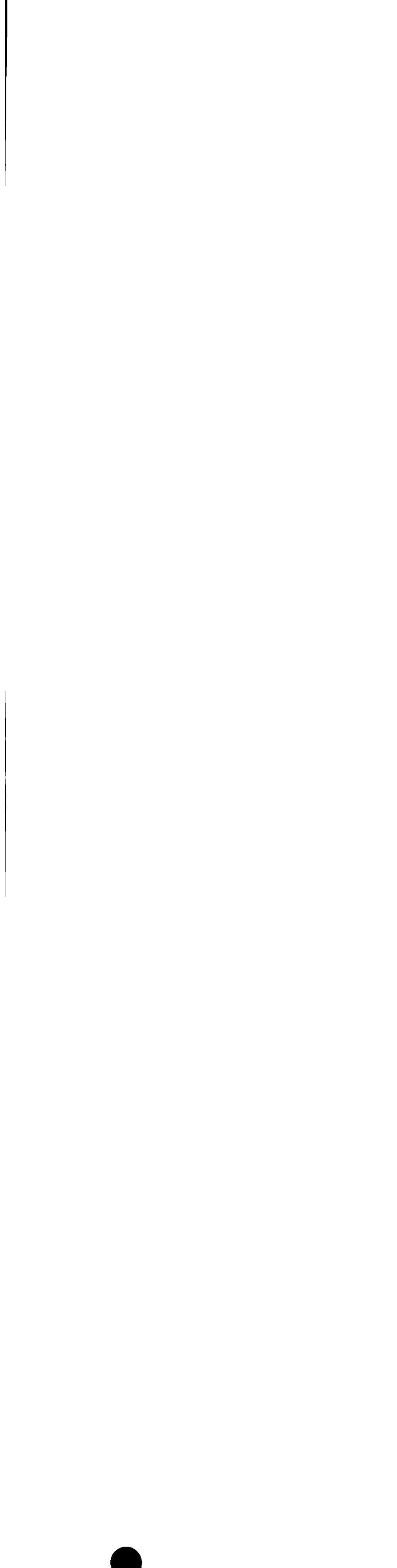




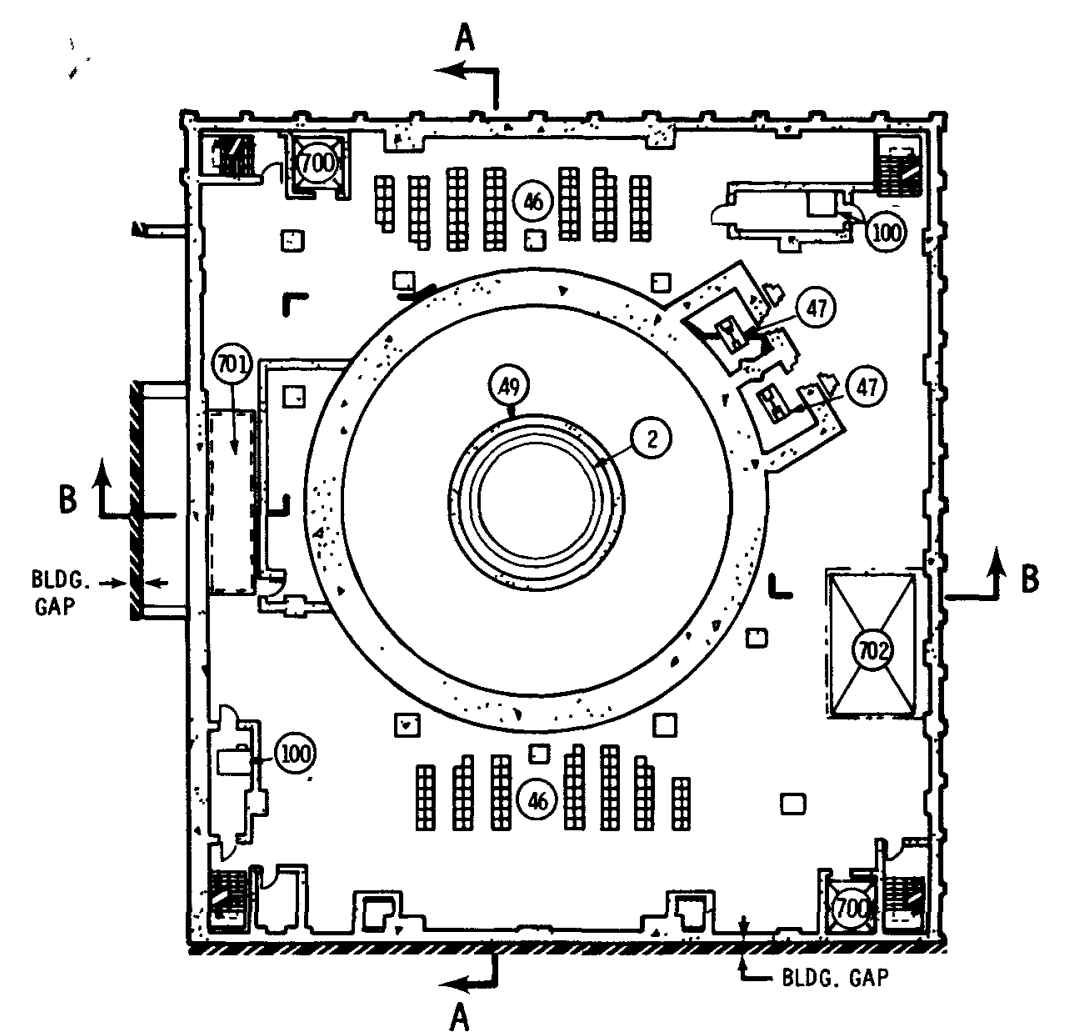

REACTOR BLDG. - FLOOR PLAN AT ELEV. 159. Im

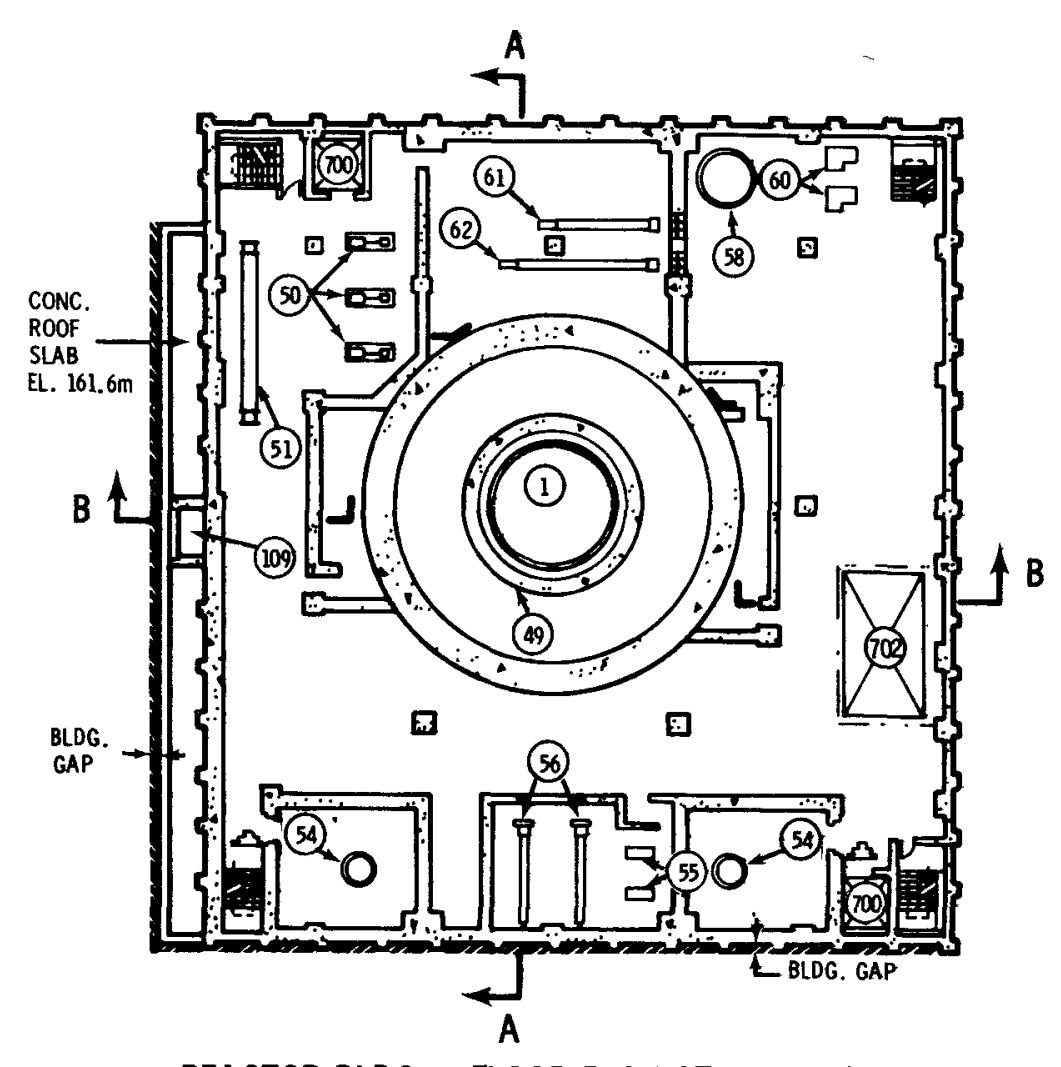

REACTOR BLDG. - FLOOR PLAN AT ELEV. $167.0 \mathrm{~m}$

'EQUIPMENT KEY

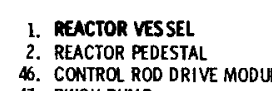

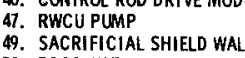

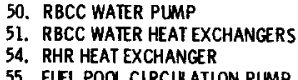

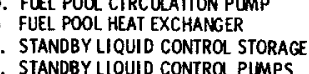

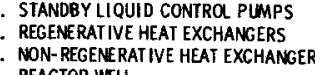

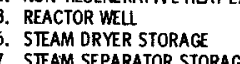

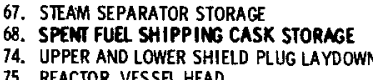

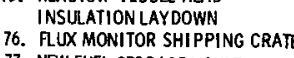

79. DRYMEL HAD LAVDOWN
\&2. UPPER POOC PLUG AAROOW
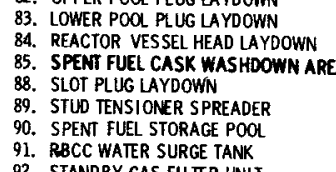

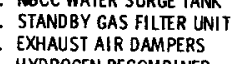

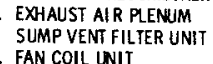

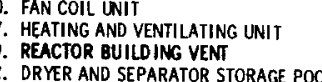

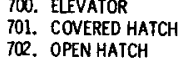

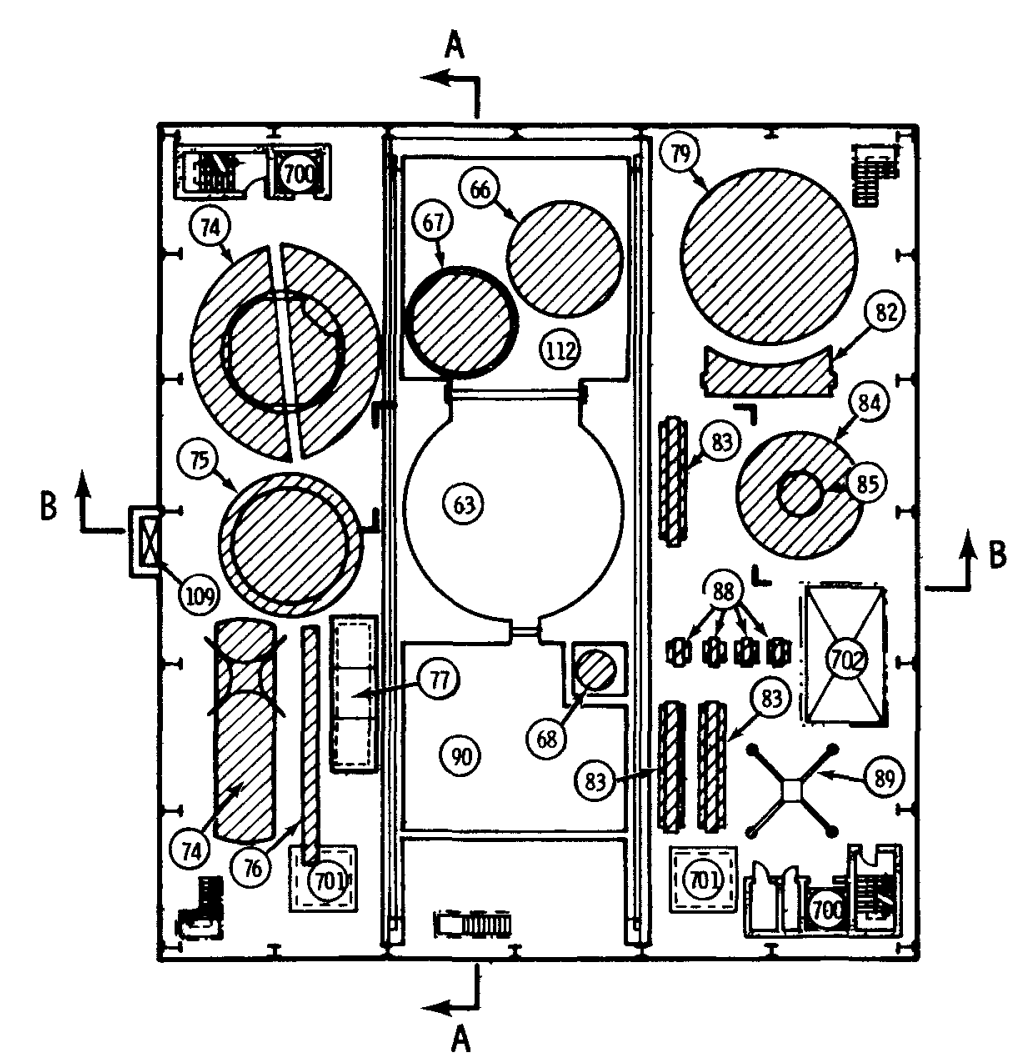

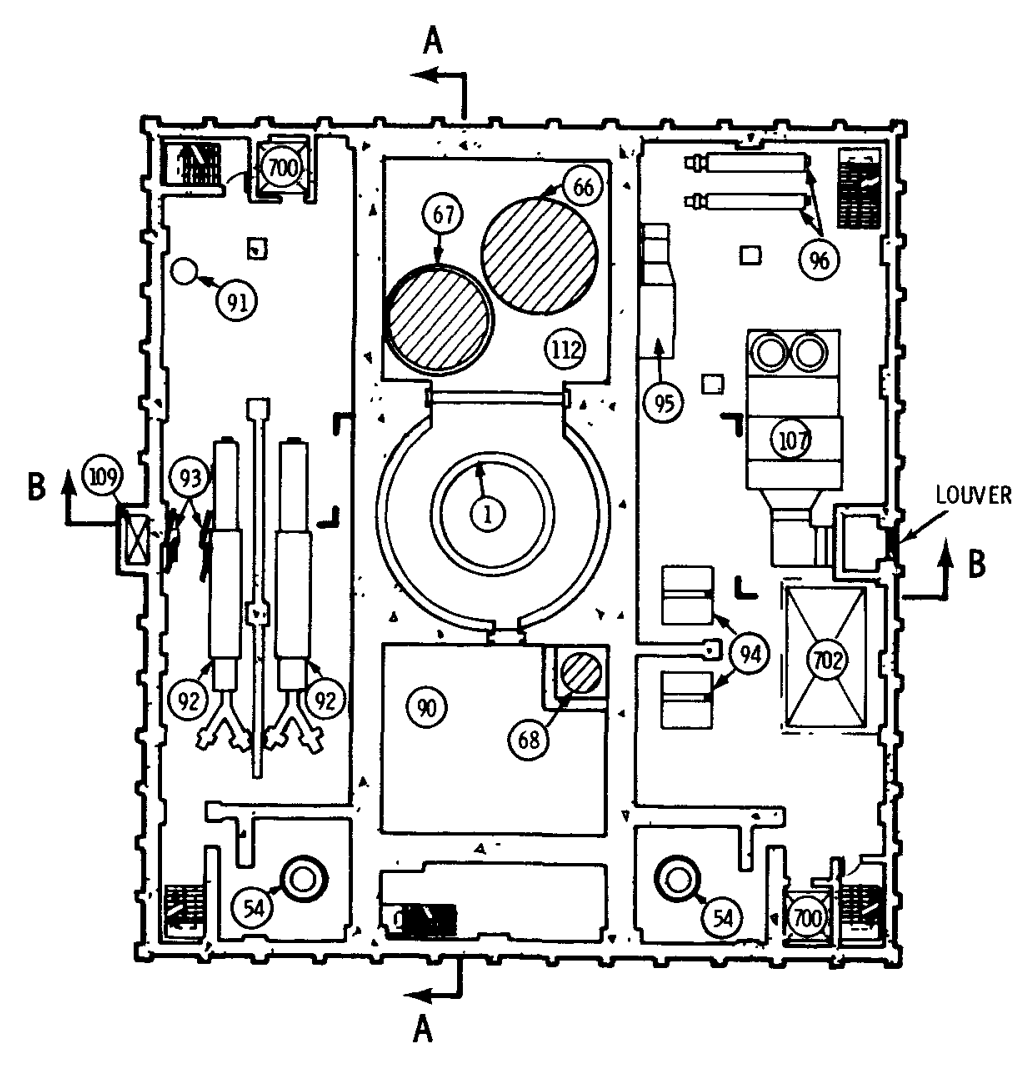

REACTOR BLDG. - FLOOR PLAN AT ELEV. $174.4 \mathrm{~m}$
REACTOR BLDG. - FLOOR PLAN AT ELEV. $185.0 \mathrm{~m}$

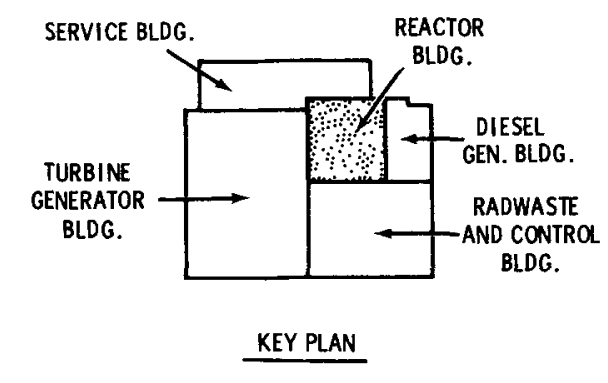




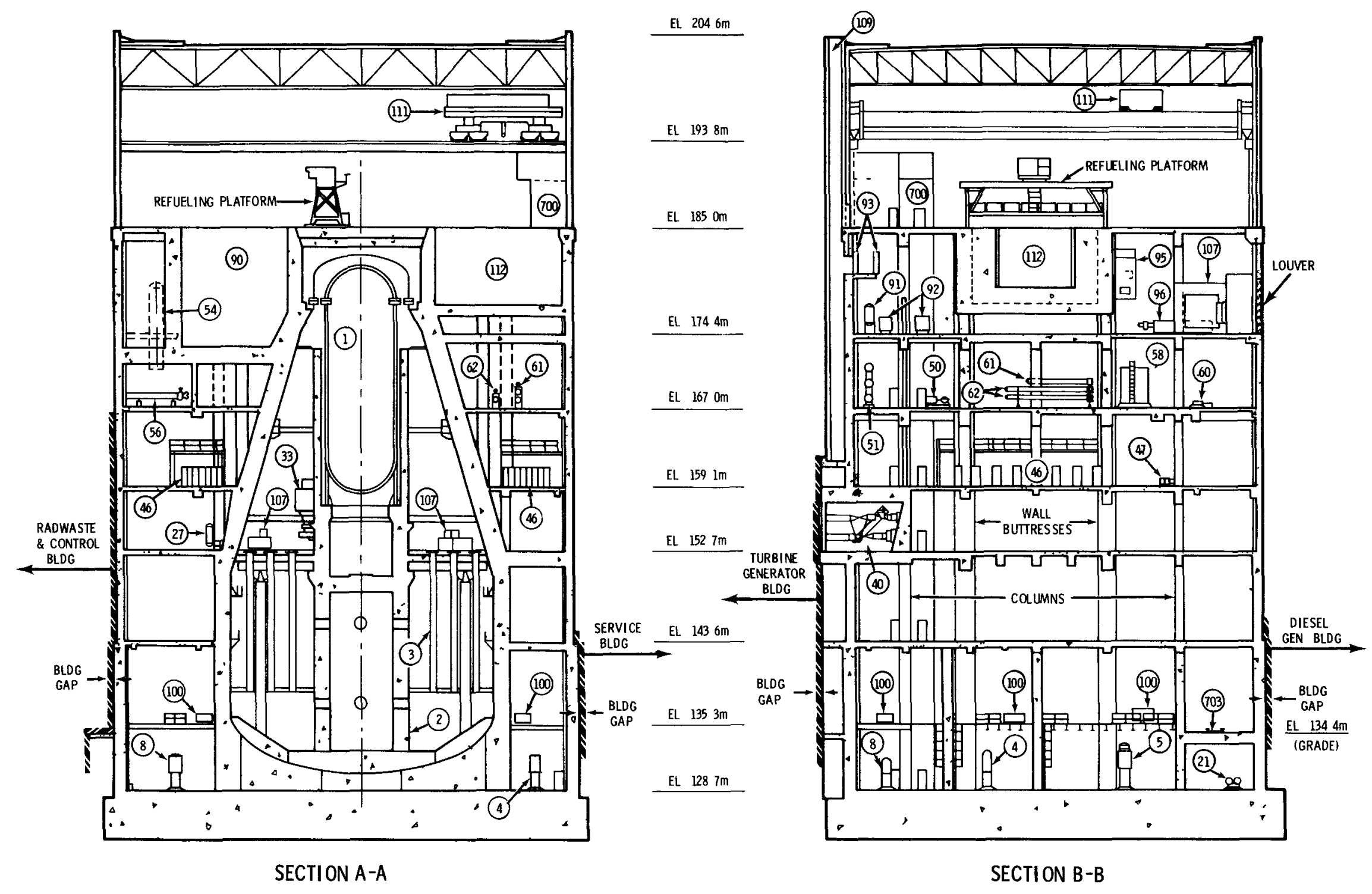

EQUIPMENT KEY

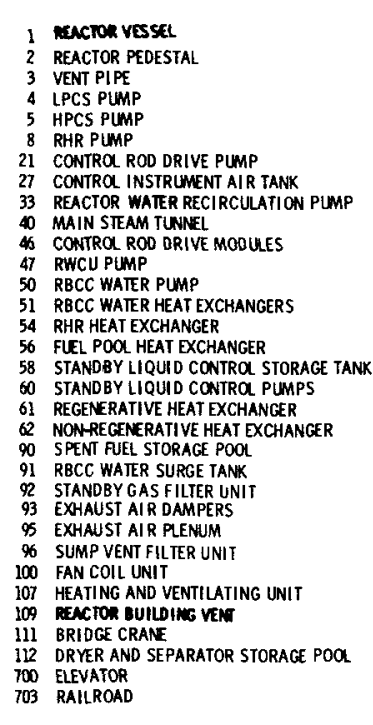

FIGURE C.2-4. Reactor Building Elevation Sections 
O 0 
The Reactor Building is a cast-in-place, reinforced concrete structure up to and including the operating floor at elevation $185.0 \mathrm{~m}$. Reinforced concrete shield walls extend above this level, $2.43 \mathrm{~m}$ high on the north exterior side and $1.83 \mathrm{~m}$ high on the west exterior side of the building, immediately inside the insulated metal exterior siding of the steel superstructure.

Above the operating floor, the building structure is constructed of structural steel members and insulated metal siding and roof decking. Joints in the superstructure paneling are designed to ensure air leak tightness. The steel superstructure supports the overhead bridge crane (115-Mg capacity) and houses refueling operations.

The foundation mat, shown in Figure C.2-5, is a common foundation that supports the steel primary containment vessel and the Reactor Building that encloses it. The foundation mat is 4.9-m thick reinforced concrete.

of the eight main floor levels, from and including the top of the foundation mat to and including the operating floor, the foundation mat level is the only one below the final plant grade, which is at elevation $134.4 \mathrm{~m}$.

The Reactor Building is rectangular in plan and elevation. The approximate inside plan dimensions of the concrete structure are $38.7 \mathrm{~m}$ by $43.6 \mathrm{~m}$. The steel superstructure is approximately $39.6 \mathrm{~m}$ by $44.5 \mathrm{~m}$ in plan. From the basement level, which is the top of the foundation mat at elevation $128.7 \mathrm{~m}$, to elevation $143.6 \mathrm{~m}$, the exterior concrete walls are $1.22 \mathrm{~m}$ thick; from elevation $143.6 \mathrm{~m}$ to the operating f7oor, elevation $185.0 \mathrm{~m}$, the exterior wall thicknesses vary from $0.46 \mathrm{~m}$ to $0.91 \mathrm{~m}$.

The height of the concrete structure is approximately $56.3 \mathrm{~m}$, measured from the top of the foundation mat, elevation $128.7 \mathrm{~m}$, to the operating floor, elevation $185.0 \mathrm{~m}$. The height of the steel superstructure is approximately $19.5 \mathrm{~m}$ from the operating floor to the top of the superstructure parapet.

Interior walls and floor slabs are of reinforced normal or high-density concrete of various thicknesses, depending on shielding requirements. In the building interior, the floor slabs are supported by reinforced concrete columns and by a biological shield wall that surrounds the primary containment vessel. 


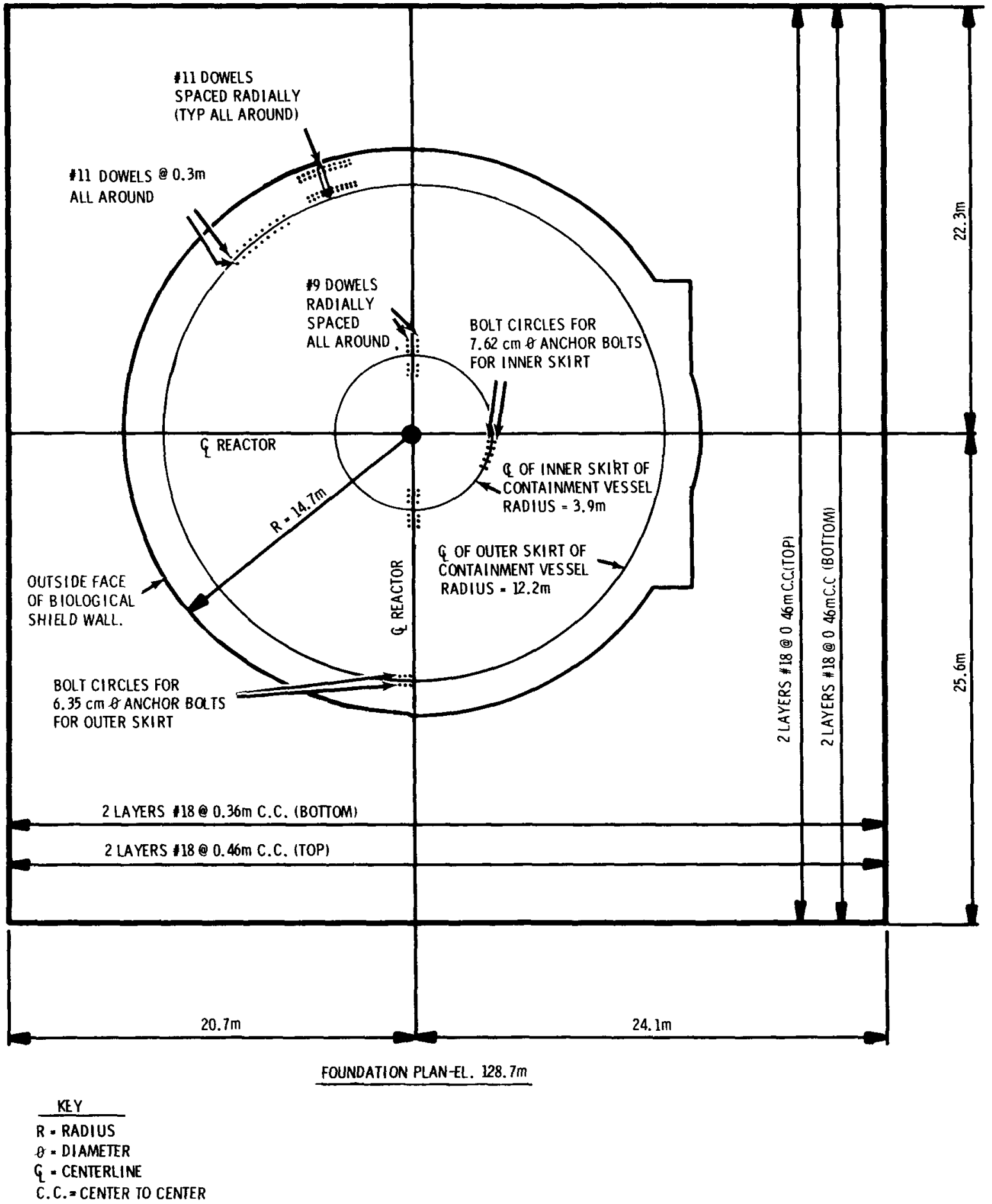

FIGURE C.2-5. Reactor Building Foundation 
The biological shield wall is a reinforced concrete structure that varies in thickness from $1.52 \mathrm{~m}$ to $1.83 \mathrm{~m}$ and extends from the top of the foundation mat to the operating floor. The top of the shield wall forms the reactor well pool cavity and is closed by means of removable, segmented, reinforced concrete shield plugs. The wall is reinforced by horizontal hoop and vertical reinforcing steel and is tied to the foundation mat by metal dowels that penetrate both structures to provide continuity.

The spent fuel storage pool (EKN 90) and the dryer and separator storage pool (EKN 112) are supported by two deep reinforced concrete beams that extend from the east and west exterior walls to the biological shield wall at each elevation above the foundation mat. These beams are constructed monolithically with and supported by the wall buttresses and the biological shield wall. Above elevation $159.1 \mathrm{~m}$, an intermediate column under each deep beam provides additional support for the pool support system.

\section{C.2.1.1 Primary Containment Vessel}

The primary containment vessel contains a drywell that houses the reactor vessel, the reactor coolant recirculating loops, and connections of the reactor primary system. It also contains a pressure suppression chamber that stores

$3160 \mathrm{~m}^{3}$ (maximum) of water and a submerged vent system that connects the drywell and the suppression pool (see Figure C.2-1).

The primary containment vessel is a free-standing steel pressure vessel with a dividing floor forming an over-under configuration inside. The vessel is enclosed in the biological shield wall, but it is separated from the wall by an annulus of compressible insulation material approximately $50 \mathrm{~mm}$ thick.

The drywell is located directly above the wetwell. The drywell configuration is basically a truncated cone with removable ellipsoidal top closure head. The suppression chamber (wetwell) is cylindrical with an ellipsoidal base. The primary containment vessel is anchored to the concrete mat foundation. The bottom of the suppression chamber is lined on the inside with reinforced concrete. The physical dimensions of the steel primary containment vessel are: 
- The diameter of the cylindrical portion at the base of the cone is approximately $26.2 \mathrm{~m}$.

- The diameter at the top of the cone is approximately $11.4 \mathrm{~m}$ and then narrows to $9.7 \mathrm{~m}$ to carry the removable head.

- The ellipsoidal bottom head, with a ratio of $2: 1$, has an inside height of approximately $6.5 \mathrm{~m}$.

- The removable ellipsoidal top closure head has an inside height of approximately $4.7 \mathrm{~m}$.

- The drywell shell height is approximately $30 \mathrm{~m}$.

- The suppression chamber shell height is approximately $22 \mathrm{~m}$.

- The overall shell height is approximately $52 \mathrm{~m}$.

The primary coritainment vessel shell plate thicknesses vary, with typical thicknesses as follows:

- bottom ellipsoidal head: from $22.2 \mathrm{~mm}$ to $38.1 \mathrm{~mm}$

- suppression chamber (wetwel1) cylinder: from $33.3 \mathrm{~mm}$ to $38.1 \mathrm{~mm}$

- drywell conical section: from $19.1 \mathrm{~mm}$ to $38.1 \mathrm{~mm}$

- removable top ellipsoidal head: $23.8 \mathrm{~mm}$.

The primary containment vessel is reinforced with internal vertical and horizontal stiffeners. Metal circumferential rings, attached to the inside face of the vessel, support pipe whip protection framework. The top closure head of the drywell is bolted to a steel flange attached to the top of the containment vessel. The vessel is provided with two concentric circular skirts on the bottom ellipsoidal head intergral with the vessel. The skirts are anchor-bolted to the concrete foundation mat and are backed up by concrete fill.

The primary containment vessel contains 171 penetrations ranging in diameter from $19.1 \mathrm{~mm}$ to $3.81 \mathrm{~m}$. Most of these penetrations also penetrate the concrete biological shield. A 3.81-m diameter penetration and a 2.69-in diameter penetration provide, respectively, equipment and personnel access to the drywel1. A 1.07-m diameter penetration provides access to the wetwell 
Table C.2-2 gives the size, quantity, general description, and general location of the rest of the primary containment vessel penetrations that penetrate the biological shield. Figure C.2-6 shows the specific location of the major penetrations through the primary containment vessel and the biological shield.

TABLE C.2-2. Primary Containment Vessel Penetration Information

\begin{tabular}{|c|c|c|c|c|c|}
\hline \multirow{3}{*}{$\begin{array}{c}\text { Nominal } \\
\text { Penetration } \\
\text { Diameter, mm }\end{array}$} & \multicolumn{4}{|c|}{ Type, Location, and Quantity of Penetrations } & \multirow{3}{*}{$\begin{array}{l}\text { Total } \\
\text { for Each } \\
\text { Diameter }\end{array}$} \\
\hline & \multicolumn{2}{|c|}{ Piping } & Instrumen & Electrical & \\
\hline & Drywe11 & Wetwe11 & Drywe11 & Wetwe 71 & \\
\hline 20 & 2 & $\ldots(a)$ & -- & -- & 2 \\
\hline 30 & - & -- & 8 & -- & 8 \\
\hline 40 & 5 & 1 & -- & -- & 6 \\
\hline 50 & 6 & 1 & -- & 4 & 11 \\
\hline 80 & -- & 2 & -- & 1 & 3 \\
\hline 100 & 2 & -- & -- & -- & 2 \\
\hline 150 & 2 & 4 & 4 & 4 & 14 \\
\hline 200 & -- & 1 & -- & -- & 1 \\
\hline 250 & 3 & -- & 25 & 3 & 31 \\
\hline 300 & 5 & 7 & 22 & 2 & 36 \\
\hline 360 & - & $\therefore$ & 3 & 1 & 4 \\
\hline 410 & 4 & -- & -- & -- & 4 \\
\hline 460 & 1 & 5 & 4 & -- & 10 \\
\hline 560 & 1 & -- & -- & -- & 1 \\
\hline 610 & -- & 10 & -- & -- & 10 \\
\hline 660 & 1 & -- & -- & -- & 1 \\
\hline 710 & 7 & -- & -- & -- & 7 \\
\hline 760 & 2 & -- & -- & -- & 2 \\
\hline 910 & 1 & -- & -- & -- & 1 \\
\hline 1070 & 2 & -- & -- & -- & 2 \\
\hline 1120 & 4 & $=$ & $=$ & $=$ & 4 \\
\hline Totals & 48 & 3] & 66 & 15 & 160 \\
\hline
\end{tabular}

(a) A dash indicates no penetrations in that category. 
8

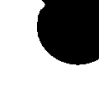




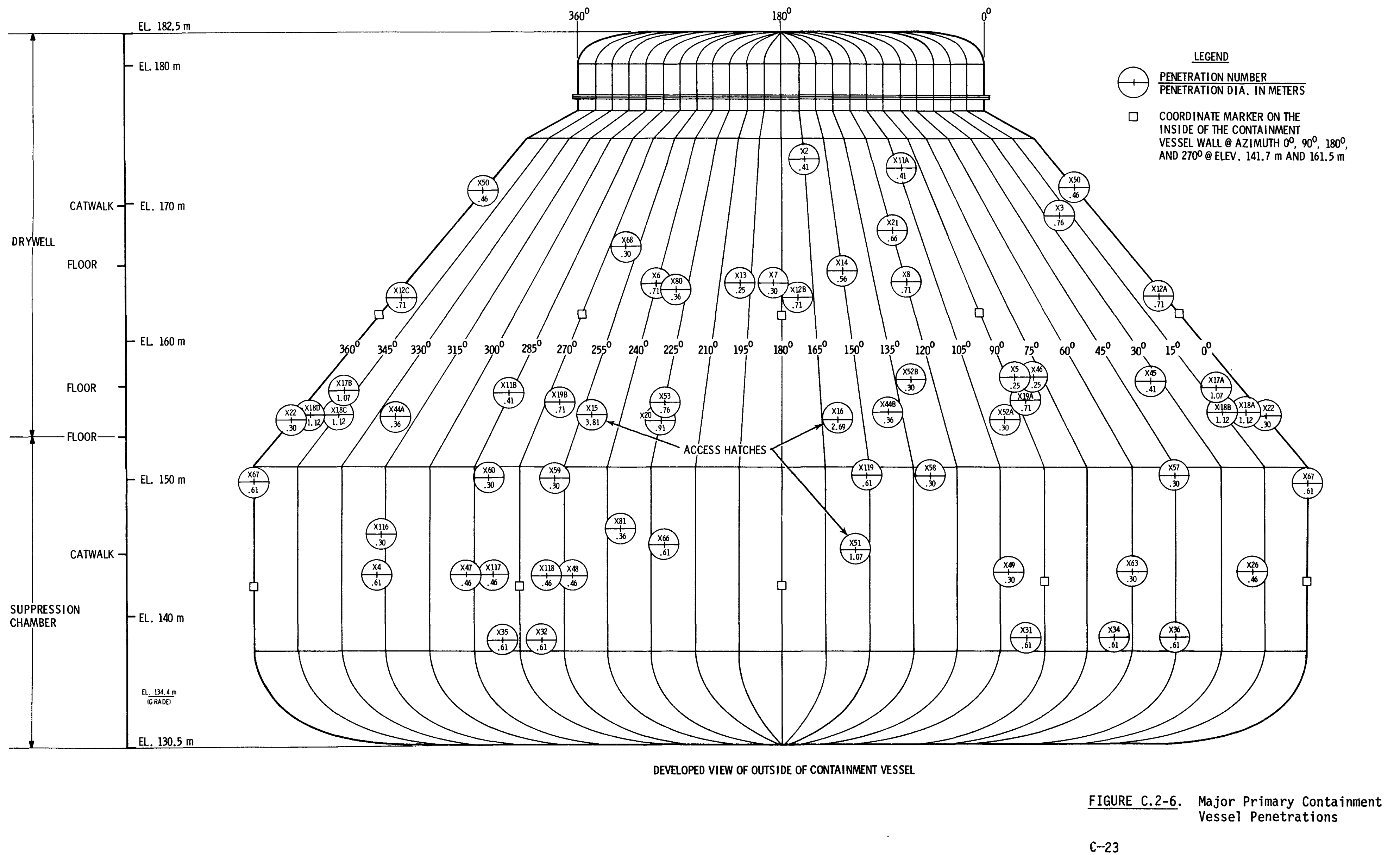


$$
\text { . }
$$ 


\section{C.2.1.2 Primary Containment Vessel Internals}

The major structural components inside the primary containment vessel are shown in Figure C.2-1, and are discussed here.

Reactor Pedestal. The reactor pedestal is a hollow, right-cylindrical reinforced concrete foundation that supports the reactor pressure vessel and the sacrificial shield wall. The bottom of the reactor pressure vessel skirt and the sacrificial shield wall are anchor-bolted directly to the top of the reactor pedestal. The bottom of the pedestal is keyed into the reinforced concrete liner inside the bottom head of the primary containment vessel and is tied directly to the reactor building foundation mat via the inner primary containment vesse1 skirt.

Except at haunches for the support of radial beams and at any other special structural features, the reactor pedestal has an inside diameter of $6.17 \mathrm{~m}$ and a shel1 thickness of $1.54 \mathrm{~m}$. Its height is approximate1y $25.6 \mathrm{~m}$. The she11 is reinforced by horizontal hoop and vertical meridional reinforcing steel.

The inside and outside surfaces of the reactor pedestal are coated with a special decontaminable epoxy coating.

Sacrificial shield Wall. The sacrificial shield wall is a vertical, cylindrical shell structure that sits atop the reactor pedestal and surrounds the lower two-thirds of the reactor pressure vessel. It is constructed of layers of inner and outer steel rings welded together and filled with concrete. Inner and outer skin plates and internal structural steel beam and box columns provide support and continuity between the ring layers and between the many penetrations that allow piping access to the reactor pressure vessel.

Except for the skin plates and other special structural aberrations, the sacrificial shield wall is $0.61 \mathrm{~m}$ thick and has a nominal inside diameter of $7.87 \mathrm{~m}$. It has a height of approximately $14.7 \mathrm{~m}$.

Drywell Floor. The drywell floor is a leak-tight pressure barrier dividing the primary containment vessel into a drywell portion above the floor and a suppression chamber (wetwe11) below the floor directly under the drywell. The drywell floor structural system consists of: 
- an outer annulus made of a $0.61-\mathrm{m}$ thick reinforced concrete slab supported by structural steel beams, by reinforced concrete columns, and by the reinforced concrete reactor pedestal

- an inner circular reinforced concrete slab, inside the reactor pedestal, $1.52 \mathrm{~m}$ thick, lower in elevation than the outer slab by approximately $2.08 \mathrm{~m}$, and constructed monolithically with, and supported by, the reactor pedestal.

Additional elements supporting the drywell floor are:

- a continuous circular closure girder embedded in the floor along its outer periphery

- a peripheral seal assembly

- shear lugs intermittently located along the outer periphery

- 17 reinforced concrete support columns equally spaced around the reactor pedestal in the suppression chamber.

Eighty-four $0.61-\mathrm{m}$ and 18 0.71-m diameter downcomer vent pipes penetrate the drywell floor into the suppression chamber. The drywell floor is coated with a special decontaminable epoxy coating.

Radial Beam Framing Systems. Structural steel beams span radially from support points on the sacrificial shield wall and the reactor pedestal to the primary containment vessel to form radial beam framing systems at various elevations in both the suppression chamber and the drywell. They provide 1) supporis for mechanical and electrical equipment, 2) platform areas for access to equipment, and 3) supports for pipe whip restraints.

Stabilizer Truss. The stabilizer truss is a circular steel truss with 16 horizontal members hinged at eight panel points at the top of the sacrificial shield wall and at eight panel points at the containment vessel wall by means of horizontal pin plate/gusset plate connections. The gusset plates are rigidly welded to the top of the sacrificial shield wall at the one end of each member and to the containment vessel at the other end. 
Reinforced Concrete Base Lining. The reinforced concrete lining inside the bottom head of the primary containment vessel provide foundation and structural continuity for concrete structures in the suppression chamber, namely the reactor pedestal and the drywell floor support co,umns. The concrete liner is anchored to the primary containment vessel by means of headed stud shear connectors welded to the vessel bottom head.

\section{C.2.2 Turbine Generator Building}

The Turbine Generator Building, shown in Figures C.2-7 through C.2-10, is a modified non-Category I structure with two floors above grade. It is designed to provide adequate protection to the main steam lines that are designed as Seismic Category I from the outermost containment isolation valves in the Reactor Building up to the turbine main steam stop valves. The Turbine Generator Building houses the turbine generator, steam condensing equipment, moisture separator reheaters, and feedwater equipment. A 182-Mg capacity overhead crane services the Turbine Generator Building.

The building exterior consists of reinforced concrete covered with metal siding from the foundation up to the operating floor level, elevation $152.7 \mathrm{~m}$. Above the operating floor, the exterior walls are insulated metal siding supported by structural steel. The roof is insulated metal decking with built-up roofing and is supported by steel trusses. The building is rectangular in plan ( $\sim 58.8 \mathrm{~m}$ by $\sim 91.4 \mathrm{~m}$ ) and in elevation ( $42.5 \mathrm{~m}$ high). The ground floor is at elevation $134.4 \mathrm{~m}$.

The Turbine Generator Building structure and the reinforced concrete turbine generator pedestal are supported on a common foundation mat. The mat is constructed of reinforced concrete of thicknesses ranging between $2.74 \mathrm{~m}$ and $3.66 \mathrm{~m}$. The mat top is at elevation $134.3 \mathrm{~m}$. The mat reinforcing bar is placed in an orthogonal pattern top and bottom, similar to that of the Reactor Building mat (refer to Figure C.2-5).

Internal walls of the Turbine Generator Building include reinforced concrete walls, concrete block wal1s, and metal partitions. The turbine (EKN 201), the main condenser (EKN 200), the moisture separator reheaters (EKN 270), the feedwater heater system (EKN 253, 254) and the condenser gas removal and 


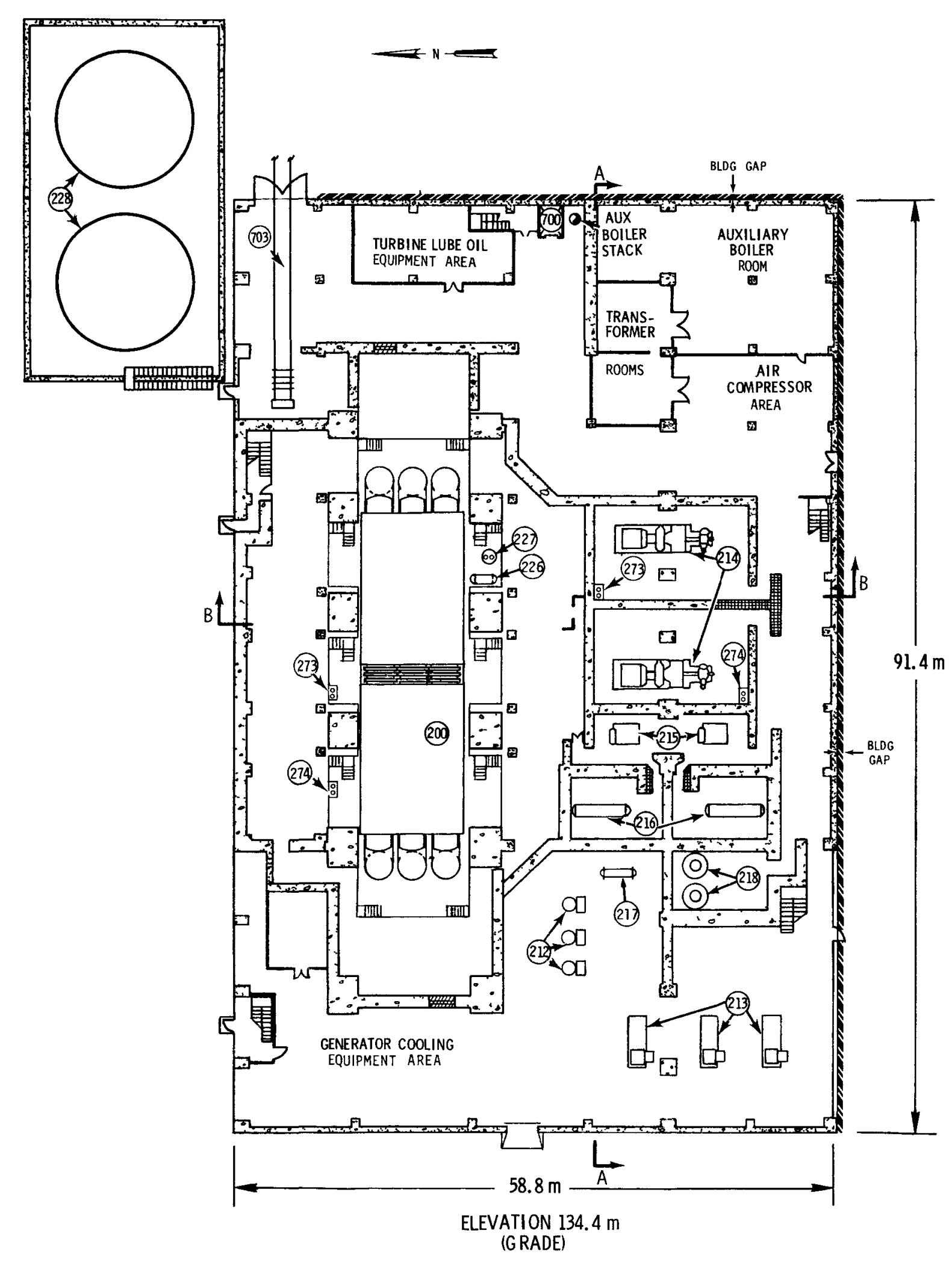

\section{EQUIPMENT KEY}

200 MAIN CONDENSER

213 CONDENSATE BOOSTER PUMPS

214 REACTOR FEEDHATER PUMPS

215 MECHANICAL VACUUM PIMPS

216 STEAM JeT AIR EJECTORS

217 GLAND SEAL STEAM CONDENS

218 CATALYTIC RECOMBINERS

226 SEAL WATER LIQUID TAM

227 PUMPED DRAIN TANK

228 COULPMANT DRAIN SUMP

274 FLOOR DRAIN SUMP

iOO ELEVATOR

703 RAILROAD TRACKS

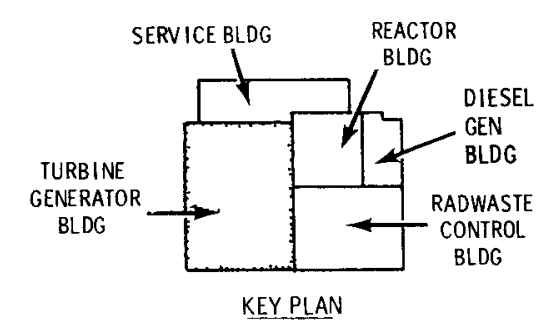




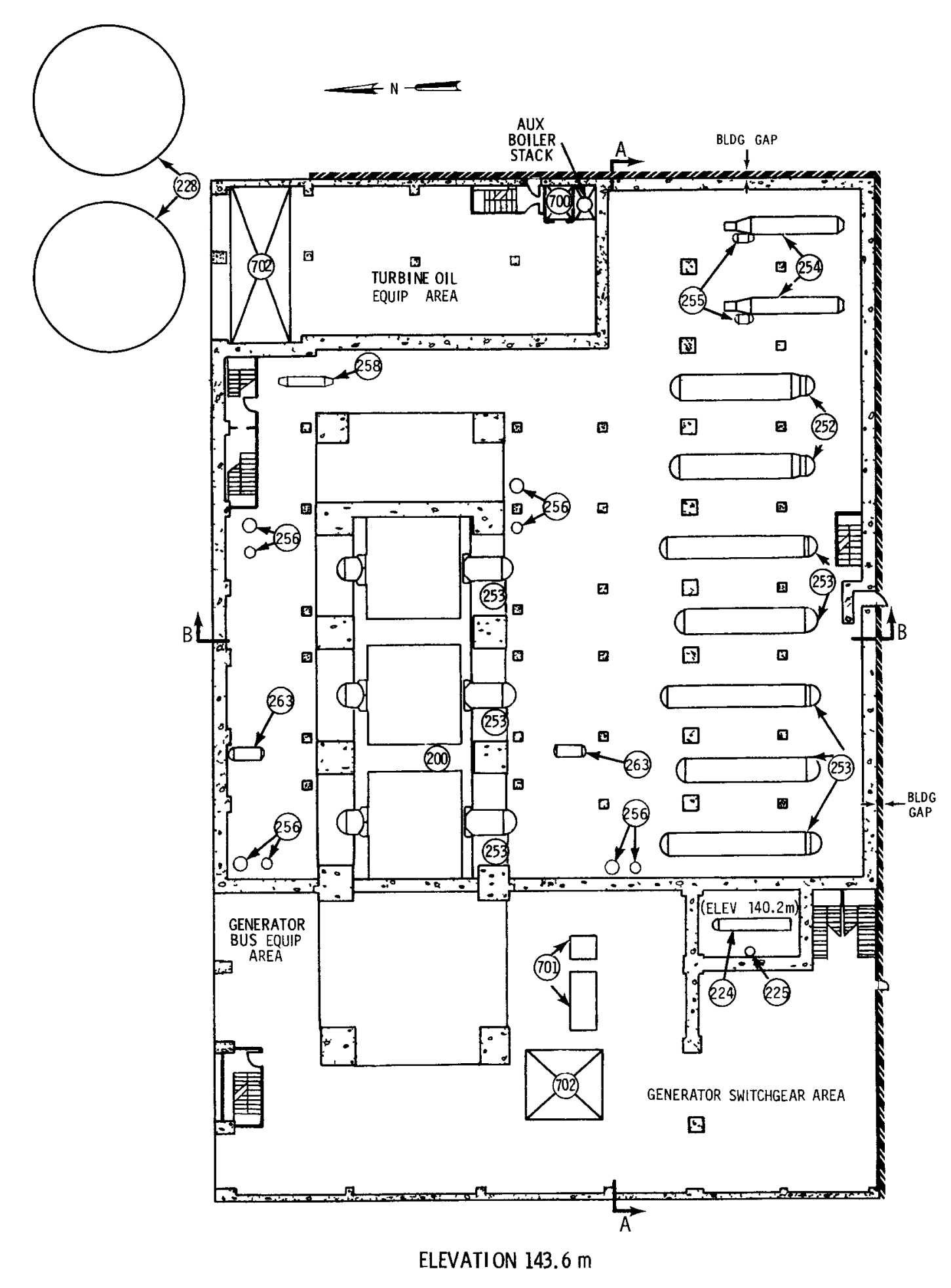

\section{EQUIPMENT KEY}

200. MAIN CONDENSER

224. OFF GAS CONDENSER
225 OFF GAS WATER SEPAPATOR

228 CONDENSATE STORAGE TANKS

252. HIGHTPRESSURE FEEDWATER HEATERS

253. LOW-PRESSURE FEEDWATER HEATERS

254. STEAM EVAPORATORS

255. EVAPORATOR DRAIN TANS

256. REHEATER DRAIN TANKS

26.

701. COVERED HATCH

702. OPEN HATCH

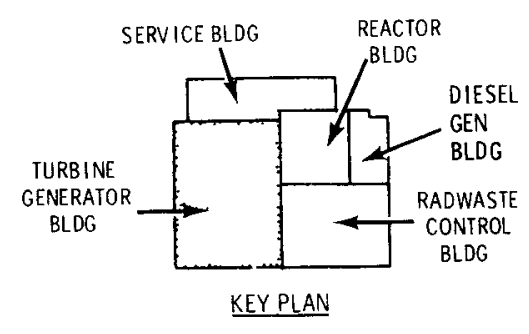





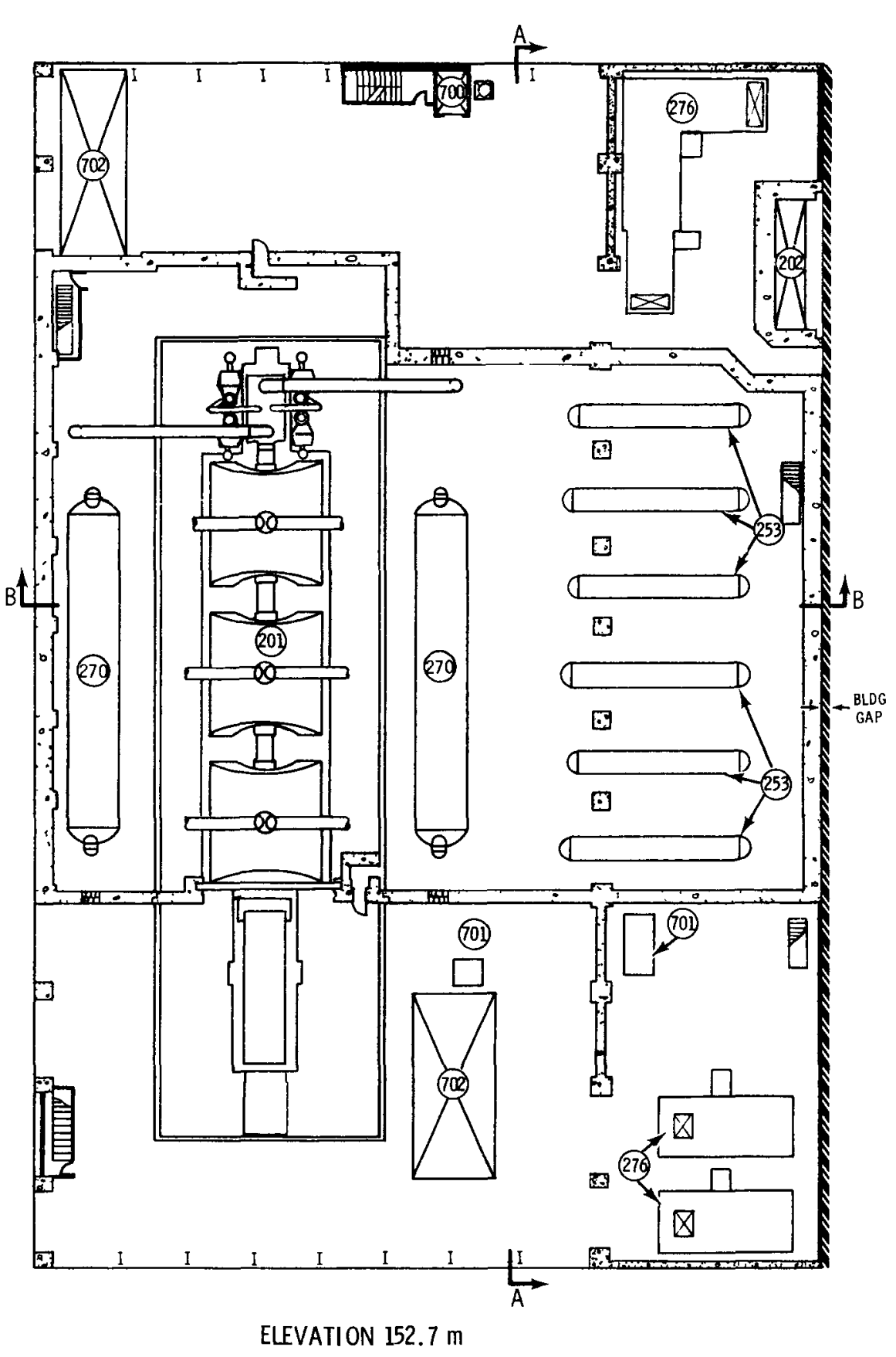

\section{EQUIPMENT KEY}

201. TURBINE GENERATOR UNIT

202 MANM STEAM ANO FELOWTER PIPE CHASE

233. LOW-PRESSURE FEEOARTER HEATERS

270. MOISURE SEPARATOR RELEATER

270.

701. COYERED HATCH

702. OPEN HATCH

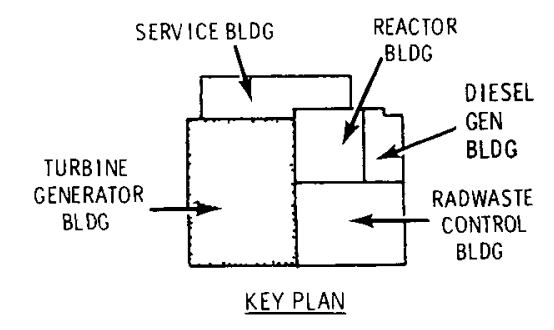


0 


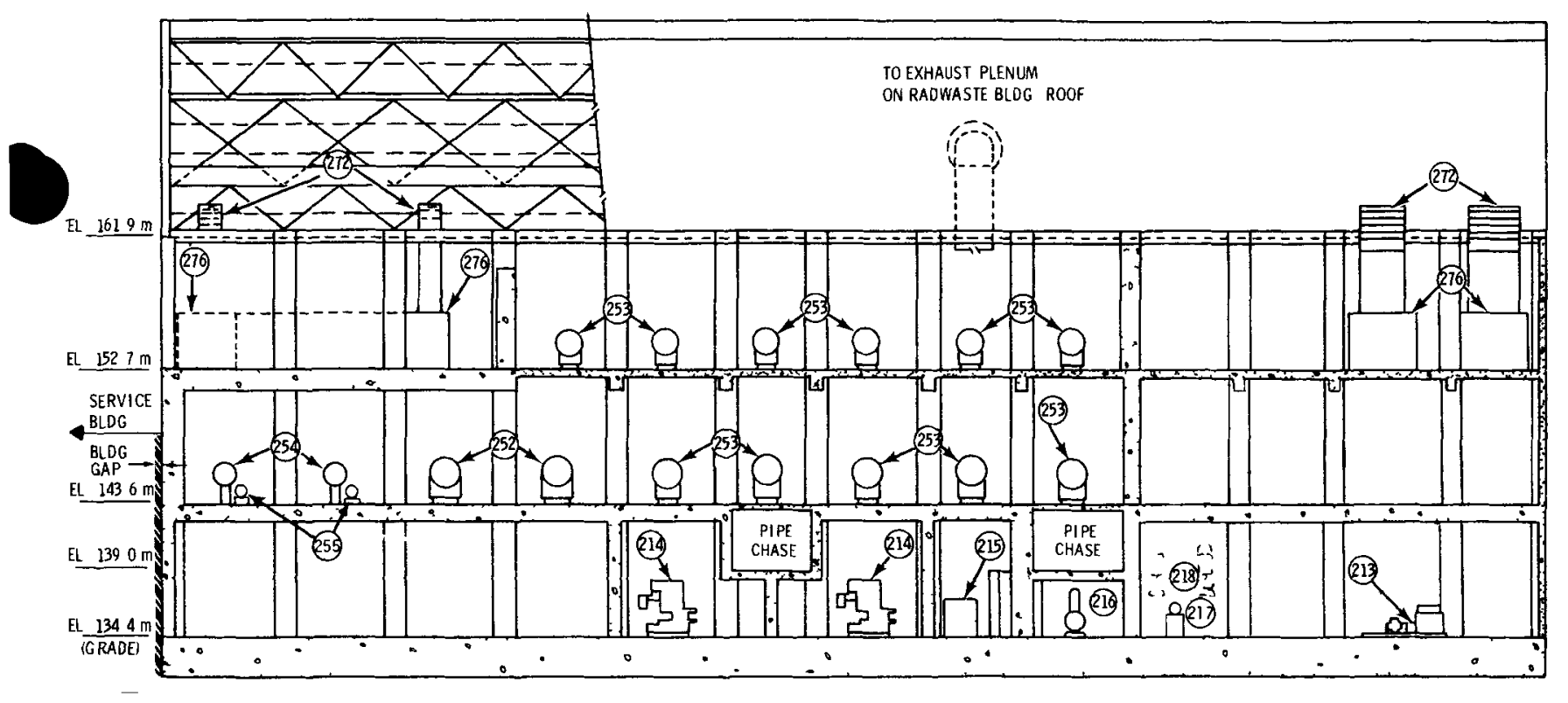

SECTIONA-A

201. TURB INE GENERATOR UNIT

213. CONDENSATE BOOSTER PUMP

214 REACTOR FEEDHATER PUMPS

216 STEAM JET AIR EJECTOR CONDENSER

217. GLAND SEAL STEAM CONDENSER

218. CATALYTIC RECOMBINERS

252 HIGH-PRESSURE FEEDHATER HEATERS

253. LOH-PRESSURE FEEDHATER HEATERS

254. STEAM EVAPORATORS

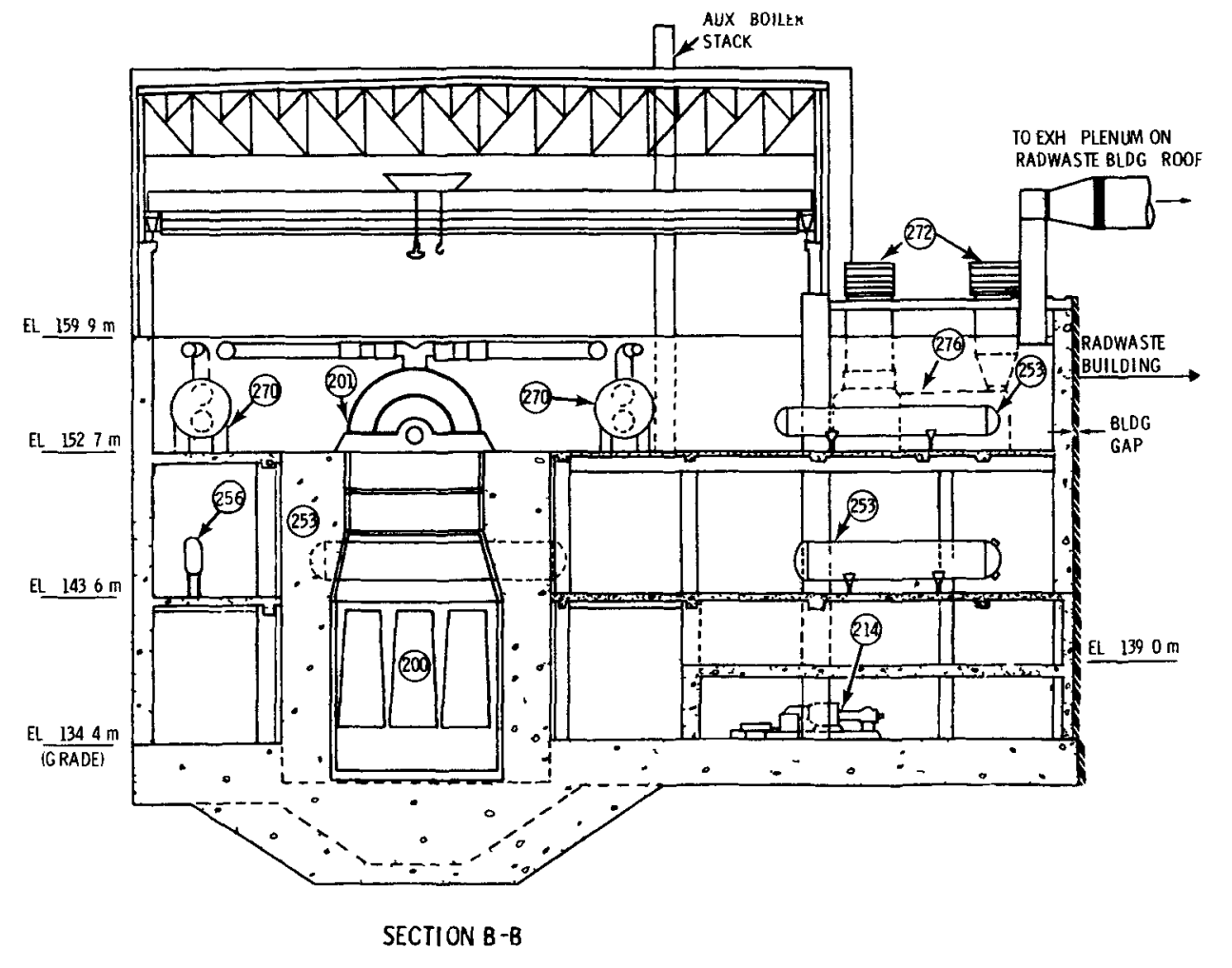

255. EVAPORATOR DRAIN TANKS

270. MOISTUR SWM TANK

272. LOUVER PENTHOUSES

276. HEATING AND VENTILATION UNITS 

handling equipment (EKN 216, 218) are surrounded by concrete walls at least $1.07 \mathrm{~m}$ thick for shielding purposes. The walls that surround the turbine generator area on elevation $152.7 \mathrm{~m}$ extend up to elevation $159.9 \mathrm{~m}$.

There are two steel tanks for storage of condensate (EKN 228) adjacent to each other and enclosed in a diked retaining area located outside the Turbine Generator Building, as shown in Figures C.2-7 and C.2-8. The retaining area is a reinforced concrete, Seismic Category I structure consisting of a structural slab on soil and four perimetral walls. The retaining area is $18.6 \mathrm{~m}$ by $34.8 \mathrm{~m}$ in plan. The four perimetral walls are approximately $5.5 \mathrm{~m}$ high. The slab is $0.61 \mathrm{~m}$ thick and the walls are $0.46 \mathrm{~m}$ thick. Construction joints are keyed. Continuous waterstops are provided in all horizontal joints between the slab and walls.

\section{C.2.3 Radwaste and Control Building}

The Radwaste and Control Building is shown in Figures C.2-11 through C.2-13. The control room tower and the radwaste area are designed to Seismic Category I criteria. The other portions of the building are designed to less stringent standards. The Radwaste and Control Building contains the following areas associated with the daily plant operation: main control room; heating, ventilating and air conditioning rooms; cable spreading room; main reactor building power distribution center; emergency battery rooms; 4160-volt and 6900-volt switchgear and relay rooms; 480-volt substation; laboratory, instrument and computer rooms; and offices and facilities for shift operating personnel. Both safety related and nonsafety related systems are housed in the Radwaste and Control Building, some of which are: the condenser off gas filter system, the radioactive waste and chemical waste systems, the reactor water cleanup demineralizer system, the fuel pool cooling and cleanup demineralizer system, the condensate demineralizer system, and the fire protection system.

The Radwaste and Control Building is rectangular in shape, being approximately $63.7 \mathrm{~m}$ by $48.8 \mathrm{~m}$ in plan and $32 \mathrm{~m}$ in overal1 height from the top of the building foundation mat at elevation $133.2 \mathrm{~m}$. The foundation mat, nominally $2.4 \mathrm{~m}$ thick and with orthogonal reinforcing similar to that in the reactor building foundation (refer to Figure (.2-5), is the only level of this building below the final plant grade. There are three main floor levels above this, and an additional partial level tops the control room tower. 
8

0 

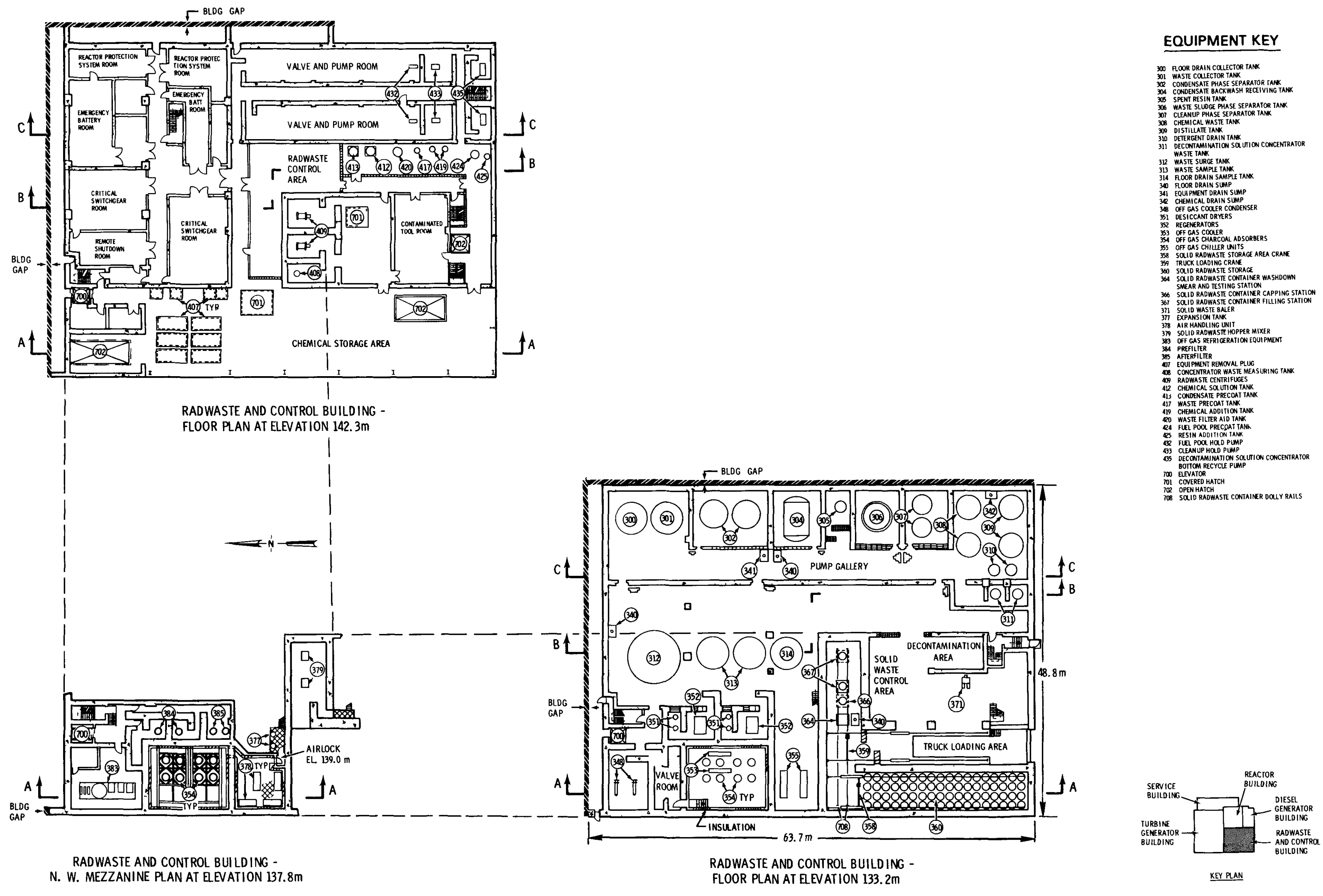

FIGURE C.2-11. Radwaste and Control Building Floor Plans - Sheet 1 


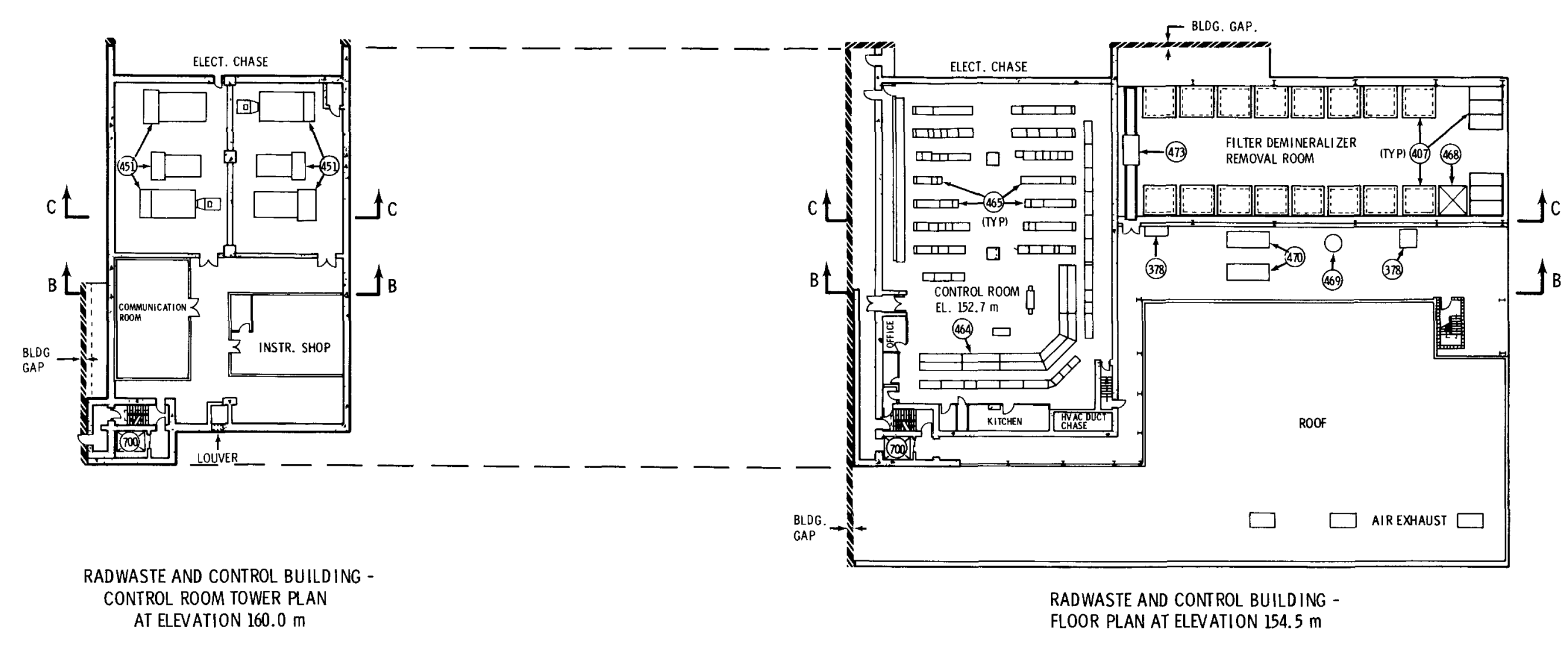

EQUIPMENT KEY

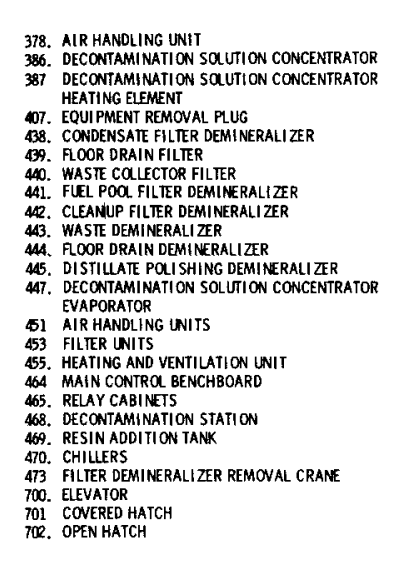

FLOOR PLAN AT ELEVATION $154.5 \mathrm{~m}$
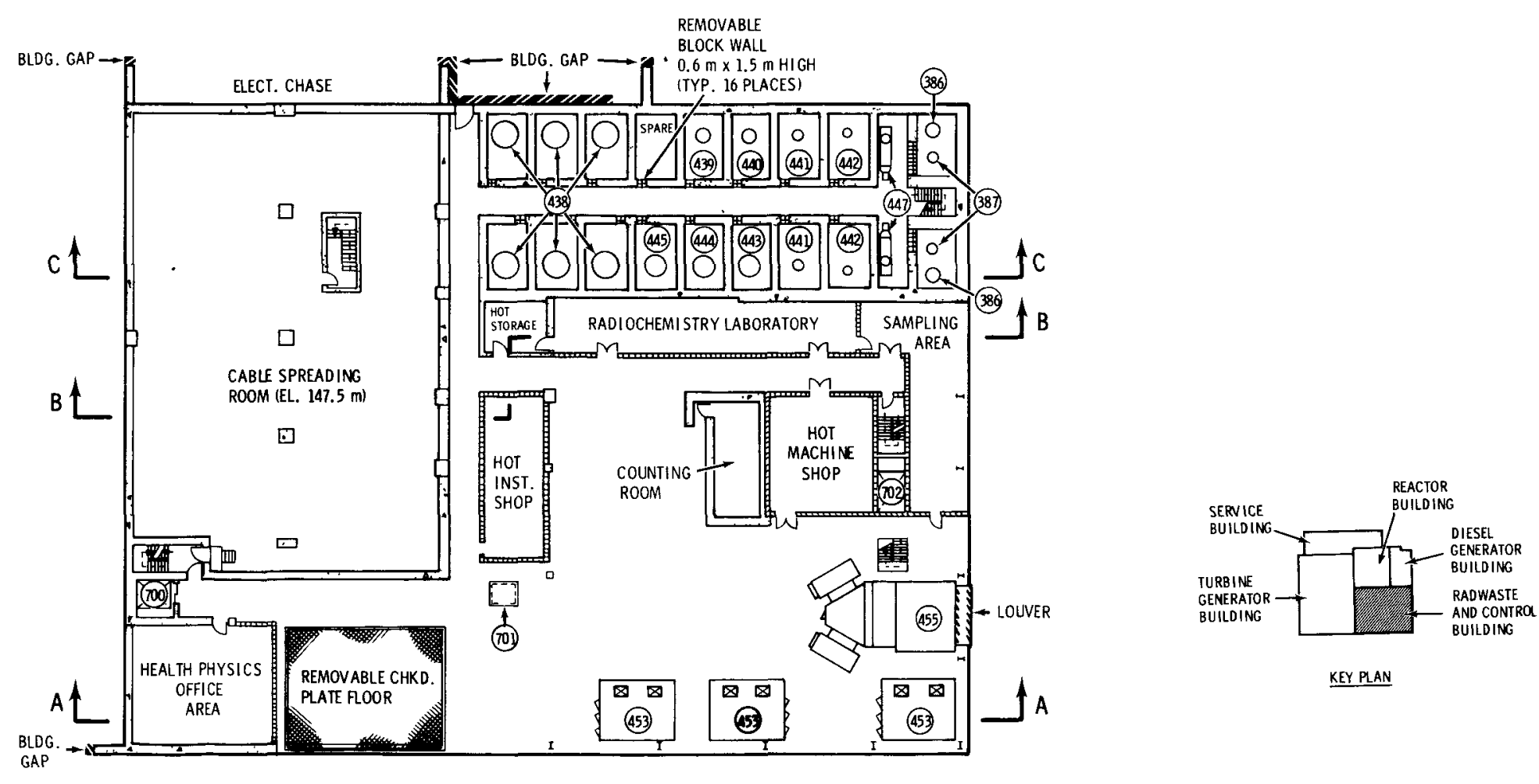
Q 


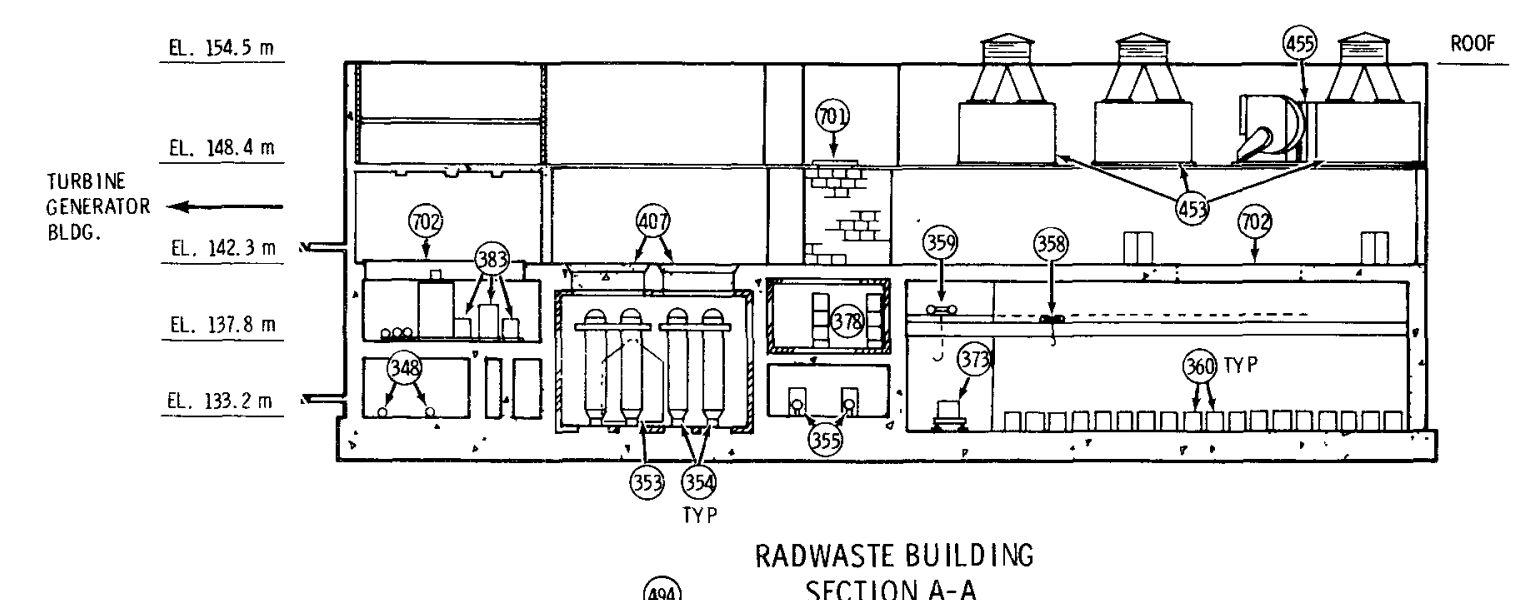

\section{EQUIPMENT KEY}
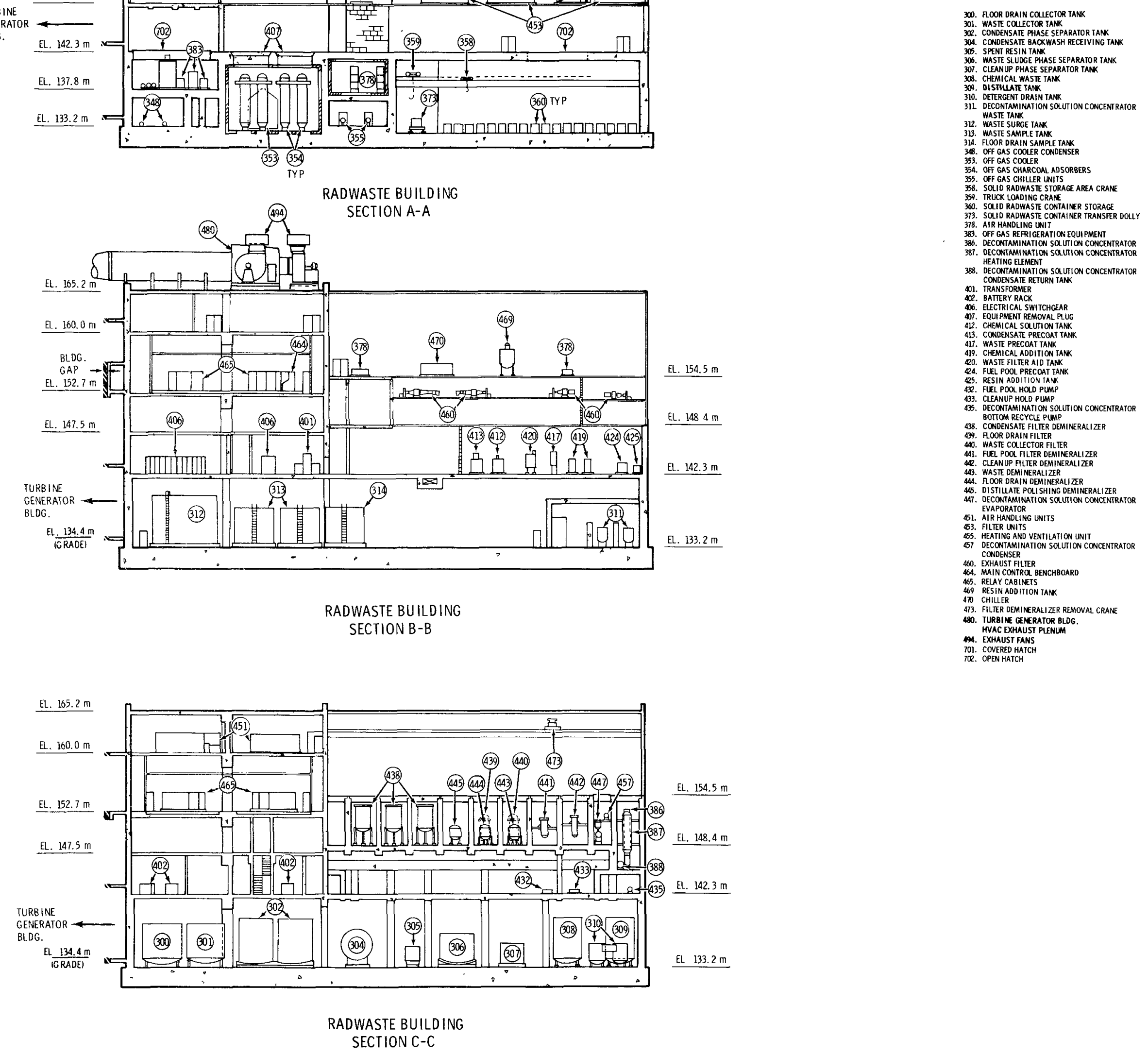
Part of the Radwaste and Control Building is a cast-in-place reinforced concrete structure and part is a structural steel framed structure. The portions of the building that are reinforced concrete are arranged to form a completely enclosed box-like structure, and are composed of concrete walls on four exterior sides and of top and bottom concrete slabs. The remaining portions of the building are made up of steel framed floors and exterior walls.

The concrete portion of the building is a diaphragm slab/shear wall-type structure, supported on a foundation mat separated and apart from the mats under each of the other structures in the plant complex. The floor and roof slabs are continuous slab and beam systems monolithically constructed. A1l exterior concrete walls are covered with metal siding.

The steel framed portions of the building consist of conventionally braced, framed wall systems with vertical bracing in bays along each wall. The girts and roof purlins are covered with insulated metal siding and insulated metal roof decking, respectively. The steel framed floors are fabricated of structural steel beams with poured concrete slabs.

Interior walls of the Radwaste and Control Building are constructed of reinforced concrete, concrete block, or metal-studded drywal1.

\section{C.2.4 Diesel Generator Building}

The Diesel Generator Building is located south of the Reactor Building and east of the Radwaste and Control Building, as shown in Figure C.1-1.

The Diesel Generator Building is rectangular in shape. It is approximately $48.5 \mathrm{~m}$ by $24.4 \mathrm{~m}$ in plan and $13.4 \mathrm{~m}$ in height from the ground floor at elevation $134.4 \mathrm{~m}$.

The building is a Seismic Category I structure with reinforced concrete diaphragm slab/shear wall-type construction. It is supported on its own foundations, which are continuous wall footings, isolated spread footings for concrete columns, and isolated equipment foundations. The ground floor is a reinforced concrete slab. 
The building has four major levels: the ground floor, the second floor, a third level consisting in part of a low roof area and in part of an enclosed floor area, and a fourth level, the high roof level. None of the floor levels are below the final plant grade.

The ground floor level is divided into four rooms separated by reinforced concrete walls. The easterly room, in turn, is divided by concrete walls extending above the ground floor slab into three subcompartments. The walls are monolithically connected to the ground floor slab. A diesel oil fuel tank is buried below each of the three subcompartments. Manholes in the ground floor slab, accessible from within each of the three subcompartments, provide access to the fuel tanks.

Three emergency diesel generators are located on the ground floor, each in a separate room. The second level houses air handling units, and the third level houses exhaust silencers.

\section{C.2.5 Service Building}

The Service Building is the last building in the main complex shown in Figure C.1-1 and is directly east of, but physically separated from, the Turbine Generator Building and the Reactor Building. It contains two stories above grade and a partial substructure. It projects $\sim 25 \mathrm{~m}$ east of the Turbine Generator Building along $52 \mathrm{~m}$ of the east Turbine Generator Building wall and $\sim 18 \mathrm{~m}$ east of the Reactor Building along $32 \mathrm{~m}$ of the east Reactor Building wall. It is $\sim 10 \mathrm{~m}$ high above grade and $\sim 6 \mathrm{~m}$ below grade.

Exterior above-grade walls of the Service Building are made of precast concrete panels. Below-grade construction is reinforced concrete. Interior walls in the area east of the Turbine Generator Building are largely steelstudded composition type, with the exception of a central quality assurance records vault that has concrete block walls. A reinforced concrete wall divides this area from the area east of the Reactor Building. All floors are reinforced concrete. The roof is made of insulated metal decking supported by steel trusses.

The Service Building area east of the Turbine Generator Building houses office, meeting, and storage facilities for the plant administrative and 
engineering staff above grade, and equipment of the plant makeup water treatment system below grade. The above-grade area east of the Reactor Building contains a high-bay machine shop serviced by an overhead crane. The belowgrade area is used for storage.

\section{C.2.6 Cooling Tower Complex}

Six circular mechanical-draft cooling towers, each $18.3 \mathrm{~m} \mathrm{high}$ and $61.0 \mathrm{~m}$ in diameter, are located some $200 \mathrm{~m}$ south of the main building complex, as shown in Figure C.1-1. In the interior of the cooling tower complex are the Circulating Water Pumphouse and two electrical buildings.

Each cooling tower is constructed basically of precast concrete modules (louvers, circumferential panels, supports, and fan deck) on a cast-in-place concrete basin. Six 149-kW, 9.1-m diameter, multiblade fans, each surrounded by a fiberglass fan cylinder, sit on top of each cooling tower. Drift eliminators and splash bars are made of asbestos cement board.

The Circulating Water Pumphouse has a structural steel and insulated metal sided superstructure and a reinforced concrete substructure, and is rectangular in plan $(19 \mathrm{~m}$ by $40 \mathrm{~m})$ and in elevation $(12 \mathrm{~m}$ above grade and $9 \mathrm{~m}$ below grade). The electrical buildings are made of structural steel with insulated metal siding and are also rectangular in plan (12 $\mathrm{m}$ by $15 \mathrm{~m}$ ) and in elevation ( $5 \mathrm{~m}$ above grade). The foundation mat is reinforced concrete.

\section{C.2.7 Spray Pond Complex}

Two spray ponds and two Standby Service water Pumphouses form a complex of Seismic Category I structures located about $200 \mathrm{~m}$ southeast of the main plant complex, as shown in Figure C.1-1. Each pond is constructed integrally with a pumphouse. Each pair of structures (pond and pumphouse) is adjacently located, but structuraliy separated.

The spray pond structures are rectangular $(73 \mathrm{~m}$ by $74 \mathrm{~m})$, reinforced concrete retention basins consisting essentially of a structural slab on soil and four perimetral exterior walls. The walls and floor slab are bounded by Quality Class I high-density backfill. Each pond is $4.6 \mathrm{~m}$ deep. The top of the perimetral walls and floor slab are respectively $0.3 \mathrm{~m}$ above and $4.3 \mathrm{~m}$ 
below the final plant grade, which is at elevation $132.3 \mathrm{~m}$ in the immediate vicinity. The floor slab is $178 \mathrm{~mm}$ thick and is placed on top of a $51-\mathrm{mm}$ unreinforced concrete subgrade leveling slab. The perimetral walls vary in thickness from $0.4 \mathrm{~m}$ at the top to $0.6 \mathrm{~m}$ at the bottom.

The pumphouses are rectangular in shape and are approximately $9.5 \mathrm{~m}$ by $18.3 \mathrm{~m}$ in plan, with the roof approximately $9.8 \mathrm{~m}$ above grade and the pumf chamber foundation approximately $8.5 \mathrm{~m}$ below grade. They are cast-in-place reinforced concrete structures and are supported on foundations consisting of spread footings and foundation mats. Each structure has four levels: the foundation slabs at the bottom of the pump chambers at elevation $124.5 \mathrm{~m}$, the electric vault and valve pit level, the main operating floor at grade-level, and the roof. The final grade in this area varies from elevations $132.8 \mathrm{~m}$ to $134.3 \mathrm{~m}$.

\section{C.2.8 Makeup Water Pumphouse}

The Makeup Water Pumphouse is located on the bank of the river that runs through a corner of the site. The structure is constructed of reinforced concrete. It contains a pump pit substructure $6.7 \mathrm{~m}$ by $6.7 \mathrm{~m}$ inside in plan and $12.7 \mathrm{~m}$ in depth, and a superstructure approximately $23.5 \mathrm{~m}$ by $11.0 \mathrm{~m}$ inside in plan and $5.2 \mathrm{~m}$ in height to the top of the roof slab.

\section{C.2.9 Auxiliary Buildings}

This section contains structural information about the other buildings shown in Figure C.1-1, namely the Office Building, the Warehouse, the Guard House, and the Gas Bottle Storage Building.

\section{Office Building}

The Office Building is located approximately $100 \mathrm{~m}$ southwest of the Radwaste and Control Building. It is a structural steel building with insulated metal siding and concrete slab floor, and is approximately $20 \mathrm{~m}$ by $30 \mathrm{~m}$ in plan and $5 \mathrm{~m}$ high at the roof crown.

\section{Warehouse}

The Warehouse is located approximately $100 \mathrm{~m}$ south of the Radwaste and Control Building and is similar in construction to the Office Building. It is approximately $30 \mathrm{~m}$ by $60 \mathrm{~m}$ in plan and $5 \mathrm{~m}$ high at the roof crown. 


\section{Guard House}

The Guard House is located directly east of the Service Building. The building is constructed of reinforced concrete below grade and precast concrete exterior above grade. The superstructure, which is approximately $15 \mathrm{~m}$ by $23 \mathrm{~m}$ in plan and $5 \mathrm{~m}$ in height, houses a central surveillance complex that is surrounded on all sides by $0.3-\mathrm{m}$ thick reinforced concrete walls and slabs. This interior structure is $7.6 \mathrm{~m}$ by $10.1 \mathrm{~m}$ inside in plan. The substructure is $7.6 \mathrm{~m}$ by $23 \mathrm{~m}$ in $\mathrm{plan}$ and $5 \mathrm{~m}$ deep.

\section{Gas Bottle Storage Building}

The Gas Bottle Storage Building is about $125 \mathrm{~m}$ north of the Turbine Generator Building. It is a precast concrete structure with reinforced concrete foundation and floor slab, and is rectangular in plan ( $9 \mathrm{~m}$ by $8 \mathrm{~m}$ ) and in elevation ( $4 \mathrm{~m}$ above grade). The floor is approximately $1 \mathrm{~m}$ above grade, at the same height as a $4-m$ by $4-m$ concrete loading dock adjoining the east side of the building.

\section{C.3 CONTAMINATED EQUIPMENT}

Descriptions of the contaminated equipment located in the Reactor Building, the Turbine Generator Building, and the Radwaste and Control Building are presented in this section.

\section{C.3.1 Reactor Building Equipment}

The Reactor Building houses the primary reactor system, reactor auxiliary and emergency cooling systems, and all the facilities required for refueling operations. It is assumed that the process equipment 1 isted in Table C.3-1, which is located outside the primary containment vessel, is contaminated since it contacts (either directly or indirectly) the contaminated reactor water, steam, or resultant condensate. Descriptions of the reactor vessel and its internals, the reactor water recirculation pumps, and the spent fuel storage pool follow.

\section{C.3.1.1 Reactor Vessel}

The reactor vessel (EKN 1), shown in Figure C.3-1, is located inside the primary containment vessel (see Figure C.2-1). It contains the core and supporting 
TABLE C.3-1. Contaminated Equipment: Reactor Building

\begin{tabular}{|c|c|c|c|}
\hline Egi(t) & Systen & 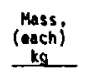 & 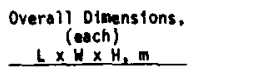 \\
\hline & Contaiment Atmosphere Control & & \\
\hline \multirow[t]{2}{*}{94} & Hydrogen Recomb1 ner (2) & 5443 & $34 \times 27 \times 23$ \\
\hline & Condensate (Nuclear Stuen) & & \\
\hline \multirow[t]{2}{*}{$\begin{array}{l}16 \\
17 \\
18\end{array}$} & 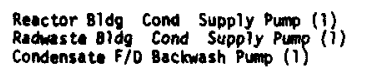 & $\begin{array}{l}340 \\
355 \\
6551\end{array}$ & 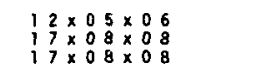 \\
\hline & Control Rod Drive (CRD) & & \\
\hline \multirow[t]{2}{*}{$\begin{array}{l}20 \\
21 \\
16 \\
\cdots-(b) \\
\cdots-\end{array}$} & 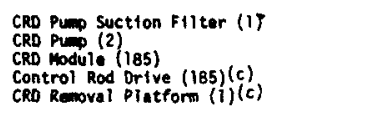 & $\begin{array}{r}181 \\
2586 \\
356 \\
205 \\
2495\end{array}$ & 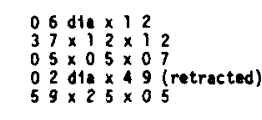 \\
\hline & Equipant Drain (Redianctive) & & \\
\hline \multirow[t]{2}{*}{$\begin{array}{c}19 \\
98\end{array}$} & $\begin{array}{l}\text { Equipant Drain Keat Exchenger (1) } \\
\text { Equipment Ora in Sump Pump (i) }\end{array}$ & $\begin{array}{l}680 \\
651\end{array}$ & 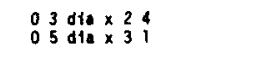 \\
\hline & Floor Prein (Redioactive) & & \\
\hline \multirow[t]{2}{*}{$\begin{array}{l}97 \\
97 \\
97 \\
97\end{array}$} & 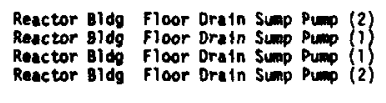 & $\begin{array}{l}524 \\
655 \\
651 \\
524\end{array}$ & 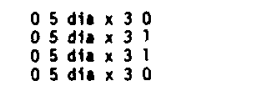 \\
\hline & Fuer Pool cooling and cleanup & & \\
\hline \multirow[t]{2}{*}{$\begin{array}{l}23 \\
55 \\
56 \\
64\end{array}$} & 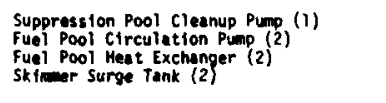 & $\begin{array}{r}528 \\
528 \\
2041 \\
3606\end{array}$ & 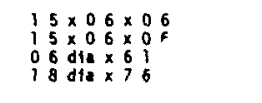 \\
\hline & High-Pressure Core Spray (HPCS) & & \\
\hline \multirow[t]{2}{*}{5} & $\begin{array}{l}\text { HPCS Puepp (1) } \\
\text { HPCS Water Leg Pump (1) }\end{array}$ & $\begin{array}{rl}27 & 443 \\
398\end{array}$ & 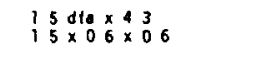 \\
\hline & Low-Pressure Core Spray (LPCS) & & \\
\hline \multirow[t]{2}{*}{4} & $\begin{array}{l}\text { LPCS Pump (1) } \\
\text { LPCS Hater Leg Pump (1) }\end{array}$ & $\begin{array}{l}9662 \\
398\end{array}$ & 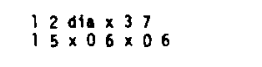 \\
\hline & MSIV Leakape Control (MSLC) & & \\
\hline \multirow[t]{2}{*}{123} & MSLC Exhaust Fan (2) & 205 & $06 \times 06 \times 06$ \\
\hline & Reactor Bullation Closed Cooling (RBCC) & & \\
\hline \multirow[t]{2}{*}{$\begin{array}{l}50 \\
51\end{array}$} & $\begin{array}{l}\text { RgcC Mater Pump (3) } \\
\text { ReCC Water Heat Exchanger (3) }\end{array}$ & $\begin{array}{l}1599 \\
7469\end{array}$ & 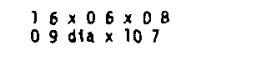 \\
\hline & Reector Core Isolation Cooling (RCIC) & & \\
\hline \multirow[t]{2}{*}{$\begin{array}{l}10 \\
11 \\
12 \\
13 \\
14 \\
15\end{array}$} & $\begin{array}{l}\text { RCIC Pump (1) } \\
\text { RCIC Water Leg Pump (1) } \\
\text { RCIC Vicuum Tank (1) } \\
\text { RCIC Condenser Pump (1) } \\
\text { RCIC Vacuum Pump (1) } \\
\text { RCIC Earometric Condenser (1) }\end{array}$ & $\begin{array}{r}6350 \\
3398 \\
408 \\
880 \\
444 \\
544\end{array}$ & 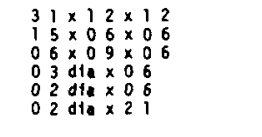 \\
\hline & Reactor Refueling & & \\
\hline \multirow[t]{2}{*}{ 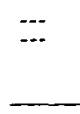 } & $\begin{array}{l}\text { Refuel ing Platform } \\
\text { Service Platform }\end{array}$ & $\begin{array}{rl}24 & 948 \\
5216\end{array}$ & \\
\hline & Reactor Hater Cleanup (RUCU) & & \\
\hline \multirow{3}{*}{$\begin{array}{l}47 \\
61 \\
62\end{array}$} & $\begin{array}{l}\text { RHCU Rec I Pculat ton Pump (2) } \\
\text { RHCU Regenerat Ive Heat Exchanger (3) }\end{array}$ & $\begin{array}{r}590 \\
4135\end{array}$ & $\begin{array}{llllllll}1 & 5 & x & 0 & 6 & x & 0 & 0 \\
0 & 8 & d 1 & 4 & x & 6 & 4\end{array}$ \\
\hline & $\begin{array}{l}\text { Redu Non-Regenerative Heat } \\
\text { Exchanger (2) }\end{array}$ & 4082 & 08 dra $\times 79$ \\
\hline & Residual Heat Removal (RHR) & & \\
\hline \multirow[t]{2}{*}{$\begin{array}{r}8 \\
9 \\
54\end{array}$} & $\begin{array}{l}\text { RHR Pump (3) } \\
\text { RRR Hater Leq Pupp } \\
\text { RHR Hest Exchenger }(1)\end{array}$ & $\begin{array}{r}7802 \\
2998 \\
29225\end{array}$ & 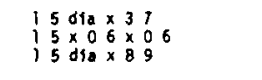 \\
\hline & Iravarsing In-Core Probe (TIP) & & \\
\hline 42 & TIP Orive Mechantsm (5) & 362 & $12 \times 08 \times 09$ \\
\hline
\end{tabular}




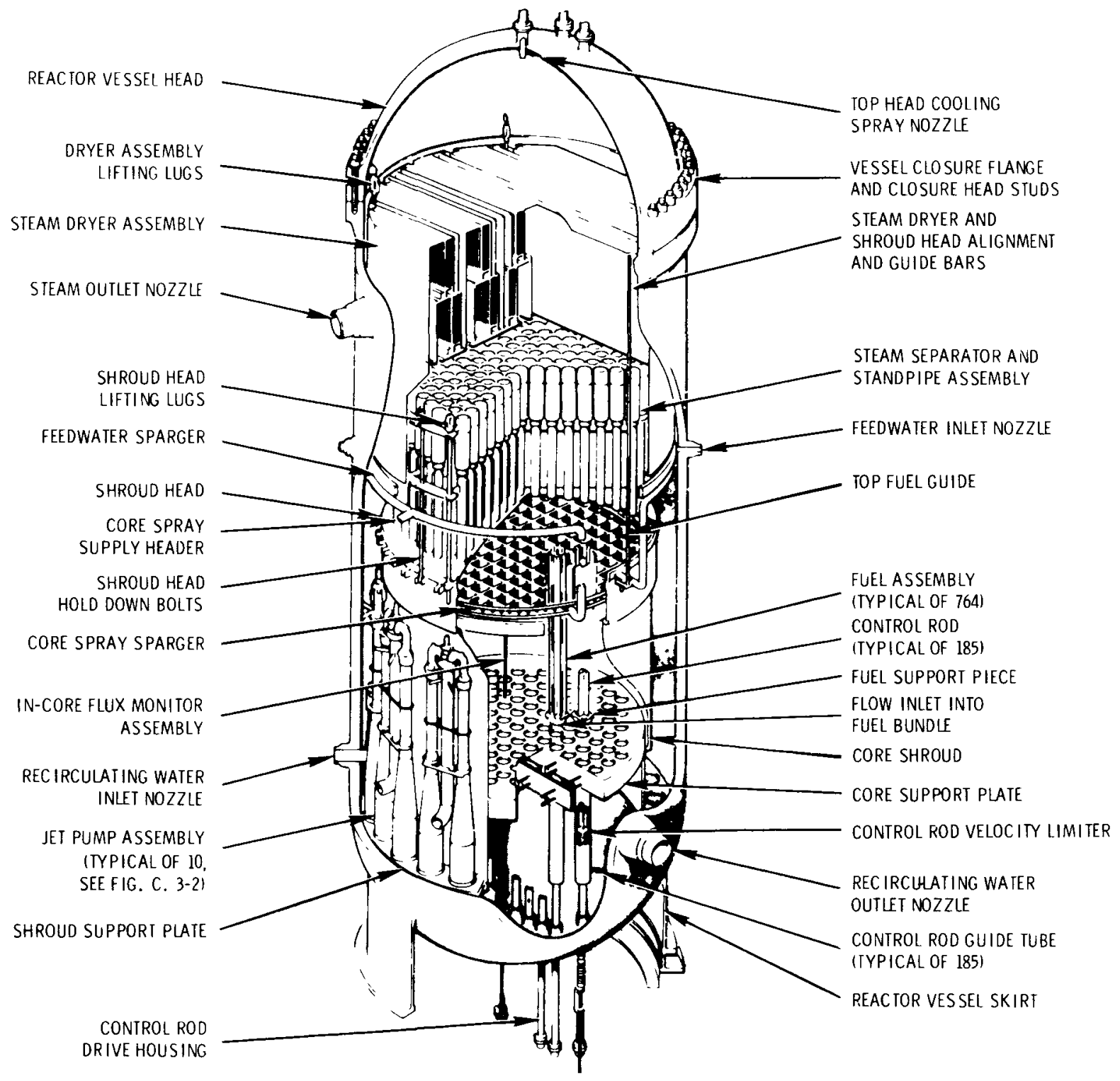

FIGURE C.3-1. Reactor Vessel and Internals 
structures; steam separators and dryers; coolant recirculation jet pumps; control rod guide tubes; distribution piping for feedwater, core sprays, and liquid control; in-core instrumentation; and other components. The main connections to the vessel include steam 1 ines, coolant recirculation 1 ines, feedwater lines, control rod drive and in-core nuclear instrumentation housings, high- and low-pressure core spray lines, residual heat removal lines, standby liquid control line, jet pump pressure-sensing lines, and water-level instrumentation.

The reactor vessel is a vertical, cylindrical pressure vessel of welded construction designed for a pressure of $8.72 \mathrm{MPa}$. The vessel is fabricated of SA533 carbon steel and is clad internally with Type 304 stainless steel (except for the top head, nozzles, and nozzle weld zones, which are unclad).

The vessel top head is secured to the reactor vessel by studs and nuts. The nuts are tightened with a stud tensioner. The vessel flanges are sealed with two concentric metal seal-rings.

The design parameters of the reactor vessel are presented in Table C.3-2.

\section{C.3.1.2 Reactor Vessel Internais}

Refer to Figure C.3-1 for a general assembly drawing of the important reactor components.

The reactor vessel internals include (exclusive of fuel, control rods, in-core nuclear instrumentation, and pressure boundary appurtenances welded to the vessel) the following components:

Core Shroud. The core shroud is a stainless steel cylindrical assembly that separates the core region from the outer annulus. The upper part of the shroud surrounds the core discharge plenum, which is bounded by the shroud head on top and the top guide below. The central portion of the shroud surrounds the fuel region and forms the longest section of the shroud. This section is bounded at the bottom by the core support plate. The lower portion of the shroud, surrounding part of the lower plenum, is welded to the reactor vessel shroud support. 


\section{TABLE C.3-2. Reactor Vessel Design Parameters}

Parameter of Interest

Internal Height from Insiae Bottom Head to Inside Top Head Shell Height to Top of Closure Flange

CRD Housing Projection Below Inside Bottom Head

ID of Shell

Minimum Shell Wall Thickness

Wall SS Cladding Thickness

Bottom Head Thickness

Closure Flange Thickness

ID of Top Head Flange

Top Head Flange Thickness

Top Head Thickness

Number of Top Head Studs

OD of Top Head Studs

Mass of Vessel with Top Head, Studs, Nuts, and Washers

Mass of Top Head

Mass of Vessel with Top Head and Internals

\begin{tabular}{|c|c|c|}
\hline Vessel Nozzles (Quantity) & $\begin{array}{l}\text { ID, } \\
\underline{\mathrm{mm}}\end{array}$ & $\begin{array}{c}\text { Elevation Above } \\
\text { Inside Bottom Head, m }\end{array}$ \\
\hline $\begin{array}{l}\text { Level Instrumentation and } \\
\text { Vessel Vent (1) }\end{array}$ & 76 & Top Head \\
\hline $\begin{array}{l}\text { Head Spray (1) } \\
\text { Spare Head (1) }\end{array}$ & $\begin{array}{l}114 \\
114\end{array}$ & $\begin{array}{l}\text { Top Head } \\
\text { Top Head }\end{array}$ \\
\hline $\begin{array}{l}\text { Ma in Steam (4) } \\
\text { Instrument (4) } \\
\text { Instrument (2) }\end{array}$ & $\begin{array}{r}610 \\
38 \\
38\end{array}$ & $\begin{array}{l}16.46 \\
15.21 \\
13.13\end{array}$ \\
\hline Feedwater (6) & 305 & 12.53 \\
\hline $\begin{array}{l}\text { Core Spray (2) } \\
\text { Residual Heat Removal (3) }\end{array}$ & $\begin{array}{l}229 \\
305\end{array}$ & $\begin{array}{r}12.17 \\
9.46\end{array}$ \\
\hline $\begin{array}{l}\text { Instrument (4) } \\
\text { Recirculation Inlet (10) }\end{array}$ & $\begin{array}{r}38 \\
279\end{array}$ & $\begin{array}{l}9.30 \\
4.60\end{array}$ \\
\hline Recirculation Outlet (2) & 533 & 4.38 \\
\hline $\begin{array}{l}\text { Jet Pump Instr. (2) } \\
\text { Core } \triangle \mathrm{p} / \mathrm{SLC}(1) \\
\text { Bottom Head Drain (1) } \\
\text { CRD Housing (185) }\end{array}$ & $\begin{array}{r}89 \\
64 \\
38 \\
127\end{array}$ & $\begin{array}{l}3.86 \\
\text { Bottom Head } \\
\text { Bottom Head } \\
\text { Bottom Head }\end{array}$ \\
\hline
\end{tabular}

Design Specification

$22.23 \mathrm{~m}$

$18.92 \mathrm{~m}$

$3.15 \mathrm{~m}$

$6.375 \mathrm{~m}$

$171 \mathrm{~mm}$

$3.18 \mathrm{~mm}$

$203 \mathrm{~mm}$

$330 \mathrm{~mm}$

$6.223 \mathrm{~m}$

$432 \mathrm{~mm}$

$114 \mathrm{~mm}$

108

$152 \mathrm{~mm}$

$748.5 \mathrm{Mg}$

$90.7 \mathrm{Mg}$

$1034.2 \mathrm{Mg}$

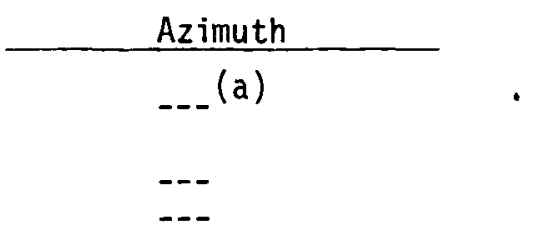

$72^{\circ}, 108^{\circ}, 252^{\circ}, 288^{\circ}$

$20^{\circ}, 160^{\circ}, 200^{\circ}, 340^{\circ}$

$10^{\circ}, 190^{\circ}$

$30^{\circ}, 90^{\circ}, 150^{\circ}, 210^{\circ}$,

$270^{\circ}, 330^{\circ}$

$120^{\circ}, 240^{\circ}$

$45^{\circ}, 135^{\circ}, 315^{\circ}$

$20^{\circ}, 160^{\circ}, 200^{\circ}, 340^{\circ}$

$30^{\circ}, 60^{\circ}, 90^{\circ}, 120^{\circ}$,

$150^{\circ}, 210^{\circ}, 240^{\circ}, 270^{\circ}$, $300^{\circ}, 330^{\circ}$

$0^{\circ}, 180^{\circ}$

$105^{\circ}, 285^{\circ}$

(a) Indicates "not applicable." 
Shroud Support Plate. The shroud support plate is a circular stainless steel plate welded to the vessel wall, forming the base of the outer annulus. This support carries the weight of the core shroud, shroud head, peripheral fuel elements, neutron sources, core support plate, top fuel guide, steam separators, and the restraining effect of components attached to the support.

Core Support Plate. The core support plate consists of a circular stainless steel plate containing bored holes and stiffened with a rim and beam structure. The plate provides lateral support and guidance for the control rod guide tubes, in-core flux monitor guide tubes, peripheral fuel support, and neutron sources. The last two items are also supported vertically by the core support plate.

The entire assembly is bolted to a support ledge between the central and lower portions of the core shroud. Alignment pins that engage slots and that bear against the core shroud are used to correctly position the assembly before it is secured.

Top Fuel Guide. The top fuel guide is formed by a series of stainless steel beams fastened to a peripheral rim and joined at right angles to form square openings. Each opening provides lateral support and guidance for four fuel assemblies or, in the case of peripheral fuel, one fuel assembly. Sockets are provided in the bottom of the beam intersections to anchor the in-core flux monitors and startup neutron sources. The rim of the top fuel guide rests on a ledge between the upper and central portions of the shroud. The top fuel guide has alignment pins that engage and bear against slots in the shroud to correctly position the assembly before it is secured. Lateral restraint is provided by wedge blocks between the top fuel guide and the shroud wall.

Control Rod Guide Tubes. The 185 control rod guide tubes extend from the top of the control rod drive housings up through holes in the core support plate. Besides being the guide for a control rod, each stainless steel tube vertically supports a four-lobed orificed fuel support piece and the four fuel assemblies surrounding the control rod. The bottom of the guide tube is supported by the control rod drive housing penetrating and welded to the 
stub tube that is welded to the reactor vessel bottom head. A thermal sleeve is inserted into the control rod drive housing from below, and is rotated to lock the control rod guide tube in place. A key is inserted into a locking slot in the bottom of the control rod drive housing to hold the thermal sleeve in position.

Jet Pumps. Two semicircular groups of 10 jet pumps are located in the outer annulus between the core shroud and the reactor vessel wall. Each stainless steel jet pump consists of an inlet riser pipe, driving nozzle, suction inlet, throat or mixing section, and diffuser with attachment braces (see Figure C.3-2). The driving nozzle, suction inlet, and throat are joined together as a removable unit. The diffuser, associated bracing, and riser pipe are permanently installed. The riser pipe is welded to the recirculation inlet nozzle thermal sleeve. The riser brace consists of cantilever beams extending from welded pads on the reactor vessel wall.

The jet pump nozzle entry section is connected to the riser by a metal-tometal, spherical-to-conical seal joint. Contact is maintained by a hold-down clamp. The throat section is supported laterally by a bracket attached to the riser. The diffuser is a gradual conical section changing to a straight cylindrical section at the lower end.

Shroud Head and Steam Separator Assembly. The shroud head and steam separator assembly consists of a flange and dome onto which is welded an array of standpipes, with an axial-flow steam separator welded to the top of each standpipe. The entire assembly is stainless steel. It mounts on the flange at the top of the shroud cylinder, forming a non-gasketed joint, and is held in place by long shroud head hold-down bolts. These bolts extend above the steam separators for easy access during removal. The entire assembly is positioned on the shroud by vertical guide rods on the inside of the reactor vessel and locating pins on the shroud flange.

Steam Dryer Assembly. The stainless steel steam dryer assembly mounts in the reactor vessel above the shroud head and steam separator assembiy. It consists of a series of vertical corrugated dryer vanes housed in perforated plates at the top of the assembly. A skirt extends down the bottom of 


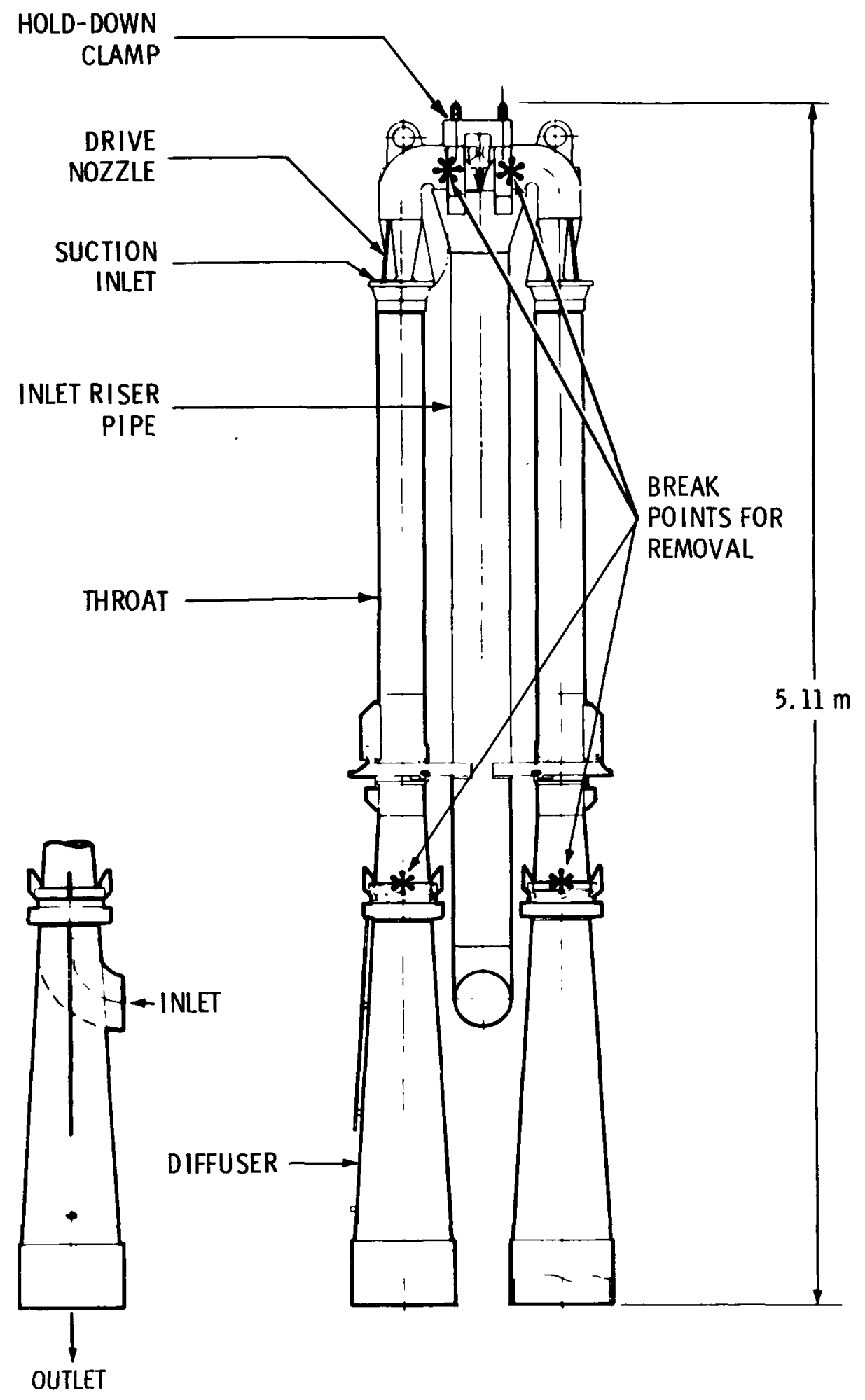

FIGURE C.3-2. Reactor Coolant Recirculation Jet Pump Assembly 
the dryer assembly housing to the elevation of the steam separator standpipes. The assembly is positioned in the vessel by the same guide rods as the shroud head. The dryer assembly rests on support brackets extending from the vessel wall, and is locked into position by brackets attached to the underside of the reactor vessel top head.

Feedwater Spargers. The feedwater spargers, located in the outer annulus, are stainless steel headers containing flow holes. An individual sparger is welded to each feedwater nozzle thermal sleeve that, in turn, is welded to the safe end of the vessel nozzle. The header is shaped to conform to the inside curvature of the reactor vessel wall. Sparger end brackets are attached to vessel wall brackets to support the spargers.

Core Spray Lines. Two core spray lines, entering the reactor vessel through the two core spray nozzles, divide immediately inside the reactor vessel. The two halves of the first line are routed to opposite sides of the reactor vessel and are supported by clamps attached to the vessel wall. The lines are then routed downward in the outer annulus and pass through the upper shroud immediately below the flange. The ends of the two spargers are supported by brackets. The other core spray line is identical, except that it enters the opposite side of the vessel and the spargers are at a slightly different elevation inside the shroud.

Top Head Cooling Spray Nozzle. The top head cooling spray nozzle is flange-mounted to a mating flange on the top reactor vessel head nozzle.

Differential Pressure and Liquid Control Line. The differential pressure and liquid control line enters the reactor vessel as two concentric pipes at a point below the core shroud. In the lower plenum, the two pipes separate. The inner pipe terminates near the lower shroud with a perforated length below the core support plate. The outer pipe terminates immediately above the core support plate and senses the pressure in the region outside the fuel assemblies.

In-Core Flux Monitor Guide Tubes. These tubes position fixed neutron detectors in the core and provide a path for the traversing in-core probes. The in-core flux monitor guide tubes extend from the top of the in-core flux 
monitor housing in the lower plenum to the top of the core support plate. A latticework of clamps, tie bars, and spacers gives lateral support and rigidity to the guide tubes. The bolts and clamps are welded.

Startup Neutron Sources. The startup neutron sources are held in place by spring pressure, and are located between the top of the core support plate and the bottom of the top fuel guide. Each source consists of two irradiated antimony rods within a single beryllium cylinder. Both the antimony and the beryllium are encased in stainless steel tubes.

\section{C.3.1.3 Reactor Water Recirculation Pumps}

Two reactor water recirculation pumps are part of two identical stainless steel reactor water recirculation loops located in the drywell external to the reactor vessel, as shown in Figure C.3-3. Each external loop contains one motor-driven recirculation pump, a flow control valve, two motor-operated shutoff valves, and a bypass around the discharge shutoff valve and the flow control valve. Each loop ends in an external manifold from which individual water inlet lines are routed to the jet pump risers within the reactor vessel. Table C.3-3 lists the design characteristics of the reactor water recirculation system.

The reactor water recirculation pump (EKN 33), shown in Figure C.3-4, is a single-suction, single-stage, double-volute, motor-driven pump. The pump drive motor is mounted on a carbon steel motor stand above the pump. Motor torque is transmitted to the pump impeller by a vertically mounted pump shaft connected to the motor shaft by a rigid coupling. The pump suction nozzle is at the bottom of the pump casing, and the discharge nozzle is at the side in the horizontal plane.

The stainless steel pump case is welded to the reactor recirculation piping. A stuffing box is attached to the pump case with case studs and nuts. The upper pump shaft components are installed in the stuffing box, which also contains a cooling jacket and inlet and outlet connection points for the cooling and seal-staging water systems. The impeller is mounted on a taper fit to the pump shaft and is retained axially by the impeller nut and capscrew. 


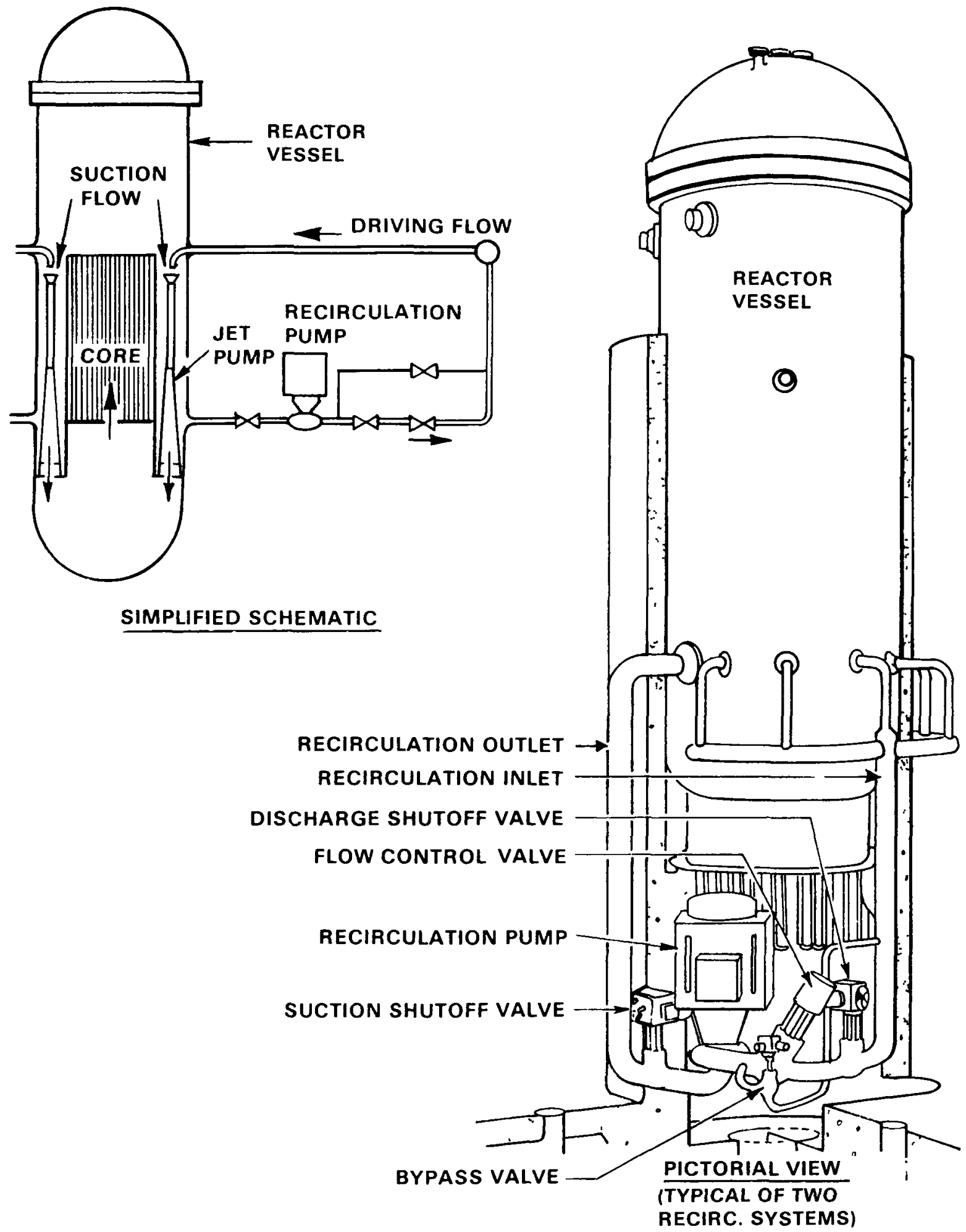

FIGURE C.3-3. Reactor Water Recirculation System 
TABLE C.3-3. Reactor Water Recirculation System Design Parameters

Parameter of Interest

External Piping Loops:

Number of Loops

Pipe Sizes (nominal 0.0.)

Pump Suction

Pump Discharge

Discharge Manifold

External Risers

Recirculation Bypass Line

Material

Recirculation Pump:

Dimensions:

Width

Depth

Height (including motor)

Mass:

Motor

Pump and Accessories

Unit Total

Motor:

Type

Power

Voltage

Frequency

Power Source

Punp -

Type

Rated Flow

Rated Head

Rated Speed

Case laterial

Flow Control Valve

Type

Materid?

Type Actuation

Diameter

Recirculation Loop Block Valve.

Number

Type

Actuator

Material

Diameter

Recirculation Loop Bypass

Valve:

Type

Actuator

Material

Diameter
Parameter Specification

$0.61 \mathrm{~m}$
$0.61 \mathrm{~m}$
$0.41 \mathrm{~m}$
$0.30 \mathrm{~m}$
$0.25 \mathrm{~m}$
Austenitic
$316 \mathrm{SS}$

316 SS

$3.25 \mathrm{~m}$

$3.57 \mathrm{~m}$
$6.17 \mathrm{~m}$

$27215 \mathrm{~kg}$

$16375 \mathrm{~kg}$

$43590 \mathrm{~kg}$

Type $K$, Vertical,

Solid Shaft, Four-

Pole Induction Motor,

$\begin{array}{lll}1 & 787 & \mathrm{rpm} \\ 6 & 637 \mathrm{kw}\end{array}$

6600 Volts $A C$,

Three-phase

$60 \mathrm{~Hz}$

Startup Transformer

Vertical, Double

Volute, single Suction,

Single Stage

$179 \mathrm{~m} / \mathrm{min}$

$254 \mathrm{~m}$

$1787 \mathrm{rpm}$

Mechanical

Austenitic

316 SS

Ball

Austenitic

316 SS

Hydraulic

$0.61 \mathrm{~m}$

2

Gate Valve

Motor

Austenitic

316 SS

$0.61 \mathrm{~m}$

Right Angle

Motor

Austenitic

316 SS

$0.25 \mathrm{~m}$ 


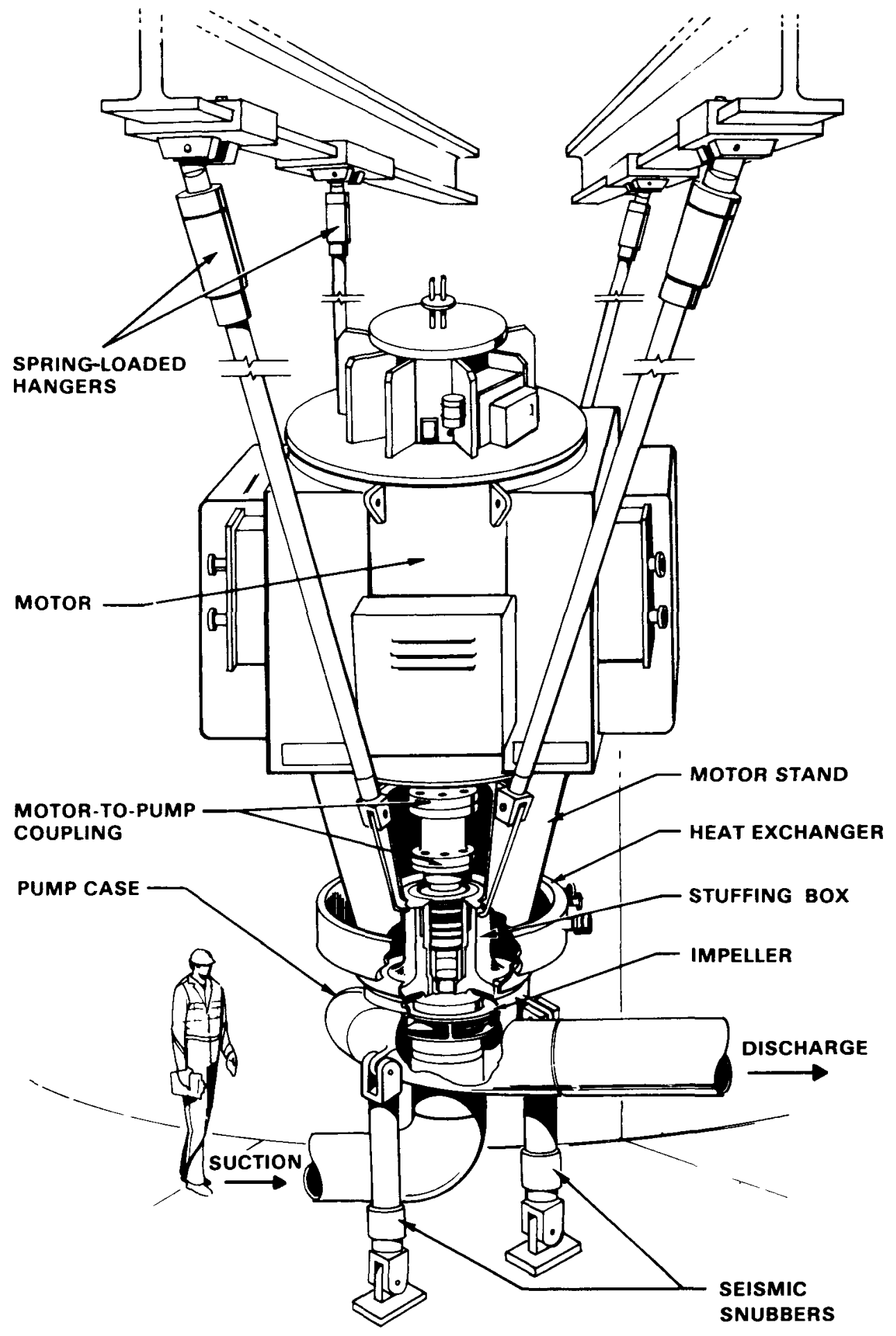

FIGURE C.3-4. Reactor Water Recirculation Pump 
Besides being held in place by its placement in the recirculation loop piping, each recirculation pump motor is suspended from the overhead radial beam system by four spring-loaded hangers. Each pump case is semi-rigidly attached to the surrounding drywell structure by three mechanical snubbers.

\section{C.3.1.4 Spent Fuel Storage Pool}

The spent fuel storage pool (EKN 90) is located in the Reactor Building, as shown in Figures C.2-3 and C.2-4. The pool, shown in Figure C.3-5, is a Seismic Category I, reinforced concrete structure completely lined with 6.4-mm stainless steel plates. The liner plates are seamwelded together and are anchored to the surrounding concrete by reinforcing members (i.e., channels, I-beams, etc.) welded to the liner plates. The pool contains fuel storage racks with enough storage locations for 2658 fuel assemblies. The pool is filled with water to a depth of approximately $11.5 \mathrm{~m}$ (water volume: $21325 \mathrm{~m}^{3}$ ). The water supply is the condensate supply system, with emergency makeup water provided by the standby service water system.

The fuel storage racks consist of cells that are square stainless steel tubes with $\mathrm{B}_{4} \mathrm{C}$ plates between them. The tube walls are $3.2 \mathrm{~mm}$ thick, and the $\mathrm{B}_{4} \mathrm{C}$ plates are $5.3 \mathrm{~mm}$ thick. The vertical tubes are welded to horizontal stainless steel grids, at the top and bottom, to form the tubes into racks and to maintain center-to-center spacing between the tubes. A 3.2-mm stainless steel plate is seal welded to the rack sides. The rack is welded to an elevated base plate that, in turn, is supported by a system of welded beams and stiffeners. The racks are welded together into modules held firmly in place by stainless steel turnbuckles attached top and bottom between the modules and the pool wall. The turnbuckles are connected at the pool wall to a steel band imbedded in the concrete wall and seal welded to the pool liner. Different rack sizes are used ( 12 by 16,12 by 13,8 by 13,7 by 18 , and 11 by 16 cell arrays) to take full advantage of the fuel storage space in the pool (see Figure C.3-5).

\section{C.3.2 Turbine Generator Building Equipment}

The Turbine Generator Building houses the equipment associated with the power conversion process. Aside from the electricity generating and distribution equipment, the turbine and generator auxiliary systems, and the auxiliary 


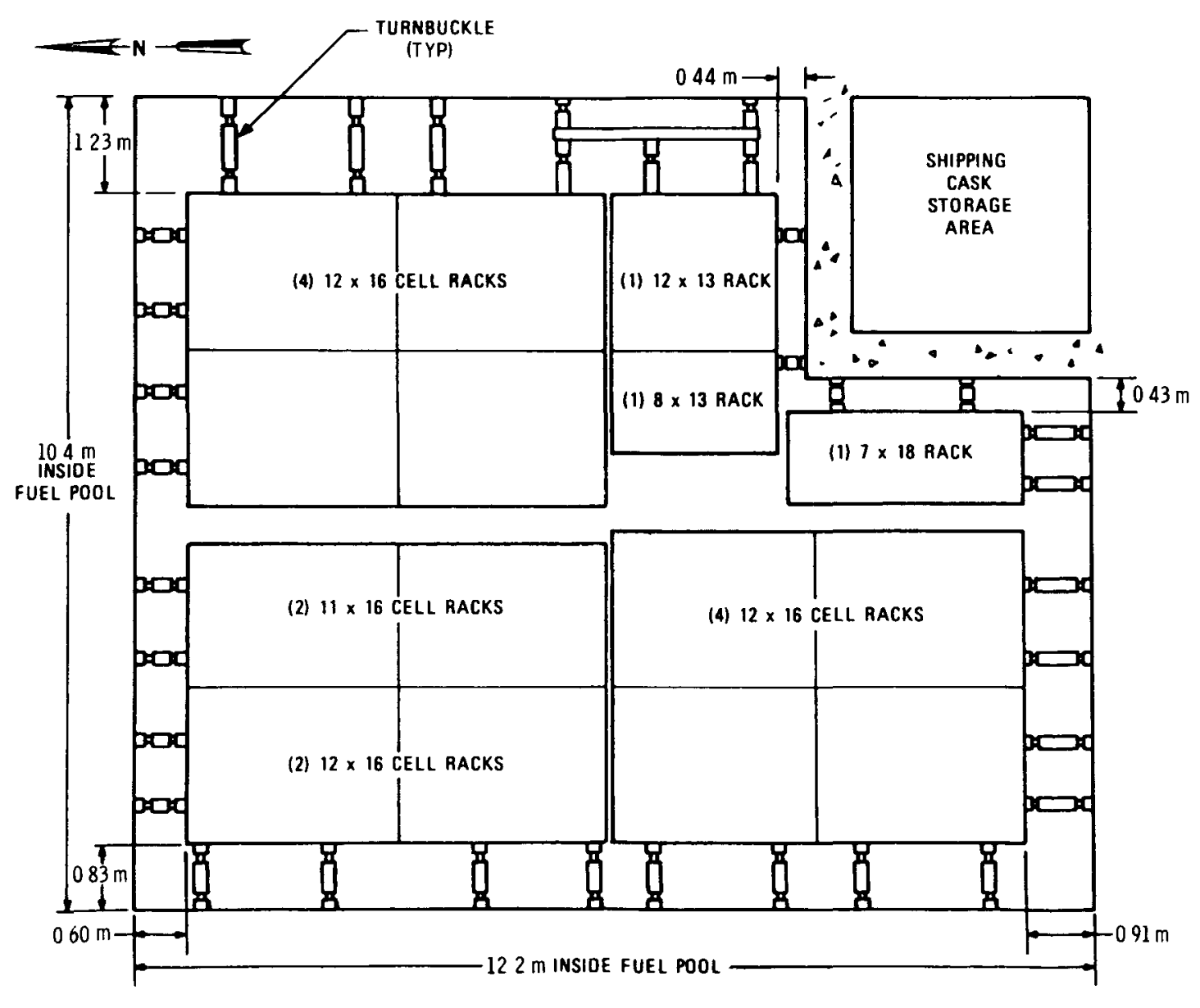

Spent Fuel Storage Pool Arrangement

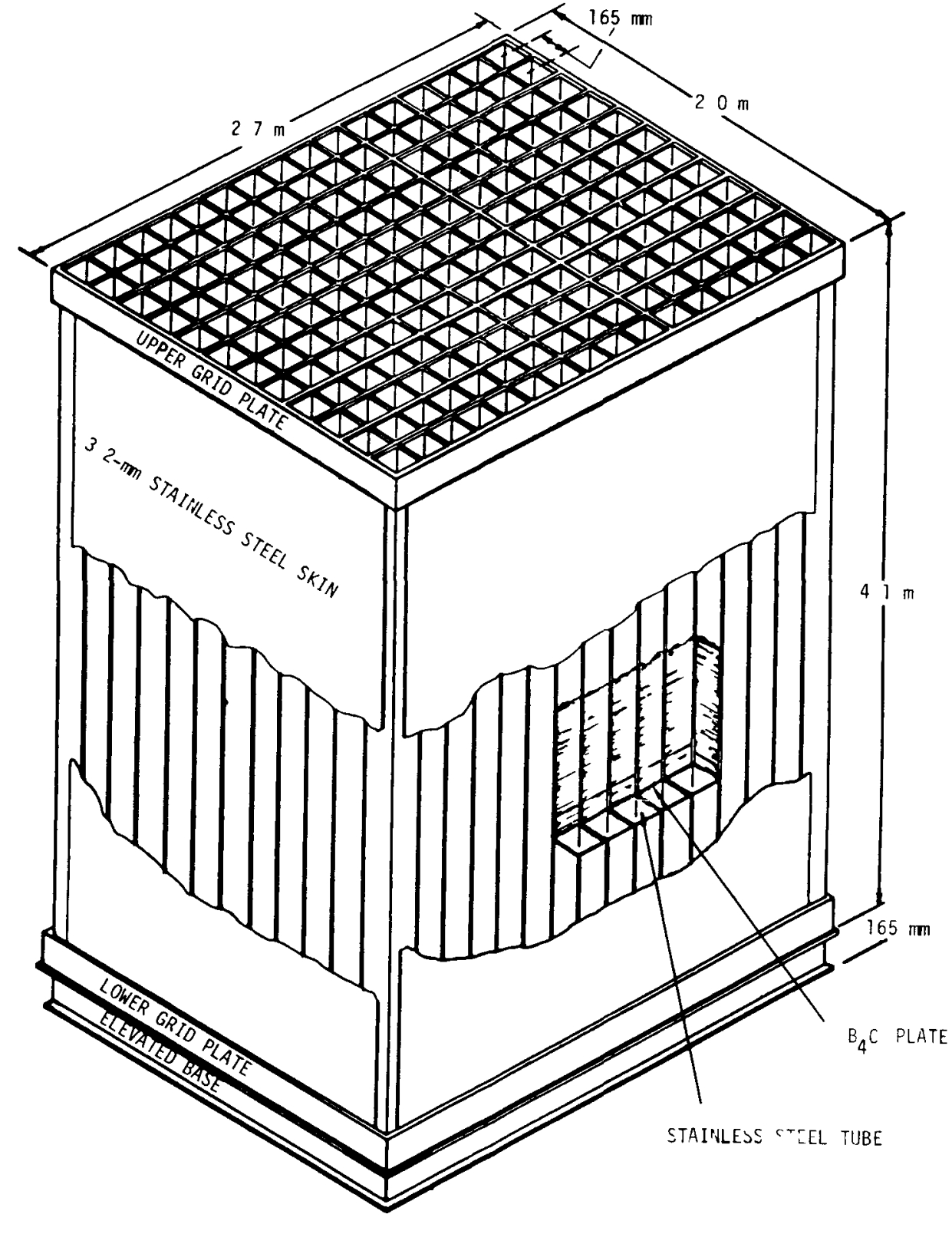

Typical Spent Fuel Storage Rack (12 x 16 Ce17s) 
boiler equipment, the equipment located in the Turbine Generator Building comes in contact (either directly or indirectly) with the steam produced in the reactor or with the resultant condensate in preparing the reactor feedwater and pumping it to the reactor. The major pieces of radioactively contaminated equipment in the Turbine Generator Building are the main turbine (EKN 201) and the main condenser (EKN 200), for which detailed descriptions follow. Table C.3-4 lists the rest of the equipment that requires special handling because of radioactive contamination.

\section{C.3.2.1 Main Turbine}

The main turbine (EKN 201), shown in Figure C.3-6, is a tandem-compound unit, consisting of one double-flow high-pressure turbine and three doubleflow low-pressure turbines. Table C.3-5 presents the physical parameters of the main turbine components.

The high-pressure turbine is a double axial flow element with one control stage followed by seven stages of reaction blading in each end. The supply steam lines enter the high-pressure element through two steam chest assemblies, one located on each side of the turbine. The steam chest inlets are the four main steam lines coming from the reactor, and the outlets are four inlet pipes to the high-pressure turbine casing. Turbine exhaust lines exit each end, four in the base and two in the cover.

Each steam chest is a horizontal, hour-glass-shaped assembly containing two horizontally mounted inlet throttle valves and two vertically mounted outlet governing valves.

The high-pressure cylinder consists of an outer casing of carbon steel, split at the horizontal centerplane to form a base and cover. The base and cover are bolted together by stud bolts. The nozzle chambers are centraliy located in the high-pressure unit, with the chamber inlets welded to the casing. The outer casing of the high-pressure turbine is supported by four arms at the top of the base.

The high-pressure turbine rotor is machined from an alloy steel forging. A separate extension shaft is bolted to the governor end of the rotor. 
TABLE C.3-4. Contaminated Equipment: Turbine Generator Building

SEN(a) $\quad$ Equipment Piece (Quantity)
Air Removal

Mass, Overall Dimensions,

(each) (each)

215. Mechanical Vacuum Pump (2)

$L \times W \times H$,

Condensate (Nuclear Steam)

212. Condensate Pump (3)

213. Condensate Booster Pump (3)

216. Steam Jet Air Ejector (2)

217. Giand Seal Steam Condenser (1)

228. Condensate Storage Tank (2)

253. Low-Pressure Feedwater Heater (3)

Low-Pressure Feedwater Heater (3)

Low-Pressure Feedwater Heater (3)
Low-Pressure Feedwater Heater (3)

Low-Pressure Feedwater Heater (3)

Low-Pressure Feedwater Heater (2)

3175

$0.6 \times 0.8 \times 0.8$

Condenser off Gas Treatment

218. Catalytic Recombiner (2)
224. Off Gas Condenser (1)
$225 . \quad$ Off Gas Water Separator (1)

Equipment Drain (Radioactive)

273. Equipment Drain Sump Pump (4)

Floor Drain (Radioactive)

274. Floor Drain Sump Pump (4)

2.6 d 1a $\times 5.9$

$\begin{array}{ll}21 & 909 \\ 12 & 020\end{array}$

$\begin{array}{rr}12 & 020 \\ 6 & 522\end{array}$

$5.5 \times 1.8 \times 1.8$

$5.8 \times 1.5 \times 3.0$

4037

50536

0.8 dra $\times 3.1$

63050

13.7 dia $\times 13.3$

51256

50349

35380

1.8 dra $\times 15.5$

253.

68946

2.1 dia $\times 14.6$

2.1 dia $\times 14.6$

1.8 dia $\times 14.0$

2.4 dia $\times 12.8$

Heater Drain

$\begin{array}{ll}\text { 255. } & \text { Evaporator Drain Tank (2) } \\ 256 . & \text { Reheater Drain Tank (4) } \\ 256 . & \text { Reheater Drain Tank (4) } \\ 263 . & \text { Moisture Separator Drain Tank (2) } \\ & \text { Ma in Steam }\end{array}$

254. Steam Evaporator (2)

258. Turbine Bypass Valve Assembly $(1)$
270 . Moisture Separator Reheater (2)

$1.4 \mathrm{~d} r \mathrm{a} \times 2.1$

$898 \quad 1.4$ dia $\times 4.7$

$272 \quad 0.3$ dia $\times 1.7$

Miscellaneous Drain and Vent

226. Seal Water Liquid Tank (1)

227. Pumped Drain Tank (1)

Reactor Feedwater

214. Reactor Feedwater Pump (2)

252. High-Pressure Feedwater Heater (2)

(a)EKN = Equipment Key Number (see Section C.2). 


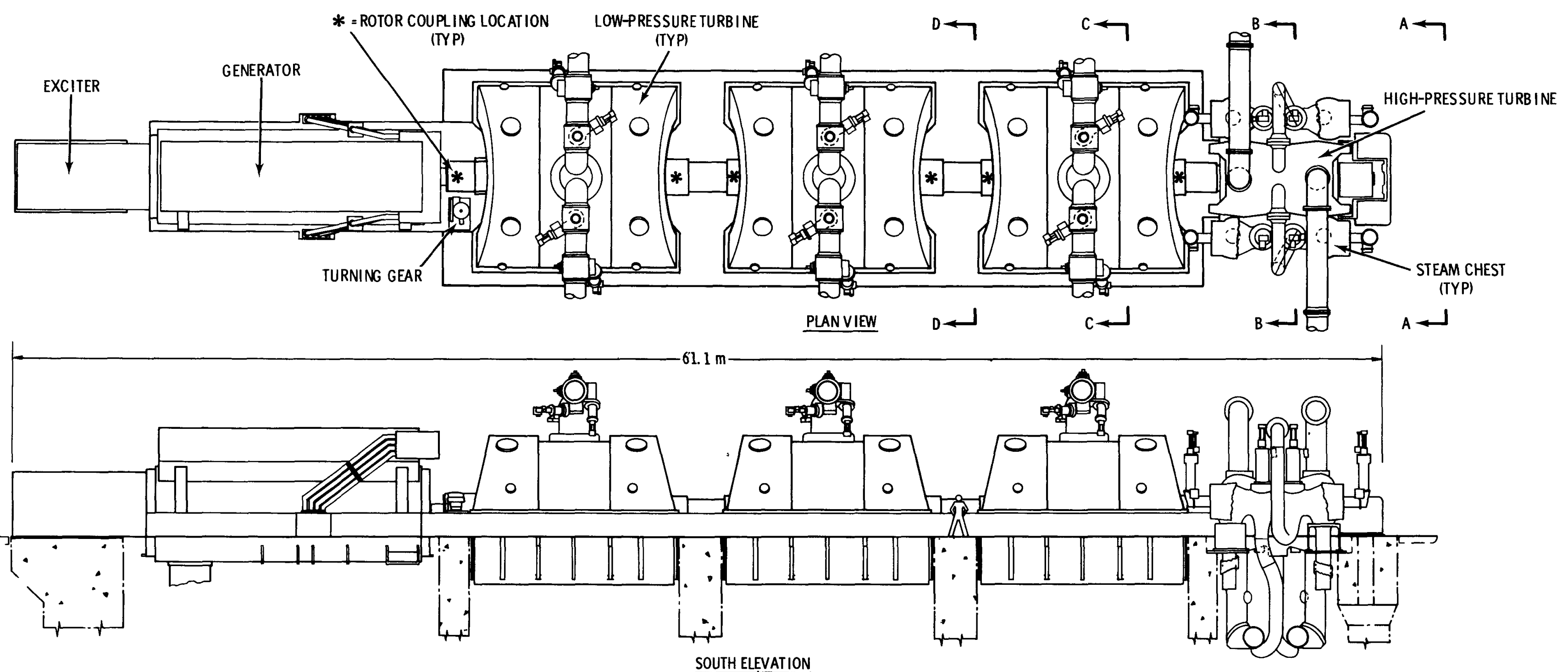

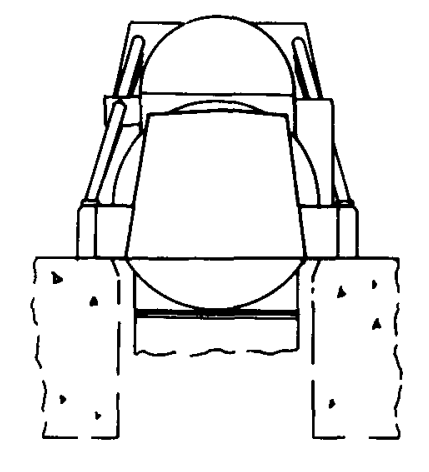

GENERATOR END VIEW

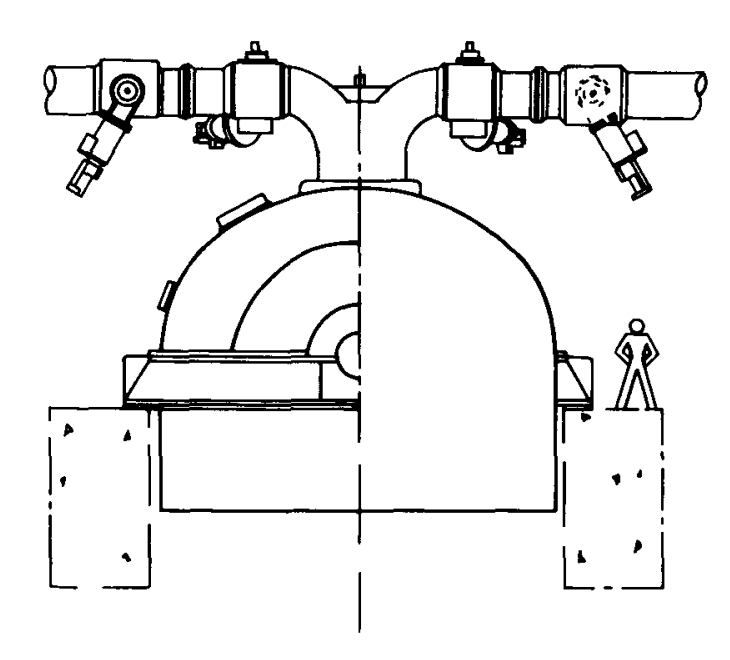

HALF SECTION D-D HALF SECTION C-C

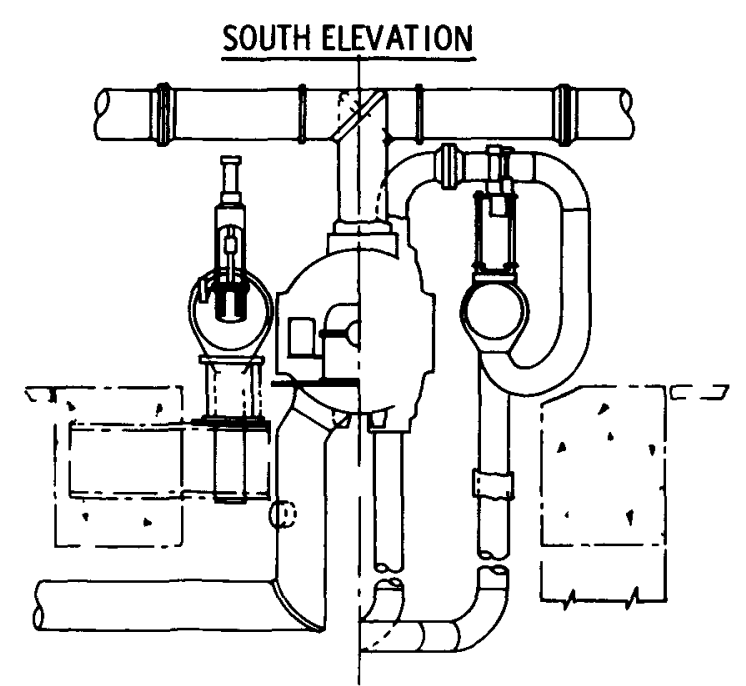

HALF SECTION A- A HALF SECTION B- B 
O 
IABLE C.3-5. Physical Parameters of the Main Turbine Components

\begin{tabular}{|c|c|c|c|c|c|}
\hline Component & $\begin{array}{c}\text { Axial } \\
\text { Length, } \\
\mathrm{m}\end{array}$ & $\begin{array}{c}\text { Width, } \\
\mathrm{m}\end{array}$ & $\begin{array}{c}\text { Height, } \\
\mathrm{m}\end{array}$ & & $\begin{array}{c}\text { Mass, } \\
\mathrm{kg}\end{array}$ \\
\hline \multicolumn{6}{|l|}{ High-Pressure Turbine } \\
\hline Cover & 5.0 & 3.8 & 3.7 & 58 & 967 \\
\hline \#1 Blade Ring Half (4 used) & 0.6 & $2.4 \mathrm{dia}$ & & 4 & 536 (each) \\
\hline \#2 Blade Ring Half (4 used) & 0.8 & $2.5 \mathrm{dia}$ & & 7 & 711 (each) \\
\hline Rotor with Extension Shaft & 8.4 & $2.2 \mathrm{dia}$ & & 52 & 163 \\
\hline Base & 7.0 & 3.8 & 3.7 & 64 & 864 \\
\hline \multicolumn{6}{|l|}{ Low-Pressure Turbine (3 each) } \\
\hline Outer Cover & 9.4 & 8.6 & 3.7 & & 287 \\
\hline \#1 Inner Cover and Base & 1.9 & 5.5 & 2.8 & 25 & 265 (each) \\
\hline \#2 Inner Cover and Base & 3.9 & 6.2 & 2.8 & 45 & 495 (each) \\
\hline Blade Ring Half (4 used) & 0.5 & $3.3 \mathrm{dia}$ & & & 631 (each) \\
\hline Rotor & 8.8 & 4.5 dia & & 88 & 677 \\
\hline Outer Base & 10.7 & 9.9 & 3.2 & 142 & 882 \\
\hline Steam Chest (2 each) & 6.1 & 1.7 & 2.1 & & 565 (each) \\
\hline
\end{tabular}

Each low-pressure turbine is a double axial flow element with eight stages of reaction blading in each end. Supply steam lines enter through the cover at the center of each element, and multiple steam extraction lines exit the base. Exhaust openings at each end go downward to the main condenser, which is located directly beneath the three low-pressure turbines.

The low-pressure turbine rotors, consisting of a series of alloy steel discs shrunk on a shaft and keyed in position, are machined from alloy steel forgings.

Each low-pressure turbine has a fabricated outer casing of carbon steel. Each outer cover is removable as a single piece. The casing is supported by 
a continuous foot (or skirt) extending around the cylinder base. The foot of each casing rests on a separate seating plate grouted to the foundation.

Flanged, rigid couplings are used to connect the rotors of the highpressure turbine, the three low-pressure turbines (with two stub shafts between), and the generator. The rotating element thus formed is supported by 10 journal bearings, and is located axially by a thrust bearing mounted at the governor end of the No. 2 low-pressure turbine.

\section{C.3.2.2. Main Condenser}

The main condenser (EKN 200) is shown in Figure C.3-7. It is a singlepass, three-bank, divided-waterbox type surface condenser built for service in conjunction with the main turbine under which it is located. It was fabricated in place.

The condenser shell is of welded carbon steel plate. The tube supports and waterboxes are likewise carbon steel. Tube sheets are constructed of a copper-zinc alloy (Admiralty meta1), as are the majority (93\%) of the approximately 43,600 32-mm 0.D. tubes. The peripheral tubes are formed from a coppernickel alloy. The dry mass of the assembled condenser is about $1570 \mathrm{Mg}$.

A low-pressure feedwater heater is mounted in each of the three steam inlets of the condenser shell. Steam extraction piping is included in the condenser necks. Rubber belt expansion joints connect the turbine exhausts to the steam inlets of the condenser.

The tube sheets are bolted in place at the ends of each shell. The tubes are expanded into the tube sheets and are held in position by 84 tube supports welded to support lugs and support pipes, which in turn are welded to the shell proper. The inlet, outlet, and intermediate water boxes are bolted to their respective tube plates. The shell sits on six foundation pads, three on each side. It is anchored to the south-central pad by $50-\mathrm{mm}$ diameter stud bolts, and is free to move on the other five pads. The hotwell, located in the bottom of the she11, has a storage capacity of $617 \mathrm{~m}^{3}$.

Numerous penetrations through the condenser shell or into the water boxes accommodate (among other things) turbine bypass steam, exhaust from the 


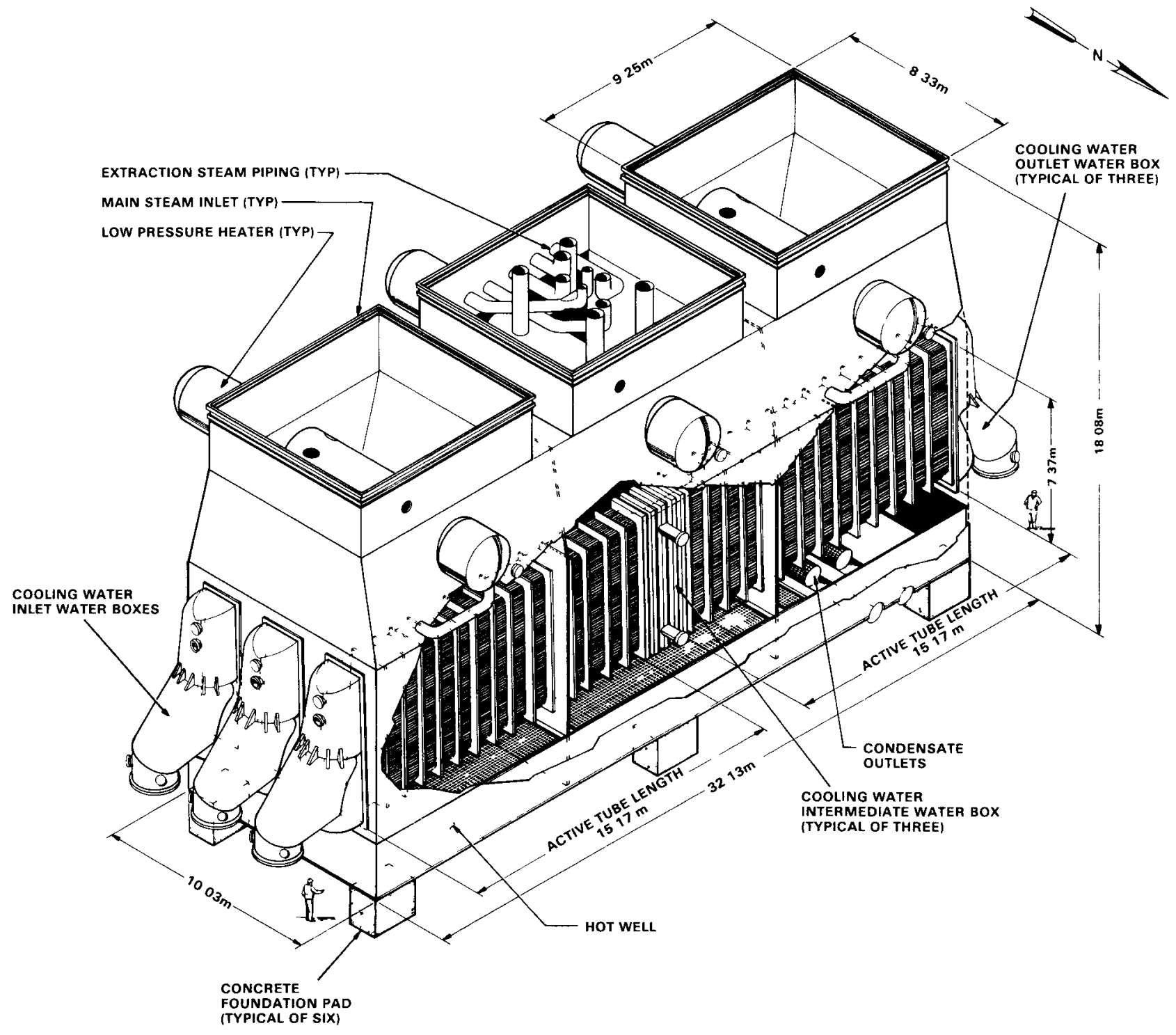

FIGURE C.3-7. Main Condenser 
feedwater pump turbines, cascading feedwater heater drains, feedwater heater shell steam, and condensate pump suction. Manways allow physical access to the interior of the condenser and the water boxes.

\section{C.3.3 Radwaste and Control Building Equipment}

The Radwaste and Control Building houses equipment associated with the liquid and solid radwaste systems, the condenser off gas treatment system, emergency electrical and control systems, and the main control room. The equipment inside of the control tower on the three highest floor elevations is assumed to be uncontaminated radioactively. Outside of the control tower, most process equipment, with few exceptions, is assumed to be radioactively contaminated. Table C.3-6 lists the contaminated equipment.

\section{C.3.4 Contaminated Piping and Valves}

The following tables 1 ist the piping and valves in plant systems that handle contaminated contents: Table C.3-7, Reactor Building; Table C.3-8, Primary Containment; Table C.3-9, Turbine Generator Building; Table C.3-10, Radwaste and Control Building; and Table C.3-11, summary of the entire plant. The primary flows in these systems are contaminated to a lesser or greater degree, although the auxiliary and utility flows may not be. However, the data in these tables do not make this distinction; all piping and valves designated by the facility owner as part of a specific system are included. 


\section{TABLE C.3-6. Contamınated Equipment: Radwaste and Control Building}

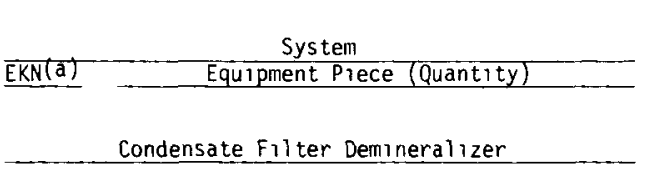

302. Condensate Phase Separator Tank (2)

304. Condensate Backwash Receiver Tank (1)

320. Condensate Sludge Discharge Mixing Pump (1)

321. Condensate Decant Pump (1)

322. Condensate Backwash Transfer Pump (1)

429. Condensate Demin. Holding Pump (6)

438. Condensate Filter Demineralizer (6)

Condenser off Gas Treatment

348. Cooler Condenser (2)

349. Moisture Separator (2)

351. Desiccant Dryer (4)

352. Dryer Regenerator (2)

353. Gas Cooler (2)
354. Charcoal Adsorber $\left(5.7 \mathrm{~m}^{3}\right.$ charcoal $)(8)$

378. Air Handing Unit (4)

384. Prefilter (2)

385. Afterfilter (2)

Equipment Drain (Radioactive)

301. Waste Collector Tank (1)

305. Spent Resin Tank (1)

312. Waste Surge Tank (1)

313. Waste Sample Tank (2)

319. Waste collector Pump (1)

323. Waste Surge Pump (1)

324. Waste Sample Pump (2)

327 Spent Resin Pump (1)

341. Equipment Drain Sump Pump (1)

431. Waste Filter Hold Pump (1)

443. Waste Demineralizer (1)

Floor Drain (Radioactive)

300. Floor Drain Collector Tank (1)

306. Waste Sludge Phase Separator Tank (1)

314. Floor Drain Sample Tank (1)

318. Floor Drain Collector Pump (1)

326. Floor Drain Sample Pump (1)

328. Waste Decant Pump (1)

330. Waste Sludge Discharge Mixing Pump (1)

340. Floor Drain Sump Pump (3)

430. Floor Drain Filter Hold Pump (1)

439. Floor Drain Filter (1)

444. Floor Drain Demineralizer (1)

(a)EKN = Equipment Key Number (see Section C 2).
Mass, Overall Dimensions,

(each) (each)

$\mathrm{kg}$

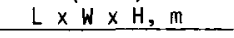

3182

6920

4.6 dia $\times 5.2$

3.7 dia $\times 64$

$15 \times 06 \times 05$

$1.5 \times 0.6 \times 0.5$

$1.5 \times 0.6 \times 0.5$

$1.1 \times 0.4 \times 0.5$

2.1 dra $\times 3.2$

0.6 dia $\times 2.4$

0.3 dia $\times 1.8$

0.9 dia $\times 12$

361

623

$3.1 \times 2.7 \times 1.8$

$3.7 \times 0.5 \times 5.5$

12 dia $\times 6.9$

2268

4082

2620

134

$3.1 \times 1.8 \times 29$

0.9 dia $\times 3.2$

0.9 dra $\times 3.2$

10241

4.9 dia $\times 5.5$

18 dia $\times 18$

7.6 dia $\times 6.7$

6968

284

284

4.5 dia $\times 4.4$

$14 \times 0.5 \times 0.8$

$1.4 \times 0.5 \times 0.8$

$1.3 \times 05 \times 07$

$11 \times 0.4 \times 0.5$

0.5 dia $\times 2.4$

$1.0 \times 05 \times 0.5$

1.2 dia $\times 34$

1.5 dia $\times 31$

$\begin{array}{rl}10241 & 49 \text { dia } \times 5.5 \\ 5497 & 4.3 \text { dia } \times 3.4 \\ 6968 & 4.5 \text { did } \times 4.4 \\ 284 & 14 \times 0.5 \times 0.8 \\ 231 & 1.3 \times 0.5 \times 0.7 \\ 102 & 1.1 \times 0.4 \times 0.5 \\ 288 & 1.4 \times 0.5 \times 05 \\ 646 & 0.5 \text { did } \times 2.4 \\ 318 & 10 \times 0.5 \times 05 \\ 1814 & 1.2 \text { dia } \times 3.4 \\ 908 & 15 \text { did. } \times 3.1\end{array}$




\section{TABLE C.3-6. Contaminated Equipment: Radwaste and Control Building (Contd)}

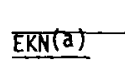

System

\begin{tabular}{l}
4 \\
4 \\
\\
\hline 3 \\
3 \\
3 \\
3 \\
33 \\
3 \\
3 \\
335 \\
335 \\
3 \\
3 \\
3 \\
3 \\
3 \\
4 \\
4
\end{tabular}

Fuel Pool Cooling and Cleanup

432. Fuel Pool Hold Pump (2)

441. Fuel Pool Filter Demineralizer (2)

Miscellaneous Waste (Radioactive)

308. Chemrcal Waste Tank (2)

309. Distillate Tank (2)

310. Detergent Drain Tank (2)

311. Decon. Solution Conc. Waste Tank (2)

331. Concentrator Feed Pump (2)

332. Chemical Waste Pump (2)

333. Distillate Tank Pump (2)

334. Detergent Drain Pump (2)

335. Decon. Solution Conc. Waste Pump (1)

342. Chemical Drain Sump Pump (1)

376. Detergent Drain Filter (1)

386. Decontamination Solution Concentrator (2)

387. Decon. Solution Conc. Heating Element (2)

408. Concentrator Waste Measuring Tank (1)

435. Decon. Solution Conc. Bottoms Recycle Pump (2)

445. Oistillate Polishing Deminerlizer (1)

457. Decon. Solution Conc. Condenser (2)

Process Waste (Radioactive)

371. Solid Waste Hydraulic Baler (1)

373. Transfer Dolly (1)

379. Hopper Mixer (2)

380. Waste Processing Pump (T)

409. Centrifuge (2)

Reactor Water Cleanup

307. Cleanup Phase Separator Tank (2)
329. Cleanup Decant Pump (1)

337. Cleanup Sludge Discharge Mixing Pump (1)

426. Cleanup Precoat Tank (1)

427. Cleanup Precoat Pump (1)

433. Cleanup Hold Pump (2)

442. Cleanup Filter Demineralizer (2)

(a)EKN = Equipment Key Number (see Section C 2)

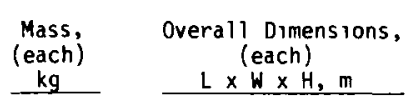

$1.1 \times 0.3 \times 0.5$

195
1568

0.9 dra $\times 4.0$

$\begin{array}{ll}5 & 030 \\ 5 & 030\end{array}$

$\begin{array}{ll}5 & 030 \\ 1 & 836\end{array}$

3.7 dia $\times 5.5$

3.7 dia $\times 5.5$

1.8 dia $\times 2.4$

1.7 dia $\times 1.7$

$1.1 \times 0.3 \times 0.6$

$1.3 \times 0.4 \times 0.5$

$1.2 \times 0.3 \times 0.4$

$1.0 \times 0.4 \times 0.5$

$1.1 \times 0.4 \times 0.5$

0.5 dia $\times 2.4$

0.3 dia $\times 0.9$

1.2 dia $\times 4.6$

1134

3409

3147

0.9 dia $\times 4.6$

0.8 dia $\times 2.4$

$1.7 \times 0.6 \times 11$

844

454

1.5 dia $x 3.1$

$0.9 \mathrm{~d}$ a $\times 3.4$

$13 \times 0.8 \times 27$

$18 \times 18 \times 18$

$23 \times 15 \times 27$

$\begin{array}{ll}1 & 134 \\ 2 & 727\end{array}$

$1.0 \times 0.3 \times 0.4$

454

$2.7 \times 1.1 \times 1.7$

2041

31 dia $x 2.7$

$11 \times 0.4 \times 0.4$

$1.2 \times 0.5 \times 0.6$

08 dia $\times 1.2$

$1.3 \times 0.4 \times 07$

$1.3 \times 0.5 \times 07$

09 dia $\times 27$ 
TABLE C.3-7. Contaminated Piping and Valves: Reactor Building

Nominal Outside Diameter, $\mathrm{mm}$

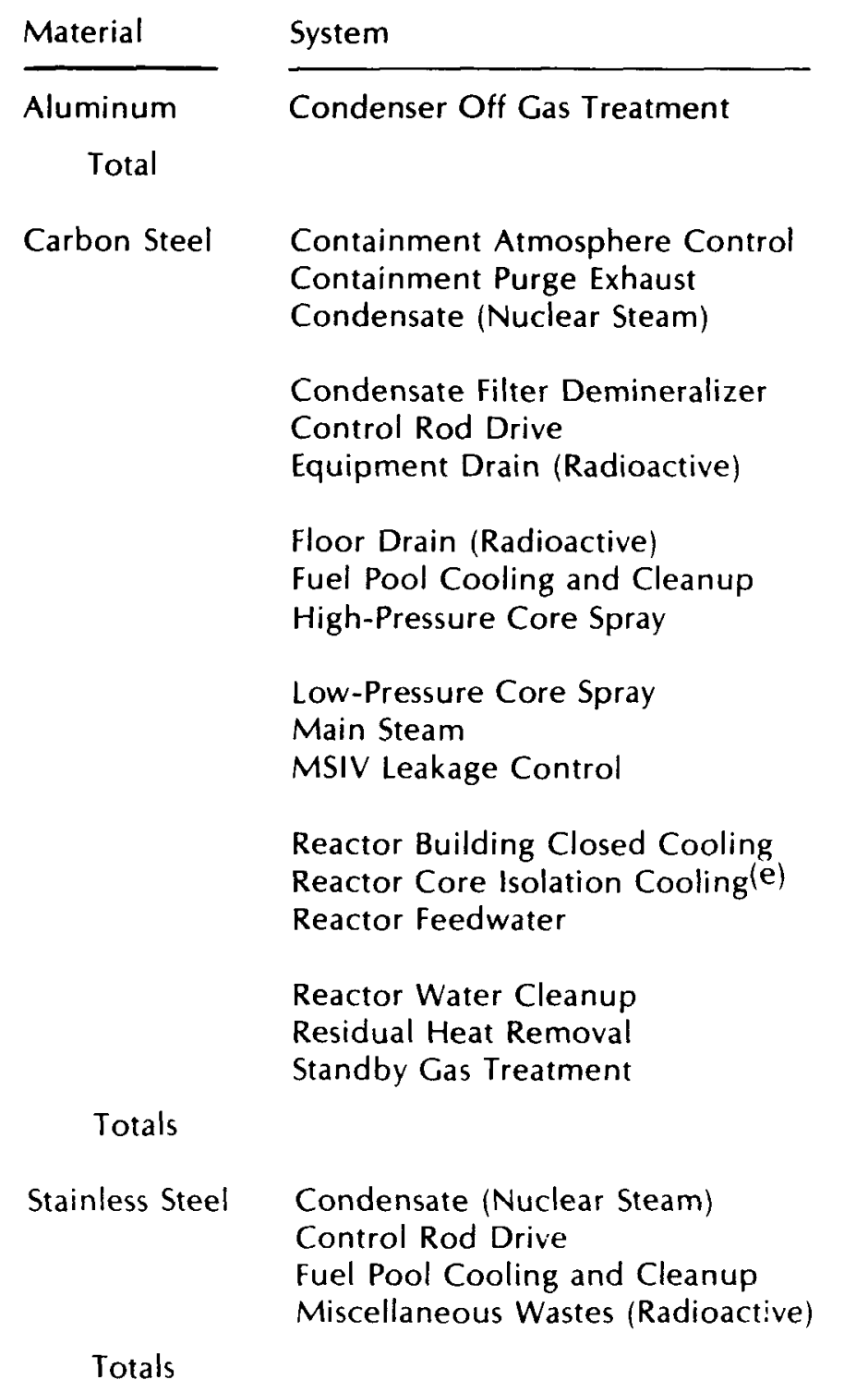

\begin{tabular}{|c|c|c|c|c|c|c|c|c|c|c|c|c|c|c|c|c|}
\hline \multicolumn{2}{|r|}{$\leq 60$} & \multicolumn{3}{|c|}{73 to 254} & \multicolumn{3}{|c|}{305 to 406} & \multicolumn{3}{|c|}{457 to 610} & \multicolumn{3}{|c|}{660 to 762} & \multicolumn{3}{|c|}{ Total } \\
\hline & ..-(a) & $31 /$ & $1020 /$ & $0^{(b)}$ & & ... & & & -.. & & & .. & & $31 /$ & $1020 /$ & 0 \\
\hline & -.- & $31 /$ & $1020 /$ & 0 & & $\ldots$ & & & -- & & & -- & & $31 /$ & $1020 /$ & 0 \\
\hline $131 /$ & $646 /$ N.A. ${ }^{(c)}$ & $324 /$ & $5076 /$ & 16 & & ..- & & & ... & & & $\ldots$ & & $455 /$ & 5722 & ${ }_{16}^{(d)}$ \\
\hline $3 /$ & 14/N.A. & & -- & & & -.- & & $59 /$ & $6929 /$ & 2 & $15 /$ & $2755 /$ & 2 & $77 /$ & $9698 /$ & \\
\hline $126 /$ & 520/N.A. & $520 /$ & $10172 /$ & 33 & $42 /$ & $3627 /$ & 0 & $47 /$ & $6357 /$ & 0 & & $\cdots$ & & $735 \%$ & $20676 /$ & 33 \\
\hline & --- & $43 /$ & $1205 /$ & 0 & & -.- & & & $\ldots$ & & & ... & & $43 /$ & $1205 /$ & 0 \\
\hline $946 /$ & $3455 /$ N.A. & $143 /$ & $6731 /$ & 8 & $3 /$ & $485 /$ & 0 & & -.. & & & $\ldots$ & & $1092 /$ & $10671 /$ & 8 \\
\hline $3 /$ & 9/N.A. & $109 /$ & $1219 /$ & 7 & & --- & & &.-- & & & $\ldots$ & & $112 /$ & $1228 /$ & 7 \\
\hline $10 /$ & $51 /$ N.A. & $380 /$ & $5455 /$ & 6 & & -.- & & & -.. & & & $\ldots$ & & $390 /$ & $5506 /$ & 6 \\
\hline $83 /$ & 317/N.A. & $438 /$ & 19 099/ & 35 & & ..- & & & $\ldots$ & & & $\ldots$ & & $521 /$ & $19416 /$ & 35 \\
\hline $61 /$ & 202/N.A. & $17 /$ & $735 /$ & 9 & $113 /$ & $26538 /$ & 5 & $25 /$ & $3825 /$ & 3 & & $\ldots$ & & $216 /$ & $31300 /$ & 17 \\
\hline $156 /$ & $660 /$ N.A. & $28 /$ & $643 /$ & 6 & $79 /$ & $7911 /$ & 4 & $24 /$ & $3679 /$ & 1 & & $\ldots$ & & $287 /$ & $12893 /$ & 11 \\
\hline $4 /$ & 7/N.A. & 131 & $293 /$ & 2 & & ... & & & -.. & & $40 /$ & 12 095/ & 4 & $57 /$ & $12395 /$ & 6 \\
\hline $1 /$ & 1/N.A. & $118 /$ & $1937 /$ & 0 & & -.. & & & --- & & & -.. & & $119 /$ & $1938 /$ & 0 \\
\hline $184 /$ & $445 /$ N.A. & $578 /$ & $17423 /$ & 26 & 731 & $5571 /$ & 4 & $41 /$ & $4332 \%$ & 0 & & ... & & $876 /$ & $27771 /$ & 30 \\
\hline $307 /$ & $1043 /$ N.A. & $385 \%$ & $20154 /$ & 19 & & ..- & & & ... & & & $\ldots$ & & 6921 & $21197 /$ & 19 \\
\hline 21 & 4/N.A. & $14 /$ & $493 /$ & 1 & & ... & & $13 /$ & $6891 /$ & 4 & & -.- & & $29 /$ & $7388 /$ & 5 \\
\hline $49 /$ & 118/N.A. & $368 /$ & $10779 /$ & 18 & & ... & & & $\ldots$ & & & ..- & & $417 /$ & $10897 /$ & 18 \\
\hline $213 /$ & 750/N.A. & $444 /$ & 8954 & 22 & 195/ & $17765 /$ & 10 & $679 /$ & $87563 /$ & 29 & & $\ldots$ & & $1531 /$ & $115032 /$ & 61 \\
\hline $44 /$ & 237/N.A. & & $\ldots$ & & & $\ldots$ & & $64 /$ & $7584 /$ & 16 & & -.. & & $108 /$ & $7821 /$ & 16 \\
\hline $2323 /$ & $8479 /$ N.A. & 39221 & $110368 /$ & 208 & $505 \%$ & $61897 /$ & 23 & $952 /$ & $127160 /$ & 55 & $55 /$ & $14850 /$ & 6 & $7757 /$ & $322754 /$ & 292 \\
\hline $15 /$ & 54/N.A. & $67 /$ & $575 /$ & 0 & $54 /$ & $2143 /$ & 0 & & ... & & & -.- & & $136 /$ & $2772 \%$ & 0 \\
\hline $6136 /$ & 18 545/N.A. & & ..- & & & $\ldots$ & & & -.. & & & ..- & & $6136 /$ & $18545 /$ & 0 \\
\hline $1 /$ & 1/N.A. & $109 /$ & $291 /$ & 7 & & --- & & & --. & & & -- & & $110 /$ & $292 /$ & 7 \\
\hline $17 /$ & 74/N.A. & $324 /$ & $3685 /$ & 3 & & --- & & & -.- & & & .-- & & 341 & $3759 /$ & 3 \\
\hline $6169 /$ & 18674 /N.A. & $500 /$ & $4551 /$ & 10 & $54 /$ & $2143 /$ & 0 & &.-- & & & -.. & & $6723 /$ & $25368 /$ & 10 \\
\hline
\end{tabular}

(a) Dashed line represents insignificant amount.

(b) The data are presented in the following format: Piping Length, $\mathrm{m} /$ Piping Mass, $\mathrm{kg} /$ Number of Valves.

(c) N.A. = not available.

(d) The total number of valves for a particular system does not include small-bore valves $51 \mathrm{~mm}$ or less in diameter.

(e) Includes a 51-mm diameter drain going to the main condenser (EKN 200) in the Turbine Generator Building.

TABLE C.3-7. Contaminated Piping and Valves: Reactor Building 
○ 
TABLE C.3-8. Contaminated Piping and Valves: Primary Containment

Nominal Outside Diameter, $\mathrm{mm}$

\begin{tabular}{|c|c|}
\hline Material & System \\
\hline \multirow[t]{5}{*}{ Carbon Steel } & $\begin{array}{l}\text { Downcomer Vent } \\
\text { Equipment Drain (Radioactive) } \\
\text { Floor Drain (Radioactive) }\end{array}$ \\
\hline & $\begin{array}{l}\text { Fuel Pool Cooling and Cleanup } \\
\text { High-Pressure Core Spray } \\
\text { Low-Pressure Core Spray }\end{array}$ \\
\hline & Main Steam \\
\hline & $\begin{array}{l}\text { Reactor Building Closed Cooling } \\
\text { Reactor Core Isolation Cooling }\end{array}$ \\
\hline & $\begin{array}{l}\text { Reactor Feedwater } \\
\text { Reactor Recirculation } \\
\text { Reactor Water Cleanup } \\
\text { Residual Heat Removal }\end{array}$ \\
\hline \multicolumn{2}{|l|}{ Totals } \\
\hline Stainless Steel & $\begin{array}{l}\text { Control Rod Drive } \\
\text { Equipment Drain (Radioactive) } \\
\text { Fuel Pool Cooling and Cleanup }\end{array}$ \\
\hline & $\begin{array}{l}\text { Miscellaneous Wastes (Radioactive) } \\
\text { Reactor Recirculation } \\
\text { Residual Heat Removal }\end{array}$ \\
\hline
\end{tabular}

\begin{tabular}{|c|c|c|c|c|c|c|c|c|c|c|c|c|c|c|c|c|}
\hline \multicolumn{2}{|r|}{$\leq 60$} & \multicolumn{3}{|c|}{73 to 254} & \multicolumn{3}{|c|}{305 to 406} & \multicolumn{3}{|c|}{457 to 610} & \multicolumn{3}{|c|}{660 to 762} & \multicolumn{3}{|c|}{ Total } \\
\hline & $\ldots$... (a) & & -.- & & & -.- & & $1178 /$ & $520546 /$ & $0^{(b)}$ & $252 /$ & $95772 /$ & 0 & $1430 /$ & $616318 /$ & 0 \\
\hline $6 /$ & 19/N.A. ${ }^{(C)}$ & $180 /$ & $2658 /$ & 2 & & -.. & & & $\cdots$ & & & $\ldots$ & & $186 /$ & $2677 /$ & $2^{(d)}$ \\
\hline $25 /$ & 136/N.A. & $48 /$ & $602 /$ & 0 & & -- & & & -- & & & --- & & $73 /$ & $738 /$ & 0 \\
\hline $11 /$ & 185/N.A. & & -.- & & & ... & & & -.. & & & --- & & $11 /$ & $185 /$ & 0 \\
\hline & --- & $1 /$ & $50 /$ & 0 & $23 /$ & $3059 /$ & 2 & & --- & & & --- & & 24 & 3 109/ & 2 \\
\hline & --. & & --- & & $25 /$ & $2795 /$ & 2 & & -.. & & & --- & & $25 /$ & $2795 /$ & 2 \\
\hline $23 /$ & $113 /$ N.A. & $424 /$ & $47306 /$ & 36 & & --- & & & -.- & & $122 /$ & $49540 /$ & 4 & $569 /$ & 96 959/ & 40 \\
\hline $112 /$ & 573/N.A. & $334 /$ & $8715 /$ & 31 & & --- & & & ... & & & -.. & & $446 /$ & $9288 /$ & 31 \\
\hline $1 /$ & 3/N.A. & 521 & $2229 /$ & 3 & & -- & & & -.- & & & --- & & $53 /$ & 22321 & 3 \\
\hline $1 /$ & 1/N.A. & & --- & & $64 /$ & 9 923/ & 0 & $40 /$ & $28410 /$ & 4 & & --- & & $105 \%$ & 38 334/ & 4 \\
\hline $21 /$ & 78/N.A. & $5 /$ & 621 & 0 & & -- & & & $\cdots$ & & & ... & & $26 /$ & $140 /$ & 0 \\
\hline $58 /$ & 248/N.A. & $38 /$ & $1538 /$ & 0 & & -- & & & --- & & & --- & & $96 \%$ & $1786 /$ & 0 \\
\hline $5 /$ & 10/N.A. & 21 & $21 /$ & 0 & .99/ & 13 983/ & 10 & $21 /$ & $5921 /$ & 1 & & -.- & & $127{ }^{\circ}$ & 19 935/ & 11 \\
\hline $263 /$ & $1366 /$ N.A. & $1084 /$ & $63181 /$ & 72 & $211 /$ & $29760 /$ & 14 & $1239 /$ & $554877 /$ & 5 & $374 /$ & $145312 /$ & 4 & $3171 /$ & $794496 /$ & 95 \\
\hline $3840 /$ & $10573 / \quad 0$ & & ... & & & --- & & & --- & & & --- & & $3840 /$ & $10573 /$ & 0 \\
\hline $1 /$ & $2 /$ N.A. & $6 /$ & $105 /$ & 0 & & --- & & & --- & & & -.- & & 71 & $107 /$ & 0 \\
\hline & --- & $4 /$ & $70 /$ & 0 & & -- & & & $\cdots$ & & & -- & & $4 \prime$ & $70 /$ & 0 \\
\hline $1 /$ & 5/N.A. & $66 /$ & $1063 /$ & 6 & & --- & & & --- & & & --- & & $67 /$ & $1068 /$ & 6 \\
\hline 8/ & $23 /$ N.A. & $34 /$ & $2173 /$ & 2 & $61 /$ & $81391 /$ & 0 & $55 /$ & $21440 /$ & 6 & & --- & & $158 /$ & $32027 /$ & $\begin{array}{l}8 \\
3\end{array}$ \\
\hline $3850 /$ & $10603 /$ N.A & $110 /$ & $3411 /$ & 8 & 64 & $8789 /$ & 3 & 551 & 21440 & 6 & & $\ldots$ & & 4079 & 442431 & 17 \\
\hline
\end{tabular}

(a) Dashed line represents insignificant amount.

(b) The data are presented in the following format: Piping Length, $\mathrm{m} /$ Piping Mass, $\mathrm{kg} /$ Number of Valves.

(d) N.A. = not available.

(d) The total number of valves for a particular location does not include small-bore valves $51 \mathrm{~mm}$ or less in diameter. 
TABLE C.3-9. Contaminated Piping and Valves: Turbine Generator Building

Nominal Outside Diameter, $\mathrm{mm}$

\begin{tabular}{|c|c|c|c|c|c|c|c|c|c|c|c|c|c|c|c|c|c|c|c|c|c|}
\hline \multirow{5}{*}{$\frac{\text { Material }}{\text { Aluminum }}$} & \multirow{5}{*}{$\begin{array}{l}\text { System } \\
\text { Air Removal } \\
\text { Condenser Off Gas Treatment } \\
\text { Heater Vent } \\
\text { Reactor Feedwater }\end{array}$} & \multicolumn{2}{|r|}{$\leq 60$} & \multicolumn{3}{|c|}{73 to 254} & \multicolumn{3}{|c|}{305 to 406} & \multicolumn{3}{|c|}{457 to 610} & \multicolumn{3}{|c|}{660 to 762} & \multicolumn{3}{|c|}{914 to 1829} & \multicolumn{3}{|c|}{ Total } \\
\hline & & & --(a) & $65 /$ & $5621 /$ & $6^{(\mathrm{b})}$ & $63 /$ & $9577 /$ & 1 & & -.- & & & -.. & & & $\ldots$ & & $128 /$ & $15198 /$ & $7^{(\mathrm{c})}$ \\
\hline & & $56 /$ & $146 /$ N.A. ${ }^{(d)}$ & $32 /$ & $1046 /$ & 4 & $53 /$ & $3139 /$ & 0 & & --- & & & --- & & & ... & & $141 /$ & $4331 /$ & 4 \\
\hline & & $353 \%$ & $1566 /$ N.A. & 736/ & 15 512/ & 49 & & --- & & & --- & & & --- & & & -- & & $1089 /$ & 17 078/ & 49 \\
\hline & & & $\cdots$ & $14 /$ & $1270 /$ & 1 & & --- & & & -- & & & $--\cdot$ & & & $\cdots$ & & $14 /$ & $1270 /$ & 1 \\
\hline Totals & & $409 /$ & 1712/N.A. & $847 /$ & $23449 /$ & 60 & $116 /$ & $12716 /$ & 1 & & --- & & & --- & & & $\cdots$ & & $1372 /$ & $37877 /$ & 61 \\
\hline \multirow[t]{12}{*}{ Carbon Steel } & Air Removal & $28 /$ & 70/N.A. & $58 /$ & $3326 /$ & 5 & $70 /$ & $5732 /$ & 0 & & --- & & & --- & & & -- & & $156 /$ & $9128 /$ & 5 \\
\hline & Bleed (Extraction) Steam & $414 /$ & $1693 /$ N.A. & $174 /$ & $7257 /$ & 21 & $361 /$ & $36265 /$ & 17 & $688 /$ & 70 102/ & 33 & & --- & & & $\cdots$ & & $1617 /$ & 115 317/ & 71 \\
\hline & Condensate (Nuclear Steam) & $784 /$ & $2480 /$ N.A. & $488 /$ & $8387 /$ & 40 & $250 /$ & $27498 /$ & 12 & $210 /$ & $53051 /$ & 48 & $53 /$ & $19345 /$ & 0 & $115 /$ & $41438 /$ & 3 & $1900 /$ & $152317 /$ & 71 \\
\hline & Condensate Filter Demineralizer & 98/ & 165/N.A. & $48 /$ & $1655 /$ & 1 & & --- & & & --- & & & --- & & & -. & & $146 /$ & $1820 /$ & 1 \\
\hline & Equipment Drain (Radioactive) & 66/ & 363/N.A. & $30 /$ & $516 /$ & 0 & & --- & & & --- & & & --- & & & --- & & $96 /$ & 879/ & 0 \\
\hline & Exhaust Steam & & 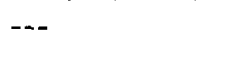 & & $\cdots$ & & & --- & & & -- & & & --- & & $47 /$ & $19814 /$ & 2 & $47 /$ & $19814 /$ & 2 \\
\hline & Floor Drain (Radioactive) & $150 /$ & $826 /$ N.A. & $76 /$ & $870 /$ & 0 & & $\cdots$ & & & -.- & & & --- & & & -.- & & $226 /$ & $1696 /$ & 0 \\
\hline & Heater Drain & $823 /$ & $3147 /$ N.A. & 977/ & $50465 /$ & 82 & $712 /$ & $62868 /$ & 31 & $331 /$ & $44704 /$ & 5 & & --- & & & --- & & $2843 i$ & 161 184/ & 118 \\
\hline & Heater Vent & $362 /$ & $1480 /$ N.A. & $321 /$ & $15897 /$ & 13 & $30 /$ & $2316 /$ & 0 & 158/ & $20741 /$ & 0 & & $\cdots$ & & & --- & & $871 /$ & $40434 /$ & 13 \\
\hline & Main Steam & $70 /$ & 327/N.A. & $269 /$ & $16359 /$ & 13 & $91 /$ & $13806 /$ & 4 & $241 /$ & $64730 /$ & 1 & $387 /$ & $200742 /$ & 0 & $397 /$ & $173630 /$ & 6 & $1455 /$ & $469594 /$ & 24 \\
\hline & Miscellaneous Drain and Vent & $525 /$ & 3 575/N.A. & $151 /$ & $4780 /$ & 14 & & $\cdots$ & & & --- & & & $\cdots$ & & & --- & & $676 /$ & $8355 /$ & 14 \\
\hline & Reactor Feedwater & $16 /$ & $27 /$ N.A. & $40 /$ & $6013 /$ & 5 & $133 /$ & $28115 /$ & 5 & $224 /$ & 132 993/ & 9 & $25 /$ & $20611 /$ & 0 & & $\cdots$ & & $438 /$ & $187759 /$ & 19 \\
\hline Totals & & $3336 /$ & 14 153/N.A. & $2632 /$ & 115 525/ & 194 & $1647 /$ & $176600 /$ & 69 & $1832 \prime$ & $386321 /$ & 96 & $465 /$ & 240 698/ & 0 & $559 /$ & $234882 /$ & 11 & $10471 / 1$ & 1168 179/ & 370 \\
\hline Stainless Steel & Condensate (Nuclear Steam) ${ }^{(\mathrm{e})}$ & & -- & $38 /$ & $1474 /$ & 0 & $103 /$ & $6421 /$ & 0 & & -- & & & -- & & & --- & & $141 /$ & $7895 /$ & 0 \\
\hline Total & & & $\ldots$ & $38 /$ & $1474 /$ & 0 & $103 /$ & $6421 /$ & 0 & & --- & & & -- & & & $\ldots$ & & $141 /$ & $7895 /$ & 0 \\
\hline
\end{tabular}

(a) Dashed line represents insignificant amount.

The data are presented in the following format: Piping Length, $\mathrm{m} /$ Piping Mass, $\mathrm{kg} /$ Number of Valves.

(c) The total number of valves for a particular system does not include small-bore valves $51 \mathrm{~mm}$ or less in diameter

(d) N.A. = not available.

Includes piping and valves that connect to the condensate storage tanks (EKN 228) located outside the

Turbine Cenerator Building. 
TABLE C.3-10. Contaminated Piping and Valves: Radwaste and Control Building

Nominal Outside Diameter, $\mathrm{mm}$

\begin{tabular}{|c|c|}
\hline Material & System \\
\hline \multicolumn{2}{|l|}{ Totals } \\
\hline \multirow[t]{4}{*}{ Carbon Steel } & $\begin{array}{l}\text { Condensate (Nuclear Steam) } \\
\text { Condensate Filter Demineralization } \\
\text { Condenser Off Gas Treatment }\end{array}$ \\
\hline & $\begin{array}{l}\text { Equipment Drain (Radioactive) } \\
\text { Floor Drain (Radioactive) } \\
\text { Fuel Pool Cooling and Cleanup }\end{array}$ \\
\hline & $\begin{array}{l}\text { Miscellaneous Wastes (Radioactive) } \\
\text { Process Vents (Radioactive) } \\
\text { Process Waste (Radioactive) }\end{array}$ \\
\hline & $\begin{array}{l}\text { Radwaste Building Closed Cooling } \\
\text { Reactor Water Cleanup }\end{array}$ \\
\hline \multicolumn{2}{|l|}{ Totals } \\
\hline Stainless Steel & $\begin{array}{l}\text { Condensate (Nuclear Steam) } \\
\text { Condenser Off Gas Treatment } \\
\text { Equipment Drain (Radioactive) }\end{array}$ \\
\hline & $\begin{array}{l}\text { Floor Drain (Radioactive) } \\
\text { Miscellaneous Wastes (Radioactive) } \\
\text { Process Waste (Radioactive) }\end{array}$ \\
\hline Totals & \\
\hline
\end{tabular}

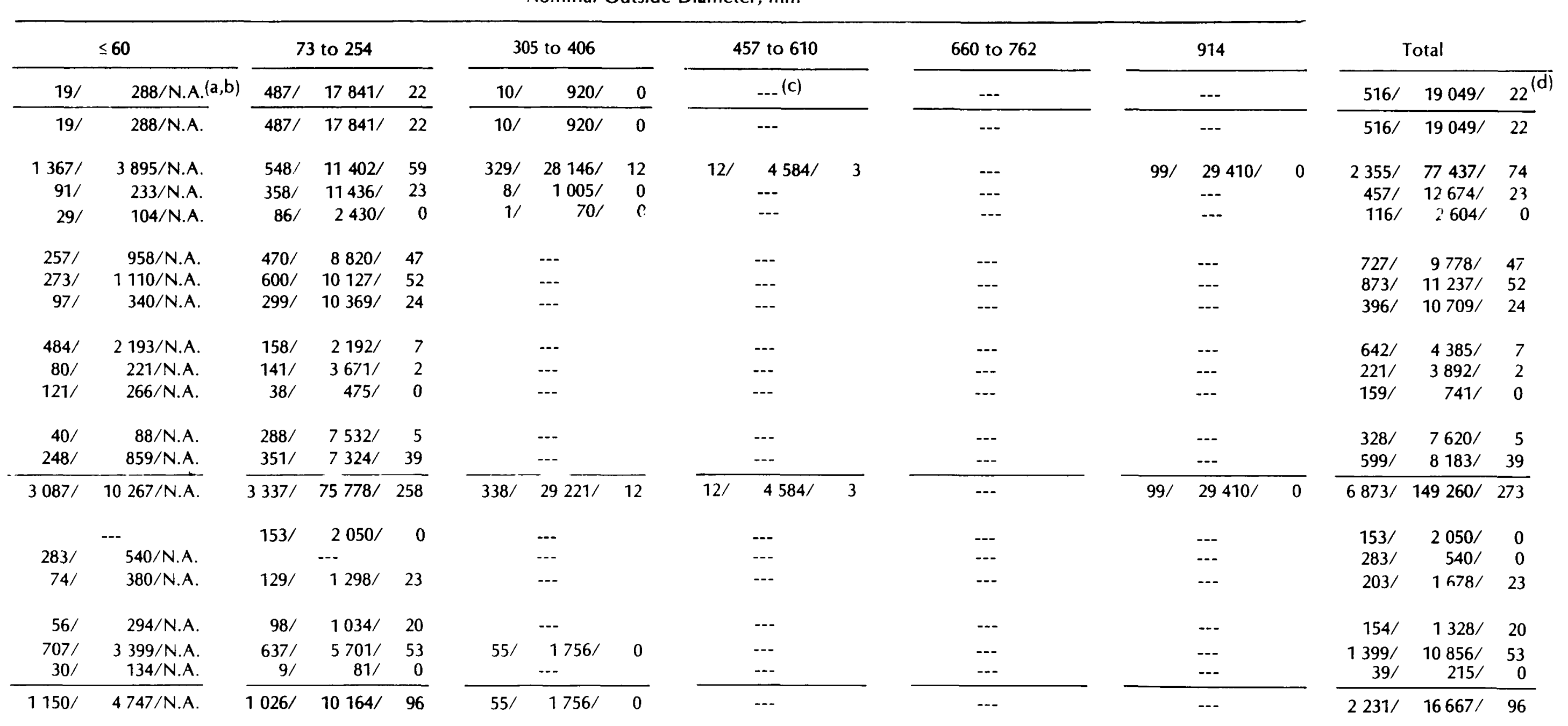

(a) The data are presented in the following format: Piping Length, $\mathrm{m} /$ Piping Mass, $\mathrm{kg} /$ Number of Valves.

(b) N.A. = not available.

Dashed line represents insignificant amount.

The total number of valves for a particular system does not include small-bore valves $51 \mathrm{~mm}$ or less in diameter

TABLE C.3-10. Contaminated Piping and Valves: Radwaste 
,

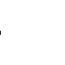


TABLE C.3-11. Summary of Contaminated Piping and Valves

Nominal Outside Diameter, $\mathrm{mm}$

\begin{tabular}{|c|c|}
\hline Material & Location \\
\hline Aluminum & $\begin{array}{l}\text { Reactor Building } \\
\text { Turbine Generator Building } \\
\text { Radwaste and Control Building }\end{array}$ \\
\hline \multicolumn{2}{|l|}{ Totals } \\
\hline Carbon Steel & $\begin{array}{l}\text { Reactor Building } \\
\text { Primary Containment } \\
\text { Turbine Generator Building } \\
\text { Radwaste and Control Building }\end{array}$ \\
\hline \multicolumn{2}{|l|}{ Totals } \\
\hline \multirow[t]{2}{*}{ Stainless Steel } & $\begin{array}{l}\text { Reactor Building } \\
\text { Primary Containment }\end{array}$ \\
\hline & $\begin{array}{l}\text { Turbine Generator Building } \\
\text { Radwaste and Control Building }\end{array}$ \\
\hline
\end{tabular}

\begin{tabular}{|c|c|c|c|c|c|c|c|c|c|c|c|c|c|c|c|c|c|c|c|}
\hline & \multirow{2}{*}{$\begin{array}{l}\leq 60 \\
\ldots \text { (a) }\end{array}$} & \multicolumn{3}{|c|}{73 to 254} & \multicolumn{3}{|c|}{305 to 406} & \multicolumn{3}{|c|}{457 to 610} & \multicolumn{3}{|c|}{660 to 762} & \multicolumn{3}{|c|}{914 to 1829} & \multicolumn{3}{|c|}{ Total } \\
\hline & & $31 /$ & $1020 /$ & $0^{(b)}$ & & $\ldots$ & & & -.. & & & $\ldots$ & & & $\ldots$ & & 31 & $1020 /$ & \\
\hline $409 /$ & $1712 /$ N.A. ${ }^{(C)}$ & $847 /$ & $23449 /$ & 60 & $116 /$ & $12716 /$ & 1 & & -- & & & $\cdots$ & & & -- & & $1372 /$ & $37877 /$ & $61^{\text {(d) }}$ \\
\hline & & & & & & & & & & & & & & & & & & & \\
\hline $428 /$ & $2000 /$ N.A. & $1365 /$ & $42310 /$ & 82 & $126 /$ & $13636 /$ & 1 & & $\cdots$ & & & --- & & & --- & & $1919 /$ & $57946 /$ & 83 \\
\hline $2323 /$ & $8479 /$ N.A. & $3922 /$ & $110368 /$ & 208 & $505 /$ & $61897 /$ & 23 & $952 /$ & $127160 /$ & 55 & $55 /$ & $14850 /$ & 6 & & -.- & & $7757 /$ & $322754 /$ & 292 \\
\hline $263 /$ & 1 366/N.A. & 1084 & $63181 /$ & 72 & $211 /$ & $29760 /$ & 18 & $1239 /$ & $554877 /$ & 1 & $374 /$ & $145312 /$ & 4 & & -.- & & $3171 /$ & 794 496/ & 95 \\
\hline $3336 /$ & 14 153/N.A. & $2632 /$ & $115525 /$ & 194 & $1647 /$ & $176600 /$ & 69 & $1832 /$ & $386321 /$ & 96 & $465 /$ & $240698 /$ & 0 & $559 /$ & $234882 /$ & 11 & $10471 / 1$ & 168 179/ & 370 \\
\hline $3087 /$ & 10267 /N.A. & $3337 /$ & $75778 /$ & 258 & $338 /$ & $29221 /$ & 12 & $12 /$ & $4584 /$ & 3 & & --- & & $99 /$ & $29410 /$ & 0 & $6873 /$ & $152139 /$ & 273 \\
\hline $9009 /$ & 34 265/N.A. & 10 975/ & $364852 \prime$ & 732 & $2701 /$ & $294478 /$ & 122 & $4035 / 1$ & 072 942/ & 155 & $894 /$ & $400860 /$ & 10 & $658 \%$ & $264292 /$ & 11 & $28272 / 2$ & 434 689/1 & 1030 \\
\hline $6169 /$ & 18 674/N.A. & $500 /$ & $4551 /$ & 10 & $54 /$ & $2143 /$ & 0 & & $\cdots$ & & & --- & & & --- & & $6723 /$ & $25368 /$ & 10 \\
\hline $3850 /$ & $10603 /$ N.A. & $110 /$ & $3411 /$ & 8 & $64 /$ & $8789 /$ & 3 & $55 /$ & $21440 /$ & 6 & & -- & & & --- & & 4 079/ & $44243 /$ & 17 \\
\hline & --- & $38 /$ & $1474 /$ & 0 & $103 /$ & $6421 /$ & 0 & & -.- & & & --- & & & --. & & $141 /$ & $7895 /$ & 0 \\
\hline $1150 /$ & $4747 /$ N.A. & $1026 /$ & $10764 /$ & 96 & $55 /$ & $1756 /$ & 0 & & $\cdots$ & & & --- & & & -.. & & $2231 /$ & $16667 /$ & 96 \\
\hline 11 169/ & 34 024/N.A. & $1674 /$ & $19600 /$ & 114 & $276 /$ & 19 109/ & 3 & $55 /$ & $21440 /$ & 6 & & $\ldots$ & & & $\ldots$ & & 13 174/ & 94 173/ & 123 \\
\hline
\end{tabular}

(a) Dashed line represents insignificant amount.
(b) The data are presented in the following form

(b) The data are presented in the following format: Piping Length, $\mathrm{m} /$ Piping Mass, $\mathrm{kg} /$ Number of Valves.

(d) N.A. = not available. 
$0 \quad 0$ 


\section{C.4 HEATING, VENTILATING AND AIR CONDITIONING SYSTEMS}

This section presents information about the various heating, ventilating and air conditioning (HVAC) systems in the Reactor Building and Primary Containment, the Turbine Generator Building, and the Radwaste and Control Building. These systems are designed to guard against the spread of airborne radioactive contamination.

The design and process information in this section has not been converted to metric units, since it is included for illustration only and is not essential to the study results.

\section{C.4.1 HVAC - Reactor Building and Primary Containment}

The HVAC systems for the Reactor Building and the Primary Containment are separate and distinct, except for an intertie used as needed for purging the Primary Containment. The following sections describe each of these systems.

\section{C.4.1.1 Reactor Building}

The Reactor Building heating and ventilating system is shown in Figure C.4-1. The system is basically a "push-pu11" heating and ventilation system, providing once-through air flow with no recirculation, consisting of the following subsystems:

- main supply system

- main exhaust system

- sump vent exhaust filter system

- emergency cooling system

- miscellaneous ventilation systems.

Equipment details are given in Table C.4-1. System descriptions follow.

Main Supply System. The Reactor Building main supply system consists of a heating and ventilation unit (EKN 107), air distribution ductwork, two isolation butterfly valves on the fresh air intake, and associated controls. The heating and ventilation unit consists of an insulated sheet metal housing containing a prefilter, steam coil, evaporative cooling section, and two $100 \%$ capacity $(97,350-\mathrm{cfm})$ vaneaxial fans. The prefilter is of the renewable roll 
8

8 


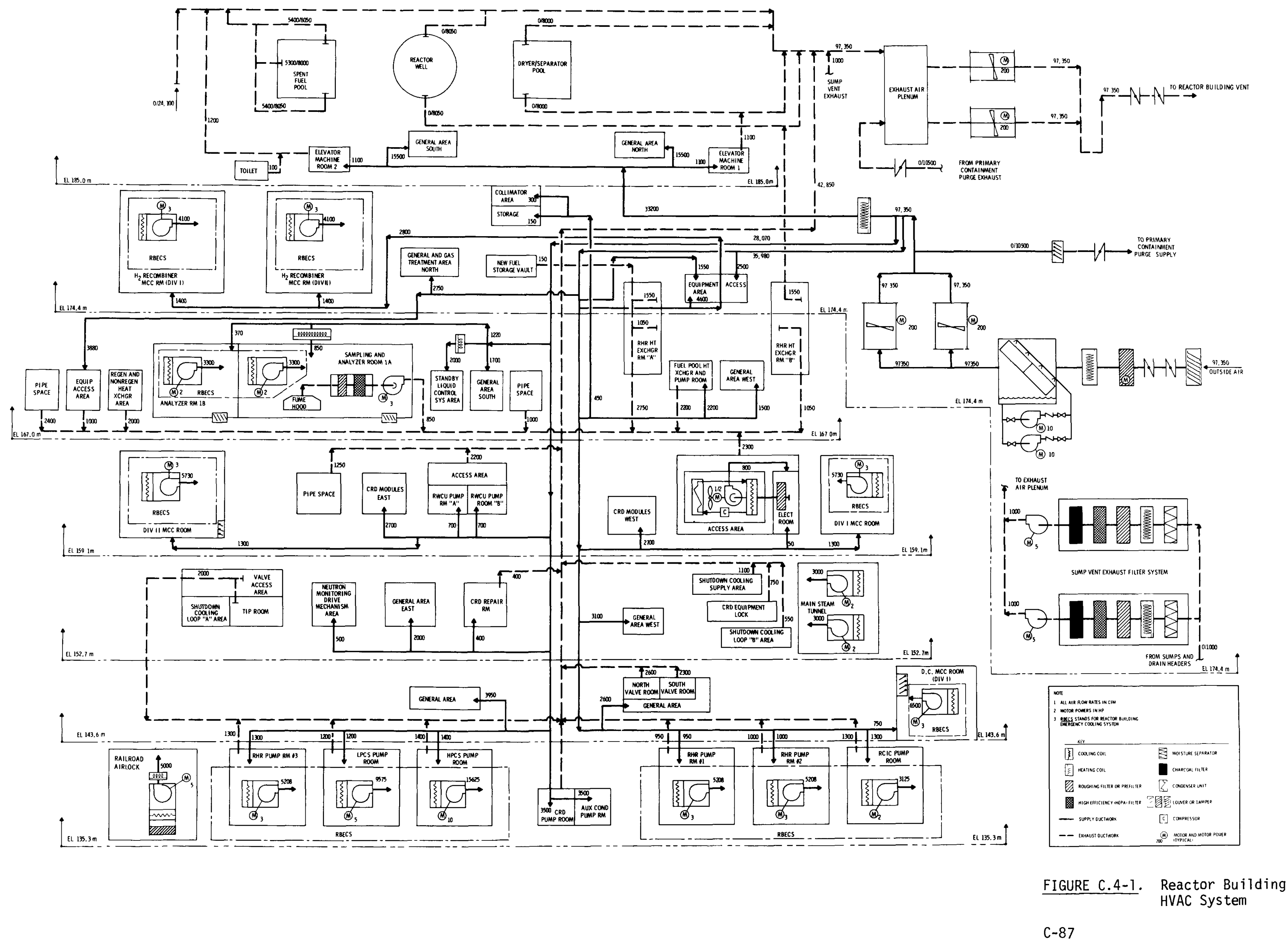


@ 8 


\section{TABLE C.4-1. Reactor Building HVAC System Component Design Data}

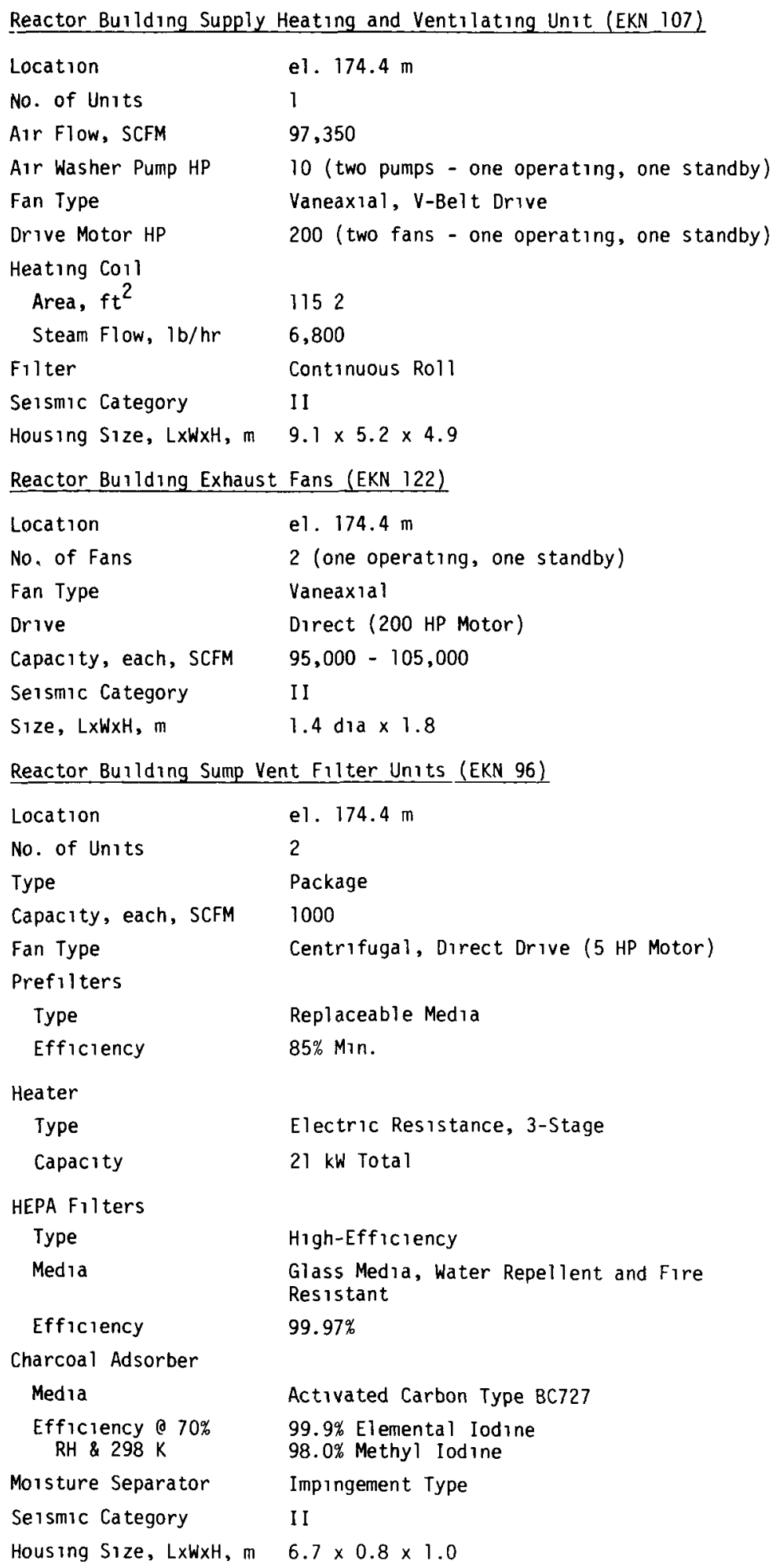




\section{TABLE C.4-1. Reactor Building HVAC System Component Design Data (Contd)}

Reactor Building Emergency Fan Coll Units (EKN 100)

\begin{tabular}{|c|c|c|c|c|c|}
\hline Location & $\begin{array}{l}\text { RHR Pump Rooms, } \\
\text { el. } 135.3 \mathrm{mt}\end{array}$ & $\begin{array}{l}\text { HPCS Pump Room, } \\
\text { el. } 135.3 \mathrm{~m}\end{array}$ & $\begin{array}{l}\text { LPCS Pump Room, } \\
\text { el. } 135.3 \mathrm{~m}\end{array}$ & $\begin{array}{l}\text { RCIC Pump Room, } \\
\text { el } 135.3 \mathrm{~m}\end{array}$ & $\begin{array}{l}\text { MCC Rooms, } \\
\text { el. } 159.1 \mathrm{~m}\end{array}$ \\
\hline No. of Units & 3 & 1 & 1 & 1 & 2 \\
\hline $\begin{array}{l}\text { Air Flow per } \\
\text { Unit, ACFM }\end{array}$ & 5,208 & 15,625 & 9,575 & 3,125 & 5,730 \\
\hline $\begin{array}{l}\text { Sensible Cooling } \\
\text { Capacity per Unit, } \\
\text { Btuh }\end{array}$ & 165,000 & 500,000 & 280,000 & 60,000 & 71,280 \\
\hline Fan Drive Motor HP & 3 & 10 & 5 & 2 & 3 \\
\hline $\begin{array}{l}\text { Cooling Water } \\
\text { Supply Service }\end{array}$ & $\begin{array}{l}\text { Standby } \\
\text { Service } \\
\text { Water }\end{array}$ & $\begin{array}{l}\text { Standby } \\
\text { Service } \\
\text { Water }\end{array}$ & $\begin{array}{l}\text { Standby } \\
\text { Service } \\
\text { Water }\end{array}$ & $\begin{array}{l}\text { Standby } \\
\text { Service } \\
\text { Water }\end{array}$ & $\begin{array}{l}\text { Standby } \\
\text { Service } \\
\text { Water }\end{array}$ \\
\hline Seismic Category & I & I & I & I & 1 \\
\hline Housing Size, LxWxH, m & $1.1 \times 1.4 \times 1.7$ & $2.4 \times 1.9 \times 18$ & $12 \times 14 \times 24$ & $12 \times 1.5 \times 1.1$ & $1.7 \times 1.1 \times 1.4$ \\
\hline Location & $\begin{array}{l}\text { D.C. MCC Room, } \\
\text { el. } 143.6 \mathrm{~m}\end{array}$ & $\begin{array}{l}\mathrm{H}_{2} \text { Recombiner Rins, } \\
\text { el. } 1744 \mathrm{~m}\end{array}$ & $\begin{array}{l}\text { RWCU Analyzer Rins, } \\
\text { el } 167.0 \mathrm{~m}\end{array}$ & & \\
\hline No. of Units & 1 & 2 & 2 & & \\
\hline $\begin{array}{l}\text { Air Flow per } \\
\text { Unit, SCFM }\end{array}$ & 6,500 & 4,100 & 3,300 & & \\
\hline $\begin{array}{l}\text { Sensible Cooling } \\
\text { Capacity per Unit, } \\
\text { Btuh }\end{array}$ & 85,000 & 53,900 & 43,000 & & \\
\hline Fan Drive Motor HP & 3 & 3 & 2 & & \\
\hline $\begin{array}{l}\text { Cooling Water } \\
\text { Supply Source }\end{array}$ & $\begin{array}{l}\text { Standby } \\
\text { Service } \\
\text { Water }\end{array}$ & $\begin{array}{l}\text { Standby } \\
\text { Service } \\
\text { Water }\end{array}$ & $\begin{array}{l}\text { Standby } \\
\text { Service } \\
\text { Water }\end{array}$ & & \\
\hline Seismic Category & I & I & I & & \\
\hline $\begin{array}{l}\text { Housing Size, LxWxH, m } \\
\text { Miscellaneous Area Vent }\end{array}$ & $\begin{array}{l}1.7 \times 14 \times 0.8 \\
\text { lation Systems }\end{array}$ & $1.5 \times 0.9 \times 12$ & $15 \times 0.9 \times 1.2$ & & \\
\hline Location & $\begin{array}{l}\text { Steam Tunnel, } \\
\text { el. } 152.7 \mathrm{~m}\end{array}$ & $\begin{array}{l}\text { RWCU Sample Hood, } \\
\text { Sample Room 1A, } \\
\text { el. } 167.0 \mathrm{~m}\end{array}$ & $\begin{array}{l}\text { Rallroad Alrlock, } \\
\text { el. } 134.4 \mathrm{~m}\end{array}$ & & \\
\hline No. of Units & 2 & 1 & 1 & & \\
\hline Fan Drive & $\begin{array}{l}\text { Direct } \\
\text { (2 HP Motor) }\end{array}$ & $\begin{array}{l}\text { Direct } \\
\text { (3 HP Motor) }\end{array}$ & $\begin{array}{l}V \text {-Belt } \\
(5 \mathrm{HP} \text { Motor) }\end{array}$ & & \\
\hline $\begin{array}{l}\text { Nominal A1r Flow } \\
\text { per Unit, SCFM }\end{array}$ & 3,000 & 850 & 5,000 & & \\
\hline $\begin{array}{l}\text { Sensible and Latent } \\
\text { Cooling Capacity at } \\
\text { Nominal Arr Flow, } \\
\text { Btuh }\end{array}$ & 97.2 & $\ldots(a)$ & 42,500 & & \\
\hline $\begin{array}{l}\text { Cooling Water } \\
\text { Supply Source }\end{array}$ & $\begin{array}{l}\text { Plant } \\
\text { Service } \\
\text { Water }\end{array}$ & -- & $\begin{array}{l}\text { Plant } \\
\text { Service } \\
\text { Water }\end{array}$ & & \\
\hline Filters & --- & $\begin{array}{l}\text { Prefilter. } \\
\text { Replaceable } \\
\text { Viscous Impingement. } \\
\text { HEPA Filter: } \\
\text { Glass Media, } \\
99.97 \text { Efficient }\end{array}$ & 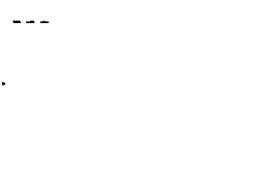 & & \\
\hline Sersmic Category & I & II & II & & \\
\hline Housing Size, $L \times W \times H, m$ & $1.2 \times 0.9 \times 1.5$ & $1.8 \times 0.9 \times 0.8$ & $2.3 \times 1.8 \times 1.8$ & & \\
\hline
\end{tabular}

(a)Dashed line means "not applicable." 
type, automatically progressed to maintain consistent pressure drop. The steam coil is of the non-freeze type, with automatic face and bypass dampers used for temperature control. The source of the heating steam during decommissioning is the auxiliary boiler (EKN 236). The evaporative cooling section is of the capillary type, with two full-capacity water recirculation pumps. Makeup water to the evaporative cooler is supplied from the plant potable water system.

During normal operation, the main supply system isolation dampers are open, and the system continuously distributes tempered, $100 \%$ outdoor air throughout the building. One supply fan is normally operating, with the second fan in standby. The standby fan starts automatically if the operating fan fails.

The Reactor Building main supply system also provides makeup air to the Primary Containment during Primary Containment purge, if needed. During purge, isolation valves direct air from the supply air system into the Primary Containment.

In the vent of a Reactor Building isolation signal, the main supply system ventilation unit stops and the two isolation dampers in the outdoor air intake close. The signals that cause Reactor Building isolation are:

- reactor vessel low-water level

- high drywell pressure

- high radiation level in the Reactor Building exhaust air plenum.

Only the last isolation signal has application during decommissioning.

Main Exhaust System. The Reactor Building main exhaust system draws air from all areas with potential radioactive contamination and discharges it to the elevated release point on the north side of the building. There are two $100 \%$-capacity $(97,350-\mathrm{cfm})$ vaneaxial fans (EKN 122) in the system. One fan normally operates, with the second fan in standby.

Approximately half of the Reactor Building exhaust air is drawn from the refueling level of the Reactor Building. Intake ducts to the main exhaust 
system are embedded around the periphery of the spent fuel pool, the dryer and separator storage pool, and the reactor well, to remove any radioactive vapors generated in the pools. Volume control dampers in the ducts from each pool control the air flow over each pool.

During Primary Containment purge, the purge air is discharged through the Reactor Building main exhaust system or through the standby gas treatment system. Ducts connect the Primary Containment drywell and suppression pool areas with both systems. The reactor building main exhaust system is normally used for purge, with the standby gas treatment system used only when an unacceptably high level of airborne radioactivity is present inside the Primary Containment.

The aforementioned isolation signals stop and isolate the Reactor Building main exhaust system and start the standby gas treatment system (EKN 92). (See Section C.5.3.)

Sump Vent Exhaust Filter System. The sump vent exhaust filter system (EKN 96) is composed of two full-capacity (1000-cfm) filter units that draw air from the sumps and drain headers and discharge it to the main Reactor Building exhaust system. Each filter unit consists of the following elements in a sheet metal housing:

- moisture separator

- electric blast coil heater

- medium-efficiency particulate prefilter

- high-efficiency particulate (HEPA) filter

- tray-type 2-inch thick charcoal adsorber filter

- centrifugal fan.

Reactor Building Emergency Cooling Systems (RBECS). Each of the 13 rooms housing critical equipment is provided with an individual air handling unit (EKN 100) fully enclosed within the room. Each air handling unit is composed of a direct-driven centrifugal fan and a cooling water coil in a sheet metal housing. Water is supplied to the water coils by the standby service water system. During normal operation all 13 air handling units are in standby. 
The units that service the emergency pump rooms start automatically upon actuation of their associated pumps. The units servicing the motor control center (MCC) equipment rooms and the analyzer rooms start automatically upon any one of the aforementioned Reactor Building isolation signals.

All units recirculate the air within the room they serve, removing the heat generated in the room via the water coil.

Miscellaneous Area Ventilation Systems. The following HVAC systems are provided to service local areas in the Reactor Building:

1. The main steam tunnel is serviced by two $100 \%$-capacity, recirculating fan coil units located within the tunnel. Both units are composed of a cooling water coil, supplied by the plant service water system, and a direct-driven centrifugal fan in a sheet metal housing.

2. The reactor water cleanup (RWCU) sample hood is provided with supply air from the Reactor Building supply air system. An electric duct heater is provided in the supply air duct. The exhaust filter unit, which draws air from the hood, is composed of a viscous impingement prefilter, a HEPA filter, and a centrifugal fan in a sheet metal housing. The exhaust fan discharges air into the Reactor Building exhaust system.

3. The railroad airlock, on grade elevation, is heated and cooled by an air handling unit that operates in a recirculation mode. The air handling unit is composed of a prefilter, cooling water coil, and centrifugal fan, all in a sheet metal housing. A $15-\mathrm{kW}$ electric blast coil heater is provided in the discharge duct for heating. $\mathrm{Pl}$ ant service water is supplied to the water coil for cooling.

\section{C.4.1.2 Primary Containment}

The Primary Containment cooling system is depicted in Figure C.4-2. Equipment details are listed in Table C.4-2. Cooling of the drywell is provided by five fan coil units. (EKN 107) that recirculate containment air through cooling water coils for heat removal. Nine recirculation fans 
8

0 


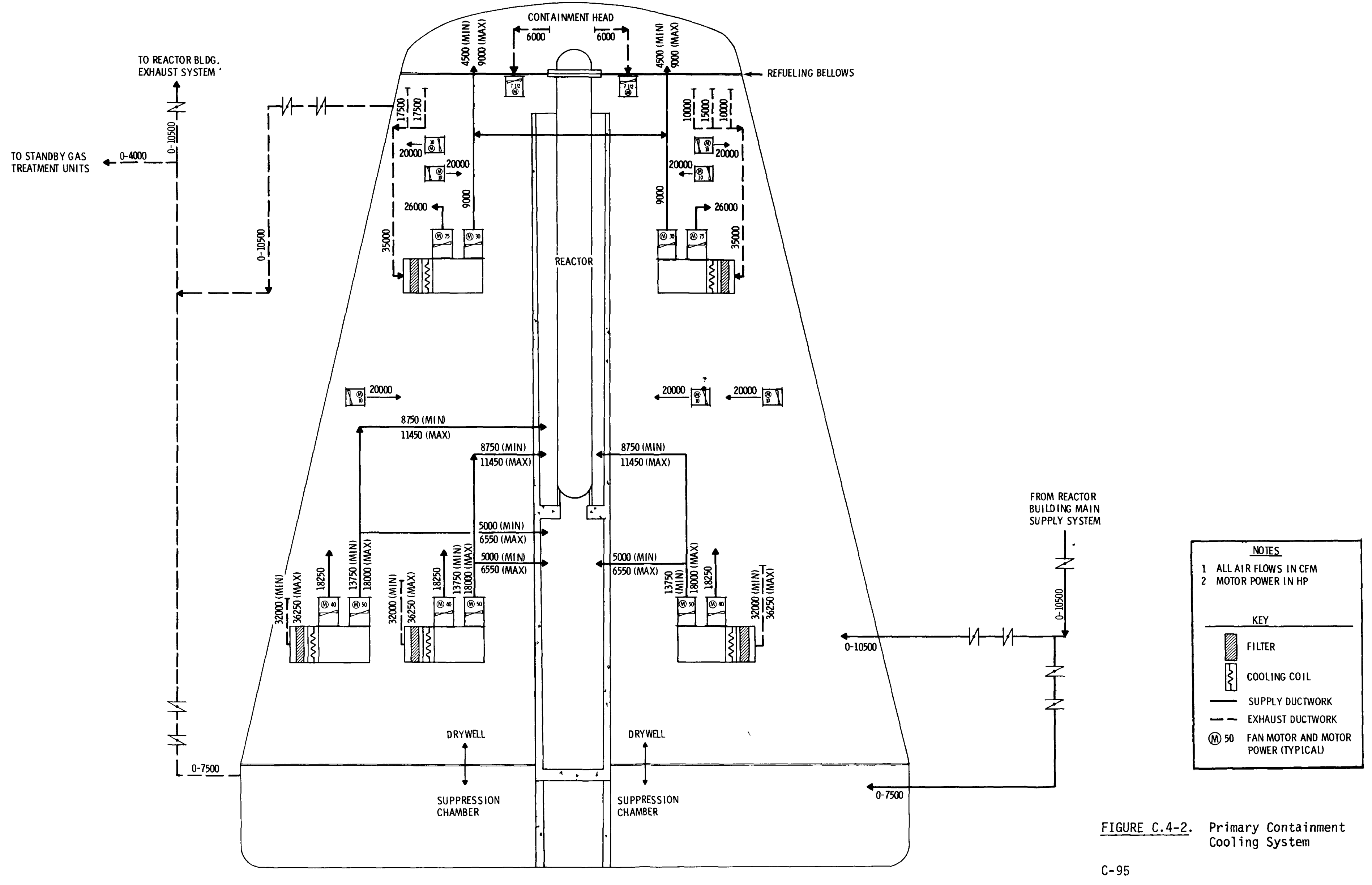


○

8 
IABLE C.4-2. Primary Containment Cooling System Component Design Data

Primary Containment Fan Coil Units (EKN 107)

\begin{tabular}{|c|c|c|}
\hline No. of Units & 3 (one standby) & 2 (one standby) \\
\hline Nominal Air Flow, each, SCFM & 32,000 & 35,000 \\
\hline $\begin{array}{l}\text { Cooling Capacity (Sensible) } \\
\text { at Nominal Air Flow, Btuh }\end{array}$ & $1,140,000$ & $1,140,000$ \\
\hline Fan Type & $\begin{array}{l}\text { Vaneaxial (two per } \\
\text { unit) }\end{array}$ & $\begin{array}{l}\text { Vaneaxial (two per } \\
\text { unit) }\end{array}$ \\
\hline Drive Motor HP & 40 and 50 , each unit & 30 and 75 , each unit \\
\hline $\begin{array}{l}\text { Cooling Water Supply } \\
\text { Source }\end{array}$ & $\begin{array}{l}\text { Reactor Building } \\
\text { Closed Cooling System }\end{array}$ & $\begin{array}{l}\text { Reactor Building } \\
\text { Closed Cooling System }\end{array}$ \\
\hline Seismic Category & $I$ & I \\
\hline $\begin{array}{l}\text { Housing Size, LxWxH, m } \\
\text { Primary Containment Head Area }\end{array}$ & $\begin{array}{l}3.4 \times 1.8 \times 2.1 \\
\text { eturn Fans (EKN 106) } \\
\end{array}$ & $3.2 \times 1.8 \times 2.1$ \\
\hline No. of Fans & 2 & \\
\hline Fan Type & Vaneaxial & \\
\hline Drive & Direct (7.5 HP Motor) & \\
\hline Capacity, each, ACFM & 6000 & \\
\hline Seismic Category & $\mathrm{I}$ & \\
\hline Size, m & 0.6 dia $\times 0.6$ & \\
\hline \multicolumn{3}{|c|}{ Primary Containment Recirculation Fans (EKN 104, 105) } \\
\hline No. of Fans & 7 & \\
\hline Fan Type & Vaneaxial & \\
\hline Drive & Direct (10 HP Motor) & \\
\hline Capacity, each, ACFM & 20,000 & \\
\hline Seismic Category & $I$ & \\
\hline Size, m & 1.1 dia $\times 1.1$ & \\
\hline
\end{tabular}


(EKN 104, 105, 106) are also provided at various locations in the drywell. Each of the five fan coil units consists of two vanexial fans (both of which operate at the same time), a cooling water coil supplied from the Reactor Building closed cooling water system, and a prefilter, all in a sheet metal housing.

Three of the drywell cooling units are located low in the drywell, and two are located at a higher level. During normal operation, two of the lower level units and one of the upper level units operate continuously to remove the heat generated in the drywe11. The third lower level unit and the second upper level unit are normally in standby.

Each of the three lower level fan coil units are provided with one $18,250-\mathrm{cfm}$ capacity vaneaxial fan that discharges directly into the general drywe11 volume, and one two-speed, 13,750/18,000-cfm vaneaxial fan that discharges, via ductwork, into the area beneath the reactor vessel and between the reactor vessel and the sacrificial shield wall. Volume dampers in the branch ducts proportion flow to the two areas served.

The two upper level fan coil units are each provided with one 26,000-cfm fan and one 9000-cfm fan. The larger fans discharge directly into the upper volume area, and the smaller fans discharge, via a shared duct header, into the containment head area above the refueling bellows. Two 6000 -cfm vaneaxial recirculation fans draw air from the containment head area and discharge it below the refueling bellows. Return air to the upper fan coil units is drawn from immediately below the refueling bellows.

The remaining seven recirculation fans produce an air flow of 20,000 $\mathrm{cfm}$ each, and are located at various locations on lower levels in the drywe 11 to increase air circulation in these locations. During normal operation, five of the fans operate.

\section{C.4.2 HVAC - Turbine Generator Building}

The heating and ventilating system of the Turbine Generator Building is primarily a "push-pul1" heating and ventilating system consisting of the following subsystems: 
- main supply system

- main exhaust system

- auxiliary boiler room ventilation system

- transformer vault ventilation system

- sample room air conditioning system.

Equipment details are given in Table C.4-3. The system is depicted in Figure C.4-3. System descriptions follow.

Ma in Supply System

The Turbine Generator Building supply air system is composed of four supply ventilation units (EKN 276) and associated distribution ductwork. The units are operated in pairs, with one pair discharging into a common supply duct system servicing the west side of the building and the other discharging into a common supply duct system servicing the east side of the building.

Each of the four ventilation units is composed of a prefilter, a steam coil with face and bypass dampers, an evaporative cooling section, and a centrifugal fan, all enclosed in an insulated sheet metal housing. The prefilters are of the renewable roll type, automatically progressed to maintain consistent pressure drop. The steam coils are of the non-freeze type, with automatic face and bypass dampers used for temperature control. The source of the heating steam during decommissioning is the auxiliary boiler (EKN 236). The evaporative cooling sections are of the capillary air washer type, with two ful1-capacity water recirculation pumps. Makeup water to the air washers is supplied from the plant potable water system.

The centrifugal fan of each ventilation unit is furnished with automatic inlet vanes that vary the air flow supply to maintain the Turbine Building at a set pressure with respect to outdoors. The nominal rates of air flow through the ventilation units are $74,750 \mathrm{cfm}$ through each of the two west units and $58,450 \mathrm{cfm}$ through each of the two east units. The fan intake ducts of each pair of ventilation units are joined by means of a manual damper, so that a single fan can draw air through both ventilation units in the event of failure of one fan. In this mode of operation, with fan inlet vanes fully open, the fan capacity can be increased approximately $50 \%$, thus minimizing the effect of a fan failure on system cooling capacity. 


\section{TABLE C.4-3. Turbine Generator Building HVAC System Component Design Data}

Turbıne Generator Buılding Supply Heating and Ventılatıng Units (EKN 276)

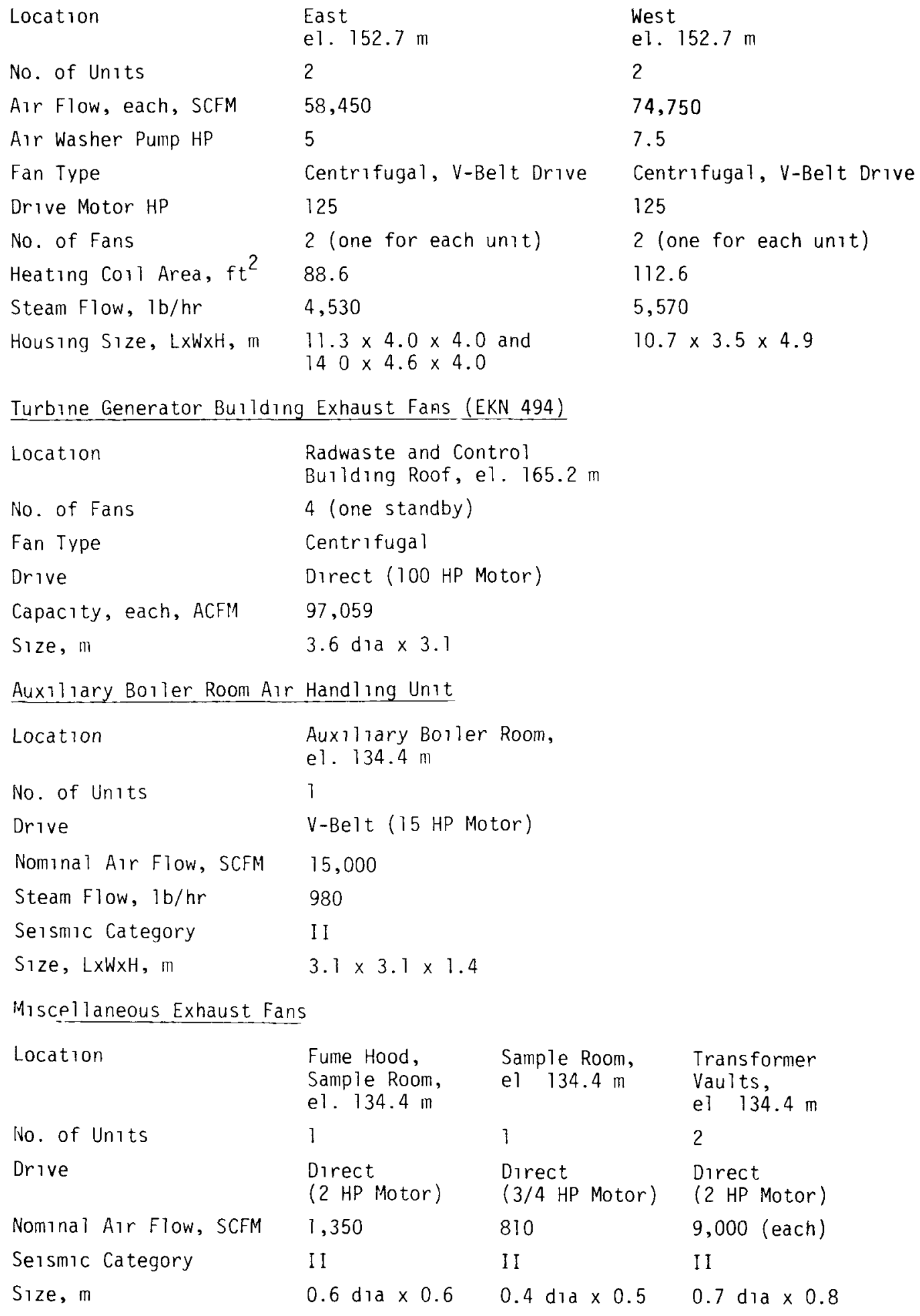

Size, m 


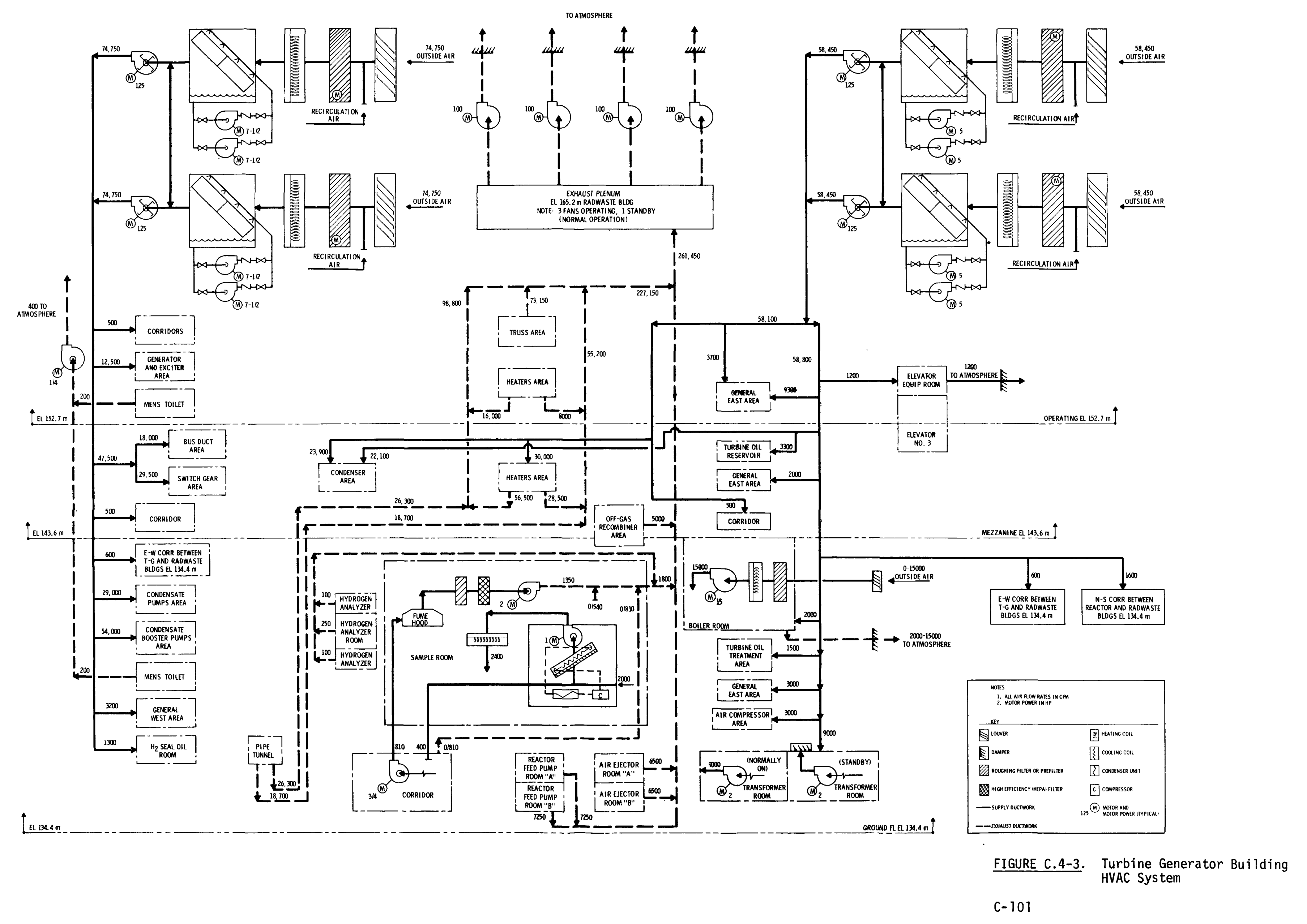


Automatic dampers provided on the intake of each ventilation unit permit the unit to draw $100 \%$ outdoor air or $100 \%$ recirculation air from the Turbine Building.

\section{Ma in Exhaust System}

The main exhaust system consists of four centrifugal fans (EKN 494) that draw air ( $97,000 \mathrm{cfm}$ each) from a central exhaust plenum (EKN 480), all mounted on the roof of the Radwaste and Control Building. Normally, three of the exhaust fans operate continuously, with one fan in standby. Constant air flow through the operating fans is maintained by volume dampers on the fan discharges.

Almost all exhaust air is drawn from the shielded areas of the Turbine Generator Building, where the potential for airborne radioactive contamination is highest, thus inducing flow from the less-contaminated areas through the shielded areas. The air in the exhaust plenum is monitored for radioactive contaminants, which are indicated on a recorder in the main control room.

Motor operated shut-off dampers in the main branches of the exhaust duct system stop exhaust flow on an area-by-area basis. Automatic volume dampers in the exhaust system draw full exhaust flow from the shielded equipment vaults on the lowest level of the Turbine Generator Building when the exhaust system is operating at reduced capacity.

\section{Auxiliary Boiler Room Ventilation System}

The auxiliary boiler room, located on the lowest level of the Turbine Generator Building, is ventilated from the Turbine Generator Building supply air system when the boiler is not operating. However, when the boiler is operating and drawing combustion air from the room, additional air $(15,000 \mathrm{cfm})$ is supplied by a separate air handling unit. The air handling unit starts automatically when the boiler is started and draws 100\% outdoor air through a weather louver, heats it as required, and discharges it into the room. Part of this air is drawn by the boiler as combustion air, with the balance of the air leaving via relief dampers in the exterior wall of the boiler room. 


\section{Transformer Vault Ventilation System}

Two transformers are located in adjacent equipment vaults in the lower level of the Turbine Generator Building, and two 9000-cfm tubeaxial fans provide ventilation. The two fans, one operating and the other in standby, exhaust air from the vaults, with makeup air being provided through ventilation openings in the walls. Both fans are powered from the critical diesel generator buses.

\section{Sample Room Air Conditioning}

The Turbine Generator Building sample room, located on the lowest level of the building, is provided with a sample hood exhaust filter system and a self-contained air conditioning system. The sample room hood air is supplied by a centrifugal fan that draws air from the corridor outside the sample room and from the room itself. Air is exhausted from the hood by a filter unit composed of a medium-efficiency prefilter, a HEPA filter, and a 1350-cfm exhaust fan, all contained in a sheet metal housing. The filter unit discharges into the main Turbine Building exhaust system.

The sample room air conditioning unit is a 5-Ton, water-cooled unit, with condensing water supplied from the plant service water system. The unit delivers $2400 \mathrm{cfm}$ in a partial recirculation mode, recirculating $2000 \mathrm{cfm}$ of room air and drawing $400 \mathrm{cfm}$ of makeup air from an adjacent corridor.

\section{C.4.3 HVAC - Radwaste and Control Building}

The heating, ventilating and air conditioning systems in the Radwaste and Control Building consist of three separate and distinct systems for the following areas:

- control tower

- condenser off gas charcoal adsorber vault

- radwaste area.

Descriptions of these systems follow. 


\section{Control Tower}

The control tower has two redundant, continuously recirculating HVAC systems with minimal fresh air intake and minimal exhaust. It is assumed that the control tower and its HVAC systems are not radioactively contaminated; therefore, no further description is necessary.

Condenser off Gas Charcoal Adsorber Vault

The condenser off gas charcoal adsorber vault has a redundant closed-1oop refrigeration system and dual air recirculation systems. This system does not operate during decommissioning, and, since it is contaminated, the air circulation equipment is discussed in Section C.3.3.

\section{Radwaste Area}

The heating and ventilating system of the radwaste area in the Radwaste and Control Building is shown in Figure C.4-4. The main system is a "push-pul1" heating and ventilating system providing once-through air flow with no recirculation. In addition; individual air conditioning systems are provided for all rooms that personnel normally occupy for extended periods of time during plant operation. Equipment details are given in Table C.4-4. System descriptions follow.

Ma in Supply System. The main radwaste area supply air system consists of a supply ventilation unit (EKN 455) and distribution ductwork. The supply ventilation unit consists of an insulated sheet metal housing containing a prefilter, steam coil, evaporative cooling section, and two $100 \%$-capacity $(82,430-\mathrm{cfm})$ centrifugal fans. The renewable roll-type prefilter is automatically progressed to maintain consistent pressure drop. The non-freezetype steam coil uses automatic face and bypass dampers for temperature control. The source of the heating steam during decommissioning is the auxiliary boiler (EKN 236). The evaporative cooling section is of the capillary type, with two ful1-capacity water recirculation pumps. Makeup water to the evaporative cooler is supplied from the plant potable water system. 


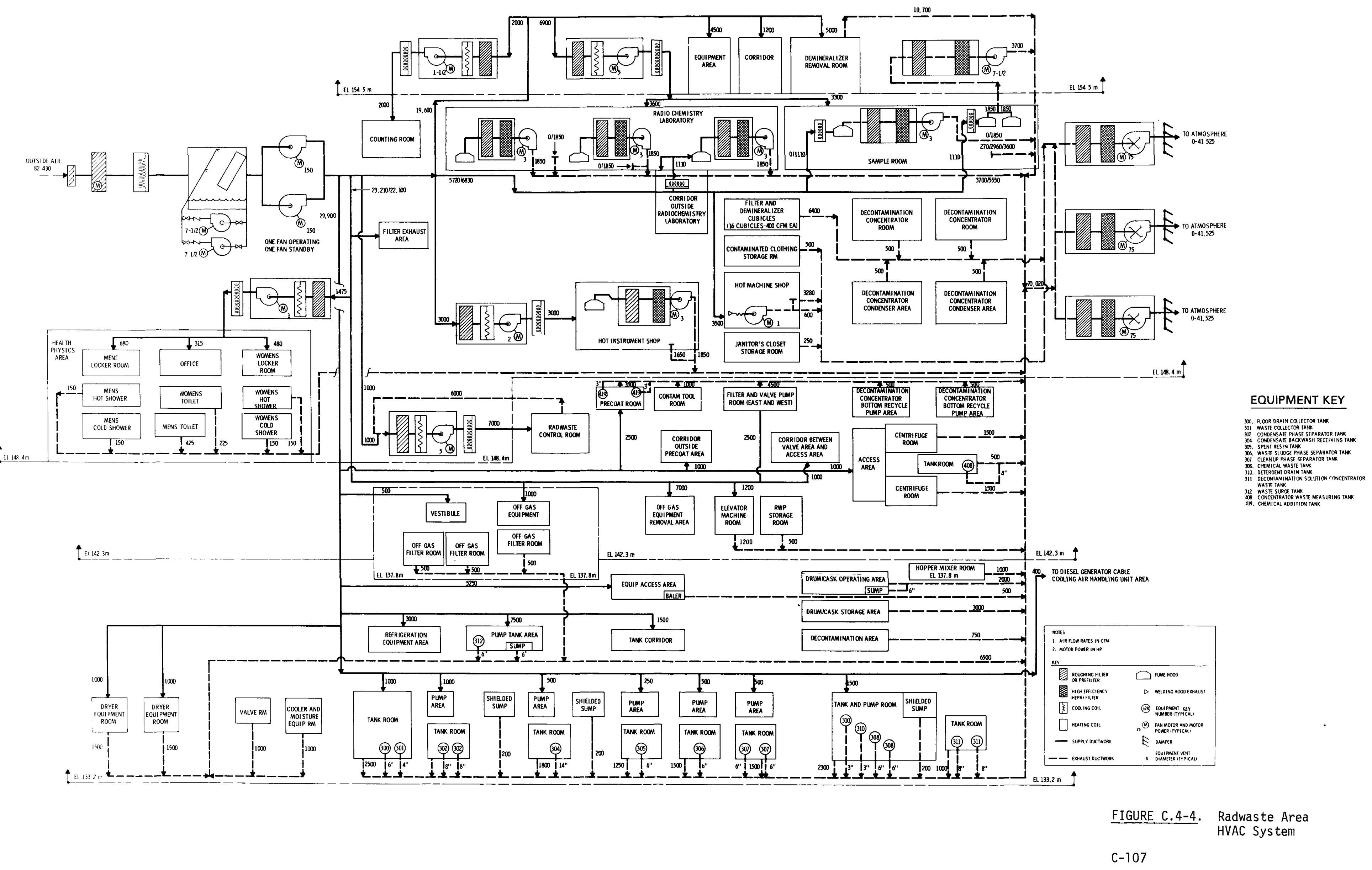




\section{TABLE C.4-4. Radwaste Area HVAC System Component Design Data}

Radwaste Area Supply Heating and Ventrlating Unit (EKN 455)

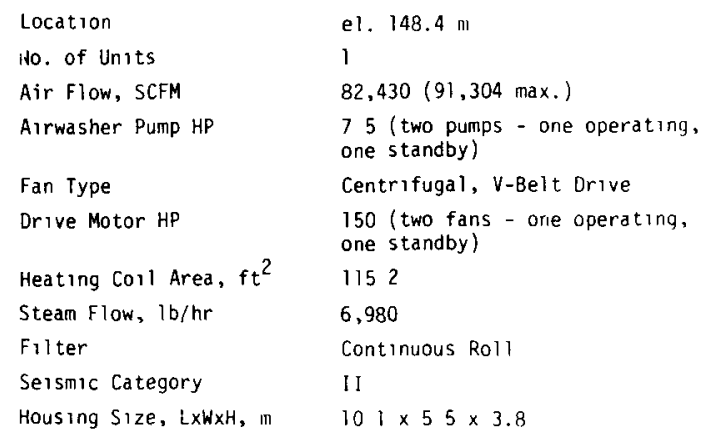

\begin{tabular}{|c|c|c|c|c|c|c|}
\hline Location & $\begin{array}{l}\text { Heal th Phvsics, } \\
\text { el } 1484 \mathrm{~m}\end{array}$ & $\begin{array}{l}\text { Radiocheili Lab, } \\
\text { el } 1545 \ldots\end{array}$ & $\begin{array}{l}\text { Hot Instr. Shop, } \\
\text { el } 1484\end{array}$ & $\begin{array}{l}\text { Radwaste Control } \\
\text { Room, el } 1484 \mathrm{~m}\end{array}$ & $\begin{array}{l}\text { Counting } \\
\text { et } 154\end{array}$ & $\begin{array}{l}19 \text { Room, } \\
+5 \mathrm{~mm}\end{array}$ \\
\hline No of Units & 1 & 1 & 1 & 1 & 1 & \\
\hline Drive & $\begin{array}{l}\text { V-Belt } \\
\text { (1 HP Motor) }\end{array}$ & $\begin{array}{l}V-3 e 1 \mathrm{t} \\
(5 \mathrm{HP} \text { (10tor) }\end{array}$ & $\begin{array}{l}y-B e i+ \\
\text { i? HP Motor) }\end{array}$ & $\begin{array}{l}V-B e 1 t \\
\text { (5 HP Motor) }\end{array}$ & $\begin{array}{l}V-B e) t \\
(15 \mathrm{HP}\end{array}$ & Motor) \\
\hline $\begin{array}{l}\text { Nominal Air } \\
\text { Flow, SCFM }\end{array}$ & 1,475 & 6.900 & 3,000 & 7,000 & 2,000 & \\
\hline $\begin{array}{l}\text { Cooling Capacity } \\
\text { (Sensible and Latent) } \\
\text { at Nominal Air Flow, } \\
\text { MBtuh }\end{array}$ & 57 & 255 & 115 & 204 & 76 & \\
\hline $\begin{array}{l}\text { Cooling Water } \\
\text { Supply Source }\end{array}$ & Chilled Water & Chilled Water & Chrlled Hater & Chilled water & Chilled & water \\
\hline Se1smic Category & II & I I & II & I1 & 11 & \\
\hline $\begin{array}{l}\text { Housing Size, LxWxH, in } \\
\text { Fume Hood Exhaust Filter }\end{array}$ & $\begin{array}{l}1.7 \times 09 \times 08 \\
\text { UnIts }(E K N 460)\end{array}$ & $24 \times 23 \times 29$ & $14 \times 17 \times 17$ & $20 \times 17 \times 24$ & $24 \times$ & $2 \times 09$ \\
\hline Location & $\begin{array}{l}\text { Radiochem Lab, } \\
\text { el } 1484 \mathrm{ll}\end{array}$ & $\begin{array}{l}\text { Hot Instr Shop, } \\
\text { el } 1484 \text { III }\end{array}$ & $\begin{array}{l}\text { Sal ple Room, } \\
\text { el } 1494 \text { : }\end{array}$ & $\begin{array}{l}\text { Sample Room, } \\
\text { el } 1545 \mathrm{~m}\end{array}$ & & \\
\hline No. of Units & 3 & 1 & 1 & 1 & & \\
\hline Drive & $\begin{array}{l}\text { Direct } \\
\text { ( } 3 \text { HP Motor) }\end{array}$ & $\begin{array}{l}\text { Direct } \\
\text { (3 HP (1otor) }\end{array}$ & $\begin{array}{l}V \text {-Belt } \\
\text { (3 } 4 \text { P Motor) }\end{array}$ & $\begin{array}{l}\text { V-Belt } \\
(75 \text { HP Motor })\end{array}$ & & \\
\hline $\begin{array}{l}\text { Nominal Air flow, } \\
\text { SCFM }\end{array}$ & $1,850($ each $)$ & 1,850 & 1,950 & $3,70 n$ & & \\
\hline $\begin{array}{l}\text { Prefilter } \\
\text { (Identical for each) }\end{array}$ & Replaceable Viscous & 5 Impungement Type & & & & \\
\hline $\begin{array}{l}\text { HEPA Filter } \\
\text { (Identical for each) }\end{array}$ & Glass Media, Water & Repellent and Fire & Resistant, 9997 & Effucient & & \\
\hline Seismic Category & II & I 1 & II & II & & \\
\hline Housing Size, $[x W \times H$, II & $24 \times 1.5 \times 11$ & $20 \times 11 \times 11$ & $26 \times 14 \times 09$ & $27 \times 14 \times 14$ & & \\
\hline
\end{tabular}


During normal plant operation, the supply unit operates continuously, providing tempered air throughout the building via the supply duct distribution system. In the event of loss of offsite power, the radwaste area supply system is inoperative.

Main Exhaust System. The radwaste area exhaust system is composed of three 50\%-capacity $(41,015-\mathrm{cfm})$ exhaust filter units (EKN 453). Each unit consists of a sheet metal housing containing a medium-efficiency cartridgetype prefilter, HEPA filter, and centrifugai fan.

During normal operation, with one unit in standby, two exhaust units draw air from a common exhaust duct system and discharge it above the Radwaste and Control Building roof. A11 exhaust is drawn from areas with the highest radioactive contamination potential, thus inducing air flow from clean areas into the potentially contaminated zones.

Individual Air Conditioning Systems. The radwaste control room, hot instrument shop, radiochemistry laboratory, sample room, counting room, and health physics office have individual air conditioning systems to maintain personnel comfort. All areas except the radwaste control room are serviced by once-through air conditioning systems. The radwaste control room, with no contamination potential during plant operation, has a partial recirculation air conditioning system.

The air conditioning for each area is provided by air handling units (EKN 378) that draw air from the radwaste area main supply system; pass it through filters, chilled water coils, and electric heaters; and discharge it into the rooms being conditioned. Chilled water is supplied to the coils from the Radwaste Building chilled water system. The conditioned air is exhausted from the rooms through vents to the balance of the building or through hoods that discharge into the main exhaust system.

The exhaust hoods in the radiochemistry laboratory, hot instrument shop, and sample room are provided with local filter units (EKN 460), composed of prefilters, HEPA filters, and fans, to remove radioactive particles from the exhaust air prior to discharge into the exhaust system. 


\section{C.5 RADWASTE SYSTEMS}

This section describes the systems in the reference BWR that handle the liquid, solid, and gaseous radwastes. Figure C.5-l shows the process flow of both the liquid and solid radwaste systems.

\section{C.5.1 Liquid Radwaste System}

The 1 iquid radwaste system is composed of a group of subsystems designed to collect, treat, and recycle different categories of waste water. These subsystems are designated as the equipment drain (radioactive) subsystem, the floor drain (radioactive) subsystem, and the miscellaneous waste (radioactive) subsystem. A simplified block flow diagram is presented in Figure C.5-2. Equipment design data are Tisted in Table C.5-1, and equipment performance data are given in Table C.5-2.

A11 liquid radwaste process streams terminate in a sample or distillate tank. Since the liquid radwaste system is operated on a batch basis, each treated batch can be sampled to ensure that the treatment is effective. If the sample indicates that the process liquid is still above acceptable radioactivity limits or is substandard in purity, the batch is recycled, either through the same treatment or through a subsystem providing a higher degree of treatment. If the sample indicates that the level of radioactivity is within limits for discharge, the processed liquid may be discharged to the river, or, if desired, to the condensate storage tanks (EKN 228).

\section{C.5.1.1 Equipment Drain (Radioactive) Subsystem}

Liquid wastes collected in the waste collector tank (EKN 301) or the waste surge tank (EKN 312) come from the following sources:

- drywel1 equipment drain sump

- Reactor Building equipment drain sump

- Radwaste Building equipment drain sump

- Turbine Generator Building equipment drain sumps (2 each)

- reactor water cleanup demineralizer system

- residual heat removal system

- cleanup phase separators (decant water)

- condensate phase separators (decant water)

- fuel pool seal rupture drains. 
8

0 


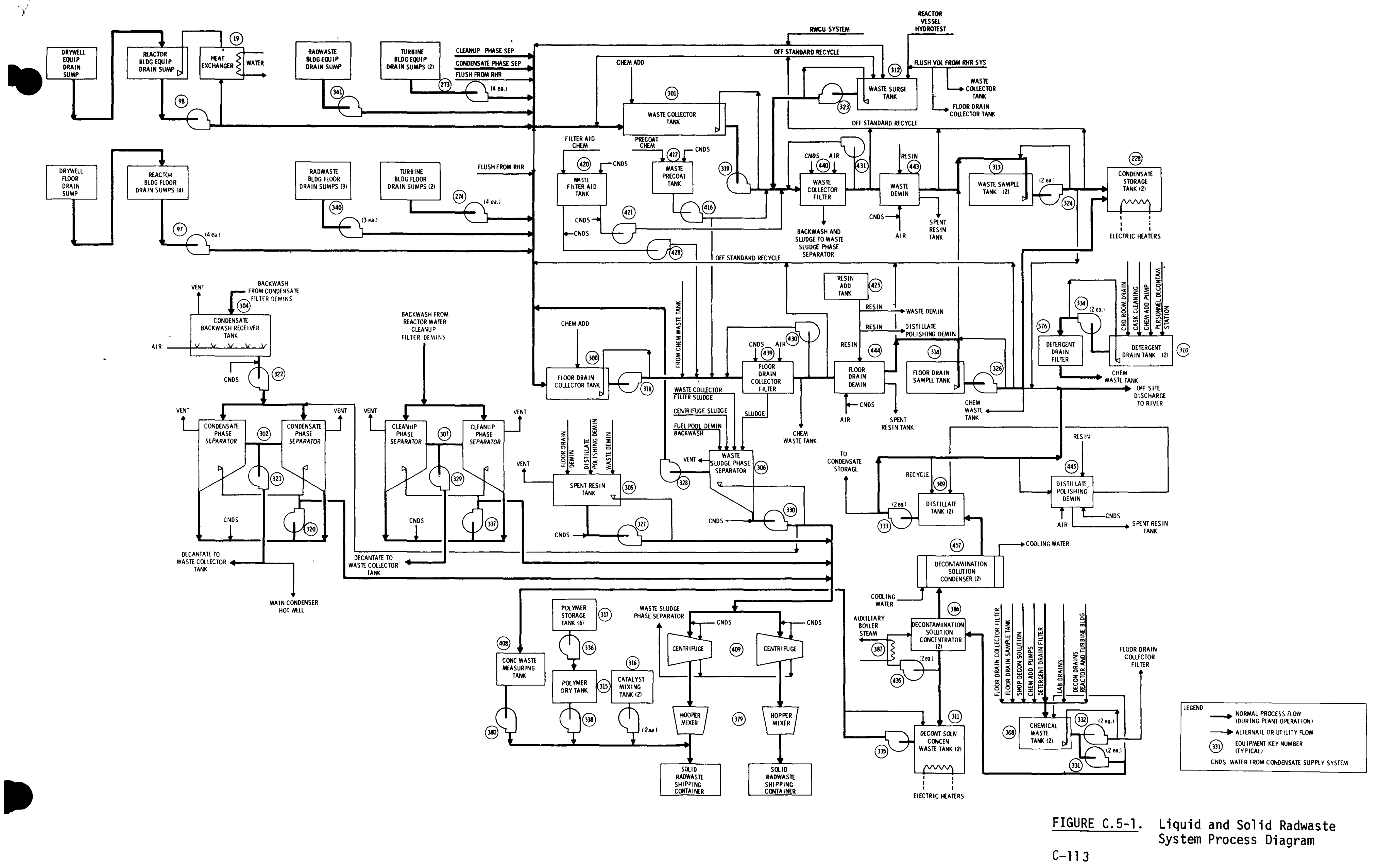


○ 8 


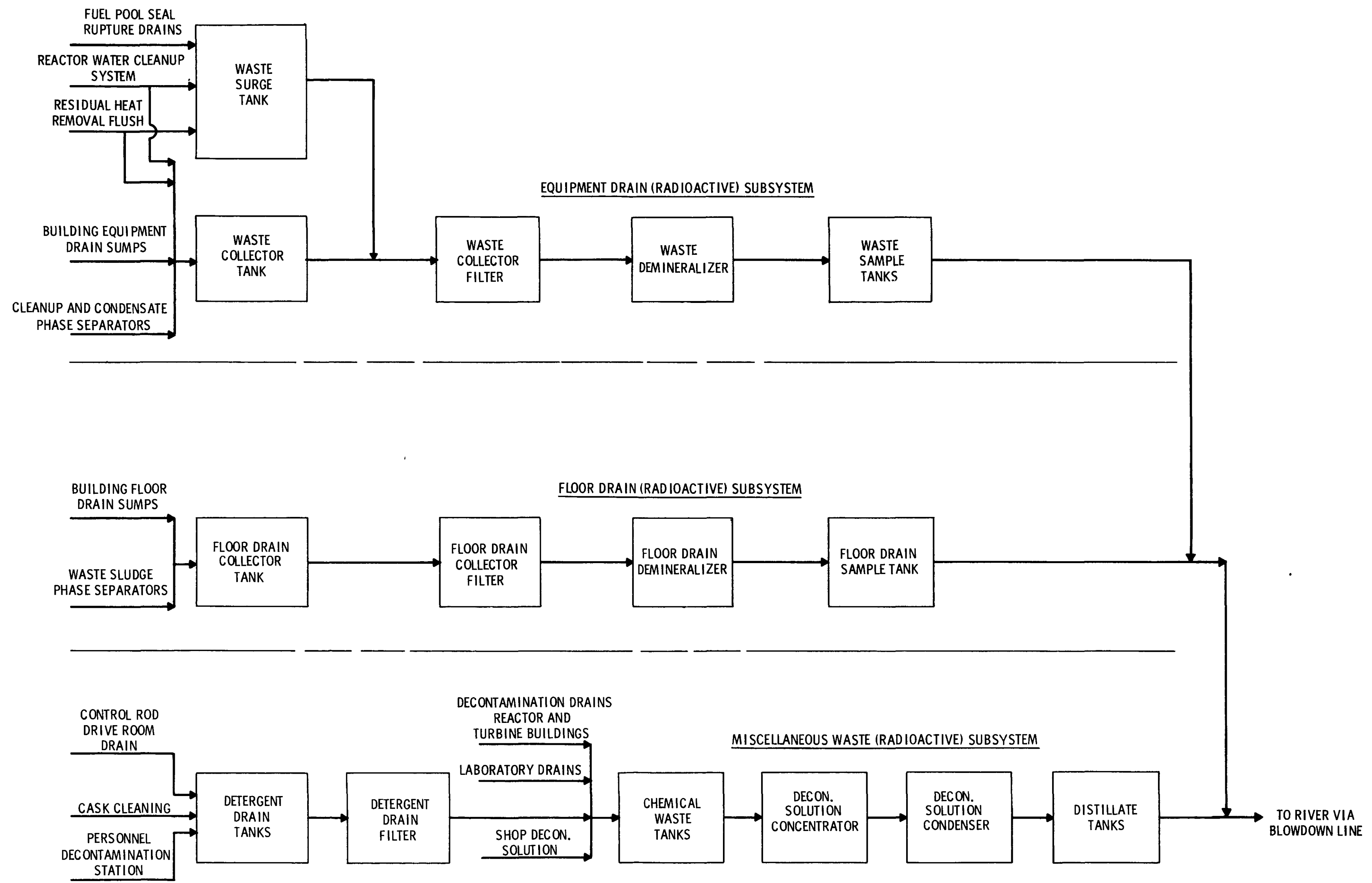

FIGURE C.5-2. Liquid Radwaste System Block 
0 


\section{TABLE C.5-1. Liquid Radwaste Equipment Design Data}

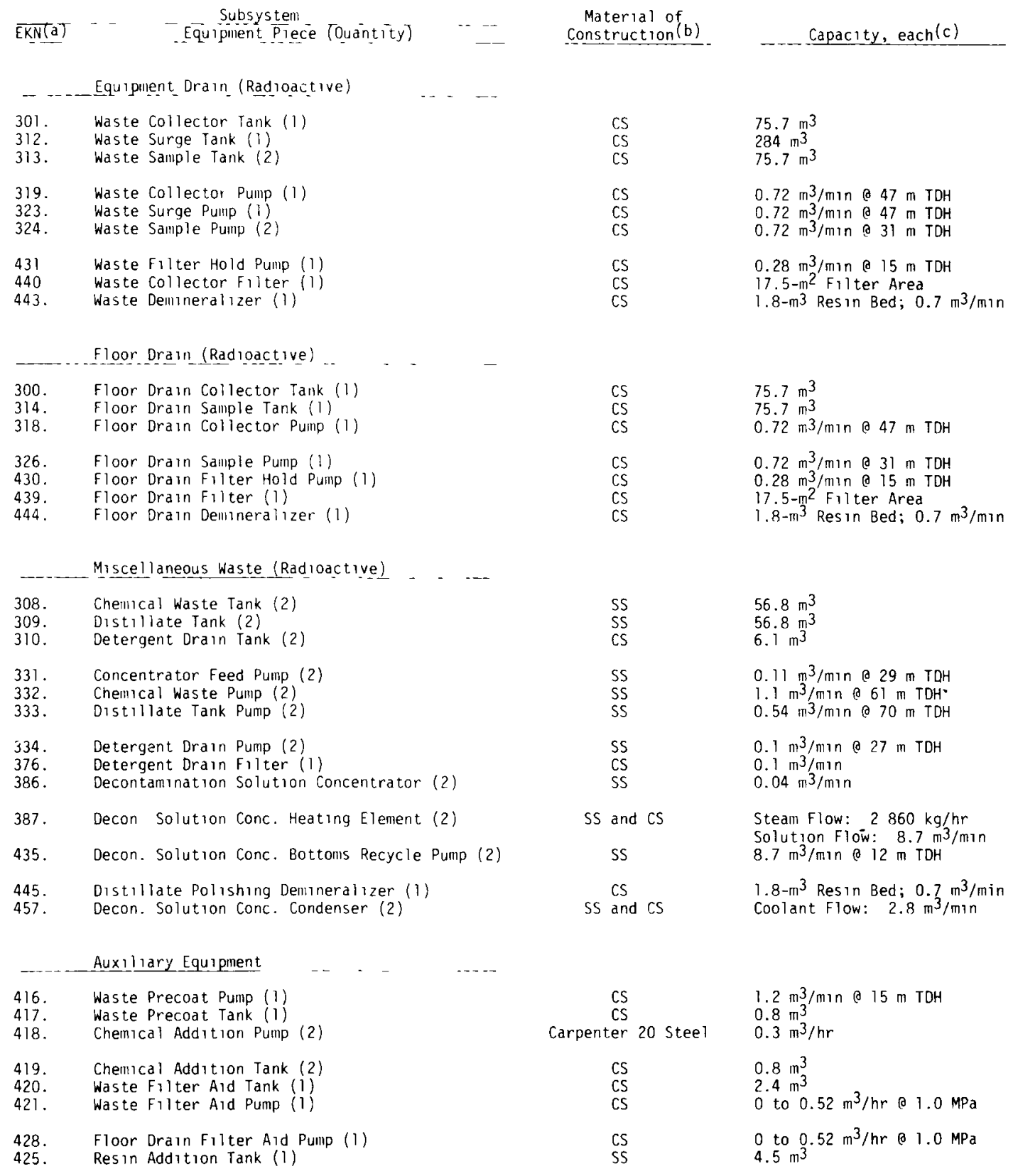

(a)EKN = Equipment Key Number (see Section C.2).

(b)CS stands for carbon steel, and SS for stainiess steel.

(c) The design pressure of the equipnient is $1.14 \mathrm{MPa}$, the design temperature is $339 \mathrm{~K}$. 
TABLE C.5-2. Liquid Radwaste Equipment

Performance Factors

Equipment

Demineralizers

Filters

Concentrators (Influent/Distillate) ${ }^{(a)}$
Radioactivity

Decontamination

Factor

Soluble 100

Insoluble 50

Soluble 1

Insoluble 2

1000

(a) Concentration Factor (Influent/Bottoms, wt\% salts) $=0.6 / 32$.

Treatment consists of filtration, demineralization, and transfer to a waste sample tank (EKN 313). After sampling and analysis, the processed liquids may be routed to the blowdown line for discharge to the river or may be reprocessed, as required.

\section{C.5.1.2 Floor Drain (Radioactive) Subsystem}

Liquid wastes collect in the floor drain collector tank (EKN 300) from the following sources:

- drywell floor drain sump

- Reactor Building floor drain sumps (4 each)

- Radwaste Building floor drain sumps (3 each)

- Turbine Generator Building floor drain sumps (2 each)

- waste sludge phase separator.

Processing consists of filtration, demineralization, and transfer to the floor drain sample tank (EKN 314) for sampling and analysis. The process liquid can be recycled for additional treatment, as necessary, or, if it meets acceptable limits, can be discharged via the blowdown line to the river.

\section{C.5.1.3 Miscellaneous Waste (Radioactive) Subsystem}

Liquid wastes collected in the chemical waste tanks (EKN 308) are from the following sources: 
- detergent drain tanks (EKN 310)

- Reactor Building and Turbine Generator Building decontamination drains

- low-purity wastes from either the equipment or floor drain subsystems

- filter demineralizer element chemical cleaning solutions

- battery room drains

- chemical system overflows and tank drains

- laboratory drains.

The high conductivity of these wastes precludes treatment by ion exchange. Because of higher chemical content, they are processed through a decontamination solution concentrator (EKN 386).

The concentrator bottoms are processed through the solid radwaste system, and the distillate is routed to a distillate tank (EKN 309). After analysis, the distillate is either routed through the distillate polishing demineralizer (EKN 445) or recycled through the concentrator to further reduce impurities, or discharged to the river via the blowdown line.

Detergent wastes are collected in the detergent drain tanks (EKN 310). These wastes are primarily laboratory and decontamination solutions that contain detergents. They are filtered through the detergent drain filter (EKN 376) prior to routing to the chemical waste tanks (EKN 308) for further processing.

\section{C.5.2 Solid Radwaste System}

The solid radwaste system collects, monitors, processes, packages, and provides temporary storage facilities for the radioactive solid wastes prior to offsite disposal. Figure C.5-3 is a block process flow diagram.

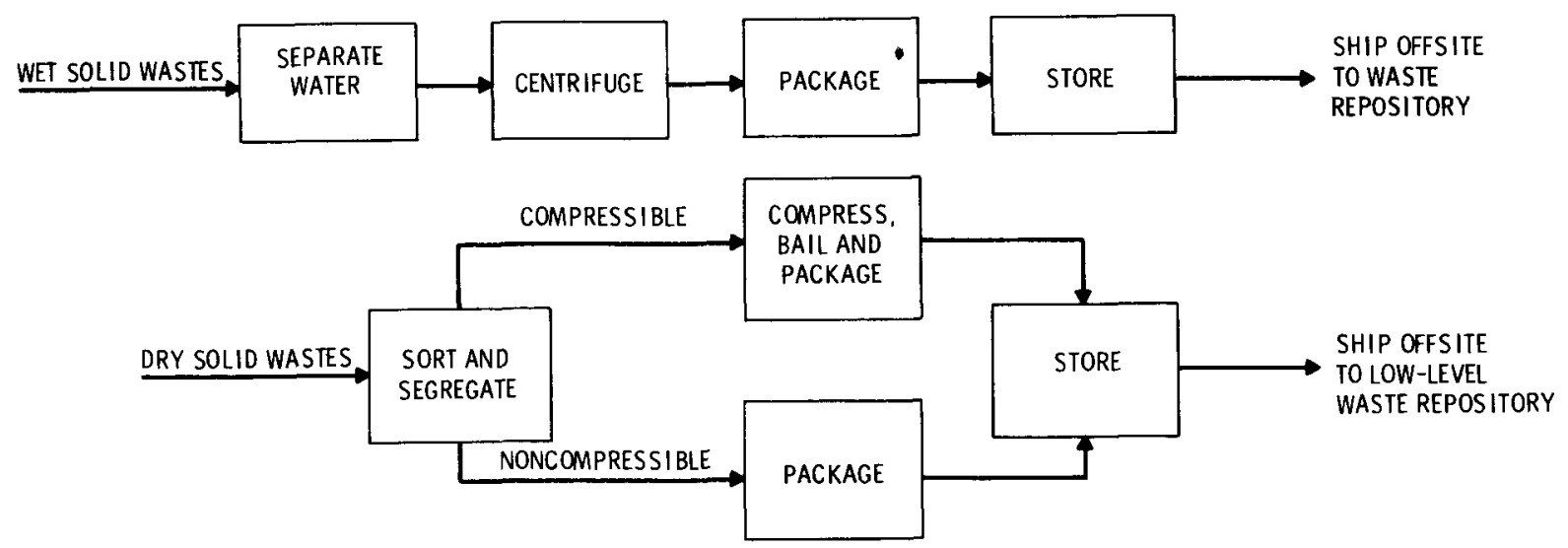

FIGURE C.5-3. Solid Radwaste System Process Diagram 
The solid radwaste system processes both wet and dry solid radioactive wastes. Wet waste includes backwash sludges, spent resins, and concentrator bottoms from the demineralizers, the filters, and the concentrators in the liquid radwaste systems. Dry waste includes rags, paper, small equipment parts, solid laboratory wastes, air filters, non-recyclable anti-contamination clothing, etc.

Backwash sludges are collected in phase separators, where they are allowed to settle. The resulting decantates are sent to the liquid radwaste system, and the sludges are transferred, together with the spent resins, to the process waste (radioactive) system. There the residual water is centrifuged off, a solidifying agent (cement and sodium silicate) and the concentrator bottoms are added, and the mixture is packaged in $1.42-\mathrm{m}^{3}$ shipping containers for ultimate offsite disposal. (a) Table C.5-3 1ists design data for equipment that handles wet solid radioactive wastes.

Dry solid radioactive wastes are segregated into compressible and noncompressible wastes. Compressible wastes are compacted into $0.21-\mathrm{m}^{3}$ steel drums. Noncompressible wastes are packaged in similar drums. This waste is shipped offsite for disposal.

\section{C.5.3 Gaseous Radwaste System}

Besides the HVAC systems described in Section C.4, the reference BWR systems that process radioactively contaminated gases are the condenser off gas treatment system and the Reactor Building standby gas treatment system.

\section{C.5.3.1 Condenser off Gas Treatment System}

Since no off gas emanates from the main condenser (EKN 200) during plant shutdown, the condenser off gas treatment system is not needed during decommissioning. Therefore, no system description is presented here. However, since the system is radioactively contaminated, the individual equipment pieces are listed in Section C.3.3.

(a)Although the reference BWR is designed to handle the $1.42-\mathrm{m}^{3}$ containers, this study assumes the use of $2.84-\mathrm{m}^{3}$ containers for consistency with the pressurized water reactor decommissioning study. (3) 


\section{TABLE C.5-3. Wet Solid Radwaste Equipment Design Data}

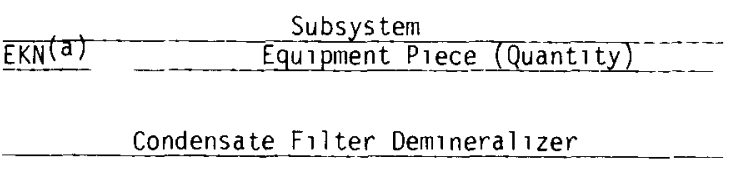

302. Condensate Phase Separator Tank (2)

304. Condensate Backwash Receiver Tank (1)

320. Condensate Sludge Discharge Mixing Pump (1)

321. Condensate Decant Pump (1)

322. Condensate Backwash Transfer Pump (1)

Equipment Drain (Radıoactive)

305. Spent Resin Tank (1)

327. Spent Resin Pump (1)

Floor Drain (Radioactive)

306. Waste Sludge Phase Separator Tank (1)

328. Waste Decant Pump (1)

330. Waste Sludge Discharge Mrxing Pump (1)

Miscellaneous Waste (Radioactive)

311. Decon. Solution Conc. Waste Tank (2)

335. Decon. Solution Conc. Waste Pump (1)

408. Concentrator Waste Measuring Tank (1)

Process Waste (Radioactive)

379. Hopper Mixer (2)

380. Waste Processing Pump (1)

409. Centrifuge (2)

Reactor Water Cleanup

307. Cleanup Phase Separator Tank (2)

329. Cleanup Decant Pump (1)

337. Cleanup Sludge Discharge Mixing Pump (1)

Auxiliary Equipment

315. Polymer Day Tank (1)

316. Catalyst Mixing Tank (2)

317. Polymer Storage Tank (6)

336. Polymer Transfer Pump (1)

338. Polymer Processing Pump (1)

-- (d) Catalyst Processing Pump (2)
Material of $(b)$
Construction

$\ldots$ Capacity, each (c)
CS and SS

SS

SS

SS

SS

SS

SS

CS and SS

SS

SS

SS

SS

SS

SS

SS

SS

CS
Polypropylene
Aluminum

CS

SS
$89.0 \mathrm{~m}^{3}$

$71.9 \mathrm{~m}^{3}$

$1.6 \mathrm{~m}^{3} / \mathrm{m}$ n a $49 \mathrm{~m} \mathrm{TDH}$

$1.7 \mathrm{~m}^{3} / \mathrm{m}$ n $015 \mathrm{~m} \mathrm{TDH}$

$1.7 \mathrm{~m}^{3} / \mathrm{mrn}$ o $15 \mathrm{~m} \mathrm{TDH}$

$4.5 \mathrm{~m}^{3}$

$0.08 \mathrm{~m}^{3} / \mathrm{min}$ o $32 \mathrm{~m} \mathrm{TDH}$

$49.2 \mathrm{~m}^{3}$

$0.2 \mathrm{~m}^{3} / \mathrm{min}$ a $15 \mathrm{~m} \mathrm{TDH}$

$0.8 \mathrm{~m}^{3} / \mathrm{min}$ a $32 \mathrm{~m} \mathrm{TOH}$

$2.7 \mathrm{~m}^{3}$
$0.11 \mathrm{~m}^{3} / \mathrm{min}$ ㅇ $21 \mathrm{~m} \mathrm{TOH}$
$1.5 \mathrm{~m}^{3}$

$1.7 \mathrm{~m}^{3}$

1.1 to $3.4 \mathrm{~m}^{3} / \mathrm{hr}$ o $0.34 \mathrm{MPa}$

$11.0 \mathrm{~m}^{3} / \mathrm{min}$ continuous input rate, $98^{\circ t}$ solids removal efficiency -

$17.0 \mathrm{~m}^{3}$

$0.2 \mathrm{~m}^{3} / \mathrm{min}$ a $15 \mathrm{~m} \mathrm{TDH}$

$0.8 \mathrm{~m} / \mathrm{min}$ \& $52 \mathrm{~m} \mathrm{TDH}$

$10 \mathrm{~m}^{3}$

$0.4 \mathrm{~m}^{3}$

$2.1 \mathrm{~m}^{3}$

$1.7 \mathrm{~m}^{3} / \mathrm{hr}$ o $0.34 \mathrm{MPa}$

0.11 to $1.1 \mathrm{~m} 3 / \mathrm{hr} 00.27 \mathrm{MPa}$

0.07 to $0.23 \mathrm{~m}^{3} / \mathrm{hr}$ o $0.34 \mathrm{MPa}$

(a) EKN = Equipment Key Number (see Section C.2).

(b) $\mathrm{CS}=$ Carbon Steel; $\mathrm{SS}=$ Stainless Steel.

(c) Equipment design pressure is $1.14 \mathrm{MPa}$, design temperature is $339 \mathrm{~K}$.

(d) No equipment key number is availabie (see Section C.2). 


\section{C.5.3.2 Reactor Building Standby Gas Treatment System}

The Reactor Building standby gas treatment system (EKN 92), shown schematically in Figure C.5-4, consists of two fully redundant filter trains mounted in separate welded steel housings located on elevation $174.4 \mathrm{~m}$ of the Reactor Building (refer to Figure C.2-3). Each filter train, exclusive of the fans, is nominally $14.1 \mathrm{~m}$ by $1.7 \mathrm{~m}$ by $2.0 \mathrm{~m}$ high and weighs approximately $3630 \mathrm{~kg}$. Each fan weighs about $550 \mathrm{~kg}$. Each filter train is composed of the following components in series:

- moisture separator

- two banks of electric blast coil heaters, one primary and one backup; each powered from separate emergency diesel-generator buses; and each composed of three 6.9-kW stages

- one bank of four fiberglass prefilters

- one bank of high-efficiency particulate air (HEPA) filters

- one 102-mm-deep bank of charcoal adsorber filters (515 kg of potassium iodide-impregnated, coconut-base charcoal)

- a second identical bank of charcoal filters

- a second bank of HEPA filters

- two ful1-capacity $\left(372-\mathrm{m}^{3} / \mathrm{min}\right)$ centrifugal fans, one primary and one backup, each powered from separate emergency diese1generator buses.

Ductwork and valving on the intake of each filter train are arranged so each unit can draw air either from the Reactor Building in the immediate vicinity of the unit or from the Primary Containment via duct connections to the Primary Containment purge exhaust 1ines. Ductwork and butterfly valves on the discharge side of each filter train are arranged so that either fan can draw air through the filter train, either discharging it out of the Reactor Building via the Reactor Building vent or recirculating it back into the Reactor Building. The Reactor Building standby gas treatment system operates during a Reactor Building isolation or during a Primary Containment purge (see Section C.4.1.1). 


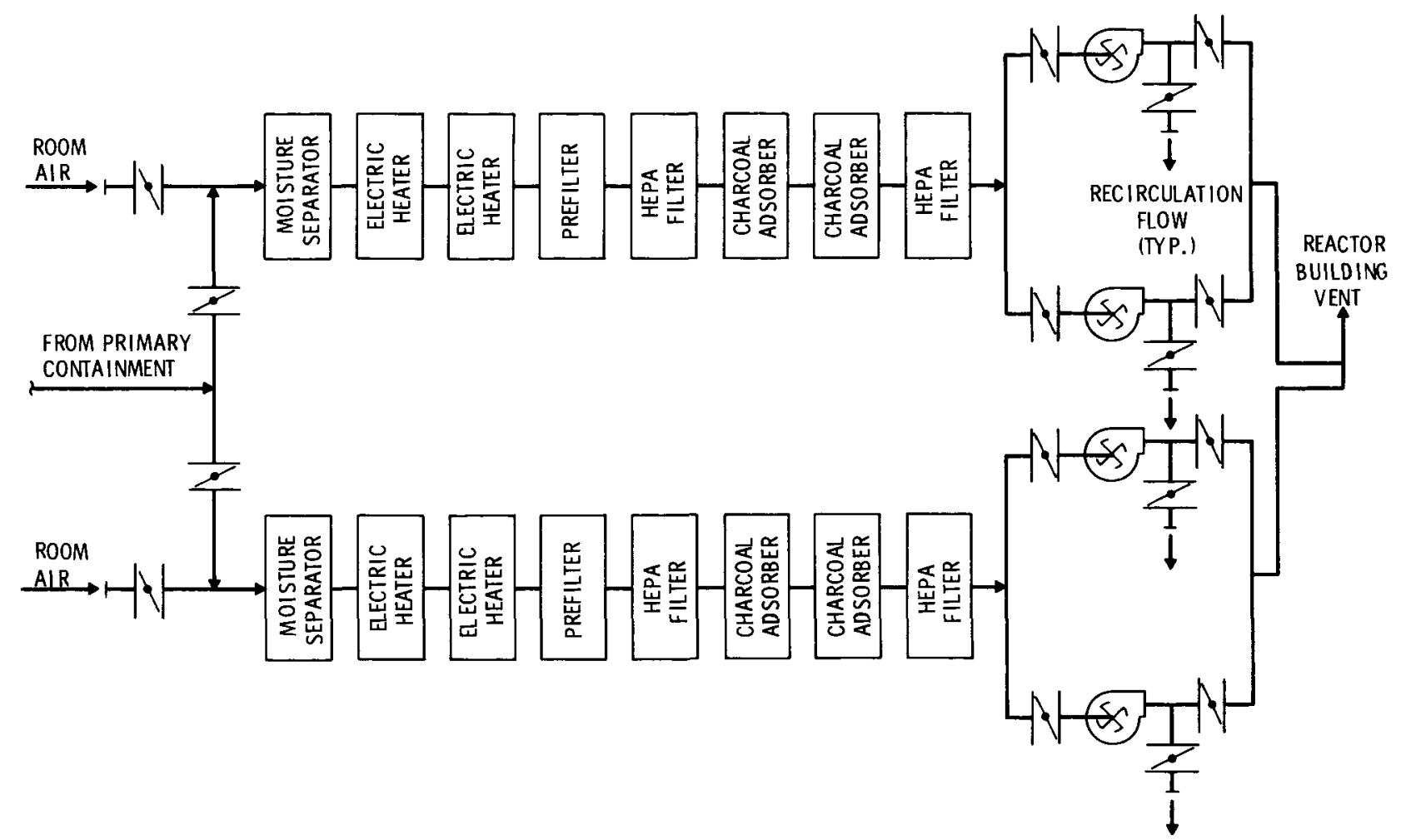

FIGURE C.5-4. Reactor Building Standby Gas Treatment System

\section{C.6 ACRONYMS, ABBREVIATIONS, AND EQUIPMENT KEY NUMBERS}

Table C.6-1 lists the acronyms and abbreviations that are used in Appendix C, and Table C.6-2 gives all the equipment key numbers and the corresponding equipment. 
TABLE C.6-1. Acronyms and Abbreviations in Appendix C

\begin{tabular}{|c|c|}
\hline BLDG & Building \\
\hline BWR & Boiling Water Reactor \\
\hline CAC & Containment Atmosphere Control \\
\hline $\mathrm{CL}$ & Clearance \\
\hline CONC or CONCEN & Concentrator \\
\hline CNDS or COND & Condensate \\
\hline CRD & Control Rod Drive \\
\hline CS & Carbon Steel \\
\hline DECON & Decontamination \\
\hline DEMIN & Demineralizer \\
\hline ECCS & Emergency Core Cooling System \\
\hline EKN & Equipment Key Number \\
\hline ELEC & Electrical \\
\hline$F / D$ & Filter Demineralizer \\
\hline FPC & Fuel Pooling Cooling and Cleanup \\
\hline FSAR & Final Safety Analysis Report \\
\hline HEPA & $\begin{array}{l}\text { High-Efficiency Particulate Air/ } \\
\text { Absolute (referring to filters) }\end{array}$ \\
\hline HPCS & High-Pressure Core Spray \\
\hline HX or HT XCHGR & Heat Exchanger \\
\hline HVAC & $\begin{array}{l}\text { Heating, Ventilating and Air- } \\
\text { Conditioning }\end{array}$ \\
\hline LPCS & Low-Pressure Core Spray \\
\hline MCC & Motor Control Center \\
\hline$M G$ & Motor-Generator \\
\hline MSIV & Main Steam Isolation Valve \\
\hline MSLC & MSIV Leakage Control \\
\hline $\mathrm{RBCC}$ & Reactor Building Closed Cooling \\
\hline RBECS & $\begin{array}{l}\text { Reactor Building Emergency Cooling } \\
\text { System }\end{array}$ \\
\hline RCIC & Reactor Core Isolation Cooling \\
\hline RH & Relative Humidity \\
\hline RHR & Residual Heat Removal \\
\hline RM & Room \\
\hline RPV & Reactor Pressure Vessel \\
\hline RWCU & Reactor Water Cleanup \\
\hline SGTS & Standby Gas Treatment System \\
\hline SLC & Standby Liquid Control \\
\hline SPLY & Supply \\
\hline SS & Stainless Steel \\
\hline SYS & System \\
\hline TDH & Total Dynamic Head \\
\hline$T-G$ & Turbine Generator \\
\hline TIP & Traversing In-Core Probe \\
\hline WPPSS & Washington Public Power Supply System \\
\hline WNP-2 & WPPSS Nuclear Project No. 2 \\
\hline
\end{tabular}




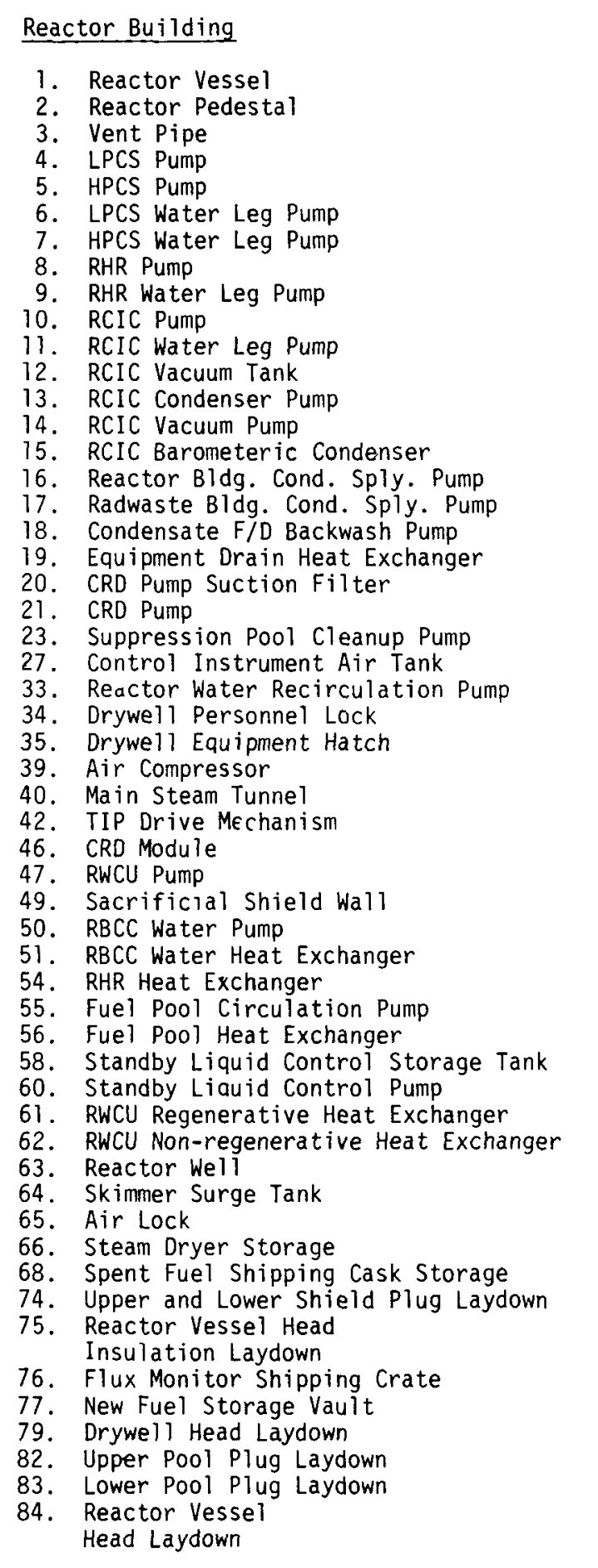

urbine Generator Building

200. Main Condenser
201. Turbine Generator Uni

202. Main Steam and Feedwater Pipe Chase

212. Condensate Pump

214. Reactor Feedwater Pump

215. Mechanical Vacuum Pump
216. Steam Jet Air Ejector

216. Steam Jet Air Ejector
217. Gland Seal Steam Condenser

218. Catalytic Recombiner

Off Gas Condenser
25. Off Gas Water Separator

. Pumped Drain Tank

. Condensate Storage Tan

Auxiliary Boiler

Low-Pressure Feedwater Heater

Steam Evaporator

Evaporator Drain Tan,

Turbine Bypass Valve Assembly

Moisture Separator Drai in Tank

Louver Penthouse

273. Equipment Drain Sump Punp
274. Floor' Drain Sump Pump
276. Turbine Generator Building Supply Heating and Ventilating

Radwaste and Control Building

300. Floor Drain Collector Tank

301. Waste Collector Tank
302. Condensate Phase Separator Tank

. Waste Sludge Phase Separator Tank

. Chemical waste

11. Decontamination Solution Concentrator

12. Waste Surge Tank

313. Waste Sample Tank
314. Floor Drain Sample Tank

316. Catalyst Mixing Tank

317. Polymer Storage Tank
318. Floor Drain Collector Pump

320. Condensate Sludge Discharge Mixing Punm

321. Condensate Decant Pump

323. Wuaste Surge Pump

358. Sol id Radwaste Storage Area Crane

360. Sol id Radwaste Container Storage
364. Sol id Radwaste Container Washdown,

366. Solid, and Testing Station

367. Solid Radwaste Container

371. Sol id Waste Baler

37. Solid Radwaste Container Transfer Dolly

376. Detergent Drain Filter

378. Air Handling Unit

383. Off Gas Refrigeration Equipment

384. Prefilter

886. Decontamination Solut

887. Decontamination Solution Concentrator

Heating Element Dolution Concentrator

Condensate Return Tank

Transformer
Battery Rack

406. Swi tchgear

407. Eauipment Removal Plug

. Concentrator Waste Measuring Tan

Chemical solution Tank

Condensate Precoat Tank
Waste Precoát Pump

. Chemical Addition Pu

. Chemical Addition Tan

Floor Drain Sample Pump

. Spent Res in Pump

Cleanup Decant Pump

Concentrator feed Pump

- Chemical Waste Pump

. Distillate Tank Pump

35. Decontamination Solution Concentrator

Waste Pump

336. Polymer Transfer Pump
337. Cleanup Sludge Discharge Mixing Pump

338. Polymer Processing Pump

341. Equipment Drain Sump Pump

348. Cooler Condenser

49. Mo isture Separator

351. Desiccant Dryer

Gas Cooler

354. Charcoal Adsorber
355. Gas Chiller Unit

421. Waste Filter Aid Pump

422. Floor Drain Filter Aid Pump

24. Fuel Pool Precoat Tank
25. Resin Addition Tank

426. Cleanup Precoat Tank
427. Cleanup Precoat Pump
429. Condensate Demineralizer

429. Condensate Dem
Holding Pump

430. Floor Drain Filter Hold Pump

431. Waste Fil ter Hold Pump
432. Fuel Pool Hold Pump

433. Cleanup Hold Pump

Contamination Solution Concentrator

Bottoms Recycle Pump
C38. Condensate Filter Demineralizer

Floor Drain Filter

441. Fuel Pool Filter Demineralizer

442. Cleanup Filter Demineralizer

443. Waste Demineralizer

445. Distillate Polishing Demineralizer
447. Decontamination Solution Concentrator

451. Air Handling

453. Radwaste Area Exhaust Filter Unit

55. Radwaste Area Supply Heating and

457. Decontamination Solution Concentrator

Condenser
Exhaust Filter unit

. Exhaust Filter Unit

Relay Cabinet

Decontamination Station
Resin Addition Tank

70. Chiller

480. Turbine Generator Building

. Turbine Generator Building

Miscellaneous Equipment

700. Elevator

701. Covered Hatch
702. Open Hatch

708. Solid Radwaste Container Dolly Rails
TABLE C.6-2. Equipment Key Numbers in Appendix C. 



\section{REFERENCES}

1. WPPSS Nuclear Project No. 2 Final Safety Analysis Report, Washington Public Power Supply System, Richland, WA, February 1977.

2. WPPSS Nuclear Project No. 2 Environmental Report, Operating License Stage, Washington Public Power Supply System, Richland, WA, March 1977.

3. R. I. Smith, G. J. Konzek and W. E. Kennedy, Jr., Technology, Safety and Costs of Decommissioning a Reference Pressurized Water Reactor Power Station, NUREG/CR-0130, Appendix-I, U.S. Nuclear Regulatory Commission Report by Pacific Northwest Laboratory, June 1978.*

*Available for purchase from the NRC/GPO Sales Program, U.S. Nuclear Regulatory Commission, Washington, D.C. 20555, and the National Technical Information Service, Springfield, Virginia 22161. 
8 


\section{APPENDIX D}

\section{RADIATION DOSE RATE AND CONCRETE SURFACE CONTAMINATION DATA}

The radiation dose rate at a specific work site has an important influence on the time needed to complete each decommissioning task. In addition, the degree of concrete contamination determines how much surface requires removal and how much contaminated rubble requires disposal. Established in this appendix are the dose rates and the concrete surface contamination levels that are assumed to be present in the reference BWR at final reactor shutdown, except for the dose rates resulting from activated material in and surrounding the reactor vessel. These 1atter dose rates are presented in Section E.1.3 of Appendix E.

\section{D.1 ESTIMATED RADIATION DOSE RATES AT SHUTDOWN}

Measured shutdown radiation dose rates were obtained from seven operational BWRs, three dual-unit plants and one single-unit plant. These plants are: Dresden Units 2 and 3 and Quad Cities Units 1 and 2 operated by Commonwealth Edison Company, Peachbottom Units 2 and 3 operated by Philadelphia Electric Company, and Monticello operated by Northern States Power Company. At the time of these measurements, the reactors had operated commercially for 3 to 8 years. Actual data on these dose rates and on their corresponding sources of radiation were provided by health physics personnel at all four plant sites. Composite values presented in this appendix are derived from these data.

\section{D.1.1 Assumptions and Definitions}

The following assumptions and definitions are made concerning dose rate conditions throughout the reference plant:

- The plant is in a shutdown/refueling mode, with no fuel movements in progress.

- "General area" refers to the radiation field not emanating specifically from one discrete source or direction in a room or area, although a 
specific source may be the sole contributor to the radiation measurement. General area readings are taken at least $1 \mathrm{~m}$ from any surface.

- "Contact" means a dose rate at the closest approach to a given surface (a surface dose rate), including the necessary corrections for geometry and source size made in the field by the health physics technician.

- Estimated radiation dose rates in specific areas where measurements are unavailable are obtained from Reference 1 . (The estimated dose rates from Reference 1 deal primarily with plant operation, and are used accordingly.)

- Crud traps that may exist at valves or at sharp bends in piping represent potential high dose rate areas that are not explicitly considered.

\section{D.1.2 Presentation of Dose Rate Data}

The radiation dose rate data assumed for the reference BWR at final shutdown are presented in Figures $0.1-1$ and D.1-2 for the Reactor Building (including Primary Containment), in Figures D.1-3 through D.1-5 for the Turbine Generator Building, and in Figures $0.1-6$ and $0.1-7$ for the Radwaste and Control Building. The measurement location is identified in Figures $0.1-1$ through D.1-7 by the equipment key number (see Section C.2 in Appendix C) and the piece of equipment for which the measurement was taken. The other buildings and structures on the reference BWR site (see Section C.I in Appendix C) are assumed to have no potential for radiation exposure.

Although some of the data from the seven operating BWRs cover a fairly wide range, all of the dose rate data shown in the figures are composite values based on those data, except those obtained from Reference 1 . In some instances, the dose rates vary by as much as a factor of 10 or more, depending on the plant operating histories and on the extent and success of prior decontamination programs. As shown in Figure D.1-8 (from Reference 2), and based on current technology only, much higher dose rates might be expected at the 


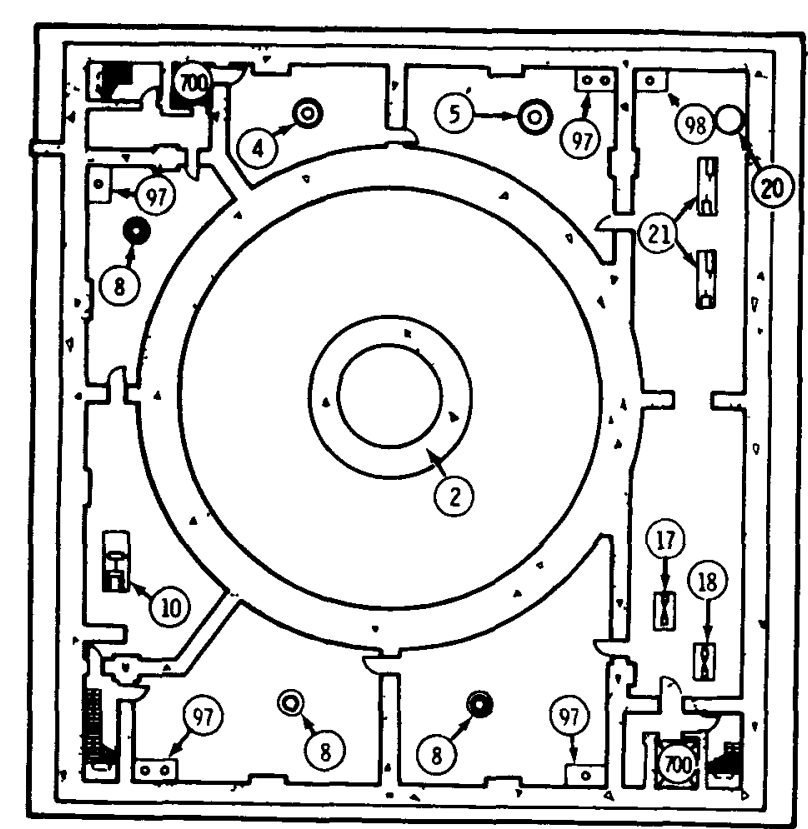

REACTOR BLDG. - FLOOR PLAN AT ELEV. $128.7 \mathrm{~m}$

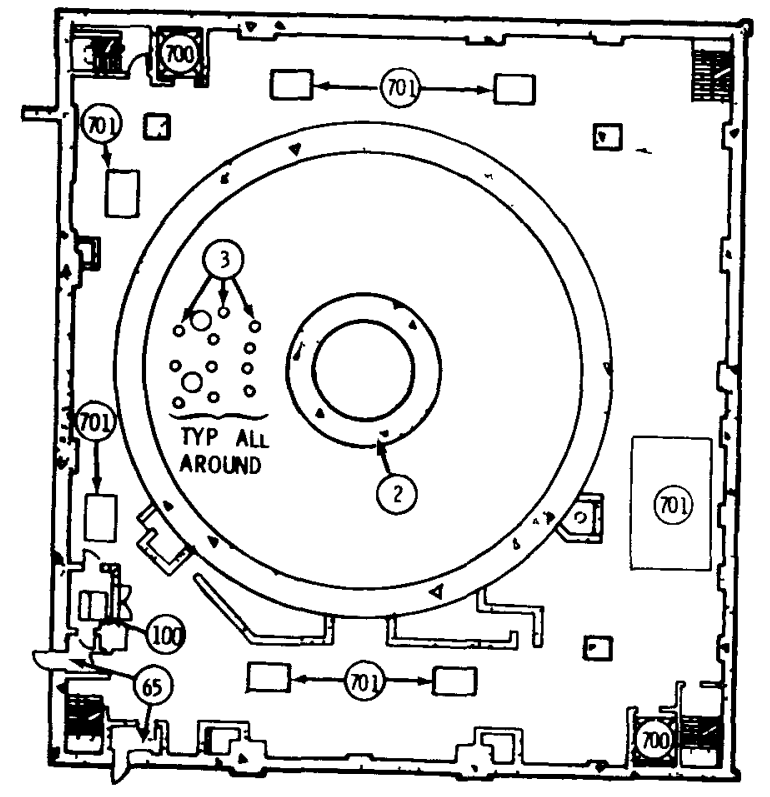

REACTOR BLDG. - FLOOR PLAN AT ELEV. $143.6 \mathrm{~m}$

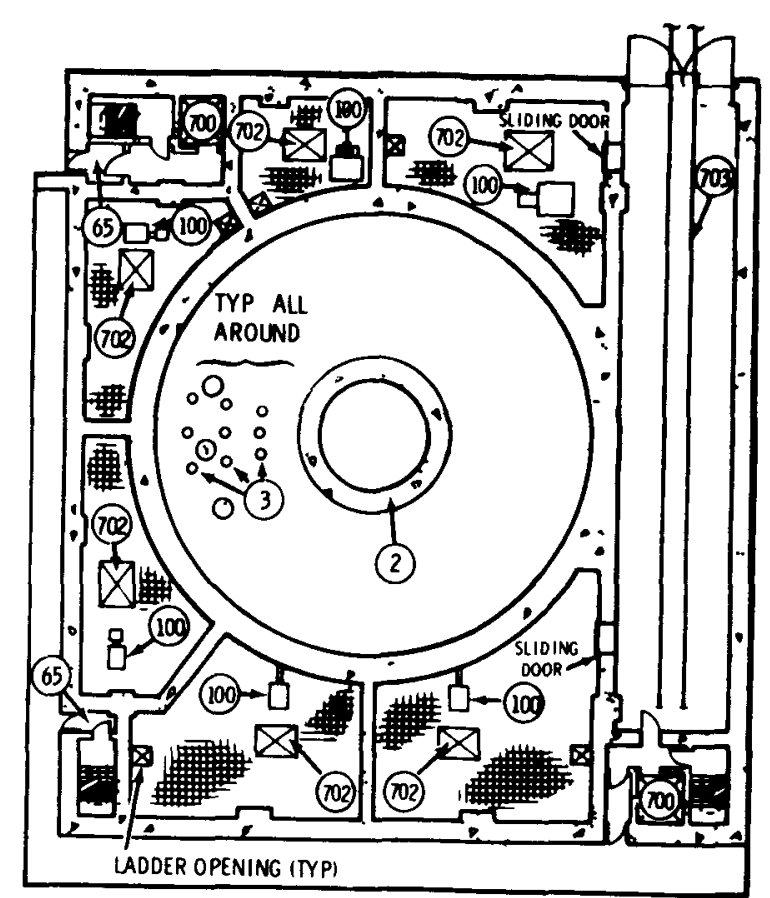

REACTOR BLDG. - FLOOR PLAN AT ELEV. $134.4 \mathrm{~m}$ AND $135.3 \mathrm{~m}$ (GRADE)
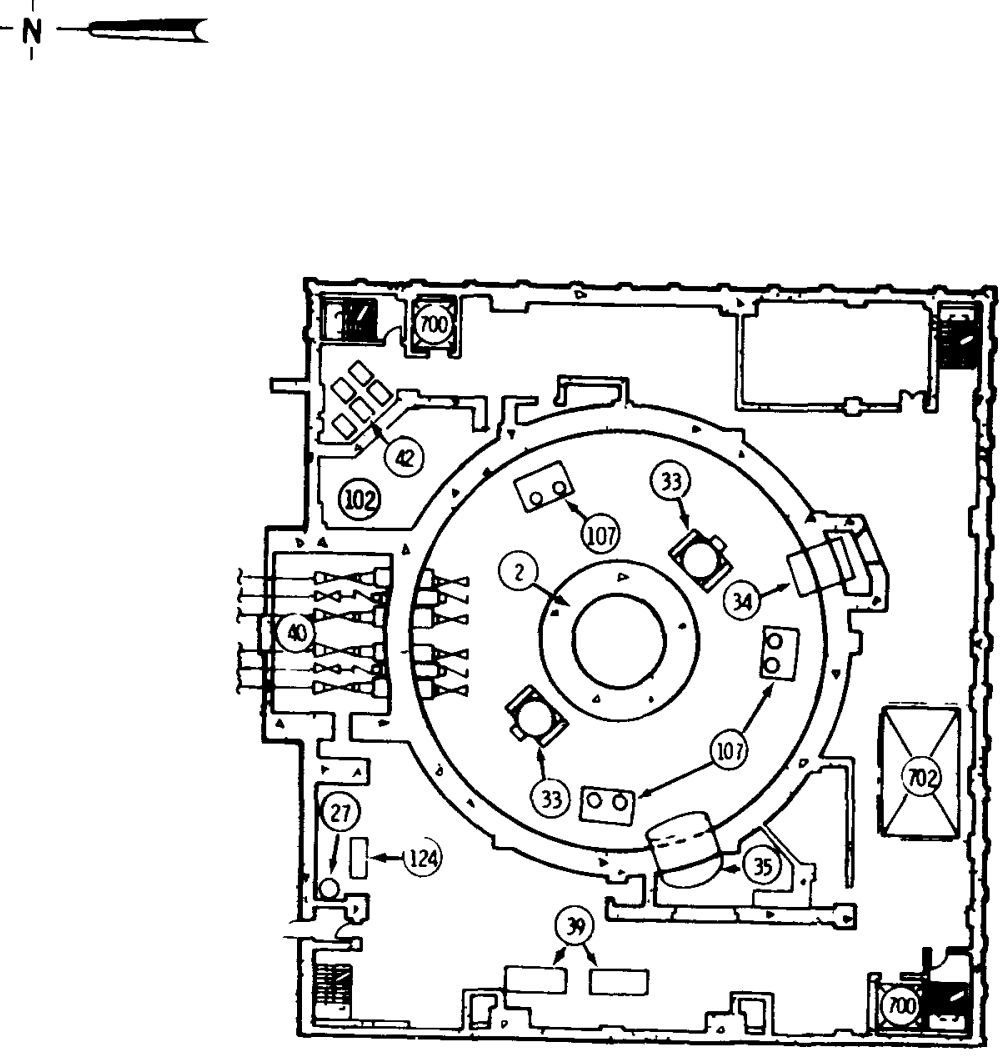

REACTOR BLDG. - FLOOR PLAN AT ELEV. $152.7 \mathrm{~m}$

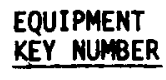

2,3 REACTOR PEDESTAL, VENT PIPES

RECTOR PEDESTI
LPCSPUP
LPCS PIPPING

HPCS PUMP

RHR PUMP
RAR PUMPP PIPING

RCIC PUMP

RCIC PUMP PIPING
RCIC PUMP

RAOWASTE BUILDING CONDENSATE

CONTROL ROD DRIVE PUMP FILTER

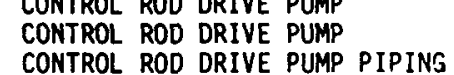

CONRROL INSTRUMENT AIR TANR

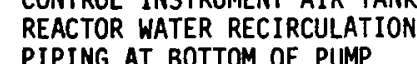

RETUR PIPING TO REACTOR

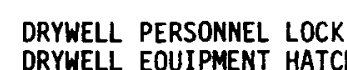

STEAM RELIIEF YGLLE FROM MAN

STTEA LIIIE AT RELLITF YALVE

MATN STEAM LINE
DRYEELL

AiR COMPRESSOR

MAT STEAS MUNELL NO VALES

TIP DRIVE MECHANISMS

ALR LOCK
FLOR DRAIN SUMP

EQUPPEENT DRAT SUM

IIP PROBE SHTELLS IN TIP ROOA

HEATING ANO VEETTLATING UNIT

AIR DRYER
ELEVYTOR

COVERED HATCH

OPEN HATCH
RAILRAD TRACK
CONOENSATE FILTER-DEMINERALII

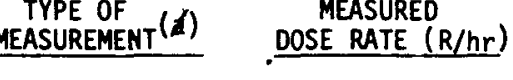
GENERA AREA
CONATACT

CONTAC

contact

GENERAL AREA $\quad .020-.050$

$\begin{array}{ll}\text { CONAACT } & .002-.008 \\ \text { CONTACT } & .050=: .060 \\ \text { GENERAL AREA } & .005=.010\end{array}$

CONTACT $\quad .018-.027$

CONTACT $\quad .020-.030$

$\begin{array}{ll}\text { CONTACT } & .080 \\ \text { CONTACT } & : 001 \\ \text { (B). } & .002\end{array}$

GENERAL AREA $\quad \leq .015^{(b)}$
CONTACT

GENERAL AREA $\leq 0025^{(b)}$

$\begin{array}{ll}\text { CONTACI } & \leq .000 \\ \text { CONACT } & .035-.370 \\ \text { Cont } & .060\end{array}$

$\begin{array}{ll}\text { CONTACT } & .035=.000 \\ \text { CONTACT } & 100=0900 \\ \text { Cont } & 100.460\end{array}$

$\begin{array}{ll}\text { GENERRL AREA } & .040-.100 \\ \text { GENERAL AREA } & 100-.04\end{array}$

CONTACT

GENERAL AREA $\quad .035=.075$

GENERAL AREA 005 (b)

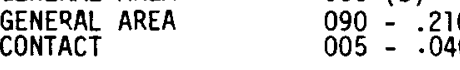

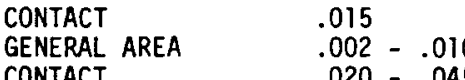

CONTACT 005

\begin{tabular}{ll} 
GENERAL AREA & .010 \\
GENERAA AREA & $.030=050$ \\
CONTACT & $.050=2.0$ \\
\hline
\end{tabular}

GENERAL AREA $>100$ (b)

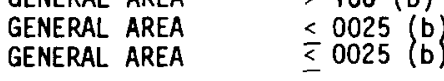

GENERAL AREA
GERERAL AREA
CONTACT

(a) General Area refers to the radiation field in a room or area, not specifically from one
discretete source or direction, although a specific source may be the sole contributor to

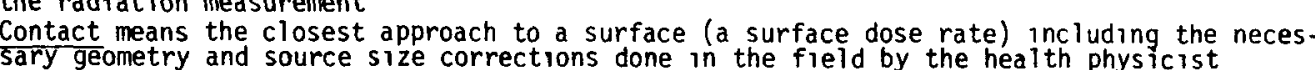

(b) Based on informat ton in Reference i, primarily a associated with plant operat ion

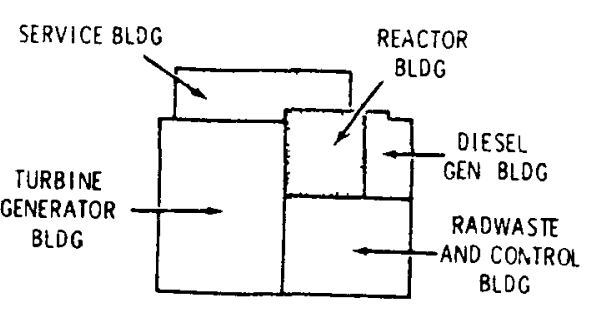

FIGURE D.1-1. Radiation Dose Rates in the Reactor Building - Sheet 1 
O 


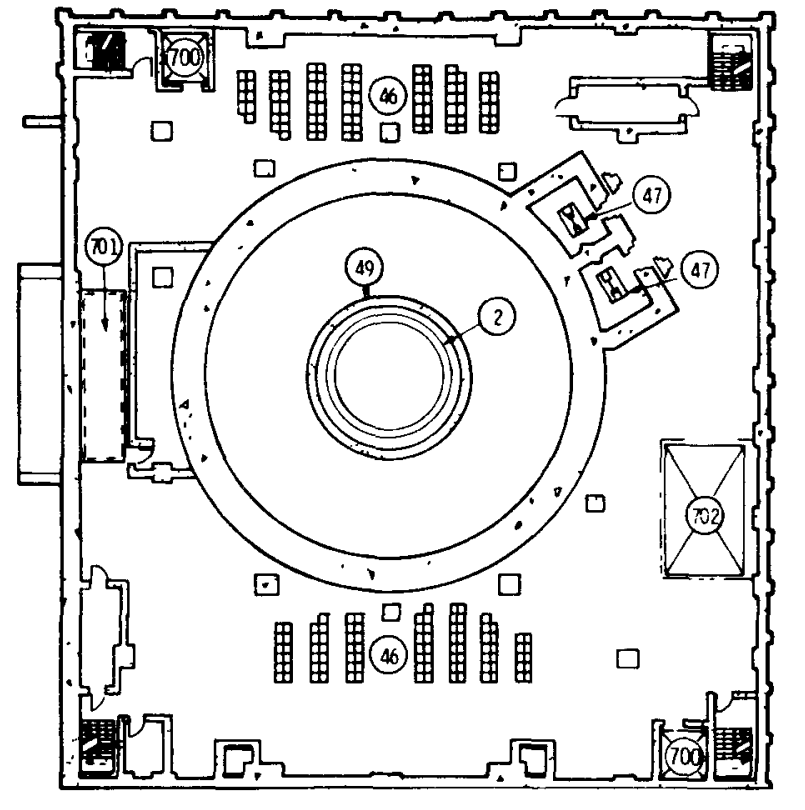

REACTOR BLDG. - FLOOR PLAN AT ELEV. $159.1 \mathrm{~m}$

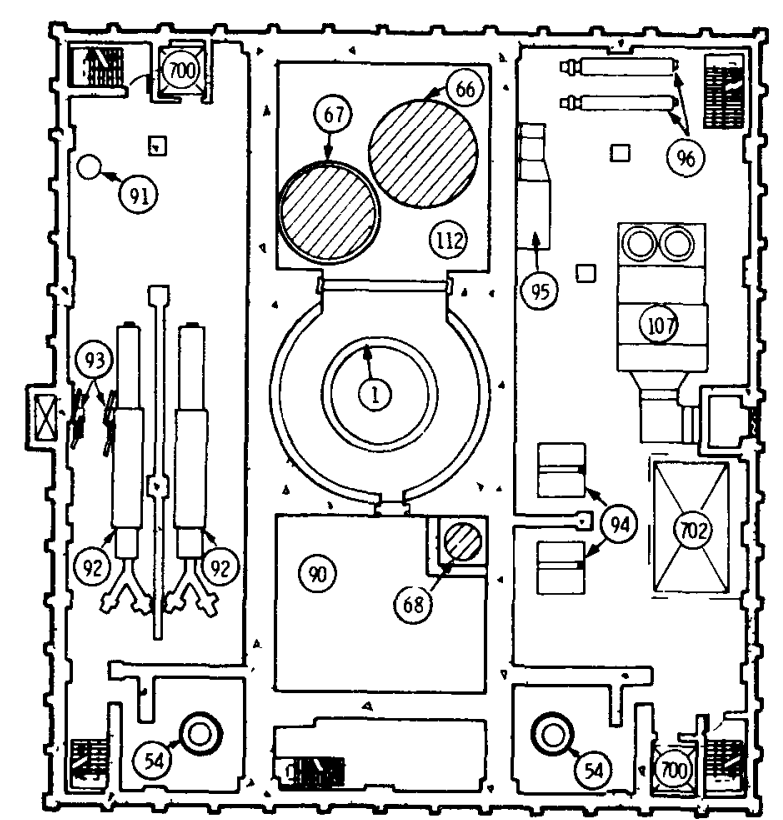

REACTOR BLDG. - FLOOR PLAN AT ELEV. $174.4 \mathrm{~m}$

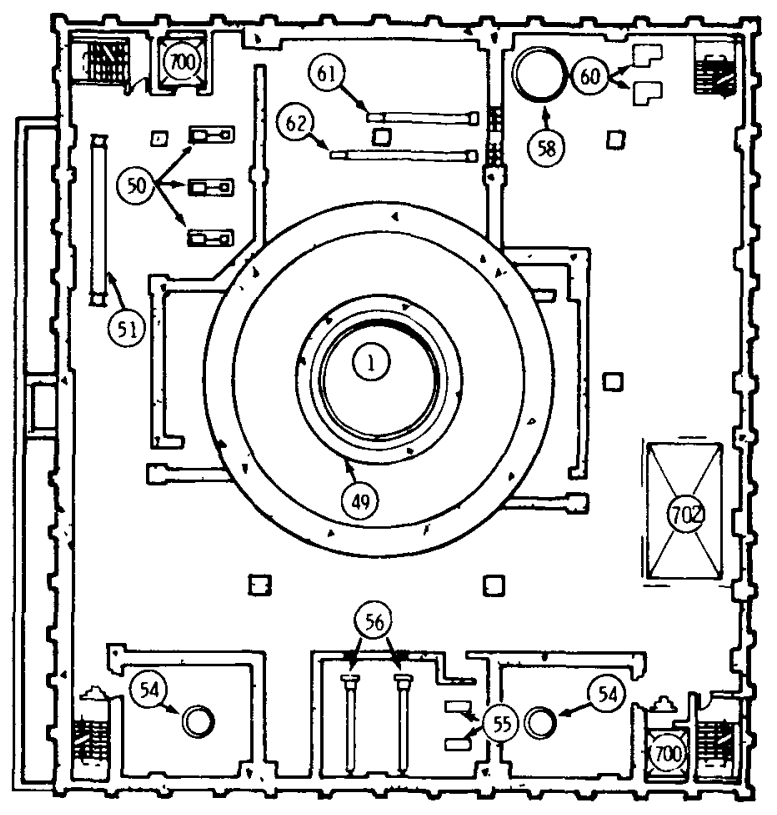

REACTOR BLDG. - FLOOR PLAN AT ELEV. $167.0 \mathrm{~m}$

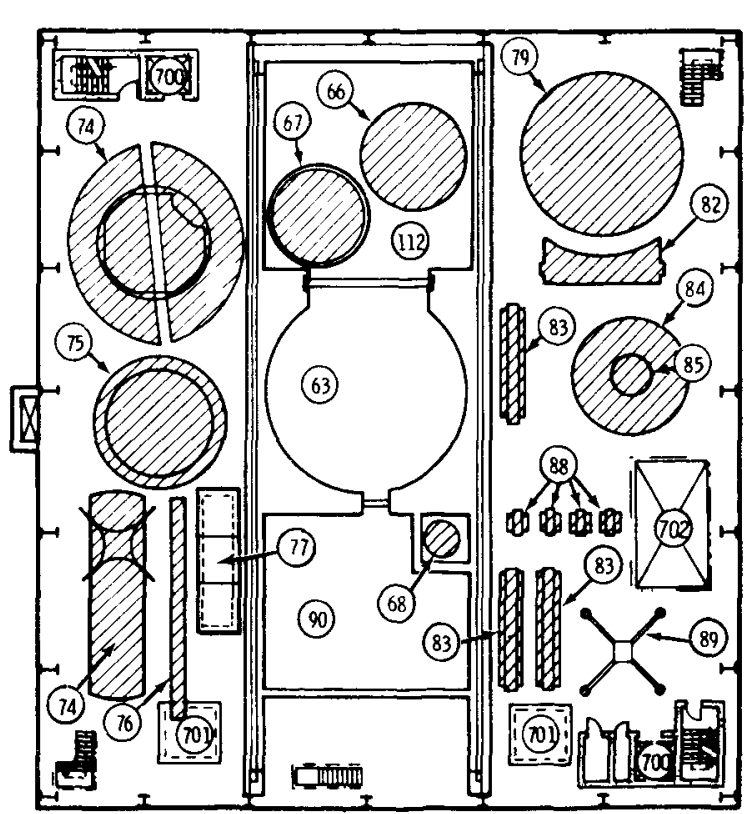

REACTOR BLDG. - FLOOR PLAN AT ELEV. $185.0 \mathrm{~m}$

\begin{tabular}{|c|c|c|c|}
\hline $\begin{array}{l}\text { EQUIPMENT } \\
\text { KEY NUMBER } \\
\end{array}$ & LOCATION & 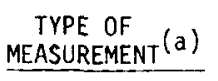 & $\begin{array}{l}\text { MEASURED } \\
\text { DOSE RATE (R/hr) }\end{array}$ \\
\hline 1 & REACTOR VESSEL (NEAR THE FEED- & & \\
\hline $\begin{array}{r}2 \\
45\end{array}$ & $\begin{array}{l}\text { WAAER NOOZZEES) } \\
\text { REACTOR PEDESTAL } \\
\text { CONTROL ROD DRIVE MOOULES }\end{array}$ & $\begin{array}{l}\text { CONTACAT } \\
\text { GEEEAL AREA } \\
\text { CONTACT }\end{array}$ & $\begin{array}{l}.700-3.0 \\
>.100(b) \\
.002-.045\end{array}$ \\
\hline 47 & $\begin{array}{l}\text { RWCU PUMPS } \\
\text { RWCU PIPANG } \\
\text { RHCU DRAIN }\end{array}$ & $\begin{array}{l}\text { CONTACT } \\
\text { CONTACT } \\
\text { CONACT }\end{array}$ & $\begin{array}{l}.100-12.0 \\
.070-.220 \\
.160-.210\end{array}$ \\
\hline $\begin{array}{l}49 \\
50\end{array}$ & $\begin{array}{l}\text { SACRIFICIAL SHIELD WALL } \\
\text { RBCC WATCR PUMP } \\
\text { RBCC WATR P PPING } \\
\text { RBCC WATER PUMP }\end{array}$ & $\begin{array}{l}\text { CONTACT } \\
\text { CONTACT } \\
\text { CONTACT } \\
\text { GENERAL AREA }\end{array}$ & $\begin{array}{l}7.100(\mathrm{~b}) \\
.005-.040 \\
.010-.080 \\
.006-.030\end{array}$ \\
\hline $\begin{array}{l}51 \\
54\end{array}$ & $\begin{array}{l}\text { RBCC WATER HEAT EXCHANGER } \\
\text { RHR HET EXCANGR } \\
\text { RHR HEAT EXCHANGER PIPING } \\
\text { RHR HEAT EXCHANGER }\end{array}$ & $\begin{array}{l}\text { CONTACT } \\
\text { CONTACT } \\
\text { CONTACT } \\
\text { GENERAL AREA }\end{array}$ & $\begin{array}{l}.020-.050 \\
.050-.250 \\
.800-.600\end{array}$ \\
\hline $\begin{array}{l}55,56 \\
58,60\end{array}$ & $\begin{array}{l}\text { FUEL POOL COOLING EQUIPMENT } \\
\text { STANBBY LIQUID CONTROL EQUI PMENT }\end{array}$ & $\begin{array}{l}\text { GENERAL AREA } \\
\text { GENERAL AREA }\end{array}$ & $\begin{array}{l}3.100(b) \\
\leq .0025(b)\end{array}$ \\
\hline 61 & $\begin{array}{l}\text { REEENERAIVE HEAT EXCHANGER } \\
\text { REGENERATVEE HEAT XXCAANGGR }\end{array}$ & CONTACT & $.300-10.0$ \\
\hline & $\begin{array}{l}\text { PIPING } \\
\text { REGENERATIVE HEAT EXCHANGER }\end{array}$ & $\begin{array}{l}\text { CONTACT } \\
\text { GENERAL AREA }\end{array}$ & $\begin{array}{l}.200-.500 \\
.020-.750\end{array}$ \\
\hline 62 & $\begin{array}{l}\text { NON-REGENERATIVE HEAT EXCHANGER } \\
\text { NON-REGENERAT IVE HEAT EXCHANGERR }\end{array}$ & CONTACT & $.320-10.0$ \\
\hline & $\begin{array}{l}\text { PIPING } \\
\text { NON-REGENERATIVE HEAT EXCHANGER }\end{array}$ & $\begin{array}{l}\text { CONTACT } \\
\text { GENERAL AREA }\end{array}$ & $. .400-.750$ \\
\hline $\begin{array}{l}63 \\
66 \\
67\end{array}$ & $\begin{array}{l}\text { REACTOR WELL POOL CAVITY } \\
\text { STERM DRYER POL } \\
\text { SHROUD EEAT \& STEAM SEPARATOR }\end{array}$ & $\begin{array}{l}\text { CONTACT } \\
\text { GENERAL AREA } \\
\text { GENERAL AREA }\end{array}$ & $\begin{array}{l}.015 \\
>.100(b)^{(0.060} \\
>.100(b)\end{array}$ \\
\hline $\begin{array}{l}68 \\
\text { N/4 } \\
74\end{array}$ & $\begin{array}{l}\text { SPENT FUEL SHIPPING CASK STORAGE } \\
\text { REVEEIING FLOOR } \\
\text { UPPER AND LOWR SHIELD PLUG }\end{array}$ & $\begin{array}{l}\text { GENERAL AREA } \\
\text { CONTACT }\end{array}$ & $\begin{array}{l}>.100(b) \\
.002-.500\end{array}$ \\
\hline & LAYDOWN & GENERAL AREA & $\leq .0025(\boldsymbol{B})$ \\
\hline $\begin{array}{l}76,79 \\
84,85,82,83 \\
89\end{array}$ & $\begin{array}{l}\text { NEW FUEL STORAGE VAULT } \\
\text { LAVODWN AREAS FoR VARIOUS } \\
\text { REACTOR PARTS }\end{array}$ & $\begin{array}{l}\text { GENERAL AREA } \\
\text { GENERAL AREA }\end{array}$ & $\begin{array}{l}\leq .015(b) \\
\leq .0025(b)\end{array}$ \\
\hline $\begin{array}{l}90 \\
91 \\
92\end{array}$ & $\begin{array}{l}\text { SPENT FUEL STORAGE POOL } \\
\text { RBCW WATER SURG TANK } \\
\text { STANDBY GAS FILTER UNIT }\end{array}$ & $\begin{array}{l}\text { GENERAL AREA } \\
\text { GEEERLL ARRA } \\
\text { GENERAL AREA }\end{array}$ & $\begin{array}{l}.002-.020 \\
.006-.030 \\
\leq .0025(b)\end{array}$ \\
\hline $\begin{array}{l}933 \\
934 \\
95\end{array}$ & 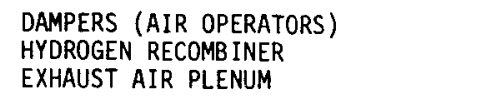 & $\begin{array}{l}\text { GENERAL AREA } \\
\text { GEEERLL ARRA } \\
\text { GENERAL AREA }\end{array}$ & 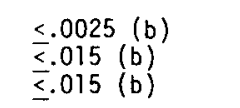 \\
\hline $\begin{array}{r}96 \\
107 \\
109 \\
112\end{array}$ & $\begin{array}{l}\text { SUMP VENT FILTER UNITS } \\
\text { HEATING \& VENTILAIING UNIT } \\
\text { REEAESE STACK OPENING } \\
\text { DRYER \& SEPARATOR STORAGE POOL }\end{array}$ & $\begin{array}{l}\text { GENERAL AREA } \\
\text { GENERAL AREA } \\
\text { GENERAL AREA } \\
\text { GENERAL AREA }\end{array}$ & $\begin{array}{l}\leq .015(b) \\
\leq .015(b) \\
\leq .001(b) \\
.002-.020\end{array}$ \\
\hline $\begin{array}{l}700 \\
701 \\
702\end{array}$ & $\begin{array}{l}\text { ELEVATOR } \\
\text { COVERED HATCH } \\
\text { OPEN HATCH }\end{array}$ & $\begin{array}{l}\text { GENERAL AREA } \\
\text { GENERAL AREA } \\
\text { GENERAL AREA }\end{array}$ & $\begin{array}{l}\leq .0025(\mathrm{~b}) \\
\leq .0025(\mathrm{~b}) \\
\leq .0025(\mathrm{~b})\end{array}$ \\
\hline
\end{tabular}

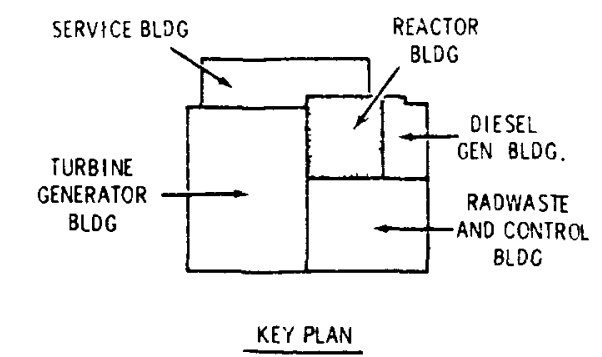

FIGURE D.1-2. Radiation Dose Rates in the Reactor Building - Sheet 2 
O 


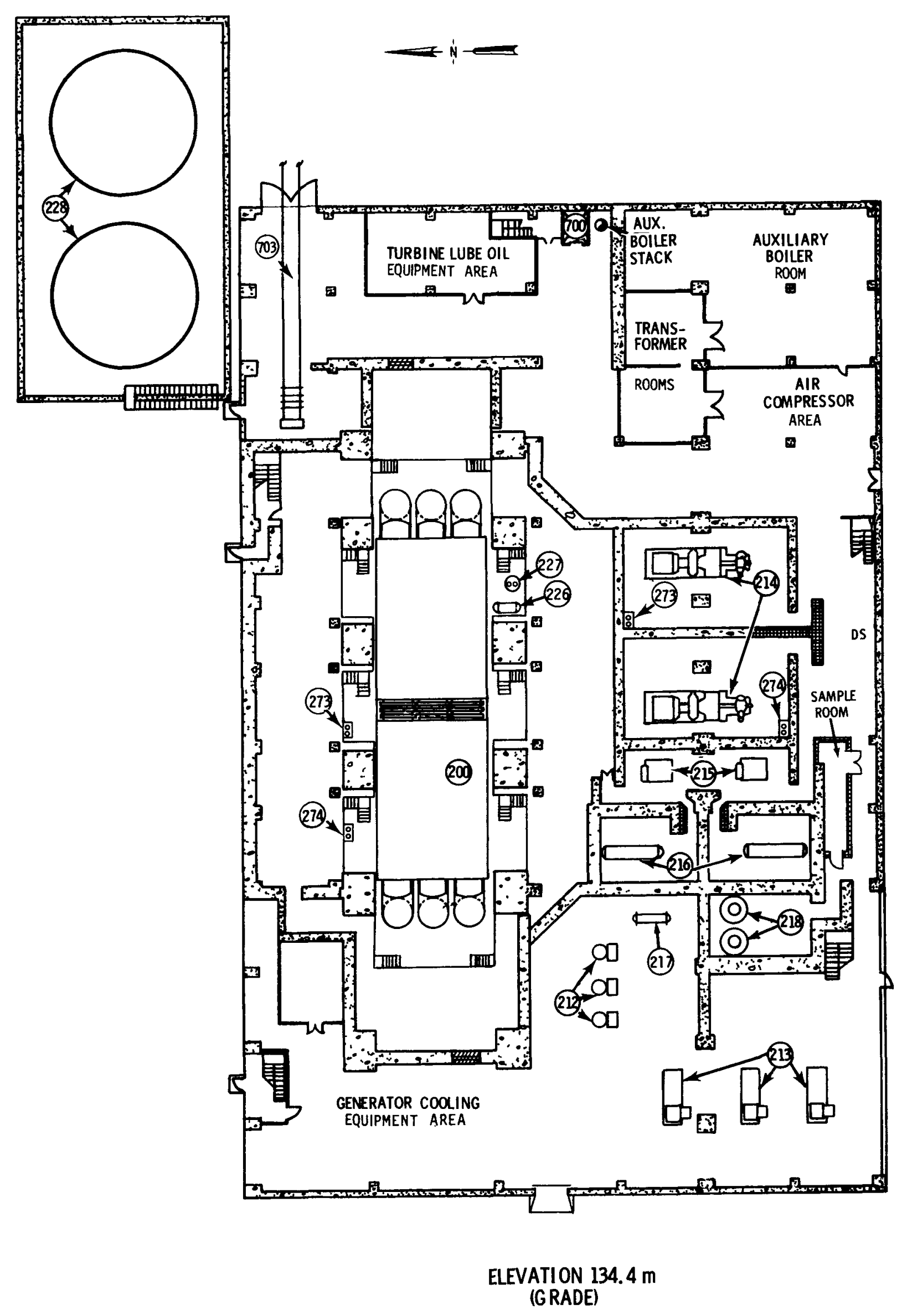

\begin{tabular}{|c|c|c|c|}
\hline $\begin{array}{l}\text { EOUIPMENT } \\
\text { KEY MUMBER }\end{array}$ & LOCATION & $\begin{array}{c}\text { TYPE OF } \\
\text { MEASUREMENT }(a)\end{array}$ & $\begin{array}{l}\text { MEASURED } \\
\text { DOSE RATE (R/hr) }\end{array}$ \\
\hline 200 & MAIN CONDENSER & CONTACT & .002 \\
\hline $\begin{array}{l}212 \\
212\end{array}$ & $\begin{array}{l}\text { CONDENSATE PUMP PIPING } \\
\text { CONDENAATE PUMP }\end{array}$ & $\begin{array}{l}\text { CONTACT } \\
\text { GENERAL AREA }\end{array}$ & $\begin{array}{l}.002 \\
.002\end{array}$ \\
\hline $\begin{array}{l}213 \\
213 \\
214\end{array}$ & 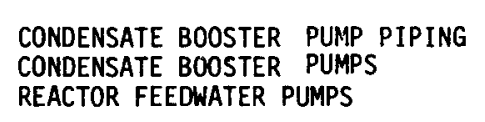 & $\begin{array}{l}\text { CONTACT } \\
\text { GENERAL AREA } \\
\text { CONTACT }\end{array}$ & $\begin{array}{l}.002 \\
.002 \\
.002\end{array}$ \\
\hline $\begin{array}{l}215 \\
215 \\
216\end{array}$ & $\begin{array}{l}\text { MECHANICAL VACUUM PUMP PIPING } \\
\text { MECCANACAL VACUM PUMPS } \\
\text { STTAM JET AIR EJECTOR CONDENSER }\end{array}$ & $\begin{array}{l}\text { CONTACT } \\
\text { GENERAL AREA } \\
\text { CONTACT }\end{array}$ & $\begin{array}{l}.002-.005 \\
.0001=.002 \\
.002-.030\end{array}$ \\
\hline $\begin{array}{l}217 \\
218 \\
218\end{array}$ & $\begin{array}{l}\text { GLAND SEAL STEAM CONDENSER } \\
\text { CATAAYYITC RECOMBINERS } \\
\text { CATALYTIC RECOMBNERS PIPING }\end{array}$ & $\begin{array}{l}\text { CONTACT } \\
\text { CONACT } \\
\text { CONAACT }\end{array}$ & $\begin{array}{l}.001 \\
.002-.005 \\
002-.015\end{array}$ \\
\hline $\begin{array}{l}226 \\
227 \\
228\end{array}$ & $\begin{array}{l}\text { SEEL HATER LIOUID TANK } \\
\text { PMMPED DOAN TANK } \\
\text { CONOENSATE STORAGE TANKS }\end{array}$ & $\begin{array}{l}\text { GENEREL AREA } \\
\text { GEEVRLL AREA } \\
\text { GEEERAL AREA }\end{array}$ & $\begin{array}{l}.002 \\
.002 \\
.001\end{array}$ \\
\hline $\begin{array}{l}273 \\
274 \\
700 \\
703\end{array}$ & 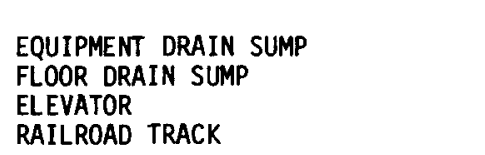 & 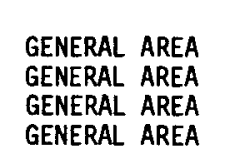 & $\begin{array}{l}>.100(\mathrm{~b}) \\
>1.00025 \\
\leq .025 \\
\leq .025 \\
\leq .025\end{array}$ \\
\hline
\end{tabular}

(a) General Area refers to the radiation field in a room or area, not specifically
from one discrete source or direction, although a specific source may be the sole contributor to the rad ataton measurement.
Contact means the closest approcach to a surface (a surface dose rate) including the

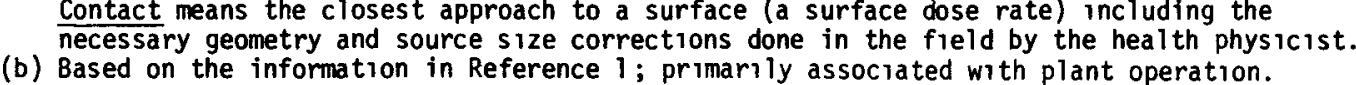

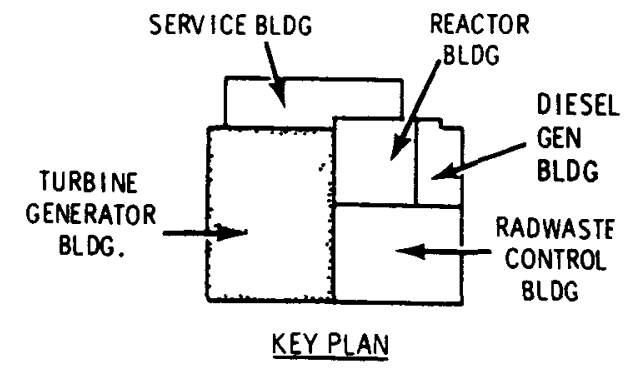

FIGURE D.1-3. Radiation Dose Rates in the Turbine Generator Building -
Elevation $134.4 \mathrm{~m}$ 
○ 0 


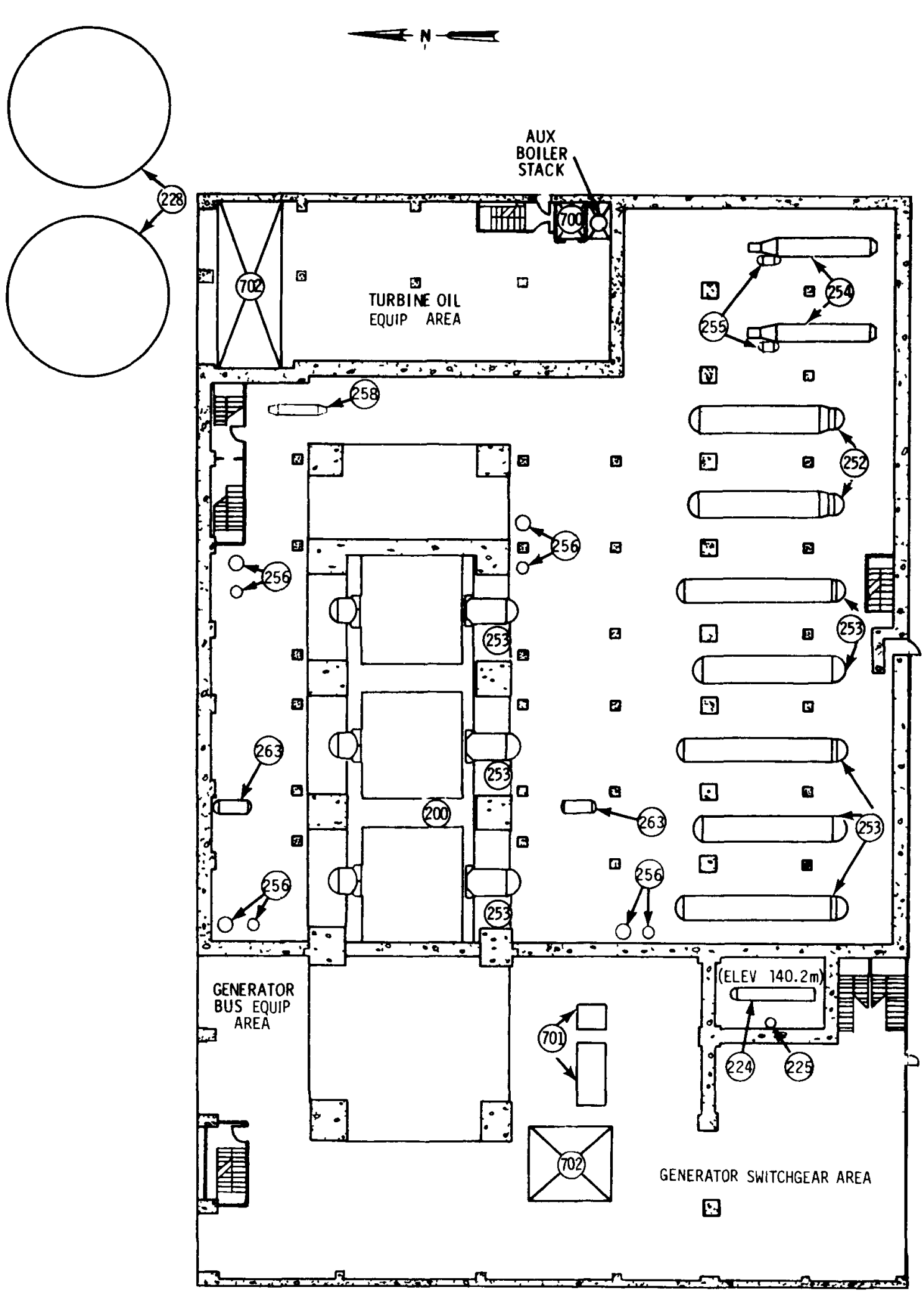

\begin{tabular}{|c|c|c|c|}
\hline $\begin{array}{l}\text { EQUPPMENT } \\
\text { KEY NUMBBER }\end{array}$ & LOCATION & $\begin{array}{l}\text { TYPE OF } \\
\text { MEASUREMENT (a) }\end{array}$ & $\begin{array}{l}\text { MEASURED } \\
\text { DOSE RATE (R/hr) }\end{array}$ \\
\hline $\begin{array}{l}2240 \\
224,225 \\
228\end{array}$ & 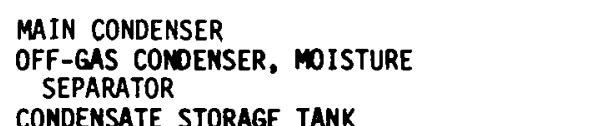 & $\begin{array}{l}\text { CONTACT } \\
\text { GENERAL AREA } \\
\text { CONTACT }\end{array}$ & $\begin{array}{l}.002 \\
.003-.020 \\
.001\end{array}$ \\
\hline 252 & HIGH-PRESSURE FEEDWATER HEATERS AND & CONTACT & $.002-.025$ \\
\hline $\begin{array}{l}253 \\
254\end{array}$ & $\begin{array}{l}\text { LOW-PRESSURE FEEDWATER HEATERS, PIPING } \\
\text { STEAM EVAPORATORS }\end{array}$ & $\begin{array}{l}\text { CONTACT } \\
\text { CONTACT }\end{array}$ & $\begin{array}{l}.002-.015 \\
.002-.010\end{array}$ \\
\hline $\begin{array}{l}255 \\
256 \\
258\end{array}$ & $\begin{array}{l}\text { EVAPORATOR DRAIN TANKS } \\
\text { REEATER DRAN TAKS } \\
\text { TURBINE BYPASS VALVE ASSERBLY }\end{array}$ & $\begin{array}{l}\text { CONTACT } \\
\text { CONACT } \\
\text { CONTACT }\end{array}$ & $\begin{array}{l}.002-.006 \\
.003\end{array}$ \\
\hline $\begin{array}{l}263 \\
700 \\
701 \\
702\end{array}$ & $\begin{array}{l}\text { MOISTURE SEPARATOR DRAIN TANK } \\
\text { ELEVATOR } \\
\text { COVERED HATCH } \\
\text { OPEN HATCH }\end{array}$ & $\begin{array}{l}\text { GENERAL AREA } \\
\text { GENERAL AREA } \\
\text { GENERAL AREA } \\
\text { GENERAL AREA }\end{array}$ & 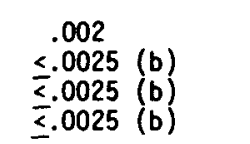 \\
\hline
\end{tabular}

(a) General Area refers to the radiation field in a room or area, not specifically from one discrete Contact means the closest approach to a surface (a surface dose rate) including the necessary

(b) Based on the information in Reference 1 ; primarily associated with plant operation.

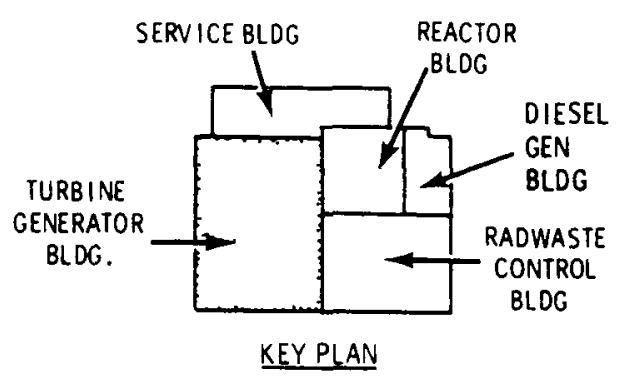


@ 


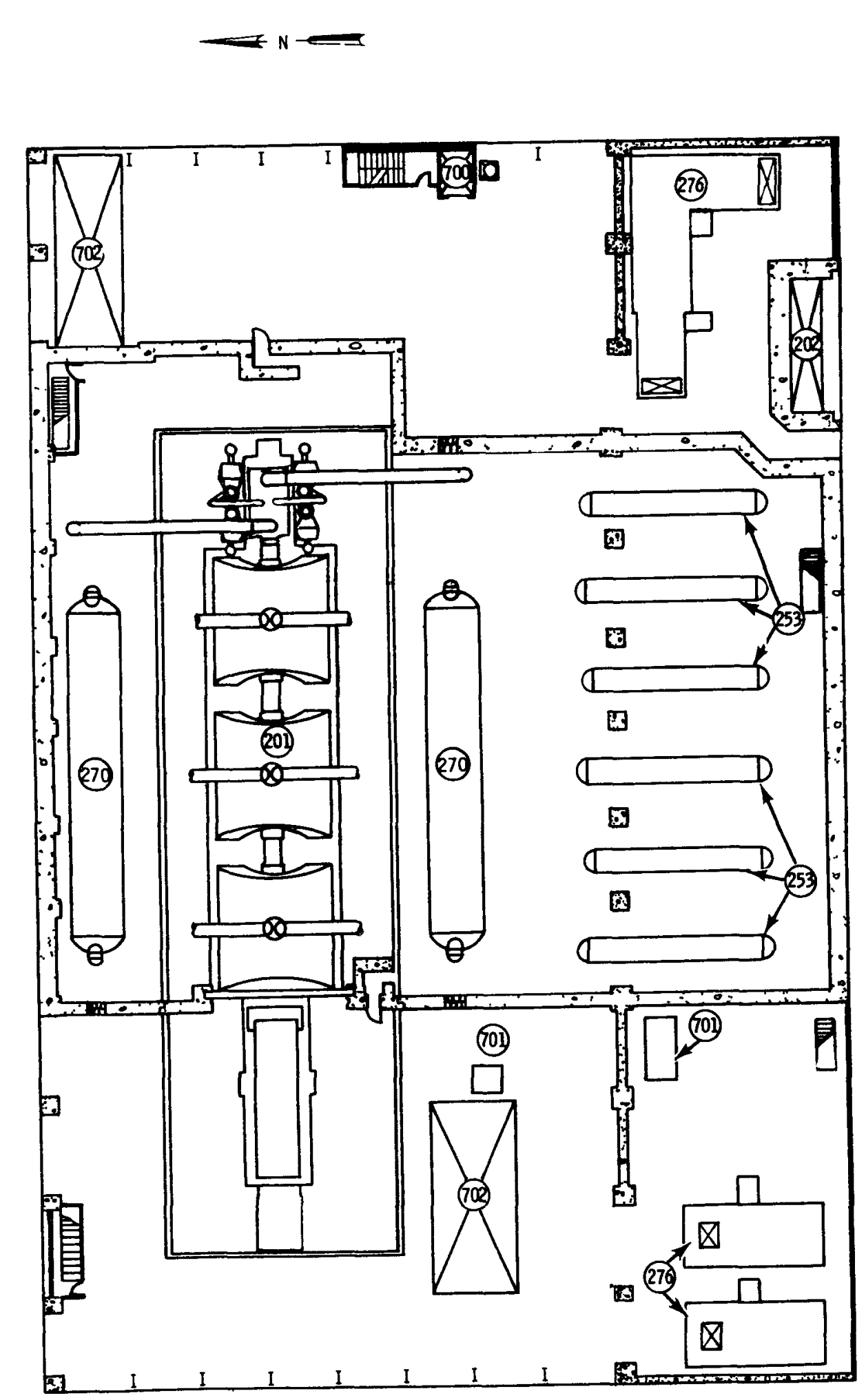

\begin{tabular}{|c|c|c|c|}
\hline $\begin{array}{l}\text { EQUIPMENT } \\
\text { KEY NUMBER }\end{array}$ & LOCATION & $\begin{array}{c}\text { TYPE OF } \\
\text { MEASUREMENT }(a) \\
\end{array}$ & $\begin{array}{l}\text { MEASURED } \\
\text { DOSE RATE (R/hr) }\end{array}$ \\
\hline $\begin{array}{l}201 \\
202 \\
253\end{array}$ & $\begin{array}{l}\text { TURBINE } \\
\text { MAN STEAM AND FEEDWATER PIPE CHASE } \\
\text { LOW-PRESSURE FEEDWATER HEATERS }\end{array}$ & $\begin{array}{l}\text { GENERAL AREA } \\
\text { GENERAL AREA } \\
\text { CONTACT }\end{array}$ & $\begin{array}{l}.001-002 \\
.002-.002\end{array}$ \\
\hline $\begin{array}{l}270 \\
276 \\
700\end{array}$ & $\begin{array}{l}\text { MOISTURE SEPARATOR REHEATER } \\
\text { HEATING AND VENTILATING UNIT } \\
\text { ELEVATOR }\end{array}$ & $\begin{array}{l}\text { GENERAL AREA } \\
\text { GENERAL AREA } \\
\text { GENERAL AREA }\end{array}$ & $\begin{array}{l}.002 \\
.001 \\
\leq .0025(b)\end{array}$ \\
\hline $\begin{array}{l}701 \\
702\end{array}$ & $\begin{array}{l}\text { COVERED HATCH } \\
\text { OPEN HATCH }\end{array}$ & $\begin{array}{l}\text { GENERAL AREA } \\
\text { GENERAL AREA }\end{array}$ & \begin{tabular}{l}
$\leq .0025(\mathrm{~b})$ \\
\hdashline $0025(\mathrm{~b})$
\end{tabular} \\
\hline
\end{tabular}

ELEVATION $152.7 \mathrm{~m}$

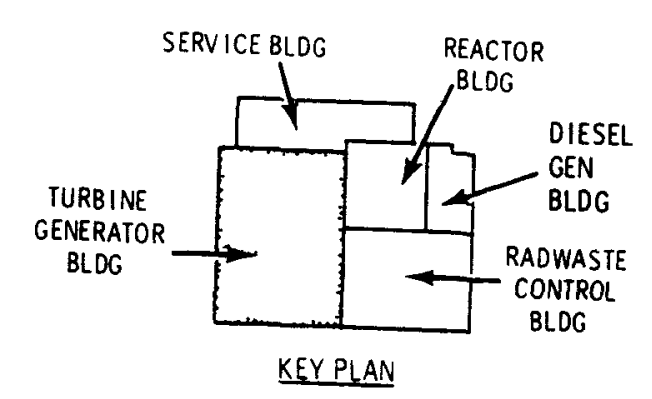

FIGURE D.1-5. Radiation Dose Rates in the Turbine Generator Building Elevation $152.7 \mathrm{~m}$ 
8 
a 0 


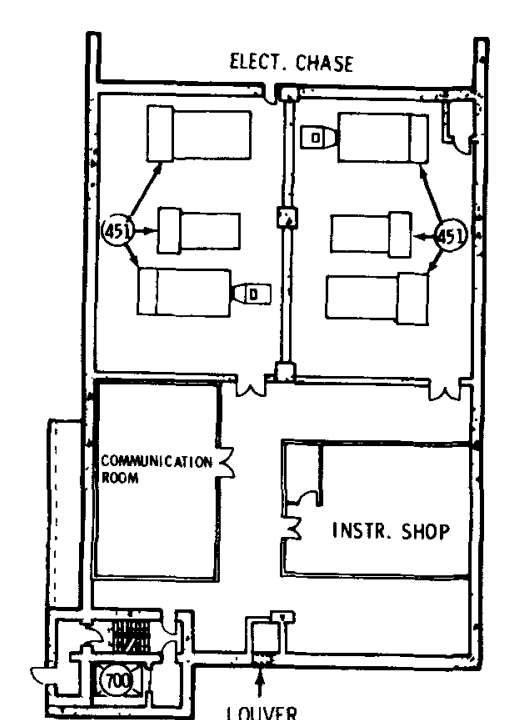

RADWASTE AND CONTROL BUILDING CONTROL ROOM TOWER PLAN
AT ELEVATION $160.0 \mathrm{~m}$

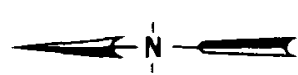

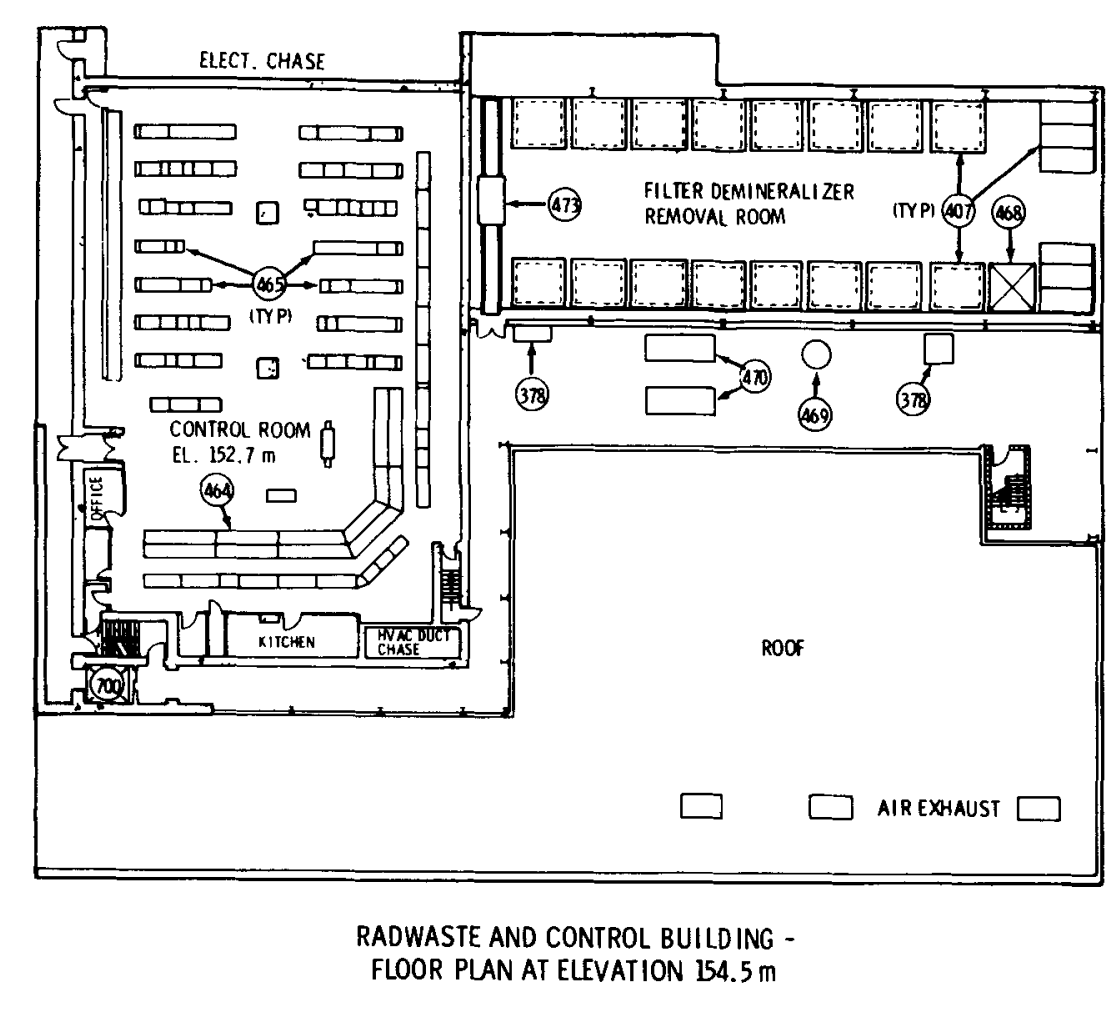

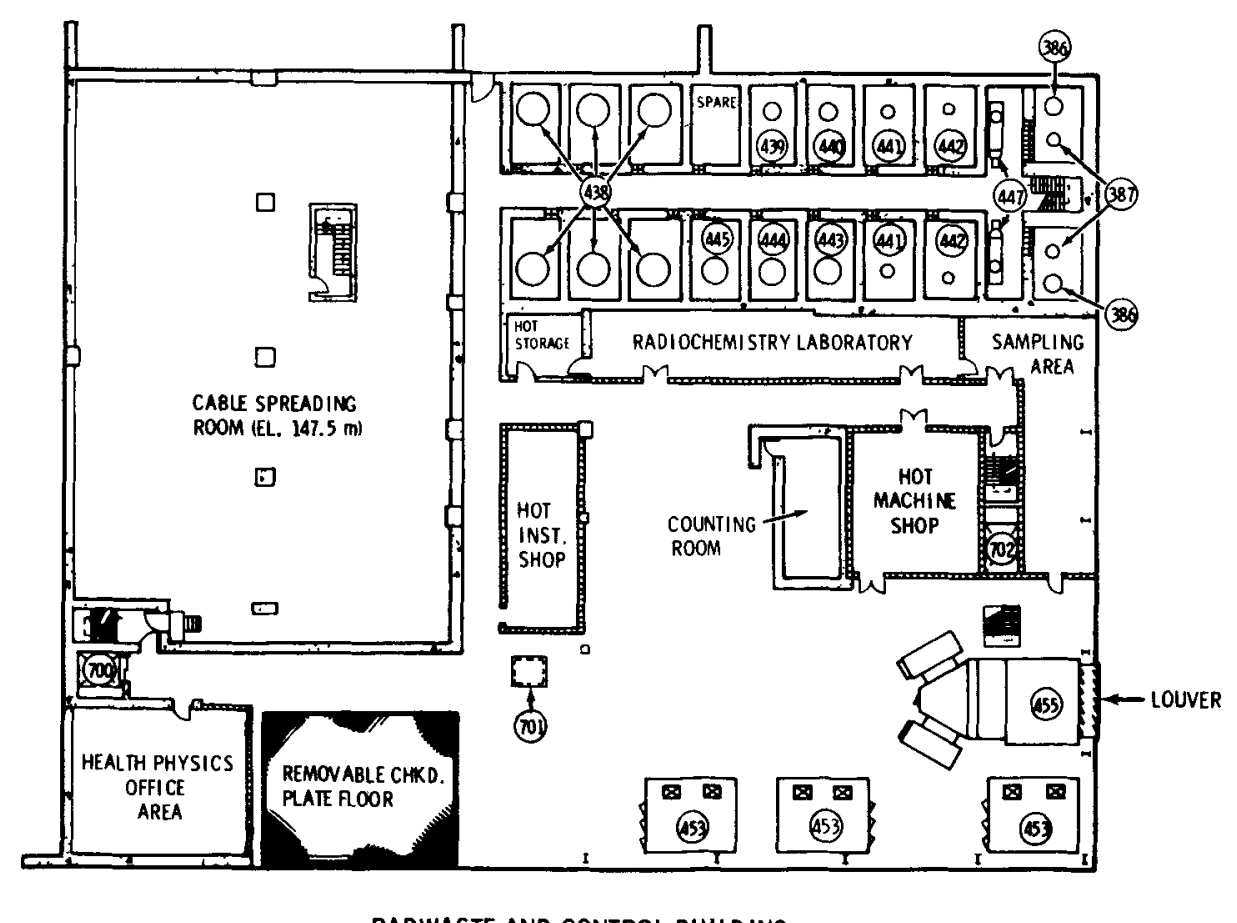

RADWASTE AND CONTROL BUILDING -
FLOOR PLAN AT ELEVATION $148.4 \mathrm{~m}$

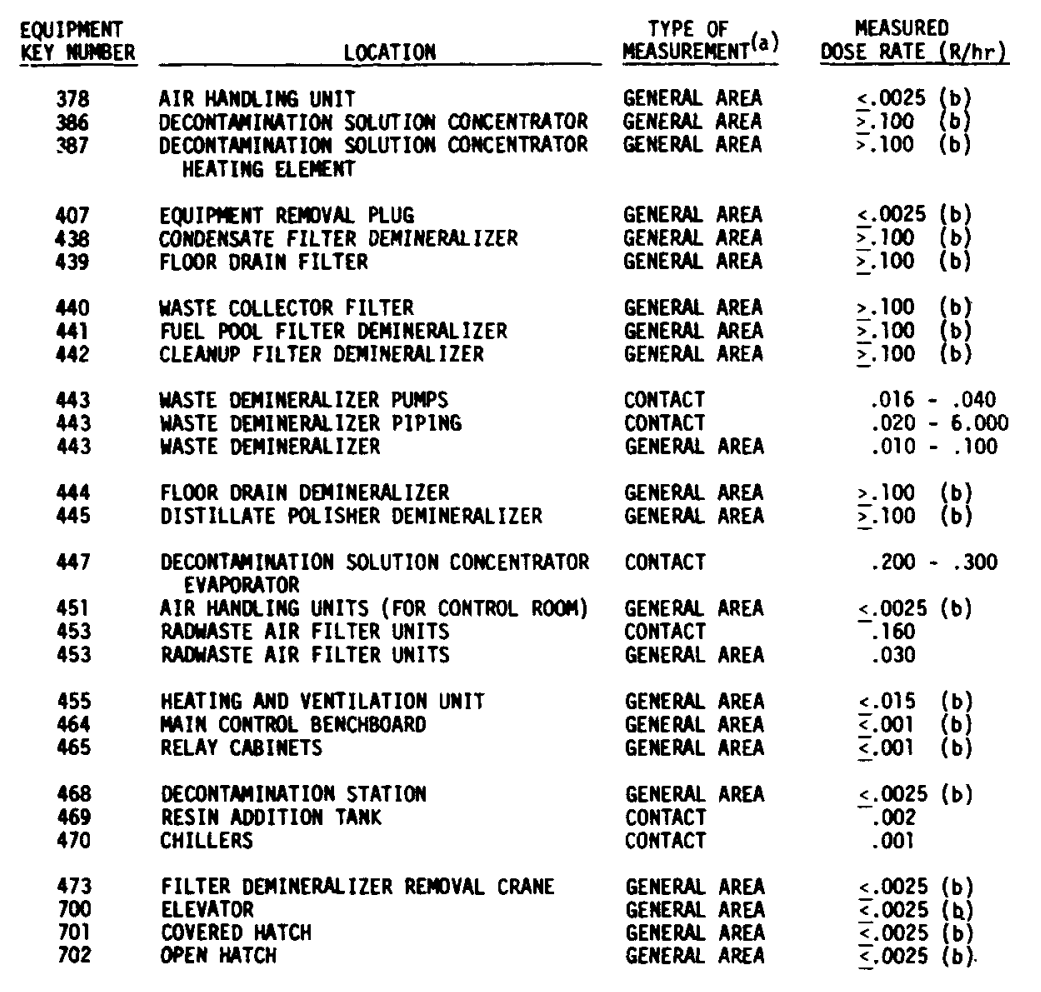

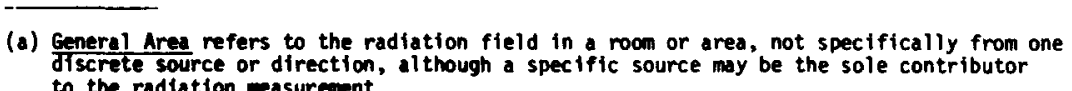

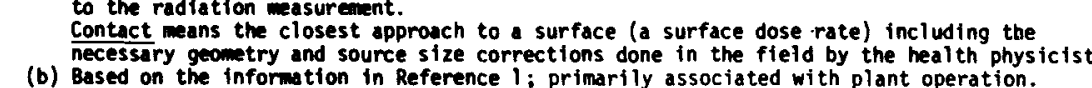

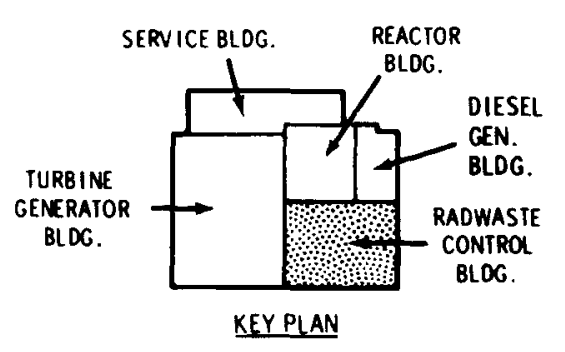

FIGURE D.1-7. Radiation Dose Rates in the Radwas Control Building Sheet 2 


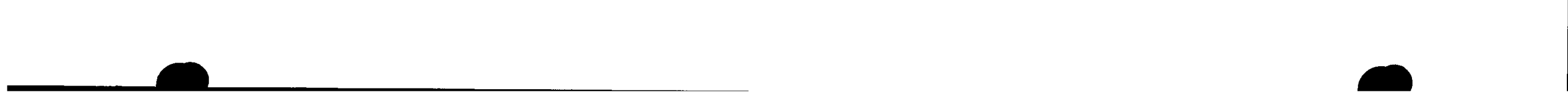




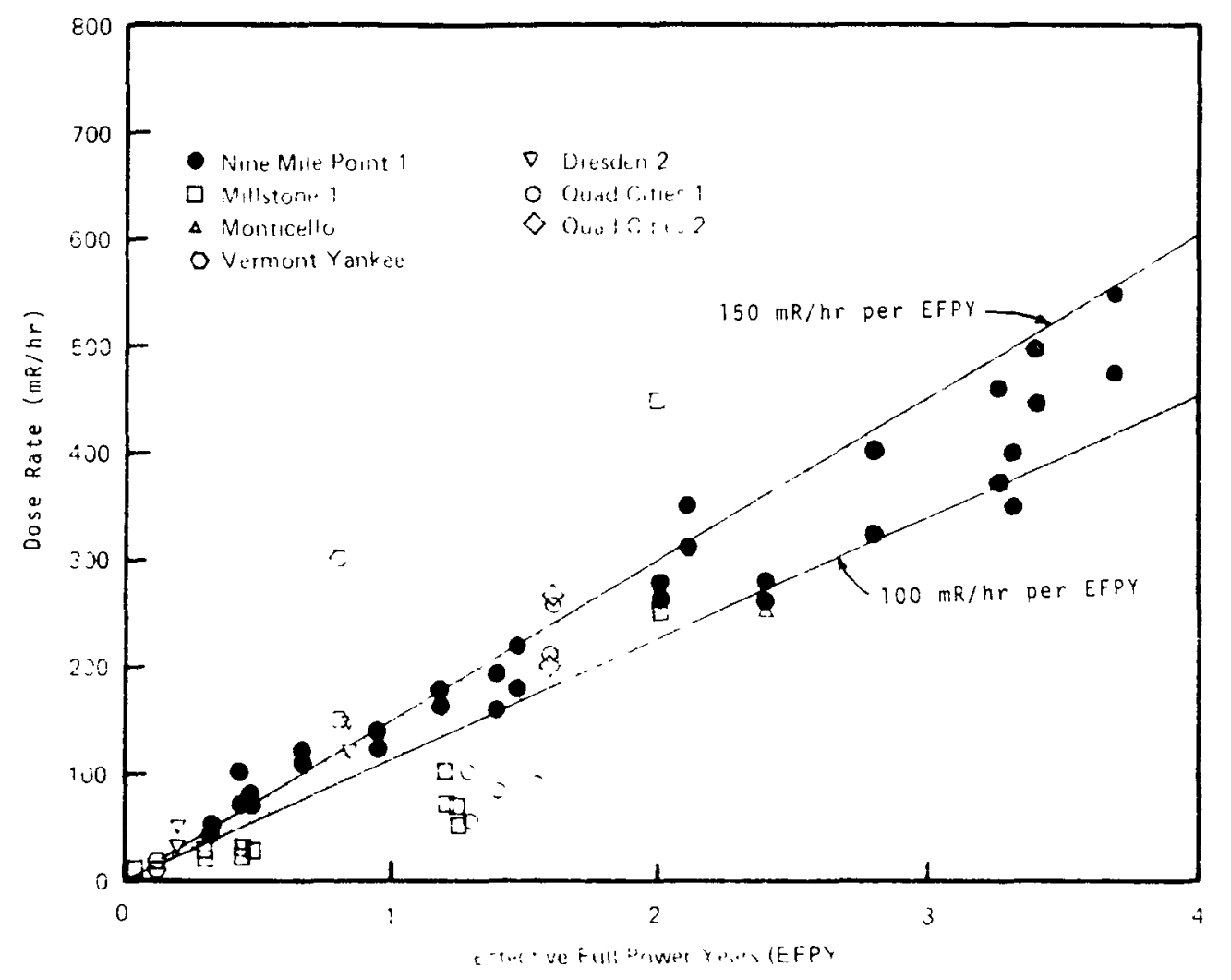

FIGURE D.1-8. Shutdown Radiation Levels on BWR Recirculation Pump Suction Piping (from Reference 2)

ion.

end of the reference BWR's operating life. However, there are a number of factors that tend to keep radiation dose rates within manageable bounds:

- During the operating lifetime of the plant, only relatively mild decontamination agents are used to periodically reduce dose rates. After final shutdown, harsher (more effective) decontamination agents and longer decontamination periods may be used, since protection of valve seats, valve operators, and various critical piping and equipment is no longer required.

- It is extremely important to minimize outage time during the plant's jS operating lifetime because of the cost of replacement power. Hence, ICbecause of a lack of available time, decontamination of some portions of the plant may not be as effective as desired. After final shutdown, if 
maximum decontamination is not achieved and high radiation readings are still being encountered, the time is available to repeat decontamination procedures or to try other decontamination agents. Such a combination of decontamination approaches is often extremely effective, thus greatly reducing dose rates.

- Current decontamination studies are focused on improved techniques for operating reactors. (3) However, it is reasonable to expect future studies to be focused on the more severe measures appropriate for decontamination during decommissioning.

- In addition to improved chemical decontamination agents, various types of mechanical decontaminating techniques are being developed and improved, such as high-pressure water-jet systems, electrolytic systems, and sonic vibrational systems.

In summation, the nuclear power industry's knowledge of decontamination methods is increasing rapidly. Therefore, it is assumed that the radiation dose rates shown in Figures $0.1-1$ through $0.1-7$ reasonably represent the dose rates that workers will encounter in performing various tasks in each of the designated areas of the reference BWR at the time of decommissioning.

\section{D.1.3 Application of Radiation Dose Rate Data}

The entire project required to complete a particular decommissioning mode is broken down into individual tasks to be performed in each specific area, and the man-hours of radiation exposure are then estimated for each task. In applying the dose rate data presented in this appendix, adjustments are made for ALARA considerations, for decontamination during decommissioning, for special shielding methods, and for other appropriate judgment considerations, as described in Appendices H, I, J, and $K$. The adjusted dose rate for each specific work site is then multiplied by the estimated man-hours of exposure for each task. After correcting for radioactive decay, the individual task exposures are totaled for the entire decommissioning effort. Radioactive decay of ${ }^{60} \mathrm{Co}$ is the basis in this study for calculating the decay factor for each task. Additional information on the makeup of the surface contamination affecting radiation dose rates in the plant is contained in Section E.2.2 of Appendix E. 


\section{D.2 ESTIMATED CONCRETE SURFACE CONTAMINATION AT SHUTDOWN}

Measured concrete surface contamination levels were obtained from the same four BWR sites: Desden, Quad Cities, Peachbottom, and Monticello. Study assumptions relating to concrete surface contamination, together with composite values from the measured levels at the four sites and estimated concrete rubble volumes for the reference BWR, are presented in the following subsections.

\section{D.2.1 Assumptions}

For this study, the following assumptions are made concerning concrete surface contamination at shutdown:

- The plant is in a shutdown/refueling mode, with no fuel movements in progress.

- "Low-level" or "high-level" surface contamination in a particular area is based on the plant process carried out in, and the accessibility and/or occupancy of, that area during plant operation. Contamination at specific locations within a given area may vary significantly from that in the general area.

- The percentage of the total area that is assumed contaminated is based on the measured data and on the plant process carried out in that location.

- Most contaminated concrete surfaces in the plant are floors; other contaminated surfaces (i.e., walls or curbs) are specifically noted.

- The spalling depth for reinforced concrete surfaces is $0.051 \mathrm{~m}$. (This represents the minimum depth of concrete cover on reinforcing bar at the reference BWR and is presumed sufficient to remove all measurable contamination.)

- Contaminated concrete block walls or concrete curbs are completely broken up and removed as contaminated rubble.

- A contaminated floor area made up of one or more removable concrete plugs is completely removed as contaminated material (i.e., no spalling or fracturing takes place). 


\section{D.2.2 Concrete Surface Contamination Data}

The data on concrete surface contamination are presented in Figures D.2-1 and D.2-2 for the Reactor Building (including Primary Containment), in Figures D.2-3 through D.2-5 for the Turbine Generator Building, and in Figures D.2-6 and D.2-7 for the Radwaste and Control Building. The equipment key number (see Section C.2 in Appendix C) of an associated piece of equipment is used to identify the location of a particular contaminated area; it is shown as the "Associated Equipment Key Number" in Figures D.2-1 through D.2-7. No concrete surface contamination is assumed in the other buildings and structures at the reference BWR site.

As are the dose rate data, the concrete surface contamination data are presented as composite values of the measured levels, although the data from the operating BWRs sometimes exhibits a fairly wide range. The data vary by a factor of 10 or more between plants, depending on the plant operating histories and on the extent and success of prior decontamination efforts.

New epoxy resin treatments for concrete surfaces are making decontamination and surface renewal easier and quicker. Also, equipment for decontamination is being invented or improved. In addition, new maintenance procedures that reduce the spread of surface contamination are constantly being devised. As a result of these considerations, the concrete surface contamination data and the contaminated concrete areas reported in Figures D.2-1 through D.2-7 are assumed to be reasonably representative of those anticipated to be present at the end of the reference BWR's operating life.

\section{D.2.3 Application of Concrete Surface Contamination Data}

The measured concrete surface contamination data are not specifically applied to any analysis in this study, except to help determine the "assumed contamination area" in a specific location and to detemine, in those instances where plant process does not dictate, specific areas of concrete surface that will probably need to be decontaminated during decommissioning. (In this study, contaminated concrete surfaces are assumed to be decontaminated to acceptable levels only by removing the surface either with a concrete spaller 
or with other physical-removal means.) The volume of concrete rubble or material that requires removal for surface decontamination is calculated as the product of 1) the total surface area associated with the particular piece of equipment, 2) the "percent of area assumed contaminated," and 3) the thickness of the material to be removed. 
8 


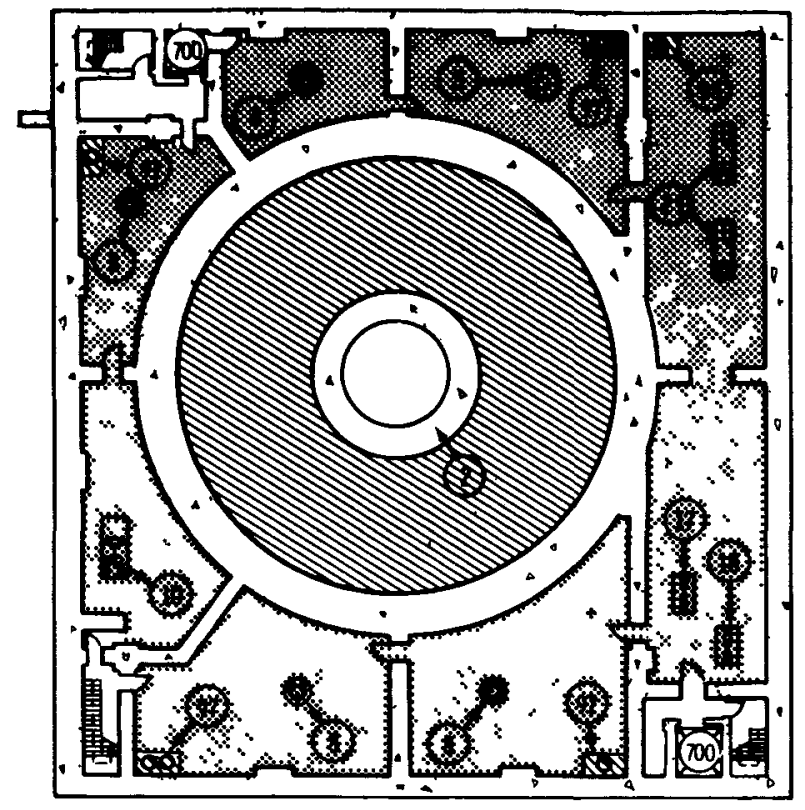

-REACTOR BLDG -FLOOR PLAN AT ELEV. $128.7 \mathrm{~m}$

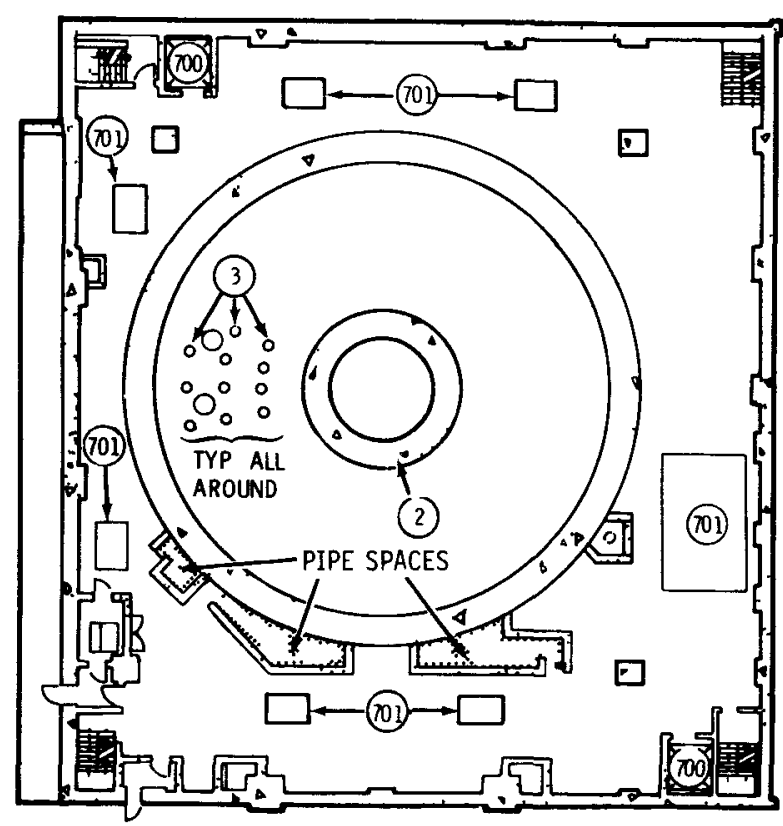

REACTOR BLDG - FLOOR PLAN AT ELEV. 143.6m

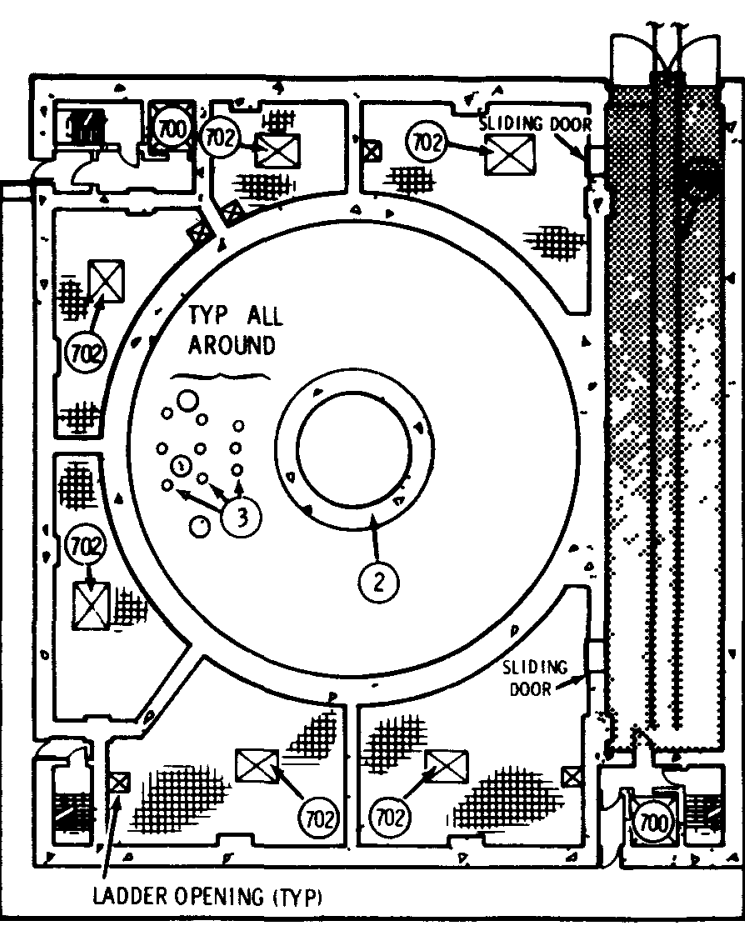

REACTOR BLDG - $100 R$ PLAN AT ELEV. $134.4 \mathrm{~m}$ AND $135.3 \mathrm{~m}$ (GRADE)
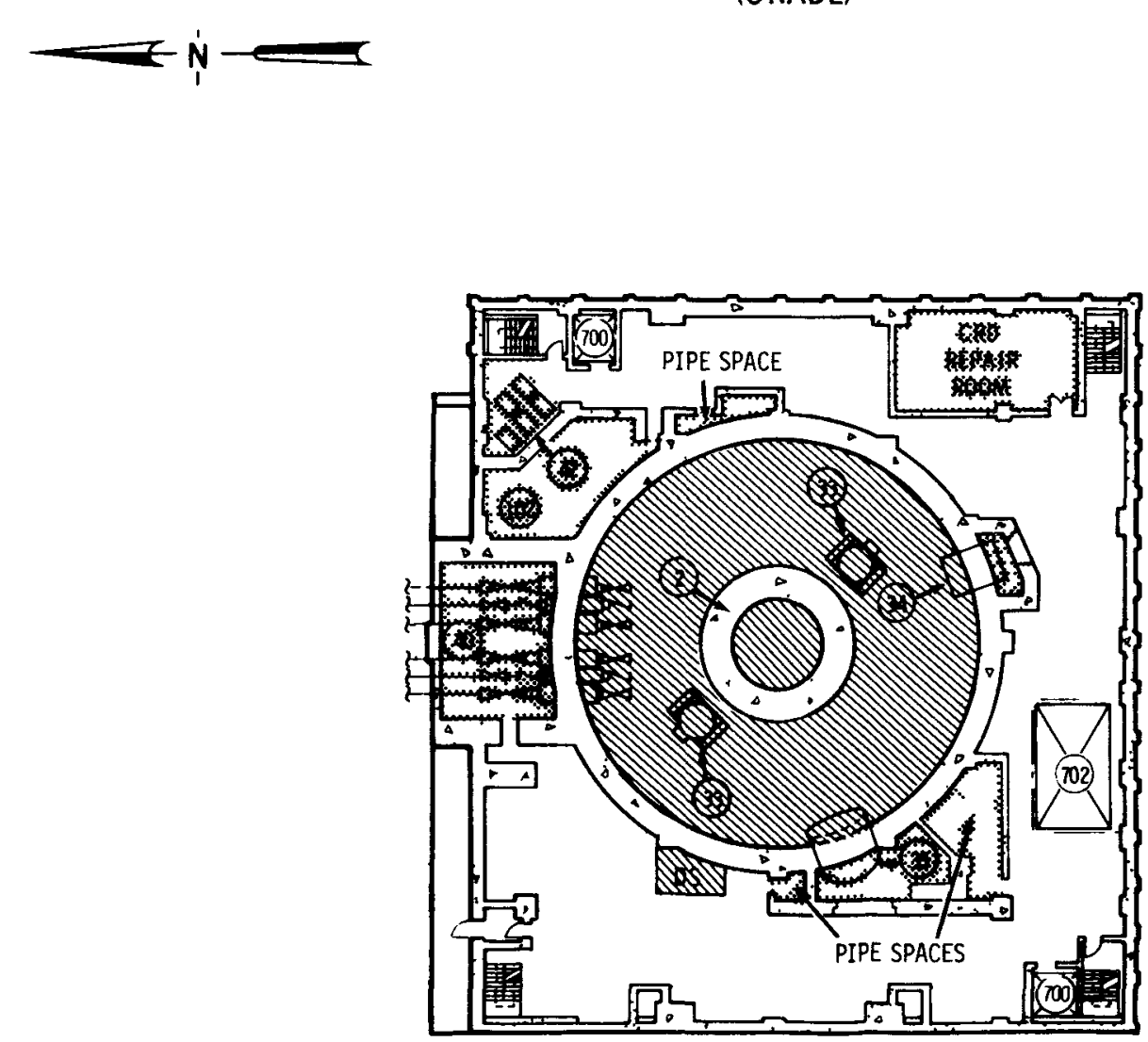

REACTOR BLDG - FLOOR PLAN AT ELEV. $152.7 \mathrm{~m}$

ASSOCIATED
EQUIPMENT

KEYY MUMBER

2,3 LOCATIOA

SUPPRESSTON CHAMBER
LOW PRESSURE CORE SPRAY PUMP ROOM RESIDUAL HEAT REMOVAL PUMP ROOMS REACTOR CORE ISOLATION COOLING PUMP ROOM RADWASTE BUILDING CONDENSATE
PUMP ANO FILTER BACKNASH PUM CONTROL ROD DRIVE PUMP ROOM REACTOR WATER RECIRCULATION PUMP AREA (DRYWELL FLOOR)
UNDER VESSEL AREA, ELEV. $152.7 \mathrm{~m}$ DRYWELL PERSONNEL LOCK ROOM DRYWELL EQUU PMENT HATCH ROOM MAIN STEAM TUNNEL CEILING PLUE TRAVERS ING IN-CORE PROBE DRIVE AREA ELE. $152.7 \mathrm{~m}$ I CRD REPAIR ROOM, ELEV. 152.7

FLOOR DRAIN SUMPS
EOUIPMENT DRAIN SUMP

TRAVERSING IN-CORE PROBE
(TIP) ROOM (TIP) ROOM

ELEVATOR AREA COVERED HATCH AREA
OPEN HATCH AREA RALLROAD AIRLOCK Total

(a) Composite of measurements taken during ma intenance outages at operatıng BWRs MEASURED
CONTAMINATION" SURFACE PERCENT OF RUBBLE
LEVI

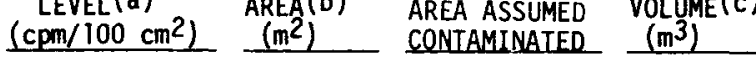
$\begin{array}{cccc}0.3-2.5 k^{(d)} & 2459 . .^{(e)} & 100 & 125.4^{(1)} \\ 0.2-5 k & 67.6 & 20 & 0.7\end{array}$ $0.2-22 k \quad 109.6$ $0.4-100 k \quad 3812$ $0.5-5.5 \mathrm{k} \quad 73.4$ M/A $(\mathrm{f})$ $0.2-12 k$ $2-2000 \mathrm{k}$

1628

$2000 \mathrm{k} \quad 418.0$

$4-150 k$

$179.4^{(\mathrm{e})}$

$\begin{array}{ll}0.2-30 k & 25.5 \\ 0.4-2 k & 68.4 \\ 0.1-2.5 k & 26.8\end{array}$

$\begin{array}{rr}0.1-12.5 \mathrm{k} & 295.0 \\ 0.1-12.5 \mathrm{k} & 26.8\end{array}$

$8-9.5 \mathrm{k}$

$0.6-35 \mathrm{~K}$

4. $-\begin{gathered}\text { N/A } \\ N / A \\ 80 \\ k\end{gathered}$

.-
-

$0 . \overline{-}-0.4$

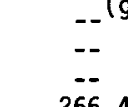

$20 \quad 1$

$20 \quad 1.1$

$100 \quad 9.1^{(1)}$

100
100
100
100

1.3
3.5
15.0
40.8

(c) Based on a contamination thickness of $0.051 \mathrm{~m}$.

() $0.3-2.5 \mathrm{k}$ stands for 300 to $2,500 \mathrm{cpm} / 100 \mathrm{~cm}^{2}$ (thr

f) Indicates "not avallable."

g) Shown for reference only; negl igible contamination assumed.
h) Includes additional volume due to removal and shipment of entire celling plug or concrete curb (1) Rubble volumes from wolthn Primary Contal nment
(j) Area beneath spent fuel cask loading hatch (EKN 702).

KEY

NO RADIOACTIVE SURFACE

LOW LEVEL RADIOACTIVE SURFAC

hon

HIGH LEVEL RADIOACTIVE
SURFACE CONTAMINATION

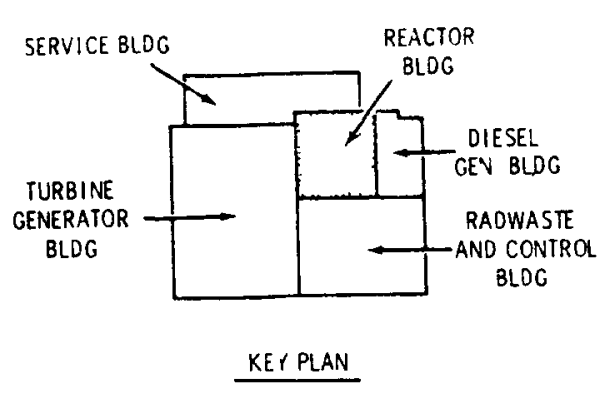
Contamination in the Reactor Building - Sheet 1 



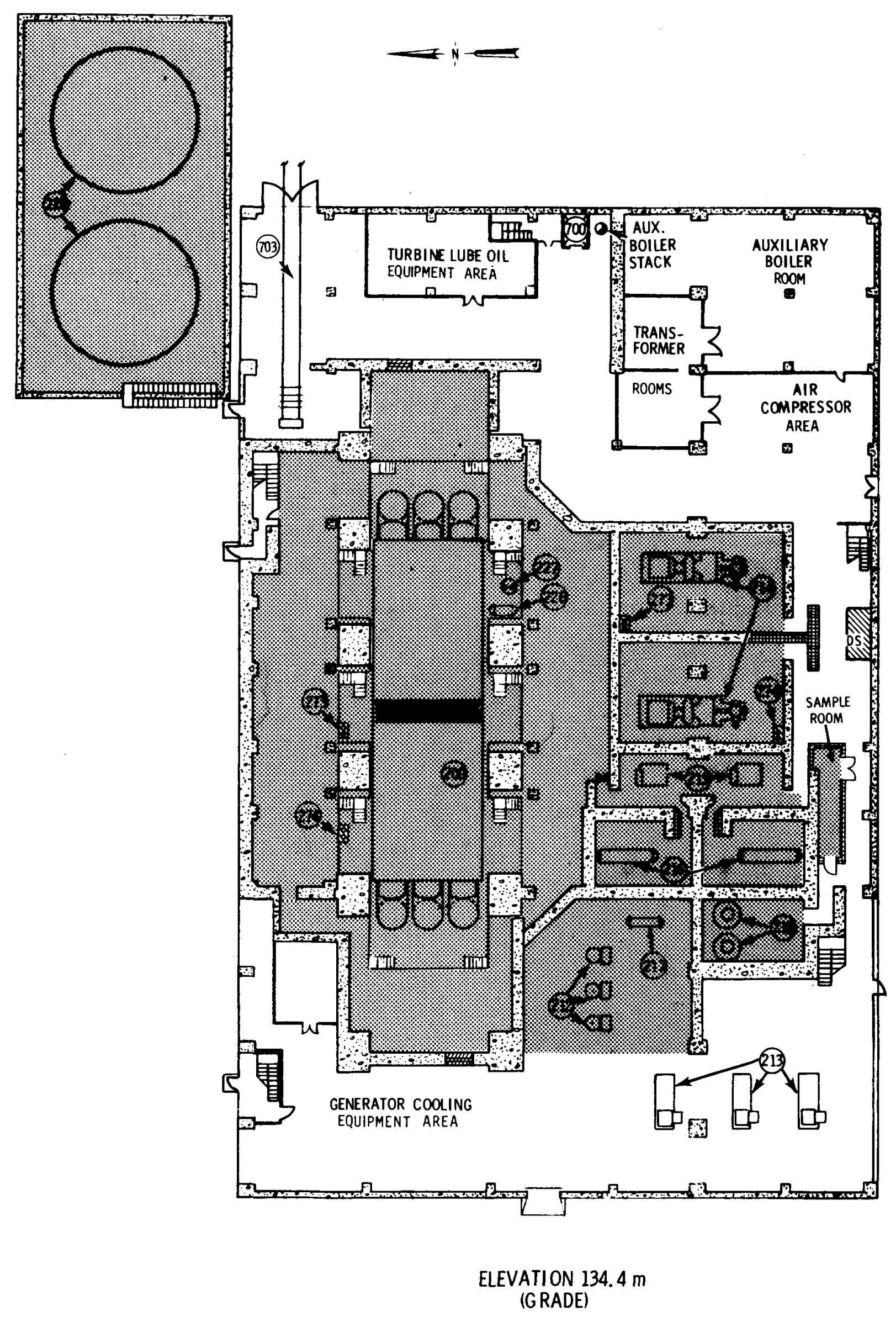

\begin{tabular}{|c|c|c|c|c|c|}
\hline $\begin{array}{l}\text { ASSOCIATED } \\
\text { EQUIPAENT } \\
\text { KEY NUMBER }\end{array}$ & LOCATION & $\begin{array}{l}\text { MEASURED } \\
\text { CONTAMINATION } \\
\text { LEVEEL (a) } \\
\left.\text { (CPM/100 } \mathrm{cm}^{2}\right)\end{array}$ & $\begin{array}{l}\text { SURFACE } \\
\text { ARER(b) } \\
\left(m^{2}\right)\end{array}$ & $\begin{array}{l}\text { PERCENT OF } \\
\text { AREA ASSUMED } \\
\text { CONTAMIMATED } \\
\end{array}$ & $\begin{array}{l}\text { RUBBLE } \\
\text { VOLUME( }(\mathrm{C}) \\
\left(\mathrm{m}^{3}\right) \\
\end{array}$ \\
\hline $212, \begin{array}{r}200 \\
217\end{array}$ & $\begin{array}{l}\text { MAIN CONDENSER AREA } \\
\text { CONDENSATE PUMP AND GLAND SEAL }\end{array}$ & $\begin{array}{l}0.2-2.5 k^{(d)} \\
0.2-25 k\end{array}$ & $\begin{array}{l}1664.8^{(\mathrm{e})} \\
217.0\end{array}$ & $\begin{array}{l}10 \\
10\end{array}$ & $\begin{array}{l}8.5 \\
1.1\end{array}$ \\
\hline 213 & 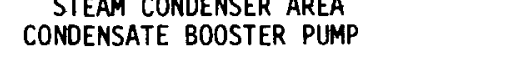 & $--(9)$ & $--(g)$ & $--(g)$ & $--(g)$ \\
\hline 竞 $214(\mathrm{~A})$ & $\begin{array}{l}\text { REACTOR FEEDHATER PUMP ROOMS } \\
\text { DS (DECONTAMINATION STATION) }\end{array}$ & $0.5-9 \mathrm{k}$ & $\underset{9.5}{1369.0(e)}$ & $\begin{array}{r}50 \\
100\end{array}$ & $\begin{array}{l}34.9 \\
0.8(h)\end{array}$ \\
\hline 215 & MECHANICAL VACUUM PUMP AREA & $0.3-4.3 k$ & 79.0 & 50 & 2.0 \\
\hline $\begin{array}{r}216 \\
218 \\
226,227\end{array}$ & $\begin{array}{l}\text { STEAM JET AIR EJECTOR ROOMS } \\
\text { CATALYYTIC RECOMBINER ROOMM } \\
\text { GLANO SLEL ANO PUMPED DRAIN } \\
\text { TANKS AREA }\end{array}$ & $\begin{array}{l}0.1-100 \mathrm{k} \\
0.2-20 \mathrm{k} \\
\mathrm{N} / \mathrm{A}\end{array}$ & $\begin{array}{l}121.0 \\
356.9(\mathrm{e}) \\
18.6\end{array}$ & $\begin{array}{r}50 \\
50 \\
100\end{array}$ & $\begin{array}{l}3.1 \\
9.1 \\
1.3(h)\end{array}$ \\
\hline $\begin{array}{l}228 \\
273 \\
274\end{array}$ & $\begin{array}{l}\text { CONDENSATE STORAGE TANK ENCLOSURE } \\
\text { EEUIPMET ORAN SUMPS } \\
\text { FLOOR DRAIN SUMPS }\end{array}$ & $\begin{array}{l}\mathrm{N} / \mathrm{A} \\
20 \mathrm{k} \\
20 \mathrm{k}\end{array}$ & $\begin{array}{l}562.4(\mathrm{e}) \\
25.1(\mathrm{e}) \\
25.1(\mathrm{e})\end{array}$ & $\begin{array}{r}5 \\
100 \\
100\end{array}$ & $\begin{array}{l}1.7 \\
1.3 \\
1.3\end{array}$ \\
\hline $\begin{array}{l}\text { N/A } \\
700 \\
703\end{array}$ & $\begin{array}{l}\text { SAMPLE ROOM, ELEV. } 134.4 \mathrm{~m} \\
\text { ELEVATOR AREA } \\
\text { RAILROAD TRACK AREA }\end{array}$ & $\begin{array}{l}N / A \\
--(g) \\
N / A\end{array}$ & $\begin{array}{l}30.8 \\
--\end{array}$ & $\begin{array}{l}20 \\
--\end{array}$ & $\begin{array}{l}1.9(h) \\
--\end{array}$ \\
\hline \multicolumn{5}{|l|}{ TOTAL } & 67.0 \\
\hline \multicolumn{6}{|c|}{ 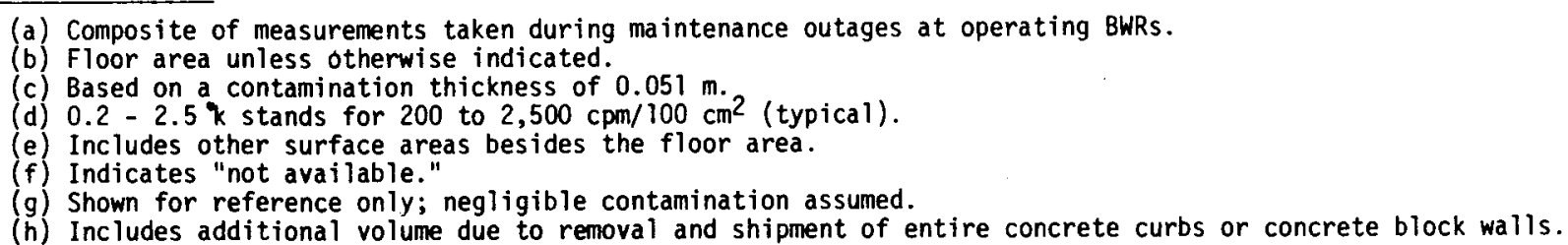 } \\
\hline
\end{tabular}

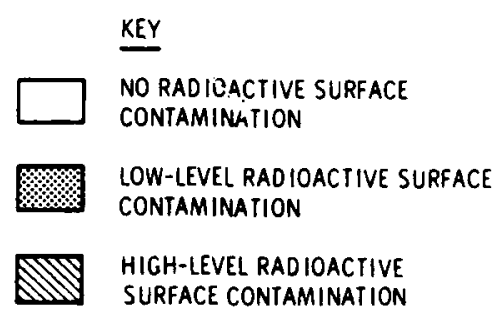

HIGH-LEVEL RADIIOACIIVE
SURFACE CONIAMINATION

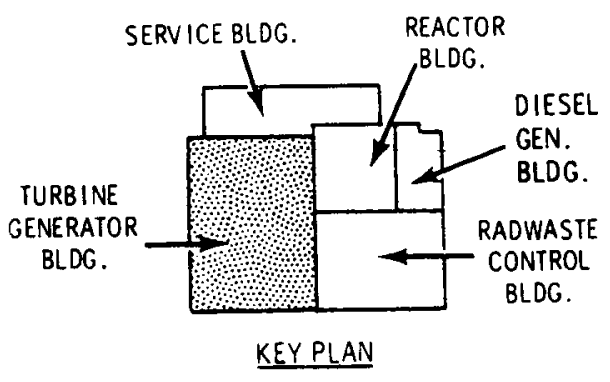

FIGURE D.2-3. Concrete Surface Contamination in the Turbine ing - Elevation 
○ 0 


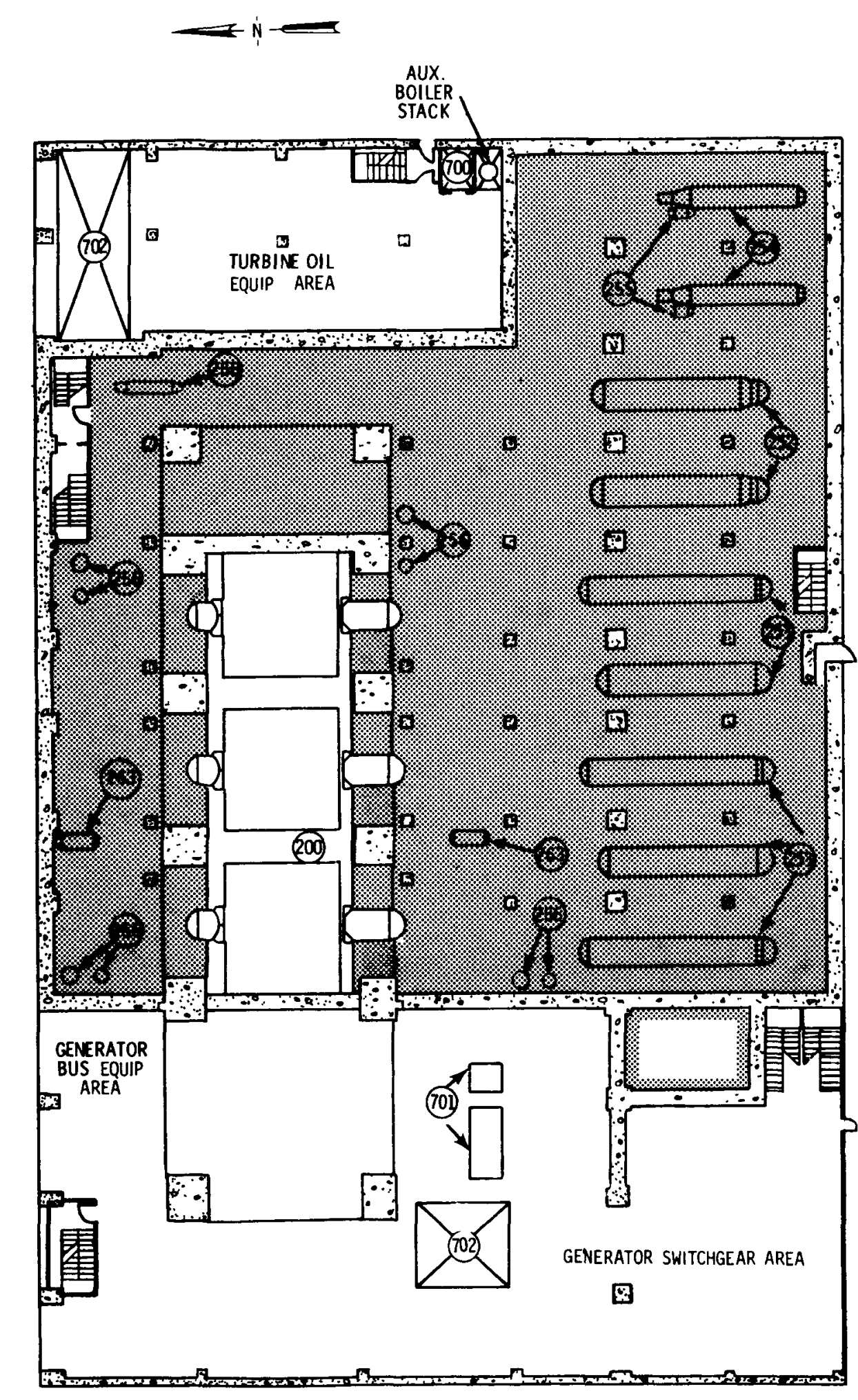

\begin{tabular}{|c|c|c|c|c|c|}
\hline $\begin{array}{l}\text { ASSOCIATED } \\
\text { EQUUPMENT } \\
\text { KEY NUMBER } \\
\end{array}$ & LOCATION & $\begin{array}{l}\text { MEASURED } \\
\text { CONTAMINATION } \\
\text { LEVEL } \\
\left(\begin{array}{l}\left.\text { (cPm/100 } \mathrm{cm}^{2}\right) \\
\end{array}\right.\end{array}$ & $\begin{array}{l}\text { SURFACE } \\
\text { AREA(b) } \\
\left(\mathrm{m}^{2}\right) \\
\end{array}$ & $\begin{array}{l}\text { PERCENT OF } \\
\text { AREA ASSUMED } \\
\text { CONTAMINATED }\end{array}$ & $\begin{array}{l}\text { RUBBLEE } \\
\text { VULUUE }(c) \\
\left(m^{3}\right) \\
\end{array}$ \\
\hline $\begin{array}{l}200 \\
252 \\
253\end{array}$ & $\begin{array}{l}\text { MAIN CONDENSER AREA } \\
\text { HIGH-PRESSURE FEEDWATER HEATER AREA } \\
\text { LOW-PRESSURE FEEDWATER HEATER AREA }\end{array}$ & $\begin{array}{l}0.2-2.7 k(d) \\
0.2-2 k k k\end{array}$ & $\begin{array}{l}391.2 \\
324.8 \\
763.2\end{array}$ & $\begin{array}{l}20 \\
20 \\
20\end{array}$ & $\begin{array}{l}4.0 \\
3.3 . \\
7.8\end{array}$ \\
\hline 254,255 & $\begin{array}{l}\text { STEAM EVAPORATORS AND EVAPORATOR } \\
\text { DRAIN TANK AREA }\end{array}$ & $N / A(f)$ & 319.4 & 20 & 3.3 \\
\hline 256,263 & $\begin{array}{l}\text { REEHATER DRAII TANKS AND MOISTURE } \\
\text { SEPARATOR AREA }\end{array}$ & $N / A$ & $908.7(e)$ & 10 & 4.6 \\
\hline 258 & TURBINE BY-PASS VALVE ASSEMBLY AREA & $30-100 k$ & 436.6 & 20 & 4.4 \\
\hline $\begin{array}{l}700 \\
701 \\
702\end{array}$ & $\begin{array}{l}\text { ELEVATOR } \\
\text { COEERED HATCH } \\
\text { OPEN HATCH }\end{array}$ & $\begin{array}{l}--(g) \\
--\end{array}$ & $\begin{array}{l}--(g) \\
--\end{array}$ & $\begin{array}{l}--(g) \\
-\because\end{array}$ & $\begin{array}{l}--(g) \\
--\end{array}$ \\
\hline
\end{tabular}

ELEVATION $143.6 \mathrm{~m}$

FIGURE D.2-4. Concrete Surface Contamination in the Turbine

Generator Build-

ing - Elevation

$\square$ NO RADIOACTIVE SURFAC

Low-level rad ofactive surface

HIGH-LEVEL RAD DOACTIVE
SURFACE CONTAMINATION

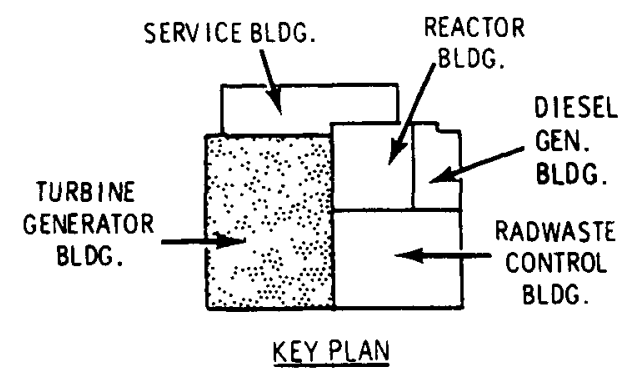

$134.4 \mathrm{~m}$ 


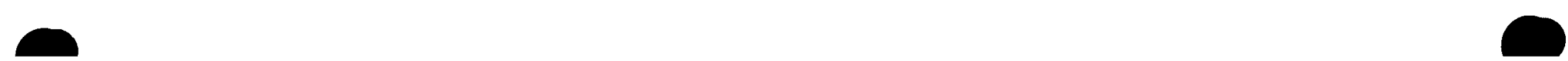




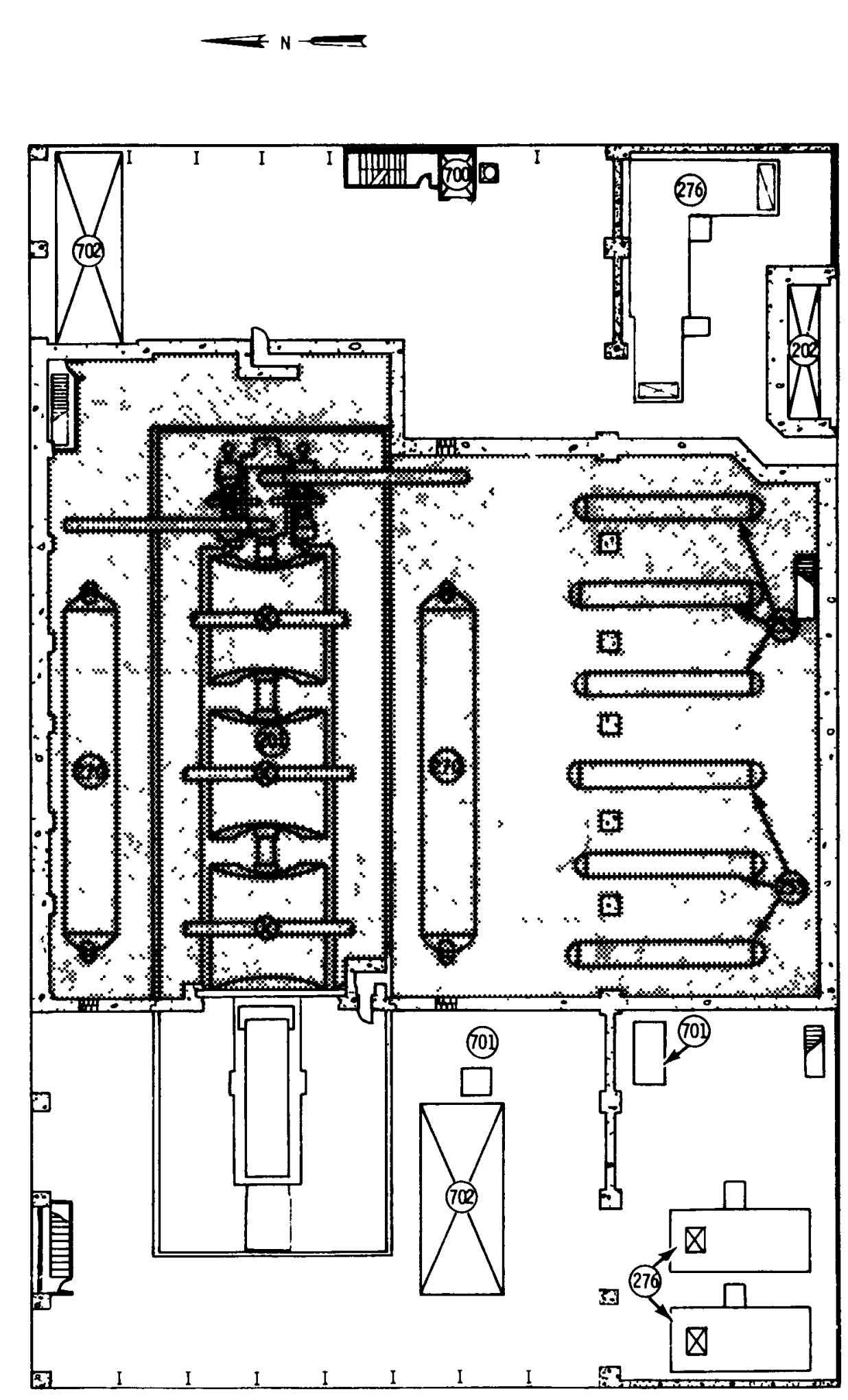

ASSOCIATED
EQUIPMENT

EQUIPMENT

201
253

270

202

276
700
701
702

701

TOTAL

(a) Composite of measurements taken during maintenance outages at operatıng BWRs

(d) $0.4 \mathrm{k}$ stands for 100 to $400 \mathrm{cmm} / 100 \mathrm{~cm}^{2}$ (typical).

(f) Shown for reference only, negi igible contamination assumed.

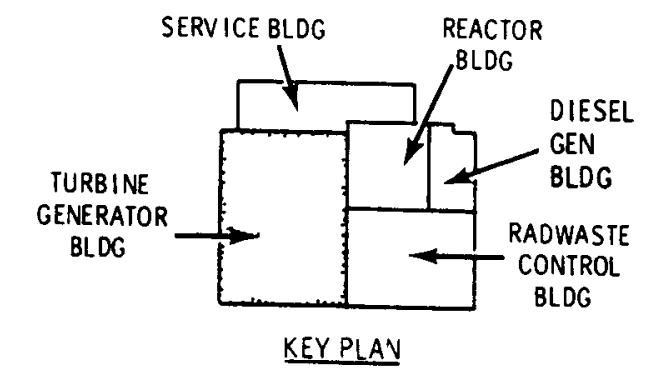

ELEVATION $152.7 \mathrm{~m}$

FIGURE 0.2-5. Concrete Surface Contamination the Turbine

Generator Building - Elevation $152.7 \mathrm{~m}$ 
a 


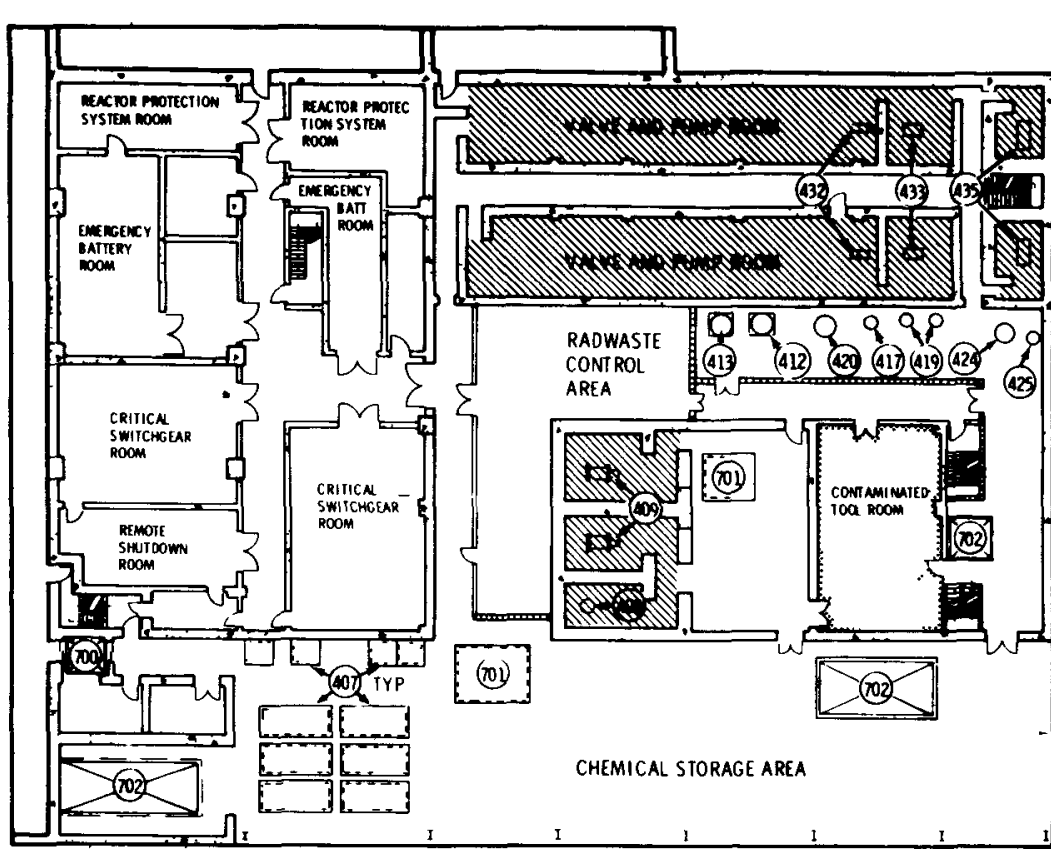

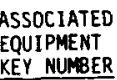

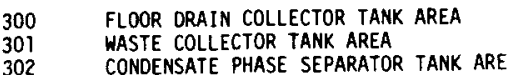

304 CONDENATE BACKASAH RECEVIVING TANK ARE

306
307
MASTEE SLLOGE PHASE SEPARATOR TANK AREA
CEAUP PHASE SEPARATOR TANK AREA CHEMICAL WAASE DIST
ORAIN TANS AREA

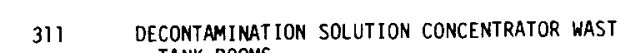

312,313
314

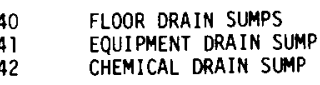

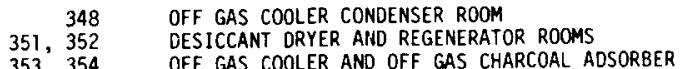

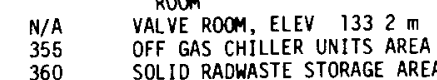

RADWASTE AND CONTROL BUILDING

$$
\longrightarrow N=
$$

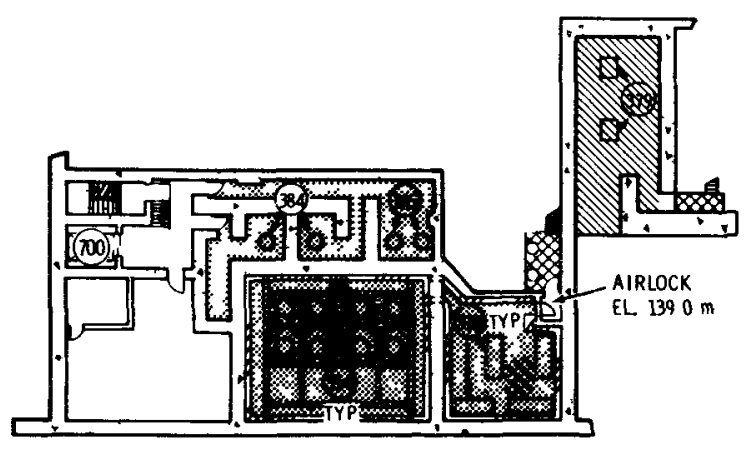

RADWASTE AND CONTROL BUILDING-
N. W. MEZZANINE PLAN AT EEVATION 137,8m
LOCAIION

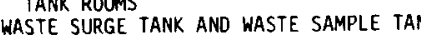

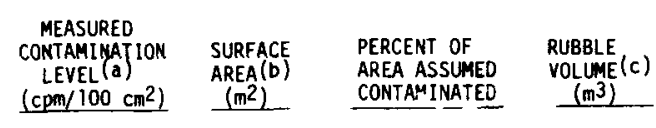

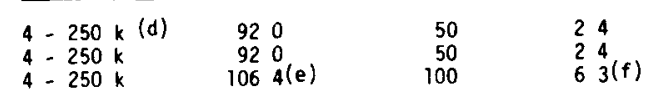

$\begin{array}{llll}4-250 k & 685(\mathrm{e}) & 100 & 41(\mathrm{f}) \\ 4-250 \mathrm{k} & 1957 & 50 & 550 \\ 4-250 k & 244(\mathrm{e}) & 100 & 24(\mathrm{f}) \\ 4.250 k & 620(\mathrm{e}) & 100 & 4(\mathrm{f})\end{array}$

$\begin{array}{cccc}4.250 k & 620(\mathrm{e}) & 100 & 47(\mathrm{f}) \\ 17-130 \mathrm{k} & 637 \mathrm{e}) & 100 & 47(\mathrm{f}) \\ 0.120 k & 1490 & 50 & 38\end{array}$

$\begin{array}{llll}N / A(g) & 337 & 100 & 17\end{array}$

$\begin{aligned} & 02-8 k \\ & 02\end{aligned}-8 k$

$\begin{array}{llll}N / A & 26 & 100 & 15 \\ N / A & 88 & 100 & 15 \\ N / A & 69 & 100 & 04 \\ N & 89 & & \end{array}$

$\begin{array}{cccc}N / A & 468 & 50 & 12 \\ N / A & 710(\mathrm{e}) & 100 & 56(f) \\ N / A & 118 & 100 & 57 \\ N & 58 & 509 & 09\end{array}$

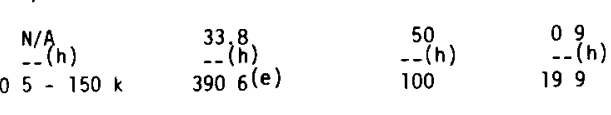

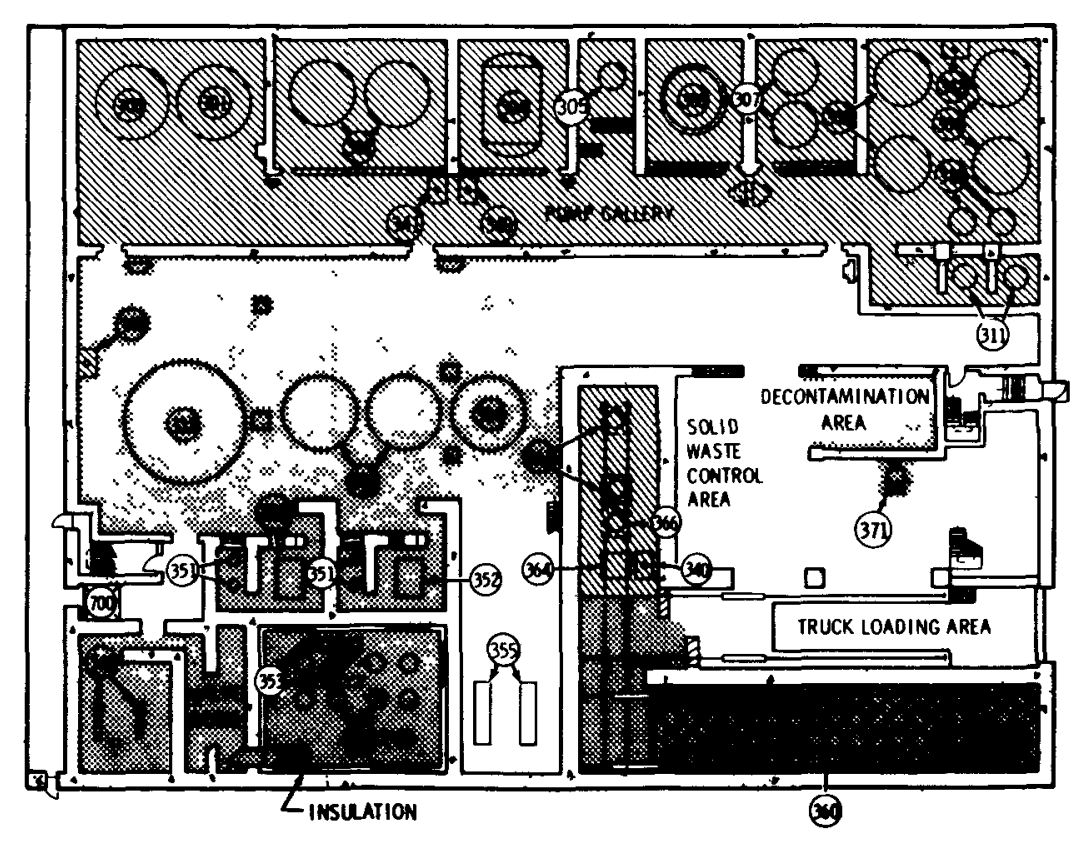

RADWASTE AND CONTROL BUILDING -

FLOP PIANAT GQVATION 133.20 -

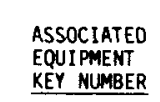

364, 366, 367 SOLID RADWASTE CONTA ANER HASHOON,

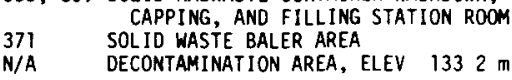

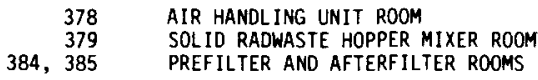

407
408
409
409

12 to to 425 CONTAMTMATED DOOL ROOM, ELEV $1423 \mathrm{~m}$

CLEAUP, HOL PPMP AREAS, VALVE AND PUND
ROOHS, ELEV $1423 \mathrm{~m}$

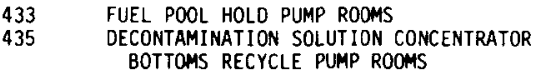

700
701
702

TOTAL

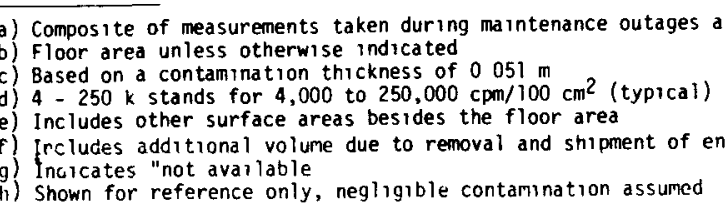
$\square \underline{\underline{K} Y}$

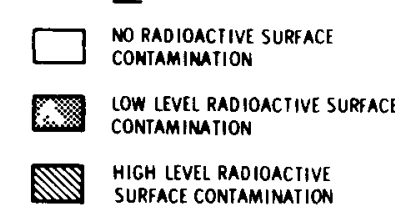

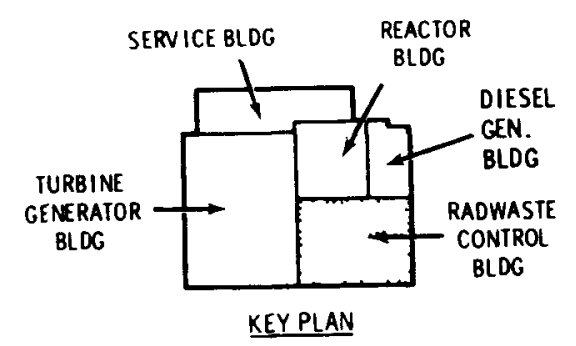

FIGURE D.2-6. Concrete Surface Contamination in the Radwaste and Control Building Sheet 


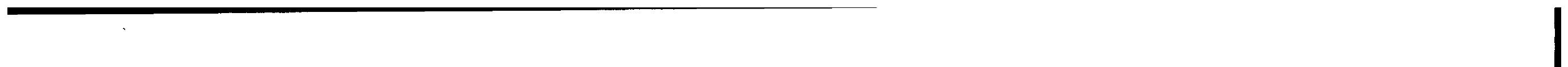

2

0 政 ( - 


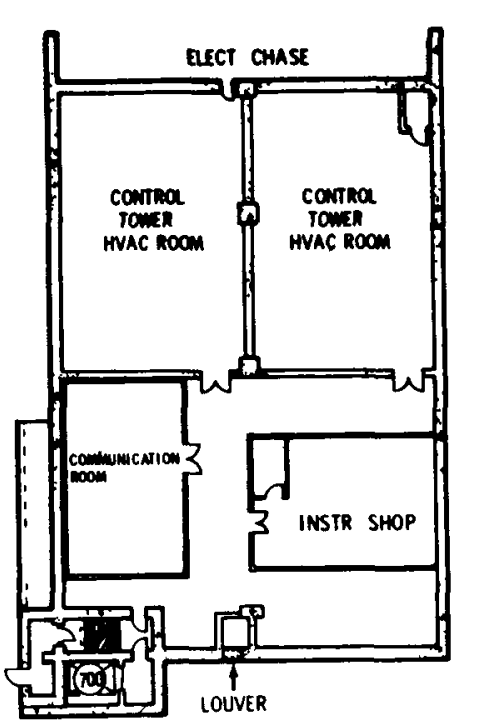

RADWASTE AND CONTROL BUILDING CONTROL ROOM TOWER PLAN

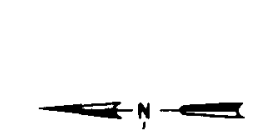

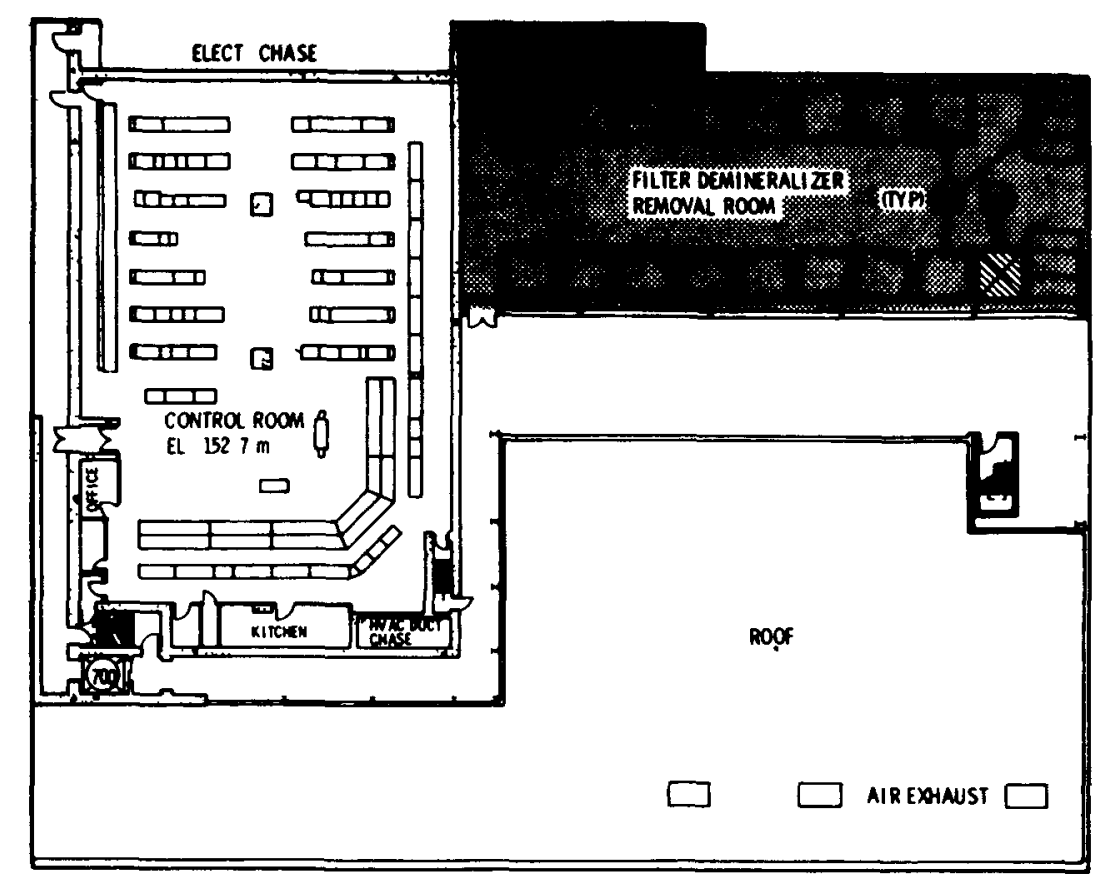

RADWASTE AND CONTROL BUILDING
FLOOR PLAN AT ELEVAFION $154.5 \mathrm{~m}$

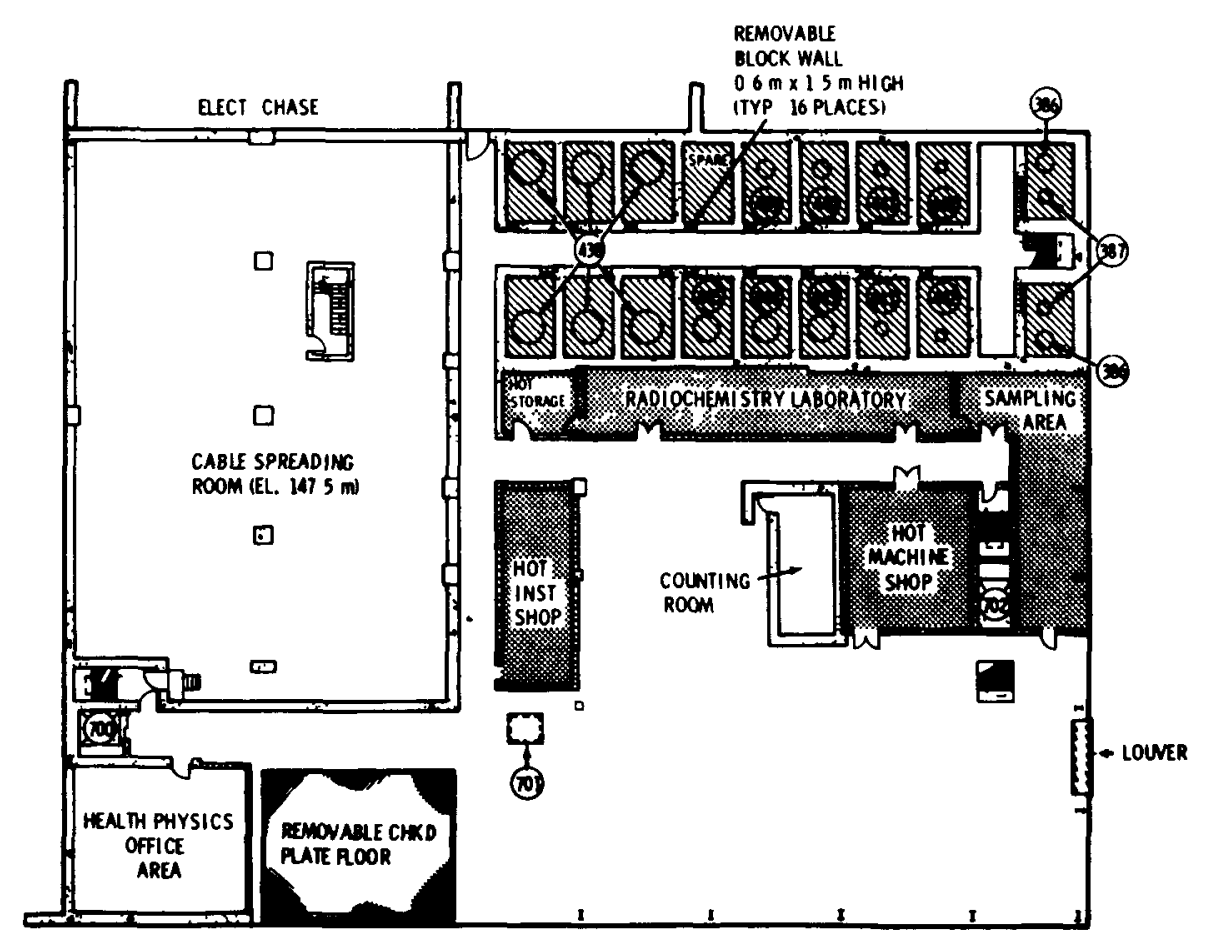

RADWASTE ANO CONTRO BUILDING -

FDOR PLAN AT BEVATION ISB.4
ASSOCIATED
EOUIPMEN
OEY

386, 387 DECONTAMIMTITON SOLUTION CONCENTRATOR ANO

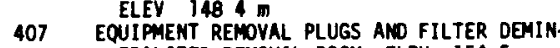

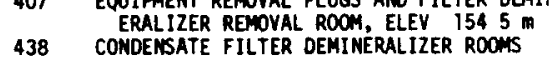

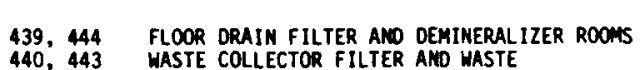

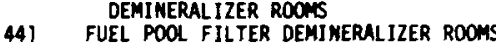

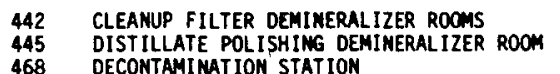

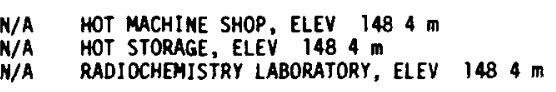

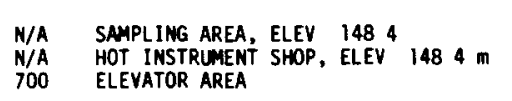

701
702 COYGRED HATCH AREA
OPEN HATCH AREA

TOTAL

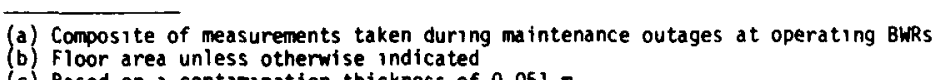

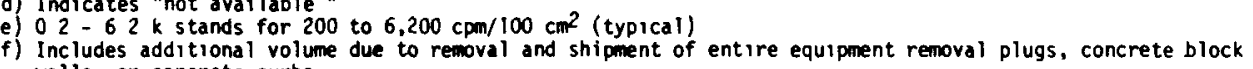
(g) Includes other surface areas besides the floor ared
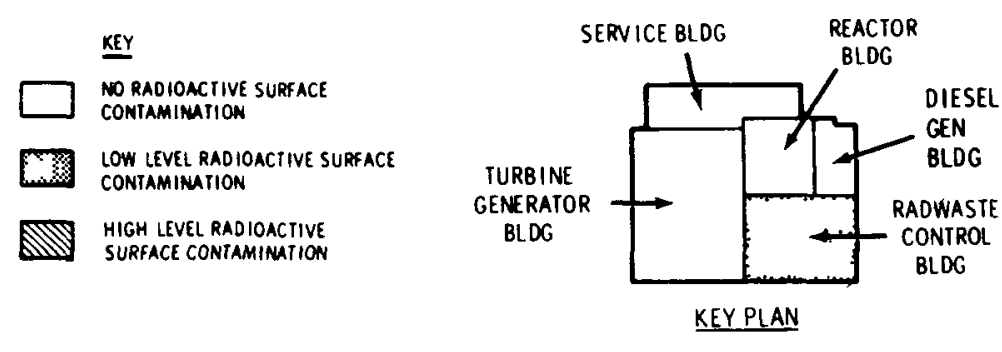

FIGURE $0.2-7$. Concrete Surface Contamination in Contamination and Control Building Sheet 2 
0 


\section{REFERENCES}

1. WPPSS Nuclear Project No. 2 Final Safety Analysis Report, Washington Public Power Supply System, Chapter 12.3, Richland, WA, March 1977.

2. S. G. Sawochka, N. P. Jacob and W. L. Pearl, Primary System Shutdown Radiation Levels at Nuclear Power Generation Stations, EPRI-404-2, Figure 3, December 1975.

3. R. L. Dillion et al., Literature Review of Dilute Chemical Decontamination Processes for Water-Cooled Nuclear Reactors, EPRI NP-1033, Prepared by Battelle, Pacific Northwest Laboratories for Electric Power Research Institute, March 1979. 


\section{APPENDIX E}

\section{RADIONUCLIDE INVENTORIES}

The estimated radionuclide inventories at the shutdown, defueled, reference BWR plant are presented in this appendix, together with supporting information and details of the calculational methods for estimating these inventories. The radionuclide inventories at the time of final reactor shutdown (excluding the irradiated spent fuel) are of two types: 1) neutronactivated components in and surrounding the reactor core, and 2) surface contamination from fission products and activated corrosion products deposited inside certain piping and equipment systems, on some structural surfaces, and on the site.

It should be recognized that the data in this appendix are calculated estimates unique to the reference BWR and are not directly applicable to any other specific BWR.

\section{E. 1 NEUTRON-ACTIVATED COMPONENTS}

The interaction of the neutrons produced in the reactor fuel with the structural materials in and around the reactor vessel radioactivates the elements in these structural materials. Detailed in this section are methods and results of, and supporting information for, the calculations that estimate the inventories and associated dose rates of the neutron-activated radionuclides in these materials.

\section{E.1.1 Radionuclide Inventories in Neutron-Activated Structural Materials}

The types and quantities of radionuclides in the activated reactor component materials at the end of the operating life of the reference BWR are derived using the methodology presented in Reference 1. The calculational models employ a homogenized zone of fuel, coolant, and control rods. The fuel in the models has an average exposure of 12,000 MWD/MTU (the midpoint in the equilibrium BWR fuel-burnup cycle). The radionuclide inventories and the methods used to generate them are discussed below. 


\section{E.1.1.1 Reference Radionuclide Inventories 1,2, and 3}

Three basic types of materials are used in and around the reactor vessel: stainless steel (type 304), carbon steel (type SA533), and concrete. Reference radionuclide inventories for these materials at final reactor shutdown are presented as follows: Table E.1-l for stainless steel (reference radionuclide inventory 1), Table E.1-2 for carbon steel (reference radionuclide inventory 2), and Table E.1-3 for concrete (reference radionuclide inventory 3 ). (a) These inventories are calculated based on the material densities of the reference BWR, the thermal neutron flux distribution at the axial midplane of the fuel zone, and 30 effective full-power years (EFPY) of operation. They represent maximum values for these materials.

These reference radionuclide inventories are used for several purposes in this study. In this section they are used to calculate the total quantities of radioactivity in the structural components in and around the reactor vessel. This information is used in determining disposal requirements and costs whenever removal of any or all of these components is required by a particular decommissioning mode. In Appendix $N$ these inventories are used in assessing public safety of decommissioning activities.

\section{E.1.1.2 Calculational Methods}

Reference 1 describes a series of steps to calculate the inventories of neutron-activated radionuclides reported above. First, the material densities and neutron cross sections of the materials in the homogenized fuel zone and in the structures surrounding the reactor core are calculated. These data are then used to generate neutron flux distributions in the fuel zone and the surrounding components. Finally, the radionuclide inventories in the major components surrounding the fuel zone in the radial direction are calculated using the neutron flux values and the material densities. More details follow.

(a) Reference radionuclide inventory 3 for neutron-activated concrete also contains radionuclides associated with the carbon-steel structural reinforcing beams in the sacrificial shield. 


\section{TABLE E.1-1. Reference Radionuclide Inventory 1,}

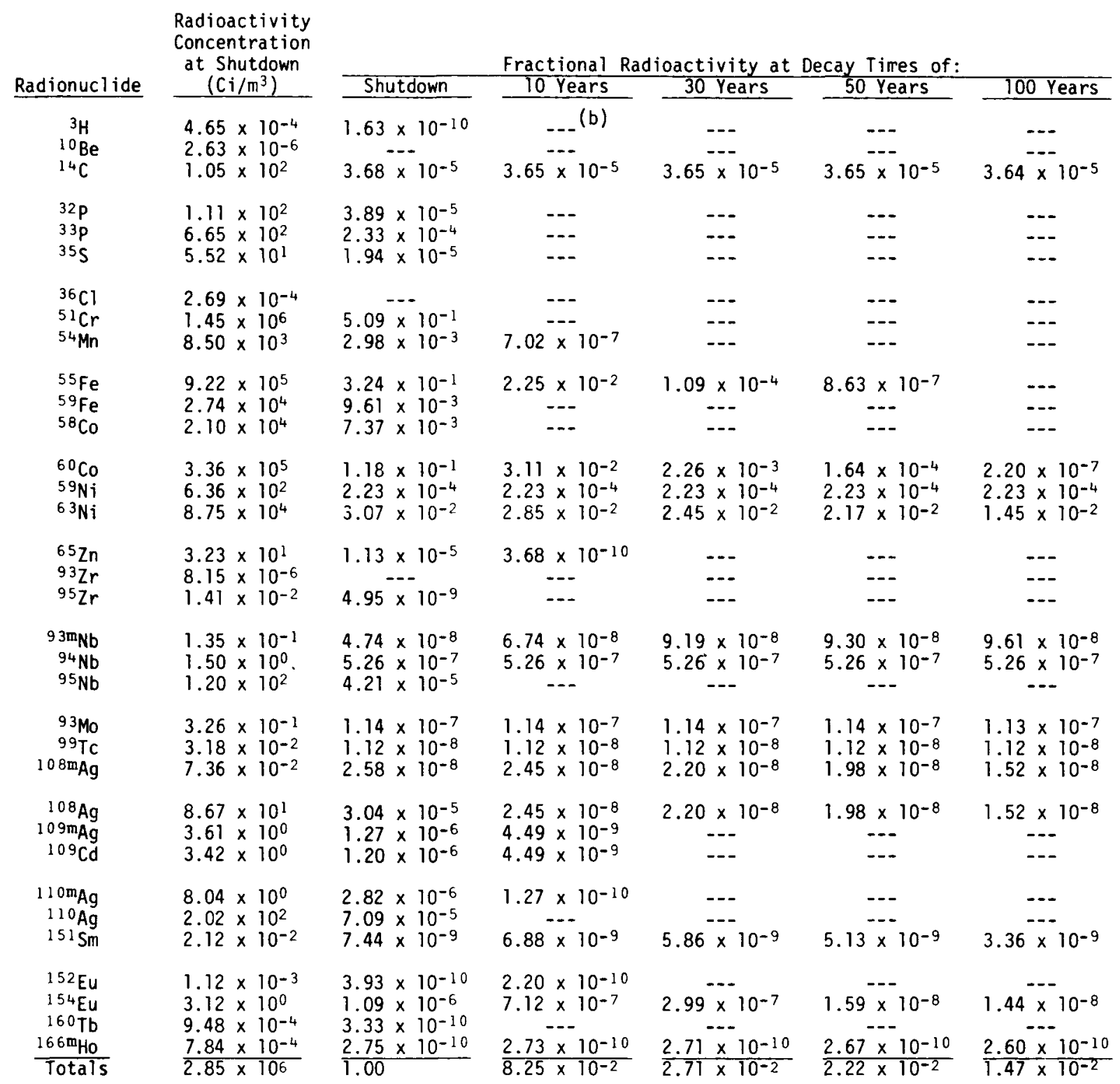

(a) Calculated at the inner surface of the 304 stainless steel core shroud, at the axial midplane of the fuel zone, for 30 EFPY of operation.

(b) Indicates a value of less than $1.00 \times 10^{-10}$. 


\section{TABLE E.1-2. Reference Radioactivity Inventory 2, Neutron-Activated Carbon Steel(a)}

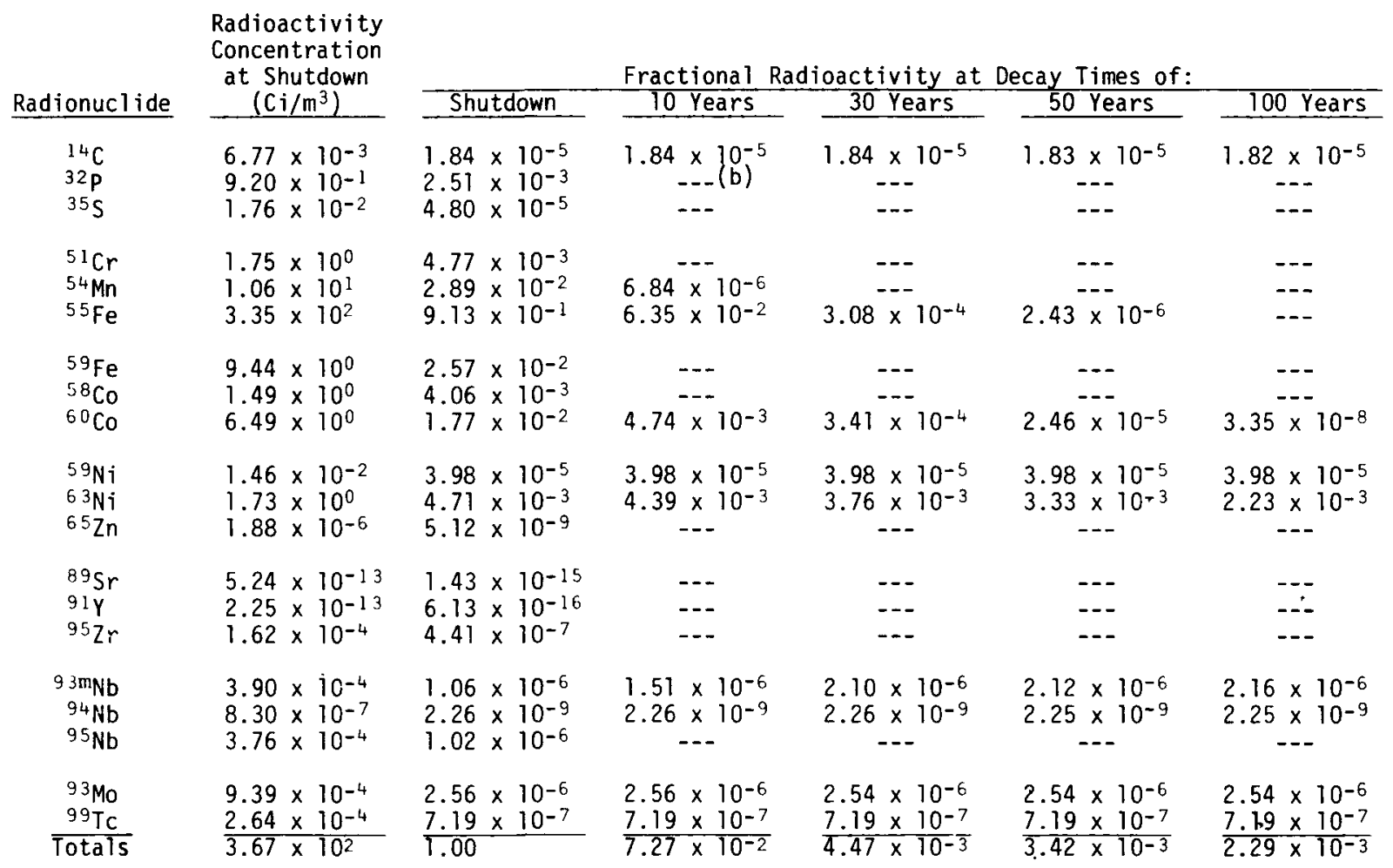

(a) Calculated at the inner surface of the SA533 carbon steel reactor vessel, at the axial midplane of the fuel zone, for 30 EFPY of operation.

(b) Indicates a value of less than $1.00 \times 10^{-10}$. 


\section{TAELE E.1-3. Reference Radionucl ide Inventory 3, Neutron-Activated Concrete(a)}

\begin{tabular}{|c|c|c|c|c|c|c|}
\hline \multirow[b]{2}{*}{ Radionuclide } & \multirow[t]{2}{*}{$\begin{array}{c}\text { Radioactivity } \\
\text { Concentration } \\
\text { at Shutdown } \\
\left(\mathrm{Ci} / \mathrm{m}^{3}\right) \\
\end{array}$} & \multirow{2}{*}{\multicolumn{5}{|c|}{ Fractional Radioactivity at Decay Times of: }} \\
\hline & & & & & 50 Years & 100 Years \\
\hline${ }_{14}^{3} \mathrm{H}$ & $2.58 \times 10^{-6}$ & $6.72 \times 10^{-7}$ & $3.83 \times 10^{-7}$ & $1.23 \times 10^{-7}$ & $4.04 \times 10^{-8}$ & $2.40 \times 10^{-9}$ \\
\hline $\begin{array}{l}{ }^{14} \mathrm{C} \\
32 \mathrm{P}\end{array}$ & $\begin{array}{l}1.36 \times 10^{-4} \\
4.35 \times 10^{-2}\end{array}$ & $3.54 \times 10^{-5}$ & $3.52 \times 10^{-5}$ & $3.52 \times 10^{-5}$ & $3.50 \times 10^{-5}$ & $3.49 \times 10^{-5}$ \\
\hline & & & & & & \\
\hline${ }^{35} \mathrm{~S}$ & $3.25 \times 10^{-3}$ & $8.46 \times 10^{-4}$ & & & $\cdots$ & $\cdots$ \\
\hline${ }^{36} \mathrm{Cl}$ & $1.21 \times 10^{-6}$ & & $3.15 \times 10^{-7}$ & $3.15 \times 10^{-7}$ & $3.15 \times 10^{-7}$ & $3.15 \times 10^{-7}$ \\
\hline${ }^{37} \mathrm{Ar}$ & $3.08 \times 10^{-2}$ & $8.02 \times 10^{-3}$ & -- & -0 & $\cdots$ & \\
\hline${ }^{39} \mathrm{Ar}$ & $5.69 \times 10^{-3}$ & $1.48 \times 10^{-3}$ & $1.45 \times 10^{-3}$ & $1.37 \times 10^{-3}$ & $1.30 \times 10^{-3}$ & $1.15 \times 10^{-3}$ \\
\hline $40 \mathrm{~K}$ & $3.67 \times 10^{-5}$ & $9.55 \times 10^{-6}$ & $9.55 \times 10^{-6}$ & $9.56 \times 10^{-6}$ & $9.56 \times 10^{-6}$ & $.9 .56 \times 10^{-6}$ \\
\hline${ }^{41} \mathrm{Ca}$ & $7.90 \times 10^{-4}$ & $2.06 \times 10^{-4}$ & $2.06 \times 10^{-4}$ & $2.06 \times 10^{-4}$ & $2.06 \times 10^{-4}$ & $2.06 \times 10^{-4}$ \\
\hline${ }^{45} \mathrm{Ca}$ & $3.91 \times 10^{-1}$ & $1.02 \times 10^{-1}$ & $2.22 \times 10^{-8}$ &.- & $-\cdots$ & $\ldots$ \\
\hline $46 S C$ & $2.10 \times 10^{-6}$ & $5.47 \times 10^{-7}$ & ... & -.- &.-- & -.- \\
\hline $51 \mathrm{cr}(\mathrm{c})$ & $1.11 \times 10^{-2}$ & $2.89 \times 10^{-3}$ & -- & $\cdots$ & $\cdots$ & $\cdots$ \\
\hline $54 \mathrm{Mn}(\mathrm{c})$ & $9.60 \times 10^{-3}$ & $2.50 \times 10^{-3}$ & $5.89 \times 10^{-7}$ & $\cdots$ & $\cdots$ & $\cdots$ \\
\hline $55 \mathrm{Fe}(\mathrm{c})$ & $3.15 \times 10^{0}$ & $8.20 \times 10^{-1}$ & $5.68 \times 10^{-2}$ & $2.76 \times 10^{-4}$ & $2.18 \times 10^{-6}$ & -. \\
\hline${ }^{59} \mathrm{Fe}(\mathrm{c})$ & $1.01 \times 10^{-1}$ & $2.63 \times 10^{-2}$ & 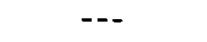 & s & $\ldots$ & -- \\
\hline${ }^{58} \mathrm{Co}(\mathrm{c})$ & $3.00 \times 10^{-3}$ & $7.81 \times 10^{-4}$ & $\cdots$ & $-\ldots$ & $\ldots$ & \\
\hline${ }^{60} \mathrm{Co}(\mathrm{c})$ & $6.45 \times 10^{-2}$ & $1.68 \times 10^{-2}$ & $4.51 \times 10^{-3}$ & $3.23 \times 10^{-4}$ & $2.34 \times 10^{-5}$ & $3.18 \times 10^{-8}$ \\
\hline $59 \mathrm{Ni}(\mathrm{C})$ & $1.24 \times 10^{-4}$ & $3.23 \times 10^{-5}$ & $3.23 \times 10^{-5}$ & $3.23 \times 10^{-5}$ & $3.23 \times 10^{-5}$ & $3.23 \times 10^{-5}$ \\
\hline $6{ }^{3} \mathrm{Ni}(\mathrm{c})$ & $1.47 \times 10^{-2}$ & $3.83 \times 10^{-3}$ & $3.54 \times 10^{-9}$ & $3.05 \times 10^{-3}$ & $2.71 \times 10^{-3}$ & $1.80 \times 10^{-3}$ \\
\hline $93 \mathrm{~m} \mathrm{Nb}$ & $10^{-6}$ & $7.94 \times 10^{-7}$ & $1.13 \times 10^{-6}$ & $1.56 \times 10^{-6}$ & $1.58 \times 10^{-6}$ & $1.61 \times 10^{-6}$ \\
\hline $93 \mathrm{Mo}$ & $7.36 \times 10^{-6}$ & $1.92 \times 10^{-6}$ & $1.91 \times 10^{-6}$ & $1.91 \times 10^{-6}$ & $1.90 \times 10^{-6}$ & $1.90 \times 10^{-6}$ \\
\hline${ }^{99} \mathrm{TC}$ & $4.08 \times 10^{-6}$ & $1.06 \times 10^{-6}$ & $1.06 \times 10^{-6}$ & $1.06 \times 10^{-6}$ & $1.06 \times 10^{-6}$ & $1.06 \times 10^{-6}$ \\
\hline $108 \mathrm{~m} \mathrm{Ag}$ & $9.73 \times 10^{-8}$ & $2.53 \times 10^{-8}$ & $2.40 \times 10^{-8}$ & $2.16 \times 10^{-8}$ & $1.94 \times 10^{-8}$ & $1.49 \times 10^{-8}$ \\
\hline $108 \mathrm{Ag}$ & $1.24 \times 10^{-4}$ & $3.23 \times 10^{-5}$ & $2.40 \times 10^{-8}$ & $2.16 \times 10^{-8}$ & $1.94 \times 10^{-8}$ & $1.49 \times 10^{-8}$ \\
\hline $109 \mathrm{~m} \mathrm{Ag}$ & $2.56 \times 10^{-10}$ & $6.67 \times 10^{-11}$ & -- & -.- & -.- & $-\cdots$ \\
\hline${ }^{109} \mathrm{Cd}$ & $2.17 \times 10^{-10}$ & $5.65 \times 10^{-11}$ & & -- & & 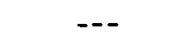 \\
\hline $110 \mathrm{mAg}$ & $6.83 \times 10^{-5}$ & $1.78 \times 10^{-5}$ & $8.05 \times 10^{-10}$ & -- & -- & -- \\
\hline $110 \mathrm{Ag}$ & $1.74 \times 10^{-3}$ & $4.53 \times 10^{-4}$ & $\ldots$ & -- & 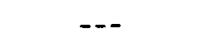 & $-1,-1$ \\
\hline $151 \mathrm{Sm}$ & $1.30 \times 10^{-3}$ & $3.39 \times 10^{-4}$ & $3.13 \times 10^{-4}$ & $2.66 \times 10^{-4}$ & $2.34 \times 10^{-4}$ & $1.53 \times 10^{-4}$ \\
\hline${ }^{152} \mathrm{Eu}$ & $1.00 \times 10^{-2}$ & $2.60 \times 10^{-3}$ & $1.54 \times 10^{-3}$ & $5.51 \times 10^{-4}$ & $1.96 \times 10^{-4}$ & $1.47 \times 10^{-5}$ \\
\hline${ }^{154} \mathrm{Eu}$ & $1.31 \times 10^{-3}$ & $3.41 \times 10^{-4}$ & $1.46 \times 10^{-4}$ & $2.70 \times 10^{-5}$ & $4.98 \times 10^{-6}$ & $7.27 \times 10^{-8}$ \\
\hline $166 \mathrm{mHO}^{2}$ & $3.91 \times 10^{-6}$ & $1.02 \times 10^{-6}$ & $1.01 \times 10^{-6}$ & $1.00 \times 10^{-6}$ & $9.91 \times 10^{-7}$ & $9.63 \times 10^{-7}$ \\
\hline Totals & $3.84 \times 70^{0}$ & $\overline{1.00}$ & $\overline{6.50 \times 10^{-2}}$ & $6.15 \times 10^{-3}$ & $4.76 \times 10^{-3}$ & $\overline{3.41 \times 10^{-3}}$ \\
\hline
\end{tabular}

(a) Calculated at the inner surface of the concrete portion of the sacrificial shield, at the axial midplane of the fuel zone, for 30 EFPY of operation.

(b) Indicates a value of less than $1.00 \times 10^{-10}$.

(c) Due largely to structural steel in the sacrificial shield. 
Material Densities and Cross Sections. The material densities (isotopic compositions) in the homogenized, exposed fuel zone are calculated using the ORIGEN code. (2) Value of thermal and epithermal cross sections for the fuelzone materials are generated by the BRT and EGGNIT codes. ${ }^{(3,4)}$ Data for BRT and EGGNIT come from the ENDF/B-IV files. ${ }^{(5)}$ For these particular calculations, the ENDF/B-IV data are consolidated into 30 energy groups by the ETOG code. (6) Four sets of cross sections for the homogenized, exposed fuel zone are calculated:

1. zero percent coolant voiding with control rods inserted

2. zero percent coolant voiding with control rods withdrawn

3. seventy percent coolant voiding with control rods inserted

4. seventy percent coolant voiding with control rods withdrawn.

The material densities used in calculating the neutron flux distributions in the fuel zone and the surrounding structural components are presented in Table E.1-4.

Neutron Flux Distributions. The distributions of neutron flux throughout the fuel zone and the surrounding components are calculated using the ANISN code. (7) The radial model is based on the material distributions at the axial midplane of the fuel zone and is shown in Figure E.1-1. The axial model is along the axial centerline of the fuel zone and is presented in Figure E.1-2.

The radial neutron flux distribution is calculated using each aforementioned fuel-zone cross section set to determine which set produces the highest flux in the region surrounding the fuel zone. As might be expected, calculations using fuel-zone cross section set 4 produces the highest flux in this region. The radial thermal neutron flux distribution calculated using set 4 is shown in Figure E.1-3.

The axial neutron flux distribution is calculated using a combination of the fuel-zone cross section sets to model the control rod positions and the steam voiding distribution (see Figure E.1-2). The calculated axial thermal neutron flux distribution is presented in Figure E.1-4. 
TABLE E.1-4. Material Densities for Calculating Neutron Flux Distributions

Material Densities in Homogenized Fuel Zone $\left(\right.$ atoms $\left./ \mathrm{cm}^{3}\right)$ (a)

\begin{tabular}{|c|c|c|c|c|}
\hline Isotope & $\begin{array}{l}0 \% \text { Coolant Void, } \\
\text { Control Rods in }\end{array}$ & $\begin{array}{l}0 \% \text { Coolant Void, } \\
\text { Control Rods out }\end{array}$ & $\begin{array}{l}70 \% \text { Coolant Void, } \\
\text { Control Rods in }\end{array}$ & $\begin{array}{l}70 \% \text { Coolant Void, } \\
\text { Control Rods out }\end{array}$ \\
\hline $\begin{array}{l}235 U \\
236 U \\
238 U\end{array}$ & $\begin{array}{l}6.449 \times 10^{19} \\
1.363 \times 10^{19} \\
5.205 \times 10^{21}\end{array}$ & $\begin{array}{l}6.449 \times 10^{19} \\
1.363 \times 10^{19} \\
5.205 \times 10^{21}\end{array}$ & $\begin{array}{l}6.449 \times 10^{19} \\
1.363 \times 10^{19} \\
5.205 \times 10^{21}\end{array}$ & $\begin{array}{l}6.449 \times 10^{19} \\
1.363 \times 10^{19} \\
5.205 \times 10^{21}\end{array}$ \\
\hline $\begin{array}{l}239 \mathrm{pu} \\
240 \mathrm{Pu} \\
241 \mathrm{Pu}\end{array}$ & $\begin{array}{l}2.113 \times 10^{19} \\
7.246 \times 10^{18} \\
2.674 \times 10^{18}\end{array}$ & $\begin{array}{l}2.113 \times 10^{19} \\
7.246 \times 10^{18} \\
2.674 \times 10^{18}\end{array}$ & $\begin{array}{l}2.113 \times 10^{19} \\
7.246 \times 10^{18} \\
2.674 \times 10^{18}\end{array}$ & $\begin{array}{l}2.113 \times 10^{19} \\
7.246 \times 10^{18} \\
2.674 \times 10^{18}\end{array}$ \\
\hline $\begin{array}{r}242 \mathrm{Pu} \\
135 \mathrm{Xe} \\
\mathrm{Zr}\end{array}$ & $\begin{array}{l}5.808 \times 10^{17} \\
6.325 \times 10^{14} \\
7.488 \times 10^{22}\end{array}$ & $\begin{array}{l}5.808 \times 10^{17} \\
6.325 \times 10^{14} \\
6.654 \times 10^{21}\end{array}$ & $\begin{array}{l}5.808 \times 10^{17} \\
6.325 \times 10^{14} \\
7.488 \times 10^{22}\end{array}$ & $\begin{array}{l}5.808 \times 10^{17} \\
6.325 \times 10^{14} \\
6.654 \times 10^{21}\end{array}$ \\
\hline $\begin{array}{r}{ }^{10} \mathrm{~B} \\
0 \\
\mathrm{H}\end{array}$ & $\begin{array}{l}1.674 \times 10^{20} \\
2.530 \times 10^{22} \\
2.894 \times 10^{22}\end{array}$ & $\begin{array}{l}0.0 \\
2.557 \times 10^{22} \\
2.948 \times 10^{22}\end{array}$ & $\begin{array}{l}1.674 \times 10^{20} \\
1.517 \times 10^{22} \\
8.683 \times 10^{21}\end{array}$ & $\begin{array}{l}0.0 \\
1.525 \times 10^{22} \\
8.844 \times 10^{21}\end{array}$ \\
\hline
\end{tabular}

Material Densities in Structural Materials Surrounding the Fuel Zone (wt\%) Element 304 Stainless Steel $\quad$ SA533 Carbon Steel Concrete(b)

$\mathrm{Cr}$

$\mathrm{Fe}$

$\mathrm{Ni}$

$\mathrm{C}$

$\mathrm{Ca}$

$\mathrm{Si}$

K

A1

$\mathrm{Na}$

0

H
19.0

67.9

10.0

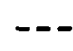

$\cdots$

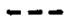

$\cdots$

$\cdots$

-.-

$\cdots$ (c)

99.3

0.5

3.4

0.02

0.2

$\begin{array}{lr}0.2 & 7.2 \\ --- & 27.6 \\ -- & 1.7 \\ -- & 4.0 \\ -- & 1.5 \\ -- & 43.7 \\ -- & 0.5\end{array}$

(a)Fuel exposed to 12,000 MWD/MTU.

(b) Includes carbon steel at the material density of the reinforcing steel in the concrete region of the sacrificial shield.

(c) Indicates none of that particular element in that particular structural material. 


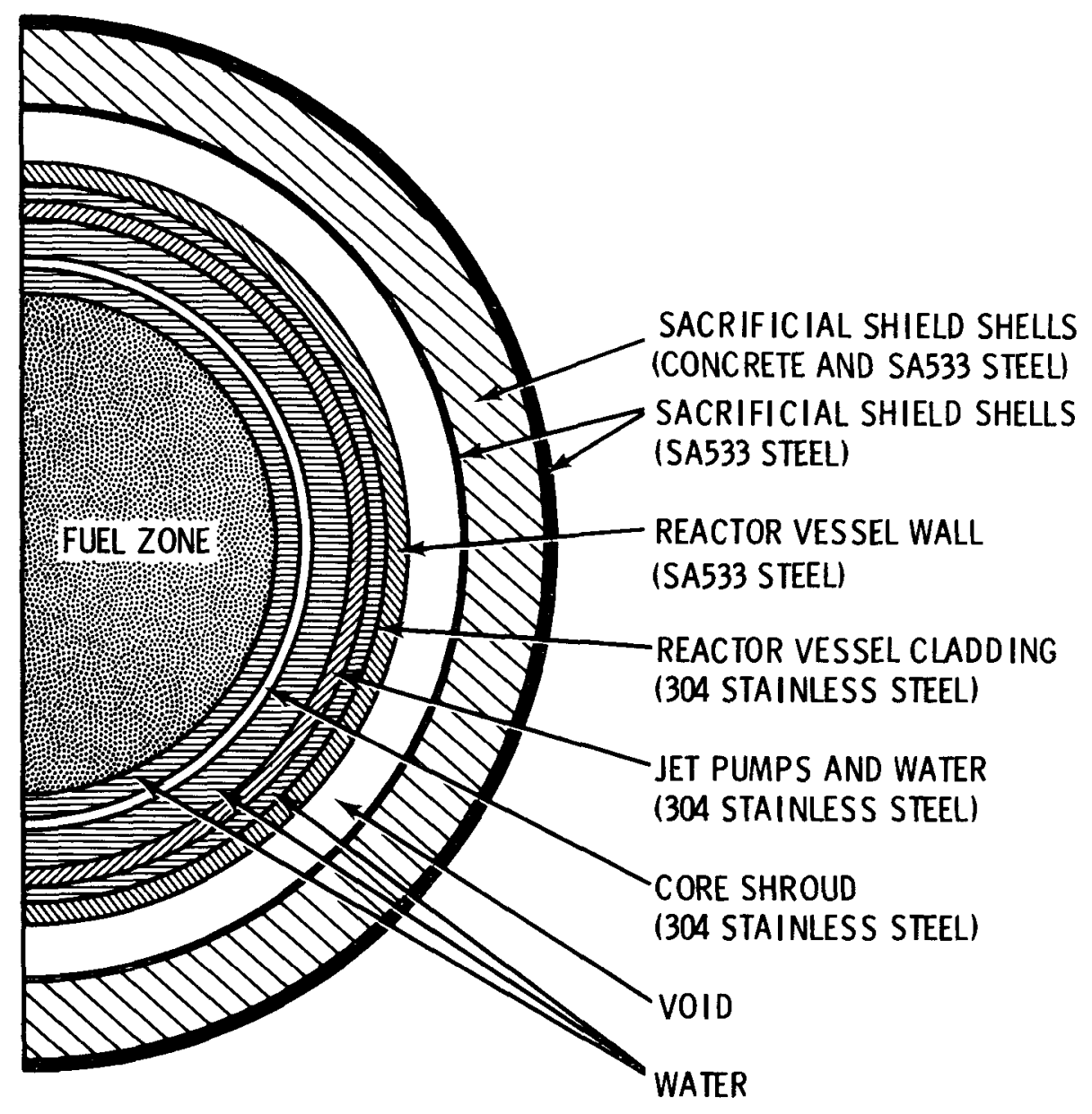

\begin{tabular}{|c|c|}
\hline REGION & $\begin{array}{l}\text { RADIAL DISTANCE TO- } \\
\text { INNER BOUNDARY, m } \\
\end{array}$ \\
\hline $\begin{array}{l}\text { FUEL ZONE } \\
\text { WATER } \\
\text { CORE SHROUD }\end{array}$ & $\begin{array}{l}0.0 \\
2.377 \\
2.579\end{array}$ \\
\hline $\begin{array}{l}\text { WATER } \\
\text { JET PUMPS AND WATER } \\
\text { WATER }\end{array}$ & $\begin{array}{l}2.630 \\
2.959 \\
3.086\end{array}$ \\
\hline $\begin{array}{l}\text { VESSEL CLADDING } \\
\text { VESSEL WALL } \\
\text { VOID }\end{array}$ & $\begin{array}{l}3.210 \\
3.215 \\
3.378\end{array}$ \\
\hline $\begin{array}{l}\text { SACRIFICIAL SHIELD INNER SHELL } \\
\text { CONCRETE AND STRUCTURAL STEEL } \\
\text { OUTER SHELL } \\
\text { OUTER BOUNDARY }\end{array}$ & $\begin{array}{l}3.937 \\
3.957 \\
4.566 \\
4.614\end{array}$ \\
\hline
\end{tabular}

FIGURE E.1-1. BWR Model for Radial Neutron Flux Distribution Calculation 


\begin{tabular}{|c|c|c|c|c|c|c|c|c|}
\hline \multirow[b]{2}{*}{ AXIAL COMPONENT } & & \multirow{2}{*}{$\begin{array}{l}\text { AXIAL LOCATION OF } \\
\text { OUTER BOUNDARY (m) } \\
\end{array}$} & \multicolumn{6}{|c|}{ MATER IAL VOLUME FRACTIONS } \\
\hline & & & $\begin{array}{l}\text { STA INLESS } \\
\text { STEEL } \\
\end{array}$ & ZIRCONIUM & VOID & $\begin{array}{l}\text { BORON } \\
\text { CARBIDE } \\
\end{array}$ & WATER & STEAM \\
\hline $\begin{array}{l}\text { STEAM } \\
\text { SEPARATOR } \\
\text { RISERS }\end{array}$ & 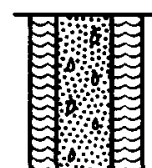 & 5.233 & 0.040 & 0.000 & 0.000 & 0.000 & 0.624 & 0.336 \\
\hline $\begin{array}{l}\text { SHROUD HEAD } \\
\text { PLATE }\end{array}$ & & $\begin{array}{l}2.972 \\
2.921\end{array}$ & 0.933 & 0.000 & 0.000 & 0.000 & 0.020 & 0.047 \\
\hline STEAM DOME & & 2.499 & 0.000 & 0.000 & 0.000 & 0.000 & 0.300 & 0.700 \\
\hline FUEL ELEMENT HANDLE & & 2.398 & 0.014 & 0.000 & 0.000 & 0.000 & 0.296 & 0.690 \\
\hline TOP FUEL GUIDE & & 2285 & 0.069 & 0.048 & 0.000 & 0.000 & 0.265 & 0.618 \\
\hline TIE PLATE & & 2.263 & 0.359 & 0.160 & 0.000 & 0.000 & 0.144 & 0.337 \\
\hline END PIN & & $\begin{array}{l}2.203 \\
2.242\end{array}$ & 0.079 & 0.160 & 0.000 & 0.000 & 0.228 & 0.533 \\
\hline END CAP & 7 & 2.235 & 0.069 & 0.370 & 0.000 & 0.000 & 0.168 & 0.393 \\
\hline PLENUM AND SPRING & & 2.032 & 0.079 & 0.120 & 0.240 & 0.000 & 0.168 & 0.393 \\
\hline GAS PLENUM & & 1.829 & 0.010 & 0.120 & 0.240 & 0.000 & 0.190 & 0.440 \\
\hline & & 1. 130 & 0.000 & 0.120 & 0.000 & 0.000 & 0.195 & 0.435 \\
\hline UPPER FUEL ZONE & & 0.560 & 0.000 & 0.120 & 0.000 & 0.000 & 0.239 & 0.391 \\
\hline (AXIAL MIDPLANE) & 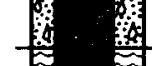 & 0.000 & 0.000 & 0.120 & 0.000 & 0.000 & 0.311 & 0.319 \\
\hline & & -0.750 & 0.000 & 0.120 & 0.000 & 0.0004 & 0.4199 & 0.2097 \\
\hline LOWER FUEL ZONE & 辰 & -1.250 & 0.000 & 0.120 & 0.000 & 0.0006 & 0.5413 & 0.0881 \\
\hline & & -1.829 & 0.000 & 0.120 & 0.000 & 0.0014 & 0.6223 & 0.0063 \\
\hline END CAP & & -1.848 & 0.000 & 0.370 & 0.000 & 0.0078 & 0.6222 & 0.0000 \\
\hline TIE PLATE & & -1860 & 0.350 & 0.200 & 0.000 & 0.0078 & 0.4422 & 0.0000 \\
\hline FUEL SUPPORT PIECE & 鹿 & -2.057 & 0.250 & 0.000 & 0.000 & 0.0078 & 0.7422 & 0.0000 \\
\hline CORE SUPPORT PLATE & & -2.108 & 0.580 & 0.000 & 0.000 & 0.0078 & 0.4122 & 0.0000 \\
\hline $\begin{array}{l}\text { FUEL ELEMENT } \\
\text { FLOW ORIFICE }\end{array}$ & & -2.210 & 0.109 & 0.000 & 0.000 & 0.0078 & 0.8834 & 0.0000 \\
\hline $\begin{array}{l}\text { CONTROL RODS } \\
\text { AND }\end{array}$ & $\Leftrightarrow$ & -5.486 & 0.064 & 0.000 & 0.000 & 0.0073 & 0.9287 & 0.0000 \\
\hline GUIDE TUBES & 国园 & -6.121 & 0.071 & 0.000 & 0.000 & 0.0000 & 0.9290 & 0.0000 \\
\hline
\end{tabular}

FIGURE E.1-2. BWR Model for Axial Neutron Flux Distribution Calculation 


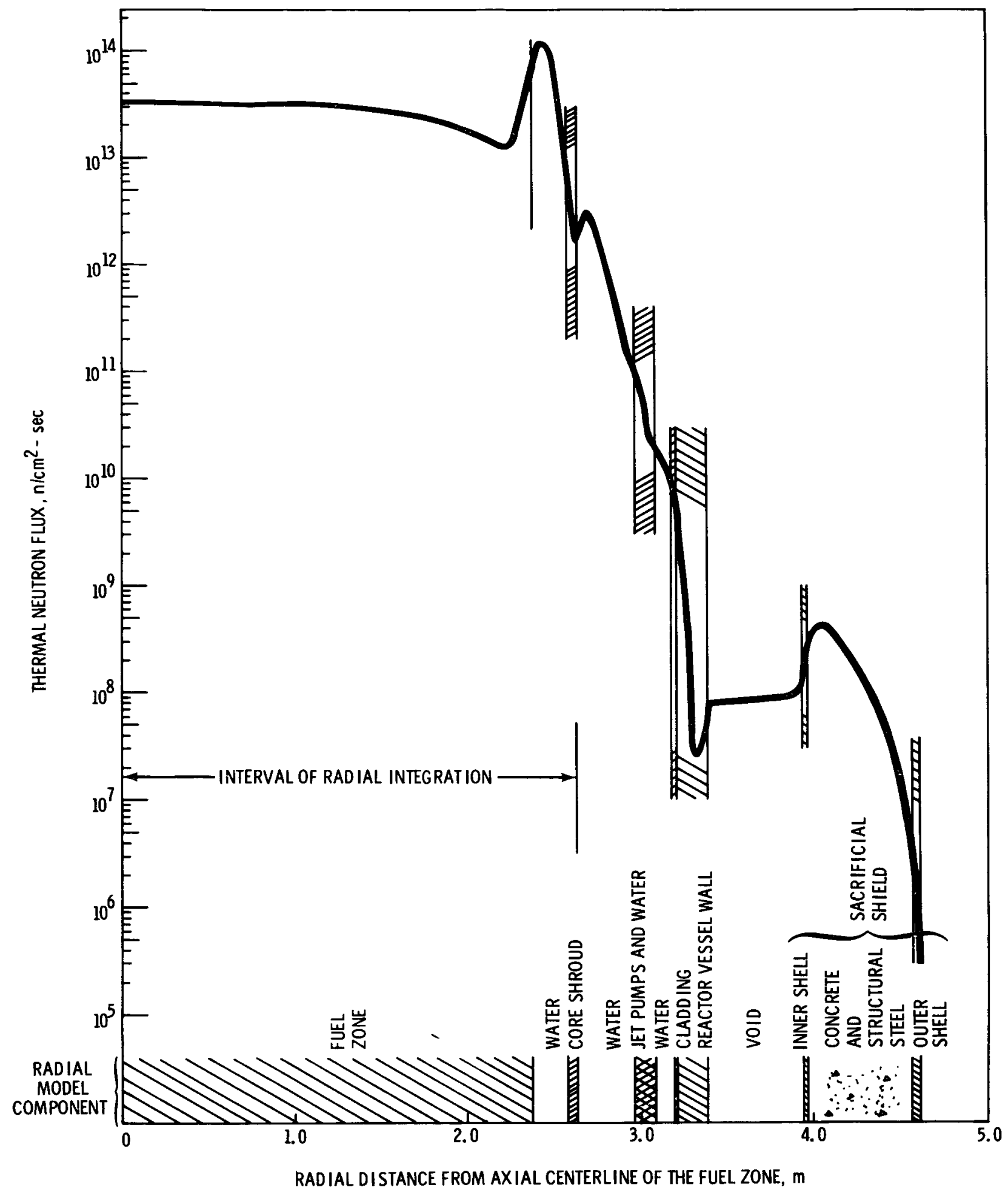

FIGURE E.1-3. Radial Thermal Neutron Flux Distribution at Core Axial Midplane 


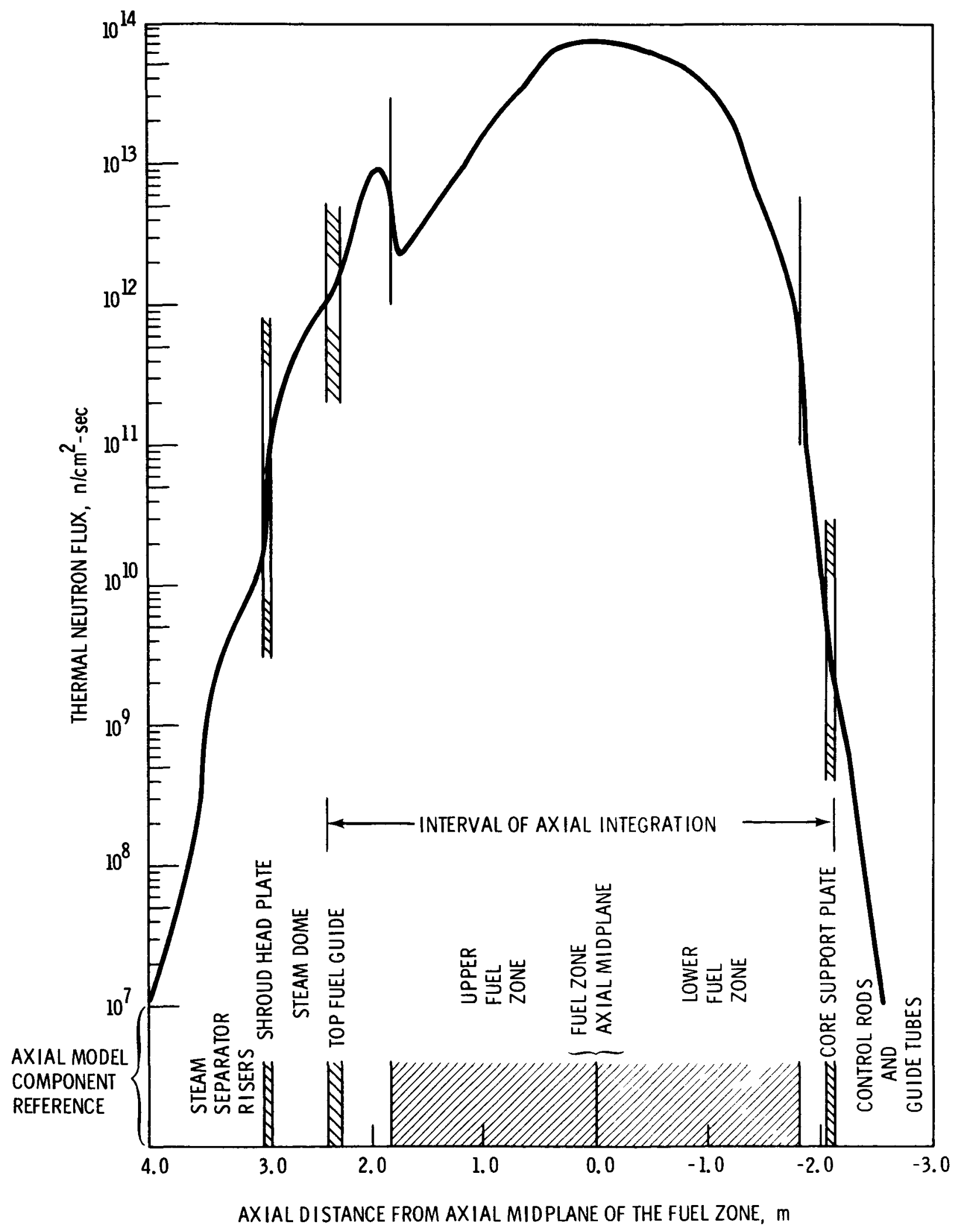

FIGURE E.1-4. Axial Thermal Neutron Flux Distribution 
Radionuclide Inventories. The neutron flux values at the components of interest surrounding the fuel zone are used in ORIGEN production-depletion calculations to obtain the radionuclide inventories in these various reactor components after 30 EFPY of reactor operation. The material compositions used in these calculations are shown in Table E.1-5.

The calculated buildups of selected radionuclides in the core shroud are illustrated in Figure E.7-5, with the concentration of each radionuclide normalized to unity at 30 EFPY. As might be expected, the shorter-lived radionuclides, such as ${ }^{55} \mathrm{Fe}$ and ${ }^{60} \mathrm{Co}$, reach an equilibrium concentration after about 23 years, while the concentrations of the long-lived radionuclides, such as ${ }^{59} \mathrm{Ni}$ and ${ }^{94} \mathrm{Nb}$, increase almost linearly with increased irradiation time.

For perspective, the Elk River Reactor had operated for about 2.5 EFPY when it was dismantled. Based on the calculations for this study, the levels of the long-lived radionuclides at Elk River were less than 10\% of those that will be present in the reference BWR after 30 EFPY. The shorter-lived radionuclides like ${ }^{55} \mathrm{Fe}$ and ${ }^{60} \mathrm{Co}$ probably reached about $50 \%$ and $30 \%$, respectively, of their 30-EFPY values at Elk River.

The calculated radioactivity concentrations in the core shroud, the reactor pressure vessel, and in the sacrificial shield at the time of final reactor shutdown are the bases for the reference radionuclide inventories presented in Section E.1.1.1. Along with the principal radionuclides from activation of major material constituents, the activation products from a number of elements that are present only in trace amounts $(\leq$ a few hundred parts per million by weight) are taken into consideration. Some of these activated trace elements have long half-lives and can contribute to the external dose rate after about 100 years of decay, as is the case of ${ }^{94} \mathrm{Nb}$.

\section{E.1.2 Estimated Total Radioactivity in Neutron-Activated Components}

The information presented in Section E.1.1 is used to estimate the total radioactivity in the reactor vessel and in the structural components in and around it. Only those components immediately surrounding the fuel zone are considered since the neutron flux levels decrease rapidly outside of that 
TABLE E.1-5. Material Compositions Used in Radionuclide Inventory Calculations

\begin{tabular}{|c|c|c|c|c|c|}
\hline \multirow[b]{2}{*}{ Element } & \multirow[b]{2}{*}{ Isotope } & \multirow{2}{*}{$\begin{array}{r}\text { Initial } \\
\text { Isotope } \\
\text { Abundance } \\
\end{array}$} & \multicolumn{3}{|c|}{ Nominal Elemental Weight Percent in } \\
\hline & & & $\begin{array}{c}\text { Tnternals } \\
304 \text { Stainless } \\
\end{array}$ & $\begin{array}{l}\text { Reactor Vessel } \\
\text { SA533 Steel } \\
\end{array}$ & $\begin{array}{c}\text { Sacrificial } \\
\text { shield Concrete } \\
\end{array}$ \\
\hline H & ${ }_{2}^{{ }_{2}}$ & $\begin{array}{r}99.985 \\
0.015\end{array}$ & $\ldots$ (a) & $m$ & 0.53 \\
\hline$c$ & $\begin{array}{l}{ }^{12} \mathrm{C} \\
{ }^{13} \mathrm{C}\end{array}$ & $\begin{array}{r}98.89 \\
1.11\end{array}$ & 008 & 0.25 & 0.03 \\
\hline N & $\begin{array}{l}14 \mathrm{~N} \\
15 \mathrm{~N}\end{array}$ & $\begin{array}{r}99.64 \\
0.36\end{array}$ & 0.04 & 0006 & 0.0013 \\
\hline 0 & $\begin{array}{l}160 \\
170 \\
180\end{array}$ & $\begin{array}{l}99.756 \\
0.039 \\
0.205\end{array}$ & $\cdots$ & $\cdots$ & 43.7 \\
\hline $\mathrm{Na}$ & $2{ }^{3} \mathrm{Na}$ & 100.0 & --- & --- & 1.5 \\
\hline Mg & $\begin{array}{l}24 \mathrm{Mg} \\
25 \mathrm{Mg} \\
26 \mathrm{Mg}\end{array}$ & $\begin{array}{l}78.00 \\
10.0 \\
11.01\end{array}$ & $\cdots$ & $\cdots$ & 0.23 \\
\hline A) & ${ }^{27} \mathrm{Al}$ & 100.0 & -- & -- & 4.0 \\
\hline S1 & $\begin{array}{l}285 i \\
29 S 1 \\
{ }^{20} S 1\end{array}$ & $\begin{array}{r}92.2 \\
4.7 \\
3.1\end{array}$ & 1.00 & 0.04 & 27.6 \\
\hline $\mathbf{P}$ & ${ }^{31 p}$ & 100.0 & 0.0005 & 0.035 & 0.0045 \\
\hline 5 & $\begin{array}{l}325 \\
335 \\
345 \\
365\end{array}$ & $\begin{array}{l}95.0 \\
0.75 \\
4.2 \\
0.015\end{array}$ & 0.03 & 0.04 & 0.12 \\
\hline$k$ & $\begin{array}{l}39 k \\
40 k \\
41 k\end{array}$ & $\begin{array}{l}93.3 \\
0.012 \\
6.7\end{array}$ & --- & --- & 1.7 \\
\hline $\mathrm{Ca}$ & $\begin{array}{l}{ }^{40} \mathrm{Ca} \\
42 \mathrm{Ca} \\
43 \mathrm{Ca} \\
44 \mathrm{Ca} \\
46 \mathrm{Ca} \\
48 \mathrm{Ca}\end{array}$ & $\begin{array}{c}96.94 \\
0.65 \\
0.14 \\
2.08 \\
0.003 \\
0.19\end{array}$ & $\cdots$ & --- & 7.2 \\
\hline $\mathrm{Cr}$ & $\begin{array}{l}50 \mathrm{Cr} \\
52 \mathrm{Cr} \\
53 \mathrm{Cr} \\
54 \mathrm{Cr}\end{array}$ & $\begin{array}{c}4.35 \\
83.79 \\
9.5 \\
2.36\end{array}$ & 17.0 & 0.52 & 0.064 \\
\hline Fe & $\begin{array}{l}54 \mathrm{Fe} \\
56 \mathrm{Fe} \\
57 \mathrm{Fe} \\
58 \mathrm{Fe}\end{array}$ & $\begin{array}{c}5.8 \\
91.7 \\
2.14 \\
0.31\end{array}$ & 685 & 9443 & $\begin{array}{l}13.4 \text { (includes } \\
\text { reinforcing steel) }\end{array}$ \\
\hline$M n$ & ${ }^{55} \mathrm{~mm}$ & 100.0 & 2.0 & 2.85 & 0.19 \\
\hline Ni & $\begin{array}{l}58 \mathrm{N1} \\
60 \mathrm{N1} \\
61 \mathrm{N1} \\
64 \mathrm{N1}^{2}\end{array}$ & $\begin{array}{r}68.3 \\
26.1 \\
1.1 \\
0.9\end{array}$ & 100 & 073 & 0.094 \\
\hline Co & ${ }^{59} \mathrm{CO}$ & 100.0 & $005-0.15$ & $0.006-0.012$ & 0.00073 \\
\hline Cu & $\begin{array}{l}{ }^{6}{ }^{3} \mathrm{Cu} \\
{ }^{5} \mathrm{Cu}\end{array}$ & $\begin{array}{l}69.2 \\
30.8\end{array}$ & 0.15 & 0.11 & 0.014 \\
\hline Mo & $\begin{array}{r}92 \% 0 \\
94 \% 0 \\
95 \% 0 \\
96 \% 0 \\
97 \%_{0} \\
98 \% 0 \\
100 \% 0\end{array}$ & $\begin{array}{r}14.8 \\
9.1 \\
15.9 \\
16.7 \\
9.5 \\
24.4 \\
9.6\end{array}$ & 005 & 0.64 & 0.082 \\
\hline Mb & $93 \mathrm{KBb}$ & 100.0 & 0.016 & $\cdots$ & $\ldots$ \\
\hline Ag & $\begin{array}{l}107 \mathrm{Ag} \\
109 \mathrm{Ag}\end{array}$ & $\begin{array}{l}51.8 \\
48.2\end{array}$ & 0.00004 & --- & 0.00008 \\
\hline cs & ${ }^{133} \mathrm{Cs}$ & 100.0 & $\cdots$ & 0.01 & $\cdots$ \\
\hline$S m$ & $\begin{array}{l}144 \mathrm{Sm} \\
147 \mathrm{sm} \\
148 \mathrm{Sm} \\
149 \mathrm{Sm} \\
150 \mathrm{Sm} \\
152 \mathrm{Sm} \\
154 \mathrm{sm}\end{array}$ & $\begin{array}{r}3.1 \\
15.1 \\
11.3 \\
13.9 \\
7.4 \\
26.7 \\
22.6\end{array}$ & 0.000001 &.- & 0.0008 \\
\hline Eu & $\begin{array}{l}151 \mathrm{Eu} \\
153 \mathrm{Eu}\end{array}$ & $\begin{array}{l}47.9 \\
52.7\end{array}$ & 0.0001 & $\cdots$ & 0.000008 \\
\hline Ho & $165_{\mathrm{HO}}$ & 100.0 & 0.000001 & $--\cdot$ & 000008 \\
\hline
\end{tabular}

(a) Indicates none included in calculations 


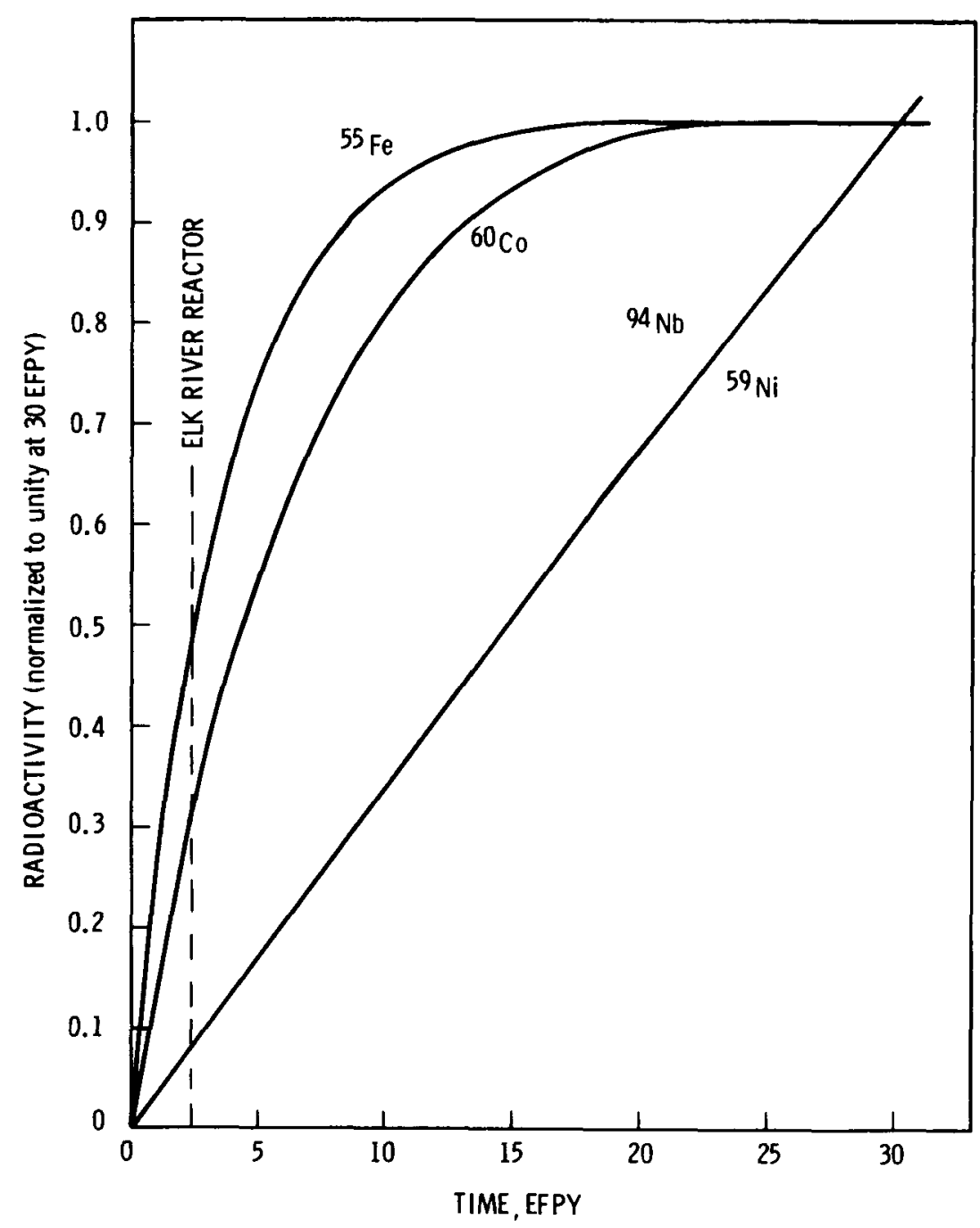

FIGURE E.1-5. Calculated Buildup of Selected Activation Products in the Core Shroud as a Function of Time at Full Power

zone. Several steps are required to compute the total radioactivity in each of the activated components. First, a graphical integration is performed on the component's longitudinal neutron flux distribution to obtain an average flux level over the activated length of the component. (For each component that radially surrounds the fuel zone, the longitudinal neutron flux distribution is assumed to be similar to the fuel-zone axial-centerline distribution shown in Figure E.1-4. For the axially distributed components, such as the top fuel guide and the core support plate, the longitudinal flux distribution 
is assumed to be similar to the radial-midplane flux distribution shown in Figure E.1-3.) This average flux level is then divided by the peak flux level of the distribution to obtain a multiplication factor that, when multiplied with the point radioactivity concentration given in Section E.1 (Table E.1-1 for stainless steel components, Table E.1-2 for carbon steel components, and Table E.1-3 for concrete components), gives a longitudinally averaged radioactivity concentration for the particular component. In like manner, a similar factor is found for the lateral flux distribution through that component. This factor is multiplied with the longitudinally averaged concentration to obtain a volume-averaged radioactivity concentration. Multiplying this average radioactivity concentration by the activated volume of the particular component gives the total radioactivity in that component.

Table E.1-6 lists the volume-averaged radioactivity concentration, the volume, and the estimated radioactivity calculated for each structural component that is assumed to contain a significant amount of neutron-activated radioactivity. The radioactivity totals in the reactor vessel and its internal components range from about $0.5 \mathrm{Ci}$ in a single control rod guide tube to about 6.3 million $\mathrm{C} i$ in the core shroud. The total radioactivity in the sacrificial

TABLE E.1-6. Estimated Total Radioactivity in Neutron-Activated Structural Components

\begin{tabular}{|c|c|c|c|c|}
\hline Component (quantity) & $\begin{array}{l}\text { Volume-Averaged Radio- } \\
\text { activity Concentration } \\
\left(\mathrm{Ci} / \mathrm{m}^{3}\right) \\
\end{array}$ & $\begin{array}{l}\text { Estimated } \\
\text { Activated } \\
\text { Volume }\left(\mathrm{m}^{3}\right)\end{array}$ & $\begin{array}{l}\text { Radioactivity per } \\
\text { Component ( } \mathrm{Ci}) \\
\end{array}$ & $\begin{array}{r}\text { Estimated Total } \\
\text { Radioactivity (Ci) }\end{array}$ \\
\hline $\begin{array}{l}\text { Core Shroud (1) } \\
\text { Jet Pump Assembly (10) }\end{array}$ & $\begin{array}{l}1.68 \times 10^{6} \\
2.62 \times 10^{4}\end{array}$ & $\begin{array}{l}3.75 \\
0.076\end{array}$ & $\begin{array}{l}6.30 \times 10^{6} \\
2.00 \times 10^{3}\end{array}$ & $\begin{array}{l}6.30 \times 10^{6} \\
2.00 \times 10^{4}\end{array}$ \\
\hline $\begin{array}{l}\text { Reactor Vessel (1) } \\
\text { Cladding } \\
\text { Shell Wall }\end{array}$ & $\begin{array}{l}1.07 \times 10^{3} \\
1.12 \times 10^{2}\end{array}$ & $\begin{array}{l}0.428 \\
15.26\end{array}$ & $\begin{array}{l}4.58 \times 10^{2} \\
1.70 \times 10^{3}\end{array}$ & $2.16 \times 10^{3}$ \\
\hline $\begin{array}{l}\text { Sacrificial Shield (1) } \\
\text { Inner Shell } \\
\text { Reinforced Concrete Region } \\
\text { Outer Shell }\end{array}$ & $\begin{array}{l}4.99 \times 10^{1} \\
4.73 \times 10^{-2} \\
8.66 \times 10^{0}\end{array}$ & $\begin{array}{r}2.19 \\
73.30 \\
6.22\end{array}$ & $\begin{array}{l}1.03 \times 10^{2} \\
3.47 \times 10^{0} \\
5.39 \times 10^{1}\end{array}$ & $1.66 \times 10^{2}$ \\
\hline $\begin{array}{l}\text { Steam Separator Assembly (1) } \\
\text { Shroud Head Plate } \\
\text { Steam Separator Risers }\end{array}$ & $\begin{array}{l}1.03 \times 10^{14} \\
2.53 \times 10^{3}\end{array}$ & $\begin{array}{l}0.841 \\
0.376\end{array}$ & $\begin{array}{l}8.65 \times 10^{3} \\
9.52 \times 10^{2}\end{array}$ & $9.60 \times 10^{3}$ \\
\hline $\begin{array}{l}\text { Top Fuel Guide (1) } \\
\text { Orificed Fuel Support (193) } \\
\text { Core Support Plate (1) }\end{array}$ & $\begin{array}{l}9.71 \times 10^{4} \\
1.01 \times 10^{3} \\
2.56 \times 10^{2}\end{array}$ & $\begin{array}{l}0.310 \\
0.0036 \\
2.54\end{array}$ & $\begin{array}{l}3.01 \times 10^{4} \\
3.63 \times 10^{0} \\
6.50 \times 10^{2}\end{array}$ & $\begin{array}{l}3.01 \times 10^{4} \\
7.01 \times 10^{2} \\
6.50 \times 10^{2}\end{array}$ \\
\hline $\begin{array}{l}\text { Incore Instrument Strings (55) } \\
\text { Control Rod (185) } \\
\text { Control Rod Guide Tube (185.) } \\
\text { Total }\end{array}$ & $\begin{array}{l}7.67 \times 10^{5} \\
5.11 \times 10^{5} \\
2.16 \times 10^{2}\end{array}$ & $\begin{array}{l}0.00026 \\
0.0019 \\
0.0024\end{array}$ & $\begin{array}{l}1.99 \times 10^{2} \\
9.61 \times 10^{2} \\
5.12 \times 10^{-1}\end{array}$ & $\begin{array}{l}1.10 \times 10^{4} \\
1.78 \times 10^{5} \\
9.47 \times 10^{1} \\
6.55 \times 10^{6}\end{array}$ \\
\hline
\end{tabular}


shield is calculated to be about $166 \mathrm{Ci}$. The total inventory in all neutronactivated components is about 6.6 million $\mathrm{Ci}$. The activated portion of the core shroud represents approximately $96 \%$ of this total inventory.

\section{E.1.3 Radiation Dose Rates from Neutron-Activated Components}

Two steps are necessary to compute the radiation dose rate at the surface of an activated structure after the level of radioactivity has been determined. First, the radiation emissions from the decaying radionuclides are characterized in terms of energy and probability of decay. Then, the transport of the radiation through the bulk structural material and the resultant dose rate exterior to the material surface are computed. These steps are discussed in more detail in the following subsections.

\section{E.1.3.1 Radioactive Decay Characteristics of Selected Radionuclides}

Many of the radionuclides present in the neutron-activated structures at the shutdown BWR have high specific radioactivity levels but, because of their particular decay half-lives or decay processes or both, do not contribute significantly to the radiation dose rate during decommissioning. Other radionuclides have lower specific radioactivity levels but produce large contributions to an external dose rate because they emit high-energy gamma rays.

The following paragraphs present the characteristics (i.e., production process, radioactive decay mode, and radioactive emissions) of selected radionuclides that represent some concern during decommissioning.

Carbon-14 $\left({ }_{6}^{14} \mathrm{C}\right)$. Carbon-14 is produced by two processes: 1) by multiple neutron capture in ${ }^{12} \mathrm{C}$ and ${ }^{13} \mathrm{C}$, and 2) by neutron capture-proton emission in ${ }^{14} \mathrm{~N}$. The second reaction is the predominant one. Both carbon and nitrogen are present in trace quantities in stainless and carbon steels. Carbon-14 has a radioactive decay half-life of about 5,750 years and decays by beta emission with a maximum energy of $156 \mathrm{keV}$. The contribution of ${ }^{14} \mathrm{C}$ to external occupational radiation exposure is insignificant since the radioactivity is bound tightly in the metal alloys. The principal concern is to prevent its release into the environment where it could enter biological internal-exposure pathways. 
Iron-55 ( $\left.{ }_{26}^{55} \mathrm{Fe}\right)$. Iron-55 is produced principally by thermal neutron capture in $5.8 \%$-abundant ${ }^{54} \mathrm{Fe}$ in iron, a constituent in stainless steel and carbon steel. The neutron capture cross section is about 3 barns. (a) Iron-55 has a decay half-life of 2.7 years and decays by orbital electron capture (EC) by the nucleus to form ${ }_{25}^{55} \mathrm{Mn}$.

Each EC event is accompanied by the emission of either x-rays or Auger electrons associated with ${ }^{55} \mathrm{Mn}$ stabilization to the ground energy state, with energies less than $7 \mathrm{keV}$. As is typical with such emissions from nuclides in this atomic number range, most ( $274 \%$ in this case) of the $x$-rays are not emitted, and Auger electrons of the same energy appear instead. Additional information on these emissions can be found in References 8 and 9 . Suffice it to say that these emissions do not contain the energy (i.e., $>68 \mathrm{keV}$ ) required to penetrate the outer dead layers of skin and, thus, do not contribute to a skin dost.

Each EC decay event is accompanied by a continuous spectrum of gamma rays from the associated inner bremsstrahlung (IB) process. The maximum energy of this spectrum is $220 \mathrm{keV}$. For computing radiation dose in this study, the IB spectrum of ${ }^{55} \mathrm{Fe}$ decay is divided into four energy ranges, with a specific yield fraction per decay event for each energy range as follows:

- 0.01 to $0.07 \mathrm{MeV}, 1.37 \times 10^{-5}$

- 0.07 to $0.12 \mathrm{MeV}, 8.37 \times 10^{-6}$

- 0.12 to $0.21 \mathrm{MeV}, 4.77 \times 10^{-6}$

- 0.21 to $0.04 \mathrm{MeV}, 8.5 \times 10^{-9}$.

Further details concerning the IB gamma spectrum from ${ }^{55} \mathrm{Fe}$ decay are given in References 10 and 11 .

Cobalt-60 $(20 \mathrm{Co})$. Cobalt-60 is produced by thermal neutron capture in $100 \%$-abundant ${ }^{59} \mathrm{Co}$, a trace constituent in a 11 three structural materials. The neutron capture cross section is about 37 barns. Cobalt-60 has a decay half-life of 5.27 years and decays by beta emission to excited energy states of ${ }_{28}^{60} \mathrm{Ni}$. Over $99 \%$ of the decay events are to an excited energy state at

(a) 1 barn is equivalent to a cross-sectional area of $10^{-22} \mathrm{~mm}^{2}$. 
2.505 MeV, which goes to the ground energy state, with a sequential emission of two gamma rays of $1.173 \mathrm{MeV}$ and $1.332 \mathrm{MeV} .{ }^{(9)}$ These are the major contributors to the dose rate from ${ }^{60} \mathrm{Co}$. The beta spectrum (maximum-energy $0.32 \mathrm{MeV}$ ) contributes a minor fraction.

Nickel-59 $(28 \mathrm{Ni})$. Nickel-59 is primarily produced by thermal neutron capture in $68.3 \%$-abundant ${ }^{58} \mathrm{Ni}$ in nickel, a constituent in stainless steel. The neutron capture cross section is about 5 barns. Nickel-59 has a decay halflife of approximately 80,000 years and decays by the EC process to ${ }_{27}^{59} \mathrm{Co}$.

Again, x-rays or Auger electrons are emitted during stabilization to the ground energy state. In the case of ${ }^{59} \mathrm{Co}$, the energies are less than $8 \mathrm{keV}$, and approximately $33 \%$ of the emissions are $x$-rays and the rest are Auger electrons. Additional information is found in References 8 and 9. These emissions do not contribute to the external radiation dose rate.

The contribution of the ${ }^{59} \mathrm{Ni}$ decay process to external dose rate comes from the EC-associated IB process. A continuous spectrum of gamma rays is emitted, with the maximum energy being $1.07 \mathrm{MeV}$. For computing radiation dose in this study, the IB spectrum of ${ }^{59} \mathrm{Ni}$ decay is divided into seven energy ranges, with a specific yield fraction per decay event for each energy range, as follows:

- 0.01 to $0.07 \mathrm{MeV}, 2.23 \times 10^{-4}$

- 0.07 to $0.12 \mathrm{MeV}, 6.25 \times 10^{-5}$

- 0.12 to $0.21 \mathrm{MeV}, 1.32 \times 10^{-4}$

- 0.21 to $0.4 \mathrm{MeV}, 3.21 \times 10^{-4}$

- 0.4 to $0.6 \mathrm{MeV}, 3.31 \times 10^{-4}$

- 0.6 to $0.9 \mathrm{MeV}, 3.24 \times 10^{-4}$

- 0.9 to $1.2 \mathrm{MeV}, 3.01 \times 10^{-5}$.

More details concerning the IB gamma spectrum from ${ }^{59} \mathrm{Ni}$ decay can be found in References 11 through 15.

Nickel-63 $\left({ }^{63} \mathrm{Ni}\right)$. Nickel-63 is produced by thermal neutron capture in $3.6 \%$-abundant ${ }^{62} \mathrm{Ni}$ in nickel, a constituent in stainless steel. The neutron capture cross section is about 15 barns. Nickel-63 has a decay half-life of 
about 100 years and decays by beta emission to ${ }_{29}^{63} \mathrm{Cu}$. The beta emissions have maximum energies of about $66 \mathrm{keV}$, which is insufficient to penetrate the outer surface of the skin. No gamma rays are emitted. Therefore, ${ }^{63} \mathrm{Ni}$ does not contribute to the external dose rate. (16) Additional information is available in Reference 17.

Molybdenum-93 $\left({ }_{42}^{93} \mathrm{Mo}\right)$. Molybdenum-93 is formed by thermal and resonance neutron capture in $14.8 \%$-abundant ${ }^{92}$ Mo in molybdenum, a minor constituent in both stainless steel and carbon steel. The thermal neutron capture cross section is about 0.045 barns, and the resonance neutron capture integral is about 0.52 barns. Molybdenum- 93 can be formed in an excited energy state at $2.45 \mathrm{MeV}$, which decays by gamma emission to the ground state with a 6.85 -hour half-life. The ground state of ${ }^{93}$ Mo decays by EC, with a half-life of about 3,500 years. Approximately $96 \%$ of the EC events proceed to an excited state of ${ }_{41}^{93} \mathrm{Nb}$ with an excitation energy of $30.4 \mathrm{keV}$. These EC events are accompanied by an IB gamma spectrum with a maximum energy of $368 \mathrm{keV}$. The yield and spectral shape of the IB gamma emissions are not amenable to definitive theoretical calculation and have not been measured experimentally. The IB yield is on the order of $3.2 \times 10^{-4}$ gammas per EC event.

The $30.4-\mathrm{keV}$ state in ${ }^{93} \mathrm{Nb}$ decays with a half-1 ife of 13.6 years. Unless chemically separated from ${ }^{93} \mathrm{Mo},{ }^{95} \mathrm{Nb}$ has an apparent decay half-life similar to ${ }^{93}$ Mo at long times ( $>13.6 \mathrm{yr}$ ) after neutron irradiation. The $30.4-\mathrm{keV}$ decay gamma rays are internally absorbed, and none have been observed experimentally. The radiation products per decay of the 30.4-keV state are primarily 10.4-keV Auger electrons and 16.6-keV niobium x-rays.

Niobium-94 $(94 \mathrm{Nb})$. Niobium-94 is formed by thermal neutron capture in $100 \%$-abundant ${ }^{93} \mathrm{Nb}$, a trace constituent in stainless steel. The thermal neutron capture cross section is about 1.1 barns. Neutron capture leads either to the ground state of ${ }^{94} \mathrm{Nb}$ or to an isomeric state that is $41 \mathrm{keV}$ above the ground state. The isomeric state decays with a half-life of 6.26 minutes. Most $(99.5 \%)$ of these decays go to the ground energy state. Thus, for longtime radiation dose rate considerations, all neutron captures lead to the ground energy state. Niobium-94 has a decay half-life of 20,300 years and 
decays by beta emission, with a maximum beta energy of $471 \mathrm{keV}$. A11 of the decays go to a single excited energy state of ${ }^{94}$ Mo at 1.574 MeV excitation. All of the decays from this state go through an excited energy state at $871 \mathrm{keV}$. Thus, each ${ }^{94} \mathrm{Nb}$ decay yields two gamma rays with energies of 703 and $871 \mathrm{keV}$, respectively; these dominate the dose rate from ${ }^{94} \mathrm{Nb}$.

Silver-108m $(108 \mathrm{~m} \mathrm{Ag})$. Silver-108m is formed by thermal and resonance neutron capture in $51.8 \%$-abundant ${ }^{107} \mathrm{Ag}$ in silver, a trace constituent in both stainless steel and concrete. The thermal neutron capture cross section is about 2 barns, and the resonance neutron capture integral is about 5 barns. Silver-108m has a decay half-1ife of 127 years and decays both by EC and by isomeric transition (IT).

The majority ( $291 \%$ ) of the decays are by EC to an excited energy state of ${ }_{48}^{108} \mathrm{Pd}$ that results in three cascade gamma rays with energies of $723 \mathrm{keV}$, $614 \mathrm{keV}$, and $434 \mathrm{keV}$, respectively. In addition, x-rays and conversion electrons with energies less than $25 \mathrm{keV}$ are produced by this decay process.

The rest ( $29 \%$ ) of the decays are by cascade IT gamma rays of $30.4 \mathrm{keV}$ and $79.2 \mathrm{keV}$ to the ground energy state of ${ }^{108} \mathrm{Ag}$, which is also radioactive. The 30.4-keV gamma ray is absorbed internally, and the $79.2 \mathrm{keV}$ gamma ray is emitted externally only in about $7 \%$ of the total $108 \mathrm{~m}_{\mathrm{Ag}}$ decay events.

Silver-108 has a decay half-1ife of 2.37 minutes and decays by beta emission, primarily to the ground energy state of ${ }_{48}^{108} \mathrm{Cd}$. However, about $2 \%$ of the decays go to the first excited energy state of ${ }^{108} \mathrm{Cd}$, which emits a $632-\mathrm{keV}$ gamma ray in the stabilization process. The average beta energy per ${ }^{108} \mathrm{Ag}$ decay is $610 \mathrm{keV}$.

The cascading gamma rays from the EC decay process and the beta and gamma

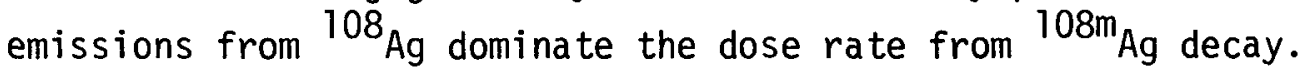

Europium-152 ( $\left.{ }_{63}^{152} \mathrm{Eu}\right)$. Europium-152 is formed by thermal and resonance neutron capture in $47.9 \%$-abundant ${ }^{151} \mathrm{Eu}$ in europium, a trace constituent in both stainless steel and concrete. The thermal neutron capture cross section is 5,900 barns, and the resonance neutron capture integral is about 2,100 barns. Europium-152 has a decay half-life of 13.3 years. It decays 
about $72 \%$ of the time by EC or positron emission ( $0.05 \%$ of the time) to many excited energy states of ${ }_{62}^{152} \mathrm{Sm}$, and the rest of the time by beta emission to several excited energy states of ${ }_{64}^{152} \mathrm{Gd}$. The result of each of these decays is the emission of cascade gamma rays in the stabilization process of each of the resultant nuclides. Inner bremsstrahlung gamma rays are negligible compared to the cascade gamma rays, but do occur since some EC events go to the ground energy state of ${ }^{152} \mathrm{Sm}$.

The decay process results in conversion electrons with a maximum energy of $294 \mathrm{keV}$ and in $x$-rays with energies up to $50 \mathrm{keV}$. The beta emissions have an average energy per decay of $125 \mathrm{keV}$ and a maximum energy of $1.475 \mathrm{MeV}$. The resultant cascade gamma rays, of which a total of 125 discrete energies are listed in the files of Reference 5, have an average energy per decay of $1.16 \mathrm{MeV}$ and a maximum energy of $1.41 \mathrm{MeV}$.

Europium-154( ${ }^{154} \mathrm{Eu}$ ). Europium-154 is formed by thermal and resonance neutron capture in $52.1 \%$-abundant ${ }^{153} \mathrm{Eu}$ in europium, a trace constituent in both stainless steel and concrete. The thermal neutron capture cross section is 310 barns, and the resonance neutron capture integral is 1,610 barns. Europium-154 has a decay half-life of 8.6 years and decays by beta emission to excited energy states of ${ }_{64}^{154} \mathrm{Gd}$. Again, many cascade gamma rays are produced in the stabilization process.

The process results in conversion electrons having a maximum energy of $198 \mathrm{keV}$ and in x-rays with energies up to $50 \mathrm{keV}$. The maximum beta energy is $1.85 \mathrm{MeV}$, and the average energy per decay is $280 \mathrm{keV}$. The resultant cascade gamma rays, of which 139 are listed in the files of Reference 5, have a maximum energy of $1.90 \mathrm{MeV}$ and an average energy per decay of $1.23 \mathrm{MeV}$.

\section{E.1.3.2 Radiation Dose Rates}

The radiation dose rates at $10 \mathrm{~mm}$ away from the inner and outer surfaces of the core shroud, reactor vessel, and sacrificial shield are calculated using the ANISN and PUSHLD codes. $(7,18)$ ANISN calculates the radiative transport and the resultant dose rate from the monoenergetic gamma rays and the inner bremsstrahlung gamma spectra, and PUSHLD calculates the transport dose rate of the low-energy $x$-rays. The results for a particular radioisotope are summed to obtain its total contribution to the dose rate. 
To check the effect of code differences on the result, PUSHLD is also used to make calculations for comparison with the ANISN results.

The computed dose rates at the time of final reactor shutdown from the radionuclides discussed in Section E.1.3.1 are given in Table E.1-7. Only those radionuclides that contribute significantly to the dose rate, either in the near term or after a long decay time, are included.

TABLE E.7-7. Calculated Radiation Dose Rates from Selected Neutron-Activated Reference BWR Components $(a)$

\begin{tabular}{|c|c|c|c|c|c|c|c|}
\hline Component & 60 Co (gama) & $94 \mathrm{Nb}$ (gamma) & $\begin{array}{l}\text { Calculated Dose Rat } \\
\text { S5Fe (IB, gamma) (D) }\end{array}$ & $\begin{array}{l}\text { te from Selected Radio } \\
\text { 5Ni (IB, gamma)(B) }\end{array}$ & $\frac{\text { onuclides (R/hr) }}{\frac{108 \mathrm{Ag}(\mathrm{g} \text { gamma })}{10}}$ & $152 \mathrm{Eu}$ (gamma) & 154EU (gamma) \\
\hline Core Shroud & & & & & & - & \\
\hline Inner Surface & $1.2 \times 10^{5}$ & $7 \times 10^{-1}$ & $8 \times 10^{-2}$ & $7 \times 10^{-2}$ & $2 \times 10^{-2}$ & $2 \times 10^{-4}$ & $5 \times 10^{-1}$ \\
\hline Outer Surface & $3.3 \times 10^{4}$ & $2 \times 10^{-1}$ & $1 \times 10^{-2}$ & $2 \times 10^{-2}$ & $\ldots$ (c) & --- & --- \\
\hline \multicolumn{8}{|l|}{ Reactor Vessel } \\
\hline Inner Surface & $1.4 \times 10^{1}$ & $1 \times 10^{-4}$ & $3 \times 10^{-5}$ & $2 \times 10^{-5}$ & -.- & -.- & -.- \\
\hline Outer Surface & $1.4 \times 10^{-1}$ & $4 \times 10^{-9}$ & $1 \times 10^{-6}$ & $7 \times 10^{-8}$ & $\cdots$ & $\ldots$ & -.. \\
\hline \multicolumn{8}{|c|}{ Sacrificial Shield } \\
\hline Inner Surface & $3.2 \times 10^{-1}$ & $\ldots$ & $3 \times 10^{-6}$ & $2 \times 10^{-7}$ & $8 \times 10^{-8}$ & $7 \times 10^{-3}$ & $7 \times 10^{-5}$ \\
\hline Outer Surface & $9 \times 10^{-4}$ & $\ldots$ & $1 \times 10^{-8}$ & $1 \times 10^{-9}$ & -.. & -.. & -.. \\
\hline
\end{tabular}

A comparison of the time-dependent radioactivity concentrations and dose rates of some selected radionuclides is shown in Figure E.1-6. The data are those calculated for the core shroud. It can be seen that, while the decay rate of ${ }^{63} \mathrm{Ni}$ controls the reduction of the total radioactivity present after the first 10 years, the decay rate of ${ }^{60}$ Co controls the reduction of the radiation dose rate for the first 70 to 80 years. After that time, the dose rate is increasingly dominated by ${ }^{94} \mathrm{Nb}$. The dose rate is the significant factor in decommissioning work, since it directly affects occupational radiation exposure and has a strong influence on work plans and methods. 


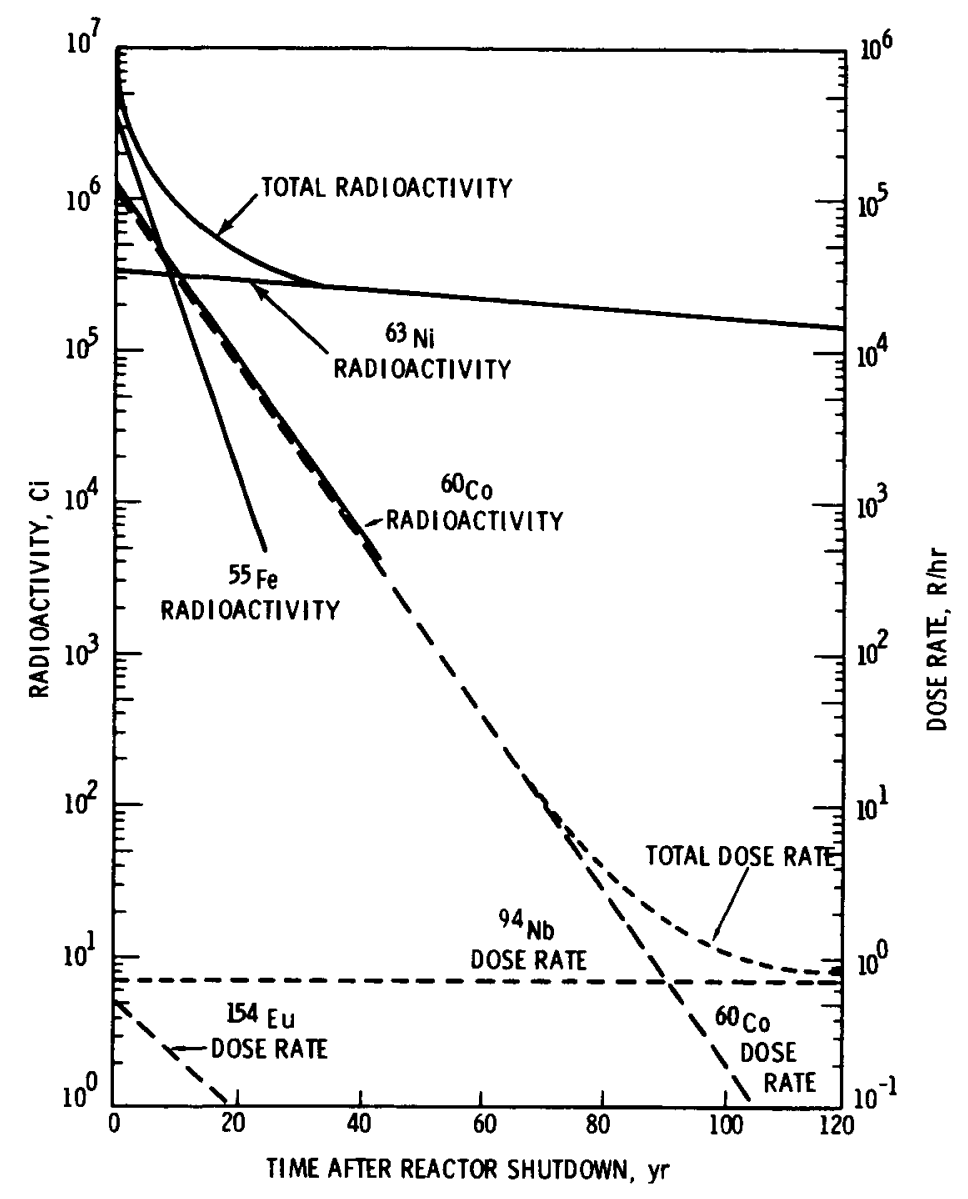

FIGURE E.1-6. Time Dependence of Radioactivity and Dose Rate in the Neutron-Activated Core Shroud

\section{E.2 SURFACE CONTAMINATION}

Activated corrosion products from structural materials in contact with the reactor water and fission products from leaking fuel both contribute to the radionuclide mixtures and levels of surface contamination. This section contains the methods and results of calculations that estimate the radionuclide inventories in internally contaminated piping and equipment systems, and also on external surfaces both inside the reference BWR facility and on the surrounding site. 


\section{E.2.1 Radionuclide Inventories in Internally Contaminated Piping and Equipment}

A thin layer of radioactive contamination is deposited on the internal surfaces of piping and equipment in the reference BWR during its normal operating lifetime. The piping and equipment systems involved are described in Appendix $C$. The composition and amount of radioactivity found on internal surfaces at plant shutdown are dependent on such reactor parameters as: 1) structural material composition, 2) reactor size, design, and operating history, and 3) reactor fuel conditions. (19) The internal surface contamination is characterized by the mixture of activated corrosion products and fission products found in the reactor water, steam, and resultant condensate.

In the following sections, the reference radionuclide inventory for piping and internal surfaces is established, and the dose rate versus deposition level relationships for various designs of piping and equipment are determined using a shielding code analysis and a unit deposition level. Inventories of total deposited radioactivity in the reference BWR are calculated using the dose rate/deposition relationships and measured dose rate data from Appendix $D$.

\section{E.2.1.1 Reference Radionuclide Inventory 4}

Specific alloys used in the structural components of the reactor coolant system play a major role in the composition of the internal surface contamination. Because of the different alloys used, differences in the activated corrosion products between a BWR and a PWR are noted. ${ }^{(20)}$ Cobalt-58 is only a minor source of radiation at a BWR, while at a PWR it is a significant contributor to the shutdown radiation levels. (21) This is because more ${ }^{58} \mathrm{Ni}$, present in materials such as Inconel-600, is found in the PWR. Through neutron capture, the ${ }^{58} \mathrm{Ni}$ is transmuted into ${ }^{58} \mathrm{Co}$. Cobalt-60 is found in greater quantity at a BWR then at a PWR because of the greater abundance of its parent $\left({ }^{59} \mathrm{Co}\right)$ in BWR structural materials. It is of concern because of its large formation cross section, its energetic decay, and its relatively long decay half-life.

Depending on the type of condenser tubes and condensate polishing system used, ${ }^{65} \mathrm{Zn}$ can also be an isotope of concern at a BWR.

Fission products from leaking reactor fuel also contribute to the internal surface contamination. Their concentrations are directly related to 
the number of leaking fuel elements in the reactor core and thus will change during plant operation.

It is not within the scope of this study to fully investigate the complex mechanisms that influence the deposition of activated corrosion products and fission products on the internal surfaces of BWR equipment and piping. After a literature review on the subject (References 19 and 21 through 25), the radionuclide composition on internal surfaces of the reference BWR at final shutdown is assumed to be that shown in Table E.2-1 (reference radionuclide inventory 4). This inventory is based on a BWR sludge sample analysis given in Reference 23, and contains representative levels of both activated corrosion products and fission products present in the reactor water systems. Reference radionuclide inventory 4 also compares closely with the mixture of radionuclides in the turbine of an operating BWR. ${ }^{(25)}$ No further attempt to characterize the composition of internal surface contamination is made.

$\begin{array}{ll}\text { TABLE E.2-1. } & \text { Reference Radionucl ide Inventory } 4 \\ \text { BWR Internal Surface Contamination }\end{array}$

\begin{tabular}{|c|c|c|c|c|c|}
\hline \multirow[b]{2}{*}{ Radionuclide } & \multicolumn{5}{|c|}{ Fractional Radioactivity at Decay Times of: } \\
\hline & Shutdown & 10 Years & 30 Years & 50 Years & 100 Years \\
\hline $51 \mathrm{Cr}$ & $2.1 \times 10^{-2}$ & $\ldots$ (b) &.-- & $\ldots$ & $\ldots$ \\
\hline${ }^{54} \mathrm{Mn}$ & $3.9 \times 10^{-1}$ & $1.3 \times 10^{-4}$ & --- & --- & --- \\
\hline & $2.5 \times 10^{-2}$ & -.. & -.. & -.- & --- \\
\hline $58 \mathrm{Co}$ & $9.3 \times 10^{-3}$ &.-- & -.- & -.- & -.- \\
\hline${ }^{60} \mathrm{Co}$ & $.7 \times 10^{-1}$ & $1.3 \times 10^{-1}$ & $9.1 \times 10^{-3}$ & $6.6 \times 10^{-4}$ & $9.2 \times 10^{-7}$ \\
\hline $65 \mathrm{Zn}$ & $6.1 \times 10^{-3}$ & $1.5 \times 10^{-7}$ & $\ldots$ & -.- & -.- \\
\hline $95 z$ & $x$ & --- & -.. & -.- & -.. \\
\hline $95 \mathrm{Nb}$ & & --- & -.- & --- & -.- \\
\hline $103 \mathrm{Ru}$ & $2.3 \times 10^{-3}$ & --- & -.- & -.- & -.- \\
\hline${ }^{106} \mathrm{Ru}$ & $2.8 \times 10^{-3}$ & $2.7 \times 10^{-6}$ & --- & --- & --- \\
\hline 13 & $1.9 \times 10^{-2}$ & &.-- & --- & --- \\
\hline${ }^{137} \mathrm{Cs}$ & $3.4 \times 10^{-2}$ & $2.7 \times 10^{-2}$ & $1.7 \times 10^{-2}$ & $1.1 \times 10^{-2}$ & $3.4 \times 10^{-3}$ \\
\hline${ }^{141} \mathrm{Ce}$ & $3.0 \times 10$ & --- & -.- & --- & -.- \\
\hline $144 \mathrm{Ce}$ & $8.1 \times 10^{-3}$ & $8.8 \times 10^{-7}$ &.-- &.-- & --- \\
\hline$\overline{\text { TotaTs }}$ & 1.0 & $1.6 \times 10^{-1}$ & $2.6 \times 10^{-2}$ & $\overline{1.2 \times 10^{-2}}$ & $\overline{3.4 \times 10^{-3}}$ \\
\hline
\end{tabular}

(a)Based on a BWR sludge sample analysis given in Reference 23.

(b) Indicates a value less than $1.0 \times 10^{-10}$. 
About $93 \%$ of the radioactivity mixture at shutdown, shown in Table E.2-1, is from activated corrosion products, with $47 \%$ of this total being ${ }^{60}$ Co.

Radionuclide characterization data for these activated corrosion products are 1isted in Table E.2-2. Fission products contribute only about $7 \%$ of the total internal surface radioactivity at shutdown.

\section{TABLE E.2-2. Activated Corrosion Product Data}

\begin{tabular}{|c|c|c|c|c|c|c|}
\hline Radionuclide & $\begin{array}{c}\text { Fractional } \\
\text { Abundance } \\
\text { on Surfaces } \\
\text { at Final } \\
\text { Shutdown } \\
\end{array}$ & $\begin{array}{c}\text { Primary } \\
\text { Source Material }\end{array}$ & $\begin{array}{l}\text { Production } \\
\text { Reaction } \\
\end{array}$ & $\begin{array}{l}\text { Half-Life } \\
\text { (days) } \\
\end{array}$ & $\begin{array}{c}\text { Gamma } \\
\text { Energy } \\
(\mathrm{MeV}) \\
\end{array}$ & $\begin{array}{l}\text { Emissions } \\
\text { Number per } \\
\text { Disintegration }\end{array}$ \\
\hline${ }^{51} \mathrm{Cr}$ & $2.1 \times 10^{-2}$ & Stainless Steel & ${ }^{50} \mathrm{Cr}(n, \gamma)$ & $2.8 \times 10^{1}$ & $3.2 \times 10^{-1}$ & $2.0 \times 10^{-2}$ \\
\hline${ }^{54} \mathrm{Mn}$ & $3.9 \times 10^{-1}$ & Carbon Steel & ${ }^{54} \mathrm{Fe}(n, p)$ & $3.1 \times 10^{2}$ & $8.4 \times 10^{-1}$ & $1.0 \times 10^{0}$ \\
\hline${ }^{59} \mathrm{Fe}$ & $2.5 \times 10^{-2}$ & Carbon Steel & ${ }^{58} \mathrm{Fe}(n, \gamma)$ & $4.5 \times 10^{1}$ & $\begin{array}{l}1.4 \times 10^{-1} \\
1.9 \times 10^{-1} \\
1.1 \times 10^{0} \\
1.3 \times 10^{0}\end{array}$ & $\begin{array}{l}1.0 \times 10^{-2} \\
3.0 \times 10^{-2} \\
5.6 \times 10^{-1} \\
4.4 \times 10^{-1}\end{array}$ \\
\hline${ }^{58} \mathrm{Co}$ & $9.3 \times 10^{-3}$ & Stainless Steel & ${ }^{58_{\mathrm{Ni}}(n, p)}$ & $7.2 \times 10^{1}$ & $\begin{array}{l}5.1 \times 10^{-1} \\
8.1 \times 10^{-1} \\
8.6 \times 10^{-1} \\
1.7 \times 10^{0}\end{array}$ & $\begin{array}{l}1.0 \times 10^{-2} \\
9.9 \times 10^{-1} \\
1.4 \times 10^{-2} \\
6.2 \times 10^{-3}\end{array}$ \\
\hline${ }^{60} \mathrm{Co}$ & $4.7 \times 10^{-1}$ & Carbon Steel & ${ }^{59}$ Co $(n, \gamma)$ & $1.9 \times 10^{3}$ & $\begin{array}{l}1.2 \times 10^{0} \\
1.3 \times 10^{0}\end{array}$ & $\begin{array}{l}1.0 \times 10^{0} \\
1.0 \times 10^{0}\end{array}$ \\
\hline${ }^{65} \mathrm{Zn}$ & $6.1 \times 10^{-3}$ & Admiralty Brass & ${ }^{64} Z n(n, \gamma)$ & $2.4 \times 10^{2}$ & $1.1 \times 10^{0}$ & $4.9 \times 10^{-1}$ \\
\hline Fission Products & $6.9 \times 10^{-2}$ & Leaking Fuel & & & & \\
\hline Total & 1.0 & & & & & \\
\hline
\end{tabular}

Reduction of the dose rate with time because of radioactive decay of the mixture is shown in Figure E.2-1. The total dose rate is normalized to unity at the time of plant shutdown. The fractional dose rates are based on the shutdown radionuclide mixture in radionuclide inventory 4 . The activated corrosion product ${ }^{60}$ co controls the dose rate of the mixture until about 50 years after final shutdown, at which time the fission product ${ }^{137} \mathrm{Cs}$ begins to dominate. 


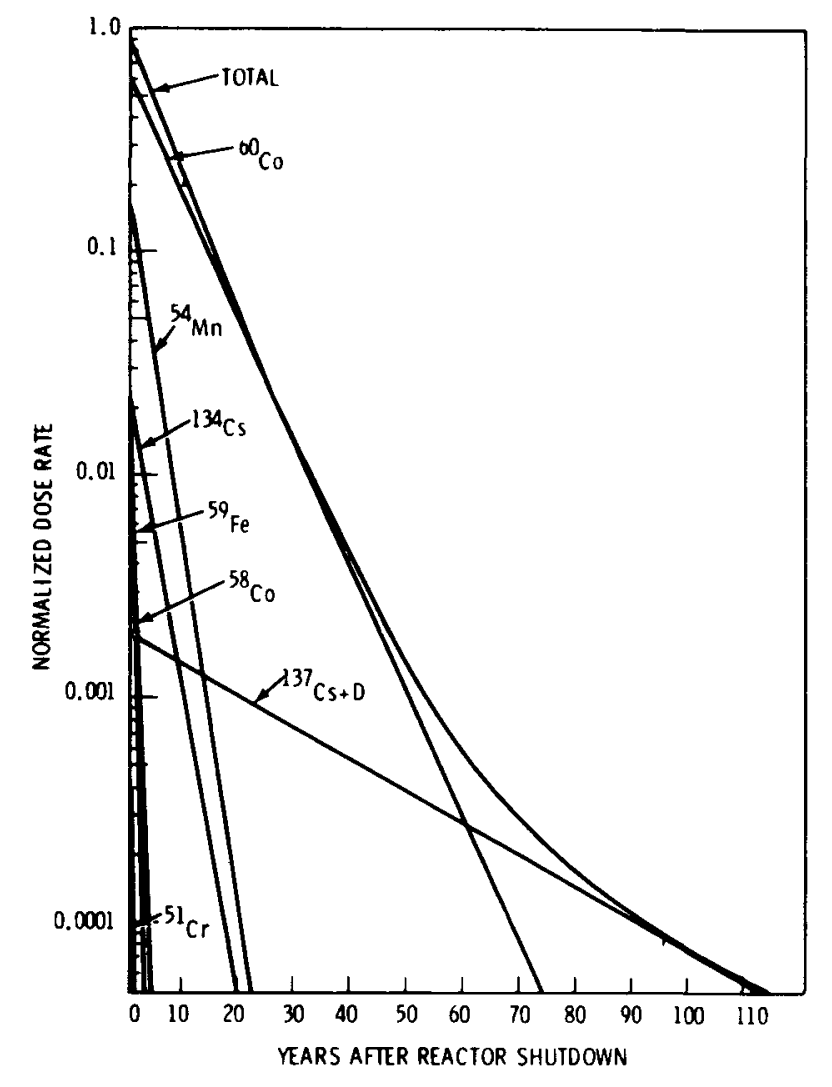

FIGURE E.2-1. Radioactive Decay of Deposited Internal Surface Contamination

\section{E.2.1.2 Dose Rates from Internally Contaminated Piping}

Dose rates from internally deposited radionuclide contamination in the reference BWR piping systems are estimated using the ISOSHLD computer program. $(26,27)$ This program is used with a unit deposition level of radionuclide inventory 4 to determine the relationship between the deposition level and the contact dose rate on the external pipe surfaces. ISOSHLD uses a point-kernel integration technique to evaluate exposure rates with a given source/detector geometry. Photon energy flux is calculated for 25 energy groups, with average energies ranging from $15 \mathrm{keV}$ to $3.0 \mathrm{MeV}$. Twelve source/detector geometries are available. Piping is modeled using cylindrical geometry.

Typical reference BWR pipe sizes and characteristic data are listed in Table E.2-3. The resulting calculated contact dose rates on external pipe surfaces as a function of the internal surface deposition levels are shown in 
TABLE E.2-3. Typical Reference-BWR Piping Characteristics

\begin{tabular}{|c|c|c|c|}
\hline $\begin{array}{l}\text { Nominal Outside } \\
\text { Diameter (mm) }\end{array}$ & $\begin{array}{c}\text { Approximate } \\
\text { Schedule }\end{array}$ & $\begin{array}{c}\text { Nominal } \\
\text { Inside } \\
\text { Diameter (mm) } \\
\end{array}$ & $\begin{array}{l}\text { Nominal Wall } \\
\text { Thickness }(\mathrm{mm})\end{array}$ \\
\hline $\begin{array}{r}60 \\
168 \\
356\end{array}$ & $\begin{array}{l}40 \\
60 \\
60\end{array}$ & $\begin{array}{l}52.5 \\
149 \\
325\end{array}$ & $\begin{array}{r}3.9 \\
9.5 \\
15.1\end{array}$ \\
\hline $\begin{array}{l}559 \\
610 \\
610\end{array}$ & $\begin{array}{r}40 \\
120 \\
160\end{array}$ & $\begin{array}{l}526 \\
518 \\
491\end{array}$ & $\begin{array}{l}16.3 \\
46.0 \\
59.5\end{array}$ \\
\hline $\begin{array}{l}711 \\
914\end{array}$ & $\begin{array}{l}40 \\
20\end{array}$ & $\begin{array}{l}670 \\
889\end{array}$ & $\begin{array}{l}20.4 \\
12.7\end{array}$ \\
\hline
\end{tabular}

Figure E.2-2. For these calculations, the modeled pipes are assumed to be filled with water, so that a comparison with dose rates measured at operating BWR power stations can be made.

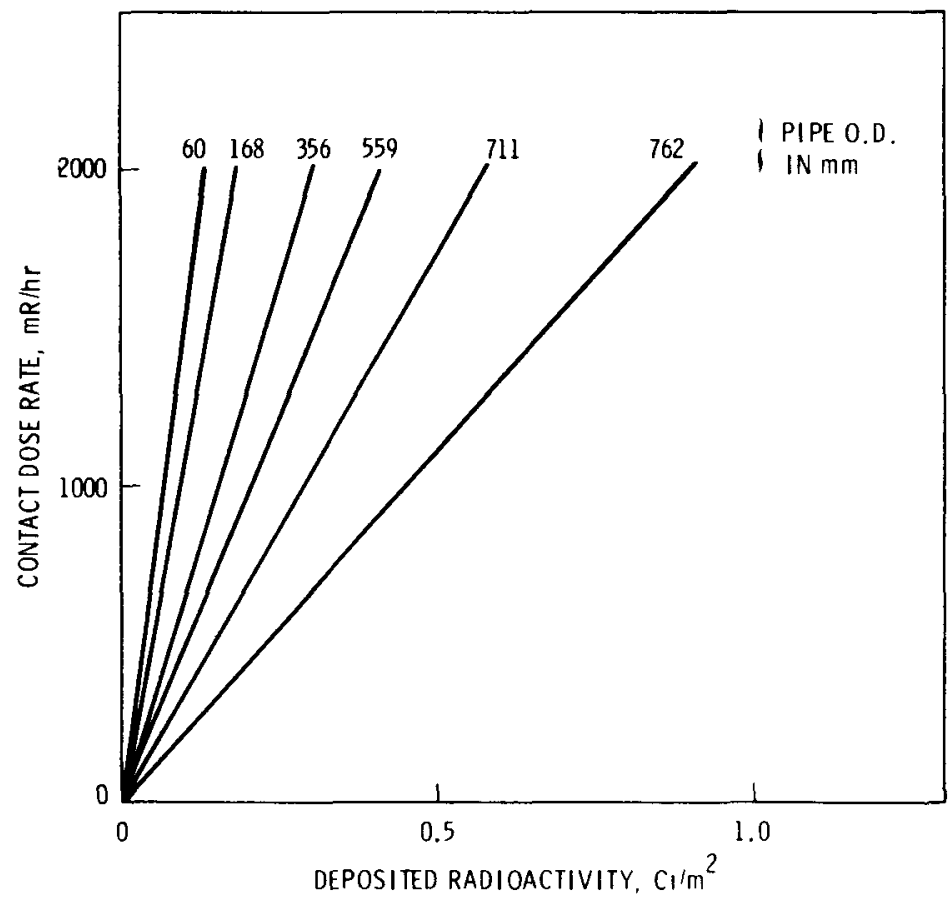

FIGURE E.2-2. Calculated Contact Dose Rates for BWR Piping as a Function of Deposited Internal Surface Radioactivity 
When the pipes are drained during decommissioning, the contact dose rates increase, since the water in the pipes is no longer a shield. For a large (914-mm outside diameter) thin-walled (schedule 20) pipe, the increase in dose rate caused by draining the pipe is calculated using the ISOSHLD program for a unit internal surface deposition. The results, shown in Figure E.2-3, indicate a rapid divergence between the calculated air-filled and water-filled contact dose rates as a function of increasing internal surface deposition. An increase in dose rate by a factor of about 3 for this size of air-filled pipe is found for the range of measured dose rates presented in Appendix $D$. Since smaller pipes act like line sources, the increase in dose rate caused by draining small pipes is much less.

The wall thickness of a pipe is a controlling factor in the dose rate versus deposition relationship for a given pipe outside diameter. Thus, the wall thickness as well as the pipe size is important in estimating the dose rate from internally contaminated pipe. A comparison of the calculated dose rate versus deposition relationships for schedule 120 and schedule 160 pipe with a $610-\mathrm{mm}$ outside diameter is shown in Figure E.2-4.

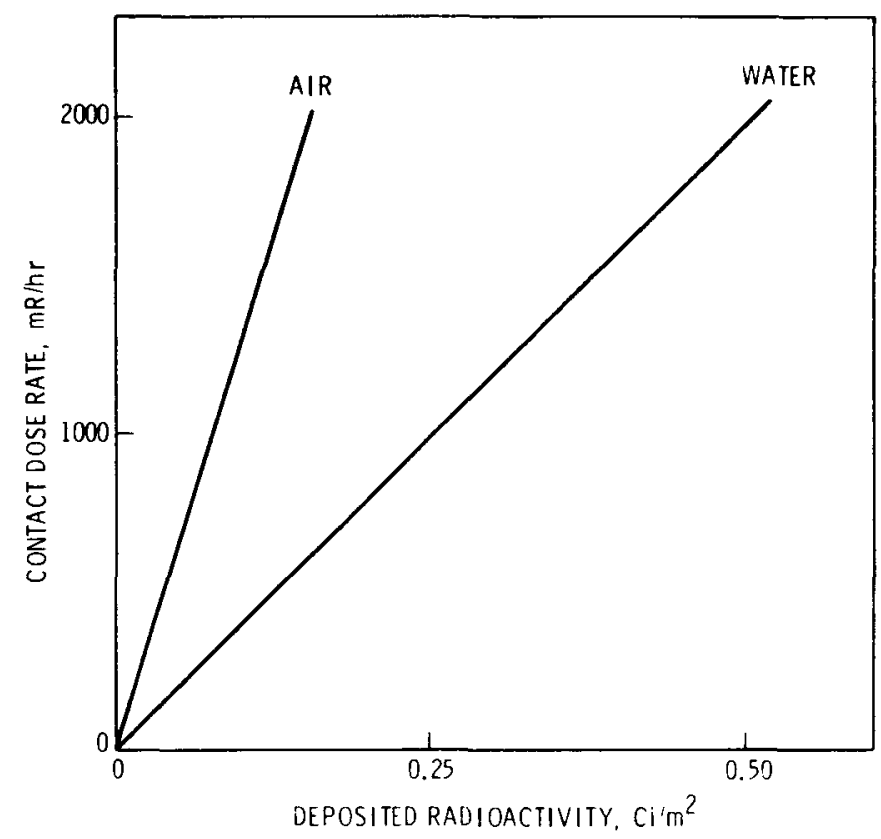

FIGURE E.2-3. Calculated Contact Dose Rates for Air-Filled and Water-Filled Schedule 20, 914-mm-OD BWR Pipe as a Function of Deposited Internal Surface Radioactivity 


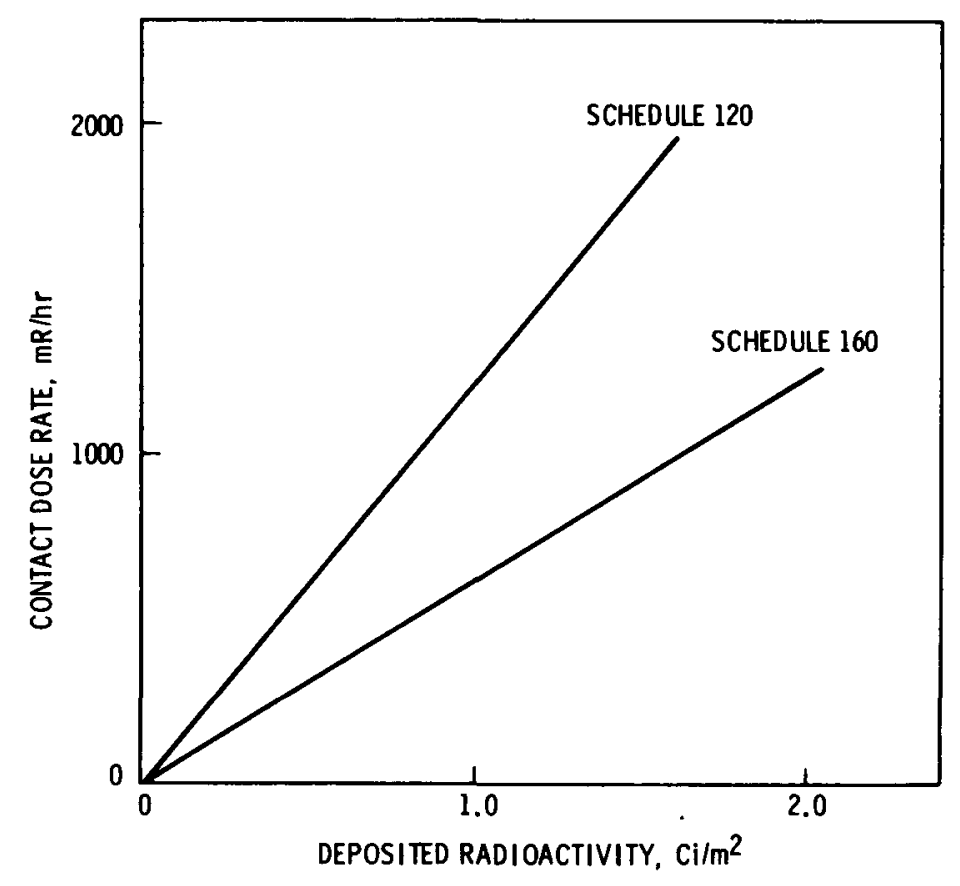

FIGURE E.2-4. Calculated Contact Dose Rates from Schedule 120 and Schedule 160, 610-mm-OD BWR Pipe as a Function of Deposited Internal Surface Radioactivity

The calculated relationship between dose rate, pipe size, and various distances in air from pipe surfaces is shown in Figure E.2-5. This figure graphically indicates that the dose rate from a small-diameter pipe quickly decreases as the distance in air increases and that the dose rate from a largediameter pipe is less affected by increased distance in air. Thus, dose rates from small-diameter pipes behave as those from line sourcés, and dose rates from large-diameter pipes behave as those from finite slabs.

\section{E.2.1.3 Estimated Total Radioactivity in Internally Contaminated Piping}

Internal surface contamination levels in BWR piping are dependent on the radionuclide concentrations in the reactor water, steam, and condensate. The deposited amounts of reference radionuclide inventory 4 inside piping at the reference BWR at plant shutdown are calculated using the following assumptions: 


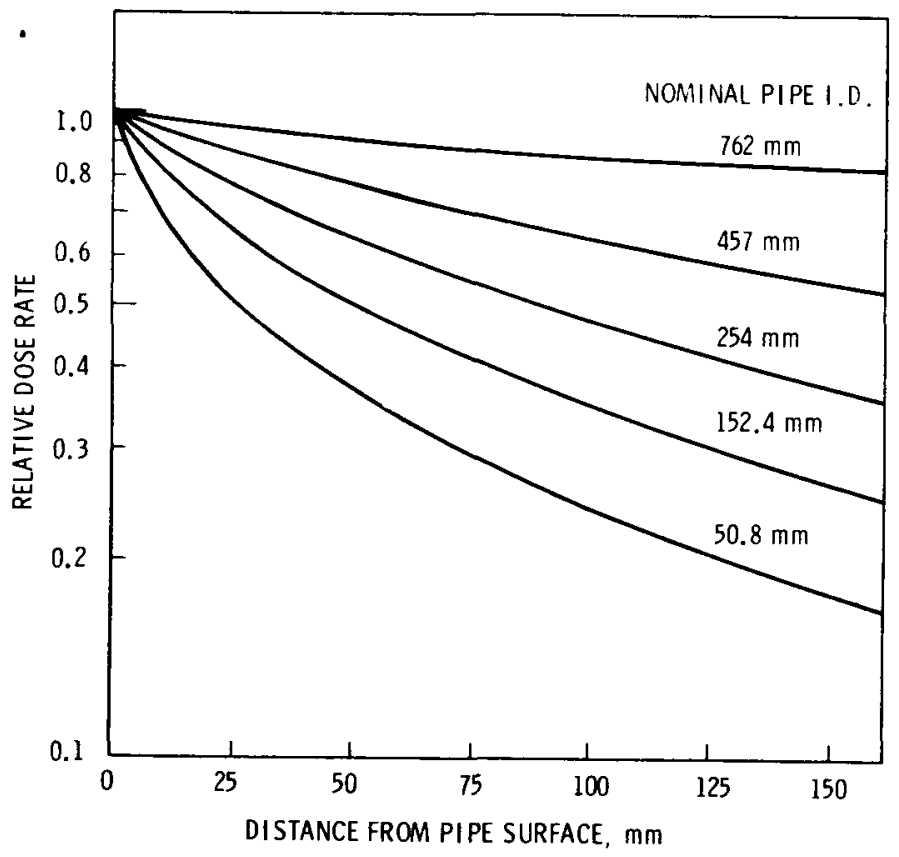

FIGURE E.2-5. Relative Dose Rate as a Function of Distance in Air from Pipe Outer Surface

- Piping is divided into three categories: reactor water, steam, and condensate. Uniform deposition in all piping of each category is assumed.

- The deposition levels for reactor water and condensate are found using representative measured dose rates in Appendix $D$ and the calculated dose rate/deposition relationships for a specific pipe size and schedule shown in Figure E.2-2.

- Since steam is less dense than liquid water, deposition levels for steam piping are calculated using the dose rate/deposition relationship for a large (914-mm-OD) pipe filled with air, shown in Figure E.2-3, and measured dose rate data from a large steam-filled pipe.

- Average pipe outside diameters are used in calculating the internal surface area of each range of pipe sizes 1 isted in Section C.3.4 of Appendix C.

A summary of the measured dose rate data and resultant deposition levels used to characterize reactor water, steam, and condensate piping systems, is shown in Table E.2-4. 
TABLE E.2-4. Piping Contact Dose Rate/Internal

Radioactivity Deposition Summary

\begin{tabular}{|c|c|c|c|c|}
\hline Pipe Category & $\begin{array}{l}\text { Nominal Outside } \\
\text { Diameter (mm) }\end{array}$ & $\begin{array}{l}\text { Wall } 1 \\
\text { Thickness (mm) } \\
\end{array}$ & $\begin{array}{c}\text { Measured } \\
\text { Contact Dose } \\
\text { Rate }(\mathrm{mR} / \mathrm{hr})(\mathrm{a}) \\
\end{array}$ & $\begin{array}{c}\text { Estimated } \\
\text { Deposition } \\
\text { Level }\left(\mathrm{Ci} / \mathrm{m}^{2}\right)(\mathrm{b}) \\
\end{array}$ \\
\hline Reactor Water & 670 & 59.5 & 700 & 1.1 \\
\hline Steam/Air & 914 & 20.4 & 70 & 0.005 \\
\hline Condensate & 670 & 46.0 & 50 & 0.05 \\
\hline
\end{tabular}

(a)From measured data presented and discussed in Appendix D.

(b) Estimated using the relationships shown in Figures E.2-2 through E.2-4.

The estimated radioactivity depositions in BWR piping are calculated using the deposition levels in Table E.2-4 and pipe information from Appendix C. The resulting values are shown in Table E.2-5. For this study, a total of $2,200 \mathrm{Ci}$ of radionuclide inventory 4 is estimated to be present on internal pipe surfaces at shutdown.

\section{E.2.1.4 Dose Rates from Internally Contaminated Equipment}

Dose rates from radioactive contamination deposited on internal surfaces of BWR equipment in contact with the reactor water are determined by modeling a nonregenerative heat exchanger in the reactor water cleanup system. This equipment is selected since it is representative of BWR equipment containing reactor water. It is about $8.5 \mathrm{~m}$ long and contains $92 \mathrm{U}$ tubes.

The surface dose rates are calculated for a unit deposition on a model of the nonregenerative heat exchanger (shown in Figure E.2-6) using the ISOSHLD computer code. The resulting surface dose rate/interrial deposition relationship is illustrated in Figure E.2-7.

\section{E.2.1.5 Estimated Total Radioactivity in Internally Contaminated Equipment}

Internal surface contamination levels in BWR equipment are estimated using the following assumptions: 
TABLE E.2-5. Estimated Contaminated Piping Internal Radioactivity Deposition

\begin{tabular}{|c|c|c|c|c|c|c|c|c|c|}
\hline \multirow[b]{2}{*}{$\frac{\text { Material }}{\text { Pipe Catego }}$} & \multicolumn{3}{|c|}{$60 \mathrm{~mm}$ Average 0.0 . } & \multicolumn{3}{|c|}{$152 \mathrm{~mm}$ Average 0.0. } & \multicolumn{3}{|c|}{$356 \mathrm{~mm}$ Average 0.0} \\
\hline & $\begin{array}{l}\text { Tength } \\
\text { (m) }\end{array}$ & $\begin{array}{l}\text { Surface } \\
\text { Area }\left(\mathrm{m}^{2}\right)\end{array}$ & $\begin{array}{l}\text { Deposited Radio- } \\
\text { activity (CI) }\end{array}$ & $\begin{array}{l}\text { Length } \\
\text { (m) }\end{array}$ & $\begin{array}{l}\text { Surface } \\
\text { Area }\left(\mathrm{m}^{2}\right)\end{array}$ & $\begin{array}{l}\text { Deposited Radio- } \\
\text { activity (Ci) }\end{array}$ & $\begin{array}{l}\text { Length } \\
\text { (m) }\end{array}$ & $\begin{array}{c}\text { Surface } \\
\text { Area }\left(m^{2}\right) \\
\end{array}$ & $\begin{array}{l}\text { Deposited Radio- } \\
\text { activity (C1) }\end{array}$ \\
\hline $\begin{array}{l}\text { Al uminum } \\
\text { Steam/Air } \\
\text { Condensate }\end{array}$ & $\begin{array}{r}4.3 \times\left(0^{2}\right. \\
--(b)\end{array}$ & $\begin{array}{c}8.1 \times 10^{1} \\
--\end{array}$ & $\begin{array}{c}4.0 \times 10^{-1} \\
\cdots\end{array}$ & $\begin{array}{l}1.4 \times 10^{3} \\
1.4 \times 10^{1}\end{array}$ & $\begin{array}{l}6.4 \times 10^{2} \\
6.7 \times 10^{0}\end{array}$ & $\begin{array}{l}3.2 \times 10^{0} \\
3.4 \times 10^{-1}\end{array}$ & $\begin{array}{c}1.3 \times 10^{2} \\
\cdots\end{array}$ & $\begin{array}{c}1.4 \times 10^{2} \\
-\cdots\end{array}$ & $\begin{array}{c}7.0 \times 10^{-1} \\
\cdots\end{array}$ \\
\hline $\begin{array}{l}\text { Carbon Steel } \\
\text { Reactor Nater } \\
\text { Steam/Air } \\
\text { Condensate }\end{array}$ & $\begin{array}{l}3.8 \times 10^{2} \\
1.2 \times 10^{3} \\
7.4 \times 10^{3}\end{array}$ & $\begin{array}{l}7.1 \times 10^{1} \\
2.2 \times 10^{2} \\
1.4 \times 10^{3}\end{array}$ & $\begin{array}{l}7.8 \times 10^{1} \\
1.1 \times 10^{0} \\
7.0 \times 10^{1}\end{array}$ & $\begin{array}{l}1.5 \times 10^{3} \\
1.8 \times 10^{3} \\
8.3 \times 10^{3}\end{array}$ & $\begin{array}{l}7.0 \times 10^{2} \\
8.8 \times 10^{2} \\
3.9 \times 10^{3}\end{array}$ & $\begin{array}{l}7.7 \times 10^{2} \\
4.4 \times 10^{0} \\
2.0 \times 10^{2}\end{array}$ & $\begin{array}{l}6.1 \times 10^{1} \\
5.6 \times 10^{3} \\
5.1 \times 10^{3}\end{array}$ & $\begin{array}{l}6.8 \times 10^{1} \\
6.3 \times 10^{3} \\
5.7 \times 10^{3}\end{array}$ & $\begin{array}{l}7.5 \times 10^{1} \\
3.2 \times 10^{1} \\
2.8 \times 10^{2}\end{array}$ \\
\hline $\begin{array}{l}\text { Stainless Steel } \\
\text { Reactor Water } \\
\text { Steam/Air } \\
\text { Condensate } \\
\text { Totals }\end{array}$ & $\begin{array}{l}8.0 \times 10^{0} \\
2.8 \times 10^{2} \\
7.0 \times 10^{3}\end{array}$ & $\begin{array}{l}1.5 \times 10^{0} \\
5.3 \times 10^{1} \\
1.3 \times 10^{3}\end{array}$ & $\begin{array}{l}1.6 \times 10^{0} \\
2.7 \times 10^{-1} \\
6.6 \times 10^{1} \\
2.2 \times 10^{2}\end{array}$ & $\begin{array}{l}3.4 \times 10^{1} \\
1.6 \times 10^{3}\end{array}$ & $\begin{array}{l}1.6 \times 10^{1} \\
7.8 \times 10^{2}\end{array}$ & $\begin{array}{l}1.8 \times 10^{1} \\
3.9 \times 10^{1} \\
\frac{3.9 \times 10^{3}}{1.0 \times 1}\end{array}$ & $\begin{array}{l}6.1 \times 10^{1} \\
2.2 \times 10^{2}\end{array}$ & $\begin{array}{l}6.8 \times 10^{1} \\
2.4 \times 10^{2}\end{array}$ & $\begin{array}{l}7.5 \times 10^{1} \\
\frac{1.2 \times 10^{1}}{4.7 \times 10^{2}}\end{array}$ \\
\hline $\begin{array}{c}\text { Material } \\
\text { Pipe Category }\end{array}$ & $\begin{array}{l}\text { Length } \\
\text { (m) }\end{array}$ & $\begin{array}{l}33 \mathrm{~mm} \text { Avera } \\
\text { Surface } \\
\text { Area }\left\langle\mathrm{m}^{2}\right\rangle\end{array}$ & $\begin{array}{l}\text { ge } 0.0 \text {. } \\
\text { Deposited Radio- } \\
\text { activity (CI) }\end{array}$ & $\begin{array}{l}\text { Length } \\
\text { (m) } \\
\end{array}$ & $\begin{array}{l}60 \mathrm{~mm} \text { Avera } \\
\text { Surface } \\
\text { Area }\left(\mathrm{m}^{2}\right)\end{array}$ & $\begin{array}{l}\text { ge } 0.0 \text {. } \\
\text { Deposited Radio- } \\
\text { activity (CI) }\end{array}$ & $\begin{array}{l}\text { Length } \\
\text { (m) }\end{array}$ & $\begin{array}{l}14 \mathrm{~mm} \text { Avera } \\
\text { Surface } \\
\text { Ared }\left(\mathrm{m}^{2}\right)\end{array}$ & $\begin{array}{l}\text { ge } 0.0 \text {. } \\
\text { Deposited Ratio- } \\
\text { activity (Ci) }\end{array}$ \\
\hline $\begin{array}{l}\text { Aluminum } \\
\text { Steam/A1r }\end{array}$ & $\cdots$ & -- & $\cdots$ & $\cdots$ & -- & -- & $\cdots$ & -- & $\cdots$ \\
\hline $\begin{array}{l}\text { Carbon Steel } \\
\text { Reactor Water } \\
\text { Steam/Air } \\
\text { Condensate }\end{array}$ & $\begin{array}{l}5.5 \times 10^{1} \\
1.2 \times 10^{3} \\
2.8 \times 10^{3}\end{array}$ & $\begin{array}{l}92 \times 10^{1} \\
2.0 \times 10^{3} \\
4.6 \times 10^{3}\end{array}$ & $\begin{array}{l}1.0 \times 10^{2} \\
1.0 \times 10^{1} \\
23 \times 10^{2}\end{array}$ & $\begin{array}{l}9.5 \times 10^{2} \\
3.7 \times 10^{2}\end{array}$ & $\begin{array}{l}2.0 \times 10^{3} \\
7.7 \times 10^{2}\end{array}$ & $\begin{array}{l}9.8 \times 10^{0} \\
3.8 \times 10^{1}\end{array}$ & $\begin{array}{l}4.4 \times 10^{2} \\
2.1 \times 10^{2}\end{array}$ & $\begin{array}{l}1.3 \times 10^{3} \\
6.1 \times 10^{2}\end{array}$ & $\begin{array}{l}6.3 \times 10^{0} \\
3.1 \times 10^{1}\end{array}$ \\
\hline $\begin{array}{l}\text { Stainless Steel } \\
\text { Reactor Water } \\
\text { Steam/Air } \\
\text { Condensate } \\
\text { Totals }\end{array}$ & $\begin{array}{c}5.5 \times 10^{1} \\
\ldots \\
\cdots\end{array}$ & $\begin{array}{c}9.2 \times 10^{1} \\
\ldots \\
-\ldots\end{array}$ & $\begin{array}{c}1.0 \times 10^{2} \\
-- \\
4.4 \times 10^{2}\end{array}$ & -.. & $\begin{array}{l}--- \\
--\end{array}$ & 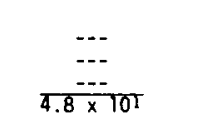 & 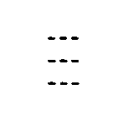 & $\begin{array}{l}--- \\
---\end{array}$ & $\frac{--}{--}$ \\
\hline
\end{tabular}

Estimated total deposited radioactivity on all contaminated piping internal surfaces $=22 \times 10^{3} \mathrm{c}$.

(a) Based on piping data in Tables C.3-7 through C.3-10, and internal deposition levels given in Table E.2-4 (b) Indicates no piping in the particular category and size.
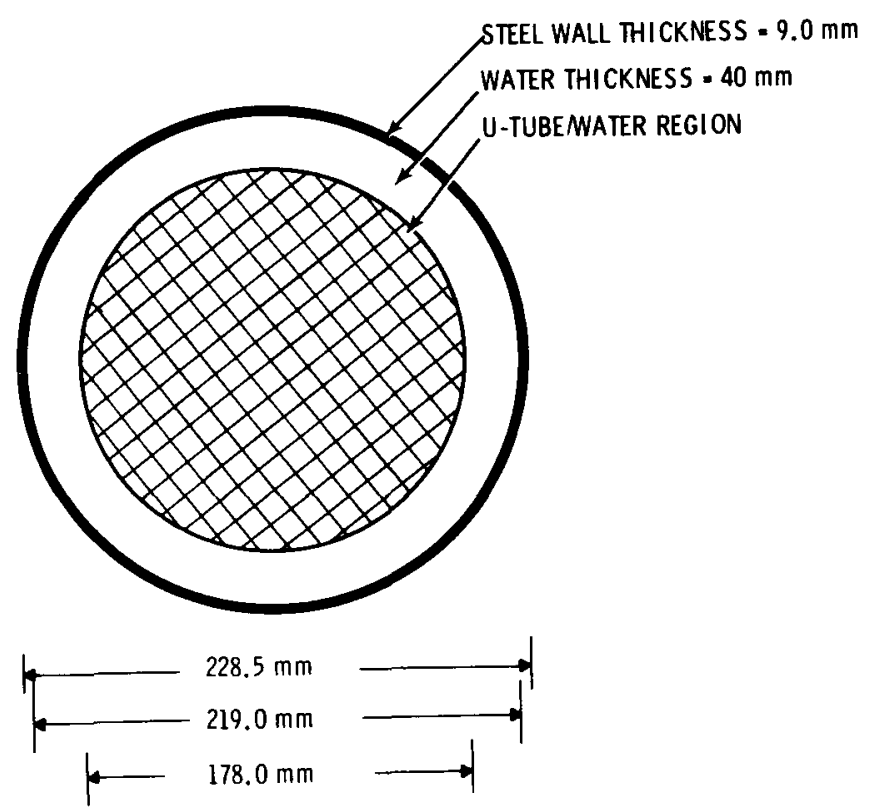

INTERNAL TUBE SURFACE AREA $=84 \mathrm{~m}^{2}$ TOTAL LENGTH $=8.5 \mathrm{~m}$

FIGURE E.2-6. Cross Section of the Cylindrical Model of a Nonregenerative Heat Exchanger 


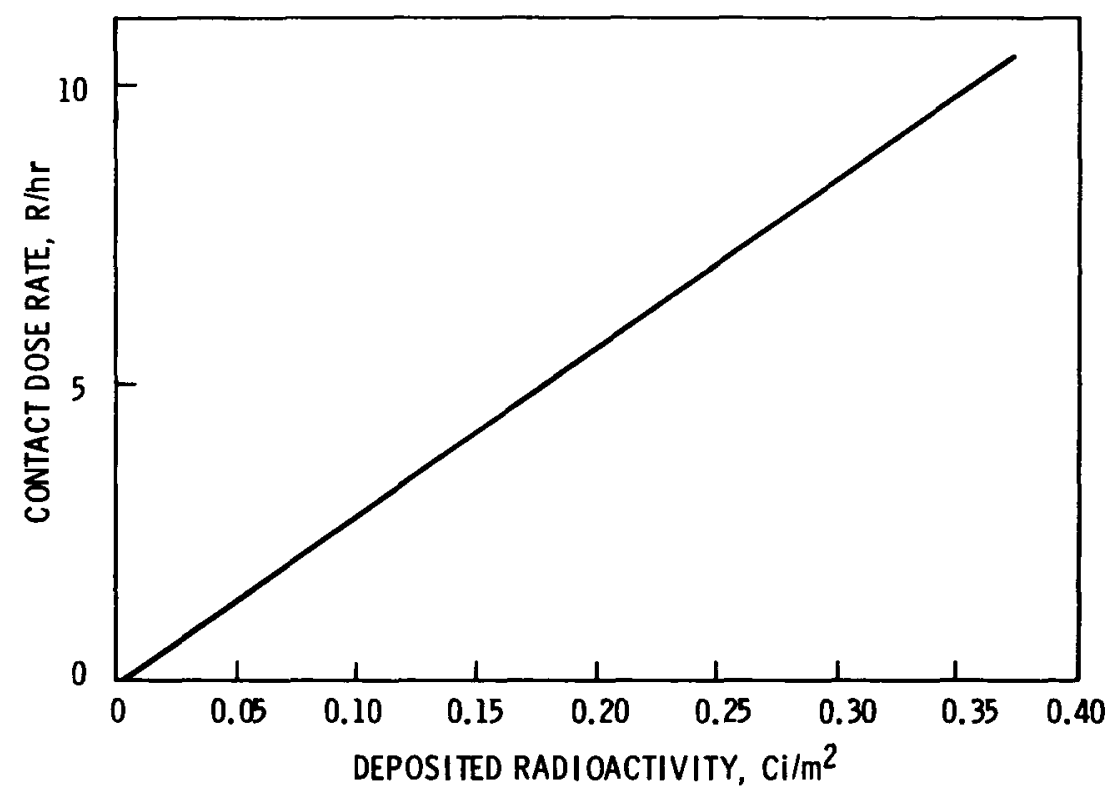

FIGURE E.2-7. Calculated Contact Dose Rate from a Nonregenerative Heat Exchanger as a Function of Deposited Internal Surface Radioactivity

1. The dose rate for the nonregenerative heat exchanger (reported in Appendix D) is $10 \mathrm{R} / \mathrm{hr}$ at contact. From Figure E.2-7, a deposition of $0.36 \mathrm{Ci} / \mathrm{m}^{2}$ is estimated. This value is used for all equipment surfaces in contact with reactor water.

2. In general, equipment in contact with steam or condensate is assumed to reach the same deposition levels calculated previously for BWR piping, with some exceptions. Steam surfaces in the turbine and heat transfer surfaces in the main condenser and the feedwater heaters are assumed to be a factor of $10 \mathrm{cleaner}$ than the corresponding piping to reflect the low dose rate levels reported in Appendix $D$.

3. Valves and pumps are assumed to be modeled by equivalent lengths of similar diameter pipe, and are included in the total for pipe.

4. Tanks in the Radwaste and Control Building that conta in concentrated waste slurries are assumed to have a deposition level 100 times higher than condensate piping. 
A summary of the deposition levels calculated for or assumed in this study is shown in Table E.2-6.

\section{TABLE E.2-6. Summary of Equipment Internal} Radioactivity Deposition Levels

\section{Equipment Category}

Reactor Water Equipment

Steam Equipment

Turbine

Condensate Equipment

Main Condenser

Feedwater Heaters

Concentrated Waste Tanks/Equipment
Radioactivity Deposition Level $\left(\mathrm{C} i / \mathrm{m}^{2}\right)$

$3.6 \times 10^{-1}$

$5.0 \times 10^{-3}$

$5.0 \times 10^{-4}$

$5.0 \times 10^{-2}$

$5.0 \times 10^{-3}$

$5.0 \times 10^{-3}$

$5.0 \times 10^{0}$

The estimated radioactivity depositions in BWR equipment are calculated using the deposition levels in Table E.2-6 and the general assumptions previously listed. The results are shown in Table E.2-7. For this study, a total of $6,300 \mathrm{Ci}$ of reference radionuclide inventory 4 is estimated to be present on internal surfaces of equipment at shutdown.

\section{E.2.2 Radionuclide Inventories on Externally Contaminated Structural Surfaces}

The radionuclide mixture found on externally contaminated structural surfaces in the reference BWR is assumed to reflect the mixture of radionuclides found in the reactor water. Leaks occurring in normally accessible areas are assumed to be repaired and cleaned up according to standard operating procedures. Leaks that occur in areas not normally accessible are assumed to accumulate and build up over the 40-year plant operating lifetime. No data relating to general surface contamination mixtures or levels are found in the literature. Therefore, for this study, the radionuclides contained in a unit leak of reactor water are assumed to accumulate on a structural surface to define the resultant radionuclide deposition. The dose rate/deposition relationship for the resulting radionuclide inventory is determined, and estimates of the total surface contamination are made. 


\section{TABLE E.2-7. Estimated Coptaminated BWR Equipment Internal Radioactivity Deposition(a)}

\begin{tabular}{|c|c|c|c|c|}
\hline$\frac{\text { Building }}{\text { Equipment Key Number(b) }}$ & Equipment Name & $\begin{array}{c}\text { Total Estimated } \\
\text { Internal Surface } \\
\text { Area }\left(\mathrm{m}^{2}\right) \\
\end{array}$ & $\begin{array}{l}\text { Radioactivity } \\
\text { Deposition } \\
\text { Level }\left(\mathrm{Ci} / \mathrm{m}^{2}\right)\end{array}$ & $\begin{array}{l}\text { Deposited Radi } \\
\text { activity (CI }\end{array}$ \\
\hline \multicolumn{5}{|l|}{ Reactor Building } \\
\hline $90,64,112$ & $\begin{array}{l}\text { Fuel Pool Heat Exchangers } \\
\text { Skimmer Surge Tanks } \\
\text { Fuel Pool, Reactor We11, Dryer and Separator Pool }\end{array}$ & $\begin{array}{l}8.0 \times 10^{2} \\
1.0 \times 10^{2} \\
1.4 \times 10^{3}\end{array}$ & $\begin{array}{l}5.0 \times 10^{-2} \\
5.0 \times 10^{-2} \\
5.0 \times 10^{-2}\end{array}$ & $\begin{array}{l}4.0 \times 10^{1} \\
5.0 \times 10^{1} \\
7.0 \times 10^{1}\end{array}$ \\
\hline $\begin{array}{l}51 \\
61 \\
62\end{array}$ & $\begin{array}{l}\text { RBCC Water Heat Exchangers } \\
\text { RWCU Regenerative Heat Exchangers } \\
\text { RWCU Nonregenerative Heat Exchangers }\end{array}$ & $\begin{array}{l}1.8 \times 10^{3} \\
2.5 \times 10^{2} \\
1.7 \times 10^{2}\end{array}$ & $\begin{array}{l}5.0 \times 10^{-2} \\
3.6 \times 10^{-1} \\
3.6 \times 10^{-1}\end{array}$ & $\begin{array}{l}9.0 \times 10^{1} \\
9.0 \times 10^{1} \\
6.0 \times 10^{1}\end{array}$ \\
\hline $\begin{array}{r}54 \\
1 \\
\text { Total }\end{array}$ & $\begin{array}{l}\text { RHR Heat Exchangers } \\
\text { Reactor Vessel }\end{array}$ & $\begin{array}{l}1.5 \times 10^{3} \\
2.6 \times 10^{3}(\mathrm{c})\end{array}$ & $\begin{array}{l}3.6 \times 10^{-1} \\
3.6 \times 10^{-1}\end{array}$ & $\begin{array}{l}5.4 \times 10^{2} \\
9.4 \times 10^{2} \\
1.9 \times 10^{3}\end{array}$ \\
\hline \multicolumn{5}{|l|}{ Turbine Generator Building } \\
\hline $\begin{array}{l}200 \\
216 \\
217\end{array}$ & $\begin{array}{l}\text { Main Condenser } \\
\text { Steam Jet Air Ejector Condenser } \\
\text { Gland Seal Steam Condenser }\end{array}$ & $\begin{array}{l}7.9 \times 10^{4} \\
1.6 \times 10^{3} \\
3.5 \times 10^{2}\end{array}$ & $\begin{array}{l}5.0 \times 10^{-3} \\
5.0 \times 10^{-2} \\
5.0 \times 10^{-2}\end{array}$ & $\begin{array}{l}3.9 \times 10^{2} \\
8.0 \times 10^{1} \\
1.7 \times 10^{1}\end{array}$ \\
\hline $\begin{array}{l}228 \\
253 \\
255\end{array}$ & $\begin{array}{l}\text { Condensate Storage Tanks } \\
\text { Low-Pressure Feedwater Heaters } \\
\text { Evaporator Orain Tanks }\end{array}$ & $\begin{array}{l}7.6 \times 10^{3} \\
7.5 \times 10^{4} \\
1.0 \times 10^{1}\end{array}$ & $\begin{array}{l}5.0 \times 10^{-2} \\
5.0 \times 10^{-3} \\
5.0 \times 10^{-2}\end{array}$ & $\begin{array}{l}8.0 \times 10^{1} \\
3.7 \times 10^{2} \\
5.0 \times 10^{-1}\end{array}$ \\
\hline $\begin{array}{l}256 \\
263 \\
201\end{array}$ & $\begin{array}{l}\text { Reheater Drain Tanks } \\
\text { Moisture Separator Drain Tank } \\
\text { Main Turbine }\end{array}$ & $\begin{array}{l}8.4 \times 10^{2} \\
3.0 \times 10^{1} \\
2.6 \times 10^{3}(\mathrm{c})\end{array}$ & $\begin{array}{l}5.0 \times 10^{-2} \\
5.0 \times 10^{-3} \\
5.0 \times 10^{-4}\end{array}$ & $\begin{array}{l}4.2 \times 10^{1} \\
1.5 \times 10^{-1} \\
1.3 \times 10^{0}\end{array}$ \\
\hline $\begin{array}{l}254 \\
258 \\
270\end{array}$ & $\begin{array}{l}\text { Stearn Evaporator } \\
\text { Turbine Bypass Valve Assembly } \\
\text { Mo isture Separator Reheaters }\end{array}$ & $\begin{array}{l}2.0 \times 10^{3} \\
1.5 \times 10^{1} \\
1.8 \times 10^{4}\end{array}$ & $\begin{array}{l}5.0 \times 10^{-3} \\
5.0 \times 10^{-3} \\
5.0 \times 10^{-3}\end{array}$ & $\begin{array}{l}1.0 \times 10^{1} \\
7.5 \times 10^{-1} \\
9.0 \times 10^{1}\end{array}$ \\
\hline $\begin{array}{r}226 \\
227 \\
252 \\
\text { Total }\end{array}$ & $\begin{array}{l}\text { Seal Water Liquid Tank } \\
\text { Pumped Drain Tank } \\
\text { High-Pressure Feedwater Heaters }\end{array}$ & $\begin{array}{l}1.2 \times 10^{1} \\
2.7 \times 10^{1} \\
1.7 \times 10^{4}\end{array}$ & $\begin{array}{l}5.0 \times 10^{-2} \\
5.0 \times 10^{-2} \\
5.0 \times 10^{-3}\end{array}$ & $\begin{array}{l}6.0 \times 10^{-1} \\
1.4 \times 10^{0} \\
8.5 \times 10^{1} \\
.2 \times 10^{3}\end{array}$ \\
\hline \multicolumn{5}{|l|}{ Radwaste and Control Building } \\
\hline $\begin{array}{l}302 \\
304 \\
301\end{array}$ & $\begin{array}{l}\text { Condensate Phase Separator Tanks } \\
\text { Condensate Backwash Receiver Tank } \\
\text { Waste Collector Tank }\end{array}$ & $\begin{array}{l}1.8 \times 10^{2} \\
8.5 \times 10^{2} \\
1.0 \times 10^{2}\end{array}$ & $\begin{array}{l}5.0 \times 10^{0} \\
5.0 \times 10^{0} \\
5.0 \times 10^{-2}\end{array}$ & $\begin{array}{l}9.0 \times 10^{2} \\
4.2 \times 10^{2} \\
5.0 \times 10^{0}\end{array}$ \\
\hline $\begin{array}{l}312 \\
313 \\
300\end{array}$ & $\begin{array}{l}\text { Waste Surge Tank } \\
\text { Waste Sample Tanks } \\
\text { Floor Drain Collector Tank }\end{array}$ & $\begin{array}{l}1.9 \times 10^{2} \\
1.6 \times 10^{2} \\
1.1 \times 10^{2}\end{array}$ & $\begin{array}{l}5.0 \times 10^{0} \\
5.0 \times 10^{-2} \\
5.0 \times 10^{-2}\end{array}$ & $\begin{array}{l}9.5 \times 10^{2} \\
8.0 \times 10^{0} \\
5.5 \times 10^{0}\end{array}$ \\
\hline $\begin{array}{l}306 \\
314 \\
308\end{array}$ & $\begin{array}{l}\text { Waste Sludge Phase Separator Tank } \\
\text { Floor Drain Sample Tank } \\
\text { Chemical Waste Tanks }\end{array}$ & $\begin{array}{l}6.1 \times 10^{1} \\
7.8 \times 10^{1} \\
1.5 \times 10^{2}\end{array}$ & $\begin{array}{l}5.0 \times 10^{0} \\
5.0 \times 10^{-2} \\
5.0 \times 10^{-2}\end{array}$ & $\begin{array}{l}3.0 \times 10^{2} \\
3.9 \times 10^{0} \\
7.5 \times 10^{0}\end{array}$ \\
\hline $\begin{array}{l}309 \\
310 \\
311\end{array}$ & $\begin{array}{l}\text { Distillate Tanks } \\
\text { Detergent Drain Tank } \\
\text { Decontamination Solution Concentration Waste Tank }\end{array}$ & $\begin{array}{l}1.5 \times 10^{2} \\
3.2 \times 10^{1} \\
2.3 \times 10^{1}\end{array}$ & $\begin{array}{l}5.0 \times 10^{-2} \\
5.0 \times 10^{-2} \\
5.0 \times 10^{0}\end{array}$ & $\begin{array}{l}7.5 \times 10^{0} \\
1.6 \times 10^{1} \\
1.2 \times 10^{2}\end{array}$ \\
\hline $\begin{array}{r}305 \\
307 \\
386 \\
\text { Total }\end{array}$ & $\begin{array}{l}\text { Spent Resin Tank } \\
\text { Cleanup Phase Separator Tanks } \\
\text { Decontamination Solution Concentrator }\end{array}$ & $\begin{array}{l}1.3 \times 10^{1} \\
6.8 \times 10^{1} \\
1.9 \times 10^{1}\end{array}$ & $\begin{array}{l}5.0 \times 10^{0} \\
5.0 \times 10^{0} \\
5.0 \times 10^{0}\end{array}$ & $\begin{array}{l}6.5 \times 10^{1} \\
3.4 \times 10^{2} \\
9.5 \times 10^{1} \\
3.2 \times 10^{3}\end{array}$ \\
\hline
\end{tabular}

Estimated total radioactivity deposited on all contaminated equipment internal surfaces $=6.3 \times 10^{3} \mathrm{Ci}$.

(a) The assumptions used to calculate the values in this table are listed in Section E.2.1.5.

(b) See Section C.2 in Appendix C.

(c) The internal surface area is estimated as being a factor of 5 times larger than the internal surface area of a right cylinder having dimensions similar to each particular piece of equipment. 


\section{E.2.2.1 Reference Radionuclide Inventory 5}

The radionuclide mixture resulting from a small continuous leak is described by the differential equation:

$$
\frac{d q}{d t}=p-\lambda q
$$

where: $q$ - the quantity of radioactivity present, $\mathrm{C} i$

$t$ - the time unit of interest, day

$\mathrm{P}$ - the leak rate, Ci/day

$\lambda$ - the decay constant, days ${ }^{-1}, 0.693 /$ half-life. $^{-1}$

Integrating Equation E.1 and solving for $q$ gives:

$$
q=\frac{p\left(1-e^{-\lambda t}\right)}{\lambda}
$$

The mixture of radionuclides found in the reactor water is shown in Table E.2-8. (28) Assuming a release of reactor water at the rate of 1 liter per day for 40 years, the resulting surface contamination inventory is found using Equation E.2. This mixture is shown in Table E.2-9 as reference radionuclide inventory 5 . This inventory is used in Appendix $F$ in determining the maximum annual dose to the maximum-exposed individual working in the decommissioned reference BWR facility. It is also used in Appendix $N$ to assess public safety impacts of decommissioning.

\section{E.2.2.2 Dose Rates from Externally Contaminated Structural Surfaces}

Dose rates from structural surface contamination inside the reference BWR are calculated using the ISOSHLD computer code with a unit deposition level of radionuclide inventory 5 . Floor surface areas are modeled by a disk source of $7-\mathrm{m}$ radius (a floor area of $154 \mathrm{~m}^{2}$ ). The dose rate $1 \mathrm{~m}$ in air above this floor as a function of the surface deposition is shown in Figure E.2-8. 
TABLE E.2-8. Reactor Water Radionuclide Concentrations in an Operating BWR

\begin{tabular}{|c|c|c|c|}
\hline$\underline{R a d i o n u c l i d e}^{(\mathrm{a})}$ & $\begin{array}{c}\text { Half-Life } \\
\text { (days) } \\
\end{array}$ & $\begin{array}{c}\text { Concentration } \\
(\mu \mathrm{Ci} / \mathrm{g})(\mathrm{b}) \\
\end{array}$ & $\begin{array}{c}\text { Fractional } \\
\text { Concentration } \\
\end{array}$ \\
\hline $\begin{array}{l}{ }^{3} \mathrm{H} \\
32 \mathrm{P} \\
{ }^{5} \mathrm{Cr}\end{array}$ & $\begin{array}{l}4.5 \times 10^{3} \\
1.4 \times 10^{1} \\
2.8 \times 10^{1}\end{array}$ & $\begin{array}{l}1 \times 10^{-2}(c) \\
2 \times 10^{-4} \\
5 \times 10^{-3}\end{array}$ & $\begin{array}{c}--(c) \\
1.5 \times 10^{-2} \\
3.8 \times 10^{-1}\end{array}$ \\
\hline $\begin{array}{l}{ }^{54} \mathrm{Mn} \\
55 \mathrm{Fe} \\
{ }^{59} \mathrm{Fe}\end{array}$ & $\begin{array}{l}3.1 \times 10^{2} \\
9.5 \times 10^{2} \\
4.5 \times 10^{1}\end{array}$ & $\begin{array}{l}6 \times 10^{-5} \\
1 \times 10^{-3} \\
3 \times 10^{-5}\end{array}$ & $\begin{array}{l}4.5 \times 10^{-3} \\
7.5 \times 10^{-2} \\
2.2 \times 10^{-3}\end{array}$ \\
\hline $\begin{array}{l}{ }^{58} \mathrm{Co} \\
6{ }^{6} \mathrm{Co} \\
6{ }^{3} \mathrm{Ni}\end{array}$ & $\begin{array}{l}7.2 \times 10^{1} \\
1.9 \times 10^{3} \\
3.6 \times 10^{4}\end{array}$ & $\begin{array}{l}2 \times 10^{-4} \\
4 \times 10^{-4} \\
1 \times 10^{-6}\end{array}$ & $\begin{array}{l}1.5 \times 10^{-2} \\
3.0 \times 10^{-2} \\
7.5 \times 10^{-5}\end{array}$ \\
\hline $\begin{array}{l}65 \mathrm{Zn} \\
{ }^{89} \mathrm{Sr} \\
{ }^{90} \mathrm{Sr}\end{array}$ & $\begin{array}{l}2.4 \times 10^{2} \\
5.3 \times 10^{1} \\
1.0 \times 10^{4}\end{array}$ & $\begin{array}{l}2 \times 10^{-4} \\
1 \times 10^{-4} \\
6 \times 10^{-6}\end{array}$ & $\begin{array}{l}1.5 \times 10^{-2} \\
7.5 \times 10^{-3} \\
4.5 \times 10^{-4}\end{array}$ \\
\hline $\begin{array}{l}90 Y \\
91 Y \\
95 \mathrm{Zr}\end{array}$ & $\begin{array}{l}2.7 \times 10^{0} \\
5.9 \times 10^{1} \\
6.5 \times 10^{1}\end{array}$ & $\begin{array}{l}6 \times 10^{-6} \\
4 \times 10^{-5} \\
7 \times 10^{-6}\end{array}$ & $\begin{array}{l}4.5 \times 10^{-4} \\
3.0 \times 10^{-3} \\
5.2 \times 10^{-4}\end{array}$ \\
\hline $\begin{array}{r}103 \mathrm{Ru} \\
106 \mathrm{Ru} \\
110 \mathrm{mAg}\end{array}$ & $\begin{array}{l}4.0 \times 10^{1} \\
3.7 \times 10^{2} \\
2.5 \times 10^{2}\end{array}$ & $\begin{array}{l}2 \times 10^{-5} \\
3 \times 10^{-6} \\
1 \times 10^{-6}\end{array}$ & $\begin{array}{l}1.5 \times 10^{-3} \\
2.2 \times 10^{-4} \\
7.5 \times 10^{-5}\end{array}$ \\
\hline $\begin{array}{c}129 \mathrm{mTe} \\
131 \mathrm{I} \\
134 \mathrm{Cs}\end{array}$ & $\begin{array}{l}3.4 \times 10^{1} \\
8.0 \times 10^{0} \\
7.5 \times 10^{2}\end{array}$ & $\begin{array}{l}4 \times 10^{-5} \\
5 \times 10^{-3} \\
3 \times 10^{-5}\end{array}$ & $\begin{array}{l}3.0 \times 10^{-3} \\
3.8 \times 10^{-1} \\
2.2 \times 10^{-3}\end{array}$ \\
\hline $\begin{array}{l}136 \mathrm{Cs} \\
137 \mathrm{Cs} \\
140 \mathrm{Ba}\end{array}$ & $\begin{array}{l}1.4 \times 10^{1} \\
1.1 \times 10^{4} \\
1.3 \times 10^{1}\end{array}$ & $\begin{array}{l}2 \times 10^{-5} \\
7 \times 10^{-5} \\
4 \times 10^{-4}\end{array}$ & $\begin{array}{l}1.5 \times 10^{-5} \\
5.2 \times 10^{-3} \\
3.0 \times 10^{-2}\end{array}$ \\
\hline $\begin{array}{l}140 \mathrm{Ca} \\
141 \mathrm{Ce} \\
144 \mathrm{Ce}\end{array}$ & $\begin{array}{l}1.7 \times 10^{0} \\
3.2 \times 10^{1} \\
2.8 \times 10^{2}\end{array}$ & $\begin{array}{l}4 \times 10^{-4} \\
3 \times 10^{-5} \\
3 \times 10^{-6}\end{array}$ & $\begin{array}{l}3.0 \times 10^{-2} \\
2.2 \times 10^{-3} \\
3.0 \times 10^{-3}\end{array}$ \\
\hline $\begin{array}{r}143 \mathrm{Pr} \\
147 \mathrm{Nd} \\
\text { Totals }\end{array}$ & $\begin{array}{l}1.4 \times 10^{1} \\
1.1 \times 10^{1}\end{array}$ & $\begin{array}{l}4 \times 10^{-5} \\
3 \times 10^{-6} \\
1.3 \times 10^{-2}\end{array}$ & $\begin{array}{l}3.0 \times 10^{-3} \\
2.2 \times 10^{-4} \\
\frac{1.0}{1.0}\end{array}$ \\
\hline
\end{tabular}

(a) Radionuclides with half-lives greater than 8 days and shortlived daughters of long-lived parents are included.

(b) Based on data from Reference 28.

(c) ${ }^{3} \mathrm{H}$ is not included in the total. 
TABLE E.2-9. Reference Radionuclide Inventory 5, BWR Structural Surface External Contamination

\begin{tabular}{|c|c|c|c|c|c|}
\hline \multirow{2}{*}{ Radionucl ide ${ }^{(a)}$} & \multicolumn{5}{|c|}{ Fractional Radioactivity at Decay Times of: } \\
\hline & Shutdown & 10 Years & 30 Years & 50 Years & 100 Years \\
\hline $32 p$ & $1.1 \times 10^{-3}$ & $-\ldots(b)$ & $-\cdots$ & --- & --- \\
\hline${ }^{51} \mathrm{Cr}$ & $5.3 \times 10^{-2}$ & --- & --- & --- & --- \\
\hline $54 \mathrm{Mn}$ & $7.2 \times 10^{-4}$ & $2.3 \times 10^{-7}$ & -- & --- & --- \\
\hline${ }^{55} \mathrm{Fe}$ & $3.7 \times 10^{-1}$ & $2.5 \times 10^{-2}$ & $1.2 \times 10^{-4}$ & $6.0 \times 10^{-7}$ & --- \\
\hline${ }^{59} \mathrm{Fe}$ & $5.3 \times 10^{-4}$ & -.- & -.. & --- & $-\ldots$ \\
\hline${ }^{58} \mathrm{Co}$ & $5.6 \times 10^{-3}$ & --- & -- & --- & --- \\
\hline $60 \mathrm{Co}$ & $2.9 \times 10^{-1}$ & $7.8 \times 10^{-2}$ & $5.6 \times 10^{-3}$ & $4.0 \times 10^{-4}$ & $5.6 \times 10^{-7}$ \\
\hline${ }^{6}{ }^{\mathrm{Ni}}$ & $3.4 \times 10^{-3}$ & $3.2 \times 10^{-3}$ & $2.8 \times 10^{-3}$ & $2.4 \times 10^{-3}$ & $1.7 \times 10^{-3}$ \\
\hline${ }^{65} \mathrm{Zn}$ & $1.8 \times 10^{-2}$ & $4.5 \times 10^{-7}$ & --- & --- & -- \\
\hline${ }^{89} \mathrm{Sr}$ & $2.0 \times 10^{-3}$ & -- & - & -- & --- \\
\hline${ }^{90} \mathrm{sr}$ & $1.5 \times 10^{-2}$ & $1.2 \times 10^{-2}$ & $7.0 \times 10^{-3}$ & $4.2 \times 10^{-3}$ & $1.2 \times 10^{-3}$ \\
\hline $90 y$ & $1.5 \times 10^{-2}$ & $1.2 \times 10^{-2}$ & $7.0 \times 10^{-3}$ & $4.2 \times 10^{-3}$ & $1.2 \times 10^{-3}$ \\
\hline $91 Y$ & $8.1 \times 10^{-4}$ & --- & --- & --- & --- \\
\hline${ }^{95} \mathrm{Zr}$ & $1.6 \times 10^{-4}$ & --- & --- & --- &.-- \\
\hline $95 \mathrm{Nb}$ & $1.6 \times 10^{-4}$ & -- & -- & -- & --- \\
\hline $10{ }^{3} \mathrm{Ru}$ & $2.9 \times 10^{-4}$ & --- & --- & --- &.-- \\
\hline $106 \mathrm{Ru}$ & $3.9 \times 10^{-4}$ & -- & --- & -- & --- \\
\hline $110 \mathrm{~m}_{\mathrm{Ag}}$ & $8.8 \times 10^{-6}$ & $3.2 \times 10^{-10}$ & --- & --- & --- \\
\hline $129 \mathrm{mTe}$ & $4.9 \times 10^{-4}$ & --- & -.- & --- & --- \\
\hline $131 \mathrm{I}$ & $1.5 \times 10^{-2}$ & -8 & -- & --- & --- \\
\hline $134 \mathrm{Cs}$ & $8.8 \times 10^{-3}$ & $3.1 \times 10^{-4}$ & $3.7 \times 10^{-7}$ & $4.4 \times 10^{-10}$ & -- \\
\hline $136 \mathrm{Cs}$ & $1.0 \times 10^{-4}$ & $-\ldots$ & $\ldots$ & ... & -.. \\
\hline $137 \mathrm{Cs}$ & $1.8 \times 10^{-1}$ & $1.4 \times 10^{-1}$ & $9.0 \times 10^{-2}$ & $5.7 \times 10^{-2}$ & $1.8 \times 10^{-2}$ \\
\hline $14^{0} \mathrm{Ba}$ & $2.0 \times 10^{-3}$ & $\cdots$ & -- & --- & --- \\
\hline${ }^{140} \mathrm{La}$ & $2.0 \times 10^{-3}$ & -- & --- & --- & -.- \\
\hline${ }^{141} \mathrm{Ce}$ & $3.4 \times 10^{-4}$ & -- &.-- & --- & --- \\
\hline${ }^{144} \mathrm{Ce}$ & $2.9 \times 10^{-4}$ & $3.1 \times 10^{-8}$ & -- & --- & --- \\
\hline $143 \mathrm{Pr}$ & $2.0 \times 10^{-4}$ & -.- & -.- & --- & --- \\
\hline $147 \mathrm{Nd}$ & $1.2 \times 10^{-5}$ & -- & --- & --- & -- \\
\hline$\overline{\text { Tota7s }}$ & $\overline{1.0}$ & $2.7 \times 10^{-1}$ & $1.1 \times 10^{-1}$ & $\overline{6.8 \times 10^{-2}}$ & $2.2 \times 10^{-2}$ \\
\hline
\end{tabular}

(a) Radionuclides with half-lives greater than 8 days and short-lived daughters of long-lived parents are included.

(b) Indicates a value less than $1.0 \times 10^{-10}$. 


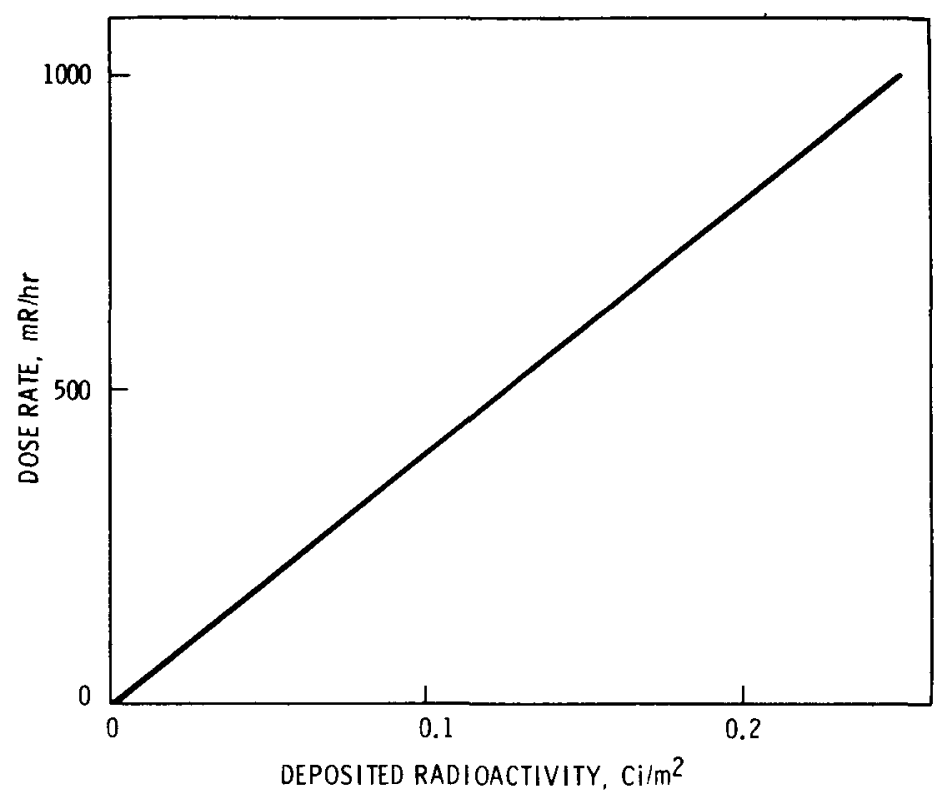

FIGURE E.2-8. Calculated Dose Rates in Air $1 \mathrm{~m}$ Above Structural Surfaces as a Function of Deposited External Surface Radioactivity

\section{E.2.2.3 Estimated Total Radioactivity on Externally Contaminated Structural Surfaces}

The deposited amounts of reference radionuclide inventory 5 present on contaminated structural surfaces in the reference BWR are estimated using the following assumptions:

1. Contaminated concrete surfaces are based on the surfaces discussed in Appendix D.

2. Since it is difficult to characterize the quantity and location of structural surface contamination, surfaces are placed in three contamination categories. The first category is defined as nonradioactive areas with no reactor water, steam, or condensate process systems. The second category is defined as low-level contamination areas with dose rates of $10 \mathrm{mR} / \mathrm{hr}$ in air $1 \mathrm{~m}$ from the surface. The third category is defined as areas of higher contamination with dose rates of $100 \mathrm{mR} / \mathrm{hr}$ in air $1 \mathrm{~m}$ from the surface.

The structural surface contamination levels that correspond to dose rates of 10 and $100 \mathrm{mR} / \mathrm{hr}$ for radionuclide inventory 5 are estimated from Figure E.2-8 
to be $2.5 \times 10^{-3} \mathrm{Ci} / \mathrm{m}^{2}$ and $2.5 \times 10^{-2} \mathrm{Ci} / \mathrm{m}^{2}$, respectively. The estimated structural surface external contamination in the reference BWR at shutdown is given in Table E.2-10. The total deposited radioactivity on structural surfaces is calculated to be about $110 \mathrm{Ci}$.

\section{TABLE E.2-10. Estimated Structural Surface External Contamination in the Reference BWR}

\begin{tabular}{|c|c|c|c|}
\hline $\begin{array}{c}\text { Bullding } \\
\text { Associated Equipment system }\end{array}$ & $\begin{array}{c}\text { Estimated } \\
\text { Contaminated } \\
\text { Surface Area }\left(m^{2}\right)(a) \\
\end{array}$ & $\begin{array}{c}\text { Radioactivity } \\
\text { Deposition } \\
\text { Level(b) } \\
\end{array}$ & $\begin{array}{c}\text { Deposited } \\
\text { Radioactivity } \\
\text { (CI) } \\
\end{array}$ \\
\hline \multicolumn{4}{|l|}{ Reactor Bullding } \\
\hline $\begin{array}{l}\text { Conta inment Atmosphere Control } \\
\text { Condensate (Nuclear Steam) } \\
\text { Control Rod Drive }\end{array}$ & $\begin{array}{l}1.6 \times 10^{1} \\
33 \times 10^{1} \\
1.8 \times 10^{2}\end{array}$ & $\begin{array}{l}1 \\
1 \\
1\end{array}$ & $\begin{array}{l}4.0 \times 10^{-2} \\
82 \times 10^{-2} \\
4.5 \times 10^{-1}\end{array}$ \\
\hline $\begin{array}{l}\text { Equipment Drain (Radioactive) } \\
\text { Floor Draln (Radioactive) } \\
\text { Fuel Pool Cooling and Cleanup } \\
\text { Fuel Pool Cooling and Cleanup }\end{array}$ & $\begin{array}{l}1.8 \times 10^{1} \\
7.4 \times 10^{1} \\
1.2 \times 10^{3} \\
2.8 \times 10^{2}\end{array}$ & $\begin{array}{l}2 \\
2 \\
1 \\
2\end{array}$ & $\begin{array}{l}4.5 \times 10^{-1} \\
1.8 \times 10^{0} \\
3.0 \times 10^{0} \\
7.0 \times 10^{0}\end{array}$ \\
\hline $\begin{array}{l}\text { High-Pressure Core Spray } \\
\text { Low-Pressure Core Spray } \\
\text { Ma in Steam }\end{array}$ & $\begin{array}{l}1.1 \times 10^{2} \\
1.4 \times 10^{1} \\
3.0 \times 10^{2}\end{array}$ & $\begin{array}{l}1 \\
1 \\
1\end{array}$ & $\begin{array}{l}2.7 \times 10^{-1} \\
3.5 \times 10^{-2} \\
7.5 \times 10^{-1}\end{array}$ \\
\hline $\begin{array}{l}\text { Miscellaneous Wastes (Radioactive) } \\
\text { Reactor Building Closed Cooling } \\
\text { Reactor Core Isolation Cooling }\end{array}$ & $\begin{array}{l}8.3 \times 10^{1} \\
1.2 \times 10^{1} \\
1.5 \times 10^{1}\end{array}$ & $\begin{array}{l}1 \\
1 \\
1\end{array}$ & $\begin{array}{l}2.1 \times 10^{-1} \\
3.0 \times 10^{-2} \\
3.8 \times 10^{-2}\end{array}$ \\
\hline $\begin{array}{l}\text { Reactor Water Cleanup } \\
\text { Reactor Water Cleanup } \\
\text { Residual Heat Removal }\end{array}$ & $\begin{array}{l}1.5 \times 10^{2} \\
1.7 \times 10^{2} \\
1.7 \times 10^{2}\end{array}$ & $\begin{array}{l}1 \\
2 \\
1\end{array}$ & $\begin{array}{l}3.8 \times 10^{-1} \\
4.2 \times 10^{0} \\
4.2 \times 10^{-1}\end{array}$ \\
\hline $\begin{array}{l}\text { Standby Gas Treatment } \\
\text { Traversing Incore Probe }\end{array}$ & $\begin{array}{l}4.0 \times 10^{1} \\
8.0 \times 10^{1}\end{array}$ & 1 & $\begin{array}{l}1.0 \times 10^{-1} \\
2.0 \times 10^{-1}\end{array}$ \\
\hline$\frac{\text { Primary Containment }}{\text { Total }}$ & $22 \times 10^{3}$ & 2 & $\frac{5.5 \times 10^{1}}{7.4 \times 10^{1}}$ \\
\hline \multicolumn{4}{|l|}{ Turbine Generator Building } \\
\hline $\begin{array}{l}\text { Air Removal } \\
\text { Condensate (Nuclear Steam) } \\
\text { Condenser off Gas Treatment }\end{array}$ & $\begin{array}{l}3.9 \times 10^{1} \\
6.6 \times 10^{2} \\
1.8 \times 10^{2}\end{array}$ & $\begin{array}{l}1 \\
1 \\
1\end{array}$ & $\begin{array}{l}9.7 \times 10^{-2} \\
16 \times 10^{-1} \\
4.5 \times 10^{-1}\end{array}$ \\
\hline $\begin{array}{l}\text { Equipment Drain (Radioactive) } \\
\text { Floor Drain (Radioactive) } \\
\text { Heater Drain }\end{array}$ & $\begin{array}{l}2.5 \times 10^{1} \\
2.5 \times 10^{1} \\
9.1 \times 10^{1}\end{array}$ & $\begin{array}{l}2 \\
2 \\
1\end{array}$ & $\begin{array}{l}6.2 \times 10^{-1} \\
6.2 \times 10^{-1} \\
2.3 \times 10^{-1}\end{array}$ \\
\hline $\begin{array}{l}\text { Main Steam } \\
\text { Miscellaneous Drain and Vent } \\
\text { Reactor Feedwater } \\
\text { Miscellaneous Wastes (Radroactive) } \\
\text { Total }\end{array}$ & $\begin{array}{l}1.7 \times 10^{2} \\
1.9 \times 10^{1} \\
6.9 \times 10^{2} \\
9.0 \times 10^{0}\end{array}$ & $\begin{array}{l}1 \\
1 \\
1 \\
1\end{array}$ & $\begin{array}{l}4.2 \times 10^{-1} \\
4.7 \times 10^{-2} \\
1.7 \times 10^{0} \\
2.2 \times 10^{-2} \\
\frac{4.4 \times 10^{0}}{}\end{array}$ \\
\hline \multicolumn{4}{|l|}{ Radwaste and Control Building } \\
\hline $\begin{array}{l}\text { Condensate Filter Demineralizer } \\
\text { Condenser Off Gas Treatment } \\
\text { Equipment Drain (Radioactive) } \\
\text { Equipment Drain (Radioactive) }\end{array}$ & $\begin{array}{l}3.6 \times 10^{2} \\
3.2 \times 10^{2} \\
4.3 \times 10^{1} \\
1.8 \times 10^{2}\end{array}$ & $\begin{array}{l}2 \\
1 \\
1 \\
2\end{array}$ & $\begin{array}{l}9.0 \times 10^{0} \\
8.0 \times 10^{-1} \\
1.1 \times 10^{-1} \\
4.5 \times 10^{0}\end{array}$ \\
\hline $\begin{array}{l}\text { Floor Drain (Radloactive) } \\
\text { Floor Drain (Radioactive) } \\
\text { Floor Pool Cooling and Cleanup }\end{array}$ & $\begin{array}{l}1.2 \times 10^{1} \\
1.9 \times 10^{2} \\
5.4 \times 10^{1}\end{array}$ & $\begin{array}{l}1 \\
2 \\
2\end{array}$ & $\begin{array}{l}3.0 \times 10^{-2} \\
4.8 \times 10^{0} \\
1.4 \times 10^{0}\end{array}$ \\
\hline $\begin{array}{l}\text { Miscellaneous Wastes (Radloactive) } \\
\text { Miscellaneous Wastes (Radioactive) } \\
\text { Process Waste (Radioactive) } \\
\text { Process Waste (Radioactive) } \\
\text { Reactor Water Cleanup } \\
\text { Total }\end{array}$ & $\begin{array}{l}2.4 \times 10^{1} \\
1.9 \times 10^{2} \\
1.8 \times 10^{2} \\
2.7 \times 10^{2} \\
1.3 \times 10^{2}\end{array}$ & $\begin{array}{l}1 \\
2 \\
1 \\
2 \\
2\end{array}$ & $\begin{array}{l}6.0 \times 10^{-2} \\
48 \times 10^{0} \\
4.5 \times 10^{-1} \\
6.7 \times 10^{0} \\
3.2 \times 10^{0} \\
3.6 \times 10^{1}\end{array}$ \\
\hline
\end{tabular}

Estimated total deposited radioactivity on contaminated external surfaces $=1.1 \times 10^{2} \mathrm{Cl}$.

(a) The surface area is estimated using information in Appendices $C$ and $D$

(a) The surface area is estimated using information
(b) $1=2.5 \times 10^{-3} \mathrm{Cl}_{1} / \mathrm{m}^{2}$, and $2=2.5 \times 10^{-2} \mathrm{C} / \mathrm{m}^{2}$ 
It should be noted that the dose rates used to estimate the structural surface external contamination are chosen to maximize the results and only partially reflect the expected levels at the time of final shutdown of the reference BWR. These dose rates are not used in calculating the occupational exposure to workers as they work around or remove the contaminated structura? surfaces. The dose rates used for that purpose are presented in Appendix $D$.

\section{E.2.3 Radionuclide Inventory on the Reference Site}

This section contains a discussion of the postulated deposited radionuclide contamination level and mixture on the reference site resulting from normal BWR operation. Accidental releases of radionuclides are not expected to significantly increase the radioactivity on the reference site and, thus, are not considered in this analysis. Information about the level and nature of the radioactive contamination present at the time of decommissioning is needed to determine the alternative future uses of the site.

\section{E.2.3.1 Radionuclide Release Data and Inventory Calculational Methods}

Low levels of radioactive contamination are present on the reference site as a result of deposition of airborne radionuclide releases during 40 years of normal BWR operation. In addition, naturally occurring radionuclides and those resulting from nuclear weapons testing are present on the site, but deposition of these latter radionuclides is not quantified in this study.

Annual airborne radionuclide releases from operating BWRs vary widely and are dependent on such plant factors as size, operating conditions, and gaseous radwaste systems. For this study, the releases are based on gaseous and particulate airborne releases from 23 operating BWRs reported for $1975 .{ }^{(29)}$ This was a time when fuel failures were higher than at present, and may produce an overestimate of normal releases expected over the operating life of a plant. The values for ${ }^{3} \mathrm{H}$ and ${ }^{14} \mathrm{C}$ are obtained from Reference 30 . The reported airborne release values are divided by the total heat production of all 23 plants to obtain an average release rate for each radionuclide. These average release rates are multiplied by the reference plant thermal production capacity, the plant availability factor, and the number of hours in a year to obtain the annual release rates from the reference plant. These are reported in Table E.2-11. 
TABLE E.2-11. Annual Airborne Radionuclide Release Rates from the Reference BWR

\begin{tabular}{|c|c|c|c|}
\hline Radionuclide & $\begin{array}{c}\text { Half-Life } \\
\text { (days) }\end{array}$ & $\begin{array}{c}\text { Average Airborne } \\
\text { Release Rate } \\
(C i / M W H t)(a) \\
\end{array}$ & $\begin{array}{l}\text { BWR Annual } \\
\text { Airborne Release } \\
\text { Rate (Ci/yr)(b) }\end{array}$ \\
\hline $\begin{array}{l}{ }^{3} \mathrm{H} \\
{ }^{14} \mathrm{C} \\
{ }^{51} \mathrm{Cr}\end{array}$ & $\begin{array}{l}4.5 \times 10^{3} \\
2.1 \times 10^{6} \\
2.8 \times 10^{1}\end{array}$ & $\begin{array}{c}--(c) \\
--(c) \\
1.6 \times 10^{-10}\end{array}$ & $\begin{array}{l}4.0 \times 10^{0}(d) \\
8.9 \times 10^{0}(d) \\
3.5 \times 10^{-3}\end{array}$ \\
\hline $\begin{array}{l}{ }^{54} \mathrm{Mn} \\
{ }^{59} \mathrm{Fe} \\
{ }^{58} \mathrm{Co}\end{array}$ & $\begin{array}{l}3.0 \times 10^{2} \\
4.5 \times 10^{1} \\
7.2 \times 10^{1}\end{array}$ & $\begin{array}{l}1.9 \times 10^{-9} \\
5.8 \times 10^{-11} \\
6.6 \times 10^{-10}\end{array}$ & $\begin{array}{l}4.1 \times 10^{-2} \\
1.3 \times 10^{-3} \\
1.4 \times 10^{-2}\end{array}$ \\
\hline $\begin{array}{l}60 \mathrm{Co} \\
65 \mathrm{Zn} \\
{ }^{69} \mathrm{Sr}\end{array}$ & $\begin{array}{l}1.9 \times 10^{3} \\
2.4 \times 10^{2} \\
5.3 \times 10^{1}\end{array}$ & $\begin{array}{l}4.1 \times 10^{-9} \\
1.8 \times 10^{-10} \\
3.1 \times 10^{-8}\end{array}$ & $\begin{array}{l}8.9 \times 10^{-2} \\
3.9 \times 10^{-3} \\
6.8 \times 10^{-1}\end{array}$ \\
\hline $\begin{array}{l}90 \mathrm{Sr} \\
90 \mathrm{Y} \\
95 \mathrm{Zr}\end{array}$ & $\begin{array}{l}1.0 \times 10^{4} \\
2.7 \times 10^{0} \\
6.5 \times 10^{1}\end{array}$ & $\begin{array}{l}6.3 \times 10^{-9} \\
6.3 \times 10^{-9} \\
1.6 \times 10^{-10}\end{array}$ & $\begin{array}{l}1.4 \times 10^{-1} \\
1.4 \times 10^{-1} \\
3.5 \times 10^{-3}\end{array}$ \\
\hline $\begin{array}{r}95 \mathrm{Nb} \\
106 \mathrm{Ru} \\
110 \mathrm{mAg}\end{array}$ & $\begin{array}{l}3.5 \times 10^{1} \\
3.7 \times 10^{2} \\
2.6 \times 10^{2}\end{array}$ & $\begin{array}{l}1.6 \times 10^{-10} \\
3.0 \times 10^{-10} \\
2.3 \times 10^{-10}\end{array}$ & $\begin{array}{l}3.5 \times 10^{-3} \\
6.5 \times 10^{-3} \\
5.0 \times 10^{-3}\end{array}$ \\
\hline $\begin{array}{l}124 \mathrm{Sb} \\
125 \mathrm{Sb} \\
131 \mathrm{I}\end{array}$ & $\begin{array}{l}6.0 \times 10^{1} \\
9.9 \times 10^{2} \\
8.0 \times 10^{0}\end{array}$ & $\begin{array}{l}7.4 \times 10^{-13} \\
4.0 \times 10^{-13} \\
9.0 \times 10^{-9}\end{array}$ & $\begin{array}{l}1.6 \times 10^{-5} \\
8.7 \times 10^{-6} \\
2.0 \times 10^{-1}\end{array}$ \\
\hline $\begin{array}{l}133 \mathrm{I} \\
134 \mathrm{CS} \\
136 \mathrm{Cs}\end{array}$ & $\begin{array}{l}8.4 \times 10^{-1} \\
7.5 \times 10^{2} \\
1.4 \times 10^{1}\end{array}$ & $\begin{array}{l}8.0 \times 10^{-9} \\
4.6 \times 10^{-9} \\
2.0 \times 10^{-11}\end{array}$ & $\begin{array}{l}1.7 \times 10^{-1} \\
1.0 \times 10^{-1} \\
4.4 \times 10^{-4}\end{array}$ \\
\hline $\begin{array}{l}137 \mathrm{Cs} \\
140 \mathrm{Ba} \\
140 \mathrm{La}\end{array}$ & $\begin{array}{l}1.1 \times 10^{4} \\
1.3 \times 10^{1} \\
1.7 \times 10^{0}\end{array}$ & $\begin{array}{l}8.6 \times 10^{-9} \\
3.7 \times 10^{-8} \\
3.7 \times 10^{-8}\end{array}$ & $\begin{array}{l}1.9 \times 10^{-1} \\
8.1 \times 10^{-1} \\
8.1 \times 10^{-1}\end{array}$ \\
\hline $\begin{array}{l}{ }^{141 \mathrm{Ce}} \\
144 \mathrm{Ce} \\
\text { Total }\end{array}$ & $\begin{array}{l}3.2 \times 10^{1} \\
2.8 \times 10^{2}\end{array}$ & $\begin{array}{l}3.8 \times 10^{-10} \\
1.3 \times 10^{-10}\end{array}$ & $\begin{array}{l}8.3 \times 10^{-3} \\
\frac{2.8 \times 10^{-3}}{3.4 \times 100}\end{array}$ \\
\hline
\end{tabular}

(a)Calculated from release data from 23 operating BWRs in 1975 (Reference 29).

(b)Calculated using the reference BWR size of $3320 \mathrm{MWt}$, plant availability factor of 0.75 , and $8.8 \times 10^{3} \mathrm{hr} / \mathrm{yr}$.

(c) No value calculated from Reference 29 data.

(d) Calculated from release value found in Reference 30 . Not included in the total since it is assumed to be released as a gas and not deposited on the site. 
Ground deposition on the site from the continuous, elevated (150-m stack height) atmospheric release is calculated. Meteorological data on joint frequency of wind speed and direction by atmospheric stability class are not available for the reference site. Therefore, these data are taken from Reference 31. With these data, standard atmospheric models are used to estimate ground deposition. (32) Radioactive decay of the released radionuclides is accounted for over the duration of the release and the following ground deposition period. Tritium $\left({ }^{3} \mathrm{H}\right)$ and ${ }^{14} \mathrm{C}$ are assumed to be released as gases and not deposited on the site. The concentrations of radionuclides deposited on the site over the 40-year plant life are calculated using the XOQDOQ computer program. ${ }^{(33)}$ No credit is taken in the calculation for plume rise from either buoyancy or momentum.

The procedure used to estimate relative deposition rates is based on numerical solutions to the flux-gradient ("K-Theory") diffusion equation. The effluent is not allowed to diffuse beyond a height of $200 \mathrm{~m}$ in a stable condition and $1000 \mathrm{~m}$ in neutral and unstable conditions. At the ground surface, a partial-sink boundary condition involving the deposition velocity is assumed. The wind and eddy diffusivity profiles required as input to the diffusion equation are those in Reference 34. Deposition velocity is allowed to vary with wind speed in accordance with an empirical equation. ${ }^{(35)}$ An areal grass density of approximately $70 \mathrm{~g} / \mathrm{m}^{2}$ is assumed. No allowance is made for normal weathering conditions (runoff, soil characteristics, and vegetational coverage) or for resuspension of deposited material.

\section{E.2.3.2 Reference Radionuclide Inventory 6}

The resulting radionuclide depositions on the reference site from 40 years of normal reference BWR operation are listed in Table E.2-12 as reference radionuclide inventory 6 . This inventory is used in Appendix $F$ in determining the maximum annual dose to the maximum-exposed individual living on the decommissioned reference site. 
TABLE E.2-12. Reference Radionucl ide Inventory 6,

Reference BWR Site Surface Contamination (a)

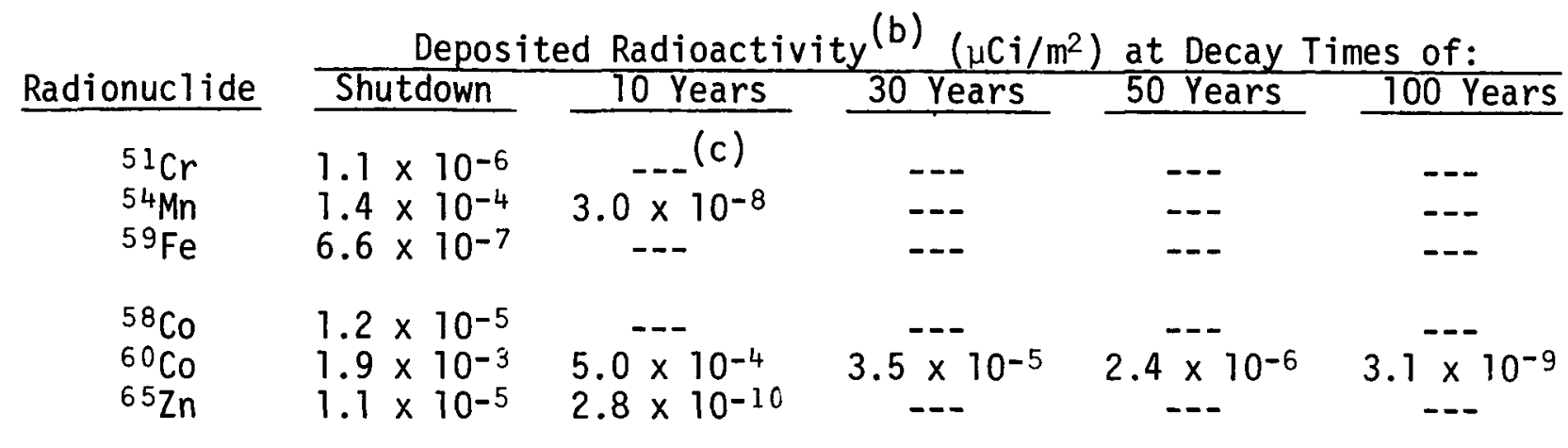

$\begin{array}{llcccc}{ }^{89} \mathrm{Sr} & 4.1 \times 10^{-4} & --- & --- & -- \\ { }^{90} \mathrm{Sr} & 1.0 \times 10^{-2} & 7.8 \times 10^{-3} & 4.7 \times 10^{-3} & 2.8 \times 10^{-3} & 8.0 \times 10^{-4} \\ 90 \mathrm{Y} & 1.0 \times 10^{-2} & 7.8 \times 10^{-3} & 4.7 \times 10^{-3} & 2.8 \times 10^{-3} & 8.0 \times 10^{-4}\end{array}$

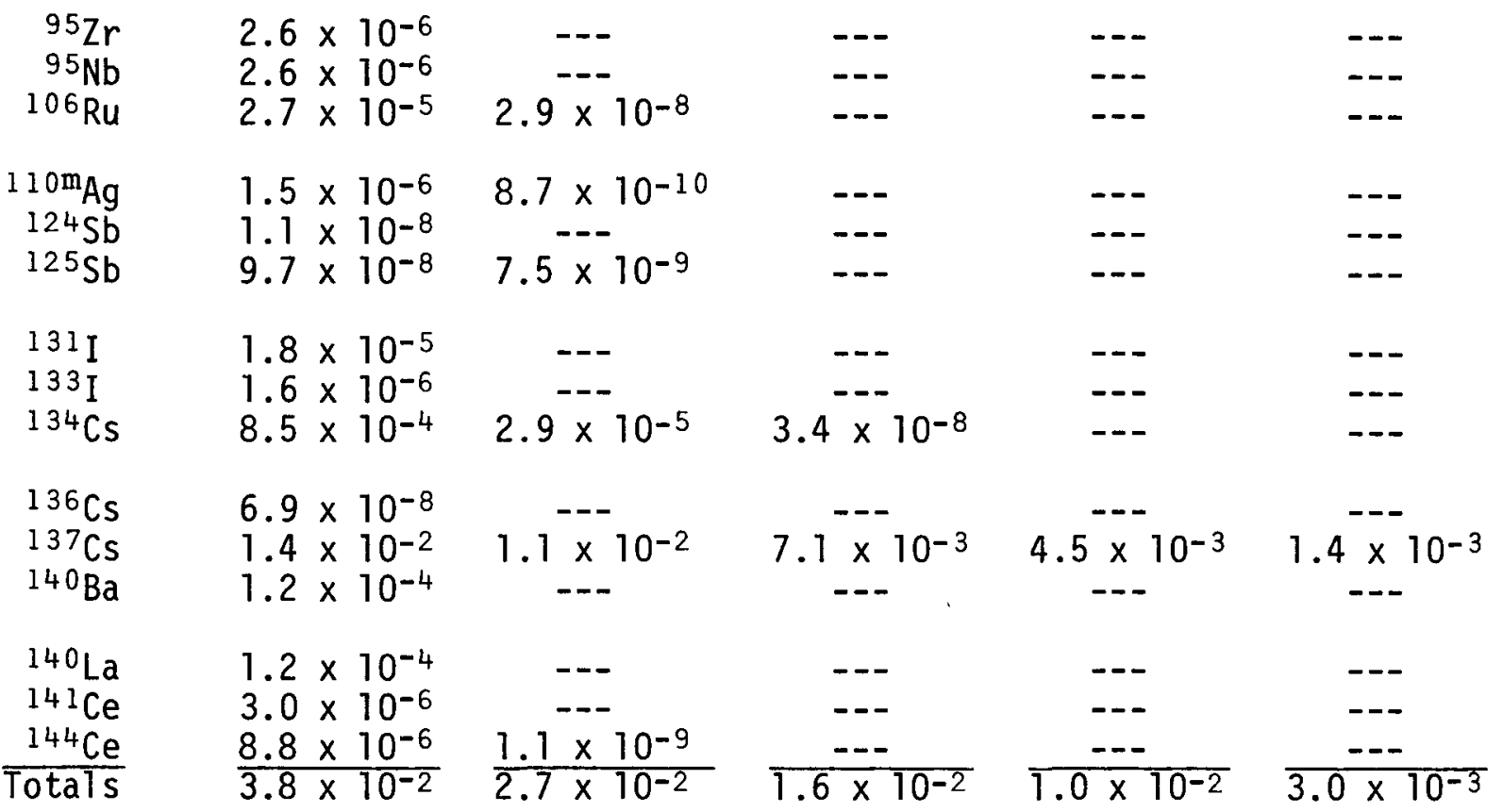

(a)Based on 1975 reported airborne radionuclide releases from 23 operating BWRs (Reference 29).

(b) Based on 30 EFPY of operation.

(c) Indicates a value less than $1.0 \times 10^{-10} \mu \mathrm{Ci} / \mathrm{m}^{2}$. 


\section{REFERENCES}

1. M. G. Zimmerman, "Radiation Exposure from Neutron Activation Products at the End of LWR Lifetime," Trans..Am. Nucl. Soc., 27:784, 1977.

2. M. J. Bel1, ORIGEN - The ORNL Isotope Generation and Depletion Code, ORNL4628, Oak Ridge Nationa1 Laboratory, Oak Ridge, TN, May 1973.

3. C. L. Bennett and W. L. Purce11, BRT-I: Battelle-Revised-THERMOS, BNWL1434, Battelle, Pacific Northwest Laboratories, Richland, WA, June 1970.

4. C. R. Richey, EGGNIT: A Multi-group Cross-Section Code, BNWL-1203, Battelle, Pacific Northwest Laboratories, Richland, WA, November 1969.

5. H. C. Honeck, ENDF/B Specifications for an Evaluated Nuclear Data File for Reactor Applications, BNL-50066 (T-467), Brookhaven National Laboratory, May 1966, Revised Ju7y 1967, and 0. Ozer and D. Garber, ENDF/B Summary Documentation, ENDF/B-201, May 1973.

6. D. E. Kusner, R. A. Dannels and S. Kellman, ETOG-l A FORTRAN IV Program to Process Data from the ENDF/B File to the MUFT, GAM, and ANISN Format, SCAP-3845-1, Westinghouse Electric Corp., December 1969.

7. W. E. Engle, Jr., A Users Manual for ANISN, A One-Dimensional Discrete Ordinates Transport Code with Anisotropic Scattering, K-1693, Oak Ridge NationaT Laboratory, Oak Ridge, TN, March 1967.

8. CRC Handbook of Chemistry and Physics, 53rd Edition, 1972-3, CRC Press, Cleveland, $\mathrm{OH}, 1972$.

9. C. M. Lederer, J. M. Hollander and I. Perlman, Table of Isotopes, Sixth Edition, John Wiley \& Sons, New York, 1967.

10. M. H. Biavati, S. J. Nassif and C. S. Wu, "Internal Bremsstrahlung Spectrum Accompanying is Electron Capture in Decay of $55 \mathrm{Fe},{ }^{131} \mathrm{Cs}$ and $204 \mathrm{Tl}$," Physical Review, 25:1364-1372, 1962.

11. R. T. Glauber and P. C. Martin, "Radioactive Capture of Orbital Electrons," Physical Review, 104:158-175, 1956.

12. Babulal Saraf, "Inner Bremsstrahlung Emitted in Electron Capture Decay of ${ }^{59} \mathrm{Ni},{ }^{77} \mathrm{~A}$, and ${ }^{55} \mathrm{Fe}, "$ Physical Review, 102:46-473, 1956.

13. Marcel Schmorak, "Virtual Electron Capture in ${ }^{59} \mathrm{Ni}$," Physical Review, 129:1668-1672, 1963.

14. R. E. Cutkosky, "Internal Bremsstrahlung," Physical Review, 95:1222-1225, 1954. 
15. W. Bambynek et al., "Orbital Electron Capture by the Nucleus," Review of Modern Physics, 49:1, January 1977.

16. U.S. NRC, Nuclear Regulatory Guide 1.109, Table E-6, p. 1.109-41, October 1977 .

17. R. D. Evans, The Atomic Nucleus, McGraw-Hill Book Co., New York, NY, p. $548,1955$.

18. J. N. Strode and H. H. Van Tuy1, PUSHLD - A Code for Calculation of Gamma Dose Rates from Plutonium in Various Geometries, USAEC Report HEDL-TME, pp. 73-89, 1973.

19. R. L. Dillon and A. B. Johnson, Jr., "Corrosion Product Generation in Water Reactors," Proceedings of the System Contamination Workshop, At lanta, GA, pp. $67-80,1976$.

20. R. I. Smith, G. J. Konzek and W. E. Kennedy, Jr., Technology Safety and Costs of Decommissioning a Reference Pressurized water Reactor Power Station, NUREG/CR-0130, Section 7, U.S. Nuclear Regulatory Commission Report by Pacific Northwest Laboratory, June 1978.*

21. J. Blok, "Characterization of Corrosion Product Deposits in the BWR," Proceedings of the System Contamination Workshop, Atlanta, GA, pp. 81-93, 1976.

22. J. Blok and J. Younger, Contribution of Fuel Rod Deposits to the Buildup of Radiation on Out-of-Core Surfaces of the Nine Mile Point 1 BWR, NEDO13461, Class 1, General Electric Company, San Jose, CA, pp. 5-22, 1977.

23. S. G. Sawochka, N. P. Jacob and W. L. Pearl, Primary System Shutdown Radiation Levels at Nuclear Power Generating Stations, EPRI 404-2, Final Report, Prepared by Nuclear Water and Waste Technology for the Electric Power Research Institute, Palo A7to, CA, pp. 8-24, 1975.

24. J. E. Cline and D. C. Hetzer, Study of Transuranium Concentration Levels in Sol id Radioactive Waste from Commercial Power Reactors, NP-637, Prepared by Science Applications, Inc. for the Electric Power Research Institute, Palo Alto, CA, pp. 17-86, 1978.

25. M. E. Meek and R. S. Gilbert, Observations on Contamination of BRP Turbine, NEDM-12093, Nucleonics Laboratory, General Electric Company, P7easanton, CA, 94566, pp. 1-10, 1970.

26. R. L. Engel, J. Greenborg and M. M. Hendrickson, ISOSHLD - A Computer Code for General Purpose Isotope Shielding Analysis, BNWL-236, Battelle, Pacific Northwest Laboratories, Richland, WA, June 1966.

27. G. L. Simmons et a1., ISOSHLD II Code Revision to Include Calculation of Dose Rates from Shielded Bremsstrahlung Sources, BNWL-236, Supplement 1, Battelle, Pacific Northwest Laboratories, RichTand, WA, March 1967.

${ }^{\star}$ Available for purchase from the NRC/GPO Sales Program, U.S. Nuclear Regulatory Commission, Washington, D.C. 20555, and the National Technical Information Service, Springfield, Virginia 22161. 
28. U.S. NRC, Calculation of Releases of Radioactive Materials in Gaseous and Liquid EffTuents from Boiling Water Reactors (BWR - Gale Code), NUREG0016, Table 2-2, pp. 2-3, 2-5, April 1976.*

29. U.S. NRC, Radioactive Materials Released from Nuclear Power Plants (1975), NUREG-0218, March 1977.*

30. H. Harty, Nuclear Energy Center Site Survey Reactor Plant Considerations, BNWL-B-457, Battelle, Pacific Northwest Laboratories, Richland, WA, 1976.

31. Environmental Report, Barnwell Nuclear Fuel Plant, Docket No., 50-332, Appendix IV, p. 18, Allied Chemica1-Nuclear Products, Inc., November 1971.

32. Meteorology and Atomic Energy 1968, TID 24190, p. 73, edited by D. H. STade, JuTy 1968.

33. J. F. Sagendorf and J. T. Gol1, XOQDOQ - Program for the Meteorological Evaluation of Routine Effluent Releases at Nuclear Power Stations, U.S. NRC Report, December 1976.

34. E. H. Markee, Jr., A Parametric Study of Gaseous Plume Depletion by Ground Surface Adsorption, USAEC Meteorological Information Meeting, AECL-2787, pp. 602-613, 1967 .

35. C. A. Pelletier and J. D. Zimbrick, "Kinetics of Environmental Radioiodine Transport Throught the Milk-Food Chain," Environmental Surveillance in the Vicinity of Nuclear Facilities, W. C. Reining, Editor, Thomas Publishers, Springfield, IL, 1970.

Available for purchase from the National Technical Information Service, Springfield, Virginia 22161. 


\section{APPENDIX $F$ \\ PUBLIC RADIATION DOSE MODELS AND CALCULATED \\ MAXIMUM ANNUAL DOSES}

This appendix contains support material required for Chapters 8 and 11 . Terminology, models, equations and parameters used in radiation dose calculations, as well as tabulated maximum annual doses to the maximum-exposed individual, are presented. The tabulated maximum annual doses are based on the reference radionuclide inventories detailed in Appendix $E$. These doses are used in determining the acceptable contamination levels for public release of the decommissioned reference BWR power station. It should be noted that the occupational radiation doses during decommissioning operations are not calculated using the dose models presented in this appendix. Rather, they are estimated using measured dose rate data, as discussed in Appendix D.

\section{F.1 RADIATION DOSE TERMINOLOGY AND DEFINITIONS}

The following terminology and definitions apply for the radiation dose calculations made for this study:

Routine Release. An atmospheric release of radionuclides from routine decommissioning tasks that is assumed to occur at a constant rate for 1 year.

Acute Release. A short-duration (usualiy less than 8 hours) release of radionuciides. The accident analysis, diccussed in Chapter 11 and Appendix $N$, are based on acute releases.

Organs of Reference. The organs of the human body for which radiation doses are calculated. For this study, the organs of reference are the total body, lungs, bone, and thyroid. The total body is the head and trunk of the human body and includes active blood-forming organs, eye lenses, and gonads.

Exposure Pathways. The potential routes by which people may be exposed to radionuclides or radiation. Radiation exposure pathways in the environment 
that are considered in this study are: external exposure to contamination deposited on the ground, ingestion of food products containing radionuclides, and inhalation of airborne radionuclides. Radiation exposure pathways inside the BWR facility are: external exposure from contaminated room surfaces and inhalation of airborne radionuclides. External exposure from airborne radionuclides (air submersion) is not considered, since previous decommissioning studies have shown this exposure pathway to be insignificant compared to the others. (1-3)

Maximum-Exposed Individual. The individual who receives the maximum radiation dose to an organ of reference. The maximum-exposed individual is assumed to reside at the location of the highest airborne radionuclide concentration. Maximized exposure pathway parameters are used.

Radiation Dose Equivalent. A quantity used to express the absorbed dose from all radiations on a common scale in units of rem. It is defined as the product of the absorbed dose in rads, a quality factor intended to allow for the effect of the microscopic distribution of absorbed energy, and other modifying factors as defined by the International Commission on Radiological Protection (ICRP).

Committed Radiation Dose Equivalent. The dose equivalent accumulated over a specific number of years from radionuclides deposited in the body from the various radiation pathways during a given year.

Collective Dose. The summation of radiation dose equivalents received by all individuals in the population of concern. It is calculated by multiplying the dose to the average individual by the population distribution for the site listed in Appendix B. Average parameter values are used for the exposure pathways.

First-Year Dose. The radiation dose equivalent accumulated during the year of the release period.

Fifty-Year Committed Dose Equivalent. The committed radiation dose equivalent for 50 years following a 1 -year exposure to radionuclides. 
Annual Dose. The radiation dose equivalent calculated during any year following the start of continuous exposure. It is the sum of the dose received by an organ of reference during the year of interest from all exposure pathways and the dose received that year from radionuclides deposited in the organ of reference during the previous years.

Maximum Annual Dose. The largest of the 50 annual doses calculated to occur during the 50 years following the start of continuous exposure.

Biological Half-life. The time required for the body to eliminate half of any substance by regular body elimination processes.

Solubility $C l$ asses $D, W$, and $Y$. Radionuclides are classified according to the rate at which they are dissolved into body fluids in the lung after inhalation. The three classifications used in this study are: Class D materials, with a maximum biological half-life of less than 1 day; Class $W$ materials, with a maximum biological half-life ranging from a few days to a few months; and Class $Y$ materials, with a maximum biological half-life of from 6 months to a few years. ${ }^{(4)}$ Table F.7-1 contains a list of the solubility classes for the elements considered in this study.

\section{F.2 GENERAL MODELS FOR ESTIMATING RADIATION DOSE}

The methodology and parameters necessary to calculate the first-year dose or the fifty-year committed dose equivalent are presented in this section. The fundamental relationship for calculating radiation doses to people from any radionuclide or exposure pathway is given in Equation $F .1$.

$$
R_{i p r}=C_{i p} U_{p} D_{i p r}
$$

where:

$R_{i p r}$ - first-year dose or fifty-year committed dose equivalent from radionuclide $i$ via exposure pathway $p$ to organ $r$ 
TABLE F.1-1. Solubility Classes for the Elements Present in the Radionuclide Inventory at Final Shutdown of the Reference BWR

\begin{tabular}{|c|c|c|}
\hline Element & $\begin{array}{c}\text { Solubility Class }(a) \\
\text { (all other } \\
\text { organs/lungs) } \\
\end{array}$ & Reference ${ }^{(b)}$ \\
\hline $\begin{array}{l}\text { Hydrogen }(H) \\
\text { Carbon }(C) \\
\text { Phosphorus (P) }\end{array}$ & $\begin{array}{l}D / D \\
D / D \\
D / W\end{array}$ & $\begin{array}{l}4 \\
4 \\
4\end{array}$ \\
\hline $\begin{array}{l}\text { Chromium }(\mathrm{Cr}) \\
\text { Manganese ( } \mathrm{Nn}) \\
\text { Iron (Fe) }\end{array}$ & $\begin{array}{l}W / Y \\
D / W \\
W / Y\end{array}$ & $\begin{array}{l}4 \\
5 \\
5\end{array}$ \\
\hline $\begin{array}{l}\text { Cobalt (Co) } \\
\text { Nickel (Ni) } \\
\text { Zinc }(\mathrm{Zn})\end{array}$ & $\begin{array}{l}W / Y \\
W / W \\
W / Y\end{array}$ & $\begin{array}{l}5 \\
4 \\
4\end{array}$ \\
\hline $\begin{array}{l}\text { Strontium }(S r) \\
\text { Yitrium }(Y) \\
\text { Zirconium }(Z r)\end{array}$ & $\begin{array}{l}D / Y \\
D / Y \\
W / Y\end{array}$ & $\begin{array}{l}5 \\
5 \\
5\end{array}$ \\
\hline $\begin{array}{l}\text { Niobium (Nb) } \\
\text { Technetium (Te) } \\
\text { Ruthenium (Ru) }\end{array}$ & $\begin{array}{l}W / Y \\
D / W \\
Y / Y\end{array}$ & $\begin{array}{l}5 \\
5 \\
5\end{array}$ \\
\hline $\begin{array}{l}\text { Iodine (I) } \\
\text { Cesium (Cs) } \\
\text { Barium (Ba) }\end{array}$ & $\begin{array}{l}D / D \\
D / D \\
D / W\end{array}$ & $\begin{array}{l}5 \\
5 \\
4\end{array}$ \\
\hline $\begin{array}{l}\text { Lanthanum (La) } \\
\text { Cerium (Ce) }\end{array}$ & $\begin{array}{l}W / Y \\
W / Y\end{array}$ & $\begin{array}{l}4 \\
4\end{array}$ \\
\hline
\end{tabular}




$$
\begin{aligned}
C_{i p} \text { - } & \text { concentration of radionuclide } i \text { in the media of exposure pathway } \\
& p ; \text { for calculations involving airborne radionuclides, } C_{i p} \text { is } \\
& \text { replaced with the term } \bar{x}_{i} \text {, which represents the average airborne } \\
& \text { concentration of radionuclide } i \\
U_{p} \text { - } & \text { usage parameter (exposure rate or intake rate) associated with } \\
& \text { exposure pathway } p \\
D_{i p r} \text { - } & \text { radiation dose equivalent factor or fifty-year committed radia- } \\
& \text { tion dose equivalent factor (for a given radionuclide } i \text {, expo- } \\
& \text { sure pathway } p \text {, and organ } r \text { ) that converts the concentration } \\
& \text { and usage parameters to the first-year dose or fifty-year commit- } \\
& \text { ted dose equivalent. }
\end{aligned}
$$

Each of the terms in the general dose equation (Equation F.1) are discussed in detail below:

$C_{i p}:$ An analysis of the radiation doses from separate exposure pathways requires a calculation of the radionuclide concentrations associated with each pathway. An external exposure analysis requires a soil concentration or surface contamination level. The radionuclide concentration in food crops grown in contaminated soil is directly related to the radionuclide concentration in the soil plow layer (a depth of $0.15 \mathrm{~m}$ ). Exposure pathways that require the concentration of radionuclides in air from airborne radionuclide releases use dilution factors discussed in the site description in Appendix $B$. They are: $7.2 \times 10^{-8} \mathrm{sec} / \mathrm{m}^{3}$ for the maximum-exposed individual located $1 \mathrm{~km}$ from the site and $2.3 \times 10^{-11} \mathrm{sec} / \mathrm{m}^{3}$ for the average member of the population residing within $80 \mathrm{~km}$ of the site.

$U_{p}$. Each radiation exposure pathway has an associated exposure rate or intake rate. Parameters used to calculate radiation doses from the consumption of food products grown in contaminated soil are listed in Table F.2-1. For the inhalation pathway, the intake rate (or ventilation rate) is assumed to be $2.7 \times 10^{-4} \mathrm{~m}^{3} / \mathrm{sec}$ for members of the public and $3.3 \times 10^{-4} \mathrm{~m}^{3} / \mathrm{sec}$ for workers with a 40 -hour work week. 
TABLE F.2-1. Parameters Used for Calculation of Radiation
Doses from Consumption of Foods $\left(\begin{array}{l}\text { a } \\ \text { Dos }\end{array}\right.$

\begin{tabular}{|c|c|c|c|c|c|}
\hline Food & $\begin{array}{l}\text { Growing } \\
\text { Period } \\
\text { (days) } \\
\end{array}$ & $\begin{array}{c}\text { Yield } \\
\left(\mathrm{kg} / \mathrm{m}^{2}\right) \\
\end{array}$ & $\begin{array}{r}\begin{array}{r}\text { old dyp } \\
\text { (days) }\end{array}(\mathrm{b}) \\
\end{array}$ & $\begin{array}{l}\text { Up, Maximum } \\
\text { Individual } \\
\text { Consumption } \\
(\mathrm{kg} / \text { year })(\mathrm{c}) \\
\end{array}$ & $\begin{array}{l}\text { Up, Average } \\
\text { Individual } \\
\text { Consumption } \\
\text { (kg/year) } \\
\end{array}$ \\
\hline $\begin{array}{l}\text { Leafy Vegetables } \\
\text { Other Above-Ground Vegetables } \\
\text { Potatoes }\end{array}$ & $\begin{array}{l}90 \\
60 \\
90\end{array}$ & $\begin{array}{l}1.5 \\
0.7 \\
4.0\end{array}$ & $\begin{array}{r}1 \\
1 \\
10\end{array}$ & $\begin{array}{r}30 \\
30 \\
110\end{array}$ & $\begin{array}{r}15 \\
15 \\
7.1\end{array}$ \\
\hline $\begin{array}{l}\text { Other Root Vegetables } \\
\text { Berries } \\
\text { Melons }\end{array}$ & $\begin{array}{l}90 \\
60 \\
90\end{array}$ & $\begin{array}{l}5.0 \\
2.7 \\
0.8\end{array}$ & $\begin{array}{l}1 \\
1 \\
1\end{array}$ & $\begin{array}{l}72 \\
30 \\
40\end{array}$ & $\begin{array}{r}47 \\
6 \\
8\end{array}$ \\
\hline $\begin{array}{l}\text { Orchard Fruit } \\
\text { Wheat } \\
\text { Other Grain }\end{array}$ & $\begin{array}{l}90 \\
90 \\
90\end{array}$ & $\begin{array}{l}1.7 \\
0.72 \\
1.4\end{array}$ & $\begin{array}{r}10 \\
10 \\
1\end{array}$ & $\begin{array}{r}265 \\
80 \\
8\end{array}$ & $\begin{array}{l}50 \\
72 \\
80\end{array}$ \\
\hline $\begin{array}{l}\text { Eggs } \\
\text { Milk } \\
\text { Beef }\end{array}$ & $\begin{array}{l}90 \\
30 \\
90\end{array}$ & $\begin{array}{l}0.84^{(d)} \\
1.3(d) \\
0.84(d)\end{array}$ & $\begin{array}{r}2 \\
2 \\
15\end{array}$ & $\begin{array}{c}30 \\
274(e) \\
40\end{array}$ & $\begin{array}{l}20 \\
230(e) \\
40\end{array}$ \\
\hline $\begin{array}{l}\text { Pork } \\
\text { Poultry }\end{array}$ & $\begin{array}{l}90 \\
90\end{array}$ & $\begin{array}{l}0.84^{(d)} \\
0.84^{(d)}\end{array}$ & $\begin{array}{r}15 \\
2\end{array}$ & $\begin{array}{l}40 \\
18\end{array}$ & $\begin{array}{r}30 \\
8\end{array}$ \\
\hline
\end{tabular}

(a) Based on information in Reference 7.

(b) Time between harvest and consumption.

(c) Only that fraction of the diet grown locally (and, therefore, potentially contaminated) is listed.

(d) Yield of animal feeds (i.e., grain or pasture grass).

(e) Units of $\ell /$ year.

$D_{i p r}$. The radiation dose equivalent factors and the fifty-year committed radiation dose equivalent factors that are used in this study for internal exposure pathways are obtained from several sources. Those for ingestion are obtained primarily from References $6,8,9,10$, and 11 , which are derived from information given by the ICRP for the body burden and the maximum permissible concentration of each radionuclide. (12) Ingestion factors not obtainable from the references are calculated by the method given in Reference 11 . In this method, effective decay energies for the radionuclides are calculated from the ICRP model, which assumes that all of a given radionuclide is in the center of a spherical organ with an appropriate effective radius. Dose factors for inhalation are calculated using the computer code DACRIN. (13) This code 
incorporates the ICRP Task Group Lung Model to calculate the dose to the lung and other organs of reference. A particle size of 1 micrometer in diameter is assumed. Radiation dose equivalent factors for internal pathways have units of mrem per year per $\mathrm{pC} i$ taken into the body during that same year. Committed radiation dose equivalent factors have units of mrem/50-yr per $\mathrm{pCi}$ taken into the body in the first year. External exposure can arise from either contaminated land or contaminated building surfaces. In this study, external dose equivalent factors are calculated for these sources using the ISOSHLD computer

code. $(14,15)$ Ground contamination is modeled by calculating the dose at a point $1 \mathrm{~m}$ in air above a semi-infinite slab of radionuclides evenly distributed in a $0.15-\mathrm{m}$ layer of soil. Total body dose rates are obtained by using a $50-\mathrm{mm}$ tissue equivalent thickness around the dose point.

Discussion of the various radiation exposure pathways considered in this study, together with appropriate modifications to the general dose equation and its parameters, are given in the following sections.

\section{F.2.1 Extérnal Exposure}

Calculation of the radiation dose resulting from external total body exposure to surface contamination is done with no modification to Equation F.l. Soil concentrations are calculated using a simple cloud-depletion model, as is described for the food ingestion pathway analysis in the next section. For routine releases from decommissioning operations, the maximum-exposed individual is assumed to be exposed to contaminated soil for 12 hours a day for a full year. The average individual is assumed to be exposed for 6 hours a day for a full year. The fifty-year committed dose equivalent for external exposure to surface contamination is equal to the first-year dose, since there is no internal radionuclide deposition.

\section{F.2.2 Ingestion}

The radiation dose equivalent or committed radiation dose equivalent to a person consuming vegetation grown on the contaminated site is given in Equation F.2. 


$$
R_{v r}=\sum_{i=1}^{n} C_{i v} U_{v} D_{i r}
$$

Similarly, the radiation dose equivalent or committed radiation dose equivalent to a person consuming a contaminated animal product is given in Equation F.3.

$$
R_{a r}=\sum_{i=1}^{n} C_{i a} U_{a} D_{i r}
$$

where:

$R_{v r}, R_{a r}$ - radiation dose equivalent or committed radiation dose equivalent from vegetation $v$ or animal a food product pathways, mrem or $\mathrm{mrem} / 50 \mathrm{yr}$

$C_{i v}, C_{i a}$ - concentration of radionuclide $i$ in vegetation $v$ or animal product a, $\mathrm{pCi} / \mathrm{kg}$ or $\mathrm{pCi} / \mathrm{l}$

$U_{v}, U_{a}$ - annual consumption of contaminated vegetable $v$ or animal products a, $\mathrm{kg}$ or $\ell$

$D_{\text {ir }}$ - radiation dose equivalent factor or committed radiation dose equivalent factor, $\mathrm{mrem} / \mathrm{pCi}$ or $\mathrm{mrem} / 50 \mathrm{yr}$ per $\mathrm{pCi}$.

Specific values of $U_{v}$ and $U_{a}$ are shown in Table F.2-l.

F.2.2.1 Deposition on Food Products or Ground Surfaces

Equation F.4 is used to describe the deposition of airborne particulate radionuclides directly on food products or ground surfaces.

$$
d_{i}=86,400 \bar{x}_{i} v_{d i}
$$

where:
$d_{i}$ - deposition rate of flux of radionuclide $i, \mathrm{pC} i /\left(\mathrm{m}^{2}-\right.$ day $)$
86,400 - dimensional conversion factor, seconds/day 
$V_{d i}$ - deposition velocity of radionuclide $i, \mathrm{~m} / \mathrm{second}$

$\bar{X}_{i}$ - annual average air concentration from airborne releases of radionuclide $\mathrm{i}, \mathrm{pCi} / \mathrm{m}^{3}$.

Specific values of the deposition velocity, $V_{d i}$, are obtained from Reference 16.

\section{F.2.2.2 Concentration in Vegetation}

The concentration of radioactive material in vegetation resulting from direct deposition onto plant foliage and uptake of prior depositions from the soil is given in Equation F.5.

$$
c_{i v}=d_{i}\left[\frac{r T_{v}\left(1-e^{\left.-\lambda_{E i} t_{e}\right)}\right.}{Y_{v} \lambda_{E i}}+\frac{B_{v i}\left(1-e^{-\lambda_{j} t_{b}}\right)}{P \lambda_{j}}\right] e^{-\lambda_{i} t_{h}}
$$

where:

$c_{i v}-$ concentration of radionuclide $i$ in the edible portion of the vegetation $\mathrm{v}, \mathrm{pCi} / \mathrm{kg}$

$\mathrm{d}_{j}$ - deposition rate or flux or radionuclide $i, \mathrm{pC} /\left(\mathrm{m}^{2}-\right.$ day $)$

$r$ - fraction of deposition retained on the vegetation (dimensionless), assumed to be 0.25 in this study

$T_{v}$ - factor for translocation of externally deposited radionuclides to the edible parts of the vegetation (dimensionless). For simplicity it is assumed in this study to be independent of the radionuclide and is 1.0 for leafy vegetables and fresh forage, and 0.1 for all other produce, including grain. (Reference 9 lists values of this parameter for various radionuclides.)

$\lambda_{i}$ - radiological decay constant for radionuclide $i$, day $^{-1}$

$\lambda_{E i}$ - effective removal constant for radionuclide $i$, day ${ }^{-1}$; $\lambda_{E i}=\lambda_{i}+\lambda_{w}$, where $\lambda_{i}$ is as defined above and $\lambda_{w}$ is the weathering removal constant for vegetation, day ${ }^{-1}$, assumed to be $0.693 / 14=5 \times 10^{-2} \mathrm{day}^{-1}$ 


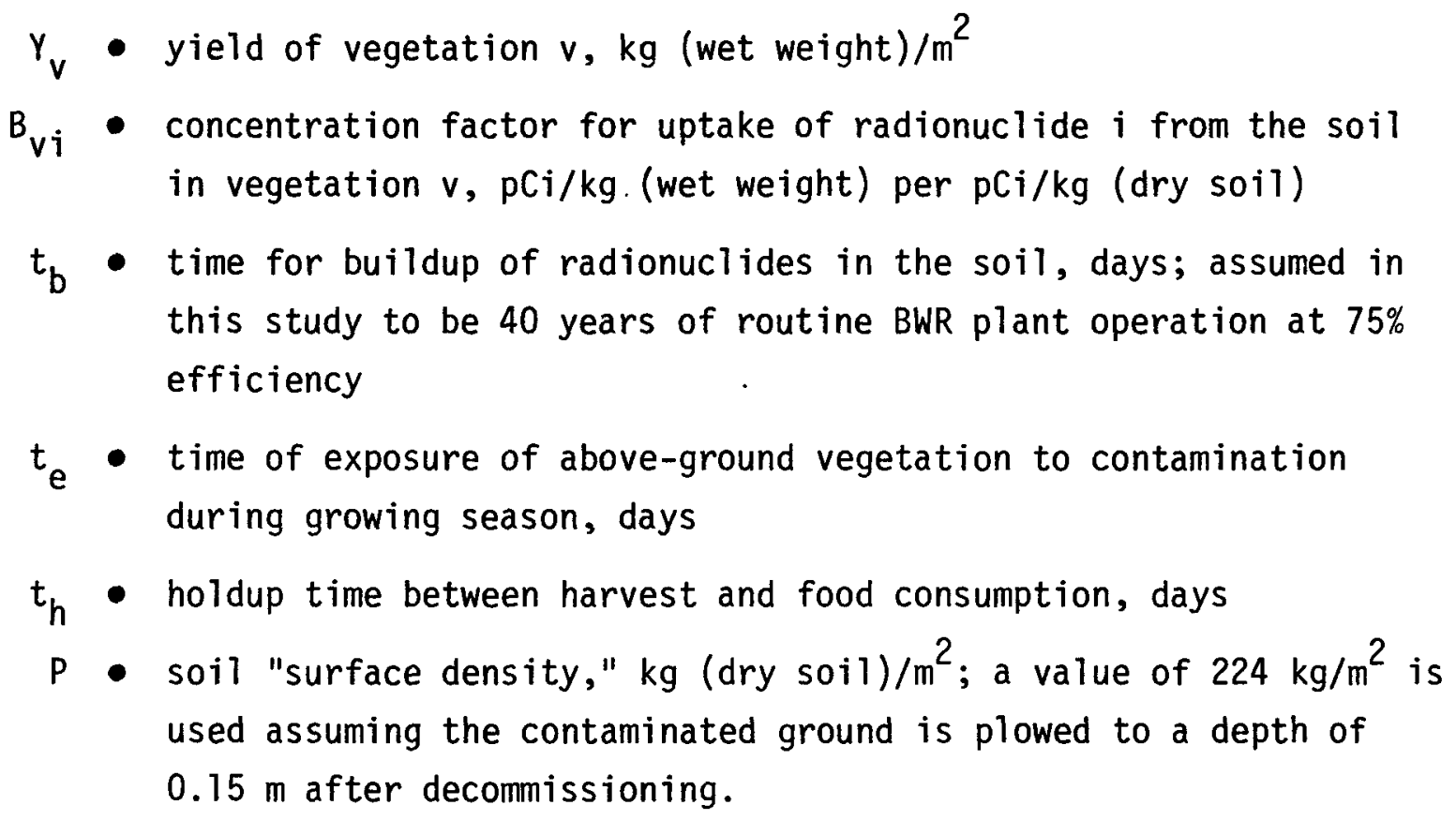

The first term inside the brackets of Equation $F .5$ relates to the concentration resulting from direct deposition on foliage during the growing season. The second term relates to the uptake from the soil and reflects the deposition throughout the 40-year BWR plant operating 1ife. Specific values for the parameters in Equation F.5 are obtained from References 7, 8, and 16.

\section{F.2.2.3 Concentration in Animal Products}

The radionuclide concentration in animal products such as meat, milk, or eggs is dependent on the amount of contaminated forage or feed eaten by the animal. This concentration is described by Equation F.6.

$$
C_{i a}=S_{i a} C_{i F} Q_{F}
$$

where:

$C_{i a}$ - concentration of radionuclide $i$ in animal product $a, p C i / k g$ or $\mathrm{pCi} / \mathrm{l}$

$S_{i a}$ - transfer coefficient of radionuclide $i$ to the edible portion of animal product a from daily intake by the animal, $\mathrm{pCi} / \mathrm{l}$ (milk) per $\mathrm{pCi} /$ day or $\mathrm{pCi} / \mathrm{kg}$ (animal product) per $\mathrm{pCi} /$ day 
$C_{i F}$ - concentration of radionuclide $i$ in feed or forage $F, \mathrm{pCi} / \mathrm{kg}$; calculated from Equation F.5

$Q_{F}$ - animal consumption rate of contaminated feed or forage $F, \mathrm{~kg} /$ day. Specific values for the parameters used in Equation F.6 are obtained from References 7, 8 and 16. Where data are lacking, comparisons are made with biological data from chemically similar elements.

\section{F.2.3 Inhalation}

The radiation dose equivalent or the committed radiation dose equivalent via inhalation is calculated using Equation F.7.

$$
R_{i r}=\sum_{i=1}^{n} \bar{x}_{i} B T D_{i r}
$$

where:

$R_{i r}$ - radiation dose equivalent or committed radiation dose equivalent to organ $r$ from radionuclide $i$, mrem or mrem/50 $\mathrm{yr}$

$\bar{X}_{\mathbf{i}}$ - annual average airborne concentration of radionuclide $i, \mathrm{pCi} / \mathrm{m}^{3}$

$B$ - ventilation rate of exposed individual:

for a chronic release, $B=2.7 \times 10^{-4} \mathrm{~m}^{3} / \mathrm{sec}$;

for an acute release, $B=3.3 \times 10^{-4} \mathrm{~m}^{3} / \mathrm{sec}(12)$

$T$ - time of exposure to the airborne radionuclide concentration, sec

$D_{i r}$ - radiation dose equivalent factor or committed radiation dose equivalent factor, $\mathrm{mrem} / \mathrm{pCi}$ or $\mathrm{mrem} / 50$ yr per $\mathrm{pCi}$.

The inhalation dose model presented in Equation F.7 is consistent with the ICRP Task Group Lung Model.

\section{F.3 MODEL FOR ESTIMATING ANNUAL DOSE}

The determination of acceptable residual contamination levels at the decommissioned reference BWR (discussed in Chapter 8 ) is made by direct comparisons of calculated annual doses with an assumed annual dose limit. The 
annual dose to internal body organs from internally deposited radionuclides tends to increase for a time (after the start of continuous exposure to a radioactively decaying source) until a maximum is reached. The annual dose then tends to decrease with time because of radioactive decay, decrease in the radionuclide concentrations of specific exposure pathways, and biological elimination of radionuclides deposited in the organ. For continuous exposure to a radioactively decaying source, the year in which the annual dose is a maximum depends on the chemical and physical characteristics of the radionuclides in the source, the organ of reference, and the exposure pathway.

The calculated first-year dose from ingested or inhaled radionuclides will most likely underestimate the maximum annual dose during continuous exposure, and therefore does not provide the best comparison to an annual dose limit. Nor is it appropriate to compare a fifty-year dose (accounting for 50 years of committed radiation dose equivalent) to an annual dose limit. Therefore, an extension of the general dose relationship given in Equation F.1 is required to calculate annual doses for each year of a continuous exposure period. The maximum annual dose occuring in the continuous exposure period is then compared to the annual dose limit to determine acceptable residual contamination levels.

Calculation of the annual dose to an organ of reference requires the dose equivalent from exposure during the year of interest. It also requires a detailed accounting of the committed dose equivalents to that organ from radionuclides deposited during previous years of intake. The general expression for annual dose calculations is deduced by inspecting the annual dose equations for the first 3 years of continuous exposure. The annual dose for the first year to an organ of reference is simply the summation of the radiation dose equivalents from all internal and external exposure pathways. For the second year, the annual dose is calculated by the following expression:

$$
A_{2}=R_{2}^{*}+\left(R_{1,2}-R_{1,1}\right)
$$


where:

$A_{2}$ - the annual dose during the second year from all exposure pathways to the organ of reference, mrem

$\mathrm{R}_{2}^{*}$ - the radiation dose equivalent in the second year to the organ of reference from all internal and external exposure pathways from intake and exposure in the second year of continuous exposure, mrem

$R_{1,2}$ - the committed dose equivalent to the organ of reference for the first two years from radionuclides internally deposited during intake from exposure pathways in the first year, mrem

$\mathrm{R}_{1,1}$ - the radiation dose equivalent to the organ of reference for the first year from radionuclides internally deposited during intake from exposure pathways in the first year (no external component to the dose equivalent), mrem.

The second-year annual dose to an organ of reference ( $A_{2}$ in Equation $F .8 a$ ) is the summation of the radiation dose equivalents from all exposure pathways during the second year and the dose equivalent resulting from the radionuclides internally deposited in that organ during the first year. The term in parentheses in Equation F.8a is the expression for the dose equivalent to the organ of reference from radionuclides deposited in that organ in the first year. It is found by subtracting the first-year dose equivalent from internally deposited radionuclides from the two-year committed dose equivalent.

The mathematical expression for the annual dose to an organ of reference in the third year of continuous exposure is shown in Equation F.8b.

$$
A_{3}=R_{3}^{*}+\left(R_{1,3}-R_{1,2}\right)+\left(R_{2,2}-R_{2,1}\right)
$$

where:

$A_{3}$ - the annual dose during the third year from all exposure pathways to the organ of reference, mrem 
$R_{3}^{*}$ - the radiation dose equivalent in the third year to the organ of reference from all internal and external exposure pathways from intake and exposure in the third year of continuous exposure, mrem.

The terms $R_{1,3}, R_{1,2}, R_{2,2}$, and $R_{2,1}$ are of similar form, each having two subscripts. The first subscript defines the year of intake or exposure after the start of continuous exposure, and the second defines the number of years used in calculating the committed dose equivalent.

The quantity in the first parentheses in Equation F.8b is the dose equivalent to the organ of reference in the third year from radionuclides deposited in the first year of continuous exposure (i.e., the difference between the 3-year committed dose equivalent and the 2-year committed dose equivalent). The quantity in the second parentheses is the dose equivalent in the third year to the organ of reference from radionuclides deposited in the second year of continuous exposure (i.e., the difference between the 2-year committed dose equivalent and the first-year committed dose equivalent).

The general expression for calculating the annual dose to an organ of reference during any year after the start of continuous exposure can be expressed as:

$$
A_{t}=R_{t}^{*}+\sum_{i=1}^{t-1}\left[R_{i,(t-i+1)}-R_{i,(t-i)}\right]
$$

where:

$A_{t}$ - the annual dose during the year $t$ from all exposure pathways to the organ of reference, mrem

$R_{t}^{*}$ - the radiation dose equivalent in year $t$ to the organ of reference from all internal and external exposure pathways from intake and exposure in the year $t$, mrem. 
The summation term represents the dose equivalent delivered to the organ of reference in year $t$ from radionuclides deposited in the organ from intake in all previous years since the start of continuous exposure.

The summation term in Equation $F .9$ is valid only for integer values of $t$ greater than 1 . For values of $t$ equal to or less than 1 , the subscripts define a non-real case, and the summation term is set equal to zero.

The annual dose, $A_{t}$, to the organ of reference is calculated for each value of $t$ from 1 to 50 , and the maximum annual dose is determined by inspection. The radionuclide inventories are adjusted for radionuclide decay and daughter-product buildup during the calculation.

To determine acceptable residual contamination levels for the BWR facility, a model of a reference room is required. Modifications to the models for the airborne exposure pathway are also required since no further airborne release occurs after decommissioning. The following sections contain discussions of these topics.

\section{F.3.1 Model of a Reference BWR Room}

To determine the acceptable contamination levels in the decommissioned BWR facility, the dimensions of a reference room must be defined. The results of a sensitivity study of the relationship between room volume, surface radionuclide levels, and calculated dose rate are shown in Figure F.3-1. Dose rates are calculated at a point in air (in a tissue equivalent $50 \mathrm{~mm}$ thick) $1 \mathrm{~m}$ above the floor of a room with $1 \mathrm{Ci} / \mathrm{m}^{2}$ of ${ }^{60} \mathrm{Co}$ uniformly distributed on the room surfaces. The curves in Figure F.3-1 graphically illustrate the difference between an evenly contaminated room and one whose walls and ceiling contain $50 \%$ and $10 \%$, respectively, of the floor contamination level. The straight line represents the dose rate from an infinite flat plane of evenly distributed ${ }^{60}$ Co contamination with a concentration of $1 \mathrm{Ci} / \mathrm{m}^{2}$. It can be seen that the dose rate for a large, non-uniformly contaminated room may exceed that of a uniformly contaminated infinite plane.

To be conservative, a room with uniformly contaminated walls, floor, and ceiling is used in this study. It has a floor area of $154 \mathrm{~m}^{2}$ and $3-\mathrm{m}-\mathrm{high}$ 


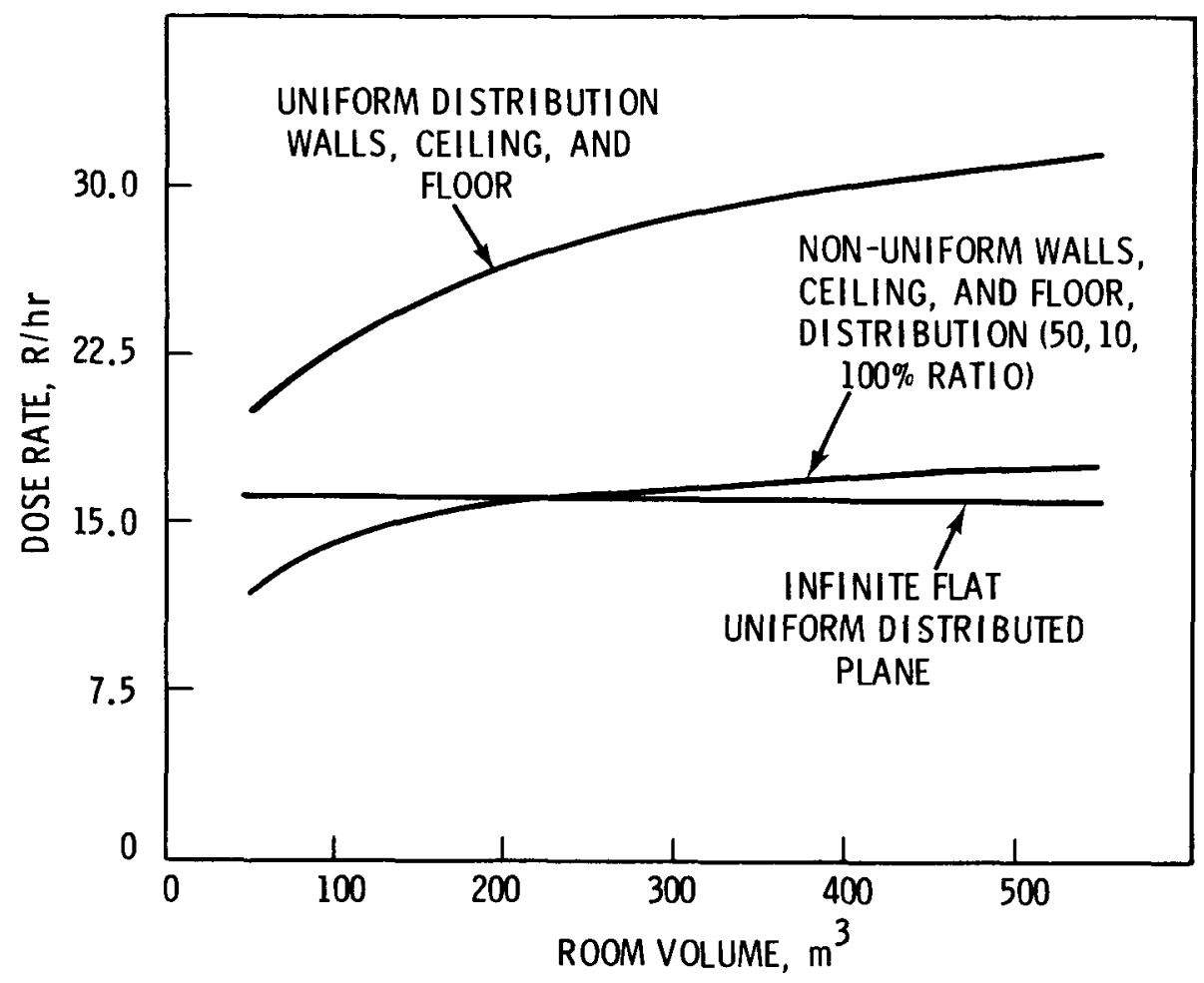

FIGURE F.3-1. Dose Rate as a Function of Room Volume for a ${ }^{60} \mathrm{Co}$ Deposition of $1 \mathrm{Ci} / \mathrm{m}^{2}$

walls, for a total volume of about $460 \mathrm{~m}^{3}$. External radiation dose equivalent factors for this reference room are calculated using the ISOSHLD computer code. $(14,15)$ Annual doses are determined for a person working in this reference room at the decommissioned BWR for 40 hours a week for 50 years. F.3.2 Airborne Radioactivity Concentrations for Annual Dose Calculations

Resuspended surface or ground contamination is assumed to be the only source of airborne radionuclides following decommissioning of the reference BWR. Airborne radionuclide concentrations for the decommissioned BWR are calculated using a resuspension analysis. The average airborne concentration is the product of a resuspension factor and the surface contamination level as shown in Equation F.10.

$$
\bar{X}=S_{f} S_{A}
$$


where:

$\bar{X}$ - average airborne concentration, $\mathrm{Ci} / \mathrm{m}^{3}$

$S_{f}$ - resuspension factor, $\mathrm{m}^{-1}$

$\mathrm{S}_{\mathrm{A}}$ - surface radioactivity deposition, $\mathrm{Ci} / \mathrm{m}^{2}$.

Inside the decommissioned BWR facility, airborne concentrations are calculated using a constant resuspension factor of $5 \times 10^{-6} \mathrm{~m}^{-1}$. This value is one tenth of the value suggested by the IAEA for surfaces with removable contamination. (17) This lower value is assumed since unrestricted release of nuclear facilities should not be contemplated with readily removable contamination remaining on accessible surfaces. Actual facility surface resuspension factors may be considerably lower than this value.

Airborne radionuclide concentrations on the reference site are calculated using a time dependent resuspension factor to account for the environmental "aging" of radionuclides. The relationship for this factor is given in Equation F.11. (18)

$$
S_{f}=\left(10^{-4} e^{-\lambda \sqrt{t}}\right)+10^{-9}
$$

where:

$$
\begin{aligned}
S_{f} & \text { resuspension factor, } \mathrm{m}^{-1} \\
10^{-4} & \text { - resuspension factor at time } t=0, \mathrm{~m}^{-1} \\
\lambda & \text { effective decay constant control1ing the availability of material } \\
& \text { for resuspension, } 0.15 \text { day }^{-1 / 2} \\
\mathrm{t} & \text { - time after deposition, days } \\
10^{-9} & - \text { resuspension factor after } 17 \text { years, } \mathrm{m}^{-1} .
\end{aligned}
$$

The second term in Equation $F .11\left(10^{-9}\right)$ is added based on the assumption that there is no further measurable decrease in the resuspension factor process after 17 years, which is the longest period for which data are available. 
This is deemed appropriate since this model is derived empirically to simulate experimental measurements, and contains no fundamental understanding of the resuspension process. (18) The time dependence of the site resuspension factor is illustrated in Figure F.3-2.

After decommissioning, unrestricted use of the site will allow activities such as unlimited farming. Therefore, the amount of surface contamination available for resuspension must be defined. For the calculation of the maximum annual doses, it is assumed that the site surface is plowed after decommissioning to a depth of $0.15 \mathrm{~m}$, and the original surface contamination is assumed to be uniformly mixed into that volume of soil. This reduces the amount of material available for resuspension.

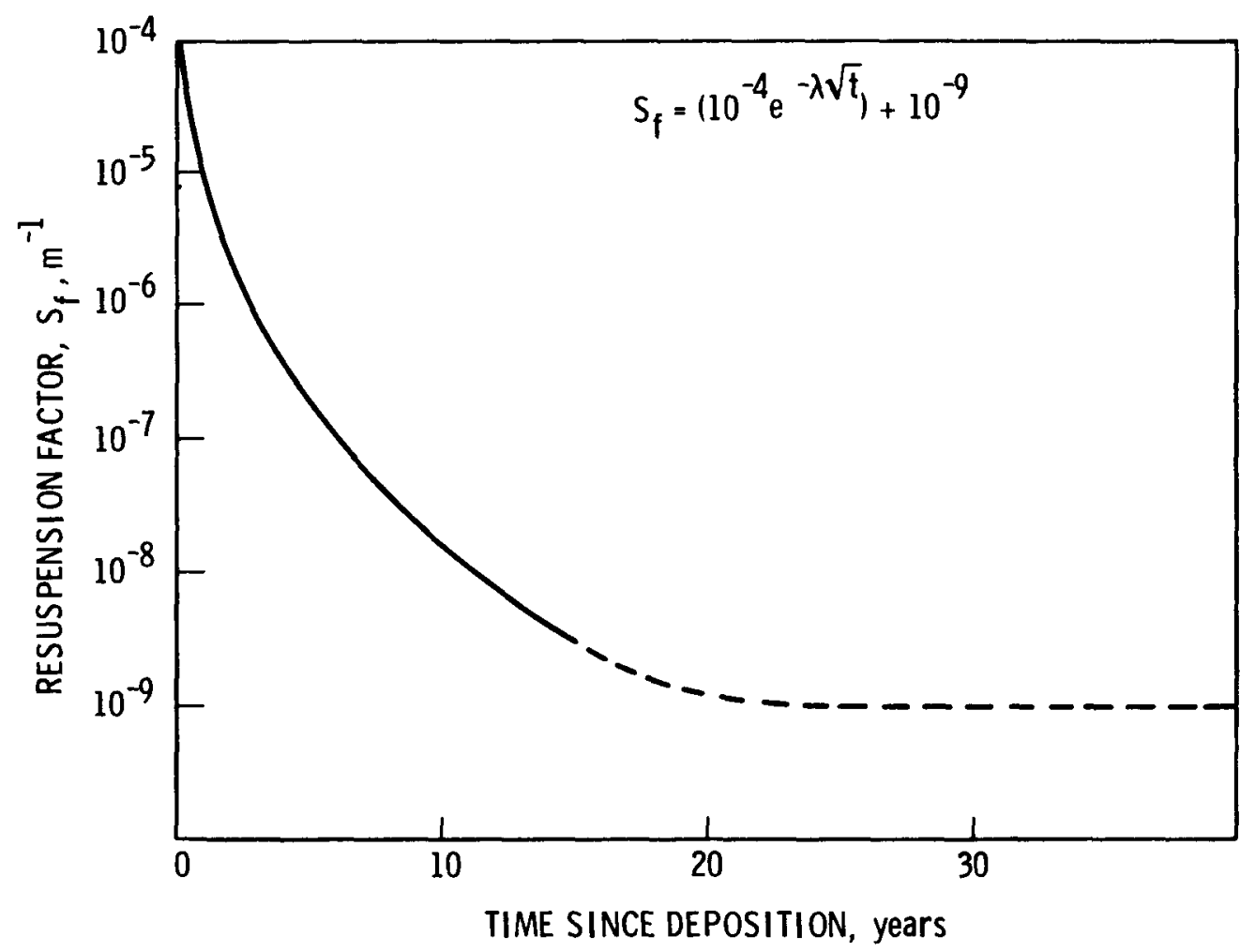

FIGURE F.3-2. Time-Dependent Surface Resuspension Factor for the Site 


\section{F.4 CALCULATED MAXIMUM ANNUAL DOSES AT THE DECOMMISSIONED REFERENCE BWR}

This section contains the assumptions, specifies the radionuclide inventories, and presents listings of the resultant calculated maximum annual doses. These maximum annual doses are used in determining the acceptable residual contamination levels for the decommissioned reference BWR that are presented in Chapter 8. Doses are calculated and reported for the maximum-exposed individual working in the BWR facility or residing on its site after decommissioning.

\section{F.4.1 Assumptions for Calculating Maximum Annual Dose}

The following assumptions are used in calculating the maximum annual doses at the decommissioned BWR:

- The radionuclide inventories are undisturbed, except for radioactive decay after plant shutdown. Doses are calculated for the mixtures at shutdown, and for decay periods of $10,30,50$, and 100 years.

- The maximum-exposed individual is considered to have realistically maximized exposure pathway parameters.

- The maximum-exposed individual working in the facility receives continuous exposure for 40 hours a week, 50 weeks a year.

- The maximum-exposed individual residing on the site is continuously exposed for 168 hours per week, 52 weeks per year.

- The airborne radionuclide concentrations are calculated using a resuspension factor of $5 \times 10^{-6} \mathrm{~m}^{-1}$ inside the facility, and the time dependent factor from Equation F.1l on the site.

\section{F.4.2 Radionuclide Inventories for Calculating Maximum Annual Dose}

The radionuclide inventories used to calculate the maximum annual doses at the decommissioned BWR are reference radionuclide inventories 5 and 6 , which are presented and discussed in Appendix E. Table E.2-7 contains a listing of reference radionuclide inventory 5 , which characterizes surface contamination inside the reference BWR. (19) Table E.2-10 contains a listing of reference radionuclide inventory 6 , which characterizes the contamination on the ground surface of the site. ${ }^{(20)}$ 


\section{F.4.3 Maximum Annual Dose Listings}

Calculated maximum annual doses to the maximum-exposed individual using the decommissioned BWR facility or its site are listed in Tables F.4-1 and F.4-2. These doses are calculated using the models, parameters, and assumptions presented earlier in this appendix. Dose pathways of concern in the reference BWR facility are inhalation of resuspended surface contamination and external exposure to surface contamination. The calculated maximum annual doses to an individual working in the decommissioned facility for 40 hours a week, 50 weeks a year, are listed in Table F.4-1. Dose pathways of concern on the decommissioned reference site are inhalation of resuspended ground contamination, external exposure to ground contamination, and ingestion of food products raised on the site. The calculated maximum annual doses to an individual residing on the reference site 24 hours a day, 52 weeks a year, are listed in Table F.4-2. These tables contain doses calculated using the radionuclide mixtures present at plant shutdown, and at decay periods of $10,30,50$, and 100 years after plant shutdown. These doses are used to determine the acceptable residual radionuclide contamination levels for unrestricted release of the decommissioned BWR facility and site, which are presented in Chapter 8. 
TABLE F.4-1. Estimated Maximum Annual Dose to the Maximum-Exposed Individual Working in the Decommissioned BWR Facility at Various Times After Shutdown (a)

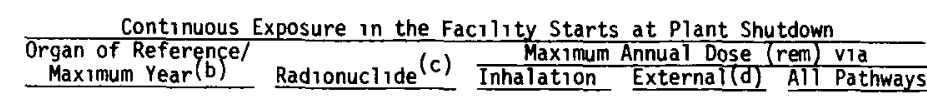
Total Body/
Year 1

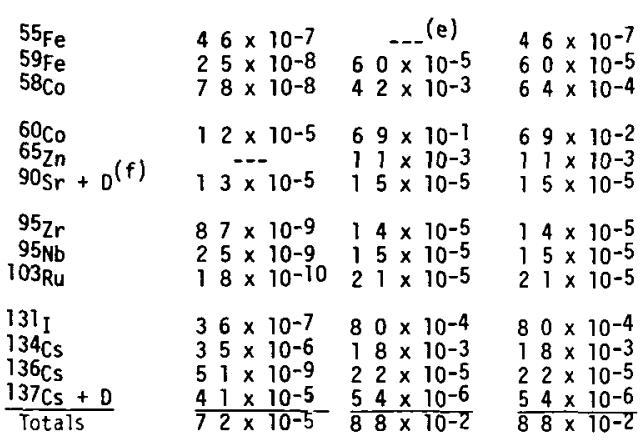

Bone/

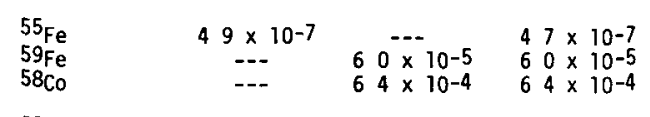

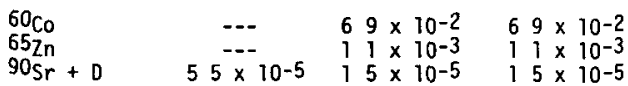

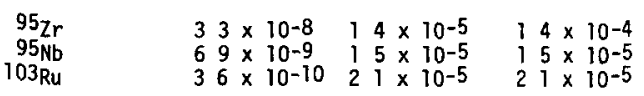

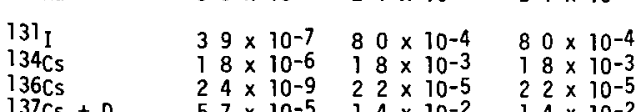

Lungs/
Year 1

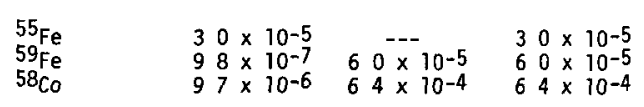

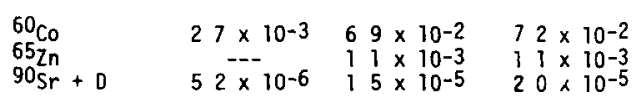

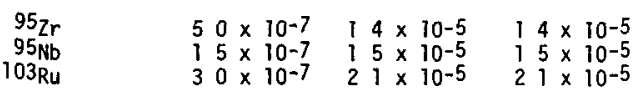

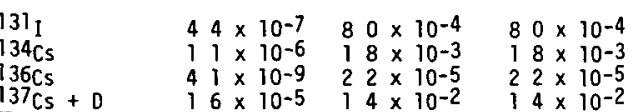

Thyrood/
Year 1

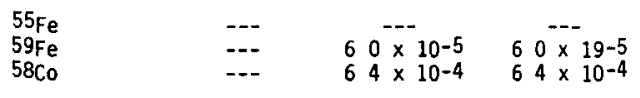

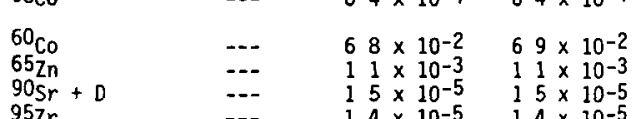

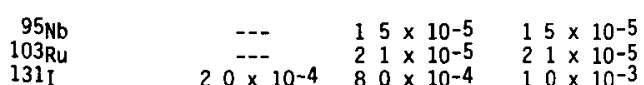

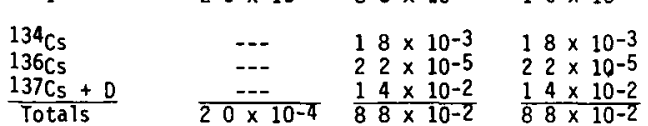

(a) Based on the reference radionuclide inventory 5 , Table E $2-9(19)$
(b) The year in which the maximum annual dose occurs after the start of con-

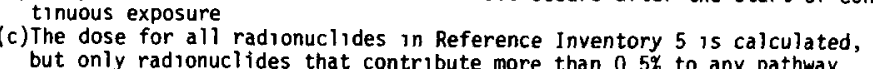

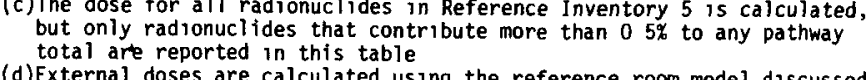

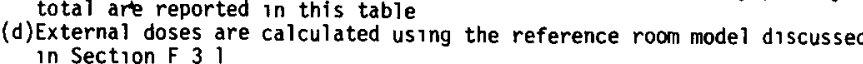

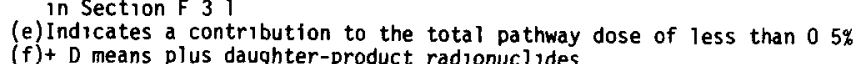

Cont 1nuous Exposure in the Facility Starts 10 Years After Plant Shutdown

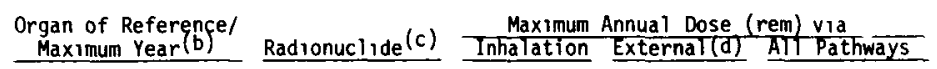
Total Body/
Year 1

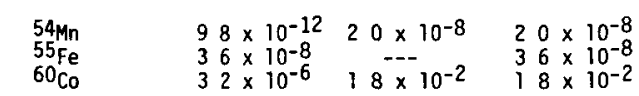

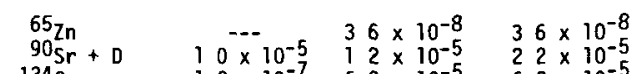

Bone/ $\frac{1345+0}{\text { Totals }} \quad \frac{33 \times 10^{-5}}{46 \times 10^{-5}} \quad \frac{11 \times 1 \times 10^{-2}}{29 \times 10^{-2}} \quad \frac{113 \times 10^{2}}{29 \times 10^{-2}}$

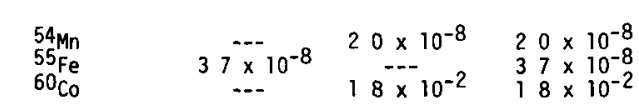

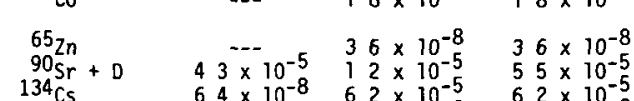

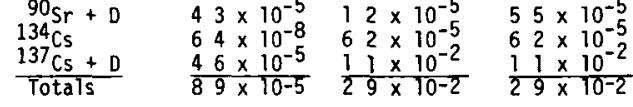

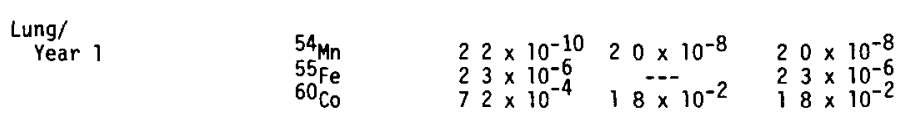

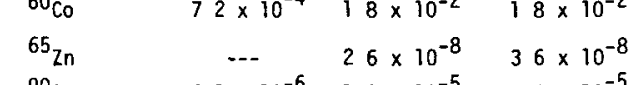

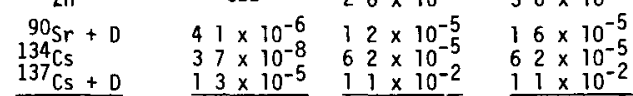

Thyroid/
Year 1

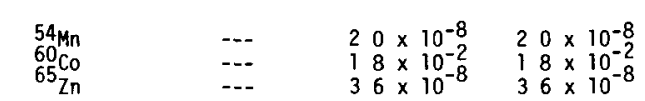

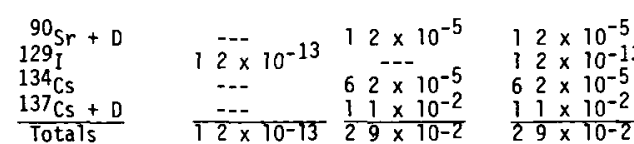

Continuous Exposure in the Facilly Starts 50 Years After Plant Shutdown

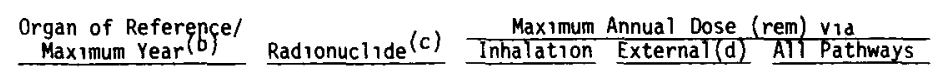
Total Body/
Year 1

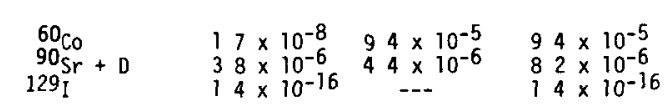

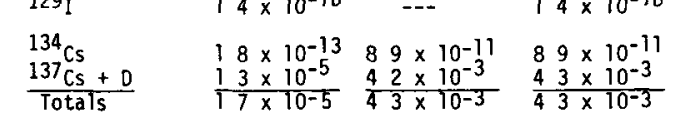
Bone/
Year 1

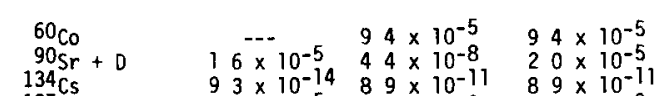

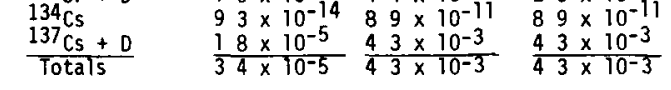

Lung/

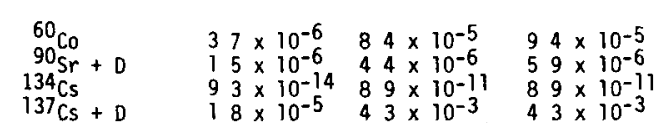

$\underset{\text { Thyroid }}{\text { Year } 1}$

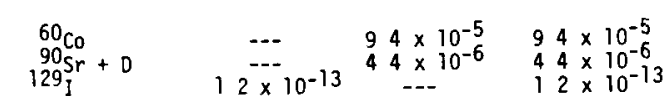

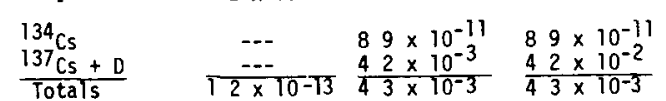

Cont inwous Exposure in the Facility Starts 30 years After Plant Shutdown

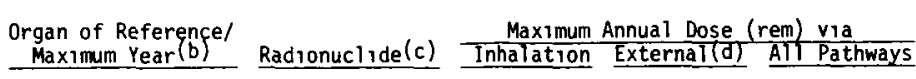
Total Bodyl
vear 1

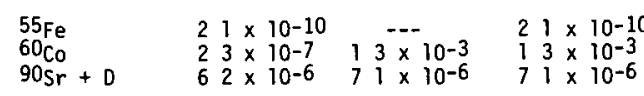

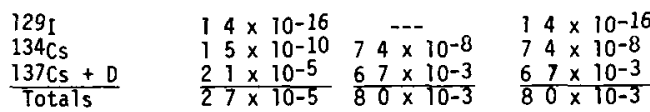

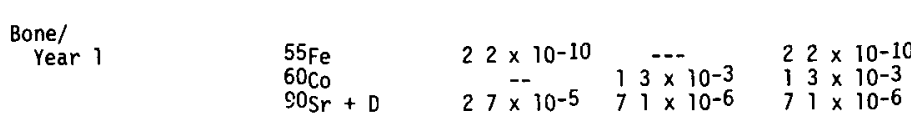

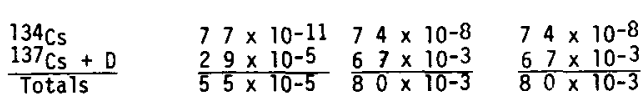

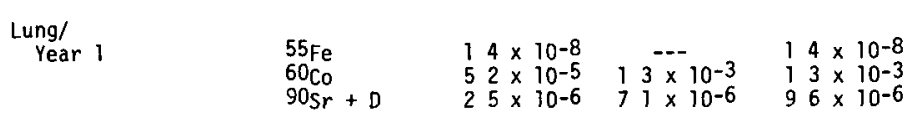

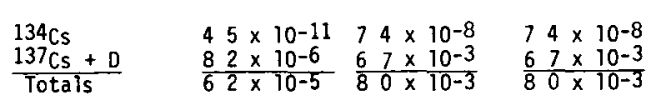

Thyrord'

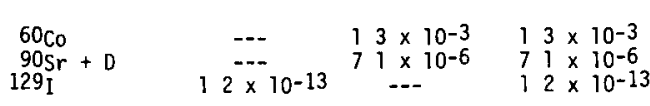

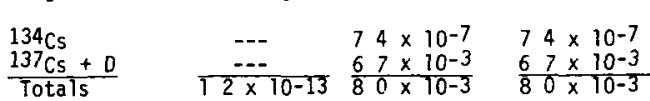

Continuous Exposure in the Facil1ty Starts 100 Years After Plant Shutdown Organ of Referenge/
Max Inum Yearlb) Total Body/
rear 1

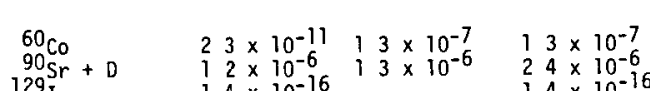

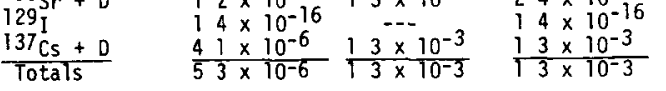

Bone/

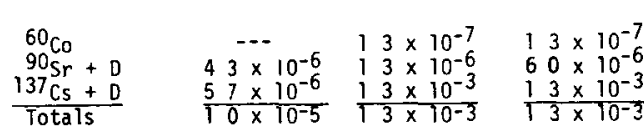

$\underset{\text { Lung/ }}{\text { Year } 1}$

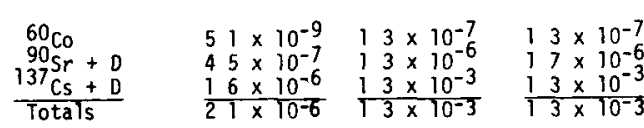
Thyroid/
Year 1

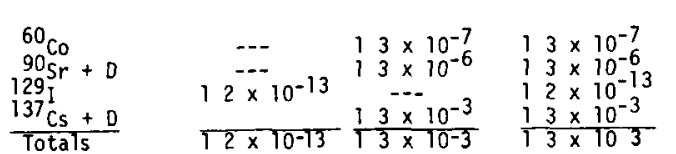

TABLE F.4-1. Estimated Maximum Annual Dose to the MaximumDose to the Maximum-
Exposed Individual Workin in the Decommissioned Times After Shutdown 
Continuous Exposure on the Site Starts at Plant Shutdown

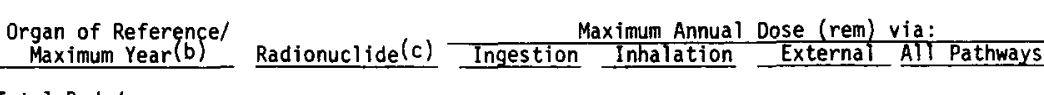
Total Body/
Year 20

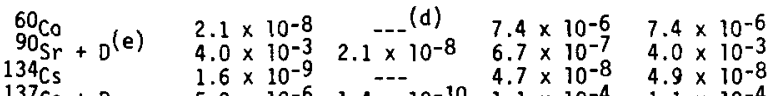

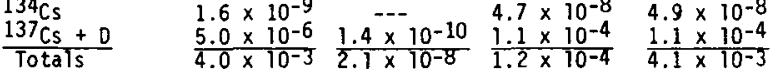

$\underset{\substack{\text { Bonef } \\ \text { Year } 21}}{2}$

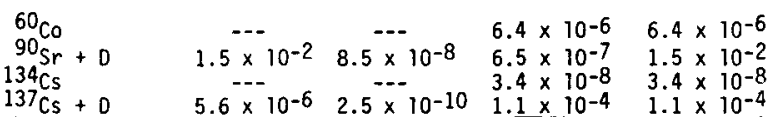

Lung/

\begin{tabular}{|c|c|c|c|}
\hline 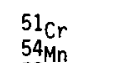 & $\ldots$ & $\ldots$ & $\begin{array}{l}6.4 \times 10^{-10} \quad 6.4 \times 10^{-10} \\
2.2 \times 10^{-6}=2.2 \times 10^{-6}\end{array}$ \\
\hline $59 \%$ & $\cdots$ & -- & $1.4 \times 10^{-8} \quad 1.4 \times 10^{-8}$ \\
\hline $\begin{array}{l}580 \\
60 \mathrm{co} \\
60 \mathrm{c}\end{array}$ & 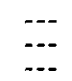 & $1.0 \times 10^{-1}$ & 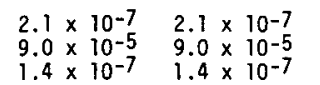 \\
\hline 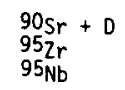 & $\begin{array}{l}\cdots \\
\cdots\end{array}$ & $\begin{array}{l}\ldots- \\
\cdots--\end{array}$ & $\begin{array}{ll}1.6 \times 10^{-8} & 1.6 \times 10^{-8} \\
3.6 \times 10^{-8} & 3.6 \times 100^{-8} \\
2.2 \times 10^{-8} & 2.2 \times 10^{-8}\end{array}$ \\
\hline & & $\ldots$ & $\begin{array}{lll}8.5 \times 10^{-7} & 8 \\
1.3 \times 10^{-7} & 8 \\
1\end{array}$ \\
\hline
\end{tabular}

$\underset{\text { Thyroid/ }}{\text { rear I }}$

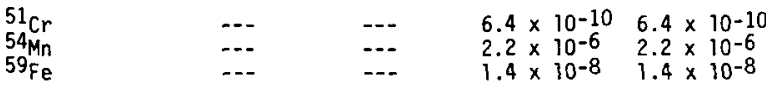

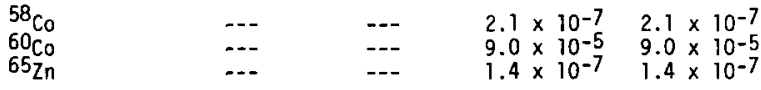

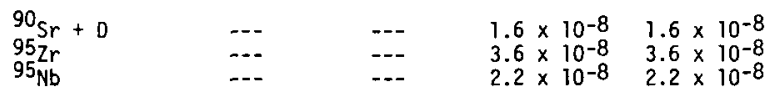

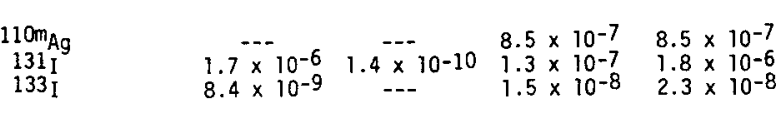

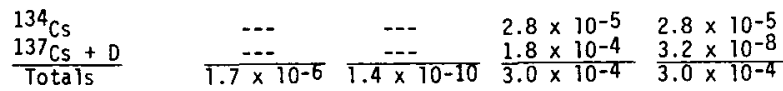

(a) Based on reference radionucl 1 de inventory 6, Table E.2-10, from 1975 reported release

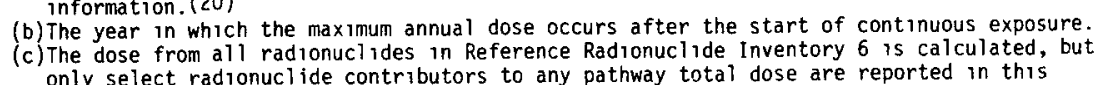
(d) Indicates a contribution to the total pathway dose of less than $0.5 \%$
Continuous Exposure on the Site Starts 10 Years After Plant Simetom

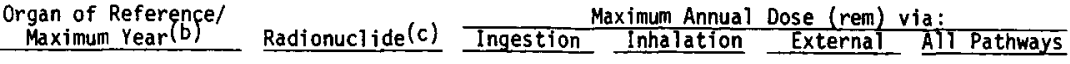
Total Body/
Year 20

Bonef
Year 21

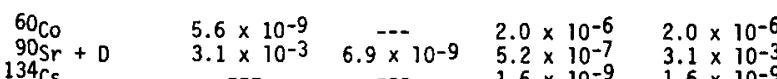

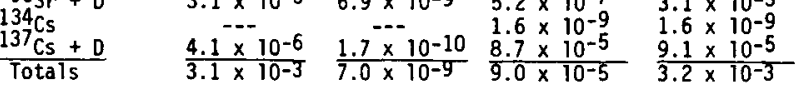

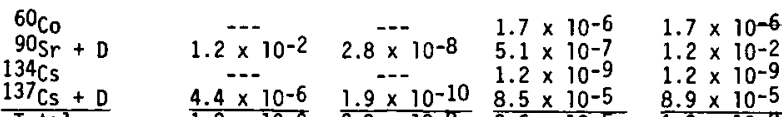

Lung/

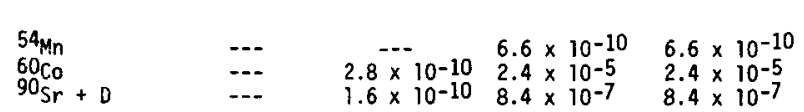

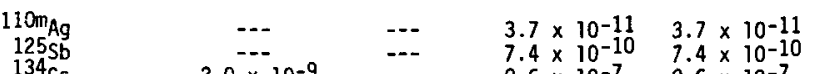

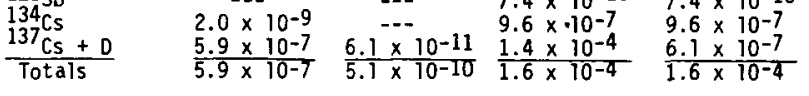

Thyroidy
Year 1

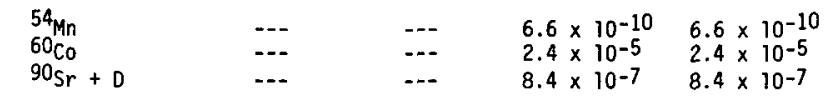

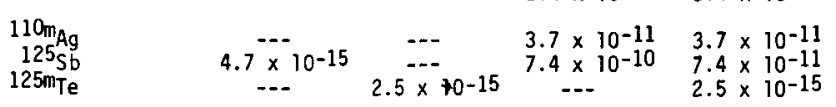

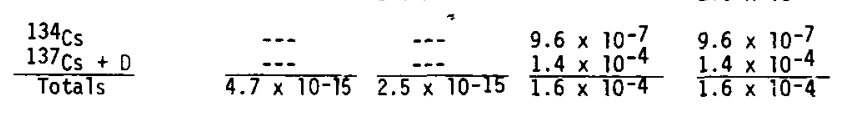

Continuous Exposure on the Site Starts 50 Years After Plant Shutdden

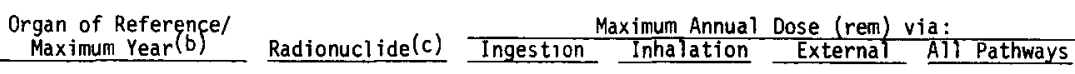

Total
Year 20 dy

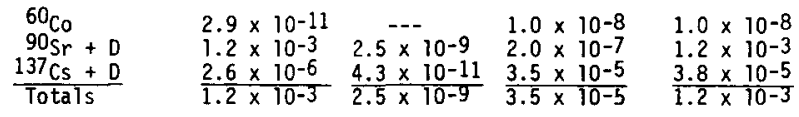

Bone/
Year 21

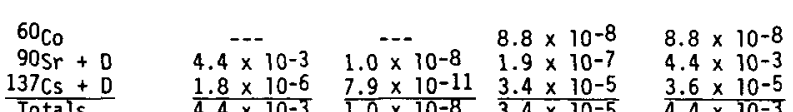

Lung/

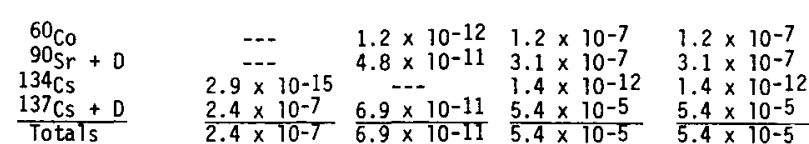

Thyroid/
Year $?$
Continuous Expossure on the Site Starts 30 Years After Plant Shutdown

Organ of Referenge/
Maximum Year Radionuclide(c) Ingestion Maximum Annual Dose (rem) via: Total Body/
Year 20

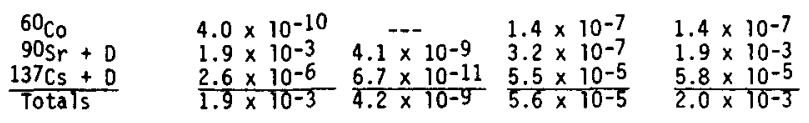

Bonel
Year 21

Lung'

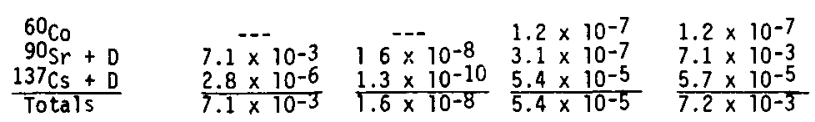

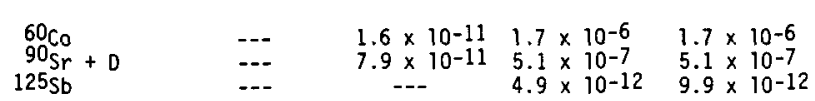

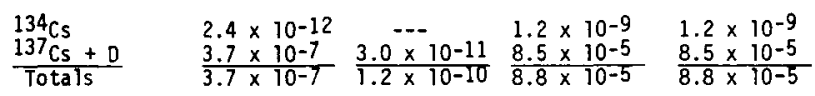

Thyroid/

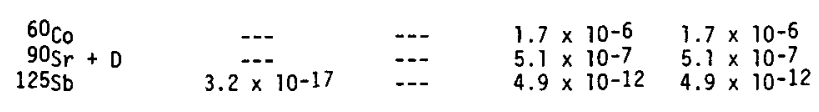

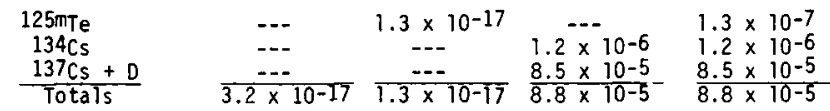

Continuous Exposure on the Site Starts 100 Years After Plant Shutdom

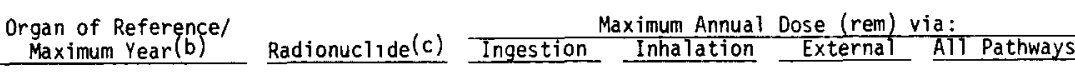
Total Body/
Year 20

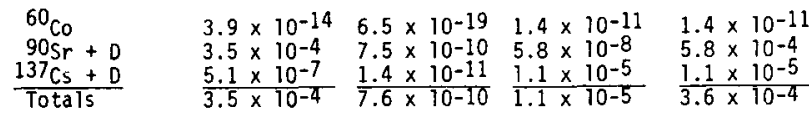

Bonef
Year 21

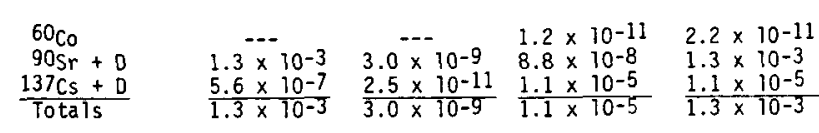

Lung/

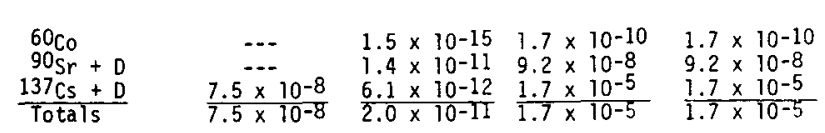

Thyroid
Year 1

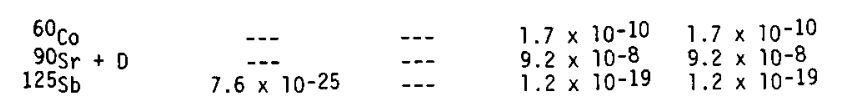

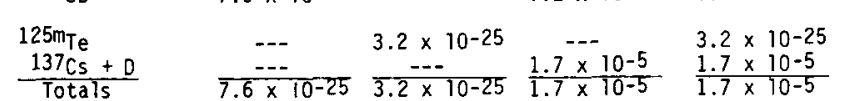

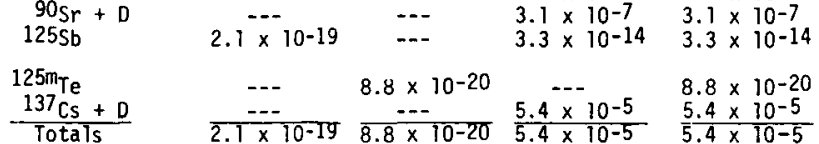

TABLE F.4-2. Estimated Maximum Annual Dose to the Maximum-

Exposed Individual Residing

on the Decommissioned

BWR Site at Various Times

After Shutdown 
Q 


\section{REFERENCES}

1. K. J. Schneider and C. E. Jenkins, Technology, Safety and Costs of Decommissioning a Reference Nuclear Fuel Reprocessing Plant, NUREG-0278, Prepared by Pacific Northwest Laboratory for the U.S. Nuclear Regulatory Commission, October 1977.*

2. R. I. Smith, G. J. Konzek and W. E. Kennedy, Jr., Technology, Safety and Costs of Decommissioning a Reference Pressurized water Reactor Power Station, NUREG/CR-0130, Prepared by Pacific Northwest Laboratory for the U.S. Nuclear Regulatory Commission, June 1978.**

3. C. E. Jenkins, E. S. Murphy and K. J. Schneider, Technology, Safety and Costs of Decommissioning a Reference Small Mixed Oxide Fuel Fabrication Plant, NUREG/CR-0129, Prepared by Pacific Northwest Laboratory for the U.S. Nuclear Regulatory Commission, February 1979. **

4. Task Group on Lung Dynamics for Committee 2 of the International Commission on Radiological Protection, "Deposition and Retention Models for Internal Dosimetry of the Human Respiratory Tract," Health Physics, 12, pp. 173-207, February 1966.

5. G. G. Killoush, D. E. Dunning, Jr., S. R. Bernard and J. C. Pleasant, Estimates of Internal Dose Equivalent to 22 Target Organs for Radionuclides Occurring in Routine Releases from Nuclear Fuel-cycle Facilities, NUREG/CR-0150, report prepared for the Nuclear Regulatory Commission by Oak Ridge National Laboratory, Oak Ridge, TN, June 1978. **

6. J. K. Soldat, et al., Models and Computer Codes for Evaluating Environmental Radiation Doses, US AEC Report BNWL-1754, Pacific Northwest Laboratory, Richland, WA, February 1974.

7. U.S. AEC, Final Environmental Statement Concerning Proposed Rule-Making Action: Numerical Guides for Design Objectives and Limiting Conditions for Radioactive Material in Light Water-Cooled Nuclear Power Reactor Effluents, WASH-1258, Directorate of Regulatory Standards, Volume 1 of 3, Tables 6B-4 and 6B-5, pp. 6B-34 and 6B-35, July 1973.

8. D. A. Baker, G. R. Hoenes and J. K. Soldat, "FOOD - An Interactive Code to Calculate Internal Radiation Doses from Contaminated Food Products." in Environmental Modeling and Simulation, Proceedings of a conference held in Cincinnati, OH, Apri] 20-22, 1976. pp. 204-208, EPA, Washington, DC, 1976.

9. J. F. Fletcher and W. L. Dotson (compilers), HERMES - Digital Computer Code for Estimating Regional Radiological Effects from the Nuclear Power Industry, US AEC Report HEDL-TME-71-169, Hanford Engineering Development Laboratory, Richland, WA, 1971.

${ }^{\star}$ Available for purchase from the National Technical Information Service, Springfield, Virginia 22161.

** Available for purchase from the NRC/GPO Sales Program, U.S. Nuclear Regulatory Commission, Washington, D.C. 20555, and the National Technical Information Service, Springfield, Virginia 22161. 
10. J. K. Soldat, Modeling of Environmental Pathways and Radiation Doses from Nuclear Facilities, USAEC Report BNWL-SA-3939, Pacific Northwest Laboratory, Richland, WA, 1971.

11. G. R. Hoenes and J. K. Soldat, Age-Specific Radiation Doses Commitment Factors for a One Year Chronic Intake, NUREG-0172, a report for the U.S. Nuclear Regulatory Commission, to be published as a supplement to ReguTatory Guide 1.109. *

12. International Commission on Radiological Protection, Report of the Task Group on Reference Man, ICRP Publication 23, Perganon Press, N.Y., 1974.

13. J. R. Houston, D. L. Strenge and E. C. Watson, DACRIN - A Computer Program for Calculating Organ Dose from Acute or Chronic Inhalation, BNWL-B-389, BattelTe, Pacific Northwest Laboratories, Richland, WA, December 1974.

14. R. L. Engel, J. Greenborg and M. M. Hendrickson, ISOSHLD - A Computer Code for General Purpose Isotope Shielding Analys is, BNWL-236, Batte17e, Pacific Northwest Laboratories, June 1966.

15. G. L. Simmons et a1., ISOSHLD II Code Revision to Include Calculation of Dose Rates from Shielded Bremsstrahlung Sources, BNWL-236, Supplement T, Battelle, Pacific Northwest Laboratories, March 1967.

16. D. A. Baker, User Guide for Computer Program FO0D, US ERDA Report BNWL-2209, Pacific Northwest Laboratories, Richland, WA, February 1977.

17. Monitoring of Radioactive Contamination on Surfaces, International Atomic Energy Agency, Technical Report Series No. 120, p. 4, Vienna, 1970.

18. L. R. Anspaugh, J. H. Shinn and P. L. Phelps, Resuspension and Redistribution of Plutonium in Soils, UCRL-76419, pp. 14-18, January 1975.

19. S. G. Sawochka, N. P. Jacob and W. L. Pearl, Primary System Shutdown Radiation Levels at Nuclear Power Generating Stations, EPRI 404-2, Final Report, Prepared by Nuclear Water and Was te Technology for the Electric Power Research Institute, pp. 8-24, Palo Alto, CA, 1975.

20. U.S. NRC, Radioactive Materials Released from Nuclear Power Plants (1975), NUREG-0218, March 1977. *

${ }^{\star}$ Available for purchase from the National Technical Information Service, Springfield, Virginia 22161. 
APPENDIX G

\section{DECOMMISSIONING METHODS}

Methods and equipment that can be used to accomplish various decommissioning activities at nuclear facilities such as the reference BWR are discussed in this appendix. These activities, in order of their presentation here, are:

- decontamination

- equipment disassembly

- radioactive waste packaging and shipping

- contamination control

- quality assurance

- environmental surveillance.

\section{G.1 DECONTAMINATION}

Three basic methods can be used to remove radioactive materials from contaminated surfaces. These are: 1) dissolution of the surface film containing the radionuclides, 2) physical cleaning of the surface, and 3) physical removal of the contaminated structural material. The various techniques used for each of these methods are discussed below.

\section{G.1.1 Surface Film Dissolution}

Two methods can be used to dissolve surface films containing radionuclide contamination: 1) chemical and 2) electrochemical. The chemical method is generally used to decontaminate the internal and (in some cases) external surfaces of in-place piping and equipment. The electrochemical method (electropolishing) can sometimes be used in situ for internal decontamination, but it is more commonly applied to disassembled or segmented piping and equipment.

\section{G.1.1.1 Chemical Decontamination}

Several chemical decontamination methods are available for radioactive contamination removal from surfaces. Some are designed for piping loops where the chemicals can be recirculated until the desired degree of decontamination is obtained. Others are designed to complete the decontamination in one pass, 
so that they can be used where recirculation is impractical. Selected chemical decontamination methods for BWR systems, with associated advantages and disadvantages, are presented in Table G.1-1. More detailed information on chemical decontamination is available in References 1 through 4. System decontamination and draining and radioactive liquid disposal during decommissioning of the reference BWR are discussed in detail in Section H.5 of Appendix H.

\section{TABLE G.1-1. Selected Chemical Decontamination Methods for BWR Systems}

Methods

Recirculatory (Loop-Type)

Alkaline permanganate, citric/ oxalic acid (citrox)

Ethylenediaminetetraacetic acid (EDTA) and citrox, 5\% solution

EDTA, nitrilotriacetic acid (NTA), and reducing agent(s)

Single-pass

Ammonium citrate and ammonium oxalate, 4 to $10 \%$ solution

Inhibited phosphoric acid $\left(\mathrm{H}_{3} \mathrm{PO}_{4}\right), \leq 10^{c}$ o solution

Hydrochloric acld ( $\mathrm{HCl}$ ), w10\% solution
Advantages

Disadvantages

Demonstrated effective solutions, nondamaging to components, decontamination factor (DF) 210 to 20

Only one cycie necessary Contaminants can be removed by a side-stream through an online cation resin bed, if desired Chemicals can be added directly to system water DF 210 to 20 at 80 to $100^{\circ} \mathrm{C}$

Produces relatively small volumes of waste solutions requiring processing. DF 22 to 10

No preconditioning required, OF $\sim 5$ to 15 at $80^{\circ} \mathrm{C}$

Demonstrated fast ( 10 to 20 min ) and effective method, DF $\sim 5$ to 10 at $80^{\circ} \mathrm{C}$

Fast, effective method for decontamination of carbon stee? (No reliable data on DF )
Generally requires repeated cycles to obtain good decontamination Generates large volumes of waste solutions requiring processing. Large tankage volume required for chemical preparation and handing

Recirculation time $\checkmark 2$ days, minımum. Potentially damaging to system components. Produces large volumes of waste solutions requiring processing and/or radioactive ion-exchange resins requiring disposal Additional R\&D needed to determine optımum conditions

Recirculation time from 1 to 7 days Requires elevated temperature $\left(\sim 150\right.$ to $\left.180^{\circ} \mathrm{C}\right)$ to be effective.

Attacks carbon steel, requiring waste solutions to be neutralized prior to long-term storage Requires up to 20 hours for maximum effectiveness Produces large volumes of waste solutions

Produces large volumes of waste solutions Possible redeposition of contaminants Most effective on carbon steel.

Incompatible with stainless steel Possible redeposition of contaminants Potentially more hazardous than other decontamination chemicals 
Isolatable equipment and piping sections in the reference BWR that are highly contaminated but not amenable to system-wide internal decontamination are postulated to be chemically decontaminated using mobile, shielded, decontamination units. Five such units, at an estimated cost of $\$ 20,000$ each, are assumed to be used.

Each unit is used for both chemical recirculation and rinse-water flushing and, after use, is itself decontaminated by backflushing. Each unit consists of two parts: 1) a remotely controlled operating unit containing a recirculating pump, an expansion tank, a thermostatically controlled electric heater, and a valve manifold; and 2) a control unit, connected by an electrical cable to the operating unit, located an appropriate distance away from the operating unit for ALARA considerations.

After isolation, the item being decontaminated is connected (with shortrun flexible hoses) to the mobile decontamination unit to form a recirculation loop. Chemicals are injected into the loop through the valve manifold at the unit, valving is aligned, and recirculation is begun. The required solution temperature is automatically maintained by the unit's electric heater during the entire recirculation period. A minimum of operator attention is required during recirculation.

\section{G.1.1.2 Electropolishing}

Electropolishing is an electrochemical process using electrolytic dissolution to produce a smooth, polished surface. It has been demonstrated effective in decontaminating a wide variety of equipment items with varying alloy compositions. (5)

The electropolishing process, shown schematically in Figure G.1-1, produces a two-fold result: 1) surface material is dissolved and removed (together with any contaminants) and 2) the new surface of the material is smoothed, minimizing recontamination from the electrolytic solution and allowing a simple water rinse (the final process step) to produce a contamination-free surface. Electropolishing offers a number of potential advantages over other decontamination processes: 
- It can be used on a wide variety of metals and their alloys, equipment geometries, and types of contamination.

- It reduces personnel radiation exposure and decontamination costs.

- It is rapid and effective.

- It can significantly reduce the amount of solid waste requiring expensive controlled storage, transportation, and disposal.

- It permits reclamation, reuse, and/or recycling of valuable materials.

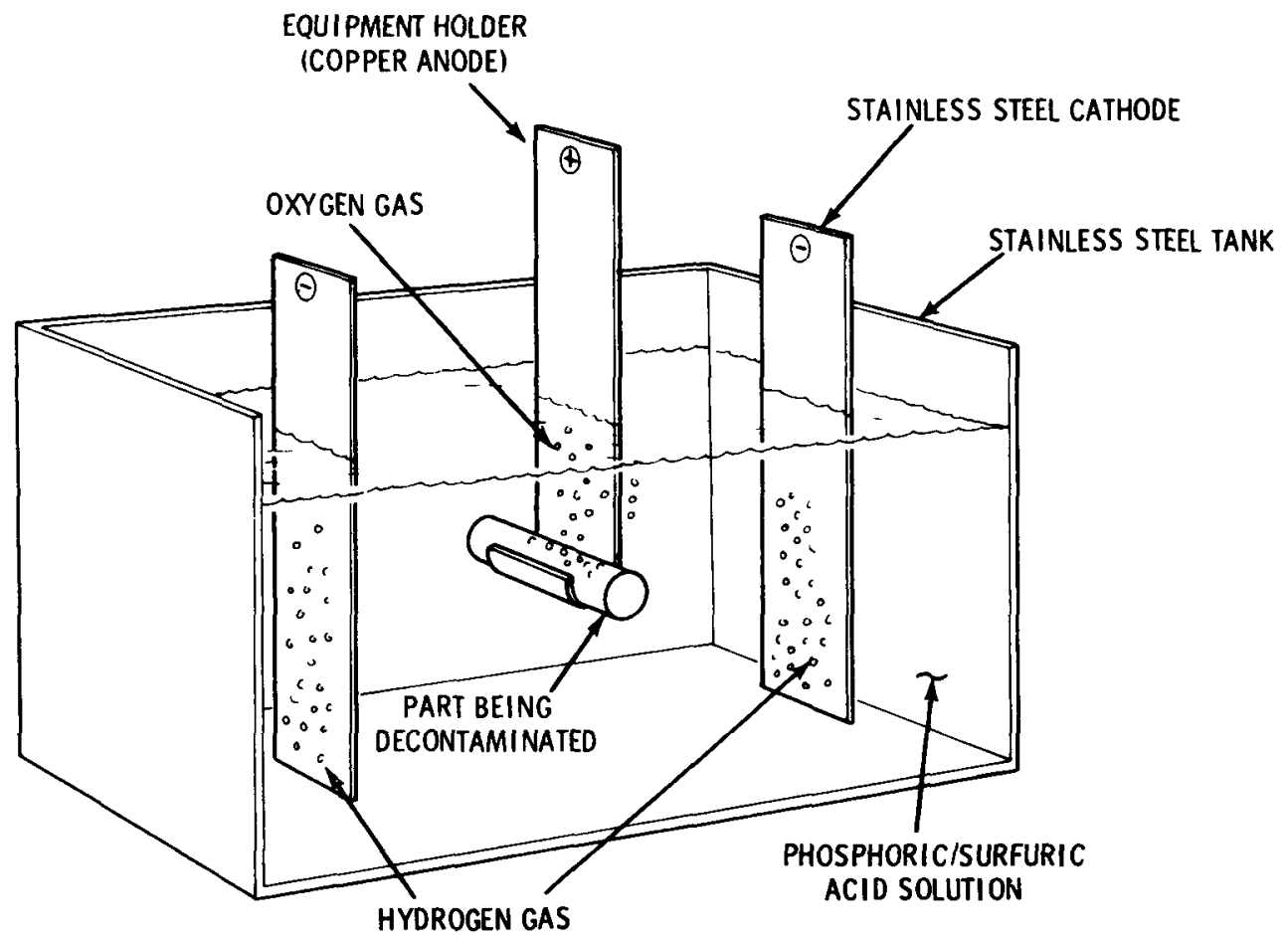

FIGURE G.1-1. Schematic Diagram of an Electropolishing Cell

For decontamination of disassembled (or segmented) piping and equipment, an electropolishing station is required. It consists of several open-top tanks: one contains the electrolyte (typically phosphoric and/or sulfuric acid) and appropriate fixtures, and the others are used for rinsing. A large constant-current, constant-voltage, DC power supply, capable of producing up to $10,000 \mathrm{~A}$ at about $10 \mathrm{~V}$, is required to provide a current density of 500 to 
$1500 \mathrm{~A} / \mathrm{m}^{2}$ at the anode surface. A recirculation system constantiy mixes the electrolyte and also provides on-line filtration and ion exchange to remove suspended solids and dissolved metal ions from the electrolyte. When the capacity of the ion-exchange column is exhausted, it is backflushed and regenerated, with the resulting waste solutions going to the in-plant liquid radwaste system for processing. An air sweep must be maintained over the electrolyte tank to sufficiently remove and dilute the hydrogen gas evolved by electrolysis during the cleaning process. The electropolisher is designed to automatically shut down if the ventilation system is inoperative, in order to prevent the accumulation of explosive concentrations of hydrogen gas.

Electropolishing can also be used for in-situ decontamination of the internal surfaces of cylindrical tanks. The electrolyte is sprayed onto the tank wall from nozzles mounted on rotating arms. A power supply provides current to these arms and, via the electrolyte stream, to the tank wall. Contaminated electrolyte is collected at the tank bottom and returned to an electrolyte handling system for cooling, filtration, and radiation monitoring. When the electrolyte becomes too contaminated, it is cleaned by processing it through the ion-exchange/filtration system of the electropolishing station and is then reused.

\section{G.1.2 Physical Cleaning}

Removal of smearable radioactive contamination from surfaces such as walls, floors, and tank exteriors can be accomplished using a variety of techniques. For small quantities of loose contamination on floors, vacuuming or simple sweeping is often effective. For more tenacious contaminants, various cleansing compounds are utilized in combination with handwiping and scrubbing techniques. Several proprietary decontamination solutions are available. Ordinary household detergents are quite effective but produce sizable quantities of waste water that may require special processing. Aerosol-type foaming cleansers are effective and eliminate the wastewater problem, but their use produces sizable quantities of contaminated wiping material.

Trichloroethylene, Freon-113, and other solvents are effective degreasing agents that can be used to decontaminate equipment surfaces. Organic solvents 
have the advantage of not being corrosive to equipment and electrical connections. However, their use generates contaminated organic solutions that must be processed. Use of organic solutions can cause degradation of plastic materials and can produce sizable quantities of contaminated wiping materials.

Variable-pressure, high- or low-velocity liquid jets are quite effective for some types of surface decontamination work. ${ }^{(6)}$ These devices are hand-held lances that can be operated by one man and can produce pressures up to about $30 \mathrm{MPa}$. Where effective, the liquid jet is a very rapid decontamination method. However, it produces significant volumes of contaminated liquid requiring processing for offsite disposal.

\section{G.1.3 Removal of Structural Material}

During facility decontamination, removal of both metal and concrete surfaces may be required. However, the techniques for metal-surface removal are the same as those for equipment disassembly, discussed in Section G.2. The present discussion is 1 imited to concrete removal.

Some concrete in nuclear facilities is contaminated below the surface and cannot be decontaminated to release levels by physical surface cleaning alone. In addition, some of the concrete and structural steel in the sacrificial shield surrounding the reactor vessel is activated as a result of neutron bombardment. In both instances, the structural materials must be physically removed and disposed of offsite to sufficiently decontaminate the facility.

Several criteria must be considered when selecting a material-removal method for a particular location. The method chosen should minimize personnel radiation exposure and airborne contamination dispersion. In addition, the size and weight of removed materials must facilitate packaging and shipping for offsite disposal.

The various methods available for concrete removal, with associated advantages and disadvantages, are listed in Table G.1-2. Of particular interest are the blasting techniques for use in bulk removal of concrete and the rocksplitting techniques for localized removal of contaminated concrete surfaces. 


\section{TABLE G.1-2. Concrete Removal Methods}

Removal Method

Blasting

Core Boring

and Rock-

Splitting

Flame Cutting

Thermic Lance Cutting
Advantages

Disadvantages

- Fast material removal rate where adjacent material damage is not of concern

- Adaptable for cutting irregular surfaces

- Adaptable to remote operation

- Adaptable to contral of size and weight of niaterial removed

- Selective removal of radioactive contamination possible

- Proven technioue used extensively in conventional mining operations

- Low noise level

- Low vibration/shock level

- No toxic gases generated

- Cooling water spray minimizes a irborne particulate material

- Moderate-to-slow cuttina speeds

- Controlled rate of material renoval

- Concrete and reinforcing steel may be cut in one operation

- Fast cutting speed

- Adaptable for remote operation

- Adaptable for pivoted circunferential cutting

- Adaptable for cutting on irregular surfaces

- No vibration/shock

- Low noise leve 1

- controlled rate of material removal

- cuts both concrete and steel without difficulty

- Fast "hole-punching" speed

- Ideallr suited for cutting irregular surfaces

- Remote operation is possible for up to approximately 3 meters

- No vibration/shock

- Low noise level

- Controlled rate of material removal

- High noise level
- May cause vibrations and shocks (vibrational control possible by limiting maximum charge per delay)

- Requires oxyacetylene torch for cutting exposed reinforcing steel

- Generates moderate quantities of dust that must be contralled

- Reinforcing steel slows cutting speed and dariayes core drill

- Requires oxycetylene torch for cutting exposed reinforcing steel

- Cooling water required for drilling may have to be filtered and recycled

- Not ideally suited for operation on irregular surfaces or in cramped quarters

- Generates coprous quantities of toxic gases and smoke

- Consumes large quantities of bottled oxygen

- Smoke can potentially spread gross contamination throughout contamination-control envelope unless adequately controlled

- Requires a through starter-hole made by a core drill to provide an outlet gas-flow path

Generates moderate quantities of toxic gases and smoke

- Requires rock jack to break away cut concrete sections

- Consumes large quantities of bottled oxygen

- Smoke can potentially spread gross contamination throughout contamination-control envelope unless adequately controlled 
Two techniques of lesser interest, primarily because of the copious quantities of toxic gases and/or smoke produced, are flame cutting and thermic lance cutting.

Flame cutting utilizes commercially available, 3-m-long by 19-mm-dia., thin-wall-conduit burning bars. Each bar contains up to seven dissimilar metals in the form of strips or strands, encased in an outer tube into which oxygen is forced during the burning process. Once ignited, the entire handheld device is consumed as it burns. After 4 to 5 minutes, with about $0.5 \mathrm{~m}$ of the bar left, the oxygen supply is shut off and the exothermic reaction stops. The remaining portion of the spent bar can be attached to a second bar and the burning process repeated, thus conserving bar material.

The thermic lance is also hand-held and uses powders of materials similar to those used in the aforementioned burning bar. The powders, together with oxygen, are forced through a tube or nozzle and ignited to form a high-temperature cutting medium.

\section{G.1.3.1 Bulk Concrete Removal}

A very effective way to remove and segment the activated concrete in the sacrificial shield is the use of explosives. (7) Because the shield's interior can easily be enclosed within ventilation-confinement envelopes, dust and airborne contamination can be effectively controlled. Placement of blasting mats $(\sim 3 \mathrm{~m}$ by $4 \mathrm{~m}$, weighing $\sim 1600 \mathrm{~kg}$ ) over the affected region prevents flying debris from penetrating the confinement envelopes. Fog sprays of water, typically used from 1 minute before to about 15 minutes after blasting, help to settle the dust created by the blasts. Although blasting sequences are designed to minimize air-pressure surges, the ventilation enclosures must be designed to withstand those pressure surges that do occur. Similarly, attention must be given to the building ventilation system to prevent surge damage to filters, with monitoring of the system to verify its continued integrity.

The first step in explosive decontamination of concrete is to drill holes to hold the explosives. In some areas, these holes may be drilled parallel to and about $127 \mathrm{~mm}$ in from the surface of the concrete to be removed, outside of 
any reinforcing steel. The holes extend beneath the entire length of the surface to be removed, and explosives are inserted in the holes. The holes are tamped with sand, if necessary, to produce the desired blast depth. In other areas, 127-mm-deep holes on 0.3-m centers may be drilled perpendicular to the surface to be removed. The holes are filled with mortar after the explosives are inserted. The explosives used may be of several varieties, as shown in Table G.7-3.

Four to five strands of 150-grain blasting cord twisted together and placed in a tube inserted in the hole are effective, as are partial sticks of dynamite. Liquid explosives can be used where it is difficult to insert solids. The size of the area to be blasted at one time is controlled, so that an accident involving the explosives used presents an acceptably low potential for damage. Explosives in the building are limited to those in actual use; those awaiting use are stored outside the building. Each blast is conducted with the individual charges sequenced to minimize the resulting shock wave. Blasting mats minimize the scattering of debris, and water sprays reduce airborne dust loading. After blasting, the area is inspected and surveyed to verify that all contamination is removed and that all explosives have detonated. The area may then be protected (by painting or with heavy plastic or canvas) to prevent recontamination during subsequent blasts.

Before an area is blasted, the ventilation system must be protected from damage due to overpressurization. In some areas, this can be accomplished by closing existing dampers during the blast; normal ventilation may be used in these areas except during the actual blast. In other areas, it may be possible to install covers over ventilation openings and remove them after a blast. Some areas require the use of an auxiliary ventilation system that draws from the blast area and exhausts, through a series of roughing filters, into the normal building ventilation system.

\section{G.1.3.2 Concrete Surface Removal}

A number of techniques can be used to remove contaminated concrete surfaces in nuclear facilities such as a BWR. A comparison of the various techniques is presented in Table G.1-4. 
TABLE G.1-3. Explosives for Bulk Concrete Removal

1. PETN (Pentaerytritol tetranitrate)

This explosive is used in the form of detonating cord. It is primarily used during the blasting of boreholes up to $5 \mathrm{~m}$ deep. In addition, it is effective for surface spalling, which requires the removal of very small burdens about $200 \mathrm{~mm}$ deep from exposed surfaces.

2. $85 \%$ High-Velocity Gelatin Dynamite

This explosive is primarily used in holes ranging in depth from $0.5 \mathrm{~m}$ to $1.5 \mathrm{~m}$ and as a partial loading in some holes when a concentration of energy is needed in a particular area. Breakage is excellent; however, it produces a crushed zone around the borehole, thus generating a larger amount of dust than the PETN.

3. Cast TNT

This explosive produces a high degree of fragmentation with less heaving effect than with conventional dynamite.

4. Binary Energy System (Liquid Explosives)

This explosive is mixed onsite and, when not mixed, is not legally classed as an explosive by most states. It is used in place of Cast TNT during the spalling of surfaces and to make shaped charges that can be used to punch holes in highdensity concrete.

5. Water Gel Explosives

A water gel explosive containing a large amount of aluminum is used as a partial replacement for the $85 \%$ dynamite. It exhibits good shattering characteristics and produces larger rubble than any of the other explosives. Its primary use is in areas with little or no reinforcing where larger size rubble is desired.

6. $\quad$ thers

High-strengh ammonia dynamite and plastics have been investigated with small-scale blasts. The effects indicated that they did not produce the desired results. 
TABLE G.1-4. Comparison of Concrete Surface Removal Techniques

\begin{tabular}{|c|c|c|c|c|}
\hline Technique & Limitation & Type of Rubble Produced & $\begin{array}{l}\quad \text { Size of } \\
\text { Air Filtration } \\
\text { System Required }\end{array}$ & $\begin{array}{l}\text { Relative } \\
\text { Removal Speer }\end{array}$ \\
\hline Sand Blasting & $\begin{array}{l}\text { Contamination embedded } \\
\text { in pores not effec- } \\
\text { tively removed }\end{array}$ & Small particles & Large & $.510 w$ \\
\hline Flame Spalling & $\begin{array}{l}\text { Heat may cause unde- } \\
\text { sirable chemical } \\
\text { reactions }\end{array}$ & Small particles & Large & Slow \\
\hline Jack Hammer & $\begin{array}{l}\text { Awkward to use on } \\
\text { walls }\end{array}$ & $\begin{array}{l}\text { Medium-sized pieces and } \\
\text { small particles }\end{array}$ & Medium & Medium Fast \\
\hline $\begin{array}{l}\text { Impactor Powered } \\
\text { Pneumatically or } \\
\text { Hydraulically }\end{array}$ & $\begin{array}{l}\text { Limited to large } \\
\text { accessible facilities }\end{array}$ & $\begin{array}{l}\text { Medium-sized pieces and } \\
\text { small particles }\end{array}$ & Medium & Fast \\
\hline Scrubber & $\begin{array}{l}\text { Awkward to use on } \\
\text { walls }\end{array}$ & Small preces and particles & Medium & Fast \\
\hline \multicolumn{5}{|l|}{ Water Cannon } \\
\hline $\begin{array}{l}\text { Handheld Modi- } \\
\text { fied } 458 \text { Maqnum } \\
\text { Rifle }\end{array}$ & $\begin{array}{l}\text { Gun powder combus- } \\
\text { tion products are } \\
\text { produced }\end{array}$ & $\begin{array}{l}\text { Small pieces coated with } \\
\text { glycerine and gun powder } \\
\text { combustion products }\end{array}$ & Sma 11 & Slow \\
\hline Rapıd-Fire Model & $\begin{array}{l}\text { Limited to large } \\
\text { accessible facilities }\end{array}$ & $\begin{array}{l}\text { Small preces coated with } \\
\text { water }\end{array}$ & Sma 11 & Fast \\
\hline $\begin{array}{l}\text { Concrete Spaller } \\
\text { with Air Drill } \\
\text { to make Holes }\end{array}$ & $\begin{array}{l}\text { Awkward to use on } \\
\text { irregular surfaces } \\
\text { or in cramped quar- } \\
\text { ters }\end{array}$ & $\begin{array}{l}\text { Medium-sized pieces and } \\
\text { small particles }\end{array}$ & Sma 11 & Medium Fast \\
\hline
\end{tabular}

Sand blasting, where the surface is mechanically eroded away, and flame spalling, where intense heat is applied to concrete surfaces, remove only a minimal surface thickness and produce large quantities of small, contaminated particles. Sand blasting primarily removes paint and a little of the concrete surface but does not effectively remove contamination in the pores of the concrete or at expansion joints. ${ }^{(9)}$ A large exhaust and air filtration system is needed with both of these methods. These two techniques are relatively slow if the contamination penetrates beyond a thin surface layer.

Two surface removal methods used more extensively than the rest are jack hammers and impactors. Jack hammers, powered by compressed air, are readily available and are easily operated by one man. They are used to chip off the surface material deep enough to remove the contamination. (9) Because they are difficult to position on walls and ceilings, jack hamers are used primarily on floors. Impactors (or hoe rams), similar in operation to jack hammers but much larger, have been used successfully in several 
decontamination projects. $(8,9)$ An impactor uses a pick chisel point that is driven into the concrete surface with high-energy impacts several times per second. Impactors are powered either pneumatically or hydraulically, and are held and positioned with linkages typical of those on tractor-mounted backhoes. A medium-size air filtration system is necessary to control the dust produced by both of these surface removal methods.

Another tool used to chip away concrete surfaces is a scrubber (or "scabbler"), a handheld tool with a gang of carbide-tipped bits. The bits rapidly impact the surface, causing small concrete pieces to be spalled. A dust shield with a vacuum attachment is placed around the bits to remove the dust generated. Dust removal increases this method's effectiveness by preventing the tool from pounding contaminated particles back into the concrete surface. The scrubber is relatively slow and is difficult to use on walls and ceilings.

The water cannon removes concrete surfaces by shooting very-high-pressure liquid jets at the surface, causing it to spall. This method has three advantages: 1) no initial surface preparation is needed, 2) the equipment does not contact the surface, and 3 ) the resulting rubble is composed of small pieces coated with liquid, thus minimizing dust generation. Two versions of the water cannon can be used. The first is a modified 458 magnum rifle that shoots solidified glycerine through a nozzle; the device is handheld and typically removes less than $20 \mathrm{~mm}$ of concrete from the surface. The second version uses stored, compressed gas to drive a piston that forces water through a smal1diameter nozzle; this large unit is mounted on a backhoe or excavator, and is therefore limited to use in large, readily accessible areas.

The last technique, use of a concrete spaller, is selected in this study as the principal method for removal of contaminated concrete surfaces. This device permits localized concrete removal to depths of 50 to $75 \mathrm{~mm}$ with no explosions and very little dust. (The principal source of dust is the dri11ing of the hole into which the splitting tool is inserted.) Surface-removal rates in the range of 5 to $7 \mathrm{~m}^{2} / \mathrm{hr}$ have been reported. (8) A dust shield with a vacuum attachment minimizes the spread of contaminated dust and can be used to collect all but the largest pieces of rubble. 
The concrete spaller consists of three basic parts: a hydraulic cylinder, a push rod, and a bit with expanding wedges. The hydraulic cylinder is attached at one end and activates the push rod, which is installed inside the bit. A schematic of the device is shown in Figure G.1-2.

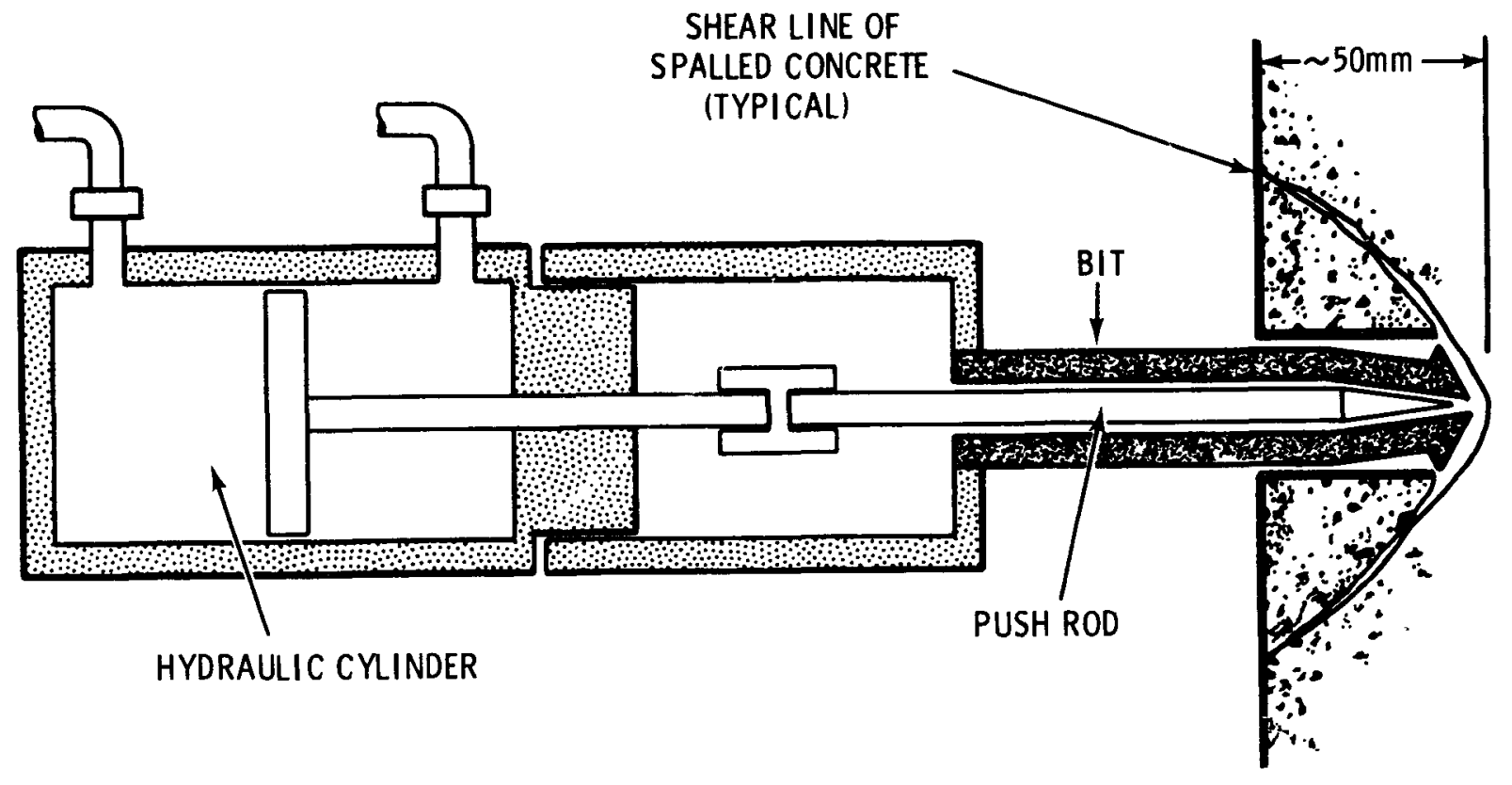

FIGURE G.1-2. Schematic of Concrete Spaller

The spaller is operated by inserting the bit into a predritled hole about $55 \mathrm{~mm}$ deep and $25 \mathrm{~mm}$ in diameter. The hydraulic cylinder is, then activated, forcing the push rod toward the end of the bit. The wedges in the bit are forced radially outward into the walls of the hole. Then, when the tip of the push rod reaches the bottom of the hole, it forces the wedges away from the bottom and causes the concrete to be spalled off.

The spaller is small, lightweight, and fully portable, and can be readily adapted to remote operation. It is connected to the hydraulic power source with hydraulic hoses. The spaller is about $0.4 \mathrm{~m}$ long, with a mass of about $10 \mathrm{~kg}$.

For rapid removal of large surfaces areas, a number of the devices can be ganged together with a corresponding set of concrete drills and operated as a unit. The spacing between holes $(0.2 \mathrm{~m}$ optimum) and the pattern of the holes 
(triangular array) are important parameters in the effectiveness of this technique. Arrangement of the concrete drills and the splitting tools into a fixedgeometry array would ensure a relatively uniform removal pattern. Combining these ganged units with a vacuum transfer system for rubble removal would result in a fast and dust-free concrete removal method, one ideally suited to nuclear facility decommissioning applications.

\section{G.2 EQUIPMENT DISASSEMBLY}

Decommissioning of a nuclear facility requires the disassembly and removal of various contaminated equipment systems. The equipment must be segmented into pieces small enough to facilitate either onsite entombment or packaging for offsite shipment and disposal, depending on the decommissioning mode selected.

Any of a number of methods can be used to disassemble and remove a particular piece of equipment. However, equipment-related parameters (e.g., size, location, design, and radioactive contamination and/or activation) and manpower/cost efficiencies of the various methods dictate the appropriate method for any given situation. In some cases, the required tools are available as part of the facility's normal operating-equipment complement; in others, the tools are readily available commercially (e.g., boltcutters, pipe saws, tubing cutters, and impact wrenches). However, some methods require the use of unique, specialized tools and equipment. These specialized items are discussed in the following subsections and include an underwater manipulator for handling cutting equipment, cutting equipment for sectioning large items, and linear-shaped explosives for certain cutting applications.

Meeting the need for special tools and equipment requires: development of functional and operational specifications for the devices required, preparation of detailed designs for noncommercial devices and for modifications to commercially available equipment, procurement or fabrication of the identified equipment items, establishment of a mockup facility for any necessary development testing, and personnel training in the operation of the equipment. 


\section{G.2.1 Underwater Manipulator}

The underwater sectioning of the neutron-activated reactor vessel and vessel internals requires a manipulator to handle the cutting equipment. The equipment for cutting these structures (e.g., the core shroud) in large BWRs must be operated and maneuvered under 7 to $25 \mathrm{~m}$ of water and in intense radiation fields. In the reference BWR, the existing refueling platform cannot be modified for this purpose, since it is required for handling and packaging the spent fuel and the neutron-activated material segments for shipment. Therefore, specially designed manipulators, such as those presented in References 10 and 11 , are required.

The particular underwater manipulator needed depends on the details of the dismantling plan and on the state-of-the-art in cutting equipment at the time. To ensure proper performance, the manipulator must be specifically designed and engineered for the planned application and must undergo extensive predismantlement testing. For dismantling the reference BWR, the total development program for this device is anticipated to cost as much as $\$ 1$ million.

The underwater manipulator for the reference BWR should be base-mounted, remotely controlled via bottom-entry services, and no taller (when mounted) than the reactor vessel flange. This would allow underwater transfer of the vessel internals sections to the dryer and separator storage pool without removing the manipulator. It should be supported radially, both at the base and at the height of the cutting equipment, for proper cutting alignment.

\section{G.2.2 Cutting Equipment}

The principal equipment anticipated to be used for cutting activated and/or contaminated items are the oxyacetylene torch, the plasma-arc torch, and the arc saw. This equipment can be used either under water or in air. The oxyacetylene torch is a relatively common device and, therefore, it is not discussed here; cutting rates and other information are available in Reference 12. Descriptions, cutting characteristics, and requirements of the plasma-arc torch and the arc saw follow. 


\section{G.2.2.1 Plasma-Arc Torch}

Plasma-arc cutting employs an extremely high-temperature, high-velocity, ionized-gas arc between the electrode in the torch and the piece to be cut. The arc is constricted by passing it through a nozzle with a small-diameter orifice. This localizes the arc so that its energy is concentrated on a small area on the work piece, where its intense heat melts the metal. The melted metal is continuously removed by the jet-like action of the gas stream to form a kerf. The heat and force of the arc stream produce a high-quality, saw-like cut. If inert gases are used, the cutting process is dependent on thermal action alone. When cutting materials such as mild steel or cast iron, increased cutting speeds can be achieved using oxygen-bearing gases. (In this case, the chemical energy obtained by the combination of oxygen with the base material is added to the arc heat to permit higher cutting speeds.) The process can be used to cut any metal. The plasma-arc torch is shown schematically in Figure G.2-1.

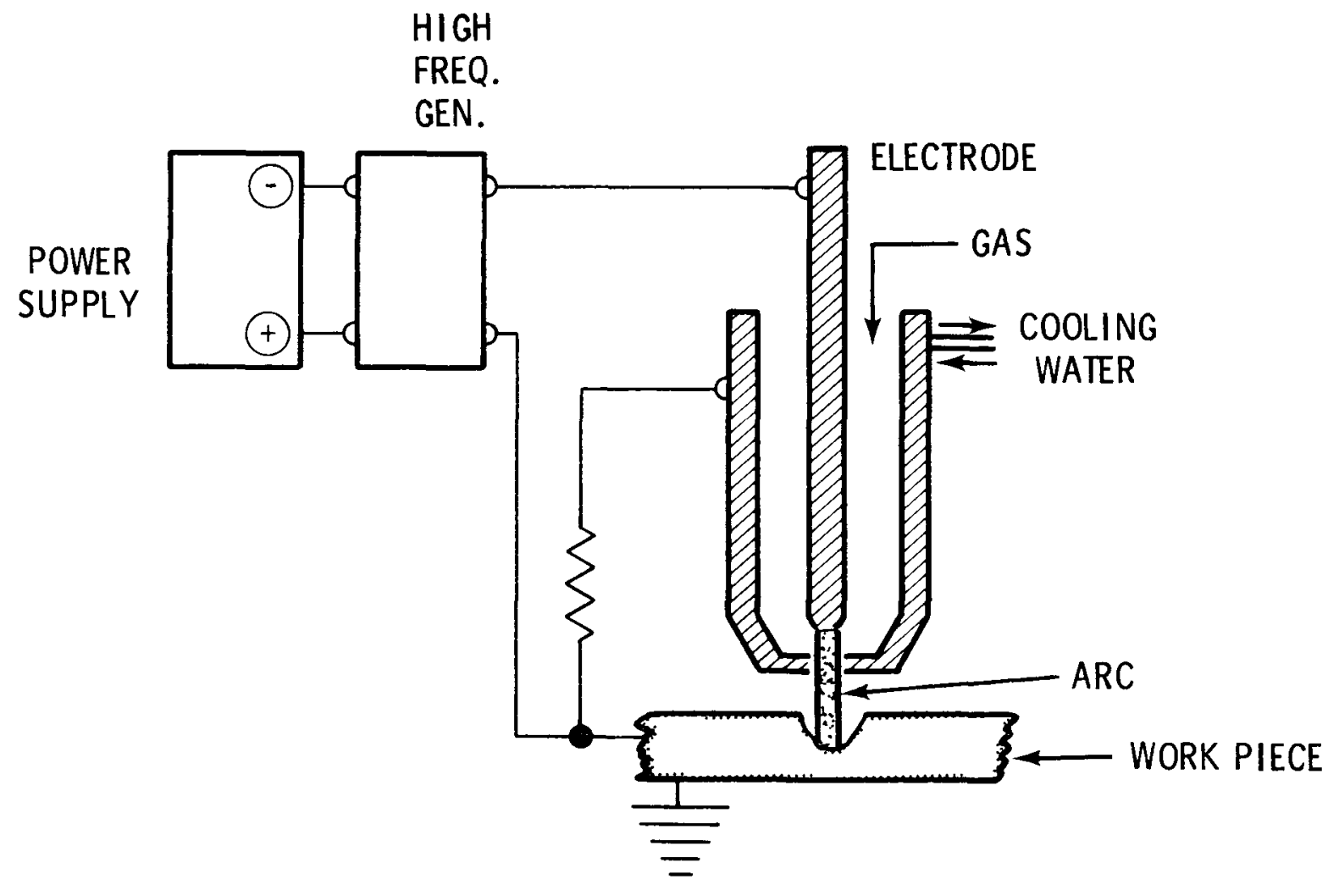

FIGURE G:2-1. Plasma-Arc Torch Schematic Diagram 
The electrical circuit is basically the same as that used for gas tungsten-arc welding, with the exception that an electrical lead is taken from the grounded work piece and passed through a resistor to the nozzle of the torch. A high-frequency spark is used to complete the circuit between the electrode and the nozzle, thereby producing a pilot arc that initiates the main arc from the electrode to the work piece. (13)

There are two types of electrode holders and cutting controls, one designed for manual cutting and the other for mechanized cutting with the torch mounted on an automatic travel mechanism. Water cooling is used to prolong the operating life of the torch. Torch surfaces are insulated to protect the operator from electrical shock. Gas pressure regulators and flowmeters control the cutting gas. A contactor, usually built into the power supply, is required for turning the power on and off.

Arc-constricting nozzles are available in a variety of diameters and shapes. The required shape and diameter of the nozzle depends on the application and the current to be used; high currents require larger-diameter orifices. Both single-port and multiport nozzles are available. Multiport nozzles generally have auxiliary ports arranged in a circle around a central orifice.

The power supplies used have open-circuit voltages in the range of 120 to 400 VDC. The high open-circuit voltage is required for heavy-duty cutting, such as severing thick plates and piercing metal as thick as $50 \mathrm{~mm}$.

Mixtures of argon or nitrogen with hydrogen are generally used for cutting stainless steel, as well as aluminum and other nonferrous metals. Nitrogen and oxygen, supplied separately to the torch and mixed in the nozzle, are used for cutting carbon steel, cast iron, and alloy steels.

For mechanized operations in air, the torch standoff distance is set between 6 and $16 \mathrm{~mm}$. The cutting current, gas type, and gas flow rate are set at values recommended by the equipment manufacturer. These values are primarily determined by the type and thickness of the material being cut. After the operator initiates the cutting arc, the sequence of operations is regulated by an automatic cutting control. 
For manual operation, the operator selects the gas flow rate and cutting current from the table of conditions supplied by the manufacturer or from data obtained from prior testing. The torch is held over the work piece, the cutting arc is struck, and the torch is manually guided along the cut. At the end of the cut, the arc automatically extinguishes, and the control automatically opens the contactor and closes the gas valves. The operator can extinguish the arc at any time simply by moving the torch away from the work piece.

The plasma-arc cutting process can be used in air or under water. It is especially adaptable to automation and is thus useful when highly radioactive material is to be cut (e.g., the pressure vessels of the Elk River Reactor in Minnesota and the Sodium Reactor Experiment in California). (7,9) As it is not necessary to start the cut at the edge of the plate, the plasma-arc torch is particularly adaptable to cutting holes in large plates and vessels. It is also well adapted to gouging applications, including pad washing and scarfing. However, because of the short torch standoff distance, plasma-arc cutting is not suitable for some applications, particularly in tight spaces. Air carbonarc cutting can be used for such work. Plasma-arc cutting is preferred where it is possible.

Some typical conditions for mechanized plasma-arc cutting of stainless steel in air are given in Table G.2-1. Recent tests with the plasma-arc torch have demonstrated its ability to cut 150-mm-thick stainless steel and 180-mmthick carbon steel. (14)

TABLE G.2-1. Typical Conditions for Plasma-Arc Cutting of Stainless Steel in Air

\begin{tabular}{|c|c|c|c|c|}
\hline $\begin{array}{l}\text { Thickness } \\
(\mathrm{mm}) \\
\end{array}$ & $\begin{array}{l}\text { Speed } \\
\text { (m/min) }\end{array}$ & $\begin{array}{l}\text { Orifice } \\
\text { Diameter } \\
\text { (mm) }\end{array}$ & $\begin{array}{l}\text { Current } \\
\text { (amps) } \\
\end{array}$ & $\begin{array}{r}\text { Gas Flow } \\
\left(\mathrm{m}^{3} / \mathrm{hr}\right)\end{array}$ \\
\hline 13 & 2.5 & 3.2 & 300 & $4.2 \mathrm{~N}_{2}$ \\
\hline 25 & 1.2 & 4.0 & 400 & $5.0 \mathrm{~N}_{2}$ \\
\hline 50 & 0.5 & 4.0 & 500 & $3.7 \mathrm{~A} \& 2.0 \mathrm{H}_{2}$ \\
\hline 75 & 0.4 & 4.8 & 500 & $3.7 \mathrm{~A} \& 2.0 \mathrm{H}_{2}$ \\
\hline 100 & 0.2 & 4.8 & 500 & $3.7 \mathrm{~A} \& 2.0 \mathrm{H}_{2}$ \\
\hline
\end{tabular}




\section{G.2.2.2 $\underline{\text { Arc Saw }}$}

The arc saw, a state-of-the-art metal-cutting device, is currently being developed for contaminated-equipment segmentation, with initial development and demonstration work already completed. (15) Results to date indicate that the device holds great promise, and additional development work will undoubtedly provide a more sophisticated, commercially available unit in the near future. The cutting process is both economical and expedient relative to other methods. Cutting speeds of around $10 \mathrm{~m} / \mathrm{min}$ are anticipated for $10-\mathrm{mm}$-thick stee $\mathrm{plate}$, with the speed being inversely proportional to the plate thickness. (16)

The prototype arc saw used a 11.2-kW motor to rotate a 0.91 -m-diameter, 6.35-mm-thick blade made of copper or mild steel. Blade speed was approximately $880 \mathrm{rpm}$, and blade cooling was accomplished by a water-spray system installed in the blade guard. A material-cut/blade-wear ratio of 20 to 1 was reported for the $0.91-\mathrm{m}$-diameter blade. It is expected that increased blade diameters may reduce associated costs. (15)

Cutting can be accomplished remotely, either in air or under water, with automatic positioning and tracking of the saw blade during cutting operations. All equipment, with the exception of the blade, is commercially available, but modifications are necessary. Blades can be made in any well-equipped machine shop. The arc saw is shown schematically in Figure G.2-2.

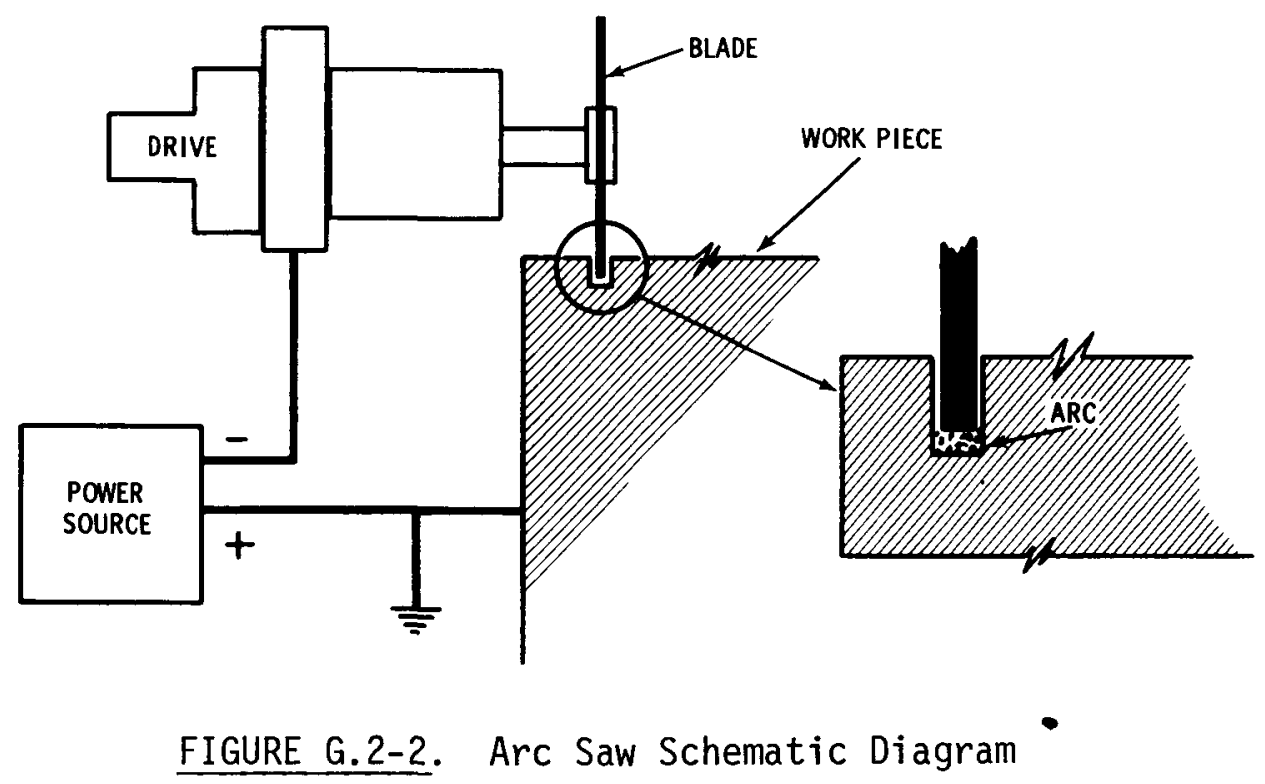


The modified power source consists of a 7500-A, 80-V open-circuit, 50-V operating $D C$ power supply of the constant-current, constant-voltage type. The controls include a servo controller for automatic positioning and tracking of the saw blade during cutting operations and a recorder to monitor voltage, amperage, blade travel, and servo current.

Low-voltage, high-amperage current is applied to the rotating blade, creating an electric arc discharge between it and the grounded work piece. The discharge spark-erodes both the blade and the work piece. The blade is advanced through the work piece to produce a kerf 1 to $4 \mathrm{~mm}$ wider than the blade thickness.

If, because of position change or vibration, a portion of the work piece falls against or pinches the blade, the point of contact spark-erodes away because the "electrical leading edge" of the blade is transferred to the point of contact. This reduces the potential for binding of the blade. Consequently, the arc saw can cut through a variety of materials, shapes, and loose components that would be difficult to cut with conventional saws.

The arc saw blade can be scaled to match the cutting requirements of the job. Blades up to 3 to $4 \mathrm{~m}$ in diameter (up to $25 \mathrm{~mm}$ thick) for cutting largediameter vessels appear to be feasible. Heavier (thicker) blades are likely to tear most non-conducting materials (non-metals) they encounter, thus eliminating the need to remove them from the work piece before cutting. It also appears that several saws could be ganged together for simultaneous parallel cutting.

\section{G.2.3 Linear-Shaped Explosive Charges}

An economical and expedient method of reducing the physical size of equipment and piping to allow further processing or packaging for disposal is the use of self-contained, linear-shaped explosive charges. This method minimizes personnel radiation exposure and is particularly advantageous in areas with high radiation levels. Linear-shaped charges have been used extensively in the last 15 to 25 years. $(17,18)$ Recently, such methods (i.e., the perforation and cutting of solids by ultra-high-velocity particles under 
explosive attack) have been used to segment and remove activated components and contaminated systems (e.g., fuel-pool liners and piping) that are not amenable to conventional removal techniques. $(9,19)$ Figure G.2-3 shows a cross section of a typically positioned linear-shaped charge.

A linear-shaped charge consists of a V-shaped tubular casing filled with an explosive (cyclotrimethylenetrinitramine) commoniy called RDX. The casing is generally copper, but other soft materials such as aluminum and lead can be used. The charges are equipped with detonators that are activated using a primacord lead having a high-explosive core of pentaerythritol tetranitrate (commonly known as PETN) that, in turn, is initiated with an electric blasting cap. Clamp-on charges, available commercially, eliminate many problems in placement, handling, and detonating. The number of charges that can be detonated at one time is limited only by the blast effect on nearby equipment. Shock-wave and fragment damage can be reduced appreciably by placing blast curtains or other barriers in the vicinity of the detonation to disrupt the shock wave and intercept the fragments. ${ }^{(20)}$

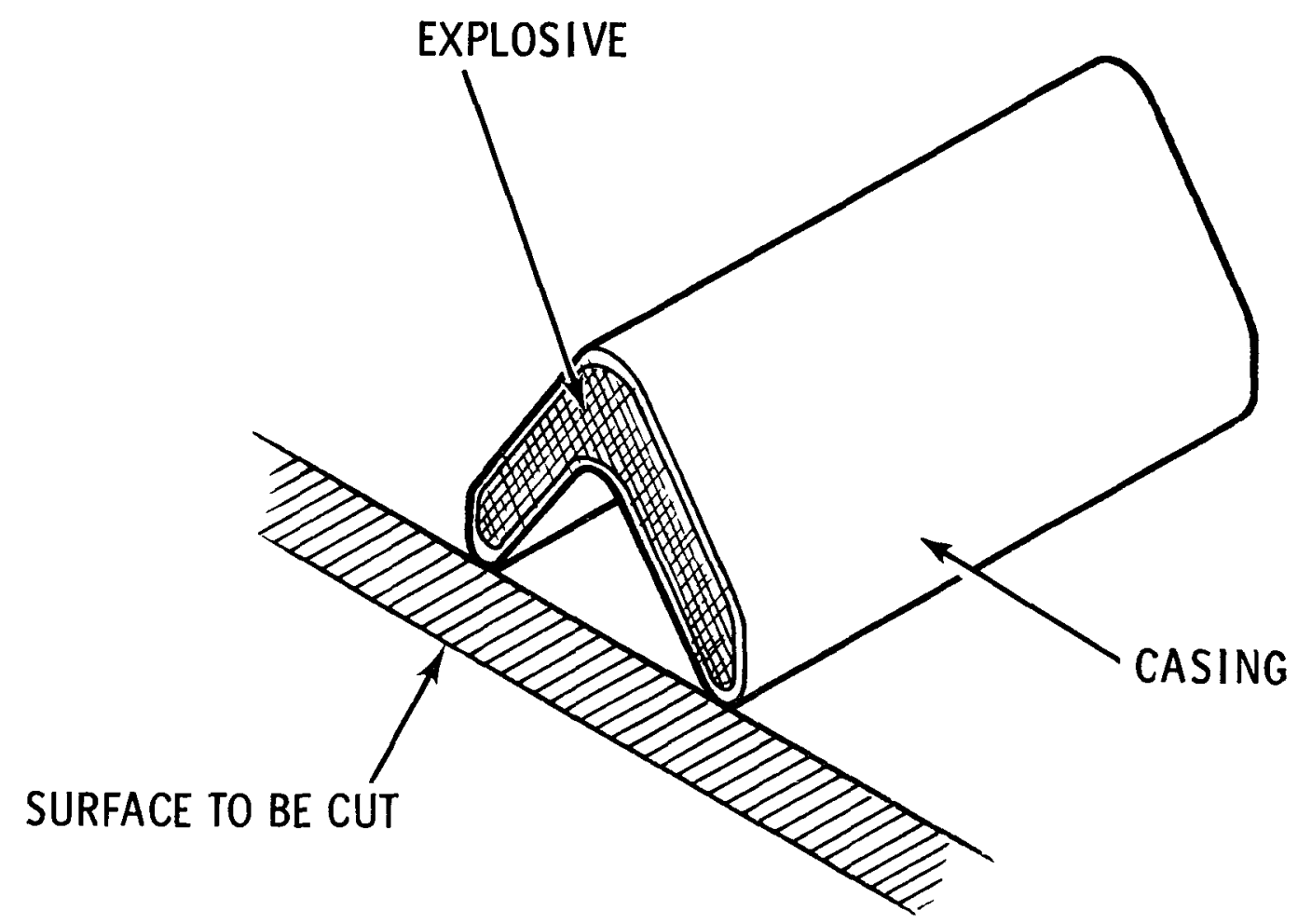

FIGURE G.2-3. Cross Section of Typically Positioned Linear-Shaped Charge 
The principle of the linear-shaped charge is that, as the detonation wave collapses the inverted $V$, the casing material becomes a jet of extremely hot metal particles traveling at very high velocity. These particles then tear through the material to be cut. The melting and subsequent fusing of the casing material with the base material being cut, together with the ragged edges of the finished cut, can make electropolishing of those edges very difficult. (5) Therefore, in-situ decontamination (either chemical or mechanical) prior to explosive cutting is recommended to minimize unnecessary waste of strategic materials.

The use of linear-shaped charges has been documented for cutting such diversely shaped objects as: $(20,21)$

- $0.61-m-0 . D$. by 16-mm-wall stainless steel pipe

- $100-\mathrm{mm}$ by $100-\mathrm{mm}$ by $10-\mathrm{mm}$-thick angle iron

- 25-mm-diameter solid stainless steel bar

- 152-mm by 10-mm-thick web "H" beam.

\section{G.3 RADIOACTIVE WASTE PACKAGING AND SHIPPING}

Radioactive wastes are generated during the decommissioning of a BWR facility. This section presents the methods and requirements for packaging these wastes and shipping them to an authorized disposal site.

\section{G.3.1 Packaging of Radioactive Wastes}

The radioactive wastes that result from decommissioning can be classified as follows:

- combustible or noncombustible

- activated or contaminated

- wet or dry.

The bulk of the decommissioning wastes from the reference BWR are dry, noncombustible, and either activated or contaminated. They include the activated reactor vessel and internals, the activated and contaminated concrete from the sacrificial shield, contaminated concrete from walls and floors, and contaminated piping and equipment. The contact radiation dose rates from these 
materials vary from a few $\mathrm{mrem} / \mathrm{hr}$ to thousands of $\mathrm{rem} / \mathrm{hr}$. Different types of packaging and shielding are required, depending on the radiation levels involved.

Disposable, $0.28-\mathrm{m}^{3}\left(0.33-\mathrm{m}^{3}\right.$ burial volume) steel cask liners are used for packaging, shipping, and burying the activated portions of the reactor vessel and of the vessel internals. These containers are estimated to cost $\$ 450$ each. In some cases, lead shielding must be added at an estimated average cost of $\$ 1.23 / \mathrm{kg}$, including labor and energy.

The bulk of the contaminated material is packaged in a standard container, illustrated in Figure G.3-1. The container is approximately $1.2 \mathrm{~m}$ by $1.2 \mathrm{~m}$ by $2.4 \mathrm{~m}$, made from plywood, and internally reinforced and sealed with fiberglass to ensure confinement of loose contamination. Containers of this type are estimated to cost $\$ 400$ each. When necessary, containers of special sizes and shapes are fabricated. Some items do not require shielding but are larger and/or heavier than can be accommodated with plywood containers. In these cases, steel containers are specially fabricated at an average cost of about $\$ 6,000$ each.

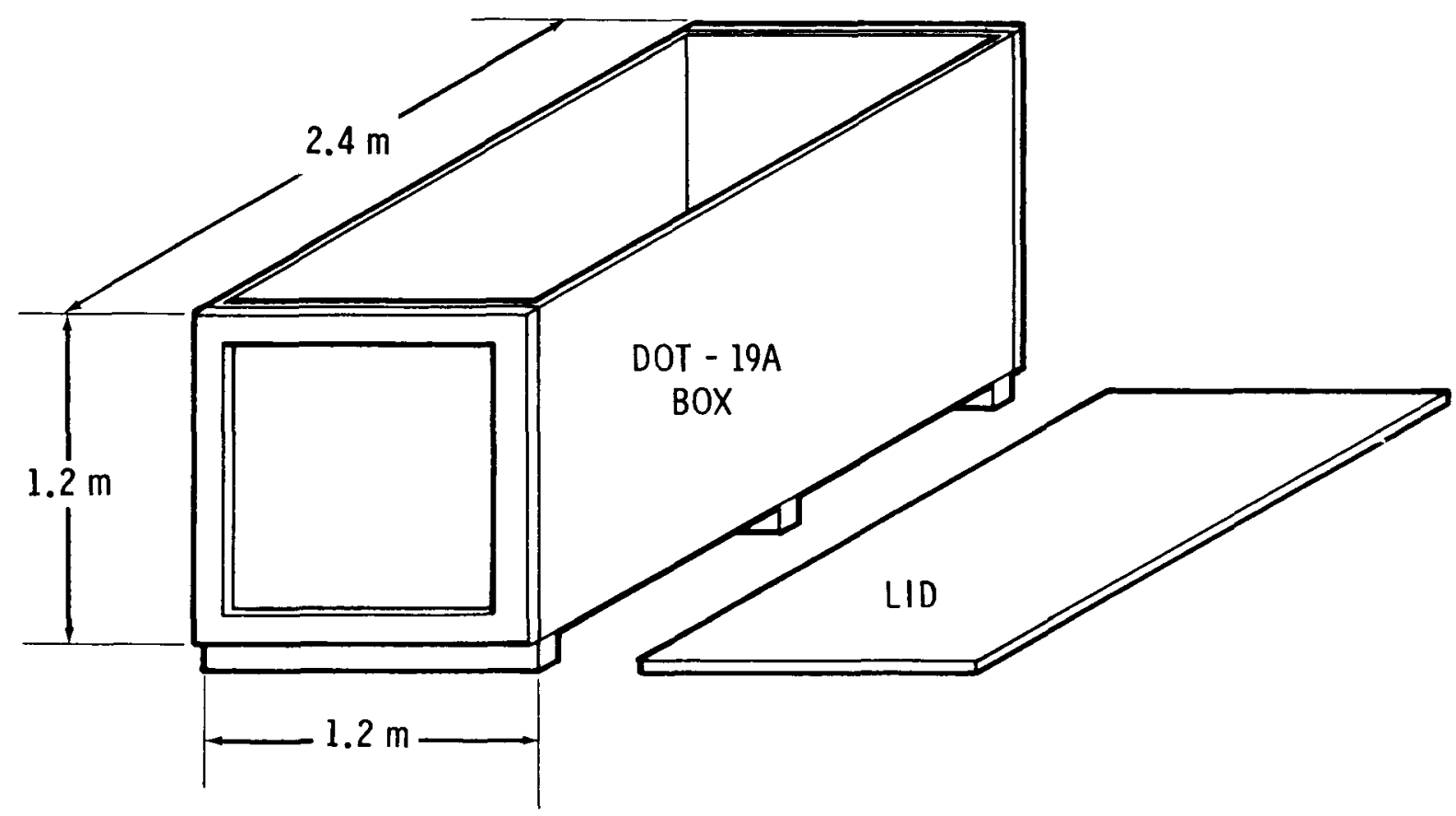

FIGURE G.3-1. Typical Plywood Shipping Container 
Certain contaminated equipment items (e.g., smal1 heat exchangers and small tanks) are packaged by capping the piping connections with welded metal covers and using the items' outer shells as the containers. The moisture separator reheaters and the feedwater heaters are cut into sections, after which each section is capped and handled as its own container.

Dry, combustible radioactive wastes include filter cartridges from liquid streams, HEPA ventilation filters, and miscellaneous cleaning materials (e.g., rags, mops, anti-contamination clothing, and plastic sheeting and bags). These materials are compacted as necessary and packaged in $0.21-\mathrm{m}^{3}$ steel drums costing $\$ 20$ each.

Standard methods are in place for handling and disposing of the radioactive liquid wastes that are generated during decommissioning. The assumed practice in the reference BWR (and numerous operating power reactors) is to concentrate the liquids by evaporation to a product that can be packaged (together with dewatered, spent ion-exchange resins) and solidified in containers prior to disposal. For this study, the containers are assumed to be $2.3-m^{3}\left(2.84-m^{3}\right.$ burial volume) steel cask liners costing $\$ 550$ each.

\section{G.3.2 Shipment of Radioactive Wastes}

The spent fuel and irradiated fuel channels from the reference BWR are assumed to be shipped offsite by rail; all other radioactive wastes are assumed to be shipped by truck. Rail shipment of spent fuel is standard operating practice at the reference plant and, therefore, is not discussed here. (References 22 and 23 discuss rail shipment of spent fuel.) Truck transport of radioactive wastes from decommissioning the reference BWR is discussed below.

A11 radioactive waste materials removed from the reference BWR during decommissioning are assumed to be shipped in exclusive-use trucks to offsite disposal, via the interstate highway system. The hauler is assumed to have the appropriate Nuclear Regulatory Commission (NRC) 1 icense and permits from the Department of Transportation (DOT) before he handles the radioactive waste material. Several commercial transportation companies have the special capabilities and trained drivers for hauling radioactive wastes. 
A11 shipments of radioactive material must be made in compliance with federal, state, and local regulations. Federal (DOT and NRC) transportation regulations establish container specifications, dose rate limits, and handling procedures to ensure the safety of the public and the transportation workers during shipment of radioactive materials. (24) In addition, for highway transport, state agencies regulate vehicle sizes and weights and, in some cases, transportation routes and times of travel.

Dose rates for highway shipments in exclusive-use vehicles must not exceed the following values (49 CFR 173.393): (25)

- $1000 \mathrm{mrem} / \mathrm{hr}$ at $1 \mathrm{~m}$ (i.e., $3 \mathrm{ft}$ ) from the external surface of a package shipped inside a closed vehicle

- $200 \mathrm{mrem} / \mathrm{hr}$ at any point on the external surface of a closed vehicle or an exposed shipping container (e.g., a shielding cask)

- $10 \mathrm{mrem} / \mathrm{hr}$ at $2 \mathrm{~m}$ from the external surface of the vehicle

- $2 \mathrm{mrem} / \mathrm{hr}$ at any normally occupied position in the vehicle.

These dose rate limits are illustrated in Figure G.3-2 for closed truck transport. (26) A11 of these criteria must be met for each shipment.

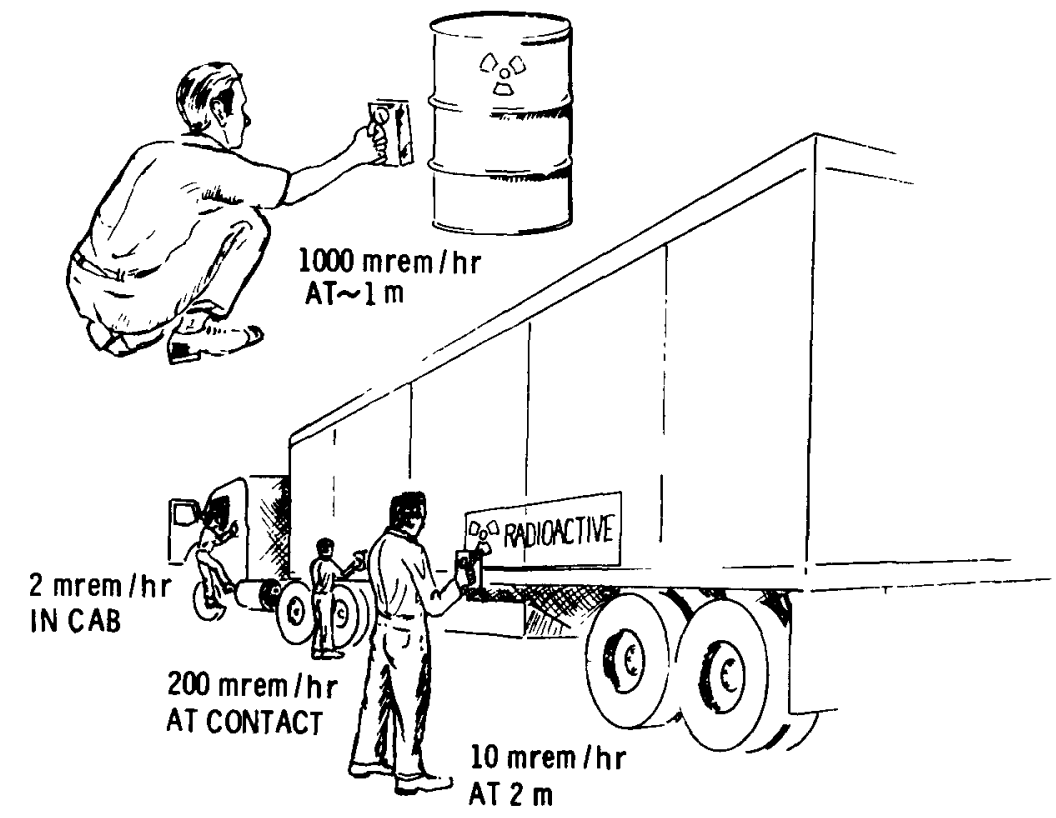

FIGURE G.3-2. Radiation Dose Limits for Closed Exclusive-Use 
Most of the activated waste packages will exceed the package surface dose-rate limit, as will some of the solidifed wet waste packages and dry combustible waste packages. These must be shipped in nondisposable shielded shipping containers, some typical examples of which are shown in Figure G.3-3.

A11 wastes are assumed to be transported to a licensed commercial lowlevel waste burial ground. Such facilities are currently available in Washington, Nevada, and South Carolina. For this study, the average one-way shipping distance is assumed to be $800 \mathrm{~km}$ for all shipments. Disposal site restrictions are assumed to limit the maximum quantity of radioactivity per shipment to 50,000 Ci. There are currently no limits on the dose rate at the surface of a disposable container, but burial costs increase with increasing surface dose rate.

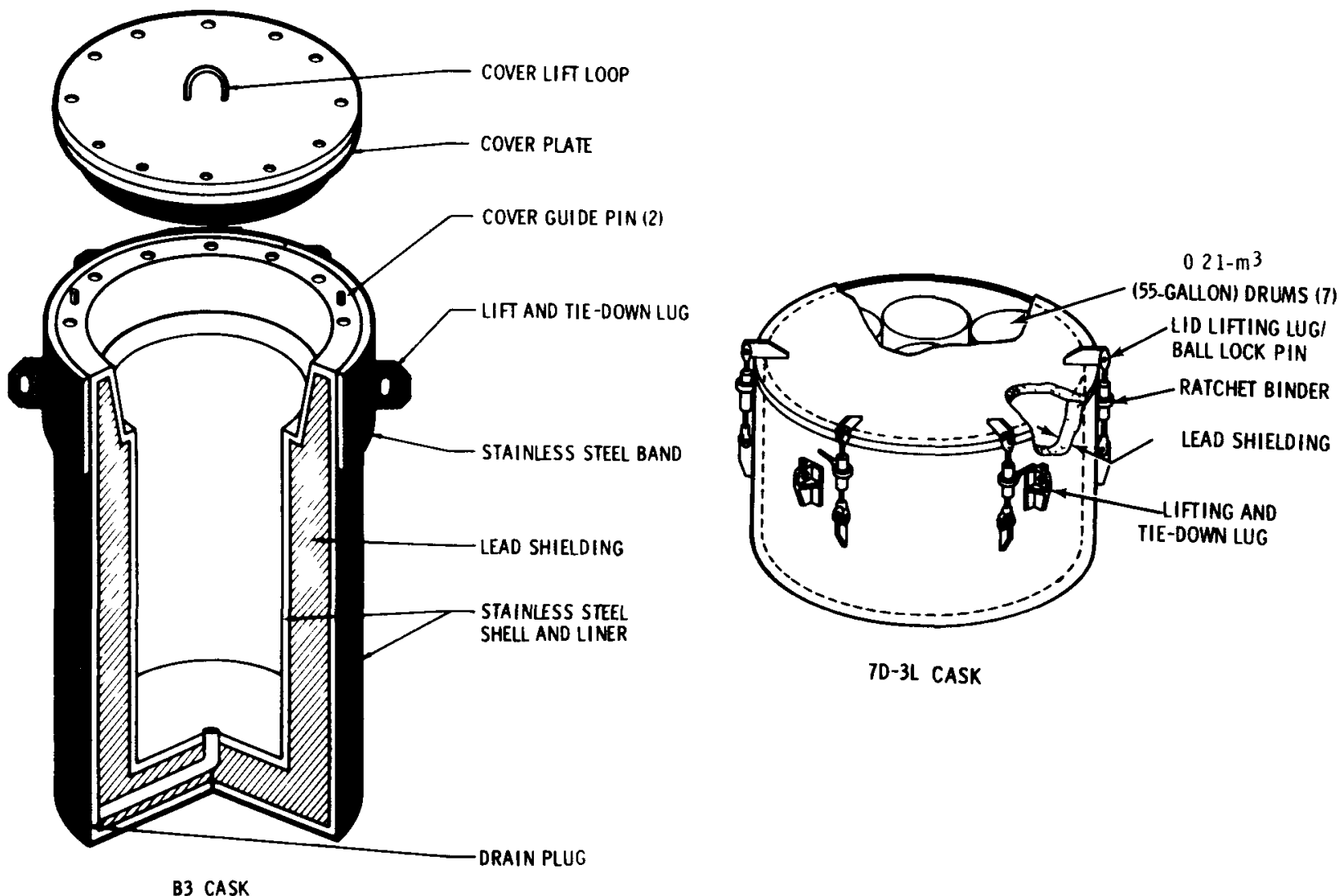

FIGURE G.3-3. Typical Shielded Shipping Containers 
A formal accident control and recovery plan is assumed to be developed before the first radioactive shipment of decommissioning waste is made. The plan is to provide for rapid and orderly utilization of utility, carrier, state, and municipal emergency personnel, as well as NRC radiological assistance teams, as required in the event that any transportation accident occurs. Procedures for control of contamination, radiation exposure, bodily injury, and property damage are included in the recovery plan. Also included are procedures for salvage and recovery of the radioactive shipment.

\section{G.4 CONTAMINATION CONTROL}

Many decommissioning activities, particularly the cutting operations required for equipment disassembly, have the potential for generating significant amounts of airborne radioactive contamination. In addition, decomissioning can involve operations in areas with smearable radioactive contamination; the movement of personnel, equipment, and materials in these areas can result in the further spread of radioactive contamination. To minimize the personnel hazard and the potential for widespread contamination of work areas, contamination control is required.

Radioactive contamination control can be divided into three basic approaches:

- local mitigation of contamination sources

- collection of contamination

- isolation of contaminated areas.

These approaches are discussed in the following subsections.

\section{G.4.1 Local Mitigation of Contamination Sources}

Mechanical or physical measures can be used to limit the spread of radioactive contamination. Two methods that have been successfully used are 1) water sprays to reduce airborne dust dispersion and 2) painting of contaminated surfaces to prevent smearing.

The wetting of dust with water or other liquids is one of the oldest methods of contamination control and can be very effective if properly used. Water sprays are widely used to control fugitive dust emissions from construc- 
tion sites. The spraying of water containing detergent (as a wetting agent) has been used in the nuclear industry to reduce dust concentrations in air. To be effective, the liquid application must be designed to blanket the dust source completely and to wet the dust particles thoroughly. Various types, sizes, and patterns of spray nozzles are used, depending on the physical properties of the dust, the type and size of the dust source, and the degree of control desired. Water sprays can be used in combination with other contamination control techniques, and are commonly used for dusty operations such as concrete removal. (9)

Nonflammable, strippable paint can be used to seal porous surfaces (e.g., concrete) to prevent penetration of contamination into the surfaces. Paint can also be used to seal smearable contamination already present on surfaces to prevent subsequent contamination spread. ${ }^{(9)}$ Spraying is generally the easiest and quickest method of application. Painting is especially useful in high-traffic areas, where smearable contamination is likely to be picked up and spread around on shoe covers and equipment wheels.

\section{G.4.2 Collection of Contamination}

Collection of radioactive contamination before it can be dispersed (preferably as it is generated) reduces the need for cleanup subsequent to some decommissioning activities. Various collection methods can be used. Vacuum collection and portable ventilation systems are discussed here.

\section{G.4.2.1 Vacuum Collection}

Contaminated materials can be collected as they are generated using vacuum systems. A dust shield with a vacuum attachment can be installed on the tool (e.g., concrete spaller or scrubber) being used. $(8,9)$ As the contaminated dust is generated, it is drawn into the vacuum system and deposited in a collection drum. The outlet air is filtered (with roughing and HEPA filters) to prevent the collected contamination from being expelled.

Various designs for vacuum collection systems are possible, depending on the required operating characteristics. One such system, shown schematically in Figure G.4-1, is described in Reference 29. This system, originally designed for collection of contaminated soil, uses a standard $0.21-\mathrm{m}^{3}$ waste drum to 


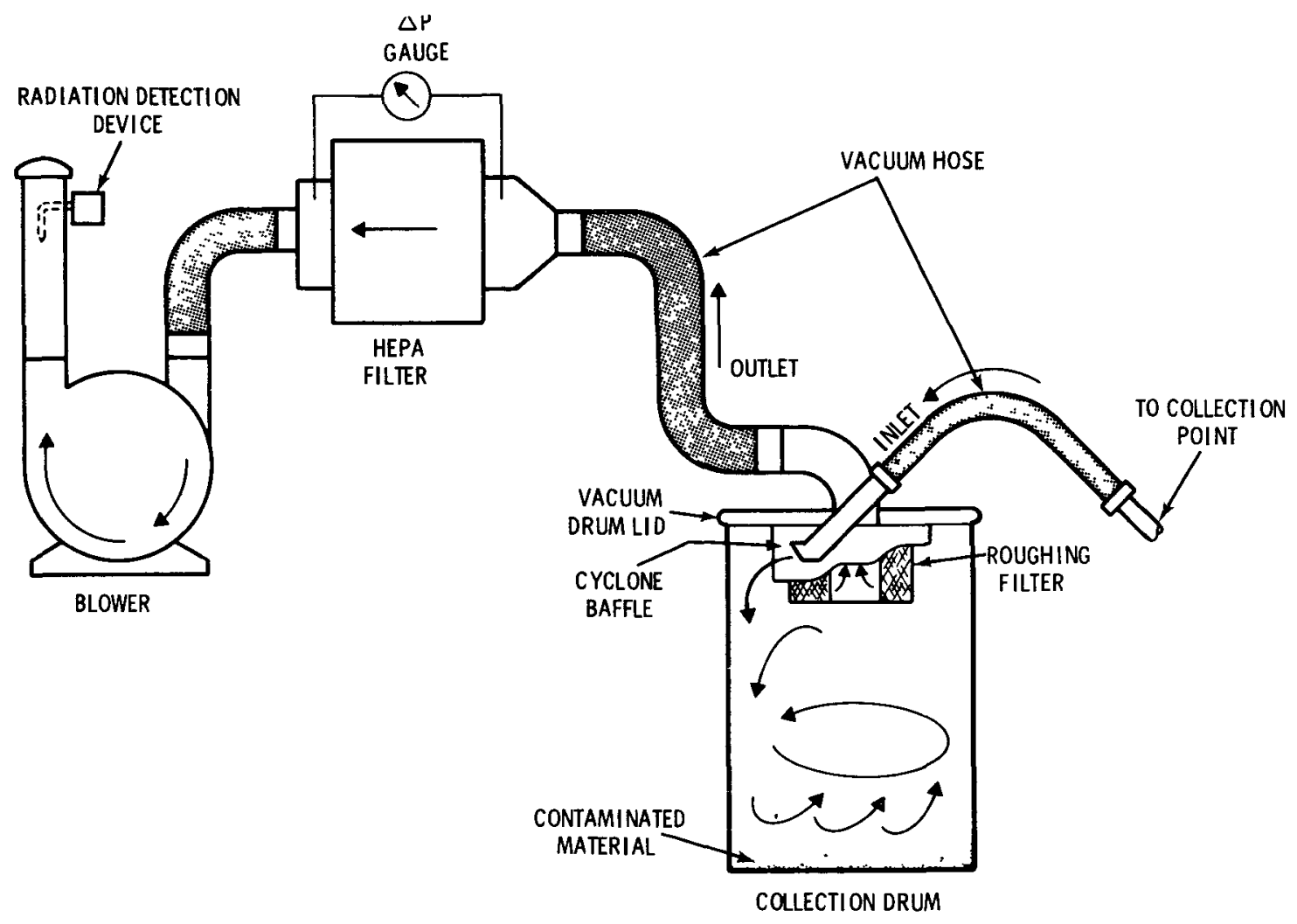

FIGURE G.4-1. Vacuum Collection System Schematic

collect the contaminated material. When the drum is filled, it is capped and sealed for disposal. A special, commercially available vacuum lid, employing a cyclone baffle arrangement to enhance dust settling, is modified to accept an inexpensive, disposable roughing filter. A HEPA filter and power/vacuumblower unit, mounted on a steel pallet, complete the system. The system is reported to be capable of pulling up to $\sim 28 \mathrm{~m}^{3} / \mathrm{min}$ of air at $110-\mathrm{mm}-\mathrm{Hg}$ vacuum, and is estimated to cost less than $\$ 5000$.

\section{G.4.2.2 Portable Ventilation Systems}

Portable ventilation systems can be used to confine and collect airborne particulates generated during decommissioning operations. (9) General design information concerning such systems is discussed at length in Reference 27. Two portable ventilation systems, a work enclosure and a fume exhauster, are discussed here.

Portable Filtered Ventilation Enclosure. A typical portable filtered ventilation enclosure unit is illustrated in Figure G.4-2. A large squirrel- 


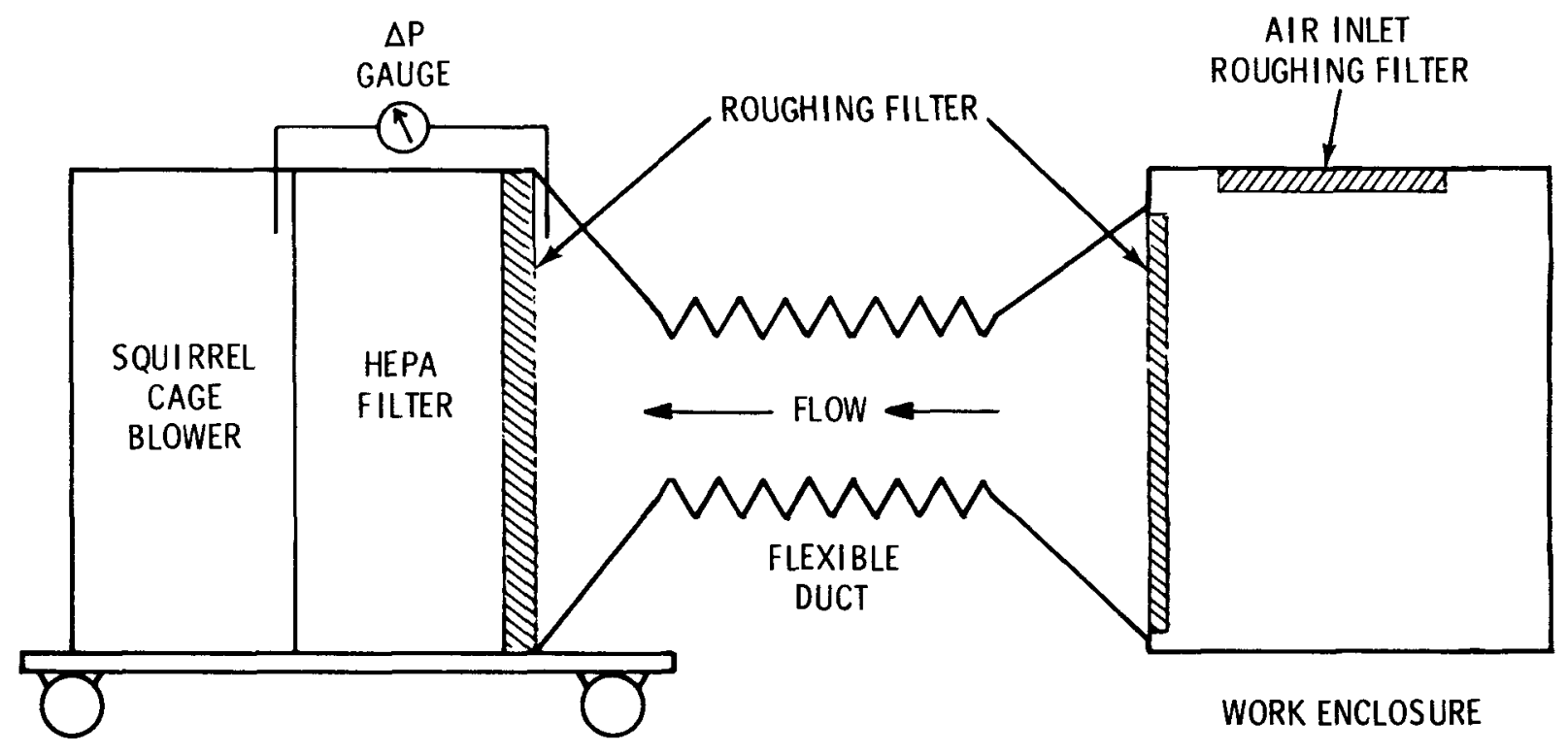

FIGURE G.4-2. Portable Filtered Ventilation Enclosure

cage blower is coupled with a high-efficiency particulate air (HEPA) filter preceded by a glass-fiber roughing filter, all mounted on a wheeled cart.

A flexible duct couples the cart unit to the enclosure unit that surrounds the work area and collects the materials being emitted. Roughing filters are installed at both the inlet and the outlet of the enclosure unit. The enclosure unit may have whatever shape best performs the required function at a particular location. A simple, rectangular open-faced box will suffice for many applications.

Radiation detection devices are used to monitor the buildup of radioactive material on the filters. A differential pressure gauge is installed across the HEPA filter to monitor the increasing pressure drop as particulates build up on the filter. Filters are changed when either the dose rate from the collected radioactive particles or the differential pressure across the HEPA filter reaches a predetermined level. 
Portable Filtered Fume Exhauster. Another type of portable filtered ventilation system, a fume exhauster, is illustrated in Figure G.4-3. This system has an electrostatic precipitator coupled with a roughing filter, HEPA filter, air-handling motor, squirrel-cage blower, and one or two free-standing intake ducts. The fume exhauster is used to collect radioactive and nonradioactive particulates at the point of generation. This high-volume ventilation system captures all types of particulate matter with efficiencies of greater than $97 \%$ for the electrostatic unit and at least $99.95 \%$ for the HEPA filter. The advantages of this unit are its portability, its ability to handle large volumes of particulate-laden air, and its generation of relatively small amounts of solid wastes (HEPA filters).

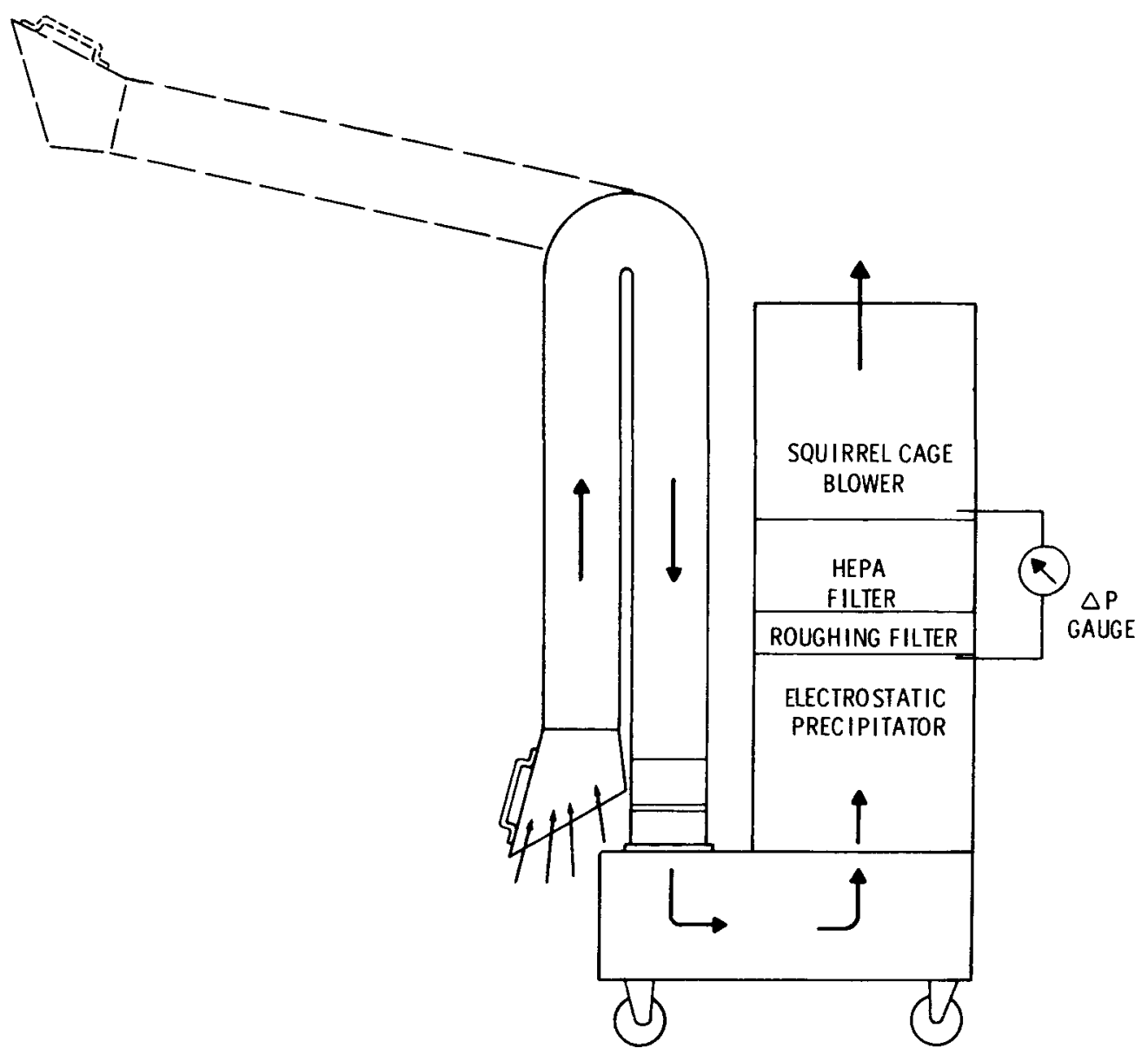

FIGURE G.4-3. Portable Filtered Fume Exhauster 
Buildup of radioactive materials on the precipitator and filters is monitored by radiation detection devices. To monitor the buildup of particulates on the filter, a differential pressure gauge is installed across the HEPA filter. The electrostatic precipitator is flushed and the filters are changed when either the dose rate from collected radioactive particles or the differential pressure across the HEPA filter reaches a predetermined level.

\section{G.4.3 Isolation of Contaminated Areas}

One method of controlling contamination is the use of barriers to isolate contaminated areas from those with lesser or no contamination. Isolation is an important tool during continuing care as well as during active decommissioning.

\section{G.4.3.1 Isolation During Active Decommissioning}

One type of barrier commonly used in the nuclear industry to isolate contaminated areas is a "greenhouse." A greenhouse is constructed by covering a framework, usually steel scaffolding or wood frame, with plastic sheeting and sealing all joints. Overlapping flaps of plastic are generally used for the door. The greenhouse is connected either to the plant ventilation system or to a portable system (see Section G.4.2.2), which prevents outward leakage of contamination by drawing a slight vacuum on the greenhouse. (9) Greenhouses can be semi-permanent, portable structures that can be moved from one location to another as needed, but are more often temporary confinement structures that are dismantled and discarded after each job.

In many cases, construction of a complete greenhouse is unnecessary. A simple plastic curtain partitioning off one section of a room may be all that is required to isolate a contaminated area. The type and degree of isolation required depends on the equipment or structures involved, the associated level and mixture of radioactive contamination, and the decommissioning operation being performed.

\section{G.4.3.2 Isolation During Continuing Care}

Prior to the continuing care period, portions of the facility containing significant amounts of radioactive contamination that are not removed during active decommissioning must be isolated from the remainder of the facility. 
Potential pathways for the migration of contamination from these areas are blocked by the installation of physical barriers. Besides acting as contamination control barriers, the barriers are designed to discourage unauthorized personnel entry into contaminated areas. Structurally substantial barriers are used, with extensive use of steel.

The preferred method of barrier installation is by welding. This method is used on piping, ventilation ductwork, and equipment penetrations. Piping is cut and plates are welded over the open ends. Rectangular plates are welded in inlet ventilation ductwork. All welds are inspected by appropriate techniques. A polysulfide adhesive is used to seal the perimeter of pipes and other. penetrations through the concrete walls into contaminated areas. Care must be taken during the sealing procedures not to interfere with any fire alarm sensors that may be present in the ducts.

The polysulfide adhesive is also used whenever seals must be formed on concrete surfaces or on metal surfaces where welding is not possible. This adhesive forms a strong, durable bond with these materials. After it has cured, the adhesive remains flexible, permitting differential thermal expansion of the two bonded surfaces without breaking the seal. This adhesive can be applied with a spatula or extrusion gun and will not run after application.

Metal doors are secured by welding them to the metal door frame. Spot welds are used where the intent is simply to make the door inoperative. Continuous welds are made or sealant is used where an airtight seal is required. Where the door frame meets the wall, it is sealed with the polysulfide adhesive.

Pressure equalization lines are installed between the outside environment and the interior of the Reactor Building, the Turbine Generator Building, and the Radwaste and Control Building. These lines prevent pressure differentials (due to temperature or atmospheric pressure changes) from developing between the insides of the buildings and the outside atmosphere. The lines are equipped with replaceable absolute filters to prevent contamination from being entrained in the air flow out of the buildings. 


\section{G.5 QUALITY ASSURANCE}

To meet the QA regulations imposed upon it, a BWR decommissioning project requires QA planning from the earliest stages. As each detailed procedure is developed, the QA portions are included. Current regulations and guides that could apply to decommissioning are discussed in Chapter 5 of Volume 1.

In this study, the QA Supervisor is assumed to report directly to the Decommissioning Superintendent. Thus, the QA staff is organizationally independent of the project staff, up to the highest possible level of the decommissioning organization.

\section{G.5.1 Method Review}

When a new procedure is written, a documented peer review is held. The review ensures that adequate consideration is given to physics, radiation, safety, accident, security, thermal, stress, QA/QC, and hydraulic analyses. Other checks, tests, and formal design reviews may be required. Other aspects that are reviewed include reliability criteria, the choice of test methods, and the choice of processes or materials. The conservatism in margins of safety established for procedures, equipment, or structures also receives documented review.

\section{G.5.2 Procurement Document Control}

The project's suppliers, including fixed-price contractors and shipping cask vendors, are selected from a QA list of qualified suppliers. QA inspections of a vendor's plant are performed as required to place new firms on the qualified list.

Procurement Document Control verifies that any QA requirements for specified hardware, materials, or services are clearly and accurately identified in procurement documents or purchase orders. This includes references to applicable drawings, specifications, standards, codes, and regulations; required records of test data, certifications, and qualifications of personnel and procedures; and special handling, shipping, or packaging requirements. This control is applied to any supplier of the specific devices and equipment vital to the project, such as environmental monitoring equipment, safety and shielding devices, radiation detection equipment, chemicals, and explosives. 


\section{G.5.3 Work Instructions, Procedures, and Drawings}

Formal documentation of work instructions and procedures, drawings, and information management procedures is required, with responsible personnel clearly identified. These procedures verify the proper completion of activities or steps in the decommissioning process (e.g., the disassembly sequences that ensure that vital services remain intact). The latest revisions of all such documentation are required to be at the work location. Changes to such documents receive the same levels of review and approval as original planning.

\section{G.5.4 Document Control}

Document Control verifies that all essential documentation receives the proper review, approval, release, change, and distribution control. An established procedure is used to eliminate obsolete or erroneous information.

\section{G.5.5 Identification and Control of Procured Items}

Inspection of purchased materials or items is performed at the time of receipt. Items must be sufficiently identified to allow proper selection for use, completion of processing, or segregation of nonconforming items. The shelf lives and the required storage and use conditions of chemicals must be clearly stated.

\section{G.5.6 Special Processes}

Decommissioning may involve several tasks requiring new or unusual work procedures (e.g., large-scale chemical decontamination work and the use of explosive charges). Special provisions are made to identify and control any unusual processes or procedures, using reviews, written procedures, and audits.

\section{G.5.7 Inspection and Test}

A11 items produced for the project must be properly inspected or verified. Inspections in the vendor's plant may be necessary for some items. Inspection instructions are required, and records of inspections are prepared and retained. Inspection of each essential operation is required, as well. 


\section{G.5.8 Calibration}

A system of calibration control is used to ensure the validity of instrument readings. Accuracy requirements and tolerances for project measurements are identified. Equipment with calibration requirements includes radiation detection devices and environmental monitoring systems. Calibration procedures for instruments that monitor and control vital services are reviewed and revised as necessary.

\section{G.5.9 Shipping and Receiving}

Special instructions are prepared for the packaging, shipping, and receiving of components and materials for the project. Included are radioactive shipments requiring QA procedures for each package type specifying all steps in the package inspection, preparation, loading, and closing. Signed checklists are used. Seals must be carefully verified on internally contaminated units having no additional outside packaging.

\section{G.5.10 Operating Status}

Identification procedures are used to prevent inadvertent operation of systems temporarily or permanently removed from service. Restricted use may be necessary for equipment (such as pumps) that has not been fully removed from service.

\section{G.5.11 Nonconformance and Corrective Action}

A11 nonconformances and resulting corrective actions are documented and the reports retained as part of the project records.

\section{G.5.12 Special Quality Records}

An index of records and their required retention periods is maintained. These records include operating logs; results of reviews, inspections, tests, audits, material analyses, and work-performance monitoring; orientation, training, and qualifications of personnel; procedures; drawings; specifications; criteria documents; procurement documents; shipping records; and nonconformance and corrective action reports. Extensive documentation of dose rate surveys is also included. 


\section{G.5.13 Quality Auditing}

Regular audits verify that each QA procedure is being followed. Examples include witnessing radioactive shipments, auditing calibrations, verifying that up-to-date procedures are at all work locations, and reviewing inspection records.

\section{G.6 ENVIRONMENTAL SURVEILLANCE}

The required levels of environmental surveillance for active decommissioning differ from those for continuing care. The programs for each of these cases follow.

\section{G.6.1 Environmental Surveillance During Active Decommissioning}

The environmental surveillance program for the operating BWR can be applied to active decommissioning as well. The following objectives are relevant:

- detection of sudden changes and evaluation of long-term trends of (radionuclide) concentration in the environment, with the intent to detect failure to adequately control releases and then to initiate appropriate actions

- assessment of the actual or potential exposure of man to radioactive materials or radiation present in his environment, or estimation of the probable upper limits of such exposure

- determination of the fate of contaminants released to the environment, especially with the intent of detecting previously unconsidered mechanisms of exposure

- Demonstration of compliance with applicable regulations and legal requirements concerning releases to the environment.

Methods, procedures, and performance criteria for environmental surveillance at nuclear facilities are discussed in detail in Reference 31.

Basic radiation-exposure and radioactive effluent-release criteria applicable to population exposure are given in Title 10 of the Code of Federal Regulations. (25) For nonradioactive contaminants, consideration must be given 
to applicable standards such as water quality criteria and the Environmental Protection Agency (EPA) ambient air quality standards. $(32,33)$ In any case, local or state air quality criteria presumably apply on a site-specific basis.

In addition, the interfaces (of the environmental monitoring program) between the plant owner, the appropriate state agencies, and the EPA should be stipulated in the application for the possession-only license.

A suggested minimum program of environmental radiological surveillance conducted outside the plant for the purpose of establishing population dose is shown in Table G.6-1. This minimum program continues untit all fuel and source material is shipped from the site. At that time, approximately 1.5 years after reactor shutdown, the program is reduced in scope.

The analytical detection limits given in the table are based on practicable routine radioactivity-measurement techniques, and in all cases should be sufficient to quantify radionuclide concentrations resulting in conservatively estimated whole-body and individual-organ doses of $<50 \mathrm{mrem} /$ year, depending upon the values derived for the disposition criteria for specific nuclides. These nuclides are identified on completion of the operational monitoring program. They are then defined in terms of concentrations in environmental media at levels that, if sustained, result in doses exceeding acceptable levels for unrestricted public use. The derivation of these levels corresponds with the site-specific method of assessing offsite doses from radioactive materials in estimated gaseous and liquid effluents (if any), and is assumed to be consistent with the recommendations of the Federal Radiation Council and the International Commission on Radiological Protection. $(34,35)$ The monitoring program is designed to integrate fully with any ongoing programs of the state where the BWR is located. Quality assurance is achieved, in part, by the site-specific state QA program and by participation in the EPA analytical quality assurance program. Sample collections and radiation measurements required to meet the schedule suggested in Table G.6-1 are assumed to be conducted according to specifications established during the operation of the reference BWR. The program, and any changes thereto, are documented with the NRC (and to other appropriate regulatory agencies) as environmental 


\section{TABLE G.6-1. Recommended Basic Environmental Monitoring Program for the Active Decommissioning Period}

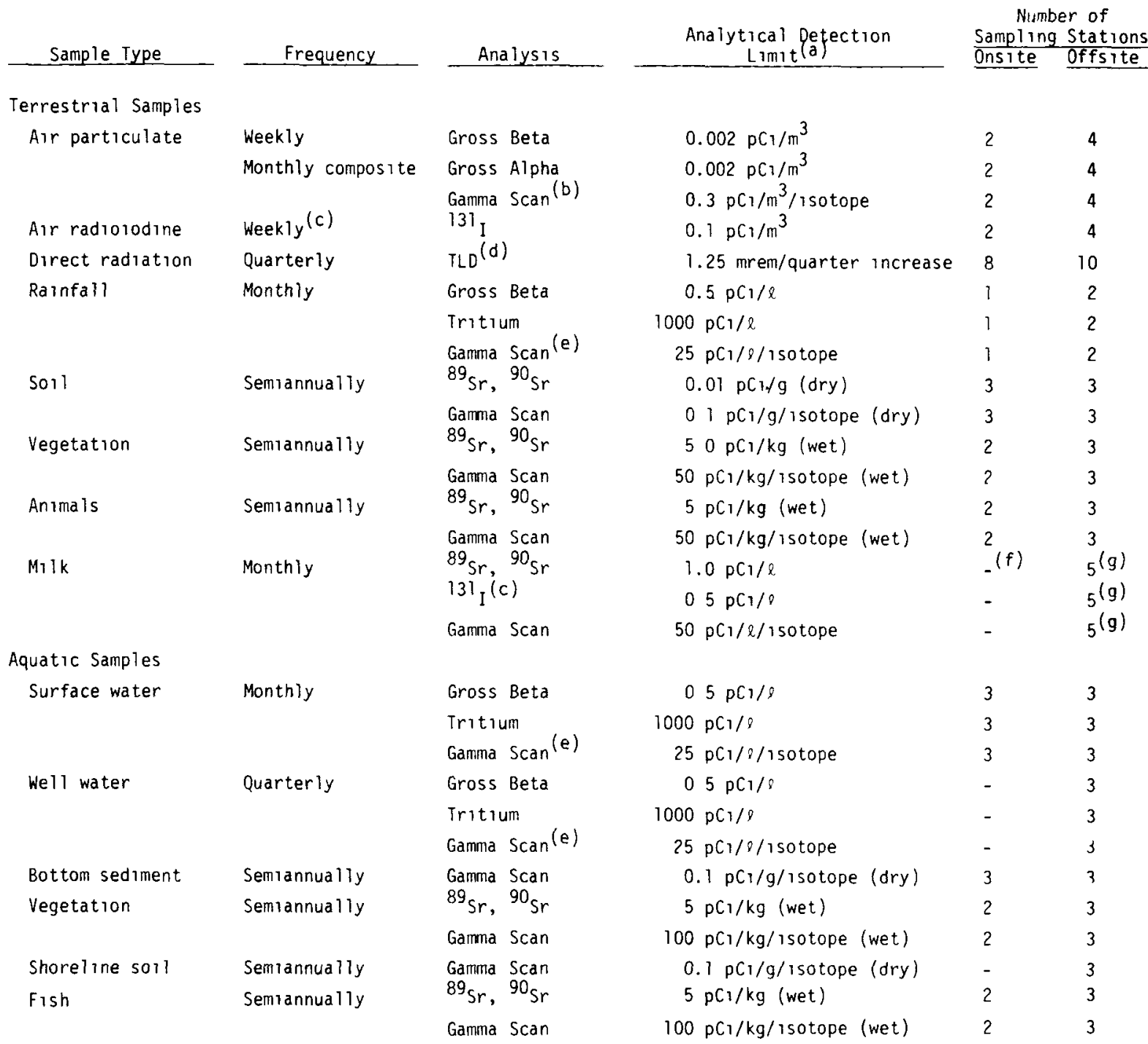

(a) Analytical detection limit is that concentration that is three standard deviations above the average concentration in a blank sample, ensures accuracy $11 \mathrm{mits}$ of $125 \%$

(b) Performed if gross beta exceeds $0.1 \mathrm{pC} 1 / \mathrm{m}^{3}$

(c) 31 I analyses needed only for first month following shutdown.

(d) Thermoluminescent dosimeter.

(e) Performed if gross beta exceeds $10 \mathrm{pC} / 1 /$

(f) Indicates no sample taken

(g) Includes one sample from a local $\mathrm{mllk}$ processor. 
technical specifications, in accordance with the terms of the possession-only license. Quality control mechanisms are exercised over all procedures involved.

Environmental monitoring during the active decommissioning period is carried out by a specialty contractor. (See Section H.4 of Appendix H.)

\section{G.6.2 Environmental Surveillance During Continuing Care}

An abbreviated version of the environmental monitoring program conducted during plant operation is carried out during continuing care. The purpose of the program is to identify and quantify releases of radioactivity to the environment. There is no intent to provide a surveillance program adequate for all potential nonroutine or accidental releases, al though the proposed program is useful in evaluating most lapses of control. For emergency situations involving radionuclide releases (from events such as fire or malicious acts) requiring prompt emergency actions to minimize public risk, special surveillance requirements would apply.

Quality control mechanisms are exercised over all procedures involved. The surveillance system operation is checked at least quarterly. Instruments are calibrated at least quarterly, and always following maintenance. Remedial measures are taken as needed. Sampling quality control may necessitate temporary reinstatement of some aspects of the facility's former procedures (e.g., multiple sampling, sample splitting, and varying sampling locations). Similar analytical quality assurance procedures, such as analyzing audit samples of known concentrations, are likely to be instituted.

Changes in background radiation levels, in environmental radiation accumulations (e.g., fallout from nuclear weapons testing), and especially in land usage and population distribution may, over a period of years, justify modifications in the post-decommissioning surveillance program. Experience will indicate, and the possession-only licensee should be alert for, trends in environmental results that would reasonably permit reduction of the program.

The entire program is anticipated to be reviewed at the following postdecommissioning milestones:

- after all fuel and source material are shipped from the site (approximately 19 months after plant shutdown) 
- 10 years after plant shutdown

- after 10 half-lives of ${ }^{60}$ Co decay (approximately 53 years), economic advantages of further decommissioning effort are ascertained by the owner, and environmental monitoring could conceivably be eliminated. The suggested minimum program of environmental surveillance, shown in Table G.6-1, continues until all fuel and source material is shipped from the site. It can then be reduced in scope. As experience is gained during the continuing care period, further reductions and/or changes are likely. 


\section{REFERENCES}

1. R. L. Dillon et al., Literature Review of Dilute Chemical Decontamination Processes for Water-Cooled Nuclear Reactors, EPRI NP-1033, Prepared by Battelle, Pacific Northwest Laboratories for Electric Power Research Institute, March 1979.

2. J. A. Partridge and R. E. Lerch, Chemical Decontamination of Metals, HEDL-SA-1880, Hanford Engineering DeveTopment Laboratory, Richland, WA, October 1979.

3. L. D. Anstine, J. C. Blomgren and P. J. Pettit, "Dilute Chemical Decontamination Program Review," presented at American Nuclear Society Conference on Decontamination and Decommissioning of Nuclear Facilities, Sun Valley, ID, September 16-20, 1979.

4. N. Eickelpasch and M. Lasch, "In-Situ Decontamination of Parts of the Primary Loop at the Gundremmingen Nuclear Power Plant," presented at American Nuclear Society Conference on Decontamination and Decommissioning of Nuclear Facilities, Sun ValTey, ID, September 16-20, 1979.

5. R. P. Allen, H. W. Arrowsmith, L. A. Charlot and J. L. Hooper, Electropolishing as a Decontamination Process: Progress and Application, PNL-SA-6858, Battelle, Pacific Northwest Laboratories, Richland, WA, April 1978.

6. J. F. Remark, "Plant Decontamination Methods Review," presented at American Nuclear Society Conference on Decontamination and Decommissioning of Nuclear Facilities, Sun Valley, ID, September 16-20, 1979.

7. Final Program Report, AEC-E1k River Reactor, C00-651-93, United Power Association, Elk River, MN, September 1974.

8. J. M. Halter and R. G. Sullivan, "Contaminated Concrete Surface Layer Removal," presented at Fourth International Conference on Contamination Control, Washington, DC, September 10-13, 1978.

9. W. D. Kittinger, B. F. Ureda and J. W. Carroll, "Experience and Techniques in Atomics International's Recent Decommissioning Programs," presented at Health Physics Society Annual Meeting, Philadelphia, PA, July 8-13, $197 \overline{9}$.

10. G. W. Meyers and W. D. Kittinger, "Progress Report on Dismantling of the Sodium Reactor Experiment," IAEA-SM-234/20, presented at American Nuclear Society Winter Meeting, Washington, DC, November 1978.

11. T. S. LaGuardia and W. J. Manion, "Reactor Decommissioning Information Pertinent to Planning," presented at American Nuclear Society Winter Meeting, Washington, DC, November $197 \overline{8}$. 
12. Standard Handbook for Mechanical Engineers, 7th Edition, T. Banmeister and L. S. Marks, pp. 13-49 through 13-51, McGraw-Hill, Inc., 1967.

13. "Welding, Cutting, and Related Processes," Welding Handbook, 6th Edition, Section Three, Part A, American Welding Society, 1970.

14. W. J. Manion, "Preparing a Handbook of Present Technology," Nuclear Engineering International, p. 43, June 1979.

15. G. A. Beitel and M. P. Schlienger, Arc Saw Testing, ARH-LD-147, Atlantic Richfield Hanford Company, Richland, WA, and Schlienger, Inc., San Rafael, CA, JuTy 1976.

16. G. A. Beite1, Remote Disassembly of Radioactively Contaminated Vessels by Means of an ARC SAW, ARH-SA-289, Atlantic Richfield Hanford Company, Richland, WA, June 1977.

17. Dupont Blaster's Handbook, 15th Edition, 1969.

18. M. A. Cook, The Science of High Explosives, American Chemical Society Monograph Series, Reinhold Book Corporation, New York, NY, 1968.

19. K. D. Kok, B. D. Linse and S. J. Basham, Jr., "Use of Linear-Shaped Explosive Charges for Reactor Dismantling," Trans. Am. Nucl. Soc. 22:635, 1975.

20. Technical Status of D\&D Programs Conducted by the Atomics International Division of Rockwell International, AI-BD-DOE-77-27, 1977.

21. J. D. Kaser and J. 0. Vining, Size Reduction of Large Contaminated Process Equipment Using Explosive Shaped Charges, BNWL-B-192, Batte17e, Pacific Northwest Laboratories, Richland, WA, November 1972.

22. Technology for Commercial Radioactive Waste Management, DOE/ET-0028, U.S. Department of Energy, Vol. 4, "Rail Transport of Spent Fuel," pp. 6.2.3 through 6.2.19, Washington, DC 20545, May 1979.

23. Alternatives for Managing Waste from Reactors and Post-Fission Operations in the LWR Fuel Cycle, ERDA-76-43, U.S. Energy Research and Development Administration, Vo1. 3, "Transportation of Spent Fuel," pp. 22.13 through 22.17, May 1976.

24. F. B. Conlon and G. L. Pettigrew, Summary of Federal Regulations for Packaging and Transportation of Radioactive Materials, BRH/DMRE-71-T, U.S. Department of Health, Education and Welfare, Public Heal th Service, Bureau of Radiological Health, Rockville, MD, February 1971.

25. Code of Federal Regulations, Government Printing Office, Washington, DC, issued annualiy. 
26. Radioactive Materials Transportation Manual, Nuclear Transport Division, Tri-State Motor Transit Co., Joplin, MO, 1974.

27. N. I. Sax, Dangerous Properties of Industrial Materials, Fourth Ed., Van Nostrand Reinhold Company, Section 2, "Industrial Air Contaminant Control," by B. Feiner, pp. 40-115, 1975.

28. D. H. Card, Early Waste Retrieval Interim Report, TREE-1047, Idaho National Engineering Laboratory, EG \& G Idaho, Inc., pp. 19-40, February 1977.

29. C. C. Meinhardt and G. M. Holter, Interim Report on Mini-Vacuum System, RH0-CD-524, Rockwel1 Hanford Operations, Richland, WA, May 1978.

30. International Commission on Radiological Protection, Principles of Environmental Monitoring Related to the Handling of Radioactive Materials, ICRP Pub. 7, Pergamon Press, Oxford, 1966.

31. J. P. Corley et al., A Guide for Environmental Radiological Surveillance at ERDA Installations, ERDA-77-24, Prepared by Battelle, Pacific Northwest Laboratories for U.S. Energy Research and Development Administration, March 1977.

32. Federal Water Quality Administration, Guidelines for State Water Quality Legislation.

33. Code of Federal Regulations, Title 40, Protection of Environment, "National Primary and Secondary Ambient Air Quality Standards," Part 50, Superintendent of Documents, GPO, Washington, DC, 1972.

34. Federal Radiation Council, Background Material for Development of Protection Standards, Report No. 2, 1961.

35. International Commission on Radiological Protection, Report of Committee II on Permissible Dose for Internal Radiation, Publication No. 2, 1959. 
APPENDIX H

\section{GENERIC DECOMMISSIONING INFORMATION}

Although all the alternative decommissioning modes are separate and distinct, they have some common requirements. This appendix provides information concerning these common requirements, in the following order:

- decommissioning staff

- planning and preparation

- specialty contractors

- essential systems and services

- system decontamination and draining and radioactive liquid handling

- equipment deactivation and contaminated area isolation.

\section{H. 1 DECOMMISSIONING STAFF}

For the reference BWR, the decommissioning staff is organized as shown in Figure H.1-1. Two main and three auxiliary parallel branches report to a decommissioning superintendent. The operational branch, under a decommissioning engineer, plans and performs the actual decommissioning tasks. The safety branch, under a health and safety supervisor, plans and conducts both radiological and industrial safety programs. The auxiliary branches handle security, financial, and quality assurance matters.

The primary decommissioning activities are performed on a two-shift, 5-dayweek basis. However, support activities (i.e., system decontamination and draining, spent-fuel/activated material shipping, and radwaste system operation) and security functions are carried out on three shifts, around-the-clock, 7 days per week. In addition, the main control room is manned full time for operation of essential systems and services.

The basic working unit is the shift, which is supervised by a shift engineer. The crew on each shift includes: a crew leader (typically a reactor operator), utility operators, and laborers, plus craftsmen (e.g., welders, pipefitters, electricians, and air-balance technicians) and health physics technicians assigned as needed. Craftsmen and health physics technicians 


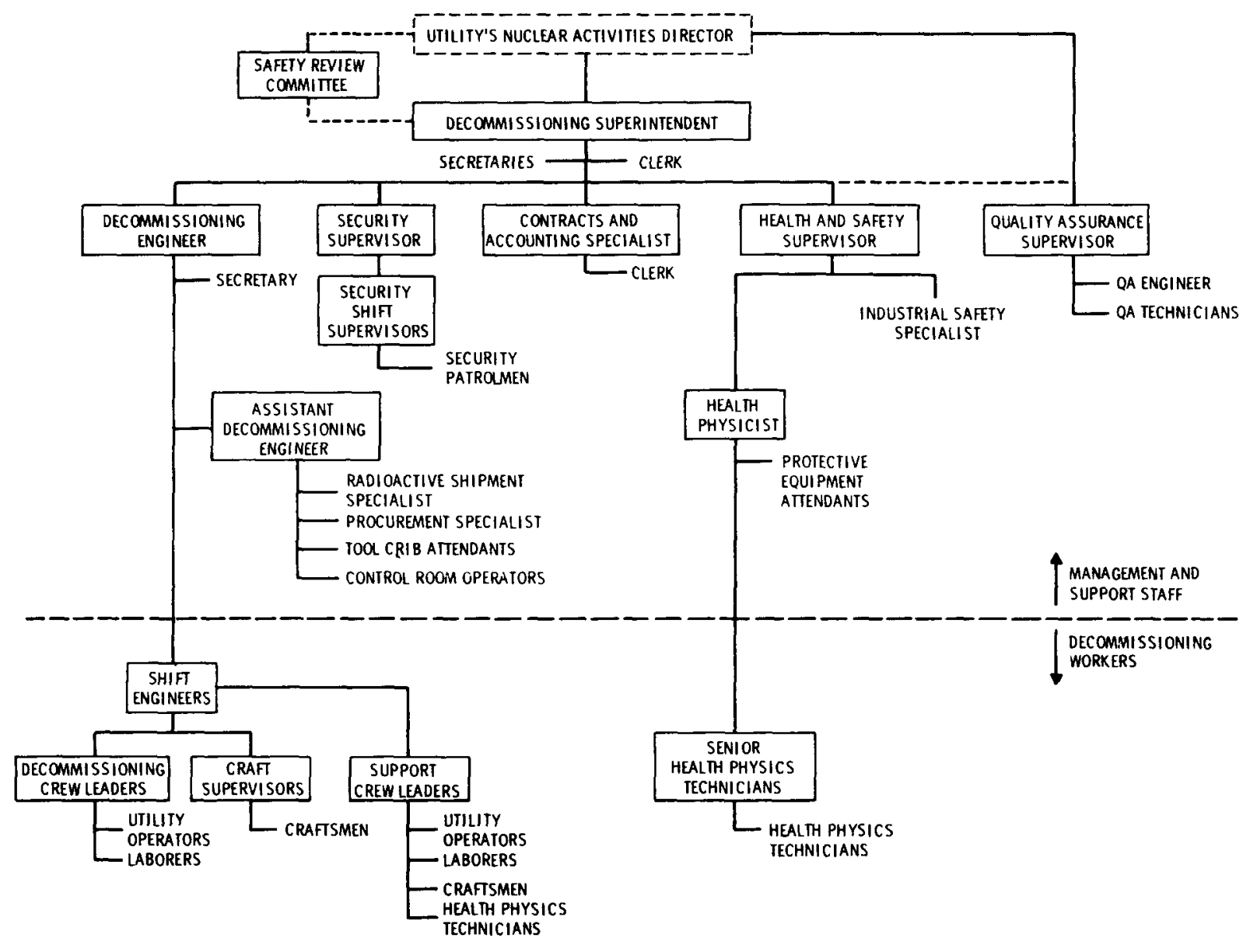

FIGURE H.I-1. Decommissioning Staff Organization

on the support crews report directly to the crew leaders because, on the third shift and on weekends, these crew leaders are the only supervisory personnel on plant. Craftsmen and health physics technicians assigned to the regular decommissioning crews report to the crafts supervisor and the senior health physics technician on the shift, respectively.

The number and specific makeup of crews required for a given decommissioning mode are discussed in the appendix detailing that mode (Appendix I, J, or K).

Detailed knowledge of and familiarity with the reference BWR increases the effectiveness of the decommissioning staff. Consequently, staff positions are filled with facility operations and maintenance personnel to the maximum extent possible. Specialty contractors and consultants are hired as needed to assist in areas outside the staff's expertise or capability. 
This discussion is limited to the decomissioning staff, and does not include utility staff members involved in predecommissioning activities prior to final plant shutdown.

Key decommissioning staff members perform the functions described in the following subsections.

Decommissioning Superintendent

Directly responsible to corporate management, the superintendent coordinates and oversees all decommissioning activities. He directs the decommissioning engineer and the health and safety supervisor, as well as security, quality assurance, and contracts and accounting, to. ensure the safety and cost-effectiveness of the decommissioning project. He provides necessary liaison with regulatory agencys and utility management.

Decommissioning Engineer

This individual plans, coordinates, and supervises the actual decommissioning tasks. He provides the engineering services and detailed procedures required to carry out the decommissioning plan safely and cost-effectively. He prepares all routine and special reports, as well as a chronological history of the project.

\section{Assistant Decommissioning Engineer}

This person supervises the decommissioning support personnel and assists the decommissioning engineer in developing detailed work procedures. He writes specifications for special equipment and tools that must be procured or fabricated. He also prepares reports requested by the decommissioning engineer.

\section{Shift Engineer}

Responsible for carrying out the actual decommissioning work during a shift, this person supervises the crew leader and craft supervisor. He reports to the decommissioning engineer. As he supervises the day-to-day performance of the shift, he recommends changes in procedures and schedules to improve the safety and/or cost-effectiveness of the project. 


\section{Crew Leader}

Reporting to the shift engineer, this individual directs the work crews in the performance of the actual decommissioning tasks.

\section{Craft Supervisor}

This person is responsible for maintenance of essential plant equipment and services as well as for assigning craft labor to particular decommissioning tasks. He instructs craftsmen in their assigned tasks and ensures the availability of required tools and supplies.

Security Supervisor

This person is responsible for site security during decommissioning. He supervises the security personnel and, if necessary, provides liaison with offsite civil authorities. The security shift supervisor directs shift activities.

Contracts and Accounting Specialist

An experienced accountant, this individual is responsible for the financial aspects of the project. He prepares procurement documents and contracts and, with approval from the decommissioning superintendent and the decommissioning engineer, disburses funds. He maintains up-to-date financial accounts and provides the decommissioning superintendent with regular summary reports.

\section{Health and Safety Supervisor}

This person (typically a senior health physicist) recommends and enforces safety policy, both radiological and industrial. He advises the decommissioning superintendent on all safety matters. He maintains the occupational radiation exposure records, and also develops and implements the environmental survey (via a specialty contractor) and the emergency preparedness programs. He supervises and is assisted by the industrial safety specialist and the health physicist.

\section{Health Physicist}

Responsible for ensuring compliance with radiation work procedures, this individual directs the activities of the health physics technicians who monitor 
all decommissioning activities, measure and record on-the-job radiation dose information, and operate the plant laboratory facilities, including sampling and analysis. The senior health physics technician assigns and trains the others on the shift.

Quality Assurance Supervisor

This person is responsible for preparing the quality assurance plan for decommissioning and works with the decommissioning engineer to implement it. To ensure the independence of the quality assurance program, he reports directly to corporate headquarters. He supervises a quality assurance unit, which maintains audit and job performance records and verifies that established safety review procedures are followed. (See Appendix G.5 for further discussion of quality assurance functions.)

\section{Safety Review Committee}

This committee advises corporate management (the utility's nuclear activities director) and the decommissioning superintendent on safety-related matters. It has six voting members: two from corporate headquarters and four independent consultants. The decommissioning superintendent, the quality assurance supervisor, the decommissioning engineer, and the health and safety supervisor are nonvoting members. Resolution of all issues requires agreement by a majority of the consultants. The committee meets about once a month during active decomissioning. The decommisssioning superintendent implements the committee's decisions.

\section{H.2 PLANNING AND PREPARATION}

The planning and preparation phase of decommissioning is an important factor in the success of the project because it lays the groundwork for all of the subsequent activities. If planning and preparation is inadequate, the safety and/or cost-effectiveness of the project may be compromised.

Planning and preparation is carried out simultaneously with the last months of reactor operation. Without detailed study of the time required, it is postulated that the planning and preparation phase spans 2 years for either immediate dismantlement or entombment and 18 months for safe storage. 
Planning and preparation includes the following concerns:

- regulatory requirements

- data gathering and analyses

- development of detailed work plans and procedures

- design, procurement, and testing of special equipment

- staff selection and training

- selection of specialty contractors

- removal of accumulated spent fuel and unneeded spent fuel storage racks

- install HEPA filters.

These are discussed in the following subsections.

\section{H.2.1 Regulatory Requirements}

Prior to the start of actual decommissioning tasks, the licensee must comply with applicable regulatory requirements. The current status of such requirements is detailed in Chapter 5 of Volume 1. This subsection summarizes the activities undertaken during planning and preparation to meet these requirements.

The major requirement is to provide the necessary documentation for amending the facility operating license to "possession-only" status and, if required, for obtaining an NRC dismantling order. In requesting an amended license, the licensee must provide:

- a description of the current facility status

- a inventory of the onsite radioactive materials

- a description of the proposed decommissioning activities

- a description of the proposed measures to prevent criticality and to minimize radioactive releases

- any proposed changes to the technical specifications (e.g., deletion of specifications relating solely to plant operation)

- safety analyses of both the proposed activities and the specification changes.

This information becomes the decommissioning plan for passive safe storage. 
In addition to the amended license, an NRC dismantling order is required for immediate dismantlement or entombment. A request for such an order must include a dismantlement plan providing:

- a description of the ultimate facility status

- a description of the dismantling activities (including radioactive material disposal and site decontamination) and the assocfated environmental and safety precautions

- a safety analysis of the dismantlement and any resultant releases

- a safety analysis of the plant in its ultimate status.

In addition to the aforementioned documentation, the licensee must submit a radioactive waste handling plant, a quality assurance plan, an environmental report, and security and safeguards plans. Updated information concerning the financial qualification of the licensee may also be required. (See Section 5.1 of Volume $i$ for further details.)

\section{H.2.2 Data Gathering and Analyses}

A large body of data is gathered and analyzed during the planning and preparation phase of decommissioning. These data support the regulatory requirements discussed above, particularly the inventory of radioactive materials and the various safety analyses. In addition, they provide the bases for planning decommissioning tasks and selecting appropriate methods and equipment.

Included in this activity is a comprehensive survey of radiation dose rates and contamination levels within the facility. This survey, taken after final reactor shutdown, provides information for determining decontamination and temporary shielding requirements. It also provides initial data on radiation dose rates likely to be encountered during the various decommissioning tasks.

\section{H.2.3 Development of Detailed Work Plans and Procedures}

Detailed work plans and procedures are developed based on the information gathered during data gathering and resultant analyses and provided to the NRC 
with the license amendment/dismantling order request. These detailed plans and procedures contain all the information required to actually carry out the decommissioning tasks. They address the following items:

- decommissioning methods

- schedules and sequences of events

- radioactive waste management

- contamination control

- radiological and industrial safety

- equipment requirements.

Quality assurance, security, and environmental constraints are also considered. The plans and procedures cover all aspects of the decommissioning project.

\section{H.2.4 Design, Procurement, and Testing of Special Equipment}

Any special equipment required to complete the decommissioning project is identified during planning and preparation. Designs and specifications are prepared for each item required. When the item is procured, it is inspected to verify that it meets specifications and complies with applicable QA and safety requirements. It is then tested to ensure that it performs as required. The testing also serves to train personnel in the use of the equipment and to provide pertinent data on its operation.

\section{H.2.5 Staff Selection and Training}

At the start of planning and preparation, a decommissioning organization is created within the utility. Staffing requirements are identified, and critical positions are filled with key engineering and operating personnel. The personnel are trained as required to fulfill their roles in the organization; special emphasis is given to the use of new and unique equipment and procedures. The decommissioning staff is discussed in detail in Section H.1.

\section{H.2.6 Selection of Specialty Contractors}

During planning and preparation, the decommissioning staff identifies the needs for any specialty contractors required to decommission the facility. These contractors perform unique services outside of the expertise or capability 
of the staff. After the needs are identified, contractors are invited to bid on the required work packages. Contractual agreements are concluded prior to the start of the actual decommissioning, if possible, to ensure the uninterrupted completion of the project. Specialty contractor requirements are discussed in Section H.3.

\section{H.2.7 Removal of Accumulated Spent Fuel And Unneeded Spent Fuel Storage Racks}

Any spent fuel stored from previous refueling activities is removed from the spent fuel storage pool and sinipped to a repository. In addition, for immediate dismantlement and entombment, the spent fuel storage racks in excess of those required for final reactor defueling are removed and shipped offsite. By removing these excess items prior to the start of the actual decommissioning, extra space is made available in the spent fuel storage pool for interim storage and packaging of activated materials removed from the facility.

\section{H.2.8 Install HEPA Filters}

Prior to the start of the actual decommissioning tasks (for all decommissioning modes, for the sake of comparison in the safety assessment), HEPA filters are installed outboard of the blowers in the HVAC exhaust systems of the Reactor Building and the Turbine Generator Building. (The Radwaste and Control Building HVAC system is already equipped with HEPA filters; see Section C.4.3.) These filters are installed to prevent the atmospheric release of airborne radioactivity generated during the decommissioning tasks, because many tasks are expected to generate airborne contamination inside the facility exceeding that produced during normal plant operation.

\section{H.3 SPECIALTY CONTRACTORS}

During decommissioning, specialty contractors are employed to provide services beyond the capability of the utility's decommissioning staff. Use of these contractors increases the overall cost-effectiveness of the project by improving the efficiency of specialty operations and reducing the need for specialized staff training. In addition, specialized experience gained from similar projects is directly applied to the decommissioning by these contractors, eliminating the mistakes and wasted effort inherent in learn-asyou-go situations. 
The specialty contractors used during immediate dismantlement of the reference BWR are:

- environmental monitoring specialists, for implementing the environmental surveillance program outlined in Section G. 6

- explosive specialists, for breaking up the sacrificial shield

- hauling contractors, for transport of packaged radioactive materials to a disposal site

- temporary radwaste handling and solidification support, for radwaste handling and final cleanup after the installed radwaste handling systems are decontaminated.

If, following dismantlement, the facility is demolished and the site restored, demolition and landscaping contractors are also required.

For safe storage and entombment, explosive specialists are not required, but the rest of the specialty contractors are the same as for dismantlement.

\section{H.4 ESSENTIAL SYSTEMS AND SERVICES}

A11 or parts of certain facility systems and services must remain in place and in service until all radioactive material is either removed from the facility or secured on the site, to prevent the release of significant quantities of radionuclides (or other hazardous materials) to the environment. Some systems and services are required for cleanup and disassembly activities. Other systems provide personnel health and safety protection. The required systems and services are listed in Table H.4-1, together with the justification for retaining each.

As areas within the facility are readied for demolition or secured for storage, the essential systems and services in these areas are deactivated and, if contaminated, removed as required. Continuous service to the remaining work areas is maintained as long as necessary. 
TABLE H.4-1. Systems and Services Required During Decommissioning

System or Service

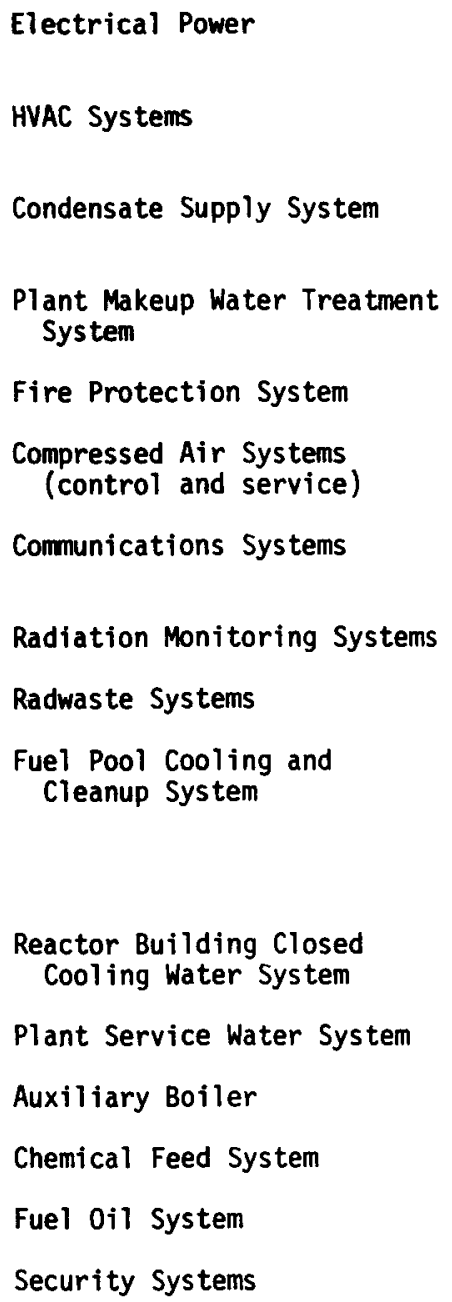

Justification

Operation of electrical equipment including HVAC, lighting, and radiation monitoring

Ventilation and radioactive contamination confinement

Water supply to spent fuel pool and radwaste systems

Decontamination, cleanup, fire protection, and potable water

Health and safety

Operation of pneumatic controls and tools; personnel fresh air supply

Facilitate and coordinate decommissioning activities

Personnel safety considerations

Treatment of radioactive liquids and solids

Cleanup and cooling of water in spent fuel storage pool while spent fuel is there; in reactor well and dryer and separator pool during defueling and reactor vessel/internals removal

Secondary cooling of other systems

Air compressor cooling

HVAC heating and radwaste concentration

Radwaste handling and water demineralization

Auxiliary boiler operation

Public safety and plant protection considerations.

For decommissioning by passive safe storage or entombment, certain systems and services are required during the continuing care period. These are:

- electrical power

- radiation monitoring systems

- security systems .

Requirements for the continuing care period of passive safe storage are discussed further in Appendix $\mathrm{J}$, and those for entombment in Appendix K. 


\section{H.5 SYSTEM DECONTAMINATION AND DRAINING AND RADIOACTIVE LIQUID HANDLING}

This section presents information concerning decontamination of selected systems and components, draining of contaminated water systems, and handling of the resultant radioactive liquids for the reference BWR. The details, time and manpower requirements, costs, and occupational radiation doses for these decommissioning activities are presented.

Since these activities are assumed to be undertaken regardless of the chosen decommissioning mode, the information in this section is presented in a manner in which it can be readily applied to each decommissioning mode.

\section{H.5.1 Details of System Decontamination and Draining and Radioactive Liquid Handling}

Upon final shutdown of the reference BWR, significant quantities of radioactive contamination are expected in certain piping and equipment systems in the Reactor Building, the Turbine Generator Building, and the Radwaste and Control Building (see Appendices $C, D$, and $E$ ). This contamination (both deposited on the internal surfaces and included in the contents of these systems), if allowed to remain, represents a hazard to the decommissioning personnel and the environment and a deterrent to effective completion of the decommissioning activities. The purpose of the decontamination, draining, and subsequent radioactive liquid handling activities is to minimize the hazard potential and to allow decommissioning to proceed on a predetermined schedule and in the most cost-effective manner. Each of these activities is discussed more fully in subsequent subsections.

\section{H.5.1.1 Key Bases and Assumptions}

For the chemical decontamination information in this section, a number of assumptions are made to establish a viable decontamination scenario for the reference BWR.

These are:

- System and component selection is based primarily on the equipment and piping radiation dose rate data represented in Appendix $D$.

- The methods used to accomplish the decontamination utilize presently available technology. 
- The decontamination achieves a minimum decontamination factor (DF) of 10 .

- The decontamination effort is carried out within the framework of existing federal regulations.

- ALARA principles of minimizing exposure to radiation are used in developing the work schedules and methods.

- The planning and preparations for decontamination of the selected systems and components takes place before the final plant shutdown, making it possible for the necessary approvals to be in place by the time the reactor is defueled.

- No water rinse is required following chemical decontamination.

A detailed, plant-specific, cost-benefit analysis is necessary to determine if a water flush following chemical-decontamination is cost-effective. The analysis should include the following considerations:

- history and results of past plant chemical decontaminations

- required amount of water, and associated costs incurred for the additional liquid radwaste management

- additional time, labor, and occupational radiation dose required

- industrial safety impacts on subsequent decommissioning activities (e.g., toxicity of residual chemicals)

- effect on overall DF.

Normally, a rinse and drain procedure is repeated as indicated by chemical analys is to assure removal of chemical solvent from a system that is to be returned to operational status. For this study, a decontamination factor of 10 is assumed to be achieved without a water flush. In addition, since removal of the anticipated minimal amounts of residual chemical cleaning solvent is not expected to present an industrial safety hazard during subsequent decommissioning activities, a water flush is assumed not a cost-effective decommissioning activity for the reference BWR.

The results obtained are specific to these bases and assumptions, and to other assumptions specifically stated throughout this section. Application of 
these results to specific situations where conditions are different from those assumed in this study could produce different conclusions.

\section{H.5.1.2 System Decontamination}

The basic methods that can be used to decontaminate contaminated system surfaces are described in Section G.1 of Appendix G. The two methods that are selected for system decontamination activities at the reference BWR are described in detail in this subsection. They are:

- chemical decontamination (recirculatory and single-pass methods)

- water-jet cleaning.

Chemical Decontamination. Chemical decontamination is considered for selected systems or components in the reference BWR that contain deposited contamination representing a radiation dose rate hazard once the system or component is drained and dried for further decommissioning effort. The systems or components to be chemically decontaminated are selected on the following bases in descending order of importance:

- expected contact radiation dose rate after draining (see Section D.l of Appendix $D$ and Section E.2 of Appendix E); systems or components with expected readings $<15 \mathrm{mR} / \mathrm{hr}$ not considered

- flow capability

- operational heating capability

- size.

The three categories of systems or components within the reference BWR that are selected for either recirculatory or single-pass chemical decontamination, together with their decontamination flow capabilities, are: 1) six reactor piping systems located primarily in the Reactor Building--recirculatory (some with piping jumpers); 2) the three contaminated drain systems located in the Reactor Building, the Turbine Generator Building, and the Radwaste and Control Building--single-pass (with mobile chemical mixing and heating units); and 3) thirty-two pieces of equipment in the liquid and solid radwaste systems located in the Radwaste and Control Building--recirculatory (with mobile chemical decontamination units described in Section G.1 of Appendix G). 
The six reactor systems are depicted in Figure $\mathrm{H} .5-1$ and include the reactor water recirculation (RRC) system, the reactor water cleanup (RWCU) system, the residual heat removal (RHR) system, the low-pressure core spray (LPCS) system, the high-pressure core spray (HPCS) system, and the fuel pool cooling and cleanup (FPC) system. The latter four systems require special piping jumpers to complete recirculation loops. The recirculation loop for each system may or may not include all the system piping. The reactor core isolation cooling (RCIC) system is not selected for chemical decontamination because it requires nuclear steam for operation of the steam-driven pump and none is available following final reactor shutdown.

While too extensive to judicially identify in a single figure, the three contaminated drain piping systems--equipment drain (radioactive) [EDR], floor drain (radioactive) [FDR], and miscellaneous waste (radioactive) [MWR] --are depicted in Figure C.5-1 of Appendix $C$ from the collection pumps or tanks onward.

The equipment pieces in the 1 iquid and solid radwaste systems that are selected for chemical decontamination are listed in Table H.5-l and also are depicted in Figure C.5-1. Because of the assumed lack of operational heating capability to achieve and maintain the proper solution temperature and because of the large volumes involved, these sytems are assumed to be drained to a minimum working volume of water prior to decontamination. This volume is assumed to be too small to prime the system pumps for recirculation through the system piping. Therefore, each individual equipment piece is assumed to be isolated from the piping and chemically decontaminated in a recirculatory loop formed with a mobile chemical decontamination unit. A special spray nozzle connection is required for a piece of equipment that exceeds the volumetric capacity of the mobile chemical decontamination unit.

Some contaminated systems in the reference BWR, for example, the main steam system, the condensate (nuclear steam) system, and the reactor feedwater system, are extremely difficult to isolate for recirculatory chemical decontamination. In addition, some equipment is not amenable to individual decontamination because of complex design or other detrimental reasons. In such cases, ALARA principles must be judiciously applied and all alternative dismantlement methods should be considered to ensure optimization of costs versus anticipated occupational exposure during decommissioning activities. 
FUEL POOL

CIRCULATION

PUMPS (2)
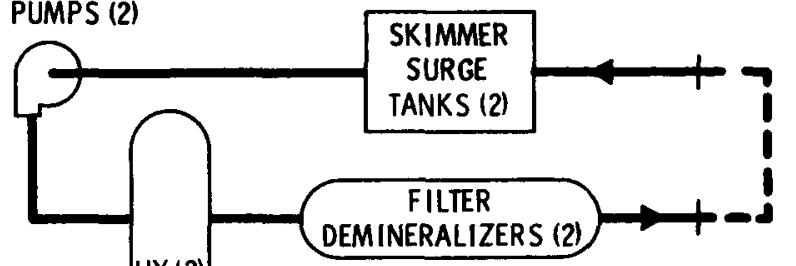

$\frac{T}{1}$
LEGEND

DECONTAMINATION LOOP

- - JUMPER

OTHER SYSTEM PIPING

FEEDWATER LINES

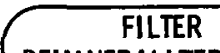

FILTER

DEMINERALIZERS(2)

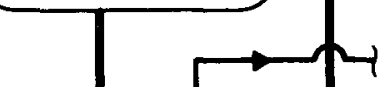

NON-REGENERATIVE HX (2)

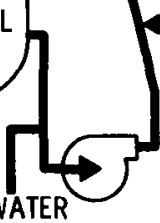

REACTOR WATER

RECIRCULATION PUMPS

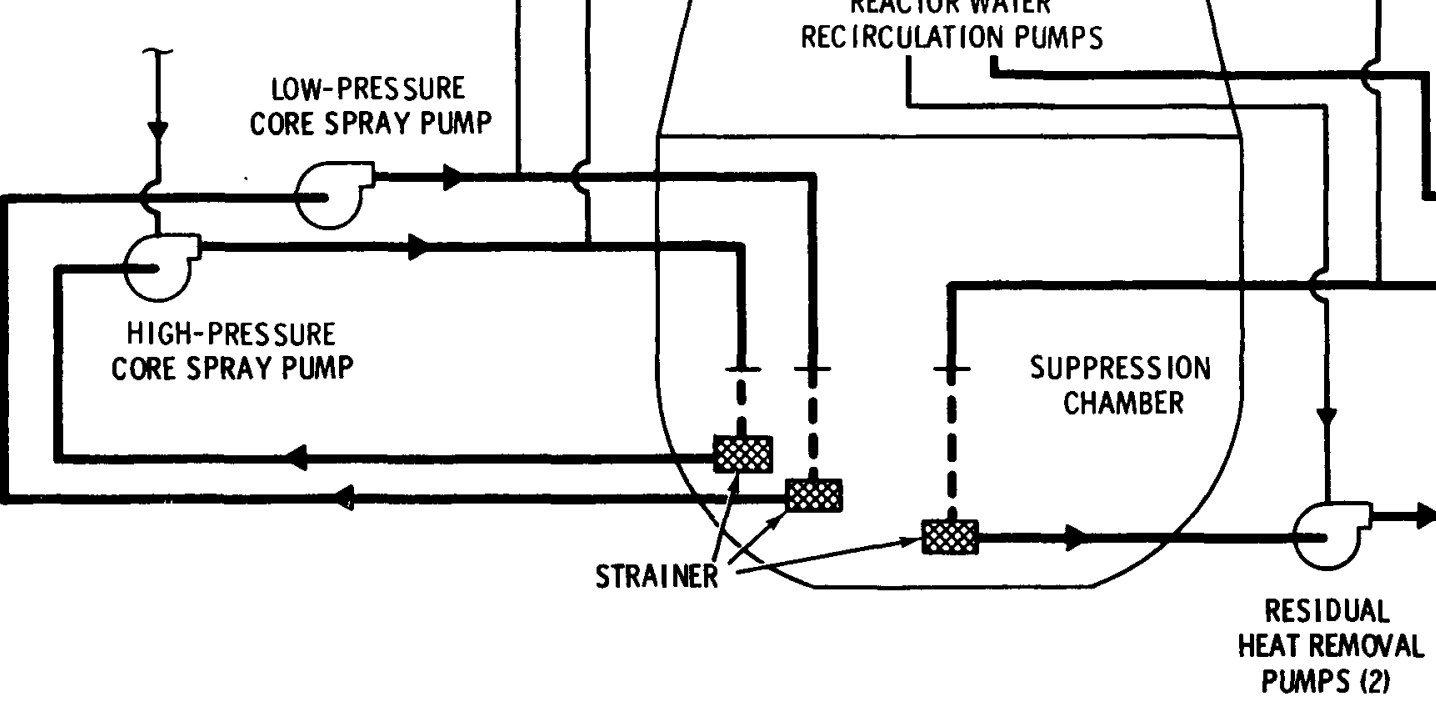

FIGURE H.5-1. Reference BWR Reactor Piping Systems Selected for Chemical Decontamination 
TABLE H.5-1. Reference BWR Liquid and Solid Radwas te Equipment Selected for Chemical Decontamination (a)

SYSTEM

\begin{tabular}{|c|c|}
\hline$E K N(b)$ & Equipment Piece (Quantity) \\
\hline & Condensate Filter Demineralizer (CPR) \\
\hline $\begin{array}{l}302 \\
304\end{array}$ & $\begin{array}{l}\text { Condensate Phase Separator (2) } \\
\text { Condensate Backwash Receiving Tank (1) } \\
\text { Equipment Drain (Radioactive) (EDR) }\end{array}$ \\
\hline $\begin{array}{l}301 \\
305 \\
312 \\
313\end{array}$ & $\begin{array}{l}\text { Waste Collector Tank (1) } \\
\text { Spent Resin Tank (1) } \\
\text { Waste Surge Tank (1) } \\
\text { Waste Sample Tank (2) } \\
\text { Floor Drain (Radioactive) (FDR) }\end{array}$ \\
\hline $\begin{array}{l}300 \\
306 \\
374\end{array}$ & $\begin{array}{l}\text { Floor Drain Collector Tank (1): } \\
\text { Waste Sludge Phase Separator (1) } \\
\text { Floor Drain Sample Tank (1) } \\
\text { Miscellaneous Waste (Radioactive) (MWR) }\end{array}$ \\
\hline $\begin{array}{l}308 \\
309 \\
310 \\
311 \\
386 \\
387 \\
\\
408 \\
457\end{array}$ & $\begin{array}{l}\text { Chemical Waste Tank (2) } \\
\text { Distillate Tank (2) } \\
\text { Detergent Drain Tank (2) } \\
\text { Decontamination Solution Concentrator Waste Tank (2) } \\
\text { Decontamination Solution Concentrator (2) } \\
\text { Decontamination Solution Concentrator Heating } \\
\text { Element (2) } \\
\text { Concentrator Waste Measuring Tank (1) } \\
\text { Decontamination Solution Concentrator Condenser (2) } \\
\text { Process Waste (Radioactive) (PWR) }\end{array}$ \\
\hline $\begin{array}{l}379 \\
409\end{array}$ & $\begin{array}{l}\text { Hopper Mixer (2) } \\
\text { Centrifuge (2) } \\
\text { Reactor Water Cleanup (RWCU) }\end{array}$ \\
\hline 307 & Cleanup Phase Separator (2) \\
\hline
\end{tabular}

(a) Recirculatory chemical decontamination is achieved with the mobile chemical decontamination units described in Section G. 1 of Appendix G.

(b) $E K N=$ Equipment Key Number (see Section C.2 of Appendix C). 
The chemical decontamination methods applicable to the system flow capabilities are shown in Table G.1-1 in Appendix G. The two selected for the reference BWR are:

- recirculatory decontamination using 5-wt\% EDTA/citrox solution

- single-pass decontamination using 10-wt\% phosphoric acid solution, which is subsequently neutralized with sodium hydroxide.

The recirculatory method is used where the chemical solution can be recirculated until the desired degree of decontamination is obtained. The singlepass method completes the decontamination in one pass and is used where recirculation is impractical.

The estimated required volumes of chemical decontamination solutions for the reference BWR are listed in Table H.5-2. The estimated total volume of the recirculatory chemical decontamination solution is $978 \mathrm{~m}^{3}$, and the neutralized single-pass chemical decontamination solutions total $79 \mathrm{~m}^{3}$. The latter volume includes $66 \mathrm{~m}^{3}$ of decontamination solution at 10-wt\% concentration of phosphoric acid and $13 \mathrm{~m}^{3}$ of neutralizing solution at 50 -wt\% concentration of sodium hydroxide. Final disposition of these chemical decontamination solutions is described in Section H.5.1.4, Radioactive Liquid Handling.

Water-Jet Cleaning. A description of water-jet cleaning is given in Section G.1.2 of Appendix $G$ and is not repeated here. High-pressure water jets are assumed used to clean the surfaces of the following:

- suppression chamber (EKN 2 and EKN 3, reference)

- reactor well pool cavity (EKN 63)

- dryer separator pool cavity (EKN 112)

- spent fuel pool cavity (EKN 90)

- the internal surfaces of the condensate storage tanks (EKN 228) and the main condenser (EKN 200)

- the external surfaces of the liquid and solid radwaste systems equipment listed in Table H.5-1. 
TABLE H.5-2. Estimated Volumes of Chemical

Decontamination Solutions

Solution Category

Source

5-wt\% EDTA/Citrox (Recirculatory)

Reactor Piping Systems (a)

RRC System

RWCU System

RHR System

LPCS System

HPCS System

FPC System

Liquid and Solid Radwaste Systems Equipment $(c)$

CPR System

EDR System

FDR System

MWR System

PWR System

RWCU System

Total, 5-wt\% EDTA/Citrox

10-wt\% Phosphoric Acid (Single-Pass)

Contaminated Drain System (a)

Reactor Building (EDR and FDR systems)

Turbine Generator Building (EDR and FDR Systems)

Radwaste and Control Building (EDR, FDR, and MWR Systems)

Total, 10-wt\% Phosphoric Acid $22^{(d)}$

${ }_{6}^{(d)}$

${ }_{51}^{(d)}$

$79^{(d)}$ $614^{(b)}$

36

Estimated

Volumes $\left(\mathrm{m}^{3}\right)$

11

157

13

16

12

15

4

978

(a) Volumes based on data contained in Tables C.3-7 through C.3-10 in Appendix C.

(b) Includes the reactor vessel volume.

(c) Volumes based on either the minimum volume to maintain pump prime in the case of small-size components or on approximately $1 / 10$ the volume of larger components in that case.

(d) Includes $84 \%$ decontamination solution and $16 \%$ neutralizing solution (sodium hydroxide at $50-w$ t\% concentration). 
In general, the water-jet decontamination activity proceeds concurrently with draining the particular volume of contaminated water. However, for effective decontamination, the internal surfaces of the main condenser are water-jet cleaned as they become exposed during disassembly.

The estimated volumes of contaminated water from water-jet cleaning activities are listed by building and by source in Table H.5-3. The total volume of contaminated water generated by these activities is $1,503 \mathrm{~m}^{3}$. Final disposition of this contaminated water is described in Section H.5.1.4, Radioactive Liquid Handling.

\section{TABLE H.5-3. Estimated Volumes of Contaminated Water from Water-Jet Cleaning}

Building

EKN(a)

2,3(Reference) Suppression Chamber

63

112

90
Reactor Well Pool Cavity

Dryer and Separator Pool Cavity

Spent Fuel Pool Cavity
Estimated

Volumes $\left(\mathrm{m}^{3}\right)$

Turbine Generator Building

228

Condensate Storage Tanks

200

Main Condensor

1285

Radwaste and Control Building

-. (b)

Liquid and solid radwaste systems equipment

Total

1503

(a)EKN = Equipment Key Number (see Section C.2 of Appendix C).

(b) See Table H.5-l for equipment key numbers. 


\section{H.5.1.3 System Draining}

Contaminated water remains in those reference BWR water systems discussed in Appendix $C$ and not selected for chemical decontamination. This water must be drained before further decommissioning of these systems can proceed. In addition, contaminated water from miscellaneous sources is assumed to be generated at the estimated rate of $4.5 \mathrm{~m}^{3} /$ day over the entire active decommissioning period.

Table H.5-4 lists the contaminated water sources and the estimated volumes. Submersible pumps, with cartridge filters in their effluent lines, are required to drain the suppression pool and the spent fuel pool. The estimated total volume of contaminated water to be drained is $15,370 \mathrm{~m}^{3}$, including $2,970 \mathrm{~m}^{3}$ from the miscellaneous sources. Final disposition of the contaminated water from system draining and miscellaneous sources is described in the following subsection.

\section{H.5.1.4 Radioactive Liquid Handling}

The chemical decontamination solutions and the contaminated water are drained to the liquid radwaste system (see Section C.5.1 of Appendix C) or to a temporary portable radwaste system. No attempt is made to identify the solution volumes that go to the temporary radwaste system, as this depends on the particular decommissioning mode. The data presented herein and in later sections assume the use of the system provided in the reference BWR.

To minimuze potential plateout and redeposition of radioactive contaminants, the hotter-than-ambient $(353 \mathrm{~K}$ ) recirculatory chemical decontamination solutions are assumed to be drained and processed as rapidly as practicable. Prompt radwaste processing, starting simultaneously with system or component draining operations, optimize these decommissioning tasks, and is assumed throughout the chemical decontamination operations. Expedient radwaste processing avoids the need for additional liquid waste storage tanks. All systems designed to control the release of hazardous material to the environemnt or to the noncontaminated portions of the facility are in operation during the decontamination and draining tasks and the subsequent liquid radwaste processing. 
TABLE H.5-4. Estimated Volumes of Contaminated Water from System Draining Activities

Building

EKN(a)

Reactor Building

2,3(Reference)

63

112

90

-- (b)

Estimated

Volumes $\left(\mathrm{m}^{3}\right)$

Source

Suppression Pool

3890

796

1110

1326

Spent Fuel Pool

Contaminated Systems: (c)

Control Rod Drive

Condensate (Nuclear Steam)

Reactor Building Closed Cooling Water

Reactor Core Isolation Cooling

Reactor Feedwater

Subtotal, Reactor Building

Turbine Generator Building

228

200

Condensate Storage Tanks

Main Condenser

3030

617

Contaminated Systems: ${ }^{(c)}$

Condensate (Nuclear Steam)

Condensate Filter Demineralizer

173

1

60

Reactor Feedwater

3881

Subtotal, Turbine Generator Building

Radwaste and Control Building

Liquid Radwaste Systems Equipment ${ }^{(d)}$
Contaminated Systems: ${ }^{(c)}$
Condensate (Nuclear Steam)
Condensate Filter Demineralizer

Subtotal, Radwaste and Control Building

1197

Reactor Building, Turbine Generator Building, and Radwaste and Control Building

\begin{tabular}{lll}
\hline- & Drains $^{(e)}$ & 2970 \\
\hline Total & $\frac{2370}{15370}$
\end{tabular}

(a) EKN = Equipment Key Number (see Section C.2 of Appendix C).

(b) Implies "too numerous to list."

(c) Volumes calculated based on data contained in Tables C.3-7 through C. 3-10 in Appendix C.

(d) Volume based on approximately $90 \%$ of original volumes drained before chemical decontamination of the equipment listed in Table H.5-1.

(e) Volume from miscellaneous sources based on a generation rate of $4.5 \mathrm{~m}^{3}$ per day over the active decommissioning period. 
The chemical decontamination solutions that contain EDTA/citrox are processed by the miscellaneous waste (radioactive) subsystem at the rate of $2.3 \mathrm{~m}^{3} / \mathrm{hr}$. The concentrator distillate is sent to the river; the concentrator bottoms go to the process waste (radioactive) system for solidification, where they are mixed with cement and encapsulated in steel cask liners. The processing of these chemical decontamination solutions produces an estimated $438 \mathrm{~m}^{3}$ of concentrator bottoms, which result in $517 \mathrm{~m}^{3}$ of concreted waste and occupy 225 steel cask liners. Of these containers, 52 are assumed to have a maximum surface radiation dose rate of $50 \mathrm{R} / \mathrm{hr}, 108$ are assumed to have a maximum surface dose rate of $\mathrm{I} R / \mathrm{hr}$, and 65 are assumed to have a maximum surface dose rate of $0.2 \mathrm{R} / \mathrm{hr}$. The average radioactivity content for each container is $600 \mathrm{Ci}$ in the first group, $12 \mathrm{Ci}$ in the second group, and $2.4 \mathrm{Ci}$ in the last group.

The chemical decontamination solutions containing phosphoric acid are assumed to be neutralized with sodium hydroxide. The neutralizing process results in a solution with an estimated $12-w t \%$ solids concentration, which is the assumed concentrator effluent limit. Therefore, the neutralized solution is assumed to go directly to the process waste (radioactive) system for solidification. The solidification process results in approximately $95 \mathrm{~m}^{3}$ of concreted waste, which occupies 42 steel cask liners. Each of these containers is assumed to have a maximum surface radiation dose rate of $0.2 \mathrm{R} / \mathrm{hr}$ and an average radioactivity content of $2.4 \mathrm{Ci}$.

The contaminated water is processed either by the equipment drain (radioactive) subsystem or the floor drain (radioactive) subsystems, at a total combined rate of $43.56 \mathrm{~m}^{3} /$ day. The effluent water is sent to the river; the resultant radioactive filter sludges and spent demineralizer resins go to the process waste (radioactive) system, where they are mixed with cement and encapsulated in steel cask liners. The radioactive filter sludges and demineralizer resins are produced at an estimated rate of $0.25 \mathrm{~m}^{3} / 100 \mathrm{~m}^{3}$ of contaminated water processed. The total volume of filter sludges and resins requiring disposal is estimated to be $42 \mathrm{~m}^{3}$. This volume is solidified and packaged in 19 steel cask liners. Each of these containers is assumed to have a maximum surface radiation dose rate of $1 \mathrm{R} / \mathrm{hr}$ and an average radioactivity content of $12 \mathrm{Ci}$. 


\section{H.5.2 Time and Manpower Requirements for System Decontamination and Draining and Radioactive Liquid Handling}

This section contains information concerning the time and manpower requirements for system decontamination and draining and radioactive liquid handing. Discrete tasks are defined for system decontamination and draining, which also include the handling requirements for the radioactive liquids from these tasks. After the time and shiftwise manpower requirements for these tasks are defined, they are integrated into each decommissioning mode's schedule to determine their sequence and schedule and their total manpower requirements for each mode. The resultant task schedules and total manpower requirements are not shown here, but are shown as integral parts of the schedules and manpower requirements presented in Appendices I, J, and K.

\section{H.5.2.1 Time Requirements}

The estimated minimum times required to complete the system decontamination and draining tasks are presented in Table H.5-5. The tasks are defined based on the building in which they are performed, their procedural and operational requirements, and their prerequisites. They are listed in Table H.5-5 according to the first two definition bases. The time requirements are determined based on the following assumptions:

- Tasks are performed 24 hours per day, 7 days per week.

- Tasks include all activities required to set up and operate the system, as well as to drain and process the radioactive liquids.

- Recirculatory chemical decontamination takes 2 days of loop operation at the proper temperature $(353 \mathrm{~K})$ to achieve the desired DF.

- Single-pass chemical decontamination solutions are neutralized prior to further processing.

- Water-jet cleaning proceeds simultaneously with the other portion of the task to which it is assigned, except in the case of the condenser where it is performed as surfaces become exposed during the dismantling process.

- Draining times and processing times are based on the processing rates of the in-house liquid radwaste systems and the volumes of liquid presented in the previous section. 
- The equipment drain (radioactive) and floor drain (radioactive) subsystems are unavailable for about 5 hours per week of operation for filter backwashes and demineralizer resin changeouts.

- The miscellaneous drain (radioactive) subsystem is unavailable for 2 days per week of operation for maintenance of the concentrators.

TABLE H.5-5. Time Requirements for System Decontamination and Draining and Radioactive Liquid Handling

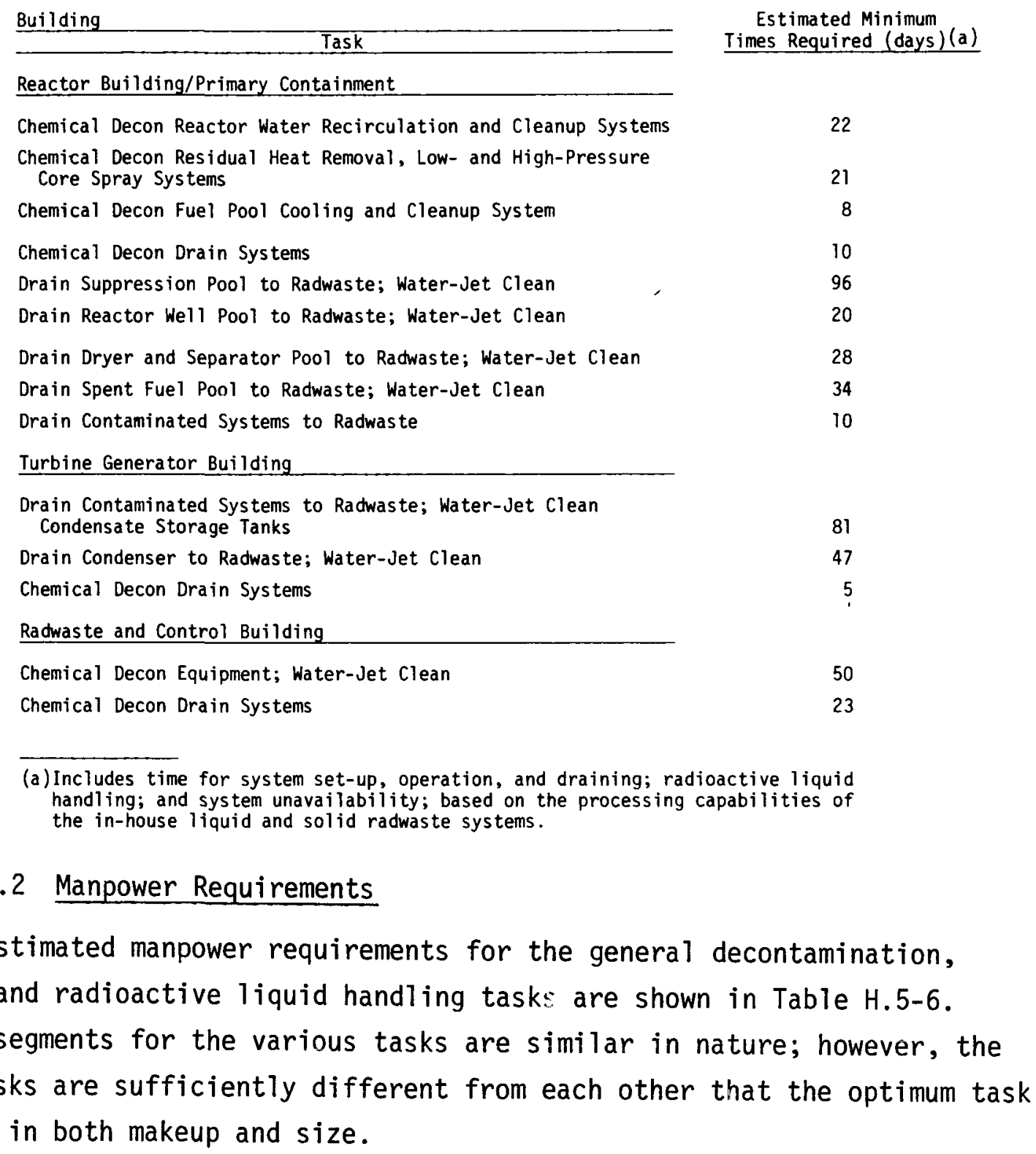

\section{H.5.2.2 Manpower Requirements}

The estimated manpower requirements for the general decontamination, draining, and radioactive liquid handling tasks are shown in Table H.5-6. Many work segments for the various tasks are similar in nature; however, the general tasks are sufficiently different from each other that the optimum task crews vary in both makeup and size. 
TABLE H.5-6. Manpower Requirements for System Decontamination

and Draining and Radioactive Liquid Handling(a)

\begin{tabular}{|c|c|c|c|c|}
\hline $\begin{array}{l}\text { Crew } \\
\text { Leader }\end{array}$ & $\begin{array}{l}\text { Utility } \\
\text { Operator }\end{array}$ & Laborer & Craftsman & $\begin{array}{c}\text { Health } \\
\text { Physics } \\
\text { Technician }\end{array}$ \\
\hline 1 & 2 & $--(c)$ & 1 & 1 \\
\hline 1 & 2 & -- & ${ }_{1}^{(d)}$ & 1 \\
\hline-- & 4 & 4 & 2 & - \\
\hline 1 & 2 & -- & -- & 1 \\
\hline -- & 1 & -- & 1 & 1 \\
\hline 1 & 4 & -- & 1 & 1 \\
\hline
\end{tabular}

(a)Those required to perform the given task, but not to satisfy the occupational dose commitment for that task; may not be required full-time.

(b)Three shifts per day, 7 days per week; a shift engineer is assumed available on regular shifts and on-call during off-shifts and weekends for emergencies.

(c) Indicates "not required."

(d) Requires the part-time services of craftsmen from different crafts.

(e) Staffed by personnel from the radioactive liquid handling crew.

\section{H.5.3 Costs for System Decontamination and Draining and Radioactive Liquid Handling}

The costs for system decontamination and draining and radioactive liquid handling that are independent of the particular decommissioning mode are presented in this section. These are costs for materials, special equipment, energy, and disposal of wet solid wastes. Manpower costs depend on the schedule and manpower loading for a particular decommissioning mode and are included in Appendices I, J, or $K$ as they pertain to the various decommissioning modes.

\section{H.5.3.1 Costs for Materials}

The materials that are required for system decontamination and draining and radioactive liquid handling include chemicals and neutralizing agent for chemical decontamination and resins for contaminated water handling. Table H.5-7 lists the costs for these materials. The costs for solidification materials for the wet solid wastes are included later as part of the costs for disposal of these wastes. 
TABLE H.5-7. Costs for Materials for System Decontamination and Draining and Radioactive Liquid Handling

\begin{tabular}{l}
$\frac{1}{\text { Material }}$ \\
\hline EDTA/Citrox Acid \\
Phosphoric Acid \\
Sodium Hydroxide \\
Filter/Demineralizer Resins
\end{tabular}

Total Cost
Estimated Amounts Required

$48830 \mathrm{~kg}^{(\mathrm{b})}$

$5900 \mathrm{~kg}(\mathrm{c})$

$$
13.5 \mathrm{~m}^{3(\mathrm{~d})}
$$

$7750 \mathrm{~kg}$ bead/

$4130 \mathrm{~kg}$ Powdex $(\mathrm{e})$

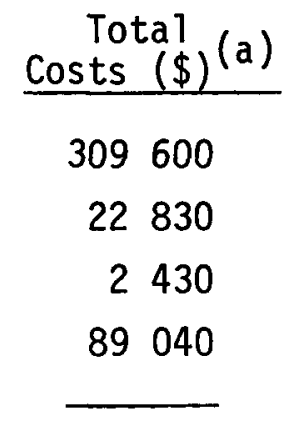

423900

(a) Based on Section M. 6 of Appendix M; rounded to the nearest $\$ 10$.

(b) Calculated at 5 -wt concentration in $978 \mathrm{~m}^{3}$ of water.

(c) Calculated at 10-wt\% concentration in $61 \mathrm{~m}^{3}$ of water.

(d) Calculated at one part sodium hydroxide to five parts phosphoric acid.

(e)Based on information supplied by Washington Public Power Supply System.

\section{H.5.3.2 Costs for Special Equipment}

Table H.5-8 shows the costs for special equipment that is assumed required for system decontamination and draining. No special equipment is required for radioactive liquid hand 1 ing.

TABLE H.5-8. Costs for Special Equipment for

System Decontamination and Draining

\section{Special Equipment}

Piping Jumper

Mobile Chemical Mixing and Heating Unit

Mobile Chemical Decontamination Unit

High-Pressure Water Jet

Submersible Pump with Disposable Filter

Total cost

\begin{tabular}{|c|c|c|}
\hline $\begin{array}{r}\text { Est } \\
\text { Number }\end{array}$ & $\begin{array}{l}\text { imated } \\
\text { Required }\end{array}$ & $\begin{array}{l}\text { Estimated } \\
\text { Costs }(\$)\end{array}$ \\
\hline & 4 & 2500 \\
\hline & 4 & 10000 \\
\hline & 5 & 100000 \\
\hline & 2 & 20000 \\
\hline & 5 & 5000 \\
\hline & & 137500 \\
\hline
\end{tabular}




\section{H.5.3.3 Costs for Energy}

The costs for the energy used during system decontamination and draining and radioactive liquid handling are given in Table H.5-9. Electricity and fuel oil are the two energy forms used. In the reference BWR, fuel oil is used in the auxilary boiler to generate steam for use in the concentrators in the miscellaneous waste (radioactive) subsystem.

TABLE H.5-9. Costs for Energy for System Decontamination and Draining and Radioactive Liquid Handling

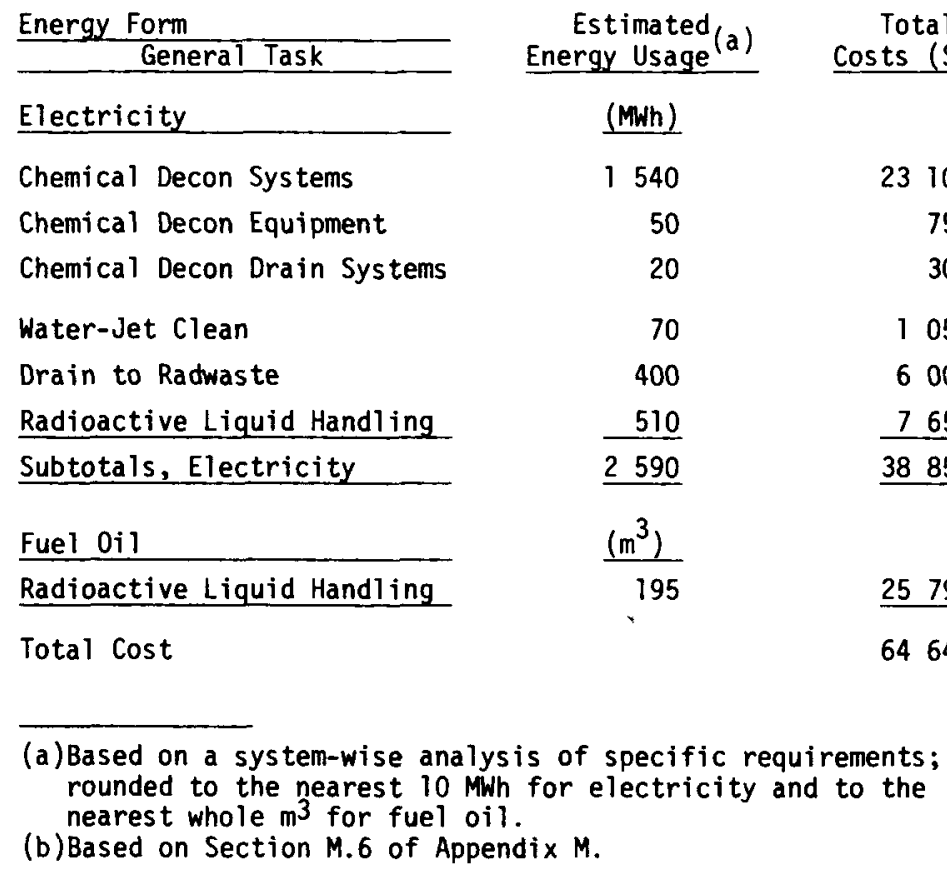

\section{H.5.3.4 Costs for Disposal of Wet Solid Wastes}

Table H.5-10 gives a breakdown of the disposal costs for all of the wet wastes generated during system decontamination and draining and radioactive liquid handling. The wet solid wastes include the concentrator bottoms, the neutralized drain decontamination solutions, and the filter sludges and spent demineralizer resins discussed in Section H.5.1.4. An estimated total of 286 truckloads are shipped to a shallow-land burial site. The wet solid wastes occupy an estimated $814 \mathrm{~m}^{3}$ of space at the burial site. The total disposal cost for the wet solid wastes is estimated to be $\$ 1,073,440$. 
TABLE H.5-10. Costs for Disposal of Wet Solid Wastes

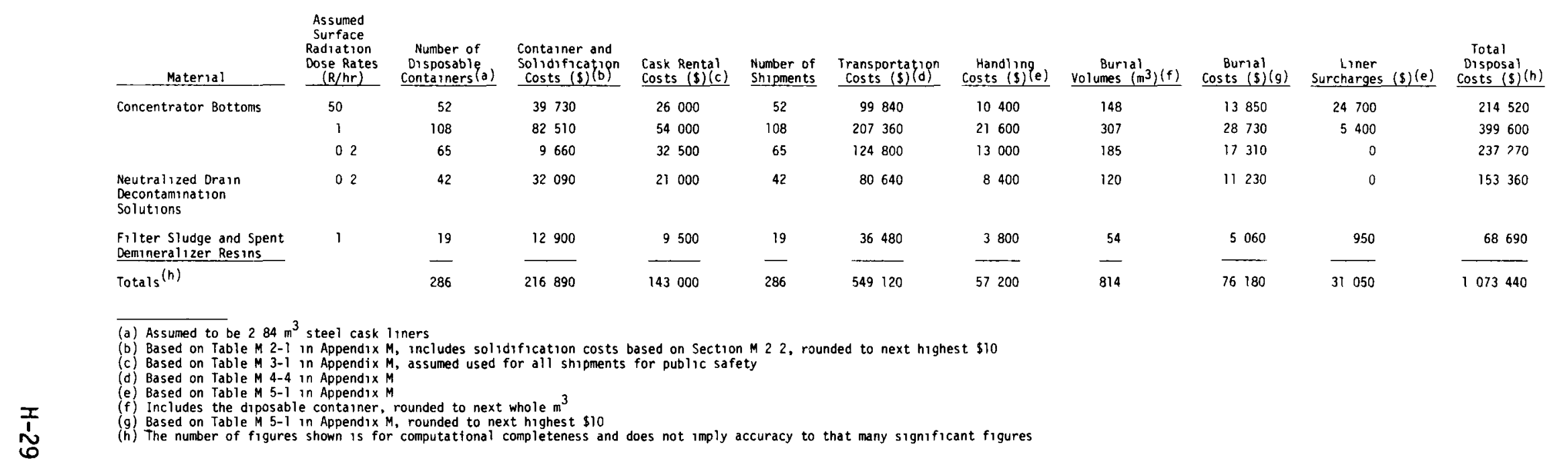




\section{H.5.4 External Occupational Radiation Dose for System Decontamination and Draining and Radioactive Liquid Handling}

Detailed estimates are made of the external occupational radiation doses that are accumulated by the decommissioning workers during system decontamination and draining and radioactive liquid handling tasks. These estimates are based on a task-by-task analysis of personnel exposure hours and expected radiation dose rates associated with each task. The results of these analyses are presented in Table H.5-11. Since the schedule and sequence of these tasks are not presented in this section, the doses in Table H.5-11 are not corrected for radioactive decay.

As can be seen from the table, one of the largest radiation doses is received by craftsmen during the ancillary task titled "Operate Radwaste Systems." This 21.6-man-rem dose is estimated for maintenance on the decontamination solution concentrators (EKN 386). Based on operating experience, the availability for concentrations in radwaste treatment systems has averaged in the range of 60 to $80 \%$ (1) The unavailability is attributed to scaling, fouling of surfaces, instrumentation failures, corrosion, and other oçcasional upsets that result in high carry-overs and require system cleaning.

\section{H.6 EQUIPMENT DEACTIVATION AND CONTAMINATED AREA ISOLATION}

When equipment and systems are no longer needed during decommissioning, they are placed in a condition that provides maximum safety with minimum maintenance. When possible, equipment is left in a condition that permits startup or salvage at a later date. Deactivation and isolation techniques include closing and securing installed valves, installing blank flanges as required, and disconnecting electrical power and other utilities. Equipment deactivation procedures are coordinated with system decontamination and draining operations. In some instances decontamination must be carried out before equipment deactivation, while in others the opposite approach may be necessary. A safety audit of all systems is performed to ensure that all flammable and other potentially hazardous materials are removed. All deactivated equipment and systems are tagged out. 
TABLE H.5-11. Estimated External Occupational Radiation Doses for System Decontamination and Draining and Radioactive Liquid Handling

\begin{tabular}{|c|c|c|c|c|c|c|c|c|c|c|}
\hline & Supervi & sors $(a)$ & $\begin{array}{l}\text { Utility } \\
\text { and Lo }\end{array}$ & $\begin{array}{l}\text { Operators } \\
\text { iborers }\end{array}$ & Craf & tsmen & $\begin{array}{l}\text { Health } \\
\text { Tech }\end{array}$ & $\begin{array}{l}\text { Physics } \\
\text { icians }\end{array}$ & Task T & otals $(b)$ \\
\hline Location & $\begin{array}{l}\text { Exposure } \\
(\operatorname{man}-\mathrm{hr})\end{array}$ & $\begin{array}{c}\text { Dose } \\
\text { (man-rem) }\end{array}$ & $\begin{array}{l}\text { Exposure } \\
\text { (man-hr) }\end{array}$ & $\frac{\text { Dose }}{\text { (man-rem) }}$ & $\begin{array}{l}\text { Exposure } \\
\text { (man-hr) }\end{array}$ & $\begin{array}{c}\text { Dose } \\
\text { (man-rem) }\end{array}$ & $\begin{array}{l}\text { Exposure } \\
\text { (man-hr) }\end{array}$ & $\begin{array}{c}\text { Dose } \\
\text { (man-rem) }\end{array}$ & $\begin{array}{l}\text { Exposure } \\
\text { (man-hr) }\end{array}$ & $\begin{array}{c}\text { Dose } \\
\text { (man-rem) }\end{array}$ \\
\hline Reactor Building/Primary Containment & & & & & & & & & & \\
\hline $\begin{array}{l}\text { Chemical Decon Reactor Water Recirculation } \\
\text { and Cleanup Systems }\end{array}$ & 4 & 0.200 & 572 & 5.143 & 8 & 0.760 & 36 & 1.836 & 620 & 7.939 \\
\hline $\begin{array}{l}\text { Chemical Decon Residual Heat Removal, } \\
\text { Low- and High-Pressure Core Spray Systems }\end{array}$ & 12 & 0.360 & 259 & 4.403 & 20 & 1.100 & 118 & 3.540 & 409 & 9.403 \\
\hline $\begin{array}{l}\text { Chemical Decon Fuel Pool Cooling and } \\
\text { Cleanup System }\end{array}$ & 2 & 0.010 & 52 & 0.312 & 2 & 0.020 & 18 & 0.108 & 74 & 0.450 \\
\hline Chemical Decon Drain Systems & $\ldots(c)$ & -- & 431 & 0.431 & 108 & 0.108 & $\cdots$ & -- & 539 & 0.539 \\
\hline $\begin{array}{l}\text { Orain Suppression Pool to Radwaste; } \\
\text { Water-Jet Clean }\end{array}$ & 27 & 0.189 & 322 & 1.932 & 27 & 0.135 & 27 & 0.135 & 403 & 2.391 \\
\hline $\begin{array}{l}\text { Drain Reactor Well Pool to Radwaste; } \\
\text { Water-Jet Clean }\end{array}$ & 3 & 0.015 & 55 & 0.275 & 5 & 0.025 & 5 & 0.025 & 68 & 0.340 \\
\hline $\begin{array}{l}\text { Drain Dryer and Separator Pool to Radwaste; } \\
\text { Water-Jet Clean }\end{array}$ & 9 & 0.045 & 97 & 0.485 & 8 & 0.040 & 8 & 0.040 & 122 & 0.610 \\
\hline $\begin{array}{l}\text { Drain Spent Fuel Pool to Radwaste; } \\
\text { Water-Jet Clean }\end{array}$ & 9 & 0.045 & 109 & 0.545 & 9 & 0.045 & 9 & 0.045 & 136 & 0.680 \\
\hline $\begin{array}{l}\text { Drain Contaminated Systems to Radwaste } \\
\text { Turbine Generator Building }\end{array}$ & -- & -- & 12 & 0.180 & 4 & 0.060 & 2 & 0.030 & 18 & 0.270 \\
\hline $\begin{array}{l}\text { Drain Contaminated Systems to Radwaste; } \\
\text { Water-Jet Clean Condensate Storage Tanks }\end{array}$ & 8 & 0.008 & 51 & 0.051 & -- & -- & 5 & 0.005 & 64 & 0.064 \\
\hline $\begin{array}{l}\text { Drain Condenser to Radwaste: Water-Jet } \\
\text { Clean }\end{array}$ & 1 & 0.001 & 10 & 0.010 & -- & -- & 1 & 0.001 & 12 & 0.012 \\
\hline $\begin{array}{l}\text { Chemical Decon Drain Systems } \\
\text { Radwaste and Control Building }\end{array}$ & -- & - & 305 & 0.305 & 76 & 0.076 & - & $-\cdot$ & 381 & 0.381 \\
\hline $\begin{array}{l}\text { Chemical Decon Equipment; } \\
\text { Water-Jet Clean }\end{array}$ & 45 & 0.195 & 360 & 21.505 & -- & -- & 45 & 0.915 & 450 & 22.615 \\
\hline $\begin{array}{l}\text { Chemical Decon Drain Systems } \\
\text { Ancillary }\end{array}$ & - & - & 435 & 0.435 & 109 & 0.109 & -- & -- & 544 & 0.544 \\
\hline Operate Radwaste Systems & $-\cdot$ & - & 286 & 1.430 & 144 & 21.600 & 36 & 0.495 & 466 & 23.525 \\
\hline Totals $(\mathrm{b})$ & 120 & 1.068 & 3356 & 37.442 & 520 & 24.078 & 310 & 7.175 & 4306 & 69.763 \\
\hline
\end{tabular}

(a) Includes shift engineers, crew leaders, craft supervisors, and sentor health physics techniclans.

(b) The number of significant figures shown is for computational conventence and does not imply precision of that degree.
(c) Indicates that category of decomissioning staff is not involved in the particular task. 
The particular method used to deactivate each system or piece of equipment is identified during the planning and preparation phase. In general, all systems not necessary to prevent the spread of contamination are deactivated when empty. A11 equipment, valves, circuit breakers, etc., are tagged when deactivated. These tags identify the piece of equipment, its system, and its condition.

The first step in equipment deactivation is a safety audit of all pumps and pipes used for chemicals or radioactive materials to ensure that all hazardous or corrosive materials have been removed. Electrical service is disconnected from all equipment not required for operation later in the decommissioning process.

Systems inside the Reactor Building, the Turbine Generator Building, and the Radwaste and Control Building are deactivated by a variety of methods. Many piping systems are isolated using the installed valves, with handles or valve operators removed. Other pipes that have contained contaminated materials are blanked where flanges are readily accessible. Other systems are drained and left open to the atmosphere. Cranes and other electrical equipment not required later in decommissioning are disabled by disconnecting electrical service to prevent their unauthorized use.

For passive safe storage, portions of the facility that contain significant amounts of radioactivity are isolated by the installation of tamper-proof barriers. Indirect access routes, however unlikely, are determined from as-built drawings and sealed. Such routes may include, but are not limited to, access through large vessels, tanks, or large-diameter pipes. Barriers are constructed by welding or bolting and sealing steel plates to block potential pathways of unauthorized entry or contamination migration. Extensive use is made of polysulfide rubber as a sealant because of its durability and flexibility. In the HVAC systems servicing these isolated areas, vents with HEPA filters are installed to allow for changes in air pressure and temperature; however, the systems themselves are deactivated. 


\section{REFERENCES}

1. U.S. NRC, Calculation of Releases of Radioactive Materials in Gaseous and Liquid Effluents from Boiling Water Reactors (BWR-GALE Code), NUREG-0016, p. 2-39, Apri1 1976.*

Available for purchase from the National Technical Information Service, Springfield, Virginia 22161. 


\section{APPENDIX I}

\section{IMMEDIATE DISMANTLEMENT DETAILS}

Immediate dismantlement is the decommissioning mode used to remove the radioactive materials from a nuclear power plant immediately following final shutdown. After the radioactive materials are shipped from the site, the facility can be released for unrestricted use. In the reference BWR, radioactive materials are present in the Reactor Building (and Primary Containment), in the Turbine Generator Building, and in the Radwaste and Control Building at the end of the operating life.

Details of immediate dismantlement of the reference BWR are discussed in this appendix, including disassembly methods, schedules and manpower requirements, costs, and external occupational radiation doses. The facility descriptions given in Appendices $C, D$, and $E$ provide the basic information for the development of the tasks, schedules, manpower loadings, costs, and occupational radiation exposure estimates. Additional design details pertinent to dismantlement of specific equipment items come from engineering drawings, manufacturer's data, and onsite inspection and consultation with construction and operating personnel of Washington Public Power Supply System.

The information in this appendix forms the bases for the activities, costs, and occupational radiation doses for immediate dismantlement presented in Chapters 9, 10, and 11 in Volume 1, respectively.

\section{I.1 DISASSEMBLY METHODS}

Following completion of planning and preparation (see Section H.2 of Appendix $\mathrm{H}$ ) and final plant shutdown, a comprehensive radiation survey of each of the three buildings is completed. These surveys are required to finalize plans for decontaminating contaminated process systems and for installing temporary shielding for personnel protection during the dismantlement of piping and equipment. Next, general cleanup is accomplished, temporary shielding is provided where needed, and staging is erected where it is first used in the dismantlement effort. 
At reactor shutdown, the reactor cooling and cleanup systems contain the normal operating inventory of radioactively contaminated water. Throughout the dismantlement of the reference BWR, the contaminated water inventories are processed through the radwaste systems as described in Section H.5 of Appendix $H$. Selected systems and components with high levels of radioactive contamination are chemically decontaminated before dismantlement, with the decontamination solutions being processed in the radwaste systems for disposal.

Contamination control envelopes in the form of portable ventilation enclosures, temporary greenhouses, or HEPA-filtered vacuum systems are provided where contaminated piping and equipment is being cut up or where contaminated concrete is being removed.

Al1 dismantlement activities are conducted in accordance with the decommissioning quality assurance plan (see Section G.5 of Appendix G) and are checked by the utility quality assurance staff. Environmental monitoring (see Section G.6 of Appendix G) during immediate dismantlement is performed by a specialty contractor.

The disassembly methods proposed for immediate dismantlement of the reference BWR employ techniques that have been used successfully and are described generically in Appendix G. Disassembly methods are discussed in the following subsections for each of the three buildings containing radioactive materials. Generic descriptions for the dismantlement of equipment located in all three buildings are not repeated after they are first discussed (i.e., for piping and equipment, contaminated concrete surfaces, and HVAC and electrical equipment).

\section{I.1.1 Reactor Building/Primary Containment}

All of the neutron-activated materials and some of the radioactively contaminated materials in the reference BWR are located in the Primary Containment. Most of the reactor vessel internals and portions of the reactor vessel and the sacrificial shield contain the neutron-activated materials. Neutron-activated components are cut into pieces that will fit steel liners for the B3 shielded shipping cask or other suitable shielded shipping cask; contaminated 
components are cut up and packaged in standard shipping boxes, $1.2 \mathrm{~m} \times 1.2 \mathrm{~m} \times$ $2.4 \mathrm{~m}$, or in specially made boxes (see descriptions in Section $\mathrm{G} .3$ of Appendix G).

In preparation for discharging the fuel, the drywell hear and the reactor vessel head are removed, the reactor vessel and the reactor well are filled with water, and the steam dryer and the steam separator are removed from the reactor vessel and placed in the dryer and separator storage pool. While the reactor is being defueled, the steam dryer and the steam separator are cut up under water into packageable segments using a plasma-arc torch and an arc saw. Since the steam dryer and the upper portion of the steam separator contain no neutron-activated material, they are packaged and disposed of as contaminated material. However, the lower portion of the steam separator (i.e., the risers and shroud head plate) is activated and is packaged in steel cask liners.

All of the internals are removed from the reactor vessel with the vessel and the reactor well filled with water. In addition, contamination control envelopes are used for all underwater cutting activities.

Following defueling, the fuel support pieces, the control rods, the control rod guide tubes, the in-core instrument strings, the top fuel guide, and the core support plate are removed from the reactor vessel using standard maintenance procedures. They are cut up in the dryer and separator storage pool using an arc saw or a plasma-arc torch, with all except the control rods and the in-core instrument strings being cut for packaging in B3 steel cask liners. Additional lead shielding is required in the cask liners containing segments of the top fuel guide. Two opposite blades of a cruciform control rod are cut off longitudinally so that the segmented control rod will lie flat. The segmented control rods and the in-core instrument strings are packaged in specially built steel containers that will fit into truck-mounted, NAC-1 spent fuel casks for shipment to the disposal site.

The feedwater inlet, core spray, and residual heat removal piping are next cut from inside the reactor vesse? and cut up in the dryer and separator storage pool. These components are assumed not activated; therefore, they are packaged in standard shipping boxes as contaminated material. 
The jet pump nozzle/throat sections (see Figure C.3-2 in Appendix C) are then removed using standard maintenance procedures and cut up in the dryer and separator pool for B3 cask shipment. Additional lead shielding is also required.

A plasma-arc torch is used to cut the core shroud into rings of packageable height. The plasma-arc torch is guided by a remotely controlled manipulator (see Section G.2.1 of Appendix G) that is installed in the reactor vessel just before core shroud removal is undertaken. Figure I.1-1 shows the positions at which the core shroud is cut circumferentially. The core shroud is the most radioactive component to be removed from the reference BWR. The rings are moved to the dryer and separator storage pool where they are cut up into segments using a plasma-arc torch. In order to meet the dose rate limits for radioactive shipments, extra shielding is needed for the central core shroud segments (between vessel internals cuts 6 and 12 shown in Figure I.1-1) in addition to that provided by the shielded shipping cask. As an economy measure, pieces of the midsection (most of the activated portion) of the reactor vessel wall are arranged in the steel cask liners to surround the core shroud segments and provide the necessary additional shielding.

The jet pump iniet riser pipes, the jet pump diffusers, and the shroud support plate are removed from the reactor vessel and cut up in the dryer and separator storage pool for packaging in standard shipping boxes as contaminated material.

The reactor vessel is remotely cut into rings of packageable height for removal to the dryer and separator storage pool. Circumferential cuts of the vessel wall are made in air using an oxyacetylene torch installed on the manipulator. Before each cut is made, the torch is positioned, the ring to be removed is rigged to the Reactor Building crane, and the water level in the reactor vessel is lowered to a level just below the circumferential cut line. Locations of the cuts for dismantling the reactor vessel are also shown in Figure [.1-1. The top four rings and the ring just above the bottom head of the vessel are not activated and are cut up under water in the dryer and separator storage pool into segments that are packaged in standard shipping boxes. The bottom head is not removed until the inner steel skin of the sacrificial shield is cut and the manipulator is removed. The rings from the center 


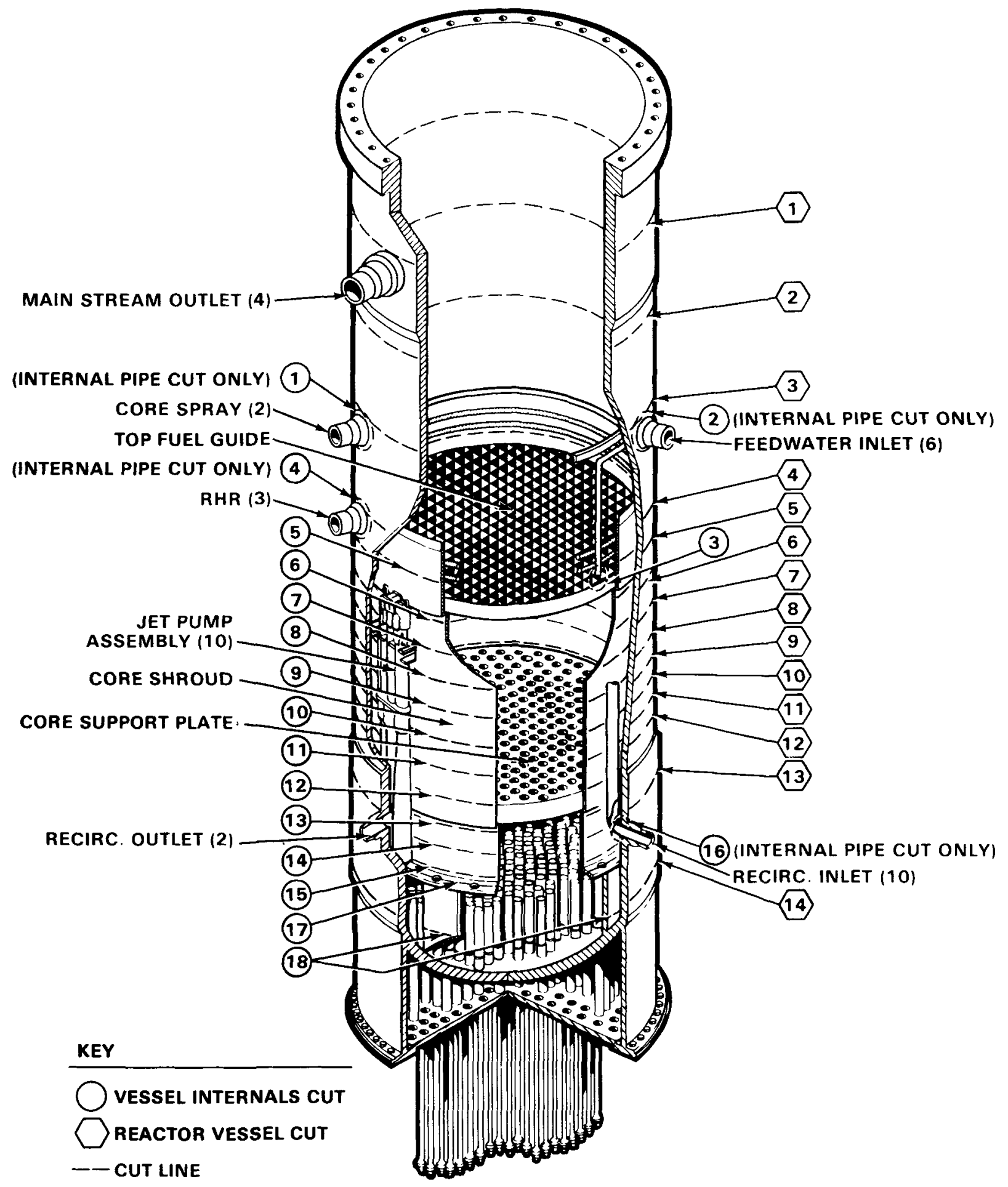

FIGURE I.1-1. Cutting Pattern for Removal of the Reactor Vessel Internals and the Reactor Vessel 
section of the reactor vessel (between reactor vessel cuts 4 and 12 shown in Figure I.1-1, and containing most of the activated portion of the reactor vesse1) are cut into pieces that are used to provide shielding for the central core shroud segments. Although the ring removed by reactor vessel cut 13 is also activated, it is too thick to use as shielding and is cut up and packaged by itself in steel cask liners.

Contaminated piping and equipment inside Primary Containment is removed, segmented, and packaged in standard or specially constructed shipping boxes for disposal. Cutting is accomplished with remote oxyacetylene cutting torches or portable power hacksaws.

The inner steel skin of the sacrificial shield is cut using an oxyacetylene torch guided by the manipulator mounted on the reactor vessel bottom head. The inner skin is cut after it is exposed by removal of rings of the reactor vessel. Cuts are made along lines that will result in packageable segments of the conerete shield when it is cut with explosives along the cuts in the skin. Matching cuts in the outer skin are made with an oxyacetylene torch. Holes for placement of explosive are drilled in the concrete along the lines of the cuts in the outer skin of the shield. The radial beams are cut with oxyacetylene torches and removed after the segments of sacrificial shield above their level are removed.

Contaminated concrete surfaces in the Reactor Building/Primary Containment are removed using the concrete spaller described in Section G.1.3.2 of Appendix G. A surface layer about $50 \mathrm{~mm}$ thick is assumed to be removed. The rubble is packaged in standard shipping boxes for disposal.

The contaminated HVAC systems and electrical equipment in the Reactor Building/Primary Containment are cut up into segments that are packaged in standard shipping boxes for disposal. Oxyacetylene torches are used for cutting.

Contaminated piping in the Reactor Building is cut into pieces that are packaged in standard shipping boxes. Cutting is accomplished with oxyacetylene torches or portable hacksaws. 
Small contaminated equipment in the Reactor Building is removed and packaged in standard shipping boxes. Large contaminated equipment with no external smearable contamination and weighing less than $20 \mathrm{Mg}$ is sealed by welding steel plates over all of the openings and shipped to the burial ground without additional packaging. Contaminated equipment too large or too heavy to be shipped as a unit is cut up, depending on its complexity, either into segments that fit into standard boxes (as is the case with the pool liners) or into segments that are sealed with welded steel plates and thus use the shell as the contamination barrier (as is the case with the residual heat removal [RHK] heat exchangers).

The stainless steel liners of the spent fuel storage pool, the dryer and separator storage pool, and the reactor well are cut up in air using a plasmaarc torch into segments that will fit in standard boxes. The spent fuel storage racks are packaged in specially built steel boxes for shipment to the burial ground.

\section{I.1.2 Turbine Generator Building}

Contamination of piping and equipment in the Turbine Generator Building results from contact with the reactor steam and steam condensate. Compared to the Primary Containment, contamination in the Turbine Generator Building is light, but fairly.extensive.

The main turbine is a very large machine that has to be dismantled and disposed of as contaminated material. Dimensions of the high-pressure turbine and the three low-pressure turbines are given in Table C.3-5 in Appendix $C$. Dismantlement of the high-pressure turbine is accomplished in the following sequence: 1) the cover is unbolted, removed, and segmented; 2) the top blade ring halves are removed and segmented; 3 ) the rotor is removed and segmented; 4) the bottom blade ring halves are removed and segmented; and 5) the base is removed and segmented. The removal sequence for each low-pressure turbine is: 1) outer cover, 2) No. 1 inner cover, 3) No. 2 inner cover, 4) top-half blade rings, 5) rotor, 6) bottom-half blade rings, 7) No. 2 inner base, 8) No. 1 inner base, and 9) outer base. Oxyacetylene torches are used for cutting the turbine components. 
Low-pressure feedwater heaters IA, IB, and IC and associated piping that are located in the steam inlets to the main condenser are water-jet cleaned to reduce the external contamination, then removed and packaged as required.

The condenser internal surfaces and the exposed external surfaces of the tube bundles are water-jet cleaned to reduce the radiation dose rate and the airborne contamination potential. The main condenser is shown in Figure C.3-7 in Appendix $C$. In each of the three banks of tubes there are two sections. The tubes in each section are supported by 14 tube support plates. The tubes are cut from between every other pair of support plates (e.g., between the first and second, third and fourth, and so on) leaving the tubes in place between the end tube sheet and the first support plate, and between the second and third support plates, the fourth and fifth support plates, and so on. The cut tube segments are packaged in standard shipping boxes. The tube sheets and support plates are cut to form segments of the tube bundle that fit in standard shipping boxes. After complete gutting, the condenser shell is segmented and packaged in standard shipping boxes.

The feedwater heaters and the moisture separator reheaters in the Turbine Generator Building are too large to transport to a burial ground in one piece. Since the external surfaces of these equipment pieces either have no smearable contamination or can be cleaned to that state, the shells of these pieces of equipment, after capping all openings, are used as shipping and burial containers. An example is the dismantlement of the two high-pressure feedwater heaters, which are $2.4 \mathrm{~m}$ in diameter and $12.5 \mathrm{~m}$ in length. Each high-pressure feedwater heater is cut into four sections with a maximum weight of $20 \mathrm{Mg}$ each. The she11 is cut circumferentially at the first designated cut line with an oxacetylene torch, and the shell section is moved back enough to make working room for cutting the tube-bundle at the same cut line. After cutting, the tube bundle section is slid into the shell section, then a steel plate is welded over the cut end of the shell section. Steel plates are likewise welded over all nozzles on the shell section. The remaining shell and tube bundle are cut at two more locations in a similar fashion, and the cut ends and the nozzles of the shell sections are sealed with welded steel plates. 
Contaminated piping, concrete surfaces, and HVAC and electrical equipment are removed as described previously for the Reactor Building/Primary Containment.

\section{I.1.3 Radwaste and Control Building}

Contaminated piping and equipment in the Radwaste and Control Building are primarily parts of the radwaste systems. Much of the liquid and solid radwastes from dismantlement of the Reactor Building and the Turbine Generator Building are processed in the radwaste systems before the systems are dismantled. A temporary, portable radwaste system is provided by a specialty contractor and is used to process liquid waste generated after dismantlement of the in-house liquid radwaste systems is started.

The techniques used in dismantling the piping and equipment in the Radwaste and Control Building are the same as those described previously for the Reactor Building and the Turbine Generator Building.

\section{I.1.4 Special Tools and Equipment}

Many of the tools and equipment needed for immediate dismantlement of the reference BWR are not needed during the plant's operating lifetime. The more unique devices used in dismantlement are described in Sections G.1, G.2, and G.4 of Appendix G. A listing of the special tools and equipment for immediate dismantlement and their functions is given in Table I.1-1.

\section{I.1.5 Summary of Disassembly Methods}

A summary of the dismantlement data for the reference BWR is given in Table 1.1-2. Dismantlement tasks that result in the removal of materials that contain neutron-activation products or are radioactively contaminated are identified, cutting data are presented, and removal conditions and methods are given.

\section{I.2 SCHEDULES AND MANPOWER REQUIREMENTS}

Development of the immediate dismantlement schedules and manpower requirements requires several steps to arrive at reasonably optimum results. The sequence in which the various systems must be decontaminated and dismantled is determined. Next, the task time requirements and the numbers and types of 


\section{TABLE I.1-1. Special Tools and Equipment for Immediate Dismantlement}

\begin{tabular}{|c|c|c|}
\hline Item & $\begin{array}{l}\text { Number } \\
\text { Required(a) }\end{array}$ & Function \\
\hline Underwater Manipulator & 1 & $\begin{array}{l}\text { Positioning and Movement of Underwater Cutting } \\
\text { Devices Used in Reactor Vessel }\end{array}$ \\
\hline Underwater Plasma-Arc Torch & 2 & Sectioning Vessel Internals \\
\hline Underwater 0xyacetylene Torch & 2 & Sectioning Reactor Vessel \\
\hline Arc Saw & 1 & $\begin{array}{l}\text { Sectioning Materials from Reactor Vessel and Inter- } \\
\text { nals }\end{array}$ \\
\hline Portable Plasma-Arc Torch & 2 & $\begin{array}{l}\text { Cutting Stainless Steel Equipment, Piping, and Pool } \\
\text { Liners }\end{array}$ \\
\hline Portable 0xyacetylene Torch & 10 & $\begin{array}{l}\text { Cutting Carbon Steel Equipment and Piping; Welding } \\
\text { Carbon Steel }\end{array}$ \\
\hline Remote-Controlled Oxyacetylene Torch & 4 & Remote Cutting of Carbon Steel Equipment and Piping \\
\hline Guillotine Pipe Saw & 10 & Cutting Piping \\
\hline Power-0perated Reciprocating Hacksaw & 10 & Sectioning Piping and Equipment \\
\hline Closed-Circuit, High-Resolution Television & 2 & Observation of Remote or Underwater Operations \\
\hline Underwater Lights and Periscopes & As Required & Illuminating and Observing Underwater Operations \\
\hline $\begin{array}{l}\text { Underwater Tools (e.g., Impact Wrenches, } \\
\text { Bolt Cutters, Tongs) }\end{array}$ & As Required & $\begin{array}{l}\text { Underwater Disassembly, Kandling, and Packaging of } \\
\text { Activated and Highly Contaninated Materials }\end{array}$ \\
\hline Subnersible Pump with Disposable Filter & 5 & $\begin{array}{l}\text { Oraining of Suppression Chamber and Spent Fuel } \\
\text { Storage Pools }\end{array}$ \\
\hline High-Pressure Water Jet & 2 & $\begin{array}{l}\text { Surface Decontamination of Suppression Chamber, } \\
\text { Tanks, Main Condenser, Pool Liners }\end{array}$ \\
\hline Pipe Jumper & 4 & Chemical Decontamination of Reactor Piping Systems \\
\hline Mobile Chemical Decontamination Unit & 5 & $\begin{array}{l}\text { Chemical Decontamination of Liquid and Solid Rad- } \\
\text { waste Equipment }\end{array}$ \\
\hline Mobile Chemical Mixing and Heating Unit & 4 & Chemical Decontamination of Drain Systems \\
\hline Scaffolding & 200 & Safe Access to Heights \\
\hline Safety Nets & As Required & $\begin{array}{l}\text { Protect Personnel Working on Elevated Equipment and } \\
\text { Structures }\end{array}$ \\
\hline $\begin{array}{l}\text { Power Operated, Mobile, Scissors-Type } \\
\text { Manlift }\end{array}$ & 6 & Safe Access to Heights \\
\hline $\begin{array}{l}\text { Power Operated, Mobile, Articulated-Arm } \\
\text { Manlift }\end{array}$ & 3 & Safe Access to Heights \\
\hline 9100-Kg Mobile Hydraulic Crane & 3 & $\begin{array}{l}\text { Removal and Packaging of Contaminated Piping and } \\
\text { Equipment }\end{array}$ \\
\hline 9100-Kg Forklift & 6 & $\begin{array}{l}\text { Packaging of Contaminated Materials, and Loading of } \\
\text { Trucks }\end{array}$ \\
\hline $\begin{array}{l}\text { Rigging Materials (e.g., Chokers, Grapples, } \\
\text { Winches, etc.) }\end{array}$ & As Required & Handling of Equipment and Piping \\
\hline $\begin{array}{l}\text { Concrete Drill with HEPA-Filtered Dust } \\
\text { Collecting System }\end{array}$ & 4 & $\begin{array}{l}\text { Drilling Holes in Concrete as Required for Blasting } \\
\text { or Surface Spalling }\end{array}$ \\
\hline Concrete Surface Spaller & 4 & Removal of Contaminated Concrete Surfaces \\
\hline Front-End Loader (Light Duty) & 3 & Cleanup and Packaging of Concrete Rubble \\
\hline Vacuum Cleaner (HEPA-Filtered) & 3 & Cleanup of Concrete Rubble Fines \\
\hline Portable Ventilation Enclosure & 10 & $\begin{array}{l}\text { Contamination Control During Cutting of Contami- } \\
\text { nated Material }\end{array}$ \\
\hline Supplied-Air Plastic Suit & 250 & $\begin{array}{l}\text { Provide Personnel with Maximum Respiratory and Body- } \\
\text { Surface Protection from Radioactive Contaminants }\end{array}$ \\
\hline Filtered-Exhaust Fan Unit & 4 & $\begin{array}{l}\text { Contamination Control and Personnel Comfort } \\
\text { During Main Condenser Removal }\end{array}$ \\
\hline Polyurethane Foam Generator & 2 & Contamination Control During HVAC Removal \\
\hline
\end{tabular}

(a)Based on a taskwise analysis of the immediate dismantlement schedule, plus spares as required. 


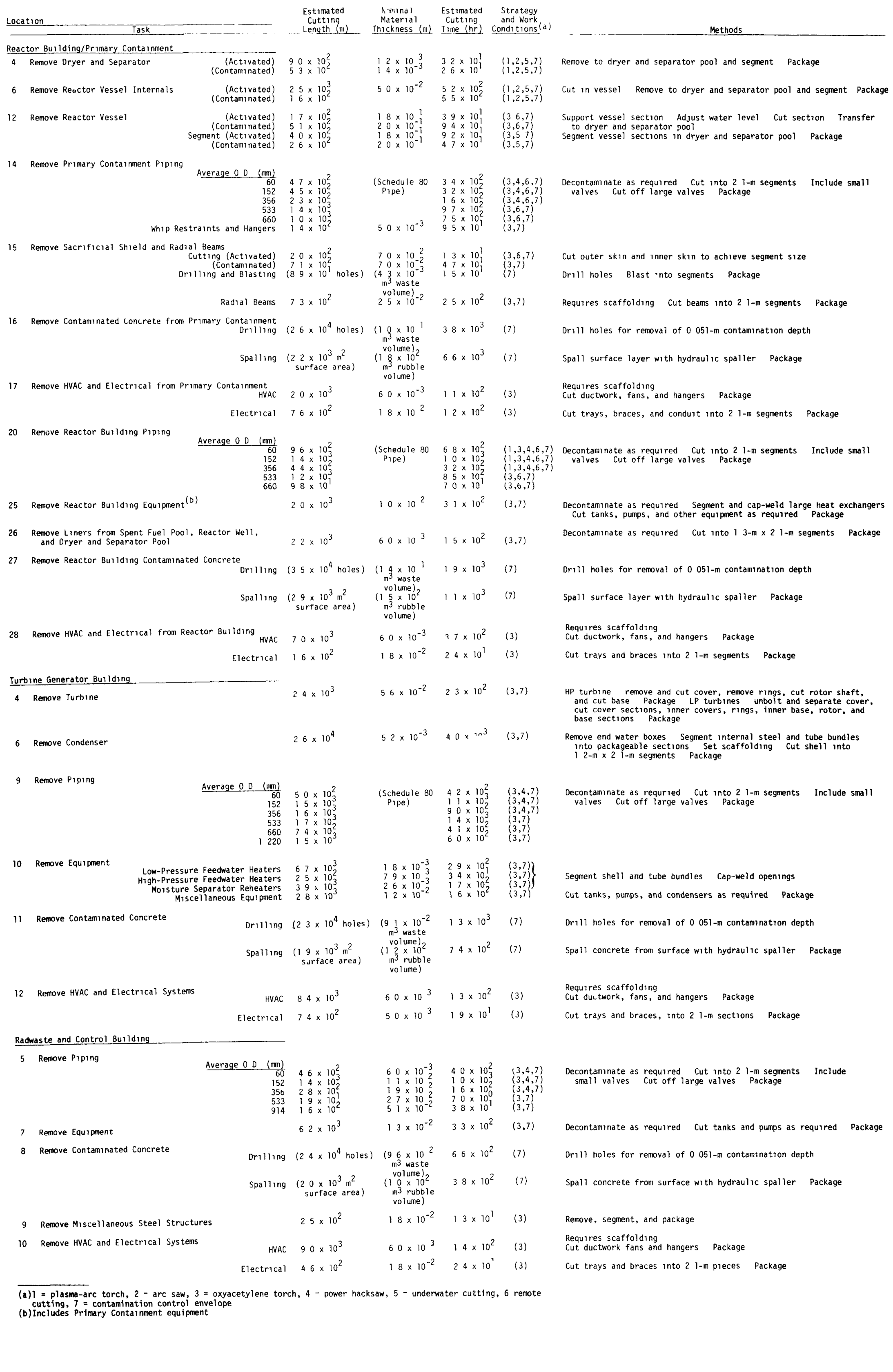


$\Omega$ 
decommissioning workers required to accomplish each task in the allotted time are estimated (the functions and organization of the decommissioning staff are discussed in Section H.l of Appendix H). Based on the estimated dose to accomplish each task, the number of workers needed to complete the radiation zone work in the allotted time and within the assumed radiation dose limits is determined. Whole-body radiation doses to the decommissioning workers are limited in accordance with 10 CFR 20.101. The supervisors, utility operators, and health physics technicians are assumed to be long-time radiation workers whose annual exposure is 1 imited to $5 \mathrm{rem} / \mathrm{yr}$ by the formula $5(\mathrm{~N}-18)$ of 10 CFR 20.101(b)(2). The craftsmen and laborers are assumed to have had little prior radiation exposure and, therefore, under 10 CFR 20.101(b)(1) and (2) may receive up to 3 rem per quarter, within the limitation of the formula $5(\mathrm{~N}-18)$. In those instances where the manpower estimated for physicially accomplishing a task results in an average dose for each person in excess of these limits, additional people are assigned to the tasks to keep the individual occupational doses below these limits. In the manpower tables presented in this section, the manpower shown is adequate both to accomplish the task and to meet these occupational dose limits.

Task schedules and decommissioning worker requirements for immediate dismantlement of the Reactor Building/Primary Containment, the Turbine Generator Building, and the Radwaste and Control Building are discussed and presented in the following three subsections. The decommissioning worker requirements given in these subsections do not include the management and support staff (see Figure H.1-1 in Appendix H). A fourth subsection presents the overall task schedule and decommissioning worker requirements and the total staff labor requirements for immediate dismantlement of the reference BWR.

\section{I.2.1 Reactor Building/Primary Containment}

Over half the effort of dismantling the reference BWR is involved in the Reactor Building/Primary Containment. All of the neutron-activated materials are in the Primary Containment and much of the material contaminated with fission products and activated corrosion products is in the Primary Containment and the Reactor Building. Based on the dismantlement methods discussed previously in Section I.1 and the occupational dose estimates presented later in Section I.4, 
the task schedule and sequence and the decommissioning worker requirements for immediate dismantlement of the Reactor Building/Primary Containment are presented in Figure I.2-1. Immediate dismantlement of the Reactor Building/Primary Containment is estimated to be accomplished in about 30 months following final reactor shutdown and is estimated to require about 2340 man-months of decommissioning worker effort.

\section{I.2.2 Turbine Generator Building}

The Turbine Generator Building has less deposited radioactive contamination per unit area than the other two buildings, and, therefore, has the lowest radiation dose rates for dismantlement of the contaminated piping and equipment. In arranging the task schedule for immediate dismantlement of the Turbine Generator Building, the work is planned so that low radiation exposure work in this building is in progress at the same time as much of the high exposure work in the other two buildings, so that by rotating workers between the buildings more efficient utilization of the manpower from an occupational dose consideration can be achieved. The task schedule and sequence and the decommissioning worker requirements for immediate dismantlement of the Turbine Generator Building are given in Figure I.2-2. Immediate dismantlement of the Turbine Generator Building is estimated to be completed 27 months following final reactor shutdown and is estimated to require approximately 640 man-months of decommissioning worker effort.

\section{I.2.3 Radwaste and Control Building}

The 1 iquid and solid radwaste systems located in the Radwaste and Control Building are needed to process most of the contaminated liquids contained in the systems at final reactor shutdown and generated during dismantlement. Consequently, the Radwaste and Control Building is the last to be dismantled. A temporary, portable radwaste system is assumed installed when expedient to process the remainder of these contaminated liquids during dismantlement of the in-house systems. Figure I.2-3 shows the task schedule and sequence and the decommissioning worker requirements for immediate dismantlement of the Radwaste and Control Building. Dismantlement of the Radwaste and Control Building starts in month 17 after final reactor shutdown and continues through 


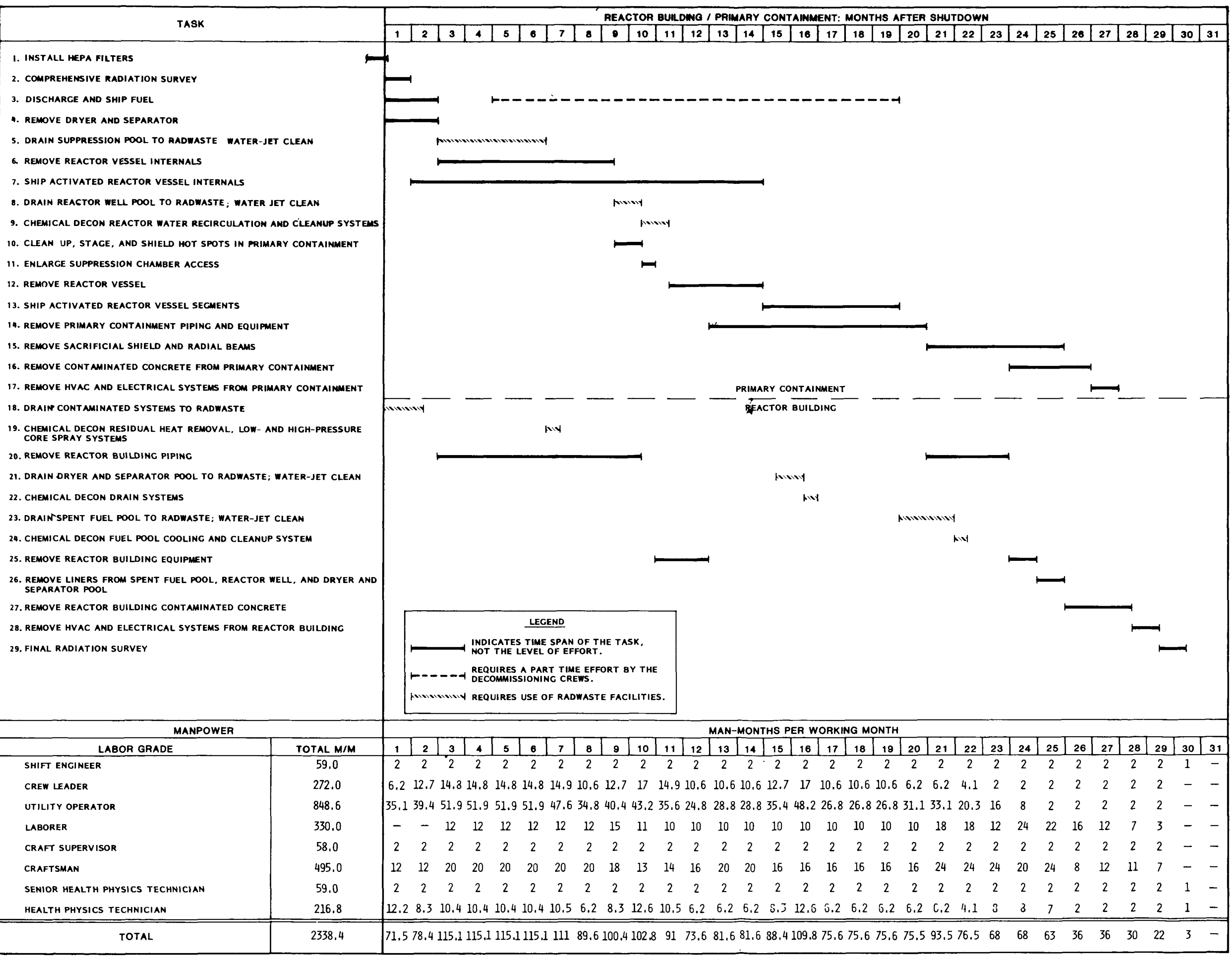

FIGURE I.2-1. Task Schedule and Sequence and Decommissioning Worker Requi rements for Immediate Dismantlement of the Reactor Building/Primary Containment 


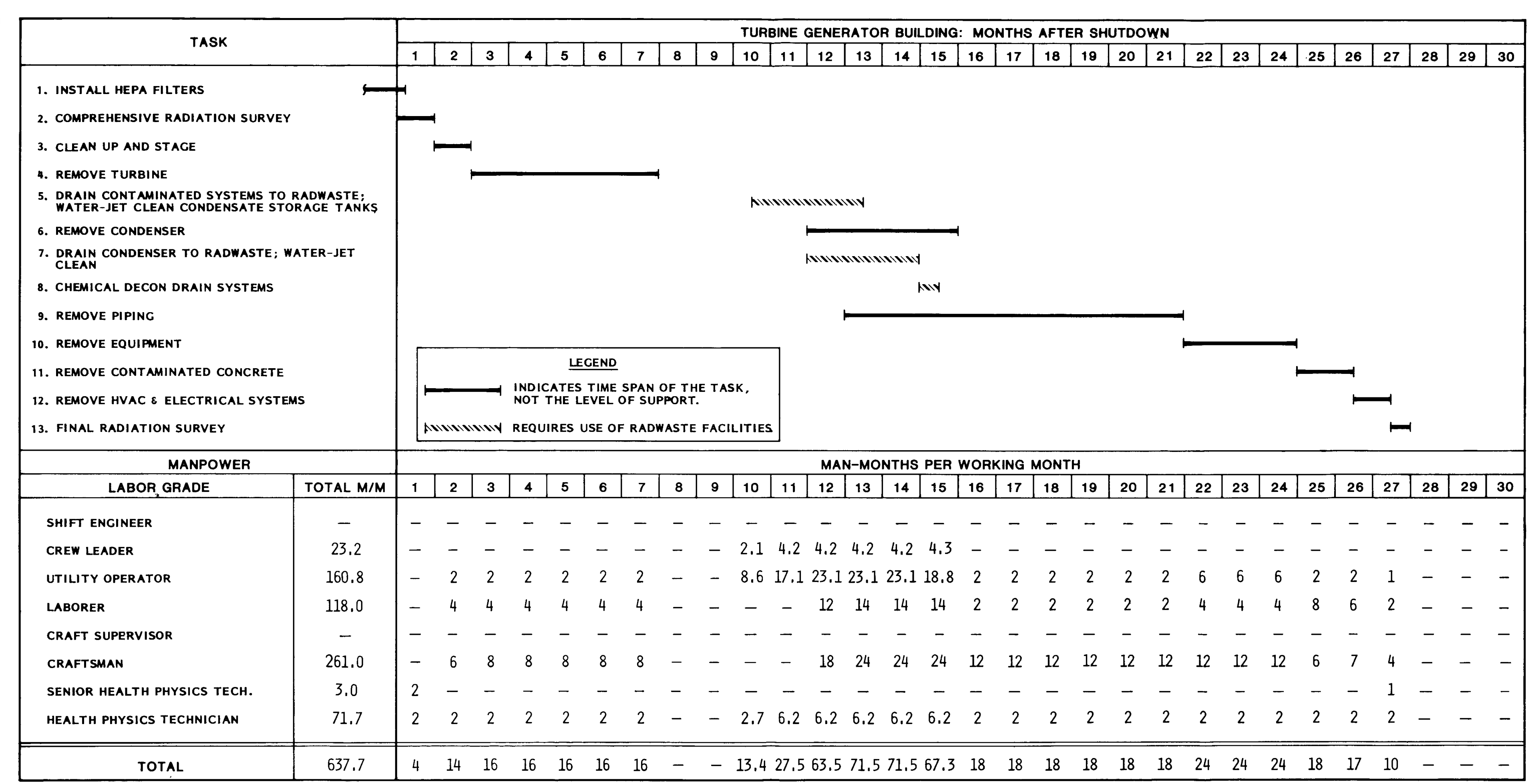

FIGURE I.2-2. Task Schedule and Sequence and Decommissioning Worker Requirements for Immediate Dismantlement of the Turbine Generator Building 
○ 


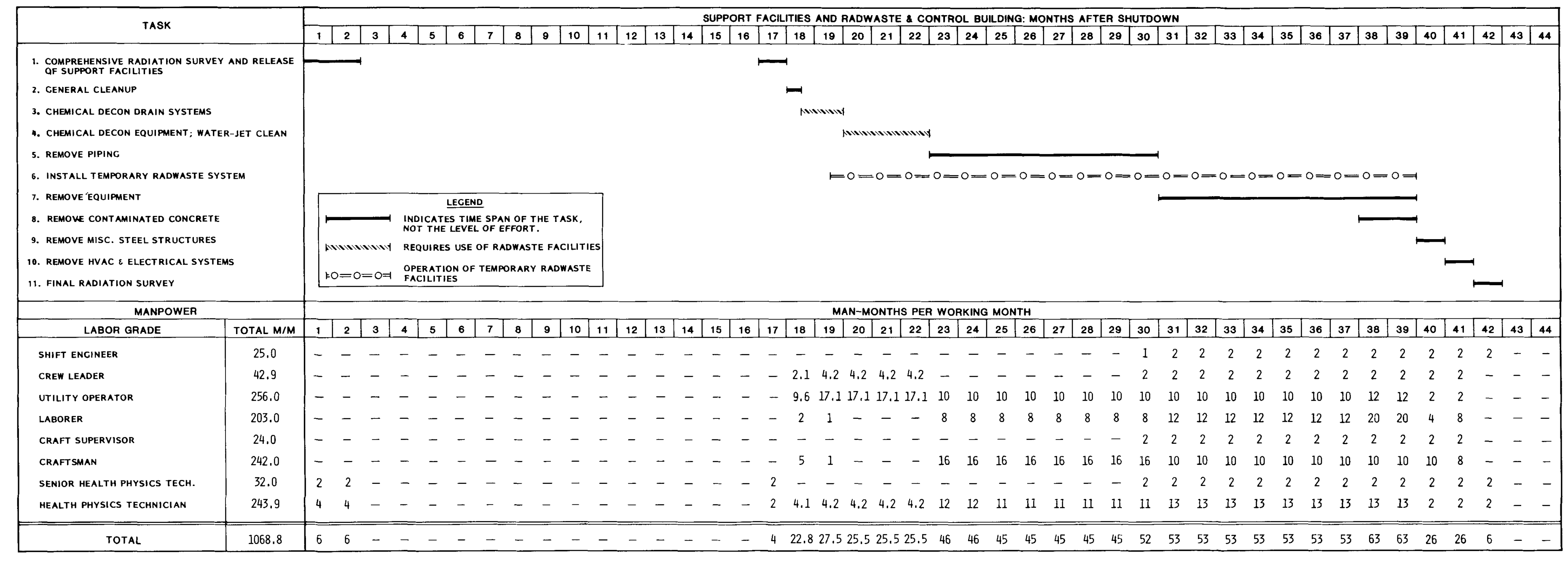

FIGURE 1.2-3. Task Schedule and Sequence and Decommissioning Worker Requirements for Immediate Dismantlement of the Rad-
Waste and Control Building 

month 42, thus requiring an estimated 25 months to complete. In addition, it is estimated to require nearly 1070 man-months of decommissioning worker effort.

\section{I.2.4 Overall Schedule and Manpower Requirements}

The overall task schedule and sequence for immediate dismantlement of the reference BWR is shown in Figure I.2-4. The planning and preparation tasks (see Section $\mathrm{H} .2$ of Appendix $H$ ) for the estimated 2-year period preceding reactor shutdown are also included. Dismantlement of the three buildings is estimated to be accomplished in 42 months after final reactor shutdown.

Immediate dismantlement tasks, with a few exceptions, are performed on two 8-hr shifts, 5 days per week. Discharge and shipment of spent fuel, shipment of neutron-activated reactor vessel internals and reactor vessel segments, decontamination and draining of systems and equipment, and operation of the radwaste systems are conducted three shifts per day, 7 days per week, as required. The overall dedicated manpower requirements for each immediate dismantlement task are given in Table I.2-1. The overall decommissioning worker requirements for the period following reactor shutdown are shown in Table 1.2-2. Slightly more than 4040 man-months of "hands-on" effort are estimated.

The total staff labor requirements for immediate dismantlement of the reference BWR are given in Table I.2-3. These requirements are given in equivalent man-years for the 2 years before and the 4 years following final reactor shutdown, and include the management and support staff as we]l as the decommissioning workers. A little more than 610 man-years of effort are estimated for immediate dismantlement of the reference BWR, including approximately 230 man-years for the management and support staff and about 380 man-years for the decommissioning workers. The following assumptions are used in making this estimate:

- The annual managementand support staff requirements are nearly identical to those specified in Reference 1, except for the control room operators, the security shift supervisors, and the security patrolmen, whose requirements are developed specifically for this study. 


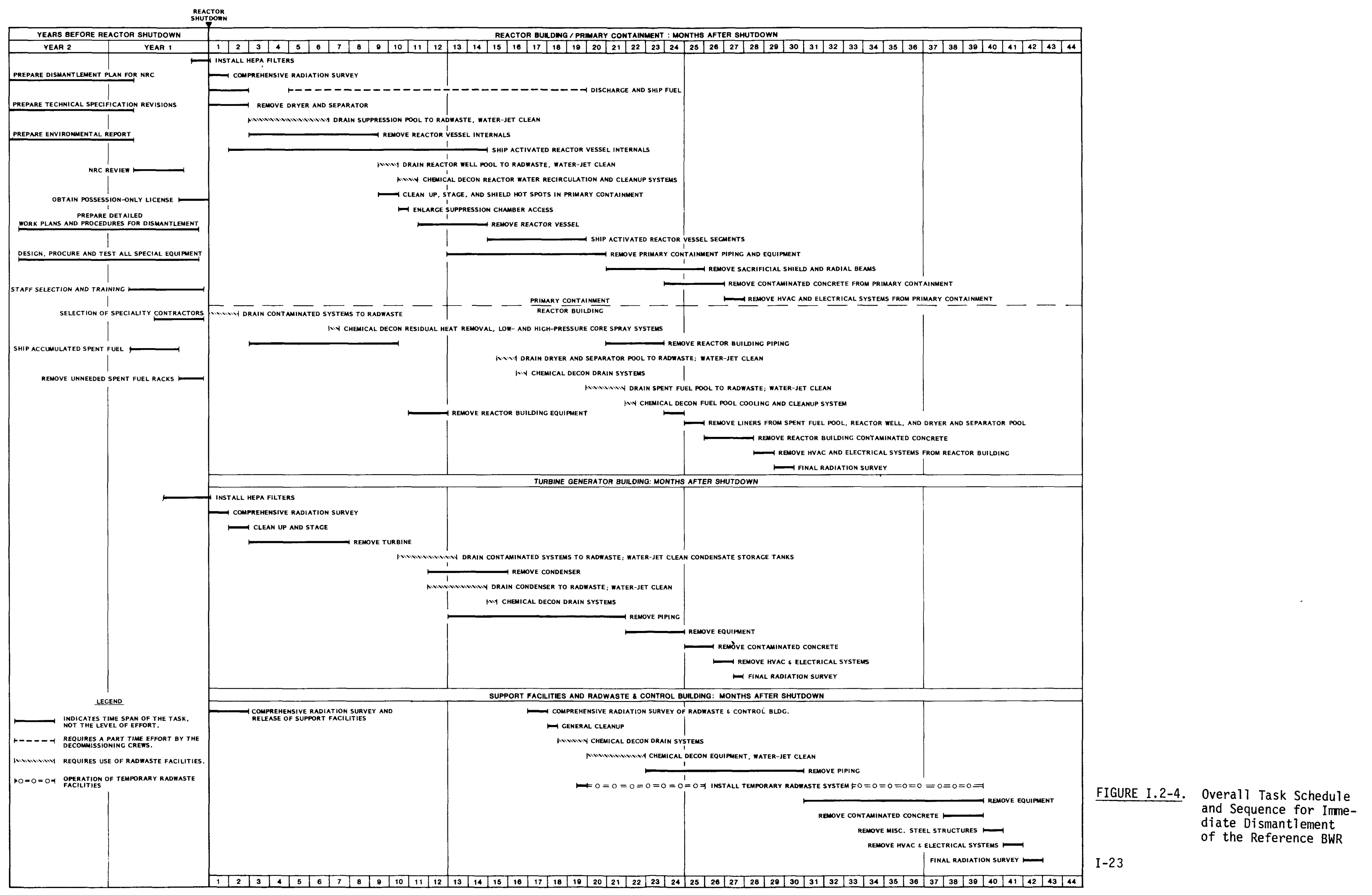


Building Task(b)

Reactor Building/Primary Containment

1. Install HEPA Filters (c)

2. Comprehensive Radiation Survey
3. Discharge and Ship Fue 1

4. Remove Dryer and Separator
5. Drain Suppression Pool to Radwaste;

6. Remove Reactor Vessel Internals

7. Ship Actjuated Reactor Vessel Inter-

8. Drain Reactor Well Pool to

Radwaste; Water-Jet Clean (e)

Chemical Decon Reactor Water Recir-
culation and Cleanup Systems (e)

10. Cleanup, Stage and Shield Hot Spots Enlarge Suppresston Chamber Access

12. Remove Reactor Vessel

13. Ship Activated Reactor Vessel

4. Remove Primary Containment Piping

15. Remove Sacrificial Shield and Radial
Beams

16. Remove Contaminated Concrete from

17. Remove HVAC and Electrical Equipment from Primary Containment
Orain Contaminated Systems to Radwaste(e)

19. Chemical Decon Residual Heat Removal, Low- and High-Pressure Core Spray Systems (e)

20. Remove Reactor Building Piping(g)
21. Drain Dryer and Separator Pool to Radwaste; Water-Jet clean (e)

22. Chemical Decon Drain Systems (e)

23. Drain Spent Fuel Pool To $(e)$ 24. Chemical Decon Fuel Pool Cooling
and Cleanup System(e) 25. Remove Reactor Building Equipment
26. Remove Liners from Spent Fuel Pool,
Reactor We1l, and Dryer and Separator Pool
Remove Reactor Building Contami-

28. Remove HVAC and Electrical Systems 29. Final Radiation Survey (h)

Turbine Generator Building

1. Install HEPA Filters $(c)$
2. Comprehensive Radiation Survey $(d)$
3. Cleanup and Stage

4. Remove Turbine Drain Contaminated Systems to Radwaste; Water-Jet Clean Conden-

6. Remove Condenser

7. Drain Condenser to Radwaste; Chemical Decon Drain Systems (e)

. Remove Piping

10. Remove Equipment

. Remove Contaninated Concrete

13. Remove HVAC \& Electrical Systems

Radwaste and Control Building

1. Comprehensive Radiation Survey and Release of Support Facilities/Compwaste \& Control Building(h)

2. General Cl eanup

3. Chemical Decon Orain Systems (e)

4. Chemical pecon Equipment; Water-Jet

6. Install Temporary Radwaste System

7. Remove Equipment

Remove Contaminated Concrete Remove Miscellaneous Steel Structures

10. Remove HVAC and Electrical Systems Dask Dedicated Manpower Requirements
Utility (a)
(man-months)
Health Physics

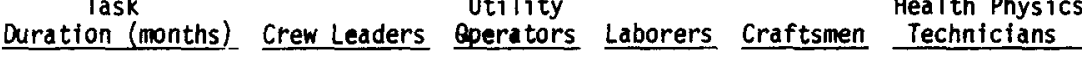

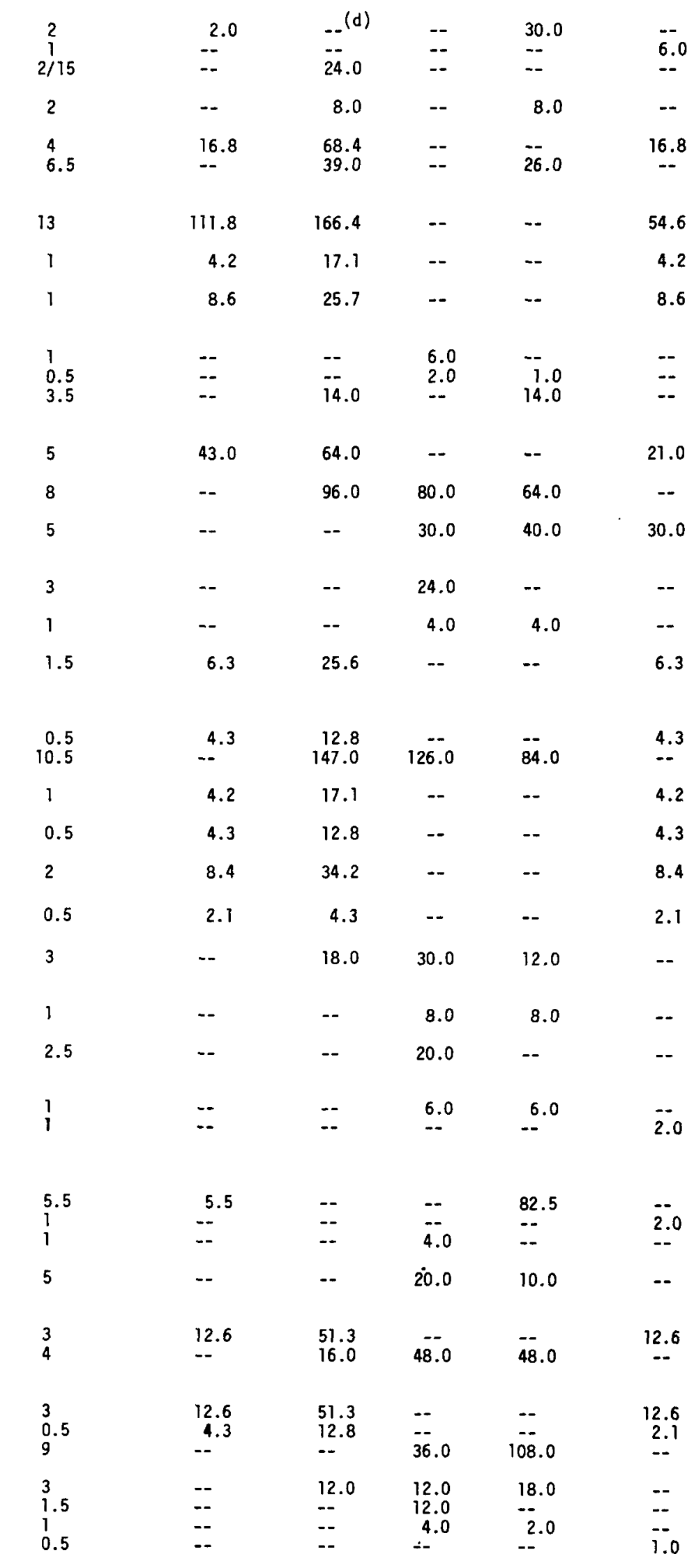

$\begin{array}{lllrrc}2 / 1 & -- & -- & -- & -- & 10.0 \\ 0.5 & -- & -- & -2.0 & 2.0 & --.3 \\ 1.5 & 6.3 & 25.6 & -- & 6.3 & 6.3 \\ & & & & & \\ 3 & 12.6 & 51.3 & -- & 12.6 & 12.6 \\ 8 & -- & 80.0 & 64.0 & 128.0 & 80.0 \\ 0.5 & -- & -- & 1.0 & 1.0 & - \\ 9 & -- & 90.0 & 108.0 & 90.0 & 90.0 \\ 2 & -- & -- & 16.0 & - & - \\ 1 & -- & -- & 4.0 & 4.0 & -- \\ 1 & -- & -- & 8.0 & 8.0 & -- \\ 1 & -- & -- & -- & -- & 2.0\end{array}$

(a) Non-dedicated personnel per shift (two-shift-per-day basis) include one shift engineer, one crew leader, one craft upervisor, and one senior health physics technician, as well as one packing and support crew (one utility operator and three craftsmen) and one health physics technician for each building undergoing active dismantlement.

(b) Al casks are conducted on two-shift-per-day basis, 5 days per week, except as noted otherwise.

(d) Indicates either no dedicated personel reguired or sufficient for consistency's sake.

lavailable to complete the task.

C) Conducted on a three-shift-per-day, 7-days-per-week basis:
f) Conducted on a three-shift-per-day, 7-days-per-week basis.

(h) Requires assigrment of additional senior heal th physics technician(s). 


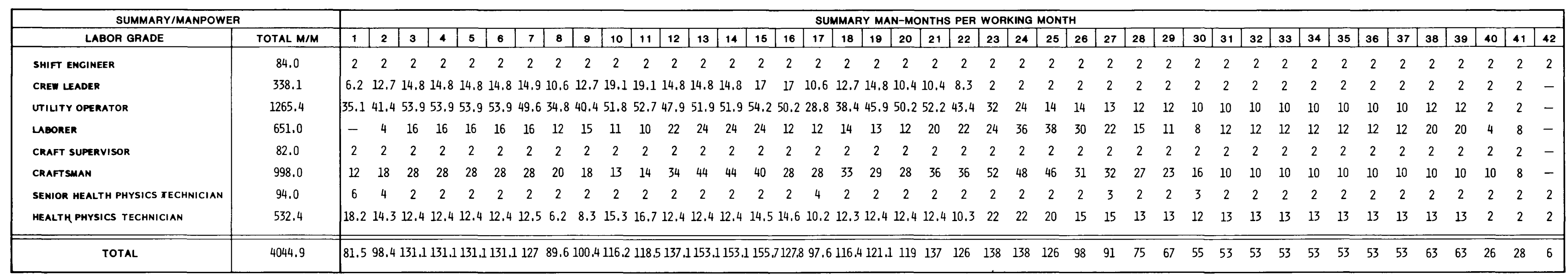




\section{TABLE 1.2-3. Staff, Labor Requirements for Immediate Dismantlement}

\begin{tabular}{|c|c|c|c|c|c|c|c|}
\hline Position & $\frac{\text { Time }}{\frac{-2}{\text { Annua }}}$ & $\frac{\text { Relative }}{1 \frac{-1}{\text { Staff }}}$ & to Final & $\frac{\text { Reactor }}{\frac{2}{\text { uirement }}}$ & $\frac{\text { Shutdo }}{\frac{3}{\operatorname{man}-y}}$ & $\frac{\text { wn (year) }}{4}$ & $\begin{array}{l}\text { Total St: } \\
\text { Labor Requ } \\
\text { Iman-year }\end{array}$ \\
\hline \multicolumn{8}{|l|}{ Management and Support Staff } \\
\hline $\begin{array}{l}\text { Decommissioning Superintendent } \\
\text { Secretary } \\
\text { Clerk }\end{array}$ & $\begin{array}{l}0.3 \\
1.0 \\
0\end{array}$ & $\begin{array}{l}1.0 \\
2.0 \\
1.0\end{array}$ & $\begin{array}{l}1.0 \\
3.0 \\
2.0\end{array}$ & $\begin{array}{l}1.0 \\
3.0 \\
2.0\end{array}$ & $\begin{array}{l}1.0 \\
3.0 \\
2.0\end{array}$ & $\begin{array}{l}0.8(b) \\
1.6 \\
0.5\end{array}$ & $\begin{array}{r}5.1 \\
13.6 \\
7.5\end{array}$ \\
\hline $\begin{array}{l}\text { Decommissioning Engineer } \\
\text { Assistant Decommissioning Engineer } \\
\text { Radioactive Shipment Specialist }\end{array}$ & $\begin{array}{l}1.0 \\
1.0 \\
0\end{array}$ & $\begin{array}{l}1.0 \\
1.0 \\
1.0\end{array}$ & $\begin{array}{l}1.0 \\
1.0 \\
1.0\end{array}$ & $\begin{array}{l}1.0 \\
1.0 \\
1.0\end{array}$ & $\begin{array}{l}1.0 \\
1.0 \\
1.0\end{array}$ & $\begin{array}{l}0.8^{(b)} \\
0.4 \\
0.4\end{array}$ & $\begin{array}{l}5.8 \\
5.4 \\
4.4\end{array}$ \\
\hline $\begin{array}{l}\text { Procurement Specialist } \\
\text { Tool Crib Attendant } \\
\text { Control Room Operator } \\
\text { (c) }\end{array}$ & $\begin{array}{l}0.3 \\
0 \\
0\end{array}$ & $\begin{array}{l}1.0 \\
0 \\
0\end{array}$ & $\begin{array}{l}1.0 \\
2.0 \\
5.0\end{array}$ & $\begin{array}{l}1.0 \\
2.0 \\
5.0\end{array}$ & $\begin{array}{l}1.0 \\
2.0 \\
5.0\end{array}$ & $\begin{array}{l}0.4 \\
0.8 \\
2.1\end{array}$ & $\begin{array}{r}4.7 \\
6.8 \\
17.1\end{array}$ \\
\hline $\begin{array}{l}\text { Security Supervisor } \\
\text { Security Shift Superyisor (d) } \\
\text { Security Patrolman(d) } \\
\text { Contracts and Accounting Specialist }\end{array}$ & $\begin{array}{l}0 \\
0 \\
0 \\
0.3\end{array}$ & $\begin{array}{l}0 \\
0 \\
0 \\
1.0\end{array}$ & $\begin{array}{r}1.0 \\
5.0 \\
39.0 \\
1.0\end{array}$ & $\begin{array}{r}1.0 \\
5.0 \\
28.0 \\
1.0\end{array}$ & $\begin{array}{r}1.0 \\
5.0 \\
13.0 \\
1.0\end{array}$ & $\begin{array}{l}0.5 \\
2.5 \\
6.5 \\
0.8\end{array}$ & $\begin{array}{r}3.5 \\
17.5 \\
86.5 \\
5.1\end{array}$ \\
\hline $\begin{array}{l}\text { Health and Safety Supervisor } \\
\text { Health Physicist } \\
\text { Protective Equipment Attendant } \\
\text { Industrial Safety Specialist }\end{array}$ & $\begin{array}{l}1.0 \\
0 \\
0 \\
0.3\end{array}$ & $\begin{array}{l}1.0 \\
0.5 \\
0 \\
1.0\end{array}$ & $\begin{array}{l}1.0 \\
1.0 \\
2.0 \\
1.0\end{array}$ & $\begin{array}{l}1.0 \\
1.0 \\
2.0 \\
1.0\end{array}$ & $\begin{array}{l}1.0 \\
1.0 \\
2.0 \\
1.0\end{array}$ & $\begin{array}{l}0.8^{(b)} \\
0.5 \\
1.0 \\
0.5\end{array}$ & $\begin{array}{l}5.8 \\
4.0 \\
7.0 \\
4.8\end{array}$ \\
\hline $\begin{array}{l}\text { Quality Assurance Supervisor } \\
\text { Quality Assurance Engineer } \\
\text { Quality Assurance Technician } \\
\text { Consultant (Safety Review) }\end{array}$ & $\begin{array}{l}0.3 \\
0.5 \\
0 \\
0.5 \\
\end{array}$ & $\begin{array}{l}1.0 \\
2.0 \\
0.5 \\
0.5 \\
\end{array}$ & $\begin{array}{l}1.0 \\
1.0 \\
4.0 \\
0.5 \\
\end{array}$ & $\begin{array}{l}1.0 \\
1.0 \\
4.0 \\
0.5 \\
\end{array}$ & $\begin{array}{l}1.0 \\
1.0 \\
4.0 \\
0.5 \\
\end{array}$ & $\begin{array}{l}0.8^{(b)} \\
0.5^{(b} \\
2.0 \\
0.3\end{array}$ & $\begin{array}{r}5.1 \\
6.0 \\
14.5 \\
2.8 \\
\end{array}$ \\
\hline Subtotals, Management and Support Staff & $\underline{6.5}$ & 15.5 & 74.5 & 63.5 & 48.5 & $\underline{24.5}$ & 233.0 \\
\hline \multicolumn{8}{|l|}{ Decommissioning Workers (e) } \\
\hline $\begin{array}{l}\text { Shift Engineer } \\
\text { Crew Leader(f) }\end{array}$ & $\begin{array}{l}1.0 \\
0\end{array}$ & $\begin{array}{l}2.0 \\
1.0\end{array}$ & $\begin{array}{r}2.0 \\
15.7\end{array}$ & $\begin{array}{r}2.0 \\
12.0\end{array}$ & $\begin{array}{l}2.0 \\
2.0\end{array}$ & $\begin{array}{l}1.0 \\
0.8\end{array}$ & $\begin{array}{l}10.0 \\
31.5\end{array}$ \\
\hline $\begin{array}{l}\text { Utility Operator }(g) \\
\text { Laborer } \\
\text { Craft Supervisor }\end{array}$ & $\begin{array}{l}0 \\
0 \\
0\end{array}$ & $\begin{array}{l}3.2 \\
0 \\
0.6\end{array}$ & $\begin{array}{r}55.0 \\
12.9 \\
2.0\end{array}$ & $\begin{array}{r}49.6 \\
19.8 \\
2.0\end{array}$ & $\begin{array}{r}12.4 \\
16.3 \\
2.0\end{array}$ & $\begin{array}{l}3.3 \\
5.3 \\
0.8\end{array}$ & $\begin{array}{r}123.5 \\
54.3 \\
7.4\end{array}$ \\
\hline $\begin{array}{l}\text { Craftsman } \\
\text { Senior Heal th Physics Technician } \\
\text { Health Physics Technician(h) }\end{array}$ & $\begin{array}{l}0 \\
0 \\
0\end{array}$ & $\begin{array}{r}10.0 \\
1.0 \\
3.0 \\
\end{array}$ & $\begin{array}{r}22.4 \\
2.5 \\
14.3 \\
\end{array}$ & $\begin{array}{r}37.2 \\
2.2 \\
14.9 \\
\end{array}$ & $\begin{array}{r}19.6 \\
2.1 \\
14.0 \\
\end{array}$ & $\begin{array}{l}4.0 \\
1.0 \\
3.8 \\
\end{array}$ & $\begin{array}{r}93.2 \\
8.8 \\
50.0 \\
\end{array}$ \\
\hline Subtotals, Decommissioning Workers & 1.0 & 20.8 & $\underline{126.8}$ & $\underline{139.7}$ & 70.4 & 20.0 & 378.7 \\
\hline Totals & 7.5 & 36.3 & 201.3 & 203.2 & 118.9 & 44.5 & 611.7 \\
\hline
\end{tabular}

(a) Rounded to the next higher 0.1 man-year.

(b) Includes an additional 4 months following active decommissioning in order to complete the documentation and other unspecified 1 icense and contract termination requirements.

(c) Based on one operator per shift in the control room, three shifts per day, 7 days per week.

(d) Based on 10 CFR Part 73 and information obtained from Washington Public Power Supply System; includes both response and access-control personnel on a three-shift, 7-day-week basis.

(e) Requirements during the 4 years following reactor shutdown are based on Table 1.2-2, unless otherwise noted; individual man-month requirements in Table $1.2-2$ are rounded to the next higher 1.0 man-month in calculating these requirements.

(f) Based on a constant loading of 15 people through month 19 following reactor shutdown, with additional personnel added as required to meet schedule demands during that period, and diminishing thereafter as the schedule allows.

(g) Based on a constant loading of 55 people through month 21 following reactor shutdown, diminishing as the schedule allows, except during months 30 through 37 when 12 trained personnel are maintained to meet the requirements during months 38 and 39 .

(h)Based on a constant loading of 13 people through month 39 following reactor shutdown, with additional personnel added as required to meet schedule demands during that period. 
- Supervisors, including the shift engineers, the craft supervisors, and the senior health physics technicians, are staffed one per shift on a two-shift, 5-day-week basis, except for additional senior health physics technicians as required for comprehensive and final radiation surveys.

- A basic force of trained crew leaders is augmented by locally available craft foremen as required.

- Utility operators are specially trained for their functions and are not readily available on the open job market; therefore, a group large enough to meet the peak manpower requirements during active decommissioning is trained during the planning and preparation phase and maintained until the schedule allows a permanent reduction.

- Laborers and craftsmen are readily available from the open job market and are hired as required.

- A basic force of health physics technicians is augmented by special contract service health physics technicians to meet schedule peaking requirements. Salary costs for these extra health physics technicians are assumed the same as for the regular ones.

The total staff labor requirements shown in Table 1.2-3 for the decommissioning workers during the 4 years following reactor shutdown exceed the overall decommissioning worker requirements presented in Table I.2-2 because of the above assumptions. This "excess" manpower is assumed used for the numerous, small, unspecified work items that accompany an activity of this magnitude.

\section{I.3 COSTS FOR IMMEDIATE DISMANTLEMENT}

The costs for immediate dismantlement of the reference BWR are presented in this section. These costs are all adjusted to early 1978 to provide consistency within this series of NRC nuclear facility decommissioning studies. (2) The estimated costs and the other possible costs for immediate dismantlement of the reference BWR are summarized and totaled in Table I:3-1.

The total cost for inmediate dismantlement is estimated at about $\$ 43.6$ million, including a $25 \%$ contingency. Costs for disposal of radioactive materials, staff labor, and energy (at approximately $25 \%, 50 \%$, and $10 \%$ of the total, 
TABLE 1.3-1. Summary of Estimated Costs for Immediate Dismantlement

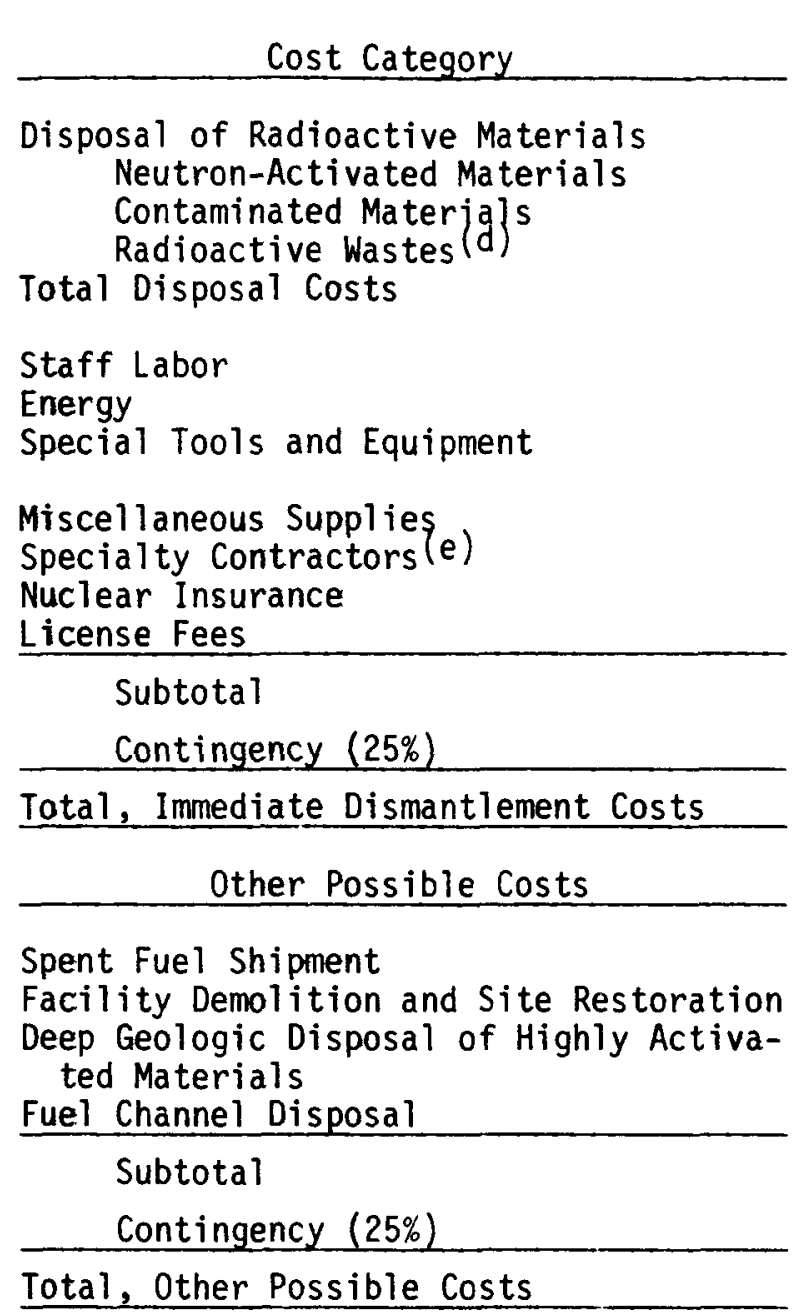

\begin{tabular}{ll} 
Estimated Costs & $\begin{array}{l}\text { Percent of } \\
\text { (\$millions) }(a, b)\end{array}$ \\
\hline
\end{tabular}

2.300

4.909

1.469

$8.678 \quad 24.9$

$17.561 \quad 50.4$

$3.579 \quad 10.1$

$2.016 \quad 5.8$

$1.859 \quad 5.3$

$0.356 \quad 1.0$

$0.800 \quad 2.3$

$\underline{0.051} \quad \underline{0.1}$

$34.840 \quad 100.0$

8.710

43.550

$$
\begin{aligned}
& 3.788^{(f)} \\
& 13.244 \\
& 0.848^{(g)} \\
& \frac{0.617^{(h)}}{18.497} \\
& \frac{4.624}{23.121}
\end{aligned}
$$

(a) Costs adjusted to early 1978.

(b) The number of significant figures shown is for computational completeness and does not imply accuracy to the nearest $\$ 1000$.

(c) Individually rounded to the nearest $0.1 \%$.

(d) Includes both wet solid wastes and dry solid wastes.

(e) Includes explosives, temporary radwaste, and environmental monitoring services.

(f) Does not include costs for handling at the reactor or costs for handling and storage at the repository; if required, shipment by special train costs an additional estimated $\$ 2.451$ million, maximum.

(g) Incremental cost in addition to the cost for shallow-land disposal of these materials; the maximum additional cost for shipment by special train is estimated at $\$ 1.254$ million.

(h)Alternate deep geologic disposal costs an estimated $\$ 1.047$ million; shipment by special train to the deep geologic disposal facility increases this cost by an estimated maximum cost of $\$ 0.456$ million. 
respectively) are the major contributors to the total cost for immediate dismantlement. Combined costs for special tools and equipment and for miscellaneous supplies make up an additional $11 \%$ of the total; combined costs for specialty contractors, nuclear insurance, and 1 icense fees contribute about $4 \%$ of the total.

The total cost for other possible immediate dismantlement requirements (i.e., spent fuel shipment, facility demolition and site restoration, deep geological disposal of highly activated materials, and fuel channel disposal) is estimated at approximately $\$ 23$ million, including a $25 \%$ contingency. This total cost could go as high as nearly $\$ 29$ million depending on the additional requirements specified in the footnotes to Table I.3-1.

Detailed cost data for the individual cost categories shown in Table I.3-1 are presented and discussed in the following subsections.

\section{I.3.1 Costs for Disposal of Radioactive Materials}

Three distinct types of radioactive materials in the reference BWR require disposal during immediate dismantlement: 1) neutron-activated materials, 2) contaminated materials, and 3) radioactive wastes. The total cost for disposal of these materials is about $\$ 8.7$ million and is approximately $25 \%$ of the total immediate dismantlement cost. The disposal cost includes the container, transportation, and burial costs, but does not include the direct labor costs for removing and packaging these materials. Labor costs are incurred regardless of the decommissioning activity and are discussed later (Section I.3.2). Table I.3-2 contains a summary of the number of shipments, the burial volumes, and the disposal costs for the radioactive materials.

The disposal costs of the three types of radioactive materials are discussed in more detail in the following subsections. 
TABLE I.3-2. Summary Information Regarding Disposal of Radioactive Materials from Immediate Dismantlement

\begin{tabular}{|c|c|c|c|}
\hline Radioactive Material Category & $\begin{array}{l}\text { Number of } \\
\text { Shipments }\end{array}$ & $\begin{array}{c}\text { Burial } \\
\text { Volumes }\left(\mathrm{m}^{3}\right)(\mathrm{a})\end{array}$ & $\begin{array}{l}\text { Disposal Costs } \\
(\$ \text { millions })(b)\end{array}$ \\
\hline $\begin{array}{l}\text { Neutron-Activated Materials } \\
\text { Metal } \\
\text { Concrete }\end{array}$ & $\begin{array}{r}303 \\
14\end{array}$ & $\begin{array}{r}138 \\
90\end{array}$ & $\begin{array}{l}2.174^{(c)} \\
0126\end{array}$ \\
\hline $\begin{array}{l}\text { Contaminated Materials } \\
\text { Metal } \\
\text { Concrete }\end{array}$ & $\begin{array}{l}676 \\
130\end{array}$ & $\begin{array}{rl}15 & 543 \\
1 & 676\end{array}$ & $\begin{array}{l}4.319 \\
0.590\end{array}$ \\
\hline $\begin{array}{l}\text { Radroactive Wastes } \\
\text { Wet Solid Wastes } \\
\text { Dry Solid Wastes } \\
\end{array}$ & $\begin{array}{r}286 \\
86 \\
\end{array}$ & $\begin{array}{l}814 \\
678 \\
\end{array}$ & $\begin{array}{l}1.073 \\
0.396 \\
\end{array}$ \\
\hline Totals & 1495 & 18939 & 8.678 \\
\hline
\end{tabular}

\footnotetext{
(a) Includes disposable containers if required.

(b) Adjusted to early 1978, the number of figures shown is for computational

completeness and does not imply accuracy to the nearest $\$ 1000$.

(c) An additional cost of $\$ 0.848 \mathrm{million}$ is required if deep geologic dis-

posal of highly activated materials is necessary.
}

\section{I.3.1.1 Neutron-Activated Materials}

All of the neutron-activated materials are contained in the reactor vessel, the vessel internals, and the sacrificial shield (see Section E.l of Appendix E), and are located inside Primary Containment. Table I.3-3 gives a detailed breakdown of the masses, the radioactivity contents, the number of pieces after segmenting, the number of packaging containers, and the disposal costs for the neutron-activated components (except the fuel channels) in the reference BWR.

The total radioactivity expected to be present in the neutron-activated materials is approximately 6.6 million curies. The packaged materials require an estimated 317 overweight truck shipments to a shallow-land burial facility and occupy an estimated $228 \mathrm{~m}^{3}$ of space at the burial facility. The total estimated cost for disposal of the neutron-activated materials in a shallowland burial facility is about $\$ 2.3$ million.

There is a possibility that the more highly activated materials may require disposal in a deep geologic disposal facility. This alternative is discussed in Section I.3.9.3.

The fuel channels are assumed to be shipped together with the spent reactor fuel to an offsite repository. However, in the event that this is not 
$\nabla$ 
TABLE I.3-3. Costs for Disposal of Neutron-Activated Materials

\begin{tabular}{|c|c|c|c|c|c|c|c|c|c|c|c|c|c|c|}
\hline Component ${ }^{(a)}$ & $\begin{array}{l}\text { Estimated (b) } \\
\text { Mass }(\mathrm{kg})\end{array}$ & $\begin{array}{l}\text { Est imated } \\
\text { Radioarctivity } \\
\text { Content }(C i)\end{array}$ & $\begin{array}{l}\text { No. of } \\
\text { pieces }\end{array}$ & $\begin{array}{l}\text { Number of } \\
\text { Disposabbe } \\
\text { Containers }(c)\end{array}$ & $\begin{array}{l}\text { Container }(d) \\
\text { costs }(s)\end{array}$ & $\begin{array}{l}\text { Cask } \\
\text { Rental } \\
\text { Costs }(s)(e)\end{array}$ & $\begin{array}{l}\text { Number of } \\
\text { Shipments }\end{array}$ & $\begin{array}{l}\text { Transport } \\
\operatorname{costs}(\$)(f)\end{array}$ & $\begin{array}{l}\text { Handling } \\
\text { Surcharges }(\$)^{(g)}\end{array}$ & $\begin{array}{l}\text { Burial } \\
\text { Volumes }\left(m^{3}\right)^{(n)}\end{array}$ & $\begin{array}{l}\text { Burial } \\
\text { Costs }(\$)^{(i)}\end{array}$ & $\begin{array}{l}\text { Liner Sur- }(j) \\
\text { charges }(\$))^{(j)}\end{array}$ & $\begin{array}{l}\text { Curie Sur- }(k) \\
\text { charges }(\$)\end{array}$ & $\begin{array}{l}\text { Total } \\
\text { oisposal } \\
\text { costs }(\mathrm{s})(\mathrm{m})\end{array}$ \\
\hline $\begin{array}{l}\text { Steam Separator Assembly }(n) \\
\text { Fuel Support p P Peces } \\
\text { control Rods and In-Core Instruments }\end{array}$ & $\begin{aligned} 9500 \\
5420 \\
19810\end{aligned}$ & $\begin{array}{r}9600 \\
\quad 700 \\
189000\end{array}$ & $\begin{array}{l}951 \\
740 \\
610\end{array}$ & $\begin{array}{l}28 p \\
14 p(p) \\
8 p\end{array}$ & $\begin{aligned} 12600 \\
6300 \\
48000\end{aligned}$ & $\begin{array}{l}14000 \\
77000 \\
27600\end{array}$ & $\begin{array}{r}14 \\
7 \\
8\end{array}$ & $\begin{array}{l}26880 \\
13440 \\
15360\end{array}$ & $\begin{array}{l}5600 \\
2800 \\
12310^{\circ}(0)\end{array}$ & $\begin{array}{l}10 \\
5 \\
15\end{array}$ & $\begin{array}{r}940 \\
470 \\
1400\end{array}$ & $\begin{array}{l}3640(0) \\
7700(0) \\
42810^{\circ}\end{array}$ & $\begin{array}{r}7320 \\
11780\end{array}$ & $\begin{array}{l}103740 \\
37710 \\
159260\end{array}$ \\
\hline $\begin{array}{l}\text { Control Rod Guide Tubes }(n) \\
\text { Jet Pump Assebmlies }(n) \\
\text { Top Fuel Guide }\end{array}$ & $\begin{array}{l}3500 \\
65000 \\
2300\end{array}$ & $\begin{array}{l}200 \\
20000 \\
30100\end{array}$ & $\begin{array}{l}370 \\
110 \\
408\end{array}$ & $\begin{array}{l}12 p \\
40 p \\
72 p\end{array}$ & $\begin{array}{r}5400(9) \\
38400(9) \\
111 \\
6000\end{array}$ & $\begin{aligned} 6000 \\
20 \\
36000\end{aligned}$ & $\begin{array}{c}6 \\
20 \\
72\end{array}$ & $\begin{aligned} 11520 \\
38 \\
138 \\
1300\end{aligned}$ & $\begin{array}{rl}2 & 400 \\
8 & 000 \\
14400\end{array}$ & $\begin{array}{l}44 \\
14 \\
24\end{array}$ & 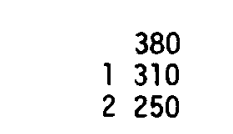 & $\begin{array}{l}3900(1) \\
85000(0) \\
1530000(0)\end{array}$ & $\begin{array}{rl}6 & 00 \\
22 & 030\end{array}$ & $\begin{array}{l}29600 \\
19780 \\
477520\end{array}$ \\
\hline $\begin{array}{l}\text { Core Support Plate } \\
\text { Core Shroud } \\
\text { Reactor Vessel wall }(n, r) \\
\text { Sacrificial Shield }(n)\end{array}$ & $\begin{array}{r}18500 \\
32000 \\
157700 \\
272000 \\
\end{array}$ & $\begin{array}{r}650 \\
6300000 \\
2760 \\
\quad 170 \\
\end{array}$ & $\begin{array}{r}258 \\
558 \\
576 \\
14 \\
\end{array}$ & $\begin{array}{r}31 p \\
13 v+127 c \\
22 p(s) \\
14 w(p) \\
\end{array}$ & $\begin{array}{l}13950 \\
63000 \\
9900 \\
84000 \\
8\end{array}$ & $\begin{array}{r}15500 \\
70000 \\
11000 \\
\end{array}$ & $\begin{array}{r}16 \\
140 \\
20 \\
14 \\
\end{array}$ & $\begin{array}{r}30720 \\
268800 \\
38400 \\
26880 \\
\end{array}$ & $\begin{aligned} 6200 \\
28000 \\
4400 \\
5600 \\
\end{aligned}$ & $\begin{array}{r}11 \\
47 \\
8 \\
90 \\
\end{array}$ & $\begin{array}{r}1030 \\
4400 \\
6800 \\
9530 \\
\end{array}$ & $\begin{array}{c}10080(0) \\
228 \\
7500 \\
7150 \\
0 \\
\end{array}$ & $\begin{array}{r}0 \\
356510 \\
0 \\
\quad 0 \\
\end{array}$ & $\begin{array}{r}77.480 \\
1019560 \\
71530 \\
126 \quad 010 \\
\end{array}$ \\
\hline Totals $\mathrm{s}^{(\mathrm{m})}$ & 526730 & 6552480 & 4595 & 381 & 393150 & 207100 & 317 & 608640 & 89710 & 228 & 22390 & 574890 & 404340 & 2300220 \\
\hline
\end{tabular}

(a) Listed in order of removal.
(b) Estimated from volumes presented in Table E.1-6 in Appendix E.

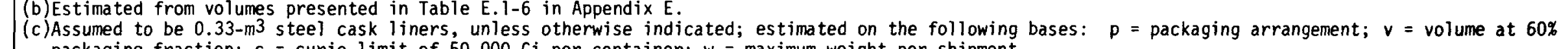
packaging fraction; $c=$ curie 1 imit of $50,000 \mathrm{Ci}$ per container; $w=$ maximum weight per shipment.

(e) Based on information in Section M.2 of Appendix M.
(e) Based on Table M.3.-1; assumes 5 days per shipment.
(f) Based on Table M.4-4, for overweight shipments.

(f) Based on Table M.4-4, for overweight shipments.
(g) Based on cask handling fee in Table M.5-1, except as otherwise noted.

(g) Based on case hisposable container; rounded to nearest whole $\mathrm{m}^{3}$.
(h) Includes the dis

(i) Based on Table M.5-1; based on volume only; rounded to nearest $\$ 10$.
(j) Based on Table M.5-1, except as otherwise noted; based on the estimated dose rate at the container surface.

(m) The number of figures shown is for computational completeness only and does not imply accuracy to that many significant figures.

$(\mathrm{n})$ Includes only the neutron-activated portion of the component, rest shipped as contaminated

(o) Based on cost estimate information supplied by Nuclear Engineering Co., Louisville, KY (minus 30\% for escalation since September 1977).

(a) Includes costs for lead shielding

(r) Includes additional mass to provide sufficient shielding for the core shroud packaging arrangement. 

possible, a presentation of the disposal costs for these components is contained in Section I.3.9.4.

\subsubsection{Contaminated Materials}

Contaminated materials in the reference BWR are assumed to include a lot of the piping and equipment located in the Reactor Building/Primary Containment, the Turbine Generator Building, and the Radwaste and Control Building. In addition, many concrete surfaces in these three buildings are assumed to be contaminated and require surface removal to a depth of about $50 \mathrm{~mm}$. Breakdowns of the disposal costs for contaminated materials are given in Table I.3-4.

Approximately $8600 \mathrm{Ci}$ (see Section E.2 of Appendix E) of radioactivity are removed with the contaminated materials. These materials require an estimated 806 truck shipments to and an estimated $17,219 \mathrm{~m}^{3}$ of space (including the disposable containers, as required) at a shallow-land burial site. The total disposal cost for contaminated materials from the reference BWR is estimated to be about $\$ 4.9$ million.

Twenty large, contaminated heat exchangers in the reference BWR require special segmenting for shipping and burial. These are the two RHR heat exchangers in the Reactor Bujlding and the 14 low-pressure feedwater heaters, the two moisture separator reheaters, and the two high-pressure feedwater heaters in the Turbine Generator Building. To comply with both overweight shipping limits using standard vehicles and burial site handling capabilities (see Sections M.4 and M.5 of Appendix M), these heat exchangers require segmenting into $4,42,26$, and 8 individually contained packages, respectively, as shown in Table I.3-4. An alternative to this, in which special equipment is used to transport the maximum allowed weights over the public highways as well as handle them at the burial site, was analyzed by William N. Lampson of Neil F. Lampson, Inc., Kennewick, Washington. The heat exchangers were assumed segmented, as required, into 35 individual packages to meet the weight limits. However, the estimated total cost for transporting and handling, but not packaging, the 35 maximumweight packages (ranging from $\$ 437,500$ to $\$ 507,500$ in 1979 dollars) is approximately twice the combined packaging (container), transportation, and handling costs ( $\$ 238,930$ in 1978 dollars) shown in Table I.3-4 for these heat exchangers. 
0 


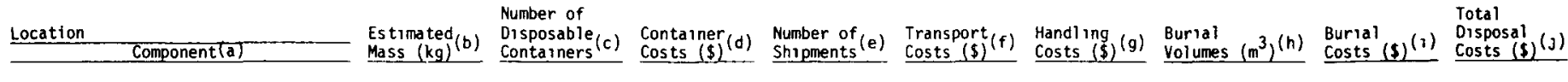
Prritary conta inment

\begin{tabular}{|c|c|c|c|c|c|c|c|c|}
\hline 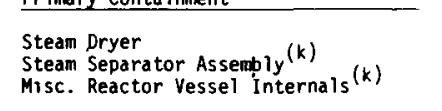 & 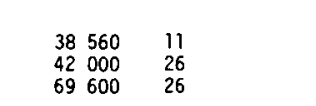 & 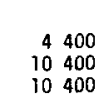 & $\begin{array}{l}3 \\
3 \\
4\end{array}$ & 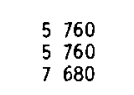 & $:$ & $\begin{array}{l}405 \\
95 \\
95\end{array}$ & 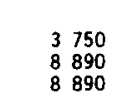 & 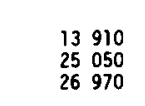 \\
\hline 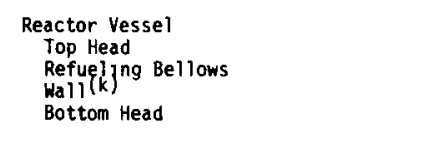 & 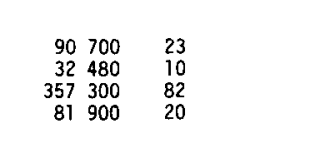 & 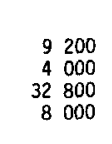 & ${ }_{4}^{20}$ & 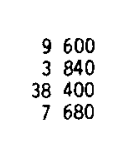 & & 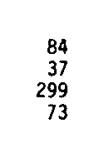 & 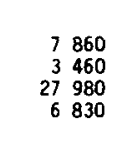 & 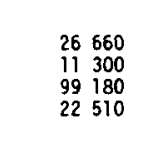 \\
\hline 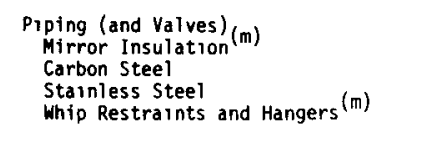 & 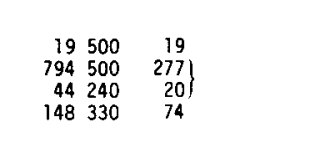 & $\begin{array}{rl}7 & 600 \\
118000 \\
29\end{array} 600$ & $\begin{array}{c}50 \\
10 \\
0\end{array}$ & $\begin{array}{l}3800 \\
96000 \\
19000\end{array}$ & & $\begin{array}{l}c_{01}^{08} \\
270\end{array}$ & $\begin{aligned} 6550 \\
10160 \\
25270\end{aligned}$ & \begin{tabular}{l}
\multicolumn{1}{c}{11990} \\
315900 \\
74070
\end{tabular} \\
\hline 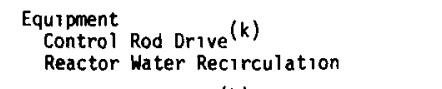 & 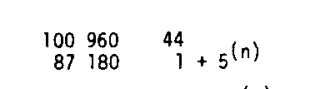 & $\begin{array}{l}17500 \\
5600\end{array}$ & $\begin{array}{l}8 \\
5\end{array}$ & $\begin{array}{llll}13560 \\
9600\end{array}$ & $374^{\circ}$ & 然 & $\begin{array}{lll}15020 \\
8240 \\
820\end{array}$ & $\begin{array}{l}0.000 \\
180\end{array}$ \\
\hline 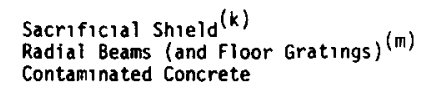 & 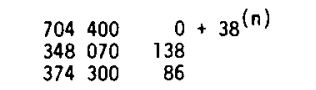 & 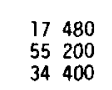 & $\begin{array}{l}38 \\
22 \\
22\end{array}$ & 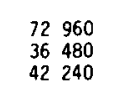 & $\begin{array}{ll}14950 \\
0 \\
0\end{array}$ & $\begin{array}{l}310 \\
503 \\
313\end{array}$ & 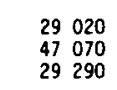 & 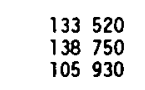 \\
\hline 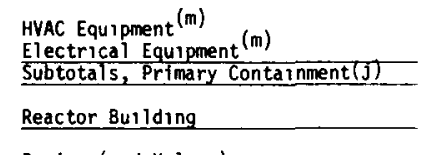 & 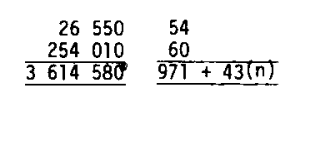 & 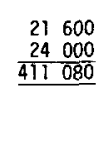 & 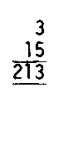 & 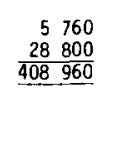 & $\begin{array}{l}0 \\
\frac{1}{17000} \\
0\end{array}$ & 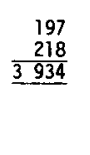 & 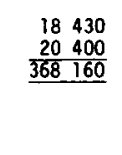 & 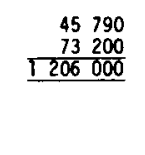 \\
\hline 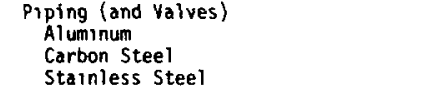 & 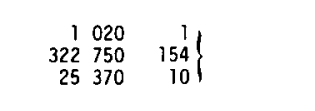 & 66000 & ${ }^{28}$ & 53760 & 0 & 601 & 56240 & \\
\hline 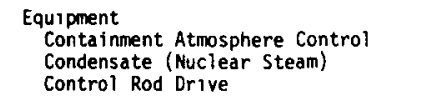 & $\begin{array}{ll}10890 & 0+2^{(n)} \\
3640 & 2 \\
71200 & 16+2^{(n)}\end{array}$ & $\begin{array}{l}2820 \\
\substack{800 \\
7 \\
720}\end{array}$ & 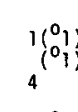 & 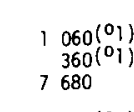 & $\begin{array}{c}50 \\
0 \\
0\end{array}$ & $\begin{array}{l}c_{8}^{8} \\
12 \\
12\end{array}$ & $\begin{array}{l}4490 \\
6750 \\
6740\end{array}$ & 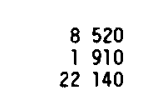 \\
\hline 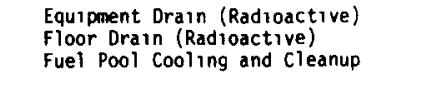 & 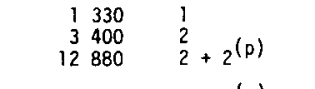 & $\begin{array}{l}400 \\
800 \\
1200\end{array}$ & 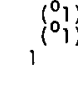 & $\begin{array}{l}170(0) 1) \\
3001 \\
1920\end{array}$ & $\begin{array}{l}0 \\
0\end{array}$ & $\begin{array}{l}\stackrel{4}{8} \\
11\end{array}$ & $\begin{array}{c}380 \\
350 \\
030\end{array}$ & 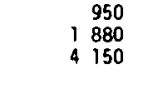 \\
\hline 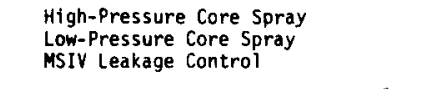 & 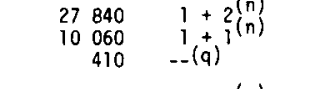 & $\begin{array}{l}1 \begin{array}{l}650 \\
1050\end{array} \\
100\end{array}$ & $\underbrace{2}_{.102}$ & $\begin{array}{l}3800(2) \\
9001021\end{array}$ & 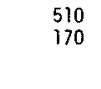 & $\begin{array}{l}11 \\
10\end{array}$ & 9 & 90 \\
\hline 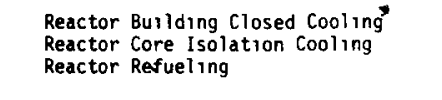 & 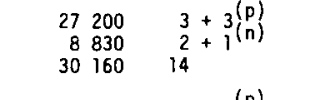 & 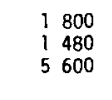 & & 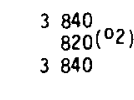 & $\begin{array}{c}3.00 \\
100 \\
0.0\end{array}$ & $\begin{array}{l}32 \\
\text { 313 } \\
51\end{array}$ & 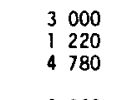 & 14200 \\
\hline 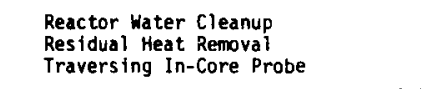 & 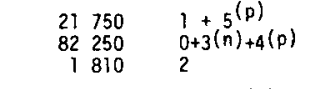 & 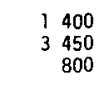 & & 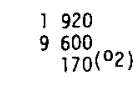 & $1990^{\circ}$ & $\begin{array}{l}22 \\
62 \\
62 \\
8\end{array}$ & $\begin{array}{l}600 \\
800 \\
750\end{array}$ & 1720 \\
\hline 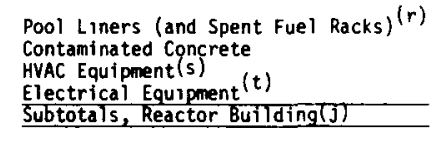 & 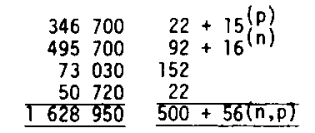 & 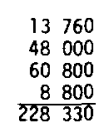 & $\begin{array}{c}18 \\
\substack{18 \\
28 \\
\frac{2}{4 M}}\end{array}$ & 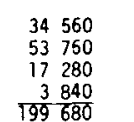 & $\begin{array}{rl}5 & 610 \\
1440 \\
0 \\
0\end{array}$ & 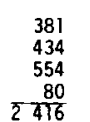 & 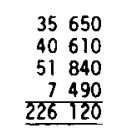 & \\
\hline
\end{tabular}

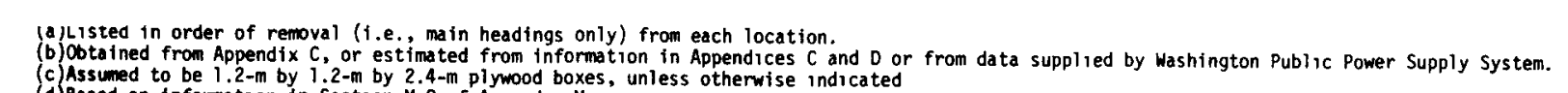

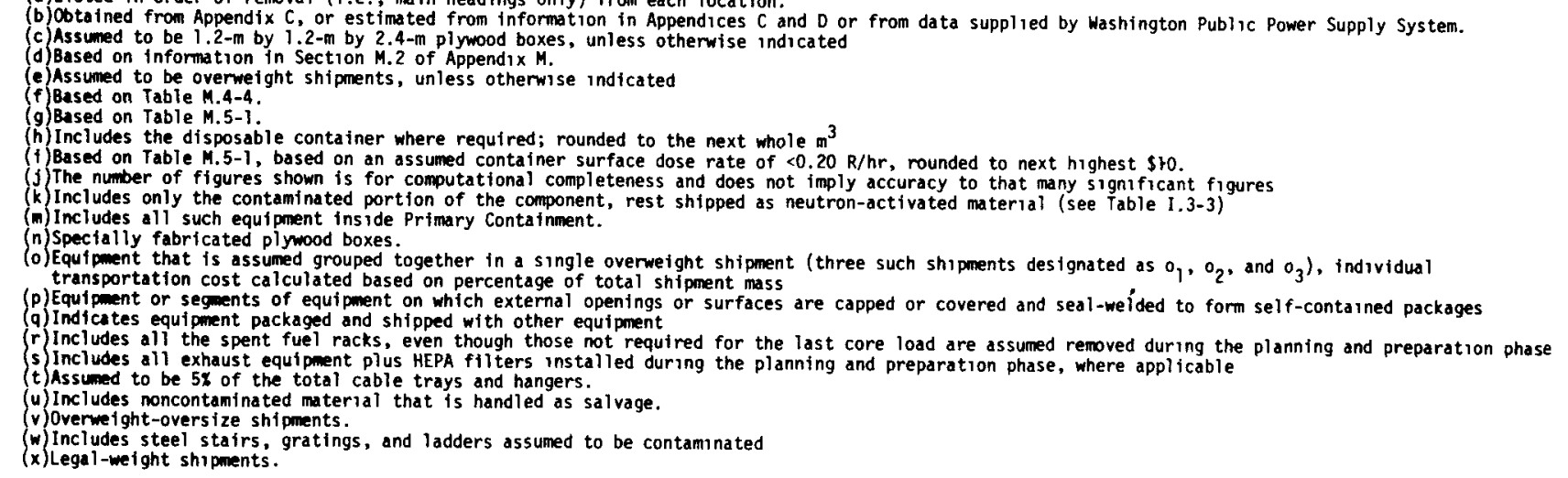

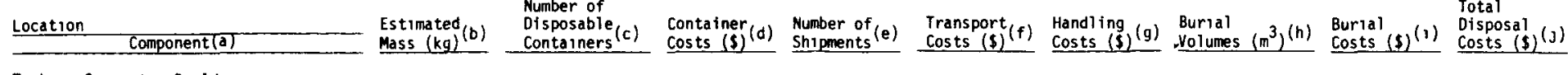
Turbine Generator Eurlding

Turbine $e^{(u)}(u)$

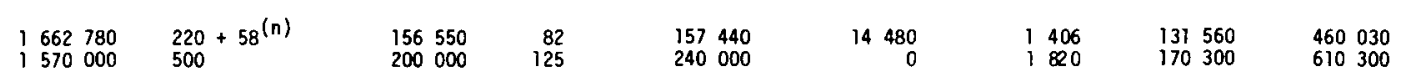

Piping (and valves)

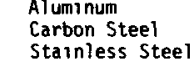

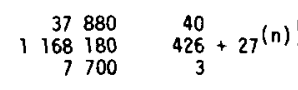

$213520 \quad 83 \quad 159350$

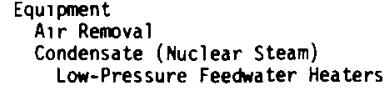

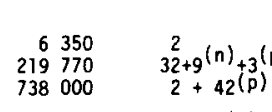

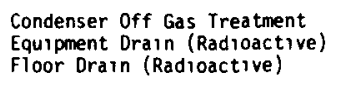

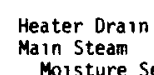

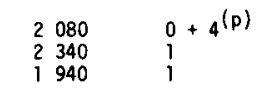

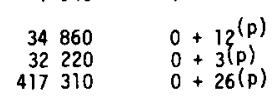

Miscellaneous oran and vet

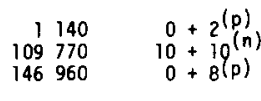

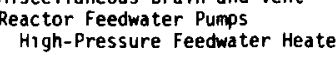

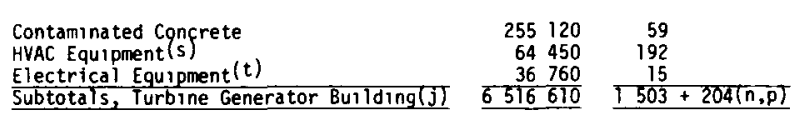

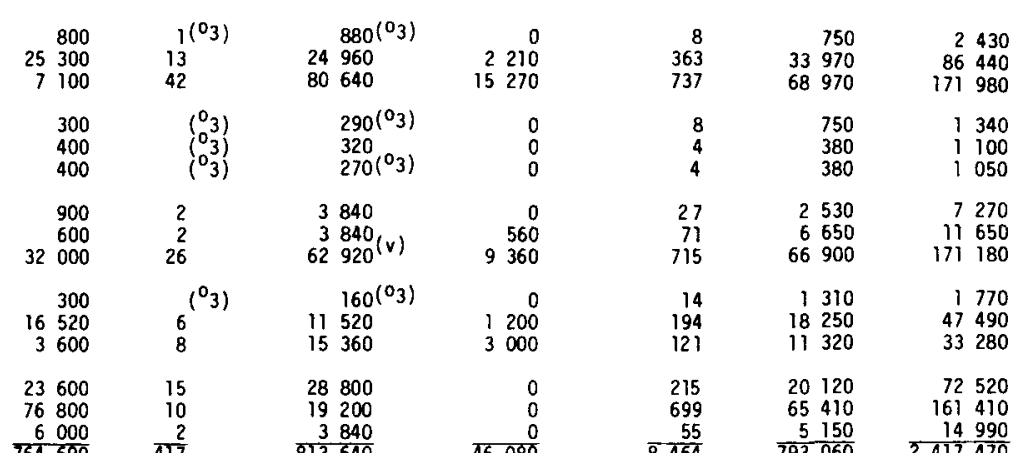
Radaraste and Control sulldang.

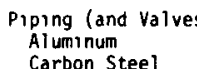

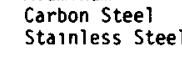

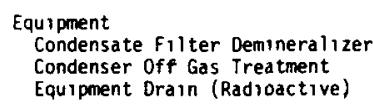

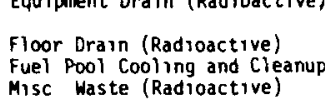

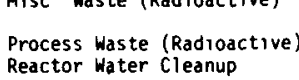

$\left.\begin{array}{rr}1950 \\ 149250 \\ 16 & 670\end{array}\right\} \quad 146$

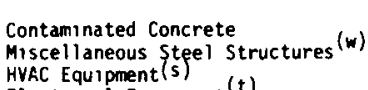

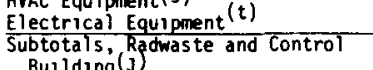

Totals (from all locect tons) $)^{(j)}$
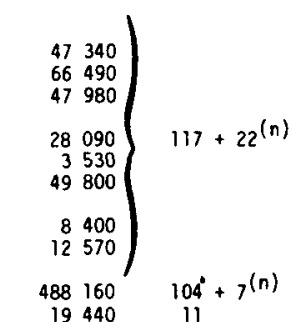

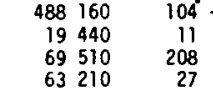

$\frac{63210}{1099500} \frac{27}{613+29(\mathrm{nn})}$

$\frac{1089500}{12849640} \frac{613+29^{(n)}}{3587+332^{(n, p)}}$

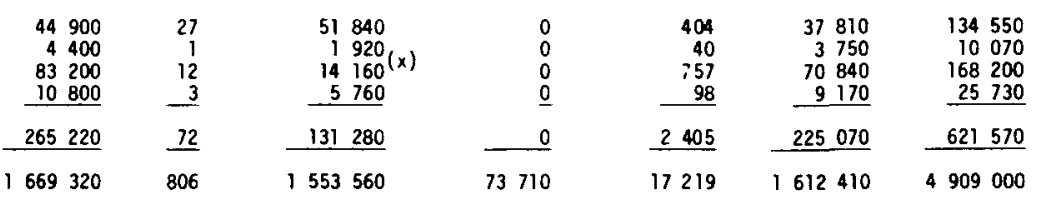


م 


\section{I.3.1.3 Radioactive Wastes}

While not a prime "product," radioactive wastes (radwastes) result directly from the immediate dismantlement of the reference BWR. Two categories of radioactive wastes are defined: wet solid wastes and dry solid wastes.

Wet solid wastes result from the processing of chemical decontamination solutions and contaminated water volumes. These wastes include concentrator bottoms, filter sludges, and spent demineralizer resins, as well as the neutralized chemical solutions from decontamination of the contaminated drain systems. These wastes are assumed mixed with a cement solidifying agent and encapsulated in a steel cask liner prior to shipping to a shallow-land burial facility. The disposal cost data for the wet solid wastes generated during immediate dismantlement are presented in Table H.5-10 in Appendix $\mathrm{H}$ and are not repeated in detail here. An estimated 286 truck shipments, $816 \mathrm{~m}^{3}$ burial space, and $\$ 1,073,400$ are required for disposal of the wet solid wastes.

Dry solid wastes include discarded contaminated materials such as plastic sheeting, rags, and anticontamination clohing. They are expected to occur as a result of most of the tasks specified in Section 1.2 and are estimated on a taskwise basis. The dry solid wastes are compacted as much as possible to reduce their volume.

Large volumes of dry solid wastes are expected to be produced during immediate dismantlement. Uncompacted volumes of $1500 \mathrm{~m}^{3}$ from the Reactor Building, $1012 \mathrm{~m}^{3}$ from the Turbine Building, and $874 \mathrm{~m}^{3}$ from the Radwaste and Control Building are estimated to be collected. These volumes are assumed to be compacted five-fold and packaged in 1428, 964, and $8320.21-\mathrm{m}^{3}$ standard steel drums, respectively. Of the total number of drums, 1000 are assumed to require shielding during shipment, with the remainder shipped unshielded in closed trucks. The two types are shipped separately, since, because of the ${ }^{60}$ co content, those requiring shielding also require Type $B$ packaging and shipping. Table I.3-5 gives a breakdown of the disposal costs for the dry solid wastes. An estimated 86 overweight truck shipments ( 72 shielded, 14 unshielded) are required to transport the compacted, packaged, dry solid wastes to a shallow-land burial facility, where they occupy an estimated $678 \mathrm{~m}^{3}$ of space. The total disposal 


\section{TABLE I.3-5. Costs for Disposal of Dry Solid Wastes}

\begin{tabular}{|c|c|c|c|c|c|c|c|c|c|c|}
\hline Source (Building) & $\begin{array}{l}\text { Number of } \\
\text { Disposable }(a) \\
\text { Containers }\end{array}$ & $\begin{array}{l}\text { Container } \\
\text { Costs }(\$)\end{array}$ & $\begin{array}{l}\text { Estimated } \\
\text { No, Requiring } \\
\text { Shielding } \\
\end{array}$ & $\begin{array}{l}\text { Cask } \\
\text { Rental } \\
\text { Costs }(\$)^{(c)} \\
\end{array}$ & $\begin{array}{l}\text { Number of } \\
\text { Shipments } \\
\text { Shielded(d)/ } \\
\text { Unshielded } \\
\end{array}$ & $\begin{array}{l}\text { Trans- } \\
\text { portation } \\
\text { Costs }(\$) \\
\end{array}$ & $\begin{array}{l}\text { Handling }(f) \\
\text { Costs }(\$)(f)\end{array}$ & $\begin{array}{l}\text { Burial } \\
\text { Volumes }\left(\mathrm{m}^{3}\right)^{(\mathrm{g})}\end{array}$ & $\begin{array}{l}\text { Burial } \\
\text { Costs }(\$)^{(h)}\end{array}$ & $\begin{array}{l}\text { Total } \\
\text { Disposal } \\
\text { Costs }(\$) \\
\end{array}$ \\
\hline Reactor & 1428 & 28560 & 443 & 31 500 & $32 / 6$ & 72960 & 12600 & 300 & 29210 & 174830 \\
\hline Turbine Generator & 964 & 19280 & 299 & 21500 & $21 / 4$ & 48000 & 8600 & 203 & 19720 & 117100 \\
\hline Radwaste and Control & 832 & $16 \quad 640$ & 258 & 18500 & $19 / 4$ & $44 \quad 160$ & 7400 & $\underline{175}$ & $17 \quad 020$ & 103720 \\
\hline Totals $(i)$ & 3224 & 64480 & 1000 & 71500 & $72 / 14$ & $165 \quad 120$ & 28600 & 678 & 65950 & 395650 \\
\hline
\end{tabular}

(a)Based on a 5:1 compaction of estimated waste volumes into standard $0.21-\mathrm{m}^{3}$ steel drums; estimated on a taskwise assessment of expected dry solid waste generation rates.

(b) Based on Table M.2-7 in Appendix M.
(c)Based on Table M.3-1; assumes a maximum of seven containers per cask and 5 days per shipment.

(e) Based on two cask loads per shipment.

(f) Based on table M. 5-1 cask handling fee.

g) Includes the disposable container: rounded to next whole $\mathrm{m}^{3}$

(h) Based on Table M.5-1; surface dose rates assumed to be 0.21 to $1.00 \mathrm{R} / \mathrm{hr}$ for those drums requiring shielding during shipment, <0.2 R/hr for all

(i) The number of figures shown is for computational completeness only and does not imply accuracy to that many significant figures. 
cost for the dry solid was.tes from the immediate dismantlement of the reference BWR is estimated at $\$ 395,650$.

The sum of the disposal costs for the wet solid wastes and the dry solid wastes is $\$ 1.469$ million, which represents the disposal cost for the radioactive wastes.

\section{I.3.2 Costs for Staff Labor}

The costs for staff labor during immediate dismantlement are shown in detail in Table I.3-6. More than 50\% of the total immediate dismantlement cost is associated with the staff labor requirements (see Table I.2-3). A total staff labor cost of about $\$ 17.6$ million is estimated for immediately dismantling the reference BWR. Specialty contractor labor is not included in this total.

The dedicated manpower costs for the immediate dismantlement tasks are given in Table I.3-7. These costs are attributed to manpower that is specifically assigned to the tasks, and do not include either non-dedicated personnel or management and support staff (see Figure H.1-1 in Appendix $\mathrm{H}$ ).

\section{I.3.3 Costs for Energy}

The costs for energy during immediate dismantlement are presented in Table I.3-8, together with the estimated usage of both electricity and fuel oil. The usage of both energy forms is estimated on a detailed analysis of the requirements for the essential systems presented in Table H.4-I in Appendix $\mathrm{H}$ and the immediate dismantlement tasks and schedule.

A total of $106,400 \mathrm{MWh}$ of electricity, costing $\$ 1,590,000$, and $14,570 \mathrm{~m}^{3}$ of fuel oil, costing $\$ 1,923,290$, are estimated to be used during immediate dismantlement. The total cost for energy is about $\$ 3.5 \mathrm{million}$ and represents about $10 \%$ of the total immediate dismantlement cost.

\section{I.3.4 Costs for Special Tools and Equipment}

Based on the information presented in Table I.1-1, the estimated costs for the special tools and equipment that are required for immediate dismantlement of the reference BWR are presented in Table 1.3-9. The estimated total cost for special tools and equipment is approximately $\$ 2.0$ million and is approximately $6 \%$ of the total immediate dismantlement cost. 
IABLE I.3-6. Costs for Staff Labor During Immediate Dismantlement

\begin{tabular}{|c|c|c|c|c|c|c|c|}
\hline Position & $\frac{T i}{-2}$ & $\frac{\text { Relativ }}{\frac{-1}{\text { nual Sta }}}$ & to Final & $\begin{array}{l}\frac{\text { Reactor's }}{2} \\
\frac{\text { sts } 1 \$ \text { th }}{\text { Th }}\end{array}$ & $\frac{u t d o w n}{\left.\frac{3}{u s a n d s}\right)(a}$ & $\frac{r}{4}$ & $\begin{array}{l}\text { Total Staff } \\
\text { Labor Costs } \\
\text { (\$ thousands } \\
\end{array}$ \\
\hline \multicolumn{8}{|l|}{ Management and Support Staff } \\
\hline $\begin{array}{l}\text { Decommissioning Superintendent } \\
\text { Secretary } \\
\text { Clerk }\end{array}$ & $\begin{array}{c}22.4 \\
20.3 \\
0\end{array}$ & $\begin{array}{l}74.5 \\
40.6 \\
20.3\end{array}$ & $\begin{array}{l}74.5 \\
60.9 \\
40.6\end{array}$ & $\begin{array}{l}74.5 \\
60.9 \\
40.6\end{array}$ & $\begin{array}{l}74.5 \\
60.9 \\
40.6\end{array}$ & $\begin{array}{l}59.6 \\
32.5 \\
10.2\end{array}$ & $\begin{array}{l}380.0 \\
276.1 \\
152.3\end{array}$ \\
\hline $\begin{array}{l}\text { Decommissioning Engineer } \\
\text { Assistant Decommissioning Engineer } \\
\text { Radioactive Shipment Specialist }\end{array}$ & $\begin{array}{c}63.5 \\
43.8 \\
0\end{array}$ & $\begin{array}{l}63.5 \\
43.8 \\
32.9\end{array}$ & $\begin{array}{l}63.5 \\
43.8 \\
32.9\end{array}$ & $\begin{array}{l}63.5 \\
43.8 \\
32.9\end{array}$ & $\begin{array}{l}63.5 \\
43.8 \\
32.9\end{array}$ & $\begin{array}{l}50.8 \\
17.6 \\
13.2\end{array}$ & $\begin{array}{l}368.3 \\
236.6 \\
144.8\end{array}$ \\
\hline $\begin{array}{l}\text { Procurement Specialist } \\
\text { Tool Crib Attendant } \\
\text { Control Room Operator }\end{array}$ & $\begin{array}{l}9.2 \\
0 \\
0\end{array}$ & $\begin{array}{c}30.7 \\
0 \\
0\end{array}$ & $\begin{array}{r}30.7 \\
46.4 \\
145.0\end{array}$ & $\begin{array}{r}30.7 \\
46.4 \\
145.0\end{array}$ & $\begin{array}{r}30.7 \\
46.4 \\
145.0\end{array}$ & $\begin{array}{l}12.3 \\
18.6 \\
60.9\end{array}$ & $\begin{array}{l}144.3 \\
157.8 \\
495.9\end{array}$ \\
\hline $\begin{array}{l}\text { Security Supervisor } \\
\text { Security Shift Supervisor } \\
\text { Security Patrolman } \\
\text { Contracts and Accounting Specialist }\end{array}$ & $\begin{array}{l}0 \\
0 \\
0 \\
11.5\end{array}$ & $\begin{array}{c}0 \\
0 \\
0 \\
38.4\end{array}$ & $\begin{array}{r}32.9 \\
153.5 \\
830.7 \\
38.4\end{array}$ & $\begin{array}{r}32.9 \\
153.5 \\
596.4 \\
38.4\end{array}$ & $\begin{array}{r}32.9 \\
153.5 \\
276.9 \\
38.4\end{array}$ & $\begin{array}{r}16.5 \\
76.8 \\
138.5 \\
30.8\end{array}$ & $\begin{array}{l}115.2 \\
537.3 \\
1842.5 \\
195.9\end{array}$ \\
\hline $\begin{array}{l}\text { Health and Safety Supervisor } \\
\text { Health Physicist } \\
\text { Protective Equipment Attendant } \\
\text { Industrial Safety Specialist }\end{array}$ & $\begin{array}{c}50.4 \\
0 \\
0 \\
13.1\end{array}$ & $\begin{array}{c}50.4 \\
19.7 \\
0 \\
43.8\end{array}$ & $\begin{array}{l}50.4 \\
39.4 \\
46.4 \\
43.8\end{array}$ & $\begin{array}{l}50.4 \\
39.4 \\
46.4 \\
43.8\end{array}$ & $\begin{array}{l}50.4 \\
39.4 \\
46.4 \\
43.8\end{array}$ & $\begin{array}{l}40.4 \\
19.7 \\
23.2 \\
21.9\end{array}$ & $\begin{array}{l}292.4 \\
157.6 \\
162.4 \\
210.2\end{array}$ \\
\hline $\begin{array}{l}\text { Quality Assurance Supervisor } \\
\text { Quality Assurance Engineer } \\
\text { Quality Assurance Technician } \\
\text { Consultant (Safety Review) }\end{array}$ & $\begin{array}{r}13.1 \\
19.7 \\
0 \\
33.5 \\
\end{array}$ & $\begin{array}{l}43.8 \\
78.8 \\
11.6 \\
33.5 \\
\end{array}$ & $\begin{array}{l}43.8 \\
39.4 \\
92.8 \\
33.5 \\
\end{array}$ & $\begin{array}{l}43.8 \\
39.4 \\
92.8 \\
33.5 \\
\end{array}$ & $\begin{array}{l}43.8 \\
39.4 \\
92.8 \\
33.5 \\
\end{array}$ & $\begin{array}{l}35.1 \\
19.7 \\
46.4 \\
20.1 \\
\end{array}$ & $\begin{array}{l}223.4 \\
236.4 \\
336.4 \\
187.6 \\
\end{array}$ \\
\hline Subtotals, Management and Support Staff & 300.5 & 626.3 & 1983.3 & 1749.0 & 1429.5 & 764.8 & 6853.4 \\
\hline \multicolumn{8}{|l|}{ Decommissioning Workers } \\
\hline $\begin{array}{l}\text { Shift Engineer } \\
\text { Crew Leader }\end{array}$ & $\begin{array}{c}43.8 \\
0\end{array}$ & $\begin{array}{l}87.6 \\
37.3\end{array}$ & $\begin{array}{r}87.6 \\
585.7\end{array}$ & $\begin{array}{r}87.6 \\
447.6\end{array}$ & $\begin{array}{l}87.6 \\
74.6\end{array}$ & $\begin{array}{r}43.8 \\
7.5\end{array}$ & $\begin{array}{r}438.0 \\
1152.7\end{array}$ \\
\hline $\begin{array}{l}\text { Utility Operator } \\
\text { Laborer } \\
\text { Craft Supervisor }\end{array}$ & $\begin{array}{l}0 \\
0 \\
0\end{array}$ & $\begin{array}{c}86.8 \\
0 \\
24.8\end{array}$ & $\begin{array}{r}1490.5 \\
334.2 \\
78.8\end{array}$ & $\begin{array}{r}1344.2 \\
512.9 \\
78.8\end{array}$ & $\begin{array}{r}336.1 \\
422.2 \\
78.8\end{array}$ & $\begin{array}{r}89.5 \\
137.3 \\
31.6\end{array}$ & $\begin{array}{l}3347.1 \\
1405.6 \\
292.8\end{array}$ \\
\hline $\begin{array}{l}\text { Craftsman } \\
\text { Senior Health Physics Technician } \\
\text { Health Physics Technician }\end{array}$ & $\begin{array}{l}0 \\
0 \\
0 \\
\end{array}$ & $\begin{array}{r}271.0 \\
32.9 \\
75.3 \\
\end{array}$ & $\begin{array}{r}607.1 \\
82.3 \\
359.0 \\
\end{array}$ & $\begin{array}{r}1008.2 \\
72.4 \\
374.0 \\
\end{array}$ & $\begin{array}{r}531.2 \\
69.1 \\
351.4 \\
\end{array}$ & $\begin{array}{r}108.4 \\
32.9 \\
95.4 \\
\end{array}$ & $\begin{array}{r}2525.9 \\
289.6 \\
1 \quad 255.1 \\
\end{array}$ \\
\hline Subtotals, Decommissioning Workers & 43.8 & 615.7 & $\underline{3} \underline{625.2}$ & 3925.7 & 1951.0 & 546.4 & 10707.8 \\
\hline Totals & 344.3 & 1242.0 & 5608.5 & 5674.7 & 3380.5 & 311.2 & 17561.2 \\
\hline
\end{tabular}

(a) Calculated as the product of the data given in Table I.2-3 and the corresponding data given in Table M.1-1 in Appendix M; rounded to the next higher $\$ 100$.

(b) The number of significant figures shown is for computational completeness and does not imply accuracy to the nearest $\$ 100$. 


\section{TABLE I.3-7. Dedicated Manpower Costs for Immediate Dismantlement}

\begin{tabular}{|c|c|c|}
\hline \multicolumn{2}{|c|}{ Buildtng } & $\begin{array}{l}\text { Dedicated } \\
\text { Manpower } \\
\text { Costs }(\$) \text { (a }\end{array}$ \\
\hline \multicolumn{3}{|c|}{ Reactor Building/Primary Containment } \\
\hline $\begin{array}{l}1 \\
2 \\
3\end{array}$ & $\begin{array}{l}\text { Install HEPA Filters } \\
\text { Comprehensive Radiation Survey } \\
\text { Discharge and Ship Fuel }\end{array}$ & $\begin{array}{ll}74 & 320 \\
12 & 550 \\
54 & 200\end{array}$ \\
\hline $\begin{array}{l}4 \\
5 \\
6\end{array}$ & $\begin{array}{l}\text { Remove Oryer and Separator } \\
\text { Drain Suppression Pool to Radwaste, Water-Jet Clean } \\
\text { Renove Reactor Vessel Internals }\end{array}$ & $\begin{array}{rr}36 & 130 \\
241 & 790 \\
146 \quad 770\end{array}$ \\
\hline $\begin{array}{l}7 \\
8 \\
9\end{array}$ & $\begin{array}{l}\text { Ship Activated Reactor Vessel Internals } \\
\text { Drain Reactor Well Pool to Radwaste, Water-Jet Clean } \\
\text { Chemical Decon Reactor Water Recirculation and Cleanup Systems }\end{array}$ & $\begin{array}{rr}837 & 370 \\
60 & 450 \\
102 \quad 740\end{array}$ \\
\hline $\begin{array}{l}10 \\
11 \\
12\end{array}$ & $\begin{array}{l}\text { Cleanup, Stage and Shield Hot Spots in Primary Containment } \\
\text { Enlarge Suppression C'Tamber Access } \\
\text { Remove Reactor Vesse? }\end{array}$ & $\begin{array}{rl}12 & 950 \\
6 & 570 \\
63 & 220\end{array}$ \\
\hline $\begin{array}{l}13 \\
14 \\
15\end{array}$ & $\begin{array}{l}\text { Ship Activated Reactor Vessel Segments } \\
\text { Remove Primary Contaimment Piping and Equipment } \\
\text { Remove Sacrificial Shield and Radial Beams }\end{array}$ & $\begin{array}{ll}322 & 070 \\
533 & 920 \\
217 & 790\end{array}$ \\
\hline $\begin{array}{l}16 \\
17 \\
18\end{array}$ & $\begin{array}{l}\text { Remove Contaminated Concrete from Primary Containment } \\
\text { Remove HVAC and Electrical Equipment from Primary Containment } \\
\text { Drain Contaminated Systems to Radwaste }\end{array}$ & $\begin{array}{ll}51790 \\
17660 \\
90560\end{array}$ \\
\hline $\begin{array}{l}19 \\
20 \\
21\end{array}$ & $\begin{array}{l}\text { Chemical Decon Residual Heat Removal, Low-and High-Pressure } \\
\text { Core Spray Systems } \\
\text { Remove Reactor Building Piping } \\
\text { Drain Oryer and Separator Pool to Radwaste, Water-Jet Clean }\end{array}$ & $\begin{array}{rr}51 & 260 \\
793 & 510 \\
60 & 450\end{array}$ \\
\hline $\begin{array}{l}22 \\
23 \\
24\end{array}$ & $\begin{array}{l}\text { Cherical Decon Drain Systems } \\
\text { Drain Spent Fuel Pool to Radwaste, Water-Jet Clean } \\
\text { Chemical Decon Fuel Pool Cooling and Cleanup System }\end{array}$ & $\begin{array}{rr}51260 \\
120900 \\
20630\end{array}$ \\
\hline $\begin{array}{l}25 \\
26 \\
27\end{array}$ & $\begin{array}{l}\text { Renove Reactor Bullding Equipment } \\
\text { Remove LIners from Spent Fuel Pool, Reactor Well, and Dryer } \\
\text { and Separator Pool } \\
\text { Remove Reactor But lding Contaminated Concrete }\end{array}$ & $\begin{array}{rr}132 & 480 \\
35 & 330 \\
43 & 160\end{array}$ \\
\hline $\begin{array}{l}28 \\
29 \\
\end{array}$ & $\begin{array}{l}\text { Remove HVAC and Electrical Systems from Reactor Building } \\
\text { Final Radiation Survey } \\
\text { Subtotal, Reactor Building }\end{array}$ & $\begin{array}{r}26500 \\
4180 \\
4222510 \\
\end{array}$ \\
\hline \multicolumn{3}{|c|}{ Turbine Generator Building } \\
\hline $\begin{array}{l}1 \\
2 \\
3\end{array}$ & $\begin{array}{l}\text { Install HEPA Filters } \\
\text { Comprehensive Radiation Survey } \\
\text { Cleanup and Stage }\end{array}$ & $\begin{array}{rr}204 & 370 \\
4 & 180 \\
8 & 630\end{array}$ \\
\hline $\begin{array}{l}4 \\
5 \\
6\end{array}$ & $\begin{array}{l}\text { Remove Turbine } \\
\text { Drain Contaminated Systems to Radwaste, water-Jet clean } \\
\text { Condensate Storage Tanks } \\
\text { Remove Condenser }\end{array}$ & $\begin{array}{rr}65 & 740 \\
181 & 340 \\
248 & 100\end{array}$ \\
\hline $\begin{array}{l}7 \\
8 \\
9\end{array}$ & $\begin{array}{l}\text { Drain Condenser to Radwaste, Water-Jet Clean } \\
\text { Chemical Decon Drain Systems } \\
\text { Remove Piping }\end{array}$ & $\begin{array}{rr}181 & 340 \\
46 & 660 \\
321 & 550\end{array}$ \\
\hline $\begin{array}{l}10 \\
11 \\
12 \\
13 \\
\end{array}$ & $\begin{array}{l}\text { Remove Equipment } \\
\text { Remove Contaminated Concrete } \\
\text { Remove HVAC and Electrical Systems } \\
\text { Final Radiation Survey }\end{array}$ & $\begin{array}{rr}93 & 640 \\
25 & 900 \\
13 & 150 \\
2090 \\
\end{array}$ \\
\hline & Subtotal, Turbine Generator Building & $1396 \quad 690$ \\
\hline \multicolumn{3}{|c|}{ Radwaste and Control Building } \\
\hline $\begin{array}{l}2 \\
3\end{array}$ & $\begin{array}{l}\text { Comprehensive Radiation Survey and Release of Support } \\
\text { Facilities, Comprehensive Radiation Survey of Radwaste and } \\
\text { Control Building } \\
\text { General Cleanup } \\
\text { Chemical Decon Drain Systems }\end{array}$ & $\begin{array}{rl}20 & 910 \\
8 & 830 \\
104 & 780\end{array}$ \\
\hline $\begin{array}{l}4 \\
5 \\
6\end{array}$ & $\begin{array}{l}\text { Chemical Decon Equipment, Water-Jet Clean } \\
\text { Remove Piping } \\
\text { Install Temporary Radwaste System }\end{array}$ & $\begin{array}{r}209790 \\
775060 \\
4 \quad 420\end{array}$ \\
\hline $\begin{array}{l}7 \\
8 \\
9\end{array}$ & $\begin{array}{l}\text { Remove Equipment } \\
\text { Remove Contaminated Concrete } \\
\text { Remove Miscellaneous Steel Structures }\end{array}$ & $\begin{array}{r}827690 \\
34530 \\
17660\end{array}$ \\
\hline \multirow[t]{2}{*}{$\begin{array}{l}10 \\
11\end{array}$} & $\begin{array}{l}\text { Remove HVAC and Electrical Systems } \\
\text { Final Radiation Survey }\end{array}$ & $\begin{array}{r}35 \quad 330 \\
4180 \\
\end{array}$ \\
\hline & Subtotal, Radwaste and Control Bullding & $2043 \quad 180$ \\
\hline
\end{tabular}

(a) 1) Calculated as the sum of the products of the data presented in Table I 2-1 (converted to man-years) and the corresponding data presented in Table $M 1-1$ in Appendix $M$, rounded to the nearest $\$ 10$ 2) Do not include non-dedicated in Figure $\mathrm{H} 1-1$ in Appendix $\mathrm{H}$ ) 3) The number of signif cant figures shown for computational completeness and does not imply accuracy to the nearest $\$ 10$ 
TABLE I.3-8. Costs for Energy During Immediate Dismantlement

$\frac{\frac{\text { Energy Form }}{\text { System(s) or Equipment }}}{\text { Electricity }}$

HVAC

Lighting

Communications

Security

Fire Protection

Compressed Air

Cranes and Hoists

Domestic Water

Contaminated Water $(d)$

Decommissioning Equipment

Subtotals, Electricity

Fuel $0 \mathrm{il}$

Building Heating

Decontamination Solution Concentrator

Subtotals, Fuel 0 il

Tota] Energy Cost

Estimated

$\underline{\begin{array}{l}\text { Energy } \\ \text { Usage(a) }\end{array} \quad \text { Costs }(\$)^{(b)}}$

(MWh)

\begin{tabular}{|c|c|}
\hline $\begin{array}{rr}52 & 150 \\
1 & 120 \\
7 & 090\end{array}$ & $\begin{array}{r}782250 \\
16800 \\
106350\end{array}$ \\
\hline $\begin{array}{ll}9 & 600 \\
& 370 \\
2 & 460\end{array}$ & $\begin{array}{r}144000 \\
5550 \\
36900\end{array}$ \\
\hline $\begin{array}{ll} & 130 \\
2 & 300 \\
1 & 150\end{array}$ & $\begin{array}{rr}1 & 950 \\
34 & 500 \\
17 & 250\end{array}$ \\
\hline
\end{tabular}

15180

227700

9780

5070

146700

76050

$\underline{106 \quad 400}$

1596.000

$\left(\mathrm{m}^{3}\right)$

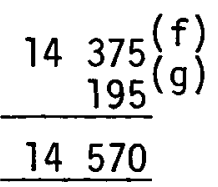

1897500 25790

1923290

3519290

(a)Based on a system/component-wise analys is of specific requirements, unless otherwise noted; rounded to the nearest 10 MWh for electricity and to the nearest whole $\mathrm{m}^{3}$ for fuel oil.

(b) Based on Section M. 6 of Appendix M.

(c) Includes the Reactor Building, the Turbine Generator Building, and the radwaste area of the Radwaste and Control Building.

(d) Includes all such systems 1 isted in Appendix C for all anticipated operations (decontamination, draining, cooling, clean-up, radwaste processing, etc.); includes appropriate information from Table H.5-9 in Appendix $\mathrm{H}$.

(e) Estimated at about $5 \%$ of the total.

(f)Assumes four heating periods during immediate dismantlement.

(g) From Table H.5-9. 
TABLE I.3-9. Costs for Special Tools and Equipment for Immediate Dismantlement

\begin{tabular}{|c|c|c|}
\hline Item & $\begin{array}{c}\text { Estimated } \\
\text { Number } \\
\text { Required }(a) \\
\end{array}$ & $\begin{array}{c}\text { Estimated Costs }(b) \\
(\$ \text { thousands }) \\
\end{array}$ \\
\hline Underwater Manipulator & 1 & 1000 \\
\hline Underwater Plasma-Arc Torch & 2 & 40 \\
\hline Underwater Oxyacetylene Torch & 2 & 10 \\
\hline Arc Saw & 1 & 100 \\
\hline Portable Plasma-Arc Torch & 2 & 40 \\
\hline Portable 0xyacetylene Torch & 10 & 10 \\
\hline Remote-Controlled Oxyacetylene Torch & 4 & 20 \\
\hline Guillotine Pipe Saw & 10 & 40 \\
\hline Power-0perated Reciprocating Hacksaw & 10 & 5 \\
\hline Closed-Circuit, High-Resolution Television & 2 & $15^{(c)}$ \\
\hline Underwater Lights and Periscopes & As Required & 5 Total \\
\hline $\begin{array}{l}\text { Underwater Tools (e.g., Impact Wrenches, } \\
\text { Bolt Cutters, Tongs) }\end{array}$ & As Required & 25 Total \\
\hline Submersible Pump with Disposable Filter & 5 & 5 \\
\hline High-Pressure Water Jet & 2 & 40 \\
\hline Pipe Jumper & 4 & 3 \\
\hline Mobile Chemical Decontamination Unit & 5 & 100 \\
\hline Mobile Chemical Mixing and Heating Unit & 4 & $10^{\circ}$ \\
\hline Scaffolding & 200 & 10 \\
\hline Safety Nets & As Required & 25 Total \\
\hline $\begin{array}{l}\text { Power-Operated, Mobile, Scissors-Type } \\
\text { Manlift }\end{array}$ & 6 & 192 \\
\hline $\begin{array}{l}\text { Power-Operated, Mobile, Articulated-Arm } \\
\text { Manl ift }\end{array}$ & 3 & 27 \\
\hline 9100-kg Mobile Hydraulic Crane & 3 & 60 \\
\hline $9100-k g$ Fork 1 ift & 6 & $80^{(d)}$ \\
\hline $\begin{array}{l}\text { Rigging Materials (e.g., Chokers, Grapples, } \\
\text { Winches) }\end{array}$ & As Required & 25 Total \\
\hline $\begin{array}{l}\text { Concrete Drill with HEPA-Filtered Dust } \\
\text { Collecting System }\end{array}$ & 4 & 8 \\
\hline Concrete Surface Spaller & 4 & 20 \\
\hline $\begin{array}{l}\text { Front-End Loader (Highly Maneuverable, } \\
\text { Light-Duty) }\end{array}$ & 3 & 30 \\
\hline Vacuum Cleaner (HEPA-Filtered) & 3 & 15 \\
\hline Portable Ventilation Enclosure & 10 & 15 \\
\hline Supplied-Air Plastic Suit & 250 & 15 \\
\hline Filtered-Exhaust Fan Unit & 4 & 16 \\
\hline Polyurethane Foam Generator & 2 & 10 \\
\hline Total Cost & & 2016 \\
\hline
\end{tabular}

Estimated
Number
Required

Underwater Manipulator

Underwater Plasma-Arc Torch

Arc Saw

Portable Plasma-Arc Torch

Guillotine Pipe Saw

Power-0perated Reciprocating Hacksaw

Closed-Circuit, High-Resolution Television

Underwater Lights and Periscopes

Underwater Tools (e.g., Impact Wrenches, , Tongs

Submersible Pump with Disposable Filter

High-Pressure Water Jet

Pipe Jumper

Mobile Chemical Decontamination Unit

Mobile Chemical Mixing and Heating Unit

caffolding

Power-Operated, Mobile, Scissors-Type

ower-Operated, Mobile, Articulated-Arm Manl ift

9100-kg Fork Tift

Rigging Materials (e.g., Chokers, Grapples,

Concrete Drill with HEPA-Filtered Dust

Concrete Surface Spaller

ront-End Loader (Highly Maneuverable,

Vacuum Cleaner (HEPA-Filtered)

Conclosure

Supplied-Air Plastic Suit

Filtered-Exhaust Fan Unit

Total Cost

As Required

5 Total

25 Total

100

10 


\section{I.3.5 Costs for Miscellaneous Supplies}

A variety of supplies are used during immediate dismantlement. These include expendable glass-fiber and HEPA filters, anticontamination clothing, cleaning and contamination control supplies (chemical agents, sweeping compounds, rags, mops, and plastic bags and sheeting), expendable hand tools, cutting and welding supplies (saw blades, torch gas, and welding rod), decontamination chemicals, and filter/demineralizer resins. The estimated costs for these items are given in Table I.3-10. The total estimated cost for miscellaneous supplies during immediate dismantlement of the reference BWR is about $\$ 1.9$ million and represents about $5 \%$ of the tota 1 immediate dismantlement cost.

\section{TABLE I.3-10. Costs for Miscellaneous Supplies} During Immediate Dismantlement

\begin{tabular}{|c|c|}
\hline Item & ( $\$$ thousands) \\
\hline \multicolumn{2}{|l|}{ Filters } \\
\hline $\begin{array}{l}\text { Reactor Building and Turbine Genera- } \\
\text { tor Building HVAC Exhausts (a) }\end{array}$ & 450 \\
\hline All Other Requirements & 137 \\
\hline Anticontamination Clothing (b) & 323 \\
\hline $\begin{array}{l}\text { Cleaning and Contamination Control } \\
\text { Supplies }\end{array}$ & 345 \\
\hline Hand Tools & 120 \\
\hline Cutting and Welding Supplies & 60 \\
\hline Decontamination Chemicals $(c)$ & 335 \\
\hline Filter/Demineralizer Resins ${ }^{(c)}$ & 89 \\
\hline Total & 1859 \\
\hline \multicolumn{2}{|c|}{$\begin{array}{l}\text { (a) Includes filters, housings, and ducting; see Section H.2.8 } \\
\text { of Appendix } \mathrm{H} \text {. } \\
\text { (b) Estimated at four changes per day per decommissioning } \\
\text { worker. See Reference } 3 \text {. } \\
\text { (c) From Table H.5-7, rounded to nearest } \$ 1000 \text {. }\end{array}$} \\
\hline
\end{tabular}




\section{I.3.6 Costs for Specialty Contractors}

The estimated costs for specialty contractors are given in Table I.3-11. As discussed in Section $\mathrm{H} .3$ of Appendix $\mathrm{H}$, these specialty contractors perform explosives work, temporary radwaste handling, and environmental monitoring. The costs for a hauling contractor are not shown in this table, but are shown as "transportation costs" in Section I.3.1 for disposal of radioactive wastes.

The total cost for specialty contractors during immediate dismantlement, excluding the hauling contractor, is $\$ 356,000$, which is about $1 \%$ of the total immediate dismantlement cost.

\section{TABLE 1.3-11. Costs for Specialty Contractors} During Immediate Dismantlement

\begin{tabular}{|c|c|c|}
\hline Specialty Contractor (a) & $\begin{array}{l}\text { Cost Estimating } \\
\text { Basis (\$/unit) }\end{array}$ & $\begin{array}{r}\text { Estimated Co } \\
(\$)\end{array}$ \\
\hline plosives & $21250 /$ job $^{(b)}$ & 21250 \\
\hline emporary Radwaste Handling & $10000 / \mathrm{mo}^{(\mathrm{c})}$ & 200000 \\
\hline nvironmental Monitoring & $38500 / y r^{(d)}$ & 134750 \\
\hline tal Cost & & 356000 \\
\hline \multicolumn{3}{|c|}{$\begin{array}{l}\text { (a)Does not include the hauling contractor, which is shown as } \\
\text { "transportation costs" in Section I.3.1 with a total cost } \\
\text { of approximately } \$ 2.9 \text { million. } \\
\text { (b)Based on information supplied by Mr. Jerry Curry of JC Drill } \\
\text { ing and Contracting, Bellevue, Washington; rounded to the } \\
\text { next higher } \$ 50 \text {. } \\
\text { (c)Based on information presented on Page } 10-4 \text { of Reference } 1 \\
\text { and corroborated with Mr. Ed Brooks of Chem-Nuclear Systems, } \\
\text { Inc., Bellevue, Washington. } \\
\text { (d) Based on information presented on Page G-37 of Reference } 1 \text {. }\end{array}$} \\
\hline
\end{tabular}

\section{I.3.7 Costs for Nuclear Insurance}

The costs for nuclear liability insurance during immediate dismantlement are estimated for an assumed policy limit of $\$ 125$ million carried through the dismantlement period and are shown in Table 1.3-12. The total estimated cost for nuclear insurance is $\$ 800,000$, which represents a little more than $2 \%$ of the total immediate dismantlement cost. 
TABLE I.3-12. Costs for Nuclear Liability Insurance

During Immediate Dismantlement(a)

\begin{tabular}{cc}
$\begin{array}{cc}\text { Year After } \\
\text { Shutdown }\end{array}$ & $\begin{array}{c}\text { Estimated Premium } \\
\text { (\$ thousands) }\end{array}$ \\
\cline { 1 - 1 } 1 & 240 \\
2 & 210 \\
3 & 210 \\
4 & $\underline{140}$ \\
\hline Total & 800
\end{tabular}

(a) Based on information presented on Page 10-8 of Reference 1.

\section{I.3.8 Costs for Licensing Fees}

The fees charged for licensing services performed by the NRC are delineated in 10 CFR Part $170 .^{(4)}$ The costs of licensing fees during immediate dismantlement of the reference BWR are shown in Table I.3-13. The total cost for licensing services is $\$ 50,800$, which is approximately $0.1 \%$ of the total immediate dismantlement cost.

\section{TABLE I.3-13. Costs for Licensing Fees puring Immediate Dismantlement $(a)$}

\section{Licensing Service Category}

Facility License Amendment (Class IV)

Health, Safety, and Environmental Inspection

Safeguards Inspection

Total

$\begin{array}{lr}\frac{\text { Fee (\$) }}{12300} & \text { Total Costs } \\ \begin{aligned} 24600^{(b)} \\ 11800 / \text { year }\end{aligned} & 2600^{(c)} \\ & {\underline{23600^{(d)}}}^{50800}\end{array}$

(a)From Reference 4

(b) Based on two license amendments, one to obtain a possession-only license prior to dismantlement and one to terminate that license following dismantlement.

(c)Based on the time the license is in force (i.e., approximately 4 years for immediate dismantlement.

(d)Based on having spent fuel on site for 19 months (i.e., two yearly fees charged). 


\subsubsection{Other Possible Cost's}

Four additional categories of costs could figure into the total immediate dismantlement cost depending on how they are classified. In this study, they are presented separately since they cannot be clearly identified as belonging to immediate dismantlement. The tasks that require these costs are:

- shipment of the spent reactor fuel to an offsite repository

- demolition of the structures and restoration of the site

- alternative disposal of the highly activated materials in a deep geologic disposal facility

- disposal of the fuel channels.

Discussions of the costs associated with these tasks are presented in the following subsections.

\subsubsection{Spent Fuel Shipment}

Since the ultimate disposition of the spent reactor fuel is not known, it is assumed in this study that the 764 fuel assemblies from the final reactor core load are shipped, together with their fuel channels, to a repository located $2400 \mathrm{~km}$ by rail from the reference BWR. The assemblies are assumed to be shipped in IF-300 rail casks, using the fuel channels as protection instead of the normal shipping baskets. Each cask shipment is assumed to carry a maximum of 18 fuel assemblies and fuel channels, to be shipped using regular freight methods, and to require 18 days round trip. Thus, 43 cask shipments are necessary to ship all the fuel and channels. The total cask rental cost (see Table M.3-1 in Appendix M) is $\$ 2,709,000$, and the total transportation cost (see Section M.4.2 of Appendix M) is $\$ 1,079,300$. Therefore, the total estimated cost for shipping the spent fuel and channels to the assumed repository is $\$ 3,788,300$. This does not include either handling costs at the reactor or handling and storage costs at the repository. The unencapsulated volume of the spent reactor fuel with the fuel channels is approximately $67 \mathrm{~m}^{3}$.

In order to meet the schedule shown in Section I.2 with the 18-day-roundtrip requirement stated above, two casks are assumed used for about $60 \%$ of the time, with one cask for the rest. This, however, does not affect the costs associated with spent fuel shipment, whether shipped individually or together. 
If special trains are required, an additional cost of $\$ 2,451,000$ would be necessary for 43 single-cask shipments (see Section M.4.2). The use of more than one cask per shipment would decrease this cost inversely to the number of casks per shipment.

\section{I.3.9.2 Facility Demolition and Site Restoration}

The costs for demolishing the decontaminated and uncontaminated structures of the reference BWR are summarized in Table L.3-1 of Appendix $L$ and are not repeated here. The total cost of $\$ 13,244,000$ (without contingency) includes labor, supplies, overheads, and profit, but not extraordinary insurance premiums, bonding, or state sales tax. Details of the cost estimates for this task, which is not required for termination of the facility nuclear license, are given in Section L. 3 of Appendix L.

\section{I.3.9.3 Deep Geologic Disposal of Highly Activated Materials}

The information presented in Table $1.3-3$ is based on the assumption that all of the neutron-activated components are placed in a shallow-land disposal site. Because of the large initial amount of radioactivity, the long halflives of ${ }^{59} \mathrm{Ni}$ and ${ }^{94} \mathrm{Nb}$, and the potential biological hazard of ${ }^{14} \mathrm{C}$, it is a possibility that the highly activated materials may require disposal as intermediate-level wastes in a deep geologic disposal facility, similar to the proposed disposal of high-level radioactive wastes and fuel cladding hulls that result from spent fuel reprocessing. An analysis is, therefore, made to estimate the additional cost of placing the highly activated materials in deep geologic storage rather than in shallow-land storage. This analysis is based on the proposed burial canisters $(0.76 \mathrm{~m}$ dia. by $3.05 \mathrm{~m}$ long) and the postulated burial costs for immediate-level wastes $\left(\$ 7100 ; \mathrm{m}^{3}\right)$ from Reference 5 .

The shroud head plate (the lower part of the steam separator assembly), the fuel support pieces, the control rods, the in-core instruments, the jet pump assemblies, the top fuel guide, the core support plate, and the core shroud are considered to be sufficiently activated to require possible deep geologic disposal. The steam separator risers, the control rod guide tubes, the reactor vessel, and the sacrificial shield are considered to be mildly activated and require only shallow-land disposal. 
The highly activated components have a calculated mass of $90,600 \mathrm{~kg}$ and, with a density of $7860 \mathrm{~kg} / \mathrm{m}^{3}$, a theoretical volume of about $11.5 \mathrm{~m}^{3}$. Assuming a $15 \%$ packing density in the burial canister (about $1.2-\mathrm{m}^{3}$ internal volume), 64 canisters are required to package these components. The total cost for the canisters (see Table M.2-1 in Appendix M) is $\$ 320,000$.

Shipment to the deep geologic disposal facility is assumed to use regular freight methods and to be in IF-300 railroad casks, with each cask carrying a maximum of three canisters. The one-way rail distance is again assumed to be $2400 \mathrm{~km}$, and the round trip is again assumed to take 18 days. A minimum of 22 single-cask shipments are required. The total cask rental cost (see Table M.3-1 in Appendix M) is $\$ 1,386,000$, and the total transportation cost (see Section M.4.2 of Appendix M) is $\$ 552,200$.

The total cost for placing the 64 loaded canisters (the total volume is $88.9 \mathrm{~m}^{3}$ ) in deep geologic disposal, at $\$ 7100 / \mathrm{m}^{3}$, is $\$ 631,190$.

The individual estimated costs for deep geologic disposal of the highly activated materials are summarized and totaled below:

\begin{tabular}{|c|c|c|c|c|}
\hline $\begin{array}{l}\text { Canister } \\
\text { Cost (\$) }\end{array}$ & $\begin{array}{l}\text { Cask Rental } \\
\text { Cost }(\$)\end{array}$ & $\begin{array}{l}\text { Transportation } \\
\text { Cost }(\$) \\
\end{array}$ & $\begin{array}{l}\text { Disposal } \\
\text { Cost }(\$)\end{array}$ & $\begin{array}{c}\text { Total } \\
\text { Cost }(\$) \\
\end{array}$ \\
\hline 20000 & 1386000 & 552200 & 631190 & 889390 \\
\hline
\end{tabular}

For the purposes of this study, it is necessary to know the incremental cost of this alternate disposal method over and above the cost of shallow-land burial. From Table I.3-3, the total cost for disposal of the highly activated components in a shallow-land disposal facility is estimated to be $\$ 2,041,030$. Thus, the incremental cost for disposing these materials in deep geologic disposal is $\$ 848,360$ more than the shallow-land burial cost. No attempt is made to estimate the effects of this alternate disposal method on the other immediate dismantlement costs that it might affect.

If a special train is required, an additional total estimated cost of $\$ 1,254,000$ is necessary for 22 single-cask shipments (see Section M.4.2). The use of more than one cask per shipment would decrease this cost inversely to the number of casks per shipment, but would not affect the disposal costs presented previously. 


\section{I.3.9.4 Fuel Channel Disposal}

The assumption that the fuel channels are shipped and stored with the spent fuel is based on practicality rather than present practice. Presentiy, this is not a viable option, and, therefore, an analysis is required to determine the alternative costs for disposing of the fuel channels as activated waste in either a shallow-land disposal facility or a deep geologic disposal facility.

It is recognized that the zircaloy-4 metal that is used for the fuel channels contains trace quantities of natural uranium, and that the irradiated fuel channels could possibly be classed as transuranic waste. However, for this analysis it is assumed that the transuranic radionuclide concentration is low enough to allow disposal of the irradiated fuel channels as non-transuranic waste similar to all the other neutron-activated materials.

No attempt is made in this analysis to determine the effect of this disposal operation on the task schedules presented in Section I.2 or the other costs presented in this section (Section I.3) that might be affected.

Shallow-Land Disposal. For shallow-land disposal, the 764 fuel channels are assumed to be cut lengthwise, packaged in specially fabricated steel boxes, and shipped in a truck-mounted, NAC-1 spent fuel cask. These packaging and shipping methods are the same as those assumed for the control rods in Section I.3.1.

Based on a $35 \%$ packing density, an estimated 31 specially fabricated stee boxes are required to package the fuel channel segments, at a total container cost of $\$ 186,000$ (see Table M.2-1 in Appendix M). For 31 overweight shipments, at $1600-\mathrm{km}, 5$-day round trips, the total cask rental cost (see Table M.3-1) is $\$ 106,950$, and the total transportation cost (see Table M.4-4) is $\$ 59,520$.

The handling surcharge is estimated to be $\$ 47,700$, based on a ratioproportion calculation with the handling surcharge reported in Table I.3-3 for the control rods. The burial volume is estimated on this same basis to be about $58 \mathrm{~m}^{3}$, and the resultant burial cost is about $\$ 5430$ (see Table M.5-1). 
For estimating the liner and curie surcharges, it is assumed that the surface dose rate and the radioactivity content of each fuel channel package are similar to those estimated for a control rod package, even though it is recognized that the radionuclide inventories in the contents of the two packages are quite different. Thus, the liner surcharge is estimated to be approximately $\$ 165,890$, and the curie surcharge is about $\$ 45,650$, again based on ratio-proportion calculations with the respective parameter values reported in Table 1.3-3 for the control rods.

The individual estimated costs for shallow-land disposal of the fuel channels are summarized and totaled below:

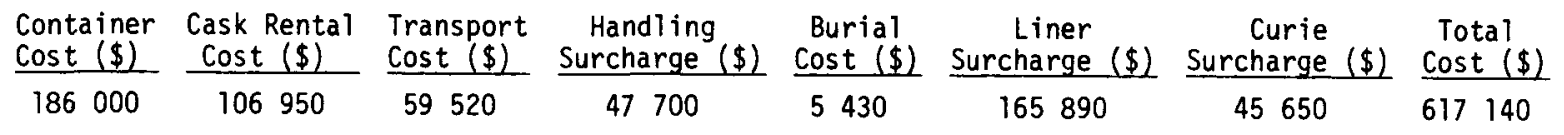

Deep Geologic Disposal. The fuel channels can also be classed as highly activated materials that may require placing in a deep geologic disposal facility. Therefore, with two exceptions, this analysis to estimate the alternate cost of deep geologic disposal of the fuel channels uses the same methods and assumptions as are used in Section I.3.9.3 in estimating this cost for the other highly activated materials. The packing density is assumed to be $25 \%$, and the volume of the segmented fuel channels is estimated using data obtained from Reference 6.

The packageable volume of the segmented fuel channels is estimated to be $6.9 \mathrm{~m}^{3}$. Twenty-three (23) burial canisters are required, at a total cost of $\$ 115,000$. A minimum of 8 single-cask shipments are required, at a total cask rental cost of $\$ 504,000$ and a total transportation cost of $\$ 208,000$. The total cost for placing the 23 loaded canisters (the total volume is $32 \mathrm{~m}^{3}$ ) in deep geologic disposal is $\$ 227,200$.

The individual estimated costs for deep geologic disposal of the fuel channels are summarized and totaled below:

$\begin{array}{llllll}\begin{array}{l}\text { Canister } \\ \text { Cost }(\$)\end{array} & \begin{array}{c}\text { Cask Rental } \\ \text { Cost }(\$)\end{array} & \frac{\begin{array}{c}\text { Transportation } \\ \text { Cost }(\$)\end{array}}{2000000} & \frac{\text { Disposal }}{20000} & \frac{\text { Cost }(\$)}{227200} & \frac{\text { Cost }(\$)}{1047000}\end{array}$


The incremental cost for this disposal alternative is $\$ 429,860$ more than for shallow-land burial.

An additional cost of $\$ 456,000$ would be required for shipping the 8 singlecask shipments by special train. Again, the use of more than one cask per shipment would decrease this special train cost inversely to the number of casks per shipment, but would not affect the disposal costs presented previously.

\section{I.4 EXTERNAL OCCUPATIONAL RADIATION DOSES FOR IMMEDIATE DISMANTLEMENT}

Detailed estimates are made of the external occupational radiation doses that are accumulated by the decommissioning workers during immediate dismantlement of the reference BWR. The estimates are based on a task-by-task analysis to determine the man-hours of effort required in radiation zone work and the anticipated dose rates associated with each task for all labor categories. Basic assumptions made in developing these estimates are: 1) every effort is made to minimize the personnel exposure to radiation (ALARA philosophy) while accomplishing a task, by the use of temporary shielding and remote handling techniques and by staying out of radiation fields when not actively participating in the work; 2) the chemical decontamination campaign is reasonably successfur, reducing all radiation dose rates from the decontaminated piping and equipment by at least a factor of $10 ; 3$ ) careful, prompt accounting of radiation doses is maintained to rapidly identify jobs that are causing excessive dose accumulations so corrective action can be taken; and 4$){ }^{60}$ Co governs the radioactive decay.

The estimated total dose for each task is corrected for radioactive decay with a decay factor calculated using the half-life of ${ }^{60} \mathrm{Co}$ and the midpoint of the timeline for the given task (shown in Figure I.2-4).

The results of these analyses and corrections are presented in Table I.4-]. The total corrected external occupational radiation dose for immediate dismantlement of the reference BWR is 1845 man-rem. Of the total, 53\% results from immediate dismantlement of the Reactor Building/Primary Containment, about $11 \%$ from immediate dismantlement of the Turbine Generator Building, nearly $32 \%$ from immediate dismantlement of the Radwaste and Control Building, and approximately $4 \%$ from ancillary tasks. 


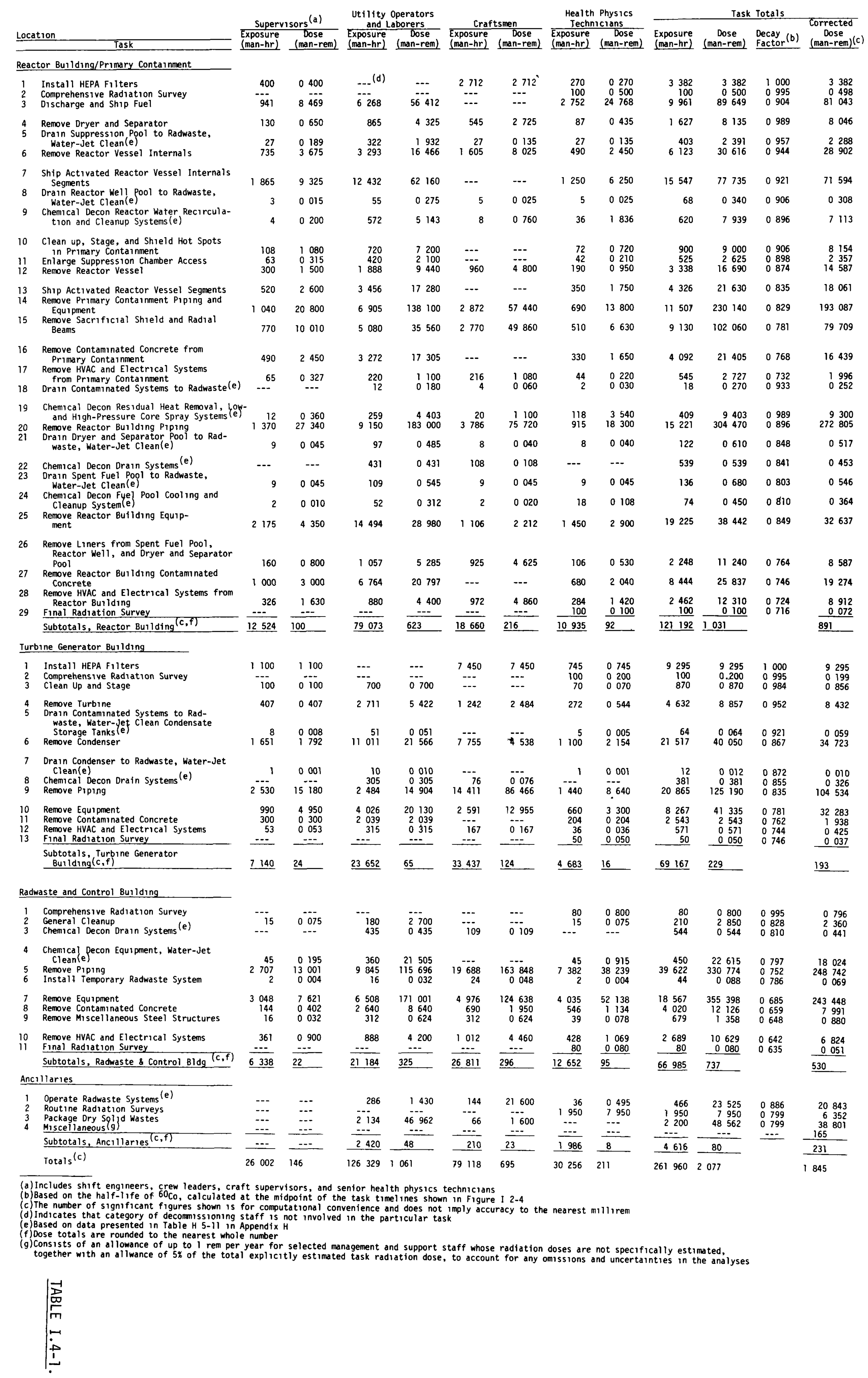


Two other tasks not showr in Table I.4-1 provide the potential for external radiation dose and occur as a direct result of immediate dismantlement:

1) transporting the radioactive materials to the disposal site, and 2) handling these materials at the disposal site. A total of 1,495 shipments of radioactive materials must be transported to, and handled at, the disposal site. The external radiation dose from transportation is discussed in Section N.5 of Appendix $N$. The external radiation dose from handling these materials at the disposal site is beyond the scope of this study since it is considered under another nuclear 1 icense. 


\section{REFERENCES}

1. R. I. Smith, G. J. Konzek and W. E. Kennedy, Jr., Technology, Safety and Costs of Decommissioning a Reference Pressurized water Reactor Power Station, NUREG/CR-0130, U.S. Nuclear Regulatory Commission Report by Pacific Northwest Laboratory, June 1978. *

2. Plan for Reevaluation of NRC Policy on Decommissioning of Nuclear Facilities, NUREG-0436, Rev. T, Section 4.1, U.S. Nuclear Regulatory Commission, Washington, DC 20555, December 1978. *

3. C. A. Pelletier and P. G. Voillegue, Potential Benefits of Reducing Occupational Radiation Exposure, AIF/NESP-010, Atomic Industrial Forum, Inc., Washington, DC 20014, May 1978.

4. U.S. Code of Federal Regulations, Title 10, Part 170, "Fees for Facilities and Materials Licenses and Other Regulatory Services under the Atomic Energy Act of 1954, As Amended," Superintendent of Documents, GPO, Washington, DC 20555, 1979.

5. K. J. Schneider and C. E. Jenkins, Technology, Safety and Costs of Decommissioning a Reference Fuel Reprocessing Plant, NUREG-0278, p. 7-129, U.S. Nuclear Regulatory Commission Report by Pacific Northwest Laboratory, September 1977. **

6. WPPSS Nuclear Project No. 2 Final Safety Analysis Report, Chapter 1.3, Washington Public Power Supply System, Richland, WA, February 1977.

₹ Available for purchase from the NRC/GPO Sales Program, U.S. Nuclear Regulatory Commission, Washington, D.C. 20555, and the National Technical Information Service, Springfield, Virginia 22161.

${ }^{\star \star *}$ Available for purchase from the National Technical Information Service, Springfield, Virginia 22161. 


\section{APPENDIX J}

PASSIVE SAFE STORAGE, CONTINUING CARE, AND DEFERRED DISMANTLEMENT DETAILS

This appendix contains the details of passive safe storage for the reference BWR. Besides the preparations made during active decommissioning following reactor shutdown, passive safe storage includes continuing care to meet the remaining requirements of the nuclear license and probable deferred dismantlement to terminate that 1 icense.

The information presented in this appendix includes the following:

- selection of passive safe storage

- passive safe storage supporting information

- preparations for passive safe storage

- passive safe storage schedules and manpower estimates

- costs for passive safe storage

- estimated external occupational radiation doses for passive safe storage

- deferred dismantlement

\section{J.1 SELECTION OF PASSIVE SAFE STORAGE}

All categories of safe storage--custodial, passive, and hardened--are open-ended, in that all require positive action at the conclusion of the period of continuing care to release the property for unrestricted use and to terminate the possession-only license.

In hardened safe storage, temporary, hardened barriers around areas containing significant quantities of residual radioactivity must be installed and may eventually be removed; thus, this category requires maximum costs for preparations and possible deferred dismantlement but minimum costs for continuing care. Custodial safe storage requires minimal preparations but requires full-time, onsite, surveillance crews during continuing care to maintain the structure, the operating equipment, and the security of the property. Passive safe storage is assumed to optimize the costs for preparations, continuing care, and possible deferred dismantlement, keeping 
the combined cost at a minimum. Thus, passive safe storage is selected in this study as the safe storage category for decommissioning the reference BWR.

The planning and preparation activities for the preparations for passive safe storage are described generically in Section $H .2$ of Appendix $H$. Work plans are developed for decommissioning the Reactor Building (including the Primary Containment), the Turbine Generator Building, and the Radwaste and Control Building. The procedures discussed in this appendix are postulated to be used to decontaminate, deactivate, and secure radioactive materials and contaminated areas within these buildings, to achieve a condition that provides protection to the public and the environment, with Timited maintenance and surveil1ance.

Areas of the facility that must be accessible during continuing care are decontaminated to unrestricted use levels. Noncombustible, contaminated materials, which are not removed from the facility, may be placed in the drained spent fuel pool, dryer separator pool, and/or pressure suppression pool. These areas are isolated from the remainder of the facility by structurally substantial physical barriers. The remaining portion of the site may be released for unrestricted use during the continuing care period.

The continuing care period begins when the preparations for passive safe storage are completed. This period is characterized by surveillance and maintenance activities designed to ensure that the facility remains in a condition that poses minimum risks to the public. The activities included in this phase are limited to environmental and facility radiation monitoring and to inspecting and repairing, as necessary, the physical barriers, the structures and the instrumentation. Security is provided by the fence around the immediate facility site (about 0.06 square kilometers), by high-security locks on entrance doors, and by electronic alarms.

It is assumed that approximately 18 months before final plant shutdown are devoted to planning and preparation. Based on detailed work plans, about 30 months (from the time of initiation of physical decommissioning tasks) are estimated to be required to prepare the facility for the period of continuing 
care. It is assumed that the facility will remain in the passive safe storage condition until deferred dismantiement takes place.

\section{J.2 PASSIVE SAFE STORAGE SUPPORTING INFORMATION}

Decommissioning methods, special tools and equipment, and essential systems and services used in preparing the reference BWR for passive safe storage are discussed in this section. These methods and considerations, in order of their presentation in the following subsections, are:

- decontamination, deactivation, and sealing methods

- spray painting

- transfer of contaminated equipment and materials

- decontamination and isolation procedure

- special tools and equipment

- essential systems and services

\section{J.2.1 Decontamination, Deactivation, and Sealing Methods}

Initially, the comprehensive decommissioning radiation survey is completed. Systems draining and decontamination tasks described in Section $\mathrm{H} .5$ of Appendix $\mathrm{H}$ begin immediately after the fuel is discharged from the reactor. Selected decontamination tasks may proceed concurrently. The primary concern is to ensure that no recontamination of clean areas occurs and that air leaving a given area flows through a filter system or, in the case of liquid effluents, through the existing contaminated waste systems.

The particular method used to decontaminate, deactivate, and seal each system or piece of equipment is identified during the planning phase. In general, all systems not necessary to prevent the spread of contamination are deactivated. Equipment deactivation, isolation of contaminated areas, and sealing techniques are described in Section H. 6 of Appendix H. Generic decontamination methods used in the preparations for passive safe storage are described in Appendix $G$.

The contaminated drains are decontaminated as described in Section $\mathrm{H} .5$ of Appendix $H$. Building sumps are decontaminated and secured. In some cases, 
after the sump pumps are decontaminated and/or removed; steel plates are welded in place to cover the sump area.

Spray painting of contaminated materials and equipment and transferring the contaminated materials and equipment are assumed to be widely used in the preparations for passive safe storage. These techniques are described in subsequent subsections.

\section{J.2.2. Spray Painting}

After the loose, readily removable contamination is removed by the physical cleaning methods described in Section G. 1 of Appendix G, the rooms or areas and their associated equipment are thoroughly spray painted before isolation or removal procedures begin. When possible, all contaminated surfaces, both inside and outside, are coated to prevent the entrainment of radioactivity in the air during the active decommissioning tasks or during subsequent surveillance and maintenance activities.

In general, if the contamination on a surface cannot be removed by wiping or washing using standard decontamination solutions, it is painted to fix the contamination in place. An example is a concrete surface that has been penetrated by contaminated liquids. While the surface might be cleaned initially, the subsurface contamination can migrate to the surface and be dispersed by air movement and/or foot traffic. On protected, interior surfaces with essentially no traffic or adverse environment, the paint coatings can be expected to last almost indefinitely. Part of the surveillance program is to monitor painted areas for deterioration of the coatings and to recoat them as necessary.

\section{J.2.3 Transfer of Contaminated Equipment and Materials}

Unsalvageable, contaminated equipment and other miscellaneous noncombustible items may be transfered to other secured, onsite retrievable storage areas, as described in Section J.1. It is anticipated that before transferring small equipment items, the items are carefully spray painted to immobilize any contamination. Freshly exposed surfaces are immediately painted to prevent dispersal of contamination. The disconnected items are carefully bagged and transferred to a retrievable storage area. The equipment and ductwork remaining 
in the work area is physically decontaminated as described in Section G.1 of Appendix $G$ and spray painted as previously described.

\section{J.2.4 Decontamination and Isolation Procedure}

The 13-point procedure given below is postulated to be used to prepare the contaminated areas throughout the Reactor Building, the Turbine Generator Building, and the Radwaste and Control Building for passive safe storage:

1. Conduct initial radiation survey.

2. Vacuum interior surface areas.

3. Deactivate nonessential systems and equipment.

4. Clean interior surface areas and exposed surfaces of equipment and piping.

5. Clean remaining hot spots.

6. Apply protective paint.

7. Transfer, as feasible, contaminated equipment and materials.

8. Decontaminate and seal vent systems.

9. Install HEPA-filtered vents.

10. Deactivate remaining nonessential systems and equipment.

11. Install intrusion alarms; provide for offsite readout for intrusion, fire, and radiation detection systems.

12. Conduct final radiation survey.

13. Secure the structure.

\section{J.2.5 Special Tools and Equipment}

Fewer special tools and equipment are required for the preparations for passive safe storage than for immediate dismantlement. No dismantlement of highly activated material or equipment is necessary, thus eliminating the need for and expense of special remote handling equipment.

A list of special tools and equipment postulated for use in preparations for passive safe storage, together with their functions, is given in Table J.2-1. 
TABLE J.2-1. Special Tools and Equipment for Preparations for Passive Safe Storage

\begin{tabular}{|c|c|c|}
\hline Item & $\begin{array}{l}\text { Estimated } \\
\text { Number } \\
\text { Required (a) } \\
\end{array}$ & Function \\
\hline Portable Oxyacetylene Torch & 2 & $\begin{array}{l}\text { Cutting carbon steel equipmert and } \\
\text { piping, welding carbonn steel }\end{array}$ \\
\hline Guillotine Pipe Saw & 2 & Cutting prping \\
\hline Power-Operated Reciprocating Hacksaw & 2 & Cutting piping \\
\hline Closed-Circuit, High-Resolution Television & 1 & Remote observation of tasks \\
\hline Sutmersible Pump with Disposable Filter & 5 & $\begin{array}{l}\text { Draining of suppression chamber and } \\
\text { spent fuel storage pools }\end{array}$ \\
\hline $\begin{array}{l}\text { High-Pressure Water Jet } \\
\text { Low-Pressure Water Jet }\end{array}$ & $\left\{\begin{array}{l}2 \\
1\end{array}\right.$ & $\begin{array}{l}\text { Surface decontamination of suppression } \\
\text { chamber, tanks, main condenser, pool } \\
\text { liners }\end{array}$ \\
\hline Pipe Jumper & 4 & $\begin{array}{l}\text { Chemical decontamination of reactor piping } \\
\text { systems }\end{array}$ \\
\hline Mobile Chemical Decontamination Unit & 5 & $\begin{array}{l}\text { Chemical decontamination of } 11 \text { quid and } \\
\text { solid radwaste equipment }\end{array}$ \\
\hline Mobrle Chemical Mixing and Heating Unit & 4 & Chemical decontamination of drain systems \\
\hline Scaffolding & 50 & Safe access to herghts \\
\hline Safety Nets & As Required & $\begin{array}{l}\text { Protect personnel working on elevated } \\
\text { equipment and structures }\end{array}$ \\
\hline Power-Operated, Mobile, Scissors-Type Manlift & 2 & Safe access to herghts \\
\hline Power-Operated, Mobıle, Articulated-Arm Manlift & 1 & Safe access to heights \\
\hline 9100-kg Capacity Forklift & 1 & $\begin{array}{l}\text { Packaging of contaminated materials, and } \\
\text { loading of trucks }\end{array}$ \\
\hline Rigging Materials (e g, chockers, grapples, winches) & As Required & Handling of equrpment and prping \\
\hline Concrete Drill with HEPA-filtered Dust Collecting System & 1 & $\begin{array}{l}\text { Drilling holes in concrete as required for } \\
\text { surface spalling }\end{array}$ \\
\hline Concrete Surface Spaller & 1 & Removal of contaminated concrete surfaces \\
\hline Front-End Loader (highly maneuverable, Irght-duty) & 1 & Cleanup and packaging tasks \\
\hline Vacuum Cleaner (HEPA- $f 11$ tered) & 3 & Cleanup tasks \\
\hline Portable Ventilation Enclosure & 3 & $\begin{array}{l}\text { Contamination control during cutting of } \\
\text { contaminated material }\end{array}$ \\
\hline Supplied-Air Plastic Suit & 100 & $\begin{array}{l}\text { Provide personnel with maximum respiratory } \\
\text { and surface protection from radioactive } \\
\text { contaminants }\end{array}$ \\
\hline Polyurethane Foam Generator & 2 & $\begin{array}{l}\text { Contamination control during HVAC isolation } \\
\text { tasks }\end{array}$ \\
\hline Paint Sprayer & 4 & Immobilization of contamination \\
\hline
\end{tabular}

(a) Based on a taskwise analysis of the schedule, plus spares, as required

\section{J.2.6 Essential Systems and Services}

During preparations for passive safe storage, certain facility systems and services must remain in place and in service for contamination control, for industrial or personnel safety, and to aid in the completion of decommissioning tasks. These systems are the same as those described in Section H.4 of Appendix $\mathrm{H}$ for immediate dismantlement and are not repeated here. 
As areas within the facility are secured for continuing care, the essential systems and services in these areas are deactivated as described previously in Section J.2.1. Continuous service to the remaining work areas is maintained as required.

After placing the facility in passive safe storage, certain systems and services are required during the continuing care period. The systems and services postulated to be required during continuing care are listed in Table J.2-2, together with the justification for retaining each. The equipment in these systems is inspected and renovated to ensure adequate reliability before the surveillance and maintenance period begins. In addition, the intrusion alarm systems within the facility and on the perimeter fence are modified to provide surveillance capability by a commercial security agency.

\section{TABLE J.2-2. Systems and Services Required During} the Continuing Care Period

\begin{tabular}{|c|c|}
\hline Systems and Services & Justification \\
\hline Electrical Power & $\begin{array}{l}\text { Operation of electrical equipment, } \\
\text { including lighting, surveillance } \\
\text { monitoring, and radiation monitoring } \\
\text { systems and alarms }\end{array}$ \\
\hline Fire Protection System & Health and safety \\
\hline $\begin{array}{l}\text { In-Plant Communications } \\
\text { Sys tem (telephone) }\end{array}$ & Personnel safety considerations \\
\hline Security Systems & $\begin{array}{l}\text { Public safety and plant protection } \\
\text { considerations }\end{array}$ \\
\hline
\end{tabular}

\section{J.3 PREPARATIONS FOR PASSIVE SAFE STORAGE}

After reactor defueling operations, draining of reactor pools and piping systems that contain radioactively contaminated water begins. This contaminated water inventory is scheduled for processing through the radwaste systems as described in Section $\mathrm{H} .5$ of Appendix H. Chemical decontamination of selected systems, also described in Section H.5, is accomplished before these systems are isolated and deactivated. The chemical decontamination solutions also are processed through the existing radwaste systems. 
The Reactor Building, the Turbine Generator Building, and the Radwaste and Control Building are given a comprehensive radiation survey to accurately determine radiation and contamination levels before they are prepared for continuing care. The site and support facilities are given a comprehensive radiation survey and, for purposes of this study, are assumed to be released for unrestricted use without further effort. A discussion of the postulated preparations for passive safe storage of the reference BWR is presented in the following subsections.

\section{J.3.1 Preparation of the Reactor Building for Passive Safe Storage}

Large quantities of neutron-activated materials and many of the radioactively contaminated areas are located in the Primary Containment Vessel (PCV). For this reason, several task steps are taken in this section that are designed to improve the isolation of this significant substructure within the Reactor Building. These steps involve sealing all major accessways into the PCV, as well as providing barriers around high-radiation-level piping areas just outside of the PCV.

At reactor shutdown, the operations proceed in the usual manner for discharging the existing fuel load. The drywell and reactor vessel heads are removed, followed by the steam dryer and steam separator. The fuel is stored and cooled as necessary and then transferred to fuel shipment casks (GE IF-300 or equivalent) for shipment to a repository. The fuel shipment operations maintain an inventory of the fuel material for accountability purposes. Rail shipments convey the nuclear fuel to its appropriate repository. Components of the reactor vessel and PCV removed during refueling are returned to their normal positions and secured as normally provided for.

Fluids from the suppression pool and reactor well pool cavities are sequenced into the radwaste system, followed by chemical decontamination of the reactor water recirculating systems and of piping and equipment intertied with other buildings undergoing preparation for passive safe storage. Valves within the PCV are closed at this time in preparation for the structure's eventual isolation. The spent fuel pool and dryer separator pool are drained, cleaned, covered, and sealed in sequence. The three major equipment and personnel hatches are sealed as described in Appendix K. 
Al1 equipment, gratings, ladders, stairs, HVAC, electrical, concrete, and other miscellaneous items requiring decontamination are cleaned. Long-lasting protective paint coatings are applied to the cleaned areas to immobilize any residual radioactivity.

The various areas of the building are isolated and sealed, where appropriate, by closing all piping valves, sealing interconnecting HVAC air passageways, and sealing rooms containing significant quantities of radiation. Both the steam tunnel and the rail tunnel are sealed and sectioned off.

A permanent seal is applied to the drywell top head of the Reactor Vessel/ PCV as a final act of isolation of this structure. Nonessential utilities are deactivated, including fans, electrical units, motors, cranes, and pumps.

Waste materials from the preparation for passive safe storage are packaged and shipped to the appropriate disposal sites.

\section{J.3.2 Preparation of the Turbine Generator Building for Passive Safe Storage}

The tasks associated with this mode of decommissioning for the Turbine Generator Building are rather straight-forward because of the low level of radioactive contamination expected to be present. Following a general cleanup, the contaminated systems are drained and the condensate storage tanks are cleaned. After the condenser hot well is drained, areas accessible to personnel, which represent about $25 \%$ of the total condenser surfaces, are cleaned using the water-jet technique.

Zones of contamination found on concrete surfaces and certain metal structures are water-jet cleaned where possible. Other areas, including the HVAC system, electrical and mechanical equipment, and other poorly accessible surfaces, are manually decontaminated. Protective coats of paint are applied to the cleaned surfaces by spray painting or by manual application where necessary. Tasks associated with isolation and sealing of equipment, piping, rooms, and HVAC ducts are handled similar to those described for the Reactor Building/PCV.

\section{J.3.3 Radwaste and Control Building}

Much of the contaminated water in the Reactor Building and the Turbine Generator Building is processed in the liquid and solid radwaste systems 
located in the Radwaste and Control Building. Once decommissioning of the radwaste systems is started, a temporary, portable radwaste system, provided by a specialty contractor, is used for final radwaste processing.

The decommissioning techniques postuiated for use in the Radwaste and Control Building are the same as those described for the Reactor Building and the Turbine Generator Building (see Section J.2 for generic methods).

\section{J.3.4 Site and Support Facilities}

The final active decommissioning task is the comprehensive radiation survey of the reference BWR site and support facilities. The existing security fence that surrounds the entire site (see Figure C.1-1 in Appendix C) is left intact and is assumed to be maintained during the continuing care period. A we11-labeled security fence, equipped with intrusion detection and alarm provisions, is constructed within the existing fence to form an easily monitored exclusion area around the Reactor Building, the Turbine Generator Building, and the Radwaste and Control Building.

Electricity requirements at the facility are nominal after the preparations for passive safe storage are completed. It is assumed that the plant's large electrical service is changed to a small electrical service near the end of the active decommissioning period to provide for the needs of the essential systems and services described in Section J.2.6.

\section{J.4 PASSIVE SAFE STORAGE SCHEDULES AND MANPOWER ESTIMATES}

Developing a reasonably optimum schedule and manpower requirements for preparations for passive safe storage requires several iterations. Initially, the sequence in which the various systems must be decontaminated, drained, and secured is determined. Similarly, the sequence for decontamination, contamination immobilization, and isolation of the various rooms and areas within the Reactor Building, the Turbine Generator Building, and the Radwaste and Control Building is determined. Then, the number and types of decommissioning workers required to accomplish each task in the alloted time is estimated. The organization of the decommissioning staff is the same as that for immediate dismantlement, as shown in Figure H.1-1 in Appendix H. Based on the radiation dose estimated to 
accomplish each task, the number of workers needed to complete the radiation zone work in the alloted time and within the assumed radiation dose limits is determined. Whole-body radiation doses to the decommissioning workers are limited in accordance with 10 CFR 20.101. The supervisors, utility operators, and health physics technicians are assumed to be long-time radiation workers whose annual exposure is 1 imited to $5 \mathrm{rem} / \mathrm{yr}$ by the formula $5(\mathrm{~N}-18)$ of 10 CFR 20.101(b)(2). The craftsmen and laborers are assumed to have had little prior radiation exposure and, therefore, under 10 CFR 20.101(b)(1) and (2) may receive up to 3 rem per quarter, within the limitation of the formula $5(\mathrm{~N}-18)$. In those instances where the manpower estimated for physicaily accomplishing a task results in an average dose for each person in excess of the limits above, additional manpower is assigned to the tasks to keep the occupational dose below these limits. In the manpower table presented in this section, the manpower shown is adequate both to accomplish the task and to meet the occupational dose limits.

The decommissioning worker requirements given in this section include neither the management and support staff (see Figure H.1-l in Appendix H) nor the specialty contractor personnel (see Section H.3 of Appendix H).

Al1 decommissioning tasks are conducted in accordance with the decommissioning quality assurance plan (see Section G.5 of Appendix G) and are checked by the utility quality assurance staff. Environmental monitoring (see Section G.6 of Appendix G) during preparations for passive safe storage is performed by a specialty contractor.

\section{J.4.1 Reactor Building/Primary Containment}

A considerable effort is necessary in the preparation for passive safe storage of this structure. Special care is taken to isolate the large amounts of radionuclides from unauthorized public access and eliminate the need for authorized inspections. The manpower required to accomplish this task is estimated to exceed 20,000 man-hours. Based on the task description discussed in Section H.3.1 and the occupational dose estimates discussed in Section J.6, the schedule and decommissioning worker requirements for passive safe storage of this building are presented in Figure J.4-1. The preparations for passive 


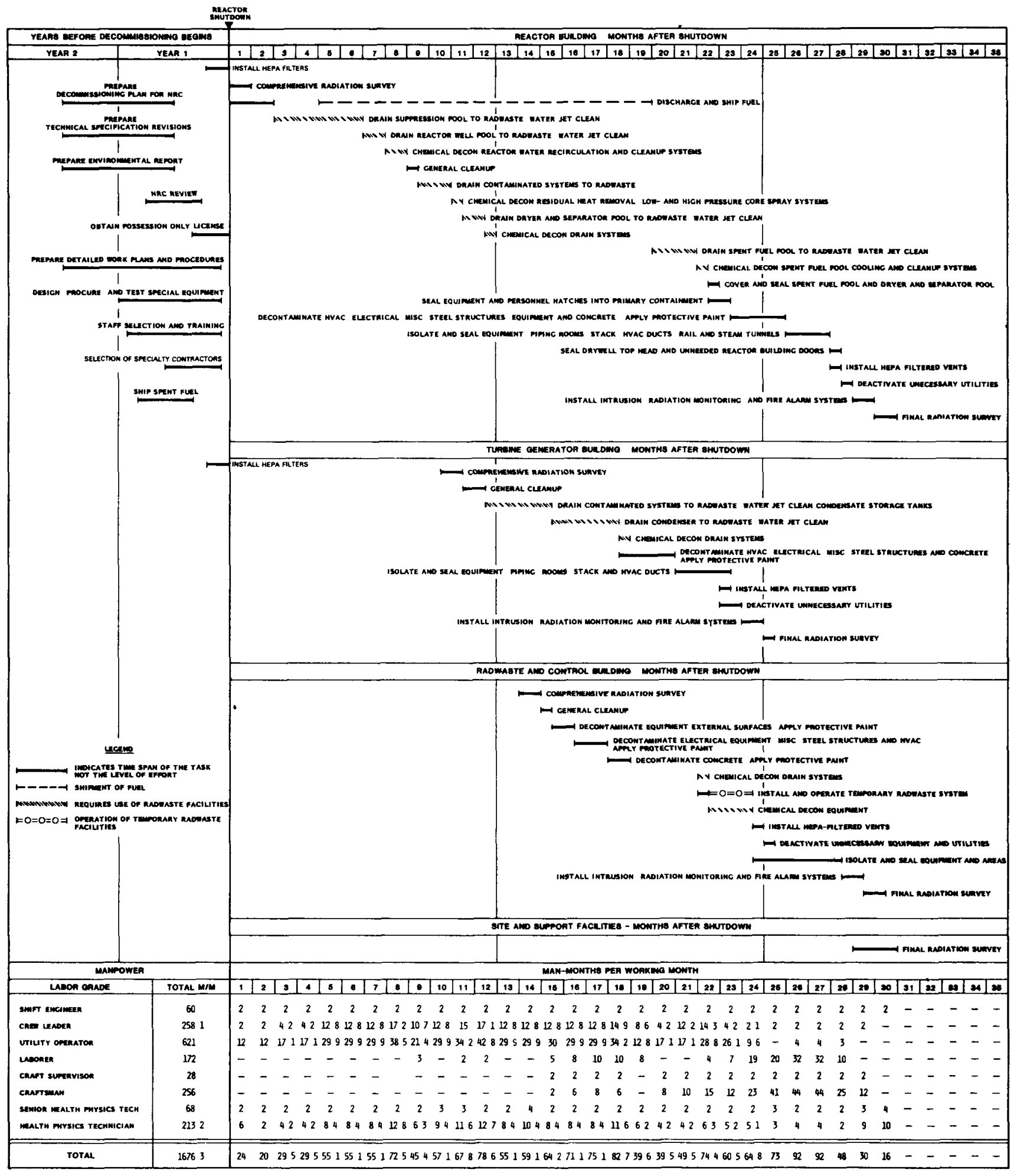

\section{FIGURE J.4-1. Task Schedule and Sequence of the Preparations for Passive Safe Storage}


safe storage are estimated to be completed about 30 months after final reactor shutdown.

\section{J.4.2 Turbine Generator Building}

The Turbine Generator Building is a rather large structure. However, the manpower required to place it in the passive safe storage mode is not proportional to its size. It is expected that considerably smaller quantities of radioactive deposition and contamination will exist in this building at reactor shutdown than in the other structures treated in this study. Much of the time necessary to decommission this building is taken up by fluid processing in the radwaste facility rather than by actual decommissioning staff activities. Except for the fluid processing, the low dose rate activities associated with this building are readily coordinated within the time frame necessary for the other two major buildings.

The schedule and decommissioning worker requirements for passive safe storage of. this building are presented in Figure J.4-1. The passive safe storage tasks are completed about 25 months following reactor shutdown.

\section{J.4.3 Radwaste and Control Building}

The liquid and solid radwaste systems located in the Radwaste and Control Building are needed to process the contaminated liquids present in the systems at reactor shutdown and the contaminated liquid wastes generated during decompissioning. Consequently, the Radwaste and Control Building is the last contaminated structure prepared for passive safe storage. A temporary, portable radwaste system is installed to process liquid wastes during decommissioning of this building. Preparations for passive safe storage of the Radwaste and Control Building are started in the 14th month after final reactor shutdown and continue through the 30th month.

\section{J.4.4 Site and Support Facilities}

The structures and site surfaces outside of the exclusion area (shown in Figure 9.2-1 in Chapter 9) but within the site perimeter fence are surveyed and assumed to be releasable for unrestricted use without further effort. However, it is recognized that extensive radiation surveys and analyses of 
soil surfaces and paved areas are required to demonstrate that the site is releasable. Determination of the level of effort actually necessary for cleanup of the site is beyond the scope of this study because of the wide range of possible conditions. However, for this study, these activities are assumed to be accomplished starting in the 29th month following final reactor shutdown and are estimated to require 8 man-months of decommissioning worker effort.

\section{J.4.5 Summary of Schedule and Manpower Estimates for Preparations for Passive Safe Storage}

The overall task schedule and sequence for preparing the reference BWR for passive safe storage is shown in Figure $3.4-i$, together with the total decommissioning worker requirements for the period following final reactor shutdown. The planning and preparation tasks (see Section H.2 of Appendix $H$ and Section J.1.1) for the 18-month period preceding reactor shutdown are also included. The preparations for passive safe storage of the Reactor Building/ Primary Containment, the Turbine Generator Building, and the Radwaste and Control Building are estimated to be accomplished during the 30-month period following final reactor shutdown. This time frame includes a 2-month radiation survey of the site and support facilities starting in the 29 th month after reactor shutdown (see Section J.4.4).

Decommissioning tasks, with a few exceptions, are accomplished on two shifts, 5 days per week. The discharge and shipment of spent fuel and the operating of the radwaste systems are conducted on three shifts per day, 7 days per week, as required. The total decommissioning worker requirements for the period following reactor shutdown are shown in Figure J.4-1. A total of 1676.3 man-months of "hands-on" effort is estimated to be required.

The total staff labor requirements for preparing the reference BWR for passive safe storage are given in Table J.4-1. The requirements are given in equivalent man-years for the 1.5 years before and the 2.5 years following final reactor shutdown, and include the management and support staff as well as the decommissioning workers. A total of 383.4 man-years is estimated to be required to place the reference BWR in passive safe storage, including 176.9 man-years for the management and support staff and 206.5 man-years for 

TABLE J.4-1.
Staff Labor Requirements for Preparations for
Passive Safe Storage

Position

\section{Management and Support Staff}

Decommissioning Superintendent
Secretary

Decommissioning Engineer

Assistant Decommissioning Engineer

Radioactive Shipment Specialist

Procurement Specialist

Tool Crib Attendant

Control Room Operator (c)

Security Supervisor

Security Shift Supervisor(d)

Security Patrolman(d)

Contracts and Accounting Specialist

Health and Safety Supervisor

Health Physicist

Protective Equipment Attendant

Industrial Safety Specialist

Quality Assurance Supervisor

Quality Assurance Engineer

Quality Assurance Technician

Consultant (Safety Review)

Subtotals, Management and Support Staff

Decomissioning Workers (e)

Shift Engineer

Crew Leader (f)

Utility Operator $(g)$

Laborer

Craft Supervisor

Craftsman

Senior Health Physics Technician

Health Physics Technician(h)

Subtotais, Decommissioning Workers

Totals
Time Relative to Final Reactor Shutdown (year)

$\frac{-2}{\text { Annual staff Labor Requirement (man-years)(a) }}$

Total Staff Labor Required (man-years)

\begin{tabular}{lllllr}
0.5 & 1.0 & 1.0 & 1.0 & $0.8(\mathrm{~b})$ & 4.3 \\
0.5 & 2.0 & 3.0 & 3.0 & $1.6^{(b)}$ & 10.1 \\
0 & 1.0 & 2.0 & 2.0 & 0.5 & 5.5 \\
0.5 & 1.0 & 1.0 & 1.0 & $0.8^{(b)}$ & 4.3 \\
0.5 & 1.0 & 1.0 & 1.0 & 0.4 & 3.9 \\
0 & 1.0 & 1.0 & 1.0 & 0.4 & 3.4 \\
0.2 & 1.0 & 1.0 & 1.0 & 0.4 & 3.6 \\
0 & 0 & 2.0 & 2.0 & 0.8 & 4.8 \\
0 & 0 & 5.0 & 5.0 & 2.1 & 12.1 \\
0 & 0 & 1.0 & 1.0 & 0.5 & 2.5 \\
0 & 0 & 5.0 & 5.0 & 2.5 & 12.5 \\
0 & 0 & 39.0 & 28.0 & 6.5 & 73.5 \\
0.2 & 1.0 & 1.0 & 1.0 & $0.8^{(b)}$ & 4.0 \\
0.5 & 1.0 & 1.0 & 1.0 & $0.8^{(b)}$ & 4.3 \\
0 & 0.5 & 1.0 & 1.0 & 0.5 & 3.0 \\
0 & 0 & 2.0 & 2.0 & 1.0 & 5.0 \\
0.2 & 1.0 & 1.0 & 1.0 & 0.5 & 3.7 \\
0.2 & 1.0 & 1.0 & 1.0 & $0.8^{(b)}$ & 4.0 \\
0.3 & 2.0 & 1.0 & 1.0 & 0.5 & 4.8 \\
0 & 0.5 & 2.0 & 2.0 & 1.0 & 5.5 \\
0.3 & 0.5 & 0.5 & 0.5 & 0.3 & 2.1 \\
\hline & 1.0 & 1.0 & & & \\
3.9 & 15.5 & 72.5 & 61.5 & 23.5 & 176.9 \\
\hline
\end{tabular}

$\underline{61.5} \quad 23.5$

176.9

$\begin{array}{rrrrrr}0.5 & 2.0 & 2.0 & 2.0 & 1.0 & 7.5\end{array}$

$\begin{array}{lllllr}0.5 & 2.0 & 2.0 & 2.0 & 1.0 & 7.5 \\ 0 & 1.0 & 15.0 & 13.3 & 0.9 & 30.2\end{array}$

$\begin{array}{llllll}0 & 3.0 & 45.0 & 32.1 & 1.0 & 81.1\end{array}$

$\begin{array}{rrrrrr}0 & 3.0 & 45.0 & 32.1 & 1.0 & 81.1 \\ 0 & 0 & 0.6 & 3.0 & 8.0 & 11.6 \\ 0 & 0.6 & 1.0 & 2.0 & 0.9 & 4.5\end{array}$

$\begin{array}{llllll}0 & 10.0 & 5.0 & 8.0 & 14.0 & 37.0\end{array}$

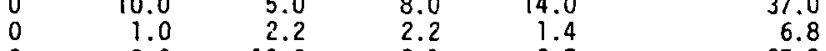

$\begin{array}{llllll}0 & 3.0 & 13.0 & 9.1 & 2.7 & \end{array}$

$\underline{0.5} \quad \underline{20.6} \quad \underline{83.8} \quad \underline{71.7} \quad \underline{29.9} \quad \underline{206.5}$

$\begin{array}{llllll}4.4 & 36.1 & 156.3 & 133.2 & 53.4 & 383.4\end{array}$

(a) Rounded to the next higher 0.1 man-year.

(b) Includes an additional 4 months following active Jecommissioning in order to complete the documentation and other unspecified license and contract termination requirements.

(c)Based on one operator per shift in the control room, three shifts per day, 7 days per week.

(d) Based on 10 CFR Part 73 and information obtained from Washington Public Power Supply System; includes both response and access contrnl personnel on a three-shift, 7-day-week basis.

(e) Requirements during the 3 years following final reactor shutdown are based on Figure J.4-1, unless otherwise noted; individual man-month requirements in Figure J.4-1 are rounded to the next higher 1.0 man-month in calculating these requirements.

(f) Based on a constant loading of 15 people tlirough month 22 following reactor shutjown, with additional personnel added as required to meet schedule demands during that period, and diminishing thereafter as the schedule allows.

(g) Based on constant loadings of 45 people through month 12 following final reactor shutdown and 35 people from month 13 through month 23 , and diminishing thereafter as the schedule allows.

(h) Based on a constant loading of 13 people through month 18 following reactor shutdown, with additional personnel added as required to meet schedule demands during that period, and diminishing thereafter as the schedule allows except during months 29 and 30 when 10 trained people are required to meet the schedule requirements. 
the decommissioning workers. The assumptions used in developing this estimate are the same as those used for immediate dismantlement (see Section 1.2-4 of Appendix I).

The staff labor requirements shown in Table J.4-1 for the decommissioning workers during the 2.5 years following final reactor shutdown exceed the total manpower presented in Figure J.4-1 because of the aforementioned assumptions. This "excess" manpower is assumed to be utilized for the numerous, small, unspecified tasks that accompany an activity of this magnitude.

\section{J.4.6 Manpower Estimates for the Continuing Care Period}

The staff organization shown in Figure J.4-2 is postulated to take control of all surveillance, maintenance, and security activities for the duration of the continuing care period. The estimated manpower requirements for continuing care of the reference BWR are summarized in Table J.4-2. A total of about 1.3 man-years per year of continuing care is estimated to adequately and safely satisfy anticipated passive safe storage requirements.

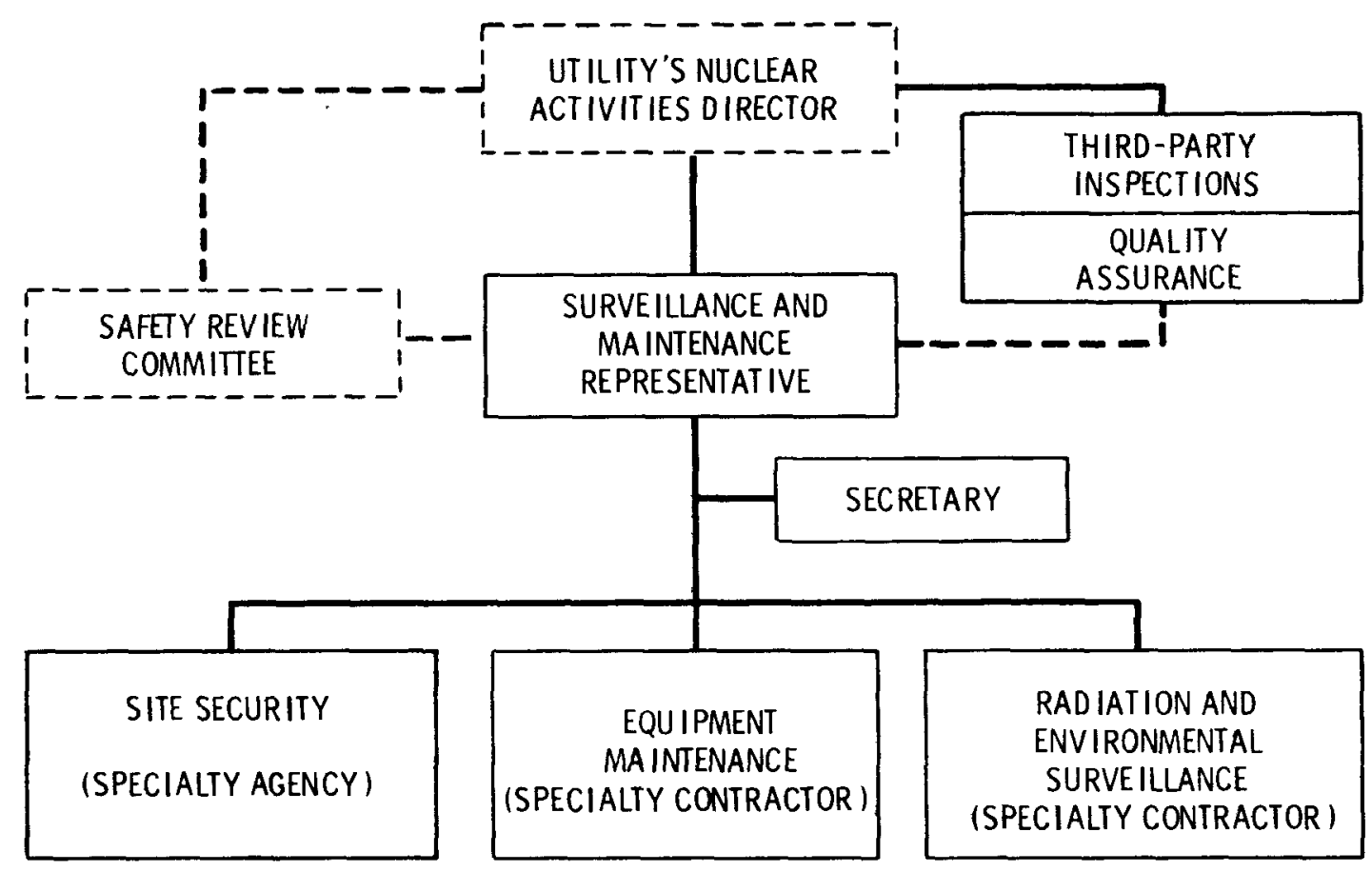

FIGURE J.4-2. Staff Organization for the Continuing Care Period 
TABLE J.4-2. Estimated Annual Manpower Requirements for the Continuing Care Period

\begin{tabular}{lll}
\multicolumn{1}{c}{ Labor } & & $\begin{array}{c}\text { Estimated } \\
\text { Man-Years/Year } \\
\text { Labor Requirement }\end{array}$ \\
\cline { 1 - 1 } $\begin{array}{l}\text { Surveillance and Maintenance } \\
\text { Representative }\end{array}$ & 0.25 \\
$\begin{array}{l}\text { Secretary } \\
\text { Repairman }\end{array}$ & 0.25 \\
Security & 0.1 \\
Third-Party Inspection & 0.3 \\
$\begin{array}{l}\text { Environmental and Radiological } \\
\text { Monitoring Program Personnel }\end{array}$ & 0.06 \\
Quality Assurance Specialist & 0.35 \\
Total & $\underline{0.03}$
\end{tabular}

\section{J.5 COSTS FOR PASSIVE SAFE STORAGE}

The estimated costs for preparing the reference BWR for passive safe storage and for continuing care are presented in this section; costs for possible deferred dismantlement are presented later in Section J.7. These costs are all adjusted to early 1978 conditions.

\section{J.5.1 Costs for Preparations for Passive Safe Storage}

The estimated costs for preparations for passive safe storage are summarized and totaled in Table J.5-1. The total cost for preparations for passive safe storage is estimated at approximately $\$ 21.3$ million. The costs for disposal of radioactive materials represent about $7 \%$ of this total. The major contributors to the total cost are staff labor and energy (at approximately 66\% and $13 \%$, respectively). The combined costs for special tools and equipment and for miscellaneous supplies make up about $10 \%$ of the total cost. The remaining $4 \%$ of the total cost is contributed by special ty contractors, nuclear insurance, and license fees.

The total cost for other possible requirements (i.e., spent fuel shipment and fuel channel disposal) during preparations for passive safe storage is 
estimated at about $\$ 5.5$ million, including a $25 \%$ contingency. This cost could go as high as $\$ 9.5$ million, depending on the possible additional requirements listed in the footnotes to Table J.5-1.

\section{TABLE J.5-1. Summary of the Estimated Costs for Preparations for Passive Safe Storage}

\begin{tabular}{|c|c|c|}
\hline Cost Category & $\begin{array}{l}\text { Estimated Costs } \\
\text { (\$ millions)(a,b) } \\
\end{array}$ & $\begin{array}{l}\text { Percent } \rho^{f} \\
\text { Total }\end{array}$ \\
\hline $\begin{array}{l}\text { Disposal of Radioactive Mate- } \\
\text { rials (Radioactive Wastes }(\bar{d}) \text { ) } \\
\text { Staff Labor } \\
\text { Energy }\end{array}$ & $\begin{array}{r}1.216 \\
11.254 \\
2.122\end{array}$ & $\begin{array}{r}7.1 \\
66.1 \\
12.5\end{array}$ \\
\hline $\begin{array}{l}\text { Special Tools and Equipment } \\
\text { Miscellaneous Supplies } \\
\text { Specialty Contractors }(e)\end{array}$ & $\begin{array}{l}0.351 \\
1.361 \\
0.196\end{array}$ & $\begin{array}{l}2.1 \\
8.0 \\
1.2\end{array}$ \\
\hline $\begin{array}{l}\text { Nuclear Insurance } \\
\text { License Fees }\end{array}$ & $\begin{array}{l}0.500 \\
0.038 \\
\end{array}$ & $\begin{array}{l}2.9 \\
0.2 \\
\end{array}$ \\
\hline Subtotal & 17.038 & 100.0 \\
\hline Contingency (25\%) & 4.260 & \\
\hline $\begin{array}{l}\text { Total, Preparations for Passive } \\
\text { Safé Storage Costs }\end{array}$ & 21.298 & \\
\hline Other Possible Costs & & \\
\hline $\begin{array}{l}\text { Spent Fuel Shipment } \\
\text { Fuel Channel Disposal }\end{array}$ & $\begin{array}{l}3.788(f) \\
0.617\end{array}$ & \\
\hline Subtotal & 4.405 & \\
\hline Contingency $(25 \%)$ & 1.101 & \\
\hline
\end{tabular}

(a) Costs adjusted to early 1978.

(b) The number of significant figures shown is for computational completeness and does not imply accuracy to the nearest $\$ 1000$.

(c) Individually rounded to the nearest $0.1 \%$.

(d) Includes both wet and dry solid wastes.

(e) Includes temporary radwaste, environmental monitoring services, and security preparations.

(f) If required, shipment by special train would cost an additional estimated $\$ 2.451$ million, maximum.

(g)Deep geologic disposal costs $(\$ 1.047$ million) and use of special trains ( $\$ 0.456$ million) could add $\$ 1.5$ million to this cost. 


\section{J.5.1.1 Costs for Disposal of Radioactive Materials}

Only radioactive wastes (wet solid wastes and dry solid wastes) in the reference BWR require disposal during preparations for passive safe storage. The total cost for disposal of these materials is about $\$ 1.2$ million and is approximately $7 \%$ of the total cost of preparations for passive safe storage. The disposal cost includes the container, transportation, and burial costs, but does not include the direct labor costs for removing and packaging these materials. Labor costs are discussed later (Section J.5.1.2). Table J.5-2 contains a summary and a total of the number of shipments, the burial volumes, and the disposal costs for the radioactive waste materials.

TABLE J.5-2. Summary of Shipments, Volumes, and Costs for Disposal of Radioactive Materials During Preparations for Passive Safe Storage

\begin{tabular}{|c|c|c|c|}
\hline Radioactive Material & $\begin{array}{l}\text { Number of } \\
\text { Shipments }\end{array}$ & 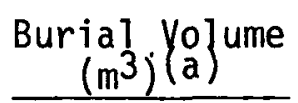 & $\begin{array}{l}\text { Disposal } C \\
\text { (\$ million }\end{array}$ \\
\hline \multicolumn{4}{|l|}{ Radioactive Wastes } \\
\hline Wet Solid Wastes & 286 & 814 & 1.073 \\
\hline Dry Solid Wastes & 32 & 241 & $\underline{0.143}$ \\
\hline Totals & 318 & 1055 & 1.216 \\
\hline
\end{tabular}

(a) Includes disposable containers.

(b) Adjusted to early 1978 conditions; the number of figures shown is for computational completeness and does not imply accuracy to the nearest $\$ 1000$.

Radioactive wastes (radwastes) result directly from preparing the reference BWR for passive safe storage. Two categories of radwastes are defined: wet solid wastes and dry solid wastes.

Wet solid wastes result from the processing of chemical decontamination solutions and contaminated water volumes and include concentrator bottoms, filter siudges, and spent demineralizer resins, as well as neutralized chemical solutions from decontamination of the contaminated drain systems. These wastes are assumed mixed with a cement solidifying agent and encapsulated in a steel cask liner prior to shipment to a shallow-land burial facility. The disposal cost data for 
wet solid wastes generated during preparations for passive safe storage are presented in Table H.5-9 in Appendix $\mathrm{H}$ and are not repeated in detail here. An estimated 286 truck shipments, $814 \mathrm{~m}^{3}$ of burial space, and $\$ 1,073,400$ are required to dispose of the wet solid wastes.

Dry solid wastes include discarded contaminated materials such as plastic sheeting, rags, and anticontamination clothing. They are expected to occur as a result of most of the tasks specified in Section J.4 and are estimated on a taskwise basis. The dry solid wastes are compacted as much as possible to reduce their volume prior to shipment to a disposal facility.

Dry solid wastes in uncompacted volumes of $365 \mathrm{~m}^{3}$ from the Reactor Building, $478 \mathrm{~m}^{3}$ from the Turbine Generator Building, and $351 \mathrm{~m}^{3}$ from the Radwaste and Control Building are estimated to be collected during the preparations for passive safe storage. These volumes are assumed to be compacted five-fold and packaged in 348,456 , and 335 standard $0.21-\mathrm{m}^{3}$ steel drums, respectively. of the total number of drums, 352 are assumed to require shielding during shipment, with the remainder shipped unshielded in closed trucks. The two types are shipped separately, since, by virtue of the ${ }^{60}$ co content, those requiring shielding also require Type B packaging. Table J.5-3 gives a breakdown of the disposal costs for the dry solid wastes. An estimated 32 overweight truck shipments (26 shielded, 6 unshielded) are required to transport the compacted, packaged, dry solid wastes to a shallow-land burial facility, where they occupy an estimated $241 \mathrm{~m}^{3}$ of space. The total disposal cost for the dry solid wastes resulting from preparing the reference BWR for passive safe storage is estimated to be $\$ 142,670$.

The sum of the disposal costs for the wet solid wastes and the dry solid wastes is $\$ 1,216,070$ and represents the total disposal cost for the radioactive materials.

\section{J.5.1.2 Costs for Staff Labor}

The costs for staff labor during preparations for passive safe storage are shown in Table J.5-4. Approximately 66\% of the total preparations cost is associated with the staff labor requirements (presented in Table J.4-1). A total staff labor cost of about $\$ 11.3$ million is estimated for preparing the 
TABLE 0.5-3. Costs for Disposal of Dry Solid Wastes

\begin{tabular}{|c|c|c|c|c|c|c|c|c|c|c|}
\hline Source (Building) & $\begin{array}{l}\text { Number of } \\
\text { Disposable } \\
\text { Containers }(a) \\
\end{array}$ & $\begin{array}{l}\text { Container } \\
\text { Costs }(\$)(b)\end{array}$ & $\begin{array}{l}\text { Estimated } \\
\text { No. Requiring } \\
\text { Shielding } \\
\end{array}$ & $\begin{array}{l}\text { Cask } \\
\text { Rental } \\
\text { Costs }(\$)^{(c)} \\
\end{array}$ & $\begin{array}{l}\text { Number of } \\
\text { Shipments } \\
\text { Shielded }(d) / \\
\text { Unshielded } \\
\end{array}$ & $\begin{array}{l}\text { Trans- } \\
\text { portation } \\
\text { Costs }(\$) \\
\end{array}$ & $\begin{array}{l}\text { Handling }(f) \\
\text { Costs }(\$)^{\prime}\end{array}$ & $\begin{array}{l}\text { Burial } \\
\text { Volumes }\left(\mathrm{m}^{3}\right)^{(\mathrm{g})}\end{array}$ & $\begin{array}{l}\text { Burial } \\
\text { Costs }(\$)^{(h)}\end{array}$ & $\begin{array}{l}\text { Total } \\
\text { Disposal } \\
\text { Costs }(\$)^{(i)} \\
\end{array}$ \\
\hline Reactor & 348 & 6960 & 108 & 7700 & $8 / 2$ & 19200 & 3000 & 3 & 7120 & 43980 \\
\hline Turbine Generator & 456 & 9120 & 140 & 10000 & $10 / 2$ & 23100 & 4000 & 96 & 9310 & 55530 \\
\hline Radwaste and Control & 1335 & 6700 & 104 & 7400 & $8 / 2$ & 19200 & 3000 & 71 & 6860 & 43160 \\
\hline Totals & 139 & 22780 & 352 & 25100 & $26 / 6$ & 61500 & 10000 & 241 & 23290 & 142670 \\
\hline
\end{tabular}

(a)Based on a 5:1 compaction of estimated waste volumes into standard $0.21-\mathrm{m}^{3}$ steel drums; estimated on a taskwise assessment of expected dry solid wastes generation rates.

(b) Based on Table M.2-1 in Appendix M.

c) Based on Table M.3-1; assumes a maximum of seven containers per cask and 5 days per shipment.

d) Assumes two casks per shipment.

erweight shipments.

(g) Includes the disposable container; rounded to next whole $\mathrm{m}^{3}$

(h) Based on Table M.5-1; surface dose rates assumed to be 0.21 to $1.00 \mathrm{R} / \mathrm{hr}$ for those drums requiring shielding during shipment, <0.2 R/hr for all

(i) The number of figures shown is for computational completeness only and does not imply accuracy to that many significant figures.
. 


\section{TABLE J.5-4. Costs for Staff Labor During Preparations for Passive Safe Storage}

\begin{tabular}{|c|c|c|c|c|c|c|}
\hline \multirow[b]{2}{*}{ Management and Support Staff } & \multicolumn{5}{|c|}{$\begin{array}{l}\text { Time Relative to Final Reactor Shutdown (year) } \\
\frac{-2}{\text { Annual Staff Labor Costs }}\left(\$ \frac{1}{2} \text { thousands)(a,b) }\right.\end{array}$} & \multirow[t]{2}{*}{$\begin{array}{r}\text { Total Staf } \\
\text { Labor Costs } \\
\text { (\$ thousand } \\
\end{array}$} \\
\hline & & & & & & \\
\hline $\begin{array}{l}\text { Decommissioning Superintendent } \\
\text { Secretary } \\
\text { Clerk }\end{array}$ & $\begin{array}{c}37.3 \\
10.2 \\
0\end{array}$ & $\begin{array}{l}74.5 \\
40.6 \\
20.3\end{array}$ & $\begin{array}{l}74.5 \\
60.9 \\
40.6\end{array}$ & $\begin{array}{l}74.5 \\
60.9 \\
40.6\end{array}$ & $\begin{array}{l}59.6 \\
32.5 \\
10.2\end{array}$ & $\begin{array}{l}320.4 \\
205.1 \\
111.7\end{array}$ \\
\hline $\begin{array}{l}\text { Decommissioning Engineer } \\
\text { Assistant Decommissioning Engineer } \\
\text { Radioactive Shipment Specialist }\end{array}$ & $\begin{array}{c}31.8 \\
21.9 \\
0\end{array}$ & $\begin{array}{l}63.5 \\
43.8 \\
32.9\end{array}$ & $\begin{array}{l}63.5 \\
43.8 \\
32.9\end{array}$ & $\begin{array}{l}63.5 \\
43.8 \\
32.9\end{array}$ & $\begin{array}{l}50.8 \\
17.6 \\
13.2\end{array}$ & $\begin{array}{l}273.1 \\
170.9 \\
111.9\end{array}$ \\
\hline $\begin{array}{l}\text { Procurement Specialist } \\
\text { Tool Crib Attendant } \\
\text { Control Room Operator }\end{array}$ & $\begin{array}{l}6.2 \\
0 \\
0\end{array}$ & $\begin{array}{c}30.7 \\
0 \\
0\end{array}$ & $\begin{array}{r}30.7 \\
46.4 \\
145.0\end{array}$ & $\begin{array}{r}30.7 \\
46.4 \\
115.0\end{array}$ & $\begin{array}{l}12.3 \\
18.6 \\
60.4\end{array}$ & $\begin{array}{l}110.6 \\
111.4 \\
350.9\end{array}$ \\
\hline $\begin{array}{l}\text { Security Supervisor } \\
\text { Security Shift Supervisor } \\
\text { Security Patrolman } \\
\text { Contracts and Accounting Specialist }\end{array}$ & $\begin{array}{l}0 \\
0 \\
0 \\
7.7\end{array}$ & $\begin{array}{c}0 \\
0 \\
0 \\
38.4\end{array}$ & $\begin{array}{r}32.9 \\
153.5 \\
830.7 \\
38.4\end{array}$ & $\begin{array}{r}32.9 \\
153.5 \\
596.4 \\
38.4\end{array}$ & $\begin{array}{r}16.5 \\
76.8 \\
138.5 \\
30.8\end{array}$ & $\begin{array}{r}82.3 \\
383.8 \\
565.6 \\
153.7\end{array}$ \\
\hline $\begin{array}{l}\text { Health and Safety Supervisor } \\
\text { Health Physicist } \\
\text { Protective Equipment Attendant } \\
\text { Industrial Safety Specialist }\end{array}$ & $\begin{array}{l}25.2 \\
0 \\
0 \\
8.8\end{array}$ & $\begin{array}{c}50.4 \\
19.7 \\
0 \\
43.8\end{array}$ & $\begin{array}{l}50.4 \\
39.4 \\
46.4 \\
43.3\end{array}$ & $\begin{array}{l}50.4 \\
39.4 \\
46.4 \\
43.8\end{array}$ & $\begin{array}{l}40.4 \\
19.7 \\
23.2 \\
21.9\end{array}$ & $\begin{array}{l}216.8 \\
118.2 \\
116.0 \\
162.1\end{array}$ \\
\hline $\begin{array}{l}\text { Quality Assurance Supervisor } \\
\text { Quality Assurance Engineer } \\
\text { Quality Assurance Technician } \\
\text { Consultant (Safety Review) } \\
\end{array}$ & $\begin{array}{r}8.8 \\
11.9 \\
0 \\
20.1 \\
\end{array}$ & $\begin{array}{l}43.8 \\
78.8 \\
11.6 \\
33.5 \\
\end{array}$ & $\begin{array}{l}43.8 \\
39.4 \\
46.4 \\
33.5 \\
\end{array}$ & $\begin{array}{l}43.8 \\
39.9 \\
46.4 \\
33.5 \\
\end{array}$ & $\begin{array}{l}35.1 \\
19.7 \\
23.2 \\
20.1 \\
\end{array}$ & $\begin{array}{l}175.3 \\
189.2 \\
127.6 \\
140.7 \\
\end{array}$ \\
\hline $\begin{array}{l}\text { Subtotals, llanagement and Sudoort Staff } \\
\text { Decommissioning Workers }\end{array}$ & 189.9 & 626.3 & 1935.9 & 1702.6 & 741.6 & 5197.3 \\
\hline $\begin{array}{l}\text { Shift Engineer } \\
\text { Crew Leader }\end{array}$ & 21.9 & $\begin{array}{l}87.6 \\
37.3\end{array}$ & $\begin{array}{r}87.6 \\
559.5\end{array}$ & $\begin{array}{r}87.6 \\
496.1\end{array}$ & $\begin{array}{l}43.8 \\
33.6\end{array}$ & $\begin{array}{r}328.5 \\
1126.5\end{array}$ \\
\hline $\begin{array}{l}\text { Utility Operator } \\
\text { Laborer } \\
\text { Craft Supervisor }\end{array}$ & $\begin{array}{l}0 \\
0 \\
0\end{array}$ & $\begin{array}{c}81.3 \\
0 \\
24.8\end{array}$ & $\begin{array}{r}1219.5 \\
15.6 \\
39.4\end{array}$ & $\begin{array}{r}869.9 \\
77.7 \\
78.8\end{array}$ & $\begin{array}{r}27.1 \\
207.2 \\
35.5\end{array}$ & $\begin{array}{l}197.3 \\
300.5 \\
178.5\end{array}$ \\
\hline $\begin{array}{l}\text { Craftsman } \\
\text { Senior Health Physics Technician } \\
\text { Health Physics Technician } \\
\end{array}$ & $\begin{array}{l}0 \\
0 \\
0\end{array}$ & $\begin{array}{r}271.0 \\
32.9 \\
75.3 \\
\end{array}$ & $\begin{array}{r}135.5 \\
72.4 \\
326.3 \\
\end{array}$ & $\begin{array}{r}216.8 \\
72.4 \\
228.5 \\
\end{array}$ & $\begin{array}{r}379.4 \\
46.1 \\
67.8 \\
\end{array}$ & $\begin{array}{r}1002.7 \\
223.8 \\
697.9 \\
\end{array}$ \\
\hline Subtotals, Decommissioning Workers & 21.9 & 610.2 & 2455.8 & $\underline{2127.8}$ & 840.5 & 6056.2 \\
\hline Totals & 211.8 & 1236.5 & 4392.7 & 3830.4 & 1582.1 & 11253.5 \\
\hline
\end{tabular}

(a) Calculated as the product of the data given in Table J.4-1 and the corresponding data given in Table M.1-1; rounded to the next higher $\$ 100$.

(b) The number of significant figures shown is for computational completeness and does not imply accuracy to the nearest $\$ 100$. 
reference BWR for passive safe storage. Specialty contractor labor is not included in this total.

\section{J.5.1.3 Costs for Energy}

The costs for energy during preparations for passive soie storage are presented in Table J.5-5, together with the estimated usage of both electricity

TABLE 3.5-5. Costs for Energy During Preparations for Passive Safe Storage

\begin{tabular}{|c|c|c|}
\hline $\begin{array}{l}\text { Energy Form } \\
\text { System(s) or Equipment }\end{array}$ & $\begin{array}{l}\text { Estimated } \\
\text { Energy } \\
\text { Usage (a) } \\
\end{array}$ & Costs $(\$)^{(b)}$ \\
\hline \multicolumn{3}{|l|}{ Electricity } \\
\hline $\begin{array}{l}\text { HVAC } \\
\text { Main Buildings }(c) \\
\text { Control Tower } \\
\text { Other Buildings }\end{array}$ & $\begin{array}{rr}36 & 700 \\
36 & 700 \\
2 & 860 \\
4 & 850\end{array}$ & $\begin{array}{rr}500 & 500 \\
550 & 500 \\
42 & 900 \\
72 & 750\end{array}$ \\
\hline $\begin{array}{l}\text { Lighting } \\
\text { Communications } \\
\text { Security }\end{array}$ & $\begin{array}{r}6810 \\
260 \\
1760\end{array}$ & $\begin{array}{rr}102 & 150 \\
3 & 900 \\
26 & 400\end{array}$ \\
\hline $\begin{array}{l}\text { Fire Protection } \\
\text { Compressed Air } \\
\text { Compressed Air }\end{array}$ & $\begin{array}{r}90 \\
810 \\
1 \quad 590\end{array}$ & $\begin{array}{rr}1 & 350 \\
12 & 150 \\
23 & 850\end{array}$ \\
\hline $\begin{array}{l}\text { Cranes and Hoists } \\
\text { Domestic Water } \\
\text { Contaminated Water }(d) \\
\text { Decommissioning Equipment }\end{array}$ & $\begin{array}{ll} & 810 \\
9 & 150 \\
9 & 780 \\
1 & 850(\mathrm{e}) \\
\end{array}$ & $\begin{array}{rr}12 & 150 \\
137 & 250 \\
146 & 700 \\
27 & 750 \\
\end{array}$ \\
\hline Subtotals, Electricity & 76510 & 1147650 \\
\hline Fuel oil & $\left(m^{3}\right)$ & \\
\hline Building Heating & $7190^{(f)}$ & 949080 \\
\hline $\begin{array}{l}\text { Decontamination Solution } \\
\text { Concentrator }\end{array}$ & $195^{(g)}$ & $25740^{(\mathrm{g})}$ \\
\hline Subtotals, Fuel $0 i l$ & 7385 & 924820 \\
\hline Total Energy Cos & & 2122470 \\
\hline
\end{tabular}

(a)Based on a system/component-wise analysis of specific requirements, unless otherwise noted; rounded to the nearest 10 MWh for electricity and to the nearest whole $\mathrm{m}^{3}$ for fuel oil.

(b) Based on Section M.6 of Appendix M.

(c) Includes the Reactor Building, the Turbine Generator Building, and the radwaste area of the Radwaste and Control Building.

(d) Includes all such systems listed in Appendix C for all anticipated operations; includes appropriate information from Table H.5-9 in Appendix H.

(e) Estimated at about $2 \%$ of the total.

(f) Assumes two heating periods during the preparations for passive safe storage.

(g)From Table H.5-9. 
and fuel oil. The usage of both energy forms is estimated based on a detailed analysis of the requirements for the essential systems presented in Table H.4-1 in Appendix $\mathrm{H}$ and the tasks and schedules during preparations for passive safe storage.

Totals of 76,510 MWh of electricity, costing $\$ 1,147,650$, and $7385 \mathrm{~m}^{3}$ of fuel oil, costing $\$ 974,820$, are estimated to be used during the preparations for passive safe storage. The total cost for energy is about $\$ 2.1$ million and is about $13 \%$ of the total cost for preparations for passive safe storage.

\section{J.5.1.4 Costs for Special Tools and Equipment}

Based on the information presented previously in Table $0.2-1$, the estimated costs for the special tools and equipment that are required for preparations for passive safe storage of the reference BWR are presented in Table J.5-6. TABLE J.5-6. Costs for Special Tools and Equipment for
Preparations for Passive Safe Storage

\begin{tabular}{|c|c|c|}
\hline Item & $\begin{array}{c}\text { Estimated } \\
\text { Number } \\
\text { Required (a) } \\
\end{array}$ & $\begin{array}{l}\text { Estimated } \\
\text { Cost } \\
\text { (\$ thousands) } \\
\end{array}$ \\
\hline $\begin{array}{l}\text { Portable Oxyacetylene Torch } \\
\text { Guillotine Pipe Saw } \\
\text { Power-Operated Reciprocating Hacksaw }\end{array}$ & $\begin{array}{l}2 \\
2 \\
2\end{array}$ & $\begin{array}{l}1 \\
8 \\
1\end{array}$ \\
\hline $\begin{array}{l}\text { Closed-Circuit, High-Resolution Television } \\
\text { Submersible Pump with Disposable Filter } \\
\text { High-Pressure Water Jet }\end{array}$ & $\begin{array}{l}1 \\
5 \\
2\end{array}$ & $5^{7.5^{(c)}}$ \\
\hline $\begin{array}{l}\text { Low-Pressure Water Jet } \\
\text { Pipe Jumper } \\
\text { Mobile Chemical Decontamination Unit }\end{array}$ & $\begin{array}{l}1 \\
4 \\
5\end{array}$ & $\begin{array}{r}15 \\
3 \\
100\end{array}$ \\
\hline $\begin{array}{l}\text { Mobile Chemical Mixing and Heating Unit } \\
\text { Scaffolding } \\
\text { Safety Nets }\end{array}$ & $\begin{array}{l}4 \\
50 \\
\text { As Required }\end{array}$ & $\begin{array}{l}10 \\
2.5 \\
10\end{array}$ \\
\hline $\begin{array}{l}\text { Power-Operated, Mobile, Scissors-Type Manlift } \\
\text { Power-Operated, Mobile, Articulated-Arm Manilift } \\
\text { 9100-kg-Capacity Forklift }\end{array}$ & $\begin{array}{l}2 \\
1 \\
1\end{array}$ & $\begin{array}{l}64 \\
9 \\
13.3\end{array}$ \\
\hline $\begin{array}{l}\text { Rigging Materials (e.g., Chockers, Grapples, Winches) } \\
\text { Concrete Drill with HEPA-Filtered Dust Collecting } \\
\text { System } \\
\text { Concrete Surface Spaller }\end{array}$ & $\begin{array}{l}\text { As Required } \\
\qquad \begin{array}{l}1 \\
1\end{array}\end{array}$ & $\begin{array}{l}5 \\
2 \\
5\end{array}$ \\
\hline $\begin{array}{l}\text { Front-End Loader (Highly Maneuverable, Light Duty) } \\
\text { Vacuum Cleaner (HEPA-Filtered) } \\
\text { Portable Ventilation Enclosure }\end{array}$ & $\begin{array}{l}1 \\
3 \\
3\end{array}$ & $\begin{array}{l}10 \\
15 \\
4.5\end{array}$ \\
\hline $\begin{array}{l}\text { Supplied-Air Plastic Suit } \\
\text { Polyurethane Foam Generator } \\
\text { Paint Sprayer }\end{array}$ & $\begin{array}{r}100 \\
2 \\
4\end{array}$ & $\begin{array}{r}6 \\
10 \\
4 \\
\end{array}$ \\
\hline Total Cost & & 350.8 \\
\hline
\end{tabular}


The estimated total cost for special tools and equipment is $\$ 350,800$, which represents approximately $2 \%$ of the total cost of preparations for passive safe storage.

\section{J.5.1.5 Costs for Miscellaneous Supplies}

A variety of supplies are used during preparations for passive safe storage. These include expendable glass-fiber and HEPA filters, anticontamination clothing, cleaning and contamination control supplies (chemical agents, sweeping compounds, rags, mops, and plastic bags and sheeting), expendable hand tools, cutting and welding supplies (saw blades, torch gas, and welding rod), carbon steel plates, decontamination chemicals, and filter/demineralizer resins. The estimated costs for these items are given in Table J.5-7. The total estimated cost for miscellaneous supplies used while preparing the reference BWR for passive safe storage is about $\$ 1.4$ million, $8 \%$ of the total cost for preparations for passive safe storage.

\section{TABLE J.5-7. Costs for Miscellaneous Supplies During} Preparations for Passive Safe Storage

\begin{tabular}{|c|c|}
\hline Item & $\begin{array}{l}\text { Estimated } \\
1 \$ \text { thous }\end{array}$ \\
\hline \multicolumn{2}{|l|}{ Filters } \\
\hline $\begin{array}{l}\text { Reactor Building and Turbine Generator Building } \\
\text { HVAC Exhausts }(a)\end{array}$ & 450 \\
\hline $\begin{array}{l}\text { Reactor Building, Turbine Generator Building, } \\
\text { and Radwaste, (E)d Control Building Isolation } \\
\text { HEPA Filters }(E)\end{array}$ & 37 \\
\hline A11 Other Requirements & 57 \\
\hline Anticontamination Clothing $(\mathrm{c})$ & 207 \\
\hline Cleaning and Contamination Control Supplies & 120 \\
\hline Hand Tools & 42 \\
\hline Cutting and Welding Supplies & 5 \\
\hline Carbon Steel Plates & 19 \\
\hline Decontamination Chemicals ${ }^{(d)}$ & 335 \\
\hline Filter/Demineralizer Resins $(d)$ & 89 \\
\hline Total & 1361 \\
\hline
\end{tabular}

(a) Includes filters, housings, and ducting; see Section H.2.8 of Appendix $\mathrm{H}$.

(b) Includes isolation filters, housings, and ducting; see Section J.2-4.

(c) Estimated at four changes per day per decommissioning worker; see Reference 1.

(d) From Table H.5-7, rounded to nearest $\$ 1000$. 


\section{J.5.1.6 Costs for Specialty Contractors}

The estimated costs for specialty contractors are given in Table J.5-8. As discussed in Section H.3 of Appendix $\mathrm{H}$, specialty contractors perform temporary radwaste handling and environmental monitoring during preparations for passive safe storage. In addition, a specialty contractor, who is responsible for security during the continuing care period, begins work during the preparations period, including making a site-security survey, reducing the size of the security area, and procuring and installing the necessary remotereadout security equipment. The costs for a hauling contractor are not shown in able J.5-8, but are shown as "transportation costs" in Section J.5.1.1 for disposal of radioactive wastes.

TABLE J.5-8. Costs for Specialty Contractors During Preparations for Passive Safe Storage

\begin{tabular}{|c|c|c|}
\hline Specialty Contractor (a) & $\begin{array}{l}\text { Cost Estimating } \\
\text { Basis (\$/unit) }\end{array}$ & $\begin{array}{c}\text { Estimated Costs } \\
(\$)\end{array}$ \\
\hline Temporary Radwaste Handling & $10000 / \mathrm{mo}^{(b)}$ & 20000 \\
\hline Environmental Monitoring & $38500 / y r^{(c)}$ & 89700 \\
\hline Security & $85800 / j_{0 b}^{(d)}$ & 85800 \\
\hline Total & & 195500 \\
\hline
\end{tabular}

(a) Does not include the hauling contractor, which is shown as "transportation costs" in Section J.5.1.1, with a total cost of $\$ 610,620$.

(b) Based on information presented on page 10-4 of Reference 2 and corroborated with Mr. Ed Brooks of Chem-Nuclear Systems, Inc., Bellevue, Washington.

(c) Based on information presented on page $\mathrm{H}-20$ of Reference 2.

(d) Based on information presented as Option C in Table H.4-3 in Reference 2.

The total cost for specialty contractors during preparations for passive safe storage, excluding the hauling contractor, is $\$ 195,500$, which is about $1 \%$ of the total cost for preparations for passive safe storage. 


\title{
J.5.1.7 Costs for Nuclear Insurance
}

The costs for nuclear liability insurance during preparations for passive safe storage are estimated for an assumed policy limit of $\$ 125$ million carried through the active decommissioning period. These costs are shown in Table J.5-9. The total estimated cost for nuclear insurance is $\$ 500,000$, which represents about $3 \%$ of the total cost for preparations for passive safe storage.

\author{
TABLE J.5-9. Costs for Nuclear Liability Insurance \\ During Preparations for Passive \\ Safe Storage(a) \\ Year After Estimated Premium \\ Shutdown \\ (\$ thousands)

\begin{tabular}{cr}
1 & 240 \\
2 & 210 \\
3 & 50 \\
\hline Total & 500
\end{tabular} \\ (a) Based on information \\ presented on Page 10-8 \\ of Reference 2.
}

\section{J.5.1.8 Costs for Licensing Fees}

The fees charged for licensing services performed by the NRC are delineated in 10 CFR Part $170 .{ }^{(3)}$ The costs for licensing fees while preparing the reference BWR for passive safe storage are shown in Table J.5-10. The total cost for licensing services is $\$ 37,850$, which is approximately $0.2 \%$ of the total cost for preparations for passive safe storage.

\section{J.5.1.9 Other Possible Costs}

Two additional categories of costs could figure into the total cost for preparations for passive safe storage, depending on how they are classified. In this study, they are presented separately, since they cannot be clearly identified as decommissioning costs. The tasks that result in these costs are: 
TABLE J.5-10. Costs for Licensing Fees During Preparations for Passive Safe Storage (a)

Licensing Service Category

Facility License Amendment (Class IV)

Health, Safety, and Environmental Inspection

Safeguards Inspection

Total cost
Fee $(\$)$ Total Costs (\$)

12300

12300

$650 /$ year $\quad 1950^{(c)}$

$11800 /$ year $23600^{(d)}$

37850

(a)From Reference 3 .

(b) Based on one license amendment (i.e., to obtain a possession-only license prior to the start of decomissioning tasks).

(c) Based on the time the license is in force (i.e., approximately 3 years during active decommissioning).

(d) Based on having spent fuel on site for 19 months (i.e., two yearly fees charged).

1) shipment of the spent reactor fuel to an offsite repository and 2) disposal of the fuel channels.

Discussions of the costs associated with these tasks are presented in the following subsections.

Spent Fuel Shipment. Since the ultimate disposition of the spent reactor fuel is not known, it is assumed in this study that the 764 fuel assemblies from the final reactor core load are shipped by rail, together with their fuel channels, to a repository located $2400 \mathrm{~km}$ from the reference BWR. The resulting costs for preparations for passive safe storage are the same as those calculated for immediate dismantlement in Section I.3.9.1 of Appendix I.

The total estimated cost for shipping the spent fuel and channels to the assumed repository is about $\$ 3.8$ million. If special trains are required, the cost is increased by up to about $\$ 2.5$ million.

Fuel Channel Disposal. The assumption that the fuel channels are shipped and stored with the spent fuel is based on practicality rather than on present practice. Presently, this is not a viable option and, therefore, an analys is is performed (in Section I.3.9.4 of Appendix I) to determine the alternative 
costs for disposing of the fuel channels as activated wastes in either a shallow-land disposal facility or a deep geologic disposal facility.

The total cost for shallow-land burial of the fuel channels is estimated to be $\$ 617,140$. Deep geologic disposal is estimated to cost $\$ 7,047,000$, or $\$ 429,860$ more than shallow-land disposal. Shipment of the fuel channels by special train would cost an additional $\$ 456,000$, maximum.

\section{J.5.2 Costs for Continuing Care During Passive Safe Storage}

The costs for continuing care during passive safe storage of the reference BWR are developed in this section. Also included are details of security during continuing care.

The organization shown in Figure J.4-2 of Section J.4.6 is postulated to take over the surveillance, maintenance, and security of the reference BWR for the duration of the continuing care period. Based on the estimated labor requirements given in Table J.4-2 and on the miscellaneous costs anticipated, the total annual costs for continuing care are tabulated in Table J.5-11.

Ongoing Environmental Monitoring Program. The estimated costs of the ongoing environmental monitoring program during the continuing care period are given in Table J.5-12. Identification of the labor-intensive tasks for the various positions are included in Table J.5-12 for completeness.

Security costs. The information contained in this subsection forms the bases for the estimated security costs during continuing care. It is assumed that at the start of the continuing care period the guard force is disbanded and replaced by private security forces and electronic intrusion systems.

The costs of a private security agency using remote surveillance equipment are given in Table J.5-13. Consideration is given to the following parameters:

- renovation and utilization of existing site security and surveillancerelated equipment

- possible relocation of the perimeter fence to include only those buildings housing activated and/or contaminated equipment areas 
TABLE J.5-11. Estimated Annual Costs for Surveillance, Maintenance, and Security During Continuing Care

\begin{tabular}{|c|c|}
\hline Labor & $\begin{array}{l}\text { Estimated } \\
\text { Annual }(a) \\
\text { Cost }(\$) \\
\end{array}$ \\
\hline $\begin{array}{l}\text { Surveillance and Maintenance Representative } \\
\text { Secretary } \\
\text { Repairman }\end{array}$ & $\begin{array}{ll}6 & 500 \\
5 & 075 \\
2 & 710\end{array}$ \\
\hline $\begin{array}{l}\text { Security } \\
\text { Third-Party Inspection } \\
\text { Environmental Radiological Monitoring Program } \\
\text { Personnel } \\
\text { Quality Assurance Specialist }\end{array}$ & $\begin{array}{rr}8 & 800(\mathrm{~b}) \\
7 & 500 \\
14 & \\
14 & 230 \\
1 & 000 \\
\end{array}$ \\
\hline Total, Labor Costs & 45815 \\
\hline Other Costs & \\
\hline $\begin{array}{l}\text { Equipment and Supplies } \\
\text { Annual Allowance for Repairs } \\
\text { Utilities and Services }\end{array}$ & $\begin{array}{ll}1 & 000 \\
5 & 000 \\
5 & 000\end{array}$ \\
\hline $\begin{array}{l}\text { License Fee } \\
\text { NEL-PIA Insurance }\end{array}$ & $\begin{array}{r}650 \\
2500 \\
\end{array}$ \\
\hline Total, Other costs & 14150 \\
\hline Subtotal & 59965 \\
\hline Contingency $(25 \%)$ & 14991 \\
\hline Total, Annual Continuing Care Costs & 74956 \\
\hline \multicolumn{2}{|c|}{$\begin{array}{l}\text { (a) The number of significant figures shown is for computational } \\
\text { completeness and does not imply accuracy to the nearest } \\
\text { dollar. } \\
\text { (b) See Table J.5-13 for initial costs. } \\
\text { (c) Third-party inspection costs are based on an assumed cost of } \\
\$ 500 \text { per man-day. }\end{array}$} \\
\hline
\end{tabular}


TABLE J.5-12. Estimated Annual Costs for an Ongoing Environmental Monitoring Program During Continuing Care

Labor
Health Physicist
Health Physicist, Supervisor
Radiochemist
Instrument Specialist
Quality Assurance Specialist
Total, Labor Costs
Contractor's 10\% Overhead and Profit
0 0ther Costs

Task $\quad \begin{gathered}\text { Estimated } \\ \text { Cost }(\$)(a)\end{gathered}$

Collect data, archive 1450 storage of samples and data.

Preparation of reports 3940 and data analysis.

Laboratory analysis 3940 of samples.

Maintain equipment, 2710 calibrations.

Audit functions.

900

12940

1290

14230

Utilities and Services

1000

Equipment and Supplies

1000

Total, Other Costs

2000

Subtotal

16230

Contingency (25\%)

4058

Total, Annual Environmental Monitoring

Program Costs

20288

(a) The number of significant figures shown is for computational completeness and does not imply accuracy to the nearest dollar. 
TABLE J.5-13. Estimated Securjty fosts During
Continuing Care $(a, b)$

Cost

Activities

\begin{tabular}{|c|c|}
\hline Activities & ( $\$$ thousands) \\
\hline Site Security Survey & $2.0^{(c)}$ \\
\hline $\begin{array}{l}\text { Reduce Circumference of } \\
\text { of Existing Security } \\
\text { Fence }\end{array}$ & $10.0^{(c)}$ \\
\hline $\begin{array}{l}\text { Utilize Portions of Exist- } \\
\text { ing Security Equipment; } \\
\text { Add Others }\end{array}$ & $40.0^{(d)}$ \\
\hline $\begin{array}{c}\text { Install Remote Readout } \\
\text { at Offsite Location }\end{array}$ & $25.0^{(c, e)}$ \\
\hline $\begin{array}{l}\text { Lease of Equipment, Main- } \\
\text { tenance, Monitoring, } \\
\text { Response (includes tem- } \\
\text { porary maintenance when } \\
\text { required), Patrol } \\
\text { (unscheduled, any hour), } \\
\text { and Supervision } \\
\end{array}$ & 8.8 \\
\hline Total (first year) & 85.8 \\
\hline $\begin{array}{l}\text { Total/year (after first } \\
\text { year) }\end{array}$ & 8.8 \\
\hline
\end{tabular}

(a) Includes onsite detection and notification systems for: security (intrusion), fire, and radiation levels.

(b) Data taken from Table H.4-3 of Reference 2.

(c) One-time cost only.

(d) One-time cost only; existing equipment allowances would be a contractural matter open to negotiation between the facility owner and the security agency. This dollar value includes installation of devices and hardware not normally found at the site. Such items include audible alarms, 24-hour video tape recorder, multiplex systems (self trouble-shooting), battery backup power where required, and capacitance perimeter fence protection.

(e) Includes installation charges for security agency hardware, which are primarily for the offsite installation costs of "slave" annuciator drops from existing plant security equipment. 
- addition of special equipment as indicated by the security agency's site survey

- installation of remote readout facilities either onsite or offsite.

In summary, security is provided during continuing care by several methods. Locks on the gates in the fence around the decommissioned facility provide the first level of security. The fence is maintained in good condition throughout the continuing care period. The locks and secured entryways of the structures and the remote surveillance equipment and alarm system provide the final level of security.

It is arranged with the security agency to assure that the surveillance and maintenance (S\&M) representative, who is thoroughly knowledgeable about the facility, can be contacted at any time. The S\&M representative is designated by the utility and is responsible for controlling authorized access into and movement within the facility. He is further charged with the responsibilities of appropriate actions and notifications regarding breaches of security, upkeep of plant surveillance and maintenance programs, and administrative reporting of these events as required by state and federal regulations. A postulated administrative reporting process and security notification chain-of-command is shown in Figure J.5-l delineating responsibilities for reportable events. It is imperative that such a notification and reporting process be kept current throughout the continuing care period.

\section{J.6 ESTIMATED OCCUPATIONAL RADIATION DOSES FOR PASSIVE SAFE STORAGE}

In this section, detailed analyses are made to estimate the external occupational radiation dose accumulated by decommissioning workers while preparing the reference BWR for passive safe storage and continuing care. The analyses are performed in the same manner as those described for immediate dismantlement in Section I.4 of Appendix I.

The total corrected external occupational radiation dose for preparations for passive safe storage is estimated to be about 375 man-rem. The dose accumulated during continuing care is estimated to be about 1.3 man-rem the 


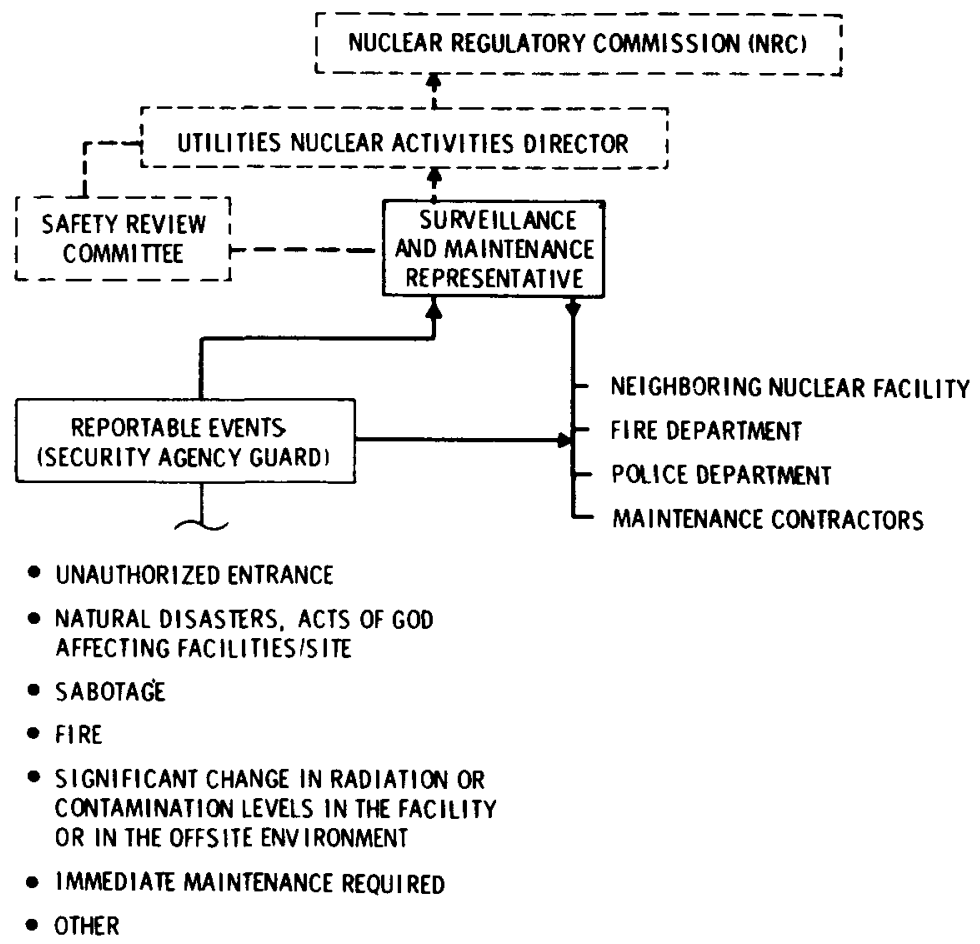

FIGURE J.5-1. Postulated Security and Administrative Notification and Reporting Process

first year, diminishing each year until after 50 years a total of 10 man-rem has been accumulated by the surveillance, maintenance, and security forces .

\section{J.6.1 Estimated External Occupational Radiation Dose During Preparations for Passive Safe Storage}

Some of the same basic activities that are performed for immediate dismantlement are also performed for the preparations for passive safe storage. These include defueling the reactor, comprehensive radiation surveys, weekly radiation surveys, general cleanup, system decontamination and draining, and radioactive liquid waste handling. Other tasks, of course, are different, but the external occupational doses for all tasks are based on a 6-hour effective working day in the radiation zone per worker, the source of radiation dose and its intensity, and the percentage of time a given worker spends working on that particular 
task. Subjective judgement is used for each task analysis regarding the percentage of time spent on that task by individual workers, since each task is different.

The results of the analyses for the preparations for passive safe storage are presented in Table J.6-1. The dose estimates for each task are corrected for radioactive decay using the half-life of ${ }^{60}$ Co to the time when the task is one-half completed.

\section{J.6.2 Estimated Occupational Radiation Dose During the Continuing Care Period}

From the types and quantities of manpower given in Section J.4-6, and the estimated radiation dose data for continuing care, the anticipated cumulative occupational external radiation dose for surveillance, maintenance, and security activities for intervals of $10,30,50$, and 100 years after final reactor shutdown are computed. During continuing care, it is postulated that the inspection and maintenance personnel spend only a small percentage (from 2 to $10 \%$ of their onsite time in radiation zones. The balance of their time is postulated to be spent in areas outside of the exclusion area or offsite.

The results of these analyses are presented in Table J.6-2. The majority of the occupational dose to personnel is accumulated during the first 30 years after shutdown of the reference BWR. Less than 0.5 man-rem total occupational external radiation dose are accumulated during the next 70 years.

\section{J.7 DEFERRED DISMANTLEMENT}

It is possible that sometime after the reference BWR is put in passive safe storage the owner will want to eliminate the continuing care responsibilities and terminate the possession-only license. A possession-only license may be terminated (in accordance with present regulations) when the facility is sufficiently decontaminated to prevent risk to the public. Depending on the length of the continuing care period, deferred dismantlement is a way to achieve the necessary decontamination of the reference BWR. 
ก 
TABLE J.6-2. Estimated Cumulative Occupational External Radiation Dose During Continuing Care

Estimated Dose for the First Year of Continuing Care

\begin{tabular}{|c|c|c|c|c|}
\hline Labor & $\begin{array}{l}\text { Estimated } \\
\text { Exposure (man-hours) }\end{array}$ & \multicolumn{2}{|c|}{$\begin{array}{l}\text { Average Dose } \\
\text { Rate }(R / h r)(a) \\
\end{array}$} & $\begin{array}{l}\text { Estimate Dose } \\
\text { (man-rem) }\end{array}$ \\
\hline $\begin{array}{l}\text { Surveillance and Maintenance } \\
\text { Representative }\end{array}$ & 26 & \multicolumn{2}{|c|}{0.005} & 0.13 \\
\hline $\begin{array}{l}\text { Repairman } \\
\text { Third-Party Inspections }\end{array}$ & $\begin{array}{l}50 \\
48\end{array}$ & \multicolumn{2}{|c|}{$\begin{array}{l}0.010 \\
0.005\end{array}$} & $\begin{array}{l}0.50 \\
0.24\end{array}$ \\
\hline $\begin{array}{l}\text { Quality Assurance Specialist } \\
\text { Radiation and Environmental } \\
\text { Surveillance }\end{array}$ & $\begin{array}{l}10 \\
50\end{array}$ & \multicolumn{2}{|c|}{$\begin{array}{l}0.002 \\
0.005\end{array}$} & $\begin{array}{l}0.02 \\
0.25\end{array}$ \\
\hline Security & 90 & \multicolumn{2}{|c|}{$0.00 \%$} & $\underline{0.18}$ \\
\hline Totals & 274 & & & 1.32 \\
\hline Cumulative Occupational Radia & tion Dose For: & \multicolumn{3}{|c|}{$\begin{array}{l}\text { Total Cumulative } \\
\text { Radiation Dose (man-rem) (b) }\end{array}$} \\
\hline \multicolumn{5}{|c|}{$\begin{array}{lll}\text { The First Year of Continuing Care (CC) } & 1.32 \\
10 \text { Years After Final Reactor Shutdown ( } 8 \text { years of CC) } & 6.53 \\
30 \text { Years After Final Reactor Shutdown ( } 28 \text { years of CC) } & 9.78\end{array}$} \\
\hline \multicolumn{3}{|c|}{$\begin{array}{l}50 \text { Years After Final Reactor Shutdown ( } 48 \text { years of CC) } \\
100 \text { Years After Final Reactor Shutdown ( } 98 \text { years of CC) }\end{array}$} & $\begin{array}{l}10.02 \\
10.04\end{array}$ & \\
\hline
\end{tabular}

The same basic activities necessary for immediate dismantlement are also assumed for deferred dismantlement following passive safe storage. Neutronactivated materials in the reactor vessel internals and the reactor vessel still require removal and segmenting remotely under water, using the same techniques that are assumed for immediate dismantlement. The sacrificial shield concrete is still radioactive due to activated trace elements, such as ${ }^{152} \mathrm{Eu}$ and ${ }^{154} \mathrm{Eu}$, and may have to be removed.

The radioactive contamination of the piping systems, equipment, pool liners, etc., is primarily ${ }^{60}$ co. Thus, for continuing care periods of less than 50 
years ( 210 half-lives for. ${ }^{60} \mathrm{Co}$ ), it is assumed the surfaces remain radioactively contaminated at levels greater than those that permit unrestricted use of the material. It is also assumed that after 50 years of decay, the radioactive contamination on the bulk of the formerly contaminated material has decayed to levels that permit release for either salvage as scrap or disposal as nonradioactive waste.

A number of dismantlement tasks are accomplished during the preparations for passive safe storage (i.e., discharging and shipping the fuel; draining and decontamination of contaminated liquid systems; and removal of radioactive wastes, such as filters, resins, and evaporator bottoms). During deferred dismantlement, the time not expended on these tasks is offset by the time spent on familiarization of the work force with the facility, removal of locks and barriers installed to secure the facility, and restoration of essential services that were unneeded during the continuing care period. Therefore, it is assumed that the basic work force and time required for deferred dismantlement are the same as for imnediate dismantlement.

\section{J.7.1 Costs for Deferred Dismantiement}

The costs of accomplishing deferred dismantlement are estimated by examining the general cost categories for immediate dismantlement shown in Table I.3-1 in Appendix I and determining the impact of the differences in accomplishing dismantlement after periods of continuing care of several lengths. It is assumed that the management and support staff is the same for deferred dismantlement as it is for immediate dismantlement. However, fewer decommissioning workers are required for deferred dismantlement, since the radiation dose rates are lower.

Estimates are given in Table J.7-1 of the volumes of the various types of radioactive materials that are packaged and shipped for burial when dismantlement starts either immediately or 10 to 30,50, and 100 years after reactor shutdown. The volume of radioactive waste from preparations for passive safe storage is also given.

The volume of activated material is assumed to remain constant over the 100-year time span. Depending on the particular radionuclides present in the 
TABLE J.7-1. Burial Volumes of Radioactive Materials from Decommissioning

\begin{tabular}{|c|c|c|c|c|c|c|}
\hline \multirow[b]{2}{*}{$\begin{array}{l}\text { Decommissioning } \\
\text { Al ternative } \\
\end{array}$} & \multirow{2}{*}{$\begin{array}{c}\text { Start of } \\
\text { Decommissioning } \\
\text { (years a fter } \\
\text { shutdown) }\end{array}$} & \multicolumn{5}{|c|}{ Burlal Volume $\left(\mathrm{m}^{3}\right)$} \\
\hline & & $\begin{array}{l}\text { Activated } \\
\text { Material }\end{array}$ & $\begin{array}{c}\text { Contaminated } \\
\text { Material }\end{array}$ & $\begin{array}{c}\text { Radioactive } \\
\text { Waste }\end{array}$ & $\begin{array}{l}\text { Alternative } \\
\text { Total } \\
\end{array}$ & $\begin{array}{c}\text { Decommissioning } \\
\text { Total } \\
\end{array}$ \\
\hline $\begin{array}{l}\text { Immed } 1 \text { a te } \\
\text { Dismant lement }\end{array}$ & 0 & 228 & 17219 & 1492 & 18939 & 18939 \\
\hline $\begin{array}{l}\text { Preparations } \\
\text { for Passive } \\
\text { Safe Storage }\end{array}$ & 0 & -- & -- & 1055 & 1055 & -- \\
\hline $\begin{array}{l}\text { Deferred } \\
\text { Dismant lement }\end{array}$ & 10 & 228 & 17219 & 437 & 17884 & 18939 \\
\hline & 30 & 228 & 17219 & 437 & 17884 & 18939 \\
\hline & 50 & 228 & 150 & 350 & 728 & 1783 \\
\hline & 100 & 228 & 150 & 240 & 618 & 1673 \\
\hline
\end{tabular}

sacrificial shield, the activated concrete may decay to unrestricted use levels in 100 years, but this is not assumed in this study.

The volume of contaminated material is assumed to remain constant through 30 years, but to decrease to $150 \mathrm{~m}^{3}$ by 50 years and thereafter.

The volume of radioactive waste estimated for dismantlement after 10 to 30 years is assumed to be the difference between the volumes for immediate dismantlement and for preparations for passive safe storage. This volume is assumed to be reduced to $350 \mathrm{~m}^{3}$ at 50 years and $240 \mathrm{~m}^{3}$ at 100 years.

Estimated costs are given in Table J.7-2 for dismantlement of the reference BWR after 10 to 30,50 , and 100 years of passive safe storage. The estimated costs for immediate dismantlement, taken from Table I.3-1 in Appendix I, are included for comparison. The only cost category that does not decrease with time is the disposal of activated material.

The total cost for each of the deferred dismantlement decommissioning options is given in Table J.7-3. The values 1 isted under "total" include the cost of continuing care during safe storage for the number of years shown. For example, the total given for deferred dismantlement starting 30 years after reactor shutdown includes the cost of preparations for passive safe storage, the cost of continuing care for the period from the end of preparations for passive safe storage until the start of dismantlement and the cost of dismantlement. 
TABLE J.7-2. Estimated Dismantlement costs

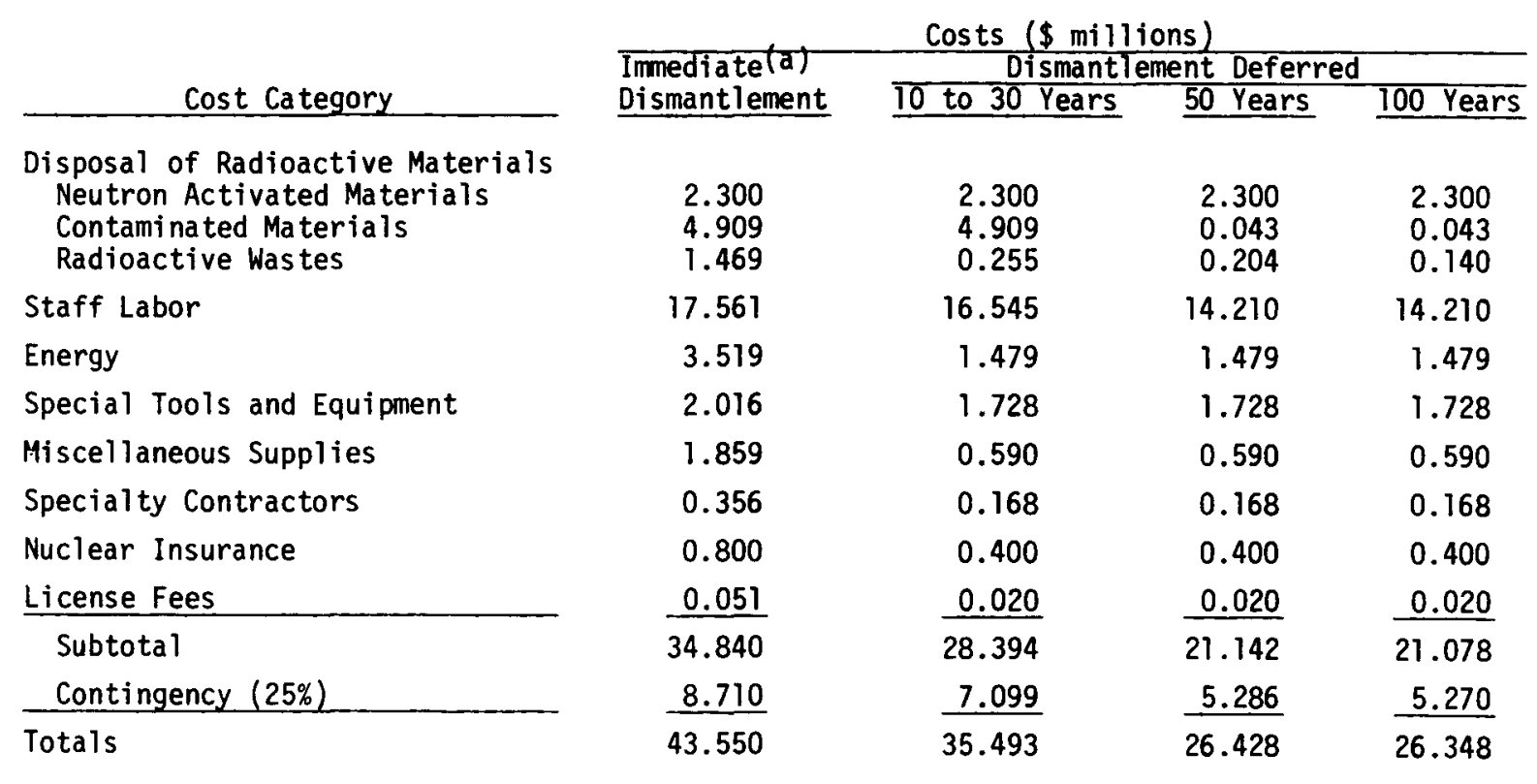

(a)From Table I.3-1 in Appendix I.

TABLE J.7-3. Total Costs for Various Decommissioning Alternatives

\begin{tabular}{|c|c|c|c|c|c|}
\hline $\begin{array}{l}\text { Years } \\
\text { After }\end{array}$ & \multicolumn{5}{|c|}{ Decommissioning Costs in Millions of 1978 Dollars } \\
\hline $\begin{array}{l}\text { Reactor } \\
\text { Shutdown }\end{array}$ & $\begin{array}{l}\text { Immediate } \\
\text { Dismantlement }\end{array}$ & $\begin{array}{c}\text { Preparations For } \\
\text { Passive Safe Storage }\end{array}$ & $\begin{array}{l}\text { Continuing } \\
\text { Care }\end{array}$ & $\begin{array}{c}\text { Deferred } \\
\text { Dismantlement } \\
\end{array}$ & Total \\
\hline 0 & 43.6 & -- & -- & -- & 43.6 \\
\hline 10 & -- & 21.3 & 0.6 & 35.5 & 57.4 \\
\hline 30 & -- & 21.3 & 2.1 & 35.5 & 58.9 \\
\hline 50 & -- & 21.3 & 3.6 & 26.4 & 51.3 \\
\hline 100 & -- & 21.3 & 7.4 & 26.3 & 55.0 \\
\hline
\end{tabular}

\section{J.7.2 Occupational Radiation Dose from Deferred Dismantlement}

For this study it is assumed that the occupational radiation dose accumulated by the decommissioning workers is controlled largely by the radiation levels of ${ }^{60}$ Co throughout the plant. Thus, if a given task performed immediately after shutdown caused a radiation dose of $N_{0}$, that same task performed $t$ years later during deferred dismantlement would cause a dose of $N(t)=N_{0} e^{-\lambda t}$, where $\lambda$ is the decay constant for ${ }^{60} c_{0}$ in years. 
Since one of the key assumptions made for deferred dismantlement is that essentially all of the same jobs are performed in approximately the same way as for immediate dismantlement, using the same techniques and equipment, the occupational radiation dose accumulated during deferred dismantlement can be estimated from the product of the dose that was accumulated during immediate dismantlement times the decay factor for ${ }^{60}$ Co over the passive safe storage period. Several of the job items given in Table I.4-1 in Appendix I for the radiation dose accumulated during immediate dismantlement, such as reactor defueling and chemical decontamination, should be subtracted from the total dose before reduction, since they are not performed during deferred dismantlement. Several other items, such as unsecuring the facility and re-establishing essential services, should be added. However, for purposes of estimating the occupational dose for deferred dismantlement, a simple reduction of the immediate dismantlement dose in proportion to the decay of ${ }^{60}$ Co over the safe storage period is a reasonable and conservative approach. These estimates are given in Table J.7-4 for dismantlement starting 10,30,50 and 100 years after reactor shutdown. After 100 years, essentially all of the remaining radioactivity is contained in the activated reactor vessel components, and the occupational radiation exposure associated with dismantlement is extremely small.

TABLE 0.7-4. Estimated Occupational Radiation Dose from Various Dismantlement Alternatives

\begin{tabular}{|c|c|c|c|c|c|}
\hline $\begin{array}{l}\text { Years } \\
\text { After }\end{array}$ & & Occupational Radiatic & Dose (man-r & & \\
\hline $\begin{array}{l}\text { Reactor } \\
\text { Shutdown }\end{array}$ & $\begin{array}{l}\text { Immediate } \\
\text { Dismantlement }\end{array}$ & $\begin{array}{l}\text { Preparations for } \\
\text { Passive Safe Storage }\end{array}$ & $\begin{array}{c}\text { Continuing } \\
\text { Care }\end{array}$ & $\begin{array}{c}\text { Deferred } \\
\text { Dismantlement }\end{array}$ & Totals \\
\hline 0 & 1845 & -- & -- & -- & 1845 \\
\hline 10 & -- & 375 & 1.3 & 495 & 871 \\
\hline 30 & -- & 375 & 6.5 & 36 & 418 \\
\hline 50 & - & 375 & 10.0 & 3 & 388 \\
\hline 100 & -- & 375 & 10.0 & $<1$ & 386 \\
\hline
\end{tabular}




\section{REFERENCES}

1. C. A. Pelletier and P. G. Voilleque, Potential Benefits of Reducing Occupational Radiation Exposure, AIF/ NESP-010, Atomic Industrial Forum, Inc., Washington, DC 20014, May 1978.

2. R. I. Smith, G. J. Konzek and W. E. Kennedy, Jr., Technology, Safety and Costs of Decommissioning a Reference Pressurized Water Reactor Power Station, NUREG/CR-0130, U.S. Nuclear Regulatory Commission Report by Pacific Northwest Laboratory, June 1978.*

3. U.S. Code of Federal Regulations, Title 10, Part 170, "Fees for Facilities and Materials Licenses and Other Regulatory Services Under the Atomic Energy Act of 1954, As Amended, "Superintendent of Documents, GPO, Washington, DC 20555, 1979.

*Available for purchase from the NRCYGPO Sales Program, U.S. Nuclear Regulatory Commission, Washington, D.C. 20555, and the National Technical Information Service, Springfield, Virginia 22161. 


\section{ENTOMBMENT DETAILS}

Entombment is one of the alternative modes considered in this study for decommissioning the reference BWR. Entombment requires the encasement of a 11 unreleasable radioactive materials not removed from the facility in concrete or other structural material sufficiently durable (strong and structurally long-lived) to ensure retention of the radioactivity until it decays to levels permitting unconditional release. (1) If the entombed radioactivity includes significant levels of long-lived neutron-activation products (e.g., ${ }^{59} \mathrm{Ni}$ with an 80,000 -year half-life), the required retention period may be exceedingly long (i.e., tens of thousands to millions of years), depending on the acceptable release limits for residual radioactivity.

This appendix discusses the following aspects of entombing the reference BWR:

- postulated entombment scenarios

- entombment tasks and schedules

- entombment costs

- radiological occupational safety of entombment.

The information in this appendix forms the bases for the activities, costs, and occupational radiation doses for entombment presented in Chapters 9, 10, and 11 in Volume 1 , respectively.

\section{K.1 POSTULATED ENTOMBMENT SCENARIOS}

Entombment of radioactive materials in the reference BWR is assumed to take place within the confines of the steel primary containment vessel and the surrounding concrete biological shield. All plant areas outside of the entombment barrier are decontaminated to allow unrestricted release if desired.

The entombment barrier consists of the primary containment vessel enclosed within a monolithic concrete envelope (the sealed biological shield) that rests 
on the Reactor Building foundation mat. Sealing of all barrier penetrations (e.g., for personnel, equipment, material, and services) is necessary. Equipment and personnel access openings, as well as the stub ends of cut-off piping, are sealed by welded plate closures. All openings through the biological shield are then filled with cast-in-place, reinforced concrete. The removable concrete head plugs are grouted in place to complete the encasement of the radioactive materials within an integral, monolithic concrete envelope. The postulated entombment structure for the reference BWR is illustrated in Figure K.1-1.

Entombment structures other than the one considered in this study may possibly be used for BWR decommissioning. Some of these possible entombment structures are independent of the plant design (i.e., generic to all BWRs). An example of this type is the entombment of the turbine generator and main condenser in place. The biological shield surrounding this equipment could be extended over the top of the equipment and all penetrations sealed to provide a durable monolithic structure. This would involve the construction of a reinforced concrete roof at the top of the shield wall, with structural columns added within the enclosed area to support the roof. In addition, reinforcing steel would be installed at all penetrations in the shield wall and the penetrations would then be filled with cast-in-place, reinforced concrete. This structure would contain enough volume to entomb the turbine generator, the main condenser, the remainder of the contaminated material in the Turbine Generator Building, and additional contaminated material removed from the Reactor Building and/or the Radwaste and Control Building.

Other entombment structure possibilities may be present in individual BWRs. These are design-dependent; they occur as a result of the specific design of the plant in question. An example of such a design-dependent entombment structure in the reference BWR is the use of the tank and pump area along the east wall of the Radwaste and Control Building at elevation $133.2 \mathrm{~m}$ (see Section C-C, Figures $\mathrm{C.2-11}$ and $\mathrm{C.2-13}$ in Appendix $\mathrm{C}$ ). Entombment in this area would involve sealing all material and services penetrations, moving the radioactive materials to be entombed into the area, and sealing the three access hatchways. Structural strengthening may also be required to increase the durability of the resulting entombment structure. 


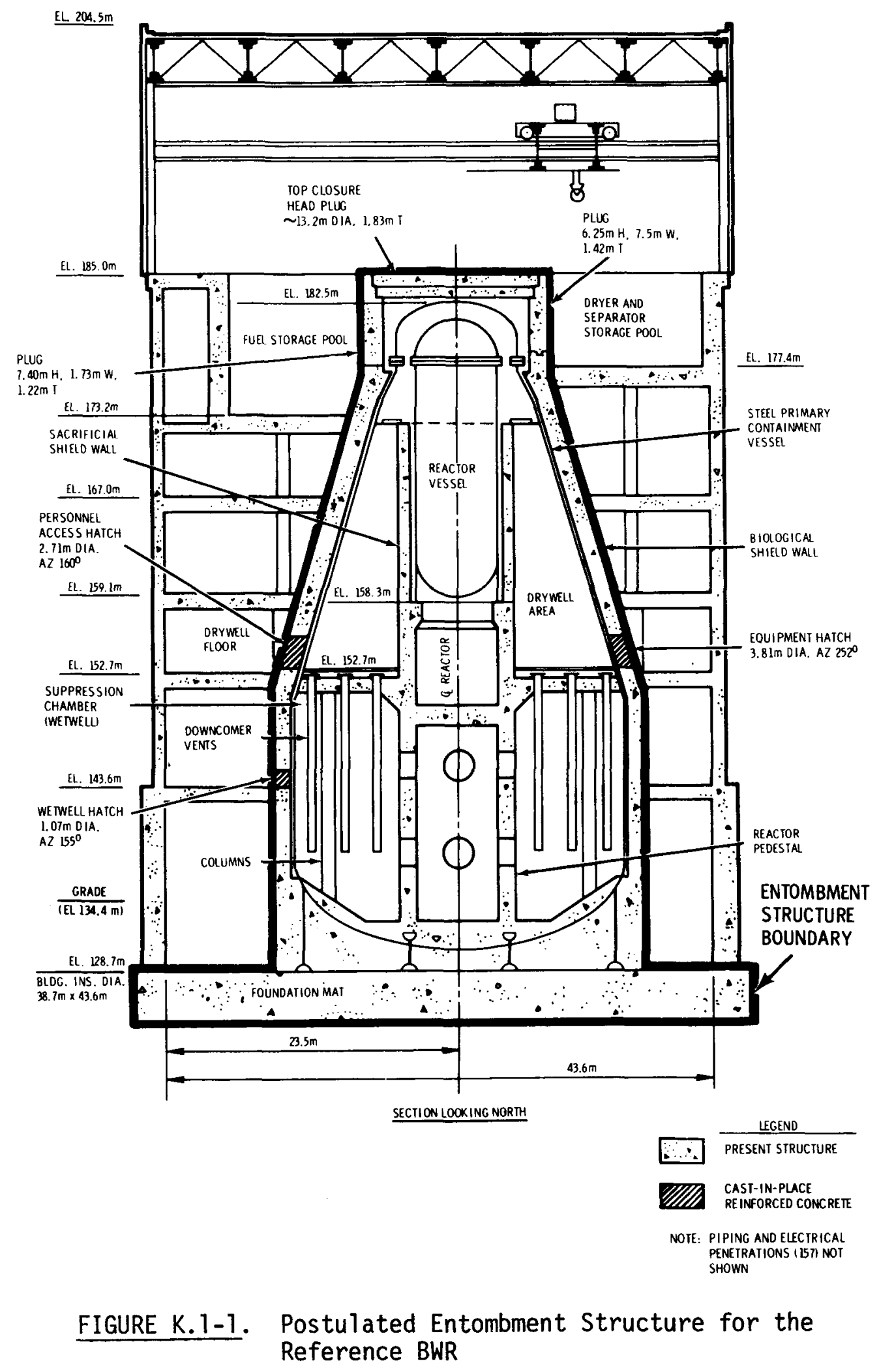


More than one entombment structure could be used in the decommissioning of a single reactor facility. This would increase the costs of construction and subsequent surveillance of the entombment barriers. However, the overall cost of decommissioning might be decreased because of the reduction or elimination of the volume of radioactive material requiring offsite disposal.

The entombment scenarios considered in this study, the adaption of the primary containment vessel to entombment, and the storage volume availability within the postulated entombment structure are discussed in the following subsections.

\section{K.1.1 Entombment Scenarios}

Two entombment scenarios, both using the postulated entombment structure shown previously in Figure K.1-1, are considered in this study: 1) entombment with the reactor vessel internals removed and 2) entombment with the reactor vessel internals in place. This latter scenario is really a form of hardened safe storage since eventual dismantlement is necessary. For both entombment scenarios, dismantlement of the facility outside the entombment structure is carried out as discussed in Section I.I of Appendix I, with the difference being that as much as possible of the contaminated equipment and material is placed in the entombment structure rather than being packaged and shipped to offsite disposal. This reduces the radioactive material disposal costs associated with initial decommissioning. The plant structures (other than the entombment structure) may also be demolished following completion of the entombment activities (see Appendix $L$ ). However, demolition of the Reactor Building is questionable for two reasons: 1) the postulated entombment structure is an integral part of the Reactor Building, with the two sharing many structural features (including the foundation), and 2) the Reactor Building, if left in place, provides a secondary barrier around the entombed materials, providing weather protection and enhanced security for the entombment structure. For these two reasons, the Reactor Building is assumed in this study to be left in place.

Further discussions of scenario 1 and scenario 2 for entombment of the reference BWR follow. 


\section{K.1.1.1 Scenario 1}

Those reactor vessel internals containing long-lived activation products $\left({ }^{59} \mathrm{Ni},{ }^{94} \mathrm{Nb}\right)$ are removed from the facility and shipped offsite to a nuclear waste repository. As much as possible of the remaining radioactive material in the plant is consolidated within the entombment structure. Because of the relatively short half-lives of the entombed radioactivity, it may be possible to terminate the nuclear license after a continuing care period of about 110 years and release (for unrestricted use) the entombment structure. It should be noted, however, that current regulations and regulatory guidance require a comprehensive survey prior to such release to verify that the radioactive contamination remaining is within acceptable release limits.

\section{K.1.1.2 Scenario 2}

The reactor vessel internals (with associated long-lived radionuclides) are left in place, and as many radioactively contaminated materials as possible are moved inside the entombment structure. Under existing regulations, the licensee is responsible for surveillance and maintenance of the entombment structure as a nuclear waste repository for an indefinite time period, unless the reactor vessel internals are subsequently removed.

\section{K.1.2 Adaptation of the Primary Containment Vessel and Biological Shield to Entombment}

The primary containment vessel is a free-standing steel pressure vessel with a floor dividing the drywell (upper portion) from the wetwell or suppression chamber (lower portion). The vessel is enclosed within the concrete biological shield wall, as shown previously in Figure K.1-1, but is separated from the wall by an annulus of compressible insulation material about $50 \mathrm{~mm}$ thick. Further description of the vessel and shield can be found in Appendix $C$.

Following chemical decontamination of the reactor and related systems (e.g., recirculation loops) and removal of all liquid volumes (see Section $\mathrm{H} .5$ of Appendix $\mathrm{H}$ ), the primary containment vessel and biological shield are ready for modification to accommodate entombment. 
For scenario 1, the reactor vessel internals are removed and shipped offsite for disposal, thus removing the long-lived activation products and also increasing the volume available for contaminated material storage inside the entombment structure.

For both entombment scenarios, the wetwell (suppression chamber) is the primary storage area for contaminated materials. Additional access to the wetwell is obtained by cutting holes in the drywell floor immediately inside the drywell personnel and equipment hatches. The downcomer vent pipes in the wetwell are cut off near the bottom surface of the drywell floor (the ceiling of the wetwel1) and then cut into shorter segments, thus allowing consolidation of their volume and more complete use of the wetwell space. Piping that penetrates the primary containment vessel (and the biological shield) is cut off flush with the interior vessel wall and at points sufficiently far away from the wall (inside) to allow adequate space for seal-welding all wall openings with steel plate. Short sections of piping or conduit removed to allow working space are placed inside the reactor pedestal in the wetwell cavity. The original wetwell hatch and the drywell access hatches are sealed with welded steel plate after the vessel valume below them is filled with contaminated materials. After seal-welding, all penetrations through the biological shield are filled with cast-in-place reinforced concrete.

The integrated schedule and sequence of tasks for adapting the primary containment vessel and the biological shield as the entombment structure and filling the structure with contaminated materials are presented later in Section K.2.

\section{K.1.3 Storage Volume Within the Entombment Structure}

The amount of contaminated material that can be entombed inside the primary containment vessel depends on the free and easily filled volume available for use within the vessel. Table K.1-l shows estimates of the gross volume; the volume displaced by existing piping equipment, and internal structures; and the net volume available for storage of contaminated material within the drywell, the wetwell, and the vessel as a whole. As shown in the table, about $13,330 \mathrm{~m}^{3}$ is available for storage in the entombment structure. For scenario 1 , the storage volume is increased by about $570 \mathrm{~m}^{3}$ by the removal of the activated reactor vessel internals, for a total of about $13,900 \mathrm{~m}^{3}$. (For scenario 2, 


\section{TABLE K.1-1. Estimated Storage Volume Within the Primary Containment Vessel}

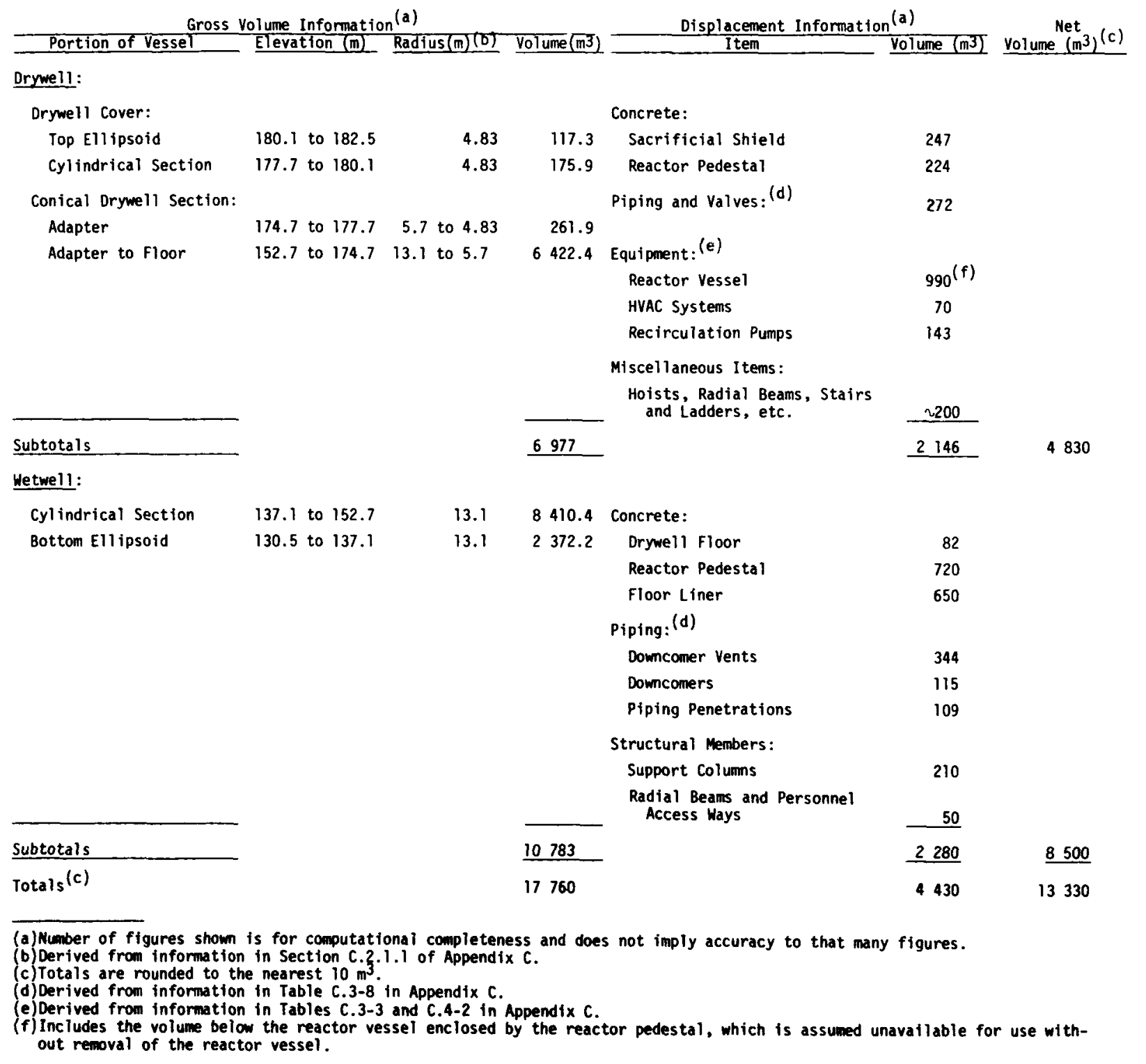


it is possible [with the dryer and separator removed] to pour smaller items, such as contaminated concrete rubble, into the reactor vessel to filter down between the internals, thus increasing the entombment storage volume by several hundred cubic meters. However, to make effective use of this space, segregation of materials by size is required. To simplify the analysis, this approach is not considered further.)

Because of the variety of shapes and sizes of both the volume available within the entombment structure and the contaminated materials to be stored there, as well as the difficulty in placing materials in some portions of the structure, a volume utilization efficiency of $50 \%$ is assumed. Therefore, $6950 \mathrm{~m}^{3}$ of contaminated material can be entombed in scenario 1 and $6665 \mathrm{~m}^{3}$ can be entombed in scenario 2. From the information presented in Section C. 3 of Appendix $C$ and summarized in Table K.1-2, an estimated volume of about $10,550 \mathrm{~m}^{3}$ of contaminated material located outside of the primary containment

TABLE K.1-2. Estimated Volumes of Contaminated Material Outside the Primary Containment Vessel

\begin{tabular}{|c|c|c|}
\hline $\begin{array}{l}\text { Material } \\
\text { Category }\end{array}$ & $\begin{array}{l}\text { Removal } \\
\text { Characteristics } \\
\end{array}$ & $\begin{array}{l}\text { Estrmatęd }(a) \\
\text { Volume }\left(\mathrm{m}^{3}\right)(\mathrm{a}) \\
\end{array}$ \\
\hline Piping and Valves & $\begin{array}{l}\text { Piping cut into } 2.1-m \text { (max.) lengths. Large- } \\
\text { bore valves removed whole. }\end{array}$ & $3981^{\text {(b) }}$ \\
\hline Small Equipment & Unsectioned, removed whole. & $518^{(c)}$ \\
\hline Large Equrpment ${ }^{(d)}$ & $\begin{array}{l}\text { Sectioned into transportable sizes, most } \\
\text { preces of } 22.4-m \text { maximum dimension. }\end{array}$ & $2122^{(c)}$ \\
\hline Large Tanks & $\begin{array}{l}\text { Sectioned into steel-plate panels of } \sim 2.4-\mathrm{m} \\
\text { maximum dimension. }\end{array}$ & $26^{(c, e)}$ \\
\hline Concrete & Rubble spalled from contaminated surfaces. & $516^{(f)}$ \\
\hline Main Turbine & Sectroned into transportable sizes. & $1406^{(g)}$ \\
\hline Ma in Condenser & $\begin{array}{l}\text { Sectioned into transportable sizes, most } \\
\text { preces of } 22.4-m \text { maximum dimension. }\end{array}$ & $1820^{(g)}$ \\
\hline Pool Liners $(\mathrm{h})$ & $\begin{array}{l}\text { Sectioned into preces of } 22.4-m \text { maximum dimen- } \\
\text { sion. }\end{array}$ & $60^{(1)}$ \\
\hline Spent Fuel Racks ${ }^{(\mathrm{J})}$ & Unsectioned, removed whole. & $308^{(1)}$ \\
\hline Total & & 10757 \\
\hline
\end{tabular}

(a) Number of figures shown is for computational completeness and does not $1 \mathrm{mply}$ accuracy to the nearest $\mathrm{m}^{3}$

(b) Calculated from data in Table C.3-11 in Appendix C, piping assumed to be of maximum diameter in selected range, for conservatism.

(c) Calculated from data in Tables C.3-1, C 3-4, and C 3-6 in Appendix C

(d) Does not include main turbine or main condenser.

(e)Calculated by dividing total mass by the approximate specific gravity of steel $(7.75)$

(f) Volume from Figures $0.2-1$ through $D$ 2-7 in Appendix $D$.

(g) Volume from Table I.3-4 in Appendix I

(h) Does not include reactor well pool liner, which is entombed in place

(1) Estimated from information in Appendix $C$ and Reference 2

(j) Includes all the spent fuel racks, even though some are removed during the planning and preparation period. 
vessel requires entombment or offsite disposal. By subtracting from this total the amount that can be entombed, it is calculated that $3600 \mathrm{~m}^{3}$ and $3885 \mathrm{~m}^{3}$ of contaminated material require packaging and shipment to offsite disposal in scenarios 1 and 2 , respectively. In addition, the reactor internals require offsite disposal in scenario 1.

The contaminated materials to be entombed are introduced into the primary containment vessel at four access points. The wetwell hatch (elevation $143.6 \mathrm{~m}$ ) is used to introduce some materials during the early stages of entombment. Two of the access points, the drywell personnel and equipment hatches (elevation $152.7 \mathrm{~m}$ ) receive the bulk of the material. (Most of this material is transferred to the wetwell through the holes in the drywell floor.) Toward the end of the entombment procedure, a limited amount of material is also introduced into the drywell from the refueling floor (elevation $185.0 \mathrm{~m}$ ) through holes cut in the refueling bellows that surround the reactor vessel flange.

A11 materials to be entombed must be segmented and moved to one of these points of access to the entombment structure. Materials within the Reactor Building are moved to the appropriate floor level in either of two ways:

1) small items (e.g., small, whole equipment pieces or boxes or bins of piping sections or concrete rubble) can be transported using the elevator (equipment key number 700 , Figures C.2-2 through C.2-4, Appendix C), and 2) larger items can be lifted through the series of aligned hatches (equipment key numbers 701 and 702, Figures C.2-2 and C.2-3) using the 113.6-Mg bridge crane at the top of the building. Materials in the Turbine Generator and Radwaste and Control Buildings are moved to the Reactor Building either directly through existing air-lock doors or indirectly by moving them outside to the Reactor Building railroad tunnel. (All materials moved outside must be adequately packaged to prevent the inadvertent spread of contamination.) Additional passageways could be cut between these three buildings by demolishing sections of intervening walls at convenient locations. However, any breaches in the walls of the Reactor Building must eventually be sealed if the building is to serve as a secondary barrier around the entombment structure, as assumed in this study. 
Once the contaminated materials are brought to the entombment structure access points, they are placed in their best storage locations in the structure. The wetwell, which receives the bulk of the material, is filled first using the lower three access points. Filling of the drywell begins using the two hatches at the 152.7-m elevation and is completed using the holes cut in the refueling bellows. Larger items placed in the wetwell are lowered into place using the 27-Mg recirculation-pump maintenance crane in the drywell (equipment key number 705, Figure 1.2-6 of Reference 2) through one of the new holes in. the drywell floor. Use of this crane requires the removal of a small portion of the steel-deck floor at the 156.3-m elevation to allow adequate working space. Larger items placed in the drywell are moved into position and stacked. Smaller items are simply dumped into the drywell through the holes in the refueling bellows to fill the spaces between the larger items.

The volume utilization efficiency could be increased (and offsite transportation and disposal costs reduced accordingly) by using any of a number of techniques, including careful selection of material placement locations, nesting of piping and other equipment, and relatively complete filling of voids in emplaced waste with. smaller items such as concrete rubble. However, this increased efficiency would likely increase manpower requirements and, consequently, manpower costs and occupational radiation exposures. It is beyond the scope of this study to optimize the storage, but this should be considered during the planning of any actual entombment project.

Some of the contaminated materials in the reference BWR are not amenable to entombment. These include certain of the large equipment items (e.g., the moisture separator reheaters), the main turbine, and the fuel storage racks. (See Table K.1-2). These materials must be packaged and shipped offsite for disposal as described in Appendix I.

\section{K.1.4 Special Tools and Equipment}

Not all of the tools and equipment needed for entombment are required during the operating phase of reactor $1 \mathrm{ife}$. The more unique devices used in entombment are described in Sections G.1, G.2, and G.4 of Appendix G. The special tools and equipment required for scenario-l entombment are the same as those 
for immediate dismantlement, which are 1isted in Table 1.1-1 of Appendix I. For scenario 2, since the reactor vessel internals remain in place, the first four items in the list are not required, but the rest of the requirements are the same.

\section{K.1.5 Summary of Disassembly Methods}

Many of the disassembly methods used for entombment are the same as those for immediate dismantlement, which are summarized in Table 1.1-2 of Appendix I. However, some methods are unique to entombment; these are summarized in Table K. 1-3.

TABLE K.1-3. Entombment Disassembly Data and Methods (a)

\begin{tabular}{|c|c|c|c|c|c|c|}
\hline \multicolumn{2}{|r|}{ Task } & \multirow{2}{*}{$\begin{array}{l}\text { Estimated } \\
\text { Cutting } \\
\text { Length }(\mathrm{m}) \\
60 \times 10^{2}\end{array}$} & \multirow{2}{*}{$\begin{array}{c}\begin{array}{c}\text { Mominal } \\
\text { Material } \\
\text { Thickness(m) }\end{array} \\
\begin{array}{c}\text { (Schedule } 80 \\
\text { Pipe) }\end{array}\end{array}$} & \multirow{2}{*}{$\begin{array}{l}\begin{array}{c}\text { Estimated } \\
\text { Cutting } \\
\text { Time (hr) }\end{array} \\
44 \times 10^{2}\end{array}$} & \multirow{2}{*}{$\begin{array}{l}\text { Strategy and } \\
\begin{array}{c}\text { Work } \\
\text { Conditions }(b)\end{array} \\
(1,2)\end{array}$} & Methods \\
\hline 8 & $\begin{array}{l}\text { Cut Suppression Pool Downcom- } \\
\text { ers and Bracing }\end{array}$ & & & & & $\begin{array}{l}\text { Cut downcomer vent pipes into three equal-length } \\
\text { segments and place in void space at bottom of } \\
\text { reactor pedestal }\end{array}$ \\
\hline \multirow[t]{3}{*}{15} & $\begin{array}{l}\text { Cut Suppression Chamber Acces- } \\
\text { ses through Drywell Floor }\end{array}$ & & & & & \\
\hline & Concrete & $\begin{array}{l}\left(16 \times 10^{1}\right. \\
\mathrm{m}^{2} \text { surface } \\
\text { area) }\end{array}$ & $61 \times 10^{-1}$ & $80 \times 10^{7}$ & $(2,3)$ & $\begin{array}{l}\text { Break out concrete from hatch areas Reinforcing } \\
\text { steel cut with oxyacetylene torch Debris drop- } \\
\text { ped into wetwell }\end{array}$ \\
\hline & Steel Beams & $11 \times 10^{1}$ & $17 \times 10^{-2}$ & $40 \times 10^{1}$ & $(1,2)$ & $\begin{array}{l}\text { Cut both ends of steel beams crossing hatch areas } \\
\text { and drop beams into wetwell }\end{array}$ \\
\hline 17 & $\begin{array}{l}\text { Cut Primary Containment Piping } \\
\text { Penetrations and Seal }\end{array}$ & $33 \times 10^{2}$ & $\begin{array}{l}\text { (Schedule } 80 \\
\text { Pipe) }\end{array}$ & $23 \times 10^{2}$ & $(1,2)$ & $\begin{array}{l}\text { Piping cut off at inside wall of primary contain- } \\
\text { ment vessel and sufficiently far away from the wall } \\
\text { to al low pipe segments to be removed and steel plates } \\
\text { to be welded over penetrations }\end{array}$ \\
\hline 18 & $\begin{array}{l}\text { Cut Drywell Bellows Access } \\
\text { Openings }\end{array}$ & $28 \times 10^{1}$ & $30 \times 10^{-2}$ & $12 \times 10^{2}$ & $(1,2,4)$ & $\begin{array}{l}\text { Holes cut through bulkhead surrounding drywell bellows } \\
\text { to allow dumping of material into drywell from refueling } \\
\text { floor }\end{array}$ \\
\hline
\end{tabular}

(a) Only tasks unique to entombment are Iisted, all tasks performed within Reactor Building, all materials are contaminated rather than neutron-

(b) $1=$ oxyacetylene torch, 2 = contamination control envelope, $3=$ jack hammer, 4 = remote cutt 1 ing

\section{K.2 ENTOMBMENT SCHEDULES AND MANPOWER ESTIMATES}

The schedules and manpower requirements for entombment are developed in the same manner and on the same bases as those for immediate dismantlement (see Section I.2 of Appendix I). The entombment schedules are quite similar to the immediate dismantlement schedule, largely because most of the tasks outside of primary containment are identical for both modes. Detailed schedules and manpower requirements are shown only for scenario-1 entombment; scenario 2 , a modification of scenario 1 , is discussed in the text. 


\section{K.2.1 Scenario-1 Entombment}

The overall schedule and sequence of tasks for scenario-1 entombment of the reference BWR are shown in Figure K.2-1, together with the decommissioning worker requirements. The planning and preparation tasks (see Section H.2 of Appendix $H$ ) for the assumed 2-year period preceding reactor shutdown are also shown in the schedule. As shown in the figure, scenario-1 entombment is estimated to require 46.5 months after reactor shutdown to complete and to involve about 4000 man-months of decommissioning worker effort.

Most entombment tasks are accomplished on a two-shift-per-day, 5-days-perweek basis. However, some tasks (e.g., shipment of neutron-activated components and operation of the radwaste systems) require three shifts per day, 7 days per week.

The manpower required to complete the entombment project is classified as either dedicated or non-dedicated. Manpower requirements for dedicated personnel (those assigned to specific tasks) are given by task in Table K.2-1. Non-dedicated personnel (those not assigned to specific tasks, but rather given general responsibilities on each shift, two shifts per day) include one shift engineer, one crew leader, one craft supervisor, and one senior health physics technician, and, for each building being actively decommissioned, one packing and support crew and one health physics technician.

The total staff labor requirements for scenario-1 entombment of the reference BWR are given in Table K.2-2. The requirements are given in equivalent man-years for the 2 years before and the 4 years following final reactor shutdown, including the management and support staff as well as the decommissioning workers. A total effort of about 630 man-years is estimated for completion of scenario-1, including 250 man-years for the management and support staff and nearly 380 man-years for the decommissioning workers. This estimate is based on the same manpower assumptions used for immediate dismantlement (see Section I.2.4 of Appendix I). Because of these assumptions, the decommissioning worker requirements in Table K.2-2 for the 4 years following reactor shutdown exceed those given at the bottom of Figure K.2-1. This "excess" manpower is 


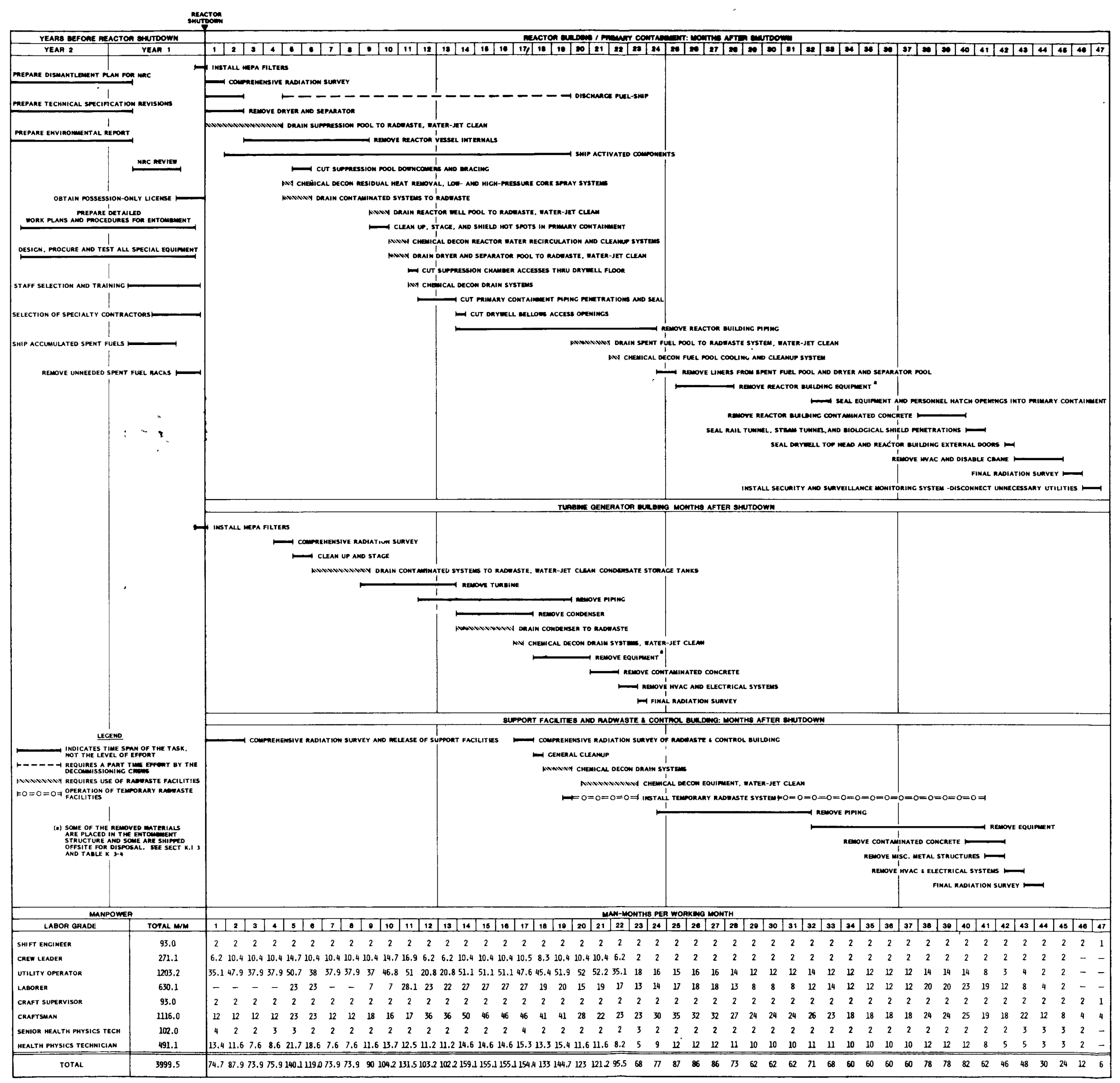

FIGURE K.2-1. Overall Schedule and Sequence and Decommissioning worker Require ments for Scenario-1 Entombment Tasks 
ـ 


\section{TABLE K.2-1. Manpower Requirements for Scenario-1 Entombent Tasks}

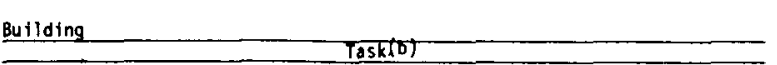

Reactor Building/Primary Contaiment

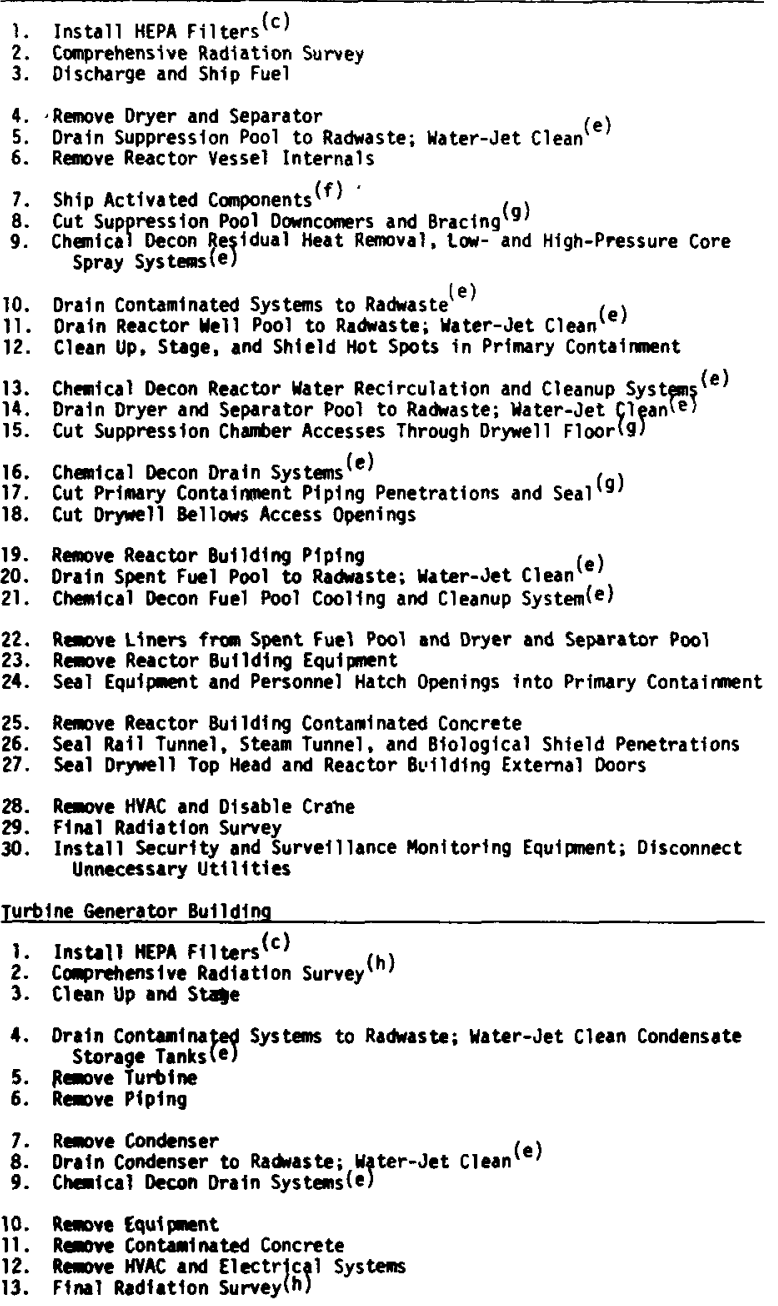

Radwaste and Control Building

1. Comprehensive Radiation Survey and Release of Support Facilitieg/Com prehensive Radiation Survey of Radwaste and Control Butlding (h)

2. General Cleanup

4. Chemical Decon Equipment; Water-Jet Clean $(e)$

5. Install Temporary Racwaste System

6. Remove Piping(g)

7. Rewove Equipment $(g)$

8. Remove contaninated Concrete

9. Remove Miscellaneous metal structures

10. Remove HMac and Electrical Systems

i1. Final Radiation Survey

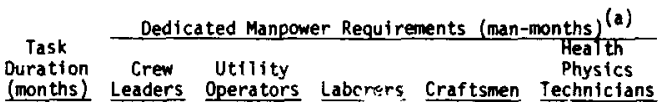

\begin{tabular}{|c|c|c|c|c|c|}
\hline 2 & 2.0 & $\ldots(d)$ & $\cdots$ & 30.0 & 60 \\
\hline $2 / 15$ & -.. & 24.0 & $\cdots$ & $\ldots$ & $\begin{array}{l}6.0 \\
---\end{array}$ \\
\hline $\begin{array}{l}2 \\
4\end{array}$ & 16.8 & $\begin{array}{r}8.0 \\
68.4\end{array}$ & 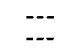 & $\begin{array}{l}8.0 \\
-\cdots\end{array}$ & 16.8 \\
\hline & & & $\cdots$ & 26.0 & \\
\hline 18 & 75.6 & 230.4 & 120 & $\cdots$ & 75.6 \\
\hline & & & & & \\
\hline & 4.9 & 12.8 & $\cdots$ & 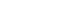 & 4.5 \\
\hline 1.5 & 6.3 & 25.7 & $\cdots$ & $\cdots$ & $\begin{array}{l}6.3 \\
4.2\end{array}$ \\
\hline 1 & $\cdots$ & $\cdots$ & 6.0 & $\cdots$ & $\cdots$ \\
\hline 1 & 8.6 & 25.7 & $\cdots$ & --- & 8.6 \\
\hline 0.5 & $\begin{array}{l}4.2 \\
-. .\end{array}$ & 11.1 & 24.1 & $\cdots$ & \\
\hline 0.5 & 4.3 & 12.8 & יבי & 160 & 4.3 \\
\hline 0.5 & -.. & $\begin{array}{l}8.0 \\
--.\end{array}$ & $\begin{array}{r}4.0 \\
4.0\end{array}$ & . & $\cdots$ \\
\hline 10.5 & & 147.0 & 126.0 & 84.0 & \\
\hline${ }_{0.5}^{2}$ & 8.4 & $\begin{array}{r}34.2 \\
4.3\end{array}$ & $\cdots$ & $\cdots$ & 8.4 \\
\hline 1 & & & & & \\
\hline 3 & $\ldots$ & 6.0 & 30.0 & 6.0 & $-\cdots$ \\
\hline 1 & -- & & 4.0 & 4.0 & \\
\hline 2.5 & $\cdots$ & $\cdots$ & 20.0 & & - \\
\hline 0.5 & $\ddot{\cdots}$ & $\cdots$ & $\begin{array}{l}6.0 \\
2.0\end{array}$ & $\begin{array}{l}2.0 \\
1.0\end{array}$ & $-\overline{-}$ \\
\hline 2.5 & $\cdots$ & $\ldots$ & 10.0 & 10.0 & \\
\hline 1 & -- & $\cdots$ & -.- & -- & 2.0 \\
\hline 1 & -- & $\cdots$ & $\cdots$ & 8.0 & $\cdots$ \\
\hline 5.5 & 5.5 & $\cdots$ & $\cdots$ & 82.5 & \\
\hline 1 & $\cdots$ & $\cdots$ & 4.0 & $\cdots$ & 2.0 \\
\hline 3 & 12.6 & 51.3 & & & 2.6 \\
\hline $\begin{array}{l}5 \\
9\end{array}$ & ...- & -.. & $\begin{array}{l}20.0 \\
36.0\end{array}$ & $\begin{array}{r}10.0 \\
108.0\end{array}$ & \\
\hline & & & & & \\
\hline $\begin{array}{l}4 \\
3\end{array}$ & 12.6 & $\begin{array}{l}\begin{array}{l}16.0 \\
51.3\end{array}\end{array}$ & $\begin{array}{l}48.0 \\
. . .\end{array}$ & 48.0 & 12.6 \\
\hline 0.5 & 4.3 & 12.8 & $\cdots$ & 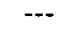 & 1 \\
\hline 3 & 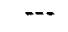 & 12.0 & 12.0 & 18.0 & ... \\
\hline 1.5 & $\ldots$ & $\cdots$ & $\begin{aligned} 12.0 \\
4.0\end{aligned}$ & 20 & \\
\hline 0.5 & --- & ... & $\cdots$ & $\cdots$ & 1.0 \\
\hline
\end{tabular}

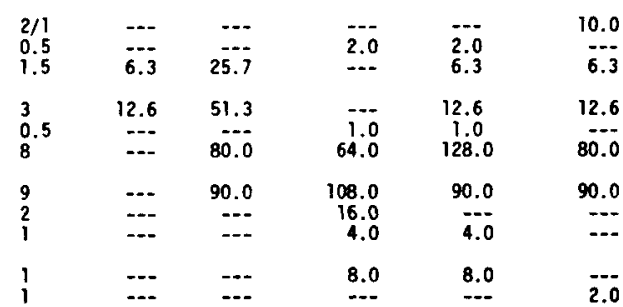

(a)Besides these dedicated personnel, non-dedicated personnel per shift (two-shift-per-day basis) include one shift engineer, one crew leader, one craft supervisor, and one senior heal th physics technician, as well as one packing and support crew (one utility operator and three craftsmen) and one health physics technician for each building undergoing active decomissioning.

(b) All tasks are conducted on a two-shift-per-day basis, 5 days per week, except as noted otherwise.

c) Performed primarily before reactor shutdown, but included here for the sake of consistency.

d) Indicates ei ther no dedicated personnel required or sufficient non-dedicated personnel available to complete the task.

e) Conducted on a three-shift-per-day basis, 7 days per week; includes operation of radwaste systems.

f) Conducted on a three-shift-per-day basis, 7 days per week.

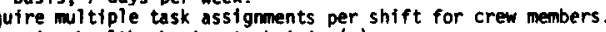

h) Requires assignient of additfonal sentor health physics technician(s). 


\section{TABLE K.2-2. Staff Labor Requirements for Scenario-1 Entombment}

Position

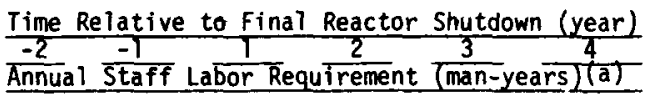

Total Staff

Labor Required (man-years)

\begin{tabular}{|c|c|c|c|c|c|c|c|}
\hline $\begin{array}{l}\text { Decommissioning Superintendent } \\
\text { Secretary } \\
\text { clerk }\end{array}$ & $\begin{array}{l}0.3 \\
1.0 \\
0\end{array}$ & $\begin{array}{l}1.0 \\
2.0 \\
1.0\end{array}$ & $\begin{array}{l}1.0 \\
3.0 \\
2.0\end{array}$ & $\begin{array}{l}1.0 \\
3.0 \\
2.0\end{array}$ & $\begin{array}{l}1.0 \\
3.0 \\
2.0\end{array}$ & $\begin{array}{l}1.2(\mathrm{~b}) \\
2.4(\mathrm{~b}) \\
0.9\end{array}$ & $\begin{array}{r}5.5 \\
14.4 \\
7.9\end{array}$ \\
\hline $\begin{array}{l}\text { Decommissioning Engineer } \\
\text { Assistant Decommissioning Engineer } \\
\text { Radioactive Shipment Specialist }\end{array}$ & $\begin{array}{l}1.0 \\
1.0 \\
0\end{array}$ & $\begin{array}{l}1.0 \\
1.0 \\
1.0\end{array}$ & $\begin{array}{l}1.0 \\
1.0 \\
1.0\end{array}$ & $\begin{array}{l}1.0 \\
1.0 \\
1.0\end{array}$ & $\begin{array}{l}1.0 \\
1.0 \\
1.0\end{array}$ & $\begin{array}{l}1.2^{(b)} \\
0.7 \\
0.7\end{array}$ & $\begin{array}{l}6.2 \\
5.7 \\
4.7\end{array}$ \\
\hline $\begin{array}{l}\text { Procurement Specialist } \\
\text { Tool Crib Attendant } \\
\text { Control Room Operator }(c)\end{array}$ & $\begin{array}{l}0.3 \\
0 \\
0\end{array}$ & $\begin{array}{l}1.0 \\
0 \\
0\end{array}$ & $\begin{array}{l}1.0 \\
2.0 \\
5.0\end{array}$ & $\begin{array}{l}1.0 \\
2.0 \\
5.0\end{array}$ & $\begin{array}{l}1.0 \\
2.0 \\
5.0\end{array}$ & $\begin{array}{l}0.7 \\
1.4 \\
3.6\end{array}$ & $\begin{array}{r}5.0 \\
7.4 \\
18.6\end{array}$ \\
\hline $\begin{array}{l}\text { Security Supervisor } \\
\text { Security Shift Superyisor (d) } \\
\text { Security Patrolman(d) } \\
\text { Contracts and Accounting Specialist }\end{array}$ & $\begin{array}{l}0 \\
0 \\
0 \\
0.3\end{array}$ & $\begin{array}{l}0 \\
0 \\
0 \\
1.0\end{array}$ & $\begin{array}{r}1.0 \\
5.0 \\
39.0 \\
1.0\end{array}$ & $\begin{array}{r}1.0 \\
5.0 \\
28.0 \\
1.0\end{array}$ & $\begin{array}{r}1.0 \\
5.0 \\
13.0 \\
1.0\end{array}$ & $\begin{array}{r}0.9 \\
4.4 \\
11.4 \\
1.2(\mathrm{~b})\end{array}$ & $\begin{array}{r}3.9 \\
19.4 \\
91.4 \\
5.5\end{array}$ \\
\hline $\begin{array}{l}\text { Health and Safety Supervisor } \\
\text { Health Physicist } \\
\text { Protective Equipment Attendant } \\
\text { Industrial Safety Specialist }\end{array}$ & $\begin{array}{l}1.0 \\
0 \\
0 \\
0.3\end{array}$ & $\begin{array}{l}1.0 \\
0.5 \\
0 \\
1.0\end{array}$ & $\begin{array}{l}1.0 \\
1.0 \\
2.0 \\
1.0\end{array}$ & $\begin{array}{l}1.0 \\
1.0 \\
2.0 \\
1.0\end{array}$ & $\begin{array}{l}1.0 \\
1.0 \\
2.0 \\
1.0\end{array}$ & $\begin{array}{l}1.2^{(b)} \\
0.8 \\
1.8 \\
0.9\end{array}$ & $\begin{array}{l}6.2 \\
4.3 \\
7.8 \\
5.2\end{array}$ \\
\hline $\begin{array}{l}\text { Quality Assurance Supervisor } \\
\text { Quality Assurance Engineer } \\
\text { Quality Assurance Technician } \\
\text { Consultant (Safety Review) }\end{array}$ & $\begin{array}{l}0.3 \\
0.5 \\
0 \\
\underline{0.5} \\
\end{array}$ & $\begin{array}{l}1.0 \\
2.0 \\
0.5 \\
0.5 \\
\end{array}$ & $\begin{array}{l}1.0 \\
1.0 \\
4.0 \\
0.5 \\
\end{array}$ & $\begin{array}{l}1.0 \\
1.0 \\
4.0 \\
0.5 \\
\end{array}$ & $\begin{array}{l}1.0 \\
1.0 \\
4.0 \\
0.5 \\
\end{array}$ & $\begin{array}{l}1.2^{(b)} \\
0.9 \\
3.5 \\
0.5 \\
\end{array}$ & $\begin{array}{r}5.5 \\
6.4 \\
16.0 \\
3.0 \\
\end{array}$ \\
\hline Subtotals, Management and Support Staff & $\underline{6.5}$ & $\underline{15.5}$ & $\underline{74.5}$ & $\underline{63.5}$ & $\underline{48.5}$ & 41.5 & $\underline{250.0}$ \\
\hline \multicolumn{8}{|l|}{ Decommissioning Workers $(e)$} \\
\hline $\begin{array}{l}\text { Shift Engineer } \\
\text { Crew Leader }\end{array}$ & $\begin{array}{l}1.0 \\
0\end{array}$ & $\begin{array}{l}2.0 \\
0.7\end{array}$ & $\begin{array}{r}2.0 \\
12.2\end{array}$ & $\begin{array}{l}2.0 \\
9.2\end{array}$ & $\begin{array}{l}2.0 \\
2.0\end{array}$ & $\begin{array}{l}1.8 \\
1.5\end{array}$ & $\begin{array}{l}10.8 \\
25.6\end{array}$ \\
\hline $\begin{array}{l}\text { Utility Operator }(g) \\
\text { Laborer } \\
\text { Craft Supervisor }\end{array}$ & $\begin{array}{l}0 \\
0 \\
0\end{array}$ & $\begin{array}{l}3.0 \\
0 \\
0.6\end{array}$ & $\begin{array}{r}52.0 \\
9.4 \\
2.0\end{array}$ & $\begin{array}{r}44.9 \\
20.6 \\
2.0\end{array}$ & $\begin{array}{r}14.5 \\
12.7 \\
2.0\end{array}$ & $\begin{array}{r}6.3 \\
10.0 \\
1.8\end{array}$ & $\begin{array}{r}120.7 \\
52.7 \\
8.4\end{array}$ \\
\hline $\begin{array}{l}\text { Craftsman } \\
\text { Senior Health Physics Technjoian } \\
\text { Health Physics Technician }(h)\end{array}$ & $\begin{array}{l}0 \\
0 \\
0\end{array}$ & $\begin{array}{r}10.0 \\
1.0 \\
3.0 \\
\end{array}$ & $\begin{array}{r}17.1 \\
2.4 \\
13.9 \\
\end{array}$ & $\begin{array}{r}36.0 \\
2.3 \\
13.6 \\
\end{array}$ & $\begin{array}{r}25.1 \\
2.0 \\
12.0 \\
\end{array}$ & $\begin{array}{r}14.9 \\
2.0 \\
6.2 \\
\end{array}$ & $\begin{array}{r}103.1 \\
.9 .7 \\
48.7 \\
\end{array}$ \\
\hline Subtotuls, Decommissioning Workers & $\underline{1.0}$ & $\underline{20.3}$ & 111.0 & 130.6 & $\underline{72.3}$ & $\underline{44.5}$ & $\underline{379.7}$ \\
\hline Totals & 7.5 & 35.8 & 185.5 & 194.1 & 120.8 & 86.0 & 629.7 \\
\hline
\end{tabular}

(a) Rounded to the next higher 0.1 man-year.

(b) Includes 4 additional months following active decomissioning in order to complete the documentation and other unspecified license and contract termination requirements; shown as part of the fourth year, even though it extends 2.5 months into the fifth year.

(c)Based on one operator per shift in the control room, three shifts ner day, 7 days per week.

(d) Based on 10 CFR Part 73 and information obtained from Washington Public Power Supply System; includes both response and access-control personnel on a three-shift, 7-day-week basis.

(e) Requirements during the 4 years following reactor shutdown are based on manpower values in Figure K.2-1, unless otherwise noted; individual man-month requirements in the figure are rounded to the next higher 1.0 man-month in calculating these requirements.

(f)Based on a constant loading of 11 people through month 21 following reactor shutdown, with additional personnel added as required to meet schedule demands during that period, and diminishing thereafter as the schedule allows.

(g)Based on a constant loading of 52 people through month 21 following reactor shutdown, diminishing thereafter as the schedule allows except during months 29 through 37 when 14 trained personnel are maintained to meet the requirements during months 38 through 40 .

(h) Based on a constant loading of 12 people through month 40 following reactor shutdown, with additional personnel added as required to meet schedule demands during that period. 
assumed to be assigned to the numerous, smal1, unspecified work items that inevitably accompany a project of this magnitude.

\section{K.2.2 Scenario-2 Entombment}

The overall schedule and sequence of tasks for scenario-2 entombment is very similar to that for scenario-1 entombment, shown previously in Figure K.2-1. For scenario 2, these scenario-1 tasks are deleted from the schedule:

- remove dryer and separator

- remove reactor vessel internals

- ship activated components.

However, this does not affect the timing of the other tasks or the overall length of the project ( 46.5 months) because the critical path of entombment tasks is unchanged. Dedicated manpower personnel requirements by task (see Table K.2-1) are also unchanged, except for the deletion of the three aforementioned tasks.

The management and support staff requirements for scenario 2 are the same as those for scenario 1, shown previously in Table K.2-2: a total of 250 man-years of management and support staff effort is required. Decommissioning worker requirements for scenario 2 are found by subtracting the dedicated manpower requirements associated with the deleted tasks from the total requirements; thus, decommissioning worker requirements total slightly more than 340 man-years. Therefore, a total effort of just over 590 man-years is estimated for completion of scenario 2.

\section{K.3 COSTS FOR ENTOMBMENT}

The estimated costs for entombment of the reference BWR (both scenarios) are presented in this section. These costs are all adjusted to early 1978 and, for consistency, the same cost estimating bases are used throughout this report for all decommissioning modes (see Appendix M). The estimated costs for both scenario-1 and scenario-2 entombment are summarized and totaled in Table K.3-1. 
TABLE K.3-1. Summary of Estimated Costs for Entombment

Cost Category

Disposal of Radioactive Materials
Neutron-Activated Materials
Contaminated Materjg]s
Radioactive Wastes $(\mathrm{d})$
Total Disposal Costs
Staff Labor
Energy
Special Tools and Equipment
Miscellaneous Supplies
Specialty Contractors $(\mathrm{e})$
Nuclear Insurance
License Fees
Subtotals
Contingencies (25\%)
Totals, Entombment Costs

Annual Continuing Care Costs
Entombment Scenario 1 \begin{tabular}{l} 
Estimated Costs \\
$(\$$ millions $)(a, b)$ Percent $p^{f}$ \\
\hline
\end{tabular}
2.394
1.846
1.469

Entombment Scenario 2 Estimated Costs
$(\$$ millions $)(\mathrm{a}, \mathrm{b})$ Percent of
Total $(\mathrm{c})$

0 1.992 1.469

\begin{tabular}{rrrrr}
5.709 & & 1.469 & & \\
\cline { 3 - 4 } 18.095 & & 17.6 & 3.461 & 12.4 \\
3.775 & 11.6 & 16.999 & 60.8 \\
2.016 & 6.2 & 3.775 & 13.5 \\
& & 0.866 & 3.1 \\
1.859 & 5.7 & 1.859 & 6.6 \\
0.172 & 0.5 & 0.172 & 0.6 \\
0.800 & 2.5 & 0.800 & 2.9 \\
0.039 & 0.1 & $\underline{0.039}$ & 0.1 \\
\hline 32.465 & 100.0 & $\underline{27.971}$ & 100.0 \\
8.116 & & $\underline{6.993}$ & \\
\hline$\underline{40.581}$ & & $\underline{34.964}$ &
\end{tabular}

$0.040 \quad 0.040$

Other Possible Costs

\begin{tabular}{|c|c|}
\hline $\begin{array}{l}3.788^{(f)} \\
8.059 \\
0.495 \\
0.617^{(\mathrm{h})} \\
\end{array}$ & $\begin{array}{l}3.788^{(f)} \\
8.059 \\
0 \\
0.617^{(i)}\end{array}$ \\
\hline 12.959 & 12.464 \\
\hline 3.240 & 3.116 \\
\hline 16.199 & 15.580 \\
\hline
\end{tabular}

(a) Costs adjusted to early 1978 .

(b) The number of significant figures shown is for computational completeness and does not imply accuracy to the nearest $\$ 1000$.

(c) Individually rounded to the nearest $0.1 \%$.

(d) Includes both wet solid wastes and dry solid wastes.

(e) Includes temporary radwaste and environmental monitoring services.

(f) If required, shipment by special train costs an estimated additional \$2.451 million, maximum.

(g) Does not include demolition of the Reactor Building or the Guardhouse.

(h) Incremental cost in addition to the cost for shallow-land burial of these materials; the maximum additional cost for shipment by special train is estimated at $\$ 1.254$ million.

(i)Alternate deep geologic disposal costs an estimated $\$ 1.047$ million; shipment by special train to the deep geologic disposal facility increases this cost by an estimated maximum of $\$ 0.456 \mathrm{mill}$ ion.

The total cost for scenario-l entombment is estimated at about $\$ 40.6$ million, including a $25 \%$ contingency; the same cost for scenario- 2 entombment is about $14 \%$ less, or about $\$ 35.0$ million total. The major contributers to the total cost of entombment are disposal of radioactive materials, staff labor, and energy (at approximately 18,56, and $12 \%$ of the total, respective?y, for scenario 1 and about 12, 61, and 13\% of the total, respectively, for scenario 2). Combined costs for special tools and equipment and for miscellaneous supplies make up an additional 12\% of the total for scenario 1 and $10 \%$ for 
scenario 2. The remaining costs, between 3 and $4 \%$ of the total for both scenarios, are contributed by specialty contractors, nuclear insurance, and license fees.

The annual costs for continuing care of the entombment structure are estimated at about $\$ 40,000$.

The total cost for other possible entombment requirements (i.e., spent fuel shipment, facility demolition and site restoration, deep geologic disposal of highiy activated materials [scenario l oniy], and fuel channel disposal) is estimated at approximately $\$ 16.2$ million for scenario 1 and $\$ 15.6$ million for scenario 2 , including $25 \%$ contingency allowances. This total cost could go as high as $\$ 21.4$ million for scenario 1 and $\$ 19.5$ million for scenario 2, depending on the possible additional requirements specified in the footnotes to Table K.3-1.

The individual cost categories shown in Table K.3-1 are developed and discussed in the following subsections.

\section{K.3.1 Costs for Disposal of Radioactive Materials}

As is the case during immediate dismantlement, three distinct types of radioactive materials in the reference $B W R$ require offsite disposal during scenario-1 entombment: 1) neutron-activated materials, 2) contaminated materials, and 3) radioactive wastes. For scenario-2 entombment, only the latter two types of material require offsite disposal because all neutron-activated materials are assumed to be entombed onsite. The total cost for disposal of these materials is about $\$ 5.7$ million for scenario 1 (about $18 \%$ of the total entombment cost) and about $\$ 3.5$ million (about $12 \%$ of the total) for scenario 2. The disposal cost includes the container, transportation, and burial costs, but does not include the direct labor costs for removing and packaging the materials. Table K.3-2 contains a summary, for both entombment scenarios, of the number of shipments, the burial volumes, and the disposal costs for the radioactive materials.

The disposal costs of the three types of radioactive materials are discussed individually in the following subsections. 
TABLE K.3-2. Summary Information Regarding Offsite Disposal of Radioactive Materials from Entombment

\begin{tabular}{|c|c|c|c|c|c|c|}
\hline \multirow[b]{2}{*}{ Radioactive Material Category } & \multicolumn{3}{|c|}{ Entombment Scenario 1} & \multicolumn{3}{|c|}{ Entombment Scenario 2} \\
\hline & $\begin{array}{l}\text { Number of } \\
\text { Shipments }\end{array}$ & $\begin{array}{l}\text { Burial } \\
\text { Volumes }\left(m^{3}\right)^{(a)} \\
\end{array}$ & $\begin{array}{l}\text { Disposal Costs } \\
(\$ \text { millions })(b) \\
\end{array}$ & $\begin{array}{l}\text { Number of } \\
\text { Shipments }\end{array}$ & $\begin{array}{l}\text { Burial } \\
\text { volumes }\left(\mathrm{m}^{3}\right)^{(a)} \\
\end{array}$ & $\begin{array}{l}\text { Disposal Co } \\
\text { (\$ millions }\end{array}$ \\
\hline Neutron-Activated Materials & 283 & 130 & $2.394^{(c)}$ & 0 & 0 & 0 \\
\hline $\begin{array}{l}\text { Contaminated Materials } \\
\text { Radioactive Wastes (e) }\end{array}$ & 330 & 6420 & 1.846 & $356^{(d)}$ & $6928^{(d)}$ & $1.992^{(d)}$ \\
\hline Wet Solid & 286 & 814 & 1.073 & 286 & 814 & 1.073 \\
\hline Dry Solid & 86 & 678 & 0.396 & 86 & 678 & 0.396 \\
\hline Totals & 985 & 8042 & 5.709 & 728 & 8420 & 3.461 \\
\hline
\end{tabular}

(a) Includes disposable containers where required.

(b)Adjusted to early 1978; the number of figures shown is for computational completeness and does not imply accuracy to the nearest $\$ 1000$.

(c)An additional cost of $\$ 0.848$ million is required if deep geologic disposal of highly activated materials is necessary.

(d) Estimated by multiplying values for scenario 1 by the ratio of the volumes of contaminated material requiring offsite disposal for scenario 2 vs. Scenario $1\left(3885 \mathrm{~m}^{3} / 3600 \mathrm{~m}^{3}\right)$, based on availability of storage space in the entombment structure (see Section K.1.3)

(e) Values assumed to be the same as for immediate dismantlement.

\section{K.3.1.1 Neutron-Activated Materials}

All of the neutron-activated materials in the reference BWR are contained in the reactor vessel, the vessel internals, and the sacrificial shield (see Section E. 1 of Appendix E), and are located inside the primary containment vessel. However, the reactor vessel and the sacrificial shield are assumed to be entombed in place and, therefore, only offsite disposal of the vessel internals is considered for scenario-1 entombment. (As stated previously, no offsite disposal of activated materials is assumed for scenario-2 entombment.) Table K.3-3 gives a detailed breakdown of the masses, the radioactivity contents, the number of pieces (after segmenting), the number of packaging containers, and the disposal costs for the offsite disposal of neutron-activated components (except the fuel channels) in the reference BWR.

The total radioactivity expected to be present in the neutron-activated materials disposed of offsite is approximately 6.6 million curies. The packaged materials are estimated to require 283 overweight truck shipments to a shallowland burial facility and to occupy $130 \mathrm{~m}^{3}$ of space at the facility. The total estimated cost for shallow-land disposal of the neutron-activated materials is about $\$ 2.4$ million.

There is a possiblity that the more highly activated materials may require deep geologic disposal. This alternative is discussed later in Section K.3.10.3. 
TABLE K.3-3. Costs for Disposal of Neutron-Activated Materials (Scenario-l Entombment)

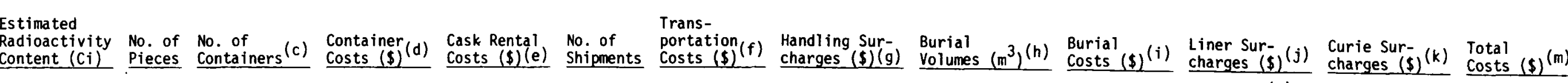

\begin{tabular}{|c|c|c|c|c|c|c|c|c|c|c|c|c|c|c|}
\hline $\begin{array}{l}\text { Steam Separator Assembly } \\
\text { Orificed Fuel Supports } \\
\text { Control Rods and In-Core Instruments }\end{array}$ & $\begin{array}{r}9500^{(n)} \\
5420(n) \\
19810^{(n)}\end{array}$ & $\begin{array}{r}9600 \\
700 \\
189000\end{array}$ & $\begin{array}{l}951 \\
740 \\
610\end{array}$ & $\begin{array}{l}28 p \\
{ }_{14 p} \\
8 p\end{array}$ & $\begin{array}{rl}12 & 600 \\
6300 \\
48000\end{array}$ & $\begin{aligned} 14000 \\
7000 \\
27600\end{aligned}$ & $\begin{array}{r}14 \\
7 \\
8\end{array}$ & $\begin{array}{l}26880 \\
13440 \\
15360\end{array}$ & $\begin{array}{l}5600 \\
28800(0) \\
12310\end{array}$ & $\begin{array}{r}10 \\
5 \\
15\end{array}$ & $\begin{array}{r}940 \\
470 \\
1400\end{array}$ & $\begin{array}{l}36400(0) \\
77700(0) \\
42810(0)\end{array}$ & $\begin{array}{c}\text { charges }(\$) \\
7320 \\
11780^{\circ}\end{array}$ & $\begin{array}{l}\text { sts }(\$) \\
103740 \\
37710 \\
159260\end{array}$ \\
\hline $\begin{array}{l}\text { Control Rod Guide Tubes } \\
\text { Jet Pump Assemblies } \\
\text { Top Fuel Guide }\end{array}$ & $\begin{array}{l}3500(n) \\
6000^{(n)} \\
2300\end{array}$ & $\begin{array}{l}200 \\
20000 \\
30100\end{array}$ & $\begin{array}{l}370 \\
110 \\
408\end{array}$ & $\begin{array}{l}12 p \\
40 p \\
72 p\end{array}$ & $\begin{array}{r}5400(q) \\
38400(q) \\
111600\end{array}$ & $\begin{aligned} 6000 \\
20000 \\
36000\end{aligned}$ & $\begin{array}{r}6 \\
20 \\
72\end{array}$ & $\begin{array}{r}11520 \\
38400 \\
138240\end{array}$ & $\begin{array}{rl}2 & 400 \\
8 & 000 \\
14 & 400\end{array}$ & $\begin{array}{r}4 \\
14 \\
24\end{array}$ & 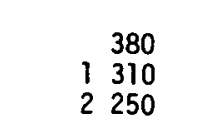 & $\begin{aligned} 3900 \\
85000 \\
153000\end{aligned}$ & $\begin{array}{rl}6 & 0 \\
6 & 700 \\
22 & 030\end{array}$ & $\begin{array}{r}29600 \\
197.810 \\
477520\end{array}$ \\
\hline $\begin{array}{l}\text { Core Support Plate } \\
\text { Core Shroud }\end{array}$ & $\begin{array}{r}18500 \\
32000 \\
\end{array}$ & $\begin{array}{r}650 \\
6300 \quad 000 \\
\end{array}$ & $\begin{array}{r}258 \\
558 \\
\end{array}$ & $\begin{array}{r}31 p \\
13 v+127 c \\
\end{array}$ & $\begin{array}{r}\begin{array}{r}13950 \\
354470^{(}\end{array} \\
\end{array}$ & $\begin{array}{r}15500 \\
70000 \\
\end{array}$ & $\begin{array}{r}16 \\
140 \\
\end{array}$ & $\begin{array}{r}30720 \\
268800 \\
\end{array}$ & $\begin{array}{r}6200 \\
28000 \\
\end{array}$ & $\begin{array}{l}11 \\
47 \\
\end{array}$ & $\begin{array}{r}1030 \\
4400 \\
\end{array}$ & $\begin{array}{r}10 \quad 080 \\
228 \quad 850 \\
\end{array}$ & $\begin{array}{r}0 \\
356 \quad 510^{0} \\
\end{array}$ & $\begin{array}{r}77480 \\
1\end{array}$ \\
\hline Totals $^{(m)}$ & 97030 & 6550150 & 4005 & 345 & 590720 & 196100 & 283 & 543360 & 79710 & 130 & 12180 & 567740. & 404340 & 2394150 \\
\hline
\end{tabular}

(a) Listed in order of removal.

(b) Estimated from values presented in Table E. $1-6$ of Appendix E.
c) Estimated on the following bases:

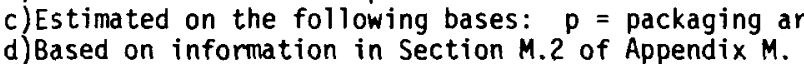

(e) Based on Table M.3-1; assumes 5 days per shipment.

(g) Based on cask handling fee in Table M.5-1, except as otherwise noted.
(h) Includes the disposable container; rounded to the nearest whole $\mathrm{m}^{3}$.

h) Includes the disposable container; rounded to the nearest whole $\mathrm{m}$.
(i) Based on Table M.5-1; based on volume only; rounded to nearest $\$ 10$.

(j)Based on Table M.5-l except as otherwise noted; based on dose rate at the container surface.

(m) The number of figures shown is for computational completeness only and does not imply accuracy to that many significant figures.

(n) Includes only the neutron-activated portion of the component, rest disposed of as contaminated material.
(o) Based on cost estimate information supplied by Nuclear Engineering Co., Louisville, KY (minus $30 \%$ for escalation since September 1977).

(p) Specially constructed steel boxes.
(q) Includes costs for lead shielding. 
The fuel channels are assumed to be shipped together with the spent reactor fuel to an offsite repository. However, in the event that this is not possible, a presentation of the disposal costs for these components is contained in Section K.3.10.4.

\section{K.3.1.2 Contaminated Materials}

Contaminated materials in the reference BWR are assumed to include much of the piping and equipment located in the Reactor Building/Primary Containment, the Turbine Generator Building, and the Radwaste and Control Building. In addition, many concrete surfaces in these three buildings are assumed to be contaminated and require surface removal to a depth of $0.051 \mathrm{~m}$. However, much of this contaminated material can be placed in the entombment structure and entombed onsite, thus significantly reducing the amount of this material requiring offsite disposal.

The cost calculations for offsite disposal of contaminated materials during entombment are based on the analysis for immediate dismantlement presented in Section I.3.1.2 of Appendix I. However, only some of the materials shown in Table I.3-4 in Appendix I require offsite disposal during entombment. "The amount of burial volume required for all contaminated materials outside of Primary Containment (from Table I.3-4 in Appendix I) is $13,285 \mathrm{~m}^{3}$. The actual volume of these contaminated materials is estimated in Table K. $1-2$ as $10,757 \mathrm{~m}^{3}$. Using these figures, the ratio of burial volume versus actual volume is estimated as 1.24. The actual volume requiring offsite disposal for scenario 1 is calculated at $3600 \mathrm{~m}^{3}$ in Section K.1.3. Multiplying this actual volume by the aforementioned volume ratio, the minimum burial volume of contaminated materials requiring offsite disposal for scenario-1 entombment is estimated to be $4446 \mathrm{~m}^{3}$.

Table K.3-4 presents breakdowns of disposal costs for contaminated materials during scenario-1 entombment. Only components assumed to be shipped offsite are shown in the table; these components are selected on the basis of size, difficulty of placing in the entombment structure, and entombment schedule. In an actual entombment project, such a material selection would probably be based on a more detailed breakdown of material categories. However, the overall cost of contaminated material disposal should not be significantly different than the cost calculated here. 


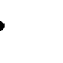


TABLE K.3-4. Costs for Disposal of Contaminated Materials Assumed to be Shipped Offsite (Scenario-1 Entombment) (a)

Location

Primary Containment

Steam Dryer

Steam Separator Assembly $(m)$

(Control Rod Drive tor Vesse $]$ Interna $1 \mathrm{~s}(\mathrm{~m})$

Equipment $(m)$

Primary Containment $(\mathrm{k})$

Reactor Building

Equipment

MSIV Leakage Control

Subtotals, Reactor Building (k)

Turbine Generator Building

Turbine
Condenser

Equipment

Low-Pressure Feedwater Heaters

Steam Evaporators/Turbine Bypass Valve Assembly

Moisture Separator Reheaters

High-Pressure Feedwater

Subtotals, Turbine Generator Building $(k)$

Radwaste and Control Building

Miscellaneous Mefar Structures $(s)$

Electrical Equipment $(v)$

Subtotals, Radwaste and Control Building $(k)$ Totals $^{(k)}$ $\underset{\text { Mastimated }(\mathrm{kg})(\mathrm{c})}{\operatorname{mas}}$

Number of
Disposable $\quad \begin{gathered}\text { Container } \\ \text { Number of }\end{gathered} \quad \begin{gathered}\text { Transpor } \\ \text { Containers }\end{gathered}$

Costs $(\$)(e)$

$\underline{\text { hipments }(f) \quad \text { Costs }(\$)(g)}$

$\begin{array}{r}\text { Handling } \\ \text { Costs }(\$)^{(h)} \\ \hline\end{array}$

Burial
Oolumes $\left(\mathrm{m}^{3}\right)$

$\left(m^{3}\right)^{(i)}$

Burial
Costs $(\$)(j)$

Total

\section{\begin{tabular}{l}
38560 \\
42000 \\
69600 \\
\hline
\end{tabular}}

$\begin{array}{r}69600 \\ 100960 \\ \hline\end{array}$

251120

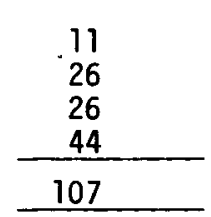

$\begin{array}{r}4400 \\ 10400 \\ 10400 \\ 17600 \\ \hline 42800 \\ \hline\end{array}$

$\begin{array}{r}3 \\ 3 \\ 4 \\ 8 \\ \hline 18 \\ \hline\end{array}$

$\begin{array}{r}5760 \\ 5760 \\ 7680 \\ 15360 \\ \hline 34560 \\ \hline\end{array}$

$\begin{array}{r}0 \\ 0 \\ 0 \\ 0 \\ \hline 0 \\ \hline\end{array}$

$\begin{array}{r}40 \\ 95 \\ 95 \\ 161 \\ \hline 391\end{array}$

$\begin{array}{r}3750 \\ 8890 \\ 8890 \\ 15070 \\ \hline 36 \quad 600 \\ \hline\end{array}$

$\begin{array}{r}13910 \\ 25050 \\ 26970 \\ 48030 \\ \hline 113960 \\ \hline\end{array}$

$\begin{array}{r}410 \\ 82250 \\ \hline 82660 \\ \hline\end{array}$

\begin{tabular}{c}
$-(n)$ \\
$0+3(0)+4(p)$ \\
\hline $0+7(0, p)$
\end{tabular}

$\begin{array}{r}3450 \\ \hline 3450 \\ \hline\end{array}$

$\frac{-}{5}$

$\begin{array}{r}-- \\ 9600 \\ \hline 9600\end{array}$

1490

$\begin{array}{r}-- \\ 62 \\ \hline 62\end{array}$

$\begin{array}{r}-- \\ 5810 \\ \hline 5810\end{array}$

$\begin{array}{r}-20 \quad 350 \\ \hline 20 \quad 350 \\ \hline\end{array}$

$\begin{array}{lll}1 & 662780 \\ 1 & 570 & 000\end{array}$

$220+58(0)$

156550
200000

82
125 $\quad \begin{array}{r}157440 \\ \end{array}$

$14 \quad 480$
0

$\begin{array}{ll}1 & 406 \\ 1 & 820\end{array}$

131560
170300

460030
610300

$738 \quad 000$
2080
$32 \quad 220$

$$
\begin{aligned}
& 2+42(p) \\
& 0+4(p)
\end{aligned}
$$$$
\begin{aligned}
& 0+4(p) \\
& 0+3(p)
\end{aligned}
$$

7100
300
600

${ }_{2}^{42}(q)$

80640
290

$15 \quad 270$
0
560

$0+26(p)$
$10+10(0)$

$10+10(0)$
$0+8(p)$

$\begin{array}{r}32000 \\ 16520 \\ 3600 \\ \hline\end{array}$

417310
109770
146950

4679110

$732+151(0, p)$

416670

$\begin{array}{r}26 \\ 6 \\ 8 \\ \hline 291 \\ \hline\end{array}$

3840

9360

$\begin{array}{r}1200 \\ 3000 \\ \hline\end{array}$

$\begin{array}{r}11520 \\ 15 \quad 360 \\ \hline\end{array}$

572010

43870

$\begin{array}{r}19440 \\ 69510 \\ 63210 \\ \hline 152 \quad 160 \\ \hline\end{array}$

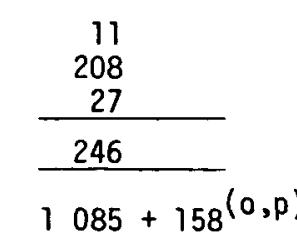

$\begin{array}{r}4400 \\ 83200 \\ 10800 \\ \hline\end{array}$

10800

98400

5165050

561320

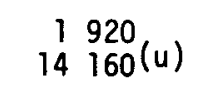

$\begin{array}{r}14760 \\ 5760 \\ \hline\end{array}$

21840 $\begin{array}{r}0 \\ 0 \\ 0 \\ \hline 0 \\ \hline\end{array}$

45360 $\begin{array}{r}737 \\ 8 \\ 71 \\ 715 \\ 194 \\ 121 \\ \hline 5072 \\ \hline\end{array}$

68970
750
6650

66900

18250

474700

3750
70840
$9 \quad 170$

9170

83760

600870
171980
1340
11650

$171 \quad 180$

$\begin{array}{r}47490 \\ 33280 \\ \hline\end{array}$

1507250

$\begin{array}{r}10070 \\ 168 \quad 200 \\ \hline\end{array}$

204000

1845560

(a) Adapted from Table I.3-4 in Appendix I; only materials requiring offsite disposal are listed.

(b) Listed in order of removal (i.e., main headings only) from each location.

(c) Astained from Appendix $C$, or estimated from information in Appendix $C$ or from dat
(d) Assumed to be $1.2-\mathrm{m}$ by $1.2-\mathrm{m}$ by $2.4-\mathrm{m}$ plywood boxes, unless otherwise indicated.

(e) Based on information in Section M. 2 of Appendix M.
(f) Assumed to be overweight shipments, unless otherwise indicated.

(f) Assumed to be overweight
(g) Based on Table M.4-4.

h) Based on Table M.5-1.

i) Includes the disposal container, where required; rounded to the next whole $\mathrm{m}^{3}$

j) Based on Table M.5-1; based on an assumed container surface dose rate of $<0.20 \mathrm{R} / \mathrm{hr}$; rounded to the next highest $\$ 10$.

(k) The number of figures shown is for computational completeness and does not imply accuracy to that many significant figures.

(m) Includes only the centanter

p) Equipment (or segments of equipment) on which external openings or surfaces are capped or covered and seal-welded to form self-contained packages.

q) Combined with other shipments.

(s) Includes steel stairs, gratings, and ladders assumed to be contaminated.

$(t)$ Includes all exhaust equipment.

(u) Legal-weight shipments.
(v) Assumed to be $5 \%$ of the total cable trays and hangers.

TABLE K.3-4. Costs for Disposal of Contaminated Materials Assumed to be Shipped Entombment) (a) 
○ 
The materials shipped offsite for disposal are estimated to require 330 truck shipments to and $6,420 \mathrm{~m}^{3}$ of burial space at a shallow-land burial site. (The burial volume is larger than the minimum burial volume calculated above, mainly because of the many large components not amenable to placement in the entombment structure.) The total disposal cost for contaminated materials during scenario-1 entombment of the reference BWR is about $\$ 1.8$ million.

For scenario-2 entombment, because the reactor vessel internals are not removed and shipped offsite, less space is available in the entombment structure. In Section K.1.3, it is calculated that $3885 \mathrm{~m}^{3}$ (actual volume) of contaminated material require offsite disposal for scenario 2 as opposed to the $3600 \mathrm{~m}^{3}$ for scenario 1. Multiplying by the ratio of these volumes, the contaminated material disposal requirements for scenario 1 are adjusted to estimate the requirements for scenario 2. The material disposed of offsite during scenario 2 entombment is thus estimated to require 356 truck shipments and to occupy $6,928 \mathrm{~m}^{3}$ of burial volume; the total estimated disposal cost is about $\$ 2.0$ mi1lion.

\section{K.3.1.3 Radioactive Wastes}

Radioactive wastes (radwastes) result directly from entombment of the reference BWR. The disposal requirements for these wastes during entombment (either scenario) are assumed to be the same as during immediate dismantlement. (See Section 1.3.1.3 of Appendix I for details of the analysis.)

Wet solid wastes are estimated to require 286 truck shipments, $816 \mathrm{~m}^{3}$ of burial space, and about $\$ 1.1$ million for disposal. Disposal of dry solid wastes is estimated to cost about $\$ 400,000$ and to require 86 overweight truck shipments and $678 \mathrm{~m}^{3}$ of shallow-land burial space. The total disposal cost for radioactive wastes, the sum of the costs for the wet solid wastes and the dry solid wastes, is about $\$ 1.5$ million.

\section{K.3.2 Costs for Staff Labor}

The costs for staff labor during scenario-l entombment are shown in detail in Table K.3-5. Approximately $56 \%$ of the total cost for scenario 1 is associated with the staff requirements (presented in Table K.2-2). A total staff labor cost of about $\$ 18.1$ million is estimated for scenario-1 entombment of the reference BWR. Specialty contractor labor is not included in this total. 


\section{TABLE K.3-5. Costs for Staff Labor During Entombment (Scenario 1)}

\begin{tabular}{|c|c|c|c|c|c|c|c|}
\hline Position & $\frac{T i}{-2}$ & $\frac{\text { Relati }}{-1}$ & ve to Fin & a) Reacto & $\frac{\text { or Shutdon }}{\frac{3}{\text { thousands }}}$ & $n($ year $)$ & $\begin{array}{r}\text { Total Sta } \\
\text { Labor Costs } \\
(\$ \text { thousan } \\
\end{array}$ \\
\hline \multicolumn{8}{|l|}{ Management and Support Staff } \\
\hline $\begin{array}{l}\text { Decommissioning Superintendent } \\
\text { Secretary } \\
\text { Clerk }\end{array}$ & $\begin{array}{l}22.4 \\
20.3 \\
0\end{array}$ & $\begin{array}{l}74.5 \\
40.6 \\
20.3\end{array}$ & $\begin{array}{l}74.5 \\
60.9 \\
40.6\end{array}$ & $\begin{array}{l}74.5 \\
60.9 \\
40.6\end{array}$ & $\begin{array}{l}74.5 \\
60.9 \\
40.6\end{array}$ & $\begin{array}{l}89.4^{(c)} \\
48.8^{(c)} \\
18.3^{(c)}\end{array}$ & $\begin{array}{l}409.8 \\
292.4 \\
160.4\end{array}$ \\
\hline $\begin{array}{l}\text { Decommissioning Engineer } \\
\text { Assistant Decommissioning Engineer } \\
\text { Radioactive Shipment Specialist }\end{array}$ & $\begin{array}{c}63.5 \\
43.8 \\
0\end{array}$ & $\begin{array}{l}63.5 \\
43.8 \\
32.9\end{array}$ & $\begin{array}{l}63.5 \\
43.8 \\
32.9\end{array}$ & $\begin{array}{l}63.5 \\
43.8 \\
32.9\end{array}$ & $\begin{array}{l}63.5 \\
43.8 \\
32.9\end{array}$ & $\begin{array}{l}76.2^{(c)} \\
30.7 \\
23.1\end{array}$ & $\begin{array}{l}393.7 \\
249.7 \\
154.7\end{array}$ \\
\hline $\begin{array}{l}\text { Procurement Specialist } \\
\text { Tool Crib Attendant } \\
\text { Control Room Operator }\end{array}$ & $\begin{array}{l}9.3 \\
0 \\
0\end{array}$ & $\begin{array}{c}30.7 \\
0 \\
0\end{array}$ & $\begin{array}{r}30.7 \\
46.4 \\
145.0\end{array}$ & $\begin{array}{r}30.7 \\
46.4 \\
145.0\end{array}$ & $\begin{array}{r}30.7 \\
46.4 \\
145.0\end{array}$ & $\begin{array}{r}21.5 \\
32.5 \\
104.4\end{array}$ & $\begin{array}{l}153.6 \\
171.7 \\
539.4\end{array}$ \\
\hline $\begin{array}{l}\text { Security Supervisor } \\
\text { Security Shift Supervisor } \\
\text { Security Patrolman } \\
\text { Contracts and Accounting Specialist }\end{array}$ & $\begin{array}{l}0 \\
0 \\
0 \\
11.6\end{array}$ & $\begin{array}{c}0 \\
0 \\
0 \\
38.4\end{array}$ & $\begin{array}{r}32.9 \\
153.5 \\
830.7 \\
38.4\end{array}$ & $\begin{array}{r}32.9 \\
153.5 \\
596.4 \\
38.4\end{array}$ & $\begin{array}{r}32.9 \\
153.5 \\
276.9 \\
38.4\end{array}$ & $\begin{array}{r}29.7 \\
135.1 \\
242.9(c) \\
46.1\end{array}$ & $\begin{array}{l}128.4 \\
595.6 \\
946.9 \\
211.3\end{array}$ \\
\hline $\begin{array}{l}\text { Health and Safety Supervisor } \\
\text { Health Physicist } \\
\text { Protective Equipment Attendant } \\
\text { Industrial Safety Specialist }\end{array}$ & $\begin{array}{l}50.4 \\
0 \\
0 \\
13.2\end{array}$ & $\begin{array}{c}50.4 \\
19.7 \\
0 \\
43.8\end{array}$ & $\begin{array}{l}50.4 \\
39.4 \\
46.4 \\
43.8\end{array}$ & $\begin{array}{l}50.4 \\
39.4 \\
46.4 \\
43.8\end{array}$ & $\begin{array}{l}50.4 \\
39.4 \\
46.4 \\
43.8\end{array}$ & $\begin{array}{l}60.5^{(c)} \\
31.6 \\
41.8 \\
39.5\end{array}$ & $\begin{array}{l}312.5 \\
169.5 \\
181.0 \\
227.9\end{array}$ \\
\hline $\begin{array}{l}\text { Quality Assurance Supervisor } \\
\text { Quality Assurance Engineer } \\
\text { Quality Assurance Technician } \\
\text { Consultant (Safety Review) } \\
\end{array}$ & $\begin{array}{l}13.2 \\
19.7 \\
0 \\
33.5 \\
\end{array}$ & $\begin{array}{l}43.8 \\
78.8 \\
11.6 \\
33.5 \\
\end{array}$ & $\begin{array}{l}43.8 \\
39.4 \\
92.8 \\
33.5 \\
\end{array}$ & $\begin{array}{l}43.8 \\
39.4 \\
92.8 \\
33.5 \\
\end{array}$ & $\begin{array}{l}43.8 \\
39.4 \\
92.8 \\
33.5 \\
\end{array}$ & $\begin{array}{l}52.6^{(c)} \\
35.5 \\
81.2 \\
33.5 \\
\end{array}$ & $\begin{array}{l}241.0 \\
252.2 \\
371.2 \\
201.0 \\
\end{array}$ \\
\hline Subtotals, Management and Support Staff & 300.9 & $\underline{62.6 .3}$ & 1983.3 & 1749.0 & 1429.5 & 1274.9 & $\geq 363.9$ \\
\hline \multicolumn{8}{|l|}{ Decommissioning Workers } \\
\hline $\begin{array}{l}\text { Shift Engineer } \\
\text { Crew Leader }\end{array}$ & $\begin{array}{c}43.8 \\
0\end{array}$ & $\begin{array}{l}87.6 \\
26.2\end{array}$ & $\begin{array}{r}87.6 \\
455.1\end{array}$ & $\begin{array}{r}87.6 \\
343.2\end{array}$ & $\begin{array}{l}87.6 \\
74.6\end{array}$ & $\begin{array}{l}78.9 \\
56.0\end{array}$ & $\begin{array}{l}473.1 \\
955.1\end{array}$ \\
\hline $\begin{array}{l}\text { Utility Operator } \\
\text { Laborer } \\
\text { Craft Supervisor }\end{array}$ & $\begin{array}{l}0 \\
0 \\
0\end{array}$ & $\begin{array}{c}81.3 \\
0 \\
23.7\end{array}$ & $\begin{array}{r}1409.2 \\
243.5 \\
78.8\end{array}$ & $\begin{array}{r}1216.8 \\
533.6 \\
78.8\end{array}$ & $\begin{array}{r}393.0 \\
329.0 \\
78.8\end{array}$ & $\begin{array}{r}170.8 \\
259.0 \\
71.0\end{array}$ & $\begin{array}{ll}3 & 271.1 \\
1 & 365.1 \\
& 331.1\end{array}$ \\
\hline $\begin{array}{l}\text { Craftsman } \\
\text { Senior Health Physics Technician } \\
\text { Health Physics Technician }\end{array}$ & $\begin{array}{l}0 \\
0 \\
0 \\
\end{array}$ & $\begin{array}{r}271.0 \\
32.9 \\
75.3 \\
\end{array}$ & $\begin{array}{r}463.5 \\
79.0 \\
348.9 \\
\end{array}$ & $\begin{array}{r}975.6 \\
75.7 \\
341.4 \\
\end{array}$ & $\begin{array}{r}680.3 \\
65.8 \\
301.2 \\
\end{array}$ & $\begin{array}{r}403.8 \\
65.8 \\
155.7 \\
\end{array}$ & $\begin{array}{r}2794.2 \\
319.2 \\
1 \quad 222.5 \\
\end{array}$ \\
\hline Subtotals, Decommissioning Workers & 43.8 & 598.0 & 3165.6 & $\underline{3652.7}$ & 2010.3 & 1261.0 & 10731.4 \\
\hline Totals & 4.7 & 224.3 & 8.9 & 401.7 & 3439.8 & 35.9 & 3 \\
\hline
\end{tabular}

(a) The number of significant figures shown is for computational completeness and does not imply accuracy to the nearest $\$ 100$.

(b) Calculated as the product of the data given in Table K.2-2 and the corresponding data qiven in Table M.1-1; rounded to the next higher $\$ 100$.

(c) Ircludes extra time, extending into the fifth year, allotted for completion of documentation and other unspecified license and contract termination requirements. 
The costs for staff labor during scenario-2 entombment are arrived at by subtracting out the costs for dedicated manpower applied to the tasks deleted from scenario 1. The deleted tasks are: 4. Remove Dryer and Separator, 6. Remove Reactor Vessel Internals, and 7. Ship Activated Components. The manpower requirements given previously in Table K.2-1 for these tasks are multiplied by the corresponding data in Table M.1-1 in Appendix M, the products are summed, and the resulting total is subtracted from the total in Table K.3-5. Thus, a total staff labor cost of about $\$ 17.0$ million is estimated for scenario 2 ; this represents about $61 \%$ of the total cost for scenario 2 .

\section{K.3.3 Costs for Energy}

The costs for energy during entombment (either scenario) are presented in Table K.3-6, together with the estimated usage of both electricity and fuel oil. The usage of both energy forms is estimated by detailed analysis of the entombment tasks and schedule and the requirements for the essential systems presented in Table H.4-1 in Appendix H.

A total of $123,470 \mathrm{MWh}$ of electricity, costing $\$ 1,852,050$, and $14,570 \mathrm{~m}^{3}$ of fuel oil, costing $\$ 1,923,290$, are estimated to be used during entombment. The total cost for energy, about $\$ 3.8$ million, is about 12 and $14 \%$ of the total entombment cost for the two scenarios, respectively.

\section{K.3.4 Costs for Special Tools and Equipment}

For scenario-1 entombment, the costs for special tools and equipment are assumed to be the same as those presented in Table I.3-9 in Appendix I for immediate dismantlement. Thus, for scenario 1, the estimated total cost for special tools and equipment is about $\$ 2.0$ million, which represents about $6 \%$ of the total cost. For scenario 2, the first four items listed in Table 1.3-9 are unnecessary. Therefore, the reduced cost for scenario 2 is about $\$ 870,000$, which is about $3 \%$ of the total cost.

\section{K.3.5 Costs for Miscellaneous Supplies}

A variety of supplies are used during entombment. The requirements and estimated costs for these items are assumed to be the same as those given in 
TABLE K.3-6. Costs for Energy During Entombment

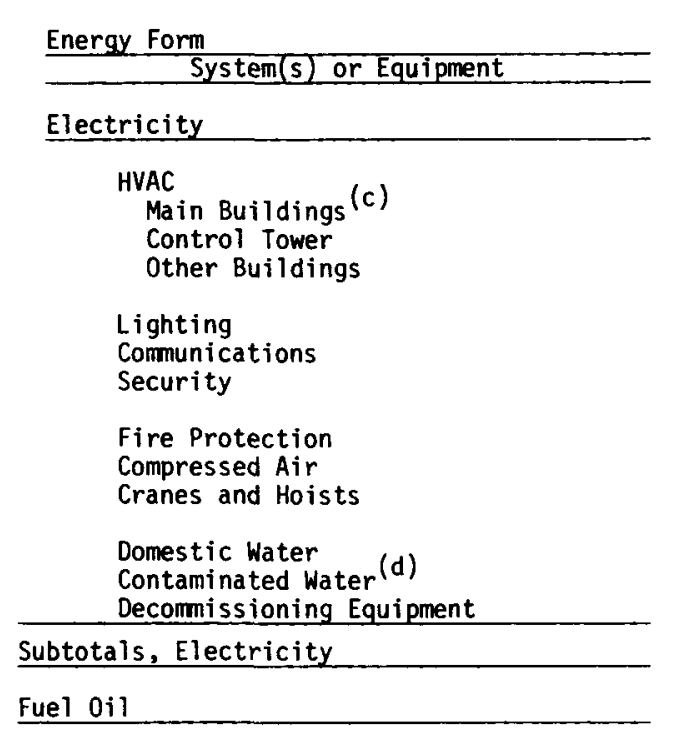

$\begin{aligned} & \text { Building Heating } \\ & \text { Decontamination Solution Concentrator }\end{aligned}$
Subtotals, Fuel 0 il

Total Energy Cost

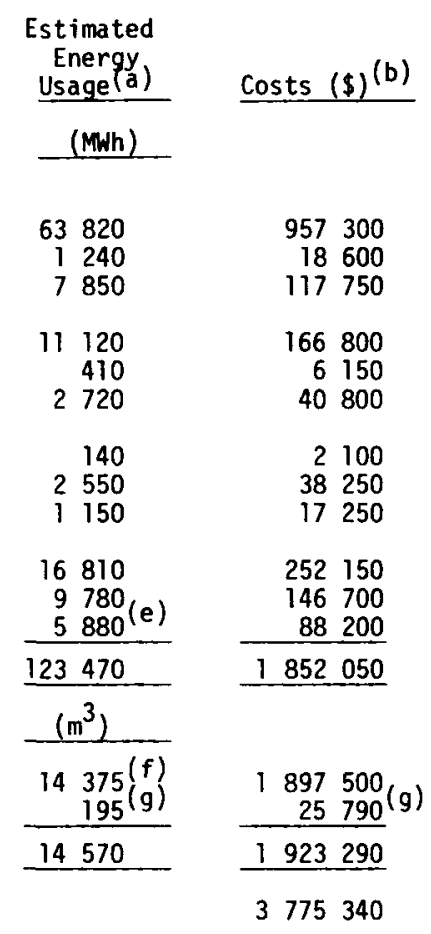

(a)Based on information presented in Table 1.3-8 in Appendix I, with values adjusted as necessary to account for differences between entombment and immediate dismantlement; rounded to the nearest $10 \mathrm{MWh}$ for electricity and to the nearest whole $\mathrm{m}^{3}$ for fuel oil.

(b) Based on Section M. 6 of Appendix M.

(c) Includes the Reactor Building, the Turbine Generator Building, and the radwaste area of the Radwaste and Control Building.

(d) Includes all such systems 1 isted in Appendix $C$ for all anticipated operations; includes appropriate information from Table H.5-9 in Appendix H.

(e)Estimated at approximately $5 \%$ of the total.

(f) Assumes four heating periods during entombment.

(g) From Table H.5-9.

Table I.3-10 in Appendix I for immediate dismantlement. The total estimated cost for miscellaneous supplies during entombment of the reference BWR (either scenario 1 or scenario 2) is about $\$ 2.2$ million, which is about 6 and $7 \%$ of the total entombment cost for the two scenarios, respectively.

\section{K.3.6 Costs for Specialty Contractors}

The estimated costs for specialty contractors are given in Table K.3-7. As discussed in Section $\mathrm{H} .3$ of Appendix $\mathrm{H}$, these specialty contractors perform temporary radwaste handling and environmental monitoring during entombment. The costs for a hauling contractor for disposal of radioactive materials are not shown in this table, but are included in Section K.3.1 as "transportation costs." 
TABLE K.3-7. Costs for Specialty Contractors During Entombment

\begin{tabular}{|c|c|c|}
\hline Specialty Contractor (a) & $\begin{array}{c}\text { Cost Estimating } \\
\text { Basis (\$/unit time) } \\
\end{array}$ & $\begin{array}{l}\text { Estimated } \\
\text { Costs }(\$)(\mathrm{b}) \\
\end{array}$ \\
\hline Temporary Radwaste Handling & $10000 / \mathrm{mo}(\mathrm{c})$ & 22500 \\
\hline Environmental Monitoring & $38500 / y r(d)$ & 149200 \\
\hline ota & & 171700 \\
\hline
\end{tabular}

(a) Does not include the hauling contractor, costs for which are shown as "transportation costs" in Section K.3.1, at a total of about $\$ 1.9$ million.

(b) Rounded to the next highest $\$ 100$.

(c) Based on information shown on page 10-4 of Reference 3 and corroborated with Mr. Ed Brooks of Chem-Nuclear Systems, Inc., Bellevue, Washington.

(d)Based on information presented on page G-37 of Reference 3.

The total cost for specialty contractors during entombment, excluding the hauling contractor, is about $\$ 172,000$, which is less than $1 \%$ of the total cost for either entombment scenario.

\section{K.3.7 Costs for Nuclear Insurance}

The costs for nuclear liability insurance during entombment are assumed to be the same as those estimated for immediate dismantlement, which are presented in Section I.3.7 of Appendix I. The total estimated cost for nuclear insurance is $\$ 800,000$ and represents less than $3 \%$ of the total cost for either entombment scenario.

\section{K.3.8 Costs of Licensing Fees}

The fees charged for licensing services performed by the NRC are delineated in 10 CFR Part 170. (4) The costs of licensing fees during entombment of the reference BWR are shown in Table K.3-8. The total cost for licensing services is $\$ 38,500$, which is approximately $0.1 \%$ of the total cost for either entombment scenario. 
TABLE K.3-8. Costs of Licensing Fees During Entombment ${ }^{(a)}$

\section{Licensing Service Category}

Facility License Amendment (Class IV)

Health, Safety, and Environmental

Inspection

Safeguards Inspection

Total
Fee $(\$)$ Total Costs $(\$)$

12300

$12300^{(b)}$

$\begin{array}{rr}650 / \text { year } & 2600^{(c)} \\ 11800 / \text { year } & 23600^{(d)}\end{array}$

38500

(a) From Reference 4.

(b) Based on one license amendment to obtain a possession-only license prior to entombment.

(c) Based on the time the license is in force (i.e., approximately 4 years for entombment).

(d) Based on having spent fuel on site for 19 months (i.e., two yearly fees charged).

\section{K.3.9 Costs for Continuing Care and Possible Deferred Dismantlement}

As discussed in Section K.1, existing regulations require the licensee to continue surveillance and maintenance of the entombment structure as a nuclear waste repository until such time as the structure is released for unrestricted use. Furthermore, a comprehensive radiation survey is required prior to such release to verify that the radioactive contamination either meets acceptable release limits or is removed from the site.

The costs for continuing care (i.e., maintenance and surveillance) of the entombment structure are assumed to be less than those for continuing care of the reference BWR in passive safe storage (see Section J.5.2. of Appendix J). Based on information presented in Reference 5, the annual continuing care costs are estimated to be about $\$ 40,000$.

While selection of entombment entails a commitment of the site for as long as required for the entombed radioactivity to decay to unrestricted release levels, there may be instances where earlier release of the site becomes imperative and dismantlement of the entombed structure is necessary. Because of the many variables involved, no firm estimate of the costs for possible deferred dismantlement of the entombment structure is made. However, these 
costs are anticipated to be at least of the same order of magnitude as those for deferred dismantlement of the reference BWR after a period of passive safe storage (see Section $\mathrm{J} .7$ of Appendix J). Although deferred dismantlement of the entombment structure involves only a portion of the original plant, the dismantlement of that portion is made more difficult and, consequently, more expensive by the possibility of having to penetrate the strong, durable entombment structure and remove the (more or less) randomly mixed materials inside for a radiation survey. In addition, the materials with radioactive contamination exceeding release limits will require packaging and shipping to an offsite disposal facility.

\section{K.3.10 0ther Possible Costs}

Four additional categories of costs could figure into the total entombment cost, depending on how they are classified. In this study, they are presented separately, since they cannot be clearly.identified as belonging to entombment. The tasks that result in these costs are:

- shipment of the spent reactor fuel to an offsite repository

- demolition of the structures other than the Reactor Building and restoration of the site

- alternative disposal of the highly activated materials in a deep geologic disposal facility

- disposal of the fuel channels.

Discussions of the costs associated with these tasks are presented in the following subsections.

\section{K.3.10.1 Spent Fuel Shipment}

Since the ultimate disposition of the spent reactor fuel is not known, it is assumed in this study that the 764 fuel assemblies from the final reactor core load are shipped by rail, together with their fuel channels, to a repository located $2400 \mathrm{~km}$ from the reference BWR. The resulting costs for entombment are the same as those calculated for immediate dismantlement in Section 1.3.9.1 of Appendix I. 
The total estimated cost for shipping the spent fuel and channels to the assumed repository is about $\$ 3.8 \mathrm{million}$. If special trains are required, the cost is increased by up to about $\$ 2.5 \mathrm{million}$.

\section{K.3.10.2 Facility Demolition and Site Restoration}

The costs for demolishing the decontaminated and uncontaminated structures of the reference BWR are summarized in Table L.3-1 of Appendix $L$ and are not repeated here. The total cost for demolishing all of the site structures is estimated at $\$ 13,244,000$ (without contingency), including labor, supplies, overheads, and profit, but not including extraordinary insurance premiums, bonding, or state sales tax. However, for entombment, the entire Reactor Building is assumed to be left standing as a secondary barrier around the entombed materials (see Section K.1.1). In addition, the Guardhouse is assumed to remain for various possible uses during continuing care. Costs for reducing the size of the exclusion area (relocating fence lines) are assumed to be offset by reduced site restoration costs due to the reduced area requiring restoration. By subtracting the costs for demolishing the Reactor Building and the Guardhouse from the total, the cost for demolition and site restoration after entombment is estimated to be $\$ 8,059,000$. Details of the cost estimates for this task, which is not required by current regulations, are given in Section L. 3 of Appendix $L$.

\section{K.3.10.3 Deep Geologic Disposal of Highly Activated Materials}

The information presented in Table K.3-3 is based on the assumption that all of the neutron-activated components are placed in a shallow-land disposal site. Because of the large initial amount of radioactivity, the long half-lives of ${ }^{59} \mathrm{Ni}$ and ${ }^{94} \mathrm{Nb}$, and the potential biological hazard of ${ }^{14} \mathrm{C}$, it is possible that the highly activated materials may require disposal in a deep geologic disposal facility, similar to the proposed disposal of high-level radioactive wastes and fuel cladding hulls that result from spent fuel reprocessing. An analysis is therefore made to estimate the additional cost of placing the highly activated materials in deep geologic storage rather than in shallow1 and storage. 
The materials possibly requiring deep geologic disposal for scenario-1 entombment are the same as those for immediate dismantlement. From the analys is presented in Section I.3.9.3 of Appendix I, the total cost of placing these materials into deep geologic disposal is $\$ 2,889,390$. Subtracting the total cost for shallow-land disposal of these materials ( $\$ 2,394,150$, from Table K.3-3), the incremental cost for disposing of these materials in deep geologic disposal is $\$ 495,240$ more than the shallow-land burial.

If a special train is required, an additional total estimated cost of $\$ 1,254,000$ is necessary for 22 single-cask shipments (see Section M.4.2). The use of more than one cask per shipment would reduce this cost inversely to the number of casks per shipment, but would not affect the disposal costs presented previously.

\section{K.3.10.4 Fuel Channel Disposal}

The assumption that the fuel channels are shipped and stored with the spent fuel is based on practicality rather than present practice. Presently, this is not a viable option and, therefore, an analysis is performed (in Section I.3.9.4 of Appendix I) to determine the alternative costs for disposing of the fuel channels as activated waste in either a shallow-land disposal facility or a deep geologic disposal facility.

The total cost for shallow-land burial of the fuel channels is estimated to be $\$ 617,140$. Deep geologic disposal is estimated to cost $\$ 1,047,000$, or $\$ 429,860$ more than shallow-land disposal. Shipment of the fuel channels by special train would cost an additional $\$ 456,000$, maximum.

\section{K.4 EXTERNAL OCCUPATIONAL RADIATION DOSE FOR ENTOMBMENT}

Detailed analysis is made of the external occupational radiation dose accumulated by the decommissioning workers during scenario-l entombment of the reference BWR. The analysis is carried out in the same manner as that described for immediate dismantlement (see Section 1.4 of Appendix I). The results of this analysis are presented in Table K.4-1. 
Supervisors (a) Utility Operators

Health Physics
Techniclans Task Totals Corrected

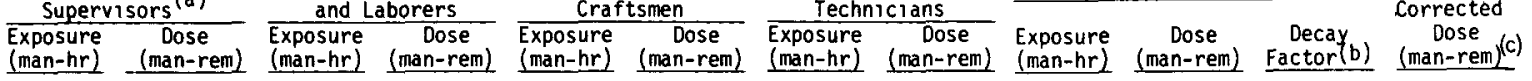

Location

Reactor Bullding/Primary Conta inment

1 Install HEPA Filters

Comprehensive Radiation Survey
Discharge and Ship Fuel

$\begin{array}{ll}* 4 & \text { Remove Dryer and Separator } \\ 5 & \text { Dran Suppression pool to Radwaste, }\end{array}$

Water-Jet Cleanesel Internals
Remove Reactor Vessel

"7 Ship Activated Reactor Vessel Internals Cut Suppression Pool Downcomers and Bracing
Chemical Decon Residual Heat Removal, Low- and High-Pressure Core Spray

10 Drain Contaminated Systems to Radwaste(e) Water-Jet Clean (e)
Clean Up, Stage, and Shield Hot Spots
in Primary Containment

Chemical Decon Reactor Water Recircula-
tion and (leanup Systems(e)

5 Cut Suppress ion Chamber Accesses Through

Chemical Decon Drain Systems $(e)$
Cut Primary Conta inment Piping Penetratons and Seal
cut Orywell Bellows Access Openings

19
Remove Reactor Bullding Piping
20
Dran Spent Fuel Pool to Radwaste,

Chemical Decon Fuel Pool. Cooling and
Cleanup System(e)

Remove L Lners from Spent Fuel Pool and
Dryer and Separator Pool

Remove Reactor Building Equipment
Seal Equipment and Personnel Hatch

Seal Rall Tunnel, Steam Tunnel, and Blological Shield Penetrations
Seal Orwell Top Head and Reactor

Remove HVAC and Disable Crane

Final Radiation Survey
Install Security and Surveillance
Monitoring $\frac{\text { Unnecessary Utilities }}{\text { Subtotals, Reactor Buflding(c,f) }}$ Turbine Generator Building

1 Install HEPA Filters
2 Comprehensive Radiation Survey
3 Clean Up and Stage

$\begin{array}{ll}5 & \text { Remove Turbine } \\ 6 & \text { Remove Piping }\end{array}$

7
8 Remove Condenser
Drain Condenser to Radwaste, Water-Jet Drain (p)denser to Radwaste, wa
Cleane)
Chemical Decon Drain Systems $(e)$

10 Remove Equipment
11 Remove Contaminated Concrete
12 Remove HVAC and Electrical Systems Building $(c, f)$
Bune Generator

Radwaste and Control Bulding

Comprehensive Radiation Survey

General Cleanup
Chemical Decon Drain Systems

4 Chemlca) Decon Equipment, water-Jet

$\begin{array}{ll}5 & \text { Intall Temporary Radwaste System } \\ 6 & \text { Remove Piping }\end{array}$

$\begin{array}{ll}7 & \text { Remove Equipment } \\ 8 & \text { Remove Contamnated Concrete } \\ 9 & \text { Remove Miscellaneous Metal Structures }\end{array}$

10 Remove HVAC and Electrical Systems Final Radiation Survey Subtotals, Re,
Building $(c$, Ancillaries

1 Operate Radwaste Systems $(e)$ Routine Radiation Surveys
Package Dry Solyd Wastes (g) Mrscellaneous $(h)$
Subtotals, Ancillaries(c,e) Totals (c) tion and (leanup Systems (e)
Orain Dryer and Separator Pool to Rad-

Remove Reactor Bullding Contaminated

Drain Contaminated Systems to Rad-
waste, Water-Jet Clean Condensate waste, Hater-Jet Clean Condensate
Storage Tanks

Remove HVAC and Electrical Systems
Final Radiation Survey
Subtotals. Turbine Generator
$400 \quad 0400$

$941 \quad 8469$

$130 \quad 0650$

$\begin{array}{rrr}27 & 0 & 189 \\ 735 & 3 & 675\end{array}$

$1865 \quad 9325$

$79 \quad 3160$

$12 \quad 0360$

$\begin{array}{ccc}12 & 0 & 360 \\ 3 & 0 & 015\end{array}$

$108 \quad 1080$

$4 \quad 0200$

90045

$40 \quad 1600$

-.- -..

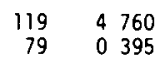

$1370 \quad 27400$

$9 \quad 0045$

20010

$\begin{array}{lll}160 & 0800 \\ 2175 & 4 & 350 \\ 3 & 0\end{array}$

$79 \quad 0395$

$1000 \quad 3000$

$119 \quad 0595$

$59 \quad 0118$

$396 \quad 1188$

$\frac{158}{10078} \frac{0158}{12}$

$1100 \quad 1100$

$-100 \quad 0100$

$\begin{array}{rrr}8 & 008 \\ 407 & 008 \\ 2530 & 15180 \\ 250 & 150\end{array}$

$1651 \quad 1792$

... 10001

\begin{tabular}{rr}
990 & 4950 \\
300 & 0300 \\
53 & $0 \quad 053$ \\
--- & -- \\
\hline
\end{tabular}

$7140 \quad 24$

$\begin{array}{llll}--15 & 0 & 075\end{array}$

$\begin{array}{rrr}45 & 0 & 195 \\ 2 & 0 & 004 \\ 2707 & 13 & 001\end{array}$

$\begin{array}{rrr}3048 & 7621 \\ 144 & 0402 \\ 16 & 0032\end{array}$

$\begin{array}{r}361 \\ \cdots \quad 0900 \\ --. \\ \hline\end{array}$

$\underline{6338} \quad 22$ \begin{tabular}{ll} 
(d) \\
\hdashline-2
\end{tabular}

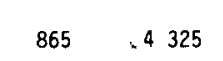

$\begin{array}{r}322 \\ 3293932 \\ \hline\end{array}$

$12432 \quad 62160$

$259 \quad 4403$

$12 \quad 0180$

$720 \quad 7200$

$572 \quad 5148$

$97 \quad 0485$

$264 \quad 26400$

$431 \quad 0431$

$792 \quad 47520$
$\ldots-$

$9150 \quad 183000$

$109 \quad 0545$

$52 \quad 0 \quad 312$

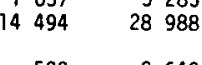

$6764 \quad 20292$

$792 \quad 3960$

$\begin{array}{lll}-.- & ---\end{array}$

$2640 \quad 7920$

$\underline{63024} \quad \underline{529} \quad \frac{1056}{15490} \quad \frac{11056}{189}$

$\begin{array}{llll}\cdots & -- & 7450 & 7450 \\ -- & 0-700 & \cdots & -\cdots\end{array}$

$\begin{array}{rrrr}2 & 51 & 0 & 051 \\ 2 & 5422 & 1 \\ 2 & 484 & 14904 & 14\end{array}$

$11011 \quad 21566 \quad 7755 \quad 86466$

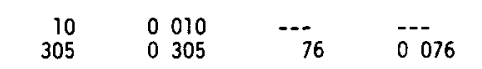

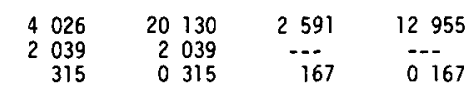

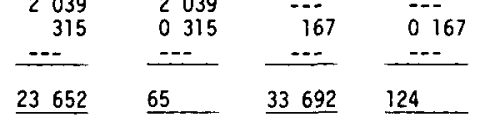

$1056 \quad 42240$

$55 \quad 0275$

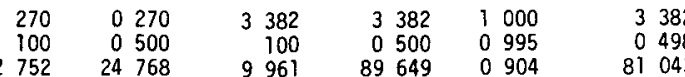

$\begin{array}{lllllll}87 & 0435 & 1627 & 8135 & 0989 & 8046\end{array}$

$\begin{array}{rrrrrrr}27 & 0 & 135 & 403 & 2391 & 0998 & 2338 \\ 490 & 2450 & 6123 & 30615 & 0 & 944 & 28\end{array}$

$\begin{array}{lllllll}1250 & 6250 & 15547 & 77735 & 0896 & 69651\end{array}$

$\begin{array}{llllll}106 & 4240 & 1769 & 70760 & 0947 & 67010\end{array}$

$\begin{array}{lllllll}118 & 3540 & 409 & 9403 & 0954 & 8970\end{array}$

$2 \quad 0030$

$72 \quad 0720$

$36 \quad 1872$

80040

$26 \quad 1300$

-.-

$\begin{array}{lll}79 & 3 & 950 \\ 53 & 0 & 265\end{array}$

$915 \quad 18300$

$9 \quad 0045$

$18 \quad 0 \quad 108$

$106 \quad 0530$
$1450 \quad 2900$

$53 \quad 0265$

$680 \quad 2040$

$79 \quad 0395$

$40 \quad 0080$

$\begin{array}{lll}264 & 0 & 792 \\ 100 & 0 & 100\end{array}$

$\frac{1795}{\underline{919}} \quad \frac{1214}{97787} \quad \frac{1214}{867} \quad 0604 \quad \frac{0733}{738}$

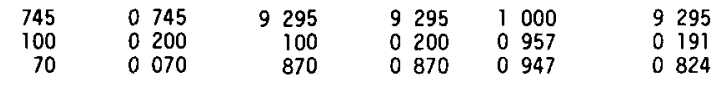

$\begin{array}{rrrrrrr}5 & 0005 & 64 & 0064 & 0926 & 0059 \\ 272 & 0544 & 4632 & 8857 & 0891 & 7892 \\ 1440 & 8640 & 20865 & 125190 & 0848 & 106 \quad 161\end{array}$

$\begin{array}{lllllll}100 & 2154 & 21517 & 40050 & 0848 & 33962\end{array}$

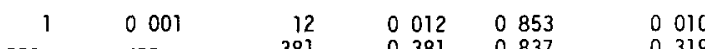

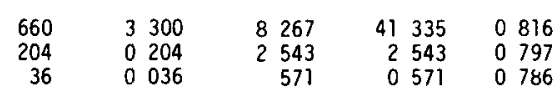

\begin{tabular}{l}
50 \\
$0 \quad 050$ \\
\hline
\end{tabular}

$\lcm{50}$

$\underline{229}$

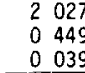

195

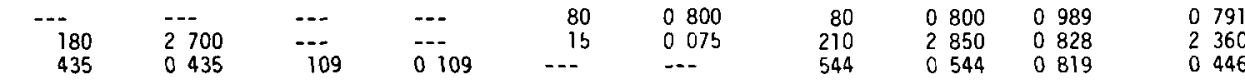

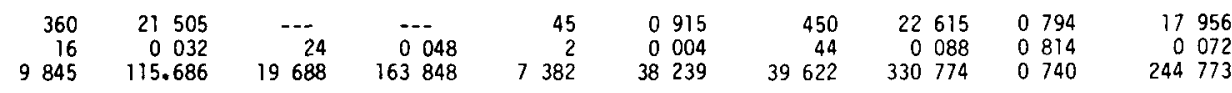

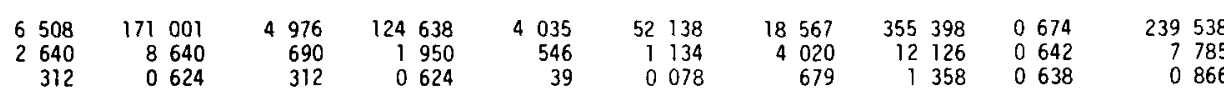

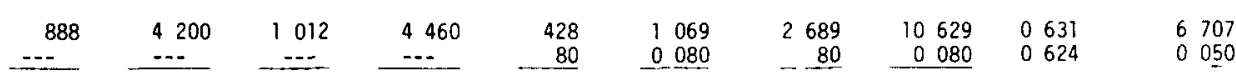

$21184 \quad 525 \quad \underline{26811} \quad \underline{296} \quad \underline{12652} \quad \underline{95} \quad \underline{6695} \quad \underline{737} \quad$ 5<1

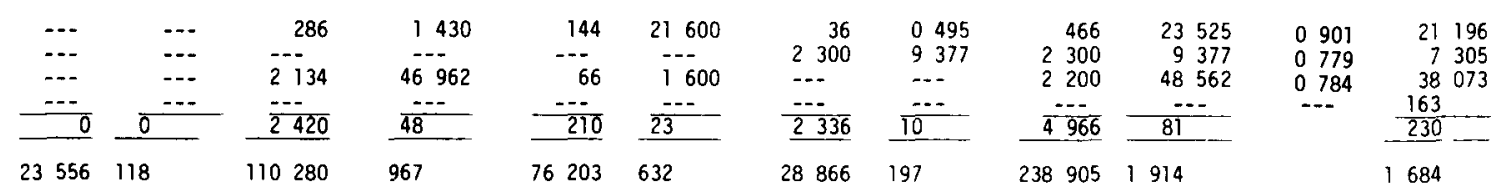

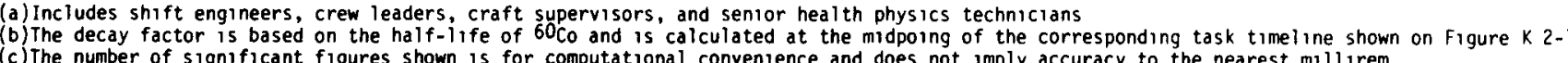

(c) The number of 5 gnif icant figures shown is for computational convenience and does not imply accuracy to the neares
(d) A dash indicates that, for the specified decormissioning task, that particular category of staff is not used

(e)Based on data presented in Table $H$ 5-11 in Appendix

(f) Dose totals are rounded to the nearest man-rem
(g) Assumed to be the same as for tmediate dismantlement

(g) Assumed to be the same as for 1 mediate
(h) Cons ists of an allowance of up to 1 rem per year for selected management and support staff whose radiation doses are not specifically est imated,
together

togetyer with an allowance of $5 \%$ of the total
analyses
These tasks deleted for entombment scenario

$\underset{\dot{\omega}}{\underline{v}}$

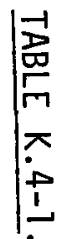

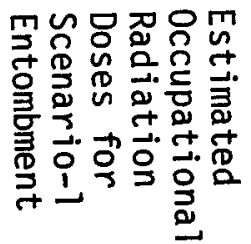


口 
The total corrected external occupational radiation dose for scenario-1 entombment is about 1684 man-rem. For scenario-2 entombment, subtraction of the doses for the deleted tasks results in a total dose of about 1573 man-rem.

Two other tasks not shown in Table K.4-1 provide the potential for external radiation dose and occur as a direct result of entombment: 1) transporting the radioactive materials to the disposal site, and 2) handling these materials at the disposal site. Totals of 985 and 728 shipments of radioactive materials must be transported to, and handled at, the disposal site for scenarios 1 and 2, respectively. The external radiation dose from transportation is discussed in Section N.5 of Appendix N. The external radiation dose from handling these materials at the disposal site is beyond the scope of this study, since it is considered under another nuclear license. 


\section{REFERENCES}

1. U.S. Atomic Energy Commission Regulatory Guide 1.86, Termination of Operating Licenses for Nuclear Reactors, June 1974.

2. WPPSS Nuclear Project No. 2 Final Safety Analysis Report, Washington Public Power Supply System, Richland, WA, March 1977.

3. R. I. Smith, G. J. Konzek and W. E. Kennedy, Jr., Technology, Safety and Costs of Decommissioning a Reference Pressurized water Reactor Power Station, NUREG/CR-0130, U.S. Nuclear Regulatory Commission Report by Pacific Northwest Laboratory, June 1978. *

4. U.S. Code of Federal Regulations, Title 10, Part 170, "Fees for Facilities and Materials Licenses and Other Regulatory Services under the Atomic Energy Act of 1954, As Amended," Superintendent of Documents, GP0, Washington, DC 20555, 1979.

5. R. I. Smith and L. M. Polentz, Technology, Safety and Costs of Decommissioning a Reference Pressurized Water Reactor Power Station, NUREG/CR-0130 Addendum, pp. 4-9 and 4-10, U.S. Nuclear Regulatory Commission Report by Pacific Northwest Laboratory, August 1979. *

6. K. J. Schneider and C. E. Jenkins, Technology, Safety and Costs of Decommissioning a Reference Fuel Reprocessing Plant, NUREG-0278, p. 7-129, U.S. Nuclear Regulatory Commission Report by Pacific Northwest Laboratory, September 1977. **

*Available for purchase from the NRC/GPO Sales Program, U.S. Nuclear Regulatory Commission, Washington, D.C. 20555, and the National Technical Information Service, Springfield, Virginia 22161.

** Available for purchase from the National Technical Information Service, Springfield, Virginia 22161. 
APPENDIX L

DEMOLITION AND SITE RESTORATION DETAILS

Once all radioactive materials in a boiling water reactor (BWR) are removed or decontaminated, the Nuclear Regulatory Commission (NRC) is requested to terminate the possession-only license and release the site for unrestricted use. Following license termination, the utility decides whether the remaining onsite structures are to be demolished or left standing. (Section 4.2 of Volume 1 contains a discussion of some of the considerations in making this decision.) Although NRC has no jurisdiction over removal of noncontaminated structures and restoration of the site, development of demolition and site restoration costs is presented in this appendix for completeness. To ensure realism, a demolition contractor was retained to develop the costs of demolition, just as though he were bidding on the job. (1)

\section{L.1 ASSUMPTIONS FOR DEVELOPMENT OF COST ESTIMATES}

The analyses of the effort and costs involved in demolishing the reference BWR structures and restoring the site are based on the following assumptions:

1. All above-ground structures on the plant site are demolished and removed.

2. Building structures are demolished down to $1 \mathrm{~m}$ below grade; holes are drilled in the sub-basement floors for drainage; the empty below-grade volumes are filled to within $1 \mathrm{~m}$ of the grade level with concrete rubble; and the last meter is backfilled with native topsoil.

3. The demolition contractor has salvage rights, with a resulting fair profit going to the contractor. The total estimated cost reflects this profit where applicable.

4. Excess rubble and other debris is disposed of at a landfill $16 \mathrm{~km}$ from the site. 


\section{L.2 FACTORS CONSIDERED IN ESTIMATION OF DEMOLITION COSTS}

Cost estimates for demolition of the reference BWR plant are influenced by several factors, including demolition methods, problem areas in cost estimation, salvage considerations, disposal of debris, labor rates, and equipment requirements. These factors are discussed in the following subsections.

\section{L.2.1 Demolition Methods}

Removal of site structures is accomplished using conventional demolition methods when possible. However, those buildings designed as Seismic Category I structures are more difficult to demolish than conventional industrial buildings.

In general, building demolition proceeds from the top down after machinery and equipment are removed. Where there is a bridge crane, it is used for moving such things as machinery, equipment, and piping.

The top structure of a steel-capped building is removed by reversing the construction procedure. A hydraulic crane and man-lift cranes, positioned on the floor below the roof, are used to remove the roofing, steel siding, and structural framework.

Heavy equipment needed for demolition of reinforced concrete buildings is hoisted to the top floor of the structure. Typical equipment includes a cable srawler crane, a crawler backhoe with a hydraulic hammer and a hydraulic shear, a track loader, and track drills.

Floor openings are cut, one above another, for dropping rubble from the upper levels to the ground level. Before being pulled down, reinforced concrete columns are weakened at the floor level either by using the hydraulic hammer or by blasting. Exterior walls are pulled in after the wall columns are "softened" and the walls are broken loose from the corners. The walls are then broken up using a wrecking ball on the cable crane. After the concrete is broken away, reinforcing steel (rebar) is cut into pieces about $1.2 \mathrm{~m}$ long using the hydraulic shear. (Cutting the rebar into $1.2-\mathrm{m}$ lengths upgrades it to prepared scrap, thus increasing its salvage value.) Floor slabs are broken 
up using the wrecking bal1. Heavily reinforced, Seismic Category I concrete structures must be drilled and blasted, since a wrecking ball will probably be ineffective. Prior to blasting, a crane is used to place blasting mats and shields.

After most of a floor is demolished, heavy equipment is moved on ramps to the next lower floor. A crane is used to lower smaller equipment from floor to flcs:. The remaining portions of the floor are then removed using the crane and wrecking ball.

\section{L.2.2 Problem Areas in Estimation of Demolition Costs}

No precedent exists for estimating the costs of demolishing the heavily reinforced, massive concrete structures of the reference BWR. The estimates presented in this appendix result from comparisons of the reference BWR structures with industrial-type structures that have been demolished. In addition, judgment factors are applied, based on experience, for the massiveness, grade of concrete, extra-heavy reinforcing steel, and the height of the structures.

An area of concern in estimating demolition costs is the value used for balling and separating the concrete from the rebar, both with and without weakening by explosives. Concrete in the reference BWR structures is high quality, extra thick, well aged, and well bonded to extra-heavy reinforcing steel. Most of the structures also have confining and self-reinforcing cross walls that restrict access and make use of a wrecking ball difficult. Singly, these factors tend to increase demolition costs markedly, and their combination compounds the effect.

\section{L.2.3 Salvage Considerations}

Salvage is ordinarily used in the wrecking industry as a contingency/ profit item to compensate for such inherent risks as unanticipated demolition difficulty, human error, and variation in employee productivity. Where salvage is easily separable from demolition (i.e., substantial mechanical or electrical equipment salvage), it is given separate consideration in estimating costs. The value of structural salvage is generally accounted for by reducing the unit demolition cost rather than by a separate itemized account. The 
costs of handling, loading, and shipping salvaged scrap are deducted from the published market price for scrap steel, with the balance credited to the facility owner. This ensures that the wrecking contractor recovers his costs, including the added expense of preserving the highest salvage value, and that the owner receives a fair allowance for the scrap.

\section{L.2.4 Transport of Demolition Debris}

Loading and hauling demolition debris generally costs more than loading and hauling dirt or gravel. Demolition trucks are not loaded or dumped as fast as dirt and gravel trucks because of their longer, higher-sided trailers and the uneven sizes of the materials they haul. Hauling costs in the wrecking industry reflect these conditions.

\section{L.2.5 Labor Rates}

The cost estimates for the demolition of the reference BWR are based on the labor rates in Seattle, Washington, in January 1978. The labor rates used in this analysis are given in Table L.2-1. The payroll costs include base pay, FICA, unemployment insurance, union contributions, state industrial insurance, property damage insurance, and medical insurance. They do not include overhead or profit. Bodily injury public liability insurance, which was formerly a nominal charge based on payroll, is not included in the payroll costs but is estimated at $9.96 \%$ of gross receipts.

TABLE L.2-1. Labor Rates for Demolition

$\begin{array}{lccc}\text { Occupation } & \text { Base Pay }(\$ / \mathrm{hr}) & \text { Payro11 Cost }(\$ / \mathrm{hr}) \\ \text { Teamsters }\left(38-\mathrm{m}^{3} \text { trucks) }\right. & 11.69 & 16.78 \\ \text { Operating Engineers - Operator } & 11.98 & 17.29 \\ & - \text { Oiler } & 11.19 & 16.34 \\ \text { Laborers } & 9.10 & 14.15\end{array}$




\section{L.2.6 Equipment Requirements for Demolition}

Because of the variety of operations involved in the demolition of the reference BWR, a number of equipment types and sizes are required. Table L.2-2 lists the major equipment items, together with the use and required number of each item.

TABLE L.2-2. Equipment Requirements For Demolition of the Reference BWR

\begin{tabular}{|c|c|c|}
\hline Item & Use & $\begin{array}{c}\text { Number } \\
\text { Required }\end{array}$ \\
\hline 200-Ton Crane & High lifts of heavy loads & 1 \\
\hline 65-Ton Crane & $\begin{array}{l}\text { Lifts and breaking ball for } \\
\text { concrete demolition }\end{array}$ & 1 \\
\hline 45-Ton Crane & $\begin{array}{l}\text { Lifts and breaking ball for } \\
\text { concrete demolition }\end{array}$ & 2 \\
\hline 25-Ton Crane & Lifts of light loads & 2 \\
\hline 50-Ton Hydraulic Crane & Dismantle roof strucutres & 2 \\
\hline 30-Ton Hydraulic Crane & Dismantle roof structures & 2 \\
\hline $1-m^{3}$ Backhoe & Clean up and load debris & 3 \\
\hline 977 Track Loader & Clean up and load debris & 2 \\
\hline Demolition Trailers w/Tractors & Haul debris & 10 \\
\hline Oxyacetylene Cutting Outfits & Cut steel and other metal & 40 \\
\hline Clamshells & Pick up debris & 2 \\
\hline Track Drills & Drill holes for explosives & 4 \\
\hline Air Hammers & Demolish concrete & 2 \\
\hline Hydraul ic Hammers & Demolish concrete & 4 \\
\hline Hydraul ic Shears & Cut rebar to salvage length & 3 \\
\hline Compressors & Power pneumatic tools & As needed \\
\hline Service Truck & Service equipment & 1 \\
\hline Breaking Balls & Demolish concrete & As needed \\
\hline Battering Ram & Demolish concrete walls & 1 \\
\hline Rigging & Move equipment and salvage & As needed \\
\hline
\end{tabular}




\section{L.3 DEMOLITION AND SITE RESTORATION COSTS}

The estimated costs for demolition and site restoration of the reference BWR after decommissioning by immediate dismantlement are summarized in Table L.3-1. These costs include labor, supplies, overhead, and profit. They do not include extraordinary insurance premiums, bonding, or state sales tax. Details of the cost estimates are given in the following subsections.

TABLE L.3-1. Summary of Estimated Costs for Demplition and Site Restoration of the Reference BWR(a)

Activity

Estimated Costs ( $\$$ thousands)

\begin{tabular}{lr} 
Structure Demolition & 5 \\
Reactor Building and Primary Containment Vessel & 3364 \\
Turbine Generator Building & 1923 \\
Radwaste and Control Building & 445 \\
Diesel Generator Building & 130 \\
Service Building & 1252 \\
Cooling Towers & 173 \\
Circulating Water Pumphouse & 282 \\
Spray Pond Complex & 43 \\
Makeup Water Pumphouse & 9 \\
Office Building & 26 \\
Warehouse & 16 \\
Guard House & 2 \\
Gas Bottle Storage Building & 410 \\
Site Restoration & 13244 \\
Subtotal & 3311 \\
Contingency (25\%) & 16555 \\
\hline Total &
\end{tabular}

(a)Estimates given in January 1978 dollars. 


\section{L.3.1 Reactor Building and Primary Containment Vessel}

Before the bridge crane is removed, it is used to remove any equipment and material in the way of the subsequent operations.

Since the biological shield outside the Primary Containment Vessel is integral with the Reactor Building, the two are demolished together. The top ring rebar of the shield is removed first to permit track drills to drill vertically into the shield wall. A triangular drilling pattern is used to optimize blasting efficiency and concrete breakage. After each blast, the rubble is cleaned up, and the rebar is cut up and, where possible, salvaged. A track loader is used to remove the broken concrete.

After they are broken loose from the corners, outside walls are pulled inward onto the working floor. Wall columns are "softened" at floor level with a hydraulic hammer or with small explosive charges, with the walls tied to prevent them from falling outward. Secondary breakage of the concrete is accomplished with a crane and wrecking ball.

The cost breakdown for the demolition of the Reactor Building and Primary Containment Vessel is given in Table L.3-2.

TABLE L.3-2. Estimated Demolition Costs for the Reactor Building and the Primary Containment Vessel

\begin{tabular}{|c|c|c|c|c|}
\hline Material/Activity & Amount & Unit & $\begin{array}{l}\text { Estimated } \\
\text { Unit Cost } \\
\text { (\$/unit) } \\
\end{array}$ & $\begin{array}{l}\text { Estimated Costs } \\
\text { ( } \$ \text { thousands) }\end{array}$ \\
\hline Structural Steel/Removal & 1699 & Mg & 151.38 & 257 \\
\hline \multicolumn{5}{|l|}{ Reinforced Concrete/ } \\
\hline Drilling and Blasting & 31368 & $\mathrm{~m}^{3}$ & 81.60 & 2560 \\
\hline $\begin{array}{l}\text { Secondary Breaking and Rubble } \\
\text { Cleanup }\end{array}$ & 31368 & $\mathrm{~m}^{3}$ & 48.00 & 1506 \\
\hline Loading, Hauling, and Disposal & 31368 & $\mathrm{~m}^{3}$ & 18.00 & 565 \\
\hline Primary Containment Vessel/Removal & 1854 & $\mathrm{Mg}$ & 151.38 & 281 \\
\hline Total & & & & 5169 \\
\hline
\end{tabular}




\section{L.3.2 Turbine Generator Building}

Although the Turbine Generator Building is not as tall or massive as the Reactor Building, it is considerably heavier and stronger than most industrial structures. Demolition methods used for this building are similar to those for the Reactor Building, described previously.

The cost breakdown for the demolition of the Turbine Generator Building is given in Table L.3-3.

TABLE L.3-3. Estimated Demolition Costs for the Turbine Generator Building

\begin{tabular}{|c|c|c|c|c|}
\hline Material/Activity & Amount & Unit & $\begin{array}{l}\text { Estimated } \\
\text { Unit Cost } \\
\text { (\$/unit) }\end{array}$ & $\begin{array}{l}\text { Estimated Costs } \\
\text { (\$thousands) }\end{array}$ \\
\hline Structural Steel/Removal & 12580 & $m^{2}$ & 29.63 & 373 \\
\hline Reinforced Concrete Above Grade/ & 31732 & $\mathrm{~m}^{3}$ & 360 & 121 \\
\hline $\begin{array}{l}\text { Secondary Breaking and Rubble } \\
\text { Cleanup }\end{array}$ & 31132 & $m^{3}$ & 36.00 & 1121 \\
\hline Loading, Hauling, and Disposal & 31132 & $m^{3}$ & 18.00 & 560 \\
\hline $\begin{array}{l}\text { Reinforced Concrete Below Grade/ } \\
\text { Drilling and Blasting } \\
\text { Secondary Breaking, Rubble }\end{array}$ & 3490 & $m^{3}$ & 24.00 & 84 \\
\hline Cleanup, Loading, and Hauling & 3490 & $m^{3}$ & 30.00 & 105 \\
\hline tal & & & & 364 \\
\hline
\end{tabular}

\section{L.3.3 Radwaste and Control Building}

Procedures for demolishing the Radwaste and Control Building are similar to those used for the Reactor Building. Since the closely spaced, selfreinforcing cross walls are particularly difficult to demolish with a crane and wrecking bal1, blasting (using track drills to drill down into the walls) is the most effective way of removing them.

The demolition cost breakdown for this building is given in Table L.3-4. 
TABLE L.3-4. Estimated Demolition costs for the Radwaste and Control Building

\begin{tabular}{|c|c|c|c|c|}
\hline Material/Activity & Amount & Unit & $\begin{array}{l}\text { Estimated } \\
\text { Unit cost } \\
\text { (\$/unit) }\end{array}$ & $\begin{array}{l}\text { Estimated Costs } \\
\text { (\$ thousands) }\end{array}$ \\
\hline Structural Steel/Removal & 6170 & $m^{2}$ & 29.63 & 183 \\
\hline \multicolumn{5}{|l|}{ Reinforced Concrete/ } \\
\hline Drilling and Blasting & 19340 & $m^{3}$ & 36.00 & 696 \\
\hline $\begin{array}{l}\text { Secondary Breaking and Rubble } \\
\text { Cleanup }\end{array}$ & 19340 & $\mathrm{~m}^{3}$ & 36.00 & 696 \\
\hline Loading, Hauling, and Disposal & 19340 & $\mathrm{~m}^{3}$ & 18.00 & 348 \\
\hline Total & & & & 1923 \\
\hline
\end{tabular}

\section{L.3.4 Diesel Generator Building}

The Diesel Generator Building is a Seismic Category I structure of reinforced concrete and, thus, is difficult and expensive to demolish. Its demolition cost breakdown is given in Table L.3-5.

TABLE L.3-5. Estimated Demolition Costs for the Diesel Generator Building

\begin{tabular}{|c|c|c|c|c|}
\hline Activity & Amount & Unit & $\begin{array}{c}\text { Estimated } \\
\text { Unit cost } \\
\text { (\$/unit) }\end{array}$ & $\begin{array}{l}\text { Estimated Costs } \\
\text { (\$ thousands) }\end{array}$ \\
\hline Drilling and Blasting & 3016 & $m^{3}$ & 81.60 & 246 \\
\hline $\begin{array}{l}\text { Secondary Breaking and Rubble } \\
\text { Cleanup }\end{array}$ & 3016 & $m^{3}$ & 48.00 & 145 \\
\hline Loading, Hauling, and Disposal & 3016 & $\mathrm{~m}^{3}$ & 18.00 & 54 \\
\hline Total & & & & 945 \\
\hline
\end{tabular}

\section{L.3.5 Service Building}

The exterior above-grade walls of the Service Building are made of precast concrete panels. Below-grade construction is of reinforced concrete. Structural steel supports the second floor, and interior walls are largely of steel-studded drywa11 construction. Costs for Service Building demolition are given in Table L.3-6. 
TABLE L.3-6. Estimated Demolition Costs for the Service Building

\begin{tabular}{|c|c|c|c|c|}
\hline Material & Amount & Unit & $\begin{array}{l}\text { Estimated } \\
\text { Unit Cost } \\
\text { (\$/unit) } \\
\end{array}$ & $\begin{array}{l}\text { Estimated Costs } \\
\text { ( } \$ \text { thousands) }\end{array}$ \\
\hline Stee 1 & 395 & $\mathrm{Mg}$ & 50.46 & 20 \\
\hline Concrete & 1838 & $m^{3}$ & 60.00 & 110 \\
\hline Total & & & & 130 \\
\hline
\end{tabular}

\section{L.3.6 Cooling Towers}

The six cooling towers are concrete structures set on cast-in-place reinforced concrete basins. The estimated costs for demolishing the towers and basins are given in Table L.3-7.

TABLE L.3-7. Estimated Demolition Costs for the Cooling Towers

\begin{tabular}{|c|c|c|c|c|}
\hline Material & Amount & Unit & $\begin{array}{l}\text { Estimated } \\
\text { Unit Cost } \\
\text { (\$/unit) } \\
\end{array}$ & $\begin{array}{l}\text { Estimated Costs } \\
\text { (\$ thousands) } \\
\end{array}$ \\
\hline $\begin{array}{l}\text { oncrete and Cement Asbestos } \\
\text { Board in Towers }\end{array}$ & 16818 & $m^{3}$ & 60.00 & 1009 \\
\hline Reinforced Concrete in Basins & 4050 & $\mathrm{~m}^{3}$ & 60.00 & 243 \\
\hline tal & & & & 1252 \\
\hline
\end{tabular}

\section{L.3.7 Circulating Water Pumphouse}

This reinforced concrete building with steel superstructure is demolished by conventional means. The cost breakdown for its demolition and removal is shown in Table L.3-8.

TABLE L.3-8. Estimated Demolition Costs for the Circulating Water Pumphouse

\begin{tabular}{|c|c|c|c|c|}
\hline Material & Amount & Unit & $\begin{array}{l}\text { Estimated } \\
\text { Unit Cost } \\
\text { (\$/unit) } \\
\end{array}$ & $\begin{array}{l}\text { Estimated Costs } \\
\text { (\$ thousands) }\end{array}$ \\
\hline Steel Superstructure & 112 & $\mathrm{Mg}$ & 151.38 & 17 \\
\hline Reinforced Concrete & 2593 & $m^{3}$ & 60.00 & 156 \\
\hline Total & & & & 173 \\
\hline
\end{tabular}




\section{L.3.8 Spray Pond Complex}

The two spray ponds and two Standby Service Water Pumphouses are Seismic Category I structures. A crane with wrecking ball is used to demolish these structures at an estimated unit cost of $\$ 60.00 / \mathrm{m}^{3}$. Thus, for $4,700 \mathrm{~m}^{3}$ of material, the total cost is $\$ 282,000$.

\section{L.3.9 Makeup Water Pumphouse}

This reinforced concrete structure is demolished with a crane and wrecking bal1. The estimated unit cost for demolition and removal is $\$ 60.00 / \mathrm{m}^{3}$. A total of $718 \mathrm{~m}^{3}$ of concrete is involved, resulting in a total cost of $\$ 43,000$.

\section{L.3.10 Office Building}

The $600-m^{2}$ steel-framed and -sided office Building is demolished by conventional means, and the floor slab is broken up using a crane with wrecking ba11. The estimated unit demolition cost is $\$ 14.68 / \mathrm{m}^{2}$ of floor area, for a tota 1 cost of $\$ 9,000$.

\section{L.3.11 Warehouse}

This $1,800-\mathrm{m}^{2}$ building is similar in construction to the Office Building. Using an estimated unit demolition cost of $\$ 14.68 / \mathrm{m}^{2}$, the total demolition cost is $\$ 26,000$.

\section{L.3.12 Guard House}

The reinforced-concrete Guard House is demolished with a crane and wrecking bal1, at an estimated unit cost of $\$ 60.00 / \mathrm{m}^{3}$. The building contains $265 \mathrm{~m}^{3}$ of concrete, resulting in a total demolition cost of $\$ 16,000$.

\section{L.3.13 Gas Bottle Storage Building}

The estimated unit cost to demolish and remove the $88-\mathrm{m}^{2}$ precast concrete Gas Bottle Storage Building is $\$ 24.77 / \mathrm{m}^{2}$ of floor area. Thus, the total removal cost is $\$ 2,000$.

\section{L.3.14 Site Restoration}

All of the subgrade portions of the reference BWR buildings are backfilled. Concrete rubble from the demolition of the structures is used as 
necessary to backfill up to a level $1 \mathrm{~m}$ below grade. To restore the site, the top meter is backfilled with native topsoil and seeded with native ground cover; costs are given in Table L.3-9.

\section{TABLE L.3-9. Estimated Site Restoration Costs}

\begin{tabular}{|c|c|c|c|}
\hline Activity & $\begin{array}{c}\text { Material } \\
\text { Required }\left(\mathrm{m}^{3}\right)\end{array}$ & $\begin{array}{l}\text { Unit Cost } \\
\left(\$ / \mathrm{m}^{3}\right) \\
\end{array}$ & $\begin{array}{c}\text { Cost } \\
(\$ \text { thousands) }\end{array}$ \\
\hline Loading and Hauling & 43320 & 7.52 & 326 \\
\hline $\begin{array}{l}\text { Placing, Grading, } \\
\text { and Seeding }\end{array}$ & 43320 & 1.94 & 84 \\
\hline Total & & & 410 \\
\hline
\end{tabular}

\section{L.4 AREAS FOR POTENTIAL COST REDUCTION}

Adoption of innovative demolition procedures can lead to significant cost reductions. Two options for potential cost reduction are discussed below.

\section{L.4.1 Crushing of Concrete}

Substantial savings on hauling costs could be made by the use of a portable rock-crushing plant to crush the concrete. Such a crusher could handle pieces up to $0.9 \mathrm{~m}$ square, provided that the rebar is less than $1.2 \mathrm{~m}$ long. The cost of crushing the concrete (as of December 1978) is quoted at $\$ 5.20$ to $\$ 6.50$ per $\mathrm{m}^{3}$, stockpile measure. This cost could be partially offset by selling or using the crushed material. An appropriate use is backfilling the below-grade portions of the buildings. If crushed concrete is used on the site, a net savings of about $\$ 6 / \mathrm{m}^{3}$ of the normal disposal costs would be realized.

\section{L.4.2 Degradation of Concrete by Heating}

An innovative method for removing the concrete in the Primary Containment Vessel is heating the concrete to the temperature $\left(650\right.$ to $\left.800^{\circ} \mathrm{C}\right)$ at which it degrades to a loose, crumbly material. The Primary Containment Vessel lends itself to this treatment, since it resembles a large furnace. However, this is an untried method and its feasibility would have to be verified on a small scale before being used on a large structure. 
The exhaust from large portable oil or gas burners could be directed into the Primary Containment Vessel through its lower penetrations. The degraded concrete could be shaken off the reinforcing skeleton with little effort. The difference in thermal expansion of steel and concrete should result in the reinforcing steel being virtually free of concrete, thus allowing the salvage of nearly $100 \%$ of the reinforcing steel.

The cost of removing the concrete by this method is estimated at about $\$ 12$ to $\$ 24$ per $\mathrm{m}^{3}$, compared to the $\$ 140-$ per $-\mathrm{m}^{3}$ cost of drilling, blasting, and secondary breaking used in the cost estimate for the Reactor Building. 
REFERENCES

1. J. M. McFarland, Report on Representative Cost Estimates for Demolition of Structures at a Boiling Water Reactor Site, PNL-3053, Prepared for Pacific Northwest Laboratory by McFarland Wrecking Corporation, Seattle, WA 98108, February 1979. 


\section{APPENDIX M}

\section{COST ESTIMATING BASES}

The cost information developed in this study is based on unit cost data presented in this appendix. Categories for which basic cost data are given include: salaries, waste packaging, cask rental, transport, waste disposal, special equipment, and services and supplies. The data presented are all late 1977 or early 1978 costs.

The unit cost data presented can be used to develop cost estimates for other decommissioning projects. However, to ensure the applicability of the estimate to any specific situation, the data should be carefully examined and adjusted as necessary.

\section{1 MANPOWER COSTS}

Salary data for typical decommissioning staff positions are given in Table M.1-1. The original 1975 data base has been adjusted by a factor of 1.29, based on the Handy-Whitman Index, to account for escalation between 1975 and 1978. (1)

\section{M.2 RADIOACTIVE WASTE PACKAGING COSTS}

The costs of packaging radioactive waste materials for disposal at a shallow-land burial site include the shipping container cost, the cost of any additional shielding, and, in the case of concentrator bottoms or ion-exchange resins, the cost of a solidifying agent. These costs are discussed in the following subsections.

\section{M.2.1 Shipping Container Costs}

The shipping containers assumed to be used for packaging radioactive waste materials for disposal are listed in Table M.2-1. A brief description, together with the displaced burial volume, the particular application, and the unit cost, is included for each type of container. 
TABLE M.1-1. Decommissioning Staff Salary Data (a)

\begin{tabular}{|c|c|c|c|c|}
\hline Position & $\begin{array}{l}\text { Base Pay } \\
(\$ / y r) \\
\end{array}$ & $\begin{array}{l}\text { Assumed } \\
\text { Overhead } \\
\text { Rate (\%) }\end{array}$ & $\begin{array}{c}\text { Cost } \\
(\$ / y r) \\
\end{array}$ & Refere \\
\hline \multicolumn{5}{|l|}{ Management and Support Staff } \\
\hline $\begin{array}{l}\text { Decommissioning Superintendent } \\
\text { Secretary } \\
\text { Clerk }\end{array}$ & $\begin{array}{ll}43 & 800 \\
13 & 500 \\
13 & 500\end{array}$ & $\begin{array}{l}70 \\
50 \\
50\end{array}$ & $\begin{array}{ll}74 & 500 \\
20 & 300 \\
20 & 300\end{array}$ & $\begin{array}{l}2 \\
3 \\
3\end{array}$ \\
\hline $\begin{array}{l}\text { Decommissioning Engineer } \\
\text { Assistant Decommissioning }\end{array}$ & 37400 & 70 & 63500 & 2 \\
\hline $\begin{array}{l}\text { Engineer } \\
\text { Radioactive Shipment Specialist }\end{array}$ & $\begin{array}{l}25800 \\
19300\end{array}$ & $\begin{array}{l}70 \\
70\end{array}$ & $\begin{array}{l}43800 \\
32900\end{array}$ & $\begin{array}{l}2 \\
3\end{array}$ \\
\hline $\begin{array}{l}\text { Procurement Special ist } \\
\text { Tool Crib Attendent } \\
\text { Control Room Operator }\end{array}$ & $\begin{array}{ll}18 & 000 \\
15 & 500 \\
19 & 300\end{array}$ & $\begin{array}{l}70 \\
50 \\
50\end{array}$ & $\begin{array}{ll}30 & 700 \\
23 & 200 \\
29 & 000\end{array}$ & $\begin{array}{c}3 \\
4 \\
\text { (b) }\end{array}$ \\
\hline \multirow{2}{*}{$\begin{array}{l}\text { Security Supervisor } \\
\text { Security Shift Supervisor } \\
\text { Security Patrolman } \\
\text { Contracts and Accounting } \\
\text { Specialist }\end{array}$} & $\begin{array}{ll}19 & 300 \\
18 & 000 \\
14 & 200\end{array}$ & $\begin{array}{l}70 \\
70 \\
50\end{array}$ & $\begin{array}{l}32900 \\
30700 \\
21300\end{array}$ & $\begin{array}{c}3 \\
(b) \\
5\end{array}$ \\
\hline & 22600 & 70 & 38400 & 2 \\
\hline $\begin{array}{l}\text { Health and Safety Supervisor } \\
\text { Health Physicist } \\
\text { Protective Equipment Attendent } \\
\text { Industrial Safety Specialist }\end{array}$ & $\begin{array}{ll}29 & 600 \\
23 & 200 \\
15 & 500 \\
25 & 800\end{array}$ & $\begin{array}{l}70 \\
70 \\
50 \\
70\end{array}$ & $\begin{array}{ll}50 & 400 \\
39 & 400 \\
23 & 200 \\
43 & 800\end{array}$ & $\begin{array}{l}3 \\
3 \\
3 \\
3\end{array}$ \\
\hline $\begin{array}{l}\text { Quality Assurance Supervisor } \\
\text { Qual ity Assurance Engineer } \\
\text { Quality Assurance Technician } \\
\text { Consultant (Safety Review) }\end{array}$ & $\begin{array}{ll}25 & 800 \\
23 & 200 \\
15 & 500 \\
67 & 000\end{array}$ & $\begin{array}{r}70 \\
70 \\
50 \\
0\end{array}$ & $\begin{array}{ll}43 & 800 \\
39 & 400 \\
23 & 200 \\
67 & 000\end{array}$ & 3 \\
\hline
\end{tabular}

Decommissioning Workers

Shift Engineer

Crew Leader

Utility Operator

Laborer

Craft Supervisor

Craftsman

Sr. Health Physics Technician

Health Physics Technician
25800

21900

18000

17300

23200

18000

19300

16800
70

70

50

50

70

50

70

50
43800

37300

(b)

27100

25900

$39^{\circ} 400$

27100

32900

25100
2

3

2

2

3

(b)

3

5

2

3

3

3

(a)Adjusted to January 1978.

(b) Study estimate. 
TABLE M.2-1. Shipping Containers for Packaging Radioactive Materials

\begin{tabular}{|c|c|c|c|}
\hline Description & $\begin{array}{c}\text { Burial } \\
\text { Volume }\left(m^{3}\right)\end{array}$ & Application & $\begin{array}{c}\text { Estimated } \\
\text { Unit Cost }(\$)\end{array}$ \\
\hline 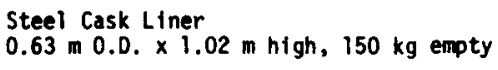 & 0.33 & $\begin{array}{l}\text { Shallow-Land Burial of Activated } \\
\text { Reactor Components }\end{array}$ & 450 \\
\hline $\begin{array}{l}\text { Steel Box } \\
\text { Specially Fabricated }\end{array}$ & Variable & $\begin{array}{l}\text { Shallow-Land Burial of Large or Odd-Shaped } \\
\text { Activated Reactor Components }\end{array}$ & 6000 \\
\hline $\begin{array}{l}\text { Fiberglassed Plywood Box } \\
1.2 \mathrm{~m} \times 1.2 \mathrm{~m} \times 2.4 \mathrm{~m}, 175 \mathrm{~kg} \text { empty }\end{array}$ & 3.64 & $\begin{array}{l}\text { Low Specific Activity Materials } \\
\text { Plping, Concrete, Contaminated Components }\end{array}$ & 400 \\
\hline $\begin{array}{l}\text { Fiberglassed Plymood Box } \\
\text { Specially Fabricated }\end{array}$ & Variable & $\begin{array}{l}\text { Low Specific Activity Material, } \\
\text { Over-Sized or Extra Heavy }\end{array}$ & $\begin{array}{l}\sim 28 / m^{2} \\
\text { of surface }\end{array}$ \\
\hline $\begin{array}{l}\text { Steel Cask Liner } \\
1.38 \mathrm{~m} 0.0 . \times 1.9 \mathrm{~m} \mathrm{high,} 680 \mathrm{~kg} \text { empty }\end{array}$ & 2.84 & Solidffied Wet Solid Wastes & 550 \\
\hline $\begin{array}{l}\text { Standard Steel Drum } \\
0.21 \mathrm{~m}^{3}, 23 \mathrm{~kg} \text { empty }\end{array}$ & 0.21 & Compacted Dry Solid Wastes & 20 \\
\hline $\begin{array}{l}\text { Stainless Steel Canister } \\
0.76 \mathrm{~m} 0 . \mathrm{D} . \times 3.05 \mathrm{~m} \text { high }\end{array}$ & 1.38 & $\begin{array}{l}\text { Alternate Deep Geologic Disposal of Highly } \\
\text { Activated Reactor Components }\end{array}$ & 5000 \\
\hline
\end{tabular}

(a) Adjusted to eariy 1978.

\section{M.2.2 Additional Shielding Costs}

In some cases, additional lead shielding must be added to shipping containers to reduce surface radiation dose rates. The addition of this shielding is estimated to cost an average of $\$ 1.23 / \mathrm{kg}$, including labor and energy.

\section{M.2.3 Solidifying Agent Costs}

In this study, it is assumed that all concentrator bottoms, neutralized drain-decontamination solutions, and ion-exchange resins are mixed with a solidifying agent and poured into steel cask liners. The assumed solidifying agent is cement blended with varying amounts of sodium silicate and proprietary leach inhibitors. The agent is added at the rate of $978 \mathrm{~kg} / \mathrm{m}^{3}$ of concentrator bottoms or neutralized drain-decontamination solutions and $498 \mathrm{~kg} / \mathrm{m}^{3}$ of resin. The cost of this solidifying agent per container ( $22.3-\mathrm{m}^{3}$ capacity) is estimated at $\$ 214$ for concentrator bottoms or neutralized drain solutions and $\$ 129$ for resin.

\section{3 CASK CHARGES}

Some of the waste material shipped to a burial site is sufficiently radioactive to require transport in reusable shielded casks. In general, it is more economical to rent such casks than to purchase them, especially the larger ones. The casks assumed in this study for use in shipping highiy radioactive materials are listed in Table M.3-1, together with physical characteristics and estimated rental charges. 
TABLE M.3-1. Shielded Casks for Shipment of Radioactive Materials

\begin{tabular}{|c|c|c|c|}
\hline Description & Tare $(\mathrm{kg})$ & Application & $\begin{array}{l}\text { Daily } \\
\text { Rental }(\$)^{(a)}\end{array}$ \\
\hline $\begin{array}{l}1.24 \mathrm{~m} 0.0 . \times 1.56 \mathrm{~m} \text { high } \\
150-\mathrm{mm} \text { Pb thickness (B3 Cask) }\end{array}$ & 9300 & Activated Components & 100 \\
\hline $\begin{array}{l}\text { NAC-1 Spent Fuel Cask } \\
\text { (Nuclear Assurance Corp.) }\end{array}$ & 22000 & Activated Control Rods & 690 \\
\hline $\begin{array}{l}1.63 \mathrm{~m} 0.0 . \times 2.34 \mathrm{~m} \text { high } \\
100-\mathrm{mm} \mathrm{Pb} \text { thickness }\end{array}$ & 16330 & Solidified Wet Solid Wastes & 100 \\
\hline $\begin{array}{l}1.95 \mathrm{~m} \mathrm{O} 0 . \mathrm{D} . \times 1.04 \mathrm{~m} \text { high } \\
50-\mathrm{mm} \mathrm{Pb} \text { thickness }(7 \mathrm{D}-3 \mathrm{~L} \text { Cask) }\end{array}$ & 7000 & $\begin{array}{l}\text { Compacted Dry Solid Wastes (maximum seven } 0.21-\mathrm{m}^{3} \\
\text { drums/cask) }\end{array}$ & 100 \\
\hline $\begin{array}{l}\text { IF-300 Spent Fuel Cask } \\
\text { (General Electric Co.) }\end{array}$ & 120000 & $\begin{array}{l}\text { Spent Fuel to Repository; Mighly Activated } \\
\text { Components to Geologic Disposal (Al ternate) }\end{array}$ & $\begin{array}{l}3500 \\
\text { (30-day } \\
\text { minimum) }\end{array}$ \\
\hline
\end{tabular}

\section{M.4 TRANSPORTATION COSTS}

Most radioactive materials resulting from decommissioning are assumed to be shipped to a burial site in exclusive-use trucks. The exceptions, both assuming rail transport, are spent fuel shipments and the alternative case where highly activated reactor components are postulated to be shipped to deep geologic disposal. The shipping costs for both truck and rail transport are discussed in the following subsections.

\section{M.4.1 Shipment by Exclusive-Use Trucks}

Transport of radioactive waste materials from the BWR to a shallow-land burial site is assumed to be by truck. A rate schedule for legal-size and -weight shipments is shown in Table M.4-1, forming the basis for transportation costs used in this study. The table is reproduced from the published rates of a carrier licensed to transport radioactive materials. ${ }^{(6)}$

The gross vehicle weight (GVW) for normal shipments by truck is assumed to be less than $20.41 \mathrm{Mg}$. A 1600-km (1000-mi) round-trip distance is assumed. Thus, from the table, shipping charges are $\$ 0.64 / \mathrm{km}(\$ 1.03 / \mathrm{mi})$, for a total round-trip cost of $\$ 1030$.

The maximum allowed GVW without special equipment and special permission varies from state to state, ranging from 30.21 to $45.36 \mathrm{Mg}$, with the majority of states having limits in the vicinity of $33.11 \mathrm{Mg}$. Overweight charges

by states also vary widely. ${ }^{(6)}$ For this study, a maximum allowed GVW of $33.11 \mathrm{Mg}$ 
TABLE M.4-1. Transportation Rates for Legal-Size and -Weight Truck Shipments (effective April 1, 1978)

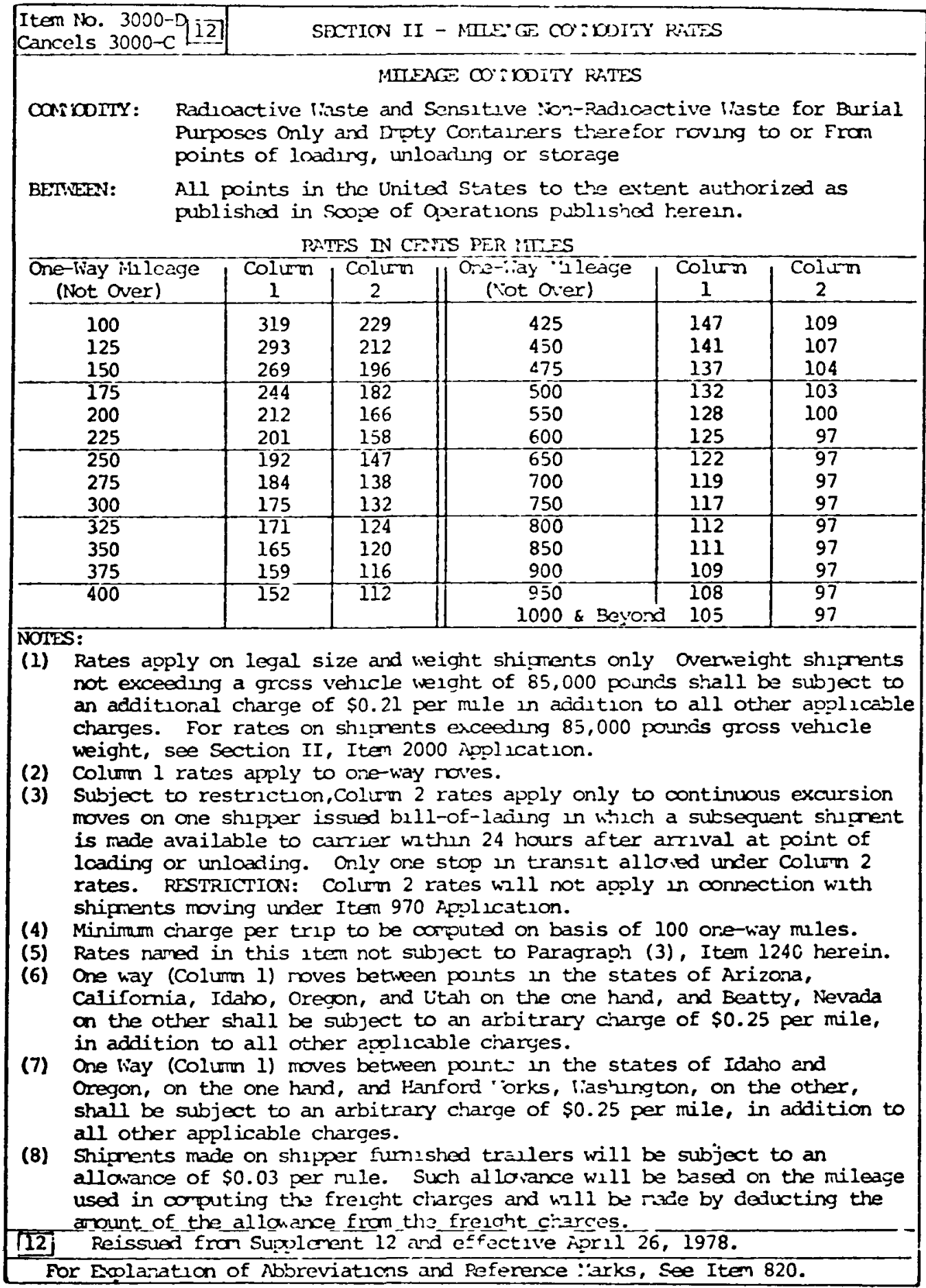


for normal shipments and the overweight charges for the state of Washington are assumed to apply (the rates for Washington state are the highest). These overweight charges are shown in Table M.4-2. An additional surcharge of $\$ 0.126$ per $\mathrm{km}$ is imposed by the carrier for shipments with GVW greater than $20.41 \mathrm{Mg}$. Shipments in excess of $33.11 \mathrm{Mg}$ GVW require special equipment and special permission. Carrier charges for these cases must be determined on a case-by-case basis.

For this study, the GVW of an unloaded exclusive-use van or tractortrailer is assumed to be $12.70 \mathrm{Mg}$. Therefore, the payload per shipment is $7.71 \mathrm{Mg}$ legal weight and $20.41 \mathrm{Mg}$ overweight.

To ensure rapid turnaround on cask shipments, a second driver is required, costing an additional $\$ 0.093 / \mathrm{km}(\$ 0.15 / \mathrm{mi}) .{ }^{(6)}$ This adds $\$ 150$ (round-trip) to the cost of each of these shipments.

TABLE M.4-2. Additional Charges when Gross Vehicle Weight Exceeds $20.41 \mathrm{Mg}(a, b)$

$\begin{array}{ccc}\text { GVW (Mg) } & \text { Charge }(\$ / \\ 20.41 \text { to } 23.13 & & 0.047 \\ 23.14 \text { to } 25.85 & & 0.093 \\ 25.86 \text { to } 28.57 & 0.140 \\ 28.58 \text { to } 31.29 & 0.233 \\ 31.30 \text { to } 34.01 & 0.326 \\ 34.02 \text { to } 36.73 & 0.420 \\ 36.74 \text { to } 47.85(\mathrm{c}) & 0.513\end{array}$

(a) In addition to the charges shown in the table, a flat charge of $\$ 5.00$ is levied.

(b) From Reference 6, for the state of Washington.

(c) Maximum GVW under any circumstances, from Reference 7 , for the state of Washington. 
In this study, the moisture separator reheaters are assumed to be segmented, their ends capped, and the segments shipped as oversize (as well as overweight) shipments. Regulations and conditions governing oversize shipments in the state of Washington are assumed. (7) Table M.4-3 summarizes the applicable requirements for oversize shipments on two-lane highways. The oversize shipments assumed in this study are estimated to cost $\$ 500 /$ shipment more than legal-size shipments of the same weight. This additional cost covers the expense of special permits and escort cars.

The base shipping costs assumed in this study for truck transport are summarized in Table M.4-4.

TABLE M.4-3. Requirements for Oversize Truck Shipments $(a)$

Characteristic Dimension of Vehicle/ Load Combination

Width

Height Length Special Permit
Required in Required in Excess of: $2.44 \mathrm{~m}(8 \mathrm{ft})$

$4.11 \mathrm{~m}(13.5 \mathrm{ft})$ $19.81 \mathrm{~m}(65 \mathrm{ft})$

\begin{tabular}{l} 
Escort Car \\
Required in \\
Excess of: \\
\hline
\end{tabular}

$3.05 \mathrm{~m}(10 \mathrm{ft})$

ft) $30.48 \mathrm{~m}(100 \mathrm{ft})$
Maximum Allowed Dimensions

$4.27 \mathrm{~m}(14 \mathrm{ft})$

$\ldots(b, c)$

$--(b)$

(a)Based on regulations in the state of Washington for two-lane highways. See Reference 7.

(b) No specific requirement, but escort car may be required at discretion of Highway Department.

(c) Heights exceeding $4.42 \mathrm{~m}(14.5 \mathrm{ft})$ are generally considered unacceptable because of the special routing and preparations required.

TABLE M.4-4. Shipping Cost per Truck Shipment

\begin{tabular}{lcccc}
\multicolumn{1}{c}{ Status } & Payload $(\mathrm{Mg})$ & & GVW $(\mathrm{Mg})$ & Cost $(\$)^{(\mathrm{a})}$ \\
\cline { 1 - 1 } Legal & 7.71 & & 20.41 & 1180 \\
Oversize & 7.71 & 20.41 & 1680 \\
Overweight & 20.41 & 33.11 & 1920 \\
Oversize and Overweight & 20.41 & 33.11 & 2420
\end{tabular}

(a) 1600-km round-trip distance, two drivers. 


\section{M.4.2 Shipment by Rail}

Shipment by rail is assumed for spent fuel and for the alternate case of deep geologic disposal of the highly activated reactor components. Assuming a round-trip distance of $4828 \mathrm{~km}$ (3000 $\mathrm{mi}$ ), the shipping cost is estimated to be $\$ 110 / \mathrm{Mg}(\$ 5 / 100 \mathrm{lb})$. (8) This amounts to about $\$ 25,100$ for a rail car carrying a GE IF-300 cask. Should a special train be required, a surcharge of $\$ 11.81 / \mathrm{km}(\$ 19 / \mathrm{mi})$, or about $\$ 57,000$ per trip, is added.

\section{M.5 WASTE DISPOSAL COSTS}

A basic assumption in this study is that all of the radioactive material removed from the reference BWR during decommissioning is placed in a shallowland burial facility. The alternative placing of the highly activated reactor components in a deep geologic repository is also considered. The unit costs of waste disposal are given in this section.

\section{M.5.1 Costs for Shallow-Land Burial}

The shallow-land burial costs used in this study are based on a late 1977 price list from Nuclear Engineering Co., Inc., which operates burial sites at Richland, Washington, and Beatty, Nevada. The costs used in this study are for the Beatty site and are given in Table M.5-1. (9)

\section{M.5.2 Costs for Deep Geologic Disposal of Highly Activated Reactor Components}

Since a facility for deep geologic disposal does not presently exist, the costs presented here are somewhat speculative. Based on an analysis and discussion presented in Reference 10, a cost of $\$ 7100 / \mathrm{m}^{3}$ is assumed for such disposal of highly activated materials. Thus, for the canisters presently considered for deep geologic disposal (1.39- $\mathrm{m}^{3}$ burial volume), the disposal charge is $\$ 9869 /$ canister.

\section{6 COSTS OF SERVICES AND SUPPLIES}

Various types of services and supplies are required for decommissioning. The estimated unit costs of the major items are discussed here. 


\section{TABLE M.5-1. Shallow-Land Burial Costs (a)}

I DISPOSAL CHARGES, NON-TRU WASTE

A. Steel Drums, Wood or Fiber Boxes

\begin{tabular}{|c|c|c|}
\hline $\begin{array}{l}\text { Container Surface } \\
\text { Dose Rate }(R / h r)(\mathrm{b})\end{array}$ & $\begin{array}{c}\text { Price per } \\
\left(\$ / \mathrm{m}^{3}\right) \\
\end{array}$ & $\frac{t \text { Volume }}{\left(\$ / \mathrm{ft}^{3}\right)}$ \\
\hline $0.00-0.20$ & 93.57 & 2.65 \\
\hline $0.21-1.00$ & 105.93 & 3.00 \\
\hline $1.01-2.00$ & 123.59 & 3.50 \\
\hline $2.01-5.00$ & 160.66 & 4.55 \\
\hline $5.01-10.00$ & 197.74 & 5.60 \\
\hline $10.01-20.00$ & 268.36 & 7.60 \\
\hline $20.01-40.00$ & 354.87 & 10.05 \\
\hline $4001-60.00$ & 547.31 & 15.50 \\
\hline $60.01-80.00$ & 674.42 & 19.10 \\
\hline $80.01-100.00$ & 741.51 & 21.00 \\
\hline$>100.00$ & request & yy reques \\
\hline
\end{tabular}

B. Disposable Liners

Container Surface
Dose Rate $(\mathrm{R} / \mathrm{hr})(\mathrm{b})$

$0.00-0.20$

$0.21-1.00$

$1.01-2.00$

$2.01-5.00$

$5.01-10.00$

$10.01-20.00$

$20.01-40.00$

$40.01-60.00$

$60.01-80.00$

$80.01-100.00$

$>100.00$

\begin{tabular}{|c|c|c|}
\hline $\begin{array}{l}\text { Surcharge } \\
\text { Per Liner } \\
\text { (\$) }\end{array}$ & $\begin{array}{l}\text { Price per } \\
\frac{\left(\$ / \mathrm{m}^{3}\right)}{}\end{array}$ & $\begin{array}{l}\text { Init voiume } \\
\frac{\left(\$ / \mathrm{ft}^{3}\right)}{}\end{array}$ \\
\hline NONE & 93.57 & 2.65 \\
\hline 50.00 & 93.57 & 265 \\
\hline 125.00 & 93.57 & 2.65 \\
\hline 175.00 & 93.57 & 2.65 \\
\hline 250.00 & 93.57 & 265 \\
\hline 325.00 & 93.57 & 265 \\
\hline 400.00 & 9357 & 2.65 \\
\hline 475.00 & 93.57 & 265 \\
\hline 550.00 & 93.57 & 2.65 \\
\hline 625.00 & 93.57 & 2.65 \\
\hline
\end{tabular}

C. Minimum Disposal Charge

$\$ 100.00 /$ shipment

II SURCHARGE(S)

A. Curie Surcharge (per shipment)
1. 0 - 100 curies
no charge
2. 101 - 300 curres
$\$ 300.00$
3. 301 - License $L 1 \mathrm{~m} 1 \mathrm{ts}$ $\$ 300.00$ plus
(1.e., 50,000 C1 max1mum) $\$ 0.05 / \mathrm{C}$ l above $300 \mathrm{C}$

B. Handling Surcharge
1. 0 - $454 \mathrm{Mg}$
$(0-10,000 \mathrm{lb})$
$2454-22.68 \mathrm{Mg}(c)$ $(10,001-50,000 \mathrm{lb})$
3. Special equipment

no charge

$\$ 50.00+2.2 \$ / \mathrm{kg}$ over $4.54 \mathrm{Mg}$ $(\$ 50.00+1 \$ / 1 \mathrm{~b}$ over $10,000 \mathrm{lb})$ by special quotation

C. Cask Handling Fee $\$ 200.00$

(a)Prices shown as of September 1977 See Reference 9

(b) Maximum reading at container surface, irrespective of physical size or configuration

(c) Limit of site equipment at Beatty 


\section{Electricity}

A principal services cost item is electric power. In this study, a unit cost of $\$ 0.015 / \mathrm{kWh}$, or $\$ 15 / \mathrm{MWh}$, is assumed for electricity.

\section{Fuel 0 il}

At the reference BWR, fuel oil is used to provide energy for building heat and radwaste concentrator operation. A unit cost of $\$ 132 / \mathrm{m}^{3}$ is assumed in this study for fuel oil.

Decontamination Chemicals

The unit costs of chemicals used for recirculatory (10op-type) decontamination are estimated to be:

- EDTA - $\$ 9.92 / \mathrm{kg}$

- Oxalic Acid - $\$ 5.36 / \mathrm{kg}$

- Citric Acid - $\$ 3.75 / \mathrm{kg}$.

For a mixture of these three chemicals, one-third each by weight, the resulting cost is $\$ 6.34 / \mathrm{kg}$.

The chemicals used for single-pass decontamination of drains are estimated to have the following unit costs:

- Phosphoric Acid - $\$ 3.87 / \mathrm{kg}$

- Sodium Hydroxide (50-wt\% solution) - $\$ 178.29 / \mathrm{m}^{3}(\$ 37.44 /$ drum).

Filter/Demineralizer Resins

The unit costs of filter/demineralizer resins used for contaminated water cleanup are estimated to be $\$ 8.36 / \mathrm{kg}$ of bead resin and $\$ 5.87 / \mathrm{kg}$ of mixed Powdex resins, at a mixture by weight of two parts cation Powdex resin to one part anion Powdex resin.

Welding and Cutting Supplies

The capping of segments of large heat exchangers requires carbon steel plate. Costs for this plate are estimated to be:

- 6.35-mm (1/4-in.) plate - $\$ 20.34 / \mathrm{m}^{2}$

- 15.88-mm (5/8-in.) plate - $\$ 49.39 / \mathrm{m}^{2}$. 
Welding and cutting requires the use of various gases. Unit costs for these are estimated to be:

- Oxygen - $\$ 2.70 / 6.34-\mathrm{m}^{3}$ cylinder, or $\$ 0.43 / \mathrm{m}^{3}$

- Acetylene - $\$ 12.65 / 6.51-\mathrm{m}^{3}$ cylinder, or $\$ 1.94 / \mathrm{m}^{3}$.

For gas-arc welding of carbon steel plate, the total unit costs for materials (including gas and welding rod) are as follows:

- 6.35-mm (1/4-in.) fillet weld - $\$ 1.25 / \mathrm{m}$

- 12.70-mm (1/2-in.) fillet weld - $\$ 5.02 / \mathrm{m}$.

Paint

The unit cost of the paint used for sealing contaminated surfaces is estimated to be $\$ 5.28 / \ell$. 


\section{REFERENCES}

1. Handy-Whitman Index of Public Utility Construction Costs, Bulletin No. 105, Section B-6, Amended January 1, 1978.

2. U.S. Department of Labor, Bureau of Labor Statistics, Bulletin, March 1975.

3. R. I. Smith, G. J. Konzek and W. E. Kennedy, Jr., Technology, Safety and Costs of Decommissioning a Reference Pressurized water Reactor Power Station, NUREG/CR-0130, Vo1. 2, p. I-2, Prepared by Pacific Northwest Laboratory for U.S. Nuclear Regulatory Commission, June 1978. *

4. Hanford Atomic Metal Trades Council Pay Scales, Richland, WA, 1975.

5. R. S. Godfrey, Ed., Building Construction Cost Data - 1975, R. S. Means Co., Inc., Duxbury, $\overline{M A}, 1975$.

6. MF-I.C.C. No. 195, Local Commodity Tariff No. 1045-E, Tri-State Motor Transit Co., Joplin, M0, May 1977.

7. Regulations and Conditions Governing Overweight and Over-Dimension Vehic-le Permits, Washington State Highway Commission, Department of Highways, OTympia, WA, September 1974.

8. W. V. Loscutoff et al., A Safety and Economic Study of Special Trains for Shipment of Spent Fuel, BNWL-2263, p. A-2, Battel7e, Pacific Northwest Laboratory, Richland, WA, December 1977.

9. Price List, Nuclear Engineering Company, San Ramon, CA, September 1, 1977.

10. K. J. Schneider and C. E. Jenkins, Technology, Safety and Costs of Decommissioning a Reference Nuclear Fuel Reprocessing Plant, NUREG-0278, Table 7.8-12, p. 7-129, Prepared by Pacific Northwest Laboratory for U.S. Nuclear Regulatory Commission, October 1977. **

\footnotetext{
ॠAvailable for purchase from the NRC/GPO Sales Program, U.S. Nuclear Regulatory Commission, Washington, D.C. 20555, and the National Technical Information Service, Springfield, Virginia 22161.

** Available for purchase from the National Technical Information Service, Springfield, Virginia 22161.
} 


\section{APPENDIX N}

\section{PUBLIC RADIOLOGICAL SAFETY ASSESSMENT DETAILS}

The purpose of this appendix is to quantify the parameters and define the methodology for estimating the public radiological safety impacts of decommissioning the reference BWR power station. For each of three separate decommissioning alternatives analyzed, atmospheric releases of radioactivity are calculated for the decommissioning tasks assumed to be performed in the reference BWR buildings. Details for estimating the public radiation exposure resulting from spent-fuel or waste shipments are also included in this appendix.

The impacts of decommissioning on the safety of the public are principally related to the hazards associated with the atmospheric release of radioactive materials during decommissioning, both from planned tasks and from accidents. The scenarios analyzed are designed to use realistically maximized parameters. These parameters are carefully chosen to cover a broad spectrum of conditions. Atmospheric release mechanisms are quantified using either measured release factors or information about known physical or chemical behaviors under the postulated conditions. The estimated routine radionuclide releases to the atmosphere are tabulated in the chronological order of the decommissioning tasks for each building for each decommissioning mode. A detailed probabilistic analysis of the postulated accident scenarios is not within the scope of this study. However, selected generic accident categories are considered that include operational accidents, natural phenomena, aircraft crashes, and mancaused events.

The following sections contain detailed discussions of the technical approach and public safety details for immediate dismantlement, safe storage, entombment, and waste transportation. A summary of this information is given in Sections 11.2 and 11.4 of Chapter 11 (Volume 1). 


\section{N. 1 TECHNICAL APPROACH}

To estimate the radiological public safety impacts of the release of radioactivity to the atmosphere from decommissioning tasks, the following basic assumptions are made:

1. The facility has fulfilled existing criteria for the containment of radionuclides for accidents and natural phenomena during its operational lifetime.

2. The spent fuel from the final core loading is assumed to be shipped from the BWR during a 15-month period for immediate dismantlement. Fuel handl ing accidents, except for transportation accidents, are assumed to be covered in the FSAR for the reference BWR and are not considered further in this study. (1)

3. To ensure proper air flow for the decommissioning workers, and to protect against uncontrolled atmospheric releases of radioactivity, HEPA filters are assumed to be installed in the Reactor Building, Turbine Generator Building, and Radwaste and Control Building exhaust ventilation systems. These filters are tested in-place on a regular basis. The measured particle collection efficiency of these HEPA filters is $99.95 \%$. (2) Airborne releases of radioactivity are assumed to take place at ground level for atmospheric dispersion calculations, and are assumed to pass through a single HEPA filter system with an assumed transmission factor. of $5 \times 10^{-4}$.(2)

4. The containment integrity of the buildings at the reference BWR is assumed to be breached only after the radioactive contamination levels are at the accepted levels for unrestricted use.

5. In areas with high levels of radioactive contamination, a temporarily installed "greenhouse," or contamination control envelope, is assumed to be used. The contamination control envelope is assumed to have a HEPA filter with a transmission factor of $5 \times 10^{-4}$ to reduce the airborne radionuclide concentrations in the BWR buildings from selected decommissioning tasks. 
6. The leakage rate from a contamination control envelope is assumed to be $10 \%$ for all tasks involving its use. This assumed leakage is used as a maximized value to account for routine ruptures or failures of the temporary structures.

7. The airflow rates assumed in this study are: $3000 \mathrm{~m}^{3} / \mathrm{hr}$ for all contamination control envelopes, $1.3 \times 10^{4} \mathrm{~m}^{3} / \mathrm{hr}$ for the Reactor Building, $2.4 \times 10^{4} \mathrm{~m}^{3} / \mathrm{hr}$ for the Turbine Generator Building, and $4.8 \times 10^{4} \mathrm{~m} / \mathrm{hr}$ for the Radwaste and Control Building.

8. Unneeded hazardous chemicals and equipment are removed after the reference BWR is shut down. Decontamination agents such as phosphoric acid, ethylenediaminetetraacetic acid (EDTA), oxalic acid, and citric acid are available in the plant. Unneeded ion exchange resins and resin beds are removed.

9. The reference radionuclide inventories referenced in this appendix refer to the inventories defined in Appendix E. These inventories characterize activated structural materials, as well as surface contamination resulting from contact with the reactor water, steam, or condensate.

10. A11 chemical or manual decontamination tasks are assumed to remove $90 \%$ of the surface contamination.

11. The airborne concentrations of dust or liquid droplets are assumed to be $1 \times 10^{-2} \mathrm{~g} / \mathrm{m}^{3}$, equal to the concentrations observed at the Elk River reactor decommissioning. $(3,4)$ For tasks involving blasting or explosions, the airborne concentrations are assumed to be a factor of 10 higher, or $1 \times 10^{-1} \mathrm{~g} / \mathrm{m}^{3}$. (5)

12. All radioactive wastes shipped offsite are assumed to be shipped in accordance with Department of Transportation (DOT) regulations. Spent reactor fuel is assumed to be shipped $2400 \mathrm{~km}$ by rail to a repository, and radioactive wastes are assumed to be shipped $800 \mathrm{~km}$ by truck to a shallow land burial ground.

13. Radiation doses to the maximum-exposed individual and to the population residing within $80 \mathrm{~km}$ of the reference site are calculated using the 
environmental data and assumptions discussed in Appendix $F$ of this study. These methods are consistant with the methods outlined in Regulatory Guide 1.109. (6)

Other assumptions relating to specific decommissioning tasks are made and discussed where they apply to the analysis of public radiation exposure.

\section{N.2 IMMEDIATE DISMANTLEMENT}

The first option considered in the safety evaluation of decommissioning the reference BWR is immediate dismantlement of the facility. This alternative results in removal of the radioactively contaminated portions of the buildings, the equipment, and the site so that unrestricted use by the public can be permitted.

The assessment of public safety during immediate dismantlement includes a consideration of both routine tasks and postulated accidents. These tasks and accidents can generate considerable amounts of airborne radioactivity, primarily in the form of solid particles and/or suspended liquid droplets. Airborne contamination control measures are assumed to be used where they are considered necessary. The use of other appropriate controls is also considered. The inventories of radioactive contamination in the reference BWR are discussed in detail in Appendix E, and are summarized in Table N.2-1.

In the following sections, the atmospheric releases from immediate dismantlement are described for both routine tasks and postulated accidents. The atmospheric releases are estimated by determining the realistic maximum atmospheric release for each task or accident, and using this value whenever the task or accident is encountered, even for areas containing lower contamination levels.

\section{N.2.1 Routine Immediate Dismantlement Tasks}

A complete discussion of the tasks for immediate dismantlement of the reference BWR is contained in Appendix I. The chronological sequence of immediate dismantlement tasks is listed in Figure I.2-2. These tasks and their time requirements are listed for the Reactor Building, Turbine Generator 
TABLE N.2-1. Summary of Radioactive Contamination at the Reference BWR

\begin{tabular}{|c|c|c|}
\hline Inventory/Location & $\begin{array}{c}\text { Reference } \\
\text { Radionuclide } \\
\text { Inventory } \\
\text { Number(a) } \\
\end{array}$ & $\begin{array}{c}\text { Radioactivity } \\
\text { Level (b) }\end{array}$ \\
\hline $\begin{array}{l}\text { Activated Stainless Steel } \\
\text { Reactor Vessel Internals } \\
\text { Separator }\end{array}$ & $\begin{array}{l}1 \\
1\end{array}$ & $\begin{array}{l}7.6 \times 10_{4}^{5} \mathrm{ci} / \mathrm{m}_{3}^{3} \\
1.0 \times 10^{4} \mathrm{Ci} / \mathrm{m}^{3}\end{array}$ \\
\hline $\begin{array}{l}\text { Activated Carbon Steel } \\
\text { Reactor Vessel } \\
\text { Sacrificial Shield } \\
\text { Shroud }\end{array}$ & $\begin{array}{l}2 \\
2 \\
2\end{array}$ & $\begin{array}{l}1.1 \times 10_{1}^{2} \mathrm{ci} / \mathrm{m}_{3}^{3} \\
5.0 \times 10^{6} \mathrm{Ci} / \mathrm{m}_{3} \\
1.7 \times 10^{\mathrm{Ci} / \mathrm{m}^{3}}\end{array}$ \\
\hline $\begin{array}{l}\text { Activated Concrete } \\
\text { Sacrificial Shield }\end{array}$ & 3 & $4.7 \times 10^{-2} \mathrm{Ci} / \mathrm{m}^{3}$ \\
\hline $\begin{array}{l}\text { Contaminated Piping } \\
\text { Reactor Water } \\
\text { Steam } \\
\text { Condensate }\end{array}$ & $\begin{array}{l}4 \\
4 \\
4\end{array}$ & $\begin{array}{l}1.1 \times 10^{0} \mathrm{Ci} / \mathrm{m}^{2} \\
5.0 \times 10^{-3} \mathrm{Ci} / \mathrm{m}_{2}^{2} \\
5.0 \times 10^{-2} \mathrm{Ci} / \mathrm{m}^{2}\end{array}$ \\
\hline $\begin{array}{l}\text { Contaminated Equipment } \\
\text { Reactor Water } \\
\text { Steam--General } \\
\text { Steam--Turbine }\end{array}$ & $\begin{array}{l}4 \\
4 \\
4\end{array}$ & $\begin{array}{l}3.6 \times 10^{-1} \mathrm{Ci} / \mathrm{m}^{2} \\
5.0 \times 10^{-3} \mathrm{Ci} / \mathrm{m}_{2}^{2} \\
5.0 \times 10^{-4} \mathrm{Ci} / \mathrm{m}^{2}\end{array}$ \\
\hline $\begin{array}{l}\text { Condensate--General } \\
\text { Condensate--Main Condenser } \\
\text { Condensate--Feedwater Heaters } \\
\text { Condensate--Waste Tanks }\end{array}$ & $\begin{array}{l}4 \\
4 \\
4 \\
4\end{array}$ & $\begin{array}{l}5.0 \times 10^{-2} \mathrm{Ci} / \mathrm{m}^{2} \\
5.0 \times 10^{-3} \mathrm{Ci} / \mathrm{m}_{2}^{2} \\
5.0 \times 10^{-3} \mathrm{Ci} / \mathrm{m}^{2} \\
5.0 \times 10^{0} \mathrm{Ci} / \mathrm{m}^{2}\end{array}$ \\
\hline $\begin{array}{l}\text { Surface Contamination } \\
\text { General Surfaces } \\
\text { Isolated Surfaces }\end{array}$ & $\begin{array}{l}5 \\
5\end{array}$ & $\begin{array}{l}2.5 \times 10^{-3} \mathrm{Ci} / \mathrm{m}^{2} \\
2.5 \times 10^{-2} \mathrm{Ci} / \mathrm{m}^{2}\end{array}$ \\
\hline
\end{tabular}

(a)These numbers refer to the reference radionuclide inventories discussed in Appendix $E$.

(b) Estimated levels before decontamination are shown.

Building, and the Radwaste and Control Building. The following subsections contain discussions of the methods used for calculating atmospheric releases of radioactivity and the public radiation doses resulting from immediate 
dismantlement of the reference BWR. Information about the routine atmospheric releases is presented in the chronological order of the immediate dismantlement tasks.

\section{N.2.1.1 Methods for Calculating Atmospheric Releases of Radioactivity}

Reference immediate dismantlement tasks are defined and analyzed to determine generic airborne release mechanisms. A summary of the reference immediate dismantlement tasks considered in this study is shown in Table N.2-2. A complete discussion of each task considered is contained below:

Radiation Survey. Radiation surveys are performed at the start of decommissioning, prior to termination of the nuclear license, and at other times during decommissioning to determine the residual levels of radioactive contamination. Radiation surveys involve crews of health physics technicians who walk through the plant and who are assumed to disturb settled radioactivity. The general housekeeping practices followed prior to. and during dismantlement determine the amount of loose surface contamination, which varies with location within the reference BWR.

The relationship between the amount of material in the air above a surface and the contamination level of that surface has been studied experimentally. ${ }^{(7)}$ This relationship is shown by Equation N.1.

$$
S_{f}=\frac{c_{a}}{c_{s}}
$$

where:

$S_{f}$ - the resuspension factor, $\mathrm{m}^{-1}$

$\mathrm{C}_{\mathrm{a}}$ - the concentration of airborne radioactivity at a given location inside a building, $\mathrm{Ci} / \mathrm{m}^{3}$

$\mathrm{C}_{\mathrm{s}}$ - the concentration of radioactivity on building surfaces, $\mathrm{Ci} / \mathrm{m}^{2}$.

Measured values of $S_{f}$ vary between $1 \times 10^{-5}$ and $2 \times 10^{-3} \mathrm{~m}^{-1}$, depending upon experimental conditions and measurement methods. $(7,8,9)$ 


\begin{tabular}{l} 
Task \\
\hline Radiation Survey \\
Surface Cleaning \\
1. Sweeping \\
2. Vacuuming \\
3. Water-Jet \\
2. Spray Leaks \\
4. Hand Washing \\
1. Liquid Leaks
\end{tabular}

Operation Description Crews of Heal th Physics TechCians Walk Through the BWR Cosidual Radioactive Contamination

\section{Small Quantities of Loose} Contamination on Floors are Removed by Manual Sweeping
with Sweeping Compounds Small quantities of Loose
Contamenation on Surfaces Are Procedures

Hand-He Id High-Pressure Water
Spray is Used to Remove Loose and Soluble Surface Contamination

Limited Areas Are Cleaned
with Mops or Sponges

Loop Chemical Decontamination is used in Piping and Loop Chemical Decontamination
is Used in Piping and

Piping or Equipment
Removal \& Segmentation
1. Cutting in Air

Piping and Equipment is Seg-
mented for Offsite Disposal

Airborne Dust is Removed from Floor Surfaces Dur-

Airborne Release

Airborne Dust is Removed from Floor Surfaces

Airborne Dust is Removed ing Vacuuming

Airborne Particles are Water Sprays

Liquids are Made Air-
borne as Sprays

Liquids are Made Air-
borne from Liquid Leaks

Piping and Equipment is Segmented
Disposal

Holes are Urilled for Insertion of Concrete Spar
Explosive Charges

Concrete Removal
1. Urilling

$\begin{array}{ll}\text { 2. Spaling } & \begin{array}{l}\text { Hydraulically Controlled } \\ \text { Concrete Spallers }\end{array} \\ \text { 3. Blasting } & \begin{array}{l}\text { Explosive Charges for } \\ \text { Concrete Removal }\end{array}\end{array}$

4. Packaging

LNG-Powered Front-End Loader

Concrete Dust is Made
Airborne (Contaminatio
Routine Atmospheric Release Calculation Summary

Resuspension Analysis:

Surface Radioactive Concentration) $x$

(Air Volume Covering floor) $x$ (Atmospheric Release)

Resuspension Analysis:

Surface Rad Cactivity Concentration) $x$

Air Volume Covering Floor) $x$
Building HEPA Transmission Factor) $=$ (Atmospheric Release)

Resuspension Analysis:

Surface Radioactivity Concentration) $\times$
Air Volume Through Vacuum (leaner) $x$ (Vacuum HEPA Transmission Factor) $x$
Building HEPA Transmission Factor)

(Atmospheric Release)

Entrainment of Contaminated Water: (Surface Radioactive Concentration) $x$ Liquid Flow Rate) $\div$ (Solution Density) $\times$
Airborne Concentration) $\times$ (Building Air Flow Rate) $x$ (Water-Jet Use Time) $x$
(Building HEPA Transmission Factor) $=$ (Atmospheric Release)

Not Calculated

Postulated Hazardous Situations

- None Analyzed - Fire in Contaminated Sweeping
Compound

- Vacuum Bag Rupture

- Spilling Contaminated Liquids - Loss of Services

Entrainment of Contaminated Water:
Surface Contamination Removal Fraction)
Internal Surface Radioactivity Concentra-

Internal Surface Radioactivity Co
tion) $x$ (Internal Surface Area) $x$

(Leak-Weighted Air-Volume) $x$

Airborne Concentration) :

Volume of Liquid) $\div$ (Density of Liquid) $x$ (Auilding HEPA Trans
Vaporized Metal is Made Airborne (Contamination

Liquids are Made Air-
borne from Spray Leaks

uid Sprays are Made irborne (Contamination

Entrainment of Spray: Internal Surface Radioactivity Concentra-
tion) $x$ (Internal Surface (Volume of Leak) $x$ (Total Liquid Volume) $x$ (Fraction of Leak to Reach HEPA System) $x$
(Building HEPA Filter Transmission Factor)

\section{Contaminated Piping or Equipment:}

Surface Radioactivity Concentration) Building HEPA Transmiss (Atmospheric Release)
Activated Piping or Equipment:.
Same as Above x (Material Thickness) (Material Density)

Entrainment of Contaminated Water:

(Airborne Radioactivity Concentration) $x$ (Airborne Radioactivity Concentration)
(Control Envelope Airflow Rate) $x$ (Cutting Time) $\times$ ((Control Envelope Leak
Rate) $x$ (Building HEPA Filter Transmission Factor) $\div$ (Water Density) $=$

Concrete Dust is Made Airborne (Contaminatio

Number of Holes) $x$ (Surface Area per Hole) $x$ (Airbornacion $x$ Air Flow Rate) $\times$ (Drilling Time) $\times$
Control Envelope Leak Rate) $\times$ (Building HEPA (Volume of Holes Drilled) $\div$ (Density of Con-
crete) $=$ (Atmospheric Release)

Not Calculated Airborne (Contaminat
Control Envelope)

Concrete Dust is Made Airborne (Contamination
Control Envelope)

Concrete Dust Generation: $x$

(Number of Blasts) $x$ (Airborne Concentra-

tion) $x$ (Radioactivity Concentration) $=$ (Density of Concrete)
(Atmospheric Release)

Not Calculated

- Loss of Services - Maarial Failures

Loss of Services - Local Loss of Contamination Control

- Loss of Services

- Lxyal totys explosion control Loss of Contamination

Loss of Services - Equipment Failure
- Cont Loss of Contamination

Concrete Dust is Made Control Envelope) 
ก 
The concentration of airborne radioactivity at a given location inside a building is calculated by rearranging Equation N.1 as shown in Equation N.2.

$$
c_{a}=s_{f} c_{s}
$$

where the terms $S_{f}, C_{s}$, and $C_{a}$ are the same as defined for Equation N.1.

The total radioactivity made airborne in a building is calculated by using an assumed average sresuspension factor associated with the radiation survey of $1 \times 10^{-4} \mathrm{~m}^{-1}$, the surface radionuclide concentrations in the building, and the total volume of air contaminated during the radiation survey as shown in Equation N.3.

$$
Q_{s}=\left(1 \times 10^{-4} \mathrm{~m}^{-1}\right) c_{s} v_{s}
$$

where:

$Q_{S}$ - the total airborne radioactivity inside a building, $\mathrm{Ci}$

$\mathrm{C}_{\mathrm{s}}$ - the surface radioactivity concentration on building surfaces, $\mathrm{Ci} / \mathrm{m}^{2}$

$v_{s}$ - the volume of air covering the surface involved in the radiation survey (assumed to be $1 \mathrm{~m}$ deep), $\mathrm{m}^{3}$.

The airborne radioactivity generation rate during the radiation survey is found by dividing the airborne radioactivity, $Q_{S}$, by the time required to perform the survey. The total radioactivity released to the atmosphere is found by multiplying the airborne radioactivity generated in each building by the HEPA filter transmission factor.

Surface Cleaning. The surface cleaning operations considered are sweeping, vacuuming and water-jet sprays.

1. Sweeping. Loose floor contamination is assumed to be removed by manual sweeping operations with the use of sweeping compounds. The amount of airborne radioactivity generated during sweeping is determined by using a resuspension factor analysis similar to the one discussed for the 
radiation survey. The amount of radioactivity made airborne is highly variable and is characterized by the properties of the loose contamination and the sweeping method. Sweeping compounds are designed to lower the resuspension by binding small particles of surface contamination to larger particles of sweeping compound.

Data from experimental studies of resuspension during sweeping are limited. One study suggests a resuspension factor of $1.9 \times 10^{-4} \mathrm{~m}^{-1}$. (8) For this study, a conservatively large resuspension factor of $5 \times 10^{-4} \mathrm{~m}^{-1}$ is used. This factor is 5 times larger than the resuspension factor assumed for the radiation survey. The resuspended radioactivity is assumed to be confined in the lower meter of air in the room in which the sweeping occurs. Thus, the airborne radioactivity in a building is calculated using the volume of air disturbed by sweeping (assumed to be the volume $1 \mathrm{~m}$ deep above the surface area swept), the surface radioactivity concentration, and the assumed resuspension factor. The total atmospheric radioactivity released from sweeping is found by multiplying the airborne radioactivity generated in each building by the HEPA filter transmission factor.

2. Vacuuming. Vacuuming can be used as an alternative to manual sweeping for removal of loose surface contamination. Thus, certain areas of the buildings considered in this study are designated for vacuuming. The vacuum exhaust is assumed to be fitted with a $99.95 \%$-efficient HEPA filter system. The airborne radioactivity in a building resulting from vacuuming is calculated by finding the product of the surface contamination level, the total area vacuumed, the assumed surface contamination removal fraction for vacuuming $(0.5)$, and the vacuum system HEPA filter transmission factor. The total radioactivity released to the atmosphere is found by multiplying the airborne radioactivity in each building from vacuuming by the building HEPA transmission factor.

3. Water-Jet Sprays. The water-jet is a hand-held high-pressure water spray designed to remove loose surface contamination. The operating water pressure is about $3.1 \times 10^{4} \mathrm{kPa}$. The principal mechanism for the generation of airborne radioactivity from the water-jet is the suspension of 1 iquid 
droplets containing contamination removed from surfaces. The water spray produces fine droplets smaller than $300 \mu \mathrm{m}$ in diameter (about the size of the droplets found in fogs or mists). Larger droplets are broken into smaller droplets as they impact on the contaminated surfaces. Thus, there is the potential for a significant formation of small droplets with a considerable variation in the total quantity of radioactivity contained in the droplets.

Direct data are not available to define the quantity of droplets formed. A conservative estimate is made by assuming that a sufficient quantity of droplets are generated to maintain an airborne liquid concentration of $1 \times 10^{-2} \mathrm{~g} / \mathrm{m}^{3}$ with vigorous mixing in air. This is the maximum mass concentration that can be found in air velocities less than $0.046 \mathrm{~m} / \mathrm{s}$. (4) Measurements have shown that there is fairly constant distribution of 10- to 20- $\mu \mathrm{m}$ diameter particles in a water-jet spray at a concentration of about $1 \times 10^{-2} \mathrm{~g} / \mathrm{m}^{3}$, including the gross entrainment of larger particles. $(10)$ Since particles smaller than $10 \mu \mathrm{m}$ are in the respirable-size range, they are potentially hazardous. The quantity of radioactivity found in these airborne droplets is influenced by factors such as the quantity of radioactivity on the surface, the solubility of the surface radioactivity in the liquid, and the contact between the liquid and the surface.

Operating parameters of the water-jet vary with the requirements of the surface decontamination effort. For this study, a water flow rate of $2.3 \times 10^{-2} \mathrm{~m}^{3} / \mathrm{min}$ and a cleaning rate of $0.77 \mathrm{~m}^{2} / \mathrm{min}$ are assumed. The water-jet is assumed to remove $90 \%$ of the surface contamination. The concentration of radioactivity in the liquid resulting from use of the water-jet is defined by Equation N.4.

$$
c_{v}=0.9 c_{s}\left(\frac{0.77 \mathrm{~m}^{2} / \mathrm{min}}{2.3 \times 10^{-2} \mathrm{~m}^{3} / \min }\right)
$$


where:

$C_{v} \bullet$ the concentration of radioactivity in the liquid resulting from use of the water-jet, $\mathrm{Ci} / \mathrm{m}^{3}$

0.9 - the fraction of the surface contamination removed by the water spray

$\mathrm{C}_{\mathrm{s}}$ - the radioactivity concentration on the building surfaces, $\mathrm{Ci} / \mathrm{m}^{2}$

0.77 the water-jet cleaning rate, $\mathrm{m}^{2} / \min$

$2.3 \times 10^{-2}$ the water flow rate for the water-jet, $\mathrm{m}^{3} / \mathrm{min}$.

The airborne radioactivity generated in a building resulting from use of the water-jet is calculated from the liquid radioactivity concentration using Equation N. 5.

$$
Q_{h}=\frac{C_{v}}{\rho}\left(1 \times 10^{-2} \mathrm{~g} / \mathrm{m}^{3}\right) F_{v} t
$$

where:

$Q_{h}$ - the airborne radioactivity in the building resulting from water-jet operations, $\mathbf{C} i$

$C_{v} \cdot$ liquid radioactivity concentration, $\mathrm{Ci} / \mathrm{m}^{3}$

$\rho$ - the density of the water-jet solution, $\mathrm{g} / \mathrm{m}^{3}$

$1 \times 10^{-2}$ - the airborne concentration, $\mathrm{g} / \mathrm{m}^{3}$

$\mathrm{F}_{\mathrm{v}}$ - the building ventilation flow rate, $\mathrm{m}^{3} / \mathrm{hr}$

$t$ - the time spent using the water-jet, hr.

The atmospheric release of radioactivity from water-jet sprays is calculated by multiplying the airborne radioactivity in the building by the building HEPA filter transmission factor.

Chemical Decontamination. Liquid and spray leaks are assumed to occur during loop chemical decontamination of piping and equipment. 
1. Liquid Leaks. A liquid leak results in a small airborne release in a building, since the liquid will retain most of the dissolved radioactive contamination until it reaches a floor drain. Therefore, only a small volume of air is assumed to contain $1 \times 10^{-2} \mathrm{~g} / \mathrm{m}^{3}$ of airborne radioactivity. The concentration of radioactivity in the decontamination solution is a function of the radioactivity removal fraction, the surface contamination level, and the volume of decontamination solution, as shown in Equation N.6.

$$
C_{v}=\frac{0.9^{C} C_{s}}{V_{c}} A_{s}
$$

where:

$\mathrm{C}_{\mathrm{v}}$ - the liquid radioactivity concentration, $\mathrm{Ci} / \mathrm{m}^{3}$

0.9 - the surface contamination removal fraction

$C_{s}$ - surface concentration of radioactivity on internal pipe and equipment surfaces, $\mathrm{Ci} / \mathrm{m}^{2}$

$V_{c}$ - the volume of decontamination solution in the loop, $\mathrm{m}^{3}$

$A_{s}$ - the internal surface area decontaminated, $m^{2}$.

It is assumed that only a small volume of air above a liquid leak becomes contaminated. This volume is assumed to be the amount of air $2 \mathrm{~m}$ deep above the floor surface area contaminated by the liquid leak. The floor surface covered by a leak is assumed to be $1 \mathrm{~m}^{2}$ for each 7 iter of leak. Thus, the total airborne radioactivity is calculated using Equation N.7.

$$
Q_{1}=\frac{v_{r}}{\rho}\left(1 \times 10^{-2} \mathrm{~g} / \mathrm{m}^{3}\right) \mathrm{c}_{v}
$$

where:

$Q_{1}$ - the airborne radioactivity in the building resulting from the liquid leak, Ci 
$V_{r}$ - the volume of room air containing the airborne release (the volume of air $2 \mathrm{~m}$-deep over the surface area contaminated, which is assumed to be $1 \mathrm{~m}^{2}$ per $1 \times 10^{-3} \mathrm{~m}^{3}$ of leak), $\mathrm{m}^{3}$

$1 \times 10^{-2}$ - the airborne concentration, $\mathrm{g} / \mathrm{m}^{3}$

$\rho$ - the density of the decontamination 1 iquid, $\mathrm{g} / \mathrm{m}^{3}$

$C_{v}$ - the liquid radioactivity concentration, $\mathrm{Ci} / \mathrm{m}^{3}$.

The total radioactivity released to the atmosphere from a liquid leak is calculated by multiplying the airborne radioactivity in the building by the building HEPA filter transmission factor.

2. Spray Leaks. Spray leaks of chemical decontamination liquids can lead to a major airborne release since the radioactive liquids are directly entrained in the building air. For this study, $0.3 \%$ of the airborne contanimation in the building is assumed to be of the correct particle size to reach the building HEPA filter. (11) Thus, the total release to the environment from spray leaks is $0.3 \%$ of the leaked radioactivity multiplied by the building HEPA filter transmission factor.

Piping or Equipment Removal. Contaminated or activated piping and equipment, are assumed to be removed and segmented for disposal during immediate dismantlement. For this study, four cutting methods are assumed to be used: arc saw, plasma-arc torch, oxyacetylene torch and power hacksaw. A summary of the cutting parameters for these methods is listed in Table N.2-3.

TABLE N.2-3. Cutting Parameters for Piping and Equipment Removal

Cutting Method

Arc Saw

Plasma Torch

0xyacetylene Torch

Power Hacksaw
Cut (kerf) Width, (m)

$9.5 \times 10^{-3}$

$3.1 \times 10^{-3}$ to $6.4 \times 10^{-3}$

$6.4 \times 10^{-3}$

$6.4 \times 10^{-3}$
Airborne Release

Metal Fragments, Vapors

Condensed Metals, Gases, Smoke Particles

Condensed Metals, Vapors

Metal Fragments, Vapors 
In this study, cutting tasks are assumed both in air and under a water cover.

1. In Air. For piping or equipment containing surface contamination, the airborne release in the building from cutting tasks in air is calculated using Equation N.8.

$$
Q_{C}=L K C_{S}
$$

where:

$Q_{C} \cdot$ the airborne radioactivity from cutting contaminated pipe or equipment, Ci

$L$ - the length of cut, $m$

$K$ - the width of the cut (kerf), $m$

$\mathrm{C}_{\mathrm{s}}$ - the surface radioactivity concentration, $\mathrm{Ci} / \mathrm{m}^{2}$.

Equation N.8 is based on the conservative assumption that all of the surface radioactive contamination associated with the cut width is vaporized and made airborne during cutting operations.

The airborne release associated with cutting neutron-activated piping or equipment is calculated using Equation N.9.

$$
Q_{C}^{-}=L K T C_{m}
$$

where:

$Q_{c}^{-} \cdot$ the airborne radioactivity from cutting neutron-activated material in air, $\mathrm{Ci}$

$L, K \bullet$ are defined previously for Equation N.8

$T \cdot$ the thickness of the material being cut, $m$

$\mathrm{C}_{\mathrm{m}}$ - the concentration of radioactivity in the material being cut, $\mathrm{Ci} / \mathrm{m}^{3}$. 
Again all material in the kerf width is conservatively assumed to be vaporized and is assumed to be airborne in the building. Equations N.8 and N.9 are used for all cutting methods in air, assuming a maximum kerf width of $6.4 \times 10^{-3} \mathrm{~m}$ for the plasma-arc torch, oxyacetylene torch and hacksaw, and $9.5 \times 10^{-3} \mathrm{~m}$ for the arc saw.

The amount of radioactivity released to the atmosphere is calculated by multiplying either $Q_{c}$ or $Q_{c}$ by the building HEPA filter transmission factor.

2. Underwater. Highly activated piping or equipment is assumed to be segmented by a remote, underwater cutting method, using either the plasmaarc torch or the arc saw. The heat and agitation associated with either of these cutting methods is assumed to drive some of the contaminated cover water into the air. In some cases, a contamination control envelope is assumed to be used to mitigate the airborne release. The total contamination suspended in the water is assumed to be the maximum value calculated for all underwater cutting tasks, thus the airborne releases are maximized.

The air in the vicinity of the cutting tasks is assumed to become filled with radioactive water vapor to a concentration of $1 \times 10^{-2} \mathrm{~g} / \mathrm{m}^{3}$ during underwater cutting tasks. Cutting parameters are assumed to be the same as those described for in-air piping or equipment removal. Equation N.10 is used to calculate the quantity of airborne radioactivity released from underwater cutting tasks.

$$
Q_{c}^{-\rho}=\frac{C_{v}}{\rho}\left(1 \times 10^{-2} \mathrm{~g} / \mathrm{m}^{3}\right) F_{v}^{\prime} t F_{c}
$$

where:

$$
\begin{aligned}
& Q_{c}^{-1} \text { - the quantity of airborne radioactivity transmitted in the } \\
& \text { building airflow, } \mathrm{Ci} \\
& \mathrm{C}_{v} \text { - the maximum concentration of radioactive material in the } \\
& \text { cover water, } \mathrm{Ci} / \mathrm{m}^{3}
\end{aligned}
$$


$\rho$ - the density of the cover water and radioactivity mixture, $\mathrm{g} / \mathrm{m}^{3}$

$1 \times 10^{-2}$ - the airborne concentration in the contamination control envelope, $\mathrm{g} / \mathrm{m}^{3}$

$F_{v} \cdot$ the ventilation flow rate, $\mathrm{m}^{3} / \mathrm{hr}$

$t$ - the duration of the cutting operation, $h r$

$\mathrm{F}_{\mathrm{C}}$ - the leak fraction of the contamination control envelope: if used, the fraction is 0.1 ; if not used, the fraction is 1.0 .

The total release to the environment from underwater cutting tasks is calculated by multiplying the quantity of radioactive contamination entering the building airflow by the transmission factor of the building HEPA filter system.

Contaminated Concrete Removal. Two methods of concrete removal are considered in this study. They are: concrete spalling and blasting.

1. Concrete Spalling. Structural concrete that cannot be decontaminated to the unrestricted-use levels by surface cleaning methods must be mechanically removed. For this study, the first methods considered is the use of concrete spallers to remove these contaminated concrete areas. Airborne contamination control is assumed to be provided by the use of a vacuum exhaust system during this dusty task. Holes are drilled into the concrete surfaces for insertion of the concrete spaller. To calculate the airborne radioactivity in a building associated with the dust generated during drilling, the volume of concrete for each hole, the number of holes drilled, the radioactive contamination level and the effectiveness of the vacuum system must be determined. Each hole is assumed to be $5.1 \times 10^{-2} \mathrm{~m}$ deep and remove a contaminated surface area of $5.0 \times 10^{-2} \mathrm{~m}^{2}$. For structural concrete with surface contamination only, the total radioactivity associated with drilling is found by multiplying the number of holes drilled by the surface area per hole by the surface contamination level. The surface contamination is assumed to be uniformly mixed in volume of dust associated with drilling the holes. A vacuum exhaust 
system is used to collect the dust generated during drilling. This system is assumed to have an airflow of $1000 \mathrm{~m}^{3} / \mathrm{hr}$ and reduce the air concentration of dust by a factor of 0.3 . The quantity of airborne radioactivity generated by drilling is given by Equation N.11.

$$
Q_{d}=\frac{N_{h}\left(5 \times 10^{-2} \mathrm{~m}^{2} / h_{01 e}\right) C_{s}}{V_{h} \rho} F_{v}^{\prime} t(0.3) 1 \times 10^{-1} \mathrm{~g} / \mathrm{m}^{3}
$$

where:

$Q_{d}$ - the quantity of radioactivity made airborne during drilling, $\mathrm{Ci}$

$\mathrm{N}_{\mathrm{h}}$ • the number of holes drilled

$5 \times 10^{-2}$ - the surface area removed per hole, $\mathrm{m}^{2} /$ hole

$\mathrm{C}_{\mathrm{s}}$ - the concentration of surface radioactivity, $\mathrm{Ci} / \mathrm{m}^{2}$

$V_{h}$ - the total volume of all holes drilled, $\mathrm{m}^{3}$

$\rho$ - the density of concrete, $2.5 \times 10^{3} \mathrm{Kg} / \mathrm{m}^{3}$

$F_{v}^{\prime} \cdot$ the vacuum system airflow rate, $1.0 \times 10^{3} \mathrm{~m}^{3} / \mathrm{hr}$

$t$ - the duration of the drilling operation, $h r$

0.3 - airborne cleanup factor

$1 \times 10^{-1}$ - the airborne concentration in the vacuum system, $\mathrm{g} / \mathrm{m}^{3}$.

The radioactivity released to the atmosphere is found by multiplying the quantity of radioactivity generated by the leakage factor from the control envelope (if one is used) and by the building HEPA filter transmission factor.

After the holes are drilled, the concrete spaller is inserted into the holes and the concrete surface is scarfed. The concrete fractures and spalls in large pieces with a relatively small amount of dust generated. Water sprays are assumed to be used to control the airborne dust during the concrete spalling. Thus, the airborne release from concrete spalling 
system is used to collect the dust generated during drilling. This system is assumed to have an airflow of $1000 \mathrm{~m}^{3} / \mathrm{hr}$ and reduce the air concentration of dust by a factor of 0.3. The quantity of airborne radiothe activity generated by drilling is given by Equation N.11.

$$
Q_{d}=\frac{N_{h}\left(5 \times 10^{-2} \mathrm{~m}^{2} / \text { hole }\right) C_{s}}{V_{h}^{\rho}} F_{v}^{\prime} t(0.3) 1 \times 10^{-1} \mathrm{~g} / \mathrm{m}^{3}
$$

where:

$Q_{d}$ - the quantity of radioactivity made airborne during drilling, $\mathrm{Ci}$

$\mathrm{N}_{h}$ - the number of holes drilled

$5 \times 10^{-2}$ - the surface area removed per hole, $\mathrm{m}^{2} /$ hole

$\mathrm{C}_{\mathrm{s}}$ - the concentration of surface radioactivity, $\mathrm{Ci} / \mathrm{m}^{2}$

$V_{h}$ - the total volume of all holes drilled, $\mathrm{m}^{3}$

$\rho$ - the density of concrete, $2.5 \times 10^{3} \mathrm{Kg} / \mathrm{m}^{3}$

$F_{v}^{\prime} \cdot$ the vacuum system airflow rate, $1.0 \times 10^{3} \mathrm{~m}^{3} / \mathrm{hr}$

$t$ - the duration of the drilling operation, $h r$

0.3 - airborne cleanup factor

$1 \times 10^{-1}$ - the airborne concentration in the vacuum system, $\mathrm{g} / \mathrm{m}^{3}$.

The radioactivity released to the atmosphere is found by multiplying the quantity of radioactivity generated by the leakage factor from the control envelope (if one is used) and by the building HEPA filter transmission factor.

After the holes are drilled, the concrete spaller is inserted into the holes and the concrete surface is scarfed. The concrete fractures and spalls in large pieces with a relatively small amount of dust generated. Water sprays are assumed to be used to control the airborne dust during the concrete spalling. Thus, the airborne release from concrete spalling

limited. $r$ this is used. for the conoccurs. I the deep ition, ictivity activity

eping for he buildvacuum er sysuuming level, 1 fracmission und by uming by

er spray ter presieration : 1 iquid 
is assumed to be insignificant when compared to the drilling operations and is not considered further in this study.

2. Concrete Blasting. Activated concrete in the sacrificial shield is assumed to be removed by blasting tasks. Holes are drilled in the concrete for inserting blasting charges. The airborne release from drilling activated concrete is calculated by using Equation N.12.

$$
Q_{d}^{\prime}=\frac{V_{h} C_{v}}{\rho} F_{v}^{\prime} t(0.3)\left(1 \times 10^{-1} \mathrm{~g} / \mathrm{m}^{3}\right)
$$

where:

$Q_{d}^{-}$- the quantity of radioactivity made airborne during drilling activated concrete, $\mathrm{Ci}$

$\mathrm{C}_{\mathrm{v}} \cdot$ the radioactivity concentration in the activated concrete, $\mathrm{Ci} / \mathrm{m}^{3}$ $v_{h}, \rho, F_{v}^{\prime}, t, 0.3$, and $1 \times 10^{-1}$ are the same as defined for Equation $N .11$. Blasting is assumed to create an airborne dust concentration of $1 \times 10^{-1} \mathrm{~g} / \mathrm{m}^{3}$ in the volume of the contamination control envelope. The airborne radioactivity generated during blasting is found using Equation N.13.

$$
Q_{b}=\frac{N_{b}\left(1 \times 10^{-1} \mathrm{~g} / \mathrm{m}^{3}\right)}{\rho} v_{e} c_{v}
$$

where:

$Q_{b}$ - the airborne radioactivity from blasting, $C i$

$\mathrm{N}_{\mathrm{b}}$ - the number of multiple-charge blasts

$1 \times 10^{-1}$ - the air concentration during blasting, $\mathrm{g} / \mathrm{m}^{3}$

$\mathrm{V}_{\mathrm{e}}$ - the volume of the contamination control envelope, $1 \times 10^{3} \mathrm{~m}^{3}$

$\rho$ - the density of concrete, $2.5 \times 10^{3} \mathrm{~kg} / \mathrm{m}^{3}$

$\mathrm{C}_{v}$ - the radioactivity concentration in the activated concrete, $\mathrm{Ci} / \mathrm{m}^{3}$. 
The amount of radioactivity released to the atmosphere from drilling or blasting activated concrete is found by multiplying $Q_{d}$ or $Q_{b}$ by the leakage fraction from the control envelope (if one is used) and by the building HEPA filter transmission factor.

\section{N.2.1.2 Atmospheric Releases from Immediate Dismantlement Tasks}

Radioactivity releases to the atmosphere resulting from immediate dismantlement tasks at the reference BWR are calculated using the general methods and equations described in Section N.2.1.1. The operational data used in the equations is listed in Tables N.2-4, N.2-5, and N.2-6 for the Reactor Building, Turbine Generator Building, and the Radwaste and Control Building, respectively. These tables contain chronological listings of the immediate dismantlement tasks, necessary safety analysis data, operational times, the associated reference radionuclide inventory numbers, and the contamination levels present for each task.

The calculated atmospheric releases of radioactivity for immediate dismantlement tasks are listed in Tables N.2-7, N.2-8, and N.2-9 for the three buildings considered. These tables contain the calculated airborne radioactivity generation rates for each task in each building, as well as the total airborne radioactivity generated inside the buildings. The total airborne radioactivity inside a building during each task is next multiplied by the transmission factors for the control envelope and the buiding HEPA filter system to obtain the calculated atmospheric release. These atmospheric releases are used in radiation dose calculations to estimate the impact of routine immediate dismantlement tasks on the public. The calculated public radiation doses are presented in the following section. Again, the reference radionucl ide inventory numbers 1 isted in Tables N.2-7, N.2-8, and N.2-9 refer to the radionuclide inventories discussed in Appendix $E$.

\section{N.2.1.3 Public Radiation Doses from Routine Immediate Dismantlement Tasks}

Radiation doses to the public from atmospheric releases of radioactivity during routine immediate dismantlement tasks are calculated using the radiation dose models discussed in Appendix F. The first-year doses and the 
TABLE N.2-4. Immediate Dismantlement Public Safety Analysis Data Summary for the Reactor Building and Primary Containment

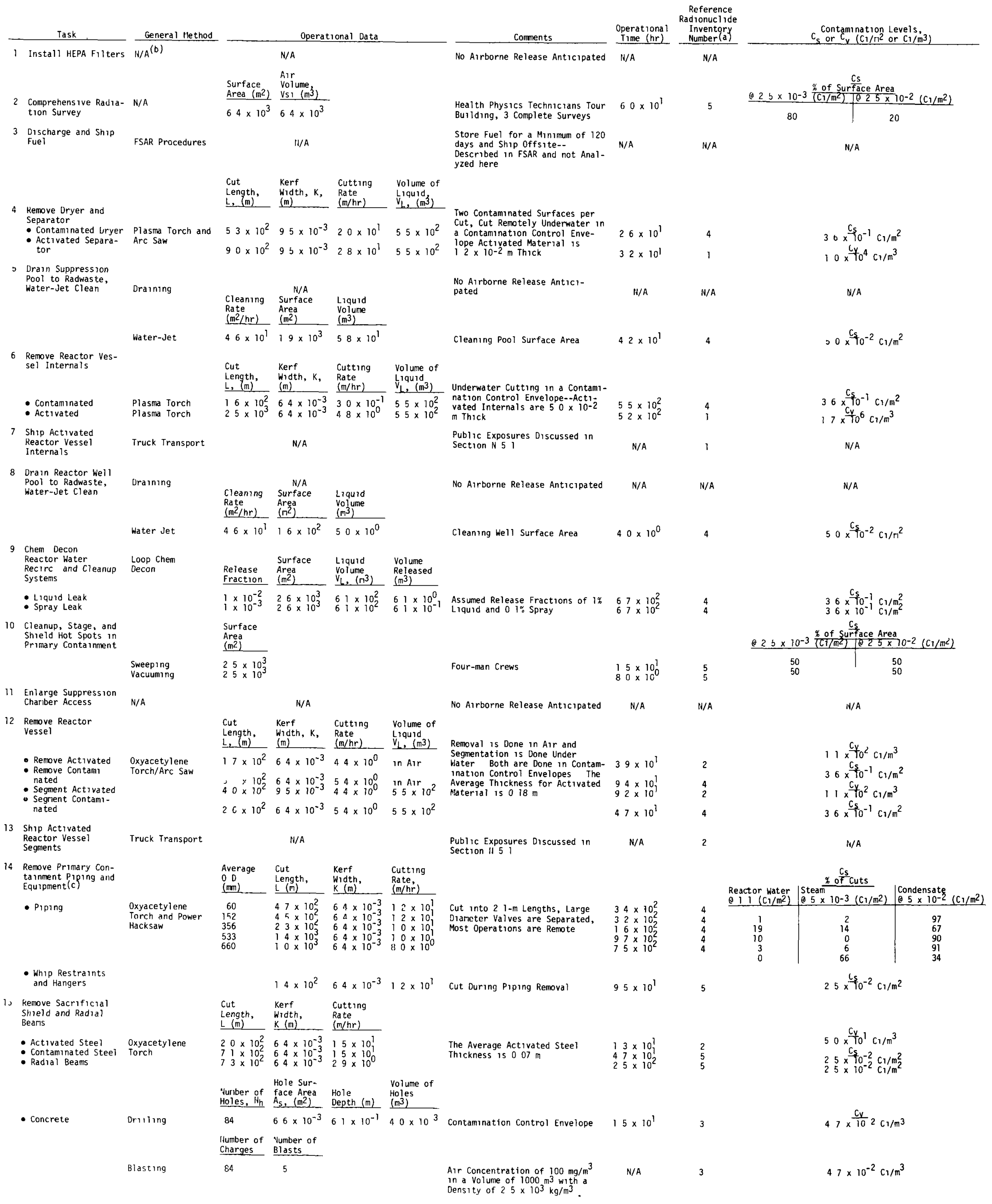

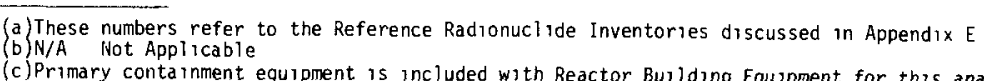

$\underset{\substack{\Lambda \\ \sim}}{2}$ 
0 
TABLE N.2-4. (cont'd)

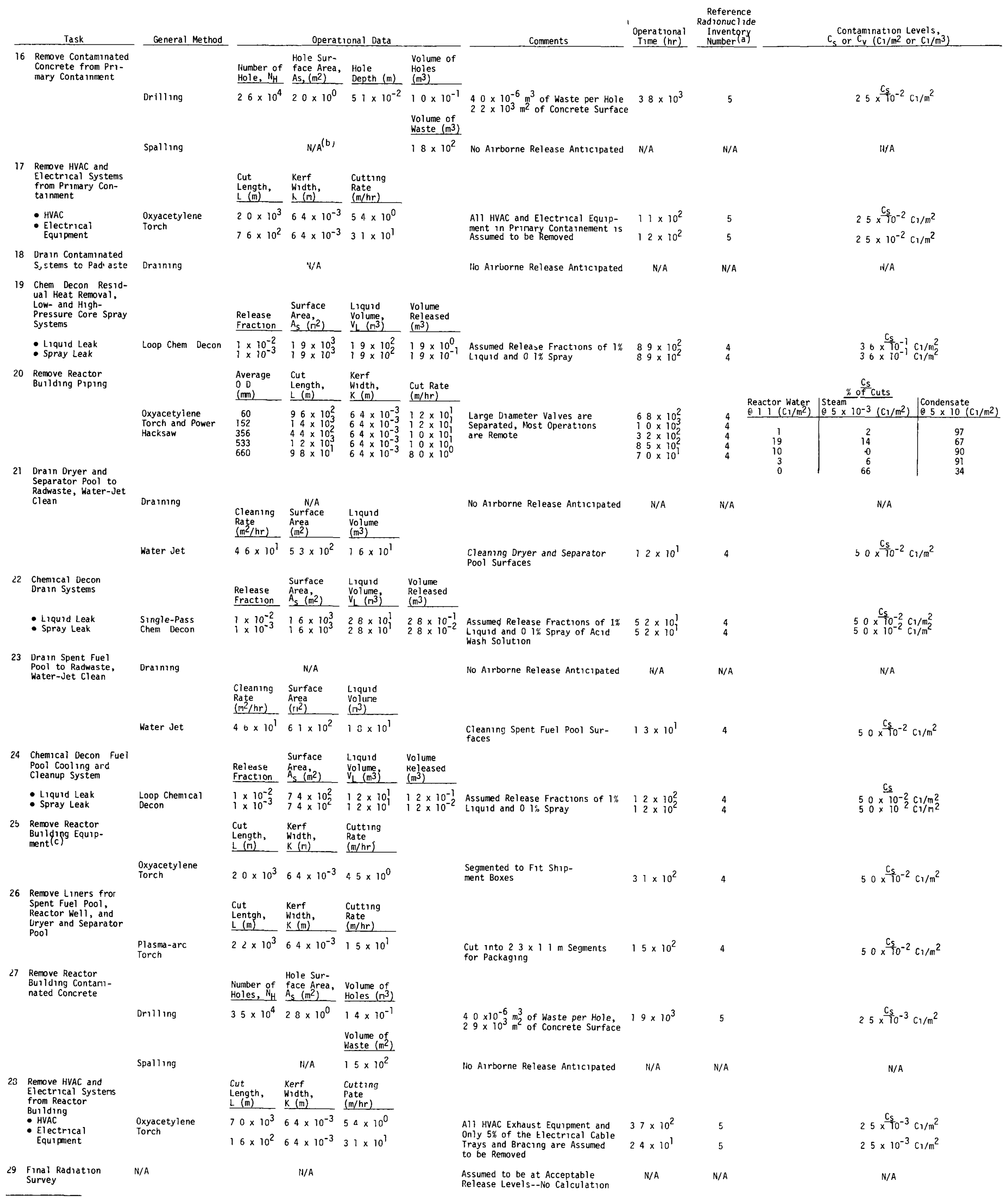

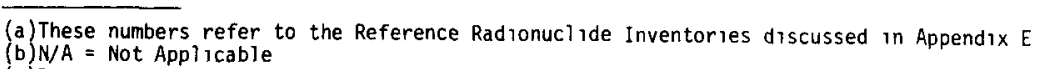

(c) Primary containment equipment is included with Reactor Building Equipment for this analysis 
a 
TABLE N.2-5. Immediate Dismantlement Public Safety Analysis Data Summary for the Turbine Generator Building

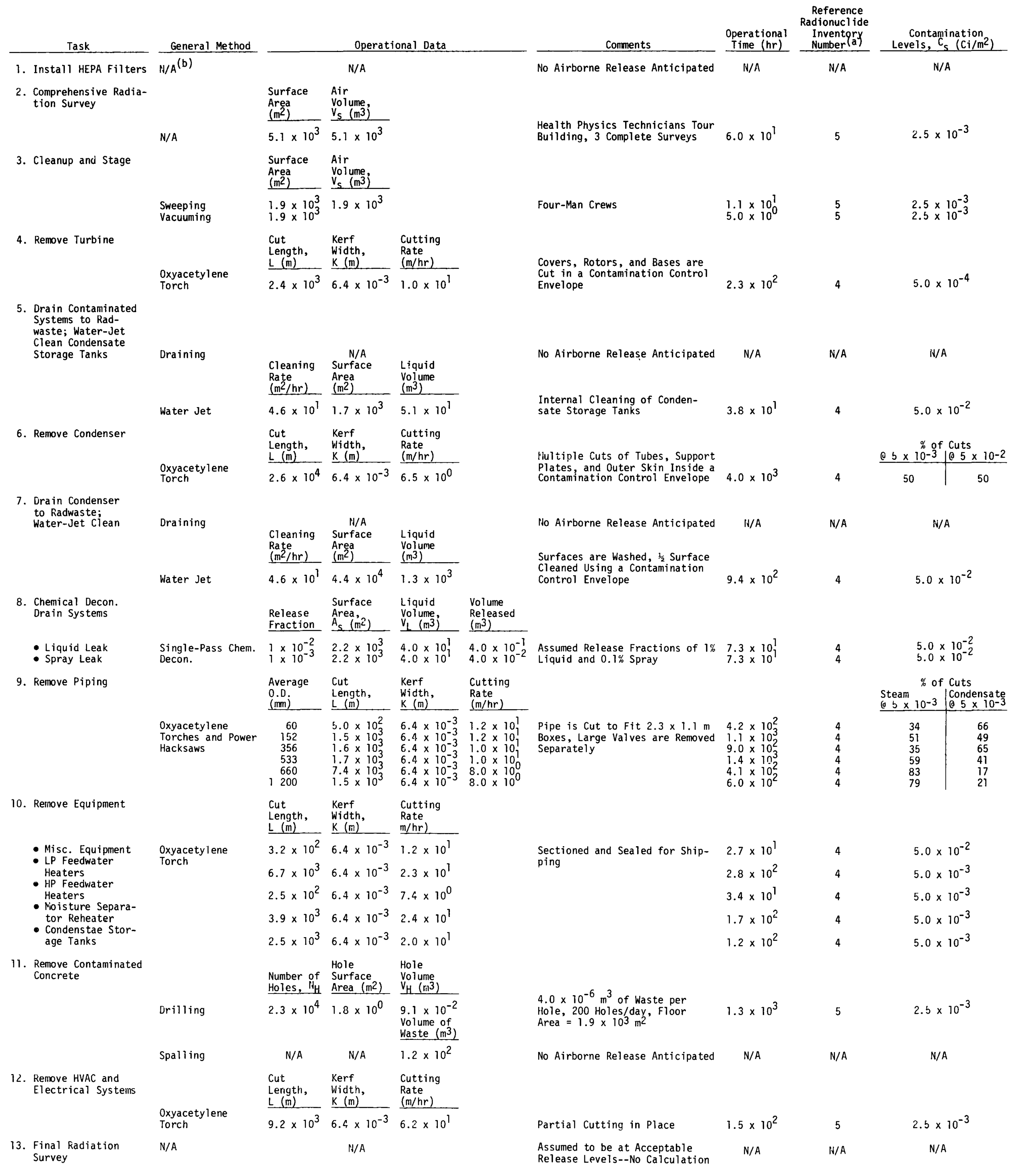

(a) These numbers refer to the Reference Radionuclide inventories discussed in Appendix $E$. (b) N/A = Not Applicable.

$z$
N
on 
TABLE N.2-6. Public Safety Analys is Data for Immediate Dismantlement of the Radwaste and Control Building

\begin{tabular}{|c|c|c|c|c|c|c|c|c|c|c|c|c|}
\hline \multirow{3}{*}{1} & \multirow[t]{3}{*}{ TAsk } & \multirow[t]{3}{*}{ General Method } & \multicolumn{4}{|c|}{ Operational Data } & \multirow{2}{*}{\multicolumn{2}{|c|}{ 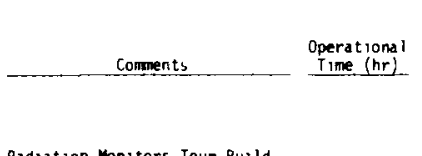 }} & \multirow[t]{2}{*}{$\begin{array}{c}\text { Reference } \\
\text { Radionucl ide } \\
\text { Inventory } \\
\text { Nugherld } \\
\end{array}$} & \multicolumn{3}{|c|}{$\begin{array}{c}\text { Contamination } \\
\text { Levels, } C_{s}\left(C_{1} / m^{2}\right) \\
\end{array}$} \\
\hline & & & \multirow{2}{*}{$\begin{array}{l}\text { Surface } \\
\text { Areag } \\
\frac{\left(m^{2}\right)}{51 \times 10^{3}}\end{array}$} & \multirow{2}{*}{$\begin{array}{l}\begin{array}{l}\text { Air } \\
\text { voiume, } \\
v_{s}\left(\mathbf{m}^{3}\right)\end{array} \\
51 \times 10^{3}\end{array}$} & & & & & & \multicolumn{3}{|c|}{$\begin{array}{l}\text { of Surface Area } \\
25 \times 10^{-3} \mid e 25 \times 10^{-2} \\
\end{array}$} \\
\hline & & & & & & & $\begin{array}{l}\text { Radiation Monitors Tour Burld- } \\
\text { ing } 3 \text { Complete Surveys }\end{array}$ & $60 \times 10^{1}$ & 5 & & 30 & 70 \\
\hline \multirow[t]{2}{*}{2} & General Cleanup & & $\begin{array}{l}\text { Surface } \\
\text { Area }\left(\mathrm{m}^{2}\right)\end{array}$ & & & & & & & & & \\
\hline & & Sweeping & $51 \times 10^{3}$ & & & & $1 / 3$ of Burlding Area Swept & $30 \times 10^{1}$ & 5 & & 30 & 70 \\
\hline \multirow[t]{2}{*}{3} & $\begin{array}{l}\text { Chenical Decon } \\
\text { Drain Systems }\end{array}$ & & $\begin{array}{l}\text { Release } \\
\text { Fraction }\end{array}$ & $\begin{array}{l}\text { Surface } \\
\text { Area, } \\
A_{S}\left(m^{2}\right)\end{array}$ & $\begin{array}{l}\text { Liquid } \\
\text { volume, } \\
V_{s}\left(n^{3}\right)\end{array}$ & $\begin{array}{l}\text { Yolume } \\
\text { Released } \\
\left(n^{3}\right)\end{array}$ & & & & & & \\
\hline & $\begin{array}{l}\text { - Liquid Leak } \\
\text { - Spray Leak }\end{array}$ & $\begin{array}{l}\text { Single-Pass } \\
\text { Chet Decon }\end{array}$ & $1 \times 10^{-2}$ & $\begin{array}{l}68 \times 10^{2} \\
68 \times 10^{2}\end{array}$ & $1 \begin{array}{l}2 \\
12 \times 10^{1}\end{array}$ & $12 \times 10^{-1}$ & $\begin{array}{l}\text { Assumed Release Fractions of } 12 \\
\text { Liquid and } 0 \text { ix Spray }\end{array}$ & $\begin{array}{l}23 \times 10^{1} \\
23 \times 10^{1}\end{array}$ & 4 & & $\begin{array}{l}50 \times 10^{-2} \\
50 \times 10^{2}\end{array}$ & \\
\hline \multirow[t]{3}{*}{4} & $\begin{array}{l}\text { Chemical Decon } \\
\text { Equilpoent, Water- } \\
\text { Jet clean }\end{array}$ & & $\begin{array}{l}\text { Cleaning } \\
\text { Ratee } \\
(-2 / h r)\end{array}$ & $\begin{array}{l}\text { Surface } \\
\text { Rate } \\
\left(m^{2}\right) \\
\end{array}$ & $\begin{array}{l}\text { Liquid } \\
\text { volume } \\
\text { (min) }\end{array}$ & & & & & $25^{2} x$ & $\begin{array}{r}\text { of Syrface } \\
\times 10^{-2}+5 \\
\end{array}$ & 100 \\
\hline & & Water-Jet & $\begin{array}{l}46 \times 10^{1} \\
\text { Release } \\
\text { Fraction } \\
\end{array}$ & $\begin{array}{l}23 \times 10^{3} \\
\text { Surface } \\
\text { Area. } \\
A_{s}\left(m^{2}\right)\end{array}$ & $\begin{array}{l}68 \times 10^{\prime} \\
\text { liguid } \\
\text { yolume } \\
y_{\perp}\left(\mathrm{m}^{3}\right) \\
\end{array}$ & $\begin{array}{l}\text { Vol ume } \\
\text { Re leased } \\
\left(m^{3}\right)\end{array}$ & Exterior Surfaces Cleaned & $49 \times 10^{1}$ & 4 & & 55 & 45 \\
\hline & $\begin{array}{l}\text { - Líquid Leak } \\
\text { - Spray Leak }\end{array}$ & $\begin{array}{l}\text { Loop Chem } \\
\text { Decon }\end{array}$ & $1 \times 10^{-2}$ & $14 \times 10_{3}^{3}$ & $15 \times 10^{2}$ & $15 \times 10^{0}$ & $\begin{array}{l}\text { Assumed Release Fractions of } 1 x \\
\text { Liquid and } 0 \text { is Spray }\end{array}$ & $\begin{array}{l}40 \times 10^{1} \\
40 \times 10^{1}\end{array}$ & 4 & & $\begin{array}{l}55 \\
55\end{array}$ & $\begin{array}{l}45 \\
45\end{array}$ \\
\hline \multirow[t]{2}{*}{5} & Renove Plping & & $\begin{array}{l}\text { Average } \\
0 \quad 0 \\
(\mathrm{~m})\end{array}$ & $\begin{array}{l}\text { Cut } \\
\text { Length. } \\
\underline{L(m)}\end{array}$ & $\begin{array}{l}\text { Kerf } \\
\text { Wtoth, } \\
\underline{K}(\mathrm{~m})\end{array}$ & $\begin{array}{l}\text { Cutting } \\
\text { Rate } \\
\text { (m/hr) }\end{array}$ & & & & $\begin{array}{l}\text { Reactor } \\
\text { Water } \\
11\end{array}$ & $\begin{array}{r}1 \text { of } \\
\text { Stea } \\
05 \times 10^{-3} \\
\end{array}$ & $\begin{array}{l}\text { cuts } \\
\text { Cond } \\
5 \times 10^{-2}\end{array}$ \\
\hline & & $\begin{array}{l}\text { Oxyacetylene and } \\
\text { Plasen Torches, } \\
\text { Power Hacksaws }\end{array}$ & $\begin{array}{l}60 \\
152 \\
356 \\
533 \\
914\end{array}$ & $\begin{array}{l}46 \times 10^{2} \\
13 \times 10^{3} \\
26 \times 10^{2} \\
199 \times 10^{2} \\
16 \times 10^{2}\end{array}$ & $\begin{array}{l}64 \times 10^{-3} \\
64 \times 10^{-3} \\
64 \times 10^{-3} \\
64 \times 10^{-3} \\
64 \times 10^{-3}\end{array}$ & $\begin{array}{llll}1 & 2 & \times & 10 \\
1 & 2 & \times & 10 \\
1 & 0 & \times & 10 \\
1 & 0 & \times 10 \\
8 & 0 & \times 10 & 10\end{array}$ & Cut into $21 \mathrm{~m}$ Lengths & $\begin{array}{l}40 \times 10^{2} \\
10 \times 10^{3} \\
166 \times 10^{2} \\
70 \times 10^{0} \\
38 \times 10^{2}\end{array}$ & $\begin{array}{l}4 \\
4 \\
4 \\
4 \\
4\end{array}$ & $\begin{array}{l}6 \\
7 \\
0 \\
0 \\
0\end{array}$ & $\begin{array}{r}10 \\
15 \\
1 \\
0 \\
0\end{array}$ & $\begin{array}{r}91 \\
78 \\
99 \\
100 \\
100\end{array}$ \\
\hline 6 & $\begin{array}{l}\text { Install Temporary } \\
\text { Raduaste System }\end{array}$ & N/A & & H/A & & & To Airborne Release Anticipated & N/A & N/A & & $N / A$ & \\
\hline \multirow[t]{2}{*}{7} & Rewove Equipment & & $\begin{array}{l}\text { Cut } \\
\text { Length, } \\
\underline{(m)} \\
\end{array}$ & $\begin{array}{l}\text { Kerf } \\
\text { Widen, } \\
\underline{\text { Ke(m) }}\end{array}$ & $\begin{array}{l}\text { Cutting } \\
\text { Rate } \\
\text { (m/hr) }\end{array}$ & & & & & 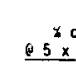 & $\begin{array}{l}\text { of Syrface } A r \\
10^{-3} \mid e 5 x\end{array}$ & $10^{-1}$ \\
\hline & & Torch & $62 \times 10^{3}$ & $64 \times 10^{-3}$ & $19 \times 10^{1}$ & & Cutting Rate & $33 \times 10^{2}$ & 4 & & 55 & 15 \\
\hline \multirow[t]{3}{*}{8} & $\begin{array}{l}\text { Resave Contasinated } \\
\text { Concrete }\end{array}$ & & $\begin{array}{l}\text { Huber of } \\
\text { Holes, Mt }\end{array}$ & $\begin{array}{l}\text { Hole } \\
\text { Surface } \\
\text { Area }\left(\mathbf{m}^{2}\right)\end{array}$ & $\begin{array}{l}\text { Hole } \\
\text { Yoluene, } \\
v_{H}\left(m^{3}\right)\end{array}$ & & & & & $025 x$ & 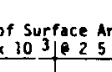 & $\begin{array}{r}\times 10-2 \\
\end{array}$ \\
\hline & & Drilling & $24 \times 10^{4}$ & $19 \times 10^{0}$ & 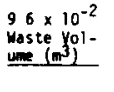 & & $\begin{array}{l}\text { In a Contamination Control } \\
\text { Envelope, } 40 \times 10^{-6} \mathrm{~m}^{3} \text { of } \\
\text { waste per Hole are Orilled } \\
\text { at } 200 \text { Holes/day (Floor Area = }\end{array}$ & $66 \times 10^{2}$ & 5 & & 30 & 70 \\
\hline & & Spalting & $\mathrm{N} \mathbf{H} / \mathrm{A}$ & $\mathrm{H} / \mathrm{A}$ & $10 \times 10^{2}$ & & $\begin{array}{l}\text { io Airbarne Release Anticipated } \\
\text { for Spalling }\end{array}$ & $38 \times 10^{2}$ & 3 & & 30 & 70 \\
\hline \multirow[t]{2}{*}{9} & $\begin{array}{l}\text { Remove Misc } \\
\text { Steel Structures }\end{array}$ & $\begin{array}{l}\text { Oxyacety lene } \\
\text { Torch and Power }\end{array}$ & $\begin{array}{l}\text { Cut } \\
\text { Length. } \\
\underline{L(a)}\end{array}$ & $\begin{array}{l}\text { Kerf } \\
\text { Width. } \\
K(m) \\
\end{array}$ & $\begin{array}{l}\text { Cutting } \\
\text { Rate } \\
\text { (a/hr) }\end{array}$ & & & & & & & \\
\hline & & Hacksews & $25 \times 10^{2}$ & $64 \times 10^{-3}$ & $19 \times 10^{1}$ & & Cut to Fit $23 \times 11-$ boxes & $13 \times 10^{1}$ & 5 & & $25 \times 10^{-3}$ & \\
\hline \multirow[t]{2}{*}{10} & $\begin{array}{l}\text { Rewove HVAC and } \\
\text { Electrical Systems }\end{array}$ & & $\begin{array}{l}\text { Cut } \\
\text { Length, } \\
\underline{L(n)}\end{array}$ & $\begin{array}{l}\text { Kerf } \\
\text { Width, } \\
\text { k }(\mathbf{s})\end{array}$ & $\begin{array}{l}\text { Cutting } \\
\text { Rate } \\
\text { (n/hr) }\end{array}$ & & & & & & & \\
\hline & & $\begin{array}{l}\text { Oxyacetylene } \\
\text { Torch } \\
\text { Power Hacksaws }\end{array}$ & $\begin{array}{l}85 \times 10^{3} \\
95 \times 10^{2}\end{array}$ & $\begin{array}{l}64 \times 10^{-3} \\
64 \times 10^{-3}\end{array}$ & $\begin{array}{l}72 \times 10^{1} \\
36 \\
6 \times 10\end{array}$ & & $\begin{array}{l}\text { A1m HVAC Exhaust Equipment and } \\
\text { only SY of the Electrical Cable } \\
\text { Trays and Bracing are Assumed } \\
\text { to be Removed }\end{array}$ & $\begin{array}{l}12 \times 10^{2} \\
22 \times 10^{1}\end{array}$ & $\begin{array}{l}5 \\
5\end{array}$ & & $\begin{array}{l}25 \times 10^{-3} \\
25 \times 10^{-3}\end{array}$ & \\
\hline 11 & Final Radiation & $N / A$ & & $K / A$ & & & $\begin{array}{l}\text { Assumed to be at Acceptable } \\
\text { Release Levels- No Release } \\
\text { Calculated }\end{array}$ & N/A & M/A & & $\mathrm{H} / \mathrm{A}$ & \\
\hline
\end{tabular}

(a)These mmbers refer to the reference radionucilide inventories discussed in Appendix $E$
(b) $M / A$. Mot Applifcable 

TABLE N.2-7. Calculated Atmospheric Releases for Immediate Dismantlement of the Reactor Building and Primary Containment

\begin{tabular}{|c|c|c|c|c|c|c|c|}
\hline Task & $\begin{array}{l}\text { General } \\
\text { Hetrod }\end{array}$ & $\begin{array}{c}\text { Operat tonal } \\
\text { Trme }(h r)\end{array}$ & $\begin{array}{c}\text { Reference } \\
\text { Rad onucl lide } \\
\text { Inventory } \\
\text { Numberlay } \\
\end{array}$ & $\begin{array}{l}\text { Airborne } \\
\text { Generd ton Rate } \\
\text { Inside But } 1 \text { 1dng } \\
\text { or Control } \\
\text { Envelope (c1/hr) }\end{array}$ & 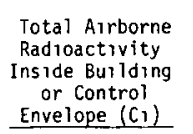 & 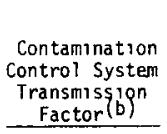 & $\begin{array}{l}\text { Total Atmos- } \\
\text { pheric Releage } \\
\text { (CI/yr) (c) } \\
\end{array}$ \\
\hline 1. Instail HEPA F117ters & $H / A^{(d)}$ & $N / A$ & $\mathrm{~W} / \mathrm{A}$ & $N / A$ & N/A & N/A & W/A \\
\hline 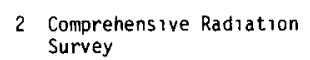 & $\begin{array}{l}\text { Radration } \\
\text { Monitors }\end{array}$ & $6.0 \times 10^{1}$ & 5 & $2.2 \times 10^{-4}$ & $14 \times 10^{-2}$ & $5 \times 10^{-4}$ & $6.8 \times 10^{-6}$ \\
\hline 3. vischarge and Ship fuel & FSAR Procedures & $1.2 \times 10^{2}$ & W/A & N/A & N/A & $5 \times 10^{-4}$ & $N / A$ \\
\hline $\begin{array}{l}\text { 4. Remove oryer and } \\
\text { Separatar } \\
\text { Contanated Dryer } \\
\text { Activated Separator }\end{array}$ & $\begin{array}{l}\text { Plasma Torch } \\
\text { and Arc Saw }\end{array}$ & $\begin{array}{l}2.6 \times 10^{5} \\
3.2 \times 10^{1}\end{array}$ & $\stackrel{4}{1}$ & $\begin{array}{l}2.0 \times 10^{-7} \\
5.6 \times 10^{-5}\end{array}$ & $\begin{array}{l}5.1 \times 10^{-6} \\
1.8 \times 10^{-3}\end{array}$ & $\begin{array}{l}5 \times 10^{-5} \\
5 \times 10^{-5}\end{array}$ & $\begin{array}{l}2.6 \times 10^{-10} \\
9.0 \times 10^{-8}\end{array}$ \\
\hline 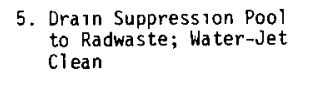 & $\begin{array}{l}\text { Oran inng } \\
\text { hater-Jet }\end{array}$ & $4.2^{1 \mathrm{~N} / \mathrm{A}} \times 10^{1}$ & $4^{N / A}$ & $20^{N / A} \times 10^{-4}$ & $8.5^{\mathrm{H} / \mathrm{A}} \times 10^{-3}$ & $\begin{array}{l}5 \times 10^{-4} \\
5 \times 10^{-4}\end{array}$ & $4.2^{1 / 1 / A} \times 10^{-6}$ \\
\hline 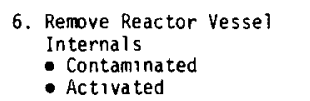 & $\begin{array}{l}\text { Plasma Torch } \\
\text { Plassana Torch }\end{array}$ & $\begin{array}{l}5.5 \times 10^{2} \\
5.2 \times 10^{2}\end{array}$ & ${ }_{i}^{4}$ & $\begin{array}{l}4.0 \times 10^{-8} \\
7.4 \times 10^{-2}\end{array}$ & $\begin{array}{l}2.2 \times 10^{-5} \\
3.9 \times 10^{1}\end{array}$ & $\begin{array}{l}5 \times 10^{-5} \\
5 \times 10^{-5}\end{array}$ & $\begin{cases}1 & \times 10^{-9} \\
9 & \times 10^{-3}\end{cases}$ \\
\hline $\begin{array}{l}\text { 7. Shp Act ivated Reactor } \\
\text { Vessel Internals }\end{array}$ & Truck Transport & N/A & 1 & See Section N. 5 & H/A & N/A & See Section \\
\hline 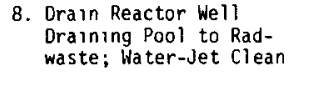 & $\begin{array}{l}\text { Orainng } \\
\text { Water-Jet }\end{array}$ & $4.0^{N / A} \times 10^{0}$ & N//4 & $2.0^{N / A} \times 10^{-4}$ & $8.1^{N / A} \times 10^{-4}$ & $\begin{array}{l}1 / 1 / A \\
5 \times 10^{-4}\end{array}$ & $\begin{array}{l}4.0 / A \\
4.10^{-7}\end{array}$ \\
\hline $\begin{array}{l}\text { 9. Chem Decon Reactor } \\
\text { hater Recirc and } \\
\text { Cleanup Systems } \\
\text { : Llound Leak } \\
\text { Sppray Leak }\end{array}$ & $\begin{array}{l}\text { Loop Chem. } \\
\text { Decon. }\end{array}$ & $\begin{array}{l}6.7 \times 10^{2} \\
6.7 \times 10^{2}\end{array}$ & ${ }_{4}^{4}$ & $\begin{array}{l}2.5 \times 10^{-7} \\
3.8 \times 10^{-6}\end{array}$ & $\begin{array}{l}17 \times 10^{-4} \\
25 \times 10^{-3}\end{array}$ & $\begin{array}{l}5 \times 10^{-4} \\
5 \times 10^{-4}\end{array}$ & $\begin{array}{l}8.3 \times 10^{-8} \\
13 \times 10^{-6}\end{array}$ \\
\hline 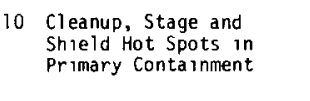 & $\begin{array}{l}\text { Sweeping } \\
\text { Vacuuming }\end{array}$ & $\begin{array}{l}1.5 \times 10^{1} \\
8.0 \times 10^{0}\end{array}$ & $\begin{array}{l}5 \\
5\end{array}$ & $\begin{array}{l}1.1 \times 10^{-3} \\
1.1 \times 10^{-3}\end{array}$ & $\begin{array}{l}17 \times 10^{-2} \\
86 \times 10^{-3}\end{array}$ & $\begin{array}{l}5 \times 10^{-4} \\
5 \times 10^{-4}\end{array}$ & $\begin{array}{l}86 \times 10^{-6} \\
43 \times 10^{-6}\end{array}$ \\
\hline $\begin{array}{l}\text { 11. Enlarge Suppression } \\
\text { Chamber Access }\end{array}$ & N/A & N/A & n/A & N/A & N/A & $5 \times 10^{-4}$ & N/A \\
\hline 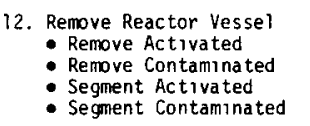 & $\begin{array}{l}\text { Oxyacetylene } \\
\text { Torch/Arc Saw }\end{array}$ & $\begin{array}{l}3.9 \times 10^{1} \\
9.4 \times 10 \\
9.2 \times 10 \\
4.7 \times 10^{1}\end{array}$ & $\begin{array}{l}2 \\
4 \\
2 \\
4\end{array}$ & $\begin{array}{l}5.5 \times 10^{-1} \\
2.5 \times 10^{-2} \\
4.1 \times 10^{-6} \\
6.5 \times 10^{-8}\end{array}$ & $\begin{array}{l}2.2 \times 10^{1} \\
2.4 \times 10^{-4} \\
3.8 \times 10^{-4} \\
3.1 \times 10^{-6}\end{array}$ & $\begin{array}{l}5 \times 10^{-5} \\
5 \times 10^{-5} \\
5 \times 10^{-5} \\
5 \times 10^{-5}\end{array}$ & $\begin{array}{l}1.1 \times 10^{-3} \\
12 \times 10^{-4} \\
1.9 \times 100^{-8} \\
1.5 \times 10^{-10}\end{array}$ \\
\hline $\begin{array}{l}\text { 13. Shpp Activated Reactor } \\
\text { Vessel Segments }\end{array}$ & Truck Transport & N/A & 2 & See Section N.5 & i/A & $N / A$ & iect \\
\hline $\begin{array}{l}\text { 14. Remove Primary Contain- } \\
\text { ment } \\
\text { ment }\end{array}$ & 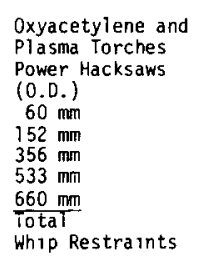 & $\begin{array}{l}3.4 \times 10^{2} \\
3.2 \times 10^{2} \\
1.6 \times 10^{2} \\
9.7 \times 10^{2} \\
7.5 \times 10^{2} \\
9.5 \times 10^{1}\end{array}$ & $\begin{array}{l}4 \\
4 \\
4 \\
4 \\
4 \\
5\end{array}$ & $\begin{array}{l}5.3 \times 10^{-4} \\
2.2 \times 10^{-3} \\
1.4 \times 10^{-3} \\
7.3 \times 10^{-4} \\
1.7 \times 10^{-4} \\
4.7 \times 10^{-4}\end{array}$ & 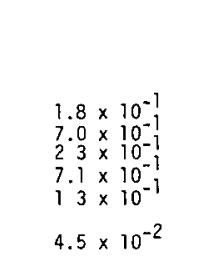 & $\begin{array}{l}5 \times 10^{-4} \\
5 \times 10^{-4} \\
5 \times 10^{-4} \\
5 \times 10^{-4} \\
5 \times 10^{-4} \\
5 \times 10^{-4}\end{array}$ & $\begin{array}{l}9.0 \times 10^{-5} \\
3.5 \times 10^{-4} \\
1.5 \times 10^{-4} \\
3.6 \times 10^{-4} \\
6.5 \times 10^{-5} \\
9.6 \times 10 \times 10-4 \\
2.2 \times 10^{-5}\end{array}$ \\
\hline 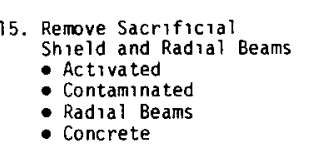 & $\begin{array}{l}\text { Oxyacetylene } \\
\text { Iorch } \\
\text { Drinl 11ng } \\
\text { Blasting }\end{array}$ & 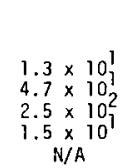 & $\begin{array}{l}2 \\
5 \\
5 \\
3 \\
3\end{array}$ & $\begin{array}{l}3.4 \times 10^{-1} \\
2.5 \times 10^{-3} \\
4.6 \times 10^{-9} \\
2.3 \times 10^{-9} \\
1.9 \times 10^{-6}\end{array}$ & 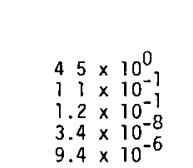 & 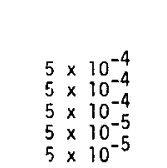 & $\begin{array}{l}2.2 \times 10^{-3} \\
5.5 \times 10^{-5} \\
5.3 \times 10 \\
1.7 \times 12 \\
4.7 \times 10-10\end{array}$ \\
\hline 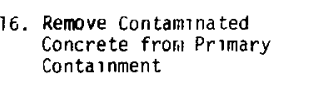 & $\begin{array}{l}\text { Driling } \\
\text { Spalling }\end{array}$ & $\begin{array}{l}3.8 \times 10^{3} \\
6.6 \times 10^{3}\end{array}$ & $\begin{array}{l}5 \\
5\end{array}$ & $6.0 \times 1 / \mathbb{N}^{0^{-6}}$ & $2.3 \times 10_{1 / A}^{-2}$ & $5 \times 10^{5 / A}$ & $1.1 \times 11^{1 / A} \mathrm{~A} 0^{-5}$ \\
\hline 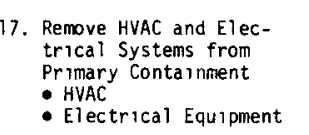 & $\begin{array}{l}\text { Oxyacetylene } \\
\text { Torch }\end{array}$ & $\begin{array}{l}1 . \times 10^{2} \\
1.2 \times 10^{2}\end{array}$ & $\begin{array}{l}5 \\
5\end{array}$ & $\begin{array}{l}2.9 \times 10^{-3} \\
1.0 \times 10^{-3}\end{array}$ & $\begin{array}{l}32 \times 10^{-1} \\
1.2 \times 10^{-1}\end{array}$ & $\begin{array}{l}5 \times 10^{-4} \\
5 \times 10^{-4}\end{array}$ & $\begin{array}{l}16 \times 10^{-4} \\
6.1 \times 10^{-5}\end{array}$ \\
\hline $\begin{array}{l}\text { 18. Orain Contaminated Sys- } \\
\text { tems to Radwaste }\end{array}$ & Draning & N/A & In/A & W/A & $\mathrm{N} / \mathrm{A}$ & $5 \times 10^{-4}$ & N/A \\
\hline
\end{tabular}

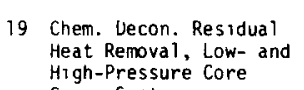

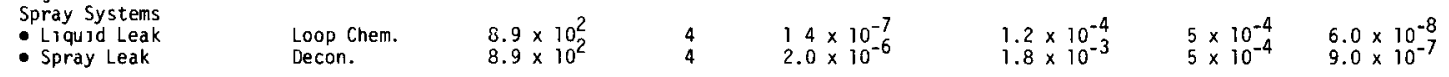

20. Rempe Reactor Bu ld-
ing p p p ping

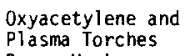

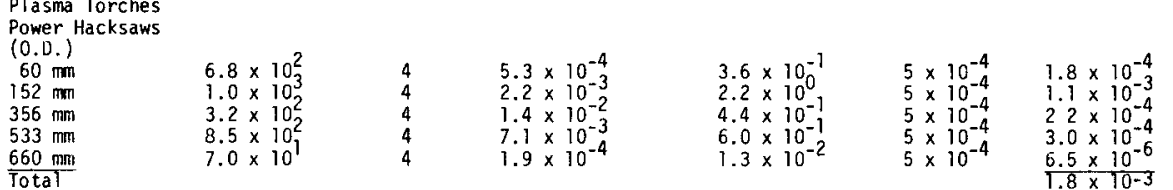

21. Drain Pryer and Separa-
tor Pool to Radwaste;
water-Jet Clean

Chemical Decon
Drain Systems

: Liquid Leak
Spray Leak

23. Drain Spent Fuel Pool
to Radwaste; Water-

to Radwaste; Water-
Jet Clean

24. Chemrcal Decon Fuel
Pool cooling and
Cleansysteak

Cleanup Systerin
: Liquid Leak
- Spray Leak

25 Remove Reactor Bur ld-

$1.2 \times 10^{1}$
and

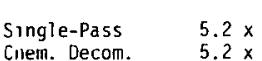

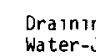

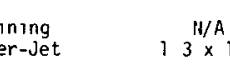

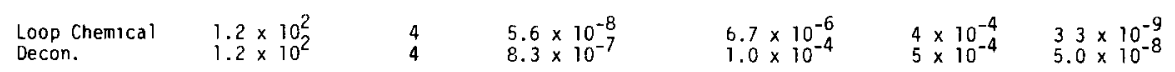

$\begin{gathered}\text { Oxycectylene } \\ \text { Torch }\end{gathered} 31 \times 10^{2} \quad 4 \quad 2.1 \times 10^{-3}$

$6.4 \times 10^{-1} \quad 5 \times 10^{-4} \quad 32 \times 10^{-4}$

26 Remove L L Iners from
Spent Fuel Pool, Reac
tor well, and Dryer

tor well, and Dryer
and Separator Pool

27 Remove Reactor Bu 1ld-
ing Contarinnated Con-

Plasma To

$1.5 \times 10^{2}$

$4.7 \times 10^{-3}$

$7.0 \times 10^{-1} \quad 5 \times 10^{-4} \quad 3.5 \times 10^{-4}$

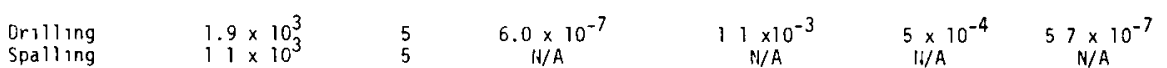

28. Remove HVAC and Elec-
trical systems from

trical systems fiec
Reactor Building

Reactor Building
- Elvectrical Equipment

Oxyacetylene $\quad 3.7 \times$

$7 \times 10^{2}$
$4 \times 10^{2}$
4

$\begin{array}{lll}1.1 \times 10^{-1} & 5 \times 10^{-4} & 5.5 \times 10^{-4} \\ 26 \times 10^{-3} & 5 \times 10^{-4} & 1.3 \times 10^{-6}\end{array}$

(a) These numbers refer to the Reference Radionucl lde Inventories discussed in Appendix $E$.

I/A

$\mathrm{N} / \mathrm{A}$

envelope and the bullding HEPA filter is $5 \times 10^{-5}$ for comparison purposes

(e) Primary containnent piping is included with reactor building equipment for this analysis.
(e) 
TABLE N.2-8. Calculated Atmospheric Releases for Immediate Dismantlement of the Turbine Generator Building

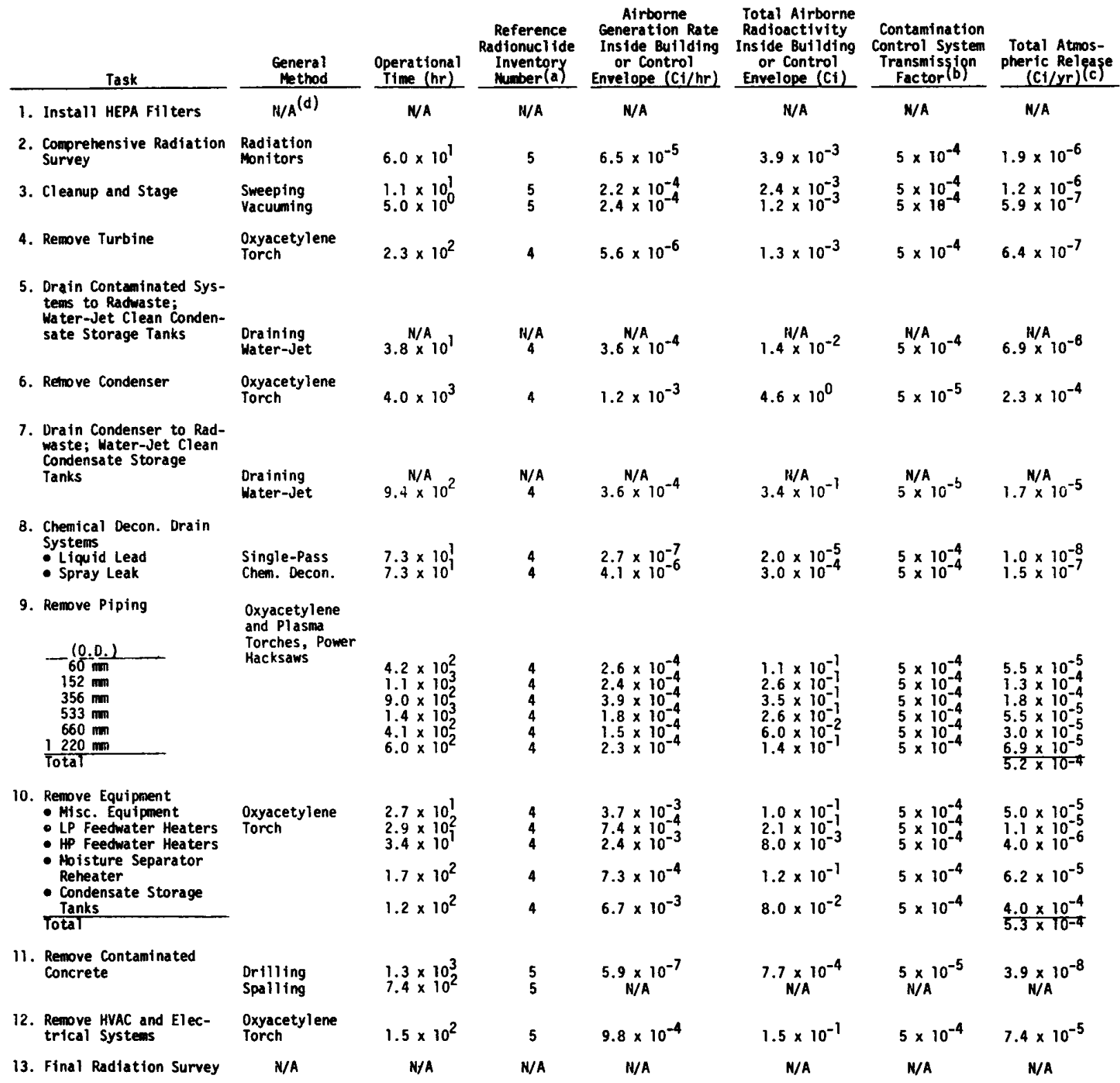

(a) These numbers refer to the reference radionuclide inventories discussed in Appendix $E$.

(b) The assumed building HEPA filter transmission factor is $5 \times 10^{-4}$. The combined transmission factor for a contamination control envelope and the building HEPA filter is $5 \times 10^{-5}$.

(c) Dose calculations are made based on annual releases for comparison purposes.

(d) $M / A=$ Not Appl icable. 
TABLE N.2-9. Calculated Atmospheric Releases for Immediate Dismantlement of the Radwaste and Control Building

\begin{tabular}{|c|c|c|c|c|c|c|c|c|}
\hline & Task & $\begin{array}{r}\text { General } \\
\text { Method }\end{array}$ & $\begin{array}{l}\text { Operational } \\
\text { Time (hr) }\end{array}$ & $\begin{array}{c}\text { Reference } \\
\text { Radionucl ide } \\
\text { Inventory } \\
\text { Number }(a) \\
\end{array}$ & $\begin{array}{c}\text { Airborne } \\
\text { Generation Rate } \\
\text { Inside Building } \\
\text { or Control } \\
\text { Envelope (Ci/hr) }\end{array}$ & $\begin{array}{l}\text { Total Airborne. } \\
\text { Radioactivity } \\
\text { Inside Building } \\
\text { or Control } \\
\text { Envelope (Ci) } \\
\end{array}$ & $\begin{array}{c}\text { Contamination } \\
\text { Control System } \\
\text { Transmission } \\
\text { Factor(b) } \\
\end{array}$ & $\begin{array}{l}\text { Total Atmos- } \\
\text { pheric Release } \\
(\mathrm{Ci} / \mathrm{yr})(\mathrm{c}) \\
\end{array}$ \\
\hline & $\begin{array}{l}\text { Comprehensive Radiation } \\
\text { Survey }\end{array}$ & $\begin{array}{l}\text { Radiation Moni- } \\
\text { tors }\end{array}$ & $6.0 \times 10^{1}$ & 5 & $4.6 \times 10^{-4}$ & $2.8 \times 10^{-2}$ & $\leq \times 10^{-4}$ & $1.4 \times 10^{-5}$ \\
\hline 2. & General Cleanup & Sweeping & $3.0 \times 10^{1}$ & 5 & $1.6 \times 10^{-3}$ & $4.6 \times 10^{-2}$ & $5 \times 10^{-4}$ & $2.3 \times 10^{-5}$ \\
\hline & $\begin{array}{l}\text { Chemical Decon. } \\
\text { Dra in Sys tems } \\
\text { - Liquid Leak } \\
\text { - Spray Leak }\end{array}$ & $\begin{array}{l}\text { Single-Pass } \\
\text { Chem. Decon. }\end{array}$ & $\begin{array}{l}2.6 \times 10 \\
2.6 \times 10^{1}\end{array}$ & $\begin{array}{l}4 \\
4\end{array}$ & $\begin{array}{l}3.4 \times 10^{-7} \\
3.5 \times 10^{-6}\end{array}$ & $\begin{array}{l}6.1 \times 10^{-6} \\
9.2 \times 10^{-5}\end{array}$ & $\begin{array}{l}5 \times 10^{-4} \\
5 \times 10^{-4}\end{array}$ & $\begin{array}{l}3.0 \times 10^{-9} \\
4.6 \times 10^{-8}\end{array}$ \\
\hline & $\begin{array}{l}\text { Chemical Decom. Equip- } \\
\text { ment; Na ter-Jet Clean } \\
\text { - Liquid Leak } \\
\text { - Spray Leak }\end{array}$ & $\begin{array}{l}\text { Water-Jet } \\
\text { Loop Chem. } \\
\text { Decon. }\end{array}$ & $\begin{array}{l}4.9 \times 10 \\
4.0 \times 10 \\
4.0 \times 10\end{array}$ & $\begin{array}{l}4 \\
4 \\
4\end{array}$ & $\begin{array}{l}3.3 \times 10^{-2} \\
1.4 \times 10^{-5} \\
2.1 \times 10^{-4}\end{array}$ & $\begin{array}{l}1.6 \times 10^{0} \\
5.7 \times 10^{-4} \\
8.6 \times 10^{-3}\end{array}$ & $\begin{array}{l}5 \times 10^{-4} \\
5 \times 10^{-4} \\
5 \times 10^{-4}\end{array}$ & $\begin{array}{l}8.1 \times 10^{-4} \\
2.8 \times 10^{-7} \\
4.3 \times 10^{-6}\end{array}$ \\
\hline b. & Rernove PIping & $\begin{array}{l}\text { Oxyacetylene } \\
\text { and P1 asma } \\
\text { Torches, Power } \\
\text { Hacksaws (0.D.) } \\
60 \mathrm{~mm} \\
152 \mathrm{~mm} \\
356 \mathrm{~mm} \\
533 \mathrm{~mm} \\
914 \mathrm{~mm} \\
\text { Total }\end{array}$ & $\begin{array}{l}4.0 \times 10^{2} \\
1.0 \times 10^{3} \\
1.6 \times 10^{2} \\
7.0 \times 10^{0} \\
3.8 \times 10^{1}\end{array}$ & $\begin{array}{l}4 \\
4 \\
4 \\
4 \\
4\end{array}$ & $\begin{array}{l}8.0 \times 10^{-4} \\
9.7 \times 10^{-4} \\
5.1 \times 10^{-4} \\
8.6 \times 10^{-5} \\
1.4 \times 10^{-3}\end{array}$ & $\begin{array}{l}3.2 \times 10^{-1} \\
9.7 \times 10^{-1} \\
8.2 \times 10^{-2} \\
6.0 \times 10^{-3} \\
5.1 \times 10^{-2}\end{array}$ & $\begin{array}{l}5 \times 10^{-4} \\
5 \times 10^{-4} \\
5 \times 10^{-4} \\
5 \times 10^{-4} \\
5 \times 10^{-4}\end{array}$ & $\begin{array}{l}1.6 \times 10^{-4} \\
4.8 \times 10^{-4} \\
4.1 \times 10^{-5} \\
3.0 \times 10^{-6} \\
2.6 \times 10^{-5} \\
7.1 \times 10^{-4}\end{array}$ \\
\hline & $\begin{array}{l}\text { Install Temporary } \\
\text { Radwaste System }\end{array}$ & $N / A^{(d)}$ & H/A & N/A & $\mathrm{N} / \mathrm{A}$ & N/A & $\mathrm{N} / \mathrm{A}$ & N/A \\
\hline & Rernove Equipment & $\begin{array}{l}\text { Oxyacetylene } \\
\text { Torch }\end{array}$ & $3.3 \times 10^{2}$ & 4 & $2.7 \times 10^{-2}$ & $9.0 \times 10^{0}$ & $5 \times 10^{-4}$ & $4.5 \times 10^{-3}$ \\
\hline & $\begin{array}{l}\text { Remove Contaminated } \\
\text { Concrete }\end{array}$ & $\begin{array}{l}\text { Drilling } \\
\text { Spalling }\end{array}$ & $\begin{array}{l}6.6 \times 10^{2} \\
3.8 \times 10^{2}\end{array}$ & $\begin{array}{l}5 \\
5\end{array}$ & $\operatorname{lin}_{\mathrm{N} / \mathrm{A}} \times \mathrm{10}^{-6}$ & $2.9 \times 10^{N / A}$ & $5 \times 10^{-5}$ & $1.4 \times 10^{-7} / A$ \\
\hline & $\begin{array}{l}\text { Remove Misc. Steel } \\
\text { Structures }\end{array}$ & $\begin{array}{l}\text { Oxyacetylene } \\
\text { Torch and Power } \\
\text { Hacksaws }\end{array}$ & $1.3 \times 10^{1}$ & 5 & $3.1 \times 10^{-4}$ & $4.0 \times 10^{-3}$ & $5 \times 10^{-4}$ & $2.0 \times 10^{-6}$ \\
\hline 10. & $\begin{array}{l}\text { Remove HVAC and Elec- } \\
\text { trical Systems }\end{array}$ & $\begin{array}{l}\text { Oxyacetylene } \\
\text { Torch } \\
\text { Power Hacksaws }\end{array}$ & $\begin{array}{l}1.2 \times 10^{2} \\
2.2 \times 10^{1}\end{array}$ & $\begin{array}{l}5 \\
5\end{array}$ & $\begin{array}{l}1.1 \times 10^{-3} \\
6.8 \times 10^{-4}\end{array}$ & $\begin{array}{l}1.4 \times 10^{-3} \\
1.5 \times 10^{-2}\end{array}$ & $\begin{array}{l}5 \times 10^{-4} \\
5 \times 10^{-4}\end{array}$ & $\begin{array}{l}6.8 \times 10^{-5} \\
7.6 \times 10^{-6}\end{array}$ \\
\hline 11. & Final Radiation Survey & & H/A & $N / A$ & $N / A$ & N/A & $\mathrm{N} / \mathrm{A}$ & N/A \\
\hline
\end{tabular}

(a) These numbers refer to the reference radionucl ide inventories discussed in Appendix $E$.

(b) The assumed building HEPA filter transmission factor is $5 \times 10^{-4}$. The combined transmission factor for a contamination control envelope and the building HEPA filter is $5 \times 10^{-5}$.

(c) Dose calculations are made based on annual releases for comparison purposes.

(d) $N / A=$ Not Applicable.

fifty-year committed dose equivalents to both the maximum-exposed individual and to the population residing within $80 \mathrm{~km}$ of the site are calculated for each of the reference BWR buildings analyzed. Each of the atmospheric releases is assumed to be a chronic release; that is, one that occurs at a uniform rate for a period of one year. A uniform chronic release is assumed so that direct comparisons of the impact of immediate dismantlement tasks can be made. 
Radiation doses from atmospheric releases of radioactivity are calculated for direct exposure, inhalation, and ingestion radiation exposure pathways. Radiation doses from air submersion are not calculated since they have been shown to be insignificant in previous decommissioning studies. $(12,13,14)$ For inhalation, radionuclides are assumed to have soluble clearance times (as defined in Appendix F) for the organs of reference, except for the lung where insoluble clearance times are assumed. For this study, the organs of reference for which radiation dose is calculated include: total body, bone, lung, thyroid, and GI-tract (lower large intestine).

Radiation doses to the maximum-exposed individual are shown in Tables N.2-10, N.2-11, and N.2-12 for atmospheric releases from immediate dismantlement tasks in the Reactor Building, Turbine Generator Building, and Radwaste and Control Building. Population doses resulting from these atmospheric releases are shown in Tables N.2-13, N.2-14, and N.2-15 for these buildings, respectively. The atmospheric dispersion $\left(\bar{X} / Q^{-}\right) \cdot$ values used in the dose calculations for routine atmospheric releases are $7.5 \times 10^{-6} \mathrm{sec} / \mathrm{m}^{3}$ for the maximumexposed individual and $2.4 \times 10^{-9} \mathrm{sec} / \mathrm{m}^{3}$ for the population. A total

population of $3.5 \times .10^{6}$ within $80 \mathrm{~km}$ of the site is assumed. More information on the reference site and the radiation dose models used in this study is found in Appendices $B$ and $F$, respectivery.

\section{N.2.2 Postulated Accidents During Immediate Dismantlement}

During immediate dismantlement, situations may arise that lead to the accidental atmospheric release of radioactivity. Accident scenarios and calculated airborne radioactivity releases considered for immediate dismantlement in this study are listed in Table N.2-16. The accidents are listed by decreasing atmospheric release. Accident scenarios are based on the technologies used during immediate dismantlement tasks. A general estimate of the frequency of occurrence of the level of the atmospheric release associated with each postulated accident is also given. The frequency of occurrence is arrived at by considering not only the probability of the accident but also the probability of an atmospheric release of the calculated magnitude. The frequency of occurrence is listed as "high" if the occurrence of a release of similar or greater magnitude per year is greater than $10^{-2}$, as "medium" if between $10^{-2}$ and $10^{-5}$, and as "low" if less than $10^{-5}$. 
TABLE N.2-10. Radiation Doses to the Maximum-Exposed Individual from Atmospheric Releases During Routine Immediate Dismantlement Tasks in the Reactor Building and Primary Containment

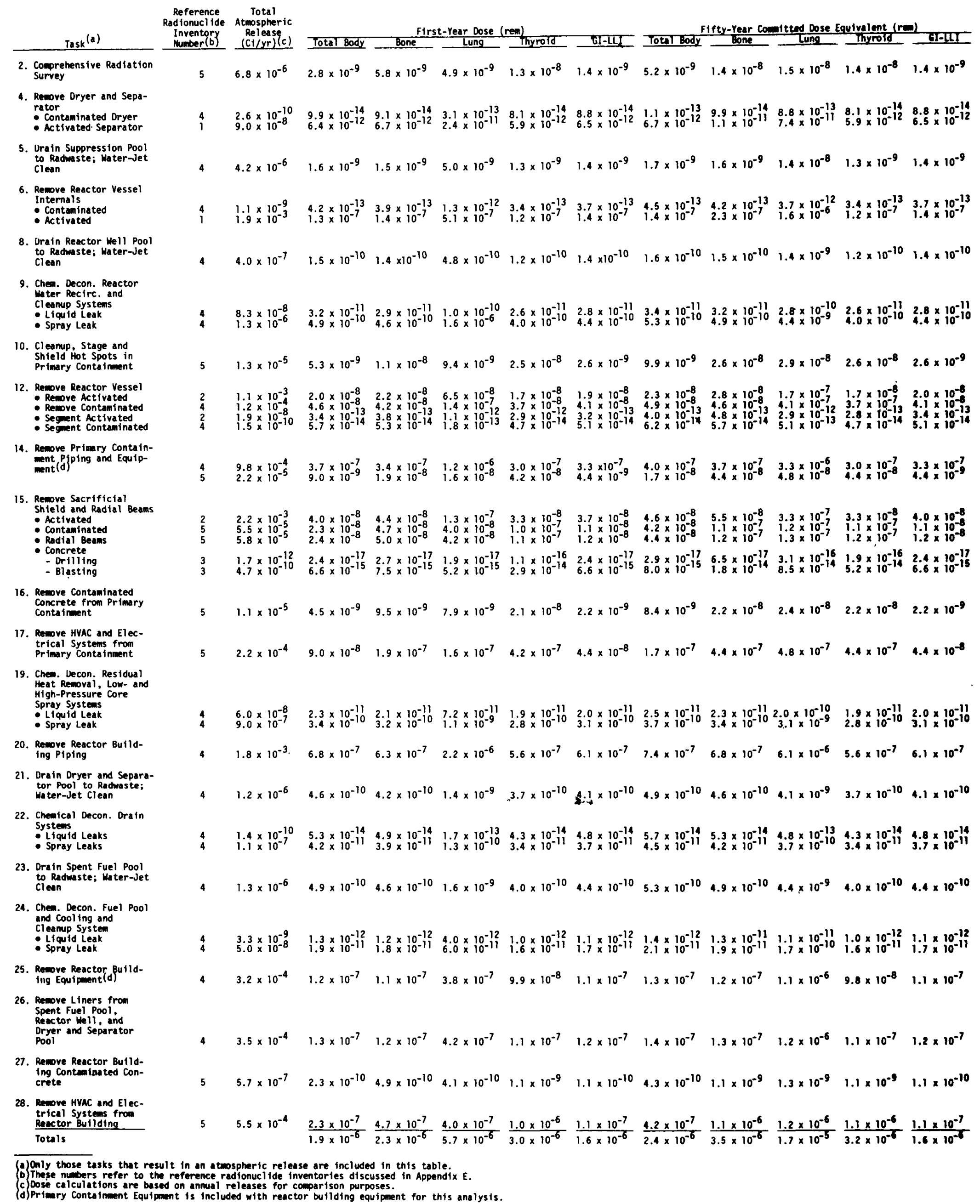

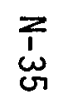


0 
TABLE N.2-11. Radiation Doses to the Maximum-Exposed Individual from Atmospheric Releases During Routine Immediate Dismantlement Tasks in the Turbine Generator Building

\begin{tabular}{|c|c|c|c|c|c|c|c|c|c|c|c|c|}
\hline $\operatorname{Task}(a)$ & $\begin{array}{l}\text { Reference } \\
\text { Radionucl ide } \\
\text { Inventory } \\
\text { Number }(b)\end{array}$ & $\begin{array}{c}\text { Total } \\
\text { Atmospheric } \\
\text { Release } \\
(C 1 / y r)(c)\end{array}$ & otal Body & Birs & $\frac{t \text {-Year Dose } 1}{\text { Lung }}$ & (rem) & 1 & & $\frac{\text { ifty-Year Com }}{\text { Eone }}$ & mitted Dose Ec & $\begin{array}{l}\text { quivalent (rem } \\
\text { Thyroid }\end{array}$ & \\
\hline $\begin{array}{l}\text { 2. Comprehensive Radiation } \\
\text { Survey }\end{array}$ & 5 & $1.9 \times 10^{-6}$ & $7.8 \times 10^{-10}$ & $1.6 \times 10^{-9}$ & $1.4 \times 10^{-9}$ & $3.6 \times 10^{-9}$ & $3.8 \times 10^{-10}$ & $1.4 \times 10^{-9}$ & $3.8 \times 10^{-9}$ & $4.2 \times 10^{-9}$ & $3.8 \times 10^{-9}$ & $3.8 \times 10^{-10}$ \\
\hline 3. Cl eanup and Stage & 5 & $1.8 \times 10^{-6}$ & $7.4 \times 10^{-10}$ & $1.5 \times 10^{-9}$ & $1.3 \times 10^{-9}$ & $3.4 \times 10^{-9}$ & $3.6 \times 10^{-10}$ & $1.4 \times 10^{-9}$ & $3.6 \times 10^{-9}$ & $4.0 \times 10^{-9}$ & $3.6 \times 10^{-9}$ & $3.6 \times 10^{-10}$ \\
\hline 4. Remove Turbine & 4 & $6.4 \times 10^{-7}$ & $2.4 \times 10^{-10}$ & $2.2 \times 10^{-10}$ & $7.7 \times 10^{-10}$ & $2.0 \times 10^{-10}$ & $2.2 \times 10^{-10}$ & $2.6 \times 10^{-10}$ & $2.4 \times 10^{-10}$ & $2.2 \times 10^{-9}$ & $2.0 \times 10^{-10}$ & $2.2 \times 10^{-10}$ \\
\hline $\begin{array}{l}\text { 5. Drain Contaminated Sys- } \\
\text { tems to Radwaste; } \\
\text { Watter-jet Clean Con- } \\
\text { densate Storage Tanks }\end{array}$ & 4 & $6.9 \times 10^{-6}$ & $2.6 \times 10^{-9}$ & $2.4 \times 10^{-9}$ & $3.3 \times 10^{-9}$ & $2.1 \times 10^{-9}$ & $2.3 \times 10^{-9}$ & $2.8 \times 10^{-9}$ & $2.6 \times 10^{-9}$ & $2.3 \times 10^{-8}$ & $2.1 \times 10^{-9}$ & $2.3 \times 10^{-9}$ \\
\hline 6. Remove Condenser & 4 & $2.3 \times 10^{-4}$ & $8.7 \times 10^{-8}$ & $8.1 \times 10^{-8}$ & $2.8 \times 10^{-7}$ & $7.1 \times 10^{-8}$ & $7.8 \times 10^{-8}$ & $9.4 \times 10^{-8}$ & $8.7 \times 10^{-8}$ & $7.8 \times 10^{-7}$ & $7.1 \times 10^{-8}$ & $7.8 \times 10^{-8}$ \\
\hline $\begin{array}{l}\text { 7. Urain Condenser to Ra } \\
\text { waste; Water-Jet Clea }\end{array}$ & 4 & $.7 \times 10^{-5}$ & $5 \times 10^{-9}$ & $0 \times 10^{-9}$ & $2.0 \times 10^{-8}$ & $5.3 \times 10^{-9}$ & $5.3 \times 10^{-9}$ & $7.0 \times 10^{-9}$ & $6.5 \times 10^{-9}$ & $5.8 \times 10^{-8}$ & $5.3 \times 10^{-9}$ & $5.8 \times 10^{-9}$ \\
\hline $\begin{array}{l}\text { 8. Chemical Lecon. Orain } \\
\text { Systens } \\
\text { : Liquid Leak } \\
\text { - Spray Leak }\end{array}$ & $\begin{array}{l}4 \\
4\end{array}$ & $\begin{array}{l}1.0 \times 10^{-8} \\
1.5 \times 10^{-7}\end{array}$ & $\begin{array}{l}3.8 \times 10^{-12} \\
5.7 \times 10^{-11}\end{array}$ & $\begin{array}{l}3.5 \times 10^{-12} \\
5.3 \times 10^{-11}\end{array}$ & $\begin{array}{l}1.2 \times 10^{-11} \\
1.8 \times 10^{-10}\end{array}$ & $\begin{array}{l}3.1 \times 10^{-12} \\
4.7 \times 10^{-11}\end{array}$ & $\begin{array}{l}3.4 \times 10^{-12} \\
5.1 \times 10^{-11}\end{array}$ & $\begin{array}{l}4.1 \times 10^{-12} \\
6.2 \times 10^{-11}\end{array}$ & $\begin{array}{l}3.8 \times 10^{-12} \\
5.7 \times 10^{-11}\end{array}$ & $\begin{array}{l}3.4 \times 10^{-11} \\
51 \times 10^{-10}\end{array}$ & $\begin{array}{l}3.1 \times 10^{-12} \\
4.7 \times 10^{-11}\end{array}$ & $\begin{array}{l}3.4 \times 10^{-12} \\
5.7 \times 10^{-11}\end{array}$ \\
\hline 9. Remove Piping & 4 & $5.2 \times 10^{-4}$ & $2.0 \times 10^{-7}$ & $1.8 \times 10^{-7}$ & $6.2 \times 10^{-7}$ & $1.6 \times 10^{-7}$ & $1.8 \times 10^{-7}$ & $2.1 \times 10^{-7}$ & $2.0 \times 10^{-7}$ & $1.8 \times 10^{-6}$ & $1.6 \times 10^{-7}$ & $1.8 \times 10^{-7}$ \\
\hline 10. Remove Equipment & 4 & $5.3 \times 10^{-4}$ & $2.0 \times 10^{-7}$ & $1.9 \times 10^{-7}$ & $6.4 \times 10^{-7}$ & $1.6 \times 10^{-7}$ & $1.8 \times 10^{-7}$ & $2.2 \times 10^{-7}$ & $2.0 \times 10^{-7}$ & $1.8 \times 10^{-6}$ & $1.6 \times 10^{-7}$ & $1.8 \times 10^{-7}$ \\
\hline $\begin{array}{l}\text { 11. Remove Contaminated } \\
\text { Concrete }\end{array}$ & 5 & $3.9 \times 10^{-8}$ & $1.6 \times 10^{-11}$ & $3.4 \times 10^{-31}$ & $2.8 \times 10^{-11}$ & $7.4 \times 10^{-11}$ & $7.8 \times 10^{-12}$ & $3.0 \times 10^{-11}$ & $1.8 \times 10^{-11}$ & $8.6 \times 10^{-11}$ & $7.8 \times 10^{-11}$ & $7.8 \times 10^{-12}$ \\
\hline $\begin{array}{l}\text { 12. Remove HVAC and Elec- } \\
\text { trical systems } \\
\text { Totals }\end{array}$ & 5 & $7.4 \times 10^{-5}$ & $\frac{3.0 \times 10^{-8}}{5.3 \times 10^{-7}}$ & $\frac{5.4 \times 10^{-8}}{5.3 \times 10^{-7}}$ & $\frac{5.3 \times 10^{-8}}{1.6 \times 10^{-6}}$ & $\frac{1.4 \times 10^{-7}}{5.5 \times 10^{-7}}$ & $\frac{1.5 \times 10^{-8}}{4.6 \times 10^{-7}}$ & $\frac{5.6 \times 10^{-8}}{5.9 \times 10^{-7}}$ & $\frac{1.5 \times 10^{-7}}{6.5 \times 10^{-7}}$ & $\frac{1.6 \times 10^{-7}}{4.6 \times 10^{-6}}$ & $\frac{1.5 \times 10^{-7}}{5.6 \times 10^{-7}}$ & $\frac{1.5 \times 10^{-8}}{4.6 \times 10^{-7}}$ \\
\hline
\end{tabular}

(a) Only those tasks that result in an atmospheric release are included in this table.

b) These numbers refer to the reference radionuclide inventories discussed in Appendix $E$.
(c) vose calculations are based on annual releases for comparison purposes. 
TABLE N.2-12. Radiation Doses to the Maximum-Exposed Individual from Atmospheric Releases During Routine Immediate Dismantlement Tasks in the Radwaste and Control Building

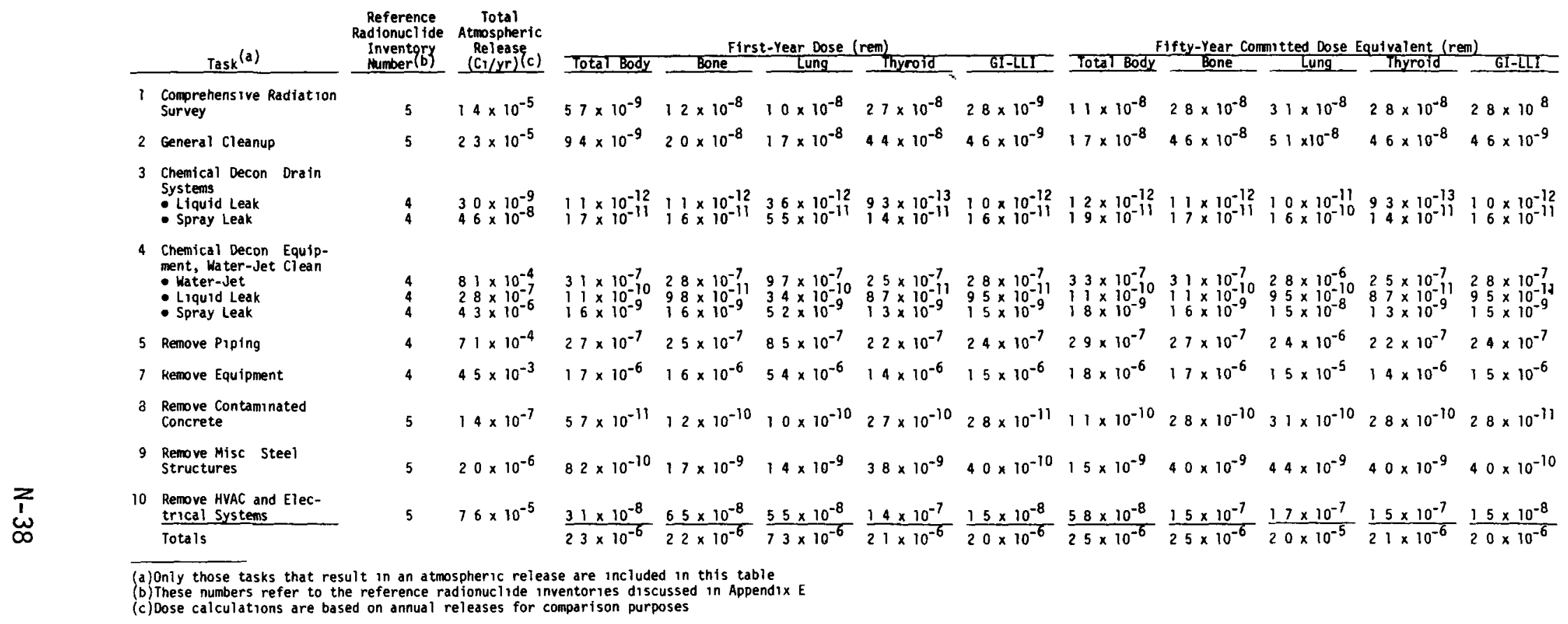


TABLE N.2-13. Radiation Doses to the Population from Atmospheric Rejeases During Routine Immediate Dismantlement

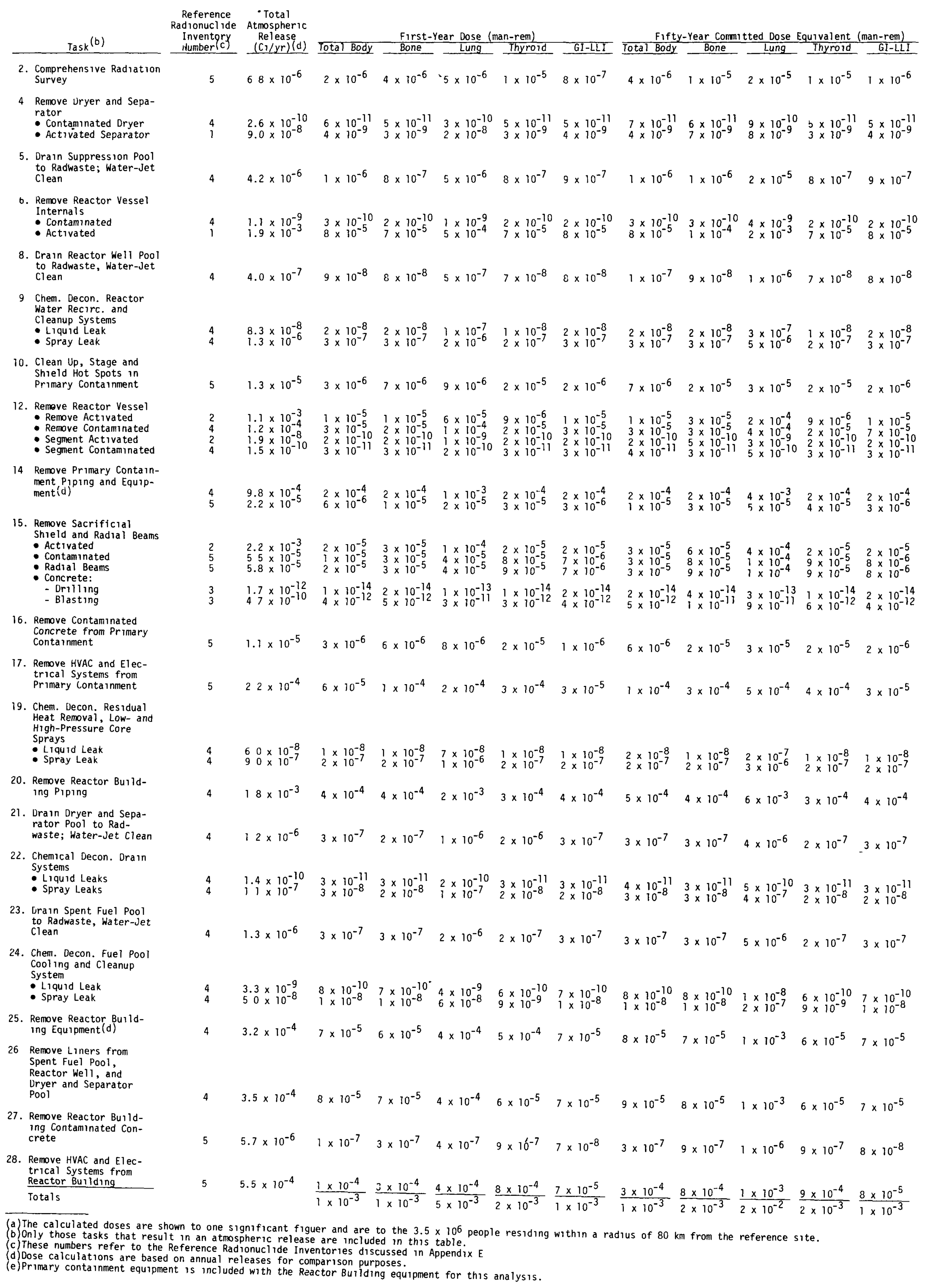



TABLE N.2-14. Radiation Doses to the Population from Atmospheric Releases During Routine Immediate Dismantlement Tasks in the Turbine Generator Building(a)

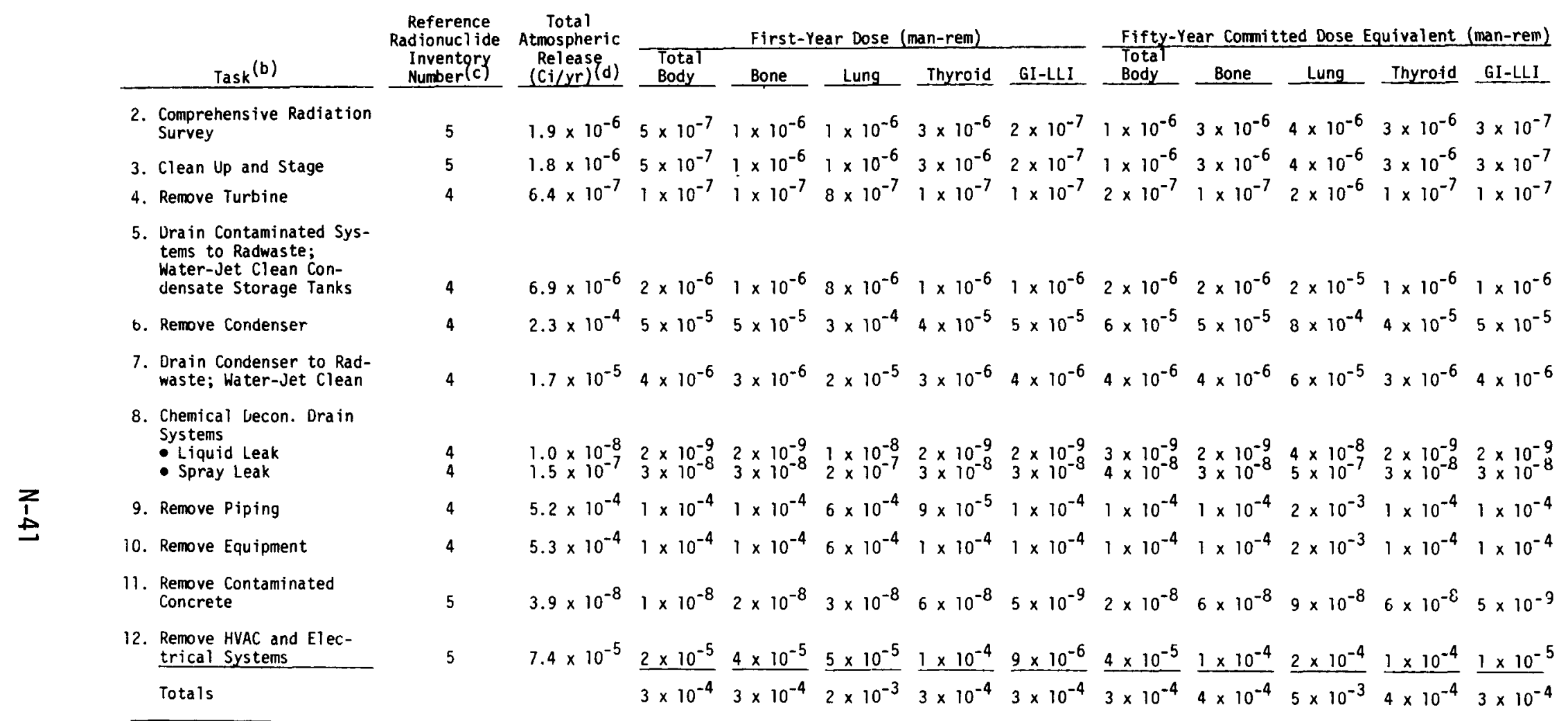

(a) The calculated doses are shown to one significant figure and are to the $3.5 \times 10^{6}$ people residing within a radius of $80 \mathrm{~km}$ from the reference site. (b) Only those tasks that result in an atmospheric release are included in this table.

c) These numbers refer to the reference radionuclide inventories discussed in Appendix $E$.

(d) Dose calculations are based on annual releases for comparison purposes. 

TABLE N.2-15. Radiation Doses to the Population from Atmospheric Releases During Routine Immediate
Dismantlement Tasks in the Radwaste and Control Building (a)

\begin{tabular}{|c|c|c|c|c|c|c|c|c|c|c|c|c|c|}
\hline \multirow{2}{*}{\multicolumn{2}{|c|}{ Task ${ }^{(b)}$}} & \multirow{2}{*}{$\begin{array}{c}\text { Reference } \\
\text { Radionucl ide } \\
\text { Inventory } \\
\text { Number }(c) \\
\end{array}$} & \multirow{2}{*}{$\begin{array}{c}\text { Total } \\
\text { Atmospheric } \\
\text { Release } \\
(\text { Ci } / \text { yr })(d) \\
\end{array}$} & \multicolumn{5}{|c|}{ First-Year Dose (man-rem) } & \multicolumn{5}{|c|}{ Fifty-Year Committed Dose Equivalent (man-rem) } \\
\hline & & & & $\begin{array}{r}\text { Total } \\
\text { Body } \\
\end{array}$ & Bone & Lung & Thyroid & GI-LLI & $\begin{array}{l}\text { Total } \\
\text { Body } \\
\end{array}$ & Bone & Lung & Thyroid & GI-LLI \\
\hline & $\begin{array}{l}\text { Comprehensive Radiation } \\
\text { Survey }\end{array}$ & 5 & $1.4 \times 10^{-5}$ & $4 \times 10^{-6}$ & $8 \times 10^{-6}$ & $1 \times 10^{-5}$ & $2 \times 10^{-5}$ & $2 \times 10^{-6}$ & $8 \times 10^{-6}$ & $2 \times 10^{-5}$ & $3 \times 10^{-5}$ & $2 \times 10^{-5}$ & $2 \times 10^{-6}$ \\
\hline 2. & General Cleanup & 5 & $2.3 \times 10^{-5}$ & $6 \times 10^{-6}$ & $1 \times 10^{-5}$ & $2 \times 10^{-5}$ & $3 \times 10^{-5}$ & $3 \times 10^{-6}$ & $1 \times 10^{-5}$ & $3 \times 10^{-5}$ & $5 \times 10^{-5}$ & $4 \times 10^{-5}$ & $3 \times 10^{-6}$ \\
\hline 3. & $\begin{array}{l}\text { Chemical Lecon. Drain } \\
\text { Systems } \\
\text { - Liquid Leak } \\
\text { - Spray Leak }\end{array}$ & $\begin{array}{l}4 \\
4\end{array}$ & $\begin{array}{l}3.0 \times 10^{-9} \\
4.6 \times 10^{-8}\end{array}$ & $\begin{array}{l}7 \times 10^{-10} \\
1 \times 10^{-8}\end{array}$ & $\begin{array}{l}6 \times 10^{-10} \\
9 \times 10^{-9}\end{array}$ & $\begin{array}{l}4 \times 10^{-9} \\
6 \times 10^{-8}\end{array}$ & $\begin{array}{l}5 \times 10^{-10} \\
8 \times 10^{-9}\end{array}$ & $\begin{array}{l}6 \times 10^{-10} \\
1 \times 10^{-8}\end{array}$ & $\begin{array}{l}8 \times 10^{-10} \\
1 \times 10^{-8}\end{array}$ & $\begin{array}{l}7 \times 10^{-10} \\
1 \times 10^{-8}\end{array}$ & $\begin{array}{l}1 \times 10^{-8} \\
2 \times 10^{-7}\end{array}$ & $\begin{array}{l}5 \times 10^{-10} \\
8 \times 10^{-9}\end{array}$ & $\begin{array}{l}6 \times 10^{-10} \\
1 \times 10^{-8}\end{array}$ \\
\hline & $\begin{array}{l}\text { Chemical Decon. Equip- } \\
\text { ment; Water-Jet Clean } \\
\text { - Wa ter-Jet } \\
\text { - Liquid Leak } \\
\text { - Spray Leak }\end{array}$ & $\begin{array}{l}4 \\
4 \\
4\end{array}$ & $\begin{array}{l}8.1 \times 10^{-4} \\
2.8 \times 10^{-7} \\
4.3 \times 10^{-6}\end{array}$ & $\begin{array}{l}2 \times 10^{-4} \\
6 \times 10^{-8} \\
1 \times 10^{-6}\end{array}$ & $\begin{array}{l}2 \times 10^{-4} \\
6 \times 10^{-8} \\
9 \times 10^{-7}\end{array}$ & $\begin{array}{l}1 \times 10^{-3} \\
3 \times 10^{-7} \\
5 \times 10^{-6}\end{array}$ & $\begin{array}{l}1 \times 10^{-4} \\
5 \times 10^{-8} \\
8 \times 10^{-7}\end{array}$ & $\begin{array}{l}2 \times 10^{-4} \\
6 \times 10^{-8} \\
9 \times 10^{-7}\end{array}$ & $\begin{array}{l}2 \times 10^{-4} \\
7 \times 10^{-8} \\
1 \times 10^{-6}\end{array}$ & $\begin{array}{l}2 \times 10^{-4} \\
6 \times 10^{-8} \\
1 \times 10^{-6}\end{array}$ & $\begin{array}{l}3 \times 10^{-3} \\
1 \times 10^{-6} \\
2 \times 10^{-5}\end{array}$ & $\begin{array}{l}1 \times 10^{-4} \\
5 \times 10^{-8} \\
8 \times 10^{-7}\end{array}$ & $\begin{array}{l}2 \times 10^{-4} \\
6 \times 10^{-8} \\
9 \times 10^{-7}\end{array}$ \\
\hline 5. & Kemove Piping & 4 & $7.1 \times 10^{-4}$ & $2 \times 10^{-4}$ & $1 \times 10^{-4}$ & $9 \times 10^{-4}$ & $1 \times 10^{-4}$ & $1 \times 10^{-4}$ & $2 \times 10^{-4}$ & $2 \times 10^{-4}$ & $3 \times 10^{-3}$ & $1 \times 10^{-4}$ & $1 \times 10^{-4}$ \\
\hline 7. & Remove Equipment & 4 & $4.5 \times 10^{-3}$ & $1 \times 10^{-3}$ & $9 \times 10^{-4}$ & $5 \times 10^{-3}$ & $8 \times 10^{-4}$ & $9 \times 10^{-4}$ & $1 \times 10^{-3}$ & $1 \times 10^{-3}$ & $2 \times 10^{-2}$ & $8 \times 10^{-4}$ & $9 \times 10^{-4}$ \\
\hline 8. & $\begin{array}{l}\text { Remove Contaminated } \\
\text { Concrete }\end{array}$ & 5 & $1.4 \times 10^{-7}$ & $4 \times 10^{-8}$ & $8 \times 10^{-8}$ & $1 \times 10^{-7}$ & $2 \times 10^{-7}$ & $2 \times 10^{-8}$ & $8 \times 10^{-8}$ & $2 \times 10^{-7}$ & $3 \times 10^{-7}$ & $2 \times 10^{-7}$ & $2 \times 10^{-8}$ \\
\hline 9. & $\begin{array}{l}\text { Remove Ifiscellaneous } \\
\text { Electrical Sys tems }\end{array}$ & 5 & $2.0 \times 10^{-6}$ & $5 \times 10^{-7}$ & $1 \times 10^{-6}$ & $1 \times 10^{-6}$ & $3 \times 10^{-6}$ & $2 \times 10^{-7}$ & $1 \times 10^{-6}$ & $3 \times 10^{-6}$ & $5 \times 10^{-6}$ & $3 \times 10^{-6}$ & $3 \times 10^{-7}$ \\
\hline 10. & $\begin{array}{l}\text { Remove HVAC and Elec- } \\
\text { trical Systems }\end{array}$ & 5 & $7.6 \times 10^{-5}$ & $2 \times 10^{-5}$ & $4 \times 10^{-5}$ & $5 \times 10^{-5}$ & $1 \times 10^{-4}$ & $9 \times 10^{-6}$ & $4 \times 10^{-5}$ & $1 \times 10^{-4}$ & $2 \times 10^{-4}$ & $1 \times 10^{-4}$ & $1 \times 10^{-5}$ \\
\hline & Totals & & & $1 \times 10^{-3}$ & $1 \times 10^{-3}$ & $7 \times 10^{-3}$ & $1 \times 10^{-3}$ & $1 \times 10^{-3}$ & $1 \times 10^{-3}$ & $2 \times 10^{-3}$ & $3 \times 10^{-2}$ & $1 \times 10^{-3}$ & $1 \times 10^{-3}$ \\
\hline
\end{tabular}

(a) The calculated doses are shown to one significant figure and are to the $3.5 \times 10^{6}$ people residing within a radius of $80 \mathrm{~km}$ from the reference site.

(b) Only those tasks that result in an atmospheric release are included in this table.

(c) These numbers refer to the reference radionuclide inventories discussed in Appendix $E$.

(d) Dose calculations are based on annual releases for comparison purposes. 
TABLE N.2-16. Postulated Accidental Atmospheric Releases During Immediate Dismantlement of the Reference BWR

\begin{tabular}{|c|c|c|c|c|c|c|}
\hline Incident & Conments & $\begin{array}{l}\text { Frequency of } \\
\text { Occurrence (a) }\end{array}$ & $\begin{array}{c}\text { Reference } \\
\text { Radionuclide } \\
\text { Inventory } \\
\text { Number (b) } \\
\end{array}$ & $\begin{array}{l}\text { Total Airborne } \\
\text { Radioactivity } \\
\text { Inside Building } \\
\text { or Control } \\
\text { Envelope (Ci) } \\
\end{array}$ & $\begin{array}{c}\text { Contamination } \\
\text { Control System } \\
\text { Transmission } \\
\text { Factor(c) } \\
\end{array}$ & $\begin{array}{l}\text { Total } \\
\text { Atmospheric } \\
\text { Release } \\
(\mathrm{Ci} / \mathrm{hr})(\mathrm{d}) \\
\end{array}$ \\
\hline $\begin{array}{l}\text { Explosion of LPG } \\
\text { Leaked from a } \\
\text { Front-End Loader }\end{array}$ & $\begin{array}{l}4.5 \mathrm{~kg} \text { of LPG leaked in the } \\
\text { reactor building during the } \\
\text { loading of activated concrete }\end{array}$ & Low & 3 & $8.6 \times 10^{-3}$ & 1.0 & $8.6 \times 10^{-3}$ \\
\hline $\begin{array}{l}\text { Vacuum Fi1 ter-Bag } \\
\text { Rupture }\end{array}$ & $\begin{array}{l}\text { Rupture of a full filter-bag } \\
\text { during surface cleaning }\end{array}$ & Medium & 5 & $1.7 \times 10^{0}$ & $5.0 \times 10^{-4}$ & $3.5 \times 10^{-4}$ \\
\hline $\begin{array}{l}\text { Contamination } \\
\text { Control Envelope } \\
\text { Rupture }\end{array}$ & $\begin{array}{l}\text { Leakage during reactor vessel } \\
\text { removal (Task } 12 \text { in the Reactor } \\
\text { Building) }\end{array}$ & High & 2 & $2.8 \times 10^{-1}$ & $5.0 \times 10^{-4}$ & $1.4 \times 10^{-4}$ \\
\hline $\begin{array}{l}\text { Oxyacetylene } \\
\text { Explosion }\end{array}$ & $\begin{array}{l}\text { Explosion during reactor vessel } \\
\text { removal (Task } 12 \text { in the Reactor } \\
\text { Building) }\end{array}$ & Medium & 2 & $2.4 \times 10^{-1}$ & $5.0 \times 10^{-4}$ & $1.2 \times 10^{-4}$ \\
\hline $\begin{array}{l}\text { Contaminated } \\
\text { Sweeping Compound } \\
\text { Fire }\end{array}$ & $\begin{array}{l}\text { A fire consumes } 0.5 \mathrm{~m}^{3} \text { of } \\
\text { sweeping compound }\end{array}$ & Mediun & 5 & $2.2 \times 10^{-3}$ & $5.0 \times 10^{-4}$ & $1.7 \times 10^{-6}$ \\
\hline $\begin{array}{l}\text { Gross Leak During } \\
\text { Loop Chemical } \\
\text { Decontamination }\end{array}$ & $\begin{array}{l}\text { A leak } 10 \text { times larger than the } \\
\text { routine leak in the Radwaste } \\
\text { and Control Building }\end{array}$ & Low & 4 & $2.1 \times 10^{-3}$ & $5.0 \times 10^{-4}$ & $1.0 \times 10^{-6}$ \\
\hline $\begin{array}{l}\text { Filter Damage } \\
\text { from Blasting } \\
\text { Surges }\end{array}$ & $\begin{array}{l}\text { Damage from routine concrete } \\
\text { blasting operations (Task is } \\
\text { in the Reactor Building) }\end{array}$ & Medium & 3 & $2.6 \times 10^{-4}$ & $5.0 \times 10^{-4}$ & $1.3 \times 10^{-7}$ \\
\hline $\begin{array}{l}\text { Combustible Waste } \\
\text { Fire }\end{array}$ & $\begin{array}{l}1 m^{3} \text { of waste is involved in } \\
\text { a fire }\end{array}$ & High & 5 & $1.2 \times 10^{-5}$ & $5.0 \times 10^{-4}$ & $6.0 \times 10^{-9}$ \\
\hline $\begin{array}{l}\text { Detonation of } \\
\text { Unused Explosives }\end{array}$ & $\begin{array}{l}\text { Detonation of a positioned } \\
\text { charge after removal of con- } \\
\text { trols (Taks } 15 \text { in the Reactor } \\
\text { Building) }\end{array}$ & Medium & 3 & $9.5 \times 10^{-7}$ & $5.0 \times 10^{-4}$ & $4.8 \times 10^{-10}$ \\
\hline $\begin{array}{l}\text { Ion Exchange } \\
\text { Res in Accidents }\end{array}$ & $\begin{array}{l}\text { Suspended in liquids with } \\
\text { remote operations --no calcula- } \\
\text { tion }\end{array}$ & $\ldots(e)$ & -- & $\cdots$ & --- & --- \\
\hline Loss of Services & $\begin{array}{l}\text { Loss of water supply, electri- } \\
\text { cal power or airflow--no cal- } \\
\text { culation }\end{array}$ & -- & -- & $\cdots$ & $-\cdots$ & --- \\
\hline Natural Phenomena & $\begin{array}{l}\text { Floods, earthquakes, tornadoes } \\
\text { or high winds--comparison to } \\
\text { design-basis--no calculation }\end{array}$ & --- & -- & -- & --- & -- \\
\hline Aircraft Crashes & $\begin{array}{l}\text { Comparison to routine opera- } \\
\text { tion probabil ity--no calcula- } \\
\text { tion }\end{array}$ & -- & $\cdots$ & --- & --- & -- \\
\hline Man-Caused Events & $\begin{array}{l}\text { Detailed analysis is beyond the } \\
\text { scope of study--no calculation }\end{array}$ & $\cdots$ & -.- & -- & --- & --- \\
\hline \multicolumn{7}{|c|}{$\begin{array}{l}\text { (a) The frequency of occurrence considers not only the probability of the accident, but also the probability of an atmospheric } \\
\text { release of the calculated magnitude. The frequency of occurrence is } 1 \text { isted as "High" if the occurrence of a release of } \\
\text { similar or greater magnitude per year is }>10^{-2} \text { as "Medium" if between } 10^{-2} \text { and } 10^{-5} \text {, and as "Low" if <10-5. } \\
\text { (b) These numbers refer to the reference radionuclide inventories discussed in Appendix E. } \\
\text { c) The assumed HEPA filter transmission factor for each building is } 5.0 \times 10^{-4} \text {. } \\
\text { d) All releases are assumed to occur in a } 1-h \text { period for comparison purposes. } \\
\text { (e) Uash indicated that no calculations were attempted for the incident listed. }\end{array}$} \\
\hline
\end{tabular}


While it is beyond the scope of this study to try to evaluate every potential accident for decommissioning a reference BWR, operational, natural phenomena, and indirect man-related events are discussed in the following subsections. Multiple failure-event accidents are not considered; that is, for each accident, only one failure event is analyzed.

\section{N.2.2.1 Postulated Operational Accidents}

Accidental atmospheric releases from incidents such as equipment failure, human error, or service conditions during routine immediate dismantlement tasks are discussed in this section. The accident analyses are based on the assumed technologies for immediate dismantlement tasks discussed in Appendix 1 .

Explosion of LPG Leaked from a Front-End Loader. The use of a liquified propane gas (LPG) -powered front-end loader for loading concrete rubble and moving light equipment is assumed in this study, since this method is consistant with current industrial mehtods. It is anticipated that by the time large scale decommissioning operations are required, an alternative method with a safer fuel supply will be available and used instead of the LPG-powered front-end loader.

Flammability limits for LPG range from a mixture of 2.1 volume $\%$ to a mixture of 9.5 volume \%. $(15,16)$ Information on the rate of pressure rise from explosions of various mixtures of propane in air are given in Table N.2-17.

TABLE N.2-17. LPG Explosion Information(a)

\begin{tabular}{|c|c|c|}
\hline $\begin{array}{c}\text { Concentration } \\
\text { in Air } \\
\text { (volume \%) } \\
\end{array}$ & $\begin{array}{l}\text { Pre-Detonation } \\
\text { Pressure (kPa) }\end{array}$ & $\begin{array}{l}\text { Rate of Pres- } \\
\text { sure Rise } \\
\text { (kPa/sec) } \\
\end{array}$ \\
\hline 3 & 510 & 8600 \\
\hline 5 & 660 & 17000 \\
\hline 7 & 330 & 240 \\
\hline
\end{tabular}

(a) Summarized from information in Reference 17. 
An accidental leak of LPG is postulated to occur during the loading of concrete rubble in the Reactor Building. The volume of the top level of the Reactor Building is about $3.3 \times 10^{4} \mathrm{~m}^{3}$, and about $1300 \mathrm{~kg}$ of propane are required to produce a flammable mixture in this volume of air. This amount of LPG far exceeds the fuel holding capacity of the front-end loader assumed in this study. Therefore, a realistic, smaller LPG leak of $4.5 \mathrm{~kg}$ is assumed, which would require about $110 \mathrm{~m}^{3}$ of air to produce a flammable mixture. This volume is about $0.3 \%$ of the total volume of the top level of the Reactor Building. An explosion of this mixture is calculated to produce a maximum pressure surge of less than $240 \mathrm{kPa}$, which would cause no structural damage to the building HEPA filter system, unless the explosion occurred after the mixture is drawn into the building ventilation ductwork. Thus, the postulated explosion of leaked LPG is assumed to occur in the building ventilation ductwork where the force of the explosion is assumed to cause a failure of the filters and blowers. Loss of the ventilation blowers would aerodynamically isolate the building from the atmosphere. Remedial action, such as sealing off vent outlets, would further limit the atmospheric release.

Radioactive contamination deposited on the HEPA filters and in the ductwork is assumed to be made airborne by the force of the LPG explosion. The explosion is postulated to occur near the end of segmenting the activated concrete in the sacrificial shield, when the filters and vents have collected the maximum quantity of reference radionuclide inventory 3 (see Table E.1-3). Information about the amount of radioactivity on the duct surfaces is not available, thus it is assumed to equal the amount of radioactivity collected on the HEPA filters.

The mass of material deposited on HEPA filters without causing serious operational problems, such as an excessive pressure drop, vary considerably with the filter construction and the particle size of the deposited material. $(18,19)$ The amount of deposited material per filter assumed for this study is $2.3 \mathrm{~kg}$ of reference radionuclide inventory 3 , with a contamination level of $4.7 \times 10^{-2} \mathrm{Ci} / \mathrm{m}^{3}$.

If the pre-filters and filters in both exhaust filter banks rupture simultaneously (with 50 filters per bank), and assuming that the ductwork does not 
rupture, about $4.3 \times 10^{-3} \mathrm{Ci}$ are released from the building to the atmosphere. If an equal amount of material is released from the walls of the ductwork, a total of $8.6 \times 10^{-3} \mathrm{Ci}$ of reference inventory 3 is released to the atmosphere. An explosion of leaked LPG resulting in this magnitude of release is estimated to have a "low" frequency of occurrence.

Vacuum Filter-Bag Rupture. Sharp objects, such as metal shards, could rupture a filter-bag during surface cleaning operations involving the use of a vacuum cleaner. When the filter-bag is ruptured, all of the collected material in the bag is assumed to become airborne in the building because of the mechanical and aerodynamic forces of the $1.4-\mathrm{m}^{3} / \mathrm{min}$ vacuum cleaner air flow. To maximize the calculation of the atmospheric release, the bag rupture is assumed to occur at the time just prior to bag change (i.e., when the filter bag is full). For the Reactor Building, about $34 \mathrm{Ci}$ of reference radionuclide inventory 5 are calculated to cover $2.5 \times 10^{3} \mathrm{~m}^{2}$ of floor surface. If vacuuming is assumed to remove 0.5 of the surface contamination, about $17 \mathrm{Ci}$ are removed from the Reactor Building. Frequent filter-bag changes are anticipated in dusty and dirty areas. Assuming 10 bag changes during the entire task, each filter-bag could contain an average of $1.7 \mathrm{Ci}$. Assuming all $1.7 \mathrm{Ci}$ becomes airborne during the bag rupture event, a total of $8.5 \times 10^{-4} \mathrm{Ci}$ of reference radionuclide inventory 5 (see Table E.2-9) would be transmitted to the environment through the building HEPA filter. This accident is estimated to have a "medium" frequency of occurrence.

Contamination Control Envelope Rupture. Rupture of the contamination contro? envelope (greenhouse) during oxyacetylene cutting is assumed to have a "high" frequency of occurrence. Small globules of molten metal have been measured to be projected up to $9 \mathrm{~m}$ from a cutting operation. (20) It is postulated that such molten particles penetrate the sheet plastic walls and increase the leakage from the contamination control envelope from 0.1 to 0.5 . This increase in leakage is assumed to occur during the removal of the reactor vessel (Task 12 in the Reactor Building) when the highest specific activity material is being cut in air. Since this task is remotely controlled, it is assumed that a large leak could occur for one hour of cutting before it is detected. Thus, $5.6 \times 10^{-1} \mathrm{Ci}$ are vaporized and made airborne, and 
$2.8 \times 10^{-1} \mathrm{Ci}$ leave the control envelope to enter the building ventilation. If the building HEPA system works as designed, the total atmospheric release is calculated to be $1.4 \times 10^{-4} \mathrm{Ci}$ of reference radionuclide inventory 2 (see Table E.1-2).

Oxyacetylene Explosion. Oxyacetylene cutting torches are assumed to be used for removing and segmenting various steel components during immediate dismantlement of the reference BWR. Acetylene gas has a flammability range of 2.5 to 80 volume \% mixed in air. ${ }^{(21,22)}$ Violent explosions can occur when acetylene and oxygen are incorrectly mixed. The degree of explosive violence depends on how closely the gas mixture approximates the ratio for complete combustion. Some maximum pressures and pressure rise rates from three acetylene/ air mixtures in the explosive range are shown in Table N.2-18. (17)

TABLE N.2-18. Example Explosive Data for Aceytylene/Air Mixtures

\begin{tabular}{|c|c|c|}
\hline $\begin{array}{l}\text { Percent of } \\
\text { Acetylene } \\
\text { in Mixture }\end{array}$ & $\begin{array}{l}\text { Maximum } \\
\text { Explo- } \\
\text { sive Pres- } \\
\text { sure (kPa) } \\
\end{array}$ & $\begin{array}{l}\text { Maximum Rate } \\
\text { of Explosive } \\
\text { Pressure Rise } \\
\text { (kPa/sec) }\end{array}$ \\
\hline 5 & 540 & 17000 \\
\hline 13 & 1000 & 8300 \\
\hline 20 & 690 & 9700 \\
\hline
\end{tabular}

Oxyacetylene explosions can occur from such causes as flow reversals, nozzle obstructions, and flashbacks (a flare going back up the gas hose). $(23,24)$ The accident is postulated to occur during the removal of the activated portion of the reactor vessel in air prior to segmenting the removed sections under water. This operation is conducted in a contamination control envelope with an assumed volume of $1000 \mathrm{~m}^{3}$. The airborne material generated as a result of the explosion is assumed to fill this volume with an airborne concentration of $1.0 \times 10^{-1} \mathrm{~g} / \mathrm{m}^{3}$. (5) Thus, a total of $100 \mathrm{~g}$ of radioactive carbon-steel dust could fill the contamination control envelope. With a radioactivity level of $1.1 \times 10^{2} \mathrm{Ci} / \mathrm{m}^{3}$ for activated carbon steel of reference radionuclide inventory 2 (see Table E.1-2), and a steel density of $8 \times 10^{6} \mathrm{~g} / \mathrm{m}^{3}$, the specific activity of this carbon-steel is calculated to be $1.4 \times 10^{-5} \mathrm{Ci} / \mathrm{g}$. Thus, $100 \mathrm{~g}$ of steel dust contains about $1.4 \times 10^{-3} \mathrm{Ci}$. 
It is reasonable to assume that the contamination control envelope HEPA filter system undergoes routine maintenance to ensure its full effectiveness. The mass of material deposited on filters without causing flow restrictions or an excessive pressure drop ( $>980 \mathrm{~Pa}$ of water gauge at rated flows) varies with filter design and the properties of the deposited material. $(18,19)$ A HEPA filter dust loading of $2.3 \mathrm{~kg}$ is assumed (the same amount assumed for the LPG explosion accident). Three pairs of HEPA and roughing filters in the contamination control envelope are calculated to contain about $14 \mathrm{~kg}$ of activated carbon-steel dust. If all of this material is made airborne by the oxyacetylene explosion, and using the specific activity of this carbon-steel of $1.4 \times 10^{-5} \mathrm{Ci} / \mathrm{g}$, a total of about $2.0 \times 10^{-1} \mathrm{Ci}$ are made airborne from the filters.

Some radioactivity will be deposited on the inside surfaces of the contamination control envelope, and it is assumed to be made airborne in the Reactor Building by the explosion. The total radioactivity generated during Task 12 oxyacteylene cutting is $22 \mathrm{Ci}$ (see Table N.2-7). Assuming that $0.2 \%$ of this radioactivity is deposited on the interior surfaces of the control envelope, and that all of it is made airborne by the explosion, an additional $4.4 \times 10^{-2} \mathrm{Ci}$ could enter the building air.

The total radioactivity made airborne in the Reactor Building by the postulated oxyacetylene explosion is found by summing the three previous airborne generation terms. They are: the radioactivity generated by the explosion inside the contamination control envelope $\left(1.4 \times 10^{-3} \mathrm{Ci}\right)$, the radioactivity removed from the control envelope HEPA filter system by the explosion $\left(2.0 \times 10^{-1} \mathrm{Ci}\right)$, and the radioactivity removed from interior surfaces in the control envelope $\left(4.4 \times 10^{-2} \mathrm{Ci}\right)$. The total airborne radioactivity in the building is $2.4 \times 10^{-1} \mathrm{Ci}$.

The effect of the transmitted shock wave from the explosion on the building HEPA filters is next investigated. The transmitted shock wave pressure is given in terms of shock wave Mach Number as: ${ }^{(25)}$

$$
P_{1}=\frac{P_{t}(\gamma-1)}{2 \gamma M_{t}^{2}-(\gamma-1)}
$$


where:

$\mathrm{P}_{1}$ - the transmitted shock wave pressure in the gas downstream, $\mathrm{Pa}$

$P_{t} \bullet$ the static pressure, $\mathrm{Pa}$

$\gamma \bullet$ the specific heat ratio $C_{p} / C_{v}$, unitless

$M_{t}$ - the transmitted shock wave Mach Number, unitless.

Assuming, $100 \mathrm{kPa}$ as the static pressure and 2.5 as the Mach Number, the downstream pressure is calculated to be $145 \mathrm{kPa}$. The Reactor Building is designed to withstand pressure gradients resulting from accident situations. It is felt that the building volume is large enough to reduce the shock wave enough by the time it reaches the building HEPA filter system so that no damage to the HEPA system occurs. Thus, the amount of radioactivity released to the environment is found by multiplying the amount of material airborne in the building by the building HEPA filter transmission factor. The total atmospheric release is $1.2 \times 10^{-4}$ of reference radionuclide inventory 2 . An oxyacetylene explosion resulting in this magnitude of airborne release is judged to have a "medium" frequency of occurrence.

Contaminated Sweeping Compound Fire. Sweeping compound is composed of sawdust treated with oil or other additives to enhance the collection of loose surface contamination. A fire is postulated to occur in used sweeping compound containing radioactivity removed from floor surfaces. The highest contamination level encountered in sweeping occurs on isolated floor surfaces in the Reactor Building and the Radwaste and Control Building with $2.5 \times 10^{-2} \mathrm{Ci} / \mathrm{m}^{2}$ of reference radionuclide inventory 5 . It is assumed that an average of $2.5 \times 10^{-4} \mathrm{~m}^{3}$ of sweeping compound is used for each $\mathrm{m}^{2}$ of surface swept. It is also assumed that the density of the sweeping compound is about the same as light wood, or about $6.0 \times 10^{5} \mathrm{~g} / \mathrm{m}^{3}$. (26) The total floor surfaces with this contamination level are: $1.2 \times 10^{3} \mathrm{~m}^{2}$ in the Reactor Building and $3.6 \times 10^{-3} \mathrm{~m}^{2}$ in the Radwaste and Control Building. Thus, a total of $1.2 \mathrm{~m}^{3}$, or $7.2 \times 10^{2} \mathrm{~kg}$ of sweeping compound are required. It is reasonable to assume that this total amount will be stored in smaller quantities, therefore a fire is postulated to occur in $0.5 \mathrm{~m}^{3}$ (or $3.0 \times 10^{2} \mathrm{~kg}$ ) of used sweeping compound.

Assuming that half of the surface contamination is removed by the sweeping compound, a total of $15 \mathrm{Ci}$ of reference radionuclide inventory Number 5 is 
contained in $0.5 \mathrm{~m}^{3}$ of used sweeping compound. The release fraction from the fire is assumed to be similar to that measured from burning waste, $1.5 \times 10^{-4}$. (27) Thus, about $2.2 \times 10^{-3} \mathrm{Ci}$ of reference radionuclide inventory 5 (see Table E.2-9) are airborne in the Radwaste and Control Building, and $1.1 \times 10^{-6} \mathrm{Ci}$ are released to the atmosphere through the building HEPA filter system. A release of this magnitude from a fire in contaminated sweeping compound is estimated to have a "medium" frequency of occurrence.

Gross Leak During Loop Chemical Decontamination. A massive failure of reactor piping during loop chemical decontamination is judged to have a "low" frequency of occurrence. There have been no such accidents in 30 years of experience with nuclear systems. Massive failures are unknown in high-pressure central steam boilers, for which there is considerably more operating experience than is currently available in the nuclear industry. (28)

Pipe failures can result from improper system designs, the use of poor quality materials, base metal defects, fabrication defects, or inadequate service conditions. (29) The loop chemical decontamination takes place about 40 years after the piping systems were put in service. In chemical decontamination, a caustic chemical is circulated in piping and equipment to remove built-up internal surface contamination. The chemical solution could deteriorate the pipe or the welds and create localized leaks. Accidental leakage could also be introduced because of human error during the chemical decontamination.

Liquid and spray leaks are assumed to occur as part of the routine release analysis. A gross leak about 10 times larger than the spray leak is assumed for this accident. Thus, $1 \%$ of the liquid in the system is assumed to be made airborne. Such a leak would be large enough to be easily detected and is assumed to last only 1 hour. The largest routine spray leak is calculated to occur in the Radwaste and Control Building during the chemical decontamination of equipment. A total of $2.1 \times 10^{-4} \mathrm{Ci} / \mathrm{hr}$ (see Table N.2-9) are calculated to be made airborne in the building during routine operation. The accidental leak is 10 times this value, or $2.1 \times 10^{-3} \mathrm{Ci} / \mathrm{hr}$. At the end of one hour, $2.1 \times 10^{-3} \mathrm{Ci}$ of material are airborne in the building, or $1.0 \times 10^{-6} \mathrm{Ci}$ of reference radionuclide inventory 4 (see Table E.2-1) are calculated to be released from the building HEPA system. 
Filter Damage from Blasting Surges. The Reactor Building and its ventilation system are designed to withstand pressure gradients from accident situations. However, some signs of pressure surge damage from concrete blasting operations were observed during decommissioning of the Elk River Reactor. ${ }^{(30)}$ There was a partial collapse of a prefilter in a local contamination control system. Thus, an airborne release is calculated for a postulated level of flter damage resulting from blasting pressure surges.

Using the same contamination control envelope as defined for the oxyactylene explosion, a total of $14 \mathrm{~kg}$ of radioactive dust is assumed to be held on the HEPA and roughing filter. Blasting operations are assumed to be used for removal of activated concrete in the sacrificial shield. Assuming a concrete density of $2.5 \times 10^{3} \mathrm{~kg} / \mathrm{m}^{3}$ and a radioactivity level of $4.7 \times 10^{-2} \mathrm{Ci} / \mathrm{m}^{3}$ of reference radionuclide inventory 3 (see Table E.1-3), the specific activity of the concrete dust on the filters is calculated to be $1.9 \times 10^{-8} \mathrm{Ci} / \mathrm{g}$. A total of $2.6 \times 10^{-4} \mathrm{Ci}$ is calculated to be in the $14 \mathrm{~kg}$ of dust on the filter. If all of this material is made airborne, and if there is no damage to the building HEPA systems from the pressure surge, a total of $1.3 \times 10^{-7} \mathrm{Ci}$ could be released to the environment.

A pressure surge from blasting that would result in this magnitude of release is judged to have a "medium" frequency of occurrence.

Combustible Waste Fire. Absorbent materials, such as rags or paper wipes, are assumed to be used for a variety of purposes during immediate dismantlement and discarded after use. Materials that have come into contact with contaminated surfaces hold small quantities of radionuclides. Anticontamination clothing (coveralls, caps, hoods, or shoe covers) become contaminated through use. Plastics are generally considered combustible, al though many kinds do not burn readily or are self-extinguishing.

It is postulated that contaminated combustible waste containing low levels of radioactivity, ignites and burns in a working area. Large amounts of these wastes are not likely to accumulate in one place, so it is assumed that one cubic meter containing $8.0 \times 10^{-2} \mathrm{Ci}$ of reference radionuclide inventory 5 (see Table E.2-9) are involved in the fire. The maximum fractional airborne 
release measured during the burning of contaminated waste under similar conditions was $1.5 \times 10^{-4}$. (27) Thus it is estimated that up to $1.2 \times 10^{-5}$ ci could be released to the ventilation system from this fire, and that about $6.0 \times 10^{-9}$ could be released to the environment. A fire that results in a release of this magnitude is estimated to have a "high" frequency of occurrence.

Detonation of Unused Explosives. Removing the sacrificial shield is accomplished by using explosive charges on the concrete after first cutting the steel skin with an oxyacetylene torch. Reinforcing steel in the concrete is cut with an oxyacetylene torch after blasting. The use of explosive charges means that special procedures are required including the use of water sprays, blasting mats, and contamination control envelopes.

If a positioned charge explodes when the water sprays are off and after the contamination control envelope has been removed, a temporary dust loading in a limited air volume will result. For this accident, it is postulated that one charge detonates and fills an air volume of $500 \mathrm{~m}^{3}$ with a dust loading of $1.0 \times 10^{-1} \mathrm{~g} / \mathrm{m}^{3}$. The radioactivity level of the activated concrete in the sacrificial shield is $4.7 \times 10^{-2} \mathrm{Ci} / \mathrm{m}^{3}$, and with a density of $2.5 \times 10^{-3} \mathrm{~kg} / \mathrm{m}^{3}$ the specific activity is $1.9 \times 10^{-8} \mathrm{Ci} / \mathrm{g}$. Thus, $9.5 \times 10^{-7} \mathrm{Ci}$ of reference radionuclide inventory 3 (see Table E.1-3) are made airborne in the building and $4.8 \times 10^{-10} \mathrm{Ci}$ are calculated to be released to the environment.

It should be noted that there are additional nonradiological hazards to employees if they are present at the time of the accidental detonation. An atmospheric release from an accidental explosive charge detonation of this magnitude is judged to have a "medium" frequency of occurrence.

Ion Exchange Resin Accidents. Both powdered and beaded resins are used in the liquid radwaste systems at the reference BWR. Expended ion exchange resins are handled by the procedures described in the FSAR. ${ }^{(31)}$ The spent resins are backwashed to a spent resin tank or to a phase separator where they are allowed to accumulate over a period of time to optimize batch processing and to permit radioactive decay. They are then centrifuged and solidified in shipping containers for offsite shipment. Since the spent resins are hydropneumatically transferred and are stored in sealed tanks, there appears to be no danger of combustion. Only accidents involving the handling of spent 
resins appear to be likely. Such accidents would lead to little airborne release becasue of the liquid nature of the wastes involved. Thus, no further analysis is attempted in this study.

Loss of Services. Loss of services, such as water supply, electrical power, or air flow, are immediately apparent to the workers performing the various dismantlement tasks. In the case of manual tasks, the operator would discontinue the task immediately upon the loss of services. Most remotely controlled tasks would be monitored frequently enough to almost immediatedly detect the loss of a service. Since the loss of services constitutes a lesser magnitude release than other postulated accidents, no further analys is is attempted in this study.

\section{N.2.2.2 Natural Phenomena}

The reference BWR is designed to meed a criterion for protection of the buildings and systems against natural phenomena. The following statement of this design criterion is made in the FSAR: "Structures, systems, and components important to safety shall be designed to withstand the effects of natural phenomena such as earthquakes, tornadoes, hurricanes, floods, tsunami and seiches without loss of capability of perform their safety functions." (32)

Furthermore, the designs of structures, systems, and components are based on withstanding the most severe natural phenomena recorded for the site plus appropriate margins to account for uncertainties in the recorded data. It is assumed that the structural integrity of the plant is preserved during the operational lifetime of the plant. It is further assumed that the structural integrity is preserved during decommissioning as long as required for safety. It is estimated that, while natural phenomena can cause severe damage to the reference BWR resulting in severe radiological public safety impacts, they are low probability events. Also, the impact of these events will be less than the impacts calculated in the FSAR design-basis accidents for the operating BWR when nuclear fuel is present in the plant. For this reason, no detailed analysis of the impacts of these phenomena is attempted beyond the brief discussions that follow. 
Floods. The FSAR considers runoff floods, surges, seiches, wave action, tsunamis, wind-generated wave action, and combinations of these phenomena. Also, a probable maximum flood is proposed. The plant is designed to be safe from damage by such a flood or other potential flooding.

Earthquakes. All systems and components designated as seismic Category I are designed to exhibit no loss of functions for earthquake ground accelerations of $0.25 \mathrm{~g}$. Category I structures at the reference BWR include the Reactor Building, the control room tower, the radwaste area, and the portions of the Turbine Generator Building that protect the steam lines.

It is estimated that the probability of an earthquake that would occur and cause damage to the plant is $10^{-7}$ per year. (33) At this probability, earthquake-induced accidents are extremely unlikely.

Tornadoes. A11 power reactors in the United States are now designed to withstand the effects of sizeable tornadoes. Significantly less that $1 \%$ of all tornadoes are expected to be as large as a design-basis tornado. The probability of such a tornado striking a nuclear power plant is on the average less than $5 \times 10^{-6}$ per year. ${ }^{(35)}$

Tests at Los Alamos showed that a 0.2-m $\times 0.2-\mathrm{m} \times 0.08-\mathrm{m}$ HEPA filter can withstand a 9-sec pressure pulse with the maximum pressure of $21 \mathrm{kPa}$ and hold without visible damage or reduction in efficiency. ${ }^{(34)}$ This pressure pulse is substantially greater than the pulse the filter would experience in the event of a design-basis tornado.

High Winds. The design-basis wind velocity for all Category $I$ and Category II structures is $168 \mathrm{~km} / \mathrm{hr}$ at $9.1 \mathrm{~m}$ above nominal ground elevation. For this study it is assumed that immediate dismantlement tasks do not reduce the ability of these structures to withstand high winds, and no releases are anticipated.

\section{N.2.2.3 Aircraft Crashes}

Each reactor site has its own potential risk from aircraft crashes based on its proximity to airports and air traffic lanes. However, current information leads to the conclusion that the risk of damage for aircraft crashes is 
low for most reactor sites. (35) Moreover, the risk is not escalated by dismantlement operations. The aircraft crash probability for most plants is very low $\left(10^{-6}\right.$ to $10^{-8}$ per year) and no further analys is is attempted.

\section{N.2.2.4 Man-Caused Events}

Accidental airborne releases of radioactivity resulting from man-caused events could cover a wide spectrum of magnitudes ranging from releases induced by casual trespassers to releases induced by armed terrorists. A detailed analysis of man-caused events during decommissioning is beyond the scope of this study since an analysis of human motives is difficult to conduct. Thus, no airborne release calculations are made.

\section{N.2.2.5 Radiation Doses from Postulated Immediate Dismantlement Accidents}

Radiation doses to the maximum-exposed individual from accidental releases of radionuclides during immediate dismantlement are calculated using the radiation dose models discussed in Appendix F. The first-year doses and the fiftyyear committed dose equivalents to the maximum-exposed individual from inhalation for the accidents 1 isted in Table N.2-16 are 1isted in Table N.2-19. Each accidental release is assumed to occur for one hour so that a comparison of the accidents can be made. The atmospheric dispersion $\left(\bar{x} / Q^{-}\right)$value used for the accidents is $6.5 \times 10^{-4} \mathrm{sec} / \mathrm{m}^{3}$.

\section{N.3 PASSIVE SAFE STORAGE}

The second decommissioning alternative considered in this study for the reference BWR is passive safe storage. This alternative is divided into three potential phases: preparations, continuing care, and probable deferred dismantlement. Preparations for passive safe storage include tasks designed to immobilize all remaining radioactive contamination and deactivate all unneeded equipment. Continuing care permits decay of short-1ived radioactivity, thus reducing the occupational radiation doses associated with probable deferred dismantlement. After a finite period of continuing care, deferred dismantiement is assumed to be required for termination of the nuclear facility license. Details of the tasks and requirements of passive safe storage are discussed in Appendix $\mathrm{J}$. 


\section{TABLE N-2.19. Radiation Doses to the Maximum-Exposed Individual from Accidental Atmospheric Releases}

During Immediate Dismantlement

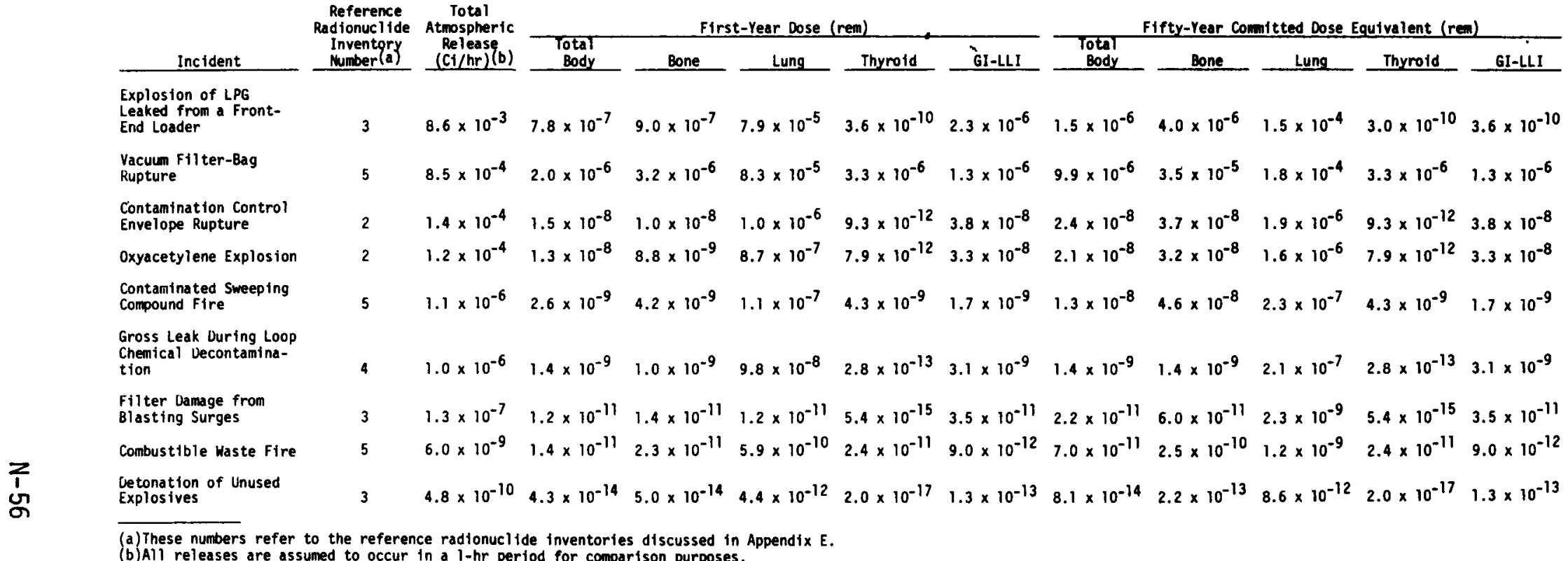

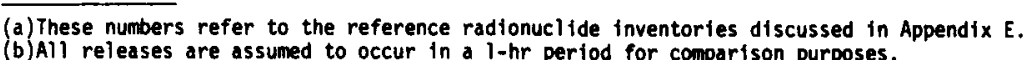


In this section, the atmospheric releases of radioactivity and the resulting radiation doses to the public from both routine tasks and postulated accidents during preparations for passive safe storage are presented. This analysis uses the same methods described in Section N.2 for immediate dismantlement.

\section{N.3.1 Routine Tasks During Preparations for Passive Safe Storage}

The task schedule and sequence during preparations for passive safe storage of the reference BWR are shown in Figure J.4-1. Several of the tasks during preparations for passive safe storage are identical to those analyzed previously in Section $\mathrm{N} .2$ for immediate dismantlement. In the cases where the tasks for these two decommissioning modes are identical, the atmospheric releases and resulting radiaiton doses from the task during preparations for passive safe storage are assumed to be identical to those reported in Section N.2. A listing of tasks for preparations for passive safe storage that shows whether a new safety analysis is required is given in Table N.3-1.

The following subsections contain discussions of the methods used to calculate the atmospheric releases and resulting public radiation doses during preparations for passive safe storage of the reference BWR. The data for and the results of new analyses for those tasks that are unique to preparations for passive safe storage are presented; summed doses for all tasks similar to immediate dismantlement are also given.

\section{N.3.1.1 Methods and Data for Calculating Atmospheric Releases of Radioactivity}

The tasks for preparations for passive safe storage are analyzed using the same airborne release mechanisms discussed previously in Section N.2.1.1 for immediate dismantlement. The summary of the analyses is shown previously in Table N.2-2, including the general activities analyzed. Four general activities that are unique to preparations for passive safe storage (i.e., manual decontamination, sealing building areas, isolating equipment, and spray painting to immobilize surface radioactive contamination) are not anticipated to result in an atmospheric release; thus, they are not analyzed further in this section. 


\section{TABLE N.3-1. Safety Analysis Requirements for Preparations for Passive Safe Storage}

1. Comprehensive Radiation Survey

2. Discharge and Ship Fuel

3. Drain Suppression Pool to Radwaste; Water-Jet Clean

4. Drain Reactor Well Pool to Radwaste; Water-Jet Clean

5. Chemical Decon Reactor Water Recirculation and Cleanup Systems

6. General Cleanup

7. Drain Contaminated Systems to Radwaste

8. Chemical Decon Residual Heat Removal, Low- and High-Pressure Core Spray Systems

9. Drain Oryer and Separator Pool to Radwaste; Water-Jet Clean

10. Chemical Decon Drain Systems

11. Drain Spent Fuel Pool to Radwaste; Water-Jet Clean

12. Chemical Decon Spent Fuel Pool Cooling and Cleanup Systems

13. Cover and Seal Spent Fuel Pool; Dryer and Separator Pool

14. Seal Equipment and Personnel Hatches into Primary Containment

15. Decontaminate HVAC, Electrical, Misc. Steel Structures and Equipment and Concrete; Apply Protective Paint

16. Isolate and Seal Equipment, Piping, Rooms, Stacks, HVAC Ducts, Rail and Steam Tunnels

17. Seal Drywell Top Head and Unneeded Reactor Building Doors

18. Install HEPA-Filtered Vents

19. Deactivate Unnecessary Utilities

20. Install Intrusion, Radiation Monitoring, and Fire Alarm Systems

21. Final Radiation Survey

Turbine Generator Building

1. Comprehensive Radiation Survey

2. General Cleanup

3. Drain Contaminated Systems to Radwaste; Water-Jet Clean Condensate Storage Tanks

4. Drain Condenser to Radwaste; Water-Jet Clean

5. Chemical Decon Drain Systems

6. Decontaminate HVAC, Electrical, Misc. Steel Structures and Concrete; Apply Protective Paint

7. Isolate and Seal Equipment, Piping, Rooms, Stack, and HVAC Ducts

8. Install HEPA-Filtered Vents

9. Deactivate Unnecessary Utilities

10. Install Intrusion, Radiation Monitoring and Fire Alarm Systems

11. Final Radiation Survey

Radwaste and Control Building

1. Comprehensive Radiation Survey

2. General Cleanup

3. Decontaminate Equipment External Surfaces; Apply Protective Paint

4. Decontaminate Electrical Equipment, Misc. Steel Structures and HVAC; Apply Protective Paint

5. Decontaminate Concrete; Apply Protective Paint

6. Chemical Decon Drain Systems

7. Install Temporary Radwaste System

8. Chemical Decon Equipment

9. Install HEPA-Fil tered Vents

10. Leactivate Unnecessary Equipment and Utilities

11. Isolate and Seal Equipment and Areas

12. Install Intrusion, Radiation Monitoring and Fire Alarm Systems

13. Final Radiation Survey 


\section{N.3.1.2 Atmospheric Releases from Preparations for Passive Safe Storage}

Public safety analysis data for the task preparations for passive safe storage are listed in Table N.3-2. The calculated atmospheric releases from the tasks are 1isted in Table N.3-3. Radiation doses to the public resulting from these releases are discussed in the following subsection.

\section{N.3.1.3 Public Radiation Doses from Routine Tasks During Preparations for Passive Safe Storage}

First-year doses and fifty-year committed dose equivalents to both the maximum-exposed individual and the population residing within $80 \mathrm{~km}$ of the site are calculated using the radiation dose models discussed in Appendix $F$. Each routine atmospheric release during preparations for passive safe storage is assumed to occur at a constant rate for a 1-year period, so direct comparisons of the public radiation doses from the various tasks can be made. The organs of reference for which radiation doses are calculated include: total body, bone, lung, thyroid, and GI-tract (lower large intestine [GI-LLI]).

Radiation doses to the maximum-exposed individual are listed in Table N.3-4; those to the population are listed in Table N.3-5. These tables list the doses from the tasks that are unique to preparations for passive safe storage and that result in an atmospheric release as well as the total doses from the tasks that are identical to immediate dismantlement, which are summed and listed separately for each building.

\section{N.3.2 Postulated Accidents During Preparation for Passive Safe Storage}

A comparison of the postulated accidents for immediate dismantlement and for passive safe storage is presented in Table N.3-6. The accidents are listed by decreasing magnitude of the calculated atmospheric release. A general estimate of the frequency of occurrence of the level of the atmospheric release associated with each postulated accident is also given. The frequency of occurrence is based on both the probability of the accident and on the probability of an atmospheric release of the calculated magnitude. The frequency of occurrence is listed as "high" if the occurrence of a release of similar or greater magnitude per year is greater than $10^{-2}$, as "medium" if between 
TABLE N.3-2. Public Safety Analysis Data for Preparations for Passive Safe Storage(a)

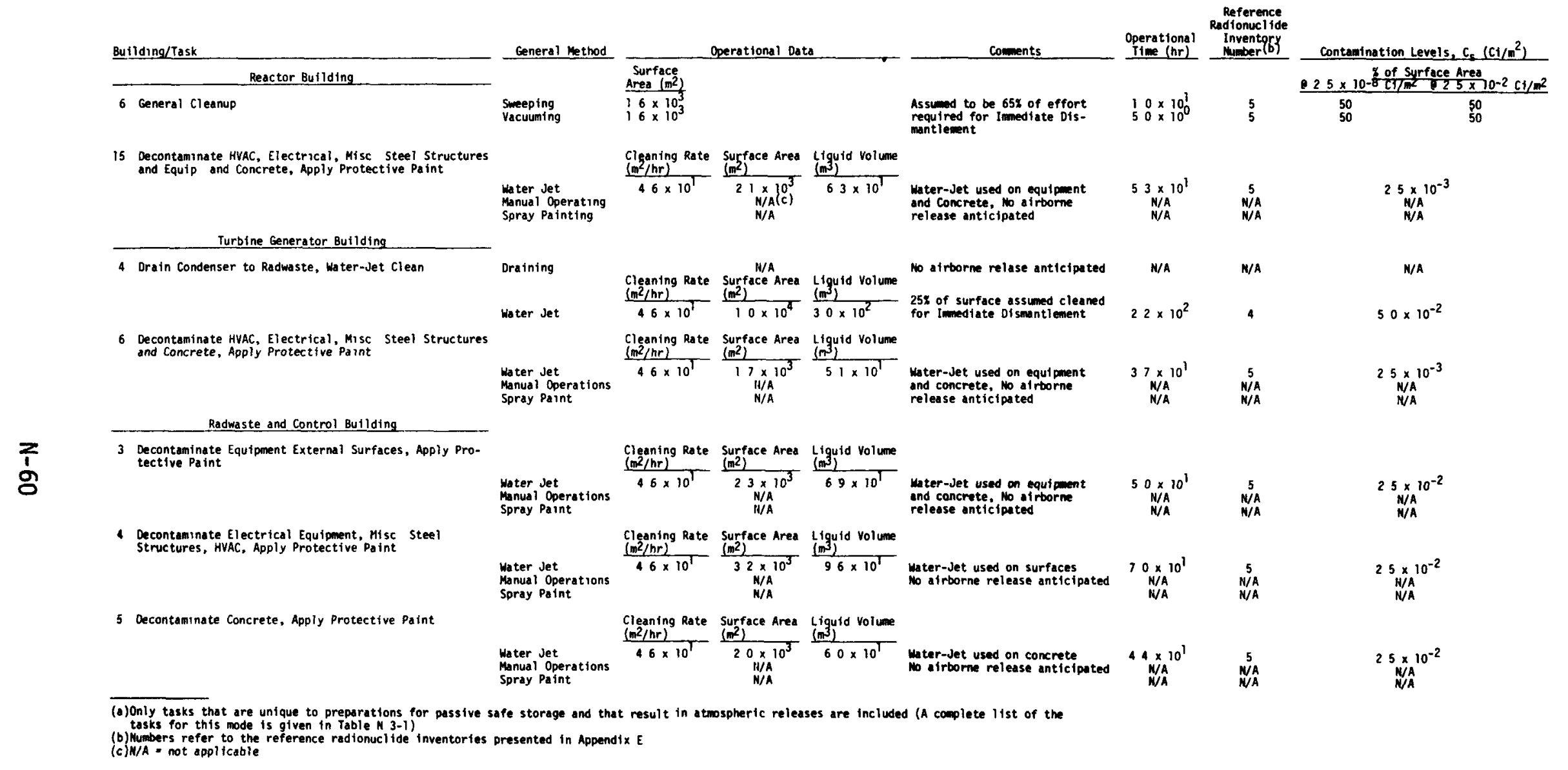


TABLE N.3-3. Calculated Atmospheric Releases During Preparations for Passive Safe Storage ${ }^{(a)}$

\begin{tabular}{|c|c|c|c|c|c|c|c|}
\hline Building/Task & $\begin{array}{l}\text { General } \\
\text { Method } \\
\end{array}$ & $\begin{array}{l}\text { Operational } \\
\text { Time (hr) }\end{array}$ & $\begin{array}{c}\text { Reference } \\
\text { Radionuclide } \\
\text { Inventgry } \\
\text { Number } b y \\
\end{array}$ & $\begin{array}{c}\text { Airborne } \\
\text { Generation Rate } \\
\text { Inside Building } \\
\text { or Control } \\
\text { Envelope } \\
\text { (Ci/hr) } \\
\end{array}$ & $\begin{array}{c}\text { Total } \\
\text { Airborne } \\
\text { Radioactivity } \\
\text { Inside Building } \\
\text { or Control } \\
\text { Envelope (Ci) } \\
\end{array}$ & $\begin{array}{c}\text { Contamination } \\
\text { Control System } \\
\text { Transmission } \\
\quad \text { Factor (C) } \\
\end{array}$ & $\begin{array}{l}\text { Annual } \\
\text { Atmospheric } \\
\text { Release } \\
\text { (Ci)(d) } \\
\end{array}$ \\
\hline \multicolumn{8}{|l|}{ Reactor Building } \\
\hline 6. General Cleanup & $\begin{array}{l}\text { Sweeping } \\
\text { Vacuuming }\end{array}$ & $\begin{array}{l}1.0 \times 10^{1} \\
5.0 \times 10^{0}\end{array}$ & $\begin{array}{l}5 \\
5\end{array}$ & $1.1 \times 10^{-3}-3 \times 10^{-3}$ & $\begin{array}{l}1.1 \times 10^{-2} \\
5.5 \times 10^{-3}\end{array}$ & $\begin{array}{l}5 \times 10^{-4} \\
5 \times 10^{-4}\end{array}$ & $\begin{array}{l}5.5 \times 10^{-6} \\
2.8 \times 10^{-6}\end{array}$ \\
\hline $\begin{array}{l}\text { 15. Decon HVAC, Electrical, } \\
\text { Misc. Stee Structures and } \\
\text { Concrete; Apply Protective } \\
\text { Paint } \\
\text { Turbine Generator Building } \\
\end{array}$ & Water Jet & $5.3 \times 10^{1}$ & 5 & $1.1 \times 10^{-5}$ & $5.9 \times 10^{-4}$ & $5 \times 10^{-4}$ & $3.0 \times 10^{-7}$ \\
\hline $\begin{array}{l}\text { 4. Drain Condenser to Rad- } \\
\text { waste; Water-Jet Cleaning }\end{array}$ & Water Jet & $2.2 \times 10^{2}$ & 4 & $3.6 \times 10^{-4}$ & $7.9 \times 10^{-2}$ & $5 \times 10^{-5}$ & $4.0 \times 10^{-6}$ \\
\hline $\begin{array}{l}\text { 6. Decon HVAC, Electrical, } \\
\text { Misc. Steel Structures and } \\
\text { Concrete; Apply Protective } \\
\text { Paint }\end{array}$ & Water Jet & $3.7 \times 10^{1}$ & 5 & $1.8 \times 10^{-5}$ & $6.7 \times 10^{-4}$ & $5 \times 10^{-4}$ & $3.3 \times 10^{-7}$ \\
\hline \multicolumn{8}{|l|}{ Radwaste and Control Building } \\
\hline $\begin{array}{l}\text { 3. Decon Equipment External } \\
\text { Surfaces; Apply Protective } \\
\text { Paint }\end{array}$ & Water Jet & $5.0 \times 10^{1}$ & 5 & $3.6 \times 10^{-4}$ & $1.8 \times 10^{-2}$ & $5 \times 10^{-4}$ & $9.0 \times 10^{-6}$ \\
\hline $\begin{array}{l}\text { 4. Decon Electrical Equipment, } \\
\text { Misc. Steel Structures, } \\
\text { HAC; Apply Protective } \\
\text { Paint }\end{array}$ & Water Jet & $7.0 \times 10^{1}$ & 5 & $3.6 \times 10^{-4}$ & $2.5 \times 10^{-2}$ & $5 \times 10^{-4}$ & $1.2 \times 10^{-5}$ \\
\hline $\begin{array}{l}\text { 5. Decon Concrete; Apply } \\
\text { Protective Paint }\end{array}$ & Water Jet & $4.4 \times 10^{1}$ & 5 & $3.6 \times 10^{-4}$ & $1.6 \times 10^{-2}$ & $5 \times 10^{-4}$ & $8.0 \times 10^{-6}$ \\
\hline
\end{tabular}

(a)Only tasks that are unique to preparations for passive safe storage and that result in atmospheric releases are included (a complete list of the tasks for this mode is given in Table N.3-1).

(b) Numbers refer to the reference radionuclide inventories presented in Appendix $E$.

(c) The building HEPA fil ter transmission factor is $5 \times 10^{-4}$; the combined transmission factor for a contamination control envelope

(d) Annual releases are given for comparison purposes. 


\section{TABLE N.3-4. Radiation Doses to the Maximum-Exposed Individual from Atmospheric Releases During}

Routine Preparations for Passive Safe Storage

\begin{tabular}{|c|c|c|c|c|c|c|c|c|c|c|c|c|}
\hline \multirow[b]{2}{*}{$\underline{B u i l d i n g} /$ Task $^{(a)}$} & \multirow{2}{*}{$\begin{array}{c}\text { Reference } \\
\text { Radionuclide } \\
\text { Inventory } \\
\text { Mumber(by } \\
\end{array}$} & \multirow{2}{*}{$\begin{array}{c}\text { Annual } \\
\text { Atmospheric } \\
\text { Release }(C i)(c) \\
\end{array}$} & \multicolumn{5}{|c|}{ First-Year Dose (rem) } & \multirow{2}{*}{\multicolumn{5}{|c|}{ Fifty-Year Comaitted Dose Equivalent (rem) }} \\
\hline & & & Total 8ody & Bone & Lung & Thyrotd & GI-LLI & Total Body & Bone & Lung & Thyroid & \\
\hline \multicolumn{13}{|l|}{ Reactor Building } \\
\hline $\begin{array}{l}\text { Tasks Identical, to Immediate } \\
\text { Di smantlement }(d)\end{array}$ & $N / A^{(e)}$ & N/A & $1.2 \times 10^{-8}$ & $2.0 \times 10^{-8}$ & $2.6 \times 10^{-8}$ & $4.1 \times 10^{-8}$ & $7.2 \times 10^{-9}$ & $1.9 \times 10^{-8}$ & $4.4 \times 10^{-8}$ & $7.6 \times 10^{-8}$ & $4.3 \times 10^{-8}$ & $7.2 \times 10^{-9}$ \\
\hline 6. General cleanup & 5 & $8.3 \times 10^{-6}$ & $3.5 \times 10^{-9}$ & $7.4 \times 10^{-9}$ & $6.2 \times 10^{-9}$ & $1.6 \times 10^{-8}$ & $1.7 \times 10^{-9}$ & $6.3 \times 10^{-9}$ & $1.7 \times 10^{-8}$ & $1.8 \times 10^{-8}$ & $1.7 \times 10^{-8}$ & $1.7 \times 10^{-9}$ \\
\hline $\begin{array}{l}\text { 15. Decon HVAC, Electrical, } \\
\text { liisc. Steel structures and } \\
\text { Equipment and Concrete. } \\
\text { Apply Protective Paint } \\
\text { Totals }\end{array}$ & $\begin{array}{c}5 \\
: / / A\end{array}$ & $\begin{array}{c}3.0 \times 10^{-7} \\
\mathrm{~N} / \mathrm{A}\end{array}$ & $\frac{1.2 \times 10^{-10}}{1.5 \times 10^{-8}}$ & $\frac{2.4 \times 10^{-10}}{2.8 \times 10^{-8}}$ & $\frac{2.2 \times 10^{-10}}{3.2 \times 10^{-8}}$ & $\frac{5.7 \times 10^{-10}}{5.8 \times 10^{-8}}$ & $\frac{6.0 \times 10^{-11}}{9.0 \times 10^{-9}}$ & $\frac{2.3 \times 10^{-10}}{2.6 \times 10^{-8}}$ & $\frac{6.0 \times 10^{-10}}{6.1 \times 10^{-8}}$ & $\frac{6.6 \times 10^{-10}}{9.5 \times 10^{-8}}$ & $\frac{6.0 \times 10^{-10}}{6.1 \times 10^{-8}}$ & $\frac{6.0 \times 10^{-11}}{9.0 \times 10^{-9}}$ \\
\hline \multicolumn{13}{|l|}{ Turbine Generator Building } \\
\hline $\begin{array}{l}\text { Tasks Identical to Immediate } \\
\text { Di ismant lement }(\mathrm{d})\end{array}$ & N/A & N/A & $4.2 \times 10^{-9}$ & $5.6 \times 10^{-9}$ & $1.1 \times 10^{-8}$ & $9.2 \times 10^{-9}$ & $3.1 \times 10^{-9}$ & $5.7 \times 10^{-9}$ & $1.0 \times 10^{-8}$ & $3.2 \times 10^{-8}$ & $9.6 \times 10^{-9}$ & $3.1 \times 10^{-9}$ \\
\hline $\begin{array}{l}\text { 4. Orain Condenser to Rad- } \\
\text { waste; Water-Jet Cleaning }\end{array}$ & 4 & $4.0 \times 10^{-6}$ & $1.5 \times 10^{-9}$ & $1.4 \times 10^{-9}$ & $4.8 \times 10^{-9}$ & $1.2 \times 10^{-9}$ & $1.4 \times 10^{-9}$ & $1.6 \times 10^{-9}$ & $1.5 \times 10^{-9}$ & $1.4 \times 10^{-8}$ & $1.2 \times 10^{-9}$ & $1.4 \times 10^{-9}$ \\
\hline $\begin{array}{l}\text { 6. Decon HVAC, Electrical, } \\
\text { Misc. Stee S Structures and } \\
\text { Concrete; Apply Protective } \\
\text { Paint } \\
\text { Totals }\end{array}$ & $\begin{array}{c}5 \\
N / A\end{array}$ & $\begin{array}{c}3.3 \times 10^{-7} \\
\text { N/A }\end{array}$ & $\frac{1.4 \times 10^{-10}}{5.8 \times 10^{-9}}$ & $\frac{2.8 \times 10^{-10}}{7.2 \times 10^{-9}}$ & $\frac{2.4 \times 10^{-10}}{1.6 \times 10^{-8}}$ & $\frac{6.3 \times 10^{-10}}{1.1 \times 10^{-8}}$ & $\frac{6.6 \times 10^{-11}}{4.6 \times 10^{-9}}$ & $\frac{2.5 \times 10^{-10}}{7.6 \times 10^{-9}}$ & $\frac{6.6 \times 10^{-10}}{1.2 \times 10^{-8}}$ & $\frac{7.3 \times 10^{-10}}{4.6 \times 10^{-8}}$ & $\frac{6.6 \times 10^{-10}}{1.1 \times 10^{-8}}$ & $\frac{6.6 \times 10^{-11}}{4.6 \times 10^{-9}}$ \\
\hline \multicolumn{13}{|l|}{ Radwaste and Control Buflding } \\
\hline $\begin{array}{l}\text { Tasks Identical } 1 \text { to Imnedrate } \\
\text { Di smantlement }(d)\end{array}$ & N/A & N/A & $3.3 \times 10^{-7}$ & $3.1 \times 10^{-7}$ & $1.0 \times 10^{-6}$ & $3.2 \times 10^{-7}$ & $2.9 \times 10^{-7}$ & $3.6 \times 10^{-7}$ & $3.9 \times 10^{-7}$ & $2.9 \times 10^{-6}$ & $3.3 \times 10^{-7}$ & $2.9 \times 10^{-7}$ \\
\hline $\begin{array}{l}\text { 3. Decon Equipment External } \\
\text { Surfaces; Apply Protective } \\
\text { Pa int }\end{array}$ & 5 & $9.0 \times 10^{-6}$ & $3.7 \times 10^{-9}$ & $7.7 \times 10^{-9}$ & $6.5 \times 10^{-9}$ & $1.7 \times 10^{-8}$ & $1.8 \times 10^{-9}$ & $6.8 \times 10^{-9}$ & $1.8 \times 10^{-8}$ & $2.0 \times 10^{-8}$ & $1.8 \times 10^{-8}$ & $1.8 \times 10^{-9}$ \\
\hline $\begin{array}{l}\text { 4. Decon Electrical Equipment, } \\
\text { Fisc. Steel Structures. } \\
\text { HVAC; Apply Protective } \\
\text { Paint }\end{array}$ & 5 & $1.2 \times 10^{-5}$ & $4.9 \times 10^{-9}$ & $1.0 \times 10^{-8}$ & $8.6 \times 10^{-9}$ & $2.3 \times 10^{-8}$ & $2.4 \times 10^{-9}$ & $9.1 \times 10^{-9}$ & $2.4 \times 10^{-8}$ & $2.6 \times 10^{-8}$ & $2.4 \times 10^{-8}$ & $2.4 \times 10^{-9}$ \\
\hline $\begin{array}{l}\text { 5. Decon Concrete; Apply } \\
\text { Protect ive Paint } \\
\text { Totals }\end{array}$ & $\begin{array}{c}5 \\
N / A\end{array}$ & $\begin{array}{c}8.0 \times 10^{-6} \\
N / A\end{array}$ & $\frac{3.3 \times 10^{-9}}{3.4 \times 10^{-7}}$ & $\frac{6.9 \times 10^{-9}}{3.4 \times 10^{-7}}$ & $\frac{5.8 \times 10^{-9}}{1.0 \times 10^{-6}}$ & $\frac{1.5 \times 10^{-8}}{3.8 \times 10^{-7}}$ & $\frac{1.6 \times 10^{-9}}{2.9 \times 10^{-7}}$ & $\frac{6.1 \times 10^{-9}}{3.8 \times 10^{-7}}$ & $\frac{1.6 \times 10^{-8}}{4.4 \times 10^{-7}}$ & $\frac{1.8 \times 10^{-8}}{3.0 \times 10^{-6}}$ & $\frac{1.6 \times 10^{-8}}{3.8 \times 10^{-7}}$ & $\frac{1.6 \times 10^{-9}}{2.9 \times 10^{-7}}$ \\
\hline Totals & N/A & N/A & $3.4 \times 10^{\circ}$ & & $1.0 \times 10^{-6}$ & $3.8 \times 10^{-7}$ & $2.9 \times 10^{-1}$ & $3.8 \times 10^{-6}$ & $4.4 \times 10^{-7}$ & $3.0 \times 10^{-6}$ & $3.8 \times 10^{-1}$ & $2.9 \times 10^{-7}$ \\
\hline
\end{tabular}


TABLE N.3-5. Radiation Doses to the Population from Atmospheric Releases During Preparations for Passive Safe Storage(a)

Building/Task ${ }^{(b)}$ $\begin{gathered}\text { Reference } \\ \text { Radionuclide } \\ \text { Inventory } \\ \text { Number(d) }\end{gathered} \begin{gathered}\text { Annual } \\ \text { Relmospherif }\end{gathered}$

\section{Reactor Bullding}

Tasks Identical to Immediate
Di smantlement

6. General Cleanup

$N / A^{(f)}$

5

15. Decon HVAC, Electrical, Misc. Steel Structures and Equipment and Concrete; Apply Protective Paint Totals

Turbille Generator Building Tasks Identical to Irmediate

4. Drain Condenser to Radwaste; Water-jet Cleaning

6. Decon HVAC, Electrical. Misc. Steel Structures and Concrete; Apply Protective Potais

Radwaste and Control Building Tasks Identical to Immediate Dismantlement $(e)$

3. Decon Equipment External Surfaces; Apply Protective

4. Decon Electrical. Equipment, Misc. Steel Structures, HVAC; Apply Protective

Decon Concrete; Apply Protective Paint Totals
N/A $\quad 7 \times 10^{-6} 1 \times 10^{-5} 2 \times 10^{-5} 3 \times 10^{-5} 5 \times 10^{-6} 1 \times 10^{-5} 3 \times 10^{-5} 9 \times 10^{-5} 3 \times 10^{-5} 5 \times 10^{-6}$ $8.3 \times 10^{-6} 2 \times 10^{-6} 5 \times 10^{-6} 6 \times 10^{-6} \quad 1 \times 10^{-5} 1 \times 10^{-6} 4 \times 10^{-6} 1 \times 10^{-5} 2 \times 10^{-5} 1 \times 10^{-5} 1 \times 10^{-6}$

$\underset{\mathrm{N} / \mathrm{A}}{3.0 \times 10^{-7}} \frac{8 \times 10^{-8}}{9 \times 10^{-6}} \frac{2 \times 10^{-7}}{2 \times 10^{-5}} \frac{2 \times 10^{-7}}{3 \times 10^{-5}} \frac{5 \times 10^{-7}}{4 \times 10^{-5}} \frac{4 \times 10^{-8}}{6 \times 10^{-6}} \frac{2 \times 10^{-7}}{2 \times 10^{-5}} \frac{5 \times 10^{-7}}{4 \times 10^{-5}} \frac{7 \times 10^{-7}}{1 \times 10^{-4}} \frac{5 \times 10^{-7}}{4 \times 10^{-5}} \frac{4 \times 10^{-8}}{6 \times 10^{-6}}$

N/A $\quad 3 \times 10^{-6} 3 \times 10^{-6} 1 \times 10^{-5} 7 \times 10^{-6} 1 \times 10^{-6} 4 \times 10^{-6} 8 \times 10^{-6} 3 \times 10^{-5} 7 \times 10^{-6} 2 \times 10^{-6}$ $4.0 \times 10^{-6} 9 \times 10^{-7} 8 \times 10^{-7} 5 \times 10^{-6} 7 \times 10^{-7} 8 \times 10^{-7} 1 \times 10^{-6} 9 \times 10^{-7} 1 \times 10^{-5} 7 \times 10^{-7} 8 \times 10^{-7}$ $3.3 \times 10^{-7}$
$\mathrm{~N} / \mathrm{A}$$\frac{9 \times 10^{-8}}{4 \times 10^{-6}} \frac{2 \times 10^{-7}}{4 \times 10^{-6}} \frac{2 \times 10^{-7}}{2 \times 10^{-5}} \frac{5 \times 10^{-7}}{8 \times 10^{-6}} \frac{4 \times 10^{-8}}{2 \times 10^{-6}} \frac{2 \times 10^{-7}}{5 \times 10^{-6}} \frac{5 \times 10^{-7}}{9 \times 10^{-6}} \frac{8 \times 10^{-7}}{4 \times 10^{-5}} \frac{5 \times 10^{-7}}{8 \times 10^{-6}} \frac{5 \times 10^{-8}}{2 \times 10^{-6}}$ N/A $\quad 2 \times 10^{-4} 2 \times 10^{-4} 1 \times 10^{-3} 2 \times 10^{-4} 2 \times 10^{-4} 2 \times 10^{-4} 3 \times 10^{-4} 3 \times 10^{-3} 2 \times 10^{-4} 2 \times 10^{-4}$ $9.0 \times 10^{-6} 2 \times 10^{-8} 5 \times 10^{-8} \quad 6 \times 10^{-3} \quad 1 \times 10^{-7} 1 \times 10^{-8} \quad 6 \times 10^{-6} \quad 1 \times 10^{-5} 2 \times 10^{-5} 1 \times 10^{-5} 1 \times 10^{-6}$ $1.2 \times 10^{-5} 3 \times 10^{-6} 7 \times 10^{-6} 8 \times 10^{-6} 2 \times 10^{-5} 1 \times 10^{-6} 6 \times 10^{-6} 2 \times 10^{-5} 3 \times 10^{-5} 2 \times 10^{-5} 2 \times 10^{-6}$ $\underset{\mathrm{N} / \mathrm{A}}{8.0 \times 10^{-6}} \frac{2 \times 10^{-6}}{2 \times 10^{-4}} \frac{4 \times 10^{-6}}{2 \times 10^{-4}} \frac{6 \times 10^{-6}}{1 \times 10^{-3}} \frac{1 \times 10^{-5}}{2 \times 10^{-4}} \frac{1 \times 10^{-6}}{2 \times 10^{-4}} \frac{4 \times 10^{-6}}{2 \times 10^{-4}} \frac{1 \times 10^{-5}}{3 \times 10^{-4}} \frac{2 \times 10^{-5}}{3 \times 10^{-3}} \frac{1 \times 10^{-5}}{2 \times 10^{-4}} \frac{1 \times 10^{-6}}{2 \times 10^{-4}}$

(a)The calculated doses are shown to one significant figure and are to the $3.5 \times 10^{6}$ people residing within a radius of $80 \mathrm{~km}$.

(b)A listing of preparation for safe storage tasks and a determination of whether they are the same as immediate dismantlement tasks is given in Table N.3-1. Only tasks that are unique to preparation for safe storage that result in an atmospheric release are listed in detail in this table. (c) Numbers refer to the reference radionuclide inventories discussed in Appendix $E$.

(d) For comparison purposes, dose calculations are made based on a continuous release for 1 year.

e) A

for passive safe storage tasks that are identical to the doses for immediate dismantlement tasks are summed and listed here.
(f) N/A $=$ not applicable. 
TABLE N.3-6. Comparison of Postulated Accidents for Immediate Dismantlement and Passive Safe Storage

\begin{tabular}{|c|c|c|c|c|c|}
\hline Incident & Comments & $\begin{array}{l}\text { Frequency of } \\
\text { Occurrence }(a) \\
\end{array}$ & $\begin{array}{c}\text { Reference } \\
\text { Radionuclide } \\
\text { Inventory } \\
\text { Number(b) } \\
\end{array}$ & $\begin{array}{c}\text { Immediate } \\
\text { Dismantlement } \\
\text { Atmospheric } \\
\text { Release } \\
(\mathrm{Ci} / \mathrm{hr})(\mathrm{c}) \\
\end{array}$ & $\begin{array}{c}\text { Passive } \\
\text { Safe Storage } \\
\text { Atmospheric } \\
\text { Release } \\
(\mathrm{Ci} / \mathrm{hr})(\mathrm{c}) \\
\end{array}$ \\
\hline $\begin{array}{l}\text { Explosion of LPG } \\
\text { Leaked from a Front- } \\
\text { End Loader }\end{array}$ & $\begin{array}{l}4.5 \mathrm{~kg} \text { of } L P G \text { leaked in the } \\
\text { reactor building during the load- } \\
\text { ing of activated concrete }\end{array}$ & Low & 3 & $8.6 \times 10^{-3}$ & $N / A^{(d)}$ \\
\hline $\begin{array}{l}\text { Vacuum Filter-Bag } \\
\text { Rupture }\end{array}$ & $\begin{array}{l}\text { Rupture of a full filter-bag dur- } \\
\text { ing surface cleanind }\end{array}$ & Medium & 5 & $8.5 \times 10^{-4}$ & $8.5 \times 10^{-4}$ \\
\hline $\begin{array}{l}\text { Contamination Control } \\
\text { Envelope Rupture }\end{array}$ & $\begin{array}{l}\text { Leakage during reactor vessel } \\
\text { removal (Task } 12 \text { in the Reactor } \\
\text { Building) }\end{array}$ & High & 2 & $1.4 \times 10^{-4}$ & N/A \\
\hline Oxyacetylene Explosion & $\begin{array}{l}\text { Explosion during reactor vessel } \\
\text { removal (Task } 12 \text { in the Reactor } \\
\text { Building) }\end{array}$ & Medium & 2 & $1.2 \times 10^{-4}$ & N/A \\
\hline $\begin{array}{l}\text { Contaminated Sweeping } \\
\text { Compound Fire }\end{array}$ & $\begin{array}{l}\text { A fire consumes } 0.5 \mathrm{~m}^{3} \text { of sweep- } \\
\text { ing compound }\end{array}$ & Medium & 5 & i. $1 \times 10^{-6}$ & $1.1 \times 10^{-6}$ \\
\hline $\begin{array}{l}\text { Gross Leak During Loop } \\
\text { Chemical Decontamina- } \\
\text { tion }\end{array}$ & $\begin{array}{l}\text { A leak } 10 \text { times larger than the } \\
\text { routine leak in the Radwaste and } \\
\text { Control Building) }\end{array}$ & Low & 4 & $1.0 \times 10^{-6}$ & $.1 .0 \times 10^{-6}$ \\
\hline $\begin{array}{l}\text { Filter Danage from } \\
\text { Blasting Surges }\end{array}$ & $\begin{array}{l}\text { Damage from routine concrete } \\
\text { blasting operations (Task } 14 \text { in } \\
\text { the Reactor Building) }\end{array}$ & Medium & 3 & $1.3 \times 10^{-7}$ & $N / A$ \\
\hline Combustible Waste Fire & $\begin{array}{l}1 \mathrm{~m}^{3} \text { of waste is involved in a } \\
\text { fire }\end{array}$ & High & 5 & $6.0 \times 10^{-9}$ & $6.0 \times 10^{-9}$ \\
\hline $\begin{array}{l}\text { Detonation of Unused } \\
\text { Explosives }\end{array}$ & $\begin{array}{l}\text { Detonation of a positioned } \\
\text { charge after removal of controls } \\
\text { (Task } 15 \text { in the Reactor Build- } \\
\text { ing) }\end{array}$ & Medium & 3 & $4.8 \times 10^{-10}$ & $N / A$ \\
\hline
\end{tabular}

(a)The frequency of occurrence considers not only the probability of the accident, but also the probability of an atmospheric release of the calculated magnitude. The frequency of gccurrence is listed as "High" if the occurrence of a release of similar or greater magnitude per year is $>10^{-2}$, as "Medium" if between $10^{-2}$ and $10^{-5}$, and as "Low" if $<10^{-5}$.

(b) These numbers refer to the reference radionuclide inventories discussed in Appendix $E$.

(c) All releases are assumed to occur in a 1-hr period for comparison purposes.

(d) $N / A=$ not applicable. 
$10^{-2}$ and $10^{-5}$, and as "low" if less than $10^{-5}$. Only accidents with a calculated atmospheric release are compared in Table N.3-6.

No accidents are postulated for preparations for passive safe storage that are different from the accidents that are postulated for immediate dismantlement. None of the tasks defined for passive safe storage involve removal of the activated steel or concrete, thus the accidents defined for immediate dismantlement involving these materials do not apply. The calculated radiation doses to the maximum-exposed individual from the accidents considered for preparations for passive safe storage are the same as the doses calculated for immediate dismantlement, as listed in Table N.2-19.

\section{N.3.3 Continuing Care}

Radioactive contamination during the continuing care period is assumed to be fixed firmly in place and is not readily available for airborne release. The tasks during continuing care involve surveillance, maintenance, and security with no operational components or equipment except for automatic monitoring or security systems. Thus, no routine airborne releases are anticipated during continuing care.

Only low probability accidents with causes external to the plant can result in an accidental release of radioactive materials during continuing care. Such causes include earthquakes or intrusion into the facility. The combination of the low probability of these events and the immobility of the radionuclide inventories will reduce the impact of accidents during continuing care. Thus, no analysis of postulated continuing care accidents is attempted in this study.

\section{N.3.4 Deferred Dismantlement}

Deferred dismantlement is assumed to be required after a period of continuing care to permit termination of the nuclear facility license. Since a period of continuing care will permit radioactive decay of the short-lived activation products and fission products, the inventories within the reference BWR will be greatly reduced. The time dependence of the reference radionuclide inventories is discussed in Appendix E. Thus, if the same procedures are used, the atmospheric releases during deferred dismantlement should be less than 
those during immediate dismantlement. The public radiation doses from either routine deferred dismantlement tasks or postulated accidents should also be less than the radiation doses calculated for immediate dismantlement. Therefore, public safety during deferred dismantlement is not further analyzed, since the radiation doses are assumed to be equal to or less than the radiation doses from immediate dismantlement, depending on the length of the continuing care period.

\section{N.4 ENTOMBMENT}

The third decommissioning alternative considered in this study is entombment. This al ternative results in removal of the radioactively contaminated portions of the buildings and equipment and utilizes onsite storage of waste by converting the primary containment vessel in the Reactor Building into a waste storage facility. Onsite storage reduces the volume of waste shipped offsite for disposal, but requires a continued license as a waste storage facility. Details of the tasks and requirements of entombment are discussed in Appendix $k$.

The inventories of radioactive contamination used in this public safety evaluation of entombment tasks are the shutdown inventories discussed in Appendix E. Shutdown inventories are used to maximize the calculated atmospheric releases.

In the following sections, the atmospheric releases of radioactivity from entombment are described for both routine tasks and postulated accidents. The atmospheric release analysis uses the same calculational methods described in Section N.2.1.1 for immediate dismantlement.

\section{N.4.1 Routine Entombment Tasks}

The chronological sequence of entombment tasks is listed in Table K.2-l in Appendix K. Entombment tasks are listed with their operational time requirements for the Reactor Building, the Turbine Generator Building, and the Radwaste and Control Building. The majority of the tasks defined for entombment are identical to the tasks defined for immediate dismantlement. For the Turbine Generator Building and the Radwaste and Control Building, the only difference between entombment and immediate dismantlement tasks is the chronological 
sequence of the tasks. Therefore, no new analysis of the atmospheric releases from entombment of these buildings is attempted. Furthermore, the atmospheric releases and resulting radiation doses to the public are assumed to be identical with those calculated previously for immediate dismantlement (see Section N.2). For the Reactor Building, a list of the entombment tasks considered and a determination of whether a new analys is is required is given in Table N.4-1.

Two scenarios of entombment are considered in Appendix $K$. In the first, it is assumed that the reactor internals are removed and shipped to a waste disposal site. In the second, the reactor internals are assumed to be left in-place. Atmospheric releases and the resulting public radiation doses are calculated only for Scenario 1. Scenario 2, with fewer tasks and smaller atmospheric releases, is not analyzed further.

The following sections contain a discussion of the methods used to calculate the atmospheric releases and resulting public radiation doses for entombment of the reference BWR. A new analysis is required only for those tasks in the Reactor Building that are unique to entombment. Dose results for the tasks that are similar to immediate dismantlement are based on the results from immediate dismantlement, with no new analysis.

\section{N.4.1.1 Methods for Calculating Atmospheric Releases of Radioactivity}

The reference entombment tasks defined in Appendix $K$ are analyzed using the same airborne release mechanisms discussed in Section N.2.1.1 for immediate dismantlement. A summary of the reference tasks considered in this study is shown in Table N.2-2. The only task used during entombment that is not defined for immediate dismantlement is the use of a jackhammer for removing concrete. For the airborne release analysis, it is assumed that the jackhammer produces airborne radioactivity in the same manner as drilling contaminated concrete. The airborne release from drilling is defined by Equation N.11 in Section N.2.1.1. Since the jackhammer works on a small area of concrete, a vacuum exhaust system is defined to reduce the quantity of airborne radioactive concrete dust. This system is assumed to have an airflow of $1000 \mathrm{~m}^{3} / \mathrm{hr}$, and reduces the air concentration of dust by a factor of 0.3 , the same factor as used for drilling. The radioactivity released to the atmosphere is found by 
TABLE N.4-1. Comparison Between Entombment and Immediate Dismantlement Tasks

Building/Task ${ }^{(a)}$

Reactor Building and Primary Containment
Analyzed in Analysis Section N.2 Required

1. Install HEPA Filters

2. Comprehensive Radiation Survey

3. Discharge and Ship Fuel

4. Remove Oryer and Separator

5. Drain Suppression Pool to Radwaste; Water-Jet Cleaning

6. Remove Reactor Vessel Internals

7. Ship Activated Components

8. Cut Suppression Pool Downcomers and Bracing

9. Chemical Decon Residual Heat Removal, Low- and High-Pressure Core Spray Systems

10. Drain Contaminated Systems to Radwaste

11. Drain Reactor Well Pool Cavity to Radwaste; Water-Jet Cleaning

12. Clean Up, Stage, and Shield Hot Spots in Primary Containment

13. Chemical Decon Reactor Water Recirculating and Clean-up Systems

14. Drain Dryer and Separator Pool to Radwaste; Water-Jet Cleaning

15. Cut Suppression Chamber Accesses Through Drywell Floor (2)

16. Chemical Decon Drain Systems

17. Cut Primary Containment Piping Penetrations and Seal

18. Cut Drywel1 Bellows Access Openings

19. Remove Reactor Building Piping

20. Drain Spent Fuel Pool to Temporary Radwaste; Water-Jet Cleaning

21. Chemical Decon Spent Fuel Pool Cooling and Cleanup Systems

22. Remove Liners from Spent Fuel Pool and Dryer and Separator Pool

23. Remove Reactor Building Equipment

24. Seal Equipment and Personnel Hatch Openings into Primary Containment

25. Remove Reactor Building Contaminated Concrete

26. Seal Rail Tunnel, Steam Tunnel and Biological Shield Penetrations

27. Seal Drywell Top Head and Reactor Building External Doors

28. Remove HVAC and Disable Crane

29. Final Radiation Survey

30. Install Security and Surveillance Monitoring Equipment--Disconnect Unnecessary Utilities

(a) Only the Reactor Building is considered since entombment tasks in the other buildings are identical to the immediate dismantlement tasks previously defined. Only entombment Scenario 1 is considered in this analysis.

multiplying the quantity of airborne radioactivity generated by the leakage fraction from the contamination control envelope (0.1) and by the building HEPA filter transmission factor.

\section{N.4.1.2 Atmospheric Releases from Entombment}

Radioactivity releases to the atmosphere resulting from entombment tasks at the reference BWR are calculated using the general methods and equations 
described in Sections N.2.1.1 and N.4.1.1. The operational data used in this analysis is listed in Table N.4-2. Again, only those tasks assumed to result in an atmospheric release that are unique to entombment are 1 isted, and these all occur in the Reactor Building. The calculated atmospheric releases of radioactivity are listed in Table N.4-3, together with the calculated airborne radioactivity generated inside the Reactor Building. The atmospheric releases are used in radiation dose calculations to estimate the radiation doses to the public from routine entombment tasks. The results of the radiation dose calculations are contained in the following section.

\section{N.4.1.3 Public Radiation Doses from Routine Entombment}

First-year doses and fifty-year committed dose equivalents to both the maximum-exposed individual and the population residing within $80 \mathrm{~km}$ of the site are calculated using the radiation dose models discussed in Appendix F. Each routine atmospheric release during entombment is assumed to occur at a constant rate for a 1-year period so that direct comparisons of the impact of entombment tasks can be made. Public radiation doses are listed for entombment Scenario 1 only. For this study, the organs of reference for which radiation doses are calculated include: total body, bone, lung, thyroid, and GI-tract (lower large intestine).

Radiation doses to the maximum-exposed individual are listed in Table N.4-4, and radiation doses to the population are listed in Table N.4-5 for entombment Scenario 1 . These tables 1 ist the tasks unique to entombment Scenario 1, and the results from the tasks previously calculated for immediate dismantlement that are identical to entombment tasks.

\section{N.4.2 Postulated Accidents During Entombment}

No entombment accidents are postulated that are different from the accidents that are postulated for immediate dismantlement in Section N.2.2. The only task defined for entombment Scenario 1 that involves removal of highly activated materials is the removal of the reactor internals. This task is performed by underwater cutting methods, and no accidents resulting in an atmospheris release are postulated. Thus, entombment accidents are less severe than those postulated for immediate dismantlement. The same accidents considered 
TABLE N.4-2. Public Safety Analysis Data for Entombment of the Reactor Building and Primary Containment

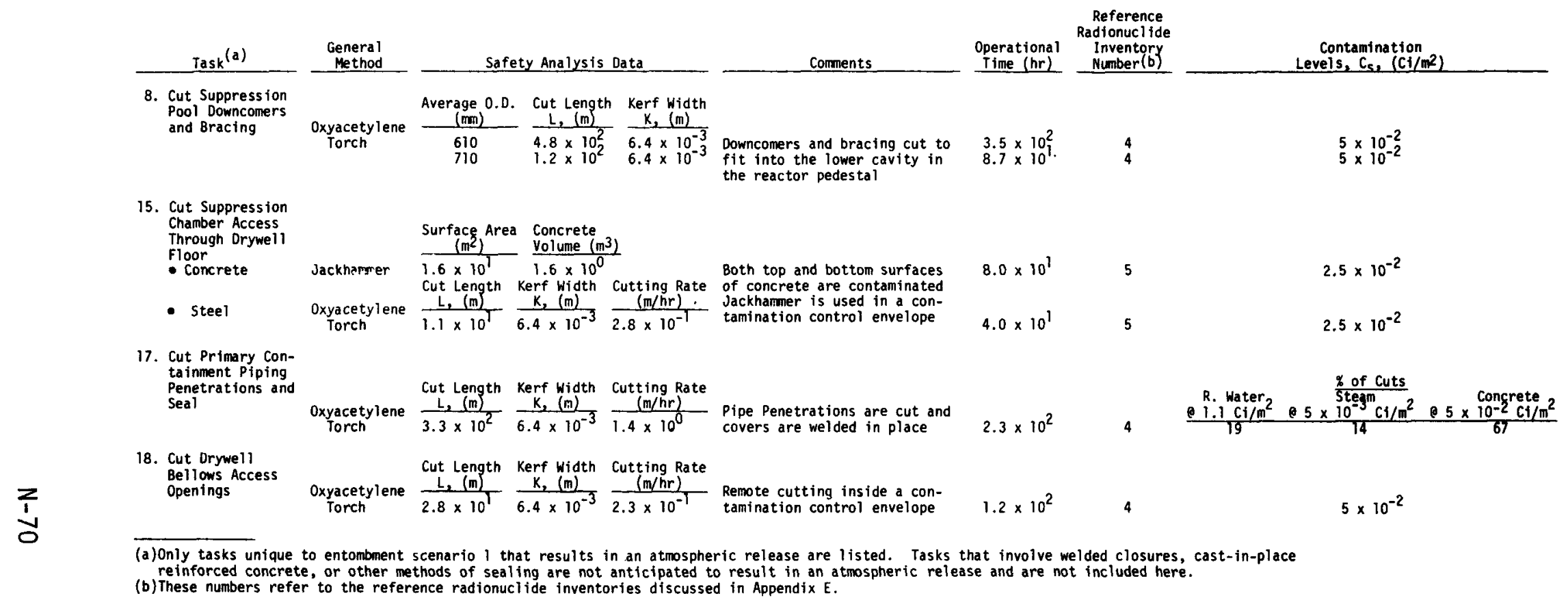


TABLE N.4-3. Calculated Atmospheric Releases for Entombment of the Reactor Building and Primary Containment

\begin{tabular}{|c|c|c|c|c|c|c|c|}
\hline $\operatorname{Task}^{(a)}$ & $\begin{array}{r}\text { General } \\
\text { Method } \\
\end{array}$ & $\begin{array}{l}\text { Operational } \\
\text { Time (hr) } \\
\end{array}$ & $\begin{array}{l}\text { Reference } \\
\text { Radionucl ide } \\
\text { Inventory } \\
\text { Number (b) } \\
\end{array}$ & $\begin{array}{c}\text { Airborne } \\
\text { Generation Rate } \\
\text { Inside Building } \\
\text { or Control } \\
\text { Envelope } \\
\text { (Ci/hr) } \\
\end{array}$ & $\begin{array}{c}\text { Total } \\
\text { Airborne } \\
\text { Radioactivity } \\
\text { Inside Building } \\
\text { or Control } \\
\text { Envelope (Ci) } \\
\end{array}$ & $\begin{array}{l}\text { Contamination } \\
\text { Control System } \\
\text { Transmissjoon } \\
\text { Factor }(c) \\
\end{array}$ & $\begin{array}{c}\text { Annual } \\
\text { Atmospheric } \\
\text { Release } \\
\text { (Ci) (d) } \\
\end{array}$ \\
\hline $\begin{array}{l}\text { 8. Cut Supression Pool Down- } \\
\text { comers and Bracing }\end{array}$ & $\begin{array}{l}\text { Oxyacetylene } \\
\text { Torch }\end{array}$ & $4.4 \times 10^{2}$ & 4 & $8.6 \times 10^{-4}$ & $3.8 \times 10^{-1}$ & $5 \times 10^{-4}$ & $1.9 \times 10^{-4}$ \\
\hline \multirow{2}{*}{$\begin{array}{l}\text { 15. Cut Suppression Chamber } \\
\text { Access Through Drywell } \\
\text { Floor } \\
\text { - Concrete } \\
\text { - Steel }\end{array}$} & \multirow{2}{*}{$\begin{array}{l}\text { Jackhammer } \\
\text { 0xyacetylene } \\
\text { Torch }\end{array}$} & $8.0 \times 10^{7}$ & 5 & $9.0 \times 10^{-7}$ & $7.2 \times 10^{-5}$ & $5 \times 10^{-5}$ & $3.6 \times 10^{-9}$ \\
\hline & & $4.0 \times 10^{1}$ & 5 & $4.4 \times 10^{-5}$ & $1.8 \times 10^{-3}$ & $5 \times 10^{-5}$ & $8.8 \times 10^{-8}$ \\
\hline $\begin{array}{l}\text { 17. Cut Primary Containment } \\
\text { Piping Penetrations and } \\
\text { Seal }\end{array}$ & $\begin{array}{l}\text { 0xyacetylene } \\
\text { Torch }\end{array}$ & $2.3 \times 10^{2}$ & 4 & $2.2 \times 10^{-3}$ & $5.1 \times 10^{-1}$ & $5 \times 10^{-4}$ & $2.6 \times 10^{-4}$ \\
\hline $\begin{array}{l}\text { 18. Cut Drywell Bellows } \\
\text { Access Openings }\end{array}$ & $\begin{array}{l}\text { 0xyacetylene } \\
\text { Torch }\end{array}$ & $1.2 \times 10^{2}$ & 4 & $7.5 \times 10^{-5}$ & $9.0 \times 10^{-3}$ & $5 \times 10^{-4}$ & $4.5 \times 10^{-6}$ \\
\hline \multicolumn{8}{|c|}{$\begin{array}{l}\text { (a) Only tasks unique to entombment scenario } 1 \text { that result in an atmospheric release are listed. Tasks that involve welded closures, } \\
\text { cast-in-place reinforced concrete, or other methods of sealing are not anticipated to result in an atmospheric release and are not } \\
\text { included here. } \\
\text { (b) These numbers refer to the reference radionculide inventories discussed in Appendix E. } \\
\text { (c) The assumed building HEPA transmission factor is } 5 \times 10^{-4} \text {. The combined transmission for a contamination control envelope and the } \\
\text { building HEPA filter is } 5 \times 10^{-5} \text {. } \\
\text { (d) For comparison purposes, dose caiculations are made based on a continuous release for } 1 \text { year. }\end{array}$} \\
\hline
\end{tabular}




\section{TABLE N.4-4. Radiation Doses to the Maximum-Exposed Individual From}

Atmospheric Releases During Routine Entombment Tasks

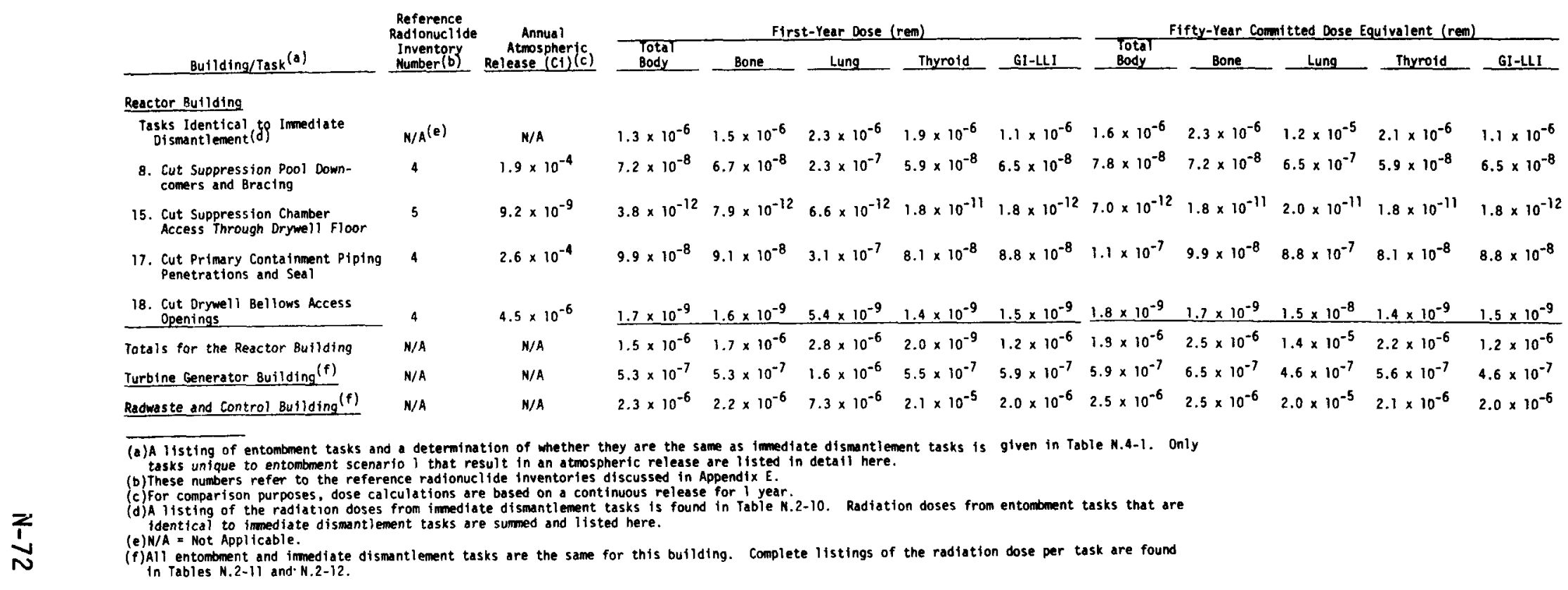


TABLE N.4-5. Radiation Doses to the Population from Atmospheric Releases During Routine Entombment Tasks(a)

\begin{tabular}{|c|c|c|c|c|c|c|c|c|c|c|c|c|}
\hline \multirow[b]{2}{*}{ Building/Task (b) } & \multirow{2}{*}{$\begin{array}{c}\text { Reference } \\
\text { Radionuclide } \\
\text { Inventory } \\
\text { Number(c) } \\
\end{array}$} & \multirow{2}{*}{$\begin{array}{c}\text { Annual } \\
\text { Atmospheric } \\
\text { Release (ci) (d) }\end{array}$} & \multicolumn{5}{|c|}{ First-Year Dose (man-rem) } & \multicolumn{5}{|c|}{ Fifty-Year Comitted Dose Equivalent (man-rem) } \\
\hline & & & $\begin{array}{l}\text { Total } \\
\text { Body } \\
\end{array}$ & Bone & Lung & Thyroid & GI-LLI & Body & Bone & Lung & Thyroid & GI-LLI \\
\hline \multicolumn{13}{|l|}{ Reactor Building } \\
\hline $\begin{array}{l}\text { Tasks Identical to Imme- } \\
\text { diate Dismantl ement }(e)\end{array}$ & $N / A^{(f)}$ & N/A & $2 \times 10^{-4}$ & $6 \times 10^{-4}$ & $3 \times 10^{-3}$ & $1 \times 10^{-3}$ & $7 \times 10^{-4}$ & $2 \times 10^{-4}$ & $1 \times 10^{-3}$ & $1 \times 10^{-2}$ & $1 \times 10^{-3}$ & $7 \times 10^{-4}$ \\
\hline $\begin{array}{l}\text { 8. Cut Suppression Pool } \\
\text { Dewncommers and } \\
\text { Bracing }\end{array}$ & 4 & $1.9 \times 10^{-4}$ & $4 \times 10^{-5}$ & $4 \times 10^{-5}$ & $2 \times 10^{-4}$ & $3 \times 10^{-5}$ & $4 \times 10^{-5}$ & $5 \times 10^{-5}$ & $4 \times 10^{-5}$ & $7 \times 10^{-4}$ & $3 \times 10^{-5}$ & $4 \times 10^{-5}$ \\
\hline $\begin{array}{l}\text { 15. Cut Suppression } \\
\text { Chamber Access } \\
\text { Through Drywel1 } \\
\text { Floor }\end{array}$ & 5 & $9.2 \times 10^{-9}$ & $2 \times 10^{-9}$ & $5 \times 10^{-9}$ & $6 \times 10^{-9}$ & $1 \times 10^{-8}$ & $1 \times 10^{-9}$ & $5 \times 10^{-9}$ & $1 \times 10^{-8}$ & $2 \times 10^{-8}$ & $1 \times 10^{-8}$ & $1 \times 10^{-9}$ \\
\hline $\begin{array}{l}\text { 17. Cut Primary Contain- } \\
\text { ment Piping Pene- } \\
\text { trating and Seal }\end{array}$ & 4 & $2.6 \times 10^{-4}$ & $6 \times 10^{-5}$ & $5 \times 10^{-5}$ & $3 \times 10^{-4}$ & $5 \times 10^{-5}$ & $5 \times 10^{-5}$ & $7 \times 10^{-5}$ & $6 \times 10^{-5}$ & $9 \times 10^{-4}$ & $5 \times 10^{-5}$ & $5 \times 10^{-5}$ \\
\hline $\begin{array}{l}\text { 18. Cut Drywell Bellows } \\
\text { Access Openings }\end{array}$ & 4 & $4.5 \times 10^{-6}$ & $1 \times 10^{-6}$ & $9 \times 10^{-7}$ & $5 \times 10^{-6}$ & $8 \times 10^{-7}$ & $9 \times 10^{-7}$ & $1 \times 10^{-6}$ & $1 \times 10^{-6}$ & $2 \times 10^{-5}$ & $8 \times 10^{-7}$ & $9 \times 10^{-7}$ \\
\hline $\begin{array}{l}\text { Totals for the Reactor } \\
\text { Building }\end{array}$ & N/A & $\mathrm{N} / \mathrm{A}$ & $3 \times 10^{-4}$ & $7 \times 10^{-4}$ & $4 \times 10^{-3}$ & $1 \times 10^{-3}$ & $8 \times 10^{-4}$ & $3 \times 10^{-4}$ & $1 \times 10^{-3}$ & $1 \times 10^{-2}$ & $1 \times 10^{-3}$ & $8 \times 10^{-4}$ \\
\hline $\begin{array}{l}\text { Turbine Generator } \\
\text { Building(g) }\end{array}$ & N/A & N/A & $3 \times 10^{-4}$ & $3 \times 10^{-4}$ & $2 \times 10^{-3}$ & $3 \times 10^{-4}$ & $3 \times 10^{-4}$ & $3 \times 10^{-4}$ & $4 \times 10^{-4}$ & $5 \times 10^{-5}$ & $4 \times 10^{-4}$ & $3 \times 10^{-4}$ \\
\hline $\begin{array}{l}\text { Radwaste and Control } \\
\text { Building }(g)\end{array}$ & $\mathrm{N} / \mathrm{A}$ & N/A & $1 \times 10^{-3}$ & $1 \times 10^{-3}$ & $7 \times 10^{-3}$ & $1 \times 10^{-3}$ & $1 \times 10^{-3}$ & $1 \times 10^{-3}$ & $2 \times 10^{-3}$ & $3 \times 10^{-2}$ & $1 \times 10^{-3}$ & $1 \times 10^{-3}$ \\
\hline
\end{tabular}

(a) The calculated doses are shown to one significant figure and are to the $3.5 \times 10^{6}$ people residing within a radius of $80 \mathrm{~km}$ from the reference site.

(b)A listing of entombment tasks and a determtnation of whether they are the same as immediate dismantlement tasks is given in Table N.4-1. Only tasks unique to entombment scenario 1 that result in an atmospheric release are listed in detail here.

(c) These numbers refer to the reference radionucl ide inventories discussed in Appendix $E$.

(d) For comparison purposes, dose calculations are based on a continuous release for 1 year.

(e)A listing of the radiation doses from immediate dismantlement tasks is found in Table N.2-13. Radiation doses from entombment tasks that are identi. cal to immediate-dismantlement tasks are surmed and listed here.

(f) N/A = not apdlicable.
(g)All entombment and inmediate dismantlement tasks are the same for this building. Complete listings of the radiation dose per task are found in Tables N.2-14 and N.2-15. 
for preparations for passive safe storage are assumed to apply for entombment. These accidents are compared to immediate dismantlement accidents in Table N.3-6. The radiation doses to the maximum-exposed individual are listed in Table N.2-19.

\section{N.5 RADIATION DOSES FROM ROUTINE TRANSPORTATION TASKS}

Calculated radiation doses to the public and to the exposed transport workers resulting from shipments of radioactive materials during decommissioning are discussed in the following subsections. Spent fuel from the final BWR core loading is assumed to be shipped by rail in an IF-300 shipping cask to a repository located $2400 \mathrm{~km}$ away. Radioactive waste materials collected during decommissioning tasks are assumed to be shipped by truck to a disposal site located $800 \mathrm{~km}$ away. The method used to estimate routine radiation doses to transportation workers and to members of the general public from these shipis based on the method given in Reference 36 . Radiation doses received by workers unloading the radioactive materials at the repository or disposal site are not considered in this study since they are assumed to occur at separate licensed facilities.

\section{N.5.1 Technical Approach}

The following assumptions are made about rail and truck shipments of radioactive materials:

1. Each shipment contains enough radioactive material (either spent fuel or waste) to result in the maximum exposure rates allowable by regulations. Department of Transportation (DOT) regulations set the following exposure limits:

- $1000 \mathrm{mR} / \mathrm{hr}$ at $1 \mathrm{~m}$ from the external surface of any package transported in a closed vehicle

- $200 \mathrm{mR} / \mathrm{hr}$ at the external surface of the vehicle

- $10 \mathrm{mR} / \mathrm{hr}$ at any point $2 \mathrm{~m}$ from the vehicle

- $2 \mathrm{mR} / \mathrm{hr}$ at any normally occupied pasition in the vehicle. (37) 
2. For spent-fuel shipments, two train brakemen spend 10 minutes during each of 15 stops (one every $160 \mathrm{~km}$ ) at an average distance of $1 \mathrm{~m}$ from the shipping cask. The average exposure rate at $1 \mathrm{~m}$ is assumed to be $25 \mathrm{mR} / \mathrm{hr}$.

3. For each truck shipment of radioactive waste, two truck drivers spend 12 hours inside the cab (with an exposure rate of $2 \mathrm{mR} / \mathrm{hr}$ ) and 1 hour outside of the cab at a distance of $2 \mathrm{~m}$ from the cargo (with an exposure rate of $10 \mathrm{mR} / \mathrm{hr}$ ).

4. For each truck shipment of radioactive waste, two garagement each spend 10 minutes at an average distance of $2 \mathrm{~m}$ from the payload (at an exposure rate of $10 \mathrm{mR} / \mathrm{hr}$ ).

5. For each truck shipment of radioactive waste, the maximum-exposed individual is located $30 \mathrm{~m}$ from the route. His dose rate is calculated to be $1.2 \times 10^{-7}$ rem per shipment.

6. On each spent-fuel or radioactive waste shipment, 10 onlookers from the general public each spend 3 minutes at an average distance of $2 \mathrm{~m}$ from the payload (at an exposure rate of $10 \mathrm{mR} / \mathrm{hr}$ ).

7. The population density along the transport corridors is 120 persons $/ \mathrm{km}^{2}$.

8. All shipments maintain an average speed of $65 \mathrm{~km} / \mathrm{hr}$; thus, the cumulative dose to the public is $2.3 \times 10^{-6} \mathrm{man}-\mathrm{rem} / \mathrm{km}$.

Using these assumptions, the following subsections contain a discussion of the radiation doses from transportation of radioactive materials during each of the three decommissioning alternatives considered in this study. Both routine and accident conditions are discussed.

\section{N.5.1.1 Rail Shipments of Spent Fuel}

Using the aforementioned assumptions, the calculated radiation doses to the railway brakemen and to the general public resulting from the transport of the final reactor core are listed in Table N.5-1. For the 43 cask shipments, 5.4 man-rem to the train brakemen and 0.45 man-rem to onlookers and the general public are calculated to result. These values are assumed to be identical for all decommissioning alternatives considered, since all require the spent fuel to be shipped offsite. 


\section{TABLE N.5-1. Calculated Radiation Doses from Rail}

Transport of Spent Fuel(a)

\begin{tabular}{lcc}
\multicolumn{1}{c}{ Group } & $\begin{array}{c}\text { Radiation Dose Per } \\
\text { Shipment, }\end{array}$ (man-rem) & \begin{tabular}{c} 
Total Radiation \\
Dose, \\
\cline { 3 - 3 } (man-rem)
\end{tabular} \\
\cline { 1 - 2 } Train Brakemen & 0.12 & $\frac{5.4}{5.4}$ \\
Total Occupational & & 0.22 \\
Onlookers & 0.005 & $\underline{0.24}$ \\
General Public & 0.006 & 0.46
\end{tabular}

(a)All doses are rounded to two significant figures. (b) Based on a total of 43 shipments of $2400 \mathrm{~km}$ each.

\section{N.5.1.2 Truck Shipments of Radioactive Waste}

The number of radioactive waste shipments required for the three decommissioning alternatives, found in Tables I.3-2, J.5-4, and K.3-2, are: 1495 for immediate dismantlement, 318 for passive safe storage, and 985 for entombment scenario 1 and 728 for entombment scenario 2. Using these numbers of shipments and the previous assumptions, radiation doses to transport workers and to the general public are calculated and are listed in Table N.5-2.

\section{N.5.2 Transportation Accidents}

Transportation accidents have a wide range of severities. Most accidents occur at low vehicle speeds and have relatively minor consequences. In general, as speed increases, accident severity also increases. However, accident severity is not a function of vehicle speed only. Other factors, (e.g., the type of accident, the kind of equipment involved, and the location of the accident) can have an important bearing on accident severity.

Furthermore, damage to a package in a transportation accident is not directly related to accident severity. In a series of accidents of the same severity, or in a single accident involving a number of packages, damage to packages may vary from none to extensive. In relatively minor accidents, serious damage to packages 
TABLE N.5-2. Calculated Radiation Doses from Routine Radioactive Waste Transportation(a)

\section{Mode/Group}

Radiation Dose

per Shipment

$($ man-rem) $(a)$

Number of

Shipments

Total Population

Dose per Group

$(\operatorname{man}-r e m)(b)$

Immediate Dismantlement

Truck Drivers

Garagemen

Total Transportation Worker Dose

Onlookers

General Public

Total Public Dose

\section{Preparations for Passive Safe Storage}

Truck Drivers

Garagemen

Total Transportation Worker Dose

Onlookers

General Public

Total Public Dose

Entombment

(Scenario 1)

Truck Drivers

Garagemen

Total Transportation Worker Dose Onlookers

General Public

Total Public Dose

(Scenario 2)

Truck Drivers

Garagemen

Total Transportation Worker Dose

Onlookers

General Public

Total Public Dose
$6.7 \times 10^{-2} \quad 1495$

$3.3 \times 10^{-3}$

1495

$5.0 \times 10^{-3}$

$1.8 \times 10^{-3}$

1495

1495

$6.7 \times 10^{-2}$

$3.3 \times 10^{-3}$

$5.0 \times 10^{-3}$

$1.8 \times 10^{-3}$ 318

318

318

21

318

1.1

22

1.6

0.6

2.2
5.0

110

7.5

$\frac{2.8}{10}$

0

$6.7 \times 10^{-2}$

$3.3 \times 10^{-3}$

$5.0 \times 10^{-3}$

$1.8 \times 10^{-3}$

$6.7 \times 10^{-2}$

$3.3 \times 10^{-3}$

$5.0 \times 10^{-3}$

$1.8 \times 10^{-3}$
985

985

985

985

728

728

728

728
66

$-3.2$

69

4.9

1.8

6.7

49

2.4

51

3.6

1.3

4.9

(a) Based on one-way trips of $800 \mathrm{~km}$.

(b)All doses are rounded to two significant figures. 
can occur from impacts on sharp objects or from being struck by other cargo. Conversely, even in very severe accidents, damage to packages may be minimal.

The probabilities of rail and truck accidents in this study are based on accident data supplied in Reference 36. Accidents are classified into five severity categories as functions of vehicle speed and fire duration. The five categories and their associated probabilities for both rail and truck accidents are shown in Table N.5-3.

TABLE N.5-3. Transportation Accident Severity Categories (a)

\begin{tabular}{|c|c|c|c|c|}
\hline \multirow{2}{*}{ Severity } & \multirow{2}{*}{$\begin{array}{c}\text { Vehicle } \\
\text { Speed }(\mathrm{km} / \mathrm{hr})\end{array}$} & \multirow{2}{*}{$\begin{array}{c}\text { Fire } \\
\text { Duration }(h r)\end{array}$} & \multicolumn{2}{|c|}{ Probability/Vehicle-km } \\
\hline & & & Rail & Truck \\
\hline Minor & $\begin{array}{r}0-50 \\
0-50 \\
50-80\end{array}$ & $\begin{array}{c}0 \\
<0.5 \\
0\end{array}$ & $\begin{array}{l}3 \times 10^{-7} \\
4 \times 10^{-9} \\
2 \times 10^{-7}\end{array}$ & $\begin{array}{l}2 \times 10^{-7} \\
4 \times 10^{-9} \\
6 \times 10^{-7}\end{array}$ \\
\hline Moderate & $\begin{array}{c}0-50 \\
50-80 \\
80-110 \\
80-110\end{array}$ & $\begin{array}{c}0.5-1.0 \\
<0.5 \\
0 \\
<0.5\end{array}$ & $\begin{array}{l}6 \times 10^{-10} \\
2 \times 10^{-9} \\
5 \times 10^{-8} \\
6 \times 10^{-10}\end{array}$ & $\begin{array}{l}3 \times 10^{-11} \\
6 \times 10^{-9} \\
2 \times 10^{-7} \\
3 \times 10^{-9}\end{array}$ \\
\hline Severe & $\begin{array}{r}0-50 \\
50-80 \\
50-80 \\
80-710 \\
>110 \\
>110\end{array}$ & $\begin{array}{c}>1.0 \\
>1.0 \\
0.5-1.0 \\
0.5-1.0 \\
0 \\
<0.5\end{array}$ & $\begin{array}{l}4 \times 10^{-11} \\
2 \times 10^{-11} \\
3 \times 10^{-10} \\
9 \times 10^{-11} \\
5 \times 10^{-10} \\
6 \times 10^{-12}\end{array}$ & $\begin{array}{l}3 \times 10^{-12} \\
6 \times 10^{-12} \\
4 \times 10^{-12} \\
4 \times 10^{-12} \\
6 \times 10^{-11} \\
6 \times 10^{-11}\end{array}$ \\
\hline
\end{tabular}

(a) Summarized from material in Reference 36.

The following subsections contain a discussion of the method of calculating the airborne radioactivity concentrations resulting from transportation accidents, and discussions of spent-fuel and radioactive waste transportation accidents. Radiation doses to the maximum-exposed individual from inhalation are presented.

\section{N.5.2.1 Calculations of the Airborne Radioactive Concentration from a Transportation Accident}

The estimation of air concentrations for short-term airborne releases at distances within $1.0 \mathrm{~km}$ of the source requires special attention. Reference 38 
contains a discussion of acceptable assumptions for evaluating design-basis, loss-of-coolant accidents at a PWR. For accidental releases with a duration of less than 8 hours, a Pasquill Type $F$ atmospheric stability, and a unidirectional $1-\mathrm{m} / \mathrm{sec}$ wind are assumed. In Figure $2(A)$ of Reference 38 , the diffusion factor $(x / 0)$ is shown as a function of both the distance from a point source and the duration of the release. For a release of less than 8 hours, the $x / Q$ value at a distance of about $200 \mathrm{~m}$ is about $10^{-2} \mathrm{sec} / \mathrm{m}^{3}$. Extension of the curve beyond the border of the figure results in an estimated $X / Q$ value of about $1 \times 10^{-1} \mathrm{sec} / \mathrm{m}^{3}$ at a distance of $100 \mathrm{~m} .{ }^{(38)}$ Because of the difficulty in modeling the air concentrations at close distances, for this study the maximum-exposed individual is assumed to be located at $100 \mathrm{~m}$ from transportation accidents.

At distances close to the release source, the diffusion of the downwind plume is influenced by the cross-sectional area of the release source. For this reason, a comparison of the extrapolated $\times / Q$ values is calculated using a building-wake model. (39) Assuming complete reflection of the plume by the ground plane, the ground-level centerline air concentration from a groundlevel release is calculated using Equation N.13:

$$
X=Q^{\prime}\left(\pi \Sigma_{y} \Sigma_{z} \bar{u}\right)^{-1}
$$

where:

$X$ - the ground-level centerline air concentration, $\mathrm{Ci} / \mathrm{m}^{3}$

$Q^{\prime}$ - the rate of release from the source, corrected for decay during transit to the exposure point, $\mathrm{Ci} / \mathrm{sec}$

$\bar{u}$ - the average ground-level wind speed in the direction of travel, $\mathrm{m} / \mathrm{s}$

$\Sigma_{y}, \Sigma_{z} \bullet$ the building-wake diffusion coefficients, in meters, calculated by: 


$$
\begin{aligned}
& \Sigma_{y}=\left(\mathrm{cA} / \pi+\sigma_{\mathrm{y}}^{2}\right)^{1 / 2} \\
& \Sigma_{z}=\left(\mathrm{CA} / \pi+\sigma_{z}^{2}\right)^{1 / 2}
\end{aligned}
$$

where:

c a factor estimating the relation of the cross-sectional area to pressure wakes ( 0.5 for this study)

$\sigma_{y}$ - the crosswind lateral standard deviation of the cloud concentration, $m$

$\sigma_{z}$ - the crosswind vertical standard deviation of the cloud concentration, $m$

Minimum values of $\sigma_{y}$ and $\sigma_{z}$ of $\sqrt{A} / 6$ are assumed for this study.

Using Equation N.13, Pasquil1 Type F centerline air concentrations for various distances and selected release source cross-sectional areas are shown in Figure $\mathrm{N} \cdot 5-1$. At about $500 \mathrm{~m}$ downwind, the curves converge. At close distances to the release source, the dependence of the building-wake modification is illustrated by the divergence of the area-dependent curves.

In Figure N.5-1, it is seen that the value of $x / Q$ taken from Reference 38 corresponds to an exposed cross-sectional area of about $30 \mathrm{~m}^{2}$. This area appears to be reasonable; therefore, a value of $3 \times 10^{-2} \mathrm{sec} / \mathrm{m}^{3}$ is used as the transportation accident $\times / Q$ located $100 \mathrm{~m}$ downwind from the accident.

\section{N.5.2.2 Accidents During Rail Transportation of Spent-Fuel}

The IF-300 cask is a water-filled railroad cask designed to transport 18 fuel assemblies with an approximate loaded weight of $63 \mathrm{Mg} .(40,41)$ Gamma shielding is provided by $0.1 \mathrm{~m}$ of depleted uranium sandwiched between stainless steel walls. Neutron shielding and heat removal are provided by the water in the cask. This cask is a rugged thick-walled container designed to provide safe transport of spent fuel, with design integrity to withstand most transport accident situations. The cask is licensed to withstand Type B package tests. Recent results of cask test programs show that this cask will withstand all 


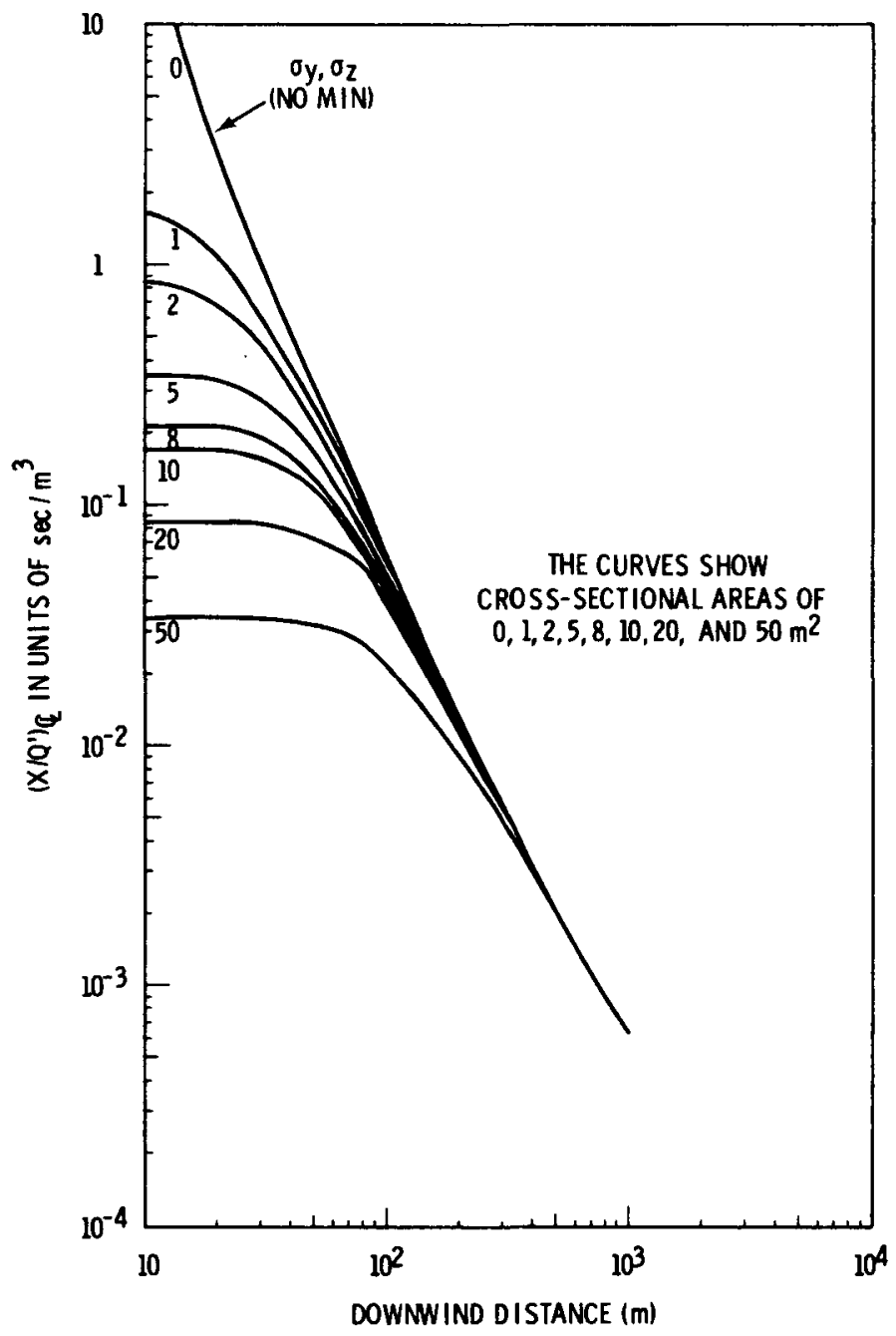

FIGURE N.5-1. Pasquill Type F Centerline $X / Q$ Values for Building-Wake Modification Factors Versus Downwind Distance

but the most severe, highly unusual types of accidents. $(42,43,44)$ For a release to occur during spent fuel transport, radioactive material must leave both the fuel cladding and the cask containment.

Postulated accidents involving spent fuel are derived from those presented in Reference 45. Since the transportation of spent fuel i,s not unique to decommissioning, and since the probabilities of accidents that lead to atmospheric releases of radionuclides from spent fuel transportation accidents are so low, 
no further analysis or dose calculations are presented in this study. A more complete discussion of the impact of spent fuel transportation accidents on public safety is given in Reference 45 .

\section{N.5.2.3 Accidents During Truck Transportation of Radioactive Wastes}

Transportation accidents involving trucks carrying radioactive waste from decomissioning the reference BWR may result in the atmospheric release of radioactive material. Accidents could occur with shipments of either Type $B$ or A packages as discussed in the following paragraphs.

Type B Package Accidents. A number of accident classes are identified and discussed in Reference 45 for Type B packages. The accident protection provided by Type $B$ overpacks and containers enables a shipment to withstand all but very severe, highly unusual accidents. Only improper packaging, severe impact, or fire is assumed to provide a mechanism for atmospheric release. The material being transported is solid and, for the most part, noncombustible; hence, even the fraction of respirable material released in a severe accident with ruptured Type B containers is expected to be smal1. (45) The most highly radioactive wastes are the neutron-activated portion of the reactor vessel and its internals, which are solid and noncombustible, and an airborne release from an accident involving this material is considered to have an extremely low probability. Therefore, no accident analysis of radioactive waste shipped in Type $B$ containers is attempted in this study. A detailed discussion of the public safety impacts of transportation accidents involving Type B containers is found in Reference 46.

Type A Package Accidents. A more realistic transportation accident is one involving wastes shipped in Type A packages. In Appendix I, shipments of compacted combustible material in Type $A$ packages are described. Accidents descriptions involving Type A packages are given in Table N.5-4 for minor accidents and in Table N.5-5 for severe accidents. Both minor and severe accidents are assumed to occur to truck shipments of combustible waste containing the mixture of radionuclides in reference radionuclide inventory 5 (Table E.2-9 in Appendix E). This inventory is composed of radionuclides in in transport groups III and IV. (47) The dominant radionuclide in this inventory is ${ }^{60} \mathrm{Co}$, a transport-group-III radionuclide. (12)

Type A packages containing 
TABLE N.5-4. Minor Accidents for Type A Packages

During Truck Transportation

Accident Description

Truck Collision or
Overturn Involves
Waste Containers

Truck Collision or Overturn and a Minor Fire $(1 / 2$ Hour or Less) Involves 1 Type $A$ Waste Container.
Sequence of Events

1. Collision or overturn accident occurs.

2. Truck leaves roadway and may overturn.

3. Type A packages may rupture, but no fire occurs.

4. Accident is reported to local and federal officials.

5. Packages recovered.

1. Collision or overturn accident occurs.

2. Truck leaves roadway and may overturn.

3. One Type A waste container is involved in a fire with $1 / 2$ hour or less duration.

4. Accident is reported to local and federal officials.

5. Packages recovered.
Atmospheric Release

None

Release fraction of $5 \times 10^{-4}$ of the contents of one waste package is assumed.

TABLE N.5-5. Severe Accidents for Type A Packages During Truck Transportation

Accident Description

Truck Collision or Overturn and a Major Fire (1 Hour or Longer) Involving 40 Type $A$ Waste Containers.
Sequence of Events

1. Collision or overturn accident occurs.

2. Truck Teaves roadway at high speed and overturns.

3. Type A packages rupture and 40 waste containers are involved in a fire.

4. Accident is reported to local and federal officials.

5. Packages recovered.
Atmospheric Release

Release fraction of $5 \times 10^{-4}$ of the contents of 40 waste packages is assumed. 
transport group III material are 1 imited to a maximum of $3 \mathrm{Ci}$ per package. (48) Since most operations that involve combustible waste are manual operations conducted in relatively low dose rate areas, the quantity of radioactivity contained in each package is assumed to be $1 \mathrm{Ci}$ for this study. For the minor accident, one package is assumed to burn and release $5 \times 10^{-4}$ of the radioactivity in the package, or $5 \times 10^{-4} \mathrm{Ci}$. (27) The resulting 50-year committed dose equivalent to the maximum-exposed individual located $100 \mathrm{~m}$ downwind is 2.2 mrem to the lung. The minor transportation accident is estimated to have a low frequency of occurrence. For the severe accident, the contents of 40 waste containers (each containing $1 \mathrm{Ci}$ of reference radionuclide inventory 5) are assumed to burn, releasing a total of $2 \times 10^{-2} \mathrm{Ci}$. The resulting 50-year committed dose equivalent to the maximum-exposed individual is $90 \mathrm{mrem}$ to the lung. The severe accident is estimated to have a low frequency of occurrence. A complete listing of the doses to the organs of the maximum-exposed individual from these accidents is given Table N.5-6. 


\section{TABLE N.5-6. Radiation Doses to the Maximum-Exposed Individual from Accidental}

Atmospheric Releases During Transportation Accidents

\begin{tabular}{|c|c|c|c|c|c|c|c|c|c|c|c|c|}
\hline \multirow[b]{2}{*}{ Incident ${ }^{(a)}$} & \multirow{2}{*}{$\begin{array}{l}\text { Reference } \\
\text { Radionucl ide } \\
\text { Inventory } \\
\text { Number (b) } \\
\end{array}$} & \multirow{2}{*}{$\begin{array}{c}\text { Total } \\
\text { Atmospheric } \\
\text { Release }\left(C_{1} / \mathrm{hr}\right)(\mathrm{c}) \\
\end{array}$} & \multicolumn{5}{|c|}{ First-Year Dose (rem) } & \multicolumn{5}{|c|}{ Fifty-Year Committed Dose Equivalent (rem) } \\
\hline & & & $\begin{array}{l}\text { Total } \\
\text { Body }\end{array}$ & Bone & Lung & Thyroid & GI-LLI & $\begin{array}{l}\text { Tota1 } \\
\text { Body }\end{array}$ & Bone & Lung & Thyroid & GI-LLI \\
\hline $\begin{array}{l}\text { Minor Transport } \\
\text { Accident }\end{array}$ & 5 & $5 \times 10^{-4}$ & $5.4 \times 10^{-5}$ & $87 \times 10^{-5}$ & $2.2 \times 10^{-3}$ & $9.0 \times 10^{-5}$ & $3.5 \times 10^{-5}$ & $2.7 \times 10^{-4}$ & $9.5 \times 10^{-4}$ & $2.2 \times 10^{-3}$ & $9.0 \times 10^{-5}$ & $3.5 \times 10^{-5}$ \\
\hline $\begin{array}{l}\text { Severe Transportatio } \\
\text { Accident }\end{array}$ & 5 & $2 \times 10^{-2}$ & $2.2 \times 10^{-3}$ & $3.5 \times 10^{-3}$ & $9.0 \times 10^{-2}$ & $3.6 \times 10^{-3}$ & $14 \times 10^{-3}$ & $1.1 \times 10^{-2}$ & $3.8 \times 10^{-2}$ & $9.0 \times 10^{-2}$ & $3.6 \times 10^{-3}$ & $1.4 \times 10^{-3}$ \\
\hline
\end{tabular}

(a) Both transportation accidents are felt to have a "low" frequency of occurrence.

(c) All 


\section{REFERENCES}

1. WPPSS Nuclear Project Number 2 Final Safety Analysis Report, Washington Public Power Supply System, Richland, WA, Vo1. 18, Chapter 15.7.4, February 1977.

2. C. A. Burchsted, J. E. Kahn and A. B. Fuller, Nuclear Air Cleaning Handbook, ERDA 76-21, pp. 42-43, March 1976.

3. Final Elk River Reactor Program Report, C00-651-93, Revised, p. F-9, United Power Association, Elk River, MN, November 1974.

4. Siting of Fuel Reprocessing and Waste Management Facilities, ORNL-4451, pp. 8-47, Oak Ridge National Laboratory, Oak Ridge, TN, JuTy 1970.

5. J. M. Selby, et al., Considerations in the Assessment of Consequences of Effluents from Mixed Oxide Fuel Fabrication Plants, BNWL-1697, Rev. T, pp. 78-79, Battelle, Pacific Northwest Laboratories, Richland, WA, June 1975.

6. US NRC, Calculation of Annual Doses to Man from Routine Releases of Reactor Effluents for the Purpose of Evaluating Complíance with 10 CFR Part .50, Appendix I, ReguTatory Guide 1.109, Rev. 1, U.S. Nuclear ReguTatory Commission, Washington, DC 20555, 1977.

7. R. T. Brunskill, "The Relationship Between Surface and Airborne Contamination," Surface Contamination, Proceedings of a Symposium Held at Gatl inburg, TN, June 1964, pp. 93-705, Pergamon Press, NY, 1967.

8. H. Glauberman, W. R. Bootman and A. J. Breslin, "Studies of the Significance of Surface Contamination," Surface Contamination, Proceedings of a Symposium Held at Gatlingurg, TN, June 1964, Pergamon Press, NY, pp. 169178, 1967.

9. I. S. Jones and S. F. Pond, "Some Experiments to Determine the Resuspension Factor of Plutonium from Various Surfaces," Surface Contamination, Proceedings of a Symposium Held at Gatlinburg, TN, June 1965, Pergamon Press, NY, pp. 83-92, 1967.

10. E. H. Garner, S. R. M. Elli is and J. A. Lacey, "The Size Distribution and Entrainment of Droplets," Trans. Inst. Chem. Engrs. 32:222-235, 1954.

11. R. Brown and L. J. York, "Sprays Formed by Flashing Liquid Spray," AICHE Journal $\underline{8}(2):$ :49-153, May 1962.

12. K. J. Schneider and C. E. Jenkins, Technology, Safety and Costs of Decommissianing a Reference Nuclear Fuel Reprocessing Plant, NUREG-0278, Prepared by Pacific Northwest Laboratory for U.S. NucTear Regulatory Commission, October 1977.*

*Available for purchase from the National Technical Information Service, Springfield, Virginia 22161. 
13. R. I. Smith, G. J. Konzek and W. E. Kennedy, Jr., Technology, Safety and Costs of Decommissioning a Reference Pressurized Water Reactor Power Station, NUREG/CR-0130, Prepared by Pacific Northwest Laboratory for U.S. NucTear Regulatory Commisison, June 1978.*

14. C. E. Jenkins, E. S. Murphy and K. J. Schneider, Technology, Safety and Costs of Decommissioning a Reference Small Mixed Oxide Fuel Fabrication Plant, NUREG/CR-0129, Prepared by Pacific Northwest Laboratory for U.S. Nuclear Regulatory Commisison, February 1979.*

15. Linde Specialty Gas Catalog, Union Carbide Corporation, Linde Division, New York, NY, 1974.

16. M. G. Zabetakis, Flammability Characteristics of Combustible Gases and Vapors, Bulletin 627, U.S. Bureau of Mines, 1965.

17. G. H. Tryon, ed., Fire Protection Handbook, National Fire Protection Association, Boston, MA, 1969.

18. C. A. Burchsted and A. B. Fuller, Design, Construction and Testing of High Efficiency Air Filtration Systems for Nuclear Applications, ORNLNSIC-65, Nuclear Safety Information Center, Oak Ridge, TN, 1970.

19. H. A. Lee, Guide to Fire Protection in Caves, Canyons and Hot Cells, ARH-3020, AtTantic Richfield Hanford Company, Richland, WA, July 1974.

20. R. Cecit Smart, The Technology of Industrial Fire and Explosion Hazards, Chapman and Hal1, Ltd., London, pp. 41-43 and pp. 128-139, 1947.

21. Fire Protection Guide on Hazardous Materials, Sixth Edition, National Fire Protection Association, Boston, MA, 1975.

22. R. C. Weast, ed., Handbook of Chemistry and Physics, 54th Edition, CRC Press, Cleveland; $\mathrm{OH}, 1973$.

23. E. S. Young, "Preventing Reverse Flow Explosions in Gas Cutting Equipment," Plant Engineering, p. 505, December 14, 1972.

24. R. Cecil Smart, The Technology of Industrial Fire and Explosion Hazards, Chapman and Ha11, Ltd., London, pp. 47-43, and pp. 128-732, 1947.

25. M. R. Busby, J. E. Kahn and J. P. Belk, "Effects of Explosion Generated Shock Waves in Ducts," Proceedings of the 14th ERDA Air Cleaning Conference, CONF-760822, pp. 270-219, 1976.

26. G. B. McKinnon, Fire Protection Handbook, National Fire Protection Association, Boston, MA, p. 3.202, 1976.

27. J. Mishima and L. C. Schwendiman, Fractional Airborne Release of Uranium (Representing Plutonium) During the Burning of Contaminated Waste, BNWL1730, Battelle, Pacific Northwest Laboratories, Richland, WA, April 1973.

Available for purchase from the NRC/GPO Sales Program, U.S. Nuclear Regulatory Commission, Washington, D.C. 20555, and the National Technical Information Service, Springfield, Virginia 22161. 
28. M. Eisenbud, "The Primary Air Pollutants--Radioactive, Their Occurrence, Sources, and Effects," Air Pollution Third Edition, Volume 1, Air Pollutants, Their Transformation and Transport, A. C. Stern, Ed., Academic Press, pp. 197-231, New York, NY, 1976.

29. H. Thielsch, "Why High Temperature Piping rails," Pressure Vessels and Piping Design and Analysis, Volume 4, Quality Assurance--Applications, Components, H. H. Waite, Ed., The American Society of Mechanical Engineers, pp. 350-375, New York, NY, 1976.

30. J. Nemec, Demolition of Radioactive and Contaminated Concrete Structures by Use of Explosives, United Power Association, p. 9, Apri1 15, 1974.

31. WPPSS Nuclear Power Project Number 2 Final Safety Analys is Report, Washington Public Power Supply System, Richland, WA, Vol. 7, Chapters 11.2 and 11.4, February 1977.

32. WPPSS Nuclear Project Number 2 Final Safety Analysis Report, Washington Public Power Supply System, Richland, WA, Vol. 6, Chapter 3.1, February 1977.

33. U.S. Nuclear Regulatory Commission, Reactor Safety Study: an Assessment of Risks in U.S. Commercial Nuclear Power Plants, WASH-1400, NUREG 74/014, October 1975.*

34. C. A. Burchsted, J. E. Kahn and A. B. Fuller, Nuclear Air Cleaning Handbook, ERDA-76-21, Oak Ridge National Laboratory, Oak Ridge, TN, 1976.

35. I. B. Wal1, "Probabilistic Assessment of Aircraft Risk for Nuclear Power Plants," Nuclear Safety 15(3):276-284, May-June 1974.

36. Directorate of Regulatory Standards, Environmental Survey of Transportation of Radioactive Materials to and from Nuclear Power Plants, WASH-1238, U.S. Atomic Energy Commission, Washington, DC, 1972.

37. U.S. Code of Federal Regulations, Title 49, Part 173.393, "Transportation," Superintendent of Documents, GPO, Washington, DC 20555, January 1978.

38. U.S. NRC, Assumptions used for Evaluating the Potential Radiological Consequences of a Loss of Coolant Accident for Pressurized Water Reactors, Regulatory Guide 1.4, Revision 2, June 1974.

39. D. H. STade, Editor, Meteorology and Atomic Energy, U.S, AEC, Division of Technical Information, 1968.

40. R. H. Jones and C. W. Smith, "General Electric Company IF-300 Spent Fuel Shipping Cask Design Experience," Proceedings of the Third International Symposium on Packaging and Transportation of Radioactive Materials, BNWL-SA-3906, Richland, WA, August 1971.

A Available for free upon written request from the U.S. Nuclear Regulatory Commission, Division of Technical Information and Document Control, Washington, D.C. 20555. 
41. IF-300 Shipping Cask Design and Analysis Report, NED0-10084-1, Nuclear FueT Department, General Electric Company, San Jose, CA, February 1973.

42. 0. A. Kelly and W. C. Stoddart, Highway Vehicle Impact Studies: Tests and Mathematical Analyses of Vehicles, Package and Tiedown Systems Capable of Carrying Radioactive Materia], ORNL-NSIC-61, Nuclear Safety Information Center, Oak Ridge National Laboratory, Oak Ridge, TN, February 1970.

43. L. B. Shappert et al., "The Full-Scale Cask Program at ORNL, "International Seminar on the Design, Construction and Testing of Packaging for the Safe Transport of Radioactive Materials, IAEA-SR-10, Vienna, Austria, August 1976.

44. H. R. Yoshimura and M. Huerta, Ful1-Scale Tests of Spent Nuclear Fuel Shipping Systems, SAND-77-5707, Sandia Laboratories, A7buquerque, NM, July 1976.

45. Technology for Commercial Radioactive Waste Management, DOE/ET 0028, Vo1. 4, Chapter 6.2, prepared by Pacific Northwest Laboratories for the U.S. Department of Energy, Richland, WA, May 1979.

46. Environmental Aspects of Commercial Radioactive Waste Management, DOE/ET-0029, Volume 2, Chapter 7.3, Prepared by Pacific Northwest Laboratories for the U.S. Department of Energy, Richland, WA, May 1979.

47. U.S. Code of Federal Regulations, Title 49, Part 173.390, "Transportation," Superintendent of Documents, GPO, Washington, DC 20555, January 1978.

48. U.S. Code of Federal Regulations, Title 49, Part 173.389, "Transportation," Superintendent of Documents, GP0, Washington, DC 20555, January 1978. 


\section{APPENDIX 0}

\section{DETAILS OF ALTERNATE STUDY BASES}

The results presented previously in this report are based on the characteristics of the reference BWR, on the conditions postulated to exist at the end of $i$ ts operating life, and on the assumption that the operating utility becomes the prime contractor for decommissioning. This appendix contains detailed information concerning the sensitivity of decommissioning costs and/or radiation doses to the following "alternate bases":

- different BWR power plant sizes

- increased radiation exposures

- different contractual arrangements

- increased nuclear waste disposal charges

- different BWR containment designs.

These alternate bases are discussed in turn in the following sections.

\subsection{SENSITIVITY OF DECOMMISSIONING COSTS AND RADIATION DOSES TO DIFFERENT BWR POWER PLANT SIZES}

In this section, a scaling factor methodology is used to determine the costs and the radiation doses for decommissioning different size BWR power plants. In the first two of the following subsections, a scaling factor relationship is first developed and then applied to determine the following aspects of decommissioning any BWR regardless of its size:

- costs for immediate dismantlement

- costs for passive safe storage

- costs for entombment

- radiation doses for these three decommissioning modes.

In the third subsection, a relationship is developed and applied to determine the cost for demolition and site restoration of any BWR. 


\subsubsection{Development of the Scaling Factor Relationship}

This subsection presents the details for and the development of a scaling factor relationship that will be applied later in Section 0.1.2 to determine the decommissioning costs and radiation doses for any BWR power plant. The following matters are presented: the BWR power plants, the BWR plant components, and the scaling factor methodology used in developing, and the actual development of the scaling factor relationship.

\subsubsection{BWR Power Plants Used}

Seven BWR power plants, including the reference BWR and ranging in power rating from 1593 MWt to 3320 MWt, are used in developing the scaling factor relationship. The BWR power plants and their power ratings are: Vermont Yankee, 1593 MWt; Oyster Creek; 1600 MWt; Montice110, 1670 MWt; Cooper, 2381 MWt; Dresden 2 or 3, 2527 MWt; Peach Bottom 2 or 3, 3293 MWt; and the reference plant, WNP-2, 3320 MWt.

The scaling factor relationship is based on information obtained from the final safety analysis reports (FSAR) for the seven plants. ${ }^{(1-7)}$ It is developed by comparing the dimensional or other physical characteristics of components of the other BWR power plants with the corresponding features of the reference BWR.

It should be noted that the BWR plants with power ratings less than 1500 MWt are early designs and are generally markedly different from the later, larger plants. Since they are generally one-of-a-kind plants, these small, early BWR plants are not included in this analysis.

It should also be noted that there are some significant differences among the later, large plants, specifically with regard to reactor containment design (i.e., the design of the drywell and the pressure suppression chamber). The three different BWR containment designs include the Mark I (1ight bulb-shaped drywell and toroidal-shaped pressure suppression chamber), the Mark II (a truncated-cone drywell atop a cylindrical suppression chamber), and the Mark III (a cylindrical drywell with an annular, weir-type suppression chamber). The effect of these three different containment designs on dismantlement costs is discussed later in Section 0.5. 


\subsubsection{BWR Plant Components Used}

Three major BWR plant components are used in developing the scaling factor relationship: 1) the reactor vessel, 2) the reactor vessel internals, and 3 ) the Reactor Building (combination of selected contents excluding che first two components). These components are described in most of the individual FSARs in sufficient detail to permit meaningful comparisons to be made with the corresponding components of the reference BWR. The components that are not described in the FSARs sufficiently well to permit comparisons with the reference plant and with each other are not examined in this analysis. It is assumed that the dismantlement costs for the unanalyzed components have the same relationship to the plant power rating as have the components that are examined.

\subsubsection{Scaling Factor Methodology Used}

The methodology used to develop the scaling factor relationship is based on comparisons of the individual BWR plant components and on the estimated costs presented in Section 1.3 of Appendix I for immediate dismantlement of each of the reference BWR components. The component comparisions are made on the physical parameter (i.e., mass, surface area, volume, or some combination thereof) that is most appropriate for the particular component.

The component comparisons for a given BWR power plant determine componentspecific scaling factors for that plant, which are weighted by cost factors based on the dismantlement costs for the respective reference-plant components and summed to create a plant-specific scaling factor. The various plant-specific scaling factors are used to develop the scaling factor relationship.

The component-specific scaling factor, $\mathrm{SF}_{C}$, is calculated by dividing the physical parameter of the specific component, $P_{C}$, from the $j$ th plant by that from the reference plant, as follows:

$$
\mathrm{SF}_{\mathrm{Cj}}=\mathrm{P}_{\mathrm{Cj}} / \mathrm{P}_{\mathrm{Cr}}
$$

Component-specific scaling factors are calculated in this manner for all plants whose FSARs provide the appropriate component parameters. For those plants whose FSARs do not provide the appropriate component parameters, these calculated 
component-specific scaling factors are fitted (by the method of least squares) to a 1 inear function that has as its independent variable the plant power ratingl (PPR) in thermal megawatts [i.e., $\left.\mathrm{SF}_{C j}=A_{C}+B_{C}\left(P P R_{j}\right)\right]$. This function is used to estimate component-specific scaling factors for those plants.

The cost factor, $\mathrm{CF}_{i}$, used to weight the component-specific scaling factor for the ith component of each plant is determined by dividing each individual cost for dismantiling the reference-plant ith component, $C_{i r}$, by the sum of the individual costs, as follows:

$$
C F_{i r}=c_{i r} / \sum_{i=1}^{n} c_{i r}
$$

The plant-specific scaling factor for the $j$ th $p l a n t, \mathrm{SF}_{\mathrm{pj}}$, is found by summing the product of the component-specific scaling factor and the respective cost factor for component $i$ with those for the other components:

$$
S F_{P j}=\sum_{i=1}^{n}\left(S F_{i j} C F_{i r}\right)
$$

The desired scaling factor relationship is developed by fitting the plantspecific scaling factors for all the plants with a linear function that again has the plant power rating as its independent variable:

$$
O S F=A+B(P P R)
$$

OSF is the "overall scaling factor" for estimating a cost or a radiation dose for any decommissioning mode applied to any BWR power plant. For example, the cost and the radiation dose for immediate dismantlement of the $j$ th power plant, $C_{d j}$ and $D_{d j}$, can be estimated by multiplying OSF evaluated at $\operatorname{PPR}_{j}\left(\operatorname{OSF}_{j}\right)$ by the cost and the radiation dose, respectively, for immediate dismantlement of the reference BWR, as follows: 


$$
\begin{aligned}
& C_{d j}=0 S F_{j} C_{d r} \\
& D_{d j}=0 S F_{j} D_{d r}
\end{aligned}
$$

The values for passive safe storage and for entombment of the $j$ th nower plant can be estimated in the same manner.

OSF is developed in the following subsection.

\subsubsection{Development of the Scaling Factor Relationship}

The development of the scaling factor relationship for decommissioning costs and radiation is broken down into the following parts:

- component-specific scaling factors and reference-plant dismantlement costs for the reactor vessel, the reactor vessel internals, and the Reactor Building, in turn (basically Equation 0.1)

- plant-specific scaling factors (Equations 0.2 and 0.3 )

- scaling factor relationship (Equation 0.4).

0.1.1.4.1 Component-Specific Scaling Factors and Reference-Plant Dismantlement Costs for the Reactor Vessel. Dismantlement of the reactor

vessel encompasses removing and segmenting the vessel, packaging the vessel segments, and transporting the packaged segments and emplacing them in a nuclear waste disposal facility. It was determined previously that the dismantlement cost for a reactor vessel is essentially proportional to the mass of the vessel. (8) Therefore, in this study, the component-specific scaling factor for a given reactor vessel dismantlement is the ratio of the mass of the given vessel to the mass of the reference BWR vessel.

The component-specific scaling factors for the reactor vessels of the selected BWR power plants are 1isted in Table 0.1-1, together with the plant power ratings and the reported reactor vessel masses. Of the five plants whose reactor vessel masses are reported in the table, only four componentspecific scaling factors are included in the least-squares fitting analys is to determine the scaling factors for the other two plants. Oyster Creek is excluded 
TABLE 0.1-1. Component-Specific Scaling Factors for BWR Reactor Vessels

\begin{tabular}{|c|c|c|c|}
\hline Power Plant & $\begin{array}{l}\text { Plant Power } \\
\text { Rating (MWt) }\end{array}$ & $\begin{array}{l}\text { Reactor Vesse1 } \\
\text { Mass (Mg) } \\
\end{array}$ & $\begin{array}{l}\text { Component-Specjfjc } \\
\text { Scal ing Factor }(a)\end{array}$ \\
\hline $\begin{array}{l}\text { Vermont Yankee } \\
\text { Oyster Creek } \\
\text { Monticello }\end{array}$ & $\begin{array}{ll}1 & 593 \\
1 & 600 \\
1 & 670\end{array}$ & $\begin{array}{l}428(b) \\
592(b) \\
--(d)\end{array}$ & $\begin{array}{l}0.572 \\
0.791 \\
0.588\end{array}(\mathrm{c})$ \\
\hline $\begin{array}{l}\text { Cooper } \\
\text { Dresden } 2 \text { or } 3 \\
\text { Peach Bottom } 2 \text { or } 3\end{array}$ & $\begin{array}{ll}2 & 381 \\
2 & 527 \\
3 & 293\end{array}$ & $\begin{array}{l}566 \\
681\end{array}$ & $\begin{array}{l}0.757(\mathrm{e}) \\
0.782(\mathrm{e}) \\
0.910\end{array}$ \\
\hline WNP-2 & 3320 & 748 & 1.000 \\
\hline
\end{tabular}

(a)Calculated as the ratio of the reactor vessel mass for the $j^{\text {th }}$ plant to to that for the reference plant, WNP-2 (Equation 0.1).

(b) Calculated from dimensional data obtained from Reference 2.

(c) Value excluded from least-squares analysis.

(d) Not available in FSAR.

(e) Value inferred from least-squares fitted equation.

because its mass is not given in the FSAR and is calculated from dimensional data obtained therefrom. It is also somewhat atypical in that its vessel wall is thicker than the walls of the other plants. The equation of the "best-fit" line through the included component-specific scaling factors is:

$$
S F_{V j}=0.211+\left(2.26 \times 10^{-4}\right) P P R_{j}
$$

Using this relationship, component-specific scaling factors are calculated for those plants whose reactor vessel mass data are unavailable or not calculable (values footnoted (e) in Table 0.1-1).

The use of a straight-line relationship can be justified on the grounds that all of the reactor vessels are designed to the same code requirements (i.e., the configurations and the design temperatures and pressures are the same for all of the power plants).

The factors considered in estimating the cost for dismantling the reactor vessel in the reference plant include removal, sectioning, packaging, transporting, and disposal at an approved waste storage facility. In Section I.3 
of Appendix I, dismantlement of the vessel is treated as a portion of the total dismantlement project, and some of the costs are not isolated (e.g., sectioning of the non-activated portions). A crew of workmen is assumed active throughout the dismantlement operation, and their activities are spread over the entire project as required to maintain a smooth progression of the overall job. As a result, some of the continuing operations that are not critical path items and that do not require special skills or equipment are not defined individually, but are considered in their entirety. The costs of these operations are lumped together as part of the total immediate dismantlement cost. It is assumed that the costs for dismantling the reactor vessel that are included in the total cost are small in relation to those costs that are individually defined.

The costs for dismantling the reference-plant reactor vessel that are defined and treated individually are listed in Tables I.3-3, I.3-4, and I.3-7 in Appendix I and are summarized in Table 0.1-2.

\section{TABLE 0.1-2. Identifiable Costs for Immediate Dismantlement of the WNP-2 \\ Reactor Vesse]}

\section{Cost Category}

Activated Material Disposal

Contaminated Material Disposal

Dedicated Staff Labor

Total
Immediate Dismantlement $\cos \dot{t}(\$)(a)$

$\begin{array}{r}71530^{(b)} \\ 159650^{(c)} \\ 385290^{(d)} \\ \hline 616470\end{array}$

159650 (c)

616470

(a)Early 1978 dollars.

(b) Based on information presented in Table I.3-3 in Appendix I.

(c) Based on information presented in Table 1.3-4.

(d) Based on information presented in Table I.3-7.

\subsection{Component-Specific Scaling Factors and Reference-Plant Dismantle-} ment Costs for the Reactor Vessel Internals. Dismantlement of the reactor vessel internals requires that they be removed from the reactor vessel and placed under water in the dryer and separator pool. The internals 
are then sectioned and packaged remotely (under water) and shipped to an approved nuclear waste storage facility for disposal. It was determined previously that the cost of dismantling the reactor vessel internals is roughly proportional to their mass. ${ }^{(8)}$ Therefore, in this study, the component-specific scaling factor for the reactor vessel internals is the ratio of the mass of the given-plant vessel internals mass to the mass of the reference BWR vessel internals.

The component-specific scaling factors for the reactor vessel internals of the selected BWR power plants are listed in Table 0.1-3, together with the plant power ratings and the reported reactor vessel internals masses. Only the four scaling factors based on FSAR information are included in the least-squares fitting analysis to determine the component-specific scaling factors for the three other plants. The equation of the "best-fit" line through the componentspecific scaling factors is:

$$
S F_{I j}=0.283+\left(1.772 \times 10^{-4}\right) P P R_{j}
$$

Using this relationship, component-specific scaling factors are calculated for those plants whose reactor vessel internals mass data are unavailable (values footnoted (c) in Table 0.1-3).

TABLE 0.1-3. Component Specific Scaling Factors for BWR Reactor Vessel Internals

\begin{tabular}{|c|c|c|c|}
\hline Power Plant & $\begin{array}{l}\text { Plant Power } \\
\text { Rating (MWt) }\end{array}$ & $\begin{array}{c}\text { Reactor Vessel } \\
\text { Internals Mass }(\mathrm{Mg})\end{array}$ & $\begin{array}{l}\text { Component-Specific } \\
\text { Scaling Factor }(a)\end{array}$ \\
\hline $\begin{array}{l}\text { Vermont Yankee } \\
\text { Oyster Creek } \\
\text { Monticello }\end{array}$ & $\begin{array}{ll}1 & 593 \\
1 & 600 \\
1 & 670\end{array}$ & $\begin{array}{l}151,(b) \\
176.4\end{array}$ & $\begin{array}{l}0.531 \\
0.567(c) \\
0.617\end{array}$ \\
\hline $\begin{array}{l}\text { Cooper } \\
\text { Dresden } 2 \text { or } 3 \\
\text { Peach Bottom } 2 \text { or } 3\end{array}$ & $\begin{array}{ll}2 & 381 \\
2 & 527 \\
3 & 293\end{array}$ & $\begin{array}{c}-(b) \\
--(b) \\
209.6\end{array}$ & $\begin{array}{l}0.705(c) \\
0.731(c) \\
0.734\end{array}$ \\
\hline WNP-2 & 3320 & 285.7 & 1.000 \\
\hline
\end{tabular}

(a)Calculated as the ratio of the reactor vessel internals mass for the $j$ th plant to that for the reference plant, WNP-2 (Equation 0.1 ).

(b) Not available in FSAR.

(c) Value inferred from least-squares fitted equation. 
The identifiable dismantlement costs for the reactor vessel internals of the reference BWR involve radioactive material disposal and staff labor. These costs are given in Tables I.3-3, I.3-4, and I.3-7 in Appendix I and are summarized in Table 0.1-4.

TABLE 0.1-4. Identifiable Costs for Immediate Dismantlement of the WNP-2 Reactor Vessel Internals

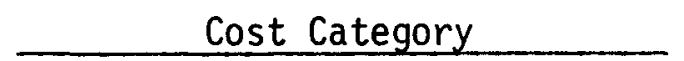

Activated Material Disposal

Contaminated Material Disposal

Dedicated Staff Labor

Total
Immediate Dismantlement Cost $(\$)(a)$

$2102680^{(b)}$

90580 (c)

$1020270^{(d)}$

3213530
(a) Early 1978 dollars.
b) Based on information presented in Table I.3-3 in Appendix I.
(c)Based on information presented in Table 1.3-4.
(d) Based on information presented in Table I.3-7.

0.1.1.4.3 Component-Specific Scaling Factors and Reference-Plant Dismantlement Costs for the Reactor Building. Besides the reactor vessel and its internals, dismantlement of the Reactor Building involves the removal, packaging, and disposal of other activated and contaminated materials. The building components that produce these materials are:

- sacrificial shield

- pressure suppression chamber

- piping systems

- HVAC and electrical equipment

- reactor refueling pools

- contaminated concrete surfaces

- miscellaneous equipment.

The appropriate physical characteristics of these building components are used to calculate the component-specific scaling factor for the Reactor Building. 
Scaling factors for all the individual building components in a given power plant are calculated, weighted, and summed in accordance with Equations 0.1 and 0.3 in Section 0.1.1.3 to determine the component-specific scaling factor for the Reactor Building of the given plant.

The identifiable reference-plant dismantlement costs for each of these building components are summarized and totaled in Table 0.1-5. The cost factors for weighting the scaling factors for the building components are also presented.

TABLE 0.1-5. Identifiable Costs for Immediate Dismantlement of the WNP-2 Reactor Building

\begin{tabular}{|c|c|c|}
\hline Building Comporient & $\begin{array}{c}\text { Immediate } \\
\text { Dismantlement } \\
\text { Cost }(\$)(a)\end{array}$ & $\begin{array}{c}\cos t \\
\text { Factor } \\
(b)\end{array}$ \\
\hline $\begin{array}{l}\text { Sacrificial Shield } \\
\text { Pressure-Suppression Chamber } \\
\text { Piping Systems }\end{array}$ & $\begin{array}{r}616070 \\
672780 \\
1800860\end{array}$ & $\begin{array}{l}0.1454 \\
0.1588 \\
0.4250\end{array}$ \\
\hline $\begin{array}{l}\text { HVAC and Electrical Equipment } \\
\text { Reactor Refueling Pools } \\
\text { Contaminated Concrete from Surfaces } \\
\text { Miscellaneous Equipment }\end{array}$ & $\begin{array}{l}269040 \\
349970 \\
119660 \\
408740 \\
\end{array}$ & $\begin{array}{l}0.0635 \\
0.0826 \\
0.0282 \\
0.0965 \\
\end{array}$ \\
\hline Totals & 4237120 & 1.0000 \\
\hline
\end{tabular}

(a) Early 1978 dollars.

(b)Calculated as the ratio of the component cost and the total of the seven component costs (Equation 0.2).

The component-specific scaling factors for the BWR Reactor Building are presented in Table 0.1-6, together with a summary of the scaling factors and cost factors for the building components, which are used to determine the component-specific scaling factors.

The scaling factors and the identifiable reference-plant dismantlement costs for each building component are discussed and presented in the following subsections. 


\section{TABLE 0.1-6. Component-Specific Scaling Factors for BWR Reactor Buildings}

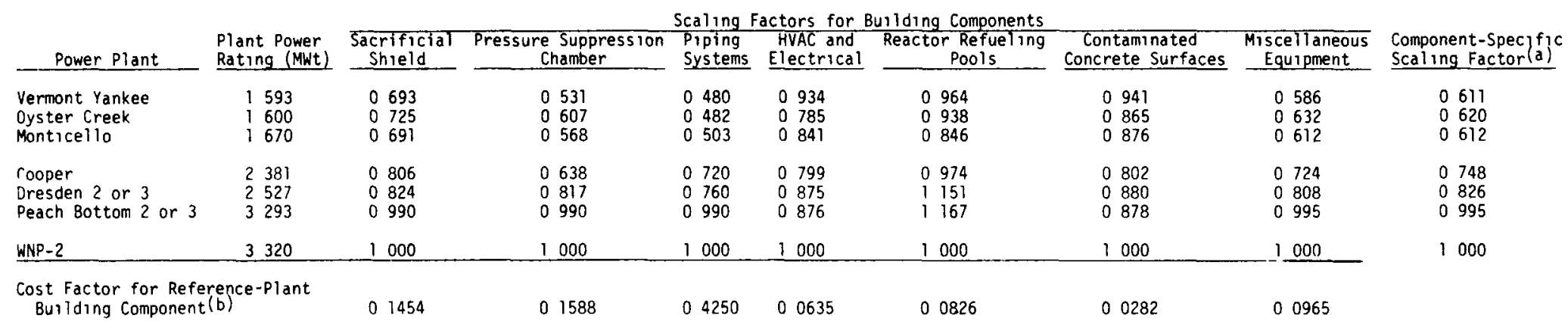

(a)Calculated as the sum of the products of the individual scaling factors and the corresponding cost factors (Equation 03 applicable) b) Same as the fractional cost presented in Table $01-5$ 
Sacrificial Shield. Dismantlement of the sacrificial shield involves removal of the shield itself as well as the surrounding radial beams and floor gratings.

The sacrificial shields in BWRs are of approximately the same thickness and relative height. Therefore, the volume of the shield is proportional to the outer surface area of the reactor vessel it surrounds. Since the dismantlement cost for the shield is proportional to the volume of the shield, the scaling factor for the sacrificial shield is the product of the reactor vessel length, $L$, and diameter, $D$, for the $j$ th plant divided by the same product for the reference plant, as developed in Table 0.1-7.

TABLE 0.1-7. Scaling Factor for BWR Sacrificial Shields

\begin{tabular}{|c|c|c|c|c|}
\hline Power Plant & $\begin{array}{l}\text { Plant Power } \\
\text { Rating (MWt) }\end{array}$ & $\begin{aligned} & R e \\
& \text { Vessel Ins } \\
& \text { Length (m) } \\
&\end{aligned}$ & $\begin{array}{l}\text { ctor } \\
\text { de Dimensions } \\
\text { Diameter (m) }\end{array}$ & Scaling Factor $(a)$ \\
\hline $\begin{array}{l}\text { Vermont Yankee } \\
\text { Oyster Creek } \\
\text { Monticello }\end{array}$ & $\begin{array}{ll}1 & 593 \\
1 & 600 \\
1 & 670\end{array}$ & $\begin{array}{l}19.24 \\
19.46 \\
19.25\end{array}$ & $\begin{array}{l}5.23 \\
5.41 \\
5.21\end{array}$ & $\begin{array}{l}0.692 \\
0.724 \\
0.690\end{array}$ \\
\hline $\begin{array}{l}\text { Cooper } \\
\text { Dresden } 2 \text { or } 3 \\
\text { Peach Bottom } 2 \text { or } 3\end{array}$ & $\begin{array}{ll}2 & 381 \\
2 & 527 \\
3 & 293\end{array}$ & $\begin{array}{l}21.72 \\
22.53 \\
22.53\end{array}$ & $\begin{array}{l}5.54(b) \\
6.38\end{array}$ & $\begin{array}{l}0.805 \\
0.854(c) \\
0.989\end{array}$ \\
\hline WNP-2 & 3320 & 22.78 & 6.38 & 1.000 \\
\hline
\end{tabular}

(a)Calculated as the ratio of the product of the reactor vessel length and diameter for the $j$ th $\mathrm{plant}$ and the same product for the reference plant, WNP-2 (Equation 0.1 applicable).

(b) Not available in FSAR.

(c) Value inferred from least-squares fitted equation.

The physical geometry of the radial beams and floor gratings surrounding the sacrificial shield suggests that the dismantlement cost for these items will vary in the same manner as those for the sacrificial shield. Therefore, the scaling factor for the sacrificial shield is assumed to apply to the radial beams and floor gratings as well. 
The equation of the "best-fit" line through the scaling factors, which is used to infer one of the scaling factors, is given below:

$$
S F_{S j}=0.418+\left(1.726 \times 10^{-5}\right) P P R_{j}
$$

The costs estimated for dismantlement of the sacrificial shield (and the radial support beams and floor gratings) from the reference BWR are listed in Table 0.1-8. These costs are summarized from Tables I.3-3, I.3-4, and 1.3-7 in Appendix I. TABLE 0.1-8. Identifiable Costs for Dismantlement of the WNP-2

\begin{tabular}{|c|c|}
\hline Cost Category & Cost $(\$)$ \\
\hline Activated Material Disposal & $126010^{(c)}$ \\
\hline Contaminated Material Disposal & $272270^{(d)}$ \\
\hline Staff Labor & $217790^{(d)}$ \\
\hline Total & 616070 \\
\hline
\end{tabular}

(a) Including the surrounding radial beams and floor gratings.

(b) Early 1978 dollars.

(c) Based on information presented in Table I.3-3 in Appendix I.

(d)Based on information presented in Table I.3-4.

(e)Based on information presented in Table I.3-7.

Pressure Suppression Chamber. In selecting an appropriate parameter to develop the scaling factor for the pressure suppression chamber, it is necessary to determine which parameters most strongly influence the dismantlement cost. The individual cost components are listed in Table 0.1-9, extracted from Tables I.3-4 and I.3-7 in Appendix I. From the data in Table 0.1-9, it is seen that draining and cleaning the pool (including disposing of the contaminated water) constitutes the major share of the cost for dismantlement of the pressure suppression chamber. Since this item is proportional to the volume of the suppression pool, the scaling factor for this pressure suppression chamber is the pool volume of the jth plant divided by the pool volume of the reference plant, as shown in Table 0.1-10. 
TABLE 0.7-9. Identifiable costs for Immediate Dismantlement of the WNP-2 Pressure Suppression Chamber

\begin{tabular}{|c|c|}
\hline Cost Category & $\begin{array}{c}\text { Immediate Dismantlement } \\
\text { Cost }(\$)(a) \\
\end{array}$ \\
\hline $\begin{array}{l}\text { Disposal of Piping and Equipment } \\
(0.35 \times \$ 315960)\end{array}$ & $110590^{(b)}$ \\
\hline $\begin{array}{l}\text { Disposal of Contaminated Concrete } \\
(0.805 \times \$ 105930)\end{array}$ & $85270^{(b)}$ \\
\hline Drain and Clean Pool & $241790^{(c)}$ \\
\hline Enlarge Wetwell Access & $6570^{(c)}$ \\
\hline $\begin{array}{l}\text { Remove Piping and Equipment }(35 \% \text { is } \\
\text { downcomer piping })(0.35 \times \$ 533920)\end{array}$ & $186870^{(c)}$ \\
\hline $\begin{array}{l}\text { Remove Contaminated Concrete }(80.5 \% \\
\text { is from wetwel1) }(0.805 \times \$ 51 \quad 790) \\
\end{array}$ & $41690^{(c)}$ \\
\hline Total & 672780 \\
\hline
\end{tabular}
(a) Early 1978 dollars.
(b) Based on information presented in Table I.3-4 in Appendix I.
(c) Based on information presented in Table I.3-7.

TABLE 0.1-10. Scaling Factors for BWR Pressure Suppression Chambers

\begin{tabular}{|c|c|c|c|}
\hline Power Plant & $\begin{array}{l}\text { Plant Power } \\
\text { Rating (MWt) }\end{array}$ & $\begin{array}{c}\text { Pressure Suppression } \\
\text { Pool Volume } \\
\left(\mathrm{m}^{3}\right) \\
\end{array}$ & Scaling Factors $(a)$ \\
\hline $\begin{array}{l}\text { Vermont Yankee } \\
\text { Oyster Creek } \\
\text { Montice1lo }\end{array}$ & $\begin{array}{ll}1 & 593 \\
1 & 600 \\
1 & 670\end{array}$ & $\begin{array}{ll}2 & 067 \\
2 & 362 \\
2 & 208\end{array}$ & $\begin{array}{l}0.531 \\
0.607 \\
0.568\end{array}$ \\
\hline $\begin{array}{l}\text { Cooper } \\
\text { Dresden } 2 \text { or } 3 \\
\text { Peach Bottom } 2 \text { or } 3\end{array}$ & $\begin{array}{ll}2 & 381 \\
2 & 527 \\
3 & 293\end{array}$ & $\begin{array}{ll}2 & 482 \\
3 & 177 \\
3 & 851\end{array}$ & $\begin{array}{l}0.638 \\
0.817 \\
0.990\end{array}$ \\
\hline WNP-2 & 3320 & 3890 & 1.000 \\
\hline
\end{tabular}

(a)Calculated as the ratio of the pool volume for the jth plant and the pool volume for the reference plant, WNP-2 (Equation 0.1 ). 
Piping Systems. Dismantlement costs for the piping systems are proportional to the mass of piping removed, packaged, and emplaced at a nuclear waste disposal facility. The mass of the piping is proportional to the volume of the piping walls, which, in turn, is proportional to the product of the wall thickness, $t$, the pipe diameter, $D$, and the pipe length, $L$. Since the wall thickness is proportional to the pipe diameter for the same design conditions of pressure and stress, the mass of the piping is proportional to the product $D^{2} \times L$, which is also proportional to the volume of the piping. The lengths are determined largely by the size of the Reactor Building, which, for the plants used, are very nearly the same. Since the piping is used primarily for the transfer of heat from the reactor under various operating conditions, the volume of the piping is generally proportional to the power rating of the plant. Thus, the scaling factor for the piping is assumed to be the ratio of the power rating of the jth plant and the power rating of the WNP-2 plant, as listed in Table 0.1-11. This scaling factor obviously reduces to zero at zero power rating, an unrealistic result. However, over the range of power ratings examined, this assumption is reasonable and adequate.

TABLE 0.1-11. Scaling Factors for BWR Reactor Building Piping Systems

\begin{tabular}{|c|c|c|}
\hline Power Plant & $\begin{array}{l}\text { Plant Power } \\
\text { Rating (MWt) }\end{array}$ & Scaling Factor $(a)$ \\
\hline $\begin{array}{l}\text { Vermont Yankee } \\
\text { Oyster Creek } \\
\text { Monticello }\end{array}$ & $\begin{array}{ll}1 & 593 \\
1 & 600 \\
1 & 670\end{array}$ & $\begin{array}{l}0.480 \\
0.482 \\
0.503\end{array}$ \\
\hline $\begin{array}{l}\text { Cooper } \\
\text { Dresden } 2 \text { or } 3 \\
\text { Peach Bottom } 2 \text { or } 3 \\
\text { WNP-2 }\end{array}$ & $\begin{array}{ll}2 & 381 \\
2 & 527 \\
3 & 293 \\
3 & 320\end{array}$ & $\begin{array}{l}0.720 \\
0.760 \\
0.990 \\
1.000\end{array}$ \\
\hline
\end{tabular}

(a) Calculated as the ratio of the plant power rating for the jth $\mathrm{plant}$ and that of the reference plant, WNP-2 (Equation 0.1).

The costs for dismantlement of the piping systems in the Reactor Building of the reference BWR are listed in Table 0.1-12. These costs are summarized from Tables I.3-4 and 1.3-7 in Appendix I. 
TABLE 0.1-12. Identifiable Costs for Dismantlement of the WNP-2 Reactor Building Piping Systems

\begin{tabular}{|c|c|}
\hline Cost Category & $\begin{array}{r}\text { Immediate Dismant } \\
\text { Cost }(\$)(a) \\
\end{array}$ \\
\hline \multicolumn{2}{|l|}{ Primary Containment Disposal (b) } \\
\hline Mirror Insulation & 17990 \\
\hline Pipe Hangers and Restraints & 74070 \\
\hline Piping ( $65 \%$ of Tota 1 ) & 205370 \\
\hline \multicolumn{2}{|l|}{ Reactor Building Disposal (b) } \\
\hline Piping and Valves & 176000 \\
\hline \multicolumn{2}{|l|}{ Staff Labor (c) } \\
\hline $\begin{array}{l}\text { Containment Piping and Equip- } \\
\text { ment }\end{array}$ & 533920 \\
\hline Reactor Building Piping & 793510 \\
\hline Total & 1800860 \\
\hline \multicolumn{2}{|c|}{$\begin{array}{l}\text { (a) Early } 1978 \text { dollars. } \\
\text { (b) Based on information presented in Table I.3-4 in } \\
\text { Appendix I. } \\
\text { (c) Based on information presented in Table I.3-7. }\end{array}$} \\
\hline
\end{tabular}

HVAC and Electrical Equipment. The HVAC system in the Reactor Building consists of ducting, blowers, heaters, coolers, and filters. The bulk of the material and most of the labor for dismantlement are associated with the ducting. For purposes of estimation, the length of ducting is assumed to be proportional to the surface area of the building. It was shown previously that the surface area of a building is proportional to the volume of the building raised to the two-thirds power, $\left(V_{B}\right)^{2 / 3}$. $(8)$ Thus, the scaling factor for the HVAC system is the total Reactor Building volume of the jth plant divided by the same volume of the reference plant, that ratio raised to the two-thirds power, $\left(V_{B j} / v_{B r}\right)^{2 / 3}$.

Similarly, the amount of electrical equipment is assumed to be proportional to the surface area of the building. Hence, the scaling factor for the 
contaminated electrical equipment is also $\left(V_{B j} / V_{B r}\right)^{2 / 3}$. However, it is assumed that only the electrical equipment in the lower section of the Reactor Building is contaminated, while the HVAC exhaust ducting throughout the entire building is contaminated. Thus, the scaling factor is a weighted average of the volume ratios of the total building and of the lower section of the building. The weighting is determined from the fractions of the dismantlement costs attributable to the HVAC and the electrical systems.

The costs estimated for the dismantlement of the HVAC and electrical systems in the reference-plant Reactor Building are given in Table 0.1-13 (obtained from Tables I.3-4 and I.3-7 in Appendix I). These costs that are uniquely identifiable with either HVAC or electrical are divided $65 \%$ and $35 \%$, respectively. Thus, the weightings for calculating the weighted scaling factor are 65\% HVAC and $35 \%$ electrical.

TABLE 0.1-13. Identifiable Costs for Dismantlement of the WNP-2 Reactor Building HVAC and Electrical Systems

\begin{tabular}{|c|c|c|}
\hline Cost Category & $\begin{array}{c}\text { Immediate Dismantlement } \\
\text { Cost }(\$)(a)\end{array}$ & $\begin{array}{l}\text { Fraction of } \\
\text { Uniquely Identi- } \\
\text { fiable Cost }(\mathrm{b})\end{array}$ \\
\hline HVAC Disposal & $175710^{(c)}$ & 0.653 \\
\hline Electrical Disposal & $93330^{(c)}$ & 0.347 \\
\hline Dedicated Staff Labor & $44160^{(d)}$ & \\
\hline Total Cost & 313200 & \\
\hline
\end{tabular}
(a)Early 1978 dollars.
(b) Total of uniquely identifiable costs is $\$ 269,040$.
(c) Based on information presented in Table I.3-4 in Appendix I.
(d) Based on information presented in Table 1.3-7.

The scaling factors for the HVAC and electrical systems are presented in Table 0.1-14. The equation of the "best-fit" line through the scaling factors (with which one scaling factor is determined) is:

$$
S F_{H E j}=0.761+\left(4.795 \times 10^{-5}\right) P P R_{j}
$$


TABLE 0.1-14. Scaling Factors for BWR Reactor Building HVAC and Electrical Systems

\begin{tabular}{|c|c|c|c|c|c|c|}
\hline Power Plant & $\begin{array}{l}\text { Plant Power } \\
\text { Rating (MWt) }\end{array}$ & Building & Volumes $\left(\mathrm{m}^{3}\right)$ & $\begin{array}{l}\text { HVAC } \\
\text { Scaling } \\
\text { Factorla) }\end{array}$ & $\begin{array}{l}\text { Electrical } \\
\text { Scaljng } \\
\text { Factorla) } \\
\end{array}$ & $\begin{array}{l}\text { Scaling } \\
\text { Factor }(b)\end{array}$ \\
\hline $\begin{array}{l}\text { Vermont Yankee } \\
\text { Oyster Creek } \\
\text { Monticello }\end{array}$ & $\begin{array}{ll}1 & 593 \\
1 & 600 \\
1 & 670\end{array}$ & $\begin{array}{r}114682 \\
101750 \\
--(c)\end{array}$ & $\begin{array}{l}86649 \\
76 \quad 483 \\
--(c)\end{array}$ & $\begin{array}{l}0.930 \\
0.796 \\
--\end{array}$ & $\begin{array}{l}0.941 \\
0.865 \\
--\end{array}$ & $\begin{array}{l}0.934 \\
0.820 \\
0.841\end{array}(d)$ \\
\hline $\begin{array}{l}\text { Cooper } \\
\text { Dresden } 2 \text { or } 3 \\
\text { Peach Bottom } 2 \text { or } 3\end{array}$ & $\begin{array}{ll}2 & 381 \\
2 & 527 \\
3 & 293\end{array}$ & $\begin{array}{rl}91 & 250 \\
104353 \\
104679\end{array}$ & $\begin{array}{ll}68 & 280 \\
78 & 383 \\
78 & 175\end{array}$ & $\begin{array}{l}0.798 \\
0.873 \\
0.875\end{array}$ & $\begin{array}{l}0.802 \\
0.880 \\
0.878\end{array}$ & $\begin{array}{l}0.799 \\
0.875 \\
0.876\end{array}$ \\
\hline WNP-2 & 3320 & $127 \quad 899$ & 94994 & 1.000 & 1.000 & 1.000 \\
\hline Cost Factor $(\mathrm{e})$ & & & & 0.653 & 0.347 & \\
\hline
\end{tabular}

(a)Calculated respectively as the ratio of the lower- or total-building volume from the $j$ th plant and the corresponding values from the reference plant, WNP-2, the ratios raised to the two-thirds power (Equation 0.1 applicable).

(b) Calculated as the sum of the products of the HVAC and electrical scaling factors with their respective cost factors (Equation 0.3 applicable).

(c) Not available in FSAR.

(d) Value inferred from the least-squares fitted equation.

(e)Fractional costs from Table 0.1-13.

Reactor Refueling Pools. Dismantlment of the reactor refueling pools (i.e., the spent fuel storage pool, the reactor well, and the dryer and separator storage pool) involves the draining and cleaning of the pools and the fuel pool cooling and cleanup system, and the removal and disposal of the spent fuel storage racks, the stainless steel pool liners, and about $50 \mathrm{~mm}$ of assumed contaminated concrete from behind the pool liners. The volume of water and the spent fuel storage racks (to a degree) are proportional to the volumetric capacities of the pools, while the pool liners and the contaminated concrete are proportional to the surface areas of the pool cavities. Therefore, it is necessary to determine the scaling factors for the reactor refueling pools as the sum of the weighted volumetric scaling factor and the weighted areal scaling factor.

The identifiable costs for immediate dismantlement of the reference-plant reactor refueling pools are summarized and categorized in Table 0.1-15, as obtained from Tables I.3-4 and I.3-7 in Appendix I. The table also presents the fractional costs (cost factors) for weighting the volumetric scaling factor and the areal scaling factor. It can be seen that about $63 \%$ of the identifiable costs are volume-related and $37 \%$ are area-related. Thus, the scaling factor for the reactor refueling pools is the sum of $63 \%$ of the volumetric scaling factor and $37 \%$ of the areal scaling factor. 
TABLE 0.1-15. Identifiable Costs for Immediate Dismantlement of the WNP-2 Reactor Refueling Pools

\section{Cost Category}

Immediate

Dismantlement

Cost $(\$)(a)$

Cost Factor

Volume-Related Costs

Material Disposal (b)

Fuel Pool Cooling and Cleanup System Spent Fuel Storage Racks

4150

0.012

44790

0.128

Dedicated Staff Labor (c)

Drain and Clean Pools

Remove and Package Spent Fuel Racks

Decontaminate Fuel Pool Cooling and Cleanup System

Subtotals, Volume-Related Costs

132.980

0.380

17660

0.050

20630

0.059

220210

0.629

Area-Related Costs

Material Disposal (b)

Pool Liners

Contaminated Concrete

$44790(d)$
51770

0.128

$51770(d) \quad 0.148$

Dedicated Staff Labor (c)

Remove Pool Liners

Remove Contaminated Concrete

Subtotals, Area-Related Costs

Totals

\begin{aligned} 17660 & $\begin{array}{l}0.050 \\ 15540\end{array}(\mathrm{~d}) \\$\hline 129760 & $\frac{0.044}{0.370} \\$\hline 349970 & \end{aligned}
(a)Early 1978 dollars.
(b) Based on information presented in Table I.3-4 in Appendix I.
(c) Based on information presented in Table I.3-7.
(d) $36 \%$ of values presented in the respective tables in Appendix I. 
The scaling factors for the reactor refueling pools are presented in Table 0.1-16, together with the related information.

TABLE 0.1-16. Scaling Factors for the Reactor Refueling Pools

\begin{tabular}{|c|c|c|c|c|c|c|}
\hline Power Plant & $\begin{array}{l}\text { Plant Power } \\
\text { Rating (MWt) }\end{array}$ & $\begin{array}{c}\begin{array}{c}\text { Reactor } \\
\text { Volume } \\
\left(\mathrm{m}^{3}\right)\end{array} \\
\end{array}$ & $\begin{array}{l}\frac{\text { Refueling Pools }}{\text { Surface Area }} \\
\frac{\left(\mathrm{m}^{2}\right)}{}\end{array}$ & $\begin{array}{l}\text { Volume- } \\
\text { Related } \\
\text { Scaling } \\
\text { Factor(a) }\end{array}$ & $\begin{array}{l}\text { Area- } \\
\text { Related } \\
\text { Scaling } \\
\text { Factor }(a) \\
\end{array}$ & $\begin{array}{l}\text { Scaling } \\
\text { Factor (b) }\end{array}$ \\
\hline $\begin{array}{l}\text { Vermont Yankee } \\
\text { Oyster Creek } \\
\text { Monticello }\end{array}$ & $\begin{array}{ll}1 & 593 \\
1 & 600 \\
1 & 670\end{array}$ & $\begin{array}{ll}1 & 178 \\
1 & 133 \\
994\end{array}$ & $\begin{array}{l}584 \\
573 \\
545\end{array}$ & $\begin{array}{l}0.889 \\
0.855 \\
0.750\end{array}$ & $\begin{array}{l}1.086 \\
1.065 \\
1.013\end{array}$ & $\begin{array}{l}0.964 \\
0.938 \\
0.846\end{array}$ \\
\hline $\begin{array}{l}\text { Cooper } \\
\text { Dresden } 2 \text { or } 3 \\
\text { Peach Bottom } 2 \text { or } 3\end{array}$ & $\begin{array}{ll}2 & 381 \\
2 & 527 \\
3 & 293\end{array}$ & $\begin{array}{ll}1 & 197 \\
1 & 474 \\
1 & 502\end{array}$ & $\begin{array}{l}594 \\
657 \\
663\end{array}$ & $\begin{array}{l}0.903 \\
1.113 \\
1.134\end{array}$ & $\begin{array}{l}1.104 \\
1.221 \\
1.232\end{array}$ & $\begin{array}{l}0.974 \\
1.151 \\
1.167\end{array}$ \\
\hline WNP-2 & 3320 & 1325 & 538 & 1.000 & 1.000 & 1.000 \\
\hline $\operatorname{Cos} t$ & & & & 0.629 & 0.370 & \\
\hline
\end{tabular}

(a)Calculated, respectively, as the ratio of the reactor refueling pools volume or surface area from the $j$ th $\mathrm{plant}$ and the corresponding values from the reference plant, WNP-2 (Equation 0.1).

(b) Calculated as the sum of the products of the volume-related and area-related scaling factors with their respective cost factors (Equation 0.3 applicable).

(c) Fractional cost subtotals from Table 0.1-15.

Contominated Concrete Surfaces. Those concrete surfaces (excluding surfaces in the reactor refueling pools and the pressure suppression chamber) into which radioactive contamination has penetrated are removed, packaged, and emplaced at a nuclear waste disposal facility. Since about $50 \mathrm{~mm}$ of surface is assumed removed, the amount of material is proportional to the surface areas involved. The surface areas involved are assumed to be the lower section of the Reactor Building. It was shown previously that the surface area of a building is proportional to its volume raised to the two-thirds power. (8) Therefore, the scaling factor for the contaminated concrete from the jth plant is the lower section volume of that plant divided by the lower section volume of the reference plant, the ratio raised to the two-thirds power, $\left(V_{L j} / V_{L r}\right)^{2 / 3}$, as presented in Table $0.1-17$, together with plant power ratings and the volumes of the building lower sections. 
TABLE 0.1-17. Scaling Factors for BWR Reactor Building Contaminated Concrete Surfaces

\begin{tabular}{|c|c|c|c|}
\hline Power Plant & $\begin{array}{l}\text { Plant Power } \\
\text { Rating (MWt) }\end{array}$ & $\begin{array}{l}\text { Volume of Building } \\
\text { Lower Section }\left(\mathrm{m}^{3}\right) \\
\end{array}$ & Scaling Factor ${ }^{(a)}$ \\
\hline $\begin{array}{l}\text { Vermont Yankee } \\
\text { Oyster Creek } \\
\text { Monticello }\end{array}$ & $\begin{array}{ll}1 & 593 \\
1 & 600 \\
1 & 670\end{array}$ & $\begin{array}{r}86 \quad 649 \\
76 \quad 483 \\
\quad--(b)\end{array}$ & $\begin{array}{l}0.941 \\
0.865 \\
0.876(c)\end{array}$ \\
\hline $\begin{array}{l}\text { Cooper } \\
\text { Dresden } 2 \text { or } 3 \\
\text { Peach Bottom } 2 \text { or } 3\end{array}$ & $\begin{array}{ll}2 & 381 \\
2 & 527 \\
3 & 293\end{array}$ & $\begin{array}{ll}68 & 280 \\
78 & 383 \\
78 & 175\end{array}$ & $\begin{array}{l}0.802 \\
0.880 \\
0.878\end{array}$ \\
\hline WNP-2 & 3320 & 94996 & 1.000 \\
\hline
\end{tabular}

\footnotetext{
(a)Calculated as the ratio of building lower section volume from the jth plant and that value from the reference plant, WNP-2, the ratio raised to the two-thirds power (Equation 0.1 applicable).

(b) Not available in the FSAR.

(c) Value inferred from least-squares analysis.
}

The equation of the "best-fit" line through the scaling factors is:

$$
\mathrm{SF}_{\mathrm{Cj}}=0.837+\left(2.334 \times 10^{-5}\right) \mathrm{PPR}_{j}
$$

The scaling factor for the Monticello plant is calculated using the above equation.

The identifiable costs estimated for immediate dismantlement of the contaminated concrete surfaces in the WNP-2 plant are again obtained from Tables I.3-4 and I.3-7 in Appendix I. They are summarized in Table 0.1-18.

MiscelZaneous Equipment. The majority of the identifiable items of equipment removed during immediate dismantlement of the Reactor Building are closely related to the reactor pressure vessel. Therefore, it is assumed that the costs of dismantling this miscellaneous equipment are proportional to the volume of the reactor pressure vessel. Thus, the scaling factor for the miscellaneous equipment is the reactor vessel volume of the $j$ th plant divided by the reactor vessel volume of the reference plant. These scaling factors, together with the plant power ratings and the plant reactor vessel volumes, are presented in Table 0.1-19. 
TABLE 0.1-18. Identifiable Costs for Immediate Dismantlement of the WNP-2 Reactor Building Contaminated Concrete Surfaces

Cost Category

Material Disposal (b)

Dedicated Staff Labor (d) Total
Immediate Dismantlement Cost $(\$)(a)$

$92038^{(c)}$

$\frac{27622^{(c)}}{119660}$

(a) Early 1978 dollars.

(b) Costs based on information presented in Table I.3-4 in Appendix I.

(c) Calculated as $64 \%$ of the cost shown in the respective table.

(d) Costs based on information presented in Table I.3-7.

TABLE 0.1-19. Scaling Factors for BWR Reactor Building Miscellaneous Equipment

\begin{tabular}{|c|c|c|c|}
\hline Power Plant & $\begin{array}{l}\text { Plant Power } \\
\text { Rating (MWt) }\end{array}$ & $\begin{array}{c}\text { Volume of } \\
\text { Reactor Vessel } \\
\left(\mathrm{m}^{3}\right) \\
\end{array}$ & Scaling Factor (a) \\
\hline $\begin{array}{l}\text { Vermont Yankee } \\
\text { Ovster Creek } \\
\text { Monticello }\end{array}$ & $\begin{array}{ll}1 & 593 \\
1 & 600 \\
1 & 670\end{array}$ & $\begin{array}{l}376 \\
406 \\
--(b)\end{array}$ & $\begin{array}{l}0.586 \\
0.632(\mathrm{c}) \\
0.612\end{array}$ \\
\hline $\begin{array}{l}\text { Cooper } \\
\text { Dresden } 2 \text { or } 3 \\
\text { Peach Bottom } 2 \text { or } 3\end{array}$ & $\begin{array}{ll}2 & 381 \\
2 & 527 \\
3 & 293\end{array}$ & $\begin{array}{l}465 \\
--(b) \\
639\end{array}$ & $\begin{array}{l}0.724(c) \\
0.808(c) \\
0.995\end{array}$ \\
\hline WNP-2 & 3320 & 642 & 1.000 \\
\hline
\end{tabular}

(a)Calculated as the ratio of the reactor vessel volume from the jth plant and that value from the reference plant, WNP-2 (Equation 0.1).

(b) Not available in the FSAR.

(c) Value inferred from least-squares fitted equation. 
The equation of the "best-fit" line through the scaling factors is given below and is used to infer the scaling factors for the miscellaneous equipment.

$$
S F_{M E j}=0.231+\left(2.284 \times 10^{-4}\right) P P \cdot R_{j}
$$

The identifiable costs for immediate dismantlement of the miscellaneous Reactor Building equipment from WNP-2 are given in Table 0.1-20, abstracted from Tables I.3-4 and I.3-7 in Appendix I.

TABLE 0.1-20. Identifiable Costs for Immediate Dismantlement of the WNP-2 Reactor Building Miscellaneous Equipment

\begin{tabular}{|c|c|}
\hline Cost & $\begin{array}{l}\text { Cost }(\$) \text { (a) } \\
\text { cos }\end{array}$ \\
\hline \multicolumn{2}{|l|}{ Equipment Disposal ${ }^{(b)}$} \\
\hline $\begin{array}{l}\text { Control Rod Drive } \\
\text { Atmosphere Control } \\
\text { Condensate }\end{array}$ & $\begin{array}{rl}14 & 350 \\
8 & 520 \\
1 & 910\end{array}$ \\
\hline $\begin{array}{l}\text { Core Spray } \\
\text { Reactor Recirculation } \\
\text { Residual Heat Removal }\end{array}$ & $\begin{array}{l}10680 \\
32220 \\
20350\end{array}$ \\
\hline $\begin{array}{l}\text { Drain } \\
\text { In-core Instrumentation }\end{array}$ & $\begin{array}{ll}2 & 830 \\
1 & 720\end{array}$ \\
\hline \multicolumn{2}{|l|}{ Dedicated Staff Labor $(\mathrm{c})$} \\
\hline $\begin{array}{l}\text { Radiation Survey } \\
\text { Reactor Coolant System Decon- } \\
\text { tamination } \\
\text { Containment Cleanup }\end{array}$ & $\begin{array}{rr}12 & 550 \\
102 & 740 \\
12 & 950\end{array}$ \\
\hline $\begin{array}{l}\text { Drain Systems Decontamination } \\
\text { Remove Equipment } \\
\text { Final Radiation Survey }\end{array}$ & $\begin{array}{rr}51 & 260 \\
132 & 480 \\
4 & 180 \\
\end{array}$ \\
\hline Total & 408740 \\
\hline \multicolumn{2}{|c|}{$\begin{array}{l}\text { (a) Early } 1978 \text { dollars. } \\
\text { (b) Based on information presented in Table I.3-4 in } \\
\text { Appendix I. } \\
\text { (c) Based on information presented in Table I.3-7. }\end{array}$} \\
\hline
\end{tabular}




\subsection{Plant-Specific Scaling Factors for the Selected BWR Power}

Plants. In the preceding subsections, component-specific

scaling factors are developed for the three selected components in the selected BWR power plants. The component-specific scaling factors for a given plant must be weighted by their respective cost factors and summed to calculate the plant-specific scaling factor for that plant. Once the plant-specific scaling factors for all the selected plants are calculated, the desired scaling factor relationship for estimating decommissioning costs and radiation doses can be derived.

The total identifiable costs for immediate dismantlement of the three selected components from the reference plant are summarized in Table 0.1-21, together with the cost factors for weighting the component-specific scaling factors.

TABLE 0.1-21. Summary of Identifiable costs for Immediate Dismantlement of the WNP-2 Selected Components

\begin{tabular}{|c|c|c|}
\hline Component & $\begin{array}{c}\text { Immediate } \\
\text { Dismantlement Cost }(\$)^{(a)}\end{array}$ & $\begin{array}{c}\text { Cost } \\
\text { Factor }\end{array}(b)$ \\
\hline Reactor Vesse1 & 616470 & 0.0764 \\
\hline Reactor Vessel Internals & 3273530 & 0.3983 \\
\hline Reactor Building & $4 \quad 237 \quad 120$ & 0.5253 \\
\hline Totals & 8067120 & 1.0000 \\
\hline
\end{tabular}

(a) Early 1978 dollars.

(b) Calculated as the ratio of the component cost and the total of the three component costs (Equation 0.2).

The plant-specific scaling factors for the selected BWR power plants are calculated using Equation 0.3 and are presented in Table 0.1-22, together with the supporting data.

0.1.1.4.5 Scaling Factor Relationship. The scaling factor relationship that can be used to estimate the costs and radiation doses of decommissioning any BWR is derived by a least-squares analysis of the plant-specific scaling 
TABLE 0.1-22. Plant-Specific Scaling Factors for the Selected BWR Power Plants

\begin{tabular}{|c|c|c|c|c|c|}
\hline Power Plant & $\begin{array}{l}\text { Plant Power } \\
\text { Rating (MWt) }\end{array}$ & $\begin{array}{l}\text { Componen } \\
\text { Reactor } \\
\text { Vessel } \\
\end{array}$ & $\begin{array}{c}\text { Specific } \\
\text { Vessel } \\
\text { Internals } \\
\end{array}$ & $\begin{array}{l}\text { ling Factnrs } \\
\text { Reactor } \\
\text { Building } \\
\end{array}$ & $\begin{array}{l}\text { Plant- } \\
\text { Specific } \\
\text { Scaling } \\
\text { Factorla) } \\
\end{array}$ \\
\hline $\begin{array}{l}\text { Vermont Yankee } \\
\text { Oyster Creek } \\
\text { Monticello }\end{array}$ & $\begin{array}{ll}1 & 593 \\
1 & 600 \\
1 & 670\end{array}$ & $\begin{array}{l}0.572 \\
0.791 \\
0.588\end{array}$ & $\begin{array}{l}0.531 \\
0.567 \\
0.617\end{array}$ & $\begin{array}{l}0.611 \\
0.620 \\
0.612\end{array}$ & $\begin{array}{l}0.576 \\
0.612 \\
0.612\end{array}$ \\
\hline $\begin{array}{l}\text { Cooper } \\
\text { Dresden } 2 \text { or } 3 \\
\text { Peach Bottom } 2 \text { or } 3\end{array}$ & $\begin{array}{ll}2 & 381 \\
2 & 527 \\
3 & 293\end{array}$ & $\begin{array}{l}0.757 \\
0.782 \\
0.910\end{array}$ & $\begin{array}{l}0.705 \\
0.731 \\
0.734\end{array}$ & $\begin{array}{l}0.748 \\
0.826 \\
0.995\end{array}$ & $\begin{array}{l}0.732 \\
0.785 \\
0.885\end{array}$ \\
\hline WNP-2 & 3320 & 1.000 & 1.000 & 1.000 & 1.000 \\
\hline Cost Factor & & 0.0764 & 0.3983 & 0.5253 & \\
\hline
\end{tabular}

(a)Calculated as the sum of the component-specific scaling factors multiplied by their respective cost factors (Equation 0.3).

factors and their respective plant power ratings, as indicated previously by Equation 0.4 in Section 0.1.1.3.

The equation of the "best-fit" line through the plant-specific scaling factors is:

$$
\text { OSF }=0.267+\left(2.035 \times 10^{-4}\right) P P R
$$

where OSF is the overall scaling factor for determining decommissioning costs and radiation doses and PPR is the plant power rating of the BWR power plant in question. This equation must be normalized to yield the total estimated cost and radiation dose for a given decommissioning mode at the reference BWR when evaluated at $\mathrm{PPR}_{r}=3320 \mathrm{MWt}$. Thus, the desired scaling factor relationship is:

$$
\text { OSF }=0.324+\left(2.035 \times 10^{-4}\right) \mathrm{PPR}
$$

Equation 0.6 is used to determine specific decommissioning costs and radiation doses for certain BWR power plants as follows in Section 0.1.2. 


\subsubsection{Application of the Scaling Factor Relationship}

The scaling factor relationship (Equation 0.6) developed in Section 0.1.1 is applied in this section to determine the following aspects of decommissioning BWR power plants of different sizes:

- cost for immediate dismantlement

- cost for passive safe storage

- cost for entombment

- radiation doses for these three decommissioning modes.

These aspects are discussed in turn in the following subsections.

\subsubsection{Cost for Immediate Dismantlement of a Different Size BWR}

Immediate dismantlement is the removal from the site, immediately following plant shutdown, of all the materials having radioactivity levels greater than permitted for unrestricted use of the property. A complete discussion of immediate dismantlement for the reference BWR is contained in Appendix I.

The cost for immediate dismantlement of the $j$ th BWR power plant, $C_{I D j}$, can be estimated by multiplying the cost for immediate dismantlement of the reference $B W R, C_{I D r}$, by $O S F_{j}$ (Equation 0.6 evaluated at $P P_{j}$ ), as follows:

$$
C_{I D j}=C_{I D r}{ }^{O S F} F_{j}
$$

For 117ustration, Table 0.1-23 presents the estimated costs for immediate dismantlement of two different size BWR power plants as well as those for the reference BWR, WNP-2.

\subsubsection{Cost for Passive Safe Storage of a Different Size BWR}

As an alternative to immediate dismantlement, a nuclear power plant may be placed in passive safe storage, with possible deferred dismantlement at some future time. Continuing care (surveillance and maintenance) of the power plant facilities is required throughout the safe storage period. A complete discussion of passive safe storage for the reference BWR is contained in Appendix $\mathrm{J}$.

Preparations for passive safe storage and deferred dismantlement after a finite period of time include many of the same operations as immediate 
TABLE 0.1-23. Estimated Costs for Immediate Dismantlement of Different Size BWR Power Plants

Power Plant

$\frac{\text { Plant Power Rating, PPR }}{\text { OSF (a) (MWt) }}$

$\mathrm{OSF}_{j}(\mathrm{a})$

Immediate Dismantlement Cost (\$ millions) ${ }^{(b)}$
WNP-2 Cooper Vermont Yankee

$\begin{array}{llll}3320 & 2381 & 1 & 593\end{array}$

$1.000 \quad 0.809$

0.648

$43.6^{(c)} \quad 35.3$

28.3

(a) Overall Scaling Factor; Equation 0.6 evaluated at PPR .

(b) Early 1978 dollars; rounded to the nearest $\$ 100,000$; does not imply accuracy to that many significant figures.

(c) Based on information presented in Table I.3-1 in Appendix I; does not include other possible costs that are delineated in Table I.3-1 and range from $\$ 23.1$ to $29.0 \mathrm{million}$.

dismantlement . Therefore, the cost of preparing a particular BWR power plant for safe storage, when compared with that cost for the reference BWR, are assumed to be in roughly the same proportion as the costs for immediate dismantlement of the respective plants. Thus, the cost for preparations for passive safe storage of the $j$ th plant, $C_{P_{j}}$, can again be estimated by multiplying the cost for preparations for passive safe storage of the reference $B W R, C_{P r}$, by $\mathrm{OSF}_{\mathrm{j}}$ (Equation 0.6 evaluated at $P P R_{j}$ ), as follows:

$$
C_{P j}=C_{P r} O S F_{j}
$$

Similarly, for deferred dismantlement,

$$
C_{D D j}=C_{D D r}{ }^{O S F}{ }_{j}
$$

Continuing care for passive safe storage involves caretaking operations, the costs of which are not expected to vary a great deal with the size of the power plant, with the possible exception of the cost for energy. The cost for energy is only a small portion of the total annual continuing care cost, $\mathrm{AC}_{\mathrm{CC}}$, and a variation in that cost does not markedly affect the total; thus, no allowance is made for power plant size in the estimated cost of continuing care. 
Based on the above information and definitions, the relationship for estimating the total cost for passive safe storage of the $j$ th BWR power plant, including deferred dismantlement after $n$ years of continuing care, $C_{P S S}$, is:

$$
C_{P S S j}=\left(C_{P r}+C_{D D r}\right) O S F_{j}+\left(A C_{C C}\right) n
$$

For illustration, Table 0.1-24 lists the estimated costs for passive safe storage of two different size BWR power plants as well as those for the reference BWR.

\section{TABLE 0.1-24. Estimated Costs for Passive Safe Storage of Different Size BWR Power Plants}

Power Plant

$\frac{\text { Plant Power Rating, } P P R_{j} \text { (MWt) }}{\operatorname{OSF} \text { (a) }}$

$\operatorname{OSF}_{j}(\mathrm{a})$

Preparations Cost (\$millions) $(b, c)$

Continuing Care Cost (\$ millions) $(b, d)$

for 10 years

for 30 years

for 50 years

for 100 years

Deferred Dismantlement Cost (\$millions) ${ }^{(b, e)}$

after 10 years

after 30 years

after 50 years

after 100 years

Totals, Passive Safe Storage (\$ millions) ${ }^{(b, f)}$

Deferred Dismantlement after

10 years

30 years

50 years

100 years
WNP-2 Cooper Vermont Yankee

$\begin{array}{lllll}3320 & 2381 & 1593\end{array}$

$\begin{array}{lll}1.000 & 0.809 & 0.648\end{array}$

$\begin{array}{lll}21.3 & 17.2 & 13.8\end{array}$

$0.6 \quad 0.6$

$2.0 \quad 2.0$

0.6

$3.4 \quad 3.4$

2.0

3.4

$\begin{array}{lll}6.9 & 6.9 & 6.9\end{array}$

\begin{tabular}{lll}
35.5 & 28.7 & 23.0 \\
35.5 & 28.7 & 23.0 \\
26.4 & 21.4 & 17.1 \\
26.3 & 21.3 & 17.0 \\
\hline
\end{tabular}

$\begin{array}{lll}57.4 & 46.5 & 37.4\end{array}$

$\begin{array}{lll}58.8 & 47.9 & 38.8\end{array}$

$51.1 \quad 42.0 \quad 34.3$

$\begin{array}{lll}54.5 & 45.4 & 37.7\end{array}$

(a)Overall Scaling Factor (Equation 0.6 evaluated at $P P R_{j}$ ).

(b) Early 1978 dollars; rounded to the nearest $\$ 100,000$; does not imply accuracy to that many significant figures.

(c) Cost for WNP-2 based on information presented in Table J.5-1 in Appendix $\mathrm{J}$; does not include other possible costs that are delineated in Table J.5-1 and range from $\$ 5.5$ to $\$ 9.7$ million.

(d) Cost for WNP-2 based on information presented in Table J.7-3.

(e) Cost for WNP-2 based on information presented in Table J.7-2.

(f) Sum of costs for preparations, continuing care for $n$ years, and deferred dismantlement after, $n$ years. 


\subsubsection{Cost for Entombment of a Different Size BWR}

Another alternative to immediate dismantlement is entombment, which is the encasement of all radioactive materials remaining on the site in concrete or other structural material that is sufficiently strong and structurally longlived to assure retention of the radioactivity until it has decayed to levels that permit unconditional release of the site. Continuing care of the entombment structure is required until such time or until all radioactivity is removed from the site. Entombment of the reference power plant is discussed in detail in Appendix K.

Basically, the operations required for preparations for entombment of a BWR include dismantlement and storage, inside the Primary Containment, of as much as possible of the contaminated material located elsewhere in the plant. The Primary Containment is then sealed to prevent the release of any radioactivity. The rest of the contaminated material is dismantled and shipped to an offsite nuclear waste disposal facility.

The entombment preparations are similar in nature to the immediate dismantlement operations; many of the same tasks are included. Therefore, it is again assumed that the ratio of the entombment costs for a particular BWR power plant to those of the reference BWR is the same as the ratio of the immediate dismantlement costs for the same plants. Thus, the estimated entombment preparation cost for the $j$ th plant, $C_{E j}$, is equal to the product of the estimated entombment preparation cost for the reference $B W R, C_{E r}$, and $\mathrm{OSF}_{j}$ (Equation 0.6 evaluated at $\left.P P R_{j}\right)$, as follows:

$$
C_{E j}=C_{E r} O S F_{j}
$$

Again, no change in total annual continuing care cost during entombment, ${ }^{A C}{ }_{C C E}$, can be assumed for a different size BWR power plant. Therefore, the total cost for entombment of the $j$ th BWR power plant after $n$ years of continuing care, $C_{T E}$, is defined by:

$$
C_{T E j}=C_{E r} O S F_{j}+\left(A C_{C C E}\right) n
$$


Not included are the costs associated with whatever actions are taken at the time the facility owner decides to terminate the nuclear license. Since those actions depend on the length of the continuing care period and on the extant regulations, no attempt is made in this analys is to predict what costs may be incurred. It is important to realize, however, that some costs will be incurred at that time, and that those costs could approach the cost for deferred dismantlement after a period of passive safe storage (see Table 0.1-24).

For illustration, Table 0.1-25 presents the estimated costs for entombment of two different size BWR power plants as well as those for the reference BWR. Two types of entombment are shown in the table: 1) "without internals" assumes the removal and offsite disposal of the reactor vessel internals, and 2) "with internals" assumes the intact retention of the internals inside the entombment structure.

TABLE 0.1-25. Estimated Costs for Entombment of Different Size BWR Power Plants

Power Plant

$\frac{\text { Plant Power Rating, PPR }}{\text { OSF }}$ (MWt)

Preparations Cost $\left(\$\right.$ millions) ${ }^{(b)}$

without internals $(c)$

with internals $(d)$

Continuing Care Cost (\$millions) ${ }^{(b, e)}$

for 100 years

for 200 years

Totals, Entombment (\$ millions) ${ }^{(b)}$

without internals for 100 years

with internals for 200 years
WNP-2 Cooper Vermont Yankee

$\begin{array}{llllll}3320 & 2 & 381 & 1 & 593\end{array}$

$1.000 \quad 0.809 \quad 0.648$

$\begin{array}{lll}40.6 & 32.9 & 26.3\end{array}$

$35.0 \quad 28.3 \quad 22.7$

$\begin{array}{lll}4.0 & 4.0 & 4.0\end{array}$

$\underline{8.0} \quad \underline{8.0} \quad \underline{8.0}$

$\begin{array}{lll}44.6 & 36.9 & 30.3\end{array}$

$\begin{array}{lll}43.0 & 36.3 & 30.7\end{array}$

(a) Overall Scaling Factor; Equation 0.6 evaluated at $P P R_{j}$.

(b) Early 1978 dollars; rounded to the nearest $\$ 100,000$; does not imply accuracy to that many significant figures.

(c) Cost for WNP-2 based on Entombment Scenario-1 information presented in Table K.3-1 in Appendix K; does not include other possible costs del ineated in Table K.3-1 for this scenario and ranging from $\$ 16.2$ to $\$ 21.4$ million.

(d) Cost for WNP-2 based on Entombment Scenario-2 information presented in Table K.3-1 for this scenario and ranging from $\$ 15.6$ to $\$ 19.5$ million.

(e) Cost based on information present in Table K.3-1 for both entombment scenarios. 


\subsubsection{Radiation Doses for Decommissioning a Different Size BWR}

The occupational and public radiological doses resulting from the different decommissioning modes considered in this report (immediate dismantlement, passive safe storage, and entombment) are discussed in detail for the reference power plant in Appendices I, J, K, and N.

The radiation produced by the activated/contaminated materials during a decommissioning operation is directly proportional to the amount of similar material types in the different power plants. The radiation doses to the decommissioning workers, to the transport workers, and to the public are roughly proportional to the mass of such materials handled. Since the cost for immediate dismantlement is largely a function of the mass of these materials handled and the amount of radioactivity present in them, the radiation doses are proportional to the costs of dismantlement.

It follows that the radiation doses to the workers and to the public are proportional to the power rating of the BWR power plant being decommissioned. Thus, an expected radiation dose for a particular decommissioning mode at the $j$ th plant, $D_{d j}$, can be estimated by multiplying the corresponding radiation dose estimated for the reference $B W R, D_{d r}$, by $O S F_{j}$ (Equation 0.6 evaluated at $P P R_{j}$ ), as follows:

$$
D_{d j}=D_{d r} O S F_{j}
$$

For illustration, Table 0.1-26 presents the estimated radiation doses for decommissioning two different size BWR plants as well as those for the reference BWR.

\subsubsection{Cost For Demolition of a Different Size BWR}

Following a BWR's decommissioning, it may be desirable to demolish the decontaminated and uncontaminated plant structures and restore the site to prefacility conditions. In this study, demolition includes removing above-grade structures to a depth of $1 \mathrm{~m}$ below grade and fracturing base floors and substructures sufficiently to permit normal drainage of surface water, and site 
TABLE 0.1-26. Estimated Radiation Doses for Decommissioning Different Size BWR Power Plants

Power Plant

Plant Power Rating, $P R_{j}$ (MWt)

OSF $_{j}(a)$

Immediate Dismantlement Doses (man-rem) ${ }^{(b)}$

Occupational

Transportation

Public

(b)
WNP-2

Passive Safe Storage Doses (man-rem)

Preparations

Continuing Care ${ }^{(f)}$

for 10 years

for 30 years

for 50 years

for 100 years

Deferred Dismantlement $(\mathrm{g})$

after 10 years

after 30 years

after 50 years

after 100 years

$$
3320
$$

1.000

2381

0.809

$185(c)$
$110(d)$
10

1493

89

1196
71
6

$$
\begin{array}{r}
\text { Occupational } \\
\text { Transportation } \\
\text { Public }
\end{array}
$$$$
\begin{array}{r}
375(e) \\
22(d) \\
2(d)
\end{array}
$$

303

243

1593

0.648
Occupational

Occupational

Occupational

Occupational

1.3

6.5

1.3

6.5

10

10

10

1.3

6.5

10

Occupational
Occupational
Occupational
Occupational

495
36
3
$<1$

400
29
2
$<1$

321

2

Entombment Doses (man-rem) (b)

without internals

Occupational
Transportation
Public
Occupational
Transportation
Public


restoration includes backfilling with concrete rubble as possible to $1 \mathrm{~m}$ below grade, leveling to grade with indigenous topsoil, and seeding with native ground cover. More details concerning demolition and site restoration of the reference BWR are contained in Appendix L.

Table L.3-1 in Appendix $L$ lists four structures whose demolition costs contribute heavily to the total demolition cost: 1) the Reactor Building and Primary Containment, 2) the Turbine Generator Building, 3) the Radwaste and Control Building, and 4) the cooling towers. In the following subsections, individual scaling relationships to estimate the demolition costs for the first, second, and fourth of these structures are developed and combined to obtain an overall relationship for estimating the demolition cost of an entire BWR power plant.

\subsubsection{Reactor Building and Primary Containment Demolition Cost}

A11 BWR power plants have Reactor Buildings and Primary Containments. The Reactor Buildings for the selected BWR power plants are of similar design but the Primary Containments are of two different designs, designated Mark I and Mark II.

The Primary Containment of a BWR is made up of a drywell and a wetwell (pressure suppresssion chamber). The Mark I and Mark II designs, as well as the later Mark III design, are described in more detail later in Section 0.5 . Both the Mark I and the Mark II designs consist of steel vessels surrounded by reinforced-concrete biological shields. Demolition requires the steel vessels to be sectioned and disposed of in addition to the concrete being broken up and disposed of. Thus, the demolition cost is proportional to the surface area of the Primary Containment. Comparison data for the Primary Containment structures of these two different designs are given in Table 0.1-27.

The steel plate used in the containment vessel is about the same thickness for both power plants. It is assumed that the concrete walls are also of comparable thickness and that their construction (reinforcing steel and type of concrete) is similar. Thus, the data in Table 0.1-27 indicate that it costs about $22 \%$ more to demolish a Mark I containment than to demolish a Mark II containment. 
TABLE 0.1-27. Comparison Data for BWR Mark I and Mark II Containment Designs

\begin{tabular}{|c|c|c|}
\hline Power Plants & Peach Bottom 2 or 3 & WNP-2 \\
\hline Plant Power Rating (MWt) & 3293 & 3320 \\
\hline Containment Design & Mark I & Mark II \\
\hline Drywell: Volume $\left(\mathrm{m}^{3}\right)$ & 6089 & 7379 \\
\hline Surface Area $\left(\mathrm{m}^{2}\right)$ & 1890 & 2299 \\
\hline Wetwe11: Volume $\left(\mathrm{m}^{3}\right)$ & 7453 & 9615 \\
\hline Surface Area $\left(\mathrm{m}^{2}\right)$ & 3155 & 1842 \\
\hline Total Surface Area & 5045 & 4141 \\
\hline
\end{tabular}

From the data given in Table L.3-2 in Appendix L, the cost of removing the Primary Containment Vesse 1 is $5.4 \%$ of the total estimated cost of demolishing the Reactor Building and the Primary Containment Vessel. Therefore, the difference in demolition cost between a Mark I containment and a Mark II containment is about $1 \%$ of the total cost for demolition of the entire Reactor Building. This difference is small enough, especially in comparison with the total demolition cost for the entire plant, that it can be safely neglected.

The cost of demolishing a Reactor Building is proportional to the amount of material in the building. It is assumed that the walls and shielding structures are the same thickness for the different reactor buildings. The demolition cost is then roughly proportional to the wall area. The relationship (developed earlier in Section 0.1.1.4.3) for estimating the wall area of the Reactor Building of the $j$ th $p l a n t$ relative to the wall area of the reference BWR Reactor Building is:

$$
S F_{C j}=0.837+\left(2.334 \times 10^{-5}\right) P P R_{j}
$$

This relationship can also be used to estimate the cost of demolishing the Reactor Building and Primary Containment of the $j$ th plant as a function of that cost for the reference power plant.

From Table L.3-2, the total cost of demolishing the Reactor Building and Primary Containment Vessel is $\$ 5,169,000$. When the above relationship is multiplied by this cost, a relationship is obtained for determining the demolition 
cost for the Reactor Building and Primary Containment Vessel of any BWR power plant, $D C_{R j}$, as a function of the plant power rating $\left(P P R_{j}\right)$, as follows:

$$
D C_{R j}=\$ 4,326,000+\$ 120.60\left(P P R_{j}\right)
$$

\subsubsection{Turbine Generator Building Demolition Cost}

The cost of demolishing the Turbine Generator Building is also proportional to the surface area of the building. Since the ratio of the surface areas of two rectangular prisms is proportional to the ratio of their volumes raised to the two-thirds power, the scaling factor for the Turbine Generator Building of the $j$ th plant is the ratio of its volume and the volume of the WNP-2 Turbine Generator Building, the ratio raised to the two-thirds power $\left(V_{T j} / V_{T r}\right)^{2 / 3}$.

The scaling factors for the Turbine Generator Buildings of selected BWR power plants are presented in Table 0.1-28, together with the plant power ratings and the building volumes.

TABLE 0.1-28. Scaling Factors for BWR Turbine Generator Buildings

\begin{tabular}{|c|c|c|c|}
\hline Power Plant & $\begin{array}{l}\text { Plant Power } \\
\text { Rating (MWt) }\end{array}$ & $\begin{array}{c}\text { Building } \\
\text { volume }\left(\mathrm{m}^{3}\right) \\
\end{array}$ & $\begin{array}{l}\text { Scaling } \\
\text { Factor (a) }\end{array}$ \\
\hline Vermont Yankee & 1593 & 109020 & 0.746 \\
\hline Oyster Creek & 1600 & 121760 & 0.657 \\
\hline Cooper & 2381 & 224700 & 0.989 \\
\hline Peach Bottom 2 or 3 & 3293 & 265040 & 0.940 \\
\hline WNP-2 & 3320 & 228400 & 1.000 \\
\hline
\end{tabular}

(a)Calculated as the ratio of the volume of the Turbine Generator Building from the $j$ th plant and that volume from the reference BWR, WNP-2, the ratio raised to the two-thirds power (Equation 0.1 applicable). 
The equation of the "best-fit" line through the scaling factors is:

$$
S F_{T j}=0.491+\left(1.540 \times 10^{-4}\right) P P R_{j}
$$

where $P P R_{j}$ is the plant power rating of the jth plant.

The cost of demolishing the Turbine Generator Building of the reference power plant is given in Table L.3-1 as $\$ 3,364,000$. The above relationship when multiplied by this cost gives a relationship for estimating the demolition cost for any BWR Turbine Generator Building, $D C_{T j}$, as a function of the power rating, as follows:

$$
D C_{T j}=\$ 1,652,000+\$ 518.10\left(P P R_{j}\right)
$$

\subsubsection{Cooling Tower Demolition Cost}

The cooling capacity of a cooling tower can be assumed roughly proportional to its internal volume (cross-sectional area times distance of air flow). It can also be assumed that the height/diameter ratio is about the same and the wall thickness does not vary widely for different sizes of cooling towers in the range of thermal powers being considered. If the shape is simplified to that of a right-circular cyclinder, the volume of concrete in the cooling tower body varies approximately as the ratio of the plant power rating of the $j$ th plant to that of the reference plant, the ratio raised to the two-thirds power $\left[\left(\mathrm{PPR}_{j} / 3320\right)^{2 / 3}\right]$. Since the demolition cost of a cooling tower is roughly proportional to the volume of concrete in the shell, the relationship to estimate the demolition cost of the cooling towers at the $j$ th power $p l a n t, D_{C j}$, obtained by multiplying this ratio by the cost for demolition of the cooling towers at the reference plant $(\$ 1,252,000$ in Table L.3-1), is:

$$
{ }^{D C} C_{j}=\$ 5,624.20\left(P P R_{j}\right)^{2 / 3}
$$




\subsubsection{Cost for Demolition of a Different Size BWR}

Since the combined demolition costs for the three aforementioned structures do not equal the total cost for demolition of the entire reference plant, the relationship for estimating the total demolition cost of a different size BWR $\left(\mathrm{TDC}_{j}\right)$ is derived by summing the three individual demolition cost relationships for these structures and normalizing the resultant relationship to yield the total demolition cost for the reference BWR when evaluated at the reference plant power rating. The relationship is:

$$
\begin{aligned}
T D C_{j} & =(N F)\left(D C_{R j}+D C_{T j}+D C_{C j}\right) \\
& =(N F)\left[\$ 5,978,000+\$ 638.70\left(P P R_{j}\right)+\$ 5624.20\left(P P R_{j}\right)^{2 / 3}\right]
\end{aligned}
$$

where NF is the normalization factor and equals 1.77 when evaluated at $T C_{r}=\$ 16,555,000$ (from Table L.3-1 in Appendix. L) and PPR $_{r}=3320$ MWt. Therefore, the relationship becomes:

$$
T D C_{j}=\$ 10,584,030+\$ 1131\left(P P R_{j}\right)+\$ 9957\left(P P R_{j}\right)^{2 / 3}
$$

For illustration, the estimated demolition costs for two different size BWRs as well as for the reference BWR are listed in Table 0.1-29.

TABLE 0.1-29. Estimated Demolition Costs for Different Size BWR Power Plants

Power Plant

Plant Power Rating, PPR (MWt)
WNP-2 Cooper Vermont Yankee

$$
3320
$$

$16555^{\text {(b) }} 15052$
1593

13744

(a)Early 1978 dollars; rounded to the nearest $\$ 1,000$; does not imply accuracy to that many significant figures.

(b) Based on information presented in Figure L.3-1 in Appendix L. 


\subsection{SENSITIVITY OF OCCUPATIONAL RADIATION DOSES AND DECOMMISSIONING COSTS TO INCREASED RADIATION DOSE RATES}

The radiation dose rate data presented in Appendix $D$ are based on composites of measured data from seven BWRs that had operated for 3 to 8 effective fullpower years. It is likely the depositions of radioactive contamination within the systems of those plants had probably not reached equilibrium levels by that time. Data on the trends in radiation dose rates from BWR coolant system piping suggest that equilibrium values may be two or three times greater than the values presented in Appendix D. ${ }^{(9)}$

In this section, the effects of a three-fold increase in the radiation dose rates on the occupational radiation doses and on the decomissioning costs are determined. It is recognized that radiation dose rates of that magnitude are unlikely to exist in operating plants since the doses to operations and maintenance personnel would be prohibitive. Chemical decontamination would likely be performed at intervals to keep the radiation dose rates at or below the present levels. Thus, the postulated three-fold increase probably represents an upper-limit situation.

\subsubsection{Occupational Radiation Doses}

For purposes of this analysis, the occupational radiation dose data given in Appendices I, J, and $\mathrm{K}$ for immediate dismantlement, preparations for passive safe storage, and entombment, respectively, are combined into general tasks that have common work conditions and requirements and that are used to determine the effects of a three-fold increase in radiation dose rates. It is assumed that the exposure times and the work conditions and requirements remain the same. Thus, an increase in radiation dose rate produces a corresponding increase in radiation dose.

The three-fold occupational radiation doses for immediate dismantiement, preparations for passive safe storage, and entombment are presented in Tables $0.2-1,0.2-2$, and $0.2-3$, respectively. Those decomissioning tasks likely to be affected by the increased radiation dose rates are so designated. Some of the remaining tasks are performed using remote or semi-remote handling and shielding and are not significantly affected by the increased dose rates. 


\section{TABLE 0.2-1. Three-Fold Occupational Radiation Doses for Immediate Dismantlement}

\begin{tabular}{|c|c|c|}
\hline Building & $\begin{array}{l}\text { Total Dose } \\
\quad(\text { a }) \\
. \text { man-rem) }\end{array}$ & $\begin{array}{r}\text { Three-Fold Do } \\
\text { (man-rem) }\end{array}$ \\
\hline Reactor Building/Primary Conta inment & & \\
\hline $\begin{array}{l}\text { *(c) Install Supplemental HEPA Filters } \\
\text { Initial Radiation Survey } \\
\text { Remove and Ship Reactor Vessel Internals }\end{array}$ & $\begin{array}{r}3.38 \\
0.50 \\
108.64\end{array}$ & 108. \\
\hline $\begin{array}{l}\text { Remove and Ship Reactor Vessel } \\
\text { * Remove and Ship Containment Internals } \\
\text { * Decontaminate Systems }\end{array}$ & $\begin{array}{r}32.65 \\
301.74 \\
17.23\end{array}$ & $\begin{array}{r}32 . \\
905 . \\
51 .\end{array}$ \\
\hline $\begin{array}{l}\text { Drain and Clean Pools } \\
\text { *Remove Reactor Building Equipment } \\
\text { Remove Contaminated Concrete } \\
\text { Final Radiation Survey }\end{array}$ & $\begin{array}{r}3.91 \\
322.94 \\
19.27 \\
0.07\end{array}$ & $\begin{array}{r}3 . \\
968 . \\
19 . \\
0 .\end{array}$ \\
\hline Subtotals, Reactor Building (d) & 810 & 2095 \\
\hline
\end{tabular}

Turbine Generator Building

Install Supplemental HEPA Filters

Initial Radiation Survey

9.29

0.20

0.60

* Preparations for Dismantlement

0.86

2.58

*Remove and Ship Turbine

*Decontaminate and Drain Systems

8.43

0.39

25.29

*Remove and Ship Condenser

34.72

104.16

*Remove Piping and Equipment

137.24

Remove Contaminated Concrete

Final Radiation Survey

1.94

Subtotals, Turbine Generator Building (d)

0.04

411.73

1.94

193

$e^{\text {(b) }}$

50

.65

5.23

3.91

.27

0.07

559

Radwaste and Control Building

*Initial Radiation Survey

* Decontaminate Systems

0.80

18.47

* Remove Piping and Equipment

492.19

2.40

55.41

Remove Miscellaneous Equipment

7.77

476.57

Remove Contaminated Concrete

10.35

Final Radiation Survey

0.05

Subtotals, Radwaste and Control

Ancillaries

Discharge and Ship Fuel

*Operate Radwaste Systems

*Routine Radiation Surveys

Package Dry Sol id Wastes

Miscellaneous

Subtotals, Ancillaries (d)

Totals (d)

\begin{tabular}{r}
81.04 \\
20.84 \\
6.35 \\
38.80 \\
165 \\
\hline 312 \\
1845
\end{tabular}

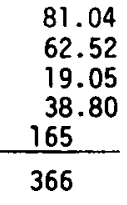

4573

(a) Based on data presented in Table 1.4-1 in Appendix I.

(b) Calculated by multiplying the effected total dose by 3 .

(c) Indicates those general tasks that are likely affected by an increase in radiation dose rates.

(d) Rounded to the nearest whole man-rem; does not imply accuracy to that many significant figures. 
TABLE 0.2-2. Three-Fold Occupational Radiation Doses for Preparations for Passive Safe Storage

Building . General Task

\begin{tabular}{|c|c|}
\hline $\begin{array}{l}\text { Total Dose } \\
\text { (man-rem) }\end{array}$ & $\begin{array}{l}\text { Three-Fold Dose } \\
\text { (man-rem) }\end{array}$ \\
\hline
\end{tabular}

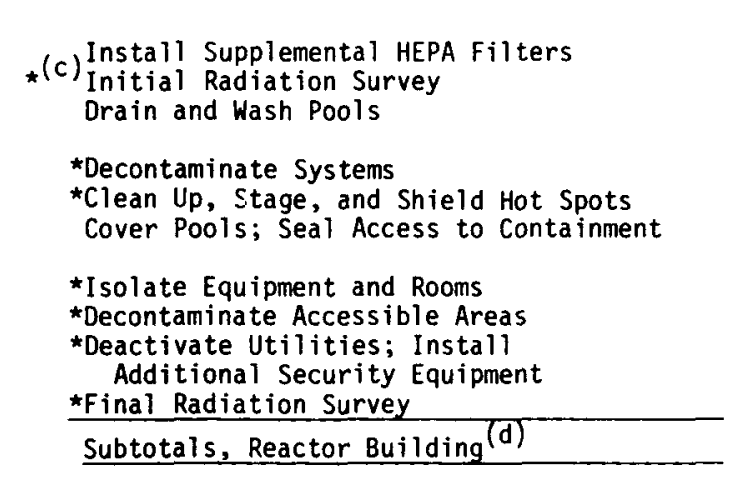

\begin{tabular}{rr}
3.38 & 3.38 \\
0.50 & 1.50 \\
3.60 & 3.60 \\
& \\
16.78 & 50.35 \\
5.71 & 17.13 \\
6.15 & 6.15 \\
& \\
25.61 & 76.83 \\
6.35 & 19.05 \\
5.75 & 17.24 \\
0.30 & 0.90 \\
\hline 74 &
\end{tabular}

Turbine Generator Building

Install Supplemental HEPA Filters

9.30

9.30

*Initial Radiation Survey

* Drain and Clean Tanks and Condenser

0.18

0.54

Decontaminate Drain System

*Isolate Equipment and Rooms

*Decontaminate Accessible Areas

0.56

1.68

0.31

3.30

0.31

9.90

*Deactivate Utilities; Install

1.07

9.87

Additional Security Equipment

*Final Radiation Survey

Subtotals, Turbine Generator Building (d)

$\underline{0.15}$

3.21

18

Radwaste and Control Building

*Initial Radiation Survey

*Chemically Decontaminate Equipment

Chemically Decontaminate Orains

0.07

16.05

0.21

*Isolate Equipment and Rooms

* Decontaminate Accessible Areas

*Deactivate Utilities; Install

Additional Security and Other Equipment

* Final Radiation Survey

Subtotals, Radwaste and Control Building (d)

0.43

48.15

45.24

35.44

35.72

1.34

106.32

$\underline{0.13}$

99

4.02

Ancillaries

\begin{tabular}{|c|}
\hline $\begin{array}{l}\text { Discharge and Ship Fuel } \\
\text { * Operate Radwaste Systems } \\
\text { * Routine Radiation Surveys } \\
\text { Package Dry Solid Wastes } \\
\text { Miscellaneous }\end{array}$ \\
\hline Subtotals, Ancillaries (d) \\
\hline
\end{tabular}

(a) Based on data presented in Table J.6-1 in Appendix 3.

(b) Calculated by multiplying the effected total dose by 3 .

(c) Indicates those general tasks that are likely affected by an increase in radiation dose rates.

(d) Rounded to the nearest whole man-rem; does not imply accuracy to that many significant figures. 


\section{TABLE 0.2-3. Three-Fold Occupational Radiation Doses for Entombment}

Building General Task

Reactor Building/Primary Conta inment

(d) Install Supplemental HEPA Filters

Initial Radiation Survey

Remove and Ship Reactor Vessel Internals

*Decontaminate Systems

Drain and Clean Pools

*Clean Up, Stage, and Shield Hot Spots

* Remove and Relocate Piping and Equipment

* Prepare Containment Structure

Remove Contaminated Concrete

Remove HVAC and Disable Crane

Final Radiation Survey

Install Monitoring Equipment; Deactivate

Utilities

Turbine Generator Building

Install Supplemental HEPA Filters

*Initial Radiation Survey

*Clean Up and Stage

*Decontaminate and Drain Systems

*Remove and Ship Turbine

*Remove Piping and Equipment

*Remove and Ship Condenser

Remove Contaminated Concrete

Remove HVAC and Electrical Systems

Final Radiation Survey

Subtotals, Turbine Generator Building (f)

Radwaste and Control Building

*Initial Radiation Survey

* Clean Up

* Decontaminate Systems

*Remove Piping and Equipment

Remove Contaminated Concrete

Remove Miscellaneous Equipment

Final Radiation Survey

Subtotals, Radwaste and Control Building $(f)$

Ancillaries

Discharge and Ship Fuel

*Operate Radwaste Systems

*Routine Radiation Surveys

Package Dry Solid Wastes

Miscellaneous

Subtotals, Ancillaries $(f)$

Totals (f)
Total Doses Three-Fold Doses (a)

\begin{tabular}{|c|c|c|c|}
\hline $\begin{array}{l}\text { Without Internals }(b) \\
\text { (man-rem) }\end{array}$ & $\begin{array}{l}\text { With Internals }(\mathrm{c}) \\
\text { (man-rem) } \\
\end{array}$ & $\begin{array}{l}\text { Without Internals } \\
\text { (man-rem) }\end{array}$ & $\begin{array}{l}\text { With Internals } \\
\text { (man-rem) }\end{array}$ \\
\hline $\begin{array}{r}3.38 \\
0.50 \\
106.60\end{array}$ & $\begin{array}{l}3.38 \\
0.50 \\
-.(\mathrm{e})\end{array}$ & $\begin{array}{r}3.38 \\
1.50 \\
106.60\end{array}$ & $\begin{array}{l}3.38 \\
1.50 \\
-.\end{array}$ \\
\hline $\begin{array}{r}16.95 \\
3.74 \\
8.15\end{array}$ & $\begin{array}{r}16.95 \\
3.74 \\
8.15\end{array}$ & $\begin{array}{r}50.85 \\
3.74 \\
24.45\end{array}$ & $\begin{array}{r}50.85 \\
3.74 \\
24.45\end{array}$ \\
\hline $\begin{array}{r}353.89 \\
139.14 \\
16.67\end{array}$ & $\begin{array}{r}353.89 \\
139.14 \\
16.67\end{array}$ & $\begin{array}{r}1061.67 \\
417.38 \\
16.67\end{array}$ & $\begin{array}{r}1061.67 \\
477.38 \\
16.67\end{array}$ \\
\hline $\begin{array}{l}7.39 \\
0.06\end{array}$ & $\begin{array}{l}7.39 \\
0.06\end{array}$ & $\begin{array}{l}7.39 \\
0.06\end{array}$ & $\begin{array}{l}7.39 \\
0.06\end{array}$ \\
\hline 0.73 & 0.73 & 0.73 & 0.73 \\
\hline 657 & 551 & 1694 & 1588 \\
\hline
\end{tabular}

9.30

0.60

2.46

1.17

23.67

417.67

7.89

33.96

2.03

0.45

$\begin{array}{r}0.04 \\ \hline\end{array}$

195
101.88

2.03

0.45

$\quad 0.04$

559
9.30

0.60

2.46

1.17

23.67

417.67

101.88

2.03

0.05

0.04

559

(a) Calculated by multiplying the respective effected total dose by 3 .

(b) Based on data presented in Table K.4-l in Appendix K.

(c) Based on information presented in Section K.4 of Appendix $K$ for Scenario-2 Entombment.

(d) Indicates those general tasks that are likely affected by an increase in radiation dose rates.

(e) This task not included in this entombment scenario.

(f) Rounded to the nearest whole man-rem; does not imply accuracy to that many significant figures. 
The other remaining events are performed after removal of the more radioactive components and are also not affected.

For the postulated three-fold increase in radiation dose rate, 4573 man-rem of occupational radiation dose are estimated (versus 1845 man-rem in Appendix I) for immediate dismantlement, 759 man-rem are estimated (versus 375 man-rem in Appendix J) for preparations for passive safe storage, and 4154 man-rem are estimated (versus 1684 man-rem in Appendix K) for entombment (without internals, entombment scenario 1 in Appendix $K$ ).

The impacts of these increased radiation doses on decommissioning costs are discussed in the following section.

\subsubsection{Decommissioning Costs}

It is obvious that at least twice as many workers are possibly required for each decommissioning mode to keep the individual radiation doses within limits. One alternative to increased manpower is to install temporary shielding in many areas to reduce the radiation dose rates to the workers during active decommissioning. A second alternative is to increase the effectiveness and scope of the chemical decontamination. A third alternative is to take a longer time to complete the active decommissioning.

The effects of the increased radiation dose rates on the following decommissioning costs, which are the only costs assumed affected, are discussed in the following subsections, with conclusions in the last subsection.

- staff labor costs

- chemical decontamination costs

- disposal costs.

\subsubsection{Staff Labor Costs}

The impact of increased radiation dose rates on staff labor costs will vary, depending on the decommissioning mode selected. For both immediate dismantlement and entombment, because of the large amount of direct contact work on the piping systems and associated equipment, the impact can be significant. For preparations for passive safe storage, the fraction of direct contact work is much less, resulting in a much smaller impact. These impacts are examined in the following subsections. 
Immediate Dismantlement. One approach used in the nuclear industry when faced with jobs involving high radiation dose rates is to employ temporary workers, work them until they have received their allowable radiation dose, and then replace them with new temporary workers, and so on until the job is finished. Because of the time required to train temporary workers and because of their lack of familiarity with the plant, it is estimated that these workers are only about $60 \%$ as efficient as the workers who come from the plant's operating staff. Thus, the staff labor costs for the decommissioning workers increase by 60 to $70 \%$. This results in an increase in staff labor costs of about $\$ 6$ million for immediate dismantlement, not including a contingency. This conclusion is based on the manpower costs given in Table I.3-6 in Appendix I and includes the following staff categories: 1) utility operators, 2) laborers, 3) craftsmen, and 4) health physics technicians.

Another approach is to employ temporary laborers to install temporary shielding wherever necessary to reduce the radiation dose rates to the levels presented in Appendix D. This approach offers only partial success in reducing the radiation dose to the decommissioning workers, since the piping and equipment have to be handled during removal, and shielding the workers during those operations would be difficult (if not impossible) in many cases. There is no clear-cut way to evaluate the cost for this approach, but it seems likely that the cost differential for staff labor is in the same range as the $\$ 6 \mathrm{million}$ estimated previously for the first approach. The cost of the additional shielding is estimated to be on the order of $\$ 100,000$. It is also likely that the radiation dose received during the placement of the shielding would cause the total occupational radiation dose for this alternative to be as high as if it were not used.

Preparations for Passive Safe Storage. The occupational radiation dose to workers during preparations for passive safe storage is increased by about $120 \%$ by the postulated three-fold increase in radiation dose rates throughout the facility. This increased dose could be received by the work force given in Appendix $\mathrm{J}$ without exceeding existing limits. Therefore, the impact of increased radiation dose rates on staff labor costs is minimal for this mode. 
Entombment. Since entombment requires dismantlement of all areas outside Primary Containment, the impact of increased radiation dose rates on staff labor costs for entombment is similar to that for immediate dismantlement. Making the same assumptions about the use of temporary laborers as for immediate dismantlement, the staff labor costs for entombment increase by about $\$ 6$ million, not including a contingency.

\subsubsection{Chemical Decontamination Costs}

The chemical decontamination method chosen in Section $\mathrm{H} .5$ of Appendix $\mathrm{H}$ uses the complexing agent EDTA combined with citric acid and oxalic acid in a one-step process. An average decontamination factor (DF) of 10 is assumed. Laboratory and in-reactor loop decontamination studies have shown that the dissolution of deposited radionuclide film proceeds in a decreasing exponential relative to the length of time of circulation. (10) The data from these studies suggest that to reduce the radiation dose rate from internally deposited radionuclides in the piping systems, longer recirculation of the decontamination solutions is required. In addition, the thermolytic and radiolytic decomposition of EDTA during the decontamination process requires monitoring and intermittent addition of the decontamination chemicals throughout the process to maintain optimum conditions for removal of the radionuclides and their suspension in the circulating fluid. Since the reduction in radiation dose rates during decontamination tends to follow an exponential decay curve, the time required to obtain a DF of 3 , in addition to the 10 assumed, increases by about $50 \%$ over that required for a DF of 10 only.

The principal cost impacts from an extended chemical decontamination effort are the cost for electricity to operate the recirculation pumps and the cost for additional staff labor. The cost for chemicals given in Appendix $\mathrm{H}$ (based on the $5 \%$ solution) is probably an upper-limit estimate, even when considering the cost for the chemicals added during the recirculation period; thus, no incremental expense is expected for the additional chemicals. Similarly, the volume of fluid to be processed is essentially the same as given in Appendix $\mathrm{H}$ (except when the scope of the chemical decontamination is increased to include additional BWR systems that, with the postulated three-fold radionuclide deposition, now meet the selection criterion on dose rate). The staff labor involved is 
roughly proportional to the recirculation time, and the additional staff labor cost is small compared to the total decommissioning cost. Therefore, the incremental cost of achieving a DF of 30 compared to a DF of 10 , is postulated to be small, probably less than $\$ 100,000$.

From a practical point of view, it is unlikely that dose rates in operating plants will be allowed to reach anything approaching three times present levels, because of the considerable difficulty such increases would cause for normal operation and maintenance. Studies are presently in progress within the nuclear industry to develop decontamination solutions that can be injected into the reactor coolant stream immediately following reactor shutdown and circulated through the primary coolant system with the fuel in place in the core. The decontamination chemicals and the suspended and dissolved radionuclides are removed from the coolant water by side-stream cleanup, resulting in reactor quality water by the end of the outage. It is anticipated that these decontaminations will produce a DF of about 2, which should be sufficient to keep the radiation dose rates at a manageable level for the life of the plant.

\subsubsection{Disposal Costs}

If the chemical decontamination is not increased, the residual radioactivity deposition in the piping and equipment would be about three times greater than is assumed in Appendix E. The effect of these higher residual radioactivity levels is seen principally in the area of container shielding, although additional containers may also be required.

of the over 5000 containers used for disposal of the contaminated material during immediate dismantlement (see Section I.3 of Appendix I), it is estimated that less than 1000 require additional shielding. An allowance of $\$ 100,000$ is suggested as reasonable for the cost of this additional shielding. The higher residual contamination level has no significant effect on the disposal costs for the neutron-activated materials, since the radiation dose rate from the activated constituents is much larger than the radiation dose rate from the deposited radioactivity. 


\subsubsection{Conclusions}

For the situation where the radiation dose rates from radionuclides deposited in the BWR systems are postulated to be three times the levels presented in Appendix $D$ :

- If no corrective actions are taken to reduce the radiation dose rates, the accumulated radiation dose to the decommissioning workers increases about 2728 man-rem, and the total decommissioning cost increases about $\$ 6$ million for additional staff labor and about $\$ 100,000$ for additional container shielding (a total increase of about $\$ 6.1$ million) for immediate dismantlement. For preparations for passive safe storage, the radiation dose increases about 384 man-rem and there is essentially no change in the cost. For entombment, the radiation dose increases about 2470 man-rem and the cost increases about $\$ 6$ million.

- If corrective action is taken, such as an extended chemical decontamination following final shutdown, the total additional cost could be as much as $\$ 100,000$.

On the basis of these estimates, it appears that additional chemical decontamination is the most cost-effective approach to handling the higher initial radiation dose rates postulated. This approach is also more consistent with the principles of ALARA, since the occupational radiation dose associated with a chemical decontamination is relatively small, compared with the radiation dose associated with installing temporary shielding or with attempting to perform the dismantlement without additional shielding. In addition, it is likely that annual decontaminations of the reactor coolant system and related systems will be standard operating practice when decontamination solutions become available, thus preventing large buildups of radionuclides in the systems.

\subsection{SENSITIVITY OF IMMEDIATE DISMANTLEMENT COSTS TO DIFFERENT CONTRACTUAL ARRANGEMENTS}

Two basic premises used in Appendix I concerning the decommissioning work force for immediate dismantlement of the reference BWR are: 1) the majority of the staff consists of personnel who were members of the facility's operating 
organization prior to shutdown of the facility, and 2) the operating utility functions as the general contractor for decommissioning.

Presently, numerous organizations provide specialized contract services to nuclear power plant owners during plant outages. It is likely that when a significant number of nuclear power plants are approaching retirement, organizations will form specifically to decommission such facilities. This section examines the postulated organization for and the impact on immediate dismantlement costs by a contract-type approach to decommissioning.

\subsubsection{Postulated Organization for Decommissioning by Contract}

The plant owner, as the licensee, is responsible for ensuring that the decommissioning work is performed in accordance with applicable regulations. Therefore, even in a contract situation, the plant owner is the prime contractor and provides the plant operations, industrial safety, and contracts and accounting as well as the quality assurance functions in addition to the overall management of the job. Specialty contractors provide the working-level supervision and the decommissioning workers. In this instance, it is assumed that separate contractors are employed to provide for health physics, security, transportation, and dismantlement. The other specialty contractors identified in Section H.2.6 of Appendix $H$ (explosives, radwaste treatment, and environmental monitoring) become subcontractors to the dismantlement contractor. The functional organization presented in Figure $\mathrm{H} .1-1$ in Appendix $\mathrm{H}$ is assumed to be modified to that shown in Figure 0.3-1.

\subsubsection{Impact on Immediate Dismantlement Costs}

The principal cost impacts associated with utilizing contractors to accomplish decommissioning of the reference BWR result from: contractual considerations, including the type of contract, the fees, and the incentives; contractor overhead rates; and contractor mobilization and demobilization. A discussion of these factors and of their impact on immediate dismantlement costs is presented in the following subsections. 


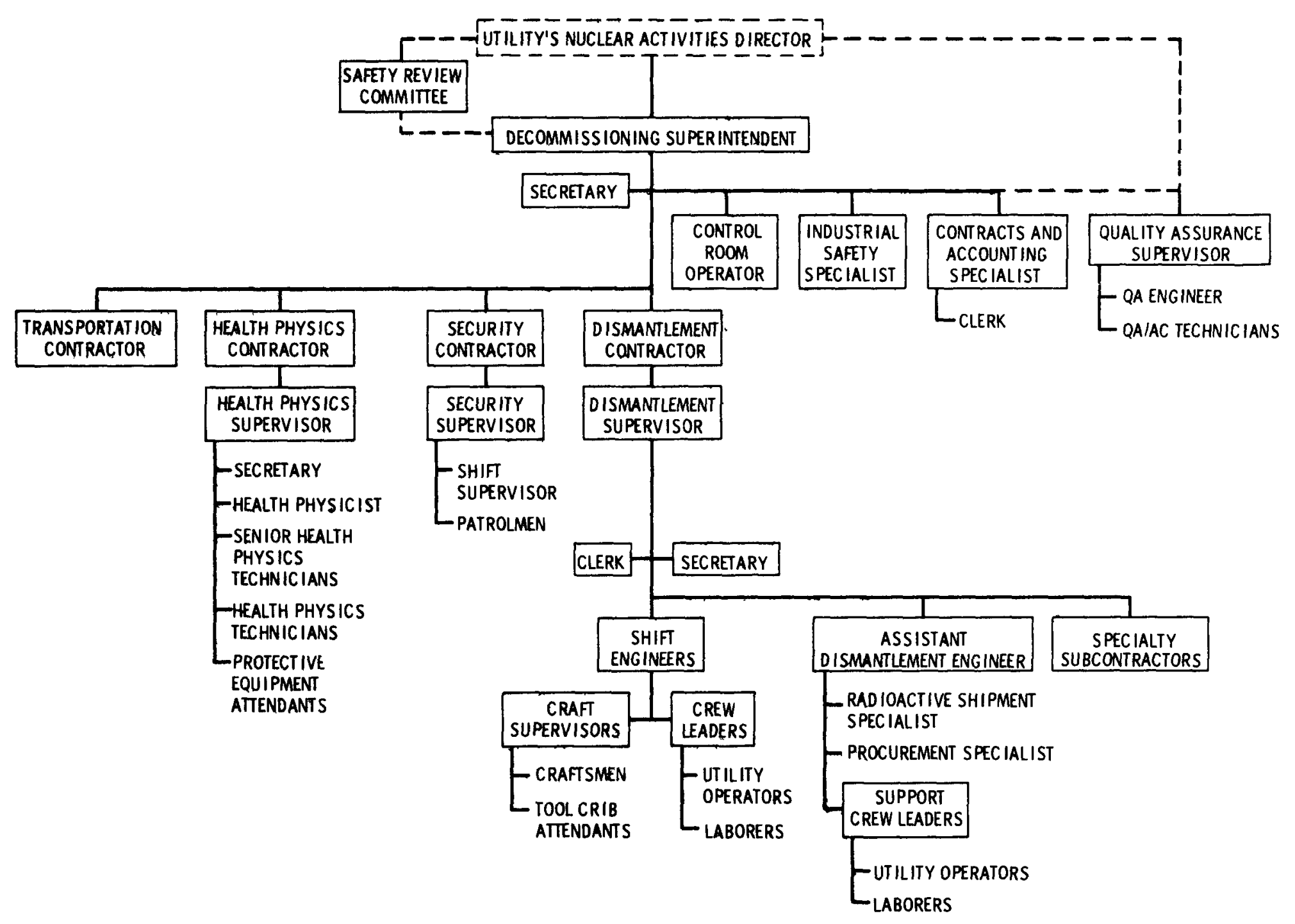

NOTE: HEALTH PHYSICS TECHNIC IANS AND CRAFTSMEN ARE ASSIGNED TO CREWS AS WORK SITUATIONS DEMAND

FIGURE 0.3-1. Postulated Qrganization for Decommissioning by Contract 


\subsubsection{Contractual Considerations}

Clearly, the degree of work let out on contract differs depending on the work that the plant owner can perform. The type of contract is primarily conditioned by financial risk or uncertainty of performance. Where specific work packages are prepared and are suitable for definitive pricing, a firm fixedprice contract best serves the interests of both contracting parties. A definitive work scope is generally necessary for bid advertisement and enhances the prospect for both competition and cost savings. In the situation where the owner maintains day-to-day surveillance and supervision of decommissioning tasks, a less definitive work statement is called for. In this situation, a cost-reimbursement contract or one that specifies a fixed price per hour of labor is most suitable.

In the safe storage mode, continuing care services can probably be fixedpriced. These services (such as radiation monitoring, buildng maintenance, and security) are readily quantifiable. It is easily understood that the least definitive decommissioning work involves dismantlement. Work involving radioactivity or high-risk skills (e.g., explosives work) has built-in inefficiencies that result in significantly higher costs. Under these circumstances, very conservative estimating is to be anticipated from the bidders. Therefore, it is prudent for utilities to include an "inefficiency" factor in budgeting for such decommissioning tasks.

Budgeting is also impacted by the long-term planning required for decommissioning. Estimates older than 1 year degrade rapidly in accuracy, if they are available at al1. General economic conditions, inflation rates, regulatory impacts, energy costs, and labor costs are all interdependent elements that require careful evaluation from either a budgeting or a cost proposal viewpoint.

Several factors need consideration when negotiating a contract. Selected contract terms and conditions that should be considered in a contract for BWR decommissioning are:

- indemnity and insurance

- third-party liability (public liability) 
- work delays

- default

- work scope changes

- licenses, permits, and approvals

- safety

- quality assurance

- labor disputes

- overtime premiums

- hazardous material handling

- accident reporting

- salvage rights.

While provisions for all of these conditions are not required in a given contract situation, all deserve consideration. Before a meaningful estimate or proposal is possible, each contract situation must be evaluated for work scope, performance period, cost risk, and terms and conditions. There are no model contracts or auditable trails to study for specific experience in contracting for nuclear power plant decommissioning. This situation is not unique but it requires proper emphasis on the part of the utility management designating a contract procurement staff.

Incentives may be considered for early completion, for reduced cost, or for some other specific performance criterion. Such incentives must be carefully determined and, as a general rule, selected on the basis of easy measurement. However, a less-objective incentive in the form of an award fee may be negotiated. The award fee, determined on the basis of subjectively measured criteria after performance, is thus a bonus, either in whole or in part, and is in addition to the base fee.

Indirect expenses vary significantly from one contractor to another within the same industry. Overheads for staff labor range from 50 to $150 \%$ of the base salary costs. Contractor profit or fee is in the range of 10 to $15 \%$ of total contractor costs, depending on such things as the type of contract and the risk of performance.

To estimate the impacts of these contractual considerations on decommissioning costs, it is necessary to make several assumptions on how selected 
costs are paid. For example, it is assumed that the utility pays the radioactive material transportation and disposal costs directly, rather than channeling these costs through the dismantlement contractor. The utility is also assumed to provide the energy needed for the job. On the other hand, the costs for special equipment and supplies, as well as those for specialty subcontractors, are assumed to flow through the dismantlement contractor and are subject to the contractor fee. Thus, of the items listed in Table I.3-1 in Appendix I, only staff labor, special equipment, miscellaneous supplies, and specialty contractors are subject to the fee. Another significant cost, not separately identified in Table I.3-1 but included in the disposal costs for radioactive materials, is for shipping containers, which are also assumed to be subject to the contractor fee.

\subsubsection{Contractor Overhead Rates}

Overkead rates applied to direct staff labor are significantly higher for the contractors than for the utility, because of the usually larger ratio of supervisory and support personnel to direct labor in contractor organizations. In addition, travel and living expenses increase the overhead costs. In view of these factors, an overhead rate of $110 \%$ is assumed applicable to all contractor direct staff labor costs.

The staff labor costs for the utility-only approach and for the combined utility-contractors approach are shown in Table 0.3-1. In the table, the projected staff labor requirements and costs, presented respectively in Tables I.2-2 and I.3-6 in Appendix I, are regrouped to reflect the organizational structure shown previously in Figure 0.3-1, and, for the utility-contractors approach, the contractors' staff labor costs are adjusted for the higher overhead rates. The combined utility-contractors operation results in a staff labor cost increase of $\$ 5.0$ million.

\subsubsection{Mobilization and Demobilization}

There are significant costs associated with establishing a contractor at the work site. These costs include providing temporary office facilities, obtaining the required special equipment, and assembling the work force. Similarly, there are costs associated with closing down the work site. These 


\section{TABLE 0.3-1. Staff Labor Requirements and Costs for Immediate Dismantlement by Contract}

\begin{tabular}{|c|c|c|c|}
\hline \multirow[b]{2}{*}{ Utility Staff } & \multirow[t]{2}{*}{$\begin{array}{l}\text { Total Staff } \\
\text { Labor Required } \\
\text { (man-years)(a) }\end{array}$} & \multirow[t]{2}{*}{$\begin{array}{l}\text { Total Staff Labor } \\
\text { Utility-0niy(c) }\end{array}$} & \multirow[t]{2}{*}{$\frac{\text { Costs (\$ thousands) }}{\text { (b) }}$} \\
\hline & & & \\
\hline $\begin{array}{l}\text { Decommissioning Superintendent } \\
\text { Secretary } \\
\text { Control Room Operator }\end{array}$ & $\begin{array}{r}5.1 \\
5.1 \\
17.1\end{array}$ & $\begin{array}{l}380.0 \\
103.5 \\
495.9\end{array}$ & $\begin{array}{l}380.0 \\
103.5 \\
495.9\end{array}$ \\
\hline $\begin{array}{l}\text { Industrial Safety Specialist } \\
\text { Contracts and Accounting Specialist } \\
\text { Clerk }\end{array}$ & $\begin{array}{l}4.8 \\
5.1 \\
4.5\end{array}$ & $\begin{array}{r}210.2 \\
195.9 \\
91.4\end{array}$ & $\begin{array}{r}210.2 \\
195.9 \\
91.4\end{array}$ \\
\hline $\begin{array}{l}\text { Quality Assurance Supervisor } \\
\text { Quality Assurance Engineer } \\
\text { Quality Assurance Technician } \\
\text { Consultant (Safety Review) } \\
\end{array}$ & $\begin{array}{r}5.1 \\
6.0 \\
14.5 \\
2.8 \\
\end{array}$ & $\begin{array}{l}223.4 \\
236.4 \\
336.4 \\
187.6 \\
\end{array}$ & $\begin{array}{l}223.4 \\
236.4 \\
336.4 \\
187.6 \\
\end{array}$ \\
\hline Subtotals, Utility Staff & 71.0 & 2460.7 & 2460.7 \\
\hline Contractors' Staffs (d) & & & \\
\hline $\begin{array}{l}\text { Health Physics Supervisor } \\
\text { Secretary } \\
\text { Health Physcist }\end{array}$ & $\begin{array}{l}5.8 \\
4.0 \\
4.0\end{array}$ & $\begin{array}{r}292.4 \\
81.2 \\
157.6\end{array}$ & $\begin{array}{l}361.2 \\
113.4 \\
194.7\end{array}$ \\
\hline $\begin{array}{l}\text { Senior Health Physics Technician } \\
\text { Health Physics Technician } \\
\text { Protective Equipment Attendant }\end{array}$ & $\begin{array}{r}8.8 \\
50.0 \\
7.0\end{array}$ & $\begin{array}{l}289.6 \\
255.1 \\
162.4\end{array}$ & $\begin{array}{l}357.7 \\
757.1 \\
227.4\end{array}$ \\
\hline $\begin{array}{l}\text { Security Supervisor } \\
\text { Security Shift Supervisor } \\
\text { Security Patrolman }\end{array}$ & $\begin{array}{r}3.5 \\
17.5 \\
86.5\end{array}$ & $\begin{array}{r}115.2 \\
537.3 \\
1842.5\end{array}$ & $\begin{array}{r}142.3 \\
322.4 \\
2579.5\end{array}$ \\
\hline $\begin{array}{l}\text { Dismantlement Supervisor } \\
\text { Clerk } \\
\text { Secretary } \\
\text { Shift Engineer }\end{array}$ & $\begin{array}{r}5.8 \\
3.0 \\
4.5 \\
10.0\end{array}$ & $\begin{array}{r}368.3 \\
60.9 \\
91.4 \\
438.0\end{array}$ & $\begin{array}{r}455.0 \\
85.3 \\
127.6 \\
541.1\end{array}$ \\
\hline $\begin{array}{l}\text { Craft Supervisor } \\
\text { Craftsman } \\
\text { Tool Crib Attendant }\end{array}$ & $\begin{array}{r}7.4 \\
93.2 \\
6.8\end{array}$ & $\begin{array}{l}292.8 \\
2525.9 \\
157.8\end{array}$ & $\begin{array}{l}361.7 \\
336.3 \\
220.9\end{array}$ \\
\hline $\begin{array}{l}\text { Crew Leader } \\
\text { Utility Operator } \\
\text { Laborer }\end{array}$ & $\begin{array}{r}31.5 \\
123.5 \\
54.3\end{array}$ & $\begin{array}{ll}1 & 152.7 \\
3 & 347.1 \\
1 & 406.6\end{array}$ & $\begin{array}{ll}1 & 423.9 \\
4 & 674.6 \\
1 & 969.5\end{array}$ \\
\hline $\begin{array}{l}\text { Assistant Dismantlement Engineer } \\
\text { Radioactive Shipment Specialist } \\
\text { Procurement Specialist }\end{array}$ & $\begin{array}{l}5.4 \\
4.4 \\
4.7 \\
\end{array}$ & $\begin{array}{l}236.6 \\
144.8 \\
144.3 \\
\end{array}$ & $\begin{array}{l}292.3 \\
178.9 \\
178.3 \\
\end{array}$ \\
\hline Subtotals, Contractors' Staffs & $\underline{540.7}$ & $15 \quad 100.5$ & $20 \quad 101.1$ \\
\hline Totals & 611.7 & 17561.2 & 22561.8 \\
\hline
\end{tabular}

(a) Based on information presented in Table I.2-3 in Appendix I.

(b) Accuracy to the nearest $\$ 1000$ is not implied.

(c) Based on information presented in Table 1.3-6.

(d) Costs for utility-contractors operation are based on the base salaries shown in Table M.1-1 in Appendix $M$ and include $110 \%$ overhead. 
costs, called mobilization and demobilization costs, vary with the size and complexity of the job. For the immediate dismantlement of a large BWR, these costs are estimated to be about $\$ 1.25$ million. (11)

\subsubsection{Impact on Immediate Dismantlement Costs}

The various cost items for the utility-contractors operation are separated into utility costs and contractor costs in Table 0.3-2 for comparison with the costs for the utility-only approach assumed for immediate dismantlement in Appendix I, which are also shown. A $15 \%$ fee is applied to all contractor costs.

TABLE 0.3-2. Comparison of Costs Estimated for Dismantlement Using the Utility-Only Approach or the Utility-Contractors Approach

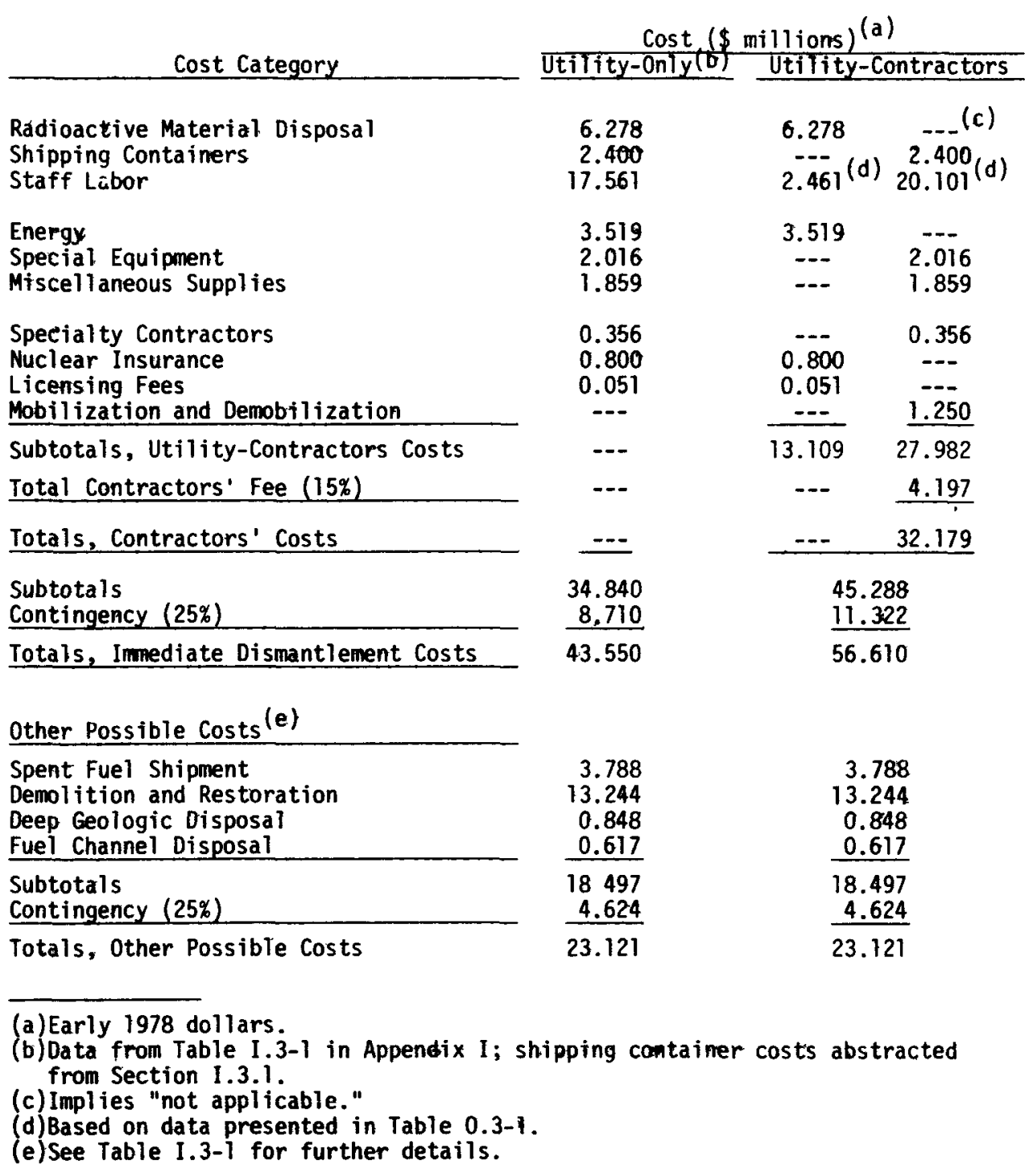


The utility-contractors approach for immediate dismantlement of the reference BWR increases the total decommissioning cost by about $30 \%$ to about $\$ 57$ million. This total does not include any incentive or bonus payments that might be negotiated for an undertaking of this magnitude.

\subsection{SENSITIVITY OF IMMEDIATE DISMANTLEMENT COSTS TO WASTE DISPOSAL CHARGES}

The costs for disposal of the radioactive materials removed from the reference BWR during immediate dismantlement, as developed in Section I.3.1. of Appendix I, are based on the assumption that all of these materials are placed in a shallow-land burial facility. These costs are developed using the fee schedule for a commercially licensed radioactive waste burial ground, published in September 1977 (see Section M.5 of Appendix M). The alternative cost of placing selected portions of the reactor vessel internals in a deep geologic disposal facility is also estimated in Section I.3. The impact of increased disposal charges on the total cost for immediate dismantlement is examined in this section for both the shallow-land burial concept and the deep geologic disposal alternative. The costs referred to in this section do not include the $25 \%$ contingency.

\subsubsection{Impact of Increases in Shallow-land Burial Charges}

The disposal costs for immediate dismantlement of the reference BWR are summarized in Table 0.4-1. The total estimated cost for immediate dismantlement is $\$ 34.840$ million, as given in Table I.3-1 in Appendix I. From that table, it can be seen that the total disposal cost constitutes about $25 \%$ of the total immediate dismantlement cost. As seen in Table 0.4-1 under "burial," the actual costs at the disposal facility constitute only $35 \%$ of the total disposal cost. Thus, less than $9 \%$ of the dismantlement cost is sensitive to the fee schedule at the disposal facility. For example, a doubling of the burial cost from $\$ 3.036$ million to $\$ 6.072$ million causes an $8.7 \%$ increase in the total immediate dismantlement cost.

The burial ground charges shown in Section M.5 of Appendix M were increased on June 1, 1978. The fees for burial (in dollars per cubic foot) increased $79 \%$ for containers with low surface radiation dose rates and $30 \%$ for containers having 
TABLE 0.4-1. Summary of Estimated Costs for Disposal of Radioctive Materials During Immediate Dismantlement

\begin{tabular}{|c|c|c|c|c|}
\hline \multirow[b]{2}{*}{ Radioactive Material Category } & \multicolumn{4}{|c|}{ Disposal Cost (\$ millions) $(a)$} \\
\hline & Containers & Transportation & Burial(b) & Total \\
\hline Activated Materials $(c)$ & 0.393 & 0.816 & 1.091 & 2.300 \\
\hline $\begin{array}{l}\text { Contaminated Materials }(d) \\
\text { Reactor Building } \\
\text { Turbine Generator Building } \\
\text { Radwaste and Control Building }\end{array}$ & $\begin{array}{l}0.639 \\
0.765 \\
0.265\end{array}$ & $\begin{array}{l}0.609 \\
0.814 \\
0.131\end{array}$ & $\begin{array}{l}0.622 \\
0.739 \\
0.225\end{array}$ & $\begin{array}{l}1.870 \\
2.417 \\
0.622\end{array}$ \\
\hline $\begin{array}{l}\text { Dry Solid Wastes(e) } \\
\text { Wet Sol id Wastes }\end{array}$ & $\begin{array}{l}0.064 \\
0.217 \\
\end{array}$ & $\begin{array}{r}0.237 \\
0.692 \\
\end{array}$ & $\begin{array}{l}0.095 \\
0.164 \\
\end{array}$ & $\begin{array}{l}0.396 \\
1.073 \\
\end{array}$ \\
\hline Totals & $\underline{2.343}$ & 3.299 & 3.036 & 8.678 \\
\hline Percent of Total & 27 & 38 & 35 & 100 \\
\hline
\end{tabular}

(a)Early 1978 dollars.

(b) Includes handling, burial, liner, and curie costs as applicable.

(c) Datar summarized from Table I.3-3 in Appendix I.

(d) Data summarized from Table I.3-4.

(e) Data summarized from Table I.3-5.

(f) Data summarized from Table H.5-9 in Appendix $H$.

high surface radiation dose rates, with a sliding scale increase in between. The basic curie surcharge per container was increased by $25 \%$. The surcharge for personnel radiation exposure was increased by $117 \%$. The new fee schedule is estimated to cause an increase in the total cost for immediate dismantlement from $\$ 3.036$ million to $\$ 4.569$ million, a $4.4 \%$ increase in the total immediate dismantlement cost.

\subsubsection{Impact of Higher Deep Geologic Disposal Costs}

The analysis presented in Section I.3.9.3 of Appendix I is based on placing the highly activated portions of the reactor vessel internals in intermediatelevel storage at a deep geologic disposal facility, as an alternative to using shallow-land disposal. In that analysis, the unit cost for emplacement is assumed to be $\$ 7,100 / \mathrm{m}^{3}$, based on information in Reference 12 . Other estimates of the cost for deep geologic emplacement range from about $\$ 9,000 / \mathrm{m}^{3}$ to about $\$ 19,000 / \mathrm{m}^{3}$, depending on whether the geologic medium is salt or various types of crystalline rock. (13)

Table 0.4-2 presents the effects of higher deep geologic emplacement costs by comparing the costs of nearly doubling and tripling the $\$ 7,100 / \mathrm{m}^{3}$ emplacement 
TABLE 0.4-2. Estimated Costs for Deep Geologic Disposal of the Highly Activated Materials

Emplacement Cost of:

$\$ 7100 / \mathrm{m}^{3(a)} \$ 14000 / \mathrm{m}^{3} \$ 21000 / \mathrm{m}^{3}$

\begin{tabular}{ll} 
Disposal Costs & \\
Container Cost & $\$ 0.320$ \\
Cask Rental Cost & $\$ 1.386$ \\
Transportation Cost & $\$ 0.552$ \\
\hline
\end{tabular}

Total Costs

Funds Not Used for Shallow-land Burial

Incremental Costs for Deep Geologic Disposal

Total Disposal Cost from Table 0.4-1

Total Disposal Costs

Percent Increase in Total Immediate

Dismantlement cost $\begin{array}{lll}0.631 & 1.245 & 1.867\end{array}$

\begin{tabular}{|c|c|c|}
\hline 2.258 & 2.258 & 2.258 \\
\hline 2.889 & 3.503 & 4.125 \\
\hline$(2.041)$ & $(2.041)$ & $(2.041)$ \\
\hline
\end{tabular}

$\begin{array}{lll}0.848 & 1.442 & 2.084\end{array}$

$\underline{8.678} \quad \underline{8.678} \quad \underline{8.678}$

$\underline{9.526} \quad \underline{10.140} \quad \underline{10.762}$

$\begin{array}{lll}2.4 & 4.1 & 6.0\end{array}$

(a)Based on information presented in Section I.3.9.3 of Appendix I.

cost assumed in Appendix I. It can be seen that doubling the emplacement cost per unit volume of waste increases the total immediate dismantlement cost by over $4 \%$. By approximately tripling the emplacement cost per unit volume, the total cost is increased by $6 \%$.

If all the activated materials, including the activated portion of the sacrificial shield, are emplaced in a deep geologic disposal facility, an estimated volume of about $467 \mathrm{~m}^{3}$ of material (based on the same assumptions used in Section I.3.9.3) requires emplacement. The total cost for such action, comprising about $\$ 3.3$ million for the emplacement (at $\$ 7,100 / \mathrm{m}^{3}$ ), about $\$ 1.7$ million for the required 336 canisters, and about $\$ 2.0$ million for transportation, is about $\$ 7.0$ million. The cost for shallow-land burial of the highly activated materials is about $\$ 2.3$ million. Thus, the total immediate dismantlement cost in this instance increases by $\$ 4.7$ million (about $13.5 \%$ ) over the cost associated with disposal of all wastes in a shallow-land burial facility.

From the discussion above, it can be seen that if only the highly activated materials are placed in a deep geologic disposal facility, the total immediate 
dismantlement cost is not very sensitive to the emplacement cost (i.e., increasing about $4 \%$ by doubling the emplacement cost). On the other hand, if all of the activated materials are placed in a deep geologic disposal facility, the total cost increases more than three times this much with no change in the emplacement cost.

In the unlikely event that all radioactive materials from immediate dismantlement are placed in a deep geologic disposal facility, the cost increase becomes quite significant. If it is again assumed that the wastes are packaged with a 15\% packing density (as in Section I.3.9.3 of Appendix I) so that the disposal volume is constant, $18,876 \mathrm{~m}^{3}$ of waste must be emplaced, at an emplacement cost (at $\$ 7,100 / \mathrm{m}^{3}$ ) of about $\$ 134$ million. The required 15,730 canisters cost over $\$ 78$ million. Thus, the cost for waste disposal in this instance, even without cask and transportation costs, becomes more than $\$ 212$ million, for an over $700 \%$ increase in the total immediate dismantlement cost when shallowland burial of all radioactive materials is assumed.

Obviously, there are strong incentives to minimize the volume of material placed in deep geologic disposal.

\subsection{SENSITIVITY OF IMMEDIATE DISMANTLEMENT COSTS TO DIFFERENT BWR CONTAINMENT DESIGNS}

The design of Primary Containment for BWR power plants has changed considerably since the first plant was constructed. The purpose of this section is to describe the various BWR containment designs and estimate their effect on the cost for immediate dismantlement.

\subsubsection{BWR Primary Containment Design Description}

The design of the reactor containment in the first few BWR power plants was not standardized. The first plants were all small (less than a few hundred MWt), and the containment designs varied. With the advent of plants larger than $1000 \mathrm{MWt}$, the containment design stabilized in the Mark I configuration. This was later superceded by the Mark II design which, in turn, has been supplanted by the Mark III design in the most recent BWR power plants. 
The differences in these three types of containment designs are discussed in the following subsections. The pertinent characteristics of these three different BWR containment designs, from three BWR power plants (including the reference plant) all of approximately the same thermal power rating, are listed in Table 0.5-1.

TABLE 0.5-1. Pertinent Characteristics of the Three Different
BWR Containment Designs (a)

Power Plant

Containment Design

Power Rating (MWt)

Suppression Pool

Pool Volume $\left(\mathrm{m}^{3}\right)$

Specific Volume $\left(\mathrm{m}^{3} / \mathrm{MWt}\right)$

Wetwel1

Volume $\left(\mathrm{m}^{3}\right)$

Specific Volume $\left(\mathrm{m}^{3} / \mathrm{MWt}\right)$

Surface Area $\left(\mathrm{m}^{2}\right)$

Specific Area $\left(\mathrm{m}^{2} / \mathrm{MWt}\right)$

Type of Surface

\begin{tabular}{|c|c|c|}
\hline Peach Bottom 2 or 3 & WNP-2 & Perry 1 or 2 \\
\hline Mark I & Mark II & Mark III \\
\hline 3293 & 3320 & 3579 \\
\hline 3851 & 3160 & 4100 \\
\hline 1.17 & 0.95 & 1.15 \\
\hline
\end{tabular}

7453

2.26

3155

0.96

All Metal
9614

2.90

$3570(c)$

1.08

Metal and Concrete $13500(b)$

3.77

4809

1.34

Metal and

Concrete

(a)The number of figures shown is for computational accuracy and does not imply accuracy to that many significant figures.

(b) Estimates from dimensions given in the PSAR. (14)

(c) Includes area of exposed steel vessel $\left(1,111 \mathrm{~m}^{2}\right)$ and area of exposed concrete surface (chamber bottom, inside and outside of reactor pedestal, and 17 support columns, $\left.2,459 \mathrm{~m}^{2}\right)$.

\subsubsection{Mark I Containment Design}

The shape of the drywell of a Mark I containment is similar to that of a inverted light bulb (see Figure 0.5-1). For the Peach Bottom 2 or 3 power plant, which is selected for this analysis, the cylindrical portion of the drywell is $11.7 \mathrm{~m}$ in diameter by $16.0 \mathrm{~m}$ high and the spherical bottom is $20.4 \mathrm{~m}$ in diameter. 


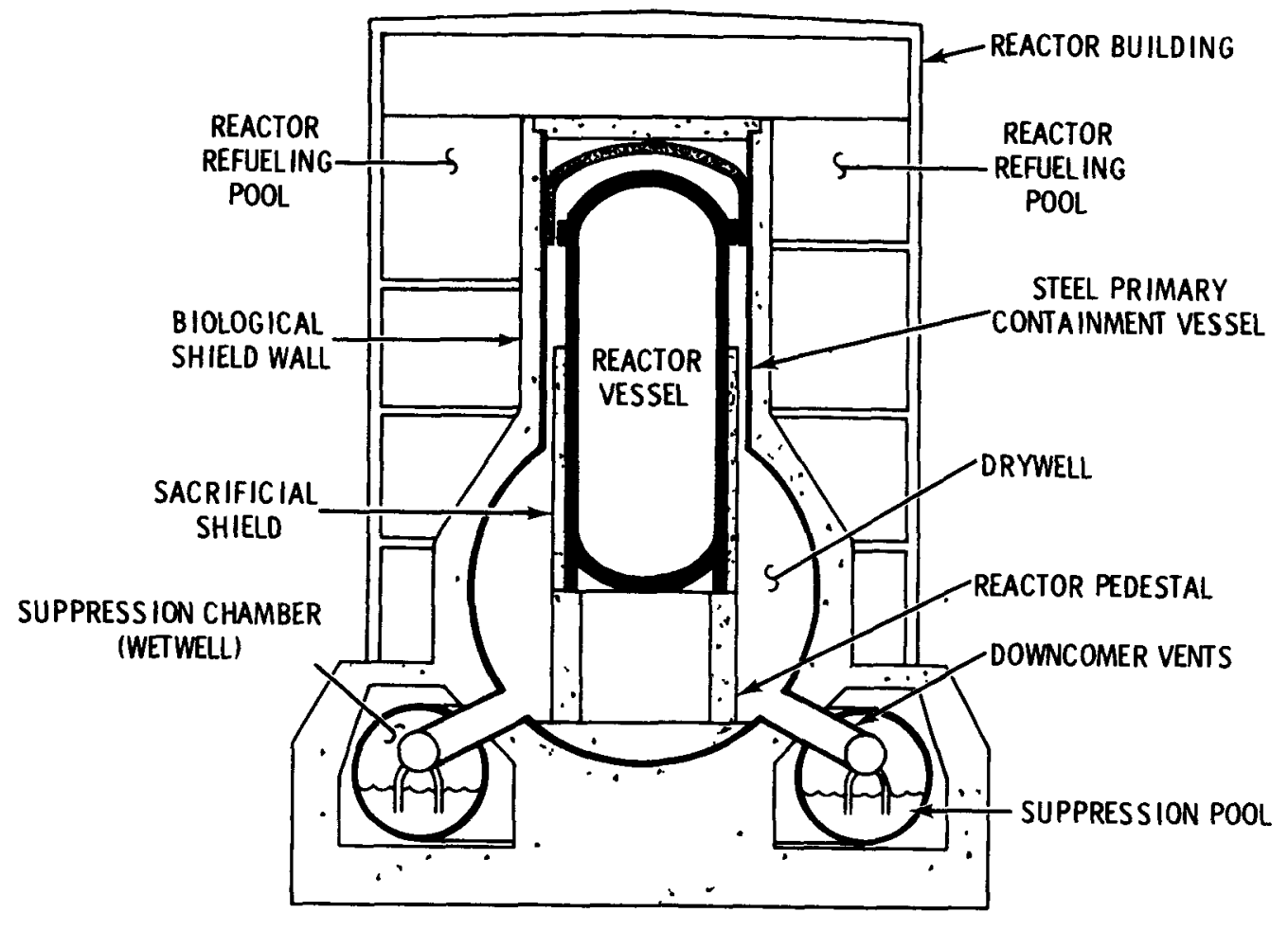

FIGURE $0.5-1$. BWR Mark I Containment

The pressure-suppression chamber (wetwell) of a Mark I containment is toroidal in shape. For the Peach Bottom 2 or 3 power plant, the torus has a cross-sectional diameter of $9.5 \mathrm{~m}$ and a major diameter of $33.8 \mathrm{~m}$. The wetwell is located just below and surrounds the drywell, as shown in Figure 0.5-1. The two chambers are connected by a series of downcomer vents, which extend radially from the lower portion of the drywell like the spokes of a wheel. The bottom portion of the wetwell is filled with water to form the suppression pool.

The reactor vessel, the reactor pedestal, and the sacrificial shield are located completely within the drywell, which together with the wetwell forms the Primary Containment. The Primary Containment is completely surrounded by the Reactor Building, which provides secondary containment.

Some 26 different BWR power plants in the United States are constructed with Mark I containment designs. 


\subsubsection{Mark II Containment Design}

The Mark II containment followed the Mark I design and has been used in some 10 different BWR power plants in this country (including the reference plant).

The drywell for the Mark II design is in the shape of a truncated right circular cone with the larger diameter at the bottom (see Figure 0.5-2). It is made of steel plate, has a concrete floor, and contains the upper portion of the reactor pedestal, the reactor vessel, and the sacrificial shield.

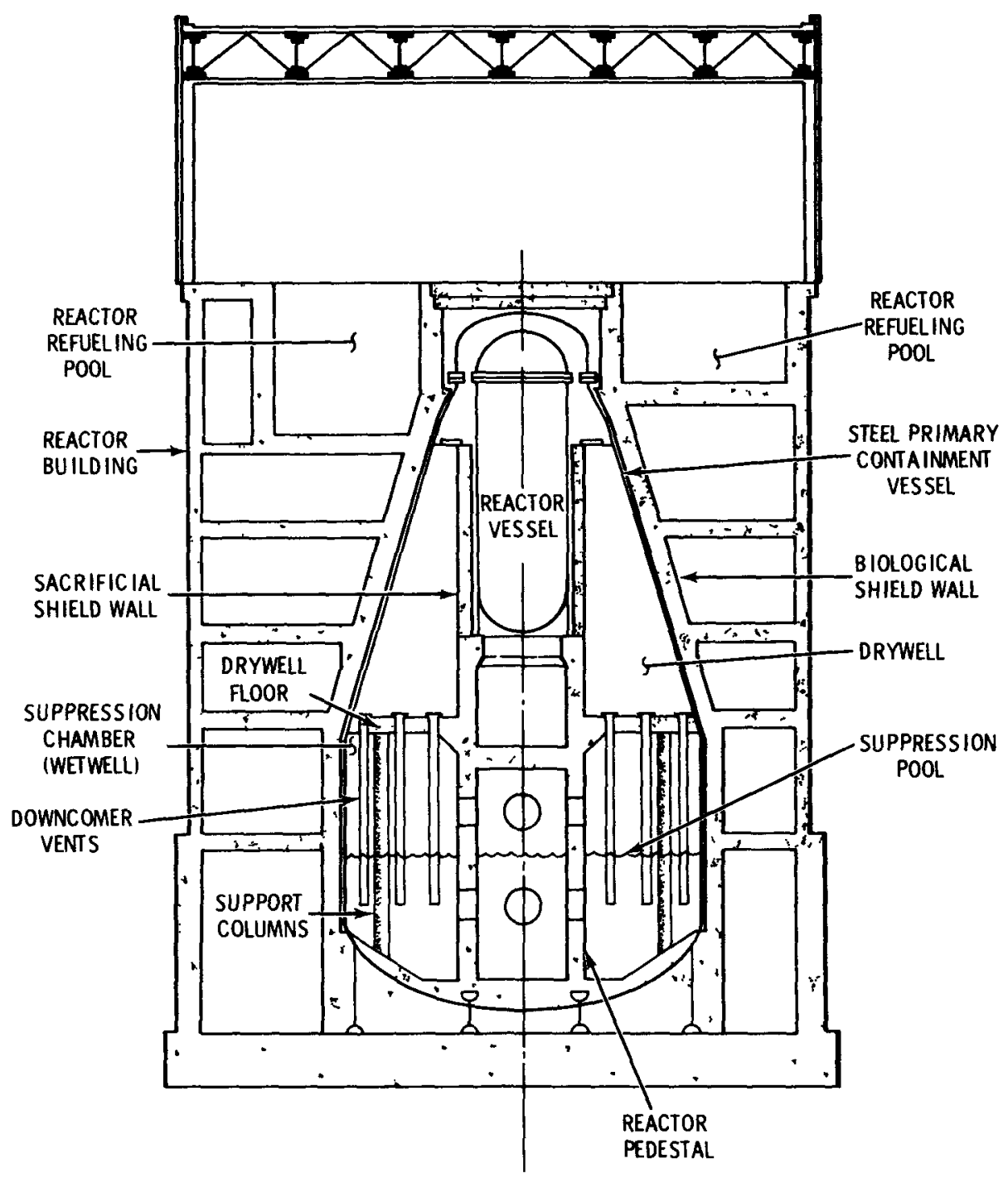

FIGURE 0.5-2. BWR Mark II Containment 
The suppression chamber is in the shape of a coffee mug with an ellipsoidal bottom and a right-circular cylindrical body. The body has the same diameter as and connects directly to the bottom end of the drywell. The two chambers are connected by downcomer vents. The wetwell is made of steel plate with the lower portion filled with a layer of concrete, which forms a structural base for and supports the reactor pedestal. The bottom of the wetwell is filled with water to form the pressure-suppression pool. In the case of the WNP-2 power plant, the wetwell is approximately $26 \mathrm{~m}$ in diameter and $20 \mathrm{~m}$ high. The drywell extends upward another $26 \mathrm{~m}$.

Again, the Reactor Building, as secondary containment, completely surrounds the Primary Containment comprising the drywell and the wetwell.

\subsubsection{Mark III Containment Design}

The latest BWR containment design is termed the Mark III design (see Figure 0.5-3). This type of containment is incorporated in some 21 different BWR power plants either in operation or presently under construction or design in this country. The BWR power plant selected for this analysis is the Perry Nuclear Power Plant, (14) unit 1 or 2 , which are rated at 3579 MWt each.

The Mark III containment design is quite different from the previous two designs in that no other building structure surrounds the containment. The steel containment vessel is cylindrical with an ellipsoidal top, as is the concrete shield which completely surrounds the vessel. The drywell and the wetwell form concentric rings surrounding the reactor vessel and bounded by the containment vessel. The lower portion of the drywell is lined with steel plate, whereas all other internal surfaces except those of the sacrificial shield are concrete.

The outer boundary of the lower portion of the drywell is the weir wall, which forms the inside boundary of the suppression pool. The outer boundary of the suppression pool is the inside face of the containment vessel, a 36.6-mdiameter steel cylinder of steel plate. The containment vessel is $46.4 \mathrm{~m}$ high and is capped by an ellipsoidal steel dome. 


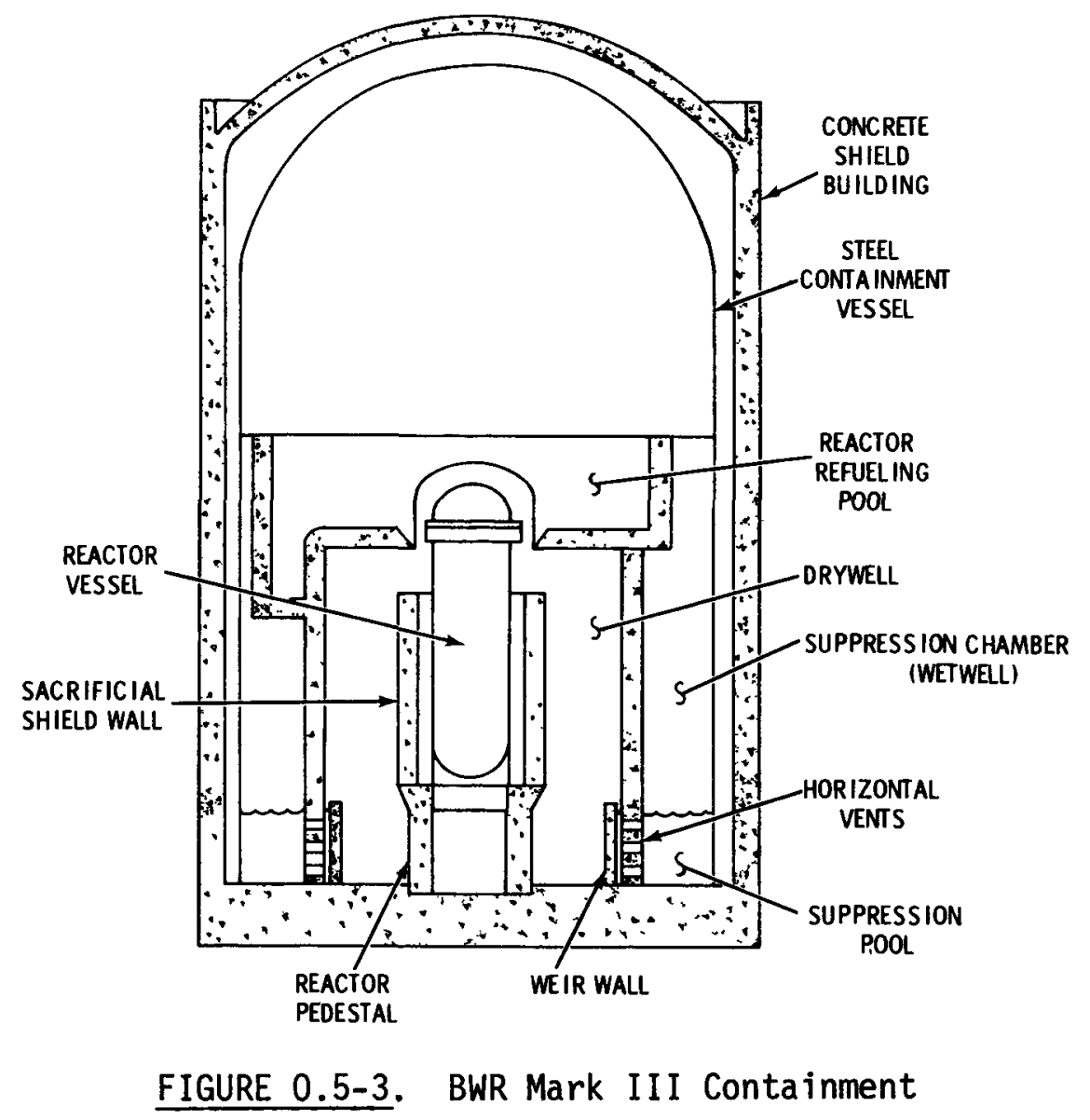

The drywell is connected to the pressure-suppression pool by means of steel tubes, which pass through the wall that forms the inner boundary of the suppression pool. The connecting tubes are located below the level of the pool, as shown in Figure 0.5-3.

\subsubsection{BWR Containment Dismantlement Cost Comparisons}

The principal costs associated with the dismantlement of a BWR containment, excepting the removal of the reactor vessel and the sacrificial shield, are: 1) treatment and disposal of the contaminated water, 2) decontamination of wetwell steel surfaces, 3) removal and disposal of contaminated concrete surfaces, and 4) removal and disposal of contaminated piping. These are discussed and compared for the three BWR containment designs in the following subsections. A concluding subsection summarizes the results of the individual comparisons. 


\subsubsection{Water Treatment and Disposal}

Treatment and disposal of the water from a pressure-suppression pool is proportional to the volume of that water. As shown previously in Table 0.5-1, the specific volumes of the water contained in the suppressian pools of the three selected BWR power plants are all similar in magnitude. For the purposes of estimating dismantling costs, it can be assumed that the volumes of the pools, and thus the costs of treatment and disposal of the water, are roughly proportional to the power ratings of the different BWR power plants. There is, therefore, no marked difference in the costs for treatment and disposal of the water from the suppression pools in the different wetwell designs (Mark I, Mark II, or Mark III) for BWR power plants of the same power rating.

\subsubsection{Decontamination of Wetwell Steel Surfaces}

The Mark I wetwell consists of a thick-walled steel vessel. The upper portion of a Mark II wetwell is a thick-walled steel cylinder. The outer boundary of the Mark III wetwell selected for this analysis is also a thick-walled steel cylinder. All of these steel wall surfaces may be decontaminated by cleaning them with a high-pressure water jet. It is estimated that this type of cleaning can be accomplished at the rate of $46 \mathrm{~m}^{2} / \mathrm{hr}$. The water used for cleaning will become contaminated, but the volume of water required $\left(0.0305 \mathrm{~m}^{3} / \mathrm{m}^{2}\right)$ is small, and it is mixed with the water from the suppression pool for treatment. In short, the cost of decontaminating steel surfaces is small, and in Appendix $H$ the surface-cleaning cost is lumped with the cost of treating the water from the suppression pool.

The total cost of cleaning the steel walls is small. The differences between the costs of cleaning the steel walls of the wetwells of the Mark I, Mark II, and Mark III designs are even smaller. Thus, the effect of the wetwell steel wall area on the total dismantlement cost due to the differences in the containment designs is negligible and can safely be ignored without affecting the accuracy of the overall dismantlement cost estimate.

\subsubsection{Removal and Disposal of Contaminated Concrete Surfaces}

The WNP-2 Mark II wetwell is a steel vessel, which is lined in the bottom with reinforced concrete. The concrete liner is the in-vessel foundational 
support for the reinforced concrete reactor pedestal and support columns, which, in turn, support the reinforced concrete drywell floor. It is assumed necessary to remove a 50-mm-thick layer from all concrete surfaces inside Primary Containment to effect satisfactory surface decontamination. The estimated total cost for removing and disposing the contaminated concrete surfaces inside Primary Containment (see Tables I.3-4 and I.3-7 in Appendix I) is $\$ 157,720$. This amount is about $0.5 \%$ of the total immediate dismantlement cost for WNP-2.

The Mark I design contains considerably less ( $10 \%$ ) concrete surface area than does WNP-2. Therefore, the cost for removal and disposal can be neglected in estimating the cost for dismantling a Mark I power plant. Moreover, since the reference plant is a Mark II design, the error, small though it is, is conservative.

As previously indicated, the Mark III design is quite different from the two earlier designs. The outer boundary of the suppression pool and wetwell is the steel containment vessel. The inner boundary is a circular reinforced concrete bulkhead (see Figure 0.5-3), which is probably coated with an epoxy paint rather than being lined with steel. In this case, the area of concrete surface (wetwell inner boundary, bulkhead inner surface, and weir wall outer surface) in the Mark III containment is the same as, or a little greater than, that for the Mark II containment. There is, therefore, essentially no difference in the costs for removal and disposal of contaminated concrete surfaces in the selected Mark II and Mark III designs.

It should be noted, however, that some other Mark III wetwells and suppression pools do not have steel-lined surfaces. In these cases, the amount of concrete surface area to be removed is greater for a Mark III design than for a Mark II design. In no case, however, is the additional estimated cost for a Mark III design as much as $1 \%$ of the total immediate dismantlement cost.

It is concluded in this instance that the differences in containment design have a negligible effect on the total dismantlement cost.

\subsubsection{Removal and Disposal of Contaminated Piping}

In this discussion, the only piping considered is the drywell-wetwell vent piping, since the process piping is assumed to be the same for all three 
containment designs. The Mark I containment design incorporates a series of large-bore vent pipes connecting the drywell to the wetwell, as previousiy discussed and as shown in Figure 0.5-1. In addition, there is a header inside the wetwell as well as a series of downcomers that drop from the header to below the surface of the suppression pool. The connecting pipes, the header, and the downcomers must be removed and disposed of during dismantlement.

In the Mark II containment design, there are a number of downcomer vent pipes that drop from the drywell floor down to a point below the surface of the suppression pool. All of these pipes must be removed and disposed of during the dismantlement operation.

The Mark III design contains a number of horizontal vent pipes that connect the suppression pool to the annular space surrounding the weir wall. These vent pipes must also be removed and disposed of during the dismantlement operation.

From the above, it can be seen that a Mark I containment contains more piping than a Mark II, and a Mark II contains more piping than a Mark III, relatively speaking. These relationships are inversely proportional to the relationships for contaminated concrete surfaces. Thus, the costs for removing and disposing of the piping tend to counteract any variations in dismantlement cost resulting from the removal and disposal of the contaminated concrete surfaces.

\subsubsection{Overall Effect of Containment Design on Dismantlement Cost}

Comparison of the four dismantlement cost factors discussed previously shows that, for BWR plants of equivalent power rating, differences in containment design have very little effect on the total cost for dismantlement of a BWR (whether Mark I, Mark II, or Mark III).

The cost for suppression pool water treatment and disposal is essentially the same for the different containment designs.

The dismantlement cost differences attributable to cleaning the wetwell steel surfaces are so small as to be inconsequential when compared with the total dismantlement cost. 
The differences in the costs of removing and disposing the contaminated concrete surfaces are small in relation to the overall dismantlement cost, as are the different costs of removing and disposing the contaminated vent piping in the containment system. In addition, the cost differentials for these two items tend to counterbalance one another, with the result that the combined effect on the total dismantlement cost is so small as to be negligible.

Considering all of the above factors, it is concluded that the effect of containment design (Mark I, Mark II, or Mark III) on the total cost of dismantling a BWR power plant is so small that it will not measurably affect the estimated cost of dismantling a BWR power plant having a containment design different from WNP-2. 


\section{REFERENCES}

1. Final Safety Analys is Report, Vermont Yankee Nuclear Power Station, Docket50271--14, Vermont Yankee Nuclear Power Corporation, Rutland, VT, January 1970.

2. Final Safety Analysis Report, Oyster Creek Nuclear Generating Station, Docket-50219--1, Jersey Central Power and Light Company, Morristown, NJ, January 1967.

3. Monticello Nuclear Generating Plant Final Safety Analys is Report, Docket50263--2, Northern States Power Company, Minneapolis, MN, October 1968.

4. Cooper Nuclear Station Safety Analys is Report, Docket-50298--13, Nebraska Public Power District, Columbus, NB, February 1971.

5. Dresden Nuclear Power Station Units 2 and 3 Safety Analysis Report, Docket50237--20, Commonweal th Edison Company, Chicago, IL, November 1967.

6. Final Safety Analysis Report, Peachbottom Atomic Power Station Units 2 and 3, Docket-50277--11, Philadelphia Electric Company, Philadelphia, PA, August 1970.

7. WPPSS Nuclear Project No. 2 Final Safety Analys is Report, Docket-50397, Washington Public Power Supply System, Richland, WA, February 1977.

8. R. I. Smith and L. M. Polentz, Technology, Safety and Costs of Decommissioning a Reference Pressurized Water Reactor Power Station - Addendum, NUREG/ CR-0130, Section 3, Prepared by Pacific Northwest Laboratory for U.S. Nuclear Regulatory Commission, August 1979.*

9. S. G. Sawochka, N. P. Jacob and W. L. Pearl, Primary System Shutdown Radiation Levels at Nuclear Power Generating Stations, EPRI 404-2, Figure 11, p. 57, December 1975.

10. K. Oertel, E. Glaser, J. Bosholm and H. J. Hoffman, Decontamination of Primary Loop Equipment with Ethylenediaminetetracetic Acid, Kernenergy, Vo1. 19, No. 1, pp. 128-132, 1976.

11. Direct testimony of R. F. Brzezinski, Consumers Power Company before the Michigan Public Service Commission, Case U-6041, March 7, 1979.

12. C. E. Jenkins and K. J. Schneider, Technology, Safety and Costs of Decommissioning a Reference Fuel Reprocessing Plant, NUREG-0278, Prepared by Pacific Northwest Laboratory for U.S. Nuclear Regulatory Commission, p. 7-129, September $1977 . \star \star$

13. Technology for Commercial Radioactive Waste, DOE/ET-0028, Vol. 1, p. 1.5.5, Pacific Northwest Laboratory Report for the U.S. Department of Energy, May 1979.

14. Perry Nuclear Power Plants Units 1 and 2 Preliminary Safety Analysis Report, Docket-50440--3, Cleveland Electric Illuminating Company, Cleveland, OH, 1973.

FAvailable for purchase from the NRC/GPO Sales Program, U.S. Nuclear Regulatory Conmission, Washington, D.C. 20555, and the National Technical Information Service, Springfield, Virginia 22161.

**Available for purchase from the National Technical Information Service, Springfield, Virginia 22161. 
1. REPORT NUMBER (Assigned by DDC)

TITLE AND SUBTITLE (Add Volume No., if appropriate) NUREG/CR-0672, Vo1. 2

2. (Leave blank)

Technology, Safety and Costs of Decommissioning a Reference Boiling Water Reactor Power Station

3. RECIPIENT'S ACCESSION NO. AUTHOR(S)

H.D. Oak, G.M. Holter, W.E. Kennedy, Jr., G.J. Konzek PERFORMING ORgANIZATION NAME AND MAILING ADDRESS (Include Zip Code)

Battelle-Pacific Northwest Laboratory Richland, WA 99352

5. DATE REPORT COMPLETED \begin{tabular}{l|l}
\hline MONTH & YEAR
\end{tabular} October 1970

DATE REPORT ISSUED \begin{tabular}{l|l}
\hline MONTH & YEAA
\end{tabular}

6. (Leave blank)

8. (Leave blank)

2. SPONSORING ORGANIZATION NAME AND MAILING ADDRESS (Include Zip Cade)

Division of Engineering Standards

Office of Standards Development

U.S. Nuclear Regulatory Commission

Washington, D.C. 20555

10. PROJECT/TASK/WORK UNIT NO

11. CONTRACT NO.

FIN No. B2117

3. TYPE OF REPORT

Technical PERIOD COVERED (Inclusive dates)

5. SUPPLEMENTARY NOTES Sept. 1977 - October 1979

6. ABSTRACT (200 words or less)

Technology, safety and cost information is given for the conceptual decommissioning of a large (1100MWe) boiling water reactor (BWR) power station. Three approaches to decommissioning, immediate dismantlement, safe storage with deferred dismantlement and entombment, were studied to obtain comparisons between costs, occupational radiation doses, potential dose to the public and other safety impacts. It also shows the sensitivity of decommissioning safety and costs to the power rating of a BWR in the range of 200 to 1100 MWe. 
UNITEO STATES

NUCLEAR REGULATORY COMMISSION WASHINGTON, D. C. $205 B 5$

OFFICIAL BUSINESS

PENALTY FOA PAIVATE USE, $\$ 300$
POSTAGE AND FEES PAID U.s. NUCLEAR REGULATORY commission

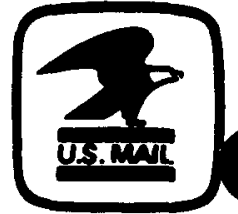

DO NOT MICROFILM
COVER 